
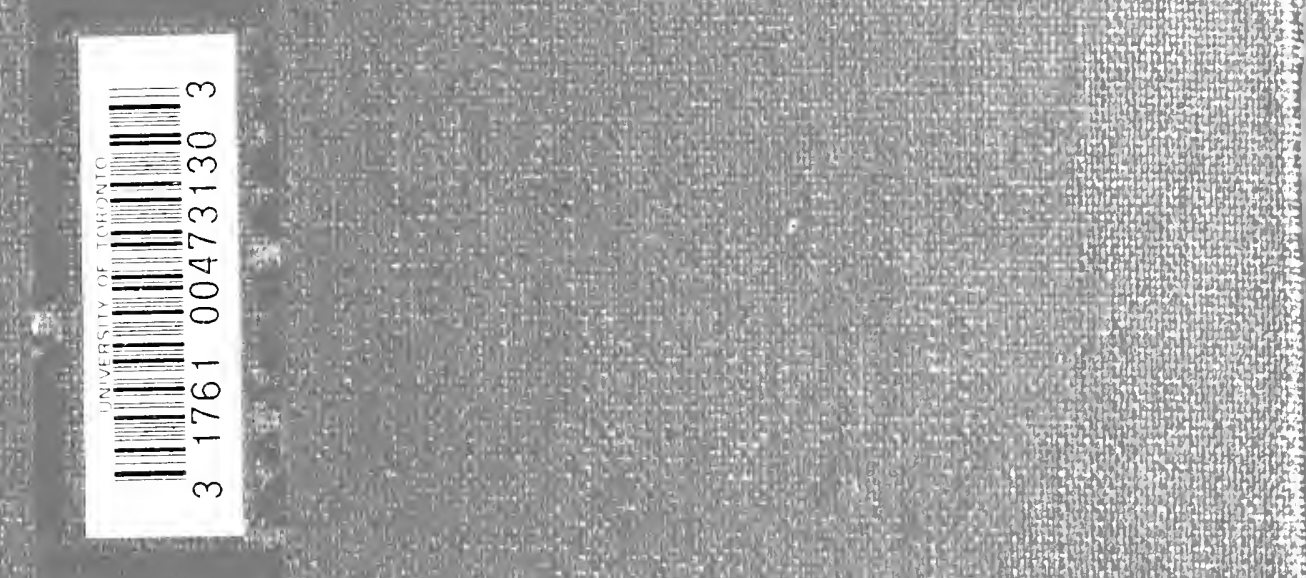
Digitized by the Internet Archive in 2008 with funding from Microsoft Corporation 






\section{AN INTRODUCTION}

T() THE:

\section{History OF MEDICINE}

WITHT WEDICAL CHRONOLOGY, SLGGESTIONS FOR STLDY ITD BIBLIOGRAPHIC DATA

\section{$(326)$}

$B Y^{r}$

FIELIDING H. GARRISON, A.B., M.D. LIEUTENANT+COLONEL, MEDICAI, CORPS, U. S. ARMY, SURGEON GENERAL'S OFFICE, WASHINC;TON, D. C.

THIRD EDITION, REIISED AND ENLARGED

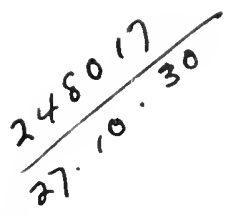

PIILADELPIIA ANI) LONDON

W. B. SA U N DERS COMPANY 
Coptrisht, 1!1:3, 1, W. B. Samoler Compans. Reprinted M:y, 1914. Revised, "ntirely reset, regriated, and recopy righted June, 1917. Revised, entirely reset, reprinted, and recepserighted sicptember, 1921 .

ALL RuGHS REARVED

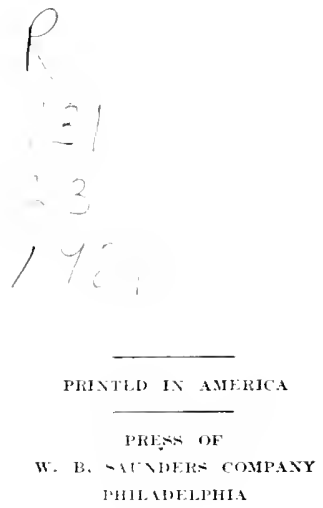


To

GENERAL WALTER I). MCCAW, U.S. ARMY HARARIAX OF THE STRGEON GENERAL'S OFFICE (I903-I3) CHIEF SCRGEON, AMERICAN EXPEDITIONARY FORCES (IGIS-IA))

IN ICKNOHELDG.MIENT

()F HI KINI) I:NCOLRAGEMENT

AND

HIS MINY COLRTLLIES

IN AID OF THE COMPLETION OF THIS BOOK 



\section{PREFACE TO THE THIRD EDITION}

Published in 1913, this book saw its second edition shortly before our entry into the European War; the issue of the present edition, at the customary three years' interval specified in the publishers' contract, has been delayed by the pressure of the writer's military and official duties. By courteous agreement of the publishers, no subsequent revision will be made for some years to come, and for necessary and sufficient reasons. As compared with a treatise on practice of medicine or any of its branches, a history of medicine is, in the nature of things, a stationary product, dealing essentially with the past, with things that have happened. If the author of such a work has succeeded in stating the facts in their true relations, if he has reason to believe that his views of things are, in the main, correct and expressed with sufficient clarity, he will not wish to make many changes, since superadded and inserted matter will, in a series of editions, destroy the freshness and individuality of any book, giving it a somewhat, medieval character, through excess of overlaid material. This method of composition, with which, it need hardly be said, the writer has no sympathy whatever, was once likened by Henry James to a heavy suit of chain mail, which, however carefully wrought, will sink the reader in erudition but not "float him upon a deeper tide," the shifting tide of modern thought and progress. During the troublous period of the European War, the author has been, at whiles, keenly conscious of the need for thoroughgoing revision in at least two of the sections, namely, those dealing with modieval and modern medicine. But recent investigation of medieval medicine, the main ambition of the foremost living medicial historians of Europe, is still "knowledge in the making," while present-day merlicine, during the war period and after, has been in a state of flux. Revision along the lines contemplated will, therefore, be marte to best advantage after a period of careful consideration and study, when the civilized world has attained a period of less unstable equilibrium; and such revision, if well considered, will require the neecsisty element of time.

What has been accomplished in the-present edition is as follows: A careful account has been rendered of the newer findings 


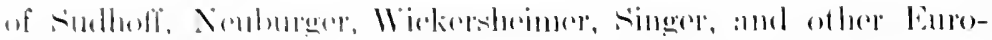

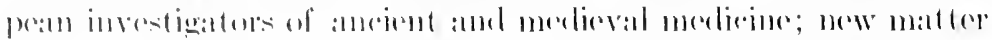

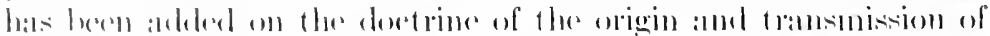

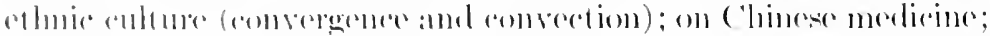

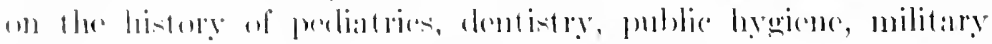

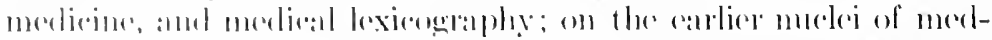

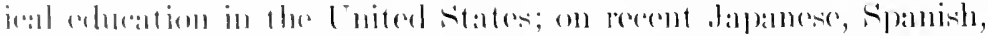

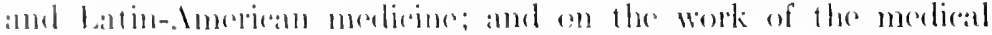
departments of armies in the Emopeam War. A number of new

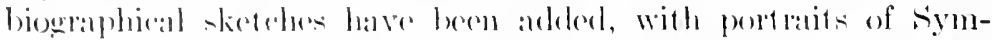
phorion ('hampier, Villomin, (imlt, Jittre, salkowski, ()ser, Max Nomburaer, and others. Errors of omisison and eommission have

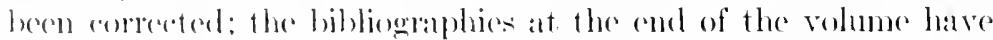

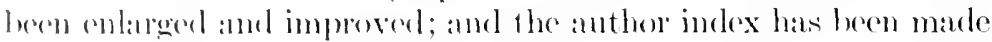
as romplete and exhaustive as possible. Sperial offort has been made to kerp) dewn the physical size and wojght of the bouk, and to preseresomething of its original plein air intention, by the use of small trpe in certain soctions. As stated in the profare of the first colition, the anthor's mimary object has heen to stimulate the medical stmlent or the busy practitioner to pursue his own studies in the history of molicine, and, jucleing from the linger number of friondly and sympathetic letters received, this (nd has lwon, in some measure, attained.

In his forward-looking "()utline of History" Mr. H. G. Wells has almost nothing to say of the influence of medicine upon human progress, althomet, as Desartes observel, it is to the science and art of melieine that the himman race must look if it is to perfect and fit itself for the gigantic social tasks and problems which are houmd up with its future development. With fine perspicacity Mr. Wells signalizes three episodes in secular history as the most important in the development of the human race and its civilization, riz., the awakening of free thought in mankind by the Ionian Creeks; the awakening of the free conseience of mankind by the Hobrew prophets: and the awakening of the sense of solidarity in mankind by the political and social revolutions of recent times. To these ho adds a fourth, and even more momentous, coefficient, namely, the need for the self-discipline of each and erery individuat in the fecling of social obligation and for personal and internatiomal good manners, that these three forces may operate for the ereatest good of the greatest number, and that the many may not continue to suffer for the crimes, whims, ineptitudes, and insanities of the few. The olject of Mr. Wells' History is to educate the individual in this sense of social obligation, and, as the Mr. Cireatheart of our Pilgrim's Progress along the "cightfold Aryan way," he has given to the historian a new and unique 
function. Assuming the best will in the world on the part of the children of the future, one may at least hope that they will contimue to produce, not Perkiniffian prigs and pramutical purists. but such interesting and whole-souled humaus as Rubens and Helena Foument, Richard steele, Charles lamb and Fammy Kiclly, Franz schubert, Rahel Levin, Théphile Romsicel, Joseph Leidy, Louis Pasteur, Henri Dumant, Joseph lister, Johanne: Brahms, Ivan Turgenieff, and William Osler. Whether Selopenhamer's famous balance-sheet between evil and good will ever be reversed or not tums upon the balance or imbalanee of social forces, in the adjustment of which medicine is destined to play a part of ever-increasing moment. With the law visibly decomposing into chicunery and the medieval mania for formalism and multitudinous verbiage, with religion too frequently debased into a cloak for fraud, modern medicine has ever heen forwarellooking, honest in its "aims, methods, and persistency," and fears not its audit. The signs and symbols are around and about us everywhere. The conquest of eommmnicable diseases, the attainment of painless, shockless, deathless surgery, the manifold devioes of sanitation, the reeognition of an interelation hetween health and disease and sociat-economic conditions, the wide-spread concern about industrial poisoning, trade diseases and atcoidents, the movement for wholesale clestruction of noxious insects, parasites, reptiles, and vermin, the relation of the neuroses to crime and the sexual genesis of crime, the relation of the intermal secretions to the neuroses and insanities, nay, even to cerebration itself, have been a few of the trends of recent medieine. The influenee of disease itself upon the trend of human history in the past is still an unwritten chapter, thrown into striking arecictental relief by the triumph of sanitation over infectious diseases in the European Viar. In our army camps the disease-carrier, whether contart or suspect, was taught to regard himself as a greater menace to his fellows and to the eommunity than the discase itself. At the Harvard Library Mr. Justin Winsor made the loan of a book conclitional upon the personal cleanliness of the applicant. One overerowded publie vehieles are still efficient ageneies in the transmission of parasitic and respiratory oliscases. Crime and Räcksichtslosiglieit are coming to be regarded as matters of social sanitation. During the European Warr, the seience of medical anthropology, and particularly of ethnic psrohology, began to loom laree and acquie even military signifieance. All this is obviously more potent, dymamic, and understamelable doetrine than the outworn patter of chanler la haule morale. Tho viewpoint of Cato the Censor does not appeal to modems. The messiage of medical history to the future is: "Come clean." 
Since the last revison of this lowk, in faret, in the very thick of the wall perionl, a larese amoment of original work of highly aredit-

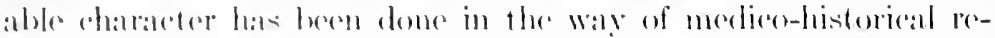
seareh. The most important of these investigations bear mpon the history of medieval sidenere and mediene, notably the massive studies of sudholf mon medieval surerey, the sehool of salepmo,

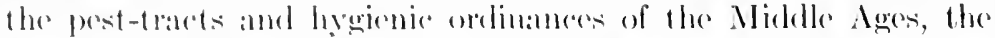
history of modieval athatome, and the graphies of merlieval prate-

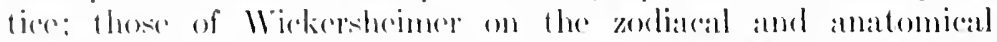
diagrams: the valuahle investigat ioms of molieval MSS. hy Charles

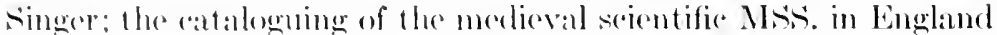
by Iorothea Waley Singer; and the studies on Aristotle by Profresor Charles s. Haskins (Hamvard University). Through such investigations as these we are begimning to understand somewhat of the vast eomplex known as medieval mediedne. In laying down plans and supplying building stones for this new edifice none have shown such umparalleled industry as Professor sulhoff, a mienty sebolar and fomtanin-head of genius and power; of the puzzle-hearled array of ascertained knowledge, none, save Allbutt, have given so intelligible a synthesis as singer. Defining weience as "the making of kmowledge," ho sets the delimitations of medieval science in time as between 400 A. D., when the ancients ceased to make knowledge, and 1453, when molern seienee, in the dynamic sense, began, with Copernicus and Vesalius. During the long interperiod, medieval science was mainly static and descriptive, and through its eentral dogma, derived from Plato and familiar to us in the I)ivina Commedia and Goethe's Faust, phenomena were studied not as leading to anything, but as illustrating the relation of the great outer universe or macroesm to the microcosm, man. Astrologe, the doetrine of the four humers, and other prognosties bereame modes of life-insuranee, in other words, only one phase of the larger insurance against "the perils of the soul." "For such an attitude of mind there could be no ultimate distinction between physical "vents, moral truths, and spiritual experience." As Taylor has shown in "The Mediaral Mind," scoence, ethics, theology. philosophy, art, and medicine were regarded not as separate categories, hut as something interrelated and interfused. Assuming this riewpoint, it is easy to comprehend why the basic sciences-anatomy, physiology, pathology-were ahmost non-existent in the Middle Iges, why internal medieine was backward, and why such practical matters as military surgery and the application of the Biblical code of sanitation were forward, even as printing, or the use of the mariner's compass, firearms, and speetacle lenses cime to be forward.

Of other recent contributions to molical history, space permits 
but brief mention of sir Clifford Allbutt's splendid and learned study on Cireek Medicine in Rome, the stimulating histories of medicine by Sulhoff and Meyer-Steineg, and of dentistry by l'rofessor Sulhoff, Professor Neuburger's studies of medicine in Josephus and the Vienna School, Singer's two volumes of Oxford "Studies," the interesting history of medieval medicine by Dr. James J. Walsh, Dr. Mortimer Frank's translation of Choulant, Dr. Jonathan Wright's commentaries on pre-Hippoeratic and Hippocratic medicine, the highly original investigations of Mexican medicine by Dr. Nicolas León, and the fortheoming volumes on the history of medicine by Sir William Osler, on the history of magic by Professor Lym Thorndike, on the medical gods by Dr. Walter A. Jayne, on medicine in Montaigne by Captain J.S. Taylor, U.S. N., and on the Florentine artist-anatomists by Dr. Edward C. Streeter. Biographies of Sir William Osler by Professor Harvey Cushing and of Joseph Leidy by Dr. Joseph Leidy, jr., are in preparation; and the announcement of histories of physiological chemistry by Professor Gowland Hopkins and of clinical methods by Dr. Erich Ebstein is a matter of keen interest to historical students. Two volumes of the medical history of German participation in the European War have already been published, much of the preliminary material of the Enghish history has been printed in serial form (National Research Council), the Canadian history is in preparation, and two volumes of the American history are alrealy in press, under the editorship of Colonel Charles Lynch, U. S. Army. Very recently, university chairs of medical history have been assigned to Dr. Eugène Menetrièr (Paris), to Professor Max Wellmann (Berlin) and to Dr. Charles singer (London); Professor Max Neuburger hats established an Institute of Medical History in the Josefinum (Vienna), and it is hoped that steps along the same progressive lines will be taken in Ameriea. During the war period, some of our best have passed away-Osler, Jacobi, Payne, Ruffer, Blanchard, Höfler, Schelenz, Valentin Rose, Gaizo, Handerson, and Mortimer Frank-and of these, none have left so distinet a void in our minds and hearts through their passing as sir William Osler. He wats a source of inspiration and encouragement to us all, and to me personally, the wisest of mentors, the kindliest of friends.

This book is, in a very real sense, a product of the surgeon Ceneral's Library, and I desire once more to thank the sucecsive Librarians of this great institution for their encouragement and their generosity in the loan of books and graphic material. In the correction of errors, I am very gonninely indebted to Geheinrat Sudhoff (Leipzig), whose utterances about English, French, 


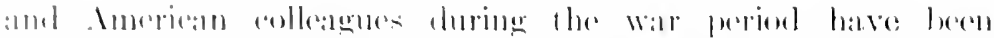

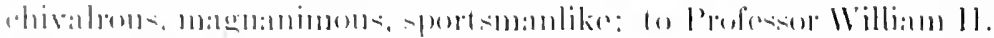

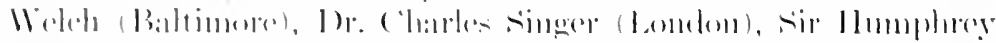

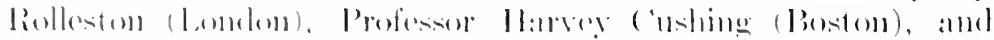

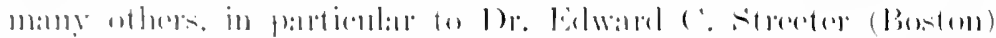

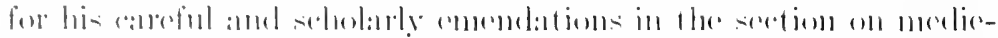

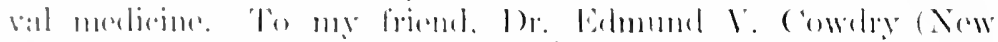

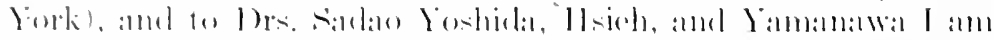

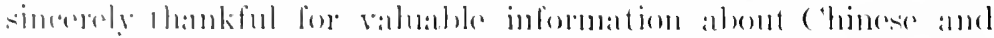

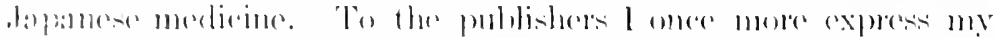

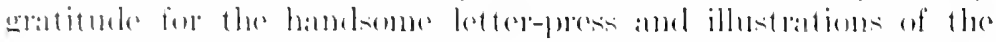

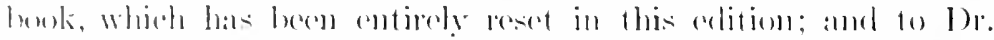

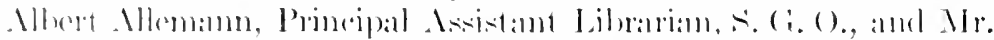

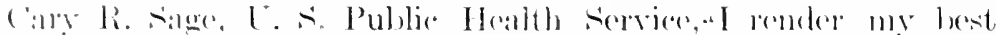
thankis for their eflieient cosperation in the arrection of the mintis.

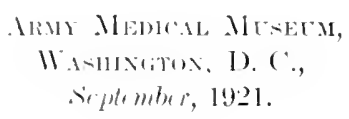

F. H. (i.

Author's Corrections.

Page 11, line 23. "National Rexeareh council" should be "National Health Insurance (Medical Researeh (ommittre)."

Page 12, line \&. "Yamamawa" should be "Yokogawa." 


\section{CONTENTS}

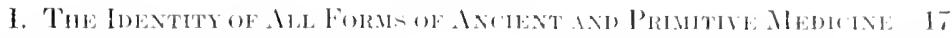

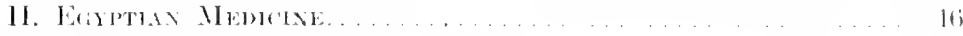

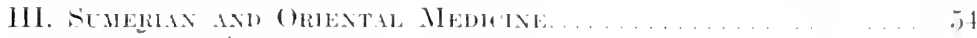

11. CiRLEK MEDHCTNE:

I. Before Hiproctites. . . . . . . . . . . .

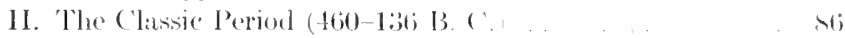

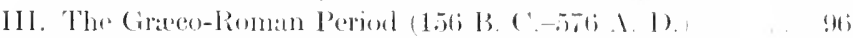

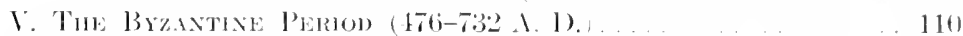

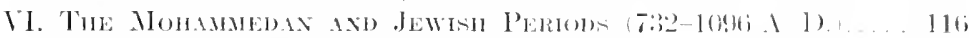

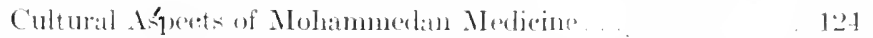

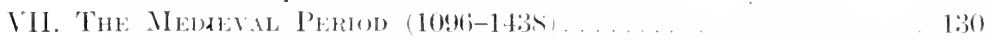

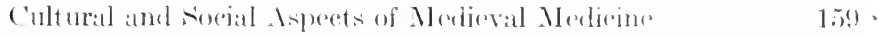

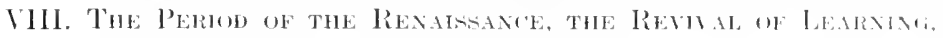

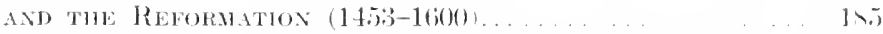

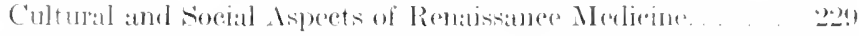

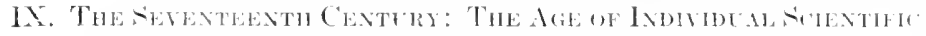

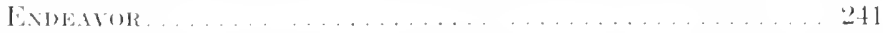

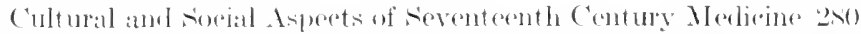

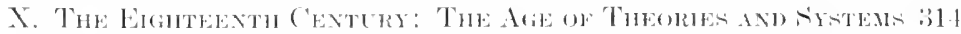

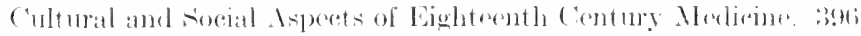

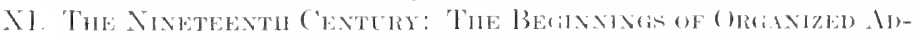

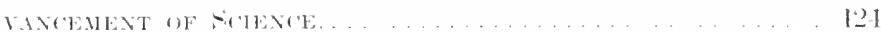

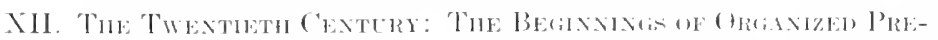

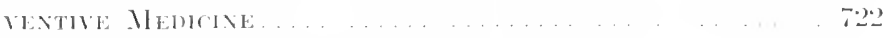

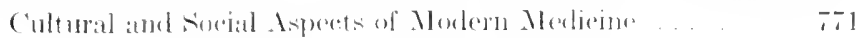

APPENDICE:

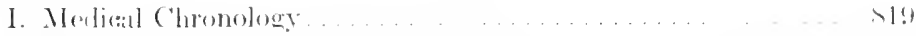

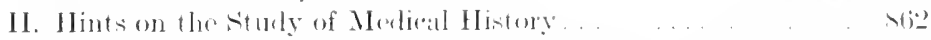

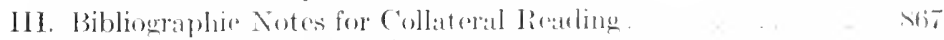

1. Histeries of Merlicine _ . . . . .

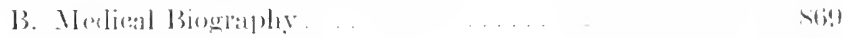

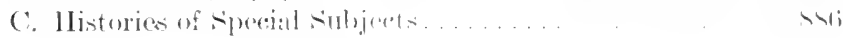

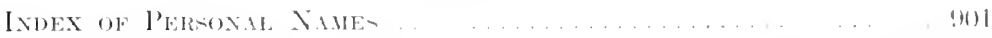

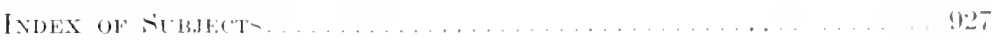



"Civilization in its higher form today, though highly complex, forms essentially a unitary mass. It has no longer to be sought out in separate luminous centers, shining like plinets through the surromnding night. Still less is it the property of (ne privileged country or people. Many as are the tongues of mortal man, its votaries, like the lmmortals, speak it single languare. Throughout the whole vast area illmmined by its guickening rays its workers are interdependent and pledged to a emmon cause."-Sin Nitucu Evans.

"For indeed it is one of the lessons of the history of science that cach age steps on the shoulders of the ages which have gone before. The value of each age is not its own, but is in part, in large part, a debt to its forerumners. And this age of ours, if, like its predecessors, it cam boast of something of which it is proud, would, conld it read the future, doubtless find much also of which

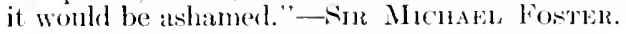

"Take from the air every aëroplane; from the roads every automothile; from the country every train; from the eities every electric light; from ship every wireless appututus; from oceans all cables; from the land all wires: from shops all motors; from office buildings every elevator, telephome and typewriter; let epilemies spreal at will; let major surgery be impossibleall this and vastly more, the bonlage of ignorance, where knowledge now makes 11: free, would be the terrible eatastrophe if the tide of time should but cbl to the childhood days of men still living!. . Therefore, whocver desires progress and prosperity, whoever woukl advance humanity to a higher plane of civilization, must further the work of the scientist in every way he possibly (:In."-WILLTAM J. HuMPHREXS.

"The development of human thought and achievement, as a whole, has not been, as commonly supposed, a continual upward progresion, nor eren the equivalent of a continums series of ascertamed results. Thoughts and inventions, which seemed on the verge of practical fruition, have often been redued to nothingness, even at the most derisive moment, through some combination of untoward circumstances; ves, even the very memory of a pathway broken into the Land of Promise is often ohliterated and what seemed aleomplished fact has hal to be recreated by laborious work covermy years, decaldes and even centuries. Just the simplest, most natural am lo in the end, almost self-erjelent liuets are the hardest to evolve and elucidate, just what was inost decisive and potent of result has been time and again overlooked by the soeker alter truth. . . The gold of historic thought, indeed, is as little to be fomm in the street as the gold of actual daily strife, and it is by no means the task of the historian of brom general soope to give the initial clew to its discovery. IIe, indeel, ain only reproduce the past with fidelity and exartitude. The intuition of the true investignator and puthfinder of todliy and tomorrow must find its own way to new gniling principles from the worls of resterday, before yesterlay, and the distant past."-Kalis srdioff.

\footnotetext{
"Doctrinaire formula-worship-that is our real enemy."-Max NedBi'koish.
}

"It is hardly an exaggeration to summarize the history of four hundred rears by saving that the leading idea of at romguering nation in relation to the ioncuered was, in 1600, to change their religion; in 1700, to change their trade; in 1so(), to change their laws, and in 1900 to ehange their drainage. Maly we not then say, that on the prow of the conguering ship in these four centuries first stood the priest, then the merehint, then the lawyer, and finatly the phrsician?"-A. Lawrener Lawell.

"Aims, methods, and persistencr are common to the medial profession of all eomentries. On its flag is inscribed what should be the life rule of all nations: Fraternity and solidarity."-Absam Jacobs. 



\title{
AN INTRODUCTION
}

\author{
TO THE
}

\section{HISTORY OF MEDICINE}

\section{THE IDENTITY OF ALL FORMS OF ANCIENT AND PRIMITIVE MEDICINE}

ONE of the best accredited doctrines of recent times is that of the unity or solidarity of folk-ways. The collective investigations of historians, ethnologists, archeologists, philologists, and sociologists reveal the singular fact that all phases of social anthropology which have to do with instinctive actions inevitably converge to a common point of similarity or identity. This is true of all myths, superstitions, laws, and social customs of primitive peoples (as also of the cruder ethnic aspects of religions) which are concerned with the fundamental instincts of self-preservation and reproduction. It is possible, as we shall see, that many strange cultural practices, such as mummification, circumcision, or the couvade, may have been deliberately transported by migrations from one continent or island and imposed upon another (Elliot Smith). But the fact remains that, for those human actions which have been defined as instinctive, as based upon the innate necessity which is the mother of invention, "folklore is an essential unity."' The mind of savage man, in its pathetic efforts to form religious and ethical systems for moral and spiritual guidance, or to beautify the commoner aspects of life with romance and poetry, has unconsciously taken the same line of least resistance, followed the same planes of cleavage. The eivilized mind differs from the savage mind only in respect of a higher evolutionary development. Human races and racial customs have changed as they became more highly specialized. The heart of man remains the same.

It follows that, under different aspects of space and time, all phases of folk-medicine and ancient medicine have been essentially

${ }^{1}$ For a good summary of the matter, see the presidential address of Charlotte S. Burne in Folk-Lore, Lond., 1911, xxii, 14-41; also, her revision of "The Handbook of Folklore" (Pub. Folk-Lore Soc., No. Ixxiii, Lond., 1914). 
alike in tendeney, differing only in unimportant details. In the light of anthropology, this proposition may be taken as proved. cunciform, hicroglyphic, runie, birch-bark, and palm-leaf inseriptions all indicate that the folk-ways of early medicine, whether Accadian or Scandinavian, Slavic or Celtic, Roman or Polynesian, have been the sime-in cach case an affatr of charms and spells, plant-lore and psychotherapy, to stave off the effects of supernatural agencies.

In rolation to the origin of ethnic traits and practices, opinion is divided into two schools. The convergence theory, originated by Arlolf Bastian in $1 S S 1,{ }^{1}$ aflims that the appearance of identieal ethnic phenomena in different relations of space and time is duc to the spontancous development of eertain "elemental ideas" (Elementargedanke), which are common to primitive man everywhere. The convection theory, originated by Friedrich Ratzel (158:22), asscrts that no isolated action or primary "elemental thought" is possible to primitive races, but that each race hits derived something from its neighbors or predecessors in sequence of time. Ratzel's theory of the geographic diffusion of ethnic culture hats been vigorously defended by Fr. von Luschan, ${ }^{3}$ and separately maintained by Elliot Smith, in his doctrine of the eonvection of "heliolithie culture." The Bastian doetrine is strongly supported by the imposing array of facts which have been assembled in furtherance of the modern theory of evolution, that the development of the individual is but an cpitome of the development of the race. Left to itself in a favorable environment, any savage tribe will inevitably evolve a culture all its own, for the regulation of food supply, sexual and soeial relations, adjustment to the unknown, manifesting itself as political cconomy, ethies, law, medicine, religion and so on. The weak point in the convection theory is that it deals with accidentals and non-essentials, such as the constant recurrence of the self-same folk-tales and proverbs all over the earth, similarities in language, artistic forms, detached cultural practices, ethnic type (Hindu and Aryan, Malay and North American Indian), ete., many (not all) of which may have been mechanically transmitted from one race or culture to another. Thus, the Africans of Benin and Cameroon learned to make armor and artistic devices in metal from North-European invaders; the Ganymede in the Vatican is strikingly reproduced in a Bulduhist relief in a eloister near Sanghao; the cobra symbol is fonnd alike in Indian, Egyptian, Seandinavian, and Aztec devices; the symbolism of the Symplegades is the same in Greek and Mayan art; but the cherchez la femme motive may well have originated seores of Trojan or other wars, and such happenings as those of CEllipus, Siegfried, Iachaon, Susanna and the Elders, are apt to occur spontaneously anywhere. EIliot Smith asserts that Americans uphold the convergence theory "as a kind of dogma" over against the convection theory, but, as a matter of fact, there are strong elements of probability in both. Hence, neither can be erected into dogma.

Of the ultimate origin of folk-ways and ideas we know little or nothing. Innumerable hypotheses have been advanced, in each case the attempt of a civilized or educated mind to interpret the workings of the primitive mind from isolated instances, and, in

1 A. Bastian: Der Völkergedanke, Berlin, 1881.

${ }^{2}$ F. Ratzel: Anthropogeographie, Stuttgart, 1882.

${ }^{3} \mathrm{~F}$. von Luschan: Zusammenhänge und Konvergenz. Mitt. d. anthrop. Gesellsch. in Wien, 1918, xlviii, 1-117. 
almost every case, the investigator has become obsessed by his particular theory to the extent of becoming a hobby-horse rider. But all anthropologists agree that the general origin of folli-watys and mores (religions or other) is social, concerned with the great question "how to live," which is different at different times, in different places, among different peoples. Of the mind of primitive man, we know that it differs from the civilized mind mainly in respect of edueation and development, that is, in the power to perroive and assign the right causes for phenomena, which gave us scince, and in eertain perceptions of "values," which gave us our standards of morality and taste. But in each of these things the primitive mind everywhere has its own natural standards, which are worthy of decpest eonsideration.

Apart from any theories as to his origin or evolution, we may assume that prehistoric man was not different from what we often find primitive man to be-a savage sunk in his animal instincts. At this stage of his existence he killed his food and fought his encmies with sticks and stones, raped his women, hid himself in eaves. and was probably not unaware of certain hygienie precautions which are instinctive in lower animals. A dog lieks its wounds, hides in holes if sick or injured, limps on three legs if maimed, tries to destroy parasites on its body, exereises, stretches, and warms in the sun, assumes a definite posture in sleeping, and seeks: out certain herbs and grasses when sick. It is not umreasonalse to suppose that actions like these may have been as instinctive in a grown-up prehistoric man as they are in a primitive child of his race today. "Man has elimbed up from some lower aninial form," says John Burroughs, "but he has, as it were, pulled the. larker up after him." We do not know when or where, how of why, this oecurred, but we do know the first rung of the ladkles. In the Hall of Anthropology of the National Museum at Washington (or in any other good collection of this kind) there are to be seen innumerable specimens of a small object in chipped flint which is the srmbol of prehistoric man's uplift, his first step in the direction of civilization. With this leaf-shaped flint in hand, ho had a new means of protecting himself against enemies, procuring and preparing food, and of mamfacturing other weapous and inplements of the same kind or of more highly specialized kinds. Now the interesting point about these prehistoric flints is that they are to be found wherever traces of the existence of man are fornd, changing in shape during the suecessive interglacial and postglacial periods, but following his migrations over the surface of the

${ }^{1}$ Usually Triticum caninum, Cynosurus crisiatus, and Agrestis canina for emesis and purgation. Cats have a known fondness for Valeriana officinalis and Nepeta calaria (catmint). 
earth. Here cropping up as spear or arrow-point, there as tool or ceremonial object, these primitive "celts," as they are called, have been exeavited from the river-drifts of England, France, and North Ameriea, in the caverns of Devonshire and the Dordogne, in the plains of Egypt and Palestine, and the frozen tundra of Siberia and Alaska, in each case bearing the same identical form. In the Early Stone Age (Palcolithic Period), up) to the Solutrean Period, the chipped celts were little more than the result of a necessarily crucle flaking of oval or ovoid stones. From the time of arrival of the pre-Chellean flint workers in Europe during the Sceond Interglicial Period, one hundred thousand years ago, each successive race had its peculiar technic of flint-chipping, its characteristic retonch, until the erude coups de poing of the Chelleans become the exquisite laurel-leaf points of Solutrean man. But in the Magdalenian period the forms are again crude, and finally dwindle away into the faultier Azilian forms and the strange trapeziform shapes of the Tardenoisian microliths. ${ }^{1}$ In the Later Stone Age (Neolithic Period) they were brought to a high point of specialization and polish, but in shape and intention they have remained the same throughout geologie space and time. Their employment in surgery by the ancient Egyptians, or in ritual circumeision by the Hebrews in the desert, goes to show the umusual veneration in which they were held by these peoples on account of their great antiquity. In what is perhaps the most interesting of American contributions to archeology, ${ }^{2}$ Professor William H. Holmes has demonstrated inductively (by working out the initial methods of chipping and flaking himself) that even among recent American Indians, like those of the Piney Branch quarries in the District of Columbia, the process of shaping and specializing the leaf-shaped flints was probably not different from that employed by Paleolithic man or even in what scem to be the rude artefacts of Eolithic man. There is apparently no distinction in space and time in the flaking of prohistoric and primitive implements. Similarly, ethnologists, as we have said, find that the folklore and other traditions and superstitions of primitive peoples have a strong family likeness at all times and places.

The common point of convergence of all medical folk-lore is the notion that spirits or other supernatural agencies are the efficient causes of disease and death. Primitive medieine is inseparable from primitive modes of religious belief. If we are to understand the attitude of the primitive mind toward the diagnosis and

1 See H. F, Osborn: Men of the Old Stone Age, New York, 1916, passim.

2 W. H. Holmes: "Stone Implements of the Potomae-Chesapeake Tidewater Province," Rep. Bur. Ethnol., 1893-4, Wash., 1897, xv, 1-152. Also: Mem. Internat. Cong. Anthrop., Chicago, 1894, 120-139, $4 \mathrm{pl}$. 
treatment of disease we must recognize that merticine, in our sense, was only one phase of a set of magic or mystic processes designed to promote human well-being, such as averting the wrath of angered gods or evil spirits, fire-making, making rain, purifying streams or habitations, fertilizing soil, improving sexual potency or fecundity, preventing or removing blight of rops and cpidemic diseases, and that these powers, originally united in one person, were he god, hero, king, sorcerer, priest, prophet, or physician, formed the savage's generic concept of "making medicine." A true medicine-maker, in the primitive sense, was the analogue of our scientific experts, philanthropists, and "efficiency engineers," a general promoter of human prosperity.

In his attempts to interpret the ways of nature, savage man, untutored because inexperieneed, first of all confused life with motion. Like Mime in Wagner's "Siegfried," he was puzzled if not awed by the rustling of leaves in the forest, the crash and flash of thunder and lightning, the flicker and play of sumlight and firclight, and he could see no causal relation between a natural object and its moving shadow, a sound and its echo, flowing water and the reflections on its surface. Winds, clouds, storms, earthquakes, and other sights and sounds in nature were to him the outward and visible signs of malevolent gods, demons, spirits, or other supernatural agencies. The natural was to him the supernatural, as it still is to many of us. He therefore worshiped the sun, the moon, the stars, trees, rivers, springs, fire, winds, and even serpents, eats, dogs, apes, and oxen; and, as he came to set up carved stocks and stones to represent these, he passed from natureworship to fetish-worship. Even in his artistic productions, the savage is at first animistic and ideographic, tends to vitalize inarimate objects, and aims at the portrayal of action and movement rather than perfection of form. ' Disease, in particular, he was prone to regard at first as an evil spirit or the work of such a spirit, to be placated or eajoled, as with other deities, by burnt offerings and sacrifice. A further association of ideas led him to regard disease as something produced by a human enemy possessing supelnatural powers, which he aimed to ward off by appropriate spells and sorcery, similar to those employed by the enemy himself. Again, his own reflection in water, his shadow in the sunlight, what he saw in reams, or in an oceasional nightmare from gluttony, sug-

1 That there is a strong resemblance between some of the eoneepts of savage and paranoiac art is strikingly shown in the remarkable earvings of a paranoiac collected by (i. Marro, Anm. de freniat., Turin, 1913, xxiii, 157-192, $6 \mathrm{pl}$. W. H. Holmes has shown that, in the savage, perfection of pattern forms and figures had to follow upon development of the metrie and geometric arts, such as the shaping of pottery, textiles, technics, and architecture. (Rep. Bur. Ethnol., 1882-3, Wash., 1886, iv, 443-465.) 
gested the existonce of a spirit-morld apsurt from his daily life and of a soml apatet from his boly, and in this way he hit mon a thirel way of looking at discase as the work of offended sprits of the deate, whether of mon, animals, or plants. These there views of

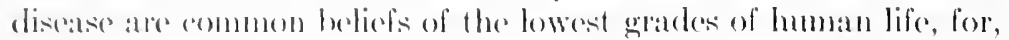

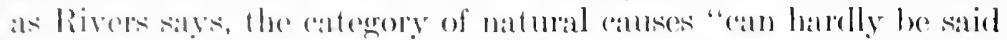

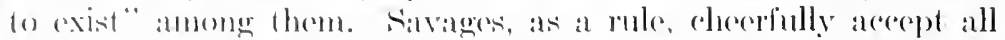
three, while a lingering boliof in human soreery and the displeasure of the eloud is always a trate of the pousant and sometimes of his desermlants in "civilized" communities. The modern Korrans are sald to number their demons "by thomsands of billions."

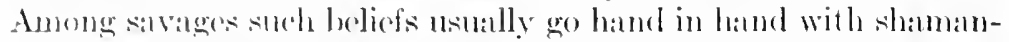
ism, an intermediate stage between polytheism and monotheism, which assumes a supreme Being or Great Spirit, with lesser divinities and demons subordinated. With the beginnings of shamanism ${ }^{1}$ w have (verywhere the advent of the medieine man and the bilbo or witelerloctor, who assmes a solemm supervisory relation to disease and its cure not unlike that of the priest to religion. The shaman handles disease almost entirely by psychotherapentic mancurers, which serve to awaken a corresponsive state of autosuggestion in his patients. Whether North American Indian or Asiatic Samoyed, he does his best to frighten away the demons of disease by assuming a terrifying aspeet, covering himself with the skins of animals so as to rescmble an enormous beast walking on its hind legs, resorting to such demonstrations as shouting, raving, slapping his hands or shaking a rattle, and pretending (or en(leavoring) to (xtract the active principle of the disease by sucking it through a hollow tube. To prevent future attacks, in other words, to keep the demon away for the future, he provides his patient with a special fetish or amulet to be worn or carriel about his person. Furthermore, any fantastic thing he may elect to do or not to do, such as passing in or out of a door or stepping over an object with intention, he considers in the light of "making medicine." We may smile at these phases of shamanistic procedure, but, except for the noise, they are not essentially different from the mincl-medicine or faith-healing of our own day. Both rely upon psychotherapy and suggestion, and for a sick savage, the fantastic clamor made about him might be conceivably as effective as the quieter methods of Christian s'cience to a modern nervous patient.

It is highly probable thit in all primitive soeieties, the priest, the magieian, and the medieine-man were one and the same, and that the powers aseribed to these ranked with eourage and the sword as means of securing leatlership or

${ }^{1}$ For the ritual of preparation and initiation of einuliclates into the four degrees of shamanism, see W. J. Hoffmann: Rep. Bur. Am. Ethnol., Wash., $1 \$ 91$, vii, $151-300$. 
kingship. As these functions beeme more sperialized and differentiated, religion beeame the exelusive belief in and worship of some universal power erreiter thin man himself; magic, a special set of proceses within the power of man, whereby he sought to prediet and control natural phenomena, usually to wreak evil and in oppesition to the will of the god or gods; and medicine, the attempt to direct and control those natural phemomena which proluer disease and death in man (Riversi). Thus religion, through the imbibitions which man put upon himoclf to attain to the godlike, became the origin of law and ethies; the secret practices of magic engendered alchemy and other branches of chemieal and physieal seienees; astrology, ast ronomy; while prinitive medicine remained more or less stationary among all peoples, always following in the wake of other scienees, until it could utilize the advances niade by physies or ehemistry. Black magic was coneerned with producing drought, famine, clisease, death, or other evils; white magic, in averting these or in such positive good as rain-making, fre-making, or promotion of vegetation. Primitive therapy, therefore, became a mode of white magic.

Primitive pathology aseribed disease to somathing projected into the body of the vietim, something taken from it, or to the effect of soreery upon some part of or some object eonnected with the borly of the patient. The first category corresponds with our infectious and toxic diseases; the second, e. $g$, the predilection of the Austratian savage for the adrenal fat of his enemirs, with the diatbetic (metabolic) and deficioney diseases. The third eategory Frazer defines as sympathetic magic (action at a distanee ${ }^{2}$ ), including homeopathic or mimetic magie (action by or upon similar objoets for good or evil) ancl contagious magic (magieal effect of a thing which has onee been in contact with a person or thing or formed part of it). As part of this cult, the soul was regarded as "the animal inside the animal, the man inside the man," a mannikin, counterpart or double, sometimes a sharlow or reflection, ${ }^{3}$ absent from the body in sleep, sometimes a truant and a wanderer, capable of being extracted from the body by an enemy, or of being deposited in some safe place to seeure immortality, or even existing as a second self or "external soul" in various plants or animals, upon whose welfare the welfare of the individual dopended. ${ }^{4}$ The "perils of the soul," in primitive medieine, were averted by complex systems of totems and taboos. On Eddystone Istand (Melanesia) nearly every disease is ascribed to eating the fruit of tabooed trees. In other parts of Melanesia disease follows upon any infraction of totemic ordinanees, stlch as killing or eating the totem (Rivers).

Thus primitive medicine, magic, and religion are inseparable, although, as in ancient Egypt or some part of modern Melanesia, leecheraft may become specialized to the point of having a doctor for every disease.

Apart from shamanism, the actual medical knowlerge of primitive man, given his limitations, was far from contemptible. As the folk-lorists point out, the function of the medicine man was a limited one, and the art of healing never progressed very far so long as it was under the sway of belief in the supernatural. As the savage advanced a little further in the knowledge which is gained from experience, it was natural that some special talent for herbdoctoring, bone-setting, and rude surgery should be developed and

${ }^{1}$ See W. H. R. Rivers, Fitzpatrick Lectures, Laneet, Lond., 1916, i, 59: 117.

? Sir James G. Frazer: The Magic Art (The Golden Bough, pt. i), London, 1913 , i, 52-219. 1911.

${ }^{3}$ Frazer: Taboo and the Perils of the Soul (Golden Bough, pt. ii), London,

${ }^{4}$ Frazer: Balder the Beautiful (Golden Bough, pt. 7), London, 1913, ii, 95-278. 
employed as a special means of livelihood by eertain individuals. Aloner with these nature-healers there went, of course, the in-

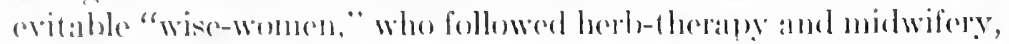
and such specialists som pereodved that a mumber of poisons ale also remerlies under varioms conditions. Medicine, which Huxley has so truly styled the foster-mother of many sodences, rably hegan with this crude plant-and poison-lore of primitive peoples.

Farly man regatrded the poisoner with the same forlere and loathing that

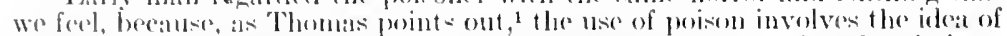
death without the possibility of motor resistance, without giving the vietim a fighting chance.

When Clyses applied to Ihe at Eplyra for a deally arrow-poison, Jlus declined, "for he had in awe the immortal gods" (Odysiey, i, 260). At the ancient Creek festival of the Thargelia, given at Athens every May, two public outeasts, sot apart for the purpose, were flogged with squills, wild fig branches or anmus eastus, and possibly stonerl to death or flung into the seat. The scipegoat, in this case, was called the Pharmakos, which also means a poisoner, sorecrer, or magieian. Whether the verb from which the word drug

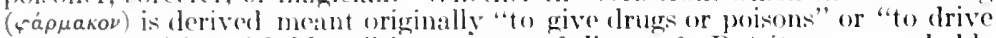
away ("vil spirits with blows" is a matter of clispute. ${ }^{2}$ But it seems probable that the original pharmacologist was eyed with suspicion.

Prinitive man's knowledge of medicinal simples was exactly like the drug phase of our modern therapentics-extensive, if not intensive - and where he made mistakes it was (as in our own case) due to the cause which Kant assigns for all human error-the inveteracy of the post hoc, propter hoc tendency in the human mind. Like many physicians today, he tried to treat the disease rather than the patient, not realizing (as we are just beginning to realize) that the drnamic effect of a drug upon the patient's body depends as much upon the delicate chemical adjustments of that body as upon the composition of the drug itself. Whenever many different remedies are proposed for a disease, it usually means that we know very little about treating the disease, and the same thing is true of a drug which is vaunted as a panacea or eure-all for many discases. "In listening to the praises of these panaceas," said Peter Krukenberg, the old Haile clinician, "we seem to be actually standing before the booth of a mountebank."3 We are not much better off than early man in this respect. Thus, the hieratic writings of the Egyptian papyri reveal an unusually extensive materia medica, the excellence of which is vouched for in the Homeric poems, and which ean today be duplicated, in extent at least, in the materia mediea of old civilizations like China or Japan, or even in our own bulky pharmacopeias. The ancient Egyptians, Chinese,

\footnotetext{
${ }^{1}$ WT. I. Thomas: Sex and Society, Chicago, 1907, 163-167.

2See Morley Roberts: The Pharmakos, Folk-Lore, Lond., 1916, xxvii, $218-224$.

${ }^{3}$ Cited by Baas.
} 
and Aztees had botanic gardens (Hill). We find that savages in widely separated countries easily get to know the most fatal arrowpoisons-curare, ouabain, veratrin, boundou-as well as the virtues of drugs, like opium, hashish, hemp, coea, cinchona, eucalyptus, sarsaparilla, acacia, kousso, copaiba, guaiac, jalap, podophyllin, or quassia. Abel and Macht have shown that the ancient European belief in the venomous nature of the toad and the power of its dried skin to eure dropsy is explained by the two alkaloids, bufagin and epinephrin, which they isolated from the tropical Bufo agua. Bufagin $\left(\mathrm{C}_{18} \mathrm{H}_{24} \mathrm{O}_{4}\right)$ has a marked diuretic action. ${ }^{1}$ IV. E. Safford has shown that the various nareotic snuffs used by the Indians of the West Indies and South America are all products of Piptadenia peregrina." Not to go further than our own country, we find the North American Indians aware that arbutus is "good" for rheumatism; lobelia for coughs and colds; wild sage tea, goldenseal, flowering dogwood, and prickly ash berries for fevers; elder, wild cherry, and sumac for colds and quinsies; wild ginger, ginseng, and euphorbia for digestive disorders; inhalations of pennyroyal for headache; sassafras or violet leaves for wounds and felons; and the roots of sassafras and sarsaparilla for "cooling and purifying the blood." In 1535-36, the Iroquois around Quebee, as Jacques Cartier relates, treated scurvy in his crew very successfully with an infusion of the bark and leaves of the hemlock spruce; and the French at Onondaga in 1657 found the sassafras leaves, recommended by the same tribe, "marvellous" for closing wounds of all kinds." The "Materia Medica Americana" (1780) of the old Anspach-Bayreuth surgeon Schoepf, who came over with the Hessian troops during the war of the Revolution, shows that the Anglo-Saxon settlers in the New World had already learned many wrinkles in herb-therapy from the red men, in addition to the very rich medical folk-lore which they undoubtedly brought with them from Old England. The plant-lore of rural England included a knowledge of the virtues of camomile-, sage-, and dandelion-teas as laxatives; of marjoram and primrose root for headache; of wormwood as a tonic; of valerian for the "nerves"; of agrimony and parsley for jaundice; of meadow-saffron (colchicum) for gout; of fennel, eye-bright (euphrasy), and rue for bad evesight; of male fern and peach-leaves for womns; of tansy as a vermifuge and

1 Abel, Nacht: J. Pharm. Exper. Therap., Balt., 1911-12, iii, 319-377.

2 Safford: Jour. Wash. Acad. Sc., 1916, vi, 547-562.

${ }^{3}$ See Yager: "Nledicine in the Forest," Oneonta, N. Y., 1910. Yager notes the infrequency of panaceas and gunshot preseriptions among the North American Indians; each remedy was administered by itself for a given condition. For the theory and formulx of Cherokee medicine, see J. Mooney: Bur. Am. Ethnol. Rep., Wash., 1891, vii, 319-369. 


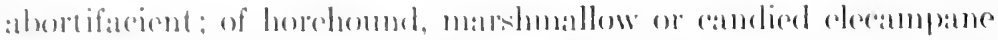

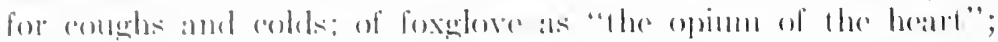

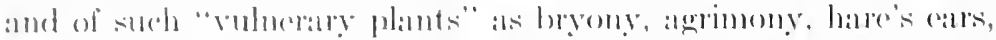

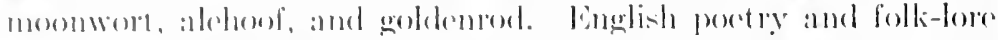

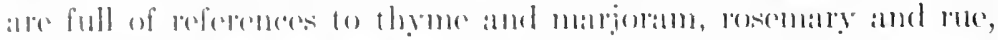
mistlotor and ash, as woll as polsoms like homloxk, loppard's bane

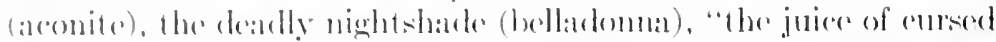

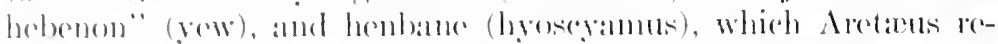

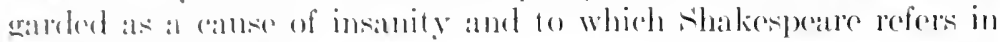
the same spirit ats

That takiss the reason privener.

Asphodel, or dittany, is often mentioned in the Homeric poems as a bahn anamst the pain of newly inflieded woumds, and the same traclition is still rurrent among the commty folk of lancashire,

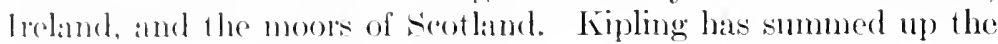
whole mattor in a chamming verse-

Alexanders and Marigold,

Eyebright, Orris and Elecampane,

Basil, Rocket, Valerian, Rue,

(Amost singing themselves they run),

Vervain, Dittany, Call-me-to-you-

Cowslip, Melilot, Rose of the Sun.

Anything green that grew out of the mould

Wis an excellent herb to our fathers of oldl.

In the use of natural or physical means against disease we dis(over that primitive man, with his woll-ventilated habitations and his hardy life in the open air, has advantages which his civilized brother often seeks or finds only on compulsion. The Indian ${ }^{1}$ knew, for example, the importance of keeping the skin, bowels, and kidneys open, and, to this end, the geyser, the warm spring, and the sweat-oven were his natural substitutes for a Turkish bath. Emesis or catharsis, followed by a vapor bath and a cold plunge, sot off by a (lose of willow-bark decoction (salicin), was the North American Indian's successful therapentic scheme in the case of intermittent and remittent fevers; a vapor bath and cimicifuga were his mainstays against rhematism. Like the ancient Babylonians, he had his fixed periods for ritual emesis and catharsis (e. g., the green-corn feast), much as our forefathers used zocliacal ralendars for blood-letting. Nassage was long known and practised by the Indians, Japanese, Malays, and East Indians. In the

${ }^{1}$ For a full account of the medicine of the twentieth century Indian, see A. Hrdlička, Bur. Am. Ethnol.. Bull. No. 34, Wash., 1908, 220-253. 
opinion of Rivers, ${ }^{1}$ maksige was imported into Melanesial by Polynesian castaways, since Polynesian massage is apparently a true rational therapentic measure, while Melanesian massage is something superimposed upon a magic rite. Hypnotism originated among the Hindus; inoculation against smallpox among the Hindus, Persians, and ('hinese. Lady Mary Wortley Momtagu got her idea of variolation from the East, and it is still cmployed annong the North and Central African tribes and races (Arnokl Klebs²). The early Japanese employed the moxa as the ('hinese did acupuncture. The Chinese of the Mongol dynasty $\left(1260^{3}\right)$ probably leaned of the use of spectacles from India via Turkestan. Snow-spectacles have been employed by polar tribes.

Surgery became a science in recent times, not so much through individual skill or specialization of instruments, as through the introduction of two new fact ors-anesthesia and antisepsis. Primitive surgery included all the rudiments of the art. The earliest surgical instrument was in all probability not the specialized leafshaped flint or "celt," already referred to, but rather some fragment unusually sharpened as to edge and point by accidental flaking, ${ }^{4}$ as in the obsidian knives of Peru. By means of these sharpened flints or of fishes' teeth, blood was let, abseesses emptied, tissues scarified, skulls trephined, and, at a later period, ritual operations like circumeision were performed, as we have seen, with the primitive celts themselves. Decompressive trephining for epilepsy or other cerebral disorders goes back to prehistorie times, the finds showing that it was often done more than once upon the same person, the bits of skull excised being used as amulets. It is said that trephining is still practised among the Aymaras of Bolivia and the Quichuas of Peru, ${ }^{5}$ and another evidence of it is the curious crosswise mutilation along the lines of the eoronal and sagittal sutures, first noticed as a common practice among the Loyalty Islanders by an English missionary, Rev. Samuel Ella, in $1874,{ }^{6}$ and which Manouvrior found afterwald in neolithic female

${ }^{1}$ IV. H. R. Rivers: Massage in Melanesia: Tr. xvii. Internat. Cong. Med., 1913, lond., 1914, teet. xxiii, 39-4'2.

"Klebs: Johns Hopkins Hosp. Bull, Balt., 1913, xxiv, 70.

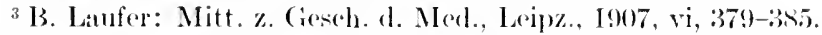

${ }^{4}$ The writer is indeloted to Prof. William H. Ilolmes for this important informaltion.

5 A. Bandelier: Vaber Trepanieren unter den hentigen Indianem Boliviass (Internat. Cong. Ameriennists, 1S94). S. J. Mozans (Rev. J. A. Z:1hm), in his "Along the Andes and Down the Amazon" (New York, 1911), pr). 206, 207, is of opinion that the fatves of Erylhrorylon cord, when chewed, have anestlest ic properties of which he gives a remarkable instanee. This would explain how easily the Peruvinns may have accomplished trephining with the aid of at sharp piece of flint or obsidian.

${ }^{6}$ Ellis: Med. Times \& Gaz., Lond., 1si4, i, 50. 
crania from Seine-et-()ise and rallod the "sincipital T" (1895"). Trephining has hern dome on the skull with sharpened prehistoric

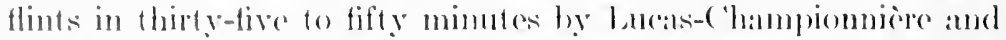
Holländer:" Printive man's wommels were dresied with moss or fresh loaves, ashes of natural balsams, and, when poisoned,

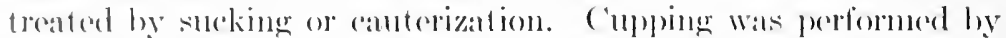
means of anmals' horns. The revulsive effects of some atceidental womend of hemortatere, or the natural and periodie process of menstruation stgegestod, no doubt, the advantages of blood-letting, which was to herome a sort of therapentic sheretanchor through the anes. For courbhing a cataract or opening an absecss, even at sharp thorn sufliced. The Jayaks of Bomeo employ a sharp root (pinjampo). In the more adraned phases of cultural development, pieces of harel wood may have heren pointed and edged, like the flint knives. Neolithe sims of stone and bone, possibly imitated from the teoth of amimals, also exist, and with these Hollïndor has performed amputation in six to seven minutes. The chararteristic signs of amputation have been fomed in prehistoric bones. ${ }^{3}$ During the Bronze and Iron Ages expert skill in metal work became an areomplished fact, and surgical instrmmentation was eorrespondingly improved. In the excavations of the swiss Lake Dwellings, which wore discovered in $1853^{4}$ the different enltural objects were found in suecessive layers, from the Stone Age (Neolithic or Alluvial Period, 3000-1500 B. C.) up to the Bronze and Iron Ages (1500-400 B. C.), and of these, the real beginnings of northern European culture are now hell to be the metal implements and objects found at La Tène. The phrase "La Tène" symbolizes, for anthropologists, the starting-point of the cultural periods following upon the three Ice Ages, with their two interglacial periods, not because the Lake Dwelling finds are necessarily the earliest iron objects known, but because they are the most representative and characteristic. La Tène was preceded by the Eolithic, Paleolithic, Neolithie, Bronze Ages, and the Iron (Halstatt) Age (700-400 B. C.). In the Bronze Age surgical saws and files were plentiful averywere, from Egypt to Midlle Europe. ${ }^{5}$ The

${ }^{1}$ L. Mimouvrier: Rav mens, de l'École d'anthrop. de Paris, 1S96, vi, 57; 1903, xiii, 431. Manouvrier thinks the sincipital $T$ may have been identical with the crucial eauterizations of the skull recommended by Avicenna and others, if not a ritual mutilation. (irön regards it as a mode of judicial torture. Sudhoff identifies it with a derivative procedure employerl by the Alexandrian surgeons for ocular catarrhs and mentioned by Celsus (vii, cap. xii, sect. 15).

${ }^{2}$ Lucas-Championnière: Trepanation néolithique, Paris, 1912.

${ }^{3}$ E. Holländer: Die Chirurgische Säge. Arch. f. klin. Chir., Berl., 1915, cvi, $317-320$.

${ }^{4}$ First investigated by Ferdinand Keller in $1853-4$.

${ }^{5}$ Holländer: Die Chirurgische säge. Areh. f. klin. Chir., Berl., 1915, evi, $320-336$. 
La Tène finds, dating from about 500 B. C. to 100 A. D., entirely distinct from Egyptian, Inclian, or Creek culture, include iron knives, needles, fibulae, swords and lances, with bracelets, necklaces, and ear-rings of Etrusean or West ('eltic patterm, and funcral urns containing human remains, showing that cremation was the rule among the La Tène people. Some time later, as, for example, among the Callo-Roman finds in France, we trace the evolution of the jointed or articulated surgical instruments, like scissors, in which cutting was done by indirect action.' With improved metal instruments, such cosmetic operations as tattooing, infibulation, boring holes for ear-rings and nose-rings, or the Mica operation (external urethrotomy), as well as amputation and lithotomy, could be essayed. The ancient Hindus performed almost every major operation except ligation of the arteries; ovariotomy has been done by Indian and Australian natives, and Felkin witnessed a native Cesarean section in Uganda in 1S7S. Both operations are said to have been performed by Cierman sowgelders in the sixteenth century.

The use of a soporific potion as a substitute for anesthesia goes back to remote antiquity, as symbolized in the twenty-first verse of the second rhapter of Cirnesis: "And the Lord Gorl "aused a dece sleep to fall upon Aclim, and he slept: and he took one of his libs, and closed up the flesh instead thereof." From the soothing Egyptian nepenthe of the Orlyssey, which Helen casts into the wine for Clysses, to the "samme de shinta" of the 'Talmud, the "bhang" of the Arabian Nights, or the "drowsy syrups" of Shakespeare"s tine, the soporific virtues of opium, Indian hemp (Cumnabis indica), the mandrake (Atropa mandragora), henbane (Hyoscyamms), dewtry (Datura stramonium), homlock (Conimm), and lettuce (Lactucarimm) appear to have been woll known to the (Orientals and the Greeks'; and, in the thirteenth and fourteenth centuries,

1see M. Bambouin: Arch. prov. de ehir., Paris, 1910, xix, 22s-23s.

${ }^{2}$ Poppy and Indian hemp were probably known to the Egyptians and consequently to the Circeks; maturagora to the Egyptians, Babylonians, and Hebrews. Theophrastus and Dioneorides were the first to mention the aphrodisiac aud soporific properties of Atrope mandragora. It is not elear whether the mandrakes which Rachol sought of lath (Cienesis xxx, 14-16) were for the former purpose or to ease the patege of childbirth. Dioscoricles was the first to speak of the employment of mandragora wine for surgioul anesthesia, and his recipe was tried ont with sue'ess by fir Bonjamin Ward Riehardson (13rit. and For. Med.-Chir. Rev., Lond., Is7 4 , Jiii). The mandraler is also mentioned by Celsus, Pliny, Apuleius, l'aul of Egina, and Mricenna, and the legends about the human shape of the root of the plant, its frieglful shrieks when uprooterl, and the necessity of employing a dog, hitched to it for this purpose, are a common foature of early linglish and German folle-lore. Drugging with Indian hemp or luenbane ("tabannuj") was eommon among the" aneient Hindus and the later Arabs, and sir Richarel Burton adds: "These have been used in surgery throughout the East for eonturies before ether and 
a misture of some of theso inglertionts ("olomm do lateribus") was formalty resommometed for stmerieal anesthesial hy the modieval

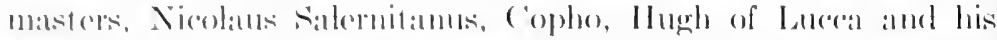

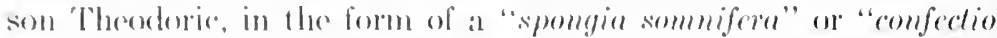

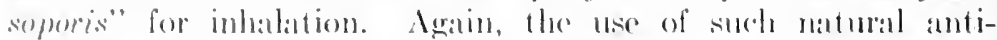
septics as oxtrome drymess, smoke (omesoto), homey, niter, and wine was long known to (a) matu. In socking an "artificial

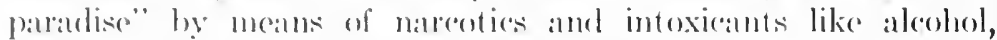
opimm, hashish, or moseal, priority certanly holomgs to primitive man, to whom we also owe such private luxuries as tea, eoffere,

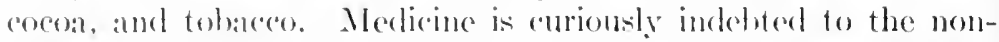
melical man for many of its innovations. As Oliver Wendell Holmes has said:

It learned from a monk how to use antimony, from a Jewit how to cure atrues, from a friar herw to cut for stome, from a soldier low to trat gout, from a silitor how to keepoff seurry, from a post misstor how to som the Eustachian tube, from a datiry-math how to prevent smallpox, and from an old marketwoman how to catel the it ch-inseet. It borrowed aeupunetne and the moxir from the Japanese hrathen, and was taught the use of lobelia by the American salvage. ${ }^{1}$

In the fiedd of olstetrics, we find the mirlwife to be one of the most ancient of professional figures. Engchmann's careful ethnic studies of posture in labor show the universal tendency of primitive and frontier women to assume attitudes best adapted to aid or hasten delivery. The obstetric chair, first mentioned in the Bible and by the Cireek writers, appears to be of great antiquity, and is still used by some races of the far East.

The development of a rational, scientific concept of the true nature of discase, not as an "entity" inside the body, but as altered physiology (dis-ease), is essontially modern, and of very reeent vintage. The most difficult problem that confronts the medical historian is: how did early man acquire correct logical thinking in regard to the treatment of disease? Concerning this

chloroform beeame the fashion in the eivilized West." (Aralian Nights, Denver eflition, vol, iv, footnote to p. 71.) Hua, a Chinese physician, is said to have used hashish in surgery about 200 B. C. According to s. J. Mlozans "Along the Andes and Down the Amazon," New York, 1911, pp. 206, 207), the ancient Peruvian Incas probably utilizel the anesthetic properties of the active principle of Erythroxylon coca in trephining. He cites a modern instance of a coquro (habitual ehewer of coca leaves) who was run over by a ear and experiencerl no apparent pain, although his foot had bren taken off in the accident.

${ }^{1}$ O. W. Holmes: Medical Essays, Boston, 18\$3, 289. For a more extensive presentation of this interesting subject, see George M. Gould's essay on "Medieal Discoveries by the Non-Medieal," in Jour. Amer. Med. Assoc., Chicago, 1903, xl, $1477-1457$.

2 George J. Engelmann: "Labor Among Primitive Peoples," St. Louis, J. H. Chambers d Co., $18 \& 2$. 
phase of the mens medica, still in process of evolution, Osler, in his Silliman Leetures, cites the beautiful, lucid exposition in Celsus:

"Some of the sick, on aceount of their eagerness. took food on the first day, some, on aeeount of loathing, abstained; and the disease in those who refrained was more relieved. Some ate during a ferer, some al little before it, others after it had subsided, and those who had waited to the end did bost. For the same reason, some at the beginming of an illness used at full diet, others a spare, and the formor were made worse. Oecurring daily, such things impressed eareful men, who noted what had best helped the sick, then begin to preseribe them. In this way, medieine bad its rise from the experiener of the recovery of some, of the death of others, distinguishing the hurtful from the salutary things.",

In his analytical studies of the development of scientifie medieine from prehistorie, folk and magie melicine, Hovorka postulates certain "laws of eongruence, in virtue of which primitive or aneient man everywhere, in space and time, deduced identical remedies for certain diseases, procering (I) liy "repetition and imitation," evolving and adopting effeetive remedies by the trying-out process; (2) by establishment of such therapeutie principles along well-trodilen paths; (3) by promoting belief and confidenee through d'viects of similarity or symbolism and through the suggestive offect of verbal and ocular magie. The fundamental phases of therapeutie reasoning are thus "the device of gaining time" until nature effects recovery or a fatal termimation, "the inquiry into the cause" where aceessible; and "the flight int" mysticim " when causes are inscrutable. ${ }^{1}$

We now come to a phase of primitive healing which is intimately comnected with even the most recent aspects of the sulbject, namely, the effect of therapeutic superstitions and the actual cure of disease through the influcnce of the mind upon the body. This is a matter which can be approached in no derisive spirit, especially in the light of modern quackery and its suceesses. The closer we look into the ways of primitive man, the more liable it is to take down our own conceit. The untutored savage, as we have seen, thought that motion of any kind is equivalent to life. Wherein does he differ from the ultra-mechanistic physiologist who reverses the equation? Simply in this, that the mind of the savago is, as Black says, ${ }^{2}$ like a looking-glass, reflecting everything and retaining nothing. As soon as an object passed from his obscrvittion its image disappeared from his mental vision and he ceased to hug the fact of its existence, still less to reason about it. The' primitive mind is, as Rowland scornfully said of "the ordinary cultivated or legal mind," essentially "discontimuous." The scientifie mind at least aims, in its methods, at contimuity of thought. The folk-mind, even today, has this inevitable tendency to mix up the post hoc with the propter hoc and to confuse accidentals with essentials. Almost any one who has lived in the comntry, for in-

${ }^{1} O$. von IIovorka: Leitmotive und Elementarmethoden der allgemeinen Heilkunde. Mitt. d. anthrop. (Gesellsely. in Wien, 1915, xxxy, 125-136. Also his Geist der Medizin, Wien and Leipzig, 1915.

${ }^{2}$ W. G. Black: Folk-Medieine, London, 1883, p. 207. 
stance, will be familiar with various rumal superstitions relating to watrts-that kitling or handling at toat may catsse them and that they an he remored hy some one touching them with pebhles or muttering (ham over them; or with the notion that stump-water is anod for frockles, while had cyesight an he remedied by the water into which the blacksmith has dipped his red-hot irom. In some parts of Holland, if a loy calrying water-lilies in his hand falls down, it is supposed to render him liable to fits. Roaders of bongfellow's "Evangeline" may recall the line which refers to maliaria as

Cured by wearing a spider bung around one's neek in a nutshell.

In Norfolk, England, this spider was tied up in a piece of mustin and pinned over the mantelpiece as a remedy for whonping-eough. In Donegal, a beetle in abottle was regalded as a cure for the latter discase; in suffolk, to dip the child, head downward, in a hole dug in a meadow; in northeast Lincolnshire, fried mice; in Yorkshire, owl-broth; in other parts of Engtand, ricling the child on a bear; in sootland, anything that might be sugeested by a man riding upon a piebali horse. Compare these fallacies, inept as they seem. With what has happened so often in the history of therapentics. A patient's eure follows secmingly upon the administration of some new-fangled remedy or drug. Inmediately, a causal relation is established and the discoverer rushes into print with the glad tidings. Statisties begin to mount up, until presently the correlation curve is perceived to have so insignificant a slope that nothing positive can be affirmed of the remedy whatever. It is then speedily consigned to the limbo of forgotten things. ${ }^{2}$ Not so with folk-remedies. The superstition becomes, as the derivation implies, something standing over; and for a very important reason, namely, that in some cases "Nature cures the disease while the remedy amuses the patient"; in others a eure is, in all probability, brought about by the effect of the mind upon the body.

Black, the leading English authority on medical folk-lore, has made a careful and exhaustive classification of the different superstitions to which average suffering humanity is liable. ${ }^{3}$ These include ideas as to the possible transference of disease, sympathetic

1 Black: Op. cit., passim.

2 J. C. Bateson cites a recorded case of a Turkish upholsterer who, during the delirium of typhus fever, trank from a pail of piekled cabbage and reenvered, whereupon the Turkish rloctors deelared eabbage-juice a specific for the disease. The next patient dring under this régime, however, they modified the dogma by saving that cabbage-juice is good for typhus provided the patient be an upholsterer. Dictet. \& Hyg. Gaz., N. Y., 1911, xxvii, pp. 297, 298.

${ }^{3}$ Black: Op. cit., pp. 34-17\%. 
relationships, the possibility of new-birth or regeneration, the effects of such aceidental specific factors as color, number, solar and lunar influences, magic writings, rings, precious stones, parts of the lower animals, and charms conmected with the names of the saints, the lore of plants, the evil eye, birth, death, and the grave. To look into these is to see clearly that "wonder is of the soul." As the savage "sees Cood in clouds, or hears him in the wind," so his ancestors saw disease not as a quality or condition of the patient, but as something material and positive inside his body-a view held even by Paracelsus. From this idea arose a notion that disease could be transferred from one body to another, as where Pliny, in his Natural History, claims that abdominal pain can be transferred to a $\log$ or a duck. Touching warts with pebloles, healing snake-bite by clapping the bleeding entrails of a bisected fowl to the wound (natural absorption), and the negro superstition of pegging a hank of the patient's hair into a tree in order to transfer chills and fever to the tree or its owner, are well-known forms of this curious belief. Sir Keneln Digby proposed the following remedy for fever and ague: "Pare the patient's nails; put the parings in a little bag, and hang the bag around the neck of a live eel, and place him in a tub of water. The eel will die, the patient will recover.",

In medieal mythology the doetrine of transference of disease derives from the idea of purification (catharsis) or lustration. The seapegoat was usually a got, or his substitute in the shape of a person, animal, or inanimate objeet, upon whieh the sins of the people might be unloarled. Amomg the Aztecs, a human being was annually sacrificed in place of Vitzliputzli or other gods. At the festival of Xipe, the Flayed Corl, the Mexicans killed all prisoners taken in war, who were flayed beforehand, the skins being worn by these enseerated to this eult. In the Roman Saturnalia, Saturn was personated by a manseapegoat, who was afterward put to death. In the Greek Thargelia, as we have seen, there were two seapegorats $\left(\varphi \alpha \rho \mu \alpha^{2} \iota^{2}\right)$. Ancient sacrifice was sometimes honorifie (hostia hom raria), a gift to the god; sometimes rathartic or piacular (hostin pincularis), to enneiliate the wrath of the good or evil powers, in which ease human saerifice was usually demanded; sometimes mystieal or saeramental, in which the god was eonceived to be slain or eaten by his worshipers (Robertion simith). In honorific sierifice, the god and his worshipers shared the saerifiee as eommensals or totem-companions, of the same totem-kin, and the victim was sometimes an animal representing a hostile totem, sometimes one saered to the gorl. In piacular sacrifice, a toten animal or plant could be substituted for the human vietim, and, in mystie sacrifice, the god was represented by a similar animal or plant to partake of which was to enter into communion with him. ${ }^{3}$ With this obseure set of eults, widely different in clifferent peoples, is ennocted the consecration of sacrificial plants or parts of sacrificial animals as therapeutic agencies. ${ }^{4}$ The Kathar-

${ }^{1}$ Cited by 0. W. Holmes, "Medieal Essays," Boston and New York, $18 s 3$, p. 381 .

${ }^{2}$ Frazer: 'The Seapegoat (Goklen Bough, pt. 6), Lond., 1913, 252; 275;306.

${ }^{3}$ N. W. Thomas: Enevel. Britan., 11 exl.. Cambridge, 1911, xxiii, 980-9s.1.

${ }^{4}$ M. Höfler: Waldl-und Baumkult (Munich, 1892); Die volksmedizinische Organotherapie, Stuttgart, 1908; Janus, Amst., 1912, xvii, 3; 76; 190. 
mata or rejects of sacrifies, eaten by the worshipers, were literally "made salered" hy the rite. "To this day the custom of "eating the god" persists in

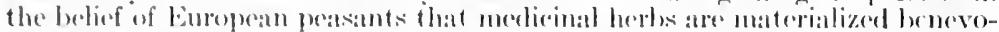

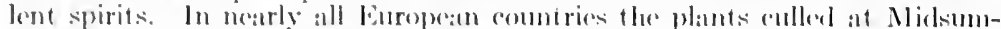

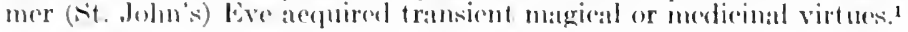

Closely commected with this idea of tramserence was the old tradition of a sympathy existing botweon palts of bodies separated in space (Frazer"s "sympathetic magic"), ammsingly illustrated in Sir Koncln Dighy's woapon-salve, which was applied to the weapon instead of the womd, and in the same worthy's

Strange hermetic powrler

That wounds nine miles point blank would solder,

By" skilful chemist with great cost

Extracted from a rotten post.

The idea of material regencration or new-birth is of Hindu (Aryan) origin and sprang from the printitive worship of the generative power of nature, the cult of the lingam and the yoni, the Hellenized form of which is so strikingly sot forth in the fourth book of Lucretins. A cleft or hole in a rock or tree was regarded as symbolie of the sacred yoni, and dhildren (even adults) afflicted with scrofula, spinal deformity, or other infirmities, were supposed to be freed from these bodily ills when passed through it. Traces of the saxon form of this superstition survive in the "holed stone" near Lanyon, Cornwall, through which serofulous children were passed natied three times, in the "Deil's Needle"." in the bed of the River Dee (Aberdeenshire) which was held to make barren women fertile if they erept through it, and in the Crick Stone in Morva, Cornwall, passage through which was esteemed a cure for any one with a "erick in the back." It was White of Selborne ${ }^{3}$ who deseribed the most recent form of this folk-belief in sympathetic magie, which consists in passing a child afflicted with hernia through a cleft in an ash-tree. In 1804, there was such a tree at the edge of Shirley Heath, on the road to Birmingham. ${ }^{4}$ As late as $189.5-6$. such trees were described as existing for this purpose in Suffolk and Richmond Park, ${ }^{5}$ and there was once a similar tree in Burtington County, New Jersey. The Scoteh custom of passing a consumptive child through a wreath of woodline, the English

${ }^{1}$ Frazer: Balder the Beautiful (Colden Bough, pt. 7), Lonton, 1913, ii, $45-75$.

2 Siee "The Stone in Scottish Folk-Medieine," by Dr. David Rorie, in the Caledonian Med. Jour., Glasgow, 1911, viii, pp. 410-415, giving an interesting photograph of the "Deil's Needle." Black).

${ }^{3}$ Gilbert White: Natural History of Selborne, 1789, p. 202 (cited by

${ }^{4}$ Gentleman's Mag., Lond., 1804, 909. Cited by Frazer.

${ }^{5}$ Folk-Lore, Lond., 1896, vii, p. 303; 1898, ix, p. 330, with photos. 
trait of crawling under a bramble bush for rhemmatism, and tho "eve of the needle tree" on the island of Innisfallen, Killarney, squeezing through which insures long life and safe delivery to woman with child, are mentioned by Black as variants of this superstition. Frazer regards the practice as a phase of sympathetic magic, associated with the idea that the "extermal som," the life of a person, is bound up with the life of a tree or plant.

Color is a factor of great moment in folk-healing; in particular, red, which the ('hinese and New Zealanders regard as hateful to evil spirits, and other peoples as a heat-producer. Red silken bands, neeklaces of eoral beads, red pills and red fire, as well ats the red coral ring and bells with which the baby euts its teoth, have all had their superstitious associations, and the virtues of the familiar red flannel cloth worn around the neek for sore throat and whooping-cough were supposed to reside "not in the flannel but in the red color."' Finsen's red-light treatment, to prevent pitting in smallpox, was once an ancient folk-belief, known to the Japanese, and employed suceessfully by Cilbertus Anglicus, Bernard do Gordon and by John of Gaddesden in the case of the son of Edward II. Aecording to Valeseus of Taranta, the rationale of the red-light treatment was the aneient "doctrine of signatures," in virtue of which a remedy was applied on aceount of some fancied resemblance, in shape or eolor, to the disease. The red cloth hangings around the smallpox patient were supposed to lower his temperature by drawing the red blood outward.

The idea that certain numerals can be saered or malignant is of Aceadian origin, eonnected with Chaldean and Babylonian astrology, and familiar to us in the Horatian "nec Babylonios tentaris numeros." Of mystic numbers, usually odd, three or a multiple of three is the most popular for luck, good or bad; seven or one of its multiples for supernatural powers. Hesiod (IVorks and Days, 76.5-828) says that the first, fourth and seventh days of the month are "holy days," the eighth $(4+4)$ and the ninth $(3 \times 3)$ "specially good for the works of man"; the twelfth $(3 \times 4)$ is better than the cleventh; the fifth "inkindly and terrible," beeause on a fifth "the Erimnyes assisted at the birth of Horeus"; the tenth is favorable for a boy to be born, the fourth for a girl; the ninth of the first month "is a good day on which to begret or" be born, both for a male and a female: it is never an wholly rvil day." It was not for nothing that there were three Fates, three Furies, nine Muses, twelve months and twelve signs of the zorliar,

I Frazer: Balder the Boantiful (Golden Bough, pt. 7), London, 1913, ii, $159-195$.

${ }^{2}$ Black: Folk-Medieine, London, 1sis3, 111. 


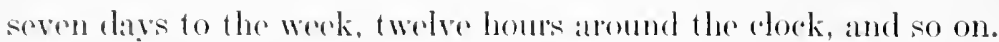

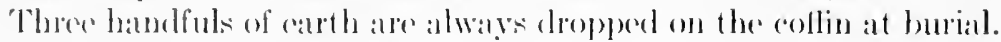
Palmists, fortume-tollors, and of hers of their kind work assiduously

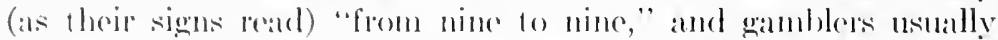
bet on odel mumbers. In Finotatud and Portugal, the seventh son of a serenth son is often regarded with horror or veneration, as one possessed of seroud sight and of hes uncamny attributes. Such folk-lomedies ats the West sissex recipe for ague- "out fasting seven sage leaves for seven mornings fasting"-alle rommon enomeh. Valesens do 'Taranta arranged his huge therapeutic Philonium in sevon books ont of a serions veneration for the solemm number seven. In ('binese medicine, five is the saced number. A reasonable aspect of number-lore in medical literature is the Hippocratic doetrine of erises and critionl days (dies nefasti) which probably derived from the teatehing of Pythagoras, who had assinilated it from the Chaldean folk-traditions. Here the folk-lore of numbers has a germ of scientific truth in that there is a certain periodieity in some of the phenomena of disease. The curves of rape, murder, and general "ruming amok" (including wars) rise in hot weather. That certain infectious diseases recur at definite periods gave rise to the doctrine of the gemius epidemicus ol cpidemic constitutions. The known periodicity of epidemic diseases from year to rear justified the old (haldaie superstition of the "evil year" (malus ammus), which, in the Middle Ages was associated with a certain serpiginous or bullous eruption in man and animals (Malum malammm²). Another superstition which came from (haldean astrology was the belief that the heavenly bodies had an influence upon disease. The sun, moon, stars, and planets were regarded as sentient, animated beings, exerting a profound influence upon human weal and woe, and, late into the seventeenth century, European mankind resorted to horoseopes (the "judicia astrorum") before attempting any enterprise of moment, and in particular to determine the proper time for bloodletting, emesis, and purgation. Health, strength, and sexual power were supposed to vary with the waxing and waning of the moon. Moonshine was supposed to be potent alike in eausing lunacy, conferring beauty, or curing warts and diseases. ${ }^{3}$ Menstruation was connected with the lunar cycles. The full-moon was a libido symbol (White ${ }^{4}$ ). To let blood when the moon and tides were at

${ }^{1}$ For a historical study of the doetrine of eritieat days, see Sudhoff: Wien. med. Woehenschr., 1902, lii, 210, 272, 321, 371. Also, R. Steele: Dies Eryptiaci, Proe. Roy. Soc. Med., Lond., 1919, xii, Seet. Hist. Med., 108-121.

2 Hoefter: Janus, Amst., 1909, xiv, 512-526.

${ }^{3}$ Frazer: Adonis (Golden Bough, pt. iv), London, 1914, ii, 140-150.

${ }^{4}$ W. A. White: Psychoanalyt. Rev., N. Y., 1913-14, i, 241-256. 
full (dies Egyptiaci) was adjudged bad practice in the Middle Ages. The lunar influence is further seen in the common suprerstition that deatl occurs, as in the case of Shakespeare's Falstaff or of Barkis in "David Copperfield," at the turning of the tide. Darwin thonght that the tidal periodicity of physiological phenomena in vertebrates might be explained by their descent from "an animal allied to the existing tidal ascidians." 1 Arrhenius, in his study of the influences of cosmic phenomena upon the organism, has compared the curves of nativity, mortality, menstruation and epileptic attacks with the periodic maxima and minima of the electrical condition of the air." ('omparable with the influence at tributed to the stars is the idea, already mentioned, that disease is a scourge or punishment inflicted by gods or demons alike and remediable only through divine or diabolic intervention. The mischievous powers, whose ideas of good and evil were apparently so interchangeable, could be propitiated of conciliated only by sacrifice, which, as Jakob Grimm pointerl out, had the double purpose (like the graft given to politicians) of keeping the powers in a good humor or of restoring good humor when necessary. "To coerce the spiritual powers, or to square them and get them on our side," says William James, "was, during enormous tracts of time, the one great object in our dealings with the natural world."3 The Greek myth of the arrows of far-darting Apollo, Bhowani, the cholera goddess of the Hindus, the many medical divinities of the Romans, the Indian and Samoyed lore of "magic bullets" (a motif in "Der Freischïtz"), the passage in the Book of Jol, in which the patriarch attributes his sufferings to "the arrows of the Almighty," Martin Luther's conviction that "pestilence, fever and other severe diseases are naught else than the devil's work," Cotton Mather's definition of sickness as "Flagellum Dei pro peccat is mundi," the medieval figurations of death as a reaper, (the "Schnitter Tod" of (ierman folk-song), the folk-superstition that erysipelas (or "wild fire") originates from fairy malice, all illustrate the strength of this deep-rooted belief, which survived in the many sermons and prayers delivered in time of pestilence throughout the seventeenth and eighteenth centuries and even crops up in our day under various guises. In process of time, medical polytheism nerged into monotheism. The Egyptian Phtah became Allah; the Chaldean Ea, the Sumerian Adapa and Gula, the Babylonian Marduk, the chthonian deities of the Grecks, the complex Roman scheme of household gods, the Druidic

${ }^{1}$ Darwin: Descent of Man, London, 1871, i, 212, footnote.

2 Arrhenius: Skandin. Arch. f. Physiol., Leipz., 1898, i, 367-416.

3 W. James: Gifford Lectures, New York, 1902. Cited by Osborn. 
Belen, the Mexiean Ixlitom, all became mified hy the symeretic process common to all folk-lore, and even the separate finctions of the demons of disease, from Babylon to medieval Europo, were eventually absolbed hy the Dovil. ()f a piece with this theory of discase was the malignant or benignant power which was sipposed to attach to erertain persomatities. A child borm on

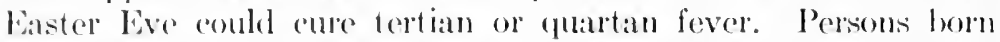
"with a caul" were supposed to be clairvoyant. "The power to heal scrofula by royal touch was part and parcel of the divine right of kings. In the West of Ireland, the blood of the Walshes, Keoghs, and Cahills is beld to be an infallible remedy for erysipelas or toothache." The medieal lore of holy men, their special dalys, the diseases they presided over and the holy wells and other things hesied by them, form a special field in itself. The saints were supposed, as usual, to have the power both of inflicting and healing diseases, most of which were, however, associated with the names of several saints. Thus the names of St. Guy, St. Vitus, and St. With are eponymic for chorea; St. Avertin, St. John, and St. Valentine stood sponsors for epilepsy, St. Hubert of Arlennes, the patron of huntsmen, eared for hydrophobia, while St. Anthony, Sit. Benediet, St. Martial, and St. Genevieve presided over ergotism. Lierler bas compiled a bulky volume made up of indices of these patron saints of medieine alone. Saered bits of pastry (Iteilbröte), (lerived, as Höfler shows, from the aneient saerificial aakes, were dedicated to these saints and eaten to ward off the partieular diseases. ${ }^{4}$

A remarkable cximple of belief in the malevolence of personality is the superstition of the evil eye which causes Orientals to wear a erescent of horns over the forehead as a safeguard, and Levantines to cross their fingers or protrude the thumb between the index and middle finger (mano fica).

This belief, as Seligmann has shown, has existed from the earliest times and is common to all human races. Mentioned in the Assyro-Babylonian incintations, declared a capital erime in the tables of the Roman Decemvirs (450 B. C.), this power of infleting evil has been aseribed variously to whote races or religious seets, to dogs, wolves, and animals of the eat family, to reptiles and mythical ereatures, like the basilisk, to statues and inanimate objeets, to gods, demons, spirits and all supernatural boings. In the Purana legend, Siva destroys a whole town with one withering glance, as Wotan destroy"s Hunding in "Die Walküre." Lord Byron, Napeleon III, Queen Maria Amelia of Portugal, the Popes Pius IX and Leo XIII and the ecmposer Offenbach were all feared for this hypnotic power. Acerding to the Roman

${ }^{1}$ A volume of studies on the innumerable medical gorts of ancient eivilizattions is in preparation by Dr. Walter A. Jayne (Denver).

2 Black: "Folk-Lore," London, 1853, p. 140.

${ }^{3}$ D. H. Kerler: "Die Patronate der IIeiligen," Ulm, 190;.

${ }^{4}$ M. Höfler: Janu: Amst., 1902, vii, $189 ; 233 ; 301$. 
writers, the evil eye was nystagmic, strabismic, dicorie or otherwise abnormal or diseased. Ovid (Amores, viii, 1j)-16) attributes at double pupil to the sorceress Dipea:

"Oculis ruoque pupilla duplex

Fulminat, et geninum lumen in orbe manet,"

and says that eyes which gaze upon the diseased will suffer themselves-

"Dun spectant oculi laesos, laeduntur et ipsi."

Persius (ii, 34) attributed evil power to inflamed or reddened eyes (urentes oculi $\left.i^{1}\right)$.

There is a strong human prejudiec against disconcerting, intensive, or forbidding appearances of the eye, as, indeed, for any abnormity, whether it be the fascinatio of the ancient Romans, the strabismic regard louche of the French writers, the jettatura of the Corsican, the mal-ocehio of the Italian, the filmy glance of sone gypsies, the "steady, ambiguous look" which Arthur Symons ascribes to Orientals, or the stony stare of the blue-eycd northern races which a line of 'Temnyson's likens to the effect of the Gorgon's head. We dislike a stare. The phrase, Sie fixieren mich, mein Herr! has caused many a duel in Germany. We have a natural aversion for a person having but one eye, because, as Charles Dickens neatly said, "popular prejudice is in favor of two." Particolored eyes or eyes each of a different color are nowise reassuring. The blind are sometimes known to develop dubious tendencies along sexual and other lines. It is easy to see from facts of this kind how the notion of the "evil eye" came to be ingrained in the beliefs of the Eastern and Levantine races, the Celts and the Afri(an Negro, and, in some cases, not without reason.

An essential part of the theory of divine or personal influence is the doctrine of amulets and talismans and, of course, the appropriate chams and spells that go with them. The amulet (from the Arabic "hamalet," a pendant) was an object usmally hung or worn about the patient's body as a safeguard against disease or other misfortune. Amulets include a motley array of strange and incongruous objects, such as the bits of erania excised in prehistoric trephining, objects of nephrite, Egyptian scarabs, the grigris of African savages, the voodoo fetishes of Hayti and Louisiana, teeth from the mouths of corpses, bones and other parts of the lower animals, the

Finger of birth-st rangled babe,

Diteb-delivered by at dral,

of the Weird Sisters in Macheth, rings marde of coffin-nails, widows' wedding-rings, rings made from pennies collected by begagars at al

1 For an exhaustive sturly of this faseinating subject, see s. Selignann, Der böse Blick, 2 v., Berlin, 1910. 
chureh poreh and ehanged for a silver coin from the offertory, "sileranent shillings" colleceted on baster sunday, and the ikons

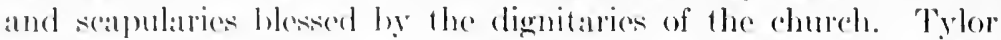
has shown that the brass objects on harness were originally Roman ammlets. In the interesting exhibit of folk-medicine in the National Museme at Mashington a buckeye or horse-chestunt (.Esculus flams), an Frish potato, a rabbit's foot, a leather strap) previonsty woln by a horse, and a carbon from an alde light are shown as sovereign charms against rhemmatism, and as Dr. Oliver Henclell Holmes used to point out, in his quizzical way, a beliof in the eflicacy of some of these anti-rhemmaties is by no means confined to the European persant and the negro. Other amulets in the Washington exhibit are the patella of a sheep and a ring made out of a coffin-mail (dug up out of a graveyard) for (ramps and epilepsy, a peony root to be carried in the pocket against insanity, and rare and precious stones for all and sundry diseases.

The folk-lore of stones is of great antiquity, and the oldest prescription in existence-that discovered in Egypt by Wr. Max Müller-displayed in the Musem of Natural History in New York, calls for the exhibition of a green stone as a fumigation against hysteria. Dr. Robert Fletcher has shown" that "scopelism." the ancient Arabic custom of piling up stones in a field, either to prevent its tillage or as a menace of death to the owner, is to be found everywhere as a symbol of the hatred of (ain for Abel, of the outlaw for the worker, of the barbarian for civilization. The lore relating to mad-stones, snake-stones, eye-stones, and wartstones is considerable. Bezoars (enteroliths or other concretions from the bodies of animals) were supposed to prevent melancholia and all kinds of poisoning, including snake-bite. In England and Scotland, holed stones (fairy mill-stones, pixy's grindstones) and elf-bolts (flint arrow-heads) were sometimes handsomely mounted and worn about the person for protection. Hildburgh's extensive studies of Spanish amulets indicate a highly developed folk-cult against the evil ere and other malevolent influences. Every horse, mule or donkey is belled, as also infants' toys, and horns; claws, beads, and other objects are usually mounted in silver and help out the quaint Spanish and gypsy scheme of personal ornamentation. $^{3}$ Precious stones came to be estecmed, in the first

1 Visitors in Washington who are interested in folk-medicine and the eultural aspects of medieal history will do well to see this unique collection, which was prepared by Rear-Admiral James M. Flint, Surgeon, U.S. N. (retired).

2 Ameriean Anthropologist, Wash., 1\$97, x, pp. 201-213.

${ }^{3}$ W. L. Hildburgh: Folk-Lore, Lond., 1906, xvii, 454; 1913, xxiv, 63; 1914, xxv, 206; 1916, xxvi, 404. 
instance, no doubt, for their rarity, but equally for their supposed potency against disease. From the engraved stones in the HighPriest's breast-plate, representing the Twelve Tribes of Israd, to the birth-stones and month-stones of our own day, there is a continuity of belief in the power of these precious objects. Many women dread to wear an opal; there is a supposed fatality about pearls, and the diamond now, as of yore, will "preserve peace" and "prevent stoms" in a household. M. Josse, in Molière's "L'Amour Médecin," archly opines that nothing is so well calculated to restore a drooping young lady to health as "a handsome set of diamonds, rubies or emeralds."

Talismans (from the Arabie "talasim") were amulets or other" charms that were carefully guarded but not necessarily worn about the person. It is highly probable that the magieal authority attaching to the ownership of these precious objects gave them an enlarged purchasing power and was thus the origin or (as in the obolus given to Charon), at least, a symbol of money and wealth, in the sense of stored up (potential) energy. Talismans were often written charms or "eharacts," such as the Hebrew phylacteries or verses from the Bible, Talmud, Koran, or Iliad. If worn about the body, such charms were termed "periapts." When the Indians saw Catlin, the explorer, reading the New York Commereial Advertiser, they thought it was "a medicine cloth for sore eyes." In the eategory of spoken charms we must include all prayers, incantations, conjurations and exorcisms used to drive away disease, as well as mystic words like ABRACADABRA, SICYCUMA, Erra Pater, Hax Pax Max, and the like. ${ }^{3}$ Thus Cato the Censor, who hated Greek medicine, endeavored to treat dislocations by repeating the following bit of gibberish: "Huat hanat ista pista sista domiabo dammaustra et luxato." Jakob Grimm found a charm in Mareellus Empiricus against dust in the eyes to be an ancient Celtic verse (Neuburger). Charles Singer cites many Greek sentences degraded by syneretism into Byzantine and British charms, notably the passage in the Greek liturgy of St. Chrysostom:

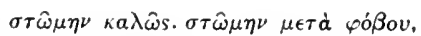

Let us stand seemly, let us stand in awe,

which became a charm for intractable hemorrhage (written on the part affected or worn as a periapt), and is still used by Macedonian peasants. ${ }^{4}$ The ehams of the Byzantine period imposed a very heavy onus of responsibility upon the several saints.

${ }^{1}$ M. Mauss: Compt. rencl. Inst. franç. d'anthrop., Par., 1914, ii, 1t-20.

A. Reinach: Ibid., 24-27.

2 Black: Op. tit., p. 49.

${ }^{3}$ Ibid., pp. 167, 168.

${ }^{4}$ C. Singer: Early English Magic and Medicine, London, 1920, 31. 
In survering these different superstitions, one point beromes of especial moment. It is highly improbable that any of the remalies mentioned antually rured discase, but there is abmulant evidence of the most trustworthy kind that there have been sick pople who got woll with the aid of nothing olse. How did they get well? Short of aleerpting the existence of stlpermatural forecs, we can only lall back upon such rague explanations as "the healing power of nature," the tendeney of nature to throw off the materies morbi or to bring unstable chemical states to equilibrium, the latter being the most platusible. But, in many cases of a nervous nature or in neurotic individuals, there is indubitable evidenee of the effect of the mind upon the body, and in such eases it is possible that a sensory impression mily so influence the vasomotor centers or the internal secretions of the ductless glands as to bring about definite chemical changes in the blood, glands, or other tissues, which, in some cases, might constitute a "cure." We know that the reverse is possible, for example, in such occurrences as the whitening of the hair from intense grief or fear, or the production of convulsions in a suckling infant whose mother has been exposed to anger, fright, or other violent emotions lefore nursing it. As Loeb strongly puts it, "Since Pawlow and his pupils have succeeded in eausing the secretion of saliva in the dog by neans of optie and atconstic signals, it no longer seems strange to us that what the philosopher terms an 'idea' is a process which can eause chemical rhanges in the bodr." Billings eompares the sensition obtained by placing the hand on a cold object in a dark room with the way in which the blood "runs cold" when one realizes that this object is a corpse. 'rile's important studies of surgical shoek show the strong analogy existing between the phenomena produced by shock, the extreme passion of fear, and the symptom-complex of Ciraves disease, particularly in regard to the pouring out of the thyroid seeretions and the destruction of the Purkinje eolls in the brain. W. B. Cannon shows that in fear, rage, or anger, the emotions which prepare the animal for fight or flight, the digestive and sexual functions are immediately inhibited, the adrenal seeretion is rapidly poured into the blood, mobilizing sugar from the hepatic glycogen up to the point of glycosuria, counteracting the effects of muscular fatigue, and hastening the coagulation time of the blood, thus giving the organism wonderful capacity for offence, defence, flight, and repair of injured tissues. A man in a fighting or frightened mood is a ductless gland phenomenon. The pathologieal effect of ideas upon the sacral autononic is seen in the

1.J. Loeb: "The Mechanistic Conception of Life," Chicago, 1912, p. 62.

2.J. ... Billings: Boston Med. \& Surg. Jour., 1S88, exviii, p. 59. 
phenomena of sexual perversion. ${ }^{1}$ Extreme mental irritation or depression ean produce dyspepsia, jaundice, chlorosis, or general decline; fright has produced cardiac palpitation and heart failure can result from a shock due to a set-back in business; rage may induce anything from precordial spasm up to angina pectoris, as in the ease of John Hunter; the outward manifestations of hysteria are innumerable; and it is well known that it is bad for any person to go under a surgieal operation with the idea that he or she will not recover. A number of eases are on record of persons mentally depressed but not otherwise umwell who have realized the imminence of their own death and predicted it with certainty. An impressive instance was given from personal recollection by Dr. John S. Billings, in his Lowell Institute lectures on the history of medicine in 1887.2 An officer of unusualy strong and active physique and in the best of health had sustained a slight flesh wound at the battle of Cettysburg. Becoming depressed in mind at the start, he declared he would die, which he clid on the fourth day. The postmortem showed that every organ was healthy and normal and the wound itself so trivial as to be a negligilse factor. Crile's whole philosophy of "anoci-association" in surgery turns upon these mysterious mental influences, the combating of which constitutes the essence of psychotherapy. People who have become dyspeptie, bilious, or melancholy from worry or hope deferred, green-sick girls and women grown hysteric from disappointment in love, usually brighten up on receipt of good news. Babinski's dismemberment of hysteria identifies its phenomeni solely with those capable of being prochuced in the hypnotic state. In treating the different neuroses, Charcot was guided almost entirely by his favorite maxim (from Coleridge): "The best inspirer of hope is the best physician," an aphorism which contains the germ of the Freudian theory of psycho-analysis-to "minister to the mind diseased" by removing the splinter of worry or misery from the brain, in order to restore the patient to a eheerful state of mental equilibrium. This faet has been utilized by all "nature healers" and faith-curists with varying degrees of success, and it is the secret of all eharlatans, from Apollonius of Tyana, Valentine Greatrakes, Cagliostro, "Spot" Ward, Joanna Stevens, Mesmer, James Graham, John St. John Long, and the Zouave Jacob down to the days of Dowieism and Eddyism. It is also the seeret of the influence of religion upon mankind, and here the priest or pastor becomes, in the truest sense, ein Arzt der Seele. In practical medieine, the principle now has a definite footing as psychotherapy.

${ }^{1} \mathrm{~W}$. B. Cannon: Bodily Changes in Pain, Hunger, Fear, and Rage. New York, 1915 .

2 J. S. Billings: Boston Med. \& surg. Jour., 18s8, exriii, p. 57. 
Psychotherapy annot knit a fractured bone, antagonize the action of poisons, of heal a speceific infection, but in many bodily ils, esperially of the nervous system, its use is far more effieient and respectable than that of many a drug which is clained to be a specific in an momaginable number of disorders.

In fine, the lesson of the mity of primitive medicine, which is only a corollary to the gencral proposition of the unity of folk-lore, is that cortain beliofs and superstitions have become ingrained in humanity through space and time, and can be cradicated only through the kind of public enlightenment which teaches that prevention is hottel thin eure. The tendency of hmmanity to seek medical assistance in time of sickness or injury has been compared with the emotional element in religion, both being based upon "a deep-lying instinct in human niture that roliof from suffering is an obtainable goal." As the supernatural element in religion appeals to humanity in its moments of dependence and weakness, so for the weary and heavy-laden, the down-trodden of the earth in the past, medical superstitions were simply a phase of what Stevenson calls "ancestral feelings." This explains the ascendency of quackery. In order to deceive their patients, as Morris holds, it was necessary for the older quacks to deceive themselves, just as no one can perpetrate an effective ghost story who does not apparently believe it. Fool and rogue being, as Carlyle says, only opposite sides of the same medal, the modern charlatan exploits suggestion, sensation, and mystery objectively and with intention, relying upon Rabelais' arch device for effective lying: Il faut mentir par nombre impair.

Thus the history of medicine is also the history of human fallibility and error. The history of the advancement of medical science, however, is the history of the discovery of a number of important fundamental principles leading to new views of disease, to the invention of new instruments, procedures, and devices, and to the formulation of public hygienic laws, all converging to the great ideal of preventive or social medicine; and this was accomplished by the arduous labor of a few devoted workers in science. The development of science has never been continuous, nor even progressive, but rather like that tangled, tortuous line which Laurence Sterne drew to represent the course of his whimsical narrative of Tristram Shandy. Ideas of the greatest scientific moment have been throttled at birth or veered into a blind alley through some current theologic prepossessions, or deprived of their chance of fruition through human indifference, narrow-mindedness, of other acciclental circumstances. It is no exaggeration to say that science

${ }^{1}$ B. M. Randolph: Wash. Med. Ann., 1912, xi, p. 152. 
owes most to the shining individualism of a few chosen spirits. Apart from this, "the suecess of a diseovery depends upon the time of its appearance."

Buckle maintained that ignorance and low-grade minds are the cause of fanaticism and superstition, and, since his equation is reversible, we may consider this proposition true if we apply it to certain fanatieal leaders of mankind, savage or civilized, who, as "moulders of public opinion," have retarled human progress. Chamfort said that there are centuries in which public opinion is the most imbecile of all opinions, but this reproach eannot be entirely saddled upon "the complaining millions of men." History teaches everywhere that permanent ignorance and superstition are the results of the oppression of mankind by fanatical overmen. In medieine, this is sometimes ludierously true. "There is nothing men will not do," says Holmes, "there is nothing they have not done to recover their health and save their lives. They have submitted to be half-drowned in water, and half-ehoked with gases, to be buried up to their chins in earth, to be seared with hot irons like galley-slaves, to be erimped with knives like codfish, to have needles thrust into their flesh, and bonfires kindled on theil skin, to swallow all sorts of abominations, and to pay for all this, as if to be singed and scalded were a costly privilege, as if blisters were a blessing, and leeches a luxury. What more ean be asked to prove their honesty and sineerity?"1 Yet while the lack of public enlightenment in certain periods produeed the stationary or discontinuous mind, there are signs that the modern organized advancement of science may bring forth rich fruit for the medieine of the future through the social coopperation of the mass of mankind with the medical profession. As the ancient Greeks hung upon the teachings of Emperlocles and Hippocrates, as modern humanity responded beautifully to the ideas of Jenner, Pasteur, and Lister, so there has been at no time a greater interest in the advancement of medicine and public health, as manifested in periodieals and newspapers, than in our own. The awakening of the people to looking after their own interests in regard to the organization and administration of public hygiene is, no doubt, the hope of the preventive medicine of the distant future. Yet, even under the best conditions, it is still possible and probable that many highly intelligent and highly educated persons will continue to hug their whims and superstitions, consult quacks, and be otherwise amenable to psychotherapy, absent treatment and "action at a distance." "To folk-medicine," says Allbutt, "doubt is unknown; it brings the peace of security."

${ }^{1}$ O. W. Holmes: "Medical Essays," Boston, 1853, pp. 37s, 379. 


\section{EGYPTIAN MEDICINE}

Wuetuse the human race is descended from several distinct. species or from al single common ancestor, "probably arboreal in his habits," is lost in the dim and unattainable past. The discoveries of the skeletal remains of human fossils at Neanderthal (1Sib), ('rô-Mingnon (1S68), Spy (1S87), Krapina (1S99), Heidelherg (1907), Le Moustier (1908), La Chapelle-aux-Saints (1908), and the recent Pilddown find (Eoanthropus Dawsoni, 1911) indialte that, even in the paleolithic or chipped-flint poriod, there was al leady considerable diversity in the cranial characters of mankind and that, in prehistoric times, the hmman brain, developed at the expense of a simian body, increases in volume as wo go backward, which would seem slightly in favor of the contention of Virchow and other German anthropologists that humanity is diverse in origin. But whether the Pithecanthropus found at Trinil River, Java, in 1891 be simian or human or, as its discoverer Dubois claimed, a mixture of hoth, all craniologic evidence seems to prove that prehistoric man was more closely akin to the higher (anthropoid) apes in structure than they are to the lower, a kinship which is also borne out by the medico-legal or "precipitin" test of blood-relationship. At the same time the gap between paleolithic and neolithic man is much greater than that between the people of the Later Stone Age and the civilizations of Egypt and Mesopotamia. The prehistory of man began with the origins of anthropoid life in the Oligocene, the transformations of ape-men into men in the Pleiocene, the extinetion of the great mammals and the dawn of the Old Stone Age Culture in the Pleistocene or Ice Age (Osborn). There is no evidence of the existence of man before the Ice Age, and whether flint implements were actually chipped in the Eolithic period is not positively known; but the fact that all subsequent remains are found embedded in successive layers of strata points to a gradual and inevitable cultural development.

In the late Pleiocene or early Pleistocene (first interglaeial stage) appeared the Trinil raes (Pitheconthropus); in the Niddle Pleistocene (second interglaeial periorl), the IIomo heidelbergensis; in the late Pleistocene (third interglacial period), the Piltdown and pre-Neanderthaloid races; at the elose of the glacial period. Neanderthal man. With the disappearance of Neanderthal man came the Crî-Magnon (Homo sapiens) with larger fore-brain and greater forethought. ${ }^{1}$

${ }^{1}$ H. F. Osborn: Nen of the Old Stone Age. New York, 1916. Sir A. Evans: Seienee, New York, 1916, 11. s. xliv, 399-409. 
In the Mousterian period" (the age of the Neanderthal skull), man was probably more ape-like than the Australian savage; in the Solutrean period, he was like the Bushmen and was already skilful in chipping flints; in the Magdalenian, he resembled the Mongolians and the Esquimaux. The Solutreans and Magdalenians were ahready mighty big-brained warriors and skilled artists, who knew how to bridle horses, make speeialized weapons, devise elothing, and execute most striking and life-like mural paintings and line engravings on stone, bone, and ivory. That the Egyptian and Sumerian eivilizations were nearer to these people than had formerly been conceived is indicated by the results of modern cave explorations and exeavations. One of the most interesting facts of recent development is that arthritis deformans or rheumatic gout, a disease found in so many Egyptian mummies, is identical with the "eave-gout" ( Höhlengicht) which Virchow found in bones of prehistoric men and bears and which is also common in the skeletons of the inhabitants of the early German forests. The chipped flint implements, of uncertain age, which are found near Fayum and elsewhere, surpass all others in delicacy of form and flaking. The fact that the neolithic chipped-flint knife was continually used by the Egyptians in embalming the dead connects their already complex civilization with prehistoric man.

It is possible that many phases of Egyptian culture were spread, even to the New World, by the mechanical process of convection.

Elliot Smith holds that between 2800 and 900 B. C. a euriously distinetive culture-complex was carried by trade and navigation from Egypt to the Mediterranean littoral, and after $900 \mathrm{~B}$. C., by the Phœenieian navigators to India; thence to Malaysia, Indonesia, and Melanesia, ultimately reaching the shores of the Americas, picking up, on the way, many modifieations and additions: from the countries through which it passed. This so-called beliolitbie eulture included sun-worship and its symbols; the building of megalithie monuments: and the rearing of gigantic stone images; the practice of mummification, $\mathrm{or}^{\circ}$ embalming the dead, even among the North Ameriean Indians (H. C. Yarrow), the practices of tattooing (Miss Buckland), piereing the ears (Park Harrison), massage (W. H. R. Rivers), eireumeision, etc.

This peenliar culture, the fantastic elements of which could never have arisen spontaneously in so many distant localities, may have influeneed the early Minoan civilization of Crete after 2800 B. C. a after 900 B. C. the Phonician navigators may have been the middlemen, while the giant eraft of Malaysia and Polynesia eonnected the mainland of Asia with the Amerieas.

1 The terms Acheulean, Mousterian, Solutrean, Magdalenian were introduced by the French anthropologist Gabriel de Mortillet to indieate the surcessive stages in the specialization of flint and other prehistorie implentents found at St. Acheul, Le Moustier, Solutré, and La Madeleine, to which have sinee been added the pre-Chellean (Mesvin), Chellean (Chelles-sur-Marno), Aurignacian (Aurignac), anel Azilian (Mas d'Azil). They are now used in a purely arbitrary way to indieate cranial and skeletal remains found in sites corresponding, in order of geologic time, with these localities.

2G. Elliot Smith: The Migrations of Early Culture, Manchester, 1915. Also, Bull. John Rylands Library, Manchester, 1916, iii, 4S-77, 3 pl. 
Our main sources of knowlerlye of the earliest known phases of Eiryptian medicine aro the modieal papyri, but even antedating these are rertain pietures (melaved on the door-posts of a tomb in the burial groumd near Memphis and described by their discoverer, 11. Max Müller, as being the caldiest known pietures of surgical operations (2500 B. C.1). Although we have reasons for believing that the Egrptians never carried surgery to the extent of opening the hody, yet here atre clatr and ummistakable representations of circmencision and possibly of surgery of the extremities and neck, the attitules and the hieroglyphe inseriptions affixed indicating that the patients are undergoing great pain. Apart from this, there is no evidence of surgery excent in the splints found on the limbs of mummies of all periods. Egyptian anatomy and physiology were of the most rudimentary character.

The medicine chest of an Egyptian queen of the eleventh lynasty (2500 B. $\left(\mathrm{C}^{2}\right)$ containing vases, spoons, dried drugs and roots is another important find. There is also an inscription on a tomb near the pyramids of Sakarah which shows it to be the resting place of a highly esteemed practitioner who served the fifth dymasty of Pharaohs about $2700 \mathrm{~B}$. C. I-em-hetep ("He who cometh in peace") was a medical demigod, the Esculapius of the Egyptians ${ }^{3}$ of the third dynasty (4500 B. C.) who was afterward worshiped at Memphis and had a temple erected in his honor upon the island of Phile. He was the earliest known physician. A papyric fragment of the second century A. D., recently published by the Egyptian exploration fund, shows that he was worshiped even in the time of Mycerinus. ${ }^{4}$ A statue of the physician Iwte, of the nineteenth dynasty (1320-1170 B. C.), is in the Imperial Museum at Leșilen. ${ }^{5}$

Besides the hieroglyphics, which were usually engraved or painted on stone, like the picture-writing of American or Australian savages, the Egyptian employed certain cursive scripts (hicratic and demotic), usually inscribed upon thin sheets of the papyrus plant.

The principal papyri are the Papyrus Ebers, translated by H. Joachim (1ऽ90) and Englished by Carl H. von Klein, the Westear (Lesser Berlin) papyrus, translaterl by Adolf Erman (1890), the Kahun papyri of the Petrie collection, translated by F. L. Griffiths (1593), the Brugsch (Greater Berlin)

1 W. Max Müller: Egyptologieal Researches, Washington, Carnegie Institution, 1906. See also J. J. Walsh: Jour. Am. Med. Assoe., Chicago, 1907, xlix, pp. 1593-1595.

${ }^{2}$ For a picture of the same, see Jour. Am. Med. Assoe., 1905, xlv, 1932.

${ }^{3}$ Kurt Sethe: Imhotep, der Asklepios der Aegypter. Leipzig, 1902. Cited by Sudhoff.

${ }^{4}$ Laneet, Lond., 1915, ii, 1204.

${ }^{5}$ A. Fonahn: Arch. f. Gesch. d. Med., Leipz., 1908-9, 375-378, pl. vi. 
and the badly preserved London Papyrus, both translated by Walter Wreszinski $(1909,1910)$, and the Hearst (Philidelphia) papyrus, eontaining about half the text of the Papyrus Ebers. The oldest are the gynecologieal and veterinary seripts of the Petrie Collection from Kahun (1893).

The most important of the medical papyri is that advertised for sale in 1869 and obtained by Georg Ebers at Thebes in 1872, which dates back to about $1550 \mathrm{~B}$. C. It consists of 110 pages of hieratic or eursive script, the text in black letter, the rubries in red. Ebers himself supposed it to be one of the lost sacred or Hermetic Books of Thoth (Hermes Trismegistus), the moon god, who, like Apollo in Greece, was the special deity of medicine.' This assumption has not stood the test of time, and the Ebers Papyrus, with its marginal notes and comments, is now regarded as a simple compilation, ${ }^{2}$ albeit a veritable édition de luxe, as if prepared for some great temple. The fact that it is written in several dialects indicates that it is an encyclopedia, made up of several treatises. It begins with a number of incantations against disease and then proceeds to list a large number of diseases in detail, with about 700 different remedies for the same. The most interesting parts are the extensive sections on the eye and ear including a recognition of the Egyptian trachoma noted by Baron Larrey in 1802, and the deseriptions of the $\bar{A} A \bar{A}$ disease, the $\mathrm{UHA}$ disease and the Uhedu (painful swelling), all three of which have been thought by Joachim to be identical with different stages of the hookworm infection (chlorosis Egyptiaca ${ }^{3}$ ). In addition to the hookworm, Filaria, Tænia, Ascaris and other parasites are mentioned and preseribed for. The large number of remedies and prescriptions eited in the Papyrus points to a highly specialized therapeusis, even in the sixteenth century B. C., but it cannot be claimed, as many seem to contend, that these 700 odd remedies indicate any special scientific advancement of the art of healing. We do not find a few well-sclected drugs, as opium, hellebore,

${ }^{1}$ The first mention of Hermes Trismegistus was found by Kirl Wessely in a papyrus of the third century A. D. from Hermopolis (Mitt. a. I. Samml. Erzh. Rainer, 1592, v, 133). Cited by Sudhoff.

2 The hieratic writing of the Ebers Papyrus had first to be rendered into hieroglyplics, by a method devised at the Orientalists' Congress in 1874. One of the first to attempt to deeipher the hieroglyphics on the Rosetta stone (1799) was the English physieian and physicist, Thomas Young. The difficult task was finally aecomplished by J. F. Champollion (1S1S-28), and earried further by Richard Lepsius (1810-84), Heinrich Brugseh (1827-94), who published a "Hieratie-Demotic Dietionary" (1867-82), Joseph Chabas (181782), (iaston Maspero, and others.

${ }^{3}$ Joachim, Papyros Ebers, Berlin, 1890. Errwin Pfister, however, thinks that the āaa disease of the Ebers and Brugsch papyri was bilharziosis, since it hieroglyph is a phallus. See Sudhoff's Areh., 1912-13, vi, pp. 12-20. Paul Richter (Ibid., 1908-9, ii, 73-83) maintains that to the Egyptians "uhedu" stood for a disease, while to moderns it only signifies a symptom (inflammation). 
hyoseymms, mod, as the later (ireck phrsiobins employed them, with skill and discrimination, but legretian therapy must inve beon, of neessity, haphazand, beratuse as we shall soe, each Egyptian physician was a nalrow specoialist, confining himself to one discase or to discases affecting onc part of the body only. Many mincrals and vegotable simples are montioned, from the salts of lead and ropper to squills, colchicum, gentian, astor oil and opium, and, as in some pharmacopeias of even the seventeenth and eighteenth centuries, those wore componmeled with such filthy ingredionts as the blood, excreta, fats and visceral parts of hirds, mammals and reptiles. A farorite regptian pomade for baldness consisted of equal parts of the fats of the lion, hippopotanus; crocodile, goose, serpent and ibex. Another ansisted simply of equal parts of writing ink and cerelorospinal fluid. An ointment for the eve consisted of a trituration of antimony in goose-fat. Another for conjunctivitis employs a ropper salt. A poultice for suppuration consisted of equal parts of a meal of dates and wheat chaff, bicarbonate of soda and seeds of endives. There is a small pediatric section in the Ebers Papyrus, mainly of prognostic and therapeutic import. Egyptian gymecology and olstetrics have been studied in the five principal papyri by Felix Reinhard.

The most interesting part of the Ebers Papyrus is the last soction of all, which treats of tumors. Here, as in the description of the $\bar{A} A \bar{A}$ disease, we find some approach to the accurate clinical pictures of Hippocrates, and many have supposed, on this slender evidence, that the Father of Medicine was indebted to Egypt for much of his knowledge. Some ethical precepts of the ancient Egyptian physicians are very much like the Hippocratic Oath in sentiment and expression, and this alone would point to the fact that pre-Hippocratic medicine in Greece had an origin closely connected with Egyptian medicine. There is, however, one marked point of divergence, namely, that later Egyptian medicine was entirely in the hands of priests, while Creck medicine, even at the time of the Trojan IVar, would seem to be entirely free from priestly domination, surgery in particular being often practised by Homer's warrior kings. Our principal authorities for the state of Egyptian medicine during the fifth century B. C. are Herodotus and Diodorus Siculus. From Herodotus we leam of the hygienic customs of the Egyptians, the gods of their worship, their ideas about medicine and their methods of embalming dead bodies. "The art of medicine," says Herodotus, "is thus divided among then: Each physician applies himself to one disease only, and not

${ }^{1}$ F. Reinhard: Arch. f. Gesch. d. Med., Leipzig, 1915-16, ix, 315; 191617. $x, 124$. 
more. All places abound in physicians; some physicians are for the eyes, others for the head, others for the teeth, others for the intestines, and other's for internal disorders." Medical practice was rigidly prescribed by the Hermetic Books of Thoth, and if a patient's death resulted from any deviation from this set line of treatment, it was regarded as a capital rime. Aristotle, writing one century later, says, in his Polities, that physicians were allowed to alter the treatment after the fourth day if the patient dicl not improve. The simple dress and frecpuent baths of the Egyptians were what is suitable in a subtropical climate and not unlike those of the Greeks. "They purge themselves every month, three diys in succession," says Herodotus, "seeking to preserve health by emeties and clysters; for they suppose that all diseases to which men are subject proceed from the food they use. And, indeed, in other respects, the Egyptians, next to the Libyans, are the most healthy people in the world, as I think, on account of the scasoms, because they are not liable to change." "This view of the old historian does not hammonize with the great frepuency of rhemutoid arthritis in the Egyptian mumules, which was probably due to exposure to a moist climate during the imundations of the Nila. The account of Egyptian embalming in Herorlotus is, in the light of all recent investigations, anthentic and aceurate and it shows that the Egyptians already knew the antiseptie virtues of extreme dryness and of certain chemicals, like nitre and common salt. The brain was first drawn out through the nostrils by an iron hook and the skull cleared of the rest by rinsing with drugs; the abdomen was then incised with a sharp flint knife, eviscerated, cleansed with wine and aromatics, filled with myrrh, cassia and spires and the wound sewed up. The body was then steeped for seventy days in sodium chloride or bicarbonate (natron) and afterwarl washed and enveloped completely in linen bandages smeared together with gum. The relatives put it in a wooden coffin, shaped like a man, which was deposited in the burial chamber along with four (anopic jars containing the viscera. As with our North Ameriean Indians, the departed spirit was furnished with food, drink and other appointments and conveniences, and there was a special ritual or Book of the Dead, which every Egyptian learned hy heart, as a sort of Basedeker to the other world. Arcording to Diodorus Sieulus, the "paraschistes," who made the initial incision with the flint knife, was held in such aversion that he was driven away with eurses, pelted with stones, and otherwise romghly handled, if caught. On the other hand, the "tariohentes," who

1 Herodotus: ii, 84 .

3 Inrodotus: ii, 77 .
2 Aristotle: Politics, iii, 15.

4 Ibid.: ii, sis. 
eviscerated the body and prepatred it for the tomb, was revered as bolonging to the priestly class. But this was probably only a perfunctery piece of ritualism. Sudhoff bas recently published some interesting platest representing the characteristic stone knives and iron books used by the Egyptian embalmers, and comrie, in an inforesting paper in Sulhoff's Archiv," describes what are probably the earliest known surgical instruments of the ancient Egyptians (about 1500 13. (.), consisting of three saber-shaped eopper knives with hooked or incurvated handles, fomel in a temb near Thebes. They are eharacteristic specimens of the Bronze Age. Elliot Smith and Wood Jones have described the effects of splints of palm fiber employed to mend fractures, and the results of healing are surprisingly good, with little shortening. ${ }^{3}$

The paleopathology of Egypt was first investigated by Fouquet in 1889. In 1907, the Egyptian goverminent instituted an areheological survey of that part of Nubia which would be subsequently flooded by the raising of the Asiram dam. The anthropological and pathological phases of the investigation were entrusted to Profesior (i. Elliot Smith, with the assistanee of F. Wood Jones and others. ${ }^{4}$ The bulletins of this inquiry, with fine atlases of plates covering mummies of all periods, from the Pre-Dymastie to the Byzantine, show that syphidis, eancer, and rickets were unknown, that rheumatoid arthritis, essentially an envirommental and not a racial affection, was "par excellence the bone disease of the ancient Egyptian and Nubian," that the tecth of the Pre-Dynastic people were uniformly good, as might be inferred from the eoarse, husky food found in the intestines, and that deposits of tartar and earies, as also true gout (yielding uric acid reactions) became more common in the New Empire, when luxurious habits were formed. There was no caries in the milk dentition of children of the Pre-Dynastic period, and when caries dil appear, it was followed by abseess formation spreading to the alveoli, showing that the Egyptians had not the slightest rudiments of dentistry. Eridences of mastoid disease, adhesions in appendicitis, pleural adhesions, fusion of the atlis to the occiput from spondylitis deformans, necrosis of bones, cranial uleeration in females from carrying water-jars, and fatal sword-euts of the skull were found. Of fractures, those in the eranium and forearm (at a uniform site near the wrist) were most common, and probably eaused by fending blows aimed at the skull with the Naboot. Fraetures of the femur were more common than today, but no fractures of the patella were found, and few below the knee-joint, the immunity probably resulting from loeomotion with bared teet and the absence of slippery pavements and eurbstones. Similarly, the snall number of fraetures in the hand and wrist suggest freedom from violence by machinery.

Elliot Smith and Sir Mare Armand Ruffer (1859-1917), in a most interesting monograph, have deseribed a genuine case of Pott's disease in a mummy of the twenty-first dynasty (circa 1000 B. C. ${ }^{5}$ ). The histological examinations

1 Sulhoff: Arch. f. Geseh. d. Med.. Leipz., 1911, v, pp. 161-171, 2 pl.

${ }^{2}$ Arch. f. Gesch. d. Med., Lejpz., 1909, iii, pp. 269-272, 1 pl.

${ }^{3}$ Brit. Med. Jour., Lond., 190s, i, 732-737.

${ }^{4}$ Egypt. Ministry of Finance. Survey Department. The Archeological Survey of Nubia. Bulletins, Nos. 1- $\bar{T}$, Cairo, 1907-11. Reports for 1907-S, Fol. II, on the human remains, by G. Elliot Smith and F. Wood Jones, with Atlas. Cairo, 1910.

${ }^{5}$ G. Elliot Smith and M. A. Ruffer: "Pott'sche Krankheit an einer ägyptischen Mumie," Giessen, 1910. 
of Ruffer demonstrated spondylitis deformans, Bouchard's nodes, ague cake, biliary ealeuli, caleification and atheroma of the arteries in variots mummies, and an reruption resembling variola in a mummy of the twentieth dynaty (1200-1100 B. C.1). Infantile paralyis is apparently represented in it steba of the eighteenth dynasty in the ('arlsbererg (ilyptothek at Copendagene. Many aneient Egrytian statuettes in bronze or varnisherl earth, representing the gods Bes and Phtah, are aceurate fignurations of achondroplasia (Chatreot ${ }^{3}$ ).

The main interest of Egyptian medieine lies in its proximity and relationship to Creck medieine. The references in Homer to the skill of the Egyptian physicians in compounding drugs bring to mind the fact that the word "chemistry" itself is deriverl from chemi (the "Black Land"), the ancient name of Egypt, whence the science was ealled the "Black Art." Doubtless the ancient Greeks learned as much of medicine as of ehemistry from these wise elders across the sea, who told solon that his people were "mere children, talkative and vain, knowing nothing of the past"; who were so skilled in metallurgy, dyeing, distillation, preparing leather, making glass, soap, alloys and amalgams, and who, in Homer's time, probably knew more anatomy and therapeutics than the Hellenes. Yet, long before the Alexandrian Period, Egyptian civilization had become absolutely stationary in character, and, in medicine, Egypt was going to school to Greece. ${ }^{4}$ As the Egyptian gods - the dog or ibis-headed Thoth (the Egyptian Hermes), the cat-headed Pacht, their deity of parturition, the beaknosed Horus, the horned ('hnum, the veiled Neith at Sais, remained forever the same, while the Creek mythology was a continuous and consistent evolution of deific figures of permanent beauty and human interest, so Greek medicine was destined to go beyond Egyptian or Oriental medicine as surely as Greek poetry, sculpture and architecture surpassed the efforts of these peoples in the same kintl.

1 Ruffer: Histologieal Studies on Egyptian Mummies, Cairo, 1911. Also, Jour. Path. and Bact, Lond., 1910-11, xv, 1; 453, 4 pl.: 1911-l2, xvi, 439, 9 pl.: $1913-14$, xviii, $149,6 \mathrm{pl}$.

2. See O. Hamburger. Bull. Soes. frane. d'hist. de mérl., Par., 1911, xi, $407-412$.

${ }^{3}$ Chareot: Les difformés ot les malades dans l'art. Paris, 1859, 12-26. F. Ballocl: Prolegomena zur Gexchiehte dee zwerghaften Götter in Egypten. Munieh dissertation (Moseow, 1913).

${ }^{4}$ See, for example, Surlhoff's studlies of the Greek papyri of the Alexandrian period (Studien z. Geseh. 1. Med., Puschmann-stiftung, Nos. 5, 6, Leipz., 1909). 


\section{SUMERIAN AND ORIENTAL MEDICINE}

In the hook of Genesis we read that Nimmel was "a mighty hunter bofore the Iorel" and that "the begimning of his kingelom Was Bahel and breeh, and Aceal and c aheh in the land of Shinar." The lamel of shinar (shumer or "Stmuer") was the southern pat of Babylonia, comprising the strip of eountry between the Euphrates and the Tligris down to the Persian Gulf, and northern Babylonia was called Acead. The Babylonian sovereigns and thoir Assyrian eonquerors always styled themselves "kings of Sumer and Acead." Before the advent of the Babylonians, it is supposed that an original non-Semitic or Sumerian race existed, about $4000-3000$ 13. C., who laid the foundations of modern civilization by the invention of pietorial writing and the development of ast ronomy. Others assume that the cursive script of the sulmorians, which, like Chinese writing, runs from right to left, was in the first instance only a sort of eipher-code used by the dominant semitic race, In any ease Mesopotamia was the starting-point of () riental (ivilization, of which the Babylonians were undoubtedly the principal founders. They were skilled in mathematies and astronomy, originated the decimal system of notation, weights and measures, made the divisions of time into twelve months in the year, seven days in the week, sixty mimutes and seconds in the hour and minute respectively, and divided the circle, as we do, into 360 degrees. They invented the cuneiform inscriptions, reading from left to right, they knew much about military tacties and the art of war, and were variously skilled in music, architecture, pottrry, glass-blowing, weaving and earpet-making. Layard found a plano-eonvex lens of rock erystal in his explorations at Nineveh.

It is said that astronomy is the oldest of the sciences, and in all arly civilizations we find it applied to the practical affairs of life as astrology. This trait is the essence of Sumerian or Accadian medicine. Wars, epidemies, famines, successions of monarehs, and other affairs of public or private life, were closely studied in relation to the precession of the equinoxes, eclipses, comets, rhanges of the moon, and stars, and other meteorologic and astronomic events, and from these fatalistic coincidences arose the idea that certain numerals are lueky or unlucky. Thus astrology and the interpretation of omens merged into prognosis and, as with all early civilizations, the first Babylonian physician was a priest or the first priest a physician. Inspection of the viscera, an essential part of augury, led to inspection of the urine, and, among 
the Babylonians, soothaying was concentrated upon the liver, terra-cotta models of which, about 3000 years old, have beon found, divided into squares and studed with prophetic inseriptions. In Ezekiel (xx1, 21) we read: "For the king of Babylom stood at the parting of the ways, at the head of the two ways to use divination: he made his arrows bright, he eomsulted with images, be looked in the liver." Neuburger points out how the priestly interest in omens might have led to the collection and collocation of clinical observations, such as facial expression, the appearances of the urine, the saliva, the blood drawn in blood-let ting, and other signs which were used as indices or tokens of recovery or death; and he goes on to say that the next step in the direction of scientific advancement would be the elimination of the supernatural from the matter.' 'This step, unfortumately, is and has been the hardest one to take in medical reasoning. So we find the Babylonian physicians regarding disease as the work of demons, which swarmed in the earth, air and water, and against which long litanies or incantations were recited.

In 1S49, Sir Henry Layard, during his excavations of the Mound Kouyunjik, opposite Mosul, the site of Nineveh, discovered the great library of some 30,000 clay tablets gatherel by King Assurbanipal of Assyria (66S-626 B. ( .), which is now in the British XÍusem. from some 800 medical tablets in this archival collection, which probably numbered 100,000, our knowledge of Assyro-Babylonian medicine is mainly derivert. In Morris Jastrow's reading 2 of these, shifting the blame for anything to demons (our disease-germs) was the Assyrian concept of cetiology; diagnosis was probably based upon simple inspection of the patient, helped out by associative memory and ferminology; urognosis (iatromancy) was divination or augury from liver-inspection (hepatoscopy), birth-omens, disease-omens and astrological signs and portents; therapy was exoreism by a special ritual, of which the exhibition of herhal remedies was a part; incantation was prophylaxis. From hepatoscopy the Babylonians learned the structure of the liver, and their clay moxlels are bet ter specimens of anatomical illustration than the five-lobed medieval figurations. Similar morkels of the liver have been found on ancient Hittite sites in Asia Mlinor, and Etrusean livers in bronze, flating from the third eentury B. C., have been found near Piacenzal. The liver, as the souree of blood, was regarded ats the seat of the soul, and as the god idtentified himself with the sacrificial animal, to inspect the liver was to see into the soul of the animal and the mind of the god. The birth-omens, which have been specially studied by Dennefelel and Jastrow, ${ }^{3}$ led to the pseudo-sciences of physiognomy and palmistry and stimmlated the study of foxtal and arlult abnormities. All possible phases of partturition and abnormities of the fortus (Homstra) were regarded as signs and tokens of the individual's future fate, as being the attendant phenomena of at new life issuing from another. An abnormally large organ (monstrum per excessum), or an abnormity on the right side. wais a token of future power and

1 Neuburger: Geschichte der Merlizin, Ftuttgart, 1906, i, 31.

2 M. Jastrow: Proc. Roy. Sioc. Mrel., sect. Hist. Mad., Lond., 1911, vii, $109-17 i$.

3 M. Jastrow: Babylonian-Assyrian Birth-Omens, Giessen, 191:3. I. Dennefelt: Babylonisch-assyrisehe Geburts-Omina, Icipzig, 1911. Jastrow Aspects of Belief and Practios in Babylonia and Axtrria. Now York. 19]1, cll. iii. 


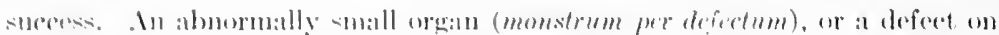

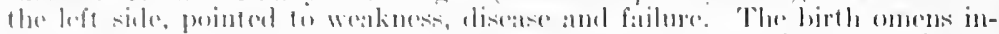

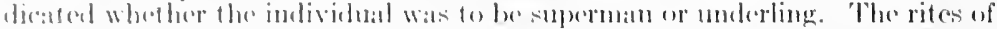

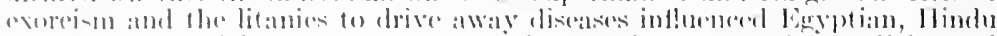

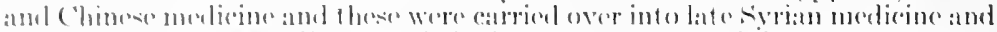

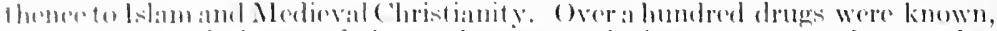

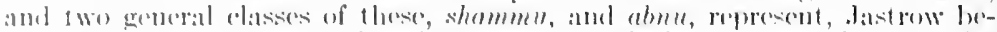

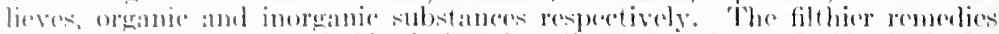

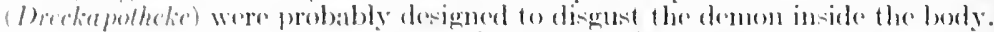

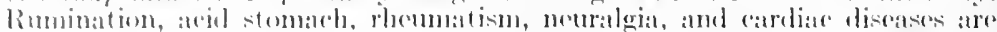

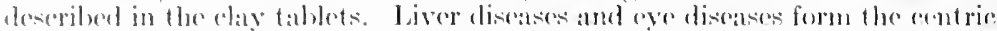

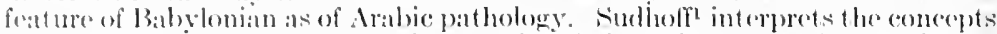
h. $\mathrm{mm}$ and siblu as epilepsy and rentagion (soizure hy domons), and, in the Mlikelle Ages, eprileptic sciziure camne to be regarded as a contagion.

The begimnings of the practice of medicine among the Babylonians have been described by Herodotus as follows: "They bring out their sick to the market place, for they have no physicians; then those who pass by the sick person confer with him about the disease, to discover whether they have themselves been afflicted with the same disease as the sick person, or have seen others so afllicted; thus the passers-by confer with him, and advise him to have recourse to the same treatment as that by which they escaped a similar disease, or as they have known to cure others. And they are not allowed to pass by a sick person in silence, without inquiring the nature of his distemper."' With the Babylonians, as Montaigne quaintly olserves, "the whole people was the physician." They eventually reached the stage at which, like the Egyptians, they had a special doctor for every disease. Whether they ever got beyond this stage we do not know, but we learn from the ('ode Hammurabi $(2250$ B. C.) that the medical profession in Babylon had advanced far enough in public esteem to be rewarded with adequate fees, carefully prescribed and regulated by law. Thus ten shekels in silver was the statutory fee for treating a wound or opening an abscess of the eve with a bronze lancet, if the patient happened to be a "gentleman"; if he were a poor man or a servant, the fee was five or two shekels respectively. If the doctor caused the patient to lose his life or his eye, he had his hands cut off in the case of the gentleman or had to render value for value in the case of a slave. It is clear from all this that the Babylonian physicians owned slaves and sometimes operated for cataract. Here as everywhere, it was surgery that made the first step in the right direction. Internal medicine, among both the Persians and the Babylonians, was occupied mainly in endeavoring to cast out the demons of disease. Jastrow cites a number of pediatric epistles, from the physician Arad-Nanâ to the King Assurbanipal

Judhoff: Arch. f, Gesch. d. Med., Leipz., 1910-11, iv, 353; 1912-13, vi, 454 .

2 Herodotus: i, 80 . 
(668-626 B. C.), on ailments of his little son, in each of which Nineb, the god of healing, and his consort Gula are involiod. Lists of animals, insects and plants are found in the cmmeiform inscriptions. Different varieties of flies, bugs and lice were noted. The wide-spread theory that a worm is the cause of toothache was of Babylonian origin. A votive object found at Susa (Persia) bears a conjuration against mosquitos. A cylinder seal in Pierpont Morgan's collection bears the "Fly Symbol" emblematic of Nergal, the Mesopotamian god of disease and death. ${ }^{1}$ The AssyroBabylonians protected themselves from the fierce sunlight with parasols, from insect pests with fly-flaps, wore Semitic plaids wound about the body terrace-wise, went in for boxing and other manly exercises, employed inflated bladders as water wings, regulated wet-nursing, buried their dead in slipper-shaped coffins and fan-shaped tombs, and policed the battle-field with the aid of vultures, by assembling the wounded and by burial in huge common trenches (Sudhoff ${ }^{2}$ ). Some advance in public hygiene was made, for the excavations of the huge Babylonian drains, of which models were recently exhibited at the Dresden Exposition, show that they understood the proper disposal of sewage. A stone privy in the palace of Sargon at Chorsabar (1300 B. C.) has been excavated.

Closely connected with Sumerian modicine in point of time is the medicine of the Jewish people, in relation to the Assyrian captivity (B. C. 722) and the Babylonian captivity (B. C. 604). The principal sources of our knowledge of Jewish medicine are the Bible and the Talmud, the first throwing only such light upon the subject as we should expect to find in the details of a legendiry historic narrative. In the Old Testament, disease is an expression of the wrath of God, to be removed only by moral reform, prayers and sacrifice; and it is God who confers both health and disease: "I will put none of these diseases upon thee, which I have brought upon the Egyptians: for I am the Lord that healeth thee" (Exodus $x v, 26)$. The priests acted as hygienic police in relation to contagions diseases, but there is not a single reference in the Bible to priests acting as physicians. The latter were a class apart, of whom we read, for example, that Joseph "commanded his servants the physicians to cmbalm his father" (Gen. L, 2), that King Asa consulted physicians instead of the Lord and "slept with his fathers" for his pains (II Chron. xv1, 12, 13), or that if two men fight and one of them be injured to the extent of having to keep his bed, the other "shall pay for the loss of his time, and shall cause

'J. Offord: Sc. Progress, Lond., 1916, x, 572.

'Sudhoff: Katalog der Internationalen Hygiene-Ausstellung. Historische Abteilung, Dresden, 1911, 20-2\$. 
him to be thoromgly healed" (Nxodus xxi, 19). "The Prophets, om the other hand, fresuenty perfolmed mirates, as where both Elijah and Elisba rasod childern foom the drat. "The "healinge" of the waters of Jorkam hy blisha (11 Kings I1, 22) is a good example of the ancient, primitive concept of "making medicene," as also the reforences to the nse of hysiop) a an a a gent of cathatsis, purification or lustration (l'salms 1, 7 ; Exodus XI, 22; Levitious XIr, $4-7,49-52)$, and the ritual of transforing leprosy to a bird (levitiens $\mathrm{x}, 1, \mathrm{I}-\mathrm{S}$ ). A striking example of the relation between the Divine wath and the officacy of prayer is to be found in the case of Hezckiah, who, "sick unto death," and told by the Lord to set his homso in order, tumed his face to the wall; his praycrs wore answered by the Prophet Isaiah who, at the Divine instance, ordered that a lump of figs be applied to the afflicted part, with the result that Hozekiah recovered (II Kings xx, 1-8). Besides the physi(rians and the high priests, who acted as public health officers, there were also professional phamacists (Exodus xxx, 25; Nchemiah III, S) and professional midwives, who are mentioned in the cases of Rachel, of Tamar, and particularly in the striking reference to the ancient Oriental usage of the obstetric chair, in the first chapter of the second book of Exolus, where Phamoh commands the midwives to slay all Jewish infants of the male sex, "when ye do the office of a midwife to the Hebrew women, and see them upon the stools." Matemal impressions form the subject of the second half of the thirticth chapter of Genesis, in which Jacob retaliates upon Laban for the deception which the latter practised upon him about Leah and Rachel by outwitting him in a method of raising sperkled and spotted livestock hardly explicable by Mendel's law. The sign-language of crooks is indicated in Proverbs vi, 13. Drcams are rightly regarded as "visions of the head," that is, emanations of the brain (Daniel Ir, 5, 13; vir, 1). The use of the primitive chipped flint in ritual ciremeision is referred to in the second book of Exodus (1r, 25), where Zipporah, the wife of Moses, "took a sharp stone and cut off the foreskin of her som." In Joshua ( , 2), Crod commanded Joshua, the successor of Moses, to make sharp knives and ciremeise the ehildren of Israel born after the Exodus from Egypt. This is the only surgical procedure mentioned in the Bible, but the use of the roller-bandinge in fractures is referred to in Ezekiel (xxx, 22) as follows: "Son of man, I have broken the arm of Pharaoh king of Egypt; and, lo, it shall not be bound up to be healed, to put a roller to bind it, to make it strong to hold the sword." Wounds were dressed, as among all ancient peoples, with oil, wine and balsams. In Deuteronomy, Moses

${ }^{1}$ The preparation of ointments by the apotheeary is referred to in Exodus xxx, 25, and their therapeutic indications in Isaiah I, 5. 
lays down a careful dietetic regimen (xiv, 3-21) and excellent rules of military hygiene, in relation to the policing of camps (xxiIr, 9-14). The census or "numbering of the people" by Moses is described in Numbers ( $1,1-49$; xxvi, 1-65), and by Joab, at the instance of David, in I Chronicles (xxi, 3-7). Acroncgaly, with supernumerary digits, is described in the case of the son of Goliath of Gath (II Samuel xxi, 20; I Chronicles xx, 6), epilepsy is mentioned (Numbers xxir, 4) and the effects of inebriety outlined (Proverbs xxin, 20-35). Nabal's apoplexy and death, from drunkenness and mental excitement, is noted in I Samuel (xxv, 36). Of the different diseases referred to in the Bible, the most important are leprosy, the "issue," and the several plagues visited upon Israel, notably the plague of Baal Peor, in which twenty-four thousand perished (Numbers xxv, 9). Yet these diseases are so vaguely alluded to that it is impossible to identify them with any latter-day equivalents. Modern dermatologists contend, for instance, that Biblical leprosy (zaraath ${ }^{\mathrm{I}}$ ), of which Naaman was healed by dipping himself "seven times in Jordan," and which was transferred (in the folk-lore sense) to Gehazi, so that "he went out from his presence a leper as white as snow," was, in reality, psoriasis. On the other hand, Iwan Bloch and others maintain that the venereal plagues mentioned in the Bible (Baalpeor and the rest) are not the same as present-day lues or gonorrhea." Plague after quail-eating is mentioned in Numbers (xI, 31-33). Highly significant is the episode of Ahaziah (II Kings I, 2), who, when ill, sent to Beelzebub at Ekron to learn if he might recover, for, according to Josephus, this god is to be equated with the Greek Zeus Apomuios, the "averter of flies." The fiery serpents mentioned in Numbers (xxi, 7) may have been the dricunculus, and Castellani holds that the discase with "emerods" in I Samuel (v, 6; vı, 4-5) was bubonic plague, because the "mice died and marred the land.",

\section{${ }^{1}$ Deseribed in Levitieus xi11, 1-46.}

${ }^{2}$ Medical sebolars, who speeulate about these uneertain details in surh dogmatic fashion, fail to consider the point, well known to mathematicians and physicists, that the inherent probability of any oecurrenee tends the eloser to zero the further we get away from it, and that the effect of any event tends to "die out asymptotically" in indefinite or infinite time. Niculapius was very much of a reality to Ilomer, Hippocrates and Celsus. To us he is wellnigh a myth. Bloch forgets that the logical oppesite of the "morbus Americanus" theory of syphilis, which he advances with such fanatical zeal, is just as likely to be true as the theory itself.

${ }^{3}$ The rodents appear in Poussin's painting "The Plague of the Plilistines" (Janus, Amst., 1898, iii, 138). It is noticeable that the evidenee of the association of mice with the plague is stronger in the Septuagint than in the Vulgate (see L. Aschoff, Janus, Amst., 1900, v, 611-613). In the Revised Version the "nati sunt nures" is absent, but verse 8 of I Samuel $v$ suggests the inguinal bubo of plague. 
The principal interest in these Biblical discases lies in the remarkible afforts made to provent them. 'The ancient Hobrews were, in latet, the fommters of prophylaxis and the high priests were

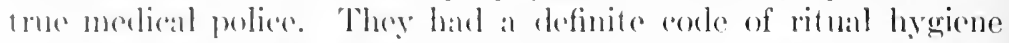

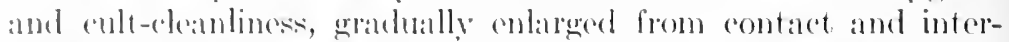
relation with different rivilizations. The book of Levitiens contanins the stomest mandiates in regard to fouching melean objects, the proper food to be aten, the purifying of women after chitdhilh, the hreicne of the menstrual periols, the abomination of sextal perversions and the prevention of contagious discases. In the remalkable chapters on the diagnosis and prevention of leprosy, gonomhea and leukormhea (Leviticus xul-xv), the nost definite common-sense directions are given in regard to segregation, disinfoction (even to the point of scraping the walls of the house or (lestroying it completely), and the old Mosaie rite of incineration of the patient's garments and other fomites. In the Midelle Ages, these precepts from Leviticus were still in force against leprosy, and the principle of isolation of patients and slspects was extended to plague, syphilis, phthisis, scabies, erysipelas, anthrax, trachoma and epilepsy (Sudhoff). Who but does not admire the rigorous Hebrew regulation of sexual hygiene which, however severe, enforced exogamy, put a ban upon perversions, and invested the figure of a good and virtuous woman with that peculiar halo of respect which has been preserved by all highly civilized nations (lown to the present time?" The institution of the Sabbath day gave tired workaday humanity a sort of permanent splint to rest upon. In short, the chief glory of Biblical medicine lies, as Neuburger rightly says, in the institution of social hrgiene as a science. How highly the physician was esteemed by the Hebrews of a later time may be gathered from the impressive language of Jesus, son of Sirach (180 B. C.):

1. Honour a physician aceording to thy need of him with the honours tlue unto him:

For verily the Lord hath ereated him.

2. For from the Most High eometh healing:

And from the King he shall rceeive a gift.

3. The skill of the phrsician shall lift up his head:

And in the sight of great men he shall be admired.

The writings of Flavius Josephus (born 37 A. D.), as investigated by Max Neuburger, ${ }^{2}$ differ frequently from the Biblical narrative in respect of medical details. Physicians are more frequently mentioned, and their definite independent status is emphasized. Visitation of epidemic diseases is more

1 It is worthy of note that the Mosaie mandates against bestiality, sexual inversion, etc., in Exodus (XXI, XxII) and Leviticus (xvIII) are the beginnings. of medical jurisprudence.

2 M. Neuburger: Die Medizin im Flavius Josephus. Reichenhall, 1920. 
frequent, and the third plague of Erypt is defined as perlieulosis, that of Baal Peor as pest, that of the Philistines as dysentery. The precepts of Jemish hygiene, particularly the Mosale rules for the isolation and purification of lepers, are given with drastic foree. Saul's molancholia is defined as demonomania with eestasy. Apoplexy may be inferred in the eases of Nabal and Alkimos. David is deseribed as feigning insanity before the King of Gath. In the later narratives, psychiatric details are frequently given, particularly in the case of Ilerod.

In cont radistinction to the written Mosaic law in the five books of the Pentateuch (Torah), the Talmud consists of the law as transmitted by verbal tradition (Mishna), with its several interpretations and commentaries (Gemara). This body of knowledge began to accumulate after the Babylonian Captivity, about 536 B. C., and is embodied in the Palestinian Talmud (370-390 A. D.) and the Babylonian Talmud (352-427 A. D.), the latter being the ordinary source of reference. The Babylonian Tahmud is essentially a law book, dating from the second century A. D., and the information about Jewish medicine conveyed in it is, in consequence, of a more definite and detailed character than we should expect to find in the half-legendary narrative of the Bible. Its most interesting feature is the light it throws upon later Jewish anatomy and surgery and upon the knowledge of post-mortem appearances which the Hebrews gained through the inspection of meat for food. Anatomy of any kind before the time of Vesalius was a thing of shreds and patches and Jewish anatomy was no exception to the rule. Only a very few of the parts of the body are mentioned in the Bible and these referenees are as vague and general as those in the Iliad. In the Talmud, the number of bones in the skeleton is variously estimated at 248 or 252, and, of these, one, the bone Luz, which was supposed to lie somewhere between the base of the skull and the cocerx, was regarded as the indestructible nueleus from which the body is to be raised from the dead at the Resurrection. This myth, which modern rabbinical anthority holds to have originated from the ancient Egrptian rite of "burying the spinal column of Osiris," was exploded by Vesalius in a striking passage in the "Fabrica."1 The Tahnud displays considerable knowledge of the osophagus, larynx, trachea, the membranes of the brain and the generative organs. The pancreas is ealled the "finger of the liver" and structures like the spleen, kidneys and spinal cord are frequently mentioned but not deseribed. The blood is held to be the vital principle, identical with the soul, and the heart is essential to life. Respiration is likened to burning. The effeet of the saliva upon food and the chuming movements of the stomach are noted, and the liver is believed to

1 See F. II. Garrion, "The Bone called 'Luz,", New York Med. Jour., 1911, xcii, pp. 149-151. 
daborate the hlood. Among the Hebrews, the flesh of diseased or injured animals was always considered unfit for food, and the antopsies, made rypon slaughtered animals to determine what was "kosher" and "trepha," threw a light npon pathologic appearances which the anciont Greoks nover ganed. Hyperemia, caseous derencration and tumers of the lumge were noted, as also atrophy and absess of the kidneys and cirrhosis and necrosis of the liver. Tropical drisentery, pallid anamia, dropsy, intestinal worms, phthirisis and seophutic stomatitis were described. Jaundice and hiliary disoulers were commonplaces of Jewish and Mohammedan medicine. Diphtheria, known as askara (Er\%ripa) or serunke (roprigxy), was so much feared by the Hobrews that the first case located in a community was immediately heraleled by a warning blast of the shofar, although the instrument was ordinarily sounded only after the occurrence of the third case of an infectious disease (Premss). There are no Hebrew words for "cough" or "phthisis," to which the arid plains of Palestine were of old inimical. Talmudic surgery included the usual "wound-surgery," with treatment by sutures and bandages, applications of wine and oil and the device of freshening the edges of old wounds to secure more perfect union. Venesection, leeching and cupping were common and, before attempting the major operations, a sleeping draught ("samme de shinta") was administered. Cesarean section, excision of the spleen, amputations, trephining, and the operation for. imperforate anus in infants were known, as also the use of the speculum and the uterine sound. Fractures and dislocations were discussed, and crutches, artificial limbs and artificial teeth employed. ${ }^{1}$ Careful rules for the hygiene and nutrition of newborn children are given. There is no evidence of specialized medical education among the Jews until the Alexandrian period, and individual Hebrew physicians did not attain any particular prominence until the Middle Ages and, more especially, in the Modern Period.

As the Hebrews attained the highest eminence among Oriental peoples in hygicne, so the ancient Hindus excelled all other nations of their time in operative surgery. In the earliest Sanskrit documents, the Rig Veda (1500 B. C.) and the Atharva Veda, medicine is entirely theurgic, and treatment consists of the usual versified spells and incantations against the demons of disease or their human agents, the witches and wizards. In the Bralıminical period ( 800 B. C. -1000 A. D.), medicine was entirely in the hands

${ }^{1}$ For further information about Biblical and Talınudie medicine, see Julius Preuss, Biblisch-Talmudische Medizin. Berlin, 1911, and the article by Dr. Charles D. Spivak in the Jewish Encyclopedia, N. Y., 1904, viii, pp. 409-414. 
of the Brahmin priests and scholars, and the center of medical education was at Benares. In an Indian rock inseription, King Asoka (circa 226 B. C.) records the ereetion of hospitals by him, and Cingalese records indicate the existence of hospitals in C'eylon in 437 and 137 B. C. Indian and Ceylonese hospitals existed as late as $368 \mathrm{~A}$. D. The three leading texts of Brahminical medicine are the Charaka Samhita, a compendium made by Charaka (second century A. D.) from an earlier work of Agnivéra, based upon the lectures of his master Atreya (sixth century B. C. ${ }^{1}$ ), the Susruta (fifth century A. D.) and the Vagbhata (seventh century A. D.). Of these, the most remarkable is Susruta, whose work, bearing the same name, is the great storehouse of Aryan surgery. Indian medicine was particularly weak in its anatomy, which consisted of purely fanciful numerations of unimaginable parts of the body, as 360 bones, 800 ligaments, 500 muscles, 300 veins, and so on. Hindu physiology presupposes that the vital processes are activated by means of the air (below the navel), the bile (between the navel and the heart) and the phlegm (above the heart), from which are derived the seven proximal principles, ehyle, blood, flesh, fat, bone, marrow, and semen. Health consists in a normal quantitative relationship of these primary constituents, disease in a derangement of their proper proportions. Diseases are again minutely subdivided, the Susruta enumerating as many as 1120 , which are classed in the two grand divisions of natural and supernatural diseases. Diagnosis was carefully made and includer inspection, palpation, auscultation and the use of the special senses. Semeiology and prognosis combined acute observation with the usual folk superstitions. As examples, witness the Susruta's very recognizable description of malarial fever, which is attributed to mosquitos, or the passage in the Bhâgavata Purana which warns people to clesert their houses "when rats fall from the roofs above, jump about and die," presumably from plague. Essential diabetes mellitus was recognized as Madhumeha or "honey-urine" (Jolly), and the symptoms of thirst, foul breath, and languor were noted (W. Ebstein). Evidences of variolation (inoculation against smallpox) have been found in the Sanscrit text Sacteya, attributod to Dhanwantari.2 In therapentics, a proper diet and regimen were carefully detailed, and baths, enemata, emetics, inhalations, gargles, blood-letting and urethral and vaginal injeetions employed. In Mareo Polo's travels, there is a description of a kind of mosquito-netting used on the Coromandel Coast to keep away flies

${ }^{1}$ Charaka's text was completed hy Dridhabala. See A. F. R. Hocrnle: Arch. f. Gesch. d. Med., Leipz., 1907-8, i, 29-40.

${ }^{2}$ Madras Courier, Jan. 2, 1919. Cited by E. von Sichrötter: Ztschr. f. irztl. Fortbild., Berl., 1919, xvi, 244. 
and rermin.' 'The materia modica of India was particularly rich. Suśruta mentions 760 medicinal plants, of which nard, cimmamon, pepper. (atrdamons, spies and sugar were native. Especial attention wats paid to aphrodisiacs and poisons, particularly antidotes for the hites of vernomons snakes and other animals. Jolly mentions sone 13 alcoholic drinks. "The soporific effects of hyoseyanus and ('ammbis indica were known, and their employment in surgieal ancsthesia was, aceording to Burton, of great antiquity. The Bower Ms., a valuable sanserit doemment on birch-bark (fifth century 13. C.), found by a native in the ruins of Mingai ('Turkestan) and purchased by Lieutenant Bower in 1890 (edited by Hoemle), corresponds with the drug-lore of the Susruta and the Charaka in many particulars. It contains a remarkable dithyramb in praise of garlic (Allium satimum ${ }^{2}$. In the obstetric chaptel of the Susruta, there is an admirable seetion on infant hygiene and nutrition, unexcelled by anything before the time of Aulus Gellius or Soranus of Ephesus. The surgieal arm of treatment in India reached, as we have said, the highest point of development attained in antiquity. The Suśruta deseribes about 121 different surgical instruments, including scalpels, lancets, saws, scissors, needles, hooks, probes, directors, sounds, foreeps, troears, eatheters, syringes, bougies and a reetal speeulum. ${ }^{3}$ These were properly handled and jointed, the blade instruments sharp enough to cut a hair and kept clean by wrapping in flannel in a box. The Hindus apparently knew every important operative procedure except the use of the ligature. They amputated limbs, eheeking hemorrhage by cauterization, boiling oil or pressure. They treated fractures and dislocations by a special splint made of withes of bamboo, which was subsequently adopted in the British Army as the "patent rattan cane sphint." They performed lithotomy (without the staff), Cesarean section, excision of tumors, and the removal of omental hernia through the serotum. Their mode of extracting cataract has survived to the present day and they were especially strong in skin-grafting and other phases of plastic surgery. The method of rhinoplasty was probably leamed from them in the first instance by the itinerant Arabian surgeons and so transmitted through private families, like the Norsini, from generation to generation even to the time of Tagliacozzi. The Hindus were especially elever in their method of teaching surgery. Realizing the importance of rapid, dexterous incision in operations

${ }^{1}$ H. sichröder: Arch. f. Schiffs- u. Tropen-Hyg., Leipz., 1917, xxi, 350.

${ }^{2}$ L. Aschoff: Janus, Amst., 1900, v, 493-501.

3See "A Short History of Aryan Medical Science," by Sir Bhagvat Sinh Jee, London, 1896, 176-186, with pictures of surgical instruments and other apparatus, on plates $1-10$. 
without anesthesia, they had the student practise at first upon plants. The hollow stalks of water lilies or the veins of large leaves were punctured and lanced, as well as the blood-vessels of dead animals. Gourds, eucumbers and other soft fruits, or leather bags filled with water were tapped or incised in lieu of hydrocele or any other disorder of a hollow cavity. Flexible models were used for bandaging, and amputations and the plastic operations were practised upon dead animals. In so teaching the student to acquire ease and surety in operating by "going through the motions," the Hindus were pioneers of many recent wrinkles on the didactic side of experimental surgery. ${ }^{1}$

Whether the Hindus influenced Cireek medicine before the time of Alexander the Great or were themselves influenced by it is not known; but it is certain that, at the time of Alexander's Indian expedition (327 B. C.), their physicians and surgeons enjoyed a well-deserved reputation for superior knowledge and skill. Some writers even maintain that Aristotle, who lived about this time, got many of his ideas from the East.

With the Mohammedan conquest, Indian medicine passed under the sway of the Arabic domination and virtually ceased to be. Its only survival in our own time consists apparently in the Vedantic practices of the various Swamis and Mahatmas who oceasionally visit this country and whose strange cult has driven many of its American adherents insane. It is interesting to note, however, that the three Englishmen who did most to put hypnotism upon a permanent basis in practical therapeuties-Braicl. Esdaile and Elliotson-undoubtedly got their ideas and some of their experience from contact with Inclia.

Chinese medicine is what our own medicine might be, had we been guided by medieval ideas down to the present time, that is, absolutely stationary. Its literature consists of a large number of works few of which are of the slightest scientific importance. Their characteristics are reverence for authority, petrified formalism and a pedantic excess of detail.

The earliest of the classies, upon which Chinese medicine is based, are the works of Huang-ti (2697 B. C.). These were done in lacquer upon strips of bamboo or palm-leaves, the tadpole characters, derived from the ancient device of making knots in strings, being arranged vertically, to accommodate themselves to

${ }^{1}$ Rearlers of Captain Marryat's novels may recall how the apothecary, Mr. Cophagus, taught venesection to the fatherless Japhet by making him, "in the first instance, puncture very scientifically all the larger veins of a cabbage leaf, until, well satisfied with the delicacy of my hand and the precision of my hand, he wound up his instructions by permitting me to breathe a vein in his own arm." Marryat, Japhet in Search of a Father, ch. iv. 
the narrow hambon surface. These tadpole idloograms, the analogue of the Egyptian pieture-witings, were later modified and donc with pen and paper.

In the Clum dynatsy (1122 13. C.), Chin Vuch Jon wrote an treatise on the arterial and viseral systems (. Vonching), which gives the woights of the different organs. In the Ming dynasty (136s $\Lambda$. 1).), Chang (hii Ping wrote at similat treatise (Leching), and in the Ching dynasty, the Emperor Chien Lang

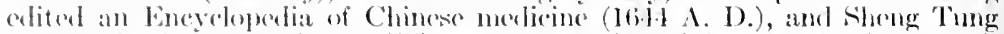
wrote a book on osteology. Chinese anatomy is mainly splanchmology, angiology and physical anthropometry. As with all carly peoples, there is a strong predileetion for number lore. There are two eosnie prineiptes, the celestial Yan (light, heat, life) and the earthy Yin (darkness, cold, drath). Life consists in the inter-action of a male and female minciple, equilibrium between which eonstitutes health and imbalanee, disease. These principles are then distributed to the different parts of the body, $e$. g., the hand receives the great fomale principle of the lung and the young male principle of the "three burning spraces," $i$. e., the thorax, abdomen and pelvis. The prineiples contain air and blood in varying quantitiss, e.g., "the great male principle has much blood and hit tle air." The function of organs is to store up, that of viscera to break down and eliminate. In the Neiching (Internal Organs) of Huangti (2ti97 B. C.), the liver stores the blood, which eontains the soul; the heart stores the pulse (spirit); the spleen the mutrition (thought); the lungs the breath (energy); the kidneys the germ principle (will). These five organs cont rol all parts of the body, e.g., the lungs produce the skin and hair, form the kidneys and eontrol the heart, which produces the blood, forms the spleen and (oontrols the kidneys. The six viseera (stomach, colon and duodenum, gallblatder, bfadder and three burning spaces) and the five organs are similarly interrelated in a sort of hierarehieal physiology, the heart being king and director, the lungs his executors, the liver his general, the gall-bladder his at torney general, the sipleen his granary offieer who creates the five tastes, the three burning spaces (filled with fat) the sewage system, draining into the bladder. This book of Huangti gives valuable measurements of the bones and alimentary traet. Physical anthropometry is elearly of Chinese origin. In the Ching period, regional anatomy was much improved by Feng Chiao Chang (164t A. D.). In the later Ching period (1796-1821), Wang Chin Jen made 24 good pietures of the organs and viscera. Angiology and osteology were eultivated as topographic aids to acupuncture (2697 B. C.), cauterization and osteopathy. Along the 12 pairs of travelling vessels, there are 365 needling or puneture points for the evacuation of the pulse (air); also 365 capillary vessels, 365 muscular junctions, 365 bones, 365 artieulations. The eranium in some systems consists of only one bone, in others of 8 in the male sex, 6 in the female; the lung has 8 lobes, the liver 7 . There is good evidence that osteology was studied from the skeletons in uncovered graves, and that dissection was performed, usually upon the bodies of exeeuted eriminals. 1

Chinese anatomy and physiology are thus dominated by the system of Huangti, with its strange antinomies of a fantastic number-lore and an exact physical anthropometry, its fabulous hierarchy of feudal and inter-social relations between the organs and viscera. Each organ is related to a color, taste, season and time of the day, has a parent and friends and enemies. The heart is the son of the liver, the son of the heart is the stomach, its friend the spleen, its enemy the kidney; red is its color, summer its season;

${ }^{1}$ For the above details I am indebted to the elear, terse and ship-shape presentation of Dr. E. T. Hsich, in Anat. Rec., Phila., 1921. 
it receives at mid-day (Welch). Other things being equal, the fantastic number-lore of Chinese physiology is no more contemptible than the mumerical system of Galen, which occupied the attention of European physicians for no less than 1700 years. But with such inadequate knowledge of human structure and function there could be very little surgery, particularly among a people whose religious convictions were against the drawing of blood or the mutilation of the body. Castration is the only operation they perform, and, while they use dry cupping and massage, they do not resort to venesection, but substitute the moxa and acupuncture. The moxa, introduced into European practice in the seventeenth cent ury, consists of little combustible cones which are applied all over the body and ignited. Acupuncture is the pricking of the body with ncedles, coarse or fine, which are sometimes twisted in the stretched skin. Both procedures are employed for purposes of counter-irritation in gouty and rheumatic disorders. Practice in acupuncture is obtained by puncturing the strategic holes of election on bronze images over pieces of paper (Cowdry). The Chinese were wonderfully clever at massage and were the first to employ the blind as masseurs. They were early acquainted with identification by finger-prints (dactyloseopy). Chinese pathology is characterized by an excessive amount of detail; for example, 10,000 varieties of fevers or 14 kinds of dysentery. In diagnosis they attach great importance to the pulse, the varieties of which are minutely subdivided and investigated by touchirg different parts of the radial artery of either hand with the fingers, after the fashion of striking the keys of a piano. In this way, six sets of pulse-data are elicited, which are connected with the different organs and their diseases. Michael Boym, a Jesuit missionary in China, first wote on (hinese pulse-lore (1666), giving plates representing their peculiar mode of feeling the pulse. His work was resurrected and published by the physician-botanist, Andreas Cleyer (1686). In his own compilation (1682), Cleyer gives wood cuts illustrating the Chinese doctrine of the pulse and the semeiology of the tongue, also thirty plates of Chinese anatomy, and other phases of medical sinology. The Chinese materia medica is unusually extensive and includes such well-known drugs as ginseng, rhubarb, pomegranate root, aconite, opium, arsenic, sulphur, and mercury (for inunction and fumigation in syphilis), and many disgusting remedies, such as the parts or excreta of animals. Millions of dollars are spent annually on clrugs. At a famous drugstore in Peking, 300 years old, it is said that $\$ 1000$ worth of native drugs are sold daily (Cowdry). Syphilis in China is said to go back to the Ming dynasty and references to gonorrhea are attributed to Huang-ti. The Hsi Yuan Lu, the official Chinese 
text-book of forensic medicine for hundreds of years, contains many empirical observations on poisons (IV Lien-Teh). The ancient (hinese knew of preventive inoculation against smallpox, which they probably got from India. Anmual statistical records of discase were aldeaty establishert in the Chon Li (1105 B. ( .), good hygicnic precepts were advaned in another book of 700 B. C., and the I Chin Ching is a well-known manual of physical culture, with illustrations. The plan of eating only cooked food, the sensible eostume of eotton and silk, the characteristie arlaptation of their arehitecture to elimate, all show the good common sense of the Chinese in these matters. But the infections discases are not ret notifiable, so that scarlatina and smallpox sweep away thousands. During the Manchurian epidenic of plague (1910-11), strategic (conters were established along the main railway lines in North China and have avaled to keep the disease out in the last five years. This is also true of the systematic rat-proofing of houses in Shanghai.

Modern medicine has been developed in China through the hospitals and medical schools established by the foreign missionaries, through similar institutions established by the governments of Great Britain (Hong Kong), Germany (Shanghai, Tsingtan), France (Canton), Japin (Peking, Shanghai, Hangkow, Mukden), by the China Medical Board of the Rockefeller Foundation (Peking), and by the Chinese government.

There are now 26 medical schools in China, the best of which are the Peking Union Medical College (Rockefeller Foundation), the Medical Department of the University of Hong Kong, the Japanese Medical School at Mukden and the Army and Naval Medical Schools at Peking and Tientsin respectively.2.

The originator of merlical missions in China was Dr. Peter Parker [1804s8], a Yale graduate, who founded the Ophthalmic Hospital at Canton (1835) and marle the unique collection of Chinese surgical paintings now in Yale. ${ }^{3}$ President Charles WT. Eliot, in a tour of China, stated that the most urgent need of its millions was medical education. To him was mainly due the foundation of the Harvard Medical School of China, the equipment of which was taken over in 1916 by the Rockefeller Foundation, along with the medical establishment of the University of Nanking. In 1916 the cornerstone of the Hunan-Yale Medical School was laid. The Chinese government has a National Medical College at Peking, the schools of military and naval medicine mentioned, and five provincial schools. The Japanese Mledical Sichool at Mukden, while actually owned by the South Manchuria Railway, is under strict governmental control, has a full-time staff, and publishes annual researches. The Rockefeller Foundation has spent seven million dollars on the Peking Union Medical College alone (1920). This establishment, with its splentlid buildings, is destined to be the nucleus of advanced merlical teaching in China. The deficiencies in Chinese medicine being mainly due to adherence to the stationary and fantastic scheme of Chinese anatomy, the sensible course has

1 Wu Lien-Teh: Nat. Med. Jour., China, Shanghai, 1916, ii, 32-36.

${ }^{2}$ E. V. Cowdry: Anat. Rec., Phila., 1921, xix.

${ }^{3}$ C. J. Bartlett: Jour. Am. Med. Assoc., Chicago, 1916, lxvii, 407-411. 
been taken of laving a firm foundation for instruction in this basic discipline. Progress is slow, owing to the preponterance of lecture hours in most of the schools, the diffienlty in obtaining material for dissection, and the inpression which seems to preval in the provineial sehools that what is to be tamght is practice of medicine and surgery and not the fundamental reienees upon whieh modern medieine is based. There is, further, the intransigenee and distrust of the native population. lack of funds on the part of the government, and at convietion of forty centuries' standing that medicine is a peor fifth-rate oretupation. Student attendance is sender, the matriculating elasses at the 26 medical schools not being more than 600 ammually for a population of millions. The National Medieal Asweiation of China had its first meetings in Shanghai on Fobruary $7-12,1916$. The Anatomieal and Anthropologieal Association of China held its first meeting at Peking on February 26, 1920. ${ }^{1}$

The Japanese are noted for their remarkable power of assimilating the culture of other nations, and, before they came in contact with European civilization, their medicine was simply an extension of Chinese medicine. Up till $96 \mathrm{~B}$. C. the healing art in Japan was passing through the mythical phases common to all forms of early medicine. ${ }^{2}$ Discase was supposed to be caused by divine influence (Kamino-no-lie), by devils and evil spirits or by spirits of the dead. Two deities, with particularly long names, presided over healing, which was further helped out by prayers and incantations, and at a later period, by internal remedies, venesection, and mineral baths. The period 96 B. C. -709 A. D. marks the ascendancy of Chincse medicine, which was introduced by way of Corea. The practitioners and teachers were priests. Pupils were sent to China at govermment expense, and by 702 A. D. there were native medical schools, with seven-year courses in internal medicine and shorter periods for the other branches. The students were made ishi or doctors after passing a final cxamination in the presence of the Minister, and women were occasionally trained as midwives. During the succeeding periods (710-1333), called the "Nara," "Heian," and so on, after the names of the different capitals of Japan, the influence of the Chinese priest-healers was still dominant, with some advances in surgical procedure, such as suturing intestinal wounds with mulberry fiber or couching a cataraet with needles. In 758, a hospital for the indigent sick was erected by Empress Komyo. The oldest Japanese medical book, the Ishinho, written by Yasuhori Tambu in 982, describes these surgical novelties, and also records the existence of lying-in hospitals and isolation houses for smallpox patients. During the medieval period, personal observations of clinical cases were recorded. The moxa, acupuncture, and many

1 Cowdry: Op. cit.

${ }^{2}$ Most of these details are taken from Y. Fujikawa's "Geschichte der Medizin in Japan," Tokyo, 1911. See, also, Léon Ardouin's "Aperȩu" (Yaris, 1884). 
of the Chinese herbal or mincral remerlies were in vogue and mas-

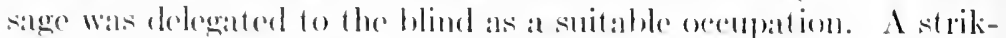
ing cont ribution of the aneient dapanese fo therapenties was their use of red latugings in the tratment of smallpox, the remedy

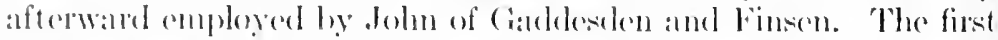
Portuguese ship fouched tapan in 1512, and with the arrival of st. Francis Xavior in 15l9 begins the rise of European influences. The physicians who ane with him and with the later missionartes-there was a Catholic rhureh at Kroto in lotis-treated the sick slatuitously, did surerieal work, founded hospitals, and planted botanic gardens. After the expukiom of the missionaries, two of their Japanese pupils settled at Salkai and fomded a sehool. The Dutch traders aume in 1597 and their ship's surgeons also rxerted some influence. A translation of Ambroïse Parés works was mate in the seventeenth century, but the importation of European books wits forbidden unt the year 1700 , after which time translations of Bochlawe, Van Swieten, Heister, and of her writers began to appear. Vaceination was intodueed by Mohnike in 1848. The medienl sehool founded by the Dutch physicians at Yoddo in 1857 passed info the hands of the government in 1860 and becance in time the present University of Tokyo. The modern or Meiji period of Japanese medicine begins with the rear of revolution, 1868, and its distinctive feature is the rise of German influences. The universities and medical academies, the state examinations, the medical societies and medical journals, are all copied after German models, and the ablest Japanese medical men of today-Shiga, Kitasato, Noguchi, Hata-have received their elucation and training in Cermany. This influence has persisted, even since the outbreak of the pan-European war. German is still the language of science in Japan, and religious ceremonies are still held at the little shinto shrine dedicated to the memory of Koch.

To sum up what is due to Oriental medicine, the Babylonians specialized in the matter of medical fees, the Jews originated medieal jurisprudence and public hygiene and ordained a weekly day of rest, the ('hinese introduced anthropometry, finger-prints, massage (osteopathy), ocupuncture, the moxa and many drugs, and the Hindus demonstrated that skill in operative surgery which has been a permanent possession of the Aryan race ever since. 


\section{GREEK MEDICINE}

\section{Before Hippocrates}

The Creeks were a Sammelvoll, a composite people, and their diverse elements-Ionian, Thessalian, Areadian, Achaian, Eolian, Dorian-gave them the self-willed independence, the restless individuality, of a momtaineer and sea-faring race, traits which were at once the secret of their greatness and their downfall. The physical geography of insular and peninsular Greece, with its deep coastwise indentations and abrupt mountain walls, isolated the whole country and its separate states in a way that made at once for intense local patriotism, and at the same time gave the cultural advantages of abunclant maritime intercourse with other nations, while such grandeur in external nature could only inspire the loftiest freedom of mind and spirit. Yet this very freedom of thought prevented Greece from becoming a nation in the end, for her people were too diverse in racial strain, pulled too many different ways, to become permanently united. Greek history is the history of several states, and these city-states "were too wilful to combine."

In the time of Grote, Greek history began with the first Olympiad (776 B. C.). Today, the origins of Greek civilization go back to at least 3400 B. C., and are found outside the Greek peninsula. Schliemann uneovered the plains of Troy in 1870-73, and unveiled the Egean civilization of Mycenæ and Tiryns (1600-1200 B. C.) in 1876-84. The Minoan eivilization of Crete. which goes back to Neolithic man, was revealed in the excavations of Sir Arthur Evans in 189t-1908. These investigations ${ }^{2}$ go to show that (rete, "a kind of half-way house between two continents," independent of the Eurasian and Eurafrican cultures, was the starting point of European civilization.

The early Minoan culture (3400-2000 B. C.), contemporaneous with the early dynasties of Egypt, the excavations lying over Neolithic strata which go back to $9000 \mathrm{~B}$. C., is characterized by polished stone axes, finely burnished pottery, steatopygous female figures of clay, with pronounced breasts, like those of Aurignaeian woman, with perhaps evidences of the worship of the p. 21

'Sir T. Clifford Allbutt: "Seience and Medievad Thought," London, 1901,

2 See Sir A. Evans: Reports of Excavations, 1900-190S in Ann. Brit. School, Athens, 1900-1908, passim. Also his "Prehistorie Tombs of Knossos" (1906), and scienee, X. Y., 1916, n. s., xliv, 399; 448. 


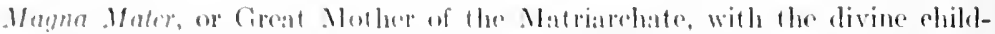

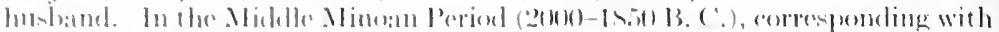

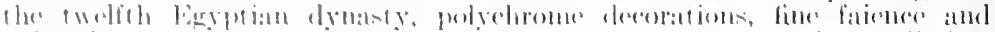

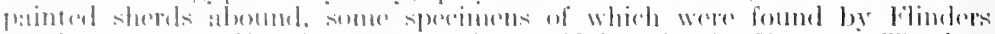

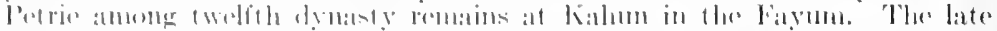

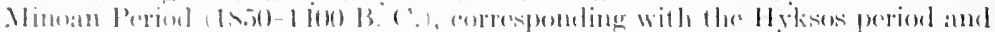

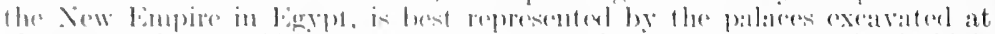

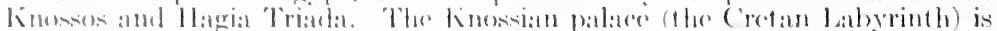

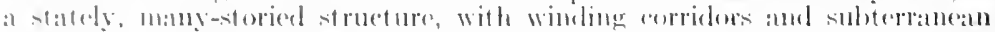

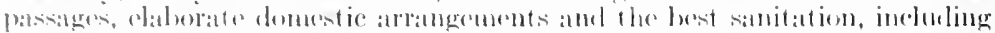

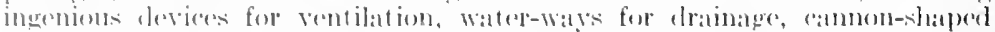
tertal cotta piping, and latrines which, in construetion, escel anything of the kind before the nineteenth eentury. "The corrielers, landings and porticos

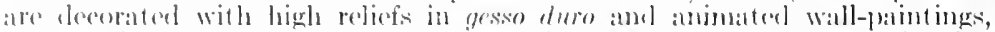

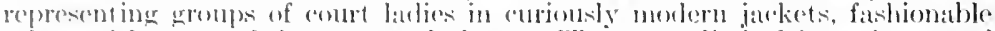

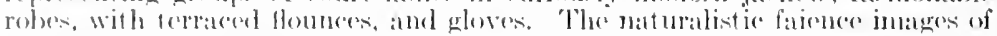

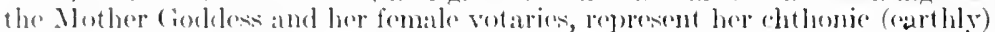
aspeet, with serpents, at tightly-waisted figure, with the neolithic bell-shatpord gnow, we appored mostern eut.

Gigantic, ormate :mphome for oil, freseo-prantings of bull-fights, with male and female toreadors (whenee the Athenian legend of the Minotater), a gaming-board of gold-plated ivory, a shrine, with eult objects and offertory rescols in place, a gypsum throne of Gothic anpect, evidence the highly sperializod culture of hinosios.

In the Egean or Myenanan culture revealed by Sehliemann, there is the sume skill in ceramies and seulpture, freseo-painting and ornamentation, the same mitsive arehitecture, as in the Lion's Gate at Iyeene. The anieonic stage of worship of trees and pillars is sueeeded by the eult of the (ireat Inther, with the elathonie snakes or uranic doves. Slateburial of the dead in eysts sunk in rock was followed by berhive tombs. The Nyceneman culture is probably smohronous with the P'elasgian, and the post-Mycenaan culture of the Honerie periond shows Minom influences. In place of the round shield and armor of the Homeric Greeks, the Minoan and Mycentan peoples used shielk covering the whole borly, and their ornaments are of the Bronze Age. The Ifomerie Greeks used iron weapons and eremated their dead. Their Olympian Ciols are not found in the Jlinoan and Mycenxan periods.

Of the early achievements of the historic Greeks, the Hellenes, Thuerdides himself says, at the beginning of his history, that "they were no great things." He points out that ancient Hellas had no settled population, wars and factions keeping the people in a state of constant migration. so that "the richest soils were always the most subject to change of masters." Under conditions like these, a restless, athletic, warlike and sea-faring people were developed whose chief interests were the active lives they led and the influence exerted upon their affairs by the gods of their worship.

As Walter Pater has so charmingly set forth, in his studies of Dionysus and "Hippolytus Veiled," it is a common error to suppose that the ancient Creeks everywhere worshiped the same Pantheon of gods. In point of fact, as being a rlivided people, the Hellenes of the mountains, the coast, the valleys, farms and riversicles had each a separate religion of their own, the whole forming,

${ }^{1}$ T. H. M. Clarke: Prehistoric Sanitation in Crete, Brit. Med. Jour., Lond., 1903, it, 597-599. 
of eomrse, an essential polytheism, in that every litte elan or village commmity worshiped its sperial god, at the sime time baying a vague gemeral reveremere to the greater gods. 'Thus, Demeter was the sperial divinity of those who lived on litus and among comfielek, Diongsus of those who altivated vineyateds, Poseidon of those who dwolt by the sea, Patlas Alheme of the Mllenians, while the lesser gods had oach a particular locality where their worship was a cult. "like a network over the hand of gracions poetic tradition," says Pater, "the local religions had heon never wholly superseded hy the worship of the great national temples." Thus we find, at the start, lhat there were many lutelary divinities of melieine among the Cireeks, with overtapping or interchangeable fundions in dilforent places. The Cirecks, as Pater says, hat not a religion, hut religions, "a theology with no central anthority, no link on historic time, liable from the first to an 1 observed transformation." Thus, Artemis (Diana), Demeter (('eres), Hermes (Mercury), Hera (Jumo), Poscidon (Neptune), Dionysus (Bacchus) were, all of them, patron gods and godklesses of the healing art, and were able, at need, to produce disease themselves. In the Hippocratic treatise "On the Sacred Disease", we read of epilepties that

"if they initate a goat, or grind their teeth, or if their right side he convulsed, they say that the mother of the gods (Cybele) is the cause. If they speak in a sharjer, shriller tone, they liken this state to a horse and say that Poseidon is the cause. . . But if foum be enitted by the mouth and the patient kick with his feet, Ares (Mars) gets the blame. But terrors which happen during the night, and fevers, and delirium, and jumpings out of bed, and frightful apparitions, and fleeing away-all these they hold to be the plots of Heeate, and the invasions of the Heroes, and use purifications and incantations, and, as appears to me, make the divinity to be most wicked and impious."

Thus, as appears from the deprecating Hippocratic allusion to Hecate, there existed, apart from the cult of the Olympian gods, a rlarker, obscurer cult, namely, the medical magic assoriated with the ritual of propitiating the soeallerl chthonian deities of the earth and the underworld. This was again not a general bedief, but eonfined to distinct localities, vaguely including the cults of the eelestial gods in their ancient chthonic aspect the eave gods, deified heroes, heroized physicians (Heroi Iatroi) and the perturbed spirits of the dead. The sarrificial rites were condueted in the witching hours before clawn and the deities invoked were never addressed directly by name, but pleno titulo, with flattering appellations. The references to chthonie deities in the (ireek authors are therefore obscure. In the (reek Pantheon, the greater $\chi \vartheta$ óv eal with Frazier's "Spirits of the Corn and the Willl." Hades (Aidoneus, Pluto), also styled "Zeus Katachthonius," Demeter ehthonia (the Corn Inther) and Persephone (Kore), goddess of death and the "poppied sleep." Hermes Psychopompos, of the golden wand and sandals, the conductor of souls to Hades (Odyssey XXIV, 1), Cerberus, Heate, the Erinnyes and all other malevolent spirits, were associated with this cult, and coördinate with it was the ritual of propitiating or invoking the departed spirits of the dead. ${ }^{2}$

I Pater: "Hippolytus V'eiled," op. cit., p. 162.

${ }^{2}$ E. Pohde: Psyche, 3. Aufl., Tübingen \& Leipzig, 1903, i, 204 and 278, passim. 
Apart from the purely religious ritual of the $x$ yon there arose an esoterie ritual therapy, derived from the ciremust ance that these dark power's controlled not only fruitfulness of the earth and in man, but could inflict or avert disease, insanity or death. Infernal deities, thirsting for the blood of human sacrifice, they were feared for their power of wreaking evil in the shape of insanity, epilepsy, hysteriat and other major nemoses. This archaic neurology is implieit in all the Greek poets, dramatists and philosophers. Thus Plato (Phadrus, 244) speaks of insunity as due to "ancient wrath," which Rohde interprets as the anger of departed souls. P're-Hippoeratic medieine was entirely prognostic and prophylactic. Prophylactie medicine was threefold: (1) Apotropaie, designed to ane't disease by ritual sacrifice; (2) Hilastic, designed to aborl disease by rites of propitiation or atonement: (3) Cat hartie, designed to east out disciso from the borty by rites of lustration (purfication). Disease, once in the body, was regarded ats at miasm, contamination or taboo cast upon the soul by angered infornal gods and spirits. The ehthonian animals and plants, sacred to these deities, and employed in lieu of human sacrifice to propitiate them, came to have associative remerlial functions, whether for purification from the stigma or as connected with the rite of communion or "cating the god," in the form of the parts of animals, sacrifieial cakes or ineenwe plants defieated to their worship. The ashes and rejeets of sacrifice (katharmata) formed a kind of sacred pharmacopocia, sometimes distributed among the worshipers and eaten hy them. as in the Asclepieia. Of the innumerable medieinal simples and animal remedies recommended by Gaten, Dioscorides and Pliny, it is obvious that but few have any pharmacologic rationale in the laboratory sense. Fach chthonian remedy became an open secret, justified by its mythologic associations. Some simples are even deseribed by Dioscorides and Pliny as the "blood" of different gorls and chthomian animals. But even as the drug

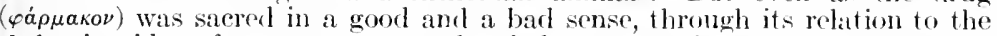
chtbonian idea of atonement or eatharsis by means of a sacrificial scapegoat (чарнако́s), so this empirieal therapy became detached from the priestly therapy of the temples, and its secret practitioners were regarded as magieians. The eareful sturly of Max Höfles shows that the modern theory of animal remedies did not originate with the Greeks, but with the doctrine of signatures (Similia similibus). From an analyws and tabulation of 1254 ancient organotherapeutic preseriptions, Hoffler shows that, except in the case of the liver, spleen and heart (all worthless), parts of the animal body were never ('mployed exclusively to heal diseases of the same parts, but in the most varied and capricious way, depending upon the tenets of the ehthonian cult. ${ }^{2}$ Aneient Greek organotherapy was "homeopathic magic" in the folklore sense, but by no means isotherapy, in the sense of "like cures like."

The chief god of healing in the Greek Pantheon was Apollo, commonly called Alexikakos (the averter of ills), whose far-darting arrows visited plagues and epidemics upon mankind and who could, at need, avert them. He was also the god of purity and wollbeing in youth, and, as Homer relates, the physician to the Olympian gods, whose wounds or diseases he cured by means of the root of the peony. Hence his name "Prean," and the epithet "sons of Pxan," as applied to physicians. Legend rolates that a knowledge ff medicine was communicated by Apollo and his sister Artemis to he Centaur Chiron, the son of Satum. As one skilled in music

${ }^{1}$ Frazer. "The homeopathic magie of at flesh diet," Spirits of the Corn ind the Will, 1912, ii, 138-168.

2 M. Höfler: Die volksmedizinische Organotherapie und ihr Verhältniss :um Kultopfer, Stuttgart, 190 S. 


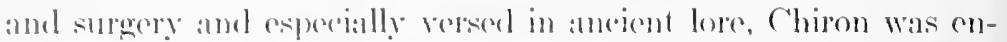

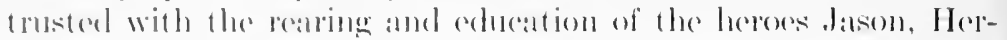

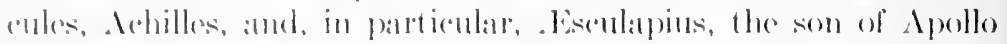
ly the nomple coromis. As l'melat sings, in his thirel l'ythian

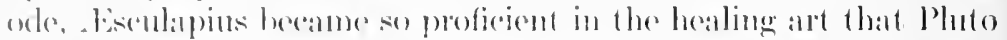
acensed him of dimbishing the number of shates in Mades, and he was destroged by a thumkerbolt of zoms. After his death he be(anme an olject of worship, and the tomples of his rult were the famous Aselepicia, of which the most eolehtated were those at cos, Epidanus, Conklus and l'ereamus. These temples, commonly

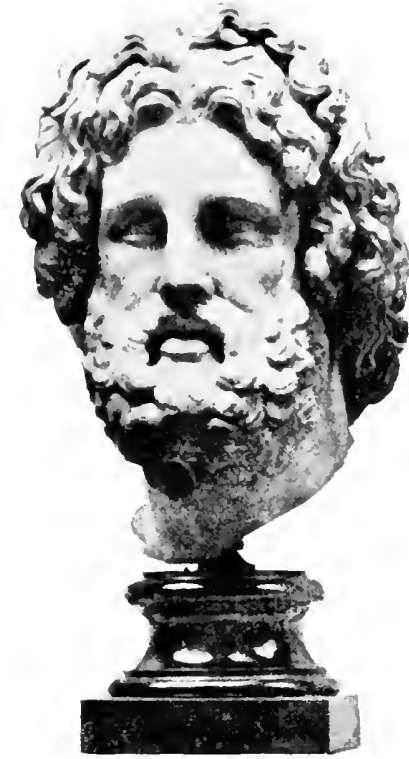

Colossal bust of Eseulapius in the British Museum. situated on wookled hills or mountain sicles, noar mimeral springs, became popularsanitaria, managed by trained pricsts and, in intention, not unlike the health-resorts of modern times. The patients were received by the physician-priests, who stired their imaginations by recounting the deeds of Fsculapius, the suceess of the temple treatment and the remedies employed. After appropliate prayers and sacrifice, the patient was further purified by a bath from the mineral spring, with massage, inunction and other methods, and, after offering up a cock or ram before the image of the god, was inducted into the special rite of "incubation" or the temple-slcep. This consisted in lying down to sleep in the sanctuary, where during the night, the priest, in the guise of the god, presented himself before the patient to administer medical advice, if he happened to be awake. If he slept, as was usually the case, the arlvice came in a dream, which was interpreted afterward by the priests, who then prescribed catharsis, emesis, blood-letting or whatever remedies secmed appropriate. If the treatment was successful and the patient cured, he then presented a thankoffering to the god, usually a model of the diseased part in wax, silver or gold, while a votive tablet giving the history of his case and its treatment was suspended in the temple.

The whole rite of incubation has been facetiously described in the "Plutus" of Aristophanes, and in more elevated and dignified style in the third chapter of Walter Pater's romance of Roman antiquity, "Mlarius the Epieurean." 
The votive tablets in the Asclepieia at Cos and Cnirlus became the permanent clinical records of the Coan and Cnirlian sehools of Merticine, of the first of which Hippoerates was himself a pupil. The Greek traveder Pausanias notieed six of these votive columns when he visited the temple at Epirlaurus about $150 \mathrm{~A}$. D., and two of them were exeat vated in recent tines by Cavvadias. Engraved upon these last were about thirty elinical eases, giving the names of the patients, their bodily ills and what was done for them. The details of symptoms and treatment are very meager. In most casses it sufficed if the gorl anointed the patient in his sleep or if one of the saced dogs or snakes in the temple licked the diseased part. One patient came with four fingers of his hand paralyzed, another was blind of one eye, another harl carried a spearpoint in his jaw for six years, another had an uleer of the stomach, another empyema, another was infested with vermin. All were reported as cured. ${ }^{1}$ These fragmentary case-histories, none of them conveying any medical infornation of positive value, are sometimes supposed to have been the startingjoint of the Hippocratic descriptions of disease.

Many antique images, in marble or terra cotta, exist, representing different parts of the body. These may be ex voto objects, or suspension in the temples, or simple plastic figurations of normal matomy. Those representing coils of intestines (in the Schlicnamn collection, Athens or the Museo dei Termi, Rome), the ehest, vith ribs (Vatican), or the situs visecrum (Vatican), are life-like nough to be simple examples of anatomic illustration in three limensions, with or without diclactic intention. ${ }^{2}$

Among the legendary children of Asculapius, by his wife, Epione, were his daughters Hygicia and Panacea, who assisted in he temple rites and fed the sacred snakes. With the ancient ireeks, as with the Egyptians, Cretans and Hindus, the serpent ras venerated as the companion of many gods or the favorite hthonian shape in which they sometimes appeared, as in the cases if the Minoan snake-goddess (Magna Mater) and Zeus Meilichios. $\mathrm{n}$ his uranie aspect, Esculapius is commonly represented as a andsome Jove-like figure, always attended by the sacred snake ntwined around a rod, a miniature Omphalos, like that of the emple of Apollo at Delphi-a plastic expression of his iatromantic ift-and a grotesque, childish figure (like a tiny-hooded monk or Iünchener Kindl) called Telesphorus, the god of convalescence. ${ }^{3}$ of the sons of Esculapius, two, Machaon and Podalirius, are nenloned in Homer's Catalogue of the Ships as learlers, commanding hirty vessels and "good physicians both." Esculapius is hinelf referred to in the Iliad as a real chieftain of Thessaly who

1 For further letails, see E. T. Withington, "Mlodieal History," London, 394, Appendix ii (pp. $370-397$ ).

2 See E. Holländer: Plastik und Medizin, Stuttgart, 1912.

${ }^{3}$ Telesphorus appears in the statues of Esculapius in the Villa Borghese ad Palazzo Massimo (Rome), in the ivory plaeque in the Liverpool Museum, nd in coins of Apamea and Nieas. In certain Eastern coins he is transformed to a cupping glass of mushroom shape. See L. Sehenk: De Telesphoro deon föttingen dissertation, 1S58), and E. Holländer: Plastik und Medizin. tut tgart, $1912,125-140$. 
learned medicine from the contam ('himon, from whose teaching, anatin, Arhilles was alhe to impart his knowledge of the healing art to his friond Patrochas. Matdaton and Podalirius are often refored to in Homer's narrative as men skilled in extracting weapons, binding up womels and applying soothing drugs. In the fourth Hiad, Maldaton is stmmoned to remove atl amow which was driven thromen the holt of Momelans, King of sparta. He arrives to find a circle of warriors a rathered about the hero, and "instantly thelempon he extracted the arrow from the woll-fitted belt. But while it was being extracted the sharp barbs were broken. 'Then he loosed the variegated belt and the girdle beneath, and the plated bolt which brass-workers had forged. But when he poreeived the wound, where the bitter shaft had fallen, having sucked out the blood, he skilfully sprinkled on it soothing remedies, which benevolent "hiron had fommoly given to his father." In the eleventh Iliad. Idomenems refers to Machaon as follows: "O Neleian Nestor, great glory of the Cirecks, come, aseond thy chariot and let Machaon momint beside thee: and direct thy solid-hoofed horses with all speed towards the ships, for a medieal man is the equal of many others, both to cut out arrows, and to apply mild remedies." It the end of the same book, Eurypylus, womded with an arrow in the thigh, calls upon Patroelus to remove it. He is borne to a tent, and there, Patroclus, "laying him at length, eut out with a knife the hitter, sharp arrow from his thigh, and washed the black blood from it with warm water. Then he applied a bitter, painassuaging root, rubbing it hetween his hands, which checked all his pains; the wound indeed dried up, and the bleeding ceased." In the thirteenth Iliad, Helenus, son of Priam, is smitten through the hand by the brass spear of Menclaus and we have a glimpse of the "great-hearted Agenor" extracting it and binding the wounded hand "sling-wise in well-twisted sheep's wool, which his attendant carried for the shepherd of the people." Homeric seenes of this kind are frequently depieted on antique vases (Daremberg) partieularly on the "bowl of Sosias" (500 B. C.), a speeimen of Creek ceranies in the Antiquarium of the Berlin Museum, representing Achilles bandaging the wounded arm of Patroclus. In the eighth Iliad (lines 81-86) there is a striking picture of the rotatory movements made by a horse which had been wounded in the brain by an arrow. The tenth Iliad (lines 25-31) contains, Cardamat is thinks, a reference to autumnal malarial fevers (the epiala of Theognis), which he attributes to the stagnant marshes and the destruetion of forests in the Bronze Age. ${ }^{1}$ That women sometimes rendered

${ }^{1}$ J. P. Cardamatis: Arch. f. Schiffs- u. Tropen-Hyg., Leipz., 1915, xix, 305 et seq. 
medical aid we gather from both Iliad and Odyssey, as in the referenees in the former to "yellow-haired Agamede, who well understood as many drugs as the wide earth nourishes," or, in the latter, to the soporific which Helen easts into the wine, a drug "which Polydamma, the wife of Thon, had given her, a woman of Egypt." In the Odysser, a healer of diseases is said to be as welcome at a feast as a prophet, a builder of ships, or even a gorllike minstrel. From these specimens of the war-surgery of the lliad it is plain that the surgeon's art was held in high esteem by the ancient Greeks, and that chicftains of high rank did not disdain to follow t. It is said that over forty different wounds are described by Homer (250 cases in all) but no details are given as to febrile or ther symptoms. The lesions were all the spear- and arrowrounds of primitive man, with no losses of limbs or crushing njuries; the mortality was 75 per cent.' The anatomic terms sed are, according to Malgaigne and Daremberg, more or less dentical with those employed by Hippocrates. There is no olscrvation of disease, but Delpech thought the description of Thersites (second Iliad) a typical picture of rickets. The scientific lisposal of the dead by cremation was a common practice of the Homeric Grecks.2

There is no mention of the Aselepieia in the Homeric poems, which date back to at least $1000 \mathrm{~B}$. C., but we may assmie that, ven then, laie physicians and surgeons were a distinct class from riests, although perhaps associated with the latter in time of reace. Apart from such "priests" and the medical nen proper, he healing art was studied by the philosophers, and practised in ome details by the "gymnasts," who bathed and amointed the rody and tried to treat wounds and injuries and even internal iseases. Greek medicine, as Osler has said, "had a triple relaionship with science, with gymmastics, and with theologr," and efore the time of Hippocrates, it was regarded simply as a branch f philosophy.

Greek philosophy before the age of Pericles was of Ionian origin nd was derived from Egypt and the East. Huxley regarded the rowth of the Ionian philosophy in the eighth to sixth centuries ;. C. as "only one of the several sporadic indications of some powerl mental ferment over the whole of the area comprised between he Egean and Northern Hindustan." This ferment, in the view f Zelia Nuttall and Elliot Smith, ${ }^{3}$ was the spread of a complex

${ }^{1}$ Holländer: Berl. klin. Wochenschr., 1916, liii, 355.

${ }^{2}$ H. Frölich: Janus, Amst., 1897-8, ii, 248-251.

${ }^{3}$ Nuttall: Archool. and Ethnol. Papers, Peaborly Mus. Harvard Tniv., ambridge, 1901, ii, 526. Elliot Smith: Bull. John Rylands Library, Manchesr, 1916, iii, 61 . 
Eurasian and Eurafrican culture he the Pronician navigators. It is significant that along the 35th parallel of North latitude we fimcl. almost simmltanemsly in point of time, Zoroaster, ('onfucius, Buddhal, Thales and Pythagoras (Wright'). 'The foumder of the

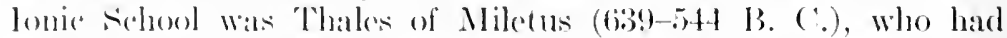
studied under the Eerpotian priests, and tamght that water is the primary olement from which all olse is derived. He was followed ly Anaximander of Milotus (611), who first mapped the heavens and mate a sucecestul prediction of an eclipse, Anaximenes of Miletus $(570-500$ B. ( .) and Heraclitus of Ephesus (circa 556460 13. (C), who, in sucession, assumed that indivisible matter (airth?), air, or fire respectively are the primordial elements. These four elements, anth, air, fire, water, were assumed by Alaxigoris of Clazomene (500-428 B. C.) to be made up of as many parts or "seed" as there are varieties of semsible or perceptible matter. These categories wore thrown into striking relief in the teaching of Empeclocles of Agrigentum in Sicily (504-443 B. ('), the picturesque hero of Matthew Arnold's poem, who as philosopher, physician, poet, traveled through the Greek eities, clad in a purple rolse, gold-einctured, laurel-rowned, long haired, severe of mien, and on account of his medical skill, was held by the people to be endowed with supernatural powers. One of his poetic framments shows the unusual reverence in which the Greek physieian was held at this time:

Ye friends, who in the mighty eity dwell

Along the vellow Aeragas, hard by

The Aeropolis, ye stewards of good works,

The stranger's refuge venerable and kind,

All hail, O friends! But unto ye I walk

As god immortal now, no more as man,

On all sides honored fittingly and well,

Crowned both with fillets, and with flowering wreaths.

When with my throngs of men and women I eome

To thriving eities I am sought by prayers,

And thousinds follow me that they may ask

The path to weal and vantage, eraving some

For orarles, whilst others seek to hear

A heating word 'gainst many' a foul disease

That all too long hath piereed with grievous pains. ${ }^{2}$

Empedocles introduced into philosophy the doctrine of the elements, earth, air, fire, water, as "the four-fold root of all things." The human body is supposed to be made up of these primordial substanees. health resulting from their balance, discase from imbalance. He holds that nothing ean be created or destroyed, and

${ }^{1} \mathrm{~J}$. Wright: Seient. Monthly, N. Y., 1920, xi, 131.

${ }^{2}$ From the interesting translations of the poetic fragments of Empedocles, by William Ellery Leonard in the Nonist, Chicago, 1907, xvii, p. 468. 
that there is only transformation, which is the modern theory of conservation of energy. Everything originates from the attraction of the four clements and is destroyed by their repulsion, and he applies the same idlea, uncter the forms of love and hate, to the moral world. Development is due to the union of dissimilar elements, deeay to the return of like to like, air to air, fire to fire, earth to earth. Empedocles is said to have raised Pantheia from a trance, to have checked an epidemic of malarial fever by draning swampy lands and to have improved the climatic condition of his native town by blocking a eleft in a mountain side. Legend relates that he ended his life by throwing himself into the crater of Mount Etna. His pupil Pausanias is said by Plutareh to have used fire in ehecking an epidemie.

The Italian School of Philosophers was founded by Pythagoras of Samos (580-489 B. ('.) at Crotona. Pythagoras was a good geometer and discoverel the pons asinorum (Euclicl, I, 47). He had studied in Egypt, whenee he probably acquirod his doctrine of the mystic power of numbers.

He held that unity being perfeetion and representing forl, the number twelve represents the whole material miverse, of which the factors three and four represent the worlds, the spheres and the primordial elements. As the monad (1) denotes the active or vital principle in nature, so the dyad (2) represents the passive principle or matter, the trial (3), the world, formed by the union of the two former, and the tetrad (4), the perfection of eternally flowing nature. Heaven is marle up of ten celestial spheres (nine of which are visible), the fixed stars, the seven planets and the earth. The distaness of the celestial spheres from the earth correspond with the proportion of sounds in the musical sicale.

Pythagoras was the first to investigate the mathematical physies of sound, and in the following way: In passing a blacksmith's shop, one day, he notieed that, when the smith's hammers were struck in rapid succession upon the anvil, the chords elicited (the octave, thirds and fifths) were all harmonious; the chord of the fourth was not. Going into the shop, he found that this was due, not to the shapes of the hammers or the foree with which they were struck, hut to the differenees in their individual weights. Upon this hint, he went home and stretehed four strings of the same material, length and thickness, suspending weights at the lower end of each, equal to the weights of the four hammers respectively. Upon striking these strings, he got the chords which he had heard in the smithy, and by subdividing the strings with other weights, he was able to construet the musieal scale. This was the earliest recorded experiment in physies, and the seale was, after his death, engraved on brass, and sot 11 in the temple of Juno at Samos. Pythagoras reasoned that the eelestial spheres might produce sounds by striking upon the surrounding other, and 
these somuts would vary with the veloeity of impact and the relative distanes. The distances of the spheres from the eath correspond. ats we have secell, to the proportion of someds in the sole, and at the hearouly bodies move aceoreling to fixed laws, the somols produced by thems must be hamoniogs. This is the doetrine of the "hammonty of the spheres." The mumber-lore of Pythagoras is thought to have exerted a profound influenere upon

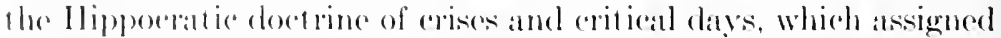
fixed periods to the resolution of different discases. More than to anything olse, the circek physicians aspired to the seiontific power of predietion. In pathologer, the plastice significance of the mumber forr was anduned, in the traching of Plato and Aristotle, with the doetrine of the four olements, as follows:

Corresponding with the clements of earth, air, fire and water were the yualities dry, cold, hot and moist, according to the scheme:

$$
\begin{array}{ll}
\text { hot }+ \text { dry }=\text { fire; } & \text { cold }+ \text { dry }=\text { earth. } \\
\text { hot }+ \text { moist }=\text { air } & \text { cold }+ \text { moist }=\text { water. }
\end{array}
$$

By reversing these equations, the four elements fire, air, earth and water, which correspoml with our hydrogen, oxygen, earbon, nitrogen,' eould be resolved into their qualitative eomponents. Long before Aristotle, probably before Hippoerates, it was held that, eorrespontling to these four elements, fire, air, water, earth, and the four qualities, hot, cold, moist, dry, are the four humors of the broly, viz., bloot, phlegm, vellow bile, and black bile. These three sets of elements, qualities and humors eould then be brought, by permutation and combination, into a complex system of arrangements, based upon the following sehene:

$$
\begin{array}{ll}
\text { hot }+ \text { moist }=\text { blood } ; & \text { ende }+ \text { moist }=\text { phlegm; } \\
\text { hot }+ \text { dry }=\text { yollow bile; } & \text { cold }+ \text { ily }=\text { black bile, }
\end{array}
$$

the different combinations giving the qualitative aspects of disease, and, by the same token, of the physiologie action of drugs. The whole arrangement made up the "humoral pathology" which regarded health and disease as the proper alljustment or imbalanee respeetively of the different components mentioned. and the seheme was further claborated by Galen and the Arabian phycians, in that remedies and their eompounds were elassified in numerieal seates aceorling to the "degrees" or relative proportions of their several qualities. Thu the Arabian pharmacists held that sugar is cold in the first degree, warm in the seeond degree, dry in the seeond degree, and moist in the first degree; cardamoms are warm in the first degree, eold by one-half a degree, dry in the first degree, and so forth. In Calen's system, the Prthagorean doctrine of numbers wits applied to every aspect of medieine. For example, there are three faenlties, natural, spiritual, animal. There are three spirits: the natural, arising from the liver; the vital, from the heart, the animal, from the brain, the three being distributed : m d diffused through the body by the veins, arteries and nerves. There are four ages of man, adolescenee (hot and moist); manhood (hot and dry); adtaneed age (cold and (try); old age (cold and morist). The eye has seren coats and three humors. There are three kinds of drinks. pure, as water; containing food, as wine; or a mixture of both, as srtups and inerlieinal draughts. There are three kinds of fevers, the ephemeral, in the spirit; the othie (hectie?), in the solids; and the putrid, in the humors; and the putrid are of four varieties, the continued (synochal), in the blood; the quoticlian, in the phleam; the tertian, in the yellow bile; the

${ }^{1}$ Pigel-Sudhoff, 64. 
quartan, in the black bile. ${ }^{1}$ In short, everything in Cialenic and Arabic medieine was mathematically subdivided, usually by the sacred numerals of Pythagoras.

In Egypt, Pythagoras learned the doctrine of transmigration of souls or metempsychosis and he is credited with being the first to establish the fact that the brain is the central organ of the higher activities, a proposition which was long afterward put to experimental proof by Flourens and Goltz.

After Pythagoras, the most important of the Greek Philosophers, with the exception of Plato and Aristotle, were his pupil, the amost mythical Alemaon, who anticipated Empedoeles in the doetrine that health is the equipoise, disease the maladjustment of any such forces as heat, cold, moisture, dryness, acidity, swcetness, ete., probably knew of the doctrine of atoms and pores, and also stated the fact that the brain is the central organ of the higher activities and the origin of the nerves; and Demorritus of Abdera (460-360 B. C.), who first stated the theory that everything in nature, including the body and the soul, is made up of atoms of different shapes and sizes, the movements of which are the cause of life and mental activity. ${ }^{2}$

During the Heroie Age, and at the time of the 'Trojan war, the dominant people in the Peloponnesus were the athletic, simpleminded Achaians, whose high regard for surgery and the surgeon was in striking contrast with the attitude of the ancient Pomans. In later times, Greek civilization was made up of two main elements, the Ionian or Attic, and the Dorie or Spartan. The composite, imaginative, artistie peoples of Ionia and the islands were interested in everything, and at once hrave and warlike, keen and business-like, serious and high-minded, or, at need, flippant and ironical. As we see them in the comedies of Aristophanes, Lucian's dialogues and the idyls of Theocritus, the city-bred (irecks were a gay, quick-minded, supremely talkative people, adoring intelligenee for itself, fonder of speculation than of material facts, keen at taking an advantage, and cheerfully complaisant as to their neighbors' morals. Yet they were the same people who could listen with reverent attention to the dramas of Eschylus and Sophocles. In striking contrast were the Dorians or Spartans, who were essentially robust, mimaginative warrors, sovere in

'For further illustrations, see the rey thoroughgoing aceount of Cialen': system by Jolannitius in the "Nedieal History" of $\mathrm{E}$. 'T. Withington (London, 1894), pp. 3\&6-396.

2 For an interesting examination of the views of these philosophers, sere the papers of Jonathan Wright in ficient. Monthly, N. Y., 1920, xi, 127-140; and New York Ned. Jour., 1918-20, passim. Wright holds Alemaron and Empedocles to be more akin to Hippocrates in theory than any other Greek phitosophers. 
such morals as they had, and like the Homeric Greeks and the ancient Romans, cultivating the body rather than the mind, as an csicential part of their seheme of military government. Under the harsh laws of Lxedurgus, engenie procreation wats compulsory. (rippled and deformed infants were exposed or thrown into the Eurotas. As with all military peoples, the Spartans were narrowly jealous, suspicious or contemptuous of achievement or prosperity in other nations. Both Ionians and spartans were extremely curious about the fut ure, and, like all people of carty civilizations, attached enormous importance to orates, presages and omons, so that prognosis wats still the essential feature of Cireck medicine before Hippocrates. Among the Sipartans, the surgeons were held in the same high regard as :unong the Ilomeric heroes, and lyeurgus classed them as non-combatant officials. Among the Attic or Ionian Greeks, the medieal profession, as we approach the Age of Perieles, is found to be more highly specialized. In the first place, general practitioners began, towird the later period, to receive stipulated fees for their services instead of the usual thank-offerings of the temples, and, further, city and district or public physicians came to be appointed at an annual salary which, for the times, was quite high in the case of Denocedes at Athens (circa 525 B. (.) about $\$ 2000$. These existed from Homer's time, are mentioned by Herodotus, and Diodorus, and were well-known in Athens from the Periclean Age down to the first eentury A. D., als evidenced in Aristophanes, and many Greek inscriptions. After this time, they beeame known as apyearpot. From the Greek institution of the public physician, the Romans derived their archiater, whence the Cierman "Arzt." In Thessaly, the land of horses, there was a publie veterinarian (Hippiatros'). There were also military and naval surgeons among the Athenians, as among the Spartans. Xenophon records that there were eight army surgeons with the expedition of the Ten Thousand, at the end of the fifth century, refers to snow-blindness and gangrene fiom frosthite, and mentions the use of silver kettles for boiling water. There were again midwives, professional lithotomists, druggists and veterinarians, and finally a speeial class, the "rhizotomi," or root gatherers, who wandered through the fields and forests collecting vegetable simples. The physieian's office was ealled the Iatreion, and was used indifferently as a dispensary, consulting room and operating theater. In the larger eities there were public Iatreia, supported by special taxes.

Medical instruction was not organized and was, in effeet, private, either under some renowned physician or received from the

1 R. Pohl: De Grecorum medicis publicis, Janus, Amst., 1905, x, 491-194. 
adherents of the different schools. On finishing his course, the graduate simply took the physician's oath of the particular medical clan or sect to which he belonged.

Such human anatomy as the (ireek physicians and surgeons learned was identical with the sculptor's knowledge of the subject, which the latter aequired through constant familiarity with the appearance of the nude body in action, either cluring the athletic contests codebrated by Pindar or in the palicstra. "It was here," salys Waldstein, "with hundreds of mude youths, not only wrestling, jumping and rumning, but endeavoring by systematic practice to remedy any defect or abnormality in any one limb or organ, that the artist, day by day, studied his anatomy of the human figure without the need of entering the disseeting room."' What Pater calls "the age of athletic prizemen" wats also the great age of Creek sculpture, and in nothing is the discriminating power of Greek intelligence more beautifully and nobly shown than in the masterpieces of the great artists of this period. In reference to their remarkable capacity for close olservation, Waldstein notes that the pectineus muscle, hidden at the base of Searpa's triangle, but highly cleveloped in the stress of Greek athletics, appears in some of their statues, although it has escaped the attention of modern artistic anatomists. ${ }^{2}$

The medical lore in the Greek poets and writers between Homer and Hippocrates is considerable and has been collated, classified as to anatomy, physiology, pathology, military medicine and medical education by ('harles Daremberg's but much of this vast territory needs further exploration in the light of recent medicine.

In regard to education and personal hygiene, the Cirecks cultivated that ideal of a harmonious development of all the individual faculties which was set aside or lost sight of during the Middle Ages, but has been steadily coming more and more to the front in later times. With such training, it is not strange that the Hellenes of the fifth century attained a degree of eivilization and a supremacy in philosophy, lyrical and dramatic poetry, sculpture and architecture, which has not been equaled by any people who came after them. And this culninating period was also the Age of Hippocrates. 401.

"Sce Charles Wallstein: "The Argive Hereum," Boston, 1902, pp. 400,

${ }^{2}$ See Waldstein: Op. cit., $1 \mathrm{s6}, \mathrm{Mp}$. xxx and xxxiv; also chlitorial in Jour. Am. Merl. Assoc., Chicago, July 15, 1911, p. 222.

${ }^{3} \mathrm{C}$. Daremberg: Etat de lat médecine entre Homère et Hippocrate, Paris, 1869. 


\section{TH: Clasite Prirat) (460-136; B. C.)}

Guropean modicine begins proporty in the Age of Pericles and its scientific advancement centers in the fignue of Hippocrates

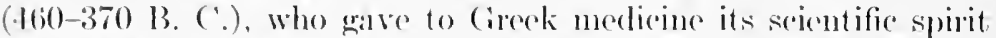
and its oflucal ideals. A rontemporary of Sophocles and Euripides, Aristoplinnes and Pindar, Socrates and Plato, Horodotus and Thuegdides, Phidias and Polygnotus, he lived at a time when the Athenian democracy had attained its highest point of development. Never, hefore or since, had so many men of genius appeared in the same namow limits of space and time. Hippocrates was

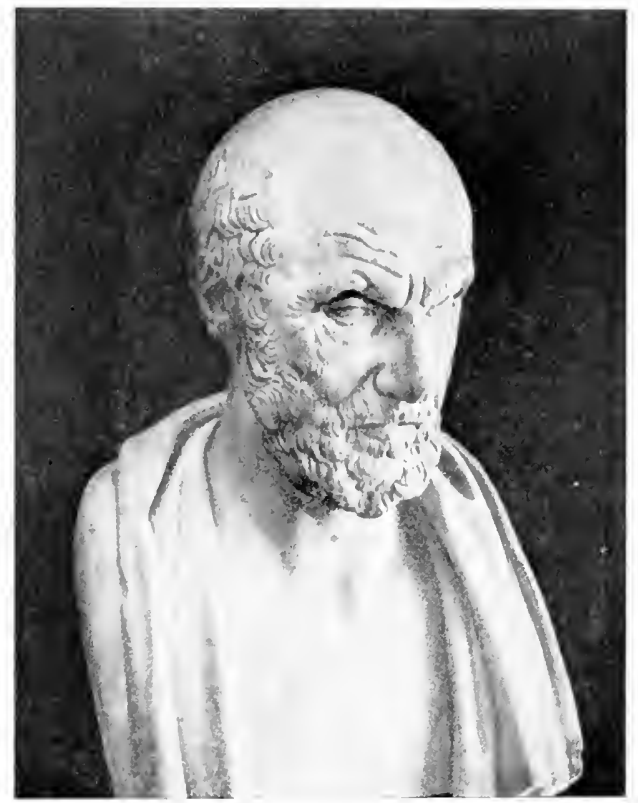

Hippocrates (460-370 B. C.). (Greek marble bust in the British Museum.)

born, according to Soranus, in the island of Cos, at the beginning of the eightieth Olympiad, of an Asclepiad family. He received his first medical instruction from his father, studied at Athens, and acquired extensive experience in travel and practice among the cities of Thrace. Thessaly, and Macedonia. The date of his death is unknown, his age being variously given as anywhere from 85 to 109 years. The eminence of Hippoerates is three-fold: he dissociated medicine from theurgy and philosophy, ${ }^{1}$ crystallized

1 "Primus quidem ex omnibus memoria dignus, ab studio sapientiæ disciplinam hanc separavit." Celsus, De re medica, Proømium. 
the loose knowledge of the C'oan and Cnidian Schools into systematic science, and gave physicians the highest moral inspiration they have. No future facts that may be dug up about amoiform or papyric medieine will quite impair the value of the great advance he made in synthetic science. Before the Age of Pericles, the Greek physician was (rither an associate of priests in times of peace or a surgeon in time of war. As the Greek mind was essentially plastic, so, in anatomy, his knowledge was mainly the sculptor" knowledge of visible or palpable parts, and, for this reason, his clinical knowledge of internal diseases was confined to externalities also. Even as

The Crecian gods were like the Gireeks, As keen-eyed, cold and fair,

so the early Hellenic physician remained essentially a surgeon rather than a clinician in his attitude toward his patients, considering only the surface indications. In cold, dry enumeration of symptoms, the Coan and Cniclian tablets and sentences, like the Egyptian papyri, might have been scientific, if the physicians: of the time had known how to group and coördinate symptoms and consequently to interpret them. All this was changed with the advent of Hippocrates. All that a man of genius could do for internal medicine, with no other instrument of precision than his own open mind and keen senses, he accomplisherl, and, with these reservations, his best descriptions of clisease are models of their kind today. To him medicine owes the art of clinical inspection and observation, and he is, above all, the exemplar of that flexible, critical, well-poised attitude of mind, ever on the lookout for sources of error, which is the very essence of the scientific spirit. As Allbutt points out, ${ }^{1}$ Hippocrates taught the Coan physicians that, in relation to an internal malady like empyema or malarial fever, the basis of all real knowledge lies in the application of the inductive method, that "grinding or rubbing in," which, better than the mere haphazard notation of symptoms, consists in going over them again and again, until the real values in the elinical picture begin to stand out of themselves. Thus, instead of attributing disease to the gods or other fantastic imaginations, like his predecessors, Hippocrates virtually founded that bedside method which was afterward employed with such signal ability by Sydenham, Heberden, Laënnec, Bright and Addison, the Dublin clinicians of the fiftics, Frerichs, Duchenne of Boulogne, and Charcot. Huchard says that the revival of the Hippocratic methods in the seventeenth century and their trimphant vindication by

\footnotetext{
1Sir T. C. Allbutt: "The Historical Relations of Medicine and Surgery," London, 1905, pp. 6-13.
} 
the eonerted seientifie movement of the nineteenth, is the whole histery of internal medicine. The eentral llippoeratic doetrine, the humoral pathology, which, as we haveseen, at tibutes all disease to disorders of the fluids of the body, has, in its original form, long sinee been discartede although some phasese of it still survive in the moelcrn theory of sorodiannosis and serotherapy. It is the method of Hipporates. the use of the mind and senses as diagnostic instruments, together with his transparent honesty and his elevated conception of the dignity of the physician's calling, his high seriousness and deep respect for his patients, that make him, by common "msent, the "Father of Medicine" and the greatest of all phỵsicians.

Claude Bernatd said that observation is a passive science, experimentation an active science. Hippocrates was not acpuainted with experiment, but no physican ever profited more by experience. Although Asclepiades called this observational method "a meditation upon death," the work of Hippocrates must be judged by its results. He described the "lilious, malarial, hemoglobinuric" fevers of Thessaly and Thrace very much as the modern Greek writers, Cardamatis, Kanellis, and the rest, have found them today, and it has often been remarked that his clinical pictures of phthisis, puerperal septicemia, epilepsy, epidemic parotitis, the quotidian, tertian, and quartan varieties of remittent fever, and some other diseases might, with a few changes and additions, take their place in any modern text-book. Many clinical cases in the Hippocratic books have been provided with a diagnosis-tag by Littré. Acrording to Paul Richter, Hippocrates described anthrax as $\pi i p$ "rpen (ignis agrestisi), the "Persian fire" of Avicenna, which Gialen wrongly interpreted as erysipelas. ${ }^{2}$ In the treatise on epidemic diseases, the correlation between paraplegia, epistaxis and influenzal fevers is noted, and lathyrism is described as impotency in the legs from continuously eating peas (II. Sect. IV, 3). Of forty-two clinical cases in Hippocrates-ahmost the only records of the kind for the next 1700 years-twenty-five are reported with characteristic sincerity as fatal, and, unlike Galen, the author has nothing whatever to say about his own clever diagnoses and remarkable cures. or of blunders on the part of his fellow practitioners. "I have written this down deliberately," says Hippocrates in one passage, "believing it is valuable to learn of unsuccessful experiments and to know the causes of their failure." 3 "He

\footnotetext{
${ }^{1}$ Epidem., vii, 20.

${ }^{2}$ Richter: Arch. f. Gesch. d. Merl., Leipz., 1912-13, vi, 2\$1-297.

${ }^{3}$ Cited by Osler in his Silliman Lectures, soon to be published by the Yale Press.
} 
seems," says Billings, "to have written mainly for the purpose of telling what he himself knew, and this motive-rare among all writers-is especially rare among writers on medicine." I Through Hippoerates, it was the chief glory of Greek medicine to have introdueed that spontaneous, first-hand study of nature, with a definitely honest intention, which is the motor power of modern science. After the Hipporatic period, the practice of taking clinical ease-histories died out, for Calen's cases were written only to puff his own reputation, and there was nothing of value up to the post-mortems of Benivieni and Vesalius.

The works attributed to Hippocrates are a Canon or scriptural body of coctrine, usually divided into four groups-the genuine, the spurious, the works of his predecessors, and those of his contemporaries and followers.2 Written in Ionic Greek, the genuine writings include, at least, those remarkable clinieal jottings, the Aphorisms (Books I-III), the treatises on Prognosis, on Epidemic. Diseases (Books I and III), on Diet in Acute Diseases, Wounds of the Head, Dislocations, Fractures and Clcors, and the exeursus, On Airs, Waters and Places, which is at once the first book ever written on medieal geoglaphy, chmatology, and anthropology, if we except the contemporary narrative of Herodotus, with whom Hippoerates is often in such striking accord. The oures, or Physician's Oath, the earliest and most impressive document in merlical ethies, is not usually regarded as a genume Hippocratic writing, but is thought to be an ancient temple oath of the Aselepiads. ${ }^{3}$ Yet both the ()ath and the Law are so much in keeping with what we know of the ethical spirit of the grat Coan that they are usually inclucled in the Hippoeratic cinon. To a modern reader, the best of the Aphorisms seem like the short-hand notes of a keen mind at the bedside, intent on establishing a true relation between generals and particulars, accidentals and cssentials. While many of them go straight to the mark, others are strongly suggestive of the kind of inadequate information that was probably convered in the Coan and chidian sentences. The Prognostics, the finished net result of the Coan Prenotions and Prorrhetics of his predecessors, show that the dignity of the Cirek physician was based more upon his ability to prediet clinical and epideniological happenings than his power to eontrol them. To this end Hippoerates instituted, for the first time, a careful, systematio,

1.J. S. Billings: "History of Surgery," New York, 1S95, p. 24.

'For a chronologie schema of the Hippocratie writings (Petersen-Littre) see Landsberg, Janus, ( Fotha, 1853, ii, 107-110.

${ }^{3}$ For a modified form of the Hippocratic oath, prepares by the late Dr. John (i. Curtis for arlministration to medical graduates, see: Ref. Handl,. Med. S.c. (Stedman), N. Y, v, 244. 
and tholough-going examination of the pationt's condition, inchul-

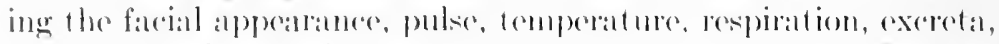
sputum, localized pains, and moxements of the body. He cren notes the ominoms symptom of pioking at the arowlid in fevers.

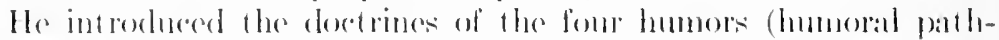

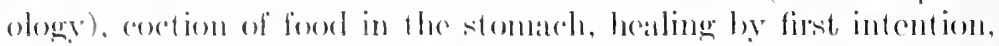

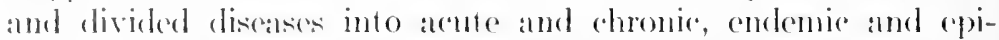
demie. The books on epidemice diseases, classical studies on the estermal ranses of epidemiss, contain the rematrable case histories and alinical pietules to which we have reforred. Not the least among these is the famons "falcios Hippocratica," that wonderful thumb-nat sketeh of the signs of atploroathing dissolution, some fourhes of which are given in shakespeare's alceoment of Falstafl's death. While there is much in the surgieal writings of Hippoerates that is faulty, incomplete, or not in alcordance with modern practice, ther are the only thine of value on the subject before the time of ('elsus. The treatises on fratetures, dislocations, and womels may be thought of as modern works in the same sense in which Matthew Arnold regareled Thuevelides as a modern writer, illustrating the wonderful capaldity of Greek intelligence for sepalating essentials from aecidentals, "the tendeney to observe farets with a critical spirit; to search for their law, not to wander among them at random; to judge by the rule of reason, not hy the impulse of prejudice or "aprice." "Some of the greatest medical seholars, Malgaigne, Littre, Petrequin, Allbutt, and the rest, have pronouncel the Hippocratic books on fractures, dislocations, and wounds, given the limitations molder which they were written, to the the equal of any similar work of a more recent day. Dislocitions of the shoulder, Hippocrates says, are "rarely inwards or outwards, but frequently and chiefly downwards," and his methods of reduction are practically those of modern times. He was particularly strong in his account of congenital dislocations, and in reducing and bandaging fractures. Ile was the first to notice that ${ }^{3}$ gibbous spine (Pott's disease) often coexists with tubercle of the lungs, and was familiar with club-foot. In his treatise on dislocations $(\$ 47)$, he describes the Calot treatment of spinal deformity by redressement forcé. He was acquainted with fracture of the clavicle and dislocation of its acromial end, and knew how to treat both conclitions. In the treatment of wounds, he says that they should never be irrigated except with clean water or wine, the dry state being nearest to the healthy, the wet to the

${ }^{1}$ Prognosis, $\$ 2$.

2Matthew Arnold: "Essays in Criticism," third series, Boston, 1910, p. 48.

${ }^{3}$ Dislocations, $\$ 41$; Aphorisms, vi, 46. 
diseased, and the aseptic advantages of extreme dryness were utilized in the avoidance of greasy dressings and the effort to bring the fresh edges of the wound into close apposition, sometimes br the use of astringents. ${ }^{1}$ Hippocrates recognizes that "rest and immobilization are of cappital importance," and to keep still is even a better sphint than bandaging. He deseribes the symptons of suppuration, and solys that, in such casses, medicated dressings, if applied at all, should be "not upon the wound itself, but around it." If water was used for irrigation, it had either to be very pure or else boiled, and the hands and nails of the operator were to be cleansed. Hippoerates gives the first description of healing by first and second intention. In his description of the operatingroom, he lays stress upon good illumination, posture of the patient, and the presence of capable assistants. He refer's to trephining and paracentesis, but apparently knew nothing of amputation. In his direetions for trephining in head injuries he notes that a wound of the left temporal region will cause convulsions on the right side and vice verse. The Hippocratic aphorism that diseases not curable by iron are curable by fire, which caused no end of surgical bungling and malpractice down to the time of Paré, is really pre-Hippocratic, being already mentioned in the Agamemnon of Exchylus. It has been traced by Balas to the ancient Itindus. In elinical diagnosis, Hipporates was the first to note the "sucussion sound," obtained by shaking the patient on al rigid seat, the car being applied to the rhest. Littré also comments on a "boiling sound," and a sound like that made by new leather. (heyneStokes respiration ("like that of a person recollecting himself") is noted in the case of Philiseus."

In therapenties, Hippocrates believed simply in assisting mature, and although he knew the use of many drugs, his seheme of treatment was usually confined to such plain expedients as fresh air, good diet, purgation, tisans of harley water, wine, massige, and hydrotherapy. In Greek merticine, black hollebore (Helleborus niger) was the universal purge, white hellebore (Veratrum album), the universal enetic.

In literary style Hippociates is like the best (ireek writers of the classic period, clear, precise, and simple. The traet on ancient mediene is the first script on medieal history. The Law, the Oath, and the diseourse On the Sacred Disease are the loftiest utterances of Greek medieine, and, whether due to Hippocrates or not, they represent the essence of his teaching. Behind the sensible

1 While the dry treatment of wounds was undoubtedly aseptie, as far as it went, Sudhoff warns us against the erroneous tendenc'y of Anagnostakis and others to regard Hippocratic wound surgery as "ant iseptic," in the modern semse.

${ }^{2}$ Epid. Dis., Bk. i, sect. 3, \$ 13, Case 1. Cited by Finlayson. 
phenomena of nature he surmiserl the existence of some tremendous powrer (cnormom), which sots things going. The argument of the "siacled bisasse," which deak with the supposed divine origin of epilopsy, was the highest reach of free thowght for eonturies, and had it boen berelod, womld have dome away forever with the foolish ideat that human ills aro caused by gods or domons.

The usual portrats of Hippocrates ropresent an old, bearded man of venerable aspert. They are in no sense "ommterfoit presontments," but only traditional. In the Clouds of Aristoplatues, there is a satirical reference to physioians as lazy, lomg-haned fopplish individuals with rings and arefully polished nails, which is supposed to have been, incidentally, a slap) at the Father of Merlicine. It is highly pohable that physicians of the Periclean Age wore their hair and bearels as much like the figures of Jove or Esculapius as possible, and wore otherwise not lacking in the selfsufficioney which chatracterized the Greeks of the period. Wre may therefore infor that the supposed portrats of Hippocrates are only valiants of the lust of Asculapius, as rentered into mathe by Praxiteles (in the British Museum), or as soon in statuettes from the shrine of Epidaurus or on the Cireck eoins of Cos, Pergamus, and Epidaurus, representing him enthroned.

The most important editions of Hippocrates are:

1. The folio Latin text of the Opera Omnia, translated and edited by Fabius Calvus, the friend and patron of Raphart, and published at Rome under the auspices of Pope Clement VII in 1525. This was the first complete edition of Hippocrates to be printed.

2. The folio editio princeps of the Greek text, publisher in the following year $(1526)$ by Allus at Venice.

3. The Based Opra Omma, arlited by Janus Comarius and printed by Froben (1538), highly prized on account of its textual and eritical aceuracy.

4. The Greek text and Latin translation of Ifieronymus Mereurialis, printed by the houke of Giunta at Venice in 1538.

5 . The Frankfurt ention of 159.5 , containing the valuable translation and commentary of Anutius Foesius, the most learned, industrious and able of the Hippoeratic commentators before the time of Littre.

4. The magnifieent ten-rolume edition of Littré himself (I'aris, 1839-61), containing the Greek text, a French translation (all the reading $<$ known having been earefully eoliated with eritical notes), a biographic introduction and special introduetions to each separate treatise. It was the work of a lifetime and is one of the triumphs of modern scholarship.

The first Greek trext of the Aphorisms wis edited by Francois Rabelais, and published at Lyons, in 1532 . The parallel fireek and Latin texts of $\mathbf{J}$. A. van der Linden (Lviden, 1665) and C. (i. Kühn (3 v., Leipzig, 1825-7) are handy and highly esteemed. Of English translations, the most valuable is that of the scoteh scholar, Franeis Alams (London, 1849), which is limited to the genuine works of Hippocrates. Next to this, the handiest for practical use is the (Eures shoisies of Charles Daremberg (Paris, 1834); an excellent German translation is that of R. Fuchs (3 v., Munich, 1s9.5-190s). The surgieal writings have been edited, with splendid commientaries, by .I. E. Petroquin (2 v., Paris, 18T-\$- ). To understand the relation of Hippoerates to modern merlieine, the bilingual anthology of Theodor Beck (Hippocrates' Erkenntnisse, Jena, 1907) is highly recommended for beginners by suthoff. 
Hippoerates voiced the spirit of an entire epoch, and after his time there was a great gap in the continuity of (ireck medicine. In suceeding centuries, the open-minded, receptive spirit of his teaching became merged into the casc-hardened formalism of dogmatists like Praxagoras, who eared more for rigid doctrine than for investigation. The dogmatists divided medical science into five branches: physiology, actiology (pathology), hyciene, semeiology and therapeutics. Of these, the later Empiries retained only the practical branches of semeiology and therapeutics, with its subdivisions of dieteties, pharmacology, surgery, and sometimes hygiene.

The greatest seientific name after Hippocrates is that of "the master of those who know," the Asclepiad Aristotle (384-322 B. (') of Stagira, who gave to medieine the beginnings of botany, zoölogs, comparative anatomy, embryology, teratology and physiology, and the use of formal logic as an instrument of precision. He taught anatomy by the dissection of animals and by his "anatomieal diagrams which are represented on the walls."' Aristotle was a pupil of Plato, whose Timaus imposed some very fantastic theories upon medical teaching for centuries, but he improved upon his master to the extent of describing about 500 species of animals (some of them fietitious), and studying their bodily structure and function. His most important works are his Historia animalium and the treatises on generation and motion.

He named the aorta, and noted an number of facts in embryology, sueh as the punctum saliens, the movements of the fetal heart, and the posisibility of superfetation. He announeed the doetrine of the primacy of the heart, an the seat of the soul and the souree of the perfeeted blood, from which the blood derives its innate heat, different from elemental fire, in that it is life-giving. He held that life may originate spontaneously from foam (pneuma, protoplasm) as Aphrodite sprang from the foam of the sea (Curtis). In spontaneons generation, he believed that the soul is derived from the air and the generative heat from the sum. In sexual generation, the semen is the vehiele of the soul and the vital heat, but "the cause of man is his father, the sun and its motions." He was the first to use the term "anthropologist," but in the sense of a vain, self-important person, the logieal opposite of the "highminded man" of his Nichomachean Ethies. His "entelechies," which he regarded as intermediaries between the soul and the body, have been revived, as a substitute for "vital prineiples," by the morphologist Drieseh.

Aristotle left his library and botanic garden to his friend and pupil. Theophrastus of Eresos $(370-286$ B. C.), who was also a physician, and was ealled the "protobotanist" because he did for

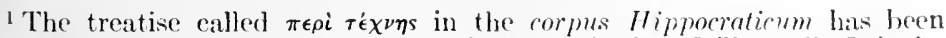
translated by Theodor Gomperz as "Die Apologie der Heilkunst" (Leipzig, 1910), and is attributed by him to a sophist of the fifth eentury, probably of the school of Protagoras.

${ }^{2}$ Aristotle: De generatione animalium, Bk. II, 743a. Cited by Choulant and Osler. 
the vegetable kingdem what Ilippoclates had previously ane for surgery and dinical medicine, in that he collated the loose plantlore of the roodmen and rhizotomists into a systematic treatise. The De Hiskria Plantarm of Theophrastus eontains descrip)tions of some 500 different plants, and is a good example of the power of the (ireek mind to solect what is important and reject the superfhoms.

As Cirene has shown, he first divided plants into flowering and flowerless, seed-plants into angiospermous and gymmospermous, deseribing their external organs in sequence from root to fruit. Before Goethe and Iinnens, he reeognized the flower as "it motamorphosed leafy branch." Ho differentiated ä̈rial roots from tendrits, and regarded fruit as " "very form and phase of seed eneasement, serel ineluded." He understood how the annual rings on the stems and trunks of trees are formed, and "without having seren a vegetable eell, yet distinguished clearly between parenchymatous and prosenehymatous tissues." The most inportant erlitions of Theophrastus are the two Allines of 1497 (Greek) and 1504 (Latin), and stapel's (ireek and Lat in text of 1644 .

Menon, another pupil of Aristotle, wrote the earliest contribution to medical history (Iatrika) after Hippoerates, a work which was mentioned by ( ialen and discovered abont 1895 in a London paprrus edited by Diels (Anomymus Londinensis).

With the founding of Alexandria (331 B. (C), Creek science and culture was firmly implanted in the ancient civilization of Egrpt. Alexandria, with its great university and library, with sueh great men as Ptolemy and Euclid, Hero and Strato, thus beeame the means of preserving the Creek texts and of spreading Greek doetrine to the East.

The colonization of Greek medieine in Egrpt led to brilliant developments in anatomy and surgery, but our knowledge of the two great Alexandrian anatonists, Herophilus and Erasistratus, the originators of clisecting, is not based upon any textual record of their writings. but was pieced together by the scholarship of Marx and Hieronymus. Both Herophilus and Erasistratus made important investigations of the nervous system, showing the relations of the larger nerves to the brain and spinal oord, and distinguishing sensory and motor nerves, with which they sometimes confused the tendons. Both are credited with a vague reference to the lacteal ressels. Herophilıs in particular deseribed the toreular Herophili and the fourth rentricle of the brain, including the calamus scriptorius; also the hyoid bone, the duodenum, and the prostate gland. and in the eve, the retina, vitreous and ciliary body. He counted the pulse with a water-clock, and made

${ }^{1}$ E. L. Circene: "Landmarks of Botanieal History," Washington, Smithsonian Inst., 1909, pp. 52-142. 
an elaborate analysis of its rate and rhythm (Osler). Erasistratus described the trachea, the auricles, valves and chorda tendinear of the heart, but claimed that the heart contains no blood. He devised the first crude respiration calorimeter, a jar in which he kept fowls, weighing them and their exereta, after feeding and completed digestion. ${ }^{1}$

Considerable light is thrown upon the Hellenic medieal culture grafted upon Egypt in the Alexandrian period-the dietetics, materia medica, pathology, regulation of wet-nursing, public baths, the surviving "etiquette" of circumcision and embalming, the temples of Serapis and Isis (Serapicia, Isicia, corresponding to the Greek Aselepieia) - in Karl Sudhoff's splendid study of Alexandrian medieine in the Oxyrhyneus and other Greek papyri."

In the third century B. C., Alexandrian medicine was introduced into Mesopotamia, and in this way Syria acquired the main body of Hippocratic doctrine via Egypt, while retaining many of the astrologic features of Assyro-Babylonian medicine. This dual system was studied by Syrian physicians for over a thousand years. An interesting Syriac text, in evidenee of this transition, has been published by Wallis Budge. ${ }^{3}$ Syria became the steppingstone or first station between Oriental, Greeo-Alexandrian and medieval medieine. In the Middle Ages, nedical translations from the Cireck texts were usually made backwards, first into Syriac, then into Arabic or Hebrew, then into Latin.

The tendencies of the school of Empirics, who sprang from the Alexandrian school in the second century before Christ, culminated in an actual development of quasi-experimental pharmacology and toxieology at the hands of physieians and wary dilettante rulers, of whom Mithridates, King of Pontus, achieved a reputation in the art of griving and taking poisons. He is said to have immunized himself against poisoning by means of the blood of ducks fed upon toxic principles, and he aspired to make a universal antidote (alexipharmacy). These "mithridates" and "theriacs," as they were called, engaged the talents of phamacists up to the beginning of the eighteenth century, and, in a manner, Mithridates may be regarded as the originator of the idea of polyvalent drugs and sera. The principal relies of this empirieal poison-lore are the treatise on poisonous animals by Apollodorus of Alexandria and

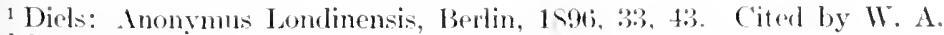
Heidel, Harvard stul. Class. Philol., 1911, xiii, 13s.

"K. Sudhoff: "Aerztlichos aus griochischen Papjous-Crkunclen. Baustein zu ciner medicinischen Kulturgeschichte des Hollenismus," in studien z. Gesch. d. Med. (Puschmann-sitiftung), Nos. 5, 6, leipzig, 1909.

"Syrian anatomy [ete.] or "The Book of Merlicines," erl. E. A. Millic Budge. $2 \mathrm{v}$, Oxford, 1913. 
two heximeter poems of Nikander on poisonous animals (Theriaca), and antidotes for poisons (. lexipharmaca), which have been presored in the two Aldine elitions of 1499 and 1523 , and in the French versification of these poents by dafeques Grevin (l'antin edition, Antwerp, 1568).

\section{IlI. The Greco-Roman Pleriod (156 B. C.-576 A. D.)}

In the early history of Rome, the minnitive, dark, small autochthonous peoples were mastered and overeome by warrors from the North, the "close-fisted Umbrian" and the "sombre, puritanical sabine." To this inmixture of races, yet another element was added, the Ethuscans, with their "lleshy bodies, almond ryes, big noses and gorgeons tastes," an ()riental race whose ceremonies and divinations "may have been witnessed by Abraham himself on his entry into Hebron." "The vast, dark background of loman medieine," says Allbutt, "for "us the soil on which Roman medieine was to be enltivated, consisted of the original small, dark race, reduced to formal or virtual servitude, degraded, but still vivacious and factious, and of an ascendant and irresistible aristocracy, mainly of northern invaders, but interpenetrated by another ruling race of oriental habits." The Southern balf of Italy and Sicily were not eomenered by the Northem invalers, but remained "Magna (irxera" from the sixth centuly B. C. to the tenth century A. D., and from Miana Ciræecia came one of the streans of cultural influences which helped to form the school of sialerno.

After the destruction of Corinth (146 B. C.), Greek medicine may be said to have migrated to Rome. Before the Greek invasion, the Romans, as the cleler Pliny tells us, "got on for 600 years without doetors," relying mainly on medicinal herbs and domestic simples, superstitious rites and religious observances. To the Romans of the Empire, the Cireck of any description was the Groculus esuriens of Juvenal. The proud Roman citizen, who had a household god for nearly every disease or physiologie function known to him, ${ }^{2}$ a domestic herbal medicine of his own, ${ }^{3}$ looked askance upon the itinerant Creek physician, despising him as a mercenary for acepting compensation for his services, and otherwise distrusting him as a possible poisoner or assassin (Pliny,

1 sir T. C. Allbutt: Brit. Med. Jour., Lond., 1909, ii, 1451.

2 These Roman gorls were worshiped under fanciful but appropriate names, as Febris, Seabies, Angeronia, Fluonia, Tterina, Cloacina, Mephites, Dea Salus, and the like.

${ }^{3}$ The favorite household remedy of the elder Cato was the eabbage. 
xxix, 7). Archagathus, who came to Rome in the year of the (ity 535 (220 B. C.), the first (ireek physician to practice there, came to be known as "carnifex" for his eruelty in surgery (Pliny, xis, 6). It is further recorded that the intrigues of the physicians Vettius Valens and Eudemus with Messalina and Livia, royal ladies both, the non-existence of laws to punish malpractice, poisoning and fratdulent manipulation of wills (by hired physicians), and the enormons number of snakes kept in private houses in pursuance of the Esculapian cult, ${ }^{1}$ did little to make medicine respectable in the eves of the austere Roman, who did not relish the intrusion of foreign irleas (Pliny, xxix, 5-8, 22). Apart from the writings of a private litterateur like ('elsus, the principal Roman contribution to medicine was the splendid sanitary engineering of the architect Vitruvius. As Cos and Alexandria were the starting-points of Crreek medicine, early and late, so the most eminent physicians in Rome came from Asia Minor, from the Schools of Pergamus, Ephesus, Tralles and Miletus (Wellmann). Greek medicine was finally established on a respectable footing in Rome through the personality, taet, and superior ability of Asclepiades of Bithynia (124 B. (.), who stood apart from the Dogmatists and the Empiries, and whose fragments are presented in Cimmpert's Greek text (Weimar, 1794). Aselepiades was a formal opponent of the Hippocratic idea that morbid conditions are due to a disturbanee of the humor's of the body (Humoralism), and attributed disease to constricted or relaxed conditions of its solid particles (Solidism). This is the so-ealled doctrine of the strictum et laxum, which was derived from the atomic theory of Democritus and has been revived at different times under such various guises as the Brunonian theory of sthenie and asthenic states, Friedrich Hoffmann's idea of tonic and atonic conditions, Broussais' theory of irritation as a cause of disease, and Rasori's doctrine of stimulus and contra-stimulus. As a logical consequence of his antagonism to Hippocrates, Asclepiades founded his therapeutic scheme on the efficieney of systematic interference as opposed to the healing power of nature; but in practice he was a real Asclepiad, wisely falling back upon the Coan régime of fresh air, light, appropriate diet, hydrotherapy, massage, clysters, local applications, and sparing internal medieation. He was the first to mention tracheotomy. His influence for good was that of a superior personality but died with him. His pupils and adherents, Themison and others, exaggerated his doctrines into a formal

${ }^{1}$ In 293 B. C., the eult of Fseulapius was introlueed into Rome in the form of a huge serpent from Epiflaurus, representing the god in his chthonian aspeet (see Ovid, Metamorphoses, B., xv, 62ti-744). 
"Methodism," white the followers of the Stoic philosophers endeatrored to fommd a sistem of mediecine lased upon the physical action and status of the vital air, or pmoma, which, taken in by the lungs, to cool the immer heat engendered hy the heart, is calried to the latfer, while the blood is derived fiom the livor. The Hellenic Renassane in Rome was thus chatucterized by three different ways of looking at disease as disturbanees of the liquid, solid or waseous constituents of the body, viz., IIumoralism, solidism, and Pnemmatism. In all this welter of theorizing, six names stand out above the rest-C'clsus, Dioscorides, Rufus, Foramus, (ialen, and Antyllus, and most of these were in reality frec-lances, that is, "Folectics." The Pnemmatic Sichool, founded by Athenarus of Attalia, and contimued by his pupil, clauclius Agathinus of Sparta, the teacher of Arehigenes and Leonidas, was the most important departure. The sirian Archigenes of Apamea (rirca 54-117 A. D.) has been shown by Max Welluann to be the source of the text of Aretaxus and of much in Aetius. ${ }^{2}$ The medical literature of the second century A. D.-Galen, Soranus, Heliodorus, Antyllus, Aretaus, as also the great collective works of the Byzantines- was made up of excerpts and paraphrases; and this tendency remained the eustom in the Middle Ages up to the Renaissance.

Although Roman medicine was almost entirely in Greek hands, the best account of it we have was the work of Aurelius Comelius Celsus, who lived in the reign of 'Tiberius C'asar. Celsus was, inferentially, not a physician, but a private gentleman of the noble family of the Comelii, who, like Cato and Varro, compiled encrelopedic treatises on medicine, agriculture, and other subjects for the benefit of the Admirable Crichtons of his own station in life. C'elsus wrote on medicine in the same spirit in which Virgil treated of veterinary matters in the third book of the Georgics, and we are led to suppose that, in accordance with Roman usage, he rendered medical assistance gratis, very much as the mistress of an old English estate or Southern plantation played Lady Bountiful among her friends and dependents. Classed by Pliny among the men of letters (auctores) rather than the medici, Celsus was ignored by the Roman practitioners of his day, and slighted as "mediocre" (mediocri vir ingenio) by Quintilian. His name is

1 Allbutt says that the Methodists and the Empiries were, in some sort, a continuation of the Coan and Cnidian schools, the former eonsidering the whole patient and his environment, the latter the locality of the disease and its local treatment. The Cnidians and the Empiries merely listed symptoms without coördinating them and were, in eonsequence, only haphazard therapeutists. see Allbutt's lectures on (ireek medleine in Rome, Brit. Med. Jour., Lond., 1909, ii, $1449 ; 1515 ; 1598$.

${ }^{2}$ Wellmann: Die pneumatische Schule bis auf Archigenes. Berlin, 1895. For a detailed aecount of the doctrines of the Pneumatic School, sce pages 131-231. 
mentioned only four times by the medieval commentators; but with the Revival of Learning, he had his revenge, in that his work (De re medicina) was one of the first medical books to be printed (1478), afterward passing through more separate editions than amost any other seientific tratise. This was due largely to the purity and precision of his literary style, his elegant Latinity assuring him the title of Cicero medicorum. Celsus is the oldest medieal doement after the Hippocratic writings, and, of the seventy-two medical authors mentioned by him, only the work of Hippocrates himself has come down to us relatively intaet. The De re medicina consists of eight books, the first four of which deal with diseases treated by diet and regimen, the last four describing those amenable to drugs and surgery. The third book contains, among other things, the first adumbration of heart disease (Cardiacus), which becane the canon of subsequent knowledge in antiquity. ${ }^{1}$ The fifth book begins with a elassified list of drugs, followed by a chapter on weights and measures, pharmaceutic methods and prescriptions, very much like a modern hand-book of therapeutics. Celsts was the first to recommend nutritive enomata. The sixth book treats of skin ${ }^{2}$ and venereal diseases as well as those of the eye, ear, nose, throat, and mouth. The seventh book is surgieal, and eontains one of the first aceounts of the use of the ligature, and a classic description of lateral lithotomy. Inder the Romans, surgery (including obstetrics and ophthalmology) attained to a degree of perfection which it was not to reach again before the time of Ambroise Paré. Surgical instrumentation, in particular, was highly specialized. Over two hundred different surgieal instruments were found at Pompeii. Herniotomy and plastic surgery were known, as well as the operations for cataract, version, and Cesarean section. Sufficient reason for all this may be found in the constant contact of the Romans with gladiatorial and military surgery, and the fact that the dissection of exeeuted criminals was sometimes allowed. Hippocrates said that "war is the only proper school for the surgeon." Celsus is also very fulf on the different malarial fevers of Italy and their treatment, on gout, and on the treatment of different kinds of insanity. He was the first important writer on medical history, and, in his Procemium, establishes the status of Hippocrates, Herophilus, Erasistratus, and other great names of the past in the spirit of one who might himself have said

I write as others wrote

On Sunimon's height.

${ }^{1}$ For a full aceount of the ancient eonception of carliac diseases, sere Landsberg: Janus, Bresl., 1S47, ii, 53-124.

${ }^{2}$ Of the forty skin diseases described by Celsus, alopecia areata is still remembered as "area Celsi." 


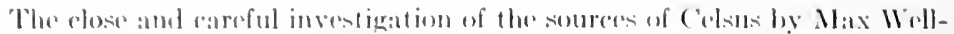

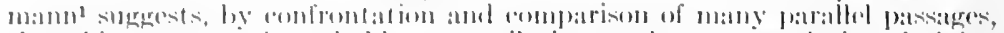

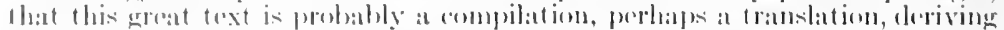

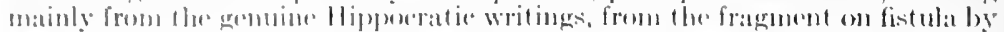

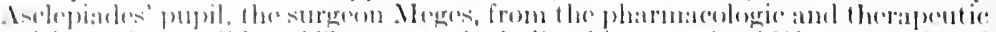

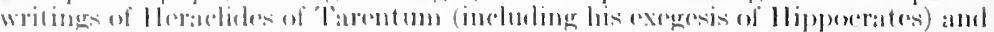

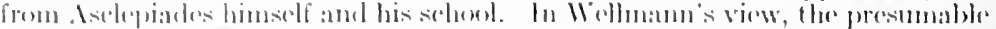
Cireek souree of (')

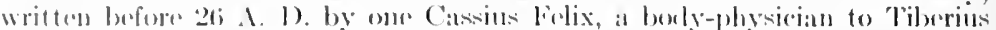

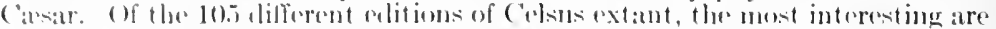

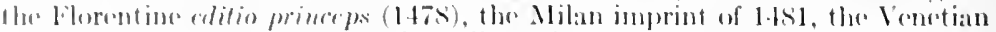
imprint of liset (the ratrest and eostlest of all), the Alline of 1525, and the

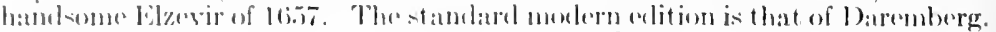

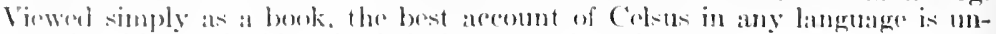

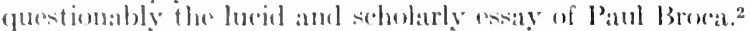

The three leatling (ireek surgeons of the period contemporary with Colsus were the Pnematists. Holiodorus, Arehigeness (both mentioned in Juvenal and the lat ter contemporaneous with ('elsus), Antylus, eontemporaneous with (ialen, all of whom have come down to us in the compilations of the Byzantine writers. Heliodorus, who antedated Celsus, gave the first aceount of ligation and torsion of blood-resseks, and was one of the first to treat stricture by internal urethrotomy. He also described head injuries, the operative treatment of hernia, circular and flap amputation. The latter procedure was fully described by Archigenes of Apamea, and both surgeons employed ligatures, which, in Galen's time, were to be bought at a special shop in the Via Sacra. Antyllus, long before Daviel, mentions the removal of cataract by extraction and suction, but his name and fame are permanently associated with his well-known method of treating aneurysms by applying two ligatures and cutting down between them, which held the field until the time of John Hunter.

Pedacins Dioscorides, the originator of the materia medica, was a Creek army surgeon in the service of Nero (54-68 A. D.), and utilized his opportunities of travel in the study of plants. His work is the authoritative souree on the materia medica of antiquity, of which he describes about 600 plants and plant-pri- eiples, orer a hundred more than Theophrastus. As Theophrastus was the first scientific botanist, so Dioscorides was the first to wrie on medical botany as an applied science. His first book deals with aromatic, oily, gummy, or resinous plant products; the second with animal products of dietetic and medicinal value and with eereals and garden herbs: the third and fourth, with the other medicinal plants. His classification was qualitative, as in a materia medica, rather than botanical, but, like Theophrast us, he recognized natural families of plants before Linneus, Adanson, and Jussieu. His

${ }^{1}$ Welhmann: A. Cornefius Celsus: eine Quedlenuntersuehung, Berlin, 1913.

"Conférences historiques de la Faeulté de médecine," Par., 1865, 445-497. 
descriptions were followed, "word by word," for sixteen centurios, and his book, says Cireene, ${ }^{1}$ has been more attentively studied by learned men than any other botanical work, with the possible exception of Bauhin's Pinax (162:3). Up to the beginning of the seventeenth century the best books on medieal botany were still simple commentaries on the treatise of Dioscoricles, which is the historid. source of most of our herbal therapy, even of the famous medieval substitutes for anesthesia. Mandragora wine (wives pavioneropiz is prescribed internally by Dioscorides as a draught for insommia or pain, and in three places ( $1 \mathrm{v}, 76$ ) he recommends it explicitly in surgical operations or cauterization, whether per os, as a clyster, or as an inhalation $\left(\mathrm{N}, 81^{2}\right)$.

The most interesting editions of Dioscorides are the Aldine of 1499 (Circek text), the Stephanus of 1516 (Latin translation of Rucllius), the rare bilingual text of Cologne (1529), and the Italian commentary of Mattioli (Venice, 1544), also extremely rare. 'The Graeo-Latin text of Kurt Sprengel (Leipzig, 182930), the definitive Greek text of Max Wellmann (1906-7), and the German translation, with marginalia, by J. Berendes (Stuttgart, 1902) are all valuable. The spurious Latin Ms. of Dyascorides de herbis femininis in the Hofbibliothek at Munich, with its 500 illustrations, as also the more complete eorlex (9332) in the Bibliotheque Nationale (Paris), which was exeeuted about 540) A. D., and was the source of Gariopontus, Macer Floridus, the Diaeta Theodori, and ot her nedieval eompilations, is now known to medieal seholars as "psendoDioseorides." ${ }^{3}$ The four authentic Greek MSS. are the codices of Naples, Constantinople (at Vienna), the illustrated Paris corlex No. 2179, and the Ms. of Nir Thomas Phillips (Cheltenham).

Aretæus the Cappadocian, who also lived either under Donitian or Hadrian (second to third century A. D.), comes nearer than any other (ireek to the spirit and method of Hippocrates, and is on this account more readily appreciated by modern readers. As Max Wellmann has shown, by careful comparison of texts, his work really derives from the writings of Archigenes, and he is thus our most important source for the teachings of the Pneumatic School. ${ }^{4}$ As a clinician, he ranks next to the Father of Medicine in the graphic accuracy and fidelity of his pictures of disease, of which he has given the classic accounts of pnemmonia, pleurisy with empyema, cliabetes, tetanus, elephantiasis, diphtheria (ulcera Syriaca), the aura in epilepsy, the first clear differentiation between cerebral and spinal paralysis, indicating the decussation of

${ }^{2}$ E. L. Greene: "Landmarks of Botanical Ilistory," Wash., 1909, 151-15i.

${ }^{2}$ For the eitations, see Husemann's elaborate study in Deutsche Ztsebr. f. Chir., L(1ipz., 1895-6, xlii, 577-587.

${ }^{3}$ H. Stadler: Janus, Amst., 1899, iv, 548-550.

4 See Wellmann: Die pnemmatische Sehule, Berlin, 1895, 22-64. The relation between Aretaus and Arehigenes was first noted by Sprengel. C. W. Klose (Janus, Gotha, 1851, i, 105; 217) maintained that Aretseus preeeled Arehigenes and was copied by him, but Wellmann's view seems the more probable. For the many attempts to fix the lifetime of Aretarus, ser Klose, p. 109. 
the promeds, and a very full aceount of the different kinds of insanity. Although uot equal to the later Aetius in the acemacy of his transeriptions from Arehigenes, Aretans is easily the most attrative modical anthor of his time. Ho was essontially a stylist, and the chatrater of his lonic (areek is sade to indieate a late period. His work is prescroed in the fanlty (iroek text of 1554, in Wigan's valuad ( lanenton l'ress adition (0xford, 1723), the beipzig text of C. (i. Köbn, and the Greek text with English translation by

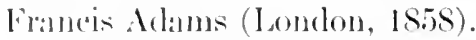

Another great eclectic was Rufus of Ephesus, who lived in the roign of Trajan (98 117 A. D). and whose literary remains and fragments have heen preserved in the Paris text of 1554 , and that of 1)arembere (Paris, 1879).

Ho wrote a little work on anatomy in which he deseribed the eapsule of the erystalline lens, the membranes of the eye, the optie chitasm, and the oviduet in the sheep. He also gave the first deseriptions of tramatie erysipelas, epithelioma, and bulonie plague (levived from Mexandrian sonrees). He adeled many new compounds to the materia mediea, of which his "hiera," a purgative containing coloesnth, became celebrated. Rufus was at good surgeon and deseribed all the known methorls of hemostasis, "digital compression, styptics, the cautery, forsion and the ligature" (Osler).

Soranus of Ephesus of the second century A. D., a follower of the Nethodist school of Asclepiades, is our leading authority on the grnecology, obstetries, and pediatrics of antiquity. His treatise on midwifery and diseases of women, preserved in Dietz's Greek text (Königsberg, 1838'), was the original of such famous works as Röslin's Rosengarten (1513), and Raynalde's "Byrthe of Mankynde" (1545). Most of the supposed innovations in these books, such as the olstetric chair or podalic version, have been traced back to Soranus. After Soranus, there were no real additions to obstetries before the time of Paré, some fifteen hundred years later. The pediatric section in Soranus is the finest contribution to the subject in antiquity, containing the most rational precepts as to infint hygiene and nutrition, with separate chapters on infantile discases, inchuling a recognizable account of rickets.

The "Natural History" of Pliny the Elder (23-79 A. D.), of which Books XX-XXXII deal exclusively with medicine, is a vast compilation of all that was known in his time of geography, meteorology, anthropologr, botany, zoölogy, and mineralogy and is interesting for its many curious facts about plants and drugs, its sidelights on Roman medicine, and its author's many slaps at physicians. After the invention of printing it passed through more than eighty editions.

${ }^{1}$ Later editions by Ermerins (1869), Valentine Rose (1882), and one in preparation by Joh. Illberg. 
It contains the original referenees to many unique things, such as seurvy (stomacaee), Druidical medieine, superfortation and atavism (ipse avnin regenerat Wthiopum), the case of Mareus Curius Dentatus, who wats born with teeth, the altifieial iron hand of Mareus sergius, the great-grandfather of Catiline, ${ }^{1}$ Mithridates' experiments with poisons, or Nero's ase of the monocle or lorgnettr (Nero princeps glaliatorum pugnas spectabat in smaragrdo), which, some writers think, may have been an actual eyeglass. The botmieal errors of Pliny remained unchallenged until the time of Nicholas Leonicenus (1492).

The ancient period closes with the name of the greatest Greek physician after Hippocrates, Galen² (131-201 A. D.), the foumder of experimental physiology. Born an architect's son at Pergamns, Galen's youth and old age were those of a peripatetic. His life was one long IIanderjahr. At Rome, where he commeneed practice in $164 \mathrm{~A}$. D., he soon attained the leadership of his profession, but retired early to devote himself to study, travel, and tearhing. Compared with Hippocrates, Galen seems like the versatile manysided man of talent as contrasted with the man of true genius. He was the most skilled practitioner of his time, but left no good accounts of clinical cases, only miraculous eures. He usually got his patients well, and to this end instituted an elaborated system of polypharmacy, ${ }^{3}$ the memory of which survives in our language in the term "galenicals," as applied to vegetable simples. Cialen's place in science is very high, but his roving disposition undoubtedly did much to (levelop) that cocksure attitude of mind which made his writings the fountain-head of ready-made theory, or what the Germans call "polypragmatism." He had an answer rady for every problem, a reason to assign for every phenomenon. He elaborated a system of pathologr which combined the humoral ideas of Hippocrates with the Pythagorean theory of the four clements and his own conception of a spirit or "pneuma" penetrating all the parts. Referring all pathologic phenomena back to these postulates, Galen, with fatal facility and ingenuity, proceecled to explain everything in the light of pure theory, thus substituting a pragmatical system of medical philosophy for the plain notation and interpretation of facts as taught by Hippocrates. The effect of this dogmatism and infallibility upon after-time was appalling: for while Galen's monotheism and piety appealed to the Moslems, his assumption of omniscience was specially adapted to appease the mental indolence and flatter the complacency of those who were swayed entirely by reverenee for authority. Ep to the time of

1 See Sudhoff: Mitt. z. Gesch. 1. Med., Leipz., 1916, xv, No. 1.

2From the fifteenth century on, the erroneous form "Claudius Cialen" has been much employed. Klebs (Prosopographio imperii Romani, 1s97, I, 374-380), shows it to be it misreading of Cl[arisimus] Gialen. (Fullhoff.)

${ }^{3}$ Asclepiades, Albutt says, tended to dissipate the specifie in the universal (physiologic therapeuties); Galen, proceeding from a theoretic monotheism, tended to lose the universal in the particular (polypharmacy). 


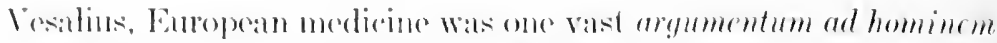
in which overething rolating to anatomy and physiology, as woll

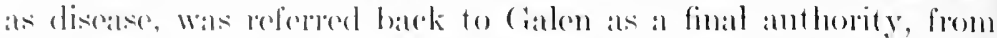
whom there could be no appeal. After his death, European

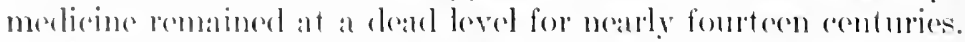

(ialen was the most voluminoms of atl the ancient weiters and the greatest of the theorists and systematists. His works ale at gigantic encyelopedia of the knowlerlge of his tine, including nine books on anatomy, seventern on physiology, six on pathology, sixteen essays on the pulse, the Megaterelme (Ars magna) or theraperuties (fomptern books), the Microtedene (Ars porva) or "practice," and thirty books on plummeg. He gave us the four classic symptoms of inflammation, differentiated pnemmonia from plenrisy, was the first to mention aneurysu, separating the tramatic from the dilated form, deseribed the different forms of phthisis, mentioning its infortious nature and poposing a full milk diet and climatotherapy (sol voyages and dry clevated places) for the disease; he understood the diathetic relation between calculus and gout, and his prescriptions inclicate a most intelligent use of opium, hyoseyamus, hellebore and eolocynth, hartshom, turpentine, alcohol (wine), sugar diet (honey), grape-juice, barley-water, and cold compresses. He introduced the doetrine of the four temperaments and set the pace for a fantastic pulse-lore or ars sphygmica, which was still in vogue in the eighteenth century. He traveled far to learn all he could about the native remedies of different regions, and even paid two special visits to the isle of Lemnos in order to investigate the therapeutic value of its sacred sealed earth (terra sigillata ${ }^{2}$. As an anatomist, Galen gave many exeellent descriptions, especially of the motor and locomotor systems, but his work was faulty and inaceurate, as being based largely on the dissection of apes and swine. He studied osteology in the ape (.Macacus ecaudatus) and from stray human skeletons, such as that of the robber he once found on a lonely mountainside. His myology was based mainly upon the study of the musculature of the Barbary ape (Macacus inums), but he elearly understood the difference between origin and insertion and knew most of the muscles and their functions, although he had little nomenclature. ${ }^{3}$ His splanchnology was defective and erroneous; his neurology is the best feature of his anatomieal work. From his dissections of the brains of oxen, he distinguished the dura mater and pia mater,

1 "Methodus Medendi," lib. v, f. 63 (Linacre's translation of 1519).

2C. J. .. Thompson: Terra sigillata. Tr. XVII. Internat. Med. Cong., 1913, Lond., 1914, sect. xxiii, 433-444.

${ }^{3}$ J. S. Milne: Calen's knowledge of muscular anatomy, ibid., 389-400. 
the eorpus callosum, the third and fourth ventricles with the iter (Frlvian aqueduct), the fornix, corpora quadrigemina, vemiform process, alamus seriptorius, hypophysis and infumlibulum. Of the twolve corebral nerves, ho knew seven pairs, also the sympatthetic ganglia, which he described as the reënforeers of the nerves. His treatise on anatonical "administration" or method was the first treatise on dissect ion, and authoritative through the centuries. His contributions to the sedence were aceepted as finalities up to the time of Vesalius. But if Calen's anatomy failed in the long rmo, through the fact that it was simian, canine, bovine, poreine, rather than hmman, and becanse he subordinated aceurate descrip)tion of structures to speculation about their functions, he was the first and foremost contributor to experimental physiology bafore Harver. He was the first to describe the cranial nerves and the sympathetic system, made the first experimental sections of the spinal cord, producing hemiplegia; profuced aphonia by coutting the recurrent laryengeal; and gave the first valiel explanation of the mechanism of respiration. He showed that the arteries contain blood (by performing the Antyllus operation), and demonstrated the motor power of the heart by showing that the blood pulsates between the heart and a ligated artery, but not beyond it. Like the Alexandrians, he inferred that the arteries and veins anastomose "through ceptain invisible and extremely small vesochs" (Osler). He also showed that an excised heart will beat outside the body, a common incident at the sarrificial rites, and good evidence that its beat does not depend upon the nervous system. In these matters Galen gave to modicine that method of putting questions to nature and of armenging things so that nature may answer them, which we call experiment. Daremberg onere repeated all of Cxalen's experinnents in the Jardin des Plantes. In his physiologic speculations about his findings, Galen spoiled his work by his mania for teleologr, which he got from Aristotles reading of nature. His bump of reverence was inordinately devoloped. and although he was right in his primary assmuption that structure follows function, his enthusiasm led him into the strangest and most arbitrary hypotheses based a priori upon his centrice idea that every thing in nature shows an element of design and the goodness of the ('reator. Modern hiologists ses the living creature and its life-history as the resultant of the parallelogram of two forees, the reaction of the innate heredity against the out or enviromment. They reason that differences in strueture are the

${ }^{1}$ For cialen's knowledge of the cerebral nerves, ser Th. Bork, Areh. f. Gesch. d. Med., Jeripz., 1909-10. iii, $110-114$.

"For Galen's technique in dissoretion and vivisertion, see Frigatrich Ellrich, Laipzig diss, (Inst. f. Ciesch. d. Mred.), 1919. 
resultant of arlaptation to the stress and strain of enviromment. But Galen, as Xomburger puts it, made his whole physiologioal theory "a skilful and well-instructed special pleading for the ause of alesign in nature," whereby he lost himself in a promi speculations "to explain natures execution before even her meehamism had beren demonstralded." His contributions to the physiology of the nervous, repiratory, and airculatory systems, howerer fatulty, were the only real knowledge for seventern centuries.

There are these (ialenice superstitions which, through their platsible chatracter, have had a great deal to do with preventing the advandement of medieal seicnee, First, the doctrine of Vitaljint. which mantained that the blood is endued with "natural spirits" in the liver, with "vital sperits" in the left ventriele of the heart, and that the vital spirits are converted into "animal spurits" in the brain, the whole organism being animated by a "pnema." Modifications of this theory, howerel attactive, have driven physiology into many a delusive blind alley, even up to the time of Driesch. Fecomd, the notion that the blood, in its transit through the body, passes from the right to the left ventricle by means of cortain imaginary invisible pores in the interventricular soptum, prevented theorists from having real insight into the circulation intil the time of Inarey." Third, the iclea that "coction" or suppuration is an escential part of the healing of wounds led to those Alabist notions of "healing by second intention," setons and laudable pus, which, although combated by Mondeville, Paracelsus and Pare, were not entirely overthrown before the advent of Listel.

Of the many erlitions of Cralen's works, the most important are the Aldine Greek text of 152.) (five volumes), the Barel edition of 1538, with the initial letter by Holbein, and the nine different editions of the Lat in text published by the house of Giunta at Venice between the years 1541 and 1625. Of Latin translations, Conrad Gesner's (Basel, 1562), with the biographic illustrations on the title page, and those of Linacre, are perhaps the most famous. Among the modern editions, the best are the twenty-volume Greek and Latin text of Kithn (Leipzig. 1\$21-333), with a vahuable index, and Daremberg's anthology in two volumes (Paris, 1851-6). Cralen's seven books of anatomy, an Arabic IS. of the Ninth Century A. D., with German translation and commentary

1 A posible exception to this statement woukl be the few physiologic experiments male by Vesalius which, however, passed unnoticed in his time.

"Galen regarded the arterial blood (charged with "vital" spirits) and the venouk blood (charged with "natural" spirits) as ebbing and flowing. back and forth, through their respective channels, but having no connection with each other except through the interventricular pores. In like manner the "animal (psychical) spirits" were supposed to eourse back and forth through the hollow nerves, which became solid after death. For a good account of this archaic physiology, see Fir Micharl Foster, "Lectures on the History of Physiology," Cambriılge, 19()1, pp. 12, 13.

${ }^{3}$ For a valuable tabulation of Calen's eitations from the older writers (ed. Kïhn), see J. Zimmermann's Berlin dissertation (1902). 
by Max Simon (Leipzig, 1906) is very valuable. 'The most famons simgle treatise of cialon is his monograph ou the physologie and toleologic asperots of

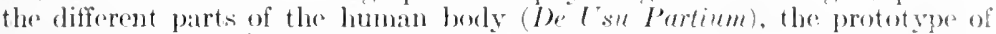

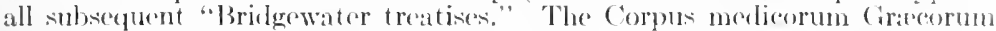
(leapzig and Berlin), a series of 'Teubner texts published under the auspires of the collective sejentific aculemies of Europe, will include all the Greek writers. The standard source for the minor Creck and (ireco-lat in writers is Valentin Rose's Anecdola graca et graco latima (Berlin, 1stit-70).

()f the condition of medicine under the Romans, comsiclerable is known, but liftle need be said. Much of Roman medicine is found in the secular writers, particularly the poets, dramatists. satirists and epigrammatists, and in the inscriptions.

Of the Latin writers, Plautus and Topence are remarkable for sidelights on obstetrics and popular medicine; Lucretims for anatomy, physiology, distetics, hygiene, climatology and the famous account of the plague at Athens which terminates his sixth look; Virgil for veterinary medicine; Horace, Juvenal, Porsiss and Martial for satirical sidelights on diseases and drugs of the time, persomal hyoiene, riminal abortion, insanity, and, with the erotic poets (Ovid, Catullus. Tibullus, Propertius) for inmimerable details about sesual viees, venereal diseases, aphrodisiaes and eosmeties; Cicero and the younger l'liny for internal medicine; Lucan for vivid aceotuts of war wounds and hites of poisonous serpents; Livy for Roman medien-military alministration; Tacitus for the anthropology of ancient (iermany; surtonius for the vices and mental disorders of the Casars. Iorace, an intinate of the phyician Antonius Musa, gives semeiologic dotails with classic enurjuion. O)id, in his account of the plague of Agina, is a lenttor cpidemiologist than Thuevdides or Lueretius. Virgil, most learned in medicine, deseribed anthras in sheep, and indicates the knowledge of eontagion from herd to herel.

\section{"Nec mala vicini pecoris contagia lacelent."}

Mosquito netting (comopenm) is mentioned by Horace and Juvenal. Aulus Gellius is quite modern in his exposition of infont livgiene and nutrition. Medieine in the Latin poets has been carofully stuklied by Prosper Meniere' and Edmond Dupouy : Birkholtz made an anthology of modical exerpts

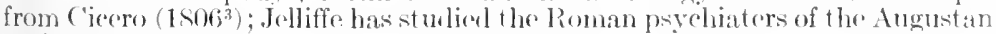
period; but the whole field, so rich in details for medieal historians, has besn but little explored.

Before the second rentury A. D., the Romans employed medical slaves (semi medici), or relied upon their special medical gots (Feloris, Scabies, Cterina, and the lest), with an occasional dilettante interest in healing on their own aceount. How the early Roman eitizens looked upon the Cireek physieians has leen seen. But even after Asclepiades, Calen, and Soranus harl made the status of medieine respectable, the Roman Quirites contimert to regard the profession as beneath them.

Some Romans, early and late, pratised or wote upon medieine, steft ats Seribonius Jargus, author of Compositiomes Wedirorum (17 A. D.), a eompilin-

1 P. Menière: Etudes módicales sur les poites latines, Paris, 1siss.

2E. Dupouy: Mélecine ot mours de l'ancienuo Rome, 2 éd., Paris, 1 \$92.

${ }^{3}$ Birkholtz: Cicero medicus, Iseipzig, 1806. 
tion of druge and proveriptions, who also left an important expectorant mix-

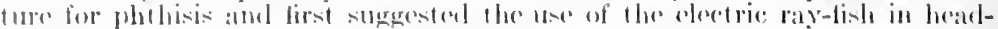

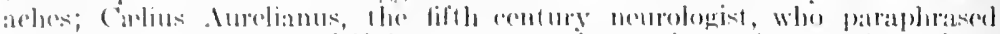

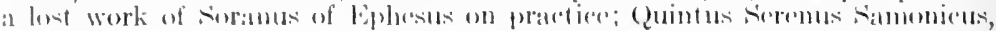

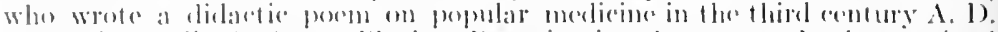

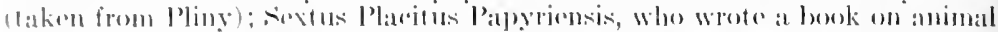

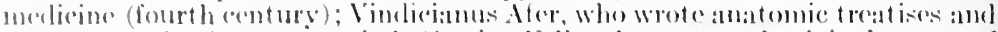
at formulary in the some period; (assine Folis, the supposed original senree of ('olsts, anel Theodorus l'riscianus, court physician to Gratian.

Besidrs the "mediei" proper, there were the herb gatherers (rhizotomi), the flug-peddlers (pharmacopola), the salve-dealers (ungunturii), the army surgeons (medici cohortis, medici legionis), and the archiatri or body physiedians to the emperers, some of whom were also public or eommunal (archiatri populares). There were also the less reputable iutrolipter, or bath at tendants, medica or female healers. sage or wise-women, obstetrice, or midwives, the professional poisoners (pharmacopori), and the depraved chatraceters who sold philters and abortifacients. A very dubious and much satirized class were the eve specialists or oculists (medici ocularii) who, each of them, sold a special eye salve stamped with his own private seal, usually compommled of salts of zine and other metals. Nearly two hundred of these seals have been found. The homse of the Vettii, excavated at Pompeii, has a mural painting, representing cupids and psyches as "muguentrari" in the act of expressing, heating, testing and selling olive oil (Peters). Many evidences of Roman medicine have been found in Britain. ${ }^{\mathrm{T}}$

A special feature of Roman medicine was the cultivation of warm public baths (therma) and of mineral springs. General hydrotherapy was introluced by Asclepiades, and no less than 1800 public bat the had been founded lluring the period 334 B. C. -180 A. D. (Haeser). The baths of Caracalla and Discletian had marble accommodations for 1600 and 3000 persons respectively, the water being supplied from the great aqueducts. The establishments for cold bathing (frigidaria) often had a swimming-pool (priscina) attached, but it is not known whether the warm baths (tepidaria, calideria) were heated as to the water or to the air of the rom. The prineipal natural -prings were the therma at Baia near Naples, Thermopyle in Cireece (espe(ially patronized by the Emperor Haririan), and, in the Roman Colonies, Aix les Bains (Aque Ciratina Allobrogum), Aix in Provence (Aqua Sertiar), Bagnères de Bigorre (Vicus Aquensis), Barlen in Switzerland (Thermopolis), Baden near Vienna (Aque Pannonice), Baden Baden (Civitas Aquensis), Aix la ('hapelle (Aquisgranum), and Wiesbaden (Aquor Mattiacenses's). Military hospitals (ralctudinaria) are mentioned by Hyginus, and have been exeavated at Neuss (Castrum Norasium) and Carnuntum (near Vienna).

The Etruscans were wonderfully skilled in dentistry. Martial mentions false teeth. Some remarkable specimens of Etruscan bridgework are pre-

1 See H. Barnes: Proc. Roy. Soe. Ned. (Seet. Hist. Med.), Lond., 191314 , vii, $71-87$.

${ }^{2}$ Haeser: "Lehrb. d. Gesch. d. Med." 3. Aufl., Leipz., 1875, i, 494. 
served in the musenm of Cormeto and have bern deseribed hy (iustini and Walsh.1

The Roman rite of lastration, or purifieation of a town-rite, forlel or borly of people within an area, by a repeated procesional aromel it, wat intimately eonnerted with the enumeration of trooges before and after battle, and the

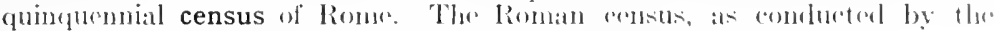
cemsors, was probaloly a matter of military necesity."

The speral talent of the Romans was for military sedenoe and

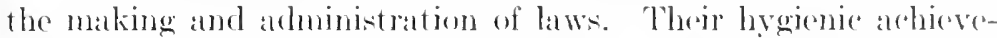
ments, such as cremation, the sensible, well-ventilated houses, the great anueducts, sewers, drains and public baths, were of far greatel conseguenes than their native literary contributions to medieine. Let reve here, as sublhoff says, they often produced hygienie results withont medical intention, things of hygienic value but of non-medical origin." Roman medicine, at best, can only be regalledel ats an offshoot or subvariety of Creck medieine.

I Guerini: "History of Dentistry," New York, 1909, (i7-76, and .J. J. Walsh, "Nerlern Progress and History," New York, 1912, 7!-10?. For ancient dental foreeps, sere sudluff: Ardi. f. Geseh. 1. Mcrl., Leipz., 190s-9, ii, .i.5- $59,3 \mathrm{pl}$.

2"Lustrum nominatum tempus quinguemialo a luendo, iel est solvendo:

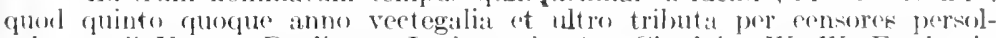
vebantur," Varro: De lingua Latina, vi, 11. Cited by W. M. Fowler in Anthropologre and the ("lassies, ()xford, 1908, 173.

${ }^{3}$ Karl sudboff: "Hygienische Gedanken und ilure Manifestationen in der Welt geschichte," Devitsche Revue, Stutt., Oet., 1911, p. 43. 


\section{THE BYZANTINE PERIOD (476-732 A. D.)}

The downfall of the Western Roman Empire was mainly due to the degeneration of the Roman stock throngh mixture with weaker and inferior races, and the soldiers who had never known defeat became an easy prey to the invading barbarians of the North, informed with the rugged and primitive virtues which they thenselves had once possessed. In the days of the Republic, the Roman had matehed the Spartan as a virile soldier and law giver, escentially simple in mind and morals. In a state of society "where wealth accumulates and men decay," he could not hold his own with the flexible, wily Greek of later times, nor with the subtle, fatalistic Oriental, both of them more agile in mind and more dexterous in action than he. Like the Normans in Sicily, or those English eolonists in Ireland, who became proverbially Hibernis ipsis Hiberniores, he foll under that strange law by which the conqueror, in the end, assimilates himself to the conquered people. By process of race-inmixture the Romans of the fifth century A. D. had aequired the "serene impartiality" of spirit which Professor Huxley attributes to the mongrel races, and some think that the malarial fevers which had begun to devastate the Italian peninsula had as much to do with weakening their fiber as the luxuries and dissipations to which they were eontinually exposed. ${ }^{1}$ Degeneration of mind and body, with consequent relaxation of morals, led to mysticism and that respect for the authority of magie and the supernatural which was to pave the way for the bigotry, dogmatiom and mental inertia of the Midclle Ages. Ender these conditions, the physician beeame more and more of a mereenary, parasite and rendor of quack medicines. Long before the downfall of Rome the magician, the thammaturgist, the professional poisoner, and the courtezan who peddled drugs-

\section{Ambubaiarum collegia, pharmocopole,}

Mendici, mime, balatrones, hoc genus omne,

were familiar figures. In the Eastern Empire, the deeomposition of intelligence was even more pronounced, and today the adjective "Byzantine" connotes little more than luxury, effemination and sloth. Through the conflict of Pagan and Christian modes of

${ }^{1}$ In particular, W. H. S. Jones: Malaria and Greek history, Manchester, 1909. His view is vigorously opposed by J. P. Cardamatis (Arch. f. Sehiffs- u. Tropen-Hyg., Leipzig, 1915, xix, 273, 301). 
thought, almost all of the intellectual energy of the period was dissipated in religious controversy, while medicine had become an affar of salves and poultices, talismans and pentagrams, with a mumbling of incantations and spells very like the backwools pranks of Tom Sawyer and Huckleberry Finn, or some of the vagaries of christian seience. There were doubtless good people. then as now, but they did not come to the front, and there is pith in Gibbon's sarcasm about two pious chatrater's of the period: "We know his vices and are ignorant of her virtues." This supine cast of mind and morals is well reflected in the Byzantine mysticism of Wagner's Parsifal, and the figure of Kundry, the soreceres minion, who brings nostrums from the far East to alleviate the sufferings of Anfortas, may serve as a sort of type and symbol of Byzantine medicine. In spite of all that has been written by C'urtis, Finlay, Zinkeisen, and others, little wore ean be claimed for Byzantium than is contained in the sentence of Allbutt: "The chief monmments of learning were stored in Byzantium until Western Europe was fit to take care of them.". The solitary thing the Eastern Empire did for European medicine was to preserve something of the language, culture and literary texts of creceer. Concerning this point, Firschberg says conchusively that Byzantium had no medieval period, but simply went on "marking time" in the past. This is borne out hy the researches of other" historians, which show that the habit of compilation established by the later Freek and Roman writer's remained a set enstom in Eastem and Western Europe eren beyond the Renaissance perioul. Although the Byzantine power lasted over a thousand vears (395$1453 \mathrm{~A}$. D.), medical history is conermel chiefly with the names of four industrious compilers who were prominent physicians in the first three eenturies of its existence. Of these, the courtier Oribasius (325-403 A. D.), a friend and physician-in-ordinary to Julian the Apostate and sometime quastor of C'onstantinople, is chiefly remarkable as a torch-bearer of knowledge rather than at an original writer, but his compilations are highly ralued by scholars in that he alwars gives his anthorities, and, so far as is known, quotes them exactly. Medicine is inclebted to him for a remarkable anthology of the works of his predecessors, many of whom (the surgeons Archigenes, Heliodorus, Ant yllus, for instance) might otherwise have been lost to posterity. (ialen in particular he expounded with loving are and did much to establish him in his central position of atthority (luring the Dark Ages. like Cialen, Oribasius took all knowlexlge for his provinee. His great

1 Sir T. C. Allbutt: Science and Modiaral Thought, Iondon, 1901, (i) Sice also his illuminating Finlayson lecture in Cilisgow Med. Jour., 1913, lxxx, 321, 422 . 
ancrelopedia of medicine comprised inderel over seventy volumes. dealing with all aspoets of the subject. Much of this has heon lost. but its anthor apitomizod his kmowledge in the littlo "symopsis" which he made for the use of his soll. His Emporista, or popmlat treatise on nedicine, had the rane nerit of avoiding any rurrent superstitions and inculeating somed therapentic doctrine. The student of medieal history will read ( )ribasius to best advantage in Daremberes splendid six-volume adition, with the parallal Fench translation (Paris, 185i-76).

Aëtius of Amida, who lived in the sixth century, A. D), was also a royal physician (to Justinian I, 527-65) and comes obsequii (lord high chamberlatin) at the comt of Byzantium. He left an extensive comprilation, msually alled the Tetrabiblion, which is a principal anthority for what we know of the work of laufus of Ephesus and Leonides in surgery, Sorams and Philumonus in gronecologr and obstetries. The first eight books were published at Venice in 15:34, the hithorto unprinted books IX-XVI being now in preparation by Max Wellmann. Aëtius gives a description of epiclemic diphtheria not unlike that of Aretaus, mentioning paralysis of the palate as a sequel, and his work contains the best account of diseases of the eye, ear, nose, throat and teeth in the literature of antiquity. He has also interesting chapters on goitre and lyclrophobia. Much of tetius, as Max Wellmann has shown, is taken from Archigenes through Philunemus. His accounts of elephantiasis, ilens, the varieties of headache, pnemmonia, pleurisy, epilepsy and the treatment of these conditions, are far more accurate than those of Aretaus, whose work also derives from the same common source. In surgery, be supplies many of the lost passages in Oribasius, and deseribes modes of procedure (tonsillotomy, urethrotomy, treatment of hemorrhoids) not found elsewhere. To him is due the first description of ligation of the brachial artery above the sac for aneurysm, which was later done by (rullemean (1594) and Anel (1710), to become in time the Hunterian method (1786) $\left(\mathrm{Osler}^{1}\right)$. Aëtius recommended many salves and plasters, and is supposed to have been a christian by reason of the chams and spells he proposes for their preparation. Thus. in preparing a plaster, he says, one should intone repeatedly, "The God of Abraham, the God of Isaac, the God of Jacob, give virtue to this medicament." To renove a bone stuck in the throat, one should ery out in a loud voice: "As Jesus C'hrist drew Lazarus from the grave, and Jonah out of the whale, thus Blasius, the martyr and servant of God, commands 'Bone eome up or go down."

10 -ler: Lancet, London, 1915, i, 950. Osler says that the original description of Aëtius was wrongly attributed by Sprengel to Philagrius. 
Alexander of Tralles (525-605), a much traveled practitionel who finally settled in Rome, was the only one of the Byzantine compilers who displayed any special originality. Although a follower of Calen, his Practica (first printed at Lyons in 150.4') contains some descriptions of disease and some plescriptions which seem to be his own, notably those containing burnt substanees. His accounts of insanity, gout and the dysenteric and choleraic disorders are above the average. He hats a highly original chapter on intestinal worms and vermifuges, and he is said to have been the first to mention rhubarb, and first recommended colchicum (hermodactyl) in gout. Like Galen, he recommends a full milk diet, change of air and sea voyages for phthisis, but his other prescriptions are often clisfigured by the obtrusion of the usual Byzantine spells and charms.

Paul of Egina (625-690), the last of the Cireck eclecties and compilers, was the author of an Exitome of medicine in seven books, first printed by the Aldine press at Venice in 1528 and 1553 , later in the modern text (with French translation) of René Briau (Paris, 1855), and Englished for the Sydenham Society by Francis Adams (London, 1834-472). Although he was a physician of high repute, we may judge how low medicine had sunk in the seventh century by his apologetic statements in regard to any lack of originality on his part. He frankly artmits that the ancients have said all that could be said on the subject and that he is only a humble seribe. Paul was, however, a very capable surgeon, and the sixth book of his Epitome was the standard work on the subject up to the time of Albucasis, who incleed drew upon it for most of his information. Paul gives original descriptions of lithotomy, trephining, tonsillotomy, paraentesis and amputation of the breast, but stopped short of opening the hest for empyema. In describing herniotomy, he recommends removal of the testicles, a mutilation which was perpetuated by the Arabians and continued to be the vogue with the outeast medieval surgeons until far into the sixteenth century. Paul gives the fullest aceount we have of the ere surgery and military surgery of antiquity. He mentions the frepueney of naval physicians in his time. He omits all referener to podalic version, and as his anthority was upheld hy the Arabians, the procedure disappears from literature until the time of Röslin anel Paré.

Among the minor writers of the Byzantine period, we may' men-

1 Modern readers may consult the admirable orition of Alexander Trallianus by Theodor Puschmann (2 vols.), Vienna, 187. -9, with German translation and biographic introduction.

${ }^{2}$ A valuable German translation, with eommentary by J. Berendes, was published in Janus, Amst., 1905-13, passim, and at Leyden (E. J. Brill, 1914). 
tion Publius Vegetius Rematus, a horse trader and farrier of the fifth century, A. D., whose Ars V'cterinaria, published at basel in 152s, eontains the first anthentic aceount of glanders; and Theophihs Protospatharius, physician and captain of the guard to the Emperor Ineraclius (60;3-(i+1), and a contemporary of Patul of Egina. He left an original description of the palmaris brevis muscle and the olfactory nerve, and wrote a treatise on the urine which for enturies uphedd the Galenic doctrine that the batter is a filtrate of the blood, secreted in the portal vein and vena eava. The same doctrine was maintaned unchanged in the thirteenth century by Johamnes Actuarius, the last of the Byzantine writers, whose elaborate treatise on the urine made the notion authoritative with the absurd "water-casters" of a later time. He is memorable as the first to use a graduated glass for examining the urine, although the markings upon it were not quantitative but qualitative, indiciting the possible position of the different scums, precipitates and sediments.

During the Byzantine period, an interesting contribution to clinical medicine was made by the Fathers of the Christian Church, namely, the deseription of the earlier epidemics of smallpox.

Eusebius described a Syrian epidemic in $302 \mathrm{~A}$. D., another was described by Gregory of Tours in 5\$1, and the term "variola" was first employed by Marius, Bishop of Avenches, in 570. It is said that the disease was also described in the Irish monastery records of $675 \mathrm{~A}$. D. as "Bolgagh" and "Galar Breac." The Chronicle of St. Denis (580) mentions diphtheria as esquinancie. Baronius described Roman epidemies of 856 and 1004, and Cedrenus records a Byzantine epidemic of 1039 as cynanche (Hirsch). Jeanselme gives a careful and circumstantial account of gout at the court of Byzantium, ${ }^{2}$ derived from the local historians and patristic writers. The symptoms of the disease were well described, the eauses located, and there was extensive treatment, but the term "arthritis" comnoted both gout and chronic rheumatism until the seventeenth century.

In 1495, a valuable illustrated collection of surgical MSS. made by the Byzantine physician, Niketas, $900 \mathrm{~A}$. D., was purchased in Crete by Janos Laskaris for Lorenzo de' Medici, was subsequently aequired by Cardinal Nicolas Rudolfi and is now one of the treasures of the Laurentian Library at Florence (Codex lxxiv, 7). This contains 30 full-sized plates illustrating the commentary of Apollonius of Kitium on the Hippocratic treatise on dislocations ( $\pi \epsilon \rho i \alpha_{\alpha} \rho \rho \rho \nu$ ) and 63 smaller cuts scattered through the pages of Soranus' treatise on bandaging. The Apollonian pictures, which are also to be found in Codex 3632 of the University Library at Bologna, are pen and brush drawings in dark brown tone representing the various manipulations and apparatus employed in reducing dislocations, the figures in each ease being surmounted by an archway of ornate Byzantine design. Their origins, Sudhoff thinks, go back to Alexandria or Cyprus, where Apollonius wrote his commentary during $\$ 1-5 \$ \mathrm{~B}$. C. They were undoubtedly transmitted directly from antiquity, ${ }^{3}$ and, therefore, represent the genuine Hippocratic traditions of sur-

${ }^{1}$ Edited by W. A. Greenhill (Oxford, 1842).

${ }^{2}$ E. Jeanselme: La goutte à Byzance. Bull, Soc. franç. d' hist. de méd., Par., 1920, xiv, 13i-164.

${ }^{3}$ Sudhoff: Beiträge zur Geschichte der Chirurgie im Mittelalter, Leipzig, $1914,4-7$. 
gical practice as transmitted through later Groek channels to Byzantiun. The two sets of pictures were reproduced in frechand style by the Renaissance artists Jan Santorinos and Franceseo Primaticeio and these reproductions were used by Guido Gudi to illustrate his surgical colleetions (Paris, 15411). The treative of Apollonius has since been reprinted, with the illustrations loy Hermann Sehöne $\left(1896^{2}\right)$. The 200 designs used by Guido Guidi have been reproduced by 11 . (Omont. ${ }^{3}$

1 'The pictures are to be found in Guido Guidi's Chiurgia e greeo in latinum conversa (Paris, 1544), in vol. iii of his "Ars Medieinalis" (Venice, 1611), in his Opera Omnia (Frankfort, 166S), and in Conrad Gesner's collection De chirurgia scriptores optimi, Zürich, 1555, 321-358 (Sudhoff).

- Apollonius von Kitium: Illustrierter Kommentar zur der Hippo-

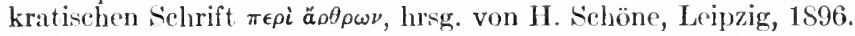

${ }^{3}$ Bibliothèqu nationale. Département des manuserits. Collection de chirurgiens grees (MIS. latin, 6566). Ed. H. Omont, Paris [s. d.]. 


\section{THE MOHAMMEDAN AND JEWISH PERIODS}

(732-1096 A. D.)

By the swords of Mohammed and his emirs, the wild ontlaw clans of the Asian and African deserts were converted into nations capable of acting as military and social units, but it was not until long after his death, when the mighty empire which he founded was subdivided into caliphates, that the sciences and arts were permitted to develop. During the period of conquest and conversion, the fanatical, fatalistic zeal of the Moskms tended naturally toward the destruction and persecution of the things of the mind. While the principal service of Istam to medicine was the preservation of Greek culture, yet the Saracens themselves were the originators not only of algebra, chemistry and geology, but of many of the so-ealled improvements or refinements of rivilization, such as strect-lamps, window-panes, fireworks, stringed instruments, cultivated fruits, perfumes, spices, and that "often-changed and oftenwashed undergarment of linen or cotton which still passes among ladies under its old Arabic name."1 In the intellectual sphere, the monotheism and the dialectic tendencies of Galen and Aristotle appealed strongly to the Mohammedans. Galen's polypharmacy in particular appealed to these natural chemists, and his haphazard "polypragmatism" was molded by them into iron-clad dogma. The Oriental idea that it is sinful to touch the human body with the hands dicl little to advance anatomy or surgery. The general trend of Oriental religious fatalism was toward contemplative brooding and resigned submission to authority and such eagerness or free-play of the mind as the Moslems possessed was expended in hair-splitting subtleties. Thus the intellectual tendencies of the Middle Ages were determined for them in advance, and, if we may trust the statements of men so different as Sir Henry Layard, Sir Henry Maine, and the ophthalmologist Hirsehberg, the great mass of the people in the East detest all reforms and scientific inquiry to this day. We call the medical authors of the Mohammedan period "Arabic" on account of the language in which they wrote, but, in reality, most of them were Persian or Spanish-born, and many of them were Jewish.

${ }^{1}$ Draper: "History of the Intellectual Development of Europe," New York, 1876 , ii, pp. 33, 34. The Alhambra, like the Cretan palace at Knossos, contains a specimen of the sanitary invention known in Europe as W. C. 
The Mohammedan physicians themselves owed their medical knowledge, in the first instance, to a persecuted sect of ('hristians. Nestorius, a priest who had been made patriarch of Constantinople in 428, taught the heretieal doetrine that Mary should not be styled the "Mother of (iod" but the "Mother of Christ." In consequence, he and his followers were driven into the desert and, like the Jews after them, took up the study of medicine because of religious and social ostracism. The Nestorian hereties gained

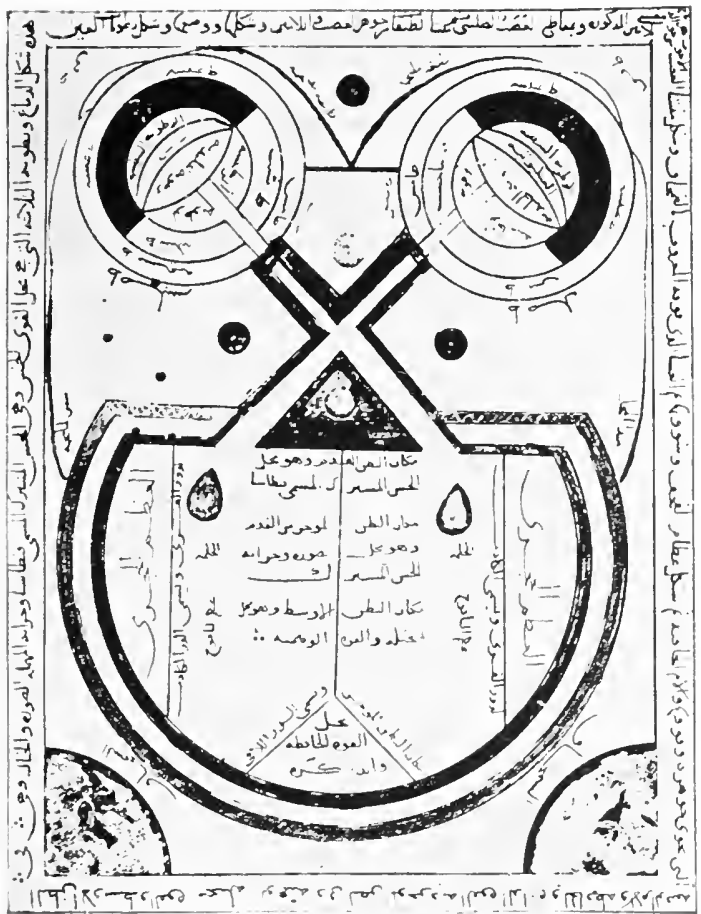

Schema of the brain, crossing of the optic nerves and cross-section of the eyes, showing lens, vitreous, retina, conjunctiva, cornea and tunies. From ils. 924 in the New Mosque at Constintinople (Pansier, Hirschberg, sudhoff).

control of the school at Edessa in Mesopotamia, with its two large hospitals, and made it a remarkable institution for teaching medicine, but were driven out by the orthodox Bishop Cyrus in 489. Fleeing to Persia, where their theologic doctrines were welcome, they established the famous school at (iondisapor, which was the true starting-point of Mohammediın medicine.

The Eastern (or Bagdad) (aliphate (750-1258) was under the sway of the Abbasides, who were friends of learning and science 


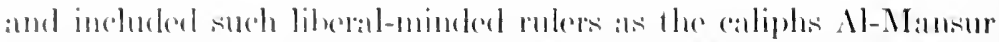

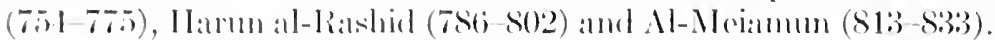

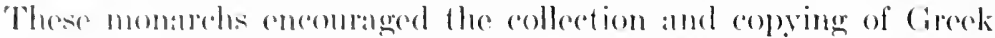

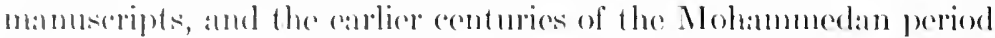

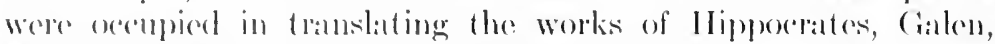

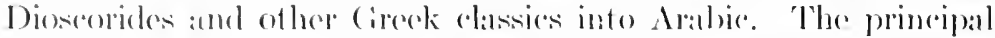

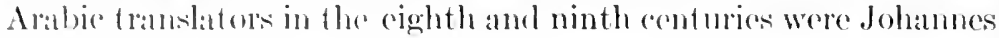

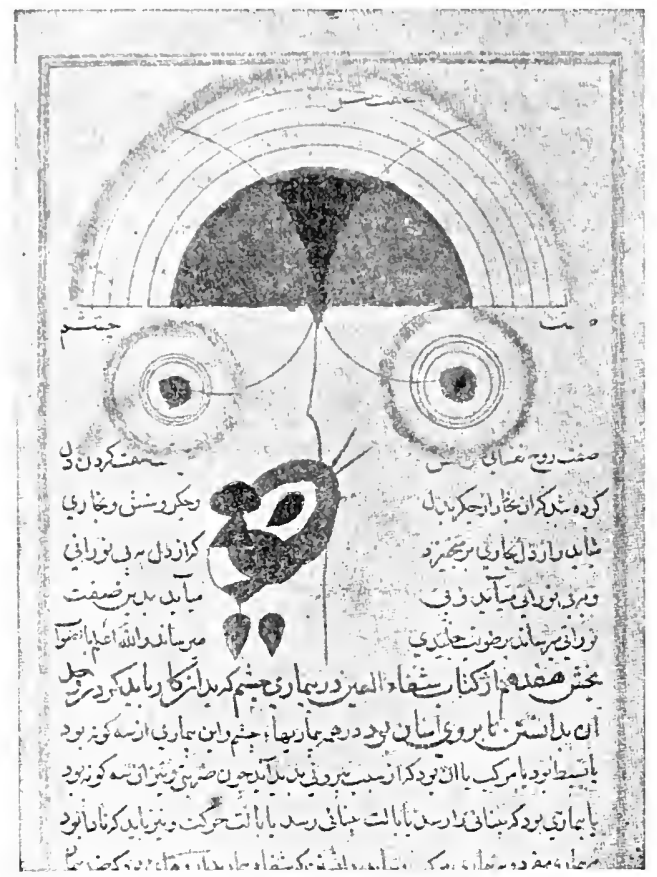

Arabir sehema of the head, eyes, and "sight spirit," which proeeeded from the brain to envelop the object of vision and earry it back to the erystalline humor. (From a Persian MIS. of the seventeenth century.) Meyerhof and Prüfer (Sulthoff's Archiv, 1912, vi, 26).

Mesuë the elder (777-837), called Janus Damascenus, a Christian who became director of the hospital at Bagdad, and the Nestorian teacher Honian ben Isaac (or Johannitius) (809-873), whom Withington calls "The Erasmus of the Arabic Renaissance." Johannitius had an adventurous career, translated Hippocrates, Galen, Oribasius, and Paul of Agina, and was in his day the leading medical spirit of Bagdad. He wrote a commentary on Galen's Microtechne (Isagoge in Artem parwam) and the oldest treatise 
in Arabic on ere diseases (IIrschlererge. The ton sections have been translated by M. Meverhof and C. Prüfer of C'airo, with an interpretation of Honain's theory of vision, and intresting plates representing the "schematic cye" (Cairene MIs.) and the Galenic "sight-spirit" (Sehgeist), which was supposed to proeeed from the brain wa the nerves to envelop the object seen, proceeding thence to the erystalline humor to complete the act of vision.

The greatest physicians of the Eastern ('aliphate were the three Persians, Rhazes, Haly Abbas, and Avicenna.

Rhazes (860-932), a great clinician, ranks with Hippocrates, Aretreus, and Sydenham as one of the original portrayers of disease. llis description of smallpox and measles is the first anthentie account in literature, a classic text, preserved in the original Arabic, with parallel Latin translation, in ('hanning's odition (London, 1766). Although smallpox had been vaguely deseribed as early as the sixth century by some of the church fathers and by the seventh eentury chromicler, Aaron (cited in the (continent of Rhazes), the aceount of Rhazes is so vivid and complete that it is almost modern. His great encyclopedia of medicine, the El Hawi, or Continens, which Haller preferred to any other Arabic treatise, is preserved in the Latin translation of Feragut (Brescia, 1486). Made up of an enormous mass of extraets from many sources, together with original clinical histories and experiments in therapeuties, it reveals Rhazes as a Galenist in theory, although he was a true follower of Hippocrates in the simplicity of his practice. The ninth book of Rhazes, which was translated by Vesalius and commentated by Gatinaria, was the source of therapentic knowledge until long after the Renaissance.

Haly ben Abbas, a Persian mage, who died in 994, was the author of the Almaleki ("Liber regius" or "Royal Book"), a work which was the canonical treatise on medicine for a hundred years, when it was superseded by the Canon of Avicema. It has never been printed in the original Arabie, but was translated into Latin in 1080 by Constantinus Africanus, who publishel it as his own work.2 This translation contains a description of small-

I Arch. f. Gesch. rl. Merl., Leipzig, 1910-11, iv, 163-190, 1 pl: 1912-13, vi, 21-33. This work is not to be confused with the Monilorium oculariorum of Haly ben Isa (Jesu Hali), an eleventh eentury writing which became the classic text-book on ophthalmology in later Islam and is still authoritative (Hirschberg). The medieval Latin translation of this mork is valueles and unintelligible. The best motern translation is that of Hirschber and Lippert (Leipzig, 1907).

2 The two principal Latin ehitions are the Venetian of 1492 and the Lyons f 1523. 
pox and "Persian firc" (malignant anthrax), also the Iatin torm for smallpox (variolit).

Ibn Sina, or Avicenna (9S0-10;36), alled "the Prince of Physicians," a convivial Omarian spirit, (mincontly successful in practice as court physician and vizier to different caliphs, was one who trod the primrose path at ease and died in the prime of life from the effect of its plasures. Ho was physician in chicf to the celebrated hospital at Bagdad, and is said to have written over one hundred works on different sulijects, only a few of which have been preserved. His wonderful description of the origin of monntains (cited by Draper and Withington) fully entitles him to be called the "Father of Geology," and it is interesting to note that two physicians, widely separated in space and time-Avicenna and Fracastorius-are the only writers who contributed anything of value to this science for centuries. Aviecmna is said to have been the first to describe the preparation and properties of sulphuric acid and alcohol. His Canon," which Haller styled a "methodic inanity," is a huge, mwicldy storchouse of learning, in which the anthor attempts to codify the whole medical knowledge of his time and to square its facts with the systems of Galen and Aristotle. Written in clear and attractive style, this gigantic tome became a fomtain-head of authority in the Nicllle Ages, for Avicemna's elaborated train of reasoning, a miracle of syllogism in its way, appealed particularly to the medieval mind, and indeed set the pace for its movement in many directions. Arnold of Villanova defined Avicenna as a professional scribbler who had stupefied European physicians by his misinterpretation of Galen (Nenburger). In fairness to Avicenna, it is proper to say that his elinical records, which he intended as an appendix to the Canon, were irrecoverably lost, and only the Arabic text of the latter, published at Rome in 1593, and at Bulak in 1877, survives. That Avicenna must have been a clever practitioner we should naturally infer from his great reputation. For example, the striking plates in the Giunta edition of 1595 show that he must have known and practised the Hippocratic method of treating spinal deformities by

1 The term "variola" was first employed in the Chroniele of Bishop Marius of Avenches, as follows: "Anno 570 . Hoc anno morbus validus cum profluvio ventris et variola Italiam Cialliamque valde afflixit, et animalia bubula per loca supraseript a maxime interierunt." Gregory of Tours, Historia Francorum, in M. Bouquet, Recueil des historiens des Gaules, Paris, 1739, ii, 1S. Cited by Paul Richter, Arch. f. Ciesch. d. Meri., Leipz., 1911-12, v, 325.

${ }^{2}$ The principal Latin erlitions of the Canon are the Milan imprint of 1473, the Paduan of 1476 and 1497 , the Venetian of $1482,1486,1490,1491$, 1494 and 1500 , the Giuntas of $1527,1541,1555,1582,1595$, and 1608 . The commentaries in toto were printed in five giant volumes by the Giunti at Venice in 1523. 
forcible reduction which was reintroduced by ('alot in 1896 . His recommendation of wine as the best dressing for wounds was very popular in medieval practice. Avicenna also describer the guineaworm (Iena medinensis.'). He described anthrax as "Persian fire" (Kanon, Bulak el. 1294 (1877), III, 118) gave a good areount of diabetes, and is said to have noticed the sweet ish taste of diabetic urine." Yet, upon the whole, the influence of the "( "anon" upon medieval medicine was bad in that it confirmed physieins in the pernicious idea that ratiocination is better than first-hand investigation. It also set back the progress of surgery by inculcating the novel doetrine that the litter art is an inferior and separate branch of medicine and by substituting the use of the cautery for the knife.

Three treatises on anatomy by Rhazes, Haly Abbas, and Aricenna have been edited by P. (le Koning $\left(1903^{3}\right)$.

Oseibia (1203-69), of Damascus, the first historian of Arabic medicine, wrote a series of hiographies of ancient physicians, still in manuscript, which was the main source of the histories of Wüstenfeld and L. Jeclerc. ${ }^{4}$

Other prominent medical figures of the Eastern Caliphate were the Hebrew physician Isaac ben Solomon, ealled Isaac Judæus (850-950), who wrote a book on uroseopy and a treatise upon dietetics (De dicta, Padua, 1487), which becañe deservedly popular in Europe; and the Arabian travelet Abdollat if (1161-1231), who visited Egypt at Saladin's instance, and while there had opportunities for studying human skeletons which convinced him that Galen's osteology must be wrong in many important respects.

The Western or Corlovan Caliphate (655-1236) attained highest prosperity under the Spanish or Ommiade dymasty (75.5) 1036), and its leading medieal authors were the surgeon Albucasis, the philosopher Averroes, and the Jewish physicians Avenzoitr and Moses Maimonides.

Albukasim, called Albucasis, a native of Cordova, flomrished in the 11th century, and was the author of a great medico-chirurgical treatise called the Altasrif (or "('ollection"), of which the surgical part survives in Chamning's Arabic text and transli-

I Arieenna, Canon, sect. III, traet. 11, cap). XXI.

${ }^{2}$ Dinquizzi: Bult. Acarl. de mél., Paris, 1913, Ixx, 631. Erich Elstoin (Ztsehr. f. Trol., Leipzig, 1915, ix, 243) shows that the liaticum preverinantes

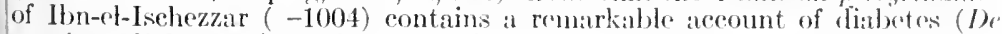
passione diabrlica) in which the thirst, polyuria, canine appetite, ete, al" noted, but not the sweetish urine.

${ }^{3}$ 'Trois traités d'anatomie arabe, Leyden, 1903.

${ }^{4}$ A Latin translation by J. J. Reiske is at Copenhagen, and the work was partly translated into French by B. R. Sanguinette (Journal asiatique, Paris, 1S54-6). 
tion (Oxford, Clarendon Press, 1778). It contains illustrations of surgieal and dental instruments (interpolated in the Venctian surgical anthologr of lis(0) and was the leading text-book on surerey in the Middle Ages up to the time of Siliedo. It consists of thre books, founderl upon the work of l'aul of Egina. The first hook doals with the use of the actual cantery, the special foature of drabian surgery, and gives deseriptions and figurations of the pexuliar instruments used; the second book contains full descriptions of lithotomy, litbotrity, amputations for gangrene and the treatment of wounds; the thind hook deals with fractures and lislocations, including fracture of the pelvis and a montion of paralysis in fracture of the spine. Albucasis was apparently the first to write on the treatment of deformities of the mouth and dental arches, and he mentions the olstetric posture which is now known as the "Walcher position." 1 In (imlt's time, the illustrations of surgical (including dental) instruments in Albucasis counted as the earliest known, but many earlier have since been discovered in medicval manuscripts by Sudhoff and others. The Oriental horror of touching the body with the hands or the knife was the sufficient reason why these pictures from the antique were not reproduced except occasionally in the manuseripts of the Persian Mohammedans.

The greatest of the Jewish physicians of the Western Caliphate was the Cordovan Avenzoar, who died in 1162. He was one of the few men of his time who had courage enough to tilt against Galenism, and by his description of the itch-mite (Acarus scabici) he may be accounted the first parasitologist after Alexancler of Tralles. He also described serous pericarditis, mediastinal abscess, pharyngeal paralysis, and inflammation of the middle ear, and he recommended the use of goat's milk in phthisis and tracheotomy. His Teisir or "Rectification of Health" is preserved in the Latin translation published at Venice in 1490.

His pupil, Averroës, also Cordovan-born (1126-1198), was more noted as a philosopher and free thinker than as a physician. His Kitab-al-Kollyat transliterated as Colliget ${ }^{2}$ (Book of Universals), an attempt to found a system of medicine upon Aristotle's philosophy, advanced the Pantheistic doctrine that the soul or nature of man is absorbed into universal nature at death. This denial of personal immortality caused Averroës to be persecuted in his own

1 "Tum decumbat mulier in collum suum, pendeantque deorsum pedes, ejus, illa vero in lectum decumbat, etc.," cited by Dr. Herbert Spencer in Lancet, Lond., 1912, i, p. 1569 . Mercurio, in La Comare (1596), also described the hanging position of Walcher.

${ }^{2}$ Published at Venice in 1482. 
lifetime, and his followers to be anathenatized during the Micklle Ages. His work is of interest only as a relic of Arabic modes of thought.

The Rabbi Moses ben Maimon, ealled Moses Maimonides (1135-1204), was court-physician to Saladin, and his treatisc on personal hygiene (Tractatus de Regimine Sanitatis) was writton for that sultan's private use. It contains some admirable procepts of diet and regimen, inchuding a rhubarb and tamarind pill, and its first edition, the Florentine imprint of 1478 , is esteened as one of the rarest of books. His tract on poisons was much cited by medieval writers, and has been translated into French in 1865) and into German by Steinschneider $\left(1873^{1}\right)$.

Such able chemists as the Arabians could not fail of being good phamacologists, and their descriptions of the materia med(a) and of the preparation of drugs became standard authority hroughout the Middle Ages. Even to this day what Osker calls "the heavy hand of the Arabian" is sensed in the enormous bulk of ur own pharmacopeias. The principal storehouse of the Arabian nateria medica is the "Jami" of Ibn Baitar, a huge thirteenth -entury compilation, describing some fourtecn hundred drugs, of rhich about 300 are said to be new. The Grabadin, or apothe'ary's manual (Antidotarium), of the eponymous or pseudonymous Mesue junior, now called "pseudo-Mesue," a mysterious Latin ompilation of the tenth or eleventh contury, of which the Arabic riginals have never been found, was the most popular conrendium of drugs in medieval Europe, and was used everywhere in their preparation. The treatise on purgatives divides the latter nto laxative (tamarinds, figs, prunes, cassia), mild (wormwood, enna, aloes, rhubarb) and drustic (jalap, scammony, colocyuth). The esteem in which these works were held is shown by the fact hat a Latin translation of both was one of the first medical books o be printed (Vonice, 1471). An important work in the Persian inguage was the materia medical of Abu Mansur," containing escriptions of 585 drugs, of which 466 are vegetable, 75 mineral nd 44 animal. The Arabic writings on toxicology up to the end f the twelf th century have been exhaustively considered by Steinshneider $\left(1871^{3}\right)$. A Persian mamuscript of the eleventh century y Ismail of Jurjani contains probably the most complete direc20.

1M. Steinschneider: Arch. f. path. Anat., [ete.], Berl., 1573, lvii, (63-

${ }^{2}$ Epitomized in Latin by R. Soligmann, Virmna, 1830-33, and translated to German under the direction of Rurlolf Kobert (Histor. Stud. a. d. pharm. ist. d. Iniv. Dorpat, 3. Heft, Halle, 1893).

37.

${ }^{3}$ M. Steinschneider: Arch. f. path. Anat., [etc.], Berl., 1871, 411, 340; 
tions of the period for examining the mrine. There is much of value on climatology and medical geography in the Arabic writers.

Cultural Aspects of Mohammedan Medicine.-In Sir Richard Burton's tramsition of the Arabian Nights," there is a tale of a spendthrift heip who has squandered all his substance except a beant iful slave girl of extraordinary talents, who, realizing her mastor's plight, wreses him to bring her before the Caliph Harun alRashid to be sold for a sum large enough to cover his losses. On secong her, the Caliph decides to test the extent of her knowledge, and has specialists put her through a lengthy cross-examination which, incidentally, furnishes us a good documentation of the social aspects of Arabian medicine. As the fair slave exploits her extensive knowledge of Mohammedan theology, law, philosophy, medicine, astronomy, astrology, music, chess-playing, and other arts and soiences, we percive that these accomplishments were also an essential part of the Arabian physician's training, and at the same time, that a certain acequantance with the Galenical system of medicine was a feature of the cultural equipment of any welleducated Mohammedan of the period. The Arabians derived their knowledge of Greek medicine from the Nestorian monks, many practical details from the Jews, and their astrologic lore from Egrpt and the far East. So the slave girl follows the Talmud in regard to the number of the bones (249), gives an exact account of the four humors, and details at length the effects of different conjunctions of the plancts. Diagnosis of internal disease is founded upon six canons: (1) The patient's actions; (2) his excreta; (3) the nature of the pain; (4) its site; (5) swelling; (6) the efluuvia of the body: and further information is elicited by "the fecl of the hands," whether firm or flabby, hot or cool, moist or dry, or by such indications as "yellowness of the whites of the eye" (jaundice) or "bending of the back" (lung clisease). The symptoms of yellow bile are a sallow complexion, (lryness of the throat, a bitter taste, loss of appetite, and rapid pulse; those of black bile, "false appetite and great mental disquict and eark and care," terminating in melancholia." Medicinal draughts are best taken "when the sap runs in the wood and the grape thickens in tha cluster and the two auspicious planets, Jupiter and Venus, are in the ascendant." (upping is most effective at the wane of the moon, with the $56-6$.

1 See E. Wiedemann: Arch. f. Geseh. d. Naturw., Leipz., 1914-15, v,

${ }^{2}$ Denver edition, 1899, vol. v, pp. 189-245 ("Abu al-Husn and his slavegirl Tawaddud'), the medieal portion being on pp. $218-226$.

${ }^{3}$ Maurice Girardeau, in his Paris Dissertation (No. 107, 1910), points out that the cholemic diathesis was perhaps the mast prominent feature of Arabic pathology. 
weather at set-fair, preferably the seventeenth of the month and on a Tuesday. This, or something like it, was about the character of Mohammedan practice toward the end of the fourteenth century, the period assigned for the composition of the Arabian Nights, and we may reasonably infer that is also fairly representative of the best period of Moslem medieine as handed down by tradition. According to Hirschberg's dictum, the peoples of Islam have not attained to modemity, but rely upon the same medical authorities which they employed in the Middle Ages.' In the past, the Arabian physician, whose professional importance was gauged by the height of his turban and the richness and length of his sleeves, was usually an astrologer and a magician, who regarded the heart is "the prince of the body," the lungs as the fan of the heart, the iver as the guard of the heart and the seat of the soul, the pit of he stomach as the seat of pleasure and the gall-bladder as the eat of courage. From the Arabic medical texts, we know that heir authors upheld the Cialenic pulse-lore, affected to arrive at naccessible data, such as the sex of the child in pregnancy by nspection of the urine (uroscopy), wrote charms in cups with "purgative ink" to mystify their patients, indeed, resorted to all anner of sensational trade-tricks and surprises in order to impose heir authority. Like some of our modern faliers, who conduct piritualistic séances, the Arab physician hired confederates, who bund out about the patient's condition in advance or even feigned J be patients themselves in order to puff his reputation.2 They bstained from dissecting out of religious conviction, left operative rrgery and venesection to the wandering specialists, and the are of women's diseases and obstetric cases to midwives: were onstantly squabbling among themselves, stipulated their foes in lvance and tried to collect at least half, if the case took an afavorable turn or did not improve. Some of the fees they reived were phenomenal. Cabriel Batischua, a favorite of Hisum -Rashid, got about $\$ 1500$ per annum "for bleeding and purging te Commander of the Faithful," besides a regular monthly salary about $\$ 2500$ and a New Year's purse of $\$ 6250$. He estimated s total fortune in fees at $\$ 10,000,000$, and on being recalled from inishment to heal Al-Meiamun, he received $\$ 125,000$, which ithington regards as the largest fee on record. Abu Nasr, ac-

1 J. Hirschberg: Geschichte der Augenheilkunde, 2. Aufl, Leipz., 190s, ii, 2 , 1.tnote. He gives several examples, $\theta \cdot g$, a Druse in Syria who in 1860 treated ( diseases from the ten centuries older canon of Honain and Haly ben Isalac. Cairene book of eye-magic of 1859 contains an illustration of $1296 \mathrm{~A}$. D., ('tc.

${ }^{2}$ The tricks of these people were legion, and formed thesubjeet of a lueubrat $n$ of Rhazes. See, in partieular, Ml. Steinsehneider: Wissensehaft und ("lurlaneric unter den Arabern im neunten Jahrhundert. Virchow's Arch, I rlin, 1866, xxxvi, 570; xxxvii, 560 . 
cording to the same authority, recoived more than $\$ 60,000$ for (uring onc of the Caliphs of stone. Most all the prominent physicians of the period aimed to curry favor with the reigning potentates or to supplant rival colleagues in their good graces. The Caliphs themsolves, after the Mohammedan passion for conquest had been sated, bec:ame loyal supporters of science and were instrumental in founding hospitals, libraries, and schools. Even private collections of books were sometimes of extraordinary extent, and all Greek, Egyptian, Indian, and Jewish eulture that did not conflict with the creed of Islam was rapiclly assimilated. As early as $707 \mathrm{~A}$. D., the Caliph El Welid had founded a hospital at Damaseus. Another was established at Cairo in 874, two at Bagdad in 918, another at Misr (Egypt) in 957, two others in the same eity in 925 and 977. In course of time dispensaries and infirmaries existed in all the important cities of the Eastern Caliphate and about 1160 a Jewish traveler found as many as sixty of these institutions in Bagdad alone. The largest and best appointed of the Mohammedan hospitals were those founded at Damaseus (1160) and Cairo (1276). In the former of these, treatment was given and drugs dispensed free of charge for three centuries. As late as 1427 it was said its fires had never been put out since its opening. The great Al-Mansur hospital of Cairo $\left(1283^{1}\right)$ was a huge quadrangular structure with fountains playing in the four courtyeards, separate wards for important diseases, wards for women and convalescents, lecture rooms, an extensive library, out-patient clinies, diet kitchens, an orphan asylum, and a chapel. It employed male and female nurses, had an income of about $\$ 100,000$, and disbursed a suitable sum to each eonvaleseent on his departure, so that he might not have to go to work at once. The patients were nourished upon a rich and attractive diet, and the slecpless were provided with soft music or, as in the Arabian Nights, with accomplished tellers of tales. The Cordovan Caliphate was equally well off in the number, if not the extent, of its hospitals, while the Bagdad Caliphate was especially noted for its ophthalmic dispensaries and lunatic asylums. The Arabians were far ahead of their European contemporaries in their kindly treatment of the insane. Medical instruction was given either at the great hospitals at Bagdad, Damaseus and Cairo, or as a special course at the academies which existed in all the cities. Of these, the Hall of Wisdom at Cairo was the most famous. The principal courses were clinieal medicine, pharmacology, and therapeutics. 'Anatomy and surgery were neglected, but chemistry was held in special esteem. Arabian medicine was, in fact, the parent of alchemy, the founder

1 Wüstenfeld: Janus, Breslau, 1846; i, 28-39. 
of which was the perhaps mythical Geber $(702-765)$, the discoverer of nitric acid and aqua regia and the describer of distillation, filtration, sublimation, water-baths, and other essentials of chemical procedure. Alchemy was combined with astrology in this wise. The ancient Chaldaic Pantheism, the doctrine of an anima mundi, or "soul of the world," with indwelling spirits in all things, was applied to whatever could be extracted from substances by fire, as "spirit," of wine, "spirit" of nitre, or the various essences and quintessences; while to the seven planets (the sun, the moon, Mars, Mereury, Jupiter, Saturn, Venus) corresponded the seven days of the week and the seven known metals (gold, silver, iron, quicksilver, tin, lead and copper). As these metals were supposed to be "generated" in the bowels of the earth, the special aim of alchemy was to find the fecundating or germinal substance, under appropriate planetary influences. Thus Geber's parable of a medicine which could heal any of six lepers was regarded by Boerhave as nothing more than allegory of the philosopher's stone for transmuting the six baser planetary metals into gold. Hand in hand with this idea of transmutation of metals went the notion of a polyvalent "elixir of life," which could cure all diseases and confer immortal youth and which was supposed to be of the nature of a "potable gold" (aurum potabile). The search for potable gold led to the discovery of aqua regia and the strong acids by Geber and Rhazes, and the quest of the elixir became the foundation of chemical pharmacentics. Even as late as the sixteenth century, we find Paracelsus still upholding Cieber's dea that everything is made of mereury, sulphur and salt, and that is "the sun rules the heart, the moon the brain, Jupiter the liver, Saturn the spleen, Mereury the lungs, Mars the bile, Venus the zidneys," so the seven planetary metals and their eompounds were pecifies for the diseases of these organs under the will of the stars. Irabian ehemistry probably survived beyond the decadence of Irabian medicine, for Leo Africanus, a traveler of the fifteenth entury, mentions a chemical society which existed at Fez at that ine. From their constant contact with strange lands and peoples, he Arabian pharmacists or "sandalom." were the exploiters if not he introducers of a vast number of new drugs; in panticular, semma, amphor, sandalwood, rhubarb, musk, myrrh, cassia, tamarind, utmeg, cloves, cubebs, aconite, ambergris and mereury; besides eing the originators of syrups, juleps, alcohol, aldehydes (all rabic terms), and the inventors of flavoring extracts made of roseater, orange and lemon peel, tragacanth, and other attractive igredients. The use of hashish (Camabis indica) and bhang ither Indian hemp or hyoseyamus) to produce drug-intoxication abannuj) or deep sleep were well known, and the unsecmly 
behavior of addiets of these drugs is described in the Arabian Nights.' King Omar asts the Princess Abrizah into a heavy shumber with "a piece of roncentrated hhang, if an elephant smelt it he would sleep from vear to your." In another tale, the thief Ahmad kamakim drugs the guards "with hemp fumes." 3 Thus the possibilities of anesthesia by inhalation were known to the Arabians, as well as to Dioseorides and the medieval surgeons, and presumably the original knowledge came from India, since the Egrptians did tuat little surgery. The Arabian apothecary shops were recularly inspected by a syndic (Muhtasib) who threatened the merehants with humiliating corporal punshments if they adulterated drugs (Guigues ${ }^{4}$ ). The effect of Arabian chemistry and pharmacy upon European medicine lasted long after the Mohimmedan power itself had waned and, with the simples of Dioscorides and Pliny, their additions to the materia medica made up the better part of the European phamacopeias for centuries.

closely connected with Mohammedan medieal culture is the influence of the Jews upon European medicine. Inder the Arabian domination, Jewish physicians were prominent figures at the courts of the ealiphs and a common belief in a stern monotheism created a strong bond of sympathy between Moslem and Hebrew. Another point of contact was the fact that the Hebrew and Mohammedan physicians, with their peculiar analytic east of mind, their intensive modes of thought and their appreciation of "values," soon acquired a right materialistic way of looking at concrete things. Thus while medical men under Christianity were still trifling with charms, amulets, saintly relics, the Cabala, and other superstitions, many of the Jewish and Mohammedan physicians were beginning to look upon these things with a certain secret contempt.

During the Middle Ages and long after, the lot of the Hebrew physician in Europe was to be used and abused. In the tenth and eleventh centuries, he was, as Billings says, "a sort of contraband luxury," "resorted to and protected by prince and prelate alike, on account of his superior scientific knowledge, but hardly countenanced for any other reason. The Council of Vienna in 1267 forbade the Jews to practise among Christians. Under the Western Caliphate, Jewish physicians were prominent figures in Spain

${ }^{1}$ Burton's Arabian Nights (Denver edition), iii, 91-93, Suppl., iv, 19; 189.

${ }^{2}$ Op. cit., ii, 122-124.

${ }^{3}$ Op. cit., iv, 71 .

${ }^{4}$ Guigues: Bull. d. sc. pharm., Paris, 1916, xxiii, 107-118. An interesting list of the substances used to adulterate various standard drugs is given.

5 J. S. Billings: "The History and Literature of Surgery" (Dennis's System of Surgery, New York, 1895, vol. i, p. 38). 
until they were banished the country in 1412, and the school of Salemo utilized them as teachers until it had developed enough home-glown talent to get along withont them. The same thing was true of Montpellier, which was closed to the Jews in 1301. There were many at Avignon up to the fifteenth century.' The interdictions put upon Jewish physicians by Popes Paul IV (1555-9) and Pius $V(1566-72)$ were lifted by Gregory XIII in 1584." Although the different emperors continued to retain Jews as their body physicians, yet, up to the time of the French Revolution, they were not allowed to study at the European universities and, being moreover excluded from the liberal professions, played little part in medicine during this period. At the outset of the modern industrial movement, they were admitted to the rights of citizenship all over Europe and given the freedom of the universities. The effect of this liberal policy was to bring forth a great array of brilliant talent which contributed very materially to the development of medicine in all its branches, as witness the work of Henle, Cohnheim, Weigert, Traube, Stricker, and Pick in pathology, Senator, Hayem and Boas in internal medicine, Romberg, Moll and Fieud in neurology, von Hebra, Kaposi, Neumann, von Zeissl and Unna in dermatology, Caspar, Lesser, Ottolenghi and Lombroso in forensic medicine, Hirsch, Marx, Pagel, Magnus and Neuburger in medical history, and, in the science of infection, Metchnikoff, Fränkel, Friedländer, Marmorek, Haffkine, Neisser, and Paul Ehrlich, ${ }^{3}$ to mention only a few well-known names.

1 For a list of Jewish physicians at Avignon, see P. Pansier, Janus, Alnst., $1910, x v, 421-451$.

${ }^{2}$ A copy of this document is in the Surgeon General's Library.

${ }^{3}$ For a more complete list of molern Jewish physicians, see F. T. Haneman's paper in the Jewish Encyclopachia, New York, 1904, viii, 421, 42.2. 


\section{THE MEDIEVAL PERIOD (1096-1438)}

THe Middle Ages, the period of feudalism and ecolesiastieism, are commonly decried for servile obeisance to atuthority, with its attending evils of bigotry, pedintly and cruelty. We regard any one who secks to suppress the truth by overbearing or underhanded mothods as "medieval-minded," and we think of special privileges, vested interests, uncarned increments, Faustrecht, and other phases of Rob Roy's "simple plan," as smacking of feudalism. Yet, in the Middle Ages, there was true "consent of the governed." The people aspired toward nationhood and solidarity rather than toward personal independence and, under these eonditions, were willing to be led and directed rather thin to think for themselves. In the wolter of race-inmixture and race-absorption that followed the downfall of the Roman Empire, it was found that Greek philosophy (neo-Platonism) was a total failure as a moral force, and the greatest need of European humanity was for a spiritual uplift, for regeneration and renewal of eharacter rather than for intellectual devclopment. Mental and moral activities were simply paralyzed by that great eataclysm. To understand the impulses which drove the hermits to the desert and founded the monasteries, one can read Gibbon, Lecky, Montalembert, Gregorovius, Froude on the break-up of Roman society, Turgenieff's wonderful evocation of a Cresarean triumph or Flaubert's miracle-play of The Temptation of St. Anthony. Matthew Arnold, with his fine historie sense, summed all this up in stirring verses:

On that hard Pagan world disgust

And secret loathing fell.

Deep weariness and sated lust

Made human life a hell.

She veiled her eagles, snapp'd her sword, And laid her sceptre down;

Her stately purple she abhorr'd, And her imperial crown.

She broke her flutes, she stopp'd her sports, Her artists could not please;

She tore her books, she shut her courts, she fled her palaces.

Thus, the Christian Chureh, with its spiritual appeal, its attractive symbolism, its splendid organization and its consolidation with Feudalism in protecting Europe from Moslem invasion, could not 
but trimph. The Crusales aroused the fecling of nationloosl. The organization of citizens against the robber barons awakened the civic consciousness. In the great struggle between collectivism and individualism which began from that hour, intellectual independence was bound to go to the wall if it came into conflict with C'hurch or State. In the Middle Ages there was immense concern lest "the centrifugal forees of soeiety overeome the centripetal." The growth of the Christian virtue of compassion toward weakness and suffering, and the more elevated and enlarged eonception of the position and mission of women that grew out of it, led to new drpartures in medicine along untried paths, particularly in nursing the sick and in erecting hospitals everywhere for their care. (Only idle bigotry could affirm that Pope and Emperor did not do a great deal for medicine in the advancement of good medical legislation. in the chartering and upbuilding of the medieval universities, in the great hospital movement of the Middle Ages and in the encouragement of individual medieal talent in many cases. Yet. as Allbutt has shown, the strife of intellects during the Ages of Faith was manifested in a way that tended to the absolute suppression of experimental seience or even of the actual verification of premises. The Cireek philosophers, as we have seen, held opinions the most clisparate without any special strife among thenselves, and above all with a certain definite immunity from persecution. To those who can appreciate the fine individualism of the Greeks, the sentiment of the English poet will not secm exagereated:

Greece, where only man whose manhood was as godhead ever trod, Bears the blind workl witness yet of light wherewith her feet are shod:

Freedom, armed of Greece, was always very man ani very God.

The medieval thinkers were all under the ban of authority, and this for the strangest, yet most potent, of reasons. From the earliest times, human ideas as to the meaning of life and the forees behind the material world have usually progressed along two distinct, often parallel, lines, viz., a tendency to deify and worship the objects or forces of external nature, culminating logically in either Pantheism or Buddhistic Pessimisn; and the rude fetishism of the savage, which passed through the successive stages of idolatry, hero-worship, ancestor-worship, polytheism, shamanism, finally merging into the pue monotheism of Islad, Christianity and Islam. Christian Theism assumes that Cod is a spirit, onmiresent and immanent in nature, yet different from it, acessible

1 The phrase is used as a criterion of good and bat government in Rooseelt's Romanes leeture on "Biologieal Analogies in History," Oxford, 1910, '. 23. 
to prayer, and eapable, at need, of divine intervention in human affairs. Pantheism simply identifies Cod with nature and natural foress. Now, in medieval times, the opposition between Theism and Pantheism took the form of a dispute between "Realists" and "Xominalists," which, says Allbutt (paraphrasing the language of John of salisbury), "engaged more of the time and passions of men than for the house of Casar to conquer and govern the world." To the medieval logician, "Realism" was just the opposite of our modern concept of a knowledge of material things. 'The Realist assumed, with Plato, that the idea is as actual as the thing itself and creative of it, the form as ral as the matter or substance and anterior to it, whence it follows that all things proced from the will of ciocl. 'The Nominalist, on the other hamel, affirmed that the form or idea is only a name or abstract eonception, existing in the mind of the observer alone, and that God, therefore, exists impersonally in each and every object of the material world. To medieval theologians, such Pantheism as this could be no less than infidelity and unbelief, since it tended to dissolve the dogmas of faith and was subversive of the ideas of divine revelation and of personal immortality, the hope held out to the Christian. To medieval physicians, such a manifesto of free-thought as the Hippocratic treatise "On the saered disease" would have been abhorrent, while Galen, with his devout monotheism and his careful Bridgewater teleology, became an object of almost veneration. Aristotle, in his Logic and Metaphysies, never made an absolutely elear distinction between the supposed reality of idea and substanee, ret public and private reading of his scientific works was forbidden by a provincial Synod at Paris in 1210 and the prohilition was repeated and extended to the Metaphysies by the Papal legate in 1215. Not until the decree of Gregory IX in 1231 fid they regain favor, to appear in the Arts Course (Paris) in 1255, and later to be regarded as an almost infallible authority. ${ }^{2}$ The more scientific writings of Aristotle were never studied in the eritical, inquiring way in which the Grecks would have regarded such things. Ptolemy said that "He who would serve the cause of truth in science must be, above all, a free thinker," yet his geocentric system of astronomy came to be defended by the Church as if an article of faith (Neuburger). The natural histories of Pliny and Aristotle were accepted by medieval authorities as beyond cavil, and imitated in the queer "Herbals" and "Bestiaries" (or Beast-Books) of the time. All reasoning was formal and de-

'For a full account of the subject, see Sir Clifford Allbutt's splendid Harveian oration, "Science and Mediæval Thought" (1901), to which the writer is very deeply indebted.

${ }^{2}$ C. H. Haskins: Harvard Stud. Class. Philol., Boston, 1909, xx, $\$ 6$. 
ductive. Until the Renaissance, there was neither induction nor experiment. Grown-up men aceepted such a tissue of solemn nonsense as the Timaus of Plato for sound physiologie doctrine. Nature herself was never questioned for her seerets, and, as Allbutt puts it, "Logic, whieh for us is but a drill, and, like all drills, a little out of fashion, was for the Middle Ages a means of discovery, nay, the very souree of truth. . . . The dialectically irresistible was the true." In the Golden Legend of Longfellow, medieval physicians and medical students are represented as frittering away their time in endless diseussions about the nature of universals, the relation between the idea and matter, and other dialectic subtleties. The Nominalist of advaneed and dogmatic type was even liable to persecution. Without going further into the lengthy disputes between Nominalists and Realists, it may be said that their adjustments of eause and effect have been traced through the ages in the "pmeuma" of Galen, the "archeus" of Paracelsus, the "animism" of Van Helmont and Stahl, the "thought and extension" of Deseartes and Spinoza, the "noumenon" and "phenomenon" of Kant, the "being and beeoming" of Hegel, the "will and idea" of Schopenhauer, and in sueh modern concepts as natural law and natural phenomenon, type and individual, foree and matter, statics and dynamics, vital principles and "the fortuitous coneurrence of physico-chemical forces." In our own day, the controversy has become merged into the opposition between Vitalism and Materialism. In the Middle Ages, the enormous expenditure of mental energy over this sterile, insolulble problem led the top-heavy feudalized scholastic to entertain an ill-concealed contempt for all mamual arts and crafts, especially for anatomy and surgery. Hence the surprising ignorance of Hippocrates in medieval times. "Had Cialen's works been lost," says Withington, "there ean be little doubt that the dark age of medieine would have been darker and more prolonged than it wats, for the medieval practitioner could no more have appreciated the higher and freer teaching of the physician of Cos than he conld have understood those grand words, 'It seemed good to the Demos,' which Hippocrates saw inscribed at the head of every decree, and heard proclaimed in every assembly."."

The fundamental error of medieval medieal seience, as Guy de Chauliac originally pointed out, and as Sir ('Tifford Allbutt, in a masterly survey, ${ }^{3}$ has demonstrated, was in the divoree of medicine

${ }^{1}$ Allbutt: Op. cit., pp. 50, 51.

2 Withington: Medical History, London, 1s94, 104.

${ }^{3}$ Sir Clifforl Allbutt: "The Historieal Relations of Medicine and surgery," London and New York, 1905. 


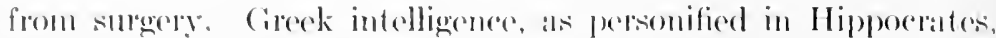

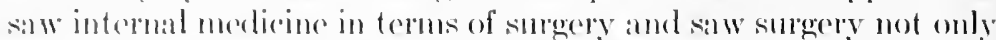
as a mode of therapy, hut as "the very right arm of intemal modirince," since, in diagnosis, the ontward and visihle signs of internal milialy (the only indieses the (ireck surgeon had) were also the mainstay of the elinician. Boginning with Avionma, medieval modical authority pushed Galen's dictum that surgery is only a mode of treatment to the extreme limit of trating the surgeon himsolf as a lacker and an inferior. The Arabian commontators of Galen and the medieval Arabists who eopied them were much obsesed with the idea, peculiar to Oriental religions, that it is undean or unholy to touch the human body with the hands under rertain conditions. As this tenet gained ground, scholastic and monastic minds became, as we have said, gradually penetrated with the conviction that redecraft is supcrior to handeraft, eulminating in the famous edict of the Council of Tours, "Eeclesia abhorret a sanguine" (1163). 'The general practice of surgery, including most of the major operitions, was, in the end, relegated to barbers, bath-keepers, sowgelders and wayfaring mountehanks, and the surgeon came to be regarded in such a menial light that, even in Prussia, up to the time of Frederick the Great, it was still one of the duties of the army surgeon to shave the officers of the line. Again the heresy imposed by the Arabist commentators of Galen, that "coetion" (suppuration) and "laudable pus" are essential to the healing of wounds, made operative surgery a perilous and meddlesome undertaking, all the more dangerous, indeed, in that the surgeon, whether scholar or mountebank, stood in jeopardy of life or limb if he operated unsuecessfully on any of the feudal lords of earth. The greatest surgeons of the time shrewdly advised their professional brethren to avoid the operative treatment of difficult or incurable eases, and, when they attempted the major operations, their eustom was to require a guarantee that no harm should come to them in the event of a fatal termination. To lift the surgieal art to its modern scientifie (aseptic) status required the genius and personal influence of the three greatest surgeons of all time-Ambroise Paré, John Hunter and Lord Lister. The principal interest of the medieval period, therefore, lies not in its internal medicine, for there was precious little of it, but in the gradual development of surgery from the ground up by faithful, sometimes obscure, followers of the craft, who (in France at least) were kept ostracized and short-coated by the edicts of the clerical bigots of St. Côme-the "chirurgiens de longue robe." The continued quarrels between St. Côme, the Paris Faculty and the barbers resulted in the admission of the latter to the practice of minor surgery in 1372 . 
Neuburger divides medieval medicine into four periods, viz., the Monastic (fifth to tenth centuries), the salemitan (eleventh to twelfth centuries), the temporary enlightemment of the thirteenth century, in which the Arabist culture was grafted upon that of the West, and the pre-Renaissance period (fourteenth century) in which this culture became dominant.

With the downfall of Rome came the Dark Ages during which Western Europe passed into a tedious period of material waste and intellectual decadence.

The transition, as Neuburger shows, was not eatastrophic, but grachal. The Germanie conquest entailed the loss of thousands of lives, the devastation of great tracts of country, the desolation of many eities and the destruetion of innumerahle landmarks of art and culture, while the East still possessed a farflung net work of marts of eommerce, covering three-fourths of the eartli's surface, and matintained its culture. In contrast with the imposing fnancial system of the East, the West, through slackening of trude, the splitting up of countries into small, separate states, and the falling back of its peoples upon agrieulture as a last resort, acquired petty, parochial forms of eeononice, holeand-eorner modes of finanee, and a general peasant eomplexion, which afforded little ineentive toward a finer conduct of life. Nations were gradually built up, but, in the process, eulture was inhibited. While the Mostem eonquerors imposed the Arabic language and culture unon the eonquered, the Germanic conquerors came under the sway of the Latinized culture of Christendom. In western Europe, Latin beeame the official language of Chureh and State. Only Latin translations of the Greek authors were read. Scienee and learning sought refuge in the bosom of the Chureh, and no less than Cassiodorus, "the last of the Romans," pointed the way.

Thus began the period of Monastic medicine, in which, along with a praiseworthy zeal for preserving the remains of ancient literature and the traditions of a rational praxis, there grew up a cult of faith-healing or theurgic therapy, an implicit belief in the miraculous healing power of the saints and of holy relies. Supernatural aid came to be more and more esteemed as the medical art showed itself to be powerless, particularly in the time of the great epidemies. Western medicine, unlike that of Byzantium and Islam, went into eclipse, and its practice, as Neuburger says, became as rudimentary and stereotyped as that of primitive man.

Under the benefieient reign of Theorlorie the (ireat (193-526), there was an inter-period of peace, with material prosperity and clue regard for art and science. The sole relie of this early (Ostrogothie period is the dietetie epistle of the Greek physician Anthimus, which is full of sound, sensible preeepts, throwing much light upon the food-staples and kitchen practices of the time. The trend of the Ostrogothic perion, indeed the principal task then set for medieval medicine, was in the way of translating, compiling and paraphrasing from the aneients, a trend which hat alrearly been established by the later Romans and the Byzantine writers. In this matter, Boèthius (circa 480-524) was the great exemplar. In the 6th century, the gradual passage of science into the hands of the elergy was aceomplished, in the face of desolating wars between the Ostrogoths and Byzantines, the incursion and establishment of the Lombards in Italy (56S-774), and devastating epidemies like the plague of Justinian (5+3). Science and eulture went to the wall, the schools of secular 
learning crumbled and disappeared, religioss \%oal and fonatical asecticism beeame the order of the day. (rushed by the lombards, left in the lureh by Byzantimm, the Latin population turned to the ( hareh for potection. Cilorified by the nimbus of ancent Rome, the chureh thus berame a real territorial power, able fo pratediere gemulue stateeraft and to protect Westerm civilization. "The Benedietmes berame the Nestorians of the IVest" (Nenburger). In the formu l'acis, where physicins oner assembled and cialen dwelt, Pope ledix

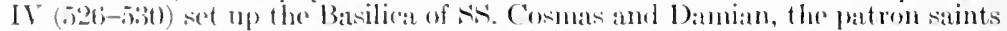
of medieme. In the same vear that dustinian edosed the sehool of Philosophy at Athens (52:4), Benediet of Nursia (- Wti-5.13) founded, on the site of an aneient temple of Apelle, the elerister of the Benedietine order at Monte Cassino; and here, after Cassiodorus ( $18(1-57.5)$ had turned the at tent ion of the monks to the value of the older writings, literary studies were assiduotusy coltivated and rows fo nurse the sick were taken as the prine duty of the order, in aceordance with the exhortation of st. Benediet (Infirmorum cura ande ommia arlhibenda

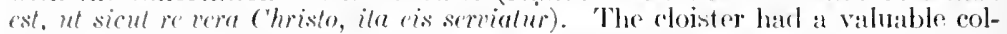
leetion of medical manuscripts. The commenterium medieinole of Benedetto Crecpi, Arehbishop of Mlilan (bs1), a didaetic hexameter poem dealing with the herbil treatment of 26 disfases, after the fashion of serenus simoniets, is a retie of this period. Another comsists of two tratises on discases and their remedies by bertharius (\$ist-s84), the learned abbet of Monte (axsino. The Lombard concuerors soon began to favor science and names of laic physicians are preserved in the Codex lombardus and elsewhere. In accordance with the precepts of Casciodorus, the aim of the time was to malke a summation of all medieal knowledge? (summa medicinor), gleaned from the Greek and Latin authors. Serenus Samonicus, pseudo-Apulesus, pseudo-Pliny and Cielius Aurelianus in therapenties, and in obstetries, the psendo-soranic midwiforybook of Mluseio, were most fitvored in these compilations. The best things of Hippoerates, Galen, Rufus, Gribasius, Alexander Trallianus, and Dioscorides were translated into Latin (5th and Sth eenturies), and, in the process of compilation, a number of spurious writings attributed to pseudo-authors were foristed off. The medical part of Pliny mixed up and seasoned with exeerpts from Cielius Auretianus, Apuleius and Vindician, beeame our "pseudo-Pliny." Many a summa medicinalis, masquerading uncles the names of Dioseorides or Oribasius, was a mere hodge-podge from different sources. Of this character, too, were the pesulenymour epistles attributed to Hippoerates, in particular the Drnamidia (De rivtulibus herbarum), the de cibis, the epistle to Ptolemy (De hominis fabrica), and the capsula ethrmea. This "jvory eapsule," a tract on the prognosis of skin affections, alleged to have been found by Cersar in the tomb of Ilippoerates, was first printed in a Milan incunable of 1481 . reprinted in Wittwer's Arrhiv (1790), and recently has been carefully studied in all the Mls. readings by Sulhoff (191(i1). Tuder the Visigothe in Spain $(507-711)$, the activities of the medieal profession were erusherl by a Draconic code of laws. With the conversion of the Visigoths to Christianity-(586), monastic merlieine took its usual course. Cloisters and church foundations even had their own physicians. A laparotomy for retained fetus in ectopic pregnancy is attributed to Bishop Paul of Merida, where Bishop Macona formded a large hospital about. 580. The most larned man of his time was Bishop Isidore of Seville (circa 570-636), author of an encyelopedia of origins and et vmologies, the fourth book of which eontains a survey of medicine, but with many false and far-feteherl derivations of medieal terms.

Ender the Merovingian monarchs (Ics rais fainénuls) in France (4\$6-741), Lat in influeness previled, but the dynasty has little to its erelit save a string of bloody eivil wars, and physicians had a hard time of it. Gregory of Tours (539-593) records that the Frankish physicians had some skill in surgery and were sometimes in request as forensie experts in trials, but even those in attendance on royalty were humiliated or put to death if they failed to cure. The people were given over to a belief in wonder-cures by strolling surgeons, to holy relies and exoreism. In time of epidemies, they came in great crowds 
to pass nightly vigils in the churches, an analogue of the temple-slece. With such erude, bungling surgery as obtained, little wonder that Gregory counselled prayer and endurance of pain. With the atvent of Charlemagne (768-81.4) as Emperor of the West (SOO), medieine came into better times. The culturil soil was prepared by the wandering Irish and Anglo-Saxon monks, who travelled from Bangor and Iona to the continent and founded the monasteries of Bobbio and St. Gall. Cloister schools were founded at Fulda by the English Boniface, at Tours by the English Alcuin (735-804), at Chartres by Fulbert (1006-1028), and became famous centers of learning. Charlemagne had a physic-garden. From the Eeclesiastical II istory of the Venerable Bede $(674-735)$, we learn that medicine was not neglected by the English monks. He tells of a cure of aphasia by methodic exercises, and left a treatise on bloodletting.

The encyclopedic "Physica" of the Abbot of Fulda and Archbishop of Mainz, Hrabanus Maurus (776-856), Aleuin's favorite pupil and the "primus praceptor Ciermanix," treats of medicine in the sixth, seventh, and eighteenth books and gives a German-Latin glosiary of anatomic terms. In the ninth century, medicine was taught as part of "Physica," which included arithmetic, astronomy, mechanies, geometry, and music, whence the physician was styled "physicus." The Hortulus of Walafrid Strabo of Suabia $(807-849)$, the best pupil of Hrabanus, describes, in 44 pleasant hexameters, the plants in the garden of the eloister at IReichenan, of which he was abbot, Anglo-Saxon literature took its start in the reign of Alfred the Cireat (871-901), and held its own until the middle of the twelf the century. The principal medical writings of the period are the Lecrh-Book of Bald, the Lacnunga, a book of Anglo-Celtic magic and translations of Apuleius and Sextus Placitus. The medieval penchant for allegory is exemplified in the Physiologus, a popular purview of the virtues and vices in the form of twelve real or fantastic animals, which was translated into all languages and although pure allegory in itself became the original of "Beast-Books" or Bestiuries. Uneler the Curolingian monarchs, Jewish physicians were much favored in France. In lower Italy, Sabbatai ben Abraham, called Donnolo (913-965) was a famous pratetitioner and his Antirlotarium, ${ }^{1}$ a formulary of some 120 remedies, is the ollest known medical work in IJobrew. The oldest medieal work in Spanish is a treatice on fevers by Isaac, a Jewish physician of the eleventh century. The olefest merlieal book in Hebrew is a book of remedies by Asaf Julieus, a Mesopotamian physician of the seventh century. ${ }^{2}$

Medicine in the eleventh and twelfth centuries was lifted to a much higher level by the School of Salerno, which, as Neuburger says, aroused the healing art from the decrepitude of half a millenium, infused new life into things and guarded as a Palladium the best traditions of ancient practice. Its origins are obseure. We only know that it came into existence in "a most mysterious way." That it was an ceclesiastical foundation is regarded by most historians as an agreeable fable convenue, for the whole character of the school was that of an isolated laical institution, a ciriters IIippocratica, in the midst of purely clerical foundations, and there is ignificant silence about Salerno in the eeclesiastical chronicles. But the city itself was a bishopric; after 974, an archbishopric; where the Benedietines had a cloister and a hospital (820), and the rienclliest relations are said to have existed between the clergy and

${ }^{1}$ Edited by Steinschneider, Berlin, 1868.

${ }^{2}$ L. Venezianer: Asaf Judrus, Strassburg, 1916-17. 
the salemitan physicians. The little seaside town of Salerno, near Naptes, was known even to the Romans as an ideal health resort. The modical toandings and traditions of its lamoms sehool, the first independent medical sehoed of the time, amme upon the dreary stagnation of the early Middle Ages, with something of the invigorating freshness of the sea. Its anatomy was based upon that of swine, its physiology and pathology were (ialenic, its diagnosis mainly pulse and mine lore, but diseases were studied firsthand, in a straight forward, spontaneous, enguging manner, therapy was rational with an atmirable seheme of dietedies, Salemitan surgery was new and original, obstefries and nursing were ably eultivated by talented women. The Salemitan masters, says Nenburger, were the first medieval physicians to cultivate medicine as an independent branch of seience. That the Salemitan medical eulture was Hellenistic, that Salerno revived some of the best traditions of creck medicine, is clue to the fact that Sicily and southermmost Italy (Magna Graecia) were still part of the Eastern Empire, and were entirely uninfluenced by Latin culture from the serenth century B. C. to the tenth century A. D. From Magna Graccia, Byzantium and Toledo came the three main streams of Greek culture, which went to the formation of the Salemitan tradition. The oldest documents of Salernitan medicine are compilations in barbarous Latin from the later Roman authors and psendo-authors, and date from the first half of the eleventh century.

Of these, the Passionarius, a handbook of special pathology and therapeutics, associated with the name of Galen and attributed to the Lombard IVarimpotus or Gariopontus (died circa 1050) is, in the opinion of Sudhoff, not a genuine Salernitan writing, but a compilation from Byzantine sources, dating back to the eighth or ninth century. 'The writings of Alfanus, Bishop of Salerno (circa 1050), the Practica of Petroncellus, an Anglo-Saxon version of the same in Cockayne's Leechdoms, and the poem Speculum hominis (circa 1050) are the only other Salernitan relics before the time of Constantinus Africanus.

Of little effect upon Salerno, and nowise an outstanding personality, Constantinus Africanus (rirca 1020-1087) is yet an important landmark on account of his strong influence upon the later Middle Ages. A native of Carthage, he gained a close knowledge of Oriental languages by extensive travel, and, returning to his native city, is said to have been persecuted as a magician. Fleeing to Italy, he lived for some time at Salemo, but whether he tanght there is uncertain. Steeperl in Arabist culture as he was, he could have exerted little influence upon the school. ${ }^{1}$ Islam was unpopular; for before the Norman conquest of Sicily, the Saracen overlords of the island had frequently menaced silerno and on one occasion forty brave Normans saved the little town from their clutehes (1016).

After 1070, we find Constantinus in the cloisters at Monte Cassino, where he ended his days in his literary work. This consisted mainly of Latin translations of Haly Abbas, Johannitius, Isaac Judæus, and the Arabized Galen and

${ }^{1}$ Sudhoff has since contradicted this earlier view in München. med. Wochenschr., 1920, lxvii, 1301. 
Hipperates. While theoe translations were little motied at salerno, the influener of Constantine ats at Latinizer of the Mrabist culture was far-reaching, ats sudhoff says, "a symptom of at great historic process," namely, the fastening of Mobaminedan modes of thought upon Western European modicine from

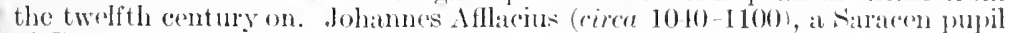
of Constantine, was the probable anthor of the Liber aureus, att ributerl to his master, and of a salernitan tract "De fetribus et urinis," whieh contains a deviere for cooling the sick-rom by dripping water from a perforaterl vessed. Taddeo Alderotti later bore witness that these transations of constantine were very fantty performances (nam ille insanus monacus in transferenelo pecentit quantitaic et qualitate'2).

Independent treatises on practice of molieine, notable for clarity of coneeption and eoncision of style were written severally by Magister Bartholomaeus, Copho junior, Johannes Platearius jumior, and by Arehimatheus, ${ }^{3}$ who also wrote an important tract on hollegetics (De instructione medici) or the etiquette of the physician's ilpproach to the bedside (De adrentu mediri ad aegrotum). The most remarkable contribution of the salernitan school to internat medicine is the 'Tractatus de acgritudinum curatione, the first example of an encyclopedic text-book of medieine, written by miny authers, and nordoubt designed for posterity as the "S"ummu medicinalis" of Silerno. It became the" standard scheol book of internal medieine in the first half of the twedfth eentury. As in each Practica listed above, it treats of local diseases seriatim, from hearl to foot (a capite arl calcem).

Among the earliest of the twelfth century eontributions to natural history was the compilation ealled Macer Floridus, it didartic hexameter poem on the therapentic virtues of 77 simples, attributed to Odo of Meuclon, which was highly popular and frequently trinslated ${ }^{4}$ and wis the original of the oldest Seandinavian medieal writing, the Danish Legelog of Henrik Ilarpestreng. The Lapidarizs or stone-book of Bishop Marbod of Rennes (dicd 1123) deals with the medical and magic virtues of 60 preeions stones.

The Salernitan productions are contained in the "Breslau Codex," ${ }^{5}$ most of which has been reproduced in the collections of Salvatore De Renzi (1853-6) and Piero Giacosa (1901). The Regimen (Sunitatis) Salernitanum or Flos medicina (1260-1300), a pocm in double rhymed hexameters, was first printed in Latin n 1484 .

Its date of origin is unknown, but Sudhoff holds that its probable protoype was a pseude-Aristotelian epistle to Alexander the Great (De regimine anitatis), Latinized by John of Toledo (Joannes Hispanus), a baptized Jew, about I130. This tract, dedieated to a Spanish princess, harl a wide circulation und was followed by a similar dietetic epistle, arldressed to Frederick II himielf by his court philosepher, Magister Theorlorus. In Arnolld of Villanovat's ime, the Salernitan Regimen, which probably did not appear before 1260, onsisted of 362 verses, which the arditions and interpolations of De Renzi ind others have expanded to 3520 . Thus the fimous Salernitan text owes

${ }^{1}$ For the Arabie sourees of Constantine, see M. Steinschneider: Virchow's ireh., Berlin, 1866 , xxvii, 35J-110.

${ }^{2}$ Preface to Expositiones in arduum aphorismorum lpocratis. Cital by Seuburger.

${ }^{3}$ For Arehimatheus, see Hans Erchenbrecher, Leipzig diss. (Inst. f. iesch. d. Med.), 1919.

${ }^{4}$ Edited by Ludwig Choulant, Leipzig, 1832.

${ }^{5}$ For a revised and classified table of contents of the Breslau Codex, see riedrich Hartmann: Die Litteratur von Früh- und Hochsalerno, Leiprig iss., 1919. Also, Sudboff: Arch. f. Geseh. d. Med., Leipz., 1920, xii, 101-1-1s. 
its origin to Toled:nn sourees, was probuhty not known cither to Froderiek II

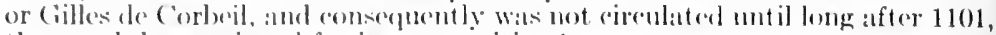
the usual dattrasigned for its composit ion.1

The lieginen eonsists of a string of very sensible dietetic and hyerente presepts, dedicated, in the soveral imprints, to the King of England (Anglomem liegi), in most of the manuseripts to the King of France (Francorum Rergi). It passed through some 240 separate oflitions, including Irish, Bohenian, Provençal and Helorew."

(Of the "Ladies of Silderno," Trotula, whom the thirteenth century trouvere Rutebenf styled "Dime "Trot" (Madame Trotle de Salerme) is eredited with a ergnecologie and cosmetic treatise l)e pessionibus mulierum, while Abella wrote De natura seminis heminis and De atra bile. In the opinion of Malgaigne and sudhotf, Trotula is not a person, but only the title of the book itself. According to laremberg and De Renzi, it is the name of the authoress, whom some suppose to have been of the Ruggiero family and the wife of the elder l'latearius.

The Antidotarium of Nicolaus Salernitanus 3 was the first formulary and one of the first medical books to be printed (in the superb typography of Nicholas Jenson, Venice, 1471). It consists of 139 complex prescriptions in alphabetic order, contains many new Eastern drugs, ako the original formula for the "anasthetic sponge" (spongia sommifera) and a table of weights and measures. The Antidotarium of Mathseus Platearius, known as "Circa instans," was the original of the first French herbal (Le grant herbier). In anatomy, Copho, one of the instructors at Salemo, wrote a primer on the dissection of the pig, based on the spurious Anatomia parva of Galen; it was reprinted in the little anatomic manual of Dryander (1537). The Anatomia of Ricardus Salemitanus, ${ }^{4}$ and an anonymous Demonstratio anatomica, are also based upon porcine structure. Another recently exhumed Anatomia of this period is that of Nicolaus Physicus. ${ }^{5}$ There were many treatises on uroscopy, in particular those of Johannes Afflacius, Johannes Platearius, the younger Archimathrens, Maurus and Lrso. Gilles de Corbeil (Egidius Corboliensis), Canon of Paris and physician to Philippe Auguste of France (1165-1213),

1 See Sudhoff: Areh. f. Gesch. d. Ned., Leipzig, 1914-15, viii, 377; 191516. ix, 1: also. Pagel-sudhoff, 173, and the Leipzig dissertation of Johannes Brinkmann: "Die apokryphen Gesundheitsregeln [ete.], 1915.

2 An attractive English versification (bilingual text) is that of Dr. John Ordronaux (Philadelphia, 1870).

${ }^{3}$ Sometimes callerl Nicolaus Prepositus (i.e., Præses of the faculty), but now to be differentiated from Nirole Prevost. Sce Wickersheimer, Bull. Soc. franç. d'hist. de méd., Paris, 1911, x, 388-397.

${ }^{4}$ Edited by Florian, Breslau, 1875.

${ }^{5}$ Edited and printed by Franz Redeker. Leipzig diss., 1917. 
wrote two poems on the pulse and the urine, ${ }^{1}$ based upon the Byzantine treatises of Theophilus Protospatharius, also a poem on the composition of medicines and a satire on the clergy (Hierapigra ad purgandos prelatos). He laments the decline of salerno after it had been sacked by Henry VI (1194). After this terrible event, according to Fgidius, the Salemitan professors degenerated into beardless striplings who cared only for books of prescriptions. In the thirteenth eentury, the medical authority of Salerno was gradually impinged upon by the great rival schools of Naples, Palermo and Montpellier, and its fame and influence became more and more of a vanishing fraction, until the great school was finally ibolished by Napoleon on November 29, 1811.

The Physica of St. Hildegarde (1099-1179), Abbess of Rupertsberg, near 3ingen, describes the healing powers of the known plants, minerals and animals, iving the German names by preference, contains precepts for the hygiene of regnaney and puerperium and rules for suppressing sexual desire. It is ateresting for its sidelights upon the medicine, botany, and gardening of welfth eentury Germany. Her little tract on clinical medicine (Cansate et urae), a medley containing many interpolations, has reeently been edited by Kaiser (Ieipzig, 1903). St. Hildegarde's "Visions" (Scivins), eontaining onderfully beautiful speeimens of the medieval art of illumination, not nlike similar drawings by William Blake, are a revelation of her roligions life. harles Singer suggests that these visions may have had a primary physieal asis, in that the shimmering, radiating figures strongly resemble the stars, blored spots, and fortification speetra associated with the scotoma seintillans migraine. ${ }^{2}$

The principal outeome of the School of Salerno was the work of vo surgeons, Roger (Ruggiero Frugardi) of Palermo and Roland Rolando Capelluti) of Parma, whose writings were independent the influence of Constantinus Afrieanus or other Arabist sources yurlt). Roger's Practica, written about 1170 (Sudhoff), relited by his pupil Roland about 1230-40 (Sudhoff ${ }^{3}$ ) and comented upon by the "Four Masters" a little later, was never" parately printed, but exists apart in manuseript, although Daremrg published a unique edition of the famous commentary "lossule quatuor magistrorum) in 1854. Roger's work became a andard text-book at Salerno, where he himself had been a student id teacher. He knew of eancer and (possibly) syphilis, deseribed case of hernia of the lungs, prescribed ashes of sponge and sea-

${ }^{1}$ Printed at Pidua (1454), and Venice (1494). Edited by I. Choulant as 'armina medica," Leipzig, 1826.

${ }^{2}$ C. Singer: Proc. Roy. Soc. Med. (Hist. Sect.), London, 1913-14, vii, $2,2$.

"Printed in the Venetian eneyeloperlic eollcetions (entitled "Cyrurgia"), cdate 1498 and 1499 , in the Juntine of 1546 , and in De Renzi's collertions. e close investigations of Sudhoff and his pupils show that the Rolandina is I. wise an independent work, the new material being mainly glosses from the Wious MSS. of the Rogerina. See Wallemar Linge: Leipzig diss., 1919. 
weed (iodides) for goiter or sorofula, employed the signifieant merrorial silves for chronic domal and parasitic affections, introlueed the seton and suture of the intestines over a hollow tube, tameht the use of styptics, sutures and ligatures in hemorrhage and the healing of wounds by soomd intention (laudable pus). Roger, Rolind and the Four Masters were succeeded by the twelfth contury surgeons, Jamerius and Hugh of Lueca (Ugo Borgognoni), who left no record of his work behind him; by Brmo of longolures, an advocate of dry (ascptic) wound treatment, whose Chimergia magna completed at Padua in 1252, is the first treatise of the time in which Arabic authors are drawn upon; by Hugh's son or disciple, Teodorico Borgognoni (120j-129)(i), Bisbop of ('ervia, whose treatise (completed in 1266) is presorved in the surgical anthology (Cyrurgia) of 1498 and 1499. Theodoric was reviled hy Guy de Chauliac as a copyist and plagiarist, probably because, like Hugh before him, he contradicted the pseudoCalenist dogma of "coction" or "laudable pus" and stood out in his day as a sturdy pioneer of a rational asepsis: "For it is not necessary, as Roger and Roland have written, as many of their disciples teach, and as all modern surgeons profess," he says, "that pus should be generated in wounds. No error can be greater than this. Such a practice is indeed to hinder nature, to prolong the disease, and to prevent the conglutination and consolidation of the wound." (Book II, ch. 27.) This simple statement, as Allbutt points out, makes Theodoric one of the most original surgeons of all time, for only Mondeville, Paracelsus and Lister upheld these minciples after him. In the long interregnum between Mondeville and Lister, "the advocates of suppuration won all along the line." Hugh and Theodoric are also memorable for the inunction cure by the mercurial salve (unguentum sarracenicum), the sparing use of the cautery, and for setting the limitations of treatment with apparatus in fractures and dislocations. Their names are also associated with the medieval substitutes for anesthesia, the origins of which, however, go back to the remote past, probably to India. ${ }^{3}$

Surgical sleeping draughts are mentioned by the Church Fathers Hilary (De trinitate) and Origen. The earliest Silernitan reference to the "soporific sponge" oceurs in the beautiful Jenson imprint of the Antidotarium of Nicholas of salerno (Venice, 1471, fol. 32 verso), probably written in the eleventh century. The sponge was steeped in a mixture of opium, hyoscyamus, mulberry juice, lettuce, hemlock, mandragora and ivy, dried, and, when moistened, inhaled by the patient, who was subsequently awakened by applying fennel-juice

${ }^{1}$ In the glosses of the Four Masters, a quill is used.

${ }^{2}$ First printed from a Munich MS. by Pagel as "Chirurgia Jamati" (Berlin, 1909). See also, the Berlin dissertation of Artur Saland (1S95).

${ }^{3}$ Husemann: Deutsch. Ztschr. f. Chir., Leipzig, 1895, xlii, 577-587. 
o the nostrik. This prescription, Ilusemann thinks, was derived from older ormula for anodyne applications of similar ingredients to the temples for nsomnia (vigilier) or eat ipplasms for local a neethesia, which are to be found in the Antidotarium of Nieholas (O)eum mandragoratum, fol. 22 verso), in the Pracica of Copho. in the Tractalus de aegritudinum curatione and even in Gaddesden and Varignana. From Nicholas, the reeipe of the spongial somnifora pasioel in to Hugh and Theodoric (confectio somnifera) and thenee to Gilbertus Inglieus (1200), Pfolspeundt (1460), (iny de Chauliae, and the low German rother Arzneibuch. The old Dioscoridean sleeping potion was taken up by Ivicenna, Serapion, Jocelyn of Furness (1177-99), lsidore of Seville, Thomats of Cantimpré, Conrarl of Megenburg, Jerome Bock, Jerome of Brunswick who substituted belladonna), Matteo Silvatieo, and Bassurala, while similar iareotie potions are mentioned in Boceaceio (viii, s; $x, 4$ ), Macehiavelli (II Mandragola), Du Bartas, Marlowe, Middeton and Shakespeare (Romeo and 'uliet, iv, 1,3 ).

Through the Middle Ages, mandragora was the soporific par excellenee, referable to opium and bemlnek, because it was not like these "cold in the burth degree" but in the third. It dangerous effects, when taken internally, re indieated in Marlowe's Jew of Malta,

"I drank of poppy and cold mandrake juice

And being asleep, belike they thought me dead,"

, which reason it was not used internally by the Salernitan surgeons.

The ablest Italian surgeon of the thirteenth eentury was Guglimo Salicetti, called Saliceto or Salicet (circa 1210-1277), a man ell edueated in hospital and on the battlefield, as also in respect university training. He was professor at Bologna (circa 1268) ter eity physician at Verona, and, during 1269-75, completed his murgial (first printed at Piacenza in $1476^{2}$ ) for the benefit of his $\mathrm{n}$, whom he brought up to the profession of medicine. Although $r$ shorter than his treatise on internal medicine, his Surgery ands out as a great landmark, or seamark in the history of the Wft, and for the following reasons ${ }^{3}$ : Saliceto did not separate srgical diagnosis from internal medicine; and kept a good record ease histories, which he held to be the foundation of his sulj:t. Book IV of his treatise contuins the first known treatise on rional or surgical anatomy (Sudhoff). He restored the use c the knife, which Arabian practice had set aside in favor of the entery; he showed how to suture divided nerves and to diagnose beding from an artery by the spurt of blood. He specifies cont: lateral paralysis as a sequel of head injuries, for which he recom-

${ }^{1}$ Completed June 7-\$, 1275.

${ }^{2}$ Translated into French, by Nieole Prevost (1yons, 1492) and again with en mentaries, by Paul l'ifteau (Toulonse, 1s9s). Silieeto's treatise on practi. (Summa consertationis et curationis) was first printed at Piacenza (circa $14 j-6)$, and his De salute corporis at Leipzig (1495). His merits as a physician he been studied in the Borlin dissertations which Pagel set for his punils, H irunow (1895), E. Loewy (1\$97), W. Herkner (1497) and O. Baseh (1S95). Fo his treatise on anatomy, see F. O. Schaarschmilt, Leipzig. diss. [Inst, f. Gr:h. d. med.1, 1919.

See Gurlt, i, 754-765; Neuburger, ii, 3\$0-3\$4, and Allbutt: "The Ilito: al Relations of Medicine and surgery," London, 1905, pp. 32, 33. 
mends a thick compress to prevent the injurious admission of air; crepitus (somitus oswis fracti) is cmphasizod as a diaguostic sign of fractures, arrow wounds ale deseribed in graphic fashion and a furriers suture is prescribed for intestinal wounds. He was the first to assign venereal contagion as the real canse of chancere, bubo and phagedenic uleers, and even reeommends a prophylactic ablutio cum aqua frigida ct roratio loci cum aceto (Neuburger). In his treatise on practice, he has left a classic description of dropsy due to contracted kichey ("durities in renibus"l), a remarkable account of melancholia, and valuable contributions to gynecology. The sound surgical principles of siticeto were very ably upheld by his pupil, Lanfranchi of Milan, who became involved in the squabhles of the Guelphs and Ghibellines and was driven out of his native town by the Visconti. At Lyons, he wote his Chirurgin para. Arriving in Paris in 1295, he found himself, as a married man, shut out of teaching at the university, where the professors were celibate eleries; and he therefore became associated with the College de Saint Come, organized before 1260 by Jean Pitard.2 surgeon to Philip the Fair $(1306-28)$. Here, by his straightforward style of lecturing and his use of hedside instruction, he beeame the virtual founder of French surgery, and died in 1315. In his Chirurgia magna, (ompleted in 1296 and dedicated to Philip the Fair (Venice, $1490^{2}$ ), Lanfrane macle a resolute and raliant stand against the medieval schism between surgery and medicine which had existed sinec Avicenna's time, stating his convietion that the surgeon should also be an internist in a neat syllogism: (Omnis practicus est theoricus: ommis cyrurgicus est practicus: ergo ommis cymurgicus est theoricus). He was the first to describe concussion of the brain, and his ehapter on the symptoms of fracture of the skull is accounted a classic. Depressed fragments and irritation of the dura are his only indications for trephining. He also differentiated between venous and arterial hemorrhage and between eancer and hypertrophy of the female breast; and such

1.aliceto: "Liber . . . in scientia medieinali," Placentia, 1476, ch. 140. see also. Haeser, "Zur Geschichte der Bright'schen Krankheit," Janus, Breslau, Is4s, iii, 371 , which gives interesting references to nephritis by the Arabic writers serapion ancl Rhazes.

2 A surgical manual by Jean Pitard, from MS. in Lüneberg (Latin) and Paris (old Freneh) is printed by sudhoff in Arch. f. Gesch. d. Med., Leipz., $1909-9$, ii, $159-27 \mathrm{~s}$.

3 Also printed in the surgical anthologies of $1498-9$. There was a French translation by G. Fvoire (Lyons, 1490), an old English version, printed by the Old English Text Society (1S91), and another (Chirurgia parea) in black letter by John Halle (London, 1565). A superb black letter translation of the Chirurgia parva into Fpanish was printed at Seville in $1495 \mathrm{by}$ "tres alemanes compañeros." The Chirurgia parva was translated into German by Otho Brunfels (strassburg, 1528). 
procedures as intubation of the sophagus, reunion of clivided nerves, and nemrotomy for tetamus are among his imnovations. Enlike saliceto, Lanfrane was a cauterist and averse to the knifr. He therefore avodded trephining, cataract extraction, or lithotomy, treating hernia with truses only, but did not hesitate to operate for emprema and wounds of the intestines, treating henorrhage by styptics, digital compression, torsion, or even the ligature. He gives careful directions for venesection, lamenting that this proeedure should the the province of the barbers. His ethical advices to the surgeon is quaint and characteristic, and although he looked upon Paris as an earthly paradise he hetd the French surgery of his day in sovereign contempt. The work of saliceto and Laufrans, coincident with the development of the great medieval miversities - Paris (1110), Bologna (1113), Oxford (1167), Montpellier (1181), Padua (1222), Naples (1224)-and the brilliant false dawu of cul-

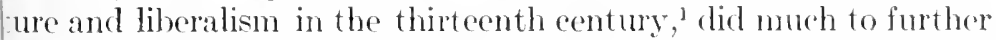
he growth of surgical talent in France, England and Flanders. from the Italian families delle Preei and da Norsia came the reciani and the Norsini, whole generations of itinerant surgeons who practised herniotonsy, lithotomy, urethrotomy and cataract xtraction as a family secret.

Contemporary with Lanfranc was his loyal follower, Henri de Aondeville (1260-1320), a hardy and original thinker, endowed ith great powers of wit and sareasm, who made a valiant last tand for the principle of a voiding suppuration by simple cleanliess, as originally taught by Hippoerates and as reintroduced hy Iugh and Theodoric. Before 1301, he was one of the four body urgeons of Philip the Fair, and in $130 t$ he delivered lectures on natomy at the University of Montpellier." The surgical treatise f Mondeville, begun in 1306 and left a torso (1316), was first edited nd printed from the several nanuscripts by Pagel in 1892, and ter translated into French by Nicaise (Paris, 18933). It abounds I directions of the rarest common sense for the ascptic treatment of ounds and in shrewd practical advice to the suregen as to the onduet of his professional life. In opposition to the salve surgery the Galenists, Mondeville advises simply to wash the wound ean and put nothing whatever into it, since "wounds dry much

1 For an interesting afeount of this Auflärum, which unfortumately did it list long, see J. J. Walsh, "The "Thirternth Cirratest of Centuries," Now ork, 1912.

2 Monfleville's anatomic treatise was reprinted from a Berlin ML. by tgel in 1 ssis.

${ }^{3} \mathrm{~A}$ fragmentary old French version of $131+$ has been published by $\mathrm{A}$. I3os aris, Sociéte des anciens textes français, $1897-9)$; another MIs. of 1475 is the Iniversity Library of Tpsala. 
better beforesupmaration than after it." Wine and other "wounddrinks" were given to strengthen the patient. in opposition to the routine pratedes of anting down his diot. for hemortage he

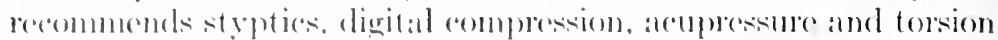
of the isolited resed by means of a slieling-noose ligature. His

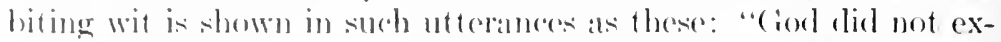
batlst all llis reative power in making (ialno." "Mlany more surgeons know how to (amse supponration than to hoal a wound."

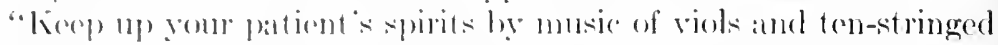
psiltery, or hy forged lotters describing the death of his enemies,

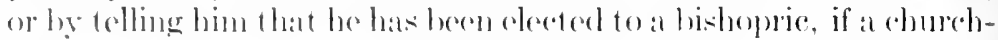
man." "Nerer dine with a patient who is in rome deht, hut get four dimner at an inn, otherwise he will eleduet his hospitality from your fere" Henris maparty in the matter of foes shows bow hatrd they wore to get in the Midelle Ages, ${ }^{2}$ and what he says about the suljocet sugerests the trpe of sumeon who hat to sucreod hy dint of hamel knocks. Like the heroes of smollett, as deseribed ly sir Waltor soott, his ronical spirit seemed to delight in things: "attonded with disgrace, montal pain, and bodily mischief to others," rot it is harel to say offhand whether this was the frut of hasth experience or the expression of supreme irong.

i man of far different type was Guy de Chauliac (1300-68), the most distingusherl autbority on surgery in the fourteently and fifteenth centuries. A country boy from Aurergne, Ciny managed, through friends, to take holyorders and to get an excellent medieal education at Toulouse, Montpellier and Paris, with a special course in anatomy at Bologna. ${ }^{3}$ He thus became the most erudite surgeon of his time, and, in due course, settled down at Arignon as physician and "eommensal ahaplain" to Popes Clement VI, Innocent VI and I rhan $\mathrm{V}$. He died on July 25, 1368.

Guy was a writer of rare learning, endowed with a fine critical and historic somse, and, incleed, the only melical historian of consequence between C'elsus and ('hampier." As àn operator, he set

1 Ste A. Raubach: Tober die Wundtrinke in der mittelalterlichen Chi. rurgir, Berlin disertation, 1496.

${ }^{2}$ The silernitan Lum dolet, arcipe was the rule, as satirically indicated b: John of Sali-bury. (Nemburger, ii, 325.) Sre alio, C. Vieillarl: Le pact

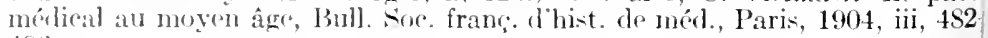
496 .

${ }^{3}$ Guy learned his anatony from Iondino's pupil, Niceolo Bertureio, an was also much influenerel by the translation of Crall'n's De usu partium mad by Niecolò de Regio $(1317-4 i 5)$.

"Guy's "chapitre singulier" on the history of medieine was edited sepe rately by Jean Canappe and printed by Etienne Dolet (Lyons, 1542). Tr value of this chapter was first emphasized by symphorien Champier in "I Guidon en franeoys." Lyons, 1503 . (F. C. Nitrecter.) 
great store by the study of human anatomy and was one of the first to take the operations for hernia and eataraet out of the hands of the strolling mountebanks, although he hesitated to cut for stone. He believed in eutting out eancer at an early stage with the knife, but employed the actual cautery in the fungous variety as well as in caries, anthrax and similar lesions. Uleers he treated by means of an investing collar or guard of sheet lead, and he suspended fractures in a sling bandage or (when in the thigh) by means of weight and pulley. He also gives an interesting summary of the

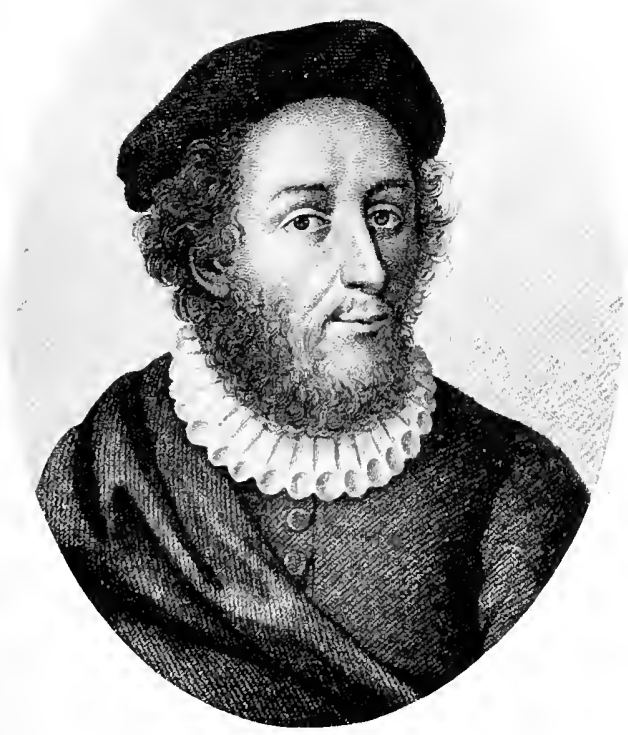

Guy de Chauliae (1300-1370).

dentistry of the period. ${ }^{1}$ He throws a great light upon the operative procedure of his time by his description of the narcotic or soporific inhalation, originally attributed to Theodoric. This, the medieval substitute for anesthesia, as above described, was in vogue up to the seventeenth century, and is frequently referred to by the Elizabethan poets and dramatists, for instance, in the well-

${ }^{1}$ For which see V. Guerini"s "History of Dentistry," Phila., 1909, pp. 142149, and J. J. Walsh's "Old-Tine Makers of Medicine," New York, 1912, pp. 319-323. 
worn citation from Thomas Middleton's tragedy of 11 omen Beware Homen (Ac1 IV, s(. 1):

l'll imilate the pilies of old stregeons

lis this lost limb, who, ere they show I hoir art,

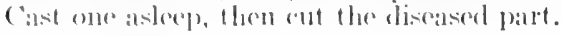

Yot, in spite of his wide experience, (iny de C'hanliac was on the whole a reatetionary in the important mattop of the treatmont of wounds and, by his great atuthority, threw back the progress of surerey for some six conturies, giving his personal weight to the doetrine that the hatling of a wound must be areomplished by the sureon's interforener-salves, plasters and other meddlingrather than hy the healing power of nature. As an athical teacher, Guy holds up a far nobler idteal to the surgeon than Henri, and his mode of expression revouls the gentleman is well as the scholar. During the (apidenies of plagne at Avignon in 1:348 and 1:360, he stuck manfully to his post as a healer of the sick, while other phrsicians fled the loculity. His most important work is the Imentarium or Chirurgia magnu, written in 1363, and first published in French translation at Lyons in $1478 .^{1}$ This book passed through many editions, translations, and abridgments (les fleurs du grand Guidon), and in the latter form it became the rade mecum or "guidon" of surgical practice even beyond the $16 \mathrm{th}$ century.

Gily's most distinguished pupil was Pietro d'Argelata (died 1423), a professor at Bologna, whose Cirurgia was printed at Venice in 1480 . The chapter on the custody of the dead body tells how he embahned the corpse of Alexander $V$. Argelata taught the dry treatment of wounds, but powdered them; was skilled in dentistry, nsod sutures and drainage-tubes in wounds, trephined the skull, incisel the linea alba in post-mortem Cesarean section and sometines operatel for hernia, stone, and fistula in ano. The latter operation attained a high degree of perfection in the hand: of John of Arderne (1306-90 [?]), the earliest of the Englis surgeons. Arderne was a well-educated man who got his trainini by an adventurous career as army surgeon in the Hundred Year

${ }^{1}$ La pratique on chirurgie du maistre Guidon de Chauliac, Lyon, Bartl elemy Buyer, 147s. The Latin text (Chirurgia) was first printed at Venic in 1490, a Venetian text in Zingua franca in 14.90, a good Latin text by Laurer Joubert, ehancellor of Montpellier (Lyons, 1578); also a French text (Roue 1615) and glosiary by his son (15.). The best modern edition is that Edouard Nicaise (Paris, 1S90). Many emmentaries and abridgments we made by symphorien Champier (1503-37), Louis Verdue (1731) and other English, German, and Spanish versions exist. The black-letter "Questyonary of Robert Wyer (Iondon, 1541) is a beautiful impression. A rare English MI owned by E. C. Streeter is deseribed by him in Proc. Charaka Club, N. Y 1916. iv, $10 \overline{\mathrm{f}}-111,2 \mathrm{pl}$. 
War. He wrote treatises on passio iliaca (appendicitis or intestinal obstruction) and gout: and an essay on elysters (1370), advoeating an instrument of his own invention. He cmployed irrigation in renal and intestinal colic, eystitis and gonorrhea. His well-illustrated treatise on fistula in ano (1376), in the opinion of its editor, D'Arey Power, introduced a well-deseribed surgieal operation for a condition which most of his predecessors had abandoned as incurable. Getting his patient into the lithotomy position, Arderne boldly incised the outer wall of the fistula in all its branches instead of fretting it by probes and ligatures; checking any hemorrhage with sponges, and avoiding all corrosive or irritating after-treatment of the wound. This asepsis, akin to Mondeville's, is a reflex of Arderne's training as a Noman surgeon. The Saxon leceh erops out in his leaning towards astrologr, charms and rort-cuming. "Nothing pleased him more than a rharm" (Power).

Giovanni Arcolani (died 1484), or Arculanus, a professor of medicine and surgery at Bologna (1422-1427) and Padua, whose treatise on surgery (I'ractica) was published at Venice in 1483, is memorable as one of the leading pioneers of dentistry and the surgery of the mouth. The surgieal seetions cont ain figurations of the instruments used, ${ }^{1}$ including aural syringes and flexible catheters. He deseribes the filling of hollow teeth with gold-leaf and gives at remarkable account of the mental symptoms of alcoholism. Otherwise he is but a typieal expositor of Avicenna and Arabian surgery.

The Chirurgia of Leonardo da Bertapaglia (died 1.460) is again only an arrangement of the fourth book of Avicenna's canon, full of Arabian polypharmacy, with strong leanings towards astrology.

The Flemish surgeon, Jean Yperman (1295-1351), whose Chirurgie was printed from the Flemish manuseript by Carolus (Ghent, 1854), by Broeckx (Antwerp, 18632), and latterly in a splendid definitive edition by van Leersum, ${ }^{3}$ was a pupil of Lamfranc's who worthily upheld his master's teaching, especially in regard to ligation and torsion of arteries.

He gives good accounts of trephining, arrow-wounds (with a special wound-drink), healing of harelip by means of freshened edges and sperial sutures, artificial feeding by a silver tube, and enlargement of the opening in reposition of prolapsed viscera. In the ehapter on leprosy, he mentions the anesthesia and the possibility of infeetion by sexual intercourse. Of the Royal Touch for serofula, he slyly notes that curable eases will get well without it (Neuburger).

${ }^{1}$ Neuburger, op, cit., ii, 508. J. J. Walsh: Old-Time Makers of Medieine, New York, 1911, and his Modern Progress and History, New York, 1912, 116-118.

${ }^{2}$ A "Traité de médecine pratique du mâtre Jehan Yperman" was also edited and published by Broeckx (Antwerp, 1867). 1912.

${ }^{3}$ E. C. van Leersum: De Cyrurgie van Meester Jan Yperman, Leyden, 
In the fourteonth antury, he was the great anthority on surgery in the low Countries.

Hand in hand with the medieval development of surgery, there necessirily went some efforl to improse the status of human anatomy. Disseeting, at first rienomsly proserilued hy law and sentiment, leceame more and more a matter of aomse, following the dearee of Emperor Froderick II in 12.10. Payne has divided medieval anatemie toatehing into three periods: First, the Salemitan (8001200), in which instruction was based upon the dissection of animals as set forth in the Anatomia P'orei of Copho, one of the Jewish instructors at Salerno; second, the Arahist period (thirteenth rentury), in which such dissections were superseded by books and lectures. The leading anthorities of this time were Richard, of Wendover, called Ricardus Anglicus (1252), physician to Gregory IX, whose work is preserved in the text of Rohert Töply (Vienna, $1902)$; and Henri de Mondeville, who, long before Anbroïse Paré. prefixed an anatomic treatise to his surgery, and who improved upon Wendover's teaching by the use of pictures, diagrams and a model of the skeleton.

The 1:) miniature paintings which IIenri employed have been reproduced and reseribed by Sudhoff from a French MS. of 1314, also a number of erude pen-drawings from MSS. at Berlin and Erfurt. ${ }^{1}$ These tiny pietures are, perhaps, the earlicst inatomie illustrations of the time, and establish several norms of tratlitional anatomy, $e . g$., the museular and visceral sehemata, which were slivishly followed for a long time. Better exeeuted are the 18 colored figures from the Anatomie of Guido de Vigevano (1345), which Wickershrimer hats reproduced from MS. 569 in the Musée Condé (Chantilly²). The anatomy in these drawings, intended to illustrate the technic of dissecting, is extremely diagrammatie. In most of these medieval MSS., the skeleton has the speetral aspect (Lemurengestalt) familiar in the many figurations of the Danee of Death, suggesting a dried disembowelled preparation with the bones shining through the skin; the stomach is inverted, giving the viseeral schema the appearanee of a bagpipe, while the spinal eolumn looks like a Malay creese.

The interest of the third period centers in the revival of human dissecting by Mondino de'Luzzi ( circa 1275-90), called Mundinus, of Bologna, whose Anathomia was completed in 1316 and first published at Padua in 1487, and later at Leipzig in 1493 by Martin Pollich von Mellerstadt. In intention, this work was really a little horn-book of dissecting, ${ }^{3}$ rather than a formal treatise on gross anatomy.

Mundinus' seheme of dissection begins with the abdominal cavity, as containing the perishable viscera. In this seetion he ineidentally deseribes abdominal paracentesis, radical cure of hernia and lithotomy, gives the differ-

1 Sudhoff: Anatomie im Mittelalter (Stud. z. Gesch. d. Med., Leipz., 1908, Heft 4, 82-89, pl. xxiv).

2 Wiekersheimer: Arch. f. Gesch. d. Med., Leipz., 1913-14, vii, 1-25, 5 pl.

s Otherwise a general medical manual (quoddam opus in medicina). 
ential diagnosis between renal and intestinal colic, and records his post-mortems on two female cadavers (January, March, 1315) to ascertain the relative size of the uterus in virgins and multipare. He next passes to the chest and neck, giving a lengthy deseription of the heart, and eoncludes with the opening of the skull. In speaking of the ear, he says we might understand the temporal bone better if it were eleaned by boiling, only this is sinful (sed propter peccatum dimittere consuevi) (Neuburger).

Although full of Galenieal errors in regard to the stiucture of the human frame, preserving the old fietive anatomy of the

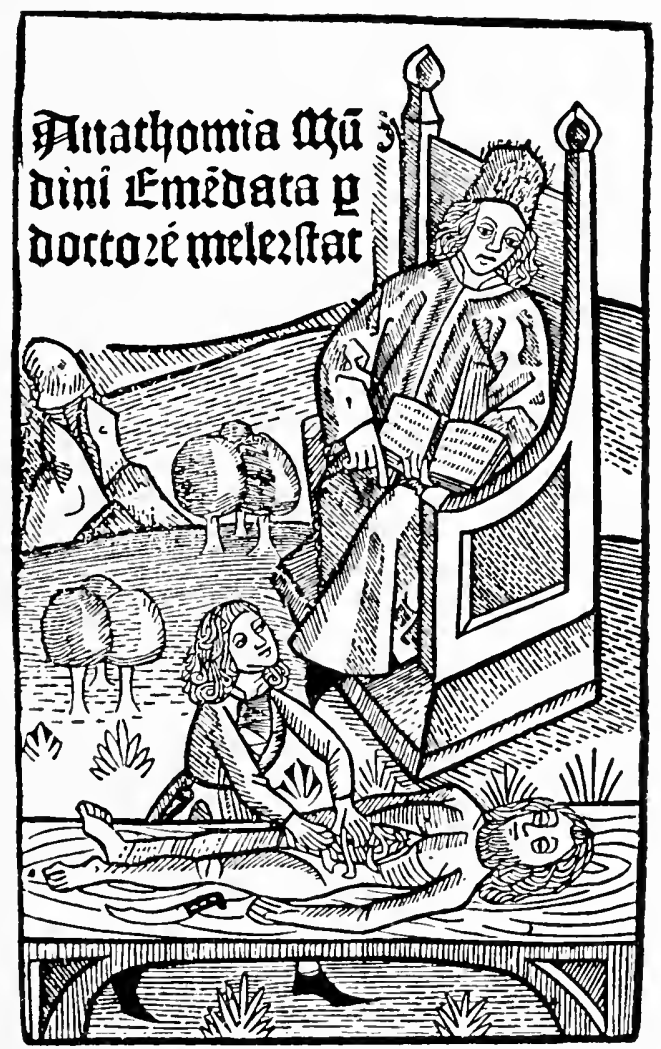

Title-page of Mundinus: "Anathomia," Leipzig, 1493.

Arabists, with the Arabic terms, this work was yet the sole textbook on anatomy for over a hundred years in all the medieval schools. It passed through 39 separate editions and translations (Mortimer Frank). Mundinus' work at Bologna was eontinued by his pupil Niccolò Bertuccio (died 1347), who taught Guy de Chauliac. After this time, dissecting gained a firmer foothold as a mode of instruetion. 
Contilo datobligno gavo a puble dissoction at Padua in 13.11. In thir-

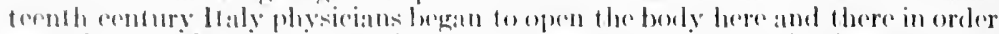

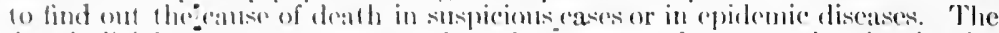
first judicial pestmortem was enduclod on a case of suspered poisoning by

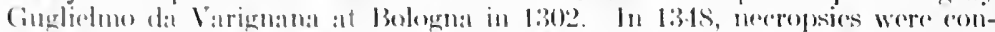

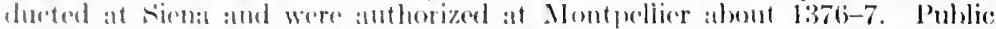

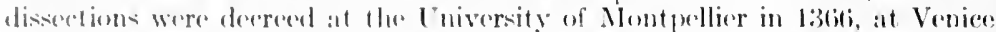

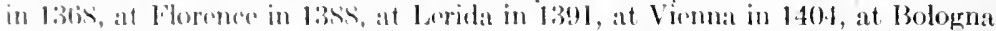
in 1.105, at l'alua in 1.29), at l'raruc in 1.160, at Paris in 1.17s, and at Tïbingen

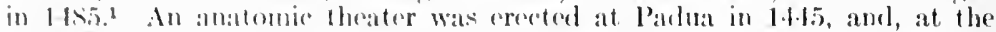

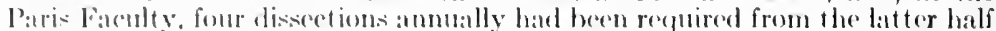
of the fifterith contury on.

Even before the aldvent of Vesalius we find the great artists of the Renaissance making discections in the hospitals at Florence (Santo Spirito), Milan and Rone; but with the exeeption of these artists, whose paintings really advanced anatomy without didactic intention, dissecting was, as Neuburger remarks, mainly a showy, ornamental feature of medieval instruction. In regard to the bull De sepulturis, issued by Pope Boniface VIII in 1300, which many suppose to have put a damper upon anatomic research, it is shown by Neuburger and Walsh that it was, in intention at least, a simple mandate to prevent the bodies of dead Crusaders from being boiled and dismembered before returning them to their relatives. ${ }^{2}$

In the thirteentl century the Arabist culture was securely grafted upon European medicine by means of Latin translations, and internal medicine in this period was essentially scholastic and monastic, that is, its rotaries were either monks or schoolmen of the type of the foremost intellectual leaders of the thirteenth century-Roger Bacon, Thomas Aquinas, Duns Scotus and Alhertus Magnus. The medieval lawvers and logicians did good service in sharpening men's minds and teaching them how to use dialecties as an instrument or weapon, but science itself could not advance so long as the pitfalls of syllogism were preferred to inductive demonstration of fact. We call the medieval writers on practice of medicine Arabists on account of their unswerving fidelity to Galenic dogma as transmuted through Mohammedan sources. The great center of this translating movement was Toledo, which, after falling into the hands of the Christians in 1085, was sought by all and sundry for its rich stores of Arabic manuscripts, while most of the Hebrew translations from the Arabic came from Provence. p. 331 .

${ }^{1}$ See F. Baker: Johns Hopkins Hosp. Bull., Balt., 1909, xx, footnote to

2 Neuburger: on. cit., ii, 432. Walsh gives the Latin text in his "Popes and Science" (New York, 1905, 413), and translates it in Ned. Library and Histor. Jour., 1906, jv, 265. 
Gerhard of Cremona (1114-87), who translated Rhazes, Serapion, 1sitic Judaus, Albucisis, and the Canon of Avicenna, was the prineipal interpreter of this Toledan treatsure-hoard; Mareus of Toledo translated some of Ciaten and the Isagoge of Johannitius; the Salernitan Jew Ferragut ben Salem translated Rhazes in Sicily (1279) and the Tacuimum sanitatis at Naples (129(i): and John of Toledo (Joannes Hispanus) profoundly influenced salermo by his Latin version of the hygienic epistle of pseudo-Aristotle. In this work of transplantation of Arabist cloctrine, the Jews, the natural intermediaries between East and West, played a considerable part, mainly in their own Hebrew versions of the Arabic. Otherwise. the Toledan influenees dirl not entirely make for good, since the so-called "translators," ignorant of Arabice. usually had some learned Jew or saracen turn the text orilly into collogulail Spanish, to be rendered into barbarous Latin currente ealamo. Through medieal, as well as linguistic, ignorince, the technical terms were simply transforrel without translation, the sense of the text was frequently distorted, and the many contractions made it otherwize unintelligible. "This great mass of Arabist doetrine was now attackerl by the scholastic physicians, who were either commentators in the orthodox sense, "agregrator"," that is, compilers of the best things in their authors, "coneiliators," that is those who sought to settle and reeoncile the eontradietions in Hollenist ame Arabist doctrine by dialeeties, or "coneorders," $i$. e., arrangers and harmonizers of the outstanding ideas and sentenees of an author in regular order. ${ }^{2}$ The chief merit in all these medieval eomplers was in their feeling for orderly arrangement. There was little independent thought. The influener of the Arabic authors inported by Constantinus Africanus was already noticeable in such early thirt senth eentury physicians as Ricarchs Anglicus, Gualtherus Agulinus, Petrus Hispanus, (illbertus Anglieus and Jean de St. Amand, canon of Tournay, who wrote a commentary on the Antidotarium of Niclolas the Salernitan, and a Rerocatimem memorie, a labor-saving compend, dewigned to save students sleepless nights over their Galen and Avicennal, and consisting of a Concordance of these authors arranged by ratehwork, an abbreviated kev to the contents of the Hippocratic and Galenie writings, and the Areolor, it contensed materia medica, which enjoved great popularity in the sehools. The founder of medical dialectirs (ind the real foumler of the Bolognese school) was Taddeo Alderotti (122:3-1303), of Florence, a allerl Tharleter. Florentinus, a writer of dry seholial and good consilia, who hegan to teach logieal or scholastie medicine at Bologna in 1260, and was a thrifty, muchenvied practitioner. Thaddeus introdued the praction of swamping a text in a veritable imundation of commentary. He early noted the faulty translations matle by Constantine, and elung to the original (ireek sourees, hut his own skill in logie-chopping suggests his training in the Canon of Avicennat. The scholistic method attained its highest development at once in Bolognal, which was then the great center of legal casuistry and forensic triumphs..3

The Conciliator differentiarum (Venice, 1471) of the heretic Peter of Abano (1250-1315), the great "I combard," who as the title of his work implies, tried to reconcile the views of the Arabists and Grecians, marks the rise of the rival school of Padua as a center of medical dialecties, of which Thaddeus and Peter were the patterns for a century. ${ }^{4}$ The Liber Pandecte Medicine of Matthæus

${ }^{1}$ Ml. Steinsehneider: Die hebräischen Tebersetzungen des Mittelalters und die Juden als Dolmetscher, Berlin, 1893. Also, Neuburger, op. cit., 329-333.

${ }^{2}$ Pagel-Sudhoff (Berlin, 1915), 181.

${ }^{3}$ Neuburger, op. cit., 375.

${ }^{4}$ Peter's Conritiator consists of 210 moot-points to be resolved by dispute, e. g., "Utrum nervi oriantur a eerebro neene?" "Itrum medicina sit seientia, necne," "An ossa sentiant," etc., which became the fashion for students" dissertations and disputations even beyond the se senteenth century. 
Sylvaticus (diod 1:312), of Mantua, one of the first incomalnula to be printol (strastume, 1470 [?]) illustrates tho same tondeney. The most prominent of the Arabists, however, wore associated with the rise of the medical school at Montpellier. Founderl abont 738, this famous sohool, like that of Salerno, was rhamingly situated noil the seat and not far from mincial baths. As ratly as 1137 , Bishop Adolhert of Manz visited the sohool to listen to its medical lecturers. St. Bernatrd refers fo the visit of the Arehbishop of lyons in his lofters (1153), and its influence in France has survived to this day. A prominent early representative of the Arabist teachings of Montpellier was the alchemist Raymond Lully (1235-1315), a native of Majorea, who, in aclchition to the philosopher's stone, soldght the "aturm potabile" or liquid golel, as a sovereign elixir against disease. Having entered the order of the Minorites, he learned Arabic through his desire to eonvert the Moslems of North Africa and, in this way, became acquainted with Arabian chemistry and brought some of its ideas into Europe. A man of similar type was the Catalan. Arnold of Villanova (1235-1312). who was a doctor of theology, law, philosophy and medicine, and counsellor or consultant to Peter III of Aragon. A follower of the Arabian chemists, he also sought an universal elixir of life, and his alchemistic tendencies, taken together with his theologic heresies, ("alused him to be anathematized after his death. He is credited with the introduction of tinctures and of brandy (aurum potabile) into the pharmacopeia, and in many ways he was a sort of refined Paracolsus, a man full of strange contradictions. He was a pioncer in the classifieation of diseases and opposed the aluuse of dialecties, the tendeney of the Parisian scholasties to lose themselves in universals and ignore particulars, as well as the footless therapentio empiricism, which lost itself in partieulars and ignored general principles.

Ite was a copious, elegant, uneritical writer, who, aceording to Symphories ('hampier, declined to revise any copy, once he had penned it. His "Breviary of I'ractice" (Milan, 1483), one of the best of the medieval handbooks, con tains mueh independent observation, and many citations from now unknow physicians. Arnoll's greatest work is the Parabolo, a set of 345 pithy aphor isms, dedicated to Philip the Fair (1300), and containing much original thought His commentary on the Regimen Sanitatis, is not to be confused with th Regimen itself, sometimes aseribed to him, nor with the other eommentar at tributahte to Magnino of Milin. ${ }^{1}$ The best modern studies of Arnold of Vi lanova are those of Hauréau, on the textual side, and Paul Diepgen, on tb. merlical side.?

\footnotetext{
1 Neuburger (ii, 391) attributes Arnold's eommentary to Magninus Med otanensis.

"Hauréau, in "Histoire littéraire de France," 1881, xxviii, 26-126, 48 Diepgen: Arch.f. Gesch. d. Med., Leipz., 1909-10, iii, 115; 188; 369; 1911-1 v. $\$ 8 ; 1912-13$, vi, 380 .
} 
Other prominent pupils of Montpellier were the surgeons Guy de Chatuliar. Arderne and Mondeville; Valescus de Taranta (1352-1417), physician to Charles VI of France, whose Tractatus de peste was one of the earliest incunabula (1470 [?]; Johannes de Tornamira, physician to Popes Gregory IX and Clement VII, for many years chanedlor of Mlontpellier and rememberol by his Introductorium (Lyons, 1490), a popular text-book on practice in the fourteenth and fifteenth centuries; Peter of Spain (1277), callod Petrus Hispanus, physician to Pope Gregory $X$ and afterward himself Pope John XX1, whose Thesaurus Pauperum was the most popular of the medieval formularies; and the learling representatives of Anglo-Norman medieine, Bernard de Gordon, Riehard of Wendover (the anatomist), Gilbertus Anglieus and John of Gaddesten.

Before the advent of the Norman eonquerors, English medicine was entirely in the hands of the Saxon leeches, whose practice was made up of charms, spells and herb-doctoring, and whose folkmedicine is preserved in the Leech-Book of Bald and other AngloSaxon "leechdoms." The Normans raised the social and intellectual status of their physicians by having them educated abroad as cleries.

Bernard de Gordon, inferentially a Scotchman, did not practice in England, but was a teicher at Montpellier from 1285 to 1307 . His Lilium Medicino, which exists in several rare manuscripts and was first published at Venice in 1496, is a characteristic Arabist text-book of the practice of medicine, nowise classic, and typical of the Middle Ages in scholastic subtlety and rigid adherence to dogma. The subject matter is well arranged; acute fever (bubonie plague), phthisis, epilepsy, scabies, ignis sacer, anthrax, trachoma, and leprosy are deseribed as contagious, and the book is notable as containing the first deseription of a modern truss and the first mention of spectacles as "oculus bercllinus." "2 The Comperdium medicina (London, 1510) of Gilbertus Anglicus (died 1250), the leading exponent of Anglo-Norman medicine, is very much like Gordon's Lily in style, arrangement of contents and modes of thought. The author avows his preference for the simple expectant treatment of Hippocrates, but hesitates to employ it for fear of seeming an odiffish. ${ }^{3}$ The most important feature of his work is an original aecount of leprosy which beeame the basis of medieval information upon the subject. Cilbert was the first to refer to smallpox as a contagious disease, a view afterward contradicted even by Sydenham. The book concludes with hygienic directions for travelers and seafarers, a literary species, which, like the hygienic regimina written for great overlords and ladies, was to become fashionable in time. ${ }^{4} \mathrm{John}$ of Gaddesden (1280 [?]-1361), a prebendary of St. Paul's, whom some think the original of Chaucer's Doctor of Physic, was physician to King Edward II of England and a fellow and professor at Merton College, Oxford. His Rosa Inglica, compiled in 1314 , and printed at Pavia in $1492,{ }^{5}$ contains an early

${ }^{1}$ See Oswald Cockayne. Leechdons, wortcunning and stareraft of early Fingland. 3 vols. London, $1864-6$.

${ }^{2}$ For the other writings of Bernard de Gordon, see R. von Töply, Mitth. z. Gesch. d. Med., Leipzig, vi, 94, and Sudhoff: Arch. f. Geseh. d. Med., Leipzig, 1916-17, x, 162-188.

${ }^{3}$ Neuburger, ii, 369 .

${ }^{4}$ See Sudhoff (Arch. f. Gesch. 1. Med., Leipz., 1910-11, iv, 263-281) on the oldest known (circa 1227) and Pagel-Sudhoff, p. 15.7.

${ }^{5}$ The later editions were those of Venice (1502), Pavia (1517), and Augsburg (1595). See G. Dock. Janus, Anst., 1907, xii, 425-435. 
roforence to the red light a rinsen troutmont of smallpox, which was already

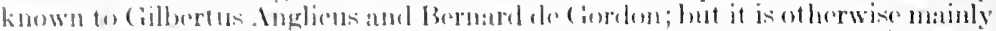

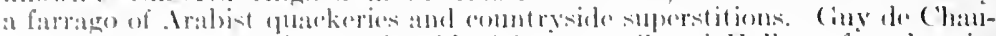

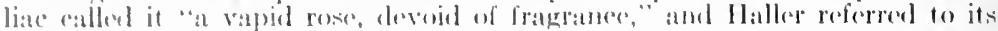

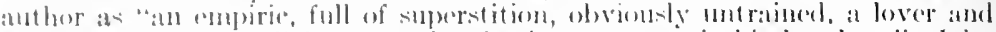

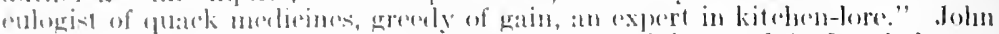

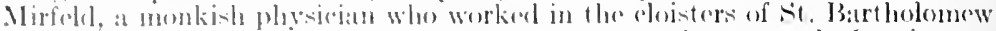

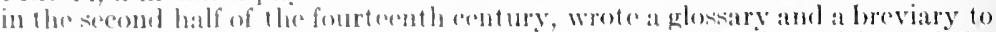

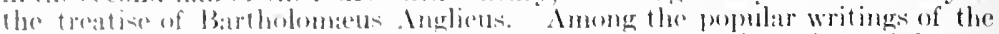

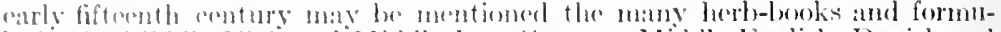

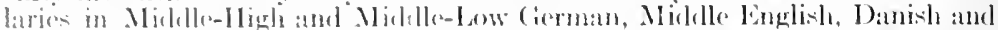

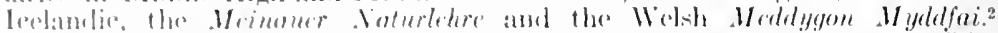

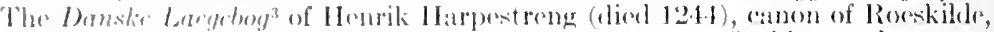

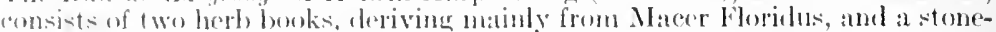

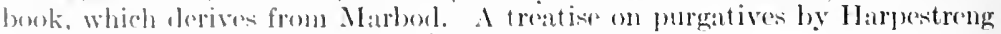

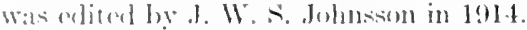

The most enduent naturalist of the thirterenth contury was the Dominiean monk, Alhert von Bollstidl (1193-1200), ('allorl Albertus Magnus, who was

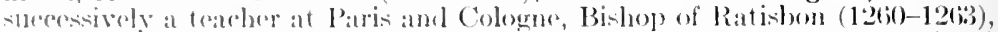

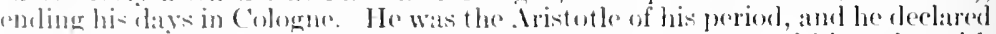
that the objere of his l'hysica was to fumish the brethren of his order with an Aristotelian Bomk of Niture. His deseriptions of plants (De regetabilibus) were batid upon his own observations and, atcording to Hallere contain the heginnings of plant gorography. Ilis work on anmals is of the sanc charactor, and he assisted Froloriek il in his work on falconry. The often reprinted work on cosmeties (De seretis mulierum), which usualiv gous by his name, was in reality a luge compilation madr by his pupil, Jlenry of Saxony. Albertus Magnus did not writo on meelieal pravetier, a subjert forbidelen to the Dominicans. His pupil, Thomas Apuinas, discuserel physologic questions in his theologic writings and advaneed the dubious animistic doctrine of qualiates occuller. Albertus Magnus was followerl by such encrelopedists as the Domini(an, Vincent do Boumvaic (Speculum mojus, 1473-5), Bartholomew Glanvil, properly Bartholomasus Inglicus (I) proprictalibus rerum), the Dominican,

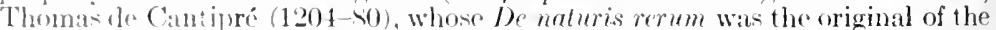
Puch der notur (13.30) of Conrat von Megenberg (1309-74), and the Tesoro of

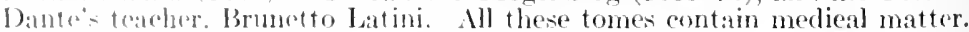

The greatest experimenter of the thirteenth century was the English Franciscan Roger Bacon (1210-92), called Doctor mirabitis, who was a comparative philologist, mathematician, astronomer, physicist, physical geographer, chemist and physician.

Ho reformed the ralemlar, dis much for the therry of lenses and vision, anticipated spectarlos, the telescope, gunpowder, diving bells, locomotives and flying machines, and was a forerunner of inductwe and experimental science. IIelicine he regarled as a means of prolonging life through alchemy (chemistry) and be approved of astrolugy and other modes of superstition on acrount of their psychotherapentic effect. ${ }^{4}$ llis principal contributions to medical literature are his astrological traets on critical days.

1 Neuburger, ii, 369:502. II. P. Cholmeley: John of Garldesclen and the Rosa Medicina, Oxford, 1912, 41. Compare Gilbert's "Compendium Medicine," Lyon- 1510, fol. 348, rerso, col. 1, with Gaddeaden (fol. 51 recto, col. II). isfil.

2 Translated by John Pughe, cdited by John Williams at Ithel, Llandovery,

${ }^{3}$ Edited by C. Molbech, 1861.

${ }^{4}$ For a full account of Roger Bacon's work in science, see the "Commemorative Essays," edited for his seventl centenary by A. C. Little (Oxford, 1914), with an account of his work in medicine by E. T. Withington. 
Three medieval writers on medical plants and simples deserve especial mention, viz., Giacomo de' Dondi (129s-1359), whose Aguregator de medicinis simplicibus, printed at Strassburg, circe 1470, by Arlolf Ruseh (the "R" printer $\left.^{1}\right)$, is one of the earliest known of medical ineunabul:a"; simone de Cordo (died 1330), whose symonyma medicina (1473) was the first dietionary of drugs and simples, under the Greek, Latin and Arabie names, and the abovementioned Matteo Silvatico, whose Pandects, also printed by Rusch at Strassburg, is a similar compilation, giving also botanic deseriptions and therapentic indieations. These three books did for the Arabie botanie terms what Hyrtl later did for the amatomie, and, in a manner, they may be regarded as the origins of our medical dictionaries.

The pre-Renaissance medicine of the fourtecnth and early fifteenth centuries was characterized by the attempt to east the Arabist tradition into a rigid mold by means of Aristotelian dialecties and assimilation to the Aristotelian philosophy. The result was that the Galenic doctrine, after translation and re-translation through the Arabic, Syrian and Hebrew glosses, was badly distorted and wrenched away from its original meaning. The "spell of Aristotle" was over all. The scholiast and the dialectician ruled supreme, until more advanced spirits became rank sophists or skeptics, thus preparing the ground for the true Revival of Learning. The medical literature of the fourteenth century was entirely receptive and passive, consisting of compilations, commentaries, glosses, glossaries, concordances, breviaries of practice (often called after the Lily and the Rose) and casuistic writings. or Consilia. In this period flourished Mundinus, Guy, Mondeville, Arderne, Yperman and Argelata.

A striking feature of elinical medicine in the fourteenth and fifteenth centuries was the writing of "Consilia" or medical casebooks, consisting of elinical reeords from the practice of wellknown physicians and letters of advice written by them to imag-

1 The fact that the "R" printer" was Adolf Rusch, and not hic employer Mentelin, was set tled by the distinguished Göttingen philologist Karl Dziatzko, in his essay "Der Drucker mit dem bizarren R" (Samm]. bibliothekswisisensch, Arbeiten, Halle, 1904, Heft 17, 13-24). Ruseh, it seems, married Mentelin's daughter, Salome, and eventually took over his business. The much disputed " $\mathrm{R}$ " is in reality a monogram of the initial Jetters of Rusch's name, which he was in the habit of inserting here and there in the books printed by him, as a sign of his handiwork during the days of his apprenticeship.

"The question, "What is the earliest printed medical book of size"." is still unsettled. The Gutenberg Laxicrkalender of 1457 of eourse antedates everything else, but it is only a sheet of paper. Mlle. Pellechet aswigns the date 1467 to Johann Gerson's three traets on self-abuse, printed by UTrich \%ell at Cologne. The date "1468" has been elaimed for Rolind of Parma's pest-tract and 1469 for Giammateo Ferrari da Grado's Prariica (Pt. 1). The question cannot be finally decided until all the known medieal incunabula have been catalogued, collated and compared as to fonts of type, filigranes (watermarks), majuseules (initial letters) and the internal evidence of biographic and other data. This inuportant task has now been undertaken by Dr. Arnold $C$. Klebs, who has already assigned dates and printers to many undated ineunabula. 
inary patientsur plse to real pupils or eountry doctors, who appealed to their superior knowlodge as ansultants.

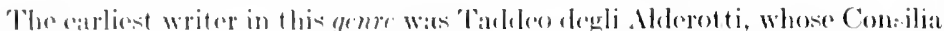
still "slunber in the mamuseripts" (sullom). The pratice was kept up by

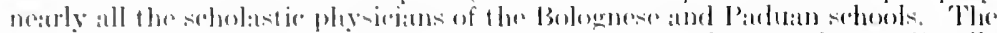

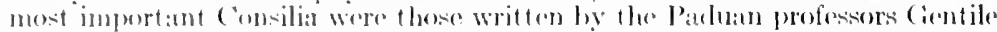

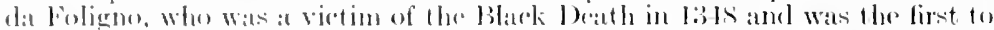

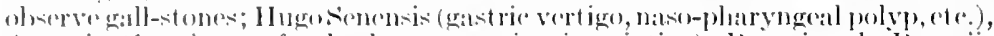

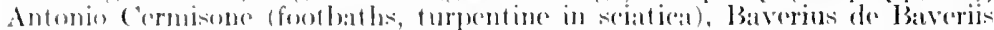

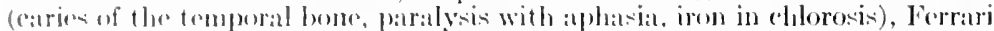
dar Cirado, and Bartolommeo . Iontagnama (1.170), a deseendant of a long line of phrsicians, an anatomict who had diseceted as many as fourteen bodies, and is surecour whe described strangulated hernia, operated for lacrimal fistula and extractorl derayed teeth. There Consilia, of which Montagnana

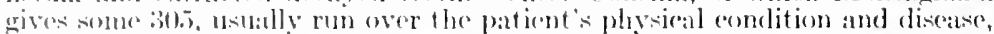
wimling up with seasonable adviee ats to what to cat, what drugs to take and

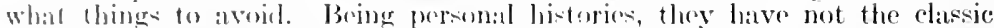

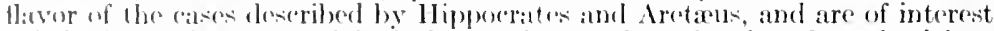
rhedfy for their many original obervations and as showing that physicians hat aldeady begun to keep careful recoris of their laily uraetice. The enstom

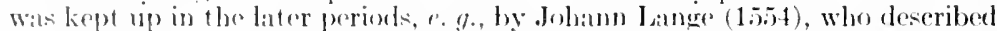

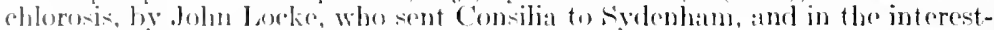
ine exchanges of medical cases in the correspondenee of Bretonneau with his pupils, Velpean and 'Trousceatu.

(of the sedulastie writers on internal mediene, (inglielmo Corvi of Brescia

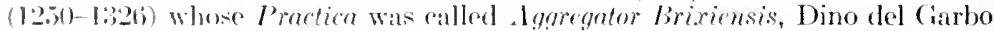
and his son Tommaso, Torrigiano di 'Torrigiani. Niceolo Bertuceio. the toacher of Ciny, Pietro di Tusignamo, the surgeon Ciovamni Arcolani, and (iovinni da Parma (Prorticrlla ${ }^{1}$ ) belonged to the Bolognese School. The rivil school of Padua, which followed the Averroistic leanings of Pietro d'. Ihano, numbered among its mateters (iontile da Foligno (died 1348), famous for his ( onsilia, Ciacomo dre" Dondi (1295-13509) and his son Giovanni, Marsilio de sint a Sophia and his nephew (ialeazzo, Giacomo della Torre called Jacobus Foroliviensis. Intteo Silvatico of Mantua, author of the famous Pandecte. Franceseis di P'iedimonte, whose supplementum Mesuce was one of the best text-books of the time on sperial pathology and therapeutics, expressing the final union of salernitan and Arabie medieine, and Nicelo Faleueci (died circa 1412), callow Nicolaus Flurentinus, anthor of a vast repertory called sermones medicinales (ist), which summarizes the whole of medieval medicine, teeming with original aitations from all the known authorities.

Before the invention of printing there bad acrumulated a huge quantity of medieal literature in manuseript, the investigation of which has been mainly the work of l'rofesor liarl Sudboff and the Institute of Medieal History at leipzig. This literature inclules many hitherto unprinted texts and textbowks of the medievid phycicians and surgeons, ealendars and schemata for blowl-lotting and purgation, "leath-prognoses" sotting forth the signs of dissolution (signa mortis). Lepraschaubricfe or medico-degal erpertises as to the civil stalls of supposititious lepers, business announcements of vagrant phyrejans, municipal ordinances against quackery, old German MSS. on farriery (Rosserzucibucher), consilia and even warning against the abuse of alcohril.

The Montpellier School includes the names of Guy, Jean de Tournemire, Johannes. Jacobi, and many other famour chanecllors and Papal physicians. The nrineipal medieal writers of the early fiftenth eentury were Ugo Benzi, ealled Hugo śenen-is (died 1439), a great medical philowopher, commentator and consiliary, who taught in all the famous Italian schools, Antonio

1See M. A. Mehner: Leipzig diss. (Inst. f. Gesch. 1. Med.), 1918, which gives a valuable list of the vegetable simples used in this Practicella. 
Cermisone, Antonio Guainerio, Savonarola, Bartolommeo Montagnana, of Padua, Areulano, Argelata, Marco Gatinaria and Giammateo Ferrari da Gralo (died 1472), professor of medicine at Pavia, whose Practica (printed 1469-71) and Consilia, contain much original observation, e.g., of writer's eramp, facial paralysis, hemoptysis in dysmenorrhea, sterility from displacement of the uterus, and the use of the pessary and the truss in uterine prolapse and hernia. In France, the Portuguese Valeseur de Taranta, a leading teacher and practitioner at Montpellier, wrote a famous traet on pest (1473-1) and a theripeutic Philonium (1490) which was often reprinted. Jacques Despars (Jacobus de Partibus), at Paris, was a commentator of Avicenna, Mesuë and Alexander Tralli:ınus.

Cultural and Social Aspects of Medieval Medicine.-During the Dark Ages (476-1000), Western European civilization was in a chaotic, formless state, the turbulent fermentation of barbaric or decadent peoples resolving themselves into new nations. Feudalism put nationhood on its feet, while the (hurch was the only foster-mother that science could find. ${ }^{1}$ In the Dark Ages, the clergy were the only class who had any pretense to education and, before the time of the School of Salerno, medicine was entirely in the hands of Jewish and Arabian physicians. ${ }^{2}$ The rest were simply vagrant quacks or stationary humbugs whose practice was discountenanced by the Church on the ground that faith, prayers and fasting were better than pagan amulets, while the sick were advised to emulate the saints in their capacity for endurance of suffering (Gregory of Tours). With the rise of the School of Salerno, European medicine began to look up a little, but, as soon as monks and clerics began to practise medicine, it was found that the sceking of merlical fees to the detriment of regular duties, the sight of many aspects of the sick that night offend modesty, the possibility of being the cause of a patient's death and other happenings were somewhat inconsistent with the original intention of holy orders, and so we find the Church instituting that long series of edicts which, in the first instance, were aimed not so much at medicine as at its malpractice by monks. ${ }^{3}$ These were the decrees of the councils of Clermont (1130), Rheims (1131), the Second Lateran (1139), Montpellier (1162), Tours (1163), Paris

${ }^{1}$ How carefully the elergy collected medical literature is evideneed by the remarkable bequest of medical books to the cathedral library at Hildesheim, as listed in the will of Bishop Bruno (1161). See Neuburger, op. cit., ii, 321322.

2 In spite of the Decretum Gratiani, excluding Jewish physieians from practising among Christians, Arehbishop Bruno of Treves (1102-24) was attended by the learned Joshua, Moses of Liège was eonsulted by the elergy in 1138, and medical practice at Prague was entircly in the hands of the Jews in the twelfth century (Neuburger, ii, 325-33).

${ }^{3}$ The earliest of these, that of Clermont (1130), refers specifienlly to the "neglecta animarum cura," the "detestanda pcrumin," and the "imputicus culus." Even in 877 the synod of Ratisbon had decreed that "Leges et physisum non studeant sacerdotes" (Neuburger). 
(1212). the Fourth Lateran (1215), and le Mans (12171), and their cremeral affect was, unfortmately, not only to stope the monkis from protetising hut to extend the special odium of these decrees to the whole modical profession. As Mllhutt says, "If Papal hulls confermed privileges, they usuatly implied or imposed restrietions." 'lhe famoms maxim of the (ommeil of Tours (Eeclesiu ubhorret a sambmine), for (xample, went wide of its supposed intention, since, in casting diseredit upon the sometimes murderous ratgibond surgeon, the woight of its anthority made the suregen of best type still an inferior to the average practitioner, even in l'rotestant Germany to the ond of the eightecnth century. Worse still, the higots of the Paris Faculty went much further than the Papal soe in widening the gilp between surgery and modicine. The Roman Pontiffs thomsclves were, some of them, liberal-minded men of the world, who did not hesitate to employ talented Jewish physicians at need and, in later times, did much to foster the arts and sciences, in Italy at least. John XXI and Paul II were physicians. "Around the Papal chair," says Allbutt, "the velvet of the laund of the Church was thicker than the iron. In the air of Rome or of Avignon the grim rigor of Paris was marvelously softened." While great harm was done to medicine by the Papal decrees which degraded the surgeon's status, we should not forget that, up to the time of the crusades, all Europe outside of Italy was in a state of barbarism and that the status of surgery in these countrics was lower than it was among the Greeks at the time of the Trojan War. A few shreds of technical knowledge may have lrifted over from far Byzantium, but the evidenee of the Niebelungenlied, the Anglo-Saxon Leech-Books, and the Norse Sagas all point to the same conclusion, viz., that the care of the sick and wounded was first in the hands of women and later intrusted to a class of men who, in war-time, were in great request but, in times of peace, ranked on a level with menials.

\section{Druidical medicine in Britain was entirely priestly.}

The Druids were a corporation of magicians, and of these, the Seer (vates) assumed iatromantic functions, with augury (inspection of sacrificial entrails) for prognosis, magie and wort-eunning for therapy. Nistletoe (all-heal) was the panacea, the six herbs, lycopodium, pulsatilla, trifolium, primula, hyoscramus and verbena were highly esteemed; artemisia, betony, bryonia, centauria, belladonna, hellebore and mandragora were known. Druidesses were also prominent in sorery, second-sight and herb-therapy. ${ }^{2}$ The Anglo-Saxon leechrloms tell the same story of charms, spells and simples. Blood-letting, purging and drugging were regulated by the moon's age. The Venerable Bede

1 Aprengel gives the sources of these deerees, viz., G. D. Mansi: Sacrorum con-iliorum nova et amplissima collectio, Florence, 1759-98, xxi, columns 459; 52); 1160: xxii, col. 1010: xxiii, col. 756.

${ }^{2}$ Neuburger, ii, 234-236. 
reckoned the period April s to May 25 as the best time, while eertain days in the interim, when the moon and tides were at full, were regarded as unlueky or Egyptian days (dies Egyptiaei), a late Roman superstition, mentioned by St. Augustine, and probably of Babylonian origin. ${ }^{1}$ Ancient Irish medicine has many signs of Oriental provenanee, particularly in the austere regulations of medical practice and quackery in the Brehon Laws, which suggest the Corle Hammurabi. A strange MS, of Roger Bacon's, written rither in Gaelic or cipher, full of remarkibly naturalistic miniature figurations of preguancy, suggests some kind of esoteric or mesneric magic, like that of the Hindu fakirs. ${ }^{2}$

In Tacitus (Germania, VII), it is said that the wounded Tentons sought their wives and mothers, who, like the professional bloodsuckers of the eighteenth eentury, applied their lips to the wounds (ad matres, ad conjuges vulnera ferunt, nec illae numerari et exigere plagas pavent). The reverence of the ancient Germans for the intuitive powers of wonan was the origin of weise Frauen, who pratised herbal medicine.

Of these, the seeresses Veleda and Aurinia, as Tacitus relates, were reverel as divinities. In the epic of "Gudrun" (1. 529) mention is also made of "wild women" (wilde Weiber), who knew of healing herbs. Demon-lore, magic, charms and amulets made up the rest of early German medicine. ${ }^{3}$ As among the Greeks, the wrath of the gods was appeased by blooly sacrifiee, the demons dispelled by exorcism, the therapeutic properties aseribed to rertain plants, parts of animals and the votive (usually heart-shaped) pastry used in sacrifice were based upon their sacral associations with thr gods in their chthonian or earthly aspect. From this eult arose a sacred pharmacopocia and a "sacrificial anatomy" (Opferanatomie), the technical terms of which were long a part of the vocabulary of German huntsmen, and eventually male up the culinary anatomy of the slaughter-pen and the kitchen (IGffer). The vernaeular names of diseases were derived in the same way, diroetly from the borlily effects or from demoniac etiology. ${ }^{5}$ To wark off the demons of disease, the gode or sacrificial priest was assisted by the aboriginal medicine-man, the lêleis or lahbi, the equivalent of the Anglo-saxon lacea (Irech). Fhepherds, herdsmen and smiths, as being natural reterinarians, also became renowned as healers, bonesetters and masseurs (Streicher) in isolated loralities.

In Russia, medicine was originally in the hands of the rolkhore or wolf-men, who, like the Druids and wise women, culled medieinal herhs and resorted to charms and spells. The earliest relic of Russian medicine is a vase of Cireek pattern exeavated at lioulOba, representing a Scythian chieftain in consultation with a volkhava, a Seythian warrior examining another's teeth and a surgeon bandaging an injured leg. This unique vase epitomizes medieval medicine and surgery up to the time of the School of

1.J. F. Payne: English medieme in the Anglo-saxon times, Oxforl, 1904.

${ }^{2}$ In the possession of Mr. Wilfred M. de Voynich.

${ }^{3}$ Neuburger, op. cit., ii, 236-240.

${ }^{4}$ M. Höfler: "Wall- und Baumkult," Munich, 1892; also "Die volksnerlizinische Organotherapie," Stuttgart, 1908. $\$ 99$.

${ }^{5}$ See Max Iöfler's learned "Deutsches Krankheitsnamenbuch," Munich, 
Salerno. After the introduction of christianity in the tenth contury, Russian mediene pased into the hands of the priesthood, the wolf-men gave place to the monks of Mount Athos, and the Russian (hureh, like the Roman, put severe interelietions upon solecry and magie. Thus religion at the start tonded to improve the status of medicine, hut speedily, if mintentionally, degraded it, as soon as it found its own medical ministrants falling into evil ways. Even the special murses or "parabolani," whom the (hureh employed to seck out the sick and convey them to places of shelter and safety, were soon shorn of their powers as they became uppish, quarrekome and overbearing. Even before this time, however, the Visigothice Code (fifth to seventh conturies) put the same severe restrictions upon medical practice that we find in the Code Hammurabi.

Before taking up a case, the physician, under the Visigothic Cole, had to make a contrict and givo pledges, and, if his patient died, he got no fee. If he injured at nobleman in venesection he had to pay 100 solidi (about \$225); if the nobleman diod, the physician was turned over to the relatives of the dereased to be dealt with as they pleased. If he killed or injured a stave, he had to replace him by one of equal value. He was forbidden to bleed a married wonnan in the absence of her relatives, for fear of the commission of adultery, and he could not visit a prisoner lest he dofeat the ends of justice by furnishing him with poison. On the other hand, it is stated that no one might east a physician into prison without a hearing, exeept in ease of murder, and that the statutory fee for instrueting medical students should be twelve solidi (\$27) each. The other "Leges barbarorum" were equally severe. Under the Bavarian Code (Lex Bajuvarum vii, 19), the administration of an abortifacient entaited a fine of one solidus in the culprit's family, cven unto the seventh generation. ${ }^{3}$

From these regulations, made by the secular arm of authority, and designed to protect the public as well as the physician, it may he gathered that, with medicine in such an unorganized condition, something more than the guardianship of Church and State was necessary to elevate the status of the healing art, and this was accomplished by improved medical legislation, by the foundation of the great medieval universities and the subsequent formation of "guilds" by the physicians themselves. Under the legal restrictions of medieval times, the surgeon worked daily and hourly in jeopardy of life or limb. ${ }^{4}$ Marileif, Chilperie's body physician,

${ }^{1}$ For a photograph of the Koul-Oba vace, see "Nouvelle Iconographie de la Salpêtrière." Paris, 1901, xiv, plate no. 72, opposite page 52S.

${ }^{2}$ First mentioned, A. D. 416, in the Corlex (de legationibus) of Emperor Thendosius (lib. xvi, tit. ii, 42-43), but alrearly known as Parapemponti, in St. Basil's arcount of his hospital at Cosarea (370-379). See C. F. Heusinger, Janus, Breslau, 1847, ii, 500-525, which eorreets the errors made by Sprengel.

${ }^{3}$ Neuburger, 25s.

${ }^{4}$ For a careful study of this subject, see Sir John Tweedy on "The Deterrent Influence of Social and Legal Restrictions on Medical Thought and Practice," Tr. Med. Leg. Soc., London, 1911, viii, pp. 1-8. Even among the 
was flogged, shorn of his possessions, and made a serf. In 580, Cuntrim, King of Burgundy, had two physicians executed upon the tomb of his queen, Austrichildes, because the latter died of plague in spite of their treatment. In 13:37, a strolling eye surgeon was thrown into the ()der because he failed to cure John of $\mathrm{Bo}$ hemia of his hindness, and in 1464, Matthias, King of Hungary, issued a prockmation that whoever cured him of an arrow wound should be richly rewarded, but, failing that, shoutd be put to death. These barbarities point their own moral, for the strolling medieval mountebanks, in couching a cataract, sometimes put out an eye, mangled the viscera in "cutting" for stone, and, in attempting to effect a "radical cure" for hernia, as Baas says, not infrequently excised "the radix of humanity itself." Allbutt gives a striking picture of a medieval ineisor who, in ligating an artery, paralyzed his patient's arm by crushing the musculo-spiral nerve and was afterward pursued with eurses by his miserable vietim whenever he dared show himself in the street. If the Church "abhorred the shedding of blood," therefore, it is fair to suppose that, in the first instance, its aversion had the same human signifirance as the wellfounded horror of hospitals and surgical operations which existed in the minds of the laity up to the end of the nineteenth eentury.

A striking illustration of the neglect of surgery is to be found in the late appearance of artificial limbs, which were known to Herodotus and Pliny.

In the Middle Ages, there was an enormous loss of limbs, due to the mutilating offects of anesthetic leprosy and ergotisin, to wounds from cannonshot (introduced at ('récy in 1346) and half-pound gunshot (P'erugia, 1364), and to gruesone judieial punishments. The stumps were commonly bound up in splints. Crutches and wooden legs, afterward so familiar in the works of Callot and Brueghel, are mentioned in the Acta sanctorum and other medieval chronicles and frequently appear in the sacred frescoes of the time. Thr iron hand is first seen in a pieture of 1400 . Goetz von Berlichingen, after losing his right hand by musket-shot at Landshut in 1504, had several hands marle, movable in the joints, with flexible fingers, capable of closure. One of thest still exists and was exhibited at Berlin in 1916.2

As the physicians looked down upon the surgeons, so the surgeons of higher alucation, who in the Middle Ages could be counted on the fingers, looked down upon the barbers. The barbers wer?

North Ameriean Indians of recent times, a medicine-man who has failed to cure in a suceession of eases is believed to have lost his eurative powers, and] may be put to death. (See A. Irrllička: Bur. An. Ethnol., Bull. No. 34 , Washington, 1908, 234.)

1 The strolling herniotomists believed castration to be necessary berans: they thought the intestines and testicles were inclosed in the same sar, which must be removed in its entirety to obviate relapses and faulty healing of the: peritoneum.

${ }^{2}$ Holländer: Berl. klin. Wchnsehr., 1916, liii, 355. 
originally trained for the purpose of bleeding and shaving the monks.

In the thirternth eentury, the Collège de Saint Côme was organized at Paris (cirm 1:210), constituting al guild the members of which were divided into the clerieal harber-surgeons or surgeons of the long robe, and the lay barbers or surgeons of the short robe, and, in 1311, 1352 and 1361, royal decrees were issued forbidding the batter to practiose surerery without being duly examined by the former. In 1372, ( Chates $V$ deereed that the barbers should be allowed to treat wounds and not be interfered with by their long-robed confrères. The samc thing happened in England, where the mister-surgeons formed a separats guild in li3ts, reeognized women physicians in 1389 , combined with the physicians about 1.21, while the "Mystery of the Barbers of London" obtained al separate charter from Edward IV on labruary 2.4, 1462, which was enrolled by the Court of Common Conneil in 1463.

In this way, barber-surgery (the surgery of the common people) became "wound-surgery," that is, was restricted to bloodletting and the healing of womds. The barbers (barbitonsores) themselves owed their business largely to the fact that, after the monks were forbidken to wear beards in 1092, smooth chins and shaving became the fashion. In Germany the barber was often a bath keeper (balneator), who, in addition to bleeding, cupping and leeching, gave enemas, picked lint and extracted teeth, and his examination or "Meisterstück" consisted in sharpening a knife or in preparing certain salves and plasters.

Throughout the Middle Ages, there were some vague attempts to formulate the principles of medical jurisprudence.

The earliest of these, as Cumston points ont, are found in the laws of the Germanie and Slavie tribes, the Salie law, the Capitularies of Charlemagne (ninth century), the Assizes of the Crusaders, and, in the thirteenth century and after, the law of Emperor Frederiek, the Decretals of the Popes and general canon laws. The procedure in such cases was often of the crudest kind, the tests being by ordeal, torture, de facto verifieation of impotenee, and "eruentation," or the spontaneous blceding of a corpse in the presence of the true murderer. The expert opinions given were usually in the nature of hairsplitting easuistry, but Cousin and Cumston ${ }^{2}$ give a number of eases from Freneh legal proeedure of the fourteenth eentury in which surgeons were commonly consulted in cases of wounds, homieide, rape, and the like.

In the year 1140, Roger II of Sicily issued an edict forbidding any one to practise medicine without proper examination, under pain of imprisonment and the sale of his belongings at auction. This important law was followed by an ordinance of larger scope

1 South (Memorials of the Craft of Surgery in England, London, 1S86, 53) says that the date of this conjoint faculty of physicians and surgeons fell somewhere between May, 1421, and May, 1423.

2André Cousin: "Essai sur les origines de la médecine légale," Paris, diss. No. 252, 1905. C. G. Cumston: Jour. Am. Inst. Crim. Law, Chieago, 1913, iii, $855-865$. 
issued by Roger's grandson, the generous and liberal-minded Hohenstauffen Emperor, Frederick II in $1224 .^{1}$

Frederiek's ediet required that a eandidate for license to praetise must be properly examined in public by the masters at salemo, the license being issued by the Emperor himself or his representative; failure to comply with the statute being again punishable by a year's imprisonment and forfeiture of property. The examination was based upon the genuine books of Hippocrates. Galen and Avieenna, and before taking it the eandidate must have studied logic for three years, medicine and surgery for five years, and have practised for one year under some experienced plyysician. The eandidate in surgery had to give evidence that he had studied the art for at least a year, in particular, human anatomy, "without which no ineision can be safely made nor any fracture treated." "The physician was required to treat the poor for nothing; to visit his patients twice a day and once a night, if neessary; to avoid eollusion with apothecaries and to inform upon them, if they adulterated or substituted drugs. The medieal fee was fixed at half a tarenus (about 35 eents) for office practice or for patients residing in the city; four tareni $(\$ 3.00)$ for out-of-town visits, the physieian paying his expenses, or three tareni (\$2.25), if the patient paid them. For a suceessful operation for anal fistulat, John of Arderne required 100 shillings at least, $£ 40$ from the well-to-do, $£ \neq 0$ with robes and a life annuity of 100 shillings annually from the weal thy. Nicholas Colnot, physician to Henry $V$ at Agincourt, was guaranteed twedvepence a day by indentures. Thomas Morstede, the king's surgeon, got the same with the usual allowanee of 100 marks ( $£ 66$ 13s. 4l.) a quarter (Power). The purchasing power of money in this period is said to have been fifteen or twenty times what it is now. The ordinary laborer's pay in England was a penny a diay als against 3 or 4 shillings now. The sale of poisons, magie potions and a phrodiviae philters was punishable by death if any person lost his life thereby; ford, drugs and apothecaries' mixtures were examined at stated intervals by inspectors; and timely regulations were made in municipal hygiene and rural hygiene, sueh as for the proper depth of graves or the suitable disposal of refuse.

Given the time at which it was issued, it would be hard to improve upon the plain scope and intention of this law, which was followed by similar ordinanees for Spain in 1283 and Cremany in 1347, and was again confirmed by Joanna of Naples in 1365.2 Frederick's elict did much to elevate the status of the respectable physician and correspondingly to diminish the number of quacks. Another eiremmstance which brought physicians to the front as medici publici was the fact that they were required to deternine the possible existence of leprosy in suspected persons (Lepraschau) in order to ascertain the eivil status of the latter. ${ }^{3}$ The improvement of the medical profession was also furthered by the introduc-

1 Tranklated by J. J. Walsh, in his "The Popes and Science," New York, $1908,420-423$.

2 Sudhofi states that the alleged ordinance for eity physieinns of 1426 , attributed to Kaiser Sigmund (1410-37), is probably mythieal, although he has discovered a eity ordinanes of 1439 , which he reproduces in Mitt. z. Gesch. d. Med., Leipz., 1912, xi, 126, 127.

${ }^{3}$ MS. forensie protoeols on suspected lepers (Lepraschaubriefe) of dates, 1357, 1380, 1397, and later have been discovered and published by Wickersheimer and Sudhoff (Arch. f. Gesch. d. Med., Lcipz., 1908-9, ii, 434; 1910-11, iv, 370$)$. 
tion of a new elmont the rise and growth of the great medieval universities, which usmally hegan as a high-school or "shedium generule," i. e. migration or assemblage of students in some locality.

The earliest of these were at Paris (1110), Bolognat (115s), ()xford (1167), Montpedlice (1ISI), and Valencia (1199); and the ltalian mniversities at

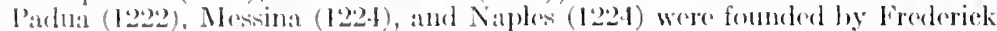

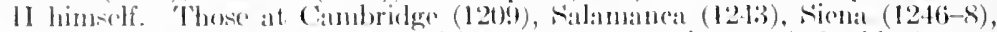

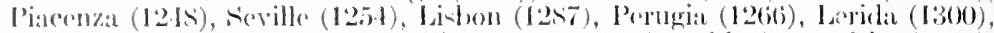

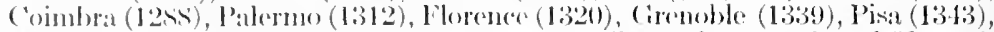
Vallatolid (1346) and P'avial (1361) followed, while the fourteenth and fifteenth centuries witnessed also the rise of the principal German and slavie universitice, in particular, P'rague (13.15), Cracow (1361), Vional (13365), Erfurt

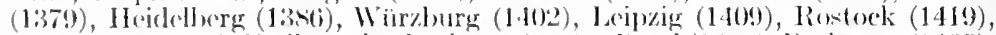

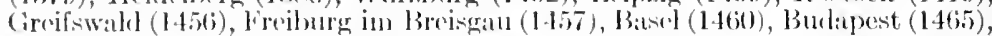

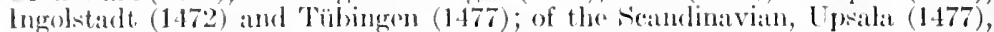
(openhagen (1478), and, in scotland, St. Andrew's (1411), Glasgow (1453) and Aberdeen (1491). After the general dispersal of students over the Continent and England to form "studios," like Salerno (medicine), Bolognal (law), and larris (theology), three types of universities or privileged corporations of students, as distinguished from the public high-school (studium generale) and private school (studium particulare) becane established. The great lawsehool of Bologna becane the type of civic university in which the rector was chected by the students, as at Piadua and sienat. The University of Paris, the center of medieval theology and philosophy (Abelard), was the type of the aclesiastical foundation, like Montpellier, Oxford and Cambridge, in which the sludents and masters eombined as a closed eorporation under a chancellor, with the votes in the hands of the masters. The studium of Niples represented the state University, like Salamanca or Lisbon, founded by a monarch with bapal recognition as "stutia generalia respectu regni." The medieal school at Montpellier formed a separate corporation, apart from the sehools of law and the arts (Neuburger). All these were soon thronged with great concourses of students, and it was through the influenee of the medieval universities that the physieian eame to be regarded in the end as a member of a "fearned profescion." The trivium (grammar, rhetorie, dialectics) and quadrivium (arithmetic, geometry, astronomy, music), mate up the "seven liberal arts," first introdneed at Bishop Fulbert's eathedral school at Chartres. Apart from these, medicine was taught ats a branch of philosophy (Physica), as set forth in Aristotle, Averroes and other Arabic writers. Bofore the Revival of Learning and the Invention of Printing, the Circek writers were seldom read in the original or "ven in a straight translation, but "doubly disguised and half burjed in glosses which not only overlaid the text but of ten supplanted it."' The favorite textbooks were the Isagoge of Johannitius, Avicenna (i, iv), Rhazes' Liber medicinalis (ix), Galen's Ars parra and the Aphorisms, Prognosties and Dietetics of Hippocrates. Most of these were contained in the well-known "Articella." The Cambridge Statutes of 1396 required the student to hear Johannitius, Philaretus De pulsibus, Theophilus De urinis, the Antidotarium of Nicolaus silernitanus and some book of Isaac Judiens onee, and the works of Galen, with glosses and commentaries twice, with cursory reading of some book on medical praxis. ${ }^{2}$ The curriculum at Tüblingen in the fourteenth cent ury, as given by IIaeser, comprised, in the first year, the first Canon of Avicenna and the ninth book of Rhazes, as expounded by Jacol of Forli and Areulanus; in the second year, the Ars pared of Galen with the eommentary of Torrigiani, and the fourth ranon of Avicenna; in the third year, the Aphorisms of Hippocrates and (again) Avicenna, with suitable commentaries. The courses and text-books were usually determined by papal bulls and the libraries of the medieval universities were small in extent, seldom exceeding a hundred or more volumes.

1 Allbutt: Science and Medieval Thought, London, 1901, 69.

${ }^{2}$ Brit. Merl. Jour., London, 1920, i, 371. 
The house-inventory of Ugolino da Montecatino, who died at Florence in 1415, gives a catalogue of his medieal library, which may be typieal for medieval Italy. The interesting eatalogue of the medical seetion of the library of the eloister at Alt-Zelle (founded 1162) has reeently been published by orie of Sudhoff's pupils." 'The professors' salaries usually ranged from $\$ 35$ to $\$ 50$ per annum. 'The term "doctor of medicine" was first applied to the Salernitan graduates by Gilles de Corbeil, in the twelfth century, and the graduation ceremonies were commonly modeled after the Salernitan pattern. The eandidate was first required to defend four theses from Aristotle, Ilippoerates, Galen and modern writer and to take an oath, the conditions of which corresponded, in the main, with the decree of Emperor Froderick. He then received "a ring, a wreath of laurel and ivy, a book first closed and then opened, the kiss of peace" and the rank of "Doctor in Philosophy and Medicine." 3 John Locke describes very much the same thing at Montpellier in 1675, and the custom of the modern German universities is along similar lines.

From monastic institutions came the European botanic garden (hortus) and physie-garden (herbularis), such as the ninth century garlen at St. Gall, which was carefully planned. 'These oblong enclosures were originally eultivated to proteet physicians and apothecaries from the drug-sellers, who attempted to monopolize the business by encouraging popular superstitions about plants.

Medical ethics and medical etiquette were regulated in detail ${ }^{4}$ by sets of stereotyped rules, the earliest of which is the Formula comitis archiatrorum of Theodorich (fifth eentury A. D.). Medical deontology and hodegeties, the savoir faire of the practitioner, were little seiences in the Middle Ages. In the Salernitan treatises of Arehimatheus, the physician is instructed to approaeh the bedside humili wultu, with the same humble mien and wall-eyed expression which we find in so many of the old miniature paintings. His remarks at table were to be punetuated by continued inquiries about the patient's condition, which he should always regard as grave, in order that either a favorable or a fatal termination might redound to his credit as wonderworking therapeutist or shrewd prognostician. He should not diminish his professional credit by ogling the patient's wife, daughter or maid-servants. Illusory treatment by harmless remedies was permissible, sinee otherwise the patient's mind might be ruffled by not getting his money's worth, while a normal recovery by the healing powers of nature might injure the physieian's therapeutic reputation. ${ }^{5}$ A later authority suggests that if a eonvalescent show signs of ingratitude in the matter of payment, he might be temporarily sickened by some harmless dosing. Gaddesden says that he kept his best remedies a secret apart from the vulgar, lest knowtedge of the same eheapen the physieian's status. Mondeville, Saliceto, Lanfrane and Arderne are all skeptical and eaustic about the ingratitude of the publie in the payment of just dues. ${ }^{6}$ Guy and Arnold of Villanova uphold the noblest ideals. Perhaps the best medieval traets on medical etiquette are the De cautelis medicorum hobendis of Alberto de Zaneariis, formerly attributed to Arnold,,$^{7}$ and the Caulele medicorum (1495)

1 W. Bombe and K. Sudhoff: Areh. f. Gesch. d. Med., Leipz., 1911-12, $r .225-239$. For the 26 medieal books in the library of Bishop Brumo of Hildesheim (1161), see Sudhoff: Ibid., 1916-17, x, 348-356, and for a fourteenth century inventory of medical MSS., Ibid., 1918-19, xi, 212-215.

${ }^{2}$ Leon Rosenblum: Leipzig diss. (Inst. f. Gesch. d. Med.), 1918.

${ }^{3}$ Before 1592 the degree at Salerno was Master or Doctor of Arts and Medicine. For three faesimile Salernitan diplomas of 1573,1640 and 1665 , see P. Capparoni: Riv. di storia erit. di se. med. e nat., 1916, vii, 65-74, 3 pl.

${ }^{4}$ Neuburger: Geschiehte der Medizin, ii, 448-455.

5 Ibid., 293-295.

'See D'Arey Power's introduetion to Arderne (Early English Text Society, No. 139), pp. xix-xxvii.

'See the inaugural dissertation of Manuel Morris (from Sudhoff's Institute), Leipzig, 1914. 
of the anatomist (iabriele Zebri, of Verona. Nedicine and quackery were freely satirized on the stage in the medieval farees and moralities, such ats Maristre P'othelin.'

The chicf glory of medieval medieine was undoubtedly in the organization of hospitals and sick nursing, ${ }^{2}$ which had its origin in the teachings of Christ. For while the germ of the hospital idea may have existed in the ancient Babylonian custom of bringing the sick into the market-place for consultation, as it were, and while the Iatreia and Asclepieia of the Greeks and the Romans may have served this purpose to some extent, the spirit of antiquity toward sickness and misfortune was not one of compassion, and the eredit of ministering to human suffering on an extended scale belongs to Christianity. The Arabian hospitals, large and liberal as were their endowments and capacity, came long after the beginning of the Christian era, and the Mohammedans probably got the idea from the Christians. The Asclepieia and other pagan temples were closed by the decree of Constantine, A. D. 335, and, very soon after, the movement of founding and building the Christian hospitals went forward, in which Helena, the mother of Constantine, is said to have played an active part. These were, in all probability, small at first, the wealthier Christians taking care of the sick in Valetudinaria, but by the accession of Julian the Apostate in 361, the movement was in full swing. In 369 , the eelebrated Basilias at Cresarea in Cappadocia was founded by St. Basil, consisting of a large number of buildings, with houses for physicians and nurses, workshops and industrial schools. It was followed by a charity hospital of 300 beds for the plague-stricken at Edessa, which was founded by St. Ephrain in 375. A hospital was founded at Alexandria by St. John the Almsgiver in 610, and, during the Byzantine period, other large hospitals arose at Ephesus, Constantinople and elsewhere. These eventually became specialized, according to Christian ideas of the obligation of charity and hospitality, as Nosocomia, or claustral hospitals for the reception and care of the sick alone: Brephotrophia, for foundlings; Orphanotrophia, for orphans; Ptochia, for the helpless poor; Gerontochia, for the aged; and Xenodochia, for poor and infirm pilgrims. At the beginning of the fifth century, hospitals began to spring up in the Western Empire. The first nosocomium in Wastern Europe was founded by Fabiola about 400, "to gather in the sick from the

1 Maurice Boutarel: Paris dissertation, 1918, No. 142. For a delightful presentation of this medieval feeling, sce Anatole France's medieal farce, "La comédie de celui qui épousa une femme muette."

${ }^{2}$ In the preparation of this section I have been much indebted to the interesting article by Dr. James J. Walsh in the Catholic Encyelopæedia, sub roce "Hospitals," and to Sudhoff's "Aus der Gesehiehte des Krankenhauswesens" (Jena, 1913). 
streets and to nurse the wretehed sufferers, wasted with poverty and disease" (St. Jerome). Others were founded in Rome by Belisarius, in the Yia Lata, and by Pelagius; and, further west, by Casarius at Arles in 542, by Childebert I at Lyons in 5 512, ${ }^{1}$ and hy Bishop Masona at Merida in 580. The Hôtel Dieu is said to have been founded between 641 and 691 by St. Landry, Bishop of Paris, and was first mentioned in 829 . A hospital was founded at Milan in 777 and the first foundling asylum by Archbishop Datheus in 787. St. Albans Hospital in England dates from the year 794. In the early Middle Ages, infirmaries and hospices grew itp alongside the eloisters. The ideal plan of St. Gall (820) included a hospital, with a room for grave cases, dwelling-houses for physicians, bath-rooms for cupping and bleeding and a pharmacy. ${ }^{2}$ The mountain xenodochia or hospices of Mont Cenis (\$25) and the Great St. Bernard (962) are still in existence. After the death of Charlemagne, the larger hospitals began to decline through subdivision or loss of revenue and, at this period, we find the monasteries, such as those of the Benedictine order at Cluny, Fulda and elsewhere, provided with private infirmaries and "eleemosynary hospitals." About this time, also, arose the various Catholic hospital orders and fraternities for looking after the sick, of which the earliest were the Parabolani who, according to Gibbon, were first organized at Alexandria during the plague of Gallienus, A. D. 253-268. Parabolani sought out the sick, not unlike the monks of St. Bernard today, but soon exceeded their authority and were gradually suppressed. The term "sorority" probably comes from Soror, who founded the hospital Santa Maria della Seala at Siena in 898. Other religious orders which sprang up about the time of the Crusades were the Alexians, the Antonines, the Beguins and the Hospitallers, the latter comprising the followers of St. Flizalbeth of Hungary, who founded two hospitals at Eisenach with a third on the Wartburg, the Sisters of St. Catherine, the order of 5t. John of Jerusalem, which was founded when the Crusaders reached the Holy ('ity in 1099 and the Tentonic Order, which was started in a field hospital outside the walls of Acre and was ipproved by Clement III in 1191. The members of the latter order vowed themselves to care for the sick and to build a hospital wherever their order was introduced, and played a great part in Germany in medieval times, eventually dying ont from lack of unds in the fifteenth eentury. Similarly, the Order of St. John of Jerusalem became merged into a purely military order and de-

1 Founded as a xenodochium under laic authority; given over to the elergy a 130 s.

${ }^{2}$ F. Keller: Bauriss des Klosters St. Gallen, Zürich, 1844. Cited by jeuburger. 
clined in the thirteonth eentury. Parallel with the specialization of mursing ordegs during the ('rusades, however, there went the great medieval hospital movement initiated by Pope Innocent III in llas, which has received the just enconium of Virchow. In 1145, Guy of Montpellier opened a hospital in homor of the Holy Ghost, which was approved by the Pope in 1198, he himself building the hospital in Rome called Santo Spirito in Sassia in 1204. The example of the Pontiff was soon followed all over Europe, with the result that nearly every eity had its Hospital of the Holy Ghost, and it became the ambition of many a prince or landerave to found a "xenodochium pauperum, debilium ot infirmorum," Virchow, in his essuy on the hospitals of the Middle Ages, ${ }^{1}$ gives a remarkable catalogue of these institutions in 15.5 (ieman eities. Many of these were, of course, meroly first ad and nursing stations of the charitable order of 'Teutonic knights, but Virchow's list shows the definite social character of the movement. In Rome, says Walsh, there were four eity hospitals in the eleventh century, six in the twelfth, ten in the thirteenth. Another circumstance which vastly aided the city hospital movement was the immense spread of leprosy in the Middle Ages. Already known to the ancient Hebrews, Greeks and Romans, this disease began to appear in Northern Europe in the sixth and seventh eenturies A. D., and its spread in connection with the (rusades was appalling, reaching its full height in the thirteenth entury. The leper, wandering abroad, an outcast from human society, condemned to eivil death by medical inspection (Leprasehau), living apart in huts in the open field, giving warning of his approach by horn or bell, became a common figure, and the subject of frequent reference in the chronicles and romances of the period, such as Der arme Heinrich of Hartmann von Aue," the Frauendienst of Ulrich von Lichtenstein, ${ }^{3}$ the Grandes Chroniques de France, ${ }^{4}$ or the unforgetable passage in the Lüneburger Chronik, which Heine paraphrased:

Living eorpses, they wandered to and fro, muffled from head to foot; a hood drawn over the face, and carrying in the hand a bell, the Lazarus-bell,

1 R. Virchow: "Krankenhäuser und Hospitalwesen," in his Ges. Abhandl. a. d. Gebiete d. öffentlichen Melicin 1. d. Seuchenlehre, Berl., 1879, ii, 1130.

2 In this poetical romance of the thirteenth century, "poor Henry," the hero, journeys to Mlontpellier and Salerno to be eured of leprosy.

3 The Frauendienst gives a ludierous sidelight on the excesses of chivalry, the leper episode representing the henpecked hero as consorting with lepers to grat if $y$ the caprices of his exacting "lady."

"Swinburne's poem of The Leper, filled with the fantastic Frauendienst spirit of the Middle Ages, is based upon an episode in this chronicle, although the alleged citation in old French at the end of the poem was written by the poet himself. 
as it was called, through which they were to give timely warning of their approach, so that every one could get ont of the way in time."

Leper hospitals were already mentioned by Gregory of Tours (circa 560) and, as leprosy spread far and wide, the advantage of these retreats for purposes of segregation became apparent and they turned out to be a potent factor in the eventual stamping out of the disease. The number of these lazar-houses (leprodochia or leprosoria), as they were then called, was extraordinary. There were some 220 in England and Scotland and 2000 in Frnee alone. ${ }^{2}$ Virchow, in his wonderful study of leprosy in the Middle Ages, has listed and deseribed, with his usual patient fidelity, an amazing number of these leper hospitals in all the Cermanic cities of the thirteenth and fourteenth centuries, ${ }^{3}$ and, while in all the medieval hospitals eare was confined to mursing and seclusion, with absolute neglect of treatment, it is elear, from his thoroughgoing narrative, that the building of the leprosoria represented a great social and hygienie movement, a wave of genuine prophylaxis as well as of human charity. Billings characterizes the true spirit of the hospital movement of the Middle Ages in the following language:

When the medieval priest established in each great eity of France a Hotel Dieu, a place for God's hospitality, it was in the interests of charity as ie understood it, ineluding both the helping of the sick poor and the affording o those who were nejther siek nor poor an opport unity and a stimulus to help heir fellow men; and doubtless the cause of humanity and religion was adanced more by the effeet on the givers than on the reerivers. ${ }^{4}$

About the beginning of the thirteenth century, the hospitals regan to pass, without friction and by mutual agreement, from the ands of the ecclesiastic authorities into those of the municipality. 3y this time there were many splendid eity hospitals, like the Iotel Dieu or the Santo Spirito, and hospital construction atained its height in the fifteenth century.

Prominent English hospitals of the medieval period were the Hospital t. Ciregory, foundel by Arehbishop Lanfrane in 10S4; St. Bartholomew's, unded in 1137 by Rahere, a jester, who joined a religious order and obtained grant of land from Henry I about 1123; the Holy Cross Hospital at Winchesar, founded 1132; St. Mary's Hospital, founded in London in 1197; and st. homas's Hospital, founded by Peter, Bishop of Winchester, in 1215 and reuilt in 1693 .

"Heinrich Heine: "Geständnisse" (Sïmmtl. Wroke, Cotta ed., Lejpz., $241,242)$.

'See P. If. Denifle: La desolation des églises, monastères et hôpitaux ndant la guerre de cent ans. Paris, 1 s.97.

${ }^{3}$ R. Virchow: "Zur Geschichte des Aussatzes und der Spitäler," Areh. path. Anat. (ete.), Berl., 1S60, xviii, 139; 273; xix, 43; 1561, xx, 166.

4 J. S. Billings: "Description of the Johns Hopkins Hospital," Baltimore, 90, p. 48. 
Few reflect that the great struggles for commereial supremacy and sal power, berimning with the Midelle Ages, and lasting for nine centuries (during which time the erouters of trate shifted sueassively from Venice to hishon, Amsterdam and London), were langely concerned with the enomous profits derived from the drug-trade.

The rise of the naval power of the Venetian liepublis (\$20-1517) began with the lucrative Mediterranean transpert service neessitated by the Cru-

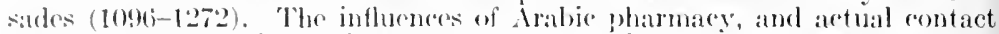
of the Crusiders with their Moslem foes, greatly enhaneed the value of far Eastern drugs. The reeorts of the eustom-house at the port of Aere (11911291), aml the later natrative of Marino simuto, show a lively traflic in aloes,

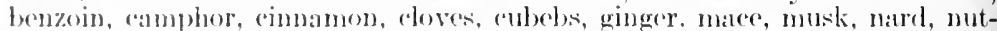
mers, opium, pepper and rhubarb (Twehireh). Balsans, spices, dyes, resins, rare wools and drugs hitd much to do with the struggles of the Venetians with the Genoese and the Turks, ealminating in the battle of lepanto (1571). The lefeat of the Cieneose in the sea-fight off Chioggia (1380) marks the height of Vonetian supremacy. The fall of Constantinople (1453) marred much of the Eastern and Egyptian trade and the high cost of pepper and other condiments gave an incentive to the l'ortuguese navigat ors. When Vaseo da (iama doubled the Calpe and sailed into (alieut (May 20, 1498), the doom of Venetian commeres was sealed. P'riuli, in his diary, reeords the gloom which foll upon the Rialto when it became known that Portuguese carricks, laden with spices, were in the harbor of Iisbon. For the next hundred years, the center of the drug trade was to be in the Portuguese eapital. ${ }^{1}$

In studying the cultural phases of medicine, there is no documentation so effective or instructive as the graphic, and for a period so remote and woll-nigh inaccessible to modern comprehension as the Middle Ages, the great cathedrals, with their stained glass windows, the liturgies, Books of Hours and illuminated missals, the chansons and epies, the miracle plays and moralities furnish us the shortest path to such comprehension. Perhaps the best sidelights upon earlier medicral medicine that we have are afforded in the miniature paintings which illuminate certain manuseript codices of the Salemitan masters, compiled and edited by Piero Giacosa in 1901.2 Onc of these, an illustration to the Turin Codex of Pliny's Natural History, represents an imposing interior, showing three phrsicians with features of unmistakably Jewish cast, clad in flowing Oriental robes and turbans, in professional attendance upon some great personage. One of them is feeling the patient's pulse, the other two stand in grave consultation, while their

1 Sce Tsehirch: Pharmakognosie, Leipzig, 1910, i, 695-702; and A. W. Linton: Jour. Am. Pharm. Assoc., Phila., 1916, v, 250-255.

2 Piero Giacosa: "Magistri Salernitani nondum editi," one vol. and atlas, Turin, fratelli Bocea, 1901. A recent Jtalian album of similar type is: G. Carbonelli and R. Ravalini: Comenti sopra alcune miniature e pit tire italiane a sogget to medico. Rome, F. Centenari, 1918. It is made up of miniatures from the Crbino codices in the Vatican, the Paris, Vienna and Casanatense cordices of the Tacuinum sanitatis, etc. 
horses champ outside; and within, long-haired pages in doublet and hose remain in waiting or converse among themselves. Another miniature on the same page shows a number of monks in a magic circle, exorcising the devil. The theurgic therapy of medieval times, with its centric feature of a devil for each disease and a particular saint to cast him out, was a crude form of the doctrine of specificity. In the many pictures of exorcism collected by Charcot and Richer from fifth century mosaics and miniatures down to set paintings, engravings and frescoes by Giot to, Francesco Vanni, Mezzasti, Rubens and other medieval and post-medieval artists, the devil is always represented in full sight, in the act of escaping from the mouth of the energumen. A cut from the Bolognese Codex of the Canon of Avicenna shows the medieval physician, in gown and biretta, lecturing to his students, as on the title page of the Mellerstadt Mundinus. A superb miniature from the Turin Codex of the El Havi of Rhazes shows a Salernitan master inspecting urine in a glass, while a humble looking patient of rustic mien stands uncovered before him, holding the urine basket in his hand. The contrast between the professional gravity of the doctor's face and the pathetic solemnity of his mute, enduring patient is one of the cleverest things in medieval art. Uroscopy or water-casting was, in fact, a favorite theme of the painter and wood-engraver down to the beginning of the eighteenth century, and the accessories in these representations are nearly always the same. The urinal became the emblem of medical practice in the Middle Ages, and was even used in some places ats a sign-board device (Neuburger). The urine was always contained in a characteristic flask of Erlenmeyer shape, sometimes graduated, and this flask was carried in an osier basket with lid and handle, looking very like a modem champagne bucket. The physician, of whatever period, is always represented as inspecting the urine in a most judicial way, often holding it up to the light in such wise that there will be no reflection or refraction from the sun's rays. Some medieval pictures represent the physician as disdaining to touch the Erlenmeyer urinal with his hands. In the frontispiece of Montagnana's treatise (1487), for instance, two Venetian pages hold up the urine in glasses while the doctors, in gowns and skullcaps, inspect it and comment upon it. An effective miniature from Avicenna, in Giacosa's collection, shows a physician in office consultation with a number of patients, each of whom stands with his osier basket in his hands while the practitioner descants upon the properties of each individual specimen of urine. Sometimes the urine was carried to the physician or wise-woman by a messen-

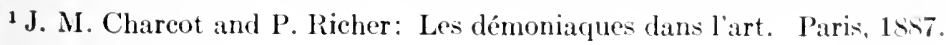


ger, the diagnosis being thus mate at a distance. As may be imalgined, offhand diagnoses of this kind were a farorite imposture of the strolling guackis, who reaped a rich harvest from the deception. Another miniature, in the Bolognese codex of Avieenna, shows us the front of an apotheary's shop, with the apperentices hatying drugs in mortars, a physician riding by on horseback, the medieine jats upon the sholves being labeled with Arabic inscriptions. The ents around the horder represent a cold bath in a rumning forrent of water, another bath of a quasi-social chatacter laken hy soveral persons together in one of the piscines or circular bathing pools, with further representations of enpping, bloodletting and the exploration of a chest wound. 'The most striking cuts in Cialcosits collection, however, are the rude pen drawings from the Codex of Roland's surgery in the Biblioteca Casanatense, representing different episodes in the surgeon's experience, such as the diagnosis of a fracture, the reduction of a dislocation, the inspection, widening, or suturing of a wound, the withdrawal of an arrow, the setting of a fracture of the jaw and so on. These pictures, crude as they are, will decidedly enhance any one's opinion of the Salemitan surgeons and must be seen to be appreciated.

The splendiul series of manuseript pietures published by Sulhoff in his reeent sturly of medieval surgery $\left(1914^{1}\right)$ afford us a unique visualization of all phases of surgical practice in the eleventh to fifteenth centuries. In these, chosen variously from the sloane and Harleian MSS. (British Museum), the Ashmole and Rawlinson MSs'. (Oxford), the Mareian Codex (Venice), we see surgeons eutting for hemorrhoids, fistulit and stricture, removing nasal polvps, opening abscesses, trephining, removing arrows, bandaging, cupping, letting blood and applying the eautery, with innumerable scenes of consultation, and schematic manikins for cauterization, cupping, venesection and zodiacal prognosis. The second part contains many illustrations of surgical instruments, and an exhaustive exegesis of hitherto unprinted Latin and German texts, which will reguire a complete reeasting of the literary history of medieval surgery by future historians. 'This is by far the most considerable contribution to the history and graphies of medieval surgery which has been made since the time of Ciurlt.

Of the costume and personal appearance of the fourteenth century surgeon we get a faint, far-away impression from the illuminated picture of John of Arderne in the Sloane MS., representing the blond-bearded Saxon surgeon in gown, cloak and cap, seated in a throne-like chair, in the act of demonstrating his mode of procedure in fistula; and from the miniature frontispiece in Nicaise's edition of Mondevile (1314), representing that sharp-featured, gray-haired master, tall and slim, in a purple gown of elerical eut, black skull-cap, red stockings and slippered feet, reading lectures with uplifted forefinger. Thirteenth century practice is well de-

${ }^{1}$ K. Sulhoff: Beiträge zur Gesehichte der Chirurgie im Mittelalter (Studien, Heft 10-12), Leipzig, 1914-18. 
pieted in the Ashmole MS. 399 in the Bodleian (Singer ${ }^{1}$ ). Sudhoff has recently reproduced a number of eonsultation scenes from the Sloane and other medieval MISS. representing pulse-taking and other features of cliagnosis. ${ }^{2}$ The Latin MS. codex of Cialen at Dresden (Dl) 92-93'), which is assigned to the second half of the fifteenth century, contains beautiful miniatures illustrating the blue, ermine-bordered mantle of the medieval physician of rank, details of uroseopy, venesection, rectal irrigation, preparation of drugs, bedside seenes, with clinical and anatomie demonstrations, showing that the living nude body was sometimes boldly used for didactic purposes in anatomic and obstetric teaching. These are by far the best of the medieal miniatures in point of artistic merit. Gilles de Corbeil satirized the fine rament and outward display of the medical celebrities in the twelfth century. Petrarch ridiculed the fourteenth eentury physieians for their rings on the fingers, tall horses, golden spurs, gorgeous (lothes and pompous airs, a far ery from a passage in Saxo Cirammaticus (I, 9), which describes King Gram (disguised as a Danish physician of the twelfth century) as "dressed in the dirtiest rags he could find and sitting among the lowest menials in the hall." A curious obsequiousness, the head cocked, in servile fashion, on one side, is noticeable in many of the medieval pictures of physicians and surgeons. The faces in all these pietures have the facile wall-eyed expression which is found even in the paintings of such masters as Giotto, Cimabue and Lucas Cranach, and which seem to suggest that there was no self-revelation in the workings of the medieval nind. The methods of the medieval artists were unmistakably objective, as in Holbein's portraits, or the life-like representations of the nude by Jan van Erck (St. Bavo altar at (Ghent) and Pollajuolo. In this connection we may mention the memorable "Stultitia" of Giotto in the Chapel of the Madomna dell'Arena at Padua, Ghirlandajo's picture of rhinophyma in the Louvre and another representation of the same disease by the younger Holbein in the Prado. Turold, a dwarf, is represented in the Bayeux Tapestry. A carved figure of a wonan, high up on one of the flying buttresses of the north side of Rheims (athedral (thirteenth century) is described as strikingly acromegalic (Leonard Mark ${ }^{4}$ ). Chareot found the facies

${ }^{1}$ C. Singer: Proc. Roy. Soe. Med. (Hist. Seet.), Lond., 1915, ix, 29-42.

${ }^{2}$ Sudhoff: Arch. f. Geseh. d. Med., Leipz., 1915-15, ix, 10; 293, 11 pl.: $1916-17, \mathrm{x}, 71,4 \mathrm{pl}$.

${ }^{3}$ All the pictures in the two-volume codex have been handsomely reprolueed by E. C. van Leersum and W. Martin in "Miniaturen der lateinischen ialenos-IIandschrift, Leyden, 1910. This unique MS. was first noticed by Shoulant.

${ }^{4}$ L. Mark: Lancet, Lond., 1914, ii, 1413. 
of erlosso-labial hemispasm in a mascanon of the Santa Maria Formosia at Vonice.

In the fifteenth eontury, there were numbers of pietures painted representing secenes in the lying-in chamber. These, contrary to modern custom and sentiment, are usually thronged with figures plying various arowations about the sick-room and some of them frankly represent the act and moment of delivery. In the foreeround of each there is the inevitable nursemaid in the act of washing the newborn infant, and, from some of these pictures, we

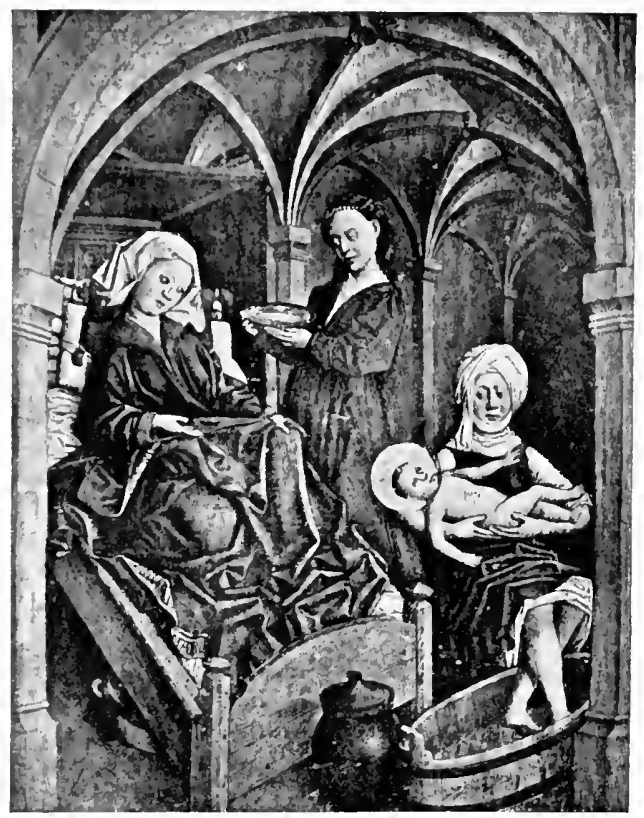

The Human Foot as a Thermometer. (Panting by a Tvrolese art ist in the Ferdinandeum at Innsbruck.) From Dr. Robert Müllerheim's "Die Wochenstube in ter Kunst" (stuttgart, 1901).

gather the curious fact that, in the Middle Ages, the sensitive naked foot was used as a sort of clinical thermometer. In a fresco of Luini's, in the Brera Gallery at Milan, the nursemaid is dipping her hand into the basin to ascertain if the water is too hot or too cold for the infant. In most of the pictures, however, a wooden tub is used, and in quite a number, notably in those representing the "Birth of the Virgin," by the clder Holbein (Augsburg Gallery), Bernhard Strigel (Berlin Gallery), and Bartholomäus Zeitblom (Augsburg and Sigmaringen Galleries), particularly in a 
"Wochenstube" of an unknown Tyrolese artist in the Ferdinandeum at Innsbruck, the nursemaid is represented, like the Highland laundresses in Waverley, with "kilted kirtle," her bare feot testing the temperature of the water in the tub. The different methods of investing an infant in its swarlding clothes are strikingly shown in the bas-relief figures in glazed elay by Anclrea della Robbia in the logeria of the spedale degli Inuocenti at Florence. ${ }^{1}$

Another important fact which is brought out in the fifteenth century pictures is that the use of spectacles had by this time become quite common.

The discovery of spectaclelenses has been variously attributed to the Chinese, to the Romans and to Roger Bacon. The only authentic reference is Pliny's statement that Nero looked at the gladiators through an emerald (smarigd), which Lessing discussed at great length in lis "Antiquarian Letters," and which, at best, can be construed only as a sort of lorgnette. It has been inferred that speetacles were invented about 128.5 from the following data: An inseription on a tomb in the chaped adjoining the ehureh of Santa Maria Maggiore (Florenee) rearls: "Here lies Salvino d'Armato degli Armati, of Florence, the inventor of spectacles.

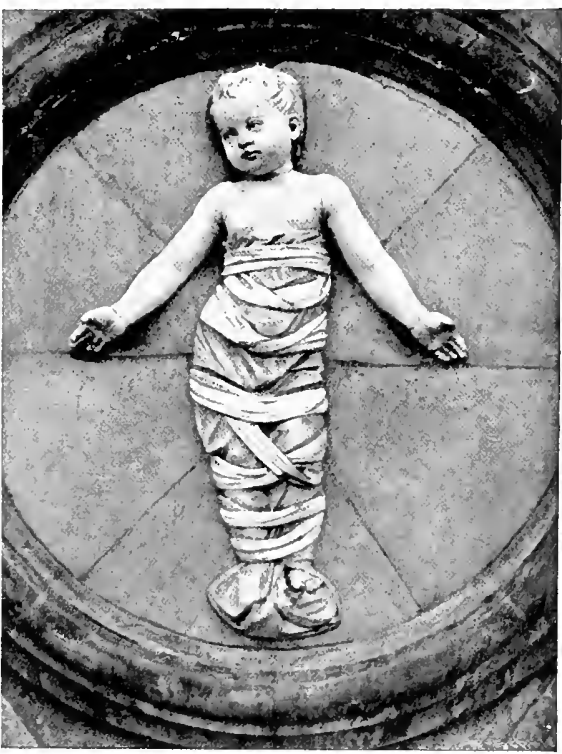

Bas-relief of Bambino in glazed clay in the Foumdling Asylum at Florence, by Andrea della Robbia (1437-1525), showing method of swaddling infants. From Dr. Robert Müllerheim's "Die Wochenstube in der Kunst" (Stuttgart, 1904). May Corl forgive his sins. He died A. D. 1317." 2 In the dictionary of the Florentine Academy (1729) we read,

1 Those who wish to sturly the relation of the fine arts to early obstetrics will find all the pietures in Witkowski's IIistoire des accouchements, Paris, 1S87, and in Robert Müllerbeim's Die Wochenstube in der Kunst, Stuttgart, 1904.

2 Through the eourtesy of IIon. Leo J. Keen:t, U. S. Consul at Florence, I am informed that the tombstone of Salvino degli Armati, which was originally over bis remains in the choister adjoining the ehureh of simta Mariat Maggiore in Florences. Was removed, with a portrait-monmment, from his grave, and placed in the chanel of the Virgin Mary, on the right silfe of the church, for preservation. The inseription, as verified, reads:

QUI DIACE SALYINO D'ARMATO DEGIA ARMATI

DI FIRENZE, INVENTOR DEGII OCCHIALI

DIO CILI PERDONI LE PEC'A'T

ANNO D. MCCCNVII. 


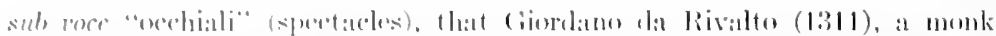

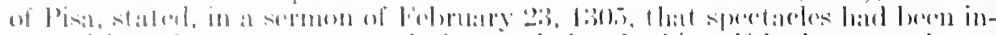

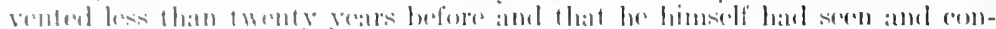

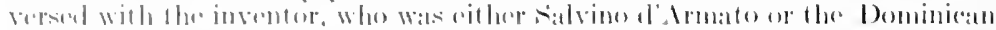

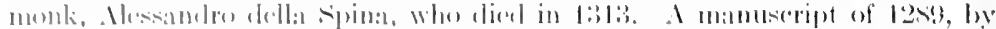

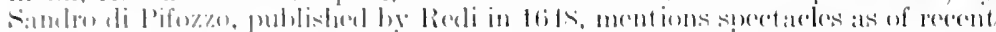

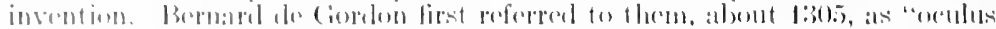

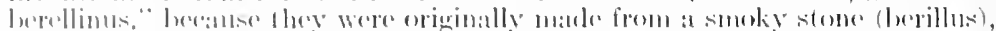

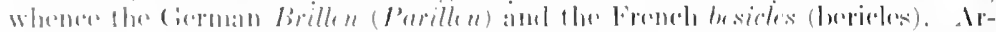

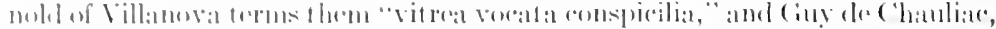

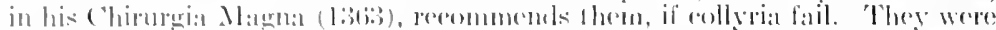

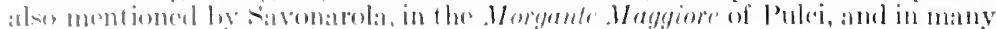

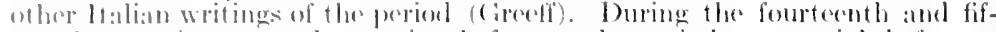

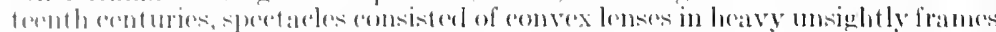
which weres solel all an morommonly high prices. They figure as a ilotail in Jan van livek's Malomna at Bruges in the hamd of the domor, Gieorg van dor

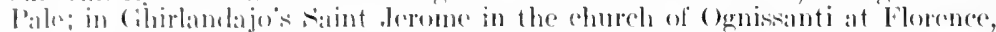

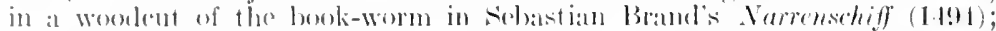
in Martin sobongeners engratring of the I Dath of Mary; in the decorations

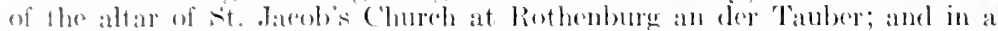
aloled pioture in a manuscript in the Tniversity Library at l'agur, repere sentine the investiture of the Elector of Brandenbure (i.117). In the last, they give the wearer the apperanere of a Chinese mandarin. The earliest

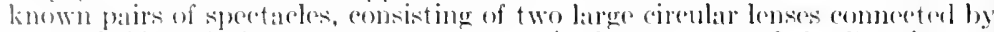
a nose-loridge of pine nez pattern, one patir the poperty of the Renaisanee humanist, Willibald Pirkheimer (1.770-1530), are now on exhibitiom in Nurem-

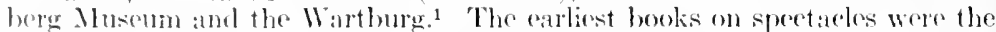

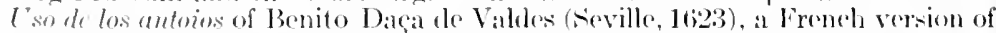
which was printed by (i. Albertotti in $1 \$ 92$, and L'orehiale allocehio by Carlo Antonio Manzini (Bologna, 16i60). The first is illustrated-has talules for sight-testing. and reeommonds spectacles in those oporated for cataract.

During the Midllle Ages, European hmmanity was plagued with epidemic diseases as never before or since, and these were van iously attributed to comets and other astral influences, to storms, the failure of crops, famines, the sinking of mountains, the effects of drought or innulation, swarms of insects, poisoning of wells by the Jews, and other absurd causes. The real predisposing factors were the rowded condition and bad sanitation of the walled medieval towns, the squalor, misrule and gross immorality ocasioned by the many wars, by the fact that Europe was overrun with wandering soldiers, students and other vagabond characters, and by the general superstition, ignorance and uncleanliness of the masses. who, even in their bath-houses, were crowded together in one common compartment, sometimes with the sexes commingled.

In the Midulle . Igre, it was enstomary to regard eight diseases as contagious, in atcordane with the psoude-salernitan resse cited by Bernard de Gordon (1307, the idea of which derives from Rhazes (singer):

Febris acuta, ptisis, pedicon, scabies, sacer ignis,

Antrax, lippa, lepra nobis contagia praestant.

1 See R. (ireeff: Dir altesten uns erhaltenen Brillen, in Arch. f. Augenh., Wiesbarcn, 1912. lxxii, 44-51; also his articles in Ztschr. f. ophthal. Optik, Berl., 1913-14, i, ii, 46, 77. 
In an ordinance of the city of Basel (1350), in the Pest Regiment of II:ans Wireker $(1450)$ and in the Tractatulus de regimine sanitatis of Sirgmund Abich of Prague (14\$1') these right diseases, in Sulloff's interpretation, correspond with the above as bubonie plague, phthisis, cpilepsy, scabies, ervipere las, anthrax, trachoma, leprosy, and those suffering from them were not permitted to enter cities, or were isolated, if in cities, or driven from them, and not permitted to sell articles of food and drink. Of these eight discalses, scabies and lepra were ofttimes syphilis. 'The notion of epilepey as contagious' sprang, Sim thotf thinks, from the aneient Assyro-Babylonian concept of scizure by demons (sibtu), the $\dot{\epsilon} \pi a \varphi \dot{\eta}$ (rontugium) of the (ircek papyri of $77-350 \mathrm{~A}$. D., as applied to the "sacred disease" (iepá vóoss) of the Hippoeratic canon.

The earliest of the great medieval pandemies were the leprosy, saint Anthony"s fire or ergotiom $\left(857^{2}\right)$, seury (I2IS3), influenza, the "I) ancing Mania" (epidemic ehorea), sweating sickness and pliea Polomica (12s7); the most forminlable were the Black Death and syphilis. Of the former, leprosy, seurvy and influenza were either introduced or spread by the Crusades. Chorea (dancing mania) was probably the result of physical degeneraey plus fantatical religious enthusiasm, and acquired the name of St. Vitus's dance from the processions of taneing patients in the strassburg epidemic of 1418 , who proceeded in this wise to the ehapel of st. Vitus in Zabern for treatmont. Piical Poloniea, the unsightly discase of matted hair, was introdueed into Poland by the Mongol invasion (1257). In a passage in the Codex Lat. 25060 of the City Library of Mumieh (pp. 54-55), exlummed by Sudhoff, a diphtheria epidemic of $\mathrm{I}+92$ is described by the Nuremberge eity physeian, Hartmann Schedel. Ergotism, variously known as igmis sacer, ignis infermalis, or st. Anthony's fire, ${ }^{5}$ was of ten as not erysijelas, but usually a characteristie disease of the Middle Ages, due to the formation of the fungus rlavieeps purpurca in spur-slaped masses upon rye, the common bread-staple of the poorer clatsises. The first allusion to it occurs in the Annals of the Convent at Xanten, near the Rhine, of date about 857 , and, even in this brief jaragraph, referenee is alrealy made to its gangrenous character and the eventual dropping off of the limbis from mortification. Later French epiclemies occurred in 944, 957, 1039, 10s?, 1096 and 1I29, which were deseribed, in the chronicles of the time, by Frodoard, Felibien and siegbert. The disease usually began with sensations of extreme coldness in the affected part, followed by intense burning pains; or eke a crop of blisters broke out, the limb beeming livid, foul and put reseent, and eventually dropping off: in either ease, after eatsing great suffering in the

${ }^{1}$ Peter Ochs: Geschichte der Stault und Landschaft Basel, Basel, 1792, pp. 452-453. Cited by Sudhoff (Wien. mexl. Wochenschr., 1913, lxiii, 307730s1. and Areh. f. Geseh. d. Med., Leipz., 1912-13, vi, 454; 1914-15, viii, Iss; 220). In a fourteenth century pest-tract of Magister Henrieus of P'rague, unearthed by surlhoff (Areh. f. Geweh. I. Ned., Leipzig, 1913-14, vii, SI-S9), the eight diseases "qui transeunt de hominitus in homimes" are reduecd to five, viz.. fevers, pest, leprosy, epilepey and eatarrhe (influenza or phthisis). These "oight diseases" are highly significant on aceount of the prophylartic measures indicated.

2 Mezeray, in his history of Franee, deseribes the epidemic of 944 and 1090 , to the latter of which he gave the name St. Anthony's fire.

${ }^{3}$ First described by Jacques de Vitry as ravaging the army of the Crusiders before Damietta (Collect. (Guizot, live, iii, \$351) and by Joinville in his Histoire de St.-Loys, Paris, 1617, 121.

${ }^{4}$ Sulhoff: Arch. f. Geseh. d. Med., leipz., 1912-13, vi, 121-126.

s'The name st. Anthony's fire was first used by the Freneh historian Mezeray, in speaking of the epidemic of I090. The Order of St. Anthony for the care of the sufferers was fomded in 1093. St. Martial, St. Cienevieve and St. Benediet were also regarded as patron saints of ergotime a fuller arecount of which may be found in the valuable historie monograph of Edvard Ehlers. See, also, the paper of Dr. Robert Fletcher in Bristol Med.-Chir. Jour., Dec., 1912, 295-315. 


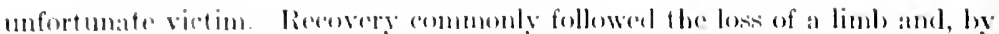
some artal sport of fille, pationts sometimes survived after losing all fom

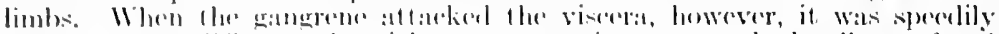

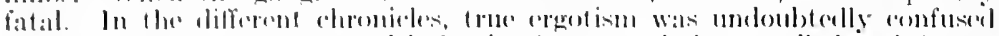

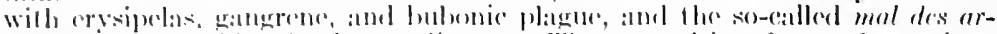

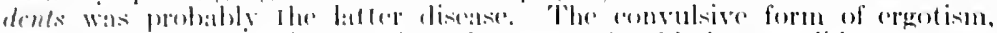

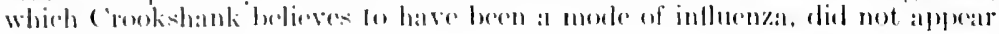
until a litce prerionl.

buring the ninth to the twollh renturies, the were many prayers, con-

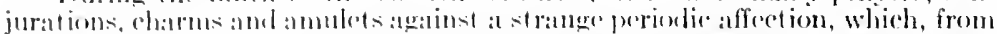

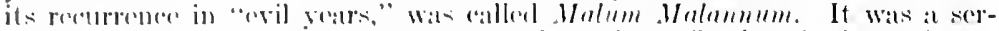

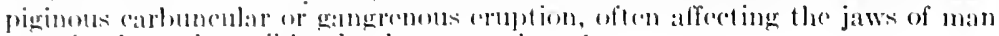

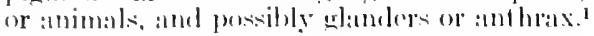

The Black Death, which atuserl the unprecedented mortality of one-fourth of the population of the earth (over sixty millions of human heings), appeared in Luropo about 1348, after devastating Asia and Afriea. From a fores in the Crimea, it spread, via Turkey, Cireece and Italy, northwatd and west ward over the whole of Europe, again attaleking it from a second focus by way of lower Austria. It broke out anew, at intervals, up to the end of the seventecnth contury. Sweeping everything before it, this terrible plague brought panic and confusion in its train and broke down all restrictions of morality, decency and humanity. Parents, children and lifelong friends forsook one another, every one striving to save only himself and to come off with a whole skin. Some took to vesecls in the open sea only to find that the pestilence was hot upon them; some prayed and fasted in sanctuaries, others gave themselves up to unbridled indulgence or, as in the Decameron of Boceaceio, one of the most graphic accounts of the plague of 1348, flecl the country to idle away their time in some safe retreat; others laped into sullen indifference and despair. The dead were hurled pell-mell into huge pits, hastily dug for the purpose, and putrefying bodies lay about everywhere in the houses and streets. "Shrift there was none; churches and chapels were open, but neither priests nor penitents entered-all went to the charnelhouse. The sexton and the physicinn were cast into the same deep and wide grave: the testator and his heirs and executors were hurled from the same cart into the same hole together.". In short, the Black Death, with its dark stains upon the skin, its hemorehages and gangrenous destruction of the lungs, its paralyzing effect upon mind and body. was, in the grim phrase of the Italians, the mortalega grande ("the great mortality"), a veritable sign and symbol of the King of Terrors. The axillary and inguinal, with the pulmonary lesions, would make it idlentical with modern Oriental

1.se M. Hoffer: Janu- Amst., 1909, xix, 512-520.

2 Cited from an old writer of the period by Dr. Robert Fleteher, in his "Tragedy of the Cireat Plague of Milan," Johni Hopkins Hosp. Bull., 1s9s, ix, 176. 
plague. It was ably described by Guy de Chauliac ("transgressio de mortalitate") Boceaccio and simon de Covino. The epidemine of 1382 was described in close detail in the De peste of Chalin de Vinario. The epidenic had at least this good effect, that it led the Venetian Republic to appoint three guardians of public health (1348), to exclude infectod and suspected ships (1374), and to make the first quarantine of infected areas (1403), so called because travelers from the Levant were isolated in a detention hospital for forty lays (quaranta giomi). This forty days' quarantine was first practised by Marseilles (1383). Ragusa first practised detention for a month (1375). The trentina gradually became a quarantina. The first lazaretto or detention station was established at Pisa, near the church of San Lazzaro, in 1464." In other cities, there were plague ordinances and private personal directions (Pestechriften), pesthonses and other hygienic improvements.

(One of the earlinst of the pest-tracts was that of John of Burgundy or Johannes ad Barbam (1365), who was identieal with sir John Mandeville. This MS. of Bearded John, which was widely duplicated, translated and copied, is astrologic in tentemey. Plange is held to be the effeet of mitsms or eorrupt vapors upon the humoral complexion of the patient, the pestilence entering at an evil emanation through the pores of the kin and truveling thence to the heart, the liver and the brin. To combat thic, bathing was interdicted, lest the pores of the skin be opened, light clict, areid fruits and drinks, and especially liberal putations of vinegall, were recommonded, the air of rooms was purified by burning juniper branches or throwing powlers on live eoals for the patient' inhalation; aromatic druge were exhibited internally and earried in the hand mixed with resin or amber (pomum ambrt), and, if the disease supervened, phebotony was the therapentic sheet-anchor. Blood was let. from the superficial vein corresponding to the partieular part affected and its enunctory or exeretory channel. As time went on, vinegar aequired a prominent status in the pest-tracts as an antireptie measure. ${ }^{2}$

The other great scourge of the Middle Ages was syphilis, which was supposed to have first appeared in epidemic form at the siege of Naples in 1495, and to have been communicated to the French invaders by the Spanish occupants, who got it (authorities conjecture) from Columbus's sailors, a visitation from the New World. That sporadic syphilis existed in antiquity and even in prehistoric times is quite within the range of probability. The supposed Neapolitan epidemic of $1495-96$, Sudhoff holds to have been an outbreak of typhoid or paratyphoid infection. ${ }^{3}$ If col-

${ }^{1}$ D. Barduzzi: Riv. di storia (rit. d. se. med., Niena, 1919, s, 167.

2 D. W. Singer: Proe. Roy. Soe. Med., Seet. Ilist. Merl., London, 1916, ix, 159-212. See also, surlhoff: Pestschiften aus den ersten 1jo Jahren nach der Epidemie des "schwarzen Todes," 1348 (Arch. f. Gesch. 1. Med. ,Leipz., 1910-18, iv-xi, passim); and G. Sticker: Die Pest (Ciessen, 190S-10).

${ }^{3}$ In confirmation of this, G. Sticker cites a camp epidemic of typhoid at Louvain and Nymwegen in 16i35, rleseribed by Diemerbroeck (O)bs. ef rurat. med., xxiv) as "vulgariter fobris gallica, a mult is etiam morbus gallieus appellabatur" (Mitt. z. Geseh. d. Med., Leipz., 1916, xv, 77). 
umhian in origin, malignam symhilis was perhalps the usual result, of the comtate of rivilizal and primilive laces, as in the "Blatek

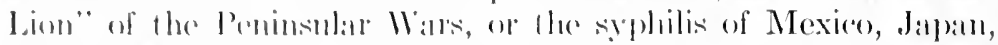

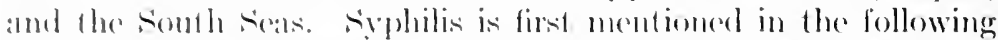

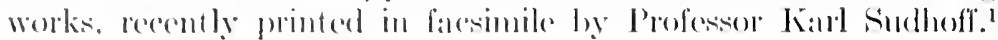

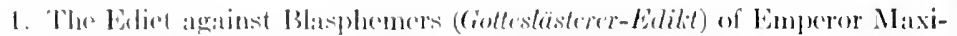
milian I, isisterl Alugust 7. 1195.

2. "The laticinim or "astrologieal vision" of the frisian poet-physieian

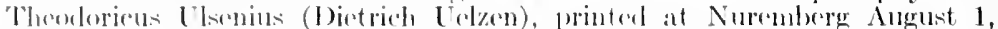
1196. with a colored print of at syphilitic hy Albrecht Diirer. (Reprinted at

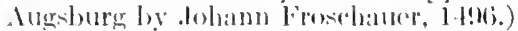

3. 'The Eulogium, a poem by Sichastian Brant, printed in Soptenber, 119 . by Joh. Bergmann von Olpe at Batsed.

4. 'The Tructulus de pestilentiali S'corra (Augsburg, Itans Schauer, October 1s. 1496), and Ein häbscher Tractat ron dem Crsprung des Bösen Franzos (Augsburg, II:ans schaner, December 17, l.196), the first of these reprinted three times at Nuremberg. Cologne, and Leiprig (1.196i), and the latter once al Nuremberg carly in 1.99.

5. The Enarratio Satyrica, a poem of the Veronese patrician, Ciorgio Sommariva, printed at Venice in I)ecember, 1496.

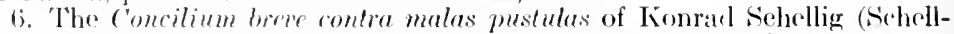
ing), physician to the Elector Palatine (printed at Heidelberg in 1496i).

7. Four pravers, one te St. Minus (Nurembere, 1496), one to St. Dionysius (Nuremberg, 1496), one printed at Viemna, 1497, and one in low German of uneertain diate.

$\therefore$ A letter from Barcelona (1495) by Nieoli Scillacio of Messina, printed in his Opuscula, Mareh 9, 1496, at P'avia showing that, in June, 1495, syphilis hat broken out at Barrelonia, simultaneously with the Naples epidemie, and was thought to have come from Franee (qui nuper ex Gallia defluxit in alias untimess).

All these tracts tend to show, Sulloff thinks, that syphilis was known in Europe before the siege of Naples, since the name of the disease had already so many different synonyms and it general semeiology seems to have been definitcly ontlined as early as 1495 .

It is also mentioned lefore the year 1501 in various tracts by Joseph Ciriumperk (1496), Nicenlis Leonieeno (1497), Johannes Widmann (1497), Bartolommer, Montignanal (1498), Bartholomeus stoler (1198), Simon Pistor (1500), Martin Pollieh (1500), and Gasparo Tor Ha $\left(1500^{2}\right)$.

The first reference to the supposed West Indian origin of syphitis is contained in a work of Diaz de Isla (Tractado contru 1 mal serpentino ${ }^{3}$ ), written abrout 1.710, and published in 1539 and $15-12$, in which the disease is said to be described as an absolutely new and unheard-of affeetion in Barcelona, brought from Ilayti by Columbus sailors in April, 1493. Isla is one of the rarest of looks, and, if we may trust current aceounts, its author had treated sailors in Columbus" fleet for syphilis before they landed at Palos, also it is said that both Monardes and Montejo speak of the disease as then prevalent in nearby

1 Kart suchoff: Graphische und typographisehe Erstlingo dor Syphilisliteratur, Leipzig, 1912. This work hould be read by rvery one who wishes to know the most recont rirws of the subjert as controlled by first-hand investigation (with typographic and photographie reproduction) of the original texts and lueuments. Suthoff has eontinued these investigations in "Aus der Frühgeschichte der syphilis" (Situl. z. Gesch. d. Med., Hft. 9), Leipzig, 1912.

2 For the texts of German traets on syphilis between 1495 and 1510 , see C. H. Fuehs: Die altesten sehriftstellei über die Lustseuehe in Deutsehland (Cöttingen, 18t3). For bibliograj)hy down to 1s99, see J. K. Prokseh: Die Litteratur über die venerischen Krankheiten, 4 v., Bonn, 1889-1900.

${ }^{3}$ For the text of Fsla, see Janus, Amst., 1901, vi, 653: 1902, vii, 31. 
Seville, where a speeial hospital was built for syphilities. The "Luenbratiuncula" of Leonlated sochmans (151S) also refer's to the West Indian origin of the disease on the anthority of sea-captains of the periogl. In faver of the Wrest Indian hypothesis, Ilut chinson contenderl that, if transmissible syphilis existed in Europe before 1492, it would have been mentioned in Chancer and Boeracecio, while it was formol in Hayti and sau Domingo affer Columbus' second vorage. Virchow matintained that the caries siect of prehistoric and preColumbian skulls was not true siphilis but either identieal with the arthritideformans ( Höhlengicht) of old cave-bears, or else caused by plants and insects, which would eliminate the quest ion of prehistorie syphilis in Europe. Medieval srphilis was first known as mal frenzoso, morbus Gallicus, mala napoletana, after the supposititious siege of Naples (1495), where it is supposed to have been communicated to the French soldier's under Charles Vill by the Spanish inhabitants. After it became epidemic, it was called the spanish, Polish, (ierman, or Turkish "pocks," from the anxiety of the different nations to shift the blame upon one another. Iwan Bloch has attempted to prove that the evidenees of mal franzoso in the eases of King Wenzel, the chorister of Mainz (1473), and Peter Marty's letter (148s) were either fabrications or forgeries. On the other haud, the exhaustive studles recently made by Karl Sudhofi show that, in the Cottrslesterereditit of Emperor Maximilian (August 7, 1495), mention is made of "malum francieum," but nothing is said about syphilis in relation to the siege of Nitples. Aceording to Guicciarlini, there was no actual siege at Naples, since Charles VIII passed through the city withont opposition on February 21, 1495. Furthermore, in moving homeward through Tuseany, the troops were besieged at Novara early in July, and did not get away until October 10th, two months after the date of Maximilian's Ediet (August 7th); yet the latter shows that the disease was well known in (iemany in July, while the actual march of events makes it clear that it could not have been spread about by wandering soldiery until long after, as Sudhoff shows. Surlholf also gives a large ummber of recipes for syphilis, indieating that, far from being helpless in the treatment of thr disease, physicians at the end of the fourteenth century were alrealy preseribing the meremrial inunctions which had been used as far back as the twelfth eentury for leprosy, ehronie eezema, and various skin eruptions. A special group of the latter, as vielding to mereury, was, sudhoff thinks, an endenic spirochetosis, in all probabilit y syphilis.? Mercury is first referred to in the circe instans of Mat thems Platearius (1140), but its external use wats already known to the Arab physicians (Astrue'). Here, mereurial salves were recommended for dermal eruptions as by all medieval surgeons from Roger down. Theodorich gives very explicit direetions for inunetion of mercury, with preeantions aganst salivation. The most. interesting of these recipes are two which sulhoff found in an old Italim manuscript at Copenhagen, daterl 14tij, the handwriting of which has been assigned by the direetors of the State Arehives in the Effizi at Florence to the first cuarter of the fifteenth century. ${ }^{3}$ These recipes rearl (16) Electurionoptimo al mal franzoso and $(\tilde{\gamma})$ Per fare siropi da male franzoso. and contain ingredients identical with those employed in the vegetable edectuaries (Kräuterlatwergen) of the early (ierman and Italian writers on syphilis. Thus, from the internal evidene of handwriting in some of the Effizi manuseripts, syphilis may have been endemie in Italy as early as 1429. The old swios arehives show that seabies Gallicame or gressa rerola was regarded ats a new disease about 1431.* Ciannozo Manetti (1396-1459), in his life of Pope Nicholas V', refers

${ }^{1}$ It is interesting to note that sydenham thought that sxphilis was irlentical with Whest African yaus; that Castellani's Treponeme perterue is hardly distinguishable from Schaudlimn's parasite, and that, for the former, "606" s a true therapia sterilisans.

2 "Prini omnium medici Arabes atsi sunt mercurium exterius athibere." Astruc. De norb. Ven. Venice, i, 156.

${ }^{3}$ Sudhoff: Mal franzoso in Italien, Giessen, 1912.

${ }^{4}$ J. H. Hotzinger: Historie ecelestiastice Novi Testamenti, Zürich, 16.51-9, iv, 9 . 


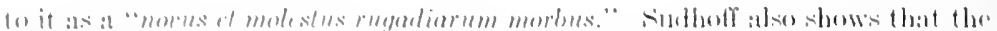

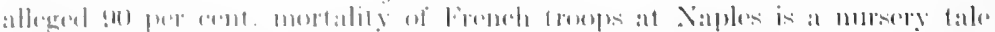

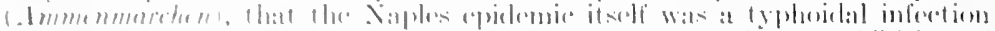

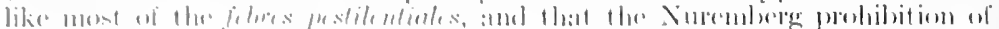

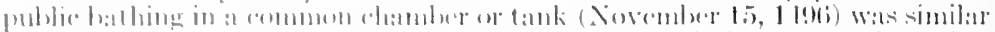

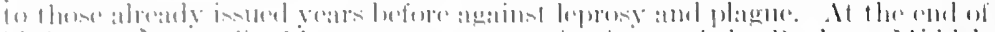

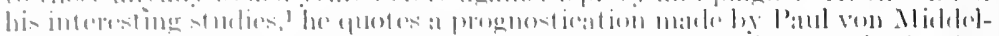

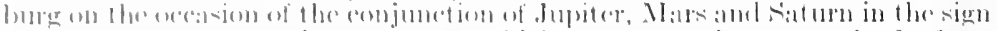

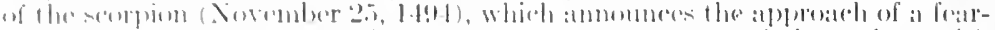

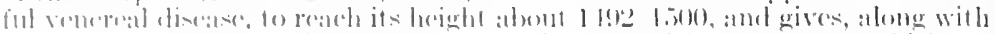

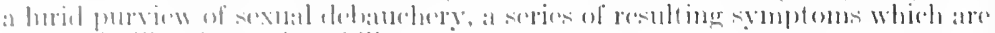

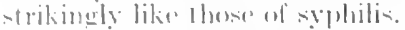

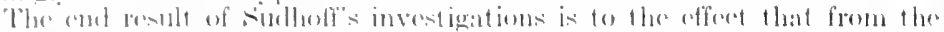

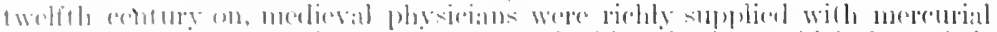

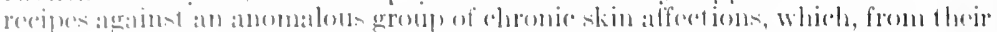

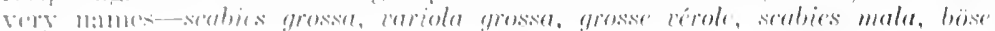

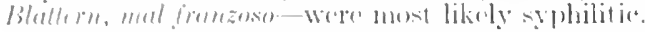

Aside flom the astrolonie riew of its cambation, the lues was laterly attributed to the rains and immelations of the same period leonionus), intereourso of a leper with a prostitute (Monardi and laracelsus), poisoning of the wolls by the spanish vicerogs of Naples (Fallopius), or to disguised human flesh oaten hy the French for ordinary meat (Formanti). It is evident that the discase mas not restrly understood at frrst, but, after it became pandemice, its sexuld origin was rocognized, and, as it splead northward and southwald from Italy, its difforent stages were more or bess accurately described between the rears 1494 and 1550. In the sixteenth rentury, the Chevalier Bayad ralled it "the rlisease of him who has it" (le mal de celui quil l'a). Mercury, which (alen had interdicterl as a "cold" poison, became the routine remedy. The introluction of the inunetion-cure and the sweating cure was, sulhoff thinks, the starting-point of curative treatment of dis(ases in hospital (curabilses ago curandi), which had hitherto been neglected. There were many sensible regulations of public stews, such as that of Henry II (1161). Meanwhile hmmanity of high and low degree had to loam the hard lesson that syphilis is "no respecter of perons." Like the omnipresent grim skeleton in Holbein's "Dance of Death," it laid hold of lords and commons, just or umjust, in the same impartial spirit, anf the illustrated books of a later time, Blankaart's, for instance, teem with pictures representing the miselies wrought by lues and the inconveniences of the chms if heroic moles of treatment in rogue. Apart from wars and famine, and even up to Ehrlich's time, syphilis has held its own with tuberculosic and alcoholism, as a prime factor in bringing about the degenerition of the hmman stock. 168.

1 Sudhoff: Aus der Frühgeschichte der syphilis, Lripzig, 1912, pp. 159- 


\section{THE PERIOD OF THE RENAISSANCE, THE REVIVAL OF LEARNING, AND THE REFORMATION (1453-1600)}

Is the transition of eivilized mankind from medieval to modern conditions, many forces were operative, but undoubtedly the most potent for the growth of individualism and release from the ban of authority were the inventions of gumpowder, which gave the coup de ertee to fendalism, and of printing, the greatest agent in uplifting mankind by self-erlusation. With the discovery of Ameriea, the discovery of the Northwest Passage by Vaseo da Gama, Magellan's circumnavigation of the globe, the establishment of heliocentric astronomy by (opernicus, and the Reformation, freedon of thought and the rritieal spirit grew apace. The effect of the revival of Cireck culture by the Byzantine scholars who poured into the Italian peninsula after the fall of constantinople (1453) was to sulstitute the spontaneous receptive attitude of Plato and Hippocrates for the dialectics and logic-chopping of Aristotle and the Calenists. Among the neo-Platonists, Leonardo da Tinci and Nicholas Cusanus were eminent in physics. The physician Fernelius made the first exact measurement of a degree of the meridian, and Carcia Hemandez, a practitioner at Palos, favored the project of Columbus, in opposition to the Cuiversity of Salamanca. Natural pereeption in science (sentir est seire) was the device of (ampanella. Petrarch attacked scholasticism, Pomponeo Pomponazzi, Ciambattista della Porta, Marsilio Ficino, Joham Wever, and Ciovanni Pico rationalized magie and astrology and opposed witcheraft, while Comelius Agrippa (Heinrich von Nettesheim) [1486-1535] progressed from occultism (De occulta philosophin) to refined skepticism (De incertitudine et rauitate scientiarum, 15302). Prime movers in this change for medicine were the great printers of the Renaissance and the so-called "medical humanists." The sack of Mainz, by Adolph of Nassau, in 1462, scattered the German printers over Europe. The Gutenberg Bible was printed in 1454. Johann Mentelin at Strassburg (1460) and Albert Pfister at Bamberg (1461) were followed by Conrad Swernherm and Arnold Pannarts, who are credited with the first books printed in Italy, the Subi-

${ }^{1}$ The daims to the invention are divided lestween Laurens Janrzoon Coster, of Haarlem (1440), and Johan Gutenberg of Mainz (1450).

2 See, Neuburger: Introduction to Puschmann IIandbuch. 


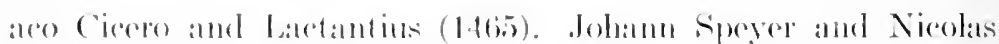

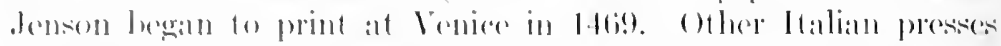

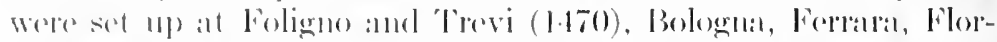

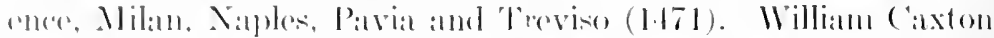

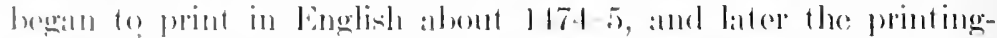

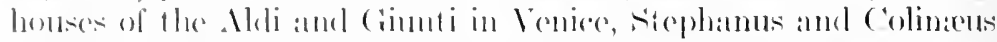
in Paris. Inotset (1)porims) and Froben in Basel, Wynkyn de

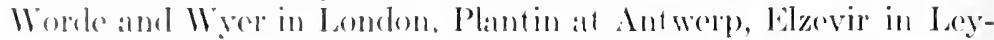
den, viod with one anothere in the issene of stately lolios and beatutihul dexts, while such alitors and tramslators as Niecolo Leoniceno

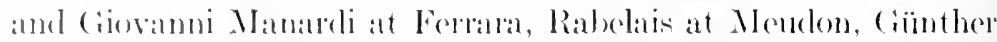
of Andernach at Strasibure, Johann Hagenbut (Cornarus) at Marburg, Piotoro Mattiolo at Rome, and Auntius Foesius at Metz, diel for Hippocrates what Linarere and cilus in England did for (ialen. These Renaissanes versions and alitions are not only remarkable for maluproaldable trpography (those of Oporinus, (olineres, and the early German printers in Fyan bearing away the palm in this respeed), but are usually fumished with good tables of contents and oftentines with subject and anthor indices at the end, giving arenate paginations. Ciovanni Malpeghino at Ravenua awakened the sense of correct Latinity and aceuracy of (xpression. The philologic study of Greek medicine supplanted the labors of the medieval "aggregators" and "conciliators;" who somght to compare and reconcile Hellenist and Arabist doetrine (Neuburger). With the medical philologists came the critical, questioning spirit in medicine.

(I) the medical humanists, Niccolo Leoniceno (Leonicenus) (1428-1524), professor of medicine at Padua, Bologna, and Ferrata, a friend of Politian and Linacre, and, like them, an elegant Latinist, made a famous translation of the Aphorisms of Hippoclates, and, towarl the close of his life, had eren begun, by request, an alcourate Latin transation of the works of Galen. He also wrote one of the carliest of the Renaissance tracts on syphilis $\left(1197^{-1}\right)$. but his chief service to science lay in the difficult task of correcting the botanical errors in the Natural History of Pliny. In Leonicenus day, this was a feat of the rarest intellectual comage. Hermolinis Barbarus, an earlice commentator, had already corrected some 500 orthographic and grammatic blunders perpetrated hy the eopyists of Pling's manuscripts, but to assert that Pliny himself could be fallible in his statements of fact savored of rankest heresy, for his writings, like those of Galen ard Aristotle,

${ }^{1}$ Libellus de enidemia, quam Itali morbum gallieum vocant vulgo brossulas, Venice, 1497 (Hain, 10019); another edition was publisned at Milan in 1497 (Hain. 10020), and a third, printerl in Gothic type, without place or date (Hain, 10018), is the earliest and rarest of all. 
were regarded as sacrosanct and unimpeachable. Accordingly, when Leonicenus, who was a good botanist, published his little tract on the errors of Pliny ${ }^{1}$ (1492), a violent storm of controversy broke loose over his head. His friend Poliziano, Colinnecio, and other non-botanists, who eared more for the letter than for the import of the old Roman's text, blazed away at the luekless commentator in truly medieval style for daring to challenge the accuracy of "our Pliny." Leonicenus stuck to his guns, however, with this important sequel, that all true botanists of later timesRuellius, Matthiolus, Cesalpinus, Cordus-acepted his emendations without eavil. In this respect Leonicenus may be said to

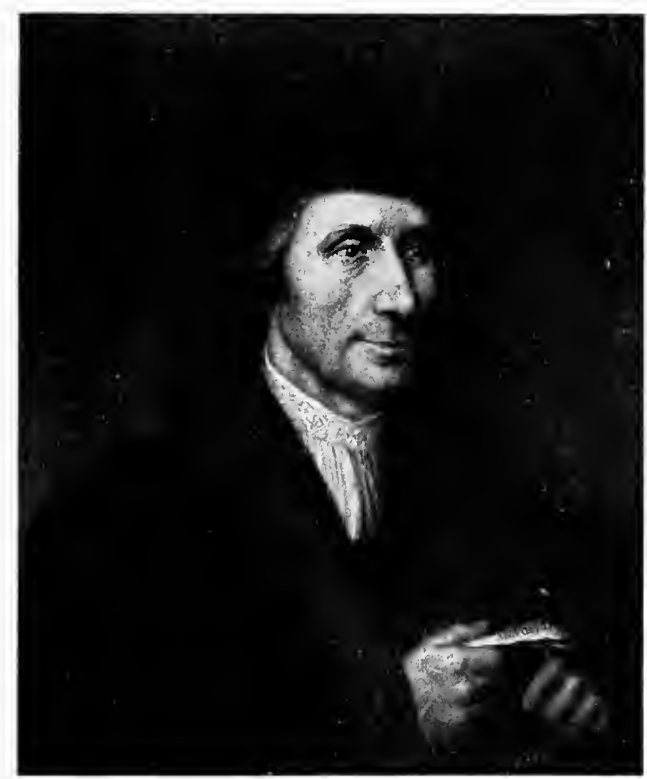

Thomas Linacre, M.D. (1460-1524).

have eleared the ground for the German "Fathers of Botany." Without the careful work of these botanist-commentators there could have been no scientific description of the materia mediea.

Thomas Linacre (1460-1524), physician to Henry VII and Henry VIII, was edueated at Oxford (1484) and in Italy, and graduated at Padua. On aceount of his services to humanism he was ealled by Fuller the "restorer of learning" in England. He is remembered especially for his grammatic works (Payne thought

${ }^{1}$ De Plinii et aliorum in medicina crroribus, Ferrara, 1492. 


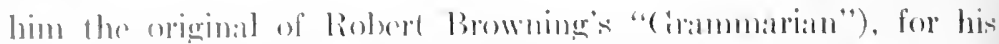

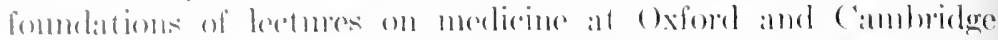

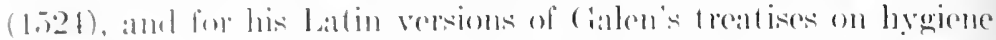

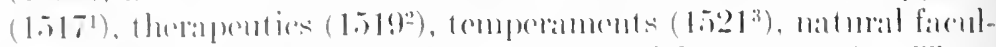

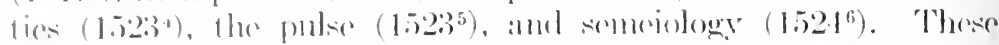

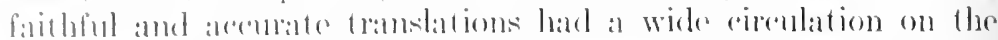

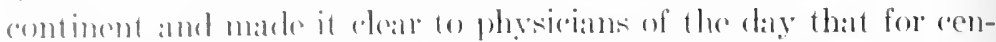
tmises they had rolied mpon gathled and serend-hand ressions of there larerite anthere.

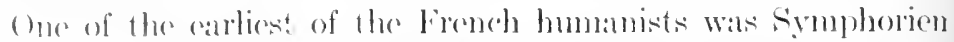
Champier (1472-15i39). of lyoms, a modical graduate of l'avia

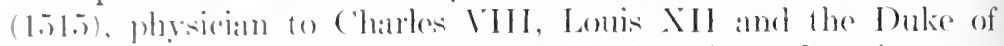
Iorraine, and anthor of Rosa Ciallica (1514), a Practica nowa (1517), and liographies of $\mathrm{Ar}-$ nohl of Villanoval $(1520)$ and

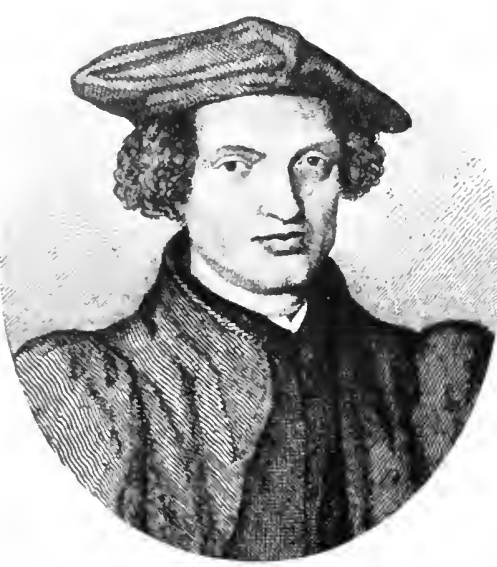

syuphorien Champier (1472-1539). Mesuc (1523). ('hamplore was one of the last of the conciliators of (ireek and Arabist doctrinc. His plan of bringing Hipporerates, Calen, C'clsus and Avicenna into a kind of symphonic relation with one another is visualized in the quaint wood englaving of a string quartet which prefaces his Symphonia Platomis (1516). In his IIortus Gallicus (1533), he was chauvinistic enough to affirm that the soil of France produces all remedies necessary for the treatment of disease, am extension of the old idea that "discasc and remedy are found together." Champier wrote the calliest and best history of medicine in his time $\left(1506^{7}\right)$ and the first medical dictionary after simone de ('ordo (1508').

${ }^{1}$ De sanitate tuemda, Paris, 1517.

2 Methodus medendi, Paris, 1519.

${ }^{3}$ De temperamentis, Cambridge, Siberch, 1521.

${ }^{4}$ De naturalibus facultatilus, London, Pynson, 1523.

${ }^{5}$ De pulsuum usu, London, Pynson, 1523.

${ }^{6}$ De symptomatum differentiis, London, Pynson, 1524.

7 Chumpier: De claris medicinæ scriptoribus, Lyons, 1506. Another history of medieine was published by Mareellus Donatus in 1586. 1508 .

8 Vocabulorum medieinalium et terminorum difficilium explanatio, Lyons, 
François Rabelais (1490-15.53), who, like Linacre, was a priest as well as a physician, made one of the first Latin translat ions of the aphorisms of Hippocrates (Lyons, 1532), the original elition of which is mureh prized by bibliophiles.' Rabelais is best known, of course, by his immortal humorous works "(iargantua" and "P'antagruel," which ane not only filled with the strangest kind of medieal arudition, but are exponents of henaissaner humanism in the broadest sense. The old medieval eustom of stuffing the youthful mind with book-leatrung is keenly ridionled, and the cireek ideal of elucation as a rlawing out of all the faculties, including the physical and social, is upheld. Rabelais was the first to lecture on medicine at Montpellier with the Greek text before bim.

Anutius Foesius, or Foes (1528-95), deroted forty rats of a laborions and useful life as city phesician in his native town of Metz, to the completion of a critical exlition of the raeck text of Hippocrates (1595), which is recognized hy scholars ererywere as unquestionably the best of its kind before the time of Littre.

In the group of medical philologists were also the botanist Leomhard Fuchs whe was the bitterest opponent of Arabiom, the rlinician Johann Lange, John Kaye (1506-73), the Dr. Caius of the Herry H'ines of If indser and the historian of the sweating sickness (1.5.) ), his teacher, (Govanni battist it dellat

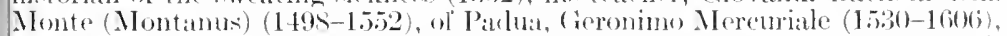
who made a critical rexgesis (Fariae lectiones) of thefleult passages in the (ireek and Latin authors, the lexicographer Joun de (oorvis (1505-77), the spaniard Franciseo Valles and the Portuguese Luis de lamos, who investigated the genuineness of the IIipporatic writing.s.

Some time after the invention of printing Ciermany entered the ficlel of medicine with a remarkable array of semil-popular treatises, most of them written, contrary to eustom, in the vernacular-the linguage of the people. Areoreling to sudhoff, the earliest printerl document rolating to medicine is the unirue "Pur'gation-( alendar" (Laxiethelender) of 1457 , printed in the type of Gutenherg's 36-line Bible, ${ }^{2}$ and contained (a sheret of papel only) in the Bibliothegue nationale at Paris. A mique copy of a "Calendar for Blook-lottinge" (Aderlesslenlender), printed at Mainz in $1462,{ }^{1}$ is one of the treasures of the fürstentere Library at Donalueschingen (Baten). These populal ahmanacs, consisting of loose latres or broarlsides, printerl on one side only. show the holel which judicial astrology (the Lasotafelliunst) hat taken upon

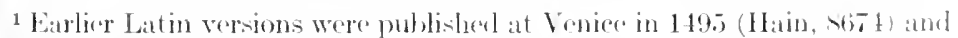
it Nuremberg in 1496 (I Iain, s675).

${ }^{2}$ For a facsimile of rither, and a full areount of all the calemente-inemalbulat, ee sulhoff's interesting "Lasstafelkunst in I)rueken des 1.5. Jahrlumelerts."

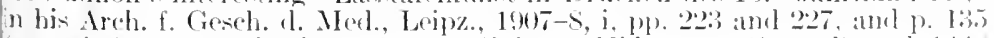
(opposite). The calendats of 1439 (Johimn Nider von Ginünd) and 1445 contain nothing medical. 


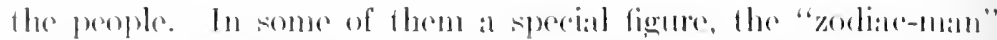

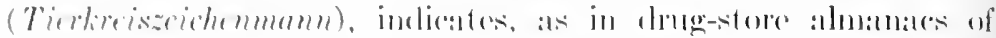

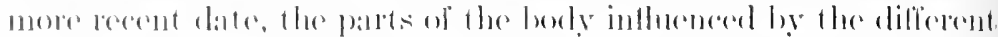

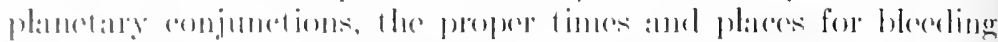

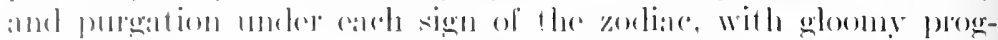

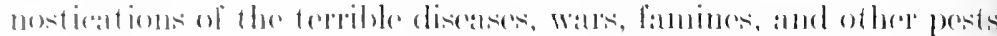

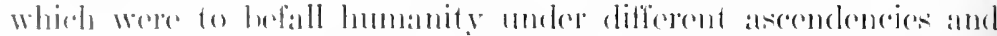

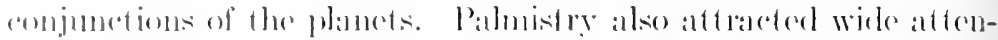
tion: the carliest publication on the sulgeet was Johann IIat lich's

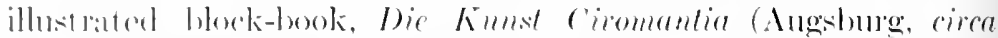

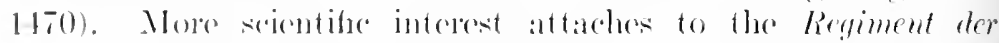
jungen Kinder of Batholomans Metlinger (Augsuma, 1+73), a

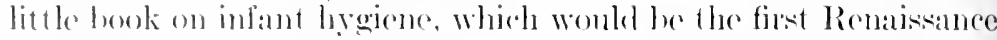
(ontribntion to pediatrics had it not heon preceded hy the De curitudinibus infantum (Padua, 1472) of P'ietro Bagellardo. A third tract hy (omelius Roelants of Merblin (Louvain, circa 145:3 - 1) extumed by Sulhoff in an incmable in the University Lihnary at Loipzig and the Hunterian Musemu at (ilaseow, was plagiarized in the peliatric treatise of Sebastianus Austrins (1510).

The Artzneibueh of Ortollf of Bavaria (Nuremberg, 147\%) was :m important Cieman text of pojular medicine in its day, followed, about 1500, by Ortollf"s quaint litile Franenbächlein, or poupular hamblbook for lying-in women. A few vars later (in 1.513) there appeared, at Worms, the Rosegarten of Enchariss Röslin, a work which bears about the same relation to Renaissance obstetries that the Anothomia of Mundinus does to medieval anatomy. Although mainly a compilation from Soranus of Ephesus, as filtered throngh the manuscript codices of Moschion, it was still the only text-book in the ficld after a lapse of fomrteen centuries. Three first elitions were issued simultaneonsly, both extremely interesting for thoir guaint cuts atrealy faintly outlined in the Mosehion colices). for the revival of podalic version as oniginally (lescriber by somuns, and for the fact that Rïslins text was miserably plagiarized by Walther Reiff in $1545,^{2}$ and also translated and rejssued by William Raynalde as The Byrihe of Manliynde, Iondon, 15tis. The ordinance issued hy the eity of Ratisbon in 15.55 for the direction of midwises (Regensburger Hebammenbuch) has been proved by Felix Nemmann" to be the earliest public dormment of this kind in the vernacular.

1 sidhoff: Janus. Amst., 1909, xiv, t67-485 (with text). For the sourecs of the work, see sudhoff, Ihid., 1915, .x., 443-45s.

2 The plagiarist lieiff should not be eonfused with the Swise obstetrician Jaeob Rueff (1500-5S), author of the "Trostbuichle" (Zürich, 1554), a midwifery of sterling character.

${ }^{3}$ Arch. f. Ciesch. I. Merl., Leipz., 1911-12, v, 132-141. 

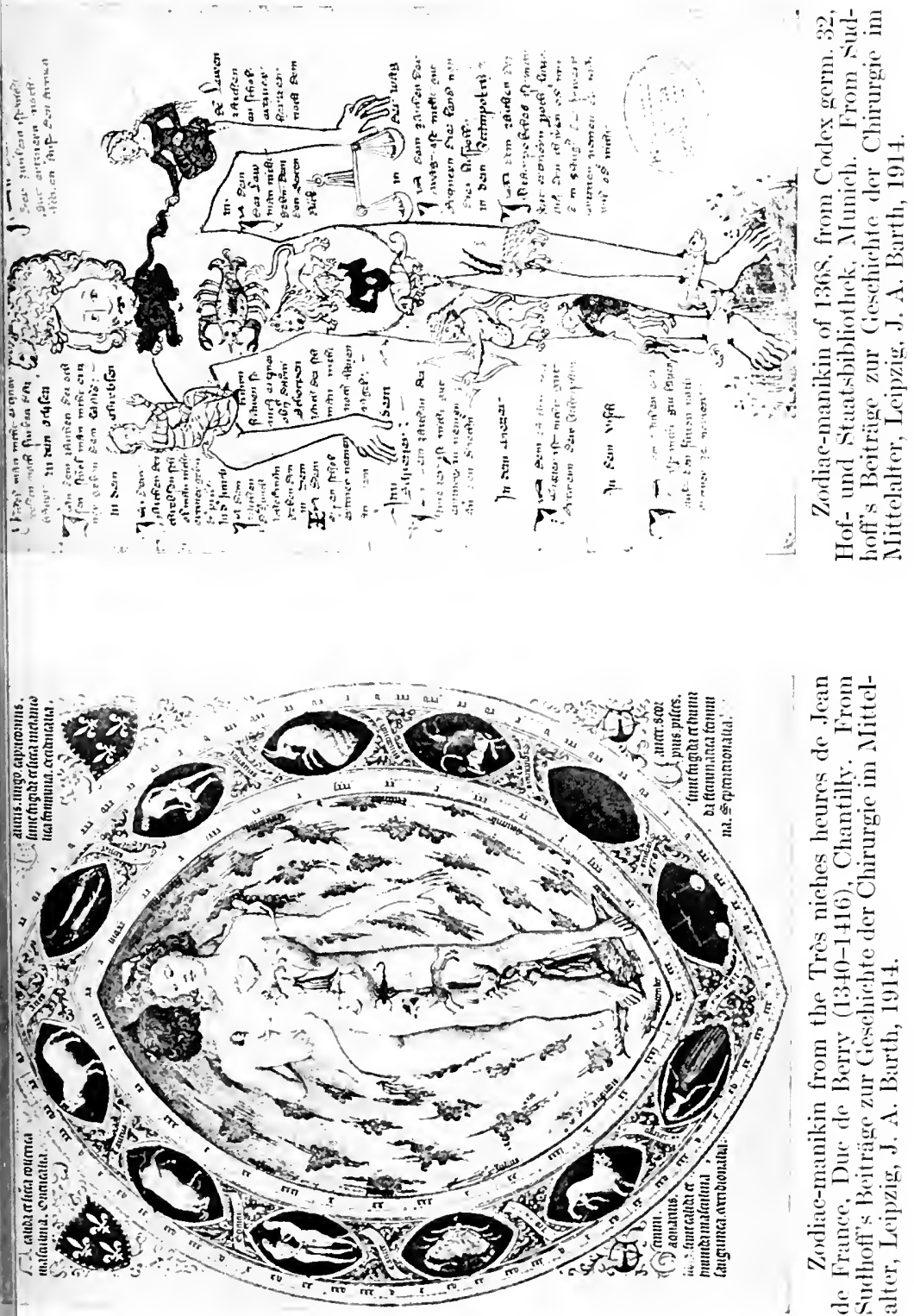


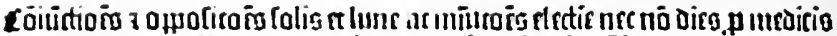

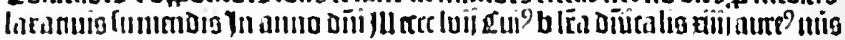

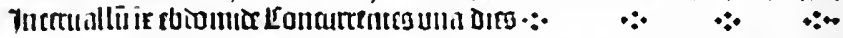

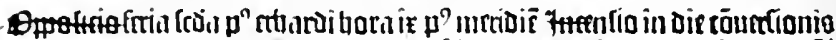

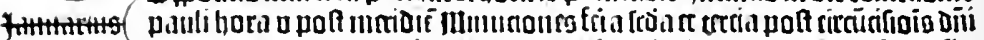

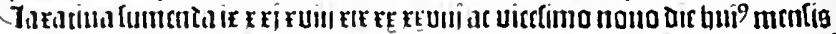

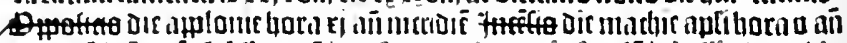

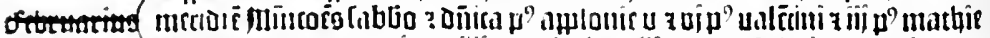

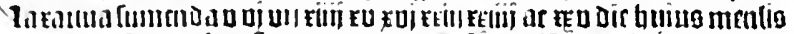

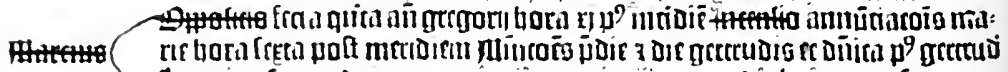

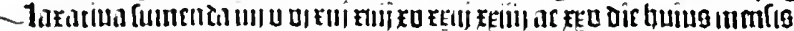

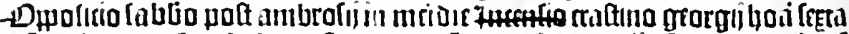

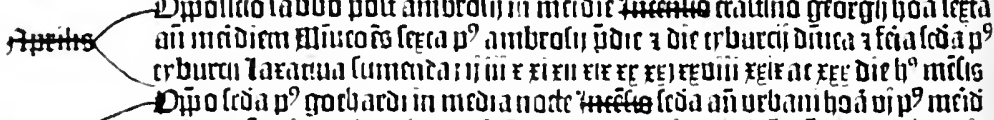

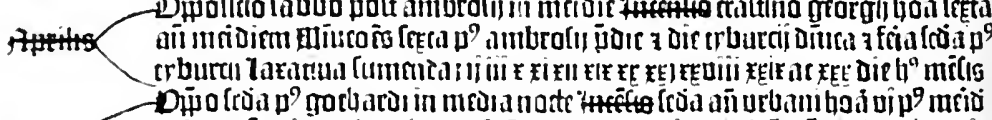

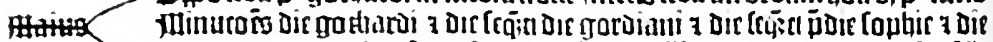

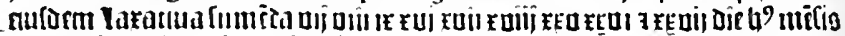
-

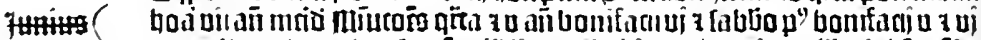

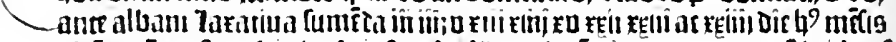

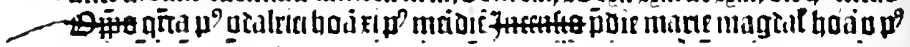

B

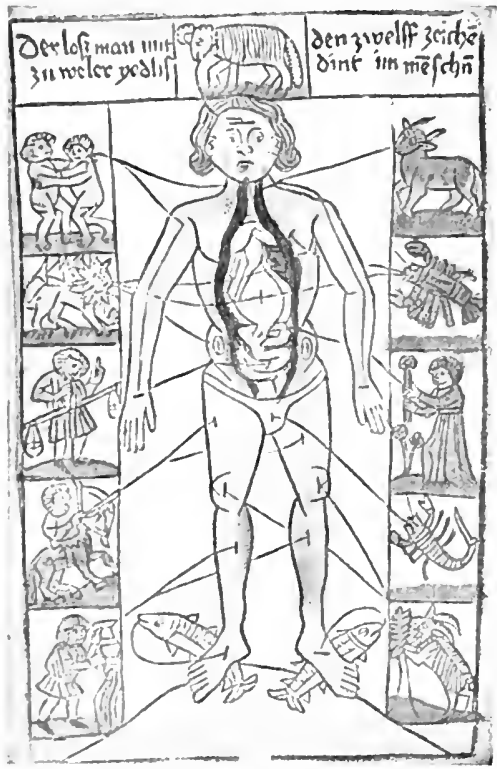

Specimens of the Lasstafellimest
$\mathrm{C}$

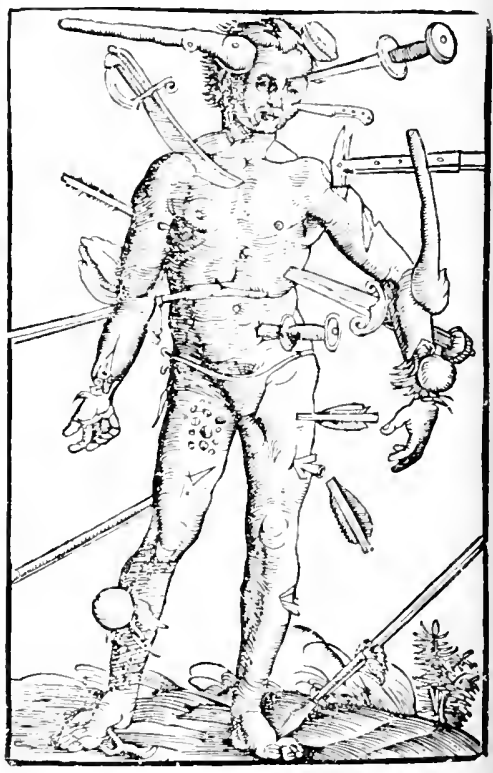

Horoseopic Medicine or Judicial Astrology). (By kind permision of Profesor Karl Sudhoff, Lniversity of Ifeipzig.) A: Fragment of Purgation Calendar (Laxierkalender), printed with the types of (iutenberg's 3t-line Bible (1457), and diseorered by Professor Fiulhoff in the Bibliothèrue nationale, Paris. B: Bloorl-letting man (Aderlaswname), from the Calendar of Regiomontanus (1475), showing the points of election for blook-fetting under the signs of the zodiac. C: Wound-man (Wundernmann), from Gersilorf"'s Feldtburh (1517), showing the sites for ligation of the different arteries of for blood-letting. C is a later evolutionary form of the old zodiacal diagrams, which eombined an exposition of planetary influences with schematia of the viscera (B). 
Perhaps the eartiest Luropean text of medical jurisprudence of consequenee is the "Constitutio Criminalis Carolina" (I'minliche Geriehtsorduung) issued by Emperor Charles $V$ in 1533, as an extension of a similar ordinanes issited by the 13ishop of Bamberg in 1507. Interesting relies of the great medieval pandemies of syphilis and bubonie plague are preserved in the eurious iracts of Widman (1497), Steber (149S), Pollich (1501), Konrad Sehellig (1502), Crünpeck (1503), Sehmatus (1515), and Ulrich von Hutten (151!), and sweating sickness is the subjeet of a great mass of pamphlets, the best known of which is the little treatisie of John Kaye or Cains (15521). Mat thacus Friedrich, a pastor of Ciörenz, wrote the earliest traet on alcoholism (Wider den Saufteuffel, 1552). Early German botany had its beginnings in the Herbarius Voquntimus, the oldest herb-book with illustrations, printed by Peter Schöffer it $\mathrm{I}_{\mathrm{a}} \mathrm{inz}$ in 1484 , and in the queer wood engravings of the Hortus sanilatis, in entirely different compilation from older writers, attributed to its editor, Johan (Wonnecke) yon Kaub or Cube (1455), which was rendered into German 1s the Gart der Gesumlleit. ${ }^{2}$ This work contained some 500 engravings which, ws Greene says, are "most wretched earieatures of plints," but it beeame son opular as to be the principal ineentive for the work of the "German Fathers," 3runfels, Fuchs, Boek, and Valerius Cordus. In France, similar compilations, ariously known ats Arbolayne (Herbolario), translated from the German Tortus sanitatis, and Le granl herbier, were widely printed (Choulant). These icunabula were in turn the origins of many English "Herbals." The Buch er Vatur of Conrad von Megenberg (Auguburg. 1475), an illustrated comilation which passed through six Angsburg editions before 1500 , was the est known compendium of natural history.

Early German surgery begins with the Bündth-Ertznei of Heinch von Pfolspeundt, a Bavarian army surgeon, whose work, ritten in 1460, remained long in mamuscript, until it was discoved at Breslau and edited by Hacser and Middeldorpf in 1868. folspeundt was only a wound surgeon, had no skill in the major berations, which he left to the cutters or "incisors," and did not now how to treat fractures and dislocations; but he learned how make artificial noses (by the Hindu method) from the wandering alians. His military experience gave him a large practice in row wounds, and his book contains the first faint allusion to owder-burns" and to the extraction of bullets by means of e sound. ${ }^{3}$ He treated wounds by second intention, used the

'For the texts of the writers on sweating sickness, see C. G. Gruncr's riptores de sudore anglico, edited by Haeser (Jena, 1847).

${ }^{2}$ For an account of the Hortus sinitatis, its history, origins and variants, L. Choulant's Craphische Inkunabeln, Iceipz., 1858, 20-75; also J. F'. ] yne's fine essay in Tr. Bibliog. Soc.. Lond., 1901-2, vi, 63-126, with many $\mathrm{i}$ istrations. Neither the Herborius Hogmetio impressus (1484) nor the (ier1.n Ortus stmiatis (1485) is identival with the Herburium of [psendo-] Apuleius. ] itonicus, printed at Rome in 1480, from a MS. at Monte Cassino, by GioTni Filippo de Lignamine, physician to Pope Sixtus IV.

${ }^{3}$ Haeser and Middeldorpf at first asserted, in their eommentary on I'fols undt (pp. xxii, xxvii), that there is no mention of gunshot wounds in the Indth-Ertznei. This was afterward shown to be incorrect by II. Froclieh (eutsehe mil.-ïrztl. Ztsehr., Berl., 1874, vol. iii, pp. 592-594), who points o the "Item vor das büchsenpülüer auss den wïnden" (Pfolspeundt, 1. 10), a) the following (p. 60): "Auch machstu solchs suchel [Sonde] wol ron eisisen nehenn ... mith dem hebstu die kleine gelödt oder kugel hiraus, die von b'hsenn hinein gesehossenn sein, unnd auch was sunst in den wunden ist." 
mareotio-inhalation recommendod he Nicholas of Salerno, and, like

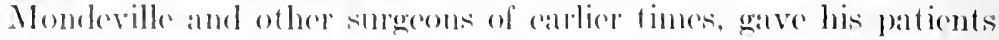

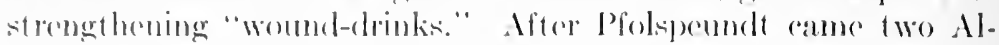

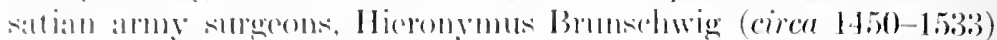

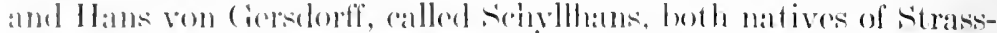

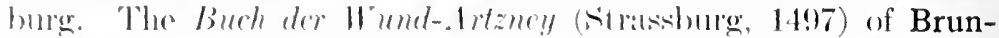

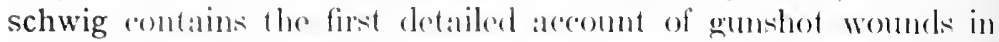
merlical liferature. He regarded such wounds as poisoned, and thoment the poison comld be best removed by pomoting suppma-

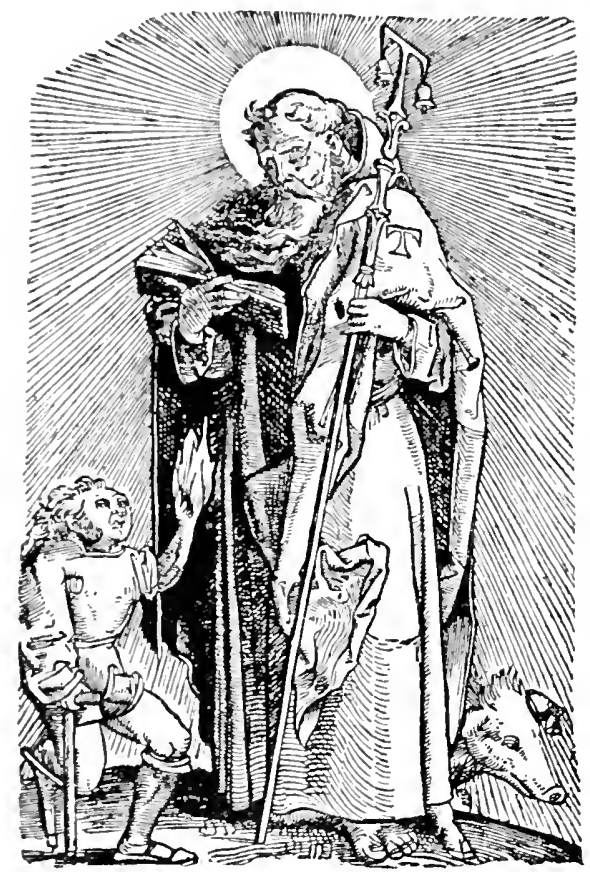

st. Inthonv with a victim of ergotism. (From Hans vou Gersdorff's Felithuch dev IVundtartzney, strassburg, 1540.) tion, usually by means of the setors. As an atrmy surgeon, Brumschwig did no major operations, confining himsolf to wounds, hous-setting, and amputation. In performing anmputation, he applied the actual autery or boiling oil to rheck hemorrhage from the stump. This book contains some of the earliest specinens of medical illustration by woodcuts, rare and corious in their kind, and the same thing is true of Gerselorff's Field-Book of Wound Surgery (Feldtbuch der II undtartzney), which was published at Strassburg in 1517. Gersdorff goes even more fully into gunshot wounds than Jerome of Brunswick. He did not regard them as poisonous: but probed for the bullet with special instruments and, like nost smrgeons of his time, poured hot oil into the wound In amputating, he "Esmarched" the limb by means of a constricting band, and, discarding the cautery, checked hemorthage by a stypti of his own derising (containing lime, vitriol, alum, aloes, and nut galls), inclosing the stump in "the bladder of a bull, ox, or hog, which may, in some cases, have been a good Listerian protective Crersdorff's book contains some of the most instructive pictures $c$ early surgical procedure in existence; in particular, the first pictur 
ever made of an amputation, and micue plates of diseases like leprosy and St. Anthony's fire. The wood-cut of the latter condition ("ignis sacer" or ergotism) represents the victim of the discase as hobbling upon a cruteh and holding up a shriveled, gangrenous hand, busting into flame, to excite the pity of Anthony, the patron-saint of the disease, who stands leaning iupon his tamcross, attended by his fathful swine. Another interesting picture book in the vernacular is the Augendienst (I)resden, 1583) of the court oculist, George Bartisch (1535-1606), the striking illustrattions of which give us a complete purview of Renaissance eyesurgery. Among these nay be mentioned the cuts showing the patient tied in a chair and ready for operation, the modes of procedure in catarart, and the perforated or stenopeic spectacles or visors (originally recommended by Paul of Egina ${ }^{1}$ ) for strabismus. As Bartisch, originally am mlettered barber-surgeon, makes a great parade of learning and Latinity in his text, aside from its pompous title, ${ }^{2}$ he is supposed to have employed a fammlus or hired scribe to polish his hook for him. None the less, this work did much to lift ophthahmology above what its author calls the "couchers and eve-destroyers" of his time. His treatise on lithotomy (1575) contains an interesting picture of the operation. The earliest printed book on the eye was the De oculis, comumque egritudinibus et curis of Bemvenuto ("alled Cirassi or (iraffeo) of Salemo (printed at Ferraria in 1475), which follows the ancients.

In the vernacular group maty be ment ioned the little ayo-books of C. Vont-

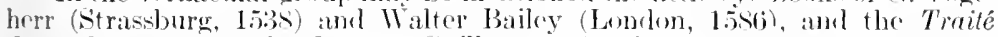
des maludies de liail by Jarques (inillemeau (Parris, 1555), decidedly the best of the Renaissaner lrooks on ophthalmology. Even the English treatise of Richard Banister (1622) is only a translation of this work.

The first medieal book to be printerl in England was ealked 1 Passing Gode Lityll Boke Necessarye and Behowefull Agenst the Pestilenes, being it small quarto of twolve leaves, attributed to the press of William de Machlinia (London, circa 145.5), translated from the Tractatus contra pestitentiam (1480), ascribed to Kimutus (Bengt Kimutison), Bishop of Vïsterïs, Sweden (1fi1), but which. a* Sulboff has shown, by paraltel eomparison of texts, wats really written by the Papal physician Joliannes Jacobi of Montpellier about 1364. ${ }^{3}$ The English version Was afterward reprinted by Wynkyn de Worde in 1510. Next came The Governale of IIelthe, printed at Caxton's press about 1191, followed, in 1.510, by The Judyeyal of Lrins, sometimes attributed to .lohm of Arderne, and probably printed by Wynkyn do Worde. In 1516, Peter Treverus, a printer in Southwark, publisbed The Grele Herball, and, in 1521,

${ }^{2}$ Paul's visor-mask is described in the Based (oporimes) odition of 1516. lib. iii, cap. 22, p. 182 . Stenopere spectacles for sepuint were also known to Pare (1575). The term "stenopeie spectacles" was introdueed by Donders (15วั4).

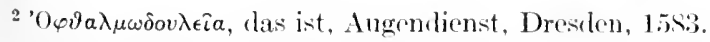

${ }^{3}$ Sudhoff: Arch. f. Gesch. (l. Med., Leipz., 1911-12, v. 56-5s. Singer: Proc. Roy. Soc. Med., Seet. Ilist. Med., Lond., 1916, 179-185. 


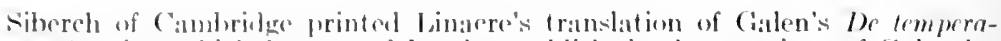
mentis, after which Proson of lomblon published other versions of Gialen hy

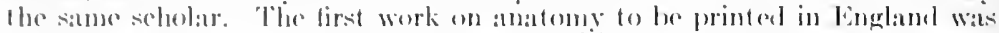

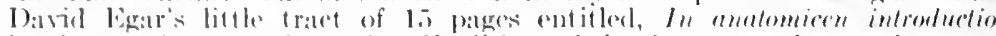
luculenta it bropis, and the first lenglish work in the romacular on the same

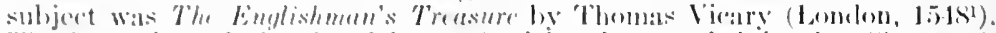

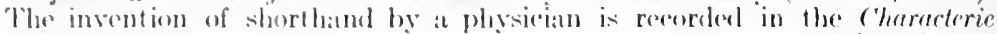
(15xi) of 'Timothy Bright (155i-1615), of which omly one (opy exists (in the Bulleian liloraryi).

The offect of these vertacular writings was to get men's minds away from seholasticism and tum them toward realitios. This Renassance tendency reached its highest development in the most prominent of the medical leaders of the sixteenth century, Paracolsts, Vesalius, and Pare-threest rong men of agresive temperamont, who, by shouldering past other mon, literally "blazed the way," not only for the general advance of medieine, but for keen and liberal thinking in all its branches.

Aureolus Theophrastus Bombastus ron Hohenheim, or Paracelsus (1493-1541), precursor of chemical pharmacology and therapentics, and the most original medical thinker of the sixtecnth century, was, in spite of his bombastic assertion of rank and lineage, ${ }^{2}$ a striking example of the very raw materials from which such aspirations are sometimes fashioned. His coarseness of fiber, though a better possession to him than vulgarity of spirit, often impeded his power to "think straight and see clear." A native of Einsiedeln, near Zürich, switzerland, he had the truculent, independent spirit commonly ascribed to the man of nountaincer race, and was one of the few writers who ever" advanced medicine by quarreling about it. Like the "roarer's" in Elizabethan comedy, or the Zamlibauer in German faree, he tried to bully and browheat his auditors and readers into accepting his views, and the writings which he dictated to his pupils are often a curious mixture of ('redulous fustian and swagger, set off by many successful guesses at truth and some remarkable intuitions. His humorous sallies, if he intended them as such, are usually of the lumpish kind that drift "from the obscene into the incomprehensible."'3 Paracelsus was the son of a leamed physician, who had a fine library, and with whom he began to study medicine. He got his doctor's degree under Lconicenus at Ferrara (1515), and picked up an unusua knowledge of alchemy, astrology, and other occult sciences from

${ }_{1}$ These data are given in a paper by the late Dr. J. F. Payne in the Brit Med. Jour., Lond., 15๑9, i, 105.5 .

2 The name "Paracelsus" is supposed to be either a free transkation c "Hohenheim" or else an indication of his superiority to Celsus. He usuall calls himself "Theophrastus ex Hohenheim eremita," $i$. e., of Einsiedeln.

${ }^{3}$ George Noore. 
the learned abbots and bishops of the country round, as also in the laboratory and mines owned by the Tyrolese alchemist, Sigismund Függer. Having the Swiss Wanderlust, he traveled all over Europe, collecting information from every souree, and by his relations with barbers, executioners, bathkeepers, gypsies, midwives, and fortune-tellers, he learned a great deal about medical practice, and incidentally acquired an unusual knowledge of folk-medicine and a permanent taste for low company. Paracelsus thought and spoke in the language of the people, was popular as no other physician before him. When he appeared as a teacher at Freiburg and Strassburg (1525), his fame as a lucky practitioner preceded him. Appointed professor of medicine and eity physician at Basel in 1527, and imbued with a lifelong reverence for Hippocrates, implanted by his teacher, Leonicenus, he began his campaign of reform by publicly burning the works of Galen and Avicenna in a bonfire and lecturing in German out of his own experience; but, a year later (1528), he was already in violent conflict with the authorities about fees, and forced to leave the city. Resuming his wandering labits, he practised all

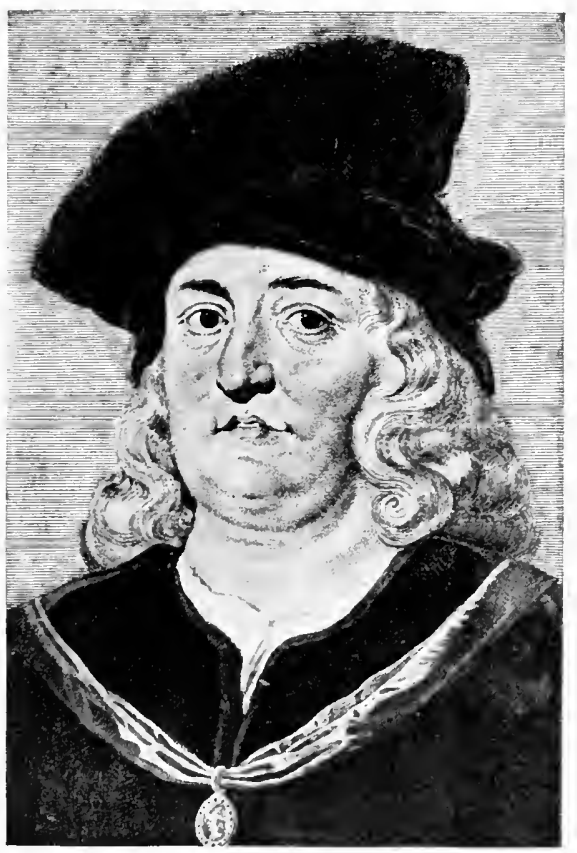

Paracelsus (1493-1541). over Germany with varying suecess, finally dying from the consequences of an injury in a tavern brawl at Salzhurg. As a pioneer in chemistry, Paracelsus was preceded by pseudo-Geber, the alchemists Allertus Magnus and Cornelius Agrippa, and followed by a swarm of chemiatrists, among then Joham Thölde, who wrote under the pseudonym of the mythical fifteenth century monk, Basil Valentine. Pseudo-Valentine is supposed to have given to chemistry hydrochloric acid, sugar of lead, the means of preparing ammonia and sulphuric acid, and, in his "Trimmphal Chariot of Antinony" (1604), fastened the latter metal upon medical practice for cen- 


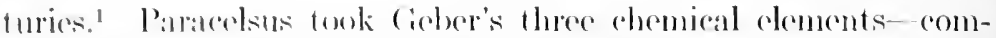
bustible sulphur, volatile moreury, residual salt-and mixed them up with a speries of theresophic lore not unlike that of the far bast, in which he is smpunsed to have trateded. Bats has emmpared

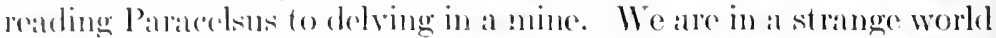
of mystic principles, macrocosms and microcosms, atrehed and areanit, onlivened by gnomes, sylvans, sprites, and salamanders. bxistene procede from (iod, all material things from the Yliaster, or primordial substonce, whilo the foree in nature which sets things groing (tho vital principle) is the Arelasus. The Archous is the eserene of life, contained in an invisible vehicle, the Mumia, and in discased conditions this Mumia must be mangetically extracted from the patient's body and inoculated into a plant bearing the signature of the discase, so that it may at tract the specific influence from the stars, discases being caused by astral influences acting mpon the "astral body" of man. Yet the author of all this highthown verbiage, the actual Paracelsus, was a capable physician and surgeon, gencrous to the poor, and however despised and rejected for coarseness, charlatanry, and possible drunkenness, a man deserving of better human remembrance. For Paracelsus was noither the refined, smpersubtle mystic of Browning's poem, nor ret the roistering, lying, tippling blackguard and quacksalver of tradition. His influence was far reaching, and his real services were great.

While philosoply, alcheny and astronomy were the pillars of his faith, his watchword in practiee wis "experimentation controlled by the authoritative literature."2 That he read his authors to some purpose is suggested by his statement that the only true physicians among the ancients were the Greeks. His pathology was mixed, but contained such good elements as the concepts of disense as a disharmony of normal functions, or life under altered conditions, as hereditary (in goiter), or as cliathetic, in gout and stone, which he regarded is "tartarie" processes, caused by the preeipitation of substances ordinarily voided from the body, the first attempt at a ehemieal etiology, and part of his general doctrine of calcifications and coneretions. His five calleses of discase (fntia) were cosmic ageneies (ens astrorum); pathologic

1 For the Basil Valentine controversy, see Kopp (Die Alchemie, 1SS6), John Ferguson (Bibliotheca Chimiea, 1906), Sudhoff's Bibliographia Paracelsica (Berlin, 1s94), C. S. Pieree, in sieience, $\mathrm{N}$. Y., 1s98, n. s. viii, 169-176, and "Basil Valentine, a seventeenth eentury hoax," by J. M. Stillmann, in Pop. Sc. Monthly, ․ Y., 1912, lxxxi, 591-600. These hold that the writings of pseudo-Valentine belong unquestionably to the early seventeenth century literature. The pieture of Basil Valentine in the lioyal Cabinet of Etchings at Minieh represents a monk, with retort and pentagram, looking very like the usual pictures of Paracelsus. The Currus trimplatis antimonii led all practitioners to preseribe antimony at the start in fevers. The vogue died out, but the drug was revived in 1657 , when its exhibition cured Louls XIV of typhoid fever. Pseudo-Valentine refers to syphilis as the nue? Krankhit der $\dot{K}$ riegsleut, recommending a mixture of antimony, lead, and mercury against it. Sudhoff.

- Experimenta ac ratio auctorum loeo mili suffragantur. Cited by 
poisons (ens veneni), inclucling autointoxications and contagia; natural eauses (ens naturale) or predisposition to disease from organic defects; psyehie eauses (ens spirituale) and divine intervention (ens deale). His pupil, Peter severinus, developed the idea of contagia (ens venenata) as animate pathology (pathologia animala).

Far in advance of his time, Paracelsus disearded Galenism and the four humors, and taught physicians to substitute chemical therapentics for alchemy; he attacked witcheraft and the strolling mountebanks who butchered the body in lieu of surgical procedure, and he opposed the silly uromancy and starcraft; he was the first to write on miners' (occupation) diseases, and the first to establish a correlation between cretinism and endemic goiter; he was ahead of his time in noting the geographic differences of disease; almost the only asepsist between Mondeville and Lister, he taught the unity of medicine and surgery, and that nature (the "natural balsam") heals wounds, and not officious meddling; he introduced mineral baths, and was one of the first to analyze them; he made opium (laudanum¹), mereury, lead, sulphur, iron, arsenic, copper sulphate, and potassium sulphate (called the "specificum purgans" Paracelsi"), a part of the pharmacopeia, and regarded zinc as an elementary substance; he distinguished alum from ferrous sulphate, and demonstrated the iron content of water by means of gallic acid; with Croll and Valerius Cordus, he popularized tinetures and alcoholic extracts; his "doetrine of signatures" was revived by Rademacher and Hahnemann; his "arcana" were directed against the causes of disease rather than the symptoms (causal therapy), and, in comparing the action of these areana, or intrinsic principles of drugs, to a spark, he grasped the idea of catalytic action, although his belief that remedies are not substantive but act through an immanent spiritual power or "quintessence" (active principle) was the cause of much mysticism. As a theorist, be believed in the descent of living organisms from the Urschleim, or primordial ooze, and Bats credits him with antieipating Darwin in his observation that the strong war down and prey upon the weak - a fact, unfortunately, within the range of any beggar or footman. His comparison of apoplexy with lightning stroke and his concept of atrophy as a drying out of the tissues show his contempt for anatomy. But none of these things can outweigh the influence which Paracelsus exerted on his time through his personality. In an age when heresy often meant death, he wasted no time in breaking butterflies upon wheels, but drove full tilt at many a superstition, risking his neek with all the recklessness of a border reiver. The importance attached to his

1 "Ich hab ein Areanum, heiss ich Laudanum, jst über das alles, wo es zum Tod reichen will," Grosse Wundirznei, i, Tr. 3, eited by Haeser. 
mane maty be gathereal from the line in shakespeaters eomedy whide hratekets it with that of (ialon.' Paracedsts was great in respect of his own time. He eleses mol soom parlicularly great in

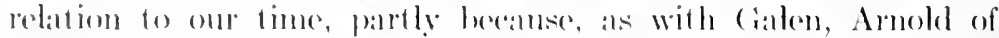
Villanoya, and others in the past, his withgs have heen overlaid

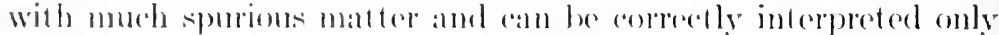
in the light of montern researeh.

The most rahamstive stmly yet mate of Paracelsus and his writings is that of Professol lial sullhof (189t-9).

The principal works of Paracdsus are lhe treatise on open wounds (1525), his ( hirmegia matma (1530), his manmal int roducing the use of meremrials in syphilis (Frankfurt, 1553), the treatise De yradibus (Based, 1568), which contains most of his innovations in chemical therapentics, his monograph on miners' diseases (Ion der Bergsucht, Dilingen, 1567), and his booklet on mineral baths (Bascel, 1576), recommending (iastein ("("astyn"), 'Töpplitz, (röppingen, and Plombiòres ("Blumbers"). The treatise on miners' discases, the result of his olservations in Fugger's mines in Tyrol, giving descriptions of miners phthisis and the effects of choke-damp, was one of the few original entributions of the time to clinical nedicine. He knew of paralysis and disturbance of speech after head injuries." In his chapter, De generatione stultorum, ${ }^{3}$ Paracelsus first notes the coincidence of eretinism and endemic goiter, a discovery also based upon original observations. in the Salzlonro region.

Apart from the huge output of the syphilegratphers-Leonicents (1497), Lateumareino (1521-314), Fralcastorius (1530). Niccolo Massa (1532), Fernolius

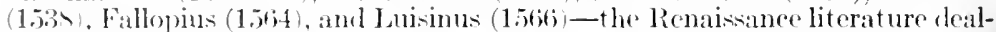
ing with the actual portrayal of disease is meager. Ciruner gives a remarkable, lint of 191 omeingereal varieties of syphilis deseribed in the period. ${ }^{5}$ To this perior belong the original descriptions of trphus fever by Fraeastorius (1546), of swetting sickness by (aius (1552), of varicella by Ingrassias (1553), of "tabardille" (Fpanish or Mifexian typhus) by Franceseo Bravo (1570), of whorpinereough ("quiver") by (iuillaume Baillou or Ballonius (15\%8), of chlorosis (morbus virgineses) in the epistles of Johamn lange (1.54), and of the

${ }^{1}$ In "All's Well That Ends Well," Ar. II, se. 3, where Lafen refers to the King's case as incurable, "to be relinquished of the artists," and Parolles replies: "so J ary, both of Gilen and Paraerdsus"-meaning, of course, that meither the Galenital nor the aldhemieal school of physieians could help him in any way.

"E. Ebstein: Deutsehe Ztsehr. f. Nervenhrilk., Leipz., 1914, liii, 131. $174-1<2$.

Printerl in his posthumous "Opera Omnia," Strassburg, 1603, ii, pp.

4E. C. Streeter has shom that the date 150.5 assigned by Astruc for Laeumareine's De morbe gallien, the best treatise on syphilis of its time, must be ehanged to 1524 or later (Tr. Internat. Cong. Mefl., 1913, Lond., 1914, sect. xxiii, 37-3-37ti). The Turin edition in the Surgeon General's Library bears the date 1.392.

${ }^{5}$ C. G. Ciruner: Morborum antiquitates, Bresiu, 1774, 85-100. 
syndrome "mountain sickness" by the Jesuit traveler Jose d'Acosta (1590). Geronimo Mercuriali (1530-1606) wrote the first systematie treatise on skin diseases (1572), a famous illustratel treatise on medieal gymnasties (1573), and one of the aurlier works on diseases of children (1553). The first treat ise on feigned diseases (De iis qui morborum simulant deprehersis) by Giambattista Silvatico, was published at Milan in 1595. The pediatrie treatise of Sebastianus Austrius (1540) deserves mention, as also the work of Prospero Alpino on Egyptian medicine (1591), and his unique treatise on medieal prognosis (1601). The Regiment of Life (1546), by 'Thomas Phayre [1510?-60], a blackletter version of the Regimen sanitatis, contains the first English contribution to pediatries (The Boke of Children).

Guillaume de Baillou (1535-1616), a Paris graduate of 1570 , whom Henri IV ehose as physician to the dauphin, and who first deseribed whooping-eough (1578) and introduced the term "rheumatism," is regarded by Crookshank as "the first epidemiologist of nodern times." His works, all published after his death, include sets of Consilia (1635-19), treatises on gynecology (1643), gout and calculus (1643) and two books on epidemies and ephemeral discases, with rase-histories and post-mortems (1640), which revive the old Hippoeratic doctrine of "epidemie constitutions," $i$. e., the external influences at work in the causation and spread of epidemies, foreshadowing mueh that was afterward taught by sydenham.

Charles Singer points out that some beginnings of tropical medicine were mate in Oviedo's description of yaws as "bubas," afterward identified by André Thevet, in 15.5s, as "no other thing than the poeks which rageth and hath power over all Europe, specially among the Frenchmen." Oviedo and Theret also mention the sandflea (Pulex penetrans). Singer draws attention to the frst book on tropical medicine, by George Wateson, entitled The Cures of the Diseased in Remote Regions (London, 159s), the scope of the work being indieated by the versified table of eontents:

\footnotetext{
"The burning fever, calde the Calenture,

The aking Tabardilla pestilent,

The Espintas priekings which men do endure,

Cameras de sangre, Fluxes violent,

Th' Erizipila, swelling the Pacient,

'Th' Tiñoso, which we the seurvey call.

Are truly bere described and cured all."
}

For a long time after Paracelsus chemistry still remained alchemy, and, in the following century, became merged into the fantastic pseudo-science of the Rosicrucians. The arch-patron of alchemy in the sixteenth eentury was the Emperor Rudolph II of Germany (1576-1612), who devoted much of his fortune and the whole of his life to the quest of potable gold, the philosopher's stone, and the elixir of life. In the spacious and gloomy chambers of his palace, the Hradsehin at Prague, he held high court with alchenists, spiritualists, juclicial astrologers, clairvoyants, and other followers of psychic "science," and no reward was considered too great for any adventurer, however disreputable, who might manage to wheedle this fantastic monareh "of dark corners." The credulous Rudolph was continually the prey of all sorts of impudent knaves and sharp practitioners, upon whom he speedily revenged himself by imprisonment or execution if they failed to

${ }^{1}$ Ann. Trop. Med. and Parasitol., Liverpool, 1912, vi, $\$ 7-101$. 
perform their promises. Mither ame the learned Cambridge scholalr, lohn Der, a solemm humbug, and his assistant, Elward Kolley, a shatp-wited impostor, to make "projections" of the bascl motals inte gold, and, ly crystal galzing in a shew-stone (now in the British Muscum), to indulge the kind of self-hypnotism fambilial to-day as "automatic writing," Kelley acting as "skryer," or clairvoyant, in the manemver. Both were richly rewarded, Dec escaping to Fingland in the nick of time, liclley remaning to hecome a landed propriet or and eques auratus of the Bohomian Kingdom, but subsequently losing his life as a punishment for his brawls and impostures. To "Cold Alley," the charlatan street of Praguc, came also Michael Sendivogius, "Count" Mareo Bragadino, Cossonhaner, and ('ornclius Drebbel, the perpetual motion man; and it was for the sake of alcheny that Rudolph brought Tyeo Brahe and Kepler together, to the material advantage of future astronomy. The forcgatherings of Rudolph's physicians, ('rato von Kraftheim, Oswald Croll, (imarinonius, Michacl Maier, and the rest, made up the Rudolphine Academy of Medicine, of which an extraordinary session was once convencel to hear Andreas Libau (Libavius) read an essay on the aurum potabile. This Libavius (1546-1616), a physician and teacher of Coburg, made a real start in chemistry, and his Alchymia (Frankfurt, 1595) is usually regarded as the first systematic treatise on the science. He had. says Bolton, "a sumptious laboratory, provided not only with every requisite for chemical experimentation, but also with means of entertaining visiting guests, including such luxuries as baths, inclosed corridors for exereise in inclement weather, and a well-stocked wine-cellar." He discovered stannic chloride, analyzed mineral waters with the balance (1597), wrote a city pharmacopeia (1606), and was one of the first to suggest the transfusion of blood (1615). His Alchymia is divided into two parts, the first dealing with the laboratory operations of chemistry, including instruments and furnaces; the latter half containing accurate and systematic descriptions of chemical substances. Of this, no fewer than 80 pages are still devoted to the philosopher's stone.

A typical follower of Paracelsus was the adventurous alchemist and swindler, Leonhard Thurnheyser zum Thurn (1531-95), of Basel, who started out as a goldsmith's apprentice, married at sixteen, and was soon embarked in a "gold-brick" imposture (selling tin coated with gold), for which he had to flee the eity and take up a roving life. He traveled far and wirle, became inspector of mines in Tyrol in 1558, and, after healing the wife of the Elector of Brandenburg of a desperate illness, became his body physician in 1578 . In Berlin, he made so much money by pawn-broking, usiry, and the sale of calen-

${ }^{1}$ For a full account of all this, see Henry Carrington Bolton's delightfu' book, "The Follies of Science at the Court of Rudolph II," Milwaukee, 1904 
dars, horoseopes, and seeret remedies, that he was able to set up a private laboratory and printing ofhee, with type-foundry attached. A scandalous latwsuit with his third wife reduced him to beggary, and be died obscurely in a cloister at Cologne. His writings, full of mestical humbuggery, are without value, although mueh has been made of his diseovery that nimeral waters yield a certain residue upon evaporation.

IIany physicians of this period were also mathematicians and anthors of some of the earliest praetical arithmeties (algorisms), notably those of Joh. Wirlman (1488), G. Valla (1501), Arnolelo do Villa Nova (1501), J. Fernelins (152S), Gemma Frisius (1540), Robert Recorde (1542), and M. Neander $\left(1.55^{1}\right)$. Of this group the most pieturesque figure was Geronimo Cardano (1501-76), whose roving life was filled with strange arlventures. A merlical graduate of Padua, he praetised medicine and professed mathematies at Milan and was professor of medieine successively at Pavia and Bologna. Cardan made his mark with his treatise on arithmetic (1539) and his algebra (Ars magna, 1545), which eontains his famous solution of cubic equations, most of which was, however, stolen from Tartaglia. Although excluderl from the College of Physicians at Milan by his illegitimate birth he gained some practice by his eure of the child of the Nilanese senator Sfondrato, and as the medical adviser of the asthmatie Arehbishop Hamilton of St. Andrew's. But he was only a medical astrologer and empiric. His best work is his natural history (De subtilitate rerum, 1550), which shows remarkable insight into biologic phenoment, and is evolutionary in its tendency. It contains a deviee for teaching the blind to read and write by the sense of touch (quomodo caeus scriberc doceri potest), which is not very different from the modern invention of Braille $\left(1 \$ 29-36^{2}\right)$. Jerome Cardan also saw the possibility of teaching the deaf by signs. His Metoposcopia (1658) is illustrated with 800 euts of human faces, an astrologic physiognomy, based upon the idea that the furrows in the forehead were influenced by the seven celestial bodies and that horoscopes might be drawn from such data.

The idlea of instructing the deaf was again taken up by Pedro Ponce de Leon (1520-84), a Benedietine monk of Sahagun, Spain, who was the first, in his own words, to teach the deaf "to speak, read, write, reckon, pray, serve at the altar, know Christian doetrine, and confess with a loud voice." His written work on the subject is lost, but his system was preserved in the treatise of Juan Pablo Bonet (1620).

That the phenomena of hypnotism, autosuggestion and psychotherapy were well known in the sixteenth century is apparent from the writings of Pomponazzi, Comclius Agrippa, Cardan, Van Helmont and Kercher. ${ }^{3}$

After the time of Mundinus, a number of anatomic treatises appeared containing the first rude attempts at pictorial representation of dissected parts. These are the so-called "graphic incunabula" of anatomy and may conveniently take in all published illustrations of the pre-Vesalian period. They are:

1. The 25 editions of Mundinus, printed between 147s and 1580, including those in Kotham.

2. The Fasciculus medicine (Venice, 1491) of Johannes de Ketham,

${ }^{2}$ D. E. Smith: Rara Arithmetica, Boston, 1905, passim.

${ }^{2}$ H. Sehetenz: Arch. f. Cesch. d. Naturwissenseh., Leipzig, 1910-12, iii, 237. About 1517, large letters eut in wood had been used by Franceseo Lueas in Spain and Rampazetto in Italy.

${ }^{3}$ See the Paris dissertation of Camille Rouzeaud (1918, No. 4), who styles the period "le siccle de l'hypnotisme." 


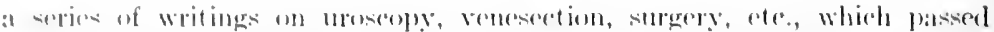

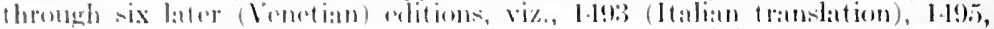

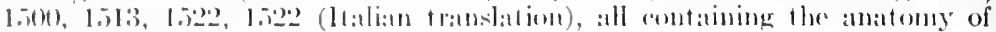
Mombinus at the enet.

3. "The skeleten of Riehard Ilasin, printed at Numembere in 1.193.

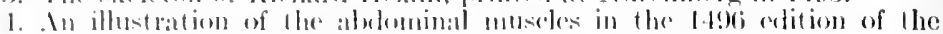

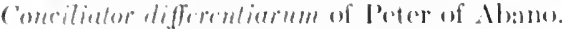

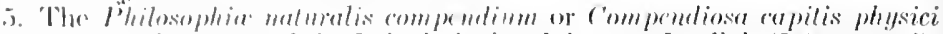

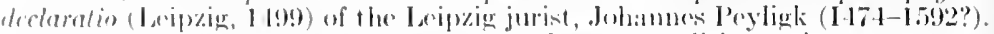

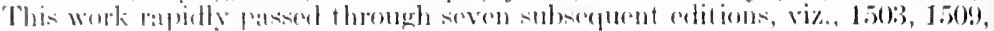

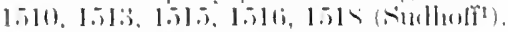

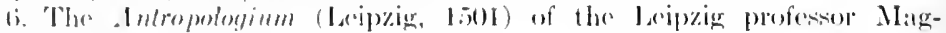

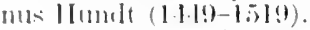

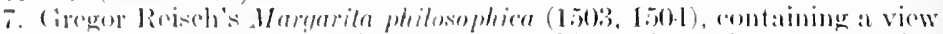

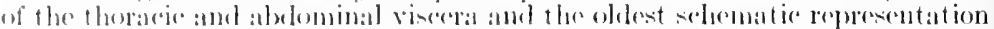

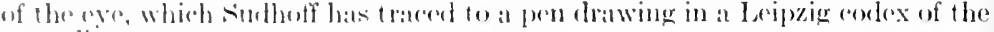
procerling centerry.

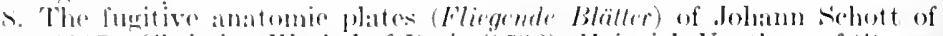

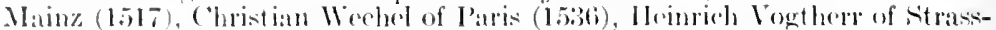
bure $(1339)$, and of liers.

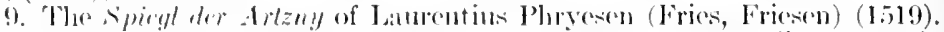

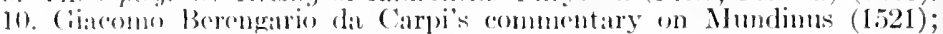

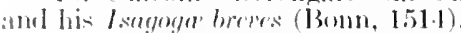

11. 'The Lnatomiar pars prior (Marburg, 1536) of Johann Eichmann or I)ryander (ation 1500).

It hals been shown, in the highly exhaustive resoarches of harl Surthoff," that none of these carlier anatomic illustrations were based upon original observation or dissection, but that, for the most part, they are purely traditional, servile copies from manuscript sketches of the past, with some little superadded touches here and there. The ninth contury Breslan codex 3714 and a twelf the entury ('openhagen MS. give the traditional pictures of the fetus in utero as handed down by Moschion. The wood-euts in Ketham 's Fasciculus represent a circle of 21 urine glasses which sulhoff has traced to a manuscript of 1400 ; sick-rom and dissecting seenes. with groups of Tenetian gentry in the costumes of the porios, and a rentakible series of chanacteristic semi-squatting figures indieating the sites of injury or clisease and the most favorable localities for applying treatment, viz., the "zodlac-man" (Tierkeisachenmemn), in which schemata of the viscera are often

I sudhoff: Arch. f. Gescl. 1. Merl., Laipz., 191.j-16, ix, 309-14, 1 pl.: $1916-17, x, 2.21$.

Fitrl sulhoff: Tradition und Naturbeobachtung in den Illustrationen medizinischer Handschriften und Frühdrucke, vornchmlich des 15. Jahrhumderts, Leipig, 1907; Ein Beitrag zur Gesehichte der Anatomie im Mittelalter. Leipzig, 190s, his highly original studies of the prelistory of Ketham in the Dls. soures, the schematic eye, the viseeral schemata and the Fünfbilderstrie (Areh. f. (iesch. 1. Med., Leipz., 1907-11;, passim); also, Walter Sildhoff's discrertation, "Die Lehre von ien Hirnvent rikeln in textlicher und graphischer Trarlition des Altertums und Nittelalters (Leipzig, 1913). For a good account of pre-Vesalian illustration in English, with reproductions of most of the figures, see P'rof. William A. Lncy's interesting essay in Jour. Morphol., Chicago, 1911, xxii, $94,-9-7$. 
overlaid by the zodiacal figures; the "blood-letting man" (Aderlassmamn), whose body is tattooed with marks indicating the bost sites for venesection under the signs of the zodiac; the "planetman" (Planetenmann) of Westem Europe, in which the planets or their symbols are substituted for the signs of the zodiac; the "siek-man" (Kranlikeitsmann), ringed about with names of diseases and vague indieations as to their location in the body; the "wound-man" (I" undenmumn), whose body is mauled and piereod all over hy stones, arrows, swords and spears, the points of incision or lesion showing where the arteries are to be sought for in ligation; and the erouching pregnant woman (Cratida), giving a crute diagrammatic view of the fetus in utero. These strange didactie pietures have all been interpreted by Sudhoff as sidelights on the almost stationary character of the medieval mind, standing out at rude indiees of its workings in relation to the three great branehes of internal medicine, surgery, and obstetries.' They have all been located by him in manuscripts of earlier centuries, for instance, the blood-letting man of 1432 in the Munich library, or the figures in a thirteenth-eentury Provençal manuseript at Basel. It was eustomary for the medieval illustrators to make a series of five schematic pietures (F ïnfbilderserie), representing the osseour, nerrous, muscular, venous, and arterial systems, to which the pregnant woman or a view of the generative organs of either sex was sometimes added, and this series has been found by sudhoff in German manuseripts, from the cloisters at Prüfening (A. D. 1154) and Scheyern (1250), in a thirteenth century Provençal MS. at Basel, and even in Persian MS. in the India office at London and the Bodleian Library at Oxford. The eurious reflex-frog posture is found even in the acupuneture mannikins of ancient (hinese medieine (Hsieh). The medieval MS. drawings were plainly intended as erude mnemonic schemata, to refresh the menory of students, perhaps even for popular instruetion. Some were purcly diagrammatie, e.g., the many MS. drawings of the schematic eye, described by Sudhoff, ${ }^{2}$ the naive gropings at localization of the functions of the brain ${ }^{3}$; the Arabic schema of crossing of the optic nerves from Constantinople, ${ }^{4}$ which resembles an Oriental prayerrug, or the thirteenth eentury schemal of the nterus and adnexa in the Bodleian (Ashmole MS. 399), which has the same appearance.5 ii, 84 .

1. Sudhoff: Arch. f. Gesch. 1. Med., Leipz., 1907-8, i, 219; 351; 1908-9,

${ }^{2}$ Ibid., 1914-15, viii, 1-21, 2 pl.

${ }^{3}$ W. Suethoff : Ibid., 1913-14, vii, 149-205, 2 pl.

4 See p. 111. $47,2 \mathrm{pl}$.

C. Singer: Proc. Roy. Soc. Med. (Hist., Sect.), Lond., 1915, ix, 4:3- 

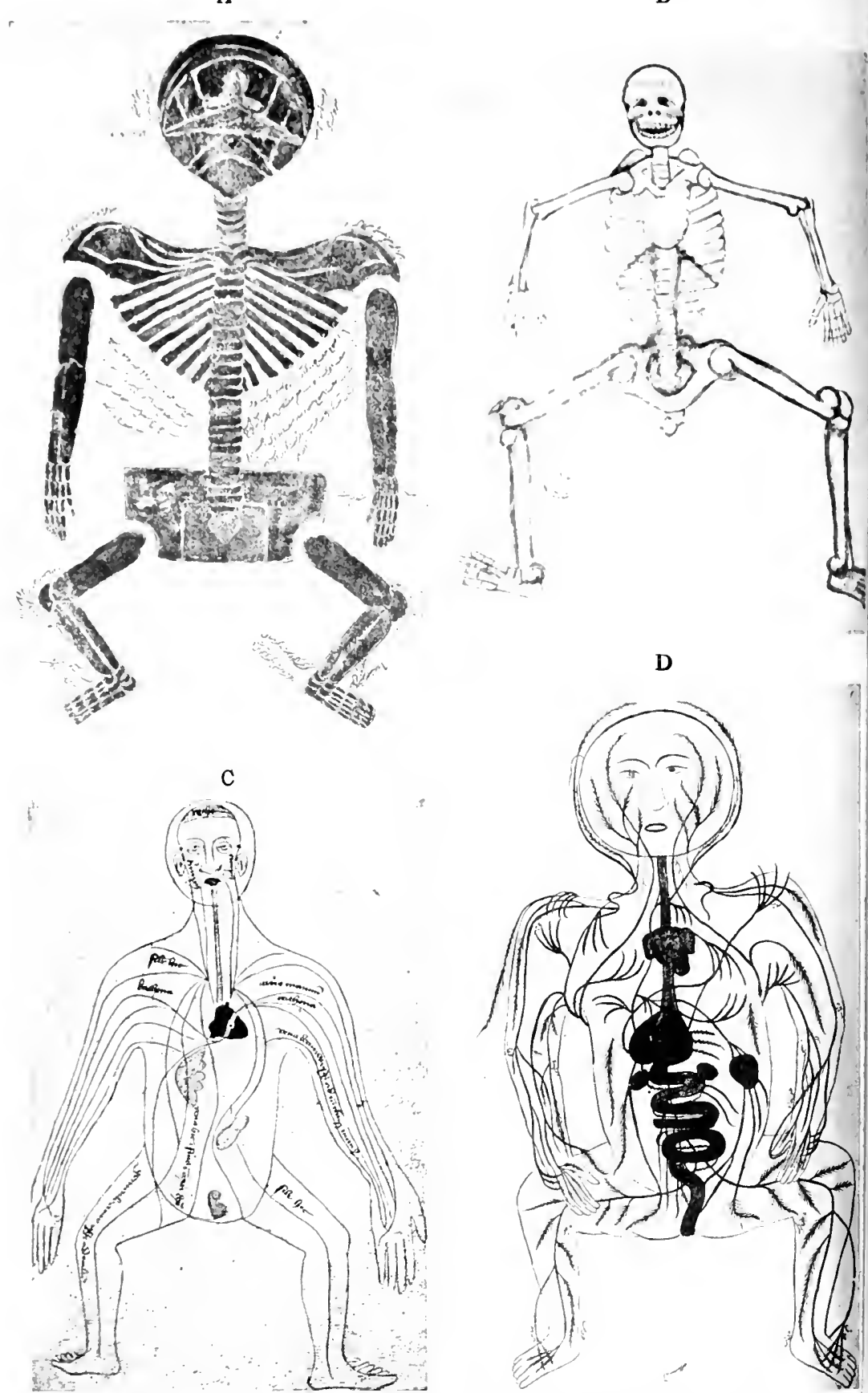

Drawing showing influence of tratition upon early anatomie illustration. (Br kind permiscion of Prof reor Karl siathoff, Cniversity of Leipzig.) A: Sketeton from Persian MS. No. 2296, India Uffiee, London. B: Skeleton in aquatint from Dresten MS. Codex 310 (A. D. 1323). C: Arterial system, from a fourtenth century MS. in the library of Prinee von Lohkowiez (Ratudnitz. Bohemia). D: Venous sistem, from Percian XIs. No. 2296, India Office, London. Roth called attention to the trarlitional character of anatomic illustration in the pre-Tesalian period, but the development of the subject is almost entirely the work of Profesion surhoff. 
In lietham's (iravida of 1.191, the parts of the body are labeled for the first time, and this is also true of Richard Helain's skeleton of 1.493, a good example of the fugitive anatomic plates which used to be exhibited in the (ioman harber-shops and bath-houses of the fifternth and sixternth centuries. This skoteton was copled by

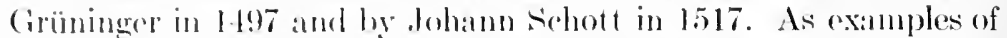
pre-Borengarian anatomy, the cuts in P'rygerk and Hundt look, in some of their details, like a child's scratching on a slate. Those in Peyligk have becen traces by Sudhofi to a series of 18 manuseript fierures in the Rosal Library at Berlin and Erfurt, which were used by Henri de Mondeville to illustrate his anatomic lectures at Montpellier ahout 1304. Phryesen has a much better executed engraving of the viscera (15i7), attributed by Bhumenbach to Johann Wacehtlin, and also given in Gersdorff's Feldtbuch (1517), which is, however, strikingly like the eruder picture in Reisch's Margarita philosophica (1504). The marginal figurations of the brain and the tongue are excellent, and five of the brain pictures were reproduced in Dryander's Anatomia (1536). Peter of Abano's Conciliator of 1496 contains the first example of the "Muslielmann," i. e., a full-length figure exhibiting its dissected muscles. In the works of Berengario da Carpi, who was the first to substitute drawing from nature for traditional schemata, this figure is represented as holding up the separate muscles for inspection, and the same motif becomes the écorché or flayed figure in Vesalius. Berengario has a tolerable skeleton, which is suspiciously like those of Hclain, Crüninger, and Schott, and his picture of the pregnant woman in a reclining at titude became afterward the theme of many variations by Stephanus and others, down to the time of Gautier d'Agoty's beautiful life-size panel in oils. These tentative efforts at representation, rare and curious as ther are, pale almost into obscurity besicle the eartoons, écorchess, and chalk drawings of the great artists of the period-Luea Signorelli, Michael Angelo, Raphael, Verocehio, and his pupil, Leonardo da Vinci. But, as shown by Edward C. Streeter, ${ }^{\prime}$ anatomy was advanced by the Florentine painters and aurifabers even before the time of Verocchio.

The temperamental fourteenth-eent ury Florentine was a "half-baked scientist." The early painters after Ciotto aspired, like all primitifs, to realism and the representation of movement, to pass from the flat-land of the ItaloByzantine mosaies and figurations in to the tri-dimensional world of verisimilitude and motion. To this end geometry, perspective, and the scienee of bodily proportion were arduously studied. The eity itself was a "very paradise of little bank clerks," who wrote "solid works on mercantile arithmetic." All the great works on perspective and human proportion, except Dürer's, eame from Florenee. In respect of naturalism in painting, Giotto's assistant and

1 Streeter: Bull. Johns Hopkins Hosp., Balt., 1916, xxvii, 113-118. 
intimate, Stefano, called the scimmia della natura, became so sucersisul that phlebotomists were said to stand before his subjecets to study the branching of the veins. An interest in dissecting probably eame about through the fact that the painters formod a sub-species of the Florentine "Guilel of Physieians and Apothecaries," which Masaceio joined, first as an apothocary (1421), then as a painter (1423). At the apothecary-shop, the painters bought thesir pigments and so came in eloser contact with the physicians at the guildfunctions. Thus dissecting, as to which the Florentine university statutes of 1357 give explicit directions, became a word of ambition with the artists, who soong got in the way of assisting at private discetions among their doctor friends or of doing a litile body-snatching on their own account. Leonardo, says streeter, is merely the end-result of this quest for uneompromising realism. Leonardo derives from Andrea del Castagno (1390-1457), through Domenico Veneziano, Alesso Baddonnetti $(1427-99)$, and Andrea Verocehio (1435-8s). Castagno, who disseeterl at Sinta Maria Nuova, was called the Donatello of painting on account of his skill in myologia detail. In this regard, ho influenerd Pollajuolo, who studied musculat ure by flaving the calaver. "The Anatomy of the Miser's Heart," at l'adua, by the sculptor Donatello, is a document in bronze of the interest taken in disisecting. Pollajuolo, Castagno, Mantegna, Isconardo, in asmer of Ruskin's, "polluted their work with the scienee of the sepulchre." On the textul side, the continum between Mundino and Leonarclo is filled in part by the anatomists Gabricle Zerbi $(1465-1505)$, of Voronia, professor at Palua, who wrote an anatomic treatise (1502), first separated the organs into systems, described the museles of the stomach and the puncta lachrymalia; Alessandro Benedetti (1460-1525), his sueessor at Padua, founder of its anatomic theater $(1490)$ and atuthor of an Anatomia (1497); Messandro Achillini (1463-1512), of Bologna, who discovered the malleus. incus, labyrinth, the ileocecal valve, and wrote an anatomy (1516); Berengario da Carpi (1470-1550), and Mare Antonio della Torre (1481-1512), professor at Padua and Pavia, who, according to Vasari, collaborated with Leonardo in an anatomic treatise.

Leonardo da Vinci (1452-1519), the greatest artist and seientist of the Italian Renaissance, was the founder of iconographic and physiologic anatomy, atthough his chalk drawings (1512) remained buried for over two hundred years, when they were noted by William Hunter (1781) and Blumenbach (1788). "In the last quarter century all the known drawings of Leonardo have been handsomely and adequately reproduced, notably those from the Royal Library at Windsor, the Ambrosian Library at Milan and the Institut de France.

Startlingly modern in their accuracy and display of physiologic knowledge, these impromptu sketches, made beside the dissected subject, reveal such acquaintance with muscular anatomy as was possible only to the Greek sculptors, and fully justify William Hunter's elain that their author was "the greatest anatomist of his epoch." Leonardo, like his forerunners, believed that a scientific knowledge of artistic anatomy-something quite different

${ }^{1}$ I manoseritti di Leonardo da Vinci (ed. Sabachnikoff-Piumati), 2 v., Paris, Turin, 1898-1901. Quaderni d'anatomia (erl. Yangensten, Hopstock and Fonahn), 4 v.. Christiana, 1911-14. Notes et desseins, 12 v., Paris, F. Rouveyre, 1901. These have been closely studied by M. Holl (Areh. f. Anat., Ieipz., 1913, 225; 1914, 37; 1915, 1) and A. C. Klebs (Bull. Med. Hist. Sioc., Chicago, 1916, 66-83; Boston Med. and Surg. Jour., 1916, clxxv, 1; 45). 
from the Greek sculptor's instinctive knowledge of the nude figure in action and repose-an be gained only at the dissecting table. Galenic anatomy he probably knew, possibly also Guy and Mundinus, but in his actual work ho was his own best teacher. He made orel 750 soparate skotches, inchuding not only delincations of muscles, but drawings of the heart, the lungs, the cervical, thoracic, abdominal and femoral blood-vesects, the bones and nerves, with deep dissertions of the viscera and cross-sections of the brain in different planes. Remarkable are his studies of the bones, the skull, the spine, the valves, muscles and vessels of the heart, his discovery of the atrio-rentrienbur band in the right heart, his crosssections of the brain and casts of its ventricles, his probable injections of the blood-resseds, his mique and accurate delineation of the statutory position of the foctus in utro, his studies of antagonistic muscles by tape models, his investigation of the hydrodymamies of the blood-current. Sometimes his notations of the origin and insertion of the muscles are too minute, because, having no aceurate nomenclature to guide him, he had to rely upon his own deductions from what he saw, which was, in any case, a great advance upon servile Galenism. He was the originator of "ross-sectional anatomy. "With a few strokes of the peneil, he demonstrated morphological relations in a manner not approached before the time of Friedrich Merkel" (Sudhoff ${ }^{1}$ ). The marginal notes, which Leonardo has recorded in mirror-writing, perhaps lest others appropriate his ideas, reveal the cautious, secretive spirit of the time. ${ }^{2}$

Among the anatonic works of the pre-Vesalian period we should, of course, include Albrecht Dürer's treatise on human proportion (De simmetria, Nuremberg, 1532), which latter was the first application of anthropometry to estheties, and is technically interesting because it contains the first attempts to represent shades and shadows in wood-engraving by means of eross-hatching.

Thoroughly as the great artists of the Renaissance may have studied external anatomy, yet dissecting for teaching purposes was still hampered by the theologic idea of the sanctity of the human body and its resurrection. Moreover, as very little anatomic material could be obtained among a sparse and slowly growing population, people were naturally averse to the possible dissection of frients or relatives. The anatomy of the schools was still the anatomy of Galen. How far such teaching had progressed may be gathered from the quaint cut on the title-page of the

1 Sudhoff: München. med. Wochenschr., 1919, lxvi, 1576.

2 That Leonardo's MIS. may have been seen and studied by others is sug. gested by a copy of one of his drawings by Dürer and by the ambiguou: sheletal figures in the Cffizi at Florence. 
Mellerstadt Mundinus (1493), in which the scholastic instructor, in long robe and biretta, wand in hand, gravely expounds Cialen by the book from his pulpit-chair, while below the long-haired barber-servant ${ }^{1}$ makes a desperate shift at demonstrating the viscera of the subject before him. The Faust who was to release the subject from these trammels and uphold the doctrine of the visum el repertum was Andreas Vesalius ${ }^{2}$ (1514-64), the most commanding figure in European medicine after Galen and before Harvey. There were plenty of dissectors and dissections before Vesalius, but he alone made anatomy what it is today - a living, working seience. It was the effect of his strong and engaging personality that made dissecting not only viable, but respectable. His eareer is one of the most romantic in the history of medicine. Flemish born, but of German extraction, a pupil of the ardent and bigoted Galenist, Jacobus Sylvius, Vesalius, in his graduating thesis, showed at first the conventional tendencies of the scholiast; but his mind was too active, his spirit too keen and independent, to feed long on the dust of ages, and he soon established a reputation for first-hand knowledge of the dissected

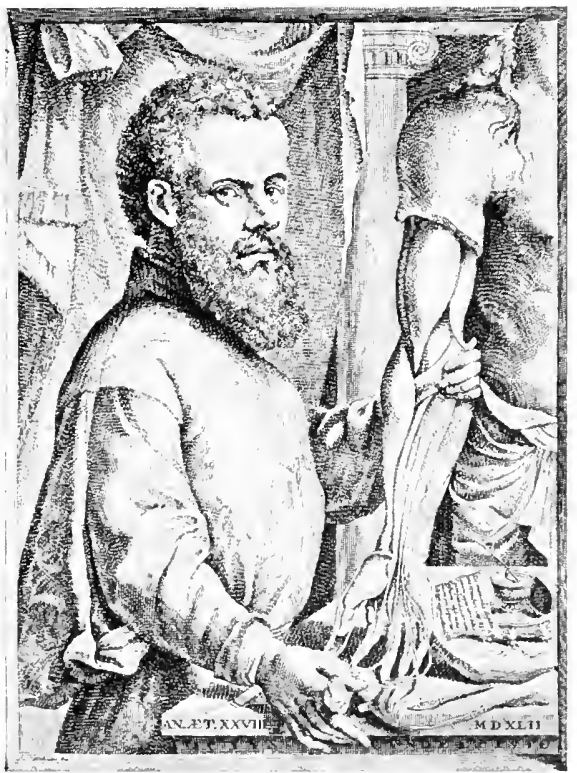

Andreas Vesalius (1514-6i4). human body, even teaching himself the difficult art, so essential to surgeon and grnecologist, of recognizing the palpable structures by an educated sense of touch. Five years' experience as public prosector at Padua, where he taught students to dissect and inspect the parts in situ, cuhninated in the magnificent De Fabrica Iumani Corporis (1543), a work which marks an epoch in breaking with the past and throwing overboard Galenical tradition. The effect of a publica-

${ }^{1}$ It is possible that this may represent Alessandra Giliani, a talented girl of Persiceto, who assisted Mundinus in dissecting.

2 Vesalius' family name was "Witing," later changed to "Wesel," where they once lived. Vesalius' coat of arms bore three weasels (uesel). 
tion so radical on a superstitious and forclock-pulling age was immodiate and solf-evident. Sirtrius, his old teather, turned

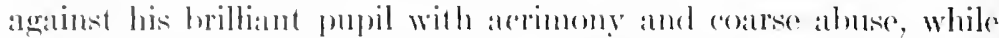

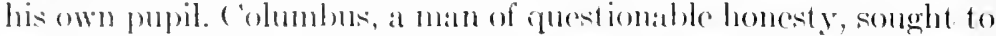
east discredit and derision on him by sharp practioe. Others were inclines to "damm with faint pratise," or joined in a enspiratey of silence, and, as a last straw, he was subjected to subterrancan persecution at the instance of anthority. Those things were not without their offect on Vesalius. His pert rait suggests a cloughty, swathy, shagery, full-blooded nature, like some of lucas ( ramach's worthies a man realy to give no odk and lake nome, so long as his opponents eonfronted him in the open; but nowise intended for the spiritual rôle of a martyr. In a fit of indignation he burned his manuscripts, left Padua, and accepted the luerative post of conte physician to Emperor ('harles V. He manried, settled down, became a comtier, and gave up anatomy so completely that, fluring the long. tedions years in Marlrid, "he could not get hold of so much as a dried skull, let alone the chance of making a dissection." He paid the penalty of "the great refusal" when his favorite pupil, Gabriele Falloppio, came to the front as a worthy sucfessor, and rumor hegan to make it clear that he himself was fast beconing the shadow of a great name-

Tesalius, who's Vesalius? This Fallopius

It is who dragged the Cialen-illol down.

On receiving the Fallopian Observationes anatomice in 1561, all the aspirations of his youth revived, if we may trust his own burning, enthusiastic words, language which fully justifies the implications of Edith Wharton's poem:

\section{At least}

I repossess my past, am once again

No courtier med 'cining the whims of kings

In muffled palace-chambers, but the free

Friendless Yesalius, with his back against the wall,

And all the world against him.

In the year 1563 Vesalius set out on a pilgrimage to Jerusalem, as a penance, some say, for an accidental human vivisection; more probably, the botanist Clusius thonght, as a pretext for getting away from his tiresome surrounclings. On his way back, in 1564, he received word of an invitation to resume his old chair at Padua, just vacated by the death of Fallopius. But his highest wish, to "once more be able to study that true Bible, as we count it, of the human body and of the nature of man," was not to be realized The sudden access of an obscure malady left Vesalius to die solitary and unfriended, on the island of Zante. 
The principal works of Vesalius include six anatomie plates (Tabula anatomicas), printed at Veniee in $153 \mathrm{~s}$, and reprinted in facsimile by vir William Sterling Maxwell in 1S74; the Epitome (Basel, 1540), an atlas compendium of the Fabrica, remarkable for the plates representing two handsome specimens of the human race, usually aseribed to Titian ${ }^{1}$; the epistle on the China root (1542), which contains much acute criticism of Galon, and is especiatly valuable for the light it throws upon the life of Vesalius; finally the Fabrica itself, published in June, 1543, a superb example of the beautiful typography of his friend Oporinus (Herbst) of Basel, sumptuonsly illustrated by Titian's pupil, Jan Kalkir, who was the first to attain what Choulant ealls the true anatomie norm, that is, a pieture at once seicntifieally exilet and artistically beautiful, summing up, as in a composite photograph, the innumerable peculiarities and minor variations in structure encountered in dissertion. The splendid wood-euts, representing majestic skeletons and flayel figures, dwarfing a background of landseape, set the fashion for over a century, and were copied or initated by a long line of anatomic illustrators, sueh as Walther Ryff, Geminus, Tortebat, ${ }^{2}$ Valverde di Hamuseo, Dulanrens, Casserius, and Bidloo. In the second Basel edition of 1552-5, the beautiful typography of Oporinus appears in enlarged font, the fanlty pagination and index of 1543 are eorrected and improved, the text is revised and more seientifie. Of the two editions, the second is much the better worth having.

While written in Latin, the "Fabrica" is truly vernacular in the sweeping scorn and violence of its language in dealing with Galenical and other superstitions. Although it eompletely disposes of Galen's osteology and muscular anatomy for all time, and, indeed, recreates the whole gross anatomy of the human body, it has never been translated. The dubious relations of the azygos vein, the rete mirabile of quadrupeds, the eanine sealenus and simian rectus abdominis, the four- and five-lobed liver, the sevensegmented sternum, the double bile-duet, the horned uterus, the interventricular pores, the hypothetic sutures in the maxillaries, all these Galenic errors are roughly swept aside, along with the bone Luz, Adam's missing rib, the os cordis cervi as a remedy for heart disease, and other current superstitions. The edition of 1552-5 closes with a chapter on vivisection in which Vesalius verifies Galen's experimental sections of the spinal cord and recurrent laryngeal nerve, proves the general funetions of musele and nerve by section, shows that artificial respiration will keep an animal alive after its chest has been opened, and that a quiescent heart may be resuscitated by the use of the bellows. In his chapter on the brain, he appears, in theory, at least, as a pioneer of experimental and eomparative psychology, rejecting the current view that the cerebral action of brutes differs from that of man. He was also a pioneer in ethnie eraniology, noting the globular shape of the skull in the Genoese, the Greeks, and the Turks, the flattened occiput and broad head (brachycephaly) in the "Germans" of his time, and the oblong skull of the Belgians. He made many

1 Titian's portrait of Vesalius is in the Pitti Palace at Florence.

2 Tortebat was a pseudonym of Roger de Piles (Choulant). 
postmortems, noting the sonile changes in the joints, the prolapse of the omentum in serotal hernia, the rote of the fossa navieularis urethare in infection, the relations of splenic to hepatic disease, and the bid coferets of corsets upon the viscera. As a clinician, he was the first to diagnose and describe anemrysm of the abdominal and thoracic artal (1555'). In 1562 he performed a suceessful opreration for cmpyema upon Don Carlos of Aragon, and was sucessiful in two other cases of this procedure, as also in excisions of the eancerous hreast. However seornful and truculent in his greneral onslaught against superstition, Vesalius displays the airy

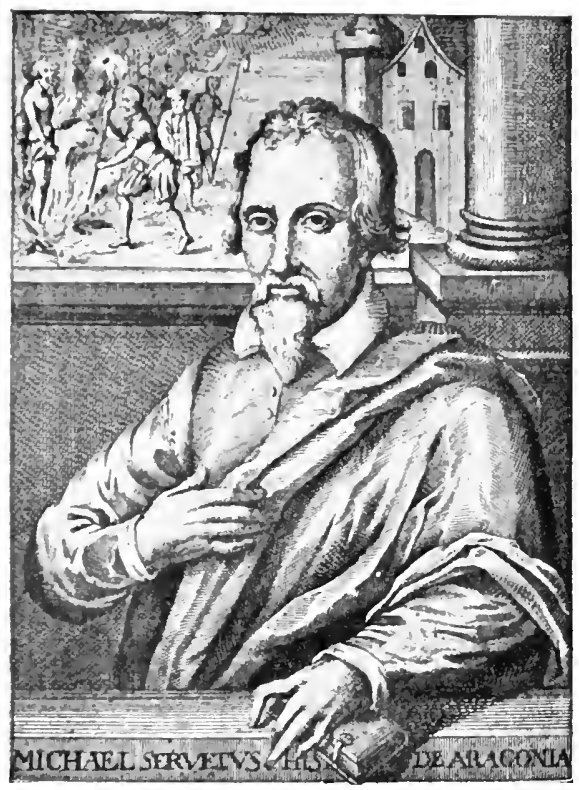

Michael Servetus (1509-53). skepticism of a man of the word in dealing with these teleologic points so dear to medieval theologians. For instance, tourhing the Galenical crux that the blood passes through certain hypothetic pores in the ventricular septum, he says, "We are driven to wonder at the handiwork of the Almighty, by means of which the blood sweats from the right into the left ventricle through passages which escape the human vision."

What fate might have befallen him had he gone further is seen in the ease of the heretic Miguel Servede or Servetus

(1509-53), whom Calvin caused to be burned at the stake for a mere juggling of verbiage, a theologic quibble. Servetus was one of the worll's martyrs for "the crime of honest thought." His discovery that the blood in the pulmonary circulation passes into the heart, after having been mixed with air in the lungs is recorded in his book, the Restitutio Christianismi (1553), of which only the copies at Paris and Vienna are known to exist, the others having been burned with him. The rare Nuremberg reprint was published in 1790 .

${ }^{1}$ See G. H. Velschius, Sylloge, Augsburg, 1667, pt. 4 (Rumber), pp. 46, 47, and Roth's Vesalius, p. 239. 
The surpassing ability of Vesalius is seen not only in his establishment of anatomie norms for the deseription and figuration of the bones and muscles, in his thorough descriptions of such parts as the eye, the ear, the accessory sinuses of the nose, the pituitary body, or the pelvie cavity, but in his clean sweep of the whole subject. His ideas were sustained by his pupil Fallopius, and opposed not only by Sylvius and Columbus, but by an anatomist of equal rank with himself, Bartolommeo Eustachi (1524-74), called Eustachius. The latter was professor at the Col-

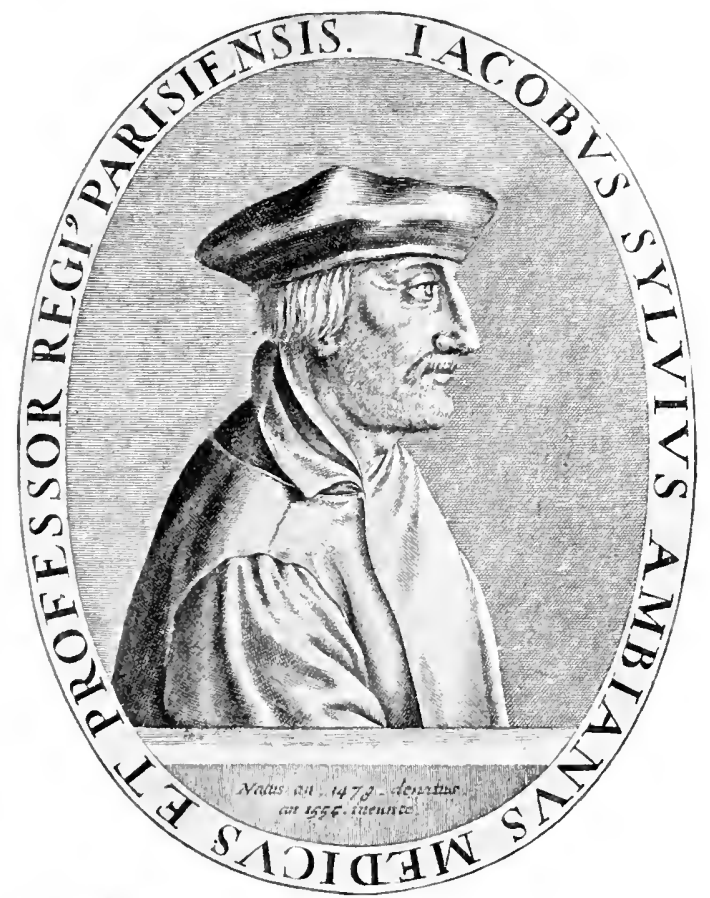

Jacques Dubois (Sylvius) (1478-1555).

legia della Sapienza in Rome, where, in 1552, he eompleted his Tabula anatomice, a set of superb plates, drawn by himself, which remained unprinted in the Papal Library for one hundred and sixty-two years. Finally Pope Clement XI presented the engraved plates to his physician, Laneisi, who, by the advice of Morgagni, published them with his own notes in 1714 , these being the first anatomic plates on copper. The execution of these plates is dry

${ }^{1}$ Vesalius called it the "glandula pituitam cerebri excipiens," and thought it sccreted the mucous discharges of the nose (Fabrica, lib. vii, cap. xi). 
and hard, hut they are more aceurate in delineation than those of Vesalius. Eustachius discovered the Eustachiatu tube, the thoracie duet, the suprarenal bodiest (1563), and the abducens nerve; aresibed the origin of the opt ie nerves, the eochleat, the pulmontary veins, the museles of the throat and neck, gave the first correct pieture of the utcrus, and wrote the best treatise of his time on the structure of the teeth (Libellus de demtibuss), giving the nerveand blood-supply. Although Eustachius declined to oppose Galenism, he was a natural genius in discovery. Jaeques Dubois $(1+78-1555)$, called Sylvius, Vesallius' teacher at Paris, was, in spite of his large following of pupils, a harsh, avaricious bigot, whose derotion to Gallen was such that he declared Vesalins to be a madman (resanus), and said, in reference to Galen's errors in human anatomy, that "Nan had changed but not for the better." Srlvius named the jugular, subclavian, renal, popliteal, and other blood-ressels, gave equally characteristic names to many of the muscles, which we still retain today, and, in his Isagoge (Venice, 1536), was one of the first to mention the Sylvian aqueduet ${ }^{2}$ and the valves in the veins.

The other opponent of Vesalius, Matteo Realdo Colombo (1516:-1559), (alled Columbus, is sometimes spoken of as the discoverer of the pulmonary circulation, but the work in which his undoubtedly excellent account is contained, his De re anatomica, was published in 1559 , at least six years after the burning of Servetus and his book; and there is some internal evidence indicating that Columbus may have plagiarized his facts from Scrvetus, as he certainly did in the case of Vesalius and Ingrassias (discovery of the stapes in the ear). Cohmbus begins his work with a title-page engraving, imitated from the frontispiece of the Fabrica, and, like Vesalius, winds up with a chapter on vivisection. ${ }^{3}$ In prosecuting vivisection, he had the cleverness to substitute dogs for hogs, but while he professed a horror for human vivisections, he seems correspondingly callous in reference to the sufferings of the canine creatures which, as he constantly reminds us, he cut up in such numbers for the anusement of this or that exalted personage. Columbus showed by vivisection that the pulmonary veins contain blood, and while he held to the ancient theory of

1 "Glandulæ renibus incumbentes," ealled "eapsulæ renales" by Spigelius (1627) and "eapsulax suprarenales" by Riolanus (162S).

${ }^{2}$ As Dr. Frank Baker has pointed out, the aqueduct between the third and fourth ventrieles of the brain, attributed by various writers indifferently to Jacobus and Franciseus Sylvius, was deseribed and figured by other anatomists long before the time of either. Johns Hopkins Hosp. Bull., Balt., 1909, vol. $\mathrm{xx}, 329-339$.

${ }^{3}$ For a very excellent tranclation of this work see Dr. L. C. Boislinière's paper on Columbu- in st. Louis Med. Rev., 1906, liv, 357-362. 
the cooling effect of respiration on the blood, he believer that, in the lungs, it is rendered "spirituous" by inmixture with air.

Gabriele Falloppio (1523-62), or Fallopius, a loyal pupil of Vesalius, discovered and described the chorda tympani, the semicircular canals, the sphenoid sinus, the ovaries (Fallopian tubes), the round ligaments, the trigeminal, auditory, and glossopharyngeal nerves, and mamed the vagina and placenta. He was also a versatile writer on surgery, syphilis, mineral waters, and other subjects. Like Berengarius and Vesalius, he was falsely accused of vivisecting human beings in his ardors of research. ${ }^{1}$ His pupil, Hieronymus Fabricius ab Aquapendente (1537-1619) was Harvey's teacher at Padua, and built, at his own expense, the fine anatomic theater in which Morgagni afterward worked. His studies of the effect of ligatures and the valves in the reins (first noted by Erasistratus, Estienne, and Cammani) influeneed Harvey in his experiments to demonstrate the circulation of the blood. He wrote many important treatises on anatomy, embryology (De formatu fotu, 1600), physiology, and a surgical Pentateuch (1592). The names of the anatomists Costanzo Varolio (1543 $-75)$, or Varolius, physician to Pope Gregory XIII, Giulio Cesare Aranzio

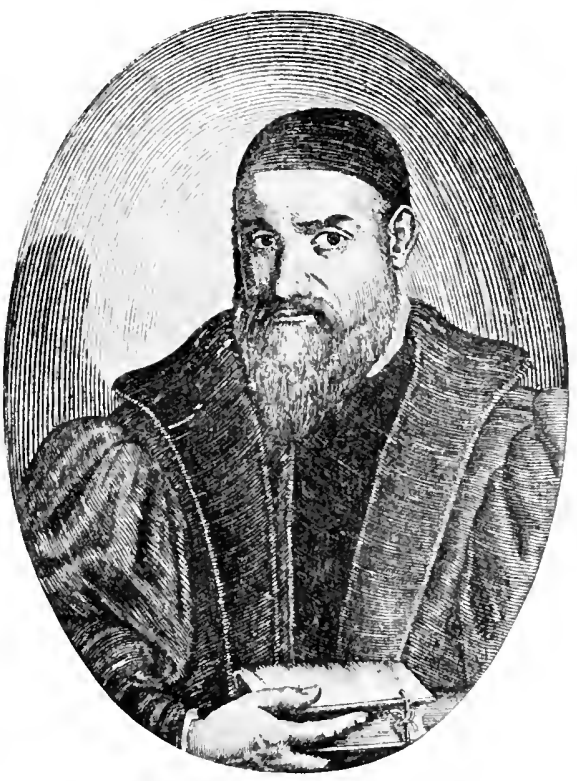

Gabriele Falloppio (1523-62). (1530-89), professor at Bologna, and Guido Guidi (died 1569), called Vidius, the organizer of the medical faculty of the College de France, have been eponymically preserved in the structures they discovered. Varolius, in particular, marle some eapital investigations of the nervous system, describing the crura cerebri, the commissure, and the pons.

${ }^{1}$ Berengarius himself explains (Commentaria, 1521, fol. 2 b) that what he calls "anatomia in vivis" was, in realit $y$, the so-ealled anatomia fortuta, $i$. $e$., the anatomic knowledge naturally gained by the surgeon in opening the body anywhere, the equivalent of Naunyn's "autopsies in vim." The prejudice of the ignorant and vulgar was exeited by the superstitious horror of surgery, the cries of the patient, etc. See Choulant, Geschichte der anatomischen Abbildung, Leipzig, 1852, 28. 
Apart from the striking woolduts in Vesilius, France and Spatu fombisher two excellent examples of analomic illustration

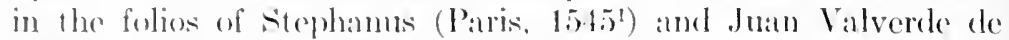

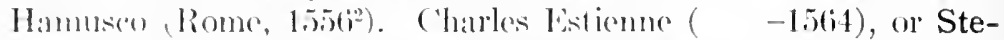
phanus, a pmpil of sivlyius at lauris, and a prominent pullisher of medical books during the Rematissuner, was persecuted and imprisoned for heresy and died in prison. Estienne was the first to mention the valves of the veins as "apophyses membranarum," and his treat ise also contains the first description of syringomycliar $\left(1545^{3}\right)$.

'The anatomy of Thomas Vicary, published in 1577 and reprinted by Furnirall for the Early English Text soelety in $1 \mathrm{~s} 8 \mathrm{~s},{ }^{4}$ has been proved by the late Dr. J. F. Payne to be at transeript of a fourtenth aentury manuscript based upon the anitomy of Lanfranc, Guy, and Mondeville, and is, therefore, valueless as at representative of Renaiswance ideas upon the subject. The book has a ertain bibliographie interest of a romantic character, in that an edition, published in 15is, was once seen or heard of by somebody, but has never since been fouml.

The effect of Vesalius on Renaissance surgery is seen in the life work of Ambroïse Paré (1510-90), who made the Fabrica popular and accessible to surgeons by writing an epitome of it in the vornacular. A rustic barber's apprentice when he cane up from the provinces to Paris in 1529, and afterward a dresser at the Hôtel Dieu, Paré became an army surgeon eight years later, was incontinently thrown into the wars, where he soon male himself the greatest surgeon of his time hy his courage, ability, and common sense. Snubbed by the College of St. Come, and ridiculed as an upstart because he wrote in his native tongue, he made his way to the front on the field of battle. Iike Tesalius and Paracelsus, he did not hesitate to thrust aside ignorance or superstition if it stool in his way. Yet this greatest of army surgeons was so well beloved by his comrades that, one night, when he slipped into Metz incognito, he was sought out and carried through the city by them in triumph; and Brantome and Sully record that he was the only Protestant to be spared (by royal mandate) at St. Bartholomew. In personality, Paré stands between his surgical peers, the rude, outspoken Hunter, and the refined, self-

1 Stephanus: De dissectione, Paris, 1545. As some of the plates in this work were signed as early as 1530-32, and are not unlike certain plates of Vesalius, some have charged the latter with plagiarism, but this would seem to be sufficiently disprovel by the appearanee of Vesalius' six Venetian plates. in 1538, seven years before Estienne's De disscetione was published (1545).

2 Juan de Valverde de Hamusco: Historia de la composicion del euerpo humano, Roma, 1556.

${ }^{3}$ Stephanus: De dissectione, $\mathbf{1 5 4 5}$, iii, eh. 35.

${ }^{4}$ It is thought that there was an edition of Vieary published in 1548 . See Payne: Brit. Med. Jour., Lond., 1896, i, 200-203. 
possessed Lister, as a man equally at home in the rigors of camp life and the slippery footing of courts.

Parés greatest contribution to surgery hinges on the baneful effect which the psendo-Hippoeratic aphorism that "diseases not curable by iron are curable by fire" excrted on the treatment of gunshot wounds, the new feature of Renaissance surgery. Ciovanni di Vigo (1460-1520), physician to Pope Julius II, had taught in his Practica (1514), like Brunschwig before him, that such wounds were poisoned bums, and, therefore, should be treated with a first dressing of boiling oil. How Parés supply of boiling oil gave out one night in camp and how he profited by the experience to the extent of letting well enough alone in future is a

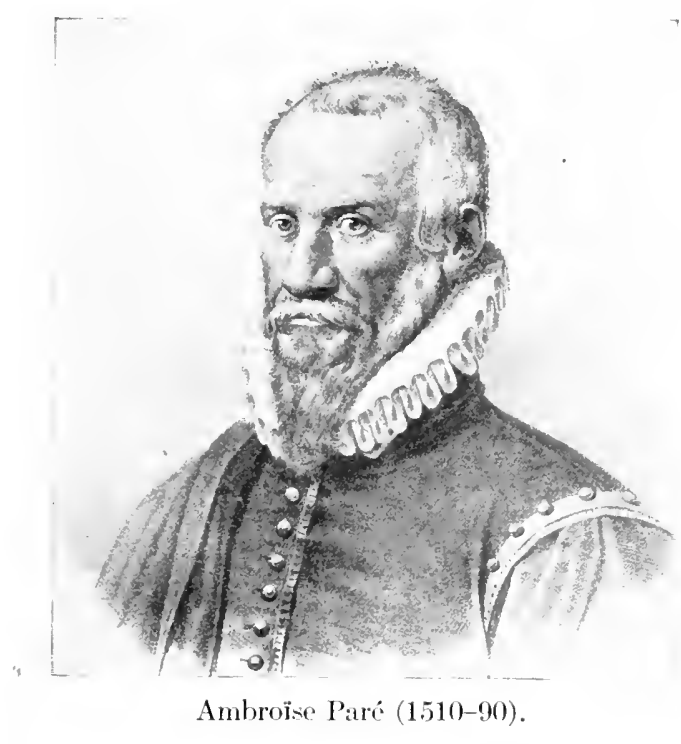

well-known story. Had it not been for his "fat of puppy-dogs," a lard or salve, which, from some tenacity of superstition, he continued to apply, he would have been a true asepsist. As it is, his relation to the healing power of nature is summed up in the famous inscription on his statue, "Je le pansay, Dicu le guarit." Paré invented many new surgical instruments, made amputation what it is to-day by reintroducing the ligature, which had almost fallen into abeyance since the time of Celsus; was the first to popularize the use of the truss in hernia; did away with the strolling surgeons' trick of eastrating the patient in herniotomy; introluced massage, artificial limbs, artificial eyes (of gold and silver), ind staphyloplasty, and made the first exarticulation of the elbow- 
joint (1536). Ho described fracture of the neck of the femur and strangury from hypertrophy of the prostate, and was the first to sugrgest syphilis as a rause of ancurysm. As Dr. Howard A. Kelly hats pointed out, he was probubly also the first to see flies as tramsmitters of infections discelse. In obstetries, it was his deseription and use of pordalid version that made the procedure viable and practicable, and he hat the courage to induce artificial labor in case of uterine hemorrhage. In dentistry, he introduced reimplantation of the teeth, and his little treatise on medical jurisprudence (1575) wats the first work of conseguence on the subject prior to the Wethodus testificandi of ('odronchi (1597).

l'arć is a garrulous, gossipy, sometimes obsenre writer, and, like other medicall eelebrities of his day, by no means free from the "valnity of solf-reference which aceompanies great and even snall reputations."' His many references to Hippocrates and the ancients lead us to suppose that, like Bartisch, he employed a secretary or pion to embellish his writings for him, since it is most unlikely that he acquired his learning by actual study. His principal works are his treatise on gunshot wounds $\left(1545^{3}\right)$, his essay on podalic version $\left(1550^{4}\right)$, his great treatise on surgery (1564), and his discourse on the mumny and the unicorn $\left(1582^{5}\right)$, which successfully disposed of an ancient therapentic superstition. A curious book is his treatise on monsters, terrestrial and marine (1573), embellished with pictures of many of the strange, hypothetic creatures which emanated from the brain of Aristotle.

The Practica Copiosa of Vigo (1514) had a suecess out of all proportion to its value, running through some 52 editions and innumerable translations, beeause it was almost the only book before Parés time which dealt with the two great problems of Renaissanee surgery, epidemie syphilis and wounds from firearms. Parés eampaign for a soothing treatment of gunshot wounds was very ably seconded by Bartolommer Maggi (1516-52) of Bologna, who, in 15.51, demonstrated experimentally that such wounds eould be neither burned nor poisoned. Another book which advanced this view was An Excellent Treatise of Hounds mode by Gonncshot (London, 1563), by the English surgeon, Thomas Gale (1507-86?). The anatomist, Giacomo Berengario da Carpi, was another pioneer in the simple treatment of gunshot wounds. He deseribes two cases of exeision of the uterus for prolapse, one performed by himsel (1517), the other by his father and nephew. ${ }^{6}$

Two other Italian surgeons well deserving of mention are Ma riano Santo di Barletta (1490-1550), a Neapolitan, who gave th'

1 Johns Hopkins Hosp. Bull., Balt., 1901, xii, 240-242.

2 Rodomontades, as they were alled, were the fashion of the period, an Brantôme wrote a whole book on the subject.

${ }^{3}$ Paré: La manière de traicter les plaỵes (etc.), Paris, 1545.

${ }^{4}$ Briefve eollection de l'administration anatomique (etc.), Paris, 1550.

${ }^{5}$ Discours, a savoir, de la mumie (ete.), Paris, 1582.

${ }^{6}$ Carpi: Commentaria, Bonn, 1521, f. ecxxv. 
original aceount of the "Marian operation" or median lithotomy $\left(1535^{-1}\right)$; and Ciasparo Tagliacozzi (1546-99), of Bologna, who in $1597^{2}$ revived the operation of rhinoplasty, which had been, during the fifteenth century, in the hands of a Sicilian family of plastic surgeons, the Brancas of Catania. For this innovation, Tagliacozzi was roundly abused by both Paré and Fallopius, and satirized during the following century in Butler's "Hudibras," while the ecclesiastics of his own time, we are told, were fain to regard such operations as meddling with the handiwork of Cod. 'Tagliacozzi's remains were exhmmed from the convent, where they reposed, to be buried in unconsecrated ground, and in 1788 the Paris Faculty interdicted face-repairing altogether. In this way plastic surgery fell into disrepute and disuse until the time of Dieffenbach. Jike the Brancas, were such itincrants as the Norsini, who were skilful in hernia and lithotomy, and the Colots, who cut for stone only. Out of this class was evolved the great Provençal surgeon, Pierre Franco (1553- ), a Huguenot driven by the Waldensian massacres into Switzerland, who did even more than Paré to put the operations for hernia, stone, and cataract upon a definite and dignified basis, ${ }^{3}$ and was the first to perform suprapubic cystotomy (1556). Felix Wütz (1518-75) was a follower of Paracelsus in the simple treatment of wounds, and a vigorous opponent of the common custom of thrusting "clouts and rags, balsam, oil, or salve" into them. His "Surgical Practice" (Practica der Wundartzney) (Basel, 1563) was, like the Traite des hemies of Franco (Lyons, 1561), written in the vernacular, and is the fresh, straightforward work of a genuine child of nature. William Clowes (1540-1604) was probably the greatest of the English surgeons during the reign of Elizabeth. Experienced both in military and in naval medicine, he became consulting surgeon at St. Bartholomew's Hospital in 1581, served as fleet surgeon against the Armada in 1588, and was afterward made physician to the Queen. His works include a treatise on gunshot wounds (London, 15914), and are pronounced by Dr. Norman Moore to be "the very best surgical writings of the Elizabethan age." As a satirist of the seamy side of medicine in his day, Clowes compares with Gideon Harvey and Butler in the seventeenth century or Snollett in the eighteenth. The Scotch army surgeon, Peter Jowe, founded the Faculty of Physicians and Surgeons of Glasgow (1599), and made the first English transla-

${ }^{1}$ Marianus Sanctus Barolitanus: De lapide renum, Venice, 1535.

${ }^{2}$ Tagliacozzi: De eurtorum chirurgia per insitionem, Veniee, 1597.

${ }^{3}$ Pierre Franco: Petit traité (Lyons, 1556) and Traité des hernies, Lyons, 1561. Edited by E. Nicaise (Paris, 1895).

${ }^{4} \mathrm{~A}$ proved practise for all young chirurgians conecrning burnings with gunpowder and wounds made with gunshot (ete.), London, 1591. 
tion of Hippoerates (1597). Ilis Whole Course of Chirurgerie (1597) passed through four oditions, and contains the first reference in binglish to ligation of the arteries in anputation. There were a numbre of spantish surgeoms in the sixternth eentury, such as fran(risco Areco (1.493-1571), who followed Vigo in the treatment of wounds, or Dionisio Daça ('hacon (1510- ), who opposed him, but their works are only of bibliographic interest.

In the year 1500, Jacol Nufer, a sow-geleler, performed a succossful ('esarean section upon his own wife--sbe livel to be seventy-seven and bore other rhilden-and this start in operative gynecology was suceeded by other Cesarean operations-those of Bain (1540), Dirlewang (1549), and so on, until we find Francois Rousset enumorating as many as 15 successful cases in his L'IIysterotomotokie (1580). Another sow-gelter perfomed double ovariotomy upon his own daughter, aceording to Johann Weyer (1515-SS), the great Dutch opponent of the persecution of witches, who was himself an able physician and a surgeon enterprising cnough to treat amenorrhea from imperforate hymen by incision of the membrane.

The growth of interest in diveases of women during the Renaissanee period is seen in the huge "Grnacia," or eneyclopedias of gyneeology, issued by Caspar Wolf (1532-160i), of Zürich, in 1566, which was later enlarged by Caspar Bauhin (1550-1621), of Basel, in 1586. These two eompilations of the best that larl been written upon the subject were afterward reprinted in one volume by Israel Spach, of Strassburg, in 1597. Encyclopedic treatises on medicine by many authors, not unlike the "up-to-date" works written on the coöperative plan in our own time, were a speeial feature of Renaissance medi('ine, and of these we may mention, in addition to the Basel eneyelopedias of gynecology, the Aldine Medici Antiqui Omnes (1547), the IIedice Artis Principes of Stephanus (1567), the Venetian anthology of mineral waters, Dc Balneis (1553), the Gesner eolleetion of surgieal treatises (Zürich, 1555), and the medical dictionaries of Symphorien Champier (1506), Lorenz Phryesen (1519), Henri Estienne, or Stephanus (1564), and Jean de Gorris or Gorræus (1564). With these may be elassed the concordance of expressions from Erotian by Eustachius (1566), the Varia Lectiones (1571) of Geronimo Mercuriali and the Economia IIippocratis, a similar exegesis by Anutius Fosius $(158 s)$.

The cager, inquiring spirit of Renaissance humanity, greedy as a growing child for new knowledge, is sensed in the immense popularity of such a work as the Hortus Sanitatis (1491), with its quaint, colored wood-cuts of real or farciful animals and plants. This picture book was so much sought after, in fact, that it was soon followed by a number of genuinely scientific treatises on botany and by extensive "Bestiaries," or animal-books, which described and figured the actual and mythologic creatures which did or did not exist from the times of Aristotle and Pliny down.

${ }^{1}$ De chirurgia scriptores optimi quique veteres et reentiores, 1555. 
Of the latter, we may mention Ambroise Parés illustrated treatise on monsters (1573), the II istoria animalium (Zürich, 1551-\$7) of the Swiss naturalist Comrad Gesner (1516-65), calted the German Pliny, and the many publications of Ulisse Aldrovandi (1522-1605) of Bologna. These rude brginnings of zoölogic scienee, as Allbutt says, "mostly after Pliny's kind," were far inferior to the works of the German Fathers of Botany. The earliest of these, Otho Brunfels (1464-1534), of Mainz, originally a Carthusian noviee, went over to Luther, graduated in medicine at Basel at the ane of sixty-five, and was appointed city physician at Berne in 1533. His Herbarm live leones (Strassburg, 1530-36), which marks an epoch in the history of botanic illustration, consists of 135 careful figurations of plants executed by Hans Weyliz, the best wood-engraver of Strassurg in his day. Brunfels prepared the work at his own expense, to offset the wretehed engravings of the Hortus Sanitatis. In his text, he makes no attempt at original plant description, but simply follows Theophrastus, Dioscorides, Pliny, and the other authorities up to his time. His Onomastilion (1543) is a dictionary of simples. He was one of the first to publish a bibliographic list of eminent physicians and their writings (1530). Next in order came the Bavarian physieian, Leonhard Fuchs (1501-66), who graduated at Ingolstadt in 1524, and after many vicissitudes (he was also an adherent of Luther), held the chair of medicine at Tübingen for thirty-one years (1535-66), where he occupied his leisure in having artists figure plants which he afterward deseribed. His De Historia Stirvium (Basel, 1542), containing over 500 plates, superior to those in Brunfels' book, which had inspired it, created such an interst that it was followed, in 1544, by a new edition, and, after 1545 , by many small-sized popular reprints. In purpose, it was entirely utilitarian, the work of a busy praetitioner who wished to inprove the actual knowledge of the materia medica over and above advaneing the science of botany. Plant description, or phytography, took its first fresh start since the days of Theophrastus in the work of Hieronymus Bock (149S1554), ealled Tragus, a poor schoolmaster and gardener, born near Heidelherg, who paid the usual penalties of sympathizing with Luther, and finally died as pastor of a little Protestant chureh at Hornbach. Tragus loved plants for themselves, and in his Now Kreutterbuch (1539), and in the Kreutterbuch of 15.6, wrote down in the vernacular his fresh first-hand descriptions of what he saw. A far greater than Tragus was Valerius Cordus (1515-44), the gifted Prussian youth, whose early death robbed scienee of one of its most promising names. As the son of the physician-bot:mist, Euricius Cordus, he is known to medicine for his discovery of sulphurie ether (oleum dulec vitrioli) in 1540 ; but botanists revere him is the young Mareellus of their science. Greene styles him "the inventor of phytography," and points out that the field-work and taxonomy of a well-equipped modern botanist were actually done "almost four centuries ago by a Grrman boy in his teens." His posthumous eommentary on Dioscorides, edited with pious hand by Conrad Gesner (Strassburg, 1561), not only deseribes some 500 new speeies of plants, the ardent seareh for which eventually cost him his life, but recreates the species listed by Dioseorides in terms of modern botany. The Dispensatorium of Cordus (Nuremberg, 1535) is of interest as the first real pharmacopeia to be published. ${ }^{1}$ It was more reprinted than any other work of its kind, passing through 35 editions and 8 translations. It was preceded by the Venetian Luminare majus (1496) and the Florentine Antidotarium (1998), and followed by the three Basel dispensatories of Leonhard Fuchs (15.5), Anutius Foosius (1561) and J. J. Weeker (1595), also the eity pharmacopeias of Mantua (1559), Antwerp (1561), Augsburg (1564), Cologne (1565), and Bergamo (15802).

${ }^{1}$ In this account of the German Fathers of Bolany I am mueh indehtert to the "Landmarks of Botanieal History," by Dr. Edward Lee Greene (Nmithsonian Misc. Collect., v, 54, Washington, 1909. pp. 169-314). Charming in style and irreproachable in scholarship, this work is cordiatly recommended to physicians as the most interesting history of early botany and materia mediea that has yet appeared.

2 Tschirch: "Die Pharmakopöe ein Spiegol ihrer Zeit," Janus, Amst., $1905, \mathrm{x}, 281 ; 337 ; 393 ; 449 ; 505$. 


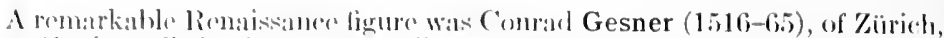

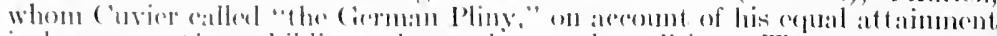

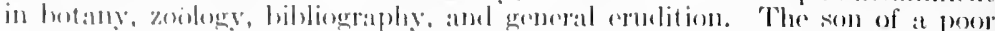
furrier, ame in great want in his carly days, he graduated in medicine at basel in 1.ill. and after a roving lifo as a practitimer in many buropean cities, he Was at lemgth appeinted professor of natural histery at Kairiel in 1555, was emothed in litit, and sacrilied his life to the plague in the following year.

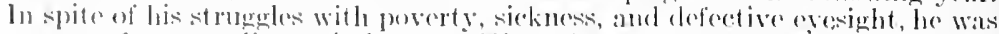

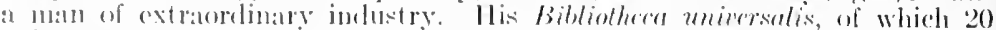
volumes were published (15.5-19), was the first example of gool bihliography before llaller's time, and is, in intention, a catalogne, in Lation, (ireck, and Hobrew, of all the writers who hase ever lived. 'The medical part was mufor-

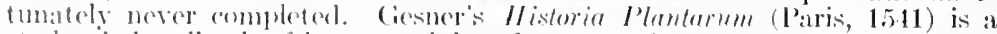

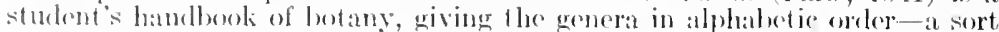
of pereliet diefionary of plants. Ile celited and published the works of Valerius

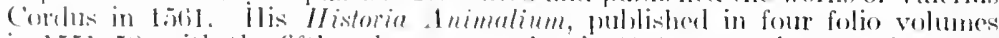

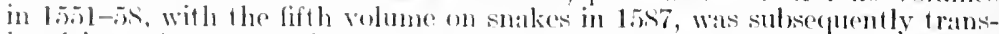
lated inte (iemuan as the Thiobuch, and berame one of the starting-points of modern \%ö̈logy. It contains some 1500 follo pages, comprising a digest of alout 250 atuthors, and illustrated with nearly at thomsand wood-ents, of which (iesuer selected some of the best of the period, inclueling Albert Diirer's rhinoecros. Ilis index of purgatives was published by froben in 15.13.1 Gesner mate some amious assays in other diroctions, such as his Mithridates, an account of 130 ) lifferent limguages, with the Lord's P'rayer translated into 22 of them; and he is known to Aprine enthusiasts through his epistles on mountain climbing and his deseription of Mount Pilatus (1555). He was also the first to describe the eanary-hird.

C'aspar Bauhin (1550)-1624) was profossor of anatomy, botany, meelicine and Greek at Basel, and afterward city physirian and reetor of the university. His greatest work is the eetebrated "Pinax" (159ti), a wonderful index or compend of all the botanic literat ure un to his time, which, it is sajol, has been more stulied and commented upon by botanists than any other work exeept that of Disscorides. Bauhin also wrote a Theatrum Botanicum which he left incomplete (165s), and a catalogue of the plants around Basel. His Theatrm Anatomioum (1592) is a valuable historic summary, as also his Anatomica Mistorin (1597). It contains an interesting aceomint of the ancient Hebrew myth of the bone "Liz," in which the latter term appears for the first time outside the Rabbinical writings.

Pierre Belon (1517-64), or Bellonius, the author of a valued treatise on coniferous plants (1553), published, in 1555, a monograph on birls, in which he compared the skeletons of birds and man in the same posture and "nearly as possible bone for bone." This was the first of those serial arrangements of homologies which Owen and Haeckel afterward made famous. In 1546-9 Belon traveled in Egypt, (ireece, and the Orient, carelully studying the ancient and modern materia medica.

Besides the German Fathers of Botany, all of whom were medical men, we should mention a number of other prominent physician-botanists of the Renaissance period who did much to make the science what it is to-day. Of these. Jean de la Ruelle (1474-1537), or Ruellius, was physician to Francis I, but later became a canon and died in the eloister. Ruellius was an able bot anist who had the courage to aceept all of Leonicenus' corrections of Pliny, made the first Latin translation of Dioscorides, with a good commentary, and in his De Natura Stirpium (Paris, 1536) was the first to give a full description of each plant, adding many new species and giving to each the popular French names, which he got by questioning the peasants and mountaineers on his excursions. Antonio IIusa Brassavola (1500-55), of Ferrara, a pupil of Lconicenus, described over 200 different kinds of syphilis, is said to have performed tracheotomy, and wrote a book of purges (15.5), and a witty imaginary conversation entitled, "An Examination of Medicinal Simples" (Examen

${ }^{1}$ Gesner: Enumeratio medicamentorum purgantium, Basel, 1543. 
omnium simplicium, Rome, 1536), in which some new drugs are permanently introduced into the pharmaeoporia. This genial idea, so characteristie of the Renaissance, of easting a botanical treatise into the form of a rialogue, had already been utilized by Euricius Cordus (1486-1535), the father of Valerius, in his Botanologicon (Cologne, 1534), in which he severely arraigns the German druggists of his time for falsely labeling their jars and receptacles with old Greek names which did not apply. Pietro Andrea Mattioli (1501-77), of Siena, ealled the Brunfels of Italy, wrote a vernacular commentary on Dioscorides (Venice, 1544)-now exceedingly rare-in which, like Brunfels, he illustrated the plants, following Ruelius in giving a full deseription of rach, and adding between 200 and 300 new speeies from southern Europe. Rembert Dodoens (1517-85) of Malines, Beloium, physician to Maximilian II and Rudolph II, was, like Gesner and Bauhin, a polyhistorian, now best remenbered as a botanist. His Cruydtboeck (Antwerp, 1553), his treatise on purgatives (1554), and other works were afterward assembled in his Stirpium historice (15S3), a huge tome, containing 1341 illustrations, whieh was the original of Gerard's Herball of 1597 . In his posthumous treatise on practice (1616), he gave an accurate account of the spasnodic form of ergotism.

Andrea Cesalpino (1524-1603), professor of medicine at Pisa, and physieian to Pope Clement VIII, is regarded by the Italians as a discoverer of the circulation before Harvey (1571-93), and has been honored by them with statues and a medical journal bearing his name. Cesalpinus had indeed grasped, as pure theory, the truth about the systemic and pulmonary circulations, viz., that the heart, in systole, sends blood into the aorta and pulmonary artery, and, in diastole, receives it back from the vena cava and pulmonary vein. But his ideas were not supported by any convineing experiments and were thrown out in a purely controversial spirit, as an additional argument against Galenism. They therefore had no influence upon his contemporaries and are to be entirely dissociated from Harvey's experimental demonstration, as bald theory from actual proof. Cesalpinus was an ardent theologian, and his Pantheism got him into trouble with the Chureh. Although a rigid Aristotelian, he was also an able naturalist, taught botany as well as medicine at Pisa, and was in charge of the Botanic Garden which had been founded there in 1543. Cesalpinus was called by Linnæus the first true systematist (primus rerus systematicus) in botany. He collected plants from all over Europe, was the first to elassify them by their fruits, ranging some 1520 plants into fifteen classes by this plan; and his great work $D e$ Plantis (Florence, 1583) led to the distinetion between systematie and applied (economic) botany.

Giovanni Battista della Porta (1536-1615), of Naples, who invented the camera obseura (1588), described the opera glass (1590), and was indeed one of the principal founders of opties, was also an opponent of witeheraft, and, in his De Humana Physiognomia (Sorrento, 1586), a forerumer of Lavater in estimating human character by the features, although he made the usital totemic error of assigning eharacteristic animal traits to individuals who 
looked like particular animals (Jastrow). He believed in the doctrine of signatures. In botany, Porta was the first ecologist, grouping plants, in his Phytognomonica (1583), according to theip geographic locale and distribution. He was a prolific writer of eomedies. Ite went in for magic, and the Accademia de' segrete, which he founded for this purpose in 1560 , was suppressed by Pope Paul III.

Pierre Bclon (1517-1564), or Bellonius, wrote an important little book on coniferous or resiniferous trees (1553) and the semplici (Venice, 1561) of Istigi Anguillara is a botanical classie. The earliest English contributions to botany were the "Ilerbals" of Richard Banckes (1525), Peter 'Treveris, (1529), Thomas Petyt (154I), William Middleton (1546), Willian Turner, ealled the Father of English Botany (1551), and of the barber-surgeon, John Gerard $\left(1597^{2}\right)$. 'The medicinat plants of the New World were described by Ovierlo y Vallez, viceroy of Mexico (1525), and by Nicholas Monardes of Seville (1565). A rhymed Promptuaire of medicinal simples by 'Thibault Lespleigney (1537) was reprinted by Paul Dorveaux in 1899. Following the investigations of the optical properties of lenses by Leonardo da Vinei and Francesco Maurolyco, the magnifying glass came to be used in the drawings of minute objects in Georg Hocfnagel's Archetypa (Frankfurt, 1592), Fabio Colonna's figures of lichens (1606), and Thomas Mouffet's MIS. on insects (15S9), published in 1631 (singer).

The medieal men we have just mentioned are, all of them, examples of the restless Renaissance spirit and, in cast of mind, they were akin to the great pathbreakers of the period, Vesalius, Paracelsus, and Paré. There is yet another group of physicians, each remarkable for achievement along isolated and original lines. Of these, Pierre Brissot (1478-1522) stands out as a reformer in the practice of bloodletting. $\mathrm{Up}$ to the time of Brissot, physicians had accepted the Arabist teaching that bleeding should be "rerulsive," that is, at a distance from the lesion. In 1514, Brissot, a professor of the Paris Faculty, deeply read in Greek medicine, made a stand for the original Hippocratic method of "derivative" bloodletting, that is, free renesection on the same side as and near to the lesion, ${ }^{3}$ which he believed to be the most effective for the removal of peceant humors. This heresy engendered a storm which resulted in the banishment of Brissot by act of Parliament and a pronouncement of Charles $I$ to the effect that such doctrine was as flagitious as Lutheranism. Clement VII and Vesalius were dragged into the controversy, which was brought to a sudden close by the fact that one of Charles V's relatives died from venesection by the Arabist method in an attack of pleurisy, and the smug op-

${ }^{1}$ Belon: De arboribus coniferis, Paris, 1553.

${ }^{2}$ Citerl by H. M. Barlow: Proc. Roy. Soc. Med., Seet. Hist. Med., Lond., 1913 , vi, 10 - -149 .

${ }^{3}$ The terms "derivative" and "revulive" are sometimes employed indifferently to signify bleeding at a distance from, instead of at the site of, the lesion. The distinction is fanciful (Littré). 
ponents of Hippocrates and Brissot were made ridieulous forever, although blood was still let in quantity until the time of Louis. A gifted pathologist was the distinguished Florentine, Antonio Benivieni ( -1502), who was an able surgeon and a remarkable pioneer in reporting postmortem sections, but regarded Galen as the last word in medicine. In his posthumous De Abditis Causis Morborum, published by the house of Giunta in 1507, he appears as a founder of pathology before Morgagni. "Before Vesalius, before Eustachius," says Allbutt, "he opened the bodies of the dead as deliberately and clearsightedly as any pathologist in the spacious times of Baillie, Bright, and Addison," and Mal-

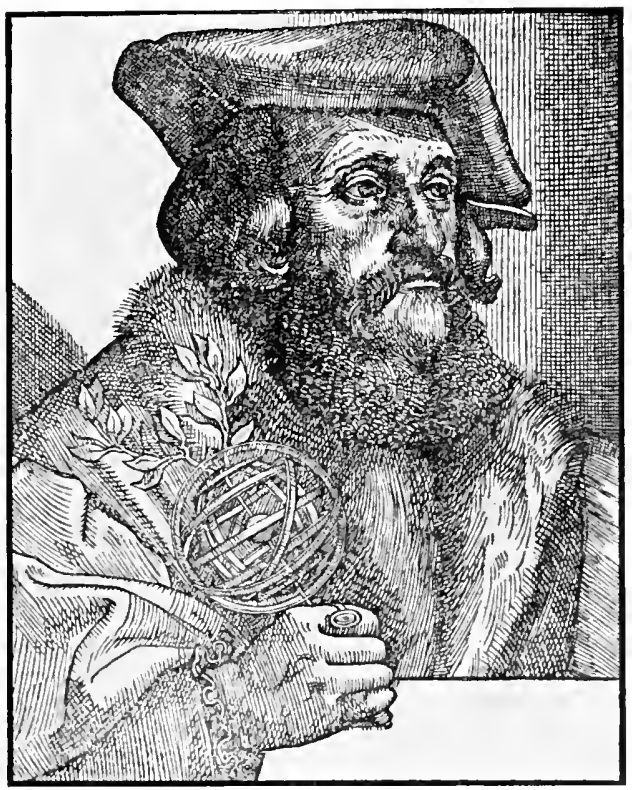

Girolamo Fracastoro (14\$4-15,53).

gaigne lias deseribed his book as "the only work on pathology which owes nothing to any one." But with all deference to authority so high, it may be doubted if so slender a performance as Benivieni's (it consists of only 54 pages) can enter into comparison with the vast array of pathologic findings and deseriptions of new diseases in Morgagni's majestie treatise. For such pioncer work as Benivieni's the time was hardly ripe, and the same thing is true of the theoretic speculations of that most original genius, Fracastorius. Girolamo Fracastoro (1484-1553), a Veronese of thick-set, hirsute appearance and jovial mien, who practised in the Lago di Garda region, was at once a physician, poet, physicist, 
geologrist, astronomer, and pathologist, and shares with Leonardo da Vinci the honor of being the first geologist to see fossil remains in the true light (15:30). He was also the first scientist to rofer to the mannetic poles of the carth (1543). His medical fame rests on that most celebrated of medical poems, Syphilis sive Morbus (iallicus (Venice, 1530), which sums up the contemporary dietetic and therapentio knowledere of the time, recognizes a venereal cause, and gave the discase its present name; and his treatise, De Contagione (1546), in which he states, with wonderful chairvoyance, the modern theory of infection by microorganisms (seminaria contagionum ${ }^{1}$ ).

Our account of Renaissance medieine may elose with the works of two original characters who were not physicians, the Venetian Luigi Cornaro (1467-1566), whose Traltato della rita sobria (Padua, 1558 ) is probably the best treatise on personal hygiene and the "simple life" in existence; and The Metamorphosis of Ajax (1596) of sir John Harington (1561-1612), the witty, graceless godson of Queen Elizabeth, who was banished from her court for writing it. The work introduces an important and indispensable improvement in sanitary engineering, but our author's treatment of his thene is entirely in the manner of Aristophanes, Rabelais, or the Zähdarm epitaph in Sartor Resartus, and the garrulous, whimsical old knight possibly got his invention from Oriental sources. Harington also made a quaint and amusing versification of the Salernitan Regimen sanitatis $\left(1607^{*}\right)$.

Carlo Ruini's treatise on the anatony and diseases of the horse and their treatment (1598), sometimes attributed to Leonardo da Vinei, ${ }^{3}$ is usually regarded as the foundation of modern veterinary medicine.

It is worth remembering that the first medical and surgical books to be printed in the new world, such as the Opera Medicinalia of Franciseo Bravo (1570) or the Summa $y$ Recopilacion de Cirugia of Alphonso Lopez de Hinojoso (1578; 2 ed., 1595), were printed in the city of Mexico.

${ }^{1}$ It is to be remembered, however, that Fracastorius nowhere refers to bacteria as living organisms (contagia animala), but describes them (as if in terms of physical chemistry) as something very like our modern "colloidal systems," although he regards them as capable of reproduction in appropriate media. As between Fracastorius and Athanasius Kircher, the decision of priority in regard to the germ theory will depend upon whether the arbiter is a materialist or a vitalist. In the De Contagione, Fracastorius also gives the first authentic account of typhus fever (1546), the "tabardillo" of contemporary Spanish and Mexican writers. 1920).

${ }^{2}$ Recently edited in a new edition by Francis R. Packard (New York,

${ }^{3}$ See Schmutzer: Arch. f. d. Gesch. d. Naturwissensch., Leipz., 1910-12, iii, $61-70$. 


\section{CULTURAL AND SOCIAL ASPECTS OF RENAISSANCE MEDICINE}

The invention of printing and the Revival of Learning, the discovery of America, and the extension of travel and commerce, the heliocentric astronomy of the physician Copernicus, the beginnings of modern physies and chemistry, the struggle between masses and elasses which began with Magna (harta (1215), the Reformation (1517), and the growth of vernacular literature, all combined to make the Renaissance a period of incessant intelleetual ferment and activity. The Byzantine Greek seholars who poured into Italy after the destriction of Constantinople have been described as "sowers of dragon's teeth," and if we judge them by their effect upon the work of Paracelsus, Vesahius, and Parce, we must regard these Humanists as the true forerunners of modern medicine. The three great leaders of Renaissance medicine were all of them experimenters in the truest sense, but before the common medical mind could be penetrated with the advantages of experimentation over superstitious observances, it was necessary to clear the ground of the accumulated rubbish of the past, and this could be accomplished only by searching, eritical study of the medical authorities of antiquity. In the different universities, the courses of medical instruction and the text-books used-Avicenna's Canon, Galen's Ars parva, the Aphorisms of Hippoerates; Dioseorides-remained about the same, ${ }^{1}$ but new and important features were gradually introduced, and the sixteenth rentury university training had a distinctive character of its.own. Bologna, Padua, and Pisa had the most popular medical faculties, and after them Paris, Montpellier, and Basel; but the wide-spread interest in general eulture soon led to the foundation of new universities at Valencia (1501), Wittenberg (1502), Santiago (1504), Toledo (1518); Marburg (1527), Cranada (1531), Königsberg (1544), Jena (1558), Douai (Lille) (1561), Helmstädt (1575), Levden (1575), Altdorf (1580), Edimburgh (1582), and Dublin (1593). Fach of these Renaissance universities was a little democracy in that the students themselves elected the rector, the professors, and the officers, and had a voice in determining the courses of study. As a rule, the members of the faculty were chosen for only one vear, and had to be renominated and reëlected for a further tenure of office. This peculiar arrangement kept the students and professors in continual movement from one university to another; a professor would sometimes give a Gastspiel of lectures in order to secure a good position, and even city physicians wandered from place

${ }^{1}$ For lists of medical books used by Craeow physerians and students in the sixteenth century, see J. Lachs: Arch. f. Gesch. d. Med., Lejpz., 1913-14, vii, $206-217$. 
to place after fulfilling their contracts. In Goethe's Faust, Mephistopheles introduces himself for the furst time as a "wandering student" (fahrender Scholastikus). C'haracters of this rolling-stone order were a feature of the time. Many of these itincrant scholars were gemuine vagabonds, so poor that they had to cke out a livelihood hy begging like tramps, singing at doors like Christuas waits, attending to odd jobs, or, their favorite experlient, stealing what they could lay their hands upon. The fagging and hazing among the different bodies of students were coarse beyond coneeption, license was umbridled, and many of them went frankly to the devil. Others, in the face of extreme poverty, led lives of noble selfdenial for the advancement of learning and scienee. 'The absolute laek of medical periodicals and a slow and expensive postal service made it necessary for even the best to move from pillar to post in order to be in touch with new phases of thought. The principal innovations in medical teaching were in the branches of anatomy and botany. There were a few attempts at bedside lecturing, and even postmortem sections for the possible confirmation of diagnoses, but these were soon done away with by popular prejudice. Dissections, however, became more frequent and were regarded, in each case, as a particular and expensive social function, for which a special papal indulgence was necessary. The cadaver was first made "respectable" by the reading of an official decree, and was then stamped with the seal of the university. Having been taken into the anatomic hall, it was next beheaded in deference to the then universal prejudice against opening the cranial cavity. The dissection was followed by such festivities as band music or even theatrical performances. All this led in time to the building of so-called anatomic theaters, notably those at Padua (1549), Montpellier (1551), and Basel (1588). In England the need for anatomic study led to the passing of the law of 1540 (32 Henry VIII, c. 42), authorizing the barbers and surgeons to use four bodies of executed criminals each year for "anathomyes," a provision which, however enlarged, remained substantially in force until the passing of the Anatomy Act of 1832. In 1564, John Caius obtained from Queen Elizabeth a formal grant of two bodies of criminals for dissections by the two holders of medical fellowships at Cambridge. ${ }^{1}$ The extreme scarcity of anatomic material everywhere made it a special ambition of each teacher or practitioner to have a skeleton of his own. 'This, in due eourse, became the germinal idea of the splendid anatomic and pathologic museums of later times, from Ruysch to the Hunters and Dupuytren. Botanic teaching in the universities was for- 
warded by special outdoor excursions in the spring and autumn, to which the apothecaries were invited and which were alwars followed by banquets and jollifications. The first chair of "simples" (lectura simplicium) was founded by Francesco Bonafede at the University of Padua in 1533, and about 1561, an ostensio simplicium, or demonstration of living plants, was added. Many universities had separate botanic gardens of their own, notably Pisa (1544), Padua (1545), of which Anguillara and Prospero Alpini were prefeets, Zürich (1560), Bologna (1568), Leyden (1577), Leipzig (1579), Montpellier (1592), and Paris (1597), which, after 1635, was known as the Jardin des Plantes. These were again the originals of the great private collections and gardens of the eighteenth century. The salary of a university professor in the sixteenth century was a dependent variable and decidedly low in the northern countries.

In Germany it ranged anywhere from $\$ 40$ to about four or five times as much. The Linacre foundations at Oxford and Cambridge provided for two professorships at $\$ 60$ each per annum and one at $\$ 30$; but Vesalius got $\$ 1000$ at Pisa. Toward the seventeenth century these sums had a purchasing value equal to about eight times the amount in modern money. 1 The salaries of city physicians and the fees eharged by physicians in private practice were proportionately low. Power says that the average fee in Elizabethan England was a mark (13s. 4d.). City physicians in Germany got anywhere from \$4.25 to $\$ 43$, court physicians from $\$ 35$ to $\$ 939$. The physicians in ordinary of Henry VII, Henry VIII, and Queen Elizabeth all received about $\$ 200$ annually. In Germany, a simple uroscopy cost about three cents; single visits anywhere from 8 to 50 cents, according to the income of the patient; consultations, $\$ 2.50$ for each physician, or $\$ 1.25$ if by letter. Johann May, the first to teach medicine at Tübingen (1477), got 30 florins for handling a medical case. ${ }^{2}$ The most lucrative phase of practice was in the treatment of syphilis, in which physicians easily made small fortunes, even down to the time of Casanova's Memoirs. Kneeling before the statue of Charles Vill at St. Denis, Thierry de Hery said to a bystanding priest: "Charles VIII is a good enough saint for me: he put 30,000 franes in my pocket when he brought the pox into France." Surgeons were fairly well paid, the fee for a fracture for instance, being about $\$ 10.50$. John of Arderne is said to have gotten 100 gold sols (\$500) for his operation for fistula in ano. The apotheearies fared best of all, if we are to judge by a bill which was sent to Queen Elizabeth amounting to about $\$ 216$ for one quarter. ${ }^{3}$ Municipal apotheeary shops in Germany, such as the old Rathsapotheke at Hannover (1566), were highly ornate structures.

Medical practice during the Renaissance period was bound up with superstition, herb-doctoring, and quackery. Petrarch ridiculed the doctors of his day for their subservience to the Arabs,

${ }^{1}$ J. J. Walsh: "Physicians' Fees Down the Ages," Internat. Clinics, Phila., 1910, 20 s., iv, p. 269.

${ }^{2}$ Med. Cor.-Bl. d. württemb. ärztl. Ver., Stuttg., 1914, lxxxiv, 609.

${ }^{3}$ 'The great center of the London drug trade in the Elizabethan era was Bucklersbury, immortalized in Falstaff's reference to "these lisping hawthorn buds, that come like women in men's apparel, and smell like Bucklersbury in simple time" (Merry Wives of Windsor, Aet III, se. III). 
their predilection for uromancy, their county-fair deceptions.' Pogrgio, the lilorentine hmmanist, pilloried the profession in his Liber factiorum $\left(1.170^{2}\right)$. In the illustrations of the period the physicim, whether in lone robe or short fur-edged pelisse, is invariably represented as inspecting a urinal. He usually believed in astrology, and went in for the lore of amulets (JassauerKunst) and the Lasistafellumst, or the determination of the proper time for purering and blook-letting hy the conjunction of the planets. Even a court physician was often an "astronomer royal," that is, a deviser of fortune-tellers almanaes. The Ludicrum Chiromanticum (1661) of Johamn Pratorius mentions sone 77 publi(ations of the sixtenth and seventeenth centuries, which were devoted to palmistry alone. The followers of Paracelsus helieved in the "doetrine of signatures," in virtue of which a drug is indicated by some fancifut associative resemblance to the disease, as trefoil for heart discase, thistle for a stitch in the side, wahnt shells for head injuries, bear's grease for baldness, topaz, the yellow colandine or turmeric for jaundice, powdered mummy for prolonging life, and so forth. We may judge of the true gratness of men like Vesalius, Leonicenus, Linacre, Fracastorius, and Benivieni, when we reflect that they alone seorned to eredit these things. In like manner only the surgeons of first rank-Paré, Gersdorff, Franco, Wïrtz, Taghiacozzi, Clowes, and Bartisch-were true surgeons. The unclassed horle of wandering cataract couchers, lithotomists, herniotomists, and booth-surgeons generally were, in the words of IVilliam Clowes," "no better than runagates or vagabonds a...," shameless in countenanee, lewd in disposition, brutish in judgment and understanding," so disreputable, in fact, that special laws had to be passed to make the status of competent surgeons reputablenotably the edict of Charles $V$ in 1548 , which had to be renewed by Pudolph II in 1577.3 The barber surgeon who shaved a eriminal condemned to death or dressed the wounds of any one tortured on the rack was regarded as himself a felon. Quackery was rampant everywhere, and in the vigorous language of the English strgeon just quoted, was practised by "tinkers, tooth-drawers, peddlers, ostlers, carters, porters, horse-gedders and horse-leeches, idiots, apple-squires, broom-men, bawds, witches, conjurers, soothsayers and sow-gelders, rogues, rat-eatchers, runagates, and proctors of spittle-houses." Another class of impostors were the tramps of the period, who, in spite of Henry. VIII's statute against

${ }^{1}$ See Henschel: Janus, Bresl., 1S46, i, 1ऽ6-223.

${ }^{2}$ Roth: Vesalius, Berlin, 1892, 192.

${ }^{3}$ For examination questions put to a German candidate in surgery in 1580, see J. W. S. Johnsson, Janus, Amst., 1910, xv, 129-142. 
"sturdy and valiant beggars," tried to impose upon the charity of the hospitals, which in those clays gave temporary shelter to all the poor. Robert Copland (1508-47), the old English printer, who was also a poet, wote an amusing versified dialogue between himself and the porter of St. Bartholomew's, ealled The Hye Way to the Spyttel House, which throws eonsiderable light on the poorlaw and free dispensary problems of the sixteenth century. ${ }^{1}$

Perhaps the worst phase of Renaissance medical practice was that of obstetrics. We know little of medieval obstetries, but we may gauge the extent of its degradation by what happened in the Renaissance period. In normal labor, a woman had an even chance if she did not succumb to puerperal fever or eclampsia. In difficult labor she was usually butchered to death, if attended by a Sairey Gamp of the time or one of the vagabond "surgeons." As a rule, only midwives attended women in labor, and in 1580 a law was passed in Germany to prevent shepherds and herdsmen from attending obstetric eases. The Renaissance pictures show that, as in the Middle Ages, the lying-in room was crowded with people bustling in every direction, giving the general impression, as Baas truly says, of "all sorts of female fussiness.". The obstetric abuses were remedied to some extent by city ordinances governing midwives, notably those of Ratisbon (1555), Frankfurt on the Main. (by idam Lonicerus, 1573), and Passau (1595). $\therefore \therefore$ :

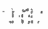

$\therefore:$ In this period, infants were commonly: breast-fed, but wet-nursing, although opposed by Phayre (1546) and others, grew apaee, and baby-farming beeame a notorious evil. The high rate of infantile mortality was die to the low status of public, domestic, and yersonal hygiene, which was held in less regard than in the Middle Ages. The teities had no drainage, and dwellinghouses, with their floors strewn with rushes and their cesspools, as described bv Erasmus, were sinks of filth and infection. ${ }^{3}$ Froude, at the beginning of liis History of England, states that the growth of the population was very slow, almost stationary, the result of high infantile mortality, and the effect of wars and epidemies upon the adult population.

Certain eriminal laws issued by the Bishop of Bamberg in 1507 , and by the Elector of Brandenburg in 1516, led to the formulation (in 1521 and 1529) of the celebrated C.C.C. (Constitutio Criminalis Carolina), or Peinliche Gerichtsordnung of Charles I, published in 1533, which authorized the judge of a court to summon physicians or midwives as expert witnesses in such nedieolegal cases as homicide, infanticide, criminal abortion, malpractice,

1 See Lancet, Lond., 1909 , ii, 1020.

${ }^{2}$ For a recent study of the lying-in room in the various periods, see $A$. Martin, Areh. f. Geseh. d. Merl., 1916-17, x, 209-250, 2 pl.

${ }^{3}$ Forsyth: Proc. Roy. Soc. Med., Lond., 1910-11, iv, pt. 1, Seet. Dis. Child., $112-116$. 
and the like; but, in deferenee to current superstitions, postmortem sambinations were not atuthorized. 'The first jucliedal postmortem in Famer wats male hy . Imbroïse Pare in 1562, after which time the pratetioe bexame common. Special laws were passed in renard to the sale of food, adulteration of drugs, alcoholic liquors," strect-cleaning, occupations, the plague, and other phases of municipal hygiene, but nothing was done to alleviate the condition of the insine, who were chained, beaten, starvel, and otherwise maltreated, and frequently died of cold. In 1547 the monastery of St. Mary of Bethlehem at London (founded in 1246) was converted into a hospital for the insane, popularly known as "Bedlam," and in a few years was amply justifying its reputation as conveyed in this term.

A special feature of Renaissance legislation in France and England was the improvement of the status of the barber surgeons. In 1505 the Paris Faculty took the barber surgeons under its wing, in order to spite the surgeons proper, of whom it was jealous, and a few years later, these "surgeons of the long robe," having failed to become a separate faculty, decided to make the best of a bad bargain by coming under the sway of the physicians. In England, in 1462, the numerous and prosperous Guild of Barbers became the Company of Barbers under Edward IV; the surgeons obtained a special charter in 1492; and in 1540, under Henry VIII, this Barber Company was united with the small and exclusive Guild of Surgeons to form the United Barber-Surgeon Company, with Thomas Vicary as its first Master. A celebrated painting of the younger Holbein represents Henry VIII, huge, bluff, and disdainful, in the act of handing this statute to Vicary, in company with fourteen other surgeons on their knees before the monarch, who does not condescend even to look at them. This picture, one of the best of Holbein's works, not only gives a superb portrait of Henry VIII, but is probably the best representation in existence of the costume and appearance of the sixteenth-century surgeon. In 1546, the king also founded the Regius Professorship of Medicine at Cambridge. A picture in the Hunterian Library at Glasgow $^{3}$ represents Dr. John Banister (1533-1610) as delivering the "Visceral Lecture" at the Barber Surgeon's Hall (London) in 1581. A dissected cadaver is exposed, above the lecturer is an opened

${ }^{1}$ It was preceded by the Bolognese post-mortem by Guglielmo da Varignana in 1302 .

Sebastian Brant, in his Narrenschiff (1494), lashes the adulteration of wine, sausages, sugar, and saffron. Wine was adulterated by artificial coloring, sweetening, and treatment with plaster-of-Paris.

${ }^{3}$ DArey Power: Proc. Roy. Soc. Med. (Sect. Hist. Med.), Lond., 191213 , vi, 18-35. 
copy of Columbus, above are the armorial bearings of the Lnited Barber Surgeon's Company, while the skeleton at the left is supported and crowned with its colors, familiar in the candy-stick red and white of the barber's' pole.

The English aet of 1511 (3. Henry VIII, cap. iii) decreed that no cne should practice medicine or surgery in London, or seven miles around and about it, without being first examined, approved and admitted by four doctors of physic or expert surgeons, acting under the Bishop of London or the Dean of St. Paul's; while beyond the seven miles precinet, the applieant must be approved by similar bodies under the bishop of the diocese or his viear general. On September $23,151 \mathrm{~s}$, at the behest of Thomas Linaere and other physicians, Henry VIII organized these licensed praetitioners into a college perpetual of doetors and grave men, authorized to practise within the seven miles precinct. This charter was confirmed by the acts of 1522 (14.-15. Henry VIII, cap. 5) and 1553 (1 Mary, St. 2, v, eap. 9) and the institution beeame the "College or Commonalty of the Faculty of Physick of London." In 1851 (21.-22. Victoria, cap. 90), it became the Royal College of Physicians of England which title was confirmed in 1860 (23.-24. Vietoria, cap. 66). The bilingual "Statutes" of this college constitute one of the earliest and most important examples of a local code of ethics. ${ }^{1}$ In 1542-3, on account of the greed of surgeons "minding their own lucres," and disdaining to help the poor, Acts 34 and 35, Henry VIII, cap. 8, were enacted, permitting common persons having knowledge of herbal and folk medicine to minister to the indigent, thus affording a loophole for unqualified practitioners, like the Kurierfreiheit of modern Germany.

During the Renaissance period, considerable advance was made in the theory and practice of military medicine. Field hospitals (ambulancias) were introduced by Queen Isabella of Spain at the siege of Malaga (August 19, 1487), and were revived by her grandson, Charles V, at the siege of Metz (1552), where Ambroise Paré, the greatest military surgeon of all time, was the central figure. At this time, army surgeons were only in attendance upon their patrons, the great captains and nobles, returning to their civilian practice at the end of a campaign; but a decree of Coligny (1550) had assigned a surgeon to care for the sick and wounded of each company of infantry. Meanwhile, real military organization and discipline had been established in the armies of Maximilian I, the regulations for the sanitary dispositions of his Landesknechte, as given by Leonhard Fronsperger (1555) being the foundation of the present medical regulations of the German army (Frölich). The directions for the disposal of the wounded and the minute assignment of duties to the chief physician in the field are quite modern, as are also the careful administrative preparations made for the besieged town by the Duke of Guise (Salignac). In the German army, the sick and wounded were sent to the baggage train, put under canvas, treated by the surgeon or barber and nursed by female camp-followers, the whole arrangement being under the administration of a hospital superintendent (Spita!meister). In Guise's forces, cases of communicable disease were isolated, the pioneers, under the provost, looked after the sanitation of Metz, the surgeon barbers were given money to carry on their functions, and the siek and wounded were at once sent to hospital. When the siege was raised, Guise and Alva established a mutual Red Cross agreement, which the Spanish again observed at the siege of Therouanne (1553), after which time prisoners and wounded enenies were not commonly massacred. After the eapture of Havre (1563), the Queen Mother planned an Inralides or retreat for infirm and aged soldiers, which, however, did not become accomplished fact until 1676 . Yet in spite of such remarkable administration, the losses were frightful and the importation of

1 The Paris Faculty had similar statutes from 1452, those of Piacenza were printed in 1569 , and many other local ethical codes followed these. 
prisoners into Metz started an epidenic of typhus, which spreat to the adjoining villages:'

()f the many epidemic diseases which hat beset Europe in the Midelle Ages, three, the sweating sickness, lepersy, and epulenic chorea, had well-nigh disappeared by the midclle of the sixteenth century. In France, Italy, Spain, England, Demmark, and switzerland, leprosy was so well stamped out that the litzarhouses were abolished, but the discase still continued to be epidemie through the seventecenth century in (iemmony, Scotland, and the Low Countries, and in Sweden and Norway lasted until the cightecnth century. The most formidable epidenies of the sixteenth century were still the plague and syphilis.

Betwen the years 1500-6s, the ravages of the plague were partieularly severe in Ciemany, Italy, and France, and, in the sixth decade, spreat all over Europe. After this time it broke out at intervals in different places in $1564,1568,1574$, and 1591 . All through the century a vast number of "Pestseluriften" were published, and the most important of these were the publie doeuments recognizing the contagious nature of the plague and proposing various methods of isolation and disinfection. Wittenberg and some of the other cities commemorated the different epidemies by striking off special coins, or pest-dollars (Wittenberger Pesttaler). The obverse of these commonly represented Moses" fiery serpent set upon a pole, with the inseription "Who looketh upon the serpent shall live". (Numbers Xxi, \&, 9); the reverse represent ad Christ crucified, with the inscription, "He that believeth on me hath everlasting life". (st. John v1, 47). There were also comet medal (1558), and medals commemorating years of famine. The most remarkable of the latter celebrated the "Annona," or right of the Papacy to limit the price of corn. Famine medals of this kind werest ruek off in honor of Popes Julius II (1505-8), Pius IV (156075); Gregory XIII (157(i-91), and Clement VIII.(1599), The Wittenberg pest-dollars and the "zencchton," arsenic-paste sewed up in dog-skin, wero worn over the heart as amulets against the pliguep.

Syphilis was less malignant in character than in the former century, and this was perbaps due to a number of really efficient remedies which were a vast improvement upon the mild vegetable concoctions of the earlier period. Alercury had become the great sheet-anchor, whether for internal or external use, alt hough opinion was pretty well divided as to its ultimate value. Leonicenus, Montagnana, and the German writers gencrally opposed its use; Fracastorius and Benivieni gave it the seal of their approval. Thierry de Hery, in his treatise of $1552,{ }^{2}$ recommended either guaiac internally or mercury by fumigation or inunction, preferably the latter. Paré's treatise on syphilis is taken almost verbatim from this work. A special feature of the antisyphilitic medication of the century was the introduetion of new drugs from

${ }^{1}$ C. L. Heizmann: Ann. Med. History, N. Y., 1917-18, i, 281-287. The basic texts are: L. Fronsperger: Vom Kayserlichen Kriegsgerichten (1566); Salignac: Le siège de Metz (Paris, 1553), and the Apologia et voyages of Paré.

${ }^{2}$ de Hery: La méthode euratoire de la maladie vénérienne, Paris, 1552. 
the Western Hemisphere. As alchemy introduced antimony, mereury, and sugar of lead, so the diseovery of America brought in guaiae (introduced in 1508-17), the root of China smilax (1525), exploited by Vesalius, sarsaparilla (1536), and sassafras. An old copper-plate of 1570 , after Stradanus, ${ }^{1}$ shows a sickroom interior, with all the stages of preparing the guaiac infusion, from chipping the huge logs to administration to the syphilitic patient. Gonorrhea became common about 1520, and one remarkable effect of these venereal diseases was the suppression of common public baths for either sex or both sexes. In the Germanic countries, these bathing establishments were a special feature of eity life, and, as depicted by the various Renaissance artists, their status was peeuliar. Many of them were frequented indiseriminately by men and women alike, all of whom sat and bathed together in one huge common vat or tank. Dürer's wood-cut of 1496 (Die Badstube) represents a group of naked men in a common bath vat, some of whom are playing musical instruments, others conversing, while a third is draining a stoup of wine. This motif of wine bibbing and general pleasaunee was frequently utilized by the lesser masters, Hans Sebald Beham, Aldegrever, Hans Baldung Grien, Hans Bock, whose pietures show the commingling of nude men and women, with scenes of feasting, eupping, and venesection in the bath. A favorite theme of Lucas Cranach and Beham was the so-called Jungbrunnen, or "Fountain of Youth," which represents a number of decrepit old women trundled in wheel-barrows to one side of a huge bath tank in which they are supposed to be rejuvenated; on the other side, they are promptly man-handled by a number of amiable youths, who hurry these reinvigorated dames up the bank to appropriate tents. These roguish pietures of the old German masters really point a moral. It was soon found that a general mixing of able-bodied men and women in a state of nature in eommon bathing pools could lead in the end only to general laxity of morals, and such places could not long be frequented by decent people. Laws were passed segregating the sexes, but the advent of leprosy, plague, and syphilis demonstrated, over and above this, that the idea of a common bath tank was bad in itself, since the latter became a simple medium of infection. In connection with Renaissance art, we should mention Dürer's celebrated wood-cut of a syphilitic $\left(1496^{2}\right)$; also the picture which he sent to his physician representing himself nude, with the legend, "Where the yellow spot is and my finger points, there an I siek

${ }^{1}$ Reproduced in H. Peters, Der Arzt, Leipzig, 1900, p. 101.

${ }^{2}$ Eneireled by 110 Latin lines by Theodoricus Ulsenius and printed at Nuremberg. 
within"; Raphacl's eartoon of St. Peter and the lame man (South Kensingtou . Iusemu); ()reagna's grisly procession of lepers in his "Triumph of leath" (Pisil); the elder Holhein's pieture of St. Elizalboth ministering to three lepors (Munich); Matthias Grïnewald's representation of bubonic platgue (Colmal (iallery, 1515), and Francesco (arotto's St. Roch in the Verona (iallery (1528), showing the typical inguinal bubo. The Venetians, Paolo Veronese and Carpaccio, painted many dwarfs (chareot). In the Uffizi (iallery at Florence there is a remarkable picture of Ferdinand I of spain, painted by Lucas van Leyden in 1524, in which the artist has given the characteristic facies of adenoid vegetations, without apparently knowing the existence of the condition in his subject. This is also true of the portrait of the acromegalic giant in the Ambras Schloss in Tyrol (1553). The prognathism of the Hapsburgs and the Medici, which is now regarded as a mode of malocelusion, appears in different portraits of these worthies. Divergent strabismus is apparent in Raphael's portrait of 'Tommaso Inghirami in the Pitti Palace (Florence). Feeling the pulse is represented in a frieze by Giovanni della Robbia in the Osperlale de Ceppo at Pistoia. Dentistry is symbolized in G. Spagna's fresco of its patroness, Saint Ajollonia (holding an extracted tooth in a forceps) in the church of San Giacomo, near Spoleto (1526), a subject which was essayed in the charming picture by Carlo Dolci (161686), later in the Corsini Gallery at Rome. The pictures of women by the younger Holbein and other artists of the German and Italian Renaissance revel in the presentation of full-bodied ideals, and particularly in the glorification of pregnancy as the chief end of womankind (Hollïnder).

Of epidemic diseases, smallpox and measles began to appear in the northern countries, notably in Germany (1493) and Sweden (157S). In 1572 there was an epidemic of learl-poisoning (called colica Pictonum) in the South of France which resembled the "Devonshire colic" of the eighteenth century, in that its probable cause was the use of lead in the cider and wine-presses. Seurvy, which appeared as early as 1218, and was first deseribed by Jacques de Vitry and Joinville (12.50), and later, in the narrative of Vasco da Gama's voyage (1498), became quite common along the coast of northern Germany, Hollind, and the Scandinavian countries, as described by Euricius Cordus (1534), George Agricola (1539), and other writers. It was also described by the poet Camoens, in the fifth canto of his Lusiad (1558). Yellow fever is said to liave exterminated the population of Ysabella, San Domingo, in 1493. Typhus fever was epidemic in Italy in 1505 and 1524-30, and was described by Fra(astorius $\left(1533^{1}\right)$ anıl Francesco Bravo $\left(1570^{2}\right)$. In Spain, after the siege of Granarla (1489), where it broke out among the Castilian troops, it was ealled cl tabardiglo (a little cloak). The Aztee disease matlazahuatl, or cocoliztli, already known in Nexieo in $1570-76,{ }^{3}$ was shown to be a tabloland disease

${ }^{1}$ Fracastoritus: De morbis contagiosis, 1533 , cap. vi.

2 Francesco Bravo: Opera medicinalia, Mexico, 1570.

${ }^{3}$ N. León: ¿Qué era el matlazahuatl y que el cocoliztli [etc.], Mexico 1919. Also, A. von Humboldt: Reise in die Aequinoctial-Gegenden vor Amerika, cited by Haeser. 
identical with tabardillo, by Stamm, in 1861.1 A tabardillo Congress was hedd in Nlexico on January 14-21, 1919. The so-called Hungarian discase (morbus Hungaricus), which spread all over Europe in 1501 and, in 1505-87, was frequently epidemic in Italy and France, is now regarded as, in all probability, typhus fever. Another disease of obseure origin and eharaeter was a sort of pneumotyphus or pleurotyphus, which was epidemic in Italy, Franee, Switzerland, Holland, and Germany between the years 1521 and 1598. An epidemie in the cloister at Bergen on the Danube, in 1527, was deseribed in the letters of a nun, Sabina, sister of Willibald Pirckheimer. ${ }^{2}$ Diphtheria, which had already been deseribed by Sehedel in 1492, was six times epidemic in Spain during the period 1581-1600, and by 1618 had spread to Italy. It was deseribed as garrotillo by Gutierrez, ${ }^{3}$ by Fontecha (1611), Villa Real (1611), Herrera (1615), and others. In Codex 1154 S of the Vienna Hofbibliothek (fol. 278 verso), it is deseribed as a new disease (nawe krannckheyt $t^{4}$ ). Whooping-eongh first appeared in the sixteenth century, and was first deseribed by Guillaume Baillou (Ballonius) in 1578. Ergotion in the gangrenous form wats prevalent in Spain in 1581 and 1590, while in Germany a form variously eonvulsive, spasmodic, stuporous or paralytic, preceded by the usual tingling, burning sensations, and known as the Kricbelkrankheit, appeared, endemie in the vears 1581, 1587, 1592, and 1595-6. In 1597 the Nedical Faculty of Marburg issued a pronouncement upon the last epidemic, declaring its cause to be the use of bread made from spurred rye. Crookshank regards Kricbelkrankheit as an epidemic influenzal encephalo-nyelitis. The epidemies of sweating sickness (Sudor Anglieus), a disease which reached Germany in 1528-9, were probably influenza. In the view of Crookshank, influenza was also at the bottom of the coqueluche and trousse galant of France, the Hauptueh of Germany (1543-6) and the mal mazzuco of Italy (1597).

\section{In the sixteenth century the Eastern drug-trade, the quest for}

"Cassia, sandal-buds and stripes

Of labdarum, and aloe-balls"

\section{fell into the hands of the Portuguese navigators.}

The story of their explorations is told in Hakluyt and Purchas' Pilgrimes. The Lusiad of Camoens tells of Vaseo da Gama's voyage around the Cape to India, which destroyed the commereial power of Venice. Ormuz and Goa were taken by Albuquerque: footholds were obtained in Ceylon for cimnamon, Sumatri for ginger and benzoin, Banda and Amboyna for nutnegs and maxe, the Molueeas for cloves, Timor for santalwood. Cochin China for aloes and pepper; Malacea was made a eustoms station and caravan trade was established in China, the source of eamphor, cimnabar, musk and snilax chins, while rhubarb was obtained from Persial. The profits of this trade were enormous. Two dueats' wortl of eloves from the Molureas fetehed 1680 dueats in London. The Spanjards also marle communieation with the Moluceas, but their spheres of influence were destined to be the lhilippines, Mexico, and Peru. Manila was founded by them in 1566 . Oviedo and Monardes deseribed the plants of the West Indies and Peru. The revolt of the Netherlands against Philip II (1569-1648) brought the Duteh into the drug marts, but the period of their ascendancy was the seventeenth century. ${ }^{5}$

1 Stamm: Nosophthorie, Berlin, 1\$61, eited by Haeser.

${ }^{2}$ E. Reicke: Arch. f. Geseh. d. Med., Leipz., 1911-12, v, 418-424.

${ }^{3}$ According to Morejon and Haeser. Nieolas Gutierrez de Angulo) (14441522) published a Tratado de la enfermedad det garrotillo of unknown dat ${ }^{2}$.

${ }^{4}$ Sudhoff: Arch. f. Gesch. d. Med., Leipz., 1912-13, vi, 127.

${ }^{5}$ See Tschireh: Pharmakognosie, Leipzig, 1910, i, 2. Abth., 716-772; and A. W. Linton: Jour. Anl. Pharm. Assoe.. Phila.. 1916, v, 366; 471. 
Hospital construction approached perfection in the fifteenth century, the greatest tochnical care boing deroted to these struetures, as in the hospital at Milan, which was opened in 1445, but not completed until 1.tis). A painting of Andrea del Sarto's at Florence represents the interior of a woman's hospital, probably for lying-in purposes. The fact that an isolation hospital and home for epilept ies was founded at the eloister of St. Valentine at Rufach (Ipper Alsace) in 1486 shows that the disease was still regarded as contagious, in aceordance with the old pseudo-Salernitan verse (Suchofit ${ }^{1}$ ). Before the Reformation there were 77 hospitals in Seotland alone, but, after that period, hospitals connected with religious institutions began to die out in the northern countries. The lazar-houses also began to diminish in number, as leprosy was gradually stamper out. Three famous English institutions of the period were the Hospital of St. Mary of Bethlehem, which was converted from a monastery into an insane asylum ("Bedlam") in 1547; Bridewell, anciently a palace, which became a penitentiary and house of correction for vagabonds and loose women in 1553; and Christ's Hospital, formerly the Grey Friars Monastery, which was chartered in 1553 as a charity for fatherless and motherless children, and became the famous school of the "Blıe Coat Boys," at which Charles Lamb and Coleridge were educated.

${ }^{1}$ Sudhoff: Arch. f. Gesch. d. Med., Leipz., 1912-13, vi, 449, 455. 


\section{THE SEVENTENTH CENTURY: THE AGE OF INDIVIDUAL SCIENTIFIC ENDEAVOR}

THE seventeenth century, the age of Shakespeare and Milton, Velasquez and Rembrandt, Bach and Purcell, Cervantes and Molière, Newton and Leibnitz, Bacon and Deseartes, Spinoza and Locke, was preëminently a period of intense individualism, intellectual and spiritual. What happened to men like Servetus and Sir Thomas More, Bruno and Dolet, Spinoza and Uriel Acosta, Galileo and Copernieus, did but lessen the dominion of the professional theologian, whether Catholic, Protestant, or Jewish. The great philosophers of the time, Spinoza, Bacon, Deseartes, Locke, all occupied themselves with different branches of natural science, and the scientific labors of physicians themselves were strongly indivuralized. Yet with the decline of collectivism there necessarily went a corresponding decline in the things that had thrived under its régime, in particular, organized nursing, charitable care of the sick, and well-managed hospitals for this purpose.

In the seventeenth century the German people, decimated and torn asunder by the ravages of the Thirty Years' War, could do little for medicine, as Baas laments, and the highest distinetion in this field was attained by England, Italy, and Holland. The age of the Armada and the Great Rebellion of 1642 was the most glorious period of English history, the age "of her greatest goldenmouthed sons," from Shakespeare, Milton, and the great line of Elizabethan dramatists, to Bacon and Locke, Raleigh and Sidnev, Vaughan and More, Herrick and Crashaw, Boyle and Wren. In this age also flourished some of the greatest English mathematicians and astronomers, Newton and Wallis, Halley and Flamsteed, Briggs and Napier. The very beginning of the eentury (1600) is memorable for the appearance of an epoch-making work in the history of physies - the De magnete ${ }^{1}$ of William Gilbert

1 This work ranks beside Newton's Principia in that it threw overboard the current Arabian Nights' superstitions attributing the deflection of the compass needle to "magnetie nountains" or magnetic influenees from the stars, and the ancient sailors' belief that garlie destroys a magnet's power. After a thoroughgoing investigation of the properties of the lorlestone, Gilbert establishes the theorem that the earth itself is a gigantic spheric magnet, a proposition which has been the starting-point of all subsequent works on terrestrial magnetie variations, magnetie storms, and of the charting of the earth's magnetic fields by Halley, Gauss, and Sabine. The florid eneomium of Dryden-

Gilbert shall live till lodestones eease to draw

is certainly true of human ehronology, if not of geologic or sidereal time. Gilbert is also memorable for the discovery of frietional electricity, to which he gave its name from the amber ( $\tilde{\eta} \lambda \epsilon \kappa \tau \rho \nu)$ employed. 
(15) $10-1603)$, who w:s physidian to Queen Flizaboth and James I, and left his books and instruments fo the Royal College of Phys-

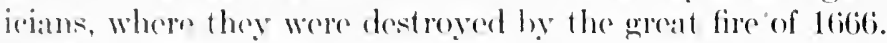

The greatest name in serenteonth e(motury medicine is that of William Harvey (1578-1657), of Folkestonc in Kent, who studied at Parlua (1599-1603) as a pupil of Fabricius and Casserius, and whose work has exerted a profomder influene upon modern medirine than that of any other man save Vesalius. The world has "heard great argument" concerning the morits and status of the De Motu Cordis, but the following sinple facts seem irrefut-

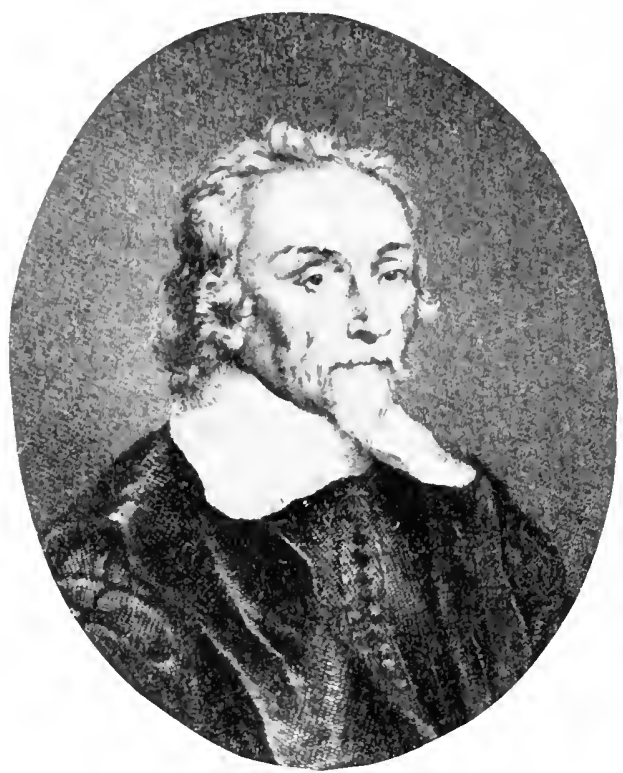

William Harvey (157S-16.57).

able and unassailable. The observation that the blood is in motion may have oceurred to the first primitive man who ever cut open a live animal or saw a wounded artery. The idea that this motion is along a definite path may well have been entertained by any ancient Egyptian or Creek, as well as by some hypothetic native of Muscovy or Illyria in Harvey's day. Galen's false concept about the pores in the ventricular septum diverted all speculation into the wrong channel for fourteen centuries, and even Servetus, who came nearest the truth, could only admit that some (not all) of the blood takes a circuit through the lungs. In the drawings which Vesalius had made, indicating the close proximity of the 
terminal twigs of arteries and veins, ${ }^{1}$ the truth about the circulation was literally staring in the face of any observer who had eves to see or wit to discover it. Even Galen had inferred anastomosis by means of invisible capillaries. Yet anatomists continued to see everything in the light of the Galenic idea of shuttle-wise ebb and flow between the closed arterial and venous systems. C'esalpinus, at best, made only a clever guess. Columbus, although he saw that the blood undergoes change in the lungs, in all likelibood appropriated the ideas of Servetus. But Harvey, who knew the whole history and literature of the subject, first made a careful review of existing theories, showing their inadequacy, and then proceeded, by experimental vivisection, ligation, and perfusion, to an inductive proof that the heart acts as a muscular force-pump in propelling the blood along, and that the blood's motion is continual, continuous, and in a cycle or circle. This was the startingpoint of purely mechanical explanations of vital phenomena. The crux of Harvey's argument - that the actual quantity and velocity of the blood, as computed by him, make it physically impossible for it to clo otherwise than return to the heart by the venous route -was the first application of the idea of measurement in any biologic investigation, and, had he chosen to express this discovery in the language of algebra (by using the symbol of inequality), it would long since have taken its proper place in the application of mathematical physies to medicine. The importance of Harvey's work, then, is not so much the discovery of the eirculation of the blood as its quantitative or mathematical demonstration. With this start, physiology became a dymamic science.

In asserting that the heart is a muscular force-pump, Harvey may have given credence to the "myogenic" theory of its antonomy (Galen), which, in any case, was soon displaced by Borelli's idea that the heart-beat has a neurogenic origin, the two views remaining in dispute to this day. In endeavoring to locate the motor power of the muscle itself, in his attempts to explain the function of the blood and the lungs, Harvey fell into the usual medieval mysticism.

The brilliant essay of the late Dr. John G. Curtis on Harvey's views gives us a clear insight in to the errors male by the great physiologist throngh philosophizing. Aristotle had taught the doctrine of the primatey of the heart, that it is the central abole of life and the soul, the hearth from which cmanates generative animal heat, something different from sterile, elemental fire, and that from the heart the blood and blook-vesiels are derived. IIarvey trans-

1 Vesalius: Fabrica, Basel, 1543, pp. 262, 265, 295, 305, 311, and platé opposite 312. See W. A. Locy: Biology and its Makers, Now York, 1908 , $49-50$.

2 J. G. Curtis: "Harvey's Views on the Circulation" (ed. F. s. Lee), New York, $191 \overline{\text { j. }}$ 
forred this primacy to tho blowe, to which the heart is only of use as a pump to kere it in motion. Ilo based this view mpon hisolservation that in the prin-

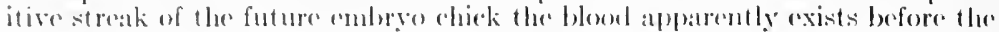

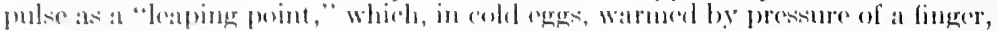

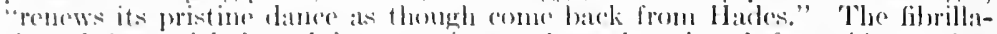
tion of the auricle in a lying or quiesernt heart he mistook for evictence that the blood is the hast part of the boely to die, although he had becen the first to revioe a quieserent leat loy perfusion (wetting it with saliva). That the: bouly is, in as soser, the explession of the soul, that the soul of man is, in sherrington's phrase, the proper integration of his whole being, that "the" soul is not in the lowly but the lowly in the soul," it was not given him to see; for the "soul" of Aristotle and the ancients ( $\psi v x \dot{\eta}$, arima) was at vague concent, axisting in thre kink, the nutritive, the sensory, the intellectual. Following his master, and like beseartes, flawey eomld bint loeate the soul some where, and so revived the ancient belief of critias that "the soul is an the blood." The soul is not, as with Aristotle, associated with the innate generative heat, "analogons to the element of the stars," but the blood itself is the "innate warnth ol first-born pselical heat," while the rirealation itsedf becones the analogue of the eirenlas motioms of the heavenly bodies. The cause of the ventricular heart-beat is attributed to the distention of the ventricle through the contraction of the aurele. but the distention of the auriele must hark back to the Aristotelian ebullition of the hot blood; and although he knew, with (ialen, of the contractile power of musche, and that the excised empty heart will beat outside the body, Harvey could not explain the simultaneous contraction of both aturieles. The doctrine of the heart as an antomatic mechanism through contractile impulses passing from musele-cell to muscle-cell, was the work of (iaskell and Engelmann. Finally, although Hippoorates had tanght that something derived from the inspired air enters the heart and is distributed thence to the borly, and although Columbus had inferred that spirituous blood is confoeted in the lungs by mixing with air, Harvey adhered to the oll doetrine that the function of respiration was to cool the hot blood. Ilo latterly saw that the fetus does not need this refrigeration, and finally gave up the problem as is "knoty subjeet." Thus Harvey, in his speculations, sided witls the philosophers (Aristotle) rather than the physicians (Cialou), but this ean retract nothing from his supreme merits as an investigator. His iews, however, retarded the development of the true physiology of respiration for a long time.

The discovery of the circulation itself was the most momentous event in medical history since Galen's time. While it was opposed by the pedantic Riolanus, ${ }^{1}$ Gassendi, Wormius, and others, it was soon supported by some of the ablest spirits of the period, including Rolfink, Sylvius de le Boë, Bartholinus, Ent, and Pecquet. Jan de Wale (1604-49), or Walæus, in particular, showed that incisions on either side of a ligature applied to an elevated blood-ressel cause the blood to ooze or to spurt, according to the direction in which it is flowing, thus affording a convincing proof of Harrey's discovery according to the laws of hydrodynamics $\left(1640^{2}\right)$.

"The status of Harvey's other treatise, De generatione animalium (16.51), is important in the history of embryology and a matter of frequent dispute. Some writers have tended to make

${ }^{1}$ Huxley styled Riolinus "a tympanitic Philistine, who would have been none the worse for a few sharp incisions."

2 Walxus: Epistolæ duæ, 1640 [ In: T. Bartholinus, Anatomia, Leyden, $15+1$, pp. 539-5+1 (plate)]. 
Harvey's merits overshadow the just claims of men like Malpighi and von Baer. Of all pronomneements made, that of Huxley still seems the somndest and the best. In his demonstration of the circulation, Harvey was brought to a standstill at one point only, viz., the capillary anastomosis between arteries and veins, which, having no microscope, be could not see. In his investigation of the embryo the minute and patient work of years was driven into an impasse for the same reason, while the manuscripts, containing his drawings and other results of experimental investigation of the embryo, were destroyed by the Parliamentary troopers who invaded his chambers in Whitchall in 1642. Long before Wolff and von Baer, he maintained, as pure theory, the doetrine of "epigenesis"- that the organism does not exist encased or preformed in the ovum, but is evolved from it by gradual building up and aggregation of its parts; yet, through his inability to see microscopically, his idea of fecundation was totally wrong, for he believed the fertilization of the ovum to be something "incorporeal"-_as iron touched by the magnet is endowed with its own powers." By such mysticisn, the famous dictum, "Omne vivum ex oro," becomes self-contradictory, since it denies the continuity of the germ-plasm. Its true importance, in Harvey's hands, was that it subverted the ancient concept that life is enincudered out of corruption (or putrefaction) - an idea still familiar in the burial service. ${ }^{2}$

Besides the De motu cordis (Frankfort, 16283) and the treatise on gerieration (16:51), we should mention the facsimile reprint of the Nis. notes for the "Pratletiones anatomica" of the Lumleian foundation (1616), which shows that Harvey had eompleted his discovery of the cireulation and was lecturing on it at least twolve years before he printed it.

Harvey, as described by Aubrey, was of short stature, with bright black eyes and raven hair, "complexion like the wainseot," quick, alert, choleric, often fingering the handle of his dagger. The resemblance of his fincly domed head to shakespeare's is a matter of comment. Like inany experimenters, he was but an indifferent practitioner. Yet he was no closet recluse, but highly honored in the worldy affairs of his clay, as witness bis publicity as Lumleian lecturer, his long association with Charles I, his

1 First stated by Franceseo Redi in the form, "omme vium re vizo."

"For a further discussion of this subject, see the admirable essay of the late Professor W. K. Brooks, on "Harvey as tmbryologist," in 13ull. Johns Hopkins Hosp., Baltimore, 1s97, viii, 167-174.

"Harvey's probable reason for printing th" "Exercitatio" at Frankfurt a. N. was that this eity was the eonter of the comtinental book-tracle until after the Thirty Years' 1 iar, and that here, overy semester, a book misket was held at which all the new books of the world might be seen and which the leading London stationers attended (Willium Stirling). 
assistance at the postmortem of "old Parr," or his merciful interrention in the affair of the "late lancashire witches." Although mot a votary of the muse, he was, in the finest semese a master of Dryeten's "other hamony of prose." Rearl, for instance, his impressionistic aceomet of the Bass Rock in a good English translation. It is a pen-picture which many a modern prosalent would he proud to sign. Maving survived long enough to live down opposition and soe his discovery areepted, Harvey prepared for approaching death with the cool self-possession of his race, meeting the end with a quiet resolution at the age of seventy-nine. While he was not ostentations in piety, his will, with its liberal legacy to the poor of his native town, revals the ideal English gentleman, tenderly solicitous of all his intimates, from Sir Charles sarborough down to his humblest body servant.

Although Harvey's publication of his discovery caused an immediate falling off in his practice, its effect 11pon medical science was as definite and far reaching as that of the Falorica. The seventeenth eentury was the great age of specialized amatomic rescarch, and was notable for a long array of individual (liscoveries and investigations, nearly every one of which had a physiologic significance. Earliest among the achievements of the post-Vesalian anatomists wis the clearing up of the old Calenical error that the veins and lymphaties of the intestines carried chyle to the liver.

This was dispelled by the discovery of the laeteal vessels in $1622^{1}$ by Gasparo Aselli (15\$1-1626), who thought they went to the liver, the mistake being eorrected by the diseovery of the thorieie duet and reeptaculum ehyli by Jean Pecquet $\left(1622-74^{2}\right)$, and of the intestinal lymphatics and their connection with the thoracie duet by Olof Rudbeck ${ }^{3}$ (1630-1702), of Sweden, in 1651. The latter discovery was also disputed as to priority by the Dane, Thomas Bartholinus (1616-80 $)$, in 1653, and by Jolyff, an Englishman, who lid not publish his elaims. Next came the finding of the pancreatic duct in Vesling's dissecting-room at Padua by his prosector, Georg Wirsung, in 1642.5 to be followed, in order of time, by sueh important English discoveries as the antrum of Highmore, in 1651, ${ }^{6}$ Glisson's cajsule in $1654,{ }^{7}$ Wharton's duet in 1656, ${ }^{8}$ the circle of Willis in $1664,{ }^{9}$ Riehard Lower's treatise on the be:trt als a muscle in $1669,{ }^{10}$ Clopton Havers' diseovery of the Haversian canals

1 G. Aselli: De lactibus, Milan, 1627. This traet is illustrated by a variegated woodent print in dull red, the first colored anatomic engraving of consefuence.

2 J. Pecquet: Experimenta nova anatomica, Paris, 1651.

${ }^{3}$ O. Rulberk: Nova exercitatio anatomica exhibens ductus hepaticos aquosos et vasa glandularum scrosa, Westeris, 1653 .

${ }_{4}^{4}$ Th. Bartholinus: De lacteis thoracicis, Copenhagen, 1652.

${ }^{5}$ Recorded on a single rare copper plate of 1642.

${ }^{6} \mathrm{X}$. Highmore: Corporis humani disquisitio anatomica, The Hague, 1651.

7 F. Gilisson: De hepate, London, 165 f.

8 T. Wharton: Adenographia, London, 1656 .

9 T. Willis: Cerebri anatome, London, 1664.

${ }^{10}$ R. Lower: Tractatus de corde, London, 1669. 
in 1691,' and Cowper's glands in 169.4..$^{2}$ Italy won distinction in Malpighi's discovery of the capillary anastomosis in the lungs (1661 3 ), which supplied the missing link in Harvey's demonstration; in Lorenzo Bellini's work on the structure of the killncys $\left(1662^{4}\right)$, and in Antonio Pacchioni's description of the so-ealled Pacehionian bodies $\left(1697^{5}\right)$. Germany is memorable through Conrad Victor Schneider's classic treatise on the membranes of the nose (De catarrhis, 1660), Meibom's demonstration of the conjunetival glands $\left(1666^{6}\right)$, Kerckring's demonstration of the intestinal valvulx conniventes $\left(1670^{7}\right)$, Brunner's discovery of the duodenal glands $\left(1682^{8}\right)$, and Ilolland by Ruysch's innovations in anatomic injecting (1665), and his many discoveries, f. $g$., the valves in the lymphaties $\left(1665^{9}\right)$, de Graaf's authentic aceount of the ovary and Gratafian follicles $\left(1672^{10}\right)$, and Nuck's glands and ducts $\left(1655^{11}\right)$. Bishop Stensen (Nicholaus Steno) (1638-86), of Denmark, discovered the parotid duet in 1662,12 and Johamn Conrad Peyer (1653-1712), of Switzerland, deseribed the lymphoid follicles in the small intestine $\left(1677^{13}\right)$ which have such an important rôle in typhoid fever. In France, Joseph Guichard Duverney (1645-1730), professor of anatomy in Paris, made some important investigations of the inner structure of the ear which led him to write the first treatise on otology (1683); and Raymond Vieussens (1641-1716), professor at Montpellier, made various studies on the anatomy of the nervous system (Neurologia universalis, 1685), the position, strueture, and pathology of the heart $(1706-15)$ and the structure of the ear. Vieussens first correctly deseribed the structure of the left ventricle, the eourse of the coronary vessels, the valve in the large coronary vein, and the centrum ovale in the brain. In his many autopsies he noted the significance of perieardial adhesions and the relation of heart disease to asthma and hydrotborax (1672-6). He noted the diagnostic features of pericardial effucion and first deseribed aortic insufficieney (1695) and mitral stenosis (1715), giving the eharaeter of the pulse and the pathological features. He also cliseovered the fermentative effect of saliva and claimed priority in the discovery of an acid in the blood.

As the anatomic woodeut had reached its height of perfection in Vesalius, so the seventeenth century was the great age of copperplate engraving. Anatomic illustration reached a high point of perfection in the striking plates in such works as Govert Bidloo's Anatomia (Amsterdam, 1685), Bernardino Genga's Anatomia (Rome, 1691), the Traité de la figure humaine, of the painter Peter Paul Rubens (1577-1640), which was published over a 1702.

1 C. Havers: Osteologia nova, London, 1691.

$2 \mathrm{~W}$. Cowper: Glandularum quarundam . . descriptio, London,

${ }^{3}$ M. Malpighi: De pulmonibus, Bologna, 1661.

${ }^{4}$ L. Bellini: De structura renum, Florence, 1662.

${ }^{5}$ A. Pacchioni: Diss. epistolaris de glandulis eonglobat is dure meningis humanx, Rome, 1705 .

${ }^{6}$ H. Meibom: De vasis palpebrarum, Helmstädt, 1666.

7 Th. Kerckring: Spicilegium anatonicum, Amsterdam, 1670.

${ }^{8}$ J. C. Brumner: Glandula tuodeni, Frankfort, 1687.

${ }^{9} \mathrm{~F}$. Ruyseh: Dilueidatio valvularum, The Hague, 1665. 1672 .

${ }^{10} \mathrm{R}$. de Graaf: De mulierum organis generatione inservientibus, Leyden,

${ }^{11}$ A. Nuck: De duetu salivali novo, Leyden, 1685.

12 N. Steno: Observationes anatomica, Leyden, 1662.

${ }^{2}$ J. C. Peyer: De glandulis intestinorum, Sehaffhausen, 1677. 
hundred years after his death (1773), the Thesauri anatomici decm (Ansterdam, 1701-16) of Frederik Ruysch (16338-1731), or the Catoptron microesmicum (1613) of Johann Remmelin (15S:3- ), of I'lm, one of the artiest anatomic atlases with superimposed plates.' A wonderful mion of scientific aceuracy with artistic perfertion was attained in the Tabula anatomice (1627) of (iullio (assorio (1561-1616), or Casserius, one of Harvey"s teachers at Padua, whose "criscerated beauties," as Dr. Holmes hats styled them, are ats attractive in appearance as their dissected parts were hedd to be instructive to the student. These Compergio-like plates of (assorius were incorporated in the atlas (1627) of Adrian vim Spicghel (1578-1625), or Spigelius, who wrote the letter-press around them, and, in this way, is usually eredited with the exquisite workmanship of the illustrations. Spieghel's name is associated with the Spigelian lobe of the liver. The 105 plates in Bidloo's Anatemy of 168.5 were actually plagiarized by Willian Cowper (1666-1709), whose Anatomy of Human Bodies (Oxford, 1698) is original only as to the text, and nine perfunctory plates supplied hy ('owper himself.2 For whimsieal originality and excuisite delicacy of detail, the plates drawn by Frederik Ruysch (1638-17313) deserve a special mention. Skeletons posed in quaintest at titudes, with appropriate mottoes of the "memento mori" variety attached, surrounded by strange reptiles, stuffed monsters, dried plants, and deep-sea creatures, constituted the favorite decorative scheme of the old Dutch anatomist, whose mortuary humors have been sublimated in Leopardi's dialogue. ${ }^{4}$

1 very important outeone of Harvey's demonstration of the cireulation was the art of anatomic injection which was alvaneerl by Swammertam, de Giraf, and Rurseh. Borengarius Carpi had filled the blool-vessels with tepid water, stephanus with air, Eustachins with eolored fluids, Malpighi and Gilisson with ink, and Willis diseoveret the cirele of Willis by injecting the brain with "aque croceta." Swammerdam aimed to get a preparation which could be injerted warm and solidify afterward. He first triesl suet, but, in 1677, hit upon wax. In 16tis, de Ciralaf introdued an improved syringe (De usu syphonis), and injected the spermatie vessels with mereury. In 1680. Swammerdam besame convineed of the impiety of anatomy, and joined a fanatical religious seet. Before doing so, however, he published his method abroald, send-

${ }^{1}$ Wrongly attributed by Baas to the publisher, Stephan Niehelspacher. The idea of representing anatomie relations by superimposed pictures was alreaty a feature of the Renaissanee "Flirgemile Blitter," was suggested by Vesalius, and utilized in L. Thurnheyseres's "Confirmatio" (1567) and Bartiseh"s "Angendienst" (1583) (Choulant).

${ }^{2}$ Birloo seolls about this in his "Gullelmus Cowper, criminis literarii citatus:" (Leyden, 1700).

${ }^{3}$ Puyseh: Thesauri anatomiei, Ansterdam, 1701-16.

" Criaromo Leopardi: "Dialogo di Federico Ruyseh e delle sue mummie," in his collective works. 
ing a preparation to the Royal Society in 1672 , and especially training Ruysch to its use. The latter introduced the new feature of applying the microscope in the injection of the finer vessels. The process was subsequently improved by Monro primus, Lieberkühn, Prochaska, Gerlach, and others, up to the time of Hyrtl's wonderful injections in two, three, and four different colors. ${ }^{1}$

The first crude attempt at comparative anatomy was made by Marco Aurelio Severino (1580-1656), whose Zoötomia Democrita (1645) antedates Malpighi, Leeuwenhoek, and Swammerdam. The woodeuts show the viscera of birds, fishes, and mammals, with some phases of their development, and slight as the comparative features are, the book is the only thing of its kind before the eighteenth century.

A remarkable comparative anatomist of the seventeenth century was Edward Tyson (1650-1708), of the University of Cambridge, who graduated there in 167s, and lectured on anatomy to the Barber Surgeons up to 1699. Tyson was the first to publish elaborate monographs on the structure of the lower animals, his memoirs on the anatomy of the porpoise (1680), the rattlesnake (16S3), and his dissections of such animal parisites as Lumbricus latus, Lumbricus teres (Ascaris lumbricoides), and Lumbricus hydropicus (hydatids), being a great advance on the Anatomia porci of Copho, the first allventure in this kind. The structures in the prepuce known as Tyson's glands are named after him, but his most important contribution to science is his OrangOutang, sive Homo Sylvestris (1699), the first work of consequence in comparative morphology. In this book Tyson compares the anatomy of man with that of monkeys, and between the two he placed what he thought was a typical pyomy-in reality, a chimpanzee, the skeleton of which is now in the South Kensington II seum of Natural History. This was the origin of the "missinglink" idea, which so many confuse with true Darwinism. Tyson's work concludes with a terminal essay setting forth that the satyrs, iegipans, cynocephali, and other mythical creatures of the ancients "are all either apes or monkeys, and not men, as formerly pretendor.". This hypothesis was aceepted by Buffon, and the existence of ape-likr or pyomy races of men was doubted until Quatrefages $\left(1 S 87^{3}\right)$ and Kollmann $\left(1 \leqslant 94^{4}\right)$ proved that they have existed and do exist in space and time.

Another important contribution to anthropology was the iclea of "eephalometric lines," conceived by the anatomint Spieghel, and which, says Meigs, 5 "may perhaps be regarded as constituting the earliest scientifie attempt at cranial measurements." These "line cephalometrice," when equal to each other in length, were Spieghel's criterion of a normatly proportioned skull, and Meigs observes that "in ascending the zoologic scale these lines apuroximate equality just in proportion as the head measured approaches the human form."

The Anthropometria (1654) of Johann Sigismund Elsholtz (1623-SS) is, as far as it goes, an illustrated seientifie treatise, following the lines laid down by Dürer.

The invention of the microseope ${ }^{6}$ opened out a new departure for medicine in the direction of the invisible world, as Cralileo's telescope had given a glimpse of the infinite vast in astronomy.

1 W. W. Keen: Early History of Practical Anatomy, Philadelphia, 1s74, passim.

2 See A. C. Harldon: History of Anthropology, New York and London, 1910, pp. $15,16$.

${ }^{3}$ A. Quatrefages: Les Pygmées, Paris, $18 \$ 7$.

${ }^{4}$ J. Kollmann: Pygmäen in Europa, 1894.

${ }^{5}$ J. A. Meigs: N. Am. Med.-Chir. Rev., 1861, v, 840, cited by Hadion.

6 The early history of the mieroseope is somewhat complex and indefinite. An excellent account of it is given by Charles Singer: Proc. Roy. Soc. Mel. (Sect. Hist. Med.), Lond., 1913-14, vii, 247-279. 
The earliest of the microscorists was the learned besuit priest, Athanasius Kircher (160)2-80), of Fuldal, who was at once a mathematician, physicist, optician, Orientalist, musician, and virtuoso, as woll as a meelical man, and who was probably the first to cmploy the microscope in investigat ing the causes of disease. In his serutinium pestis (Rome, 16iss) he not only details seven experiments upon the nature of putrefact ion, showing how maggots and other living creatures are developed in decaying matter, but found that the hood of plague patients was filled with a eountless brood of "worms," not pereeptible to the naked eve, but to be seen in all putrefying matter through the microscope. While

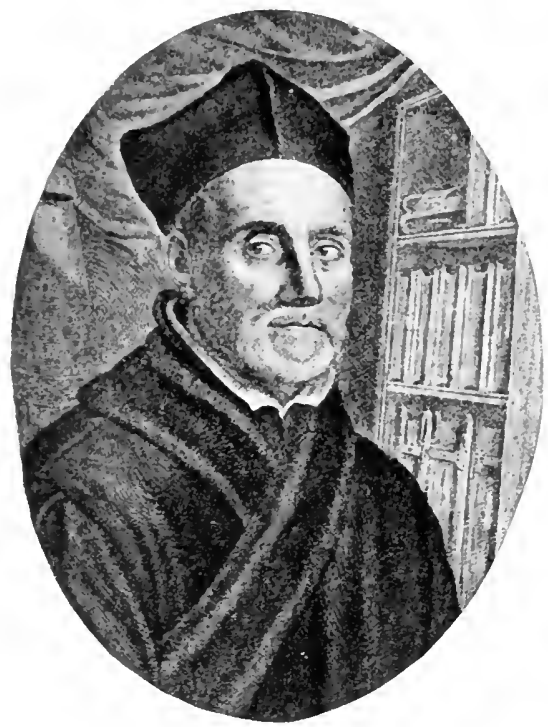

Athanasius Kircher (1602-80).

Kircher's "worms," as Friedrich Loeffler ${ }^{1}$ claimed, were probably nothing more than pus-cells and rouleaux of red blood-corpuscles, since he could not possibly have seen the Bacillus pestis with a $32-$ power mieroseope, yet it is quite within the range of possibility for him to have seen the larger mieroörganisms, and he was undoubtedly the first to state in explicit terms the doctrine of a "contagium animatum" as the cause of infectious disease. In his Physiologia Kircheriana he was also the first to record an experiment in hypnotism or provoked eatalepsy in animals $\left(1680^{2}\right)$. Another early worker with the microscope was Robert Hooke (1635-1703), a mechanieal genius who anticipated many modern diseoveries and inventions and who laid elaim to all that were thinkable in the period in which he lived. Hooke's Micrographia (London, 1665) contains many fine plates, representing the histology of vegetable structures, and the first use of the term "cell" in this connection. This book probably inspired the works of Nebemiah Grew (1641$1712)$ on vegetable histology and physiology $(1671,1682)$. Grew,

${ }^{1}$ Fr. Loeffler: Vorlesungen über die geschichtliche Entwicklung der Lehre von den Bacterien, Leipzig, 1857, pp. 1,2.

${ }^{2}$ Kircher also treated of the curative powers of magnetism in his "Magnes sive de Arte Magnetica" (1643), which contains a description of "tarantism." 
whom Haller styled "an industrious observer of nature in every" direction," was probably the first to consider the existence of sex in plants.

Jan Swammerdam (1637-80), whose interest in natural history was awakened by the fact that his father's apothecary-shop contained the finest eollection of exotie fauna in Amsterdam, was an expert in microscopic dissecting long before he began to study medicine. Having literally grown up among zoölogie specimens, he never practised, but devoted his short life to arduous and splendid labors in minute anatomy and embryology. His career was that of a scientific enthusiast who lived up to the prineiple aliis inserviendo consumor, and his best work is contained in the huge Bybel der Natuur, which Boerhave published long after his death (Ansterdam, 1737), comprising some 53 plates with accurate life histories, giving the finer anatomy of the bees, the mayflies, the snail, the clam, the squid, and the frog. The drawings in this collection surpass all other contemporary work in exquisite delieacy and accuracy of detail. Swammerdam was the first to diseern and describe the red blood-corpuscles (16.58), diseovered the valves of the lymphaties (1664), discovered the medico-legal fact that the fetal lungs will float after respiration has taken place (1667), and, in 1677, devised the method of injeeting blood-vessels with wax, which was afterward claimed by Ruyseh. He was also no mean experimental physiologist, ${ }^{1}$ studying the movements of the heart, the lungs, and the muscles by plethysmographic methods which are almost modern.

A very great microscopist was Antonj van Leeuwenhoek, of Delft (1632-1723), who, as an inheritor of well-to-do brewers, led an easy-going life, the greater part of which was devoted to the study of natural history. He had some 247 microscopes with 419 lenses, most of which were ground by himself, and onee sent 26 mieroscopes to London as a present to the Royal Society, of which he became a Fellow in 1680. The directors of the Fast India Company sent him specimens, and even Peter the Great visited his collection in 1689 . Leenwenhoek was a strong man of marvelous industry, and during his long life he sent as many as 375 scientific papers to the Royal Society and 27 to the French Aeademy of Seiences. These Ontledingen en Ontdeklingen (Leyden, 1696) contain, in addition to a vast amount of work on animal-

1 For a good account of Swammerdam's work in experimental physiology see W. Stirling, Some A postles of Physiology, London, 1902, pp. 34, 135, with interesting illustrations. The life of Swanmerdam has been made the subject of a fascinating "culturhistoriseher Roman," by Hermann Klencke, entitled Swammerdam oder die Offenbarung der Natur (3 vols., Leipzig, 1stio), which is well worth reading for the light it throws upon social life and cultural conditions in the seventeenth century. 
cular and plant histology, many discoveries of capital importance to mediene. Leemorenhock was the first to describe the spermatozo: (originally pointed out to him by the student. Hamen in 1674); gatre the first complete acoomt of the red hlood-eorpuscles (1674); discovered the striped chamater of voluntary muscle and the structure of the arytalline lens; was the first to see protozoa under the mieroseope (1655); fomnd microobrganisms in the teeth, giving, for the first time, aremate figurations of bacterial chains and (lumps as woll as of individual spirilla and bacilli (September 17, $168.3)$; and demonstrated the capillary anastomosis between the

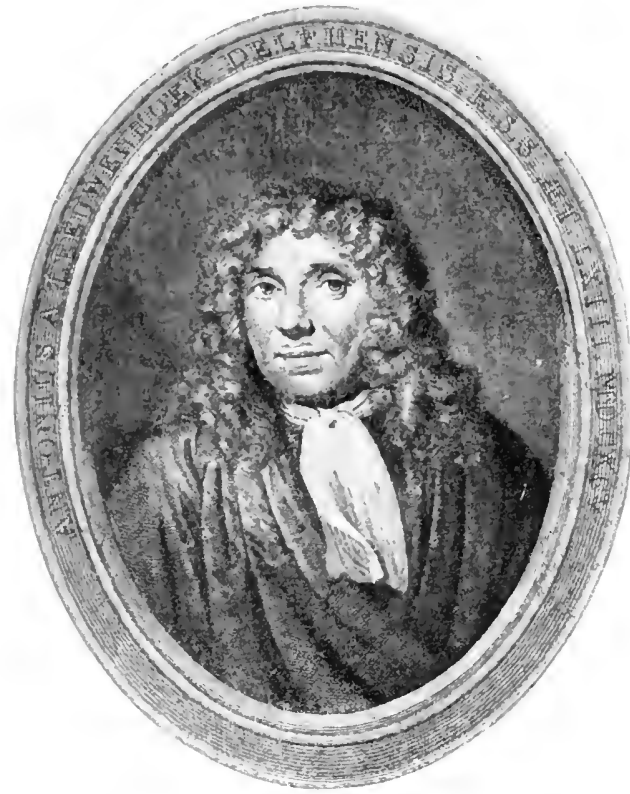

Antonj van Leeuwenhoek (1632-1723).

arteries and veins, which Malpighi had already seen in 1660 withont attaching much importance to it. It was Malpighi's discovery and Lcenwenhoek's thorough work on the capillary circulation which finally completed Harvey's demonstration. The portrait of this tremendous worker represents a strong, sturdy figure in whose countenance Richardson diserns "the quict force of Cromwell and the delicate disdain of Spinoza."

The greatest of the microscopists, however, was Marcello Malpighi (1628-94), the founder of histology, who was professor of anatomy at Bologna, Pisa, and Messina, and physician to Pope Innocent XII (1691-94). Famed in biology for his works on the 
anatomy of the silkworm and the morphology of plants, he made an epoch in medicine by his investigations of the embryology of the chick and the histology and physiology of the glands and viscera. The 12 plates accompanying his Royal Society memoirs, De formatione pulli in ovo (1673) and De ovo incubato, make him the founder of descriptive or iconographic embryology, surpassing all other contemporary workers on the subject in the aceurate notation of such minutix as the aortic arches, the head-fold, the neural groove, the cerebral and optic vesicles. Malpighi described the

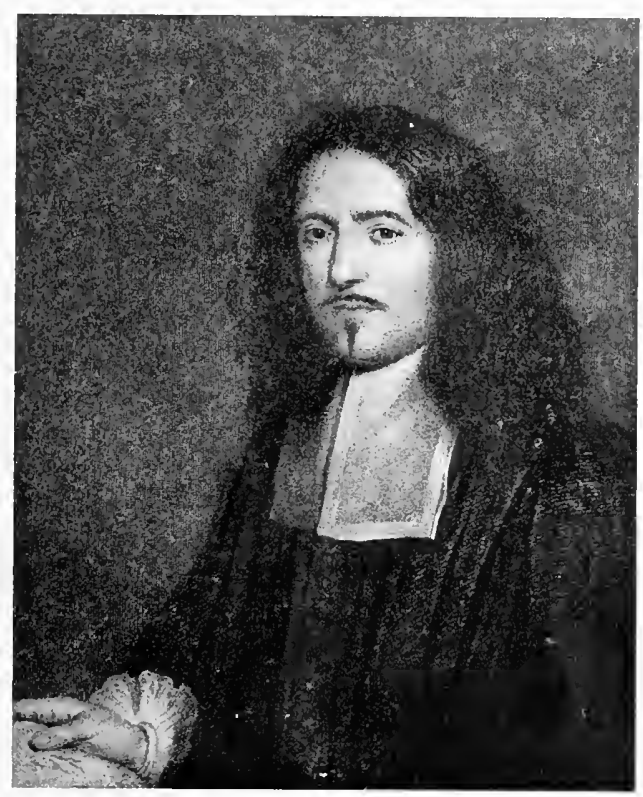

Marcello Malpighi (1628-94). (From the painting by Tabor, Royal Society.)

ed blood-corpuscles in 1665 (seven years after Swammerdam) as fat globules looking like a rosary of red coral." He discovered he rete mucosum, or Malpighian layer of the skin, and proved hat the papillæe of the tongue are organs of taste. Perhaps his reatest work is the De pulmonibus (1661), which overthrew the urrent coneeptions of the pulmonary tissues as "parenchymatous," emonstrating their true vesicular nature, the eapillary anastomosis etween arteries and veins, and how the trachea terminates in ronchial filaments. Of his discovery of the eapillaries (1660), raser Harris has well said that "Harvey made their existence a 
logionl necossity: Malpighi malde it a histological cortanty."1 His work on the structure of the livere, spleen, and kidneys (I6660) did much to alvane the physiologic knowledge of these viscera, and his namo has hern eponymieally preserved in the Malpighian bodies of the kidney and spleen. 'This book also contains the first aceount of those lymphadenomatous formations (general enlargement of lymphatios with molules in spleen ${ }^{3}$ ) which were fully desoribod by Hodgkin in 1832, and which Wilks, in 1856, called Hodgkin's disoase, or psendo-loukemia. Malpighi's mivate life was embitered by the coarse personal attacks of his Pisan colleague Borelli, and by an oid-time feud (of which he bore the brunt) between his family and a neighboring clan of the ominous

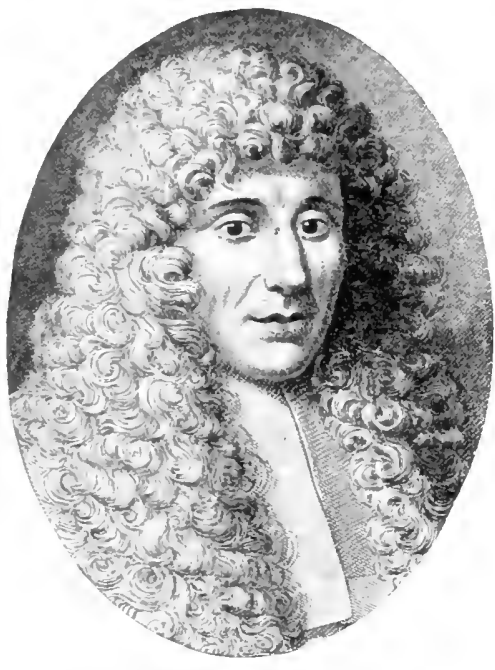

Francesco Redi (1626-94). and significant name of Sbaraglia. As in the case of Harvey and John Hunter, some of his best work was lost to posterity by the wanton destruction of valuable manuscripts. In personality, Malpighi was a gentle, fair-minded, sympathetic nature, and, among the sick, a patient and devoted Asclepiad. The memory of Malpighi is one of "sweetness and light," and, in his capacity for acute observation, he verified the remark of Thoreau that the laws of the universe are "forever on the side of the most sensitive." He is not only one of medicine's greatest names, but one of its most attractive personalities. ${ }^{4}$

The first hard blow to the doctrine of spontaneous generation was given by the Italian naturalist, Francesco Redi (1626-94), of Arezzo, who confuted the idea, then current, that grubs and maggots develop spontaneously in decaying matter. ${ }^{5}$ He exposed meat in jars, some of which were uncovered, the others being cov-

Nature, June 29, 1911, 584.

De viscerum structura, Bonn, 1666.

${ }^{3}$ De viscerum structura, Bonn, 1666, 12.5, 126. 1897.

4 A monument to Malpighi was unveiled at Crevalcuore on September 8 ,

${ }^{5}$ Experientia circa generationem insectorum, Amsterdam, 1671. Redi is also said to have been one of the first to analyze food. 
ered with parehment and wire gauze. In due course maggots appeared in the first two, but, in the latter, developed on top of the gauze. This conclusive object-lesson settled the matter, so far as the spontaneous generation of visible ereatures was concerned. Leeuwenhoek's discovery of bacteria and the reast plant was to raise the question in another form and leave it in clispute until the time of Schwann and Pasteur.

Apart from the produetions of the great mierographic or morphologic botanists of the seventeenth century-Hooke, Cirew, Malpighi-some grod work was done in systematic or taxonomic botany. The English botanist, John Ray (1627-1705), separated llowering from flowerless plants in his "Methodus plantarum" (London, 16s2), and further divided the former elass into monoeotyledlonous and cliectyledonous. Ray "stood for the whole plant," as the botanists say, in his elassification. Robert Mlorison (1610-831), the first professor of botany at Oxford, made a systematic arrangement of plants in 18 classes, distinguishing them as woody and herbaceous, flower-bearing and fruitpearing, after the fashion of Cesalpinus (1672-80). ${ }^{1}$ Augustus Quirinus Rivinus (1652-1723), of Leipzig, classified the plants by the petals of the flowrs (1691-99) and wrote an introduction to botany (1690), illustrating these. works at great expense from drawings by capable artists. Ho wrote a Censura of officinal preparations (1701), in which he elassifies all useless and undeirable remedies, studied the diseases of Leipzig and Wittenberg, and advanced - pathologia animata, ascribing most diseases to mites and minute worms, with kind of antitoxic therapy (Neuburger). Toward the end of the century the avorite system of classification of plants was that of Joseph-I'itton de Tourneort (1656-1708), the author of Elemens de botanigue (1694) and Institutiones ei herbaria (1700), in which be deseribed 8000 speeies, arranged in 21 classes, ecording to the form of the corolla. This system held the field until the ime of Linnaus, who, like Tournefort, exaggerated the importance of the ower as a fundamentum divisionis.

The zoölogic investigations of Swammerdam, Leeuwenhock, Redi, and Ialpighi were supplemented by the work of Martin Lister (1638-1711), hysician to Queen Anne, Oläus Worm (15s8-16.54), of the Wormian bones, ntonio Vallisnieri, and others, who, like the great leaders of the time, devoted eir attention mainly to entomology.

Theoretic medicine in the seventeenth century naturally folwed the trend of physiologic doctrine, and this struck into two ifferent paths, the iatromathematical and iatroehemical. Great dvances in chemistry were made by Boyle, Willis, Mayow, and thers, and the period was preëminently an age of discoveries in stronomy and mathematieal physies. Following the publication : Copernieus' treatise on the revolution of the planets around the In (1543), Galileo had invented the teleseope in 1609, Kepler had ated the laws governing planetary motion in 1609-18, and New'n's statement of the law of gravitation (1682) was followed by te publication of his Principia in 1687. Logarithms were inented by Napier (1614) and Briggs (1617), Deseartes founded alytic geometry in 1637, Pascal published his contributions to

${ }^{1}$ Morison: Præludia Botanica, 1672, and Plantarum Historia L'niversalis, so. 
the theory of probahilities in 16.5.t, while Newt on ereated the differcutial calculus in 1665-6it, and stated the hinomial theorem in 1609. Von (incricke, a hurgomaster of Magdeburg, invented the arr-pump in 16:1; 'Torricelli, the barometer in 1643; and Hooke, a (ompoumel microseope in 1665. Such important discoveries and inventions as these were not without their influence upon medieine. The Iatromathematical School, hy which all physiologic happenings were trated as rigid comsequences of the liaws of physics, was

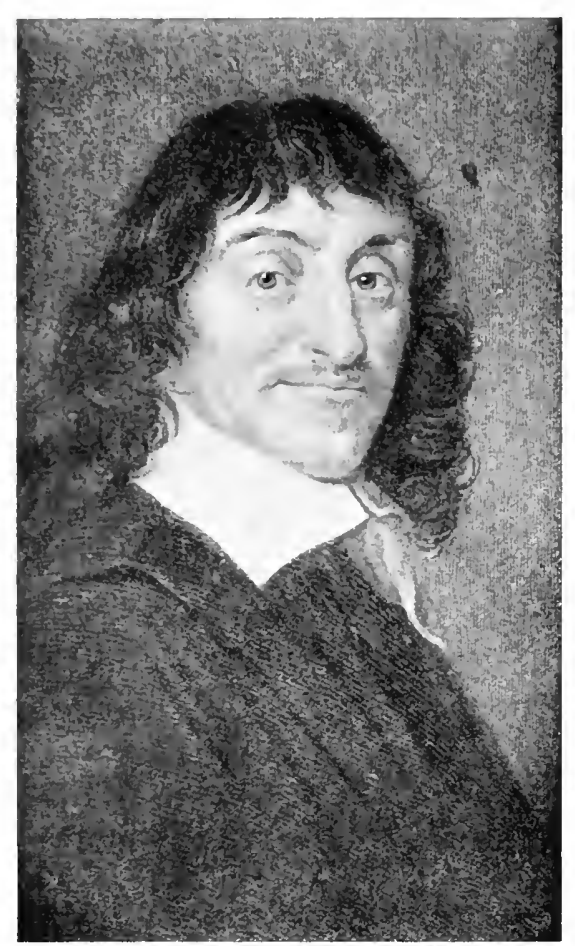

René Descartes (1596-1650). represented by Descartes, Borelli, and Sanctorius. The protagonists of the Iatrochemical School, which regarded all vital phenomena as chemical in essence, were van Helmont, Sylvius, and Willis.

The De homine of René Descartes (1662) is usually regarded as the first European text-book on physiology, although it was only a popular and theoretic exposition of the subject. In this respect, Sir Michael Foster has likened it to Herbert Spencer's Principles of Biology. It treats of the human body as a material machine, directed by a rational soul located in the pineal gland. Descartes grasped the dynamic importance of Harvey's discovery, but, like all his eontemporaries, was a theoretic Galenist in ascribing the movements of the heart to its internal fire or heart. In his treatise, Des passions de l'ame (1649), he gives the first experiment in reflex action-the familiar one of making a person bat his eyes by aiming a mock blow at them-with the correct explanation of the phenomenon.

The mechanical view of the human organism was applied in a striking way by the Neapolitan mathematician, Giovanni Alfonso Borelli (1608-79), whose De motu animalium (1680-81) at once suggests a follower of Harvey. A pupil of Galileo, Borelli profited 
much by a long association with his colleague Malpighi, and his rigorous mathematical reasoning swept away many current superstitions about the true functions of the muscles, the lungs, and the stomach. He treated locomotion, respiration, and digestion (the grinding and crushing action of the stomach) as purely mechanical processes. His ultimate theory of muscular action was dubious, as based upon the erroneous idea that a contracting muscle actually increases in bulk by reason of a fermentation started in its substance from a liquid discharged through the nerves-the succus nerieus - which was Borelli's substitute for the Galenic "animal spirits." In this way Borelli originated the neurogenic theory of the heart's action, in virtue of which the heart-beat is attributed to the action of extrinsic or intrinsic nerves.

The extreme of iatrophysical doctrine in Italy was reached by Malpighi's pupil, Giorgio Baglivi (166S-1706), whom Clement XI appointed to the chair of medical theory in the Collegio della Sapienza. Disgusted, as a student, with the fact that medical practice was no longer guided by experience but

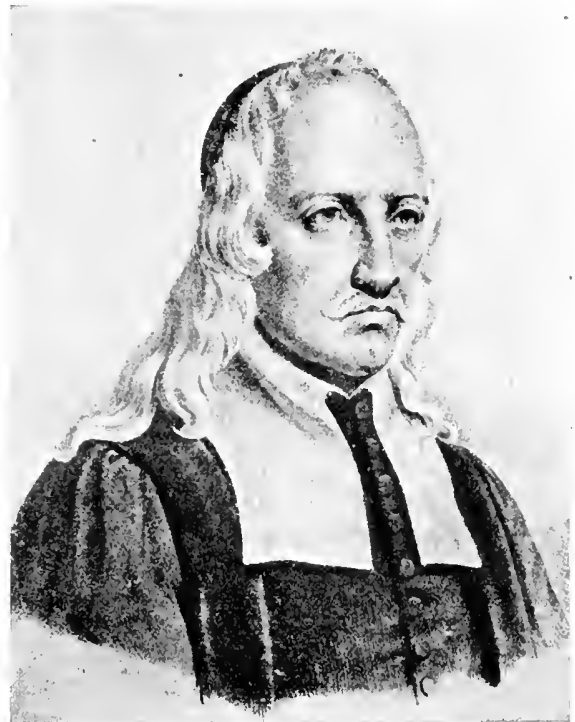

Giovanni Alfonso Borelli (1608-79). had become a monstrous assemblage of heterodox opinions, Baglivi devised a theoretic system of his own.

He pushed the mechanical allegory to the extent of dividing the human machine into innumerable smaller machines, likened the teeth to seissors, the chest to a bellows, the stomach to a flask, the viscera and glands to sieves, the heart and vessels to it waterwork (Neuburger ${ }^{2}$ ).

But directly he entered the sick-room, Baglivi dropped all these fine theories as the eonclusions of immature laboratory logic. He was a highly successful physician, a true follower of Hippocrates

1 For the detailed history of this doctrine, see M. del Gaizo: Atti d. r. Accad. med. chir. di Napoli, 1916, lxx, \$5-107.

${ }^{2}$ Neuburger: Puschmann's Handbuch, Jena, 1903, ii, 53. 
at the bedside, and he lierl of hatrd work. "To frequent societies,"

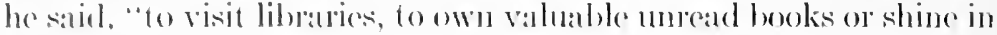
all the jommals does not in the least antribute to the comfort of the sick."

The men of the Iatromathematieal sehool knew or cared little ahout the new seienee of chemistry, and their offorts finally dwindled away into such sterile cecentricities as Archibald Pitarin's attempt to base the whole of medieal practice upon mechanical principles, Edward Barry's attempts to estimate a man's age from the frequeney of his pulse, or Clifford Wintringham's offorts to woigh an individual sucrmatozoön. But the effect of mathematienl and experimental physies moon modicine was manifosted in more important ways, notably in the first at tempt to put pulse counting and clinical themometry upon a working basis.

In the fifteenth century Cardinal Cusanus (Nikolaus Krebs of

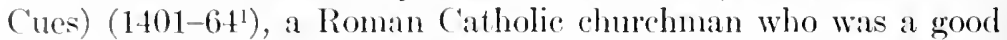
mathematieian, made some timely suggestions in his Dialogue on statics (1450) as to the possible clinical value of weighing the blood and the urine, and of comparing the frecueney of the pulse and respiration in disease with that in a nomal control, as estimated by the clepsydra, or water-clock. 'These, however, were not put into effect or carried into practice, and remained unnoticed by sureceling generations. Between 1593 and 1597 , as Dr. Weir Mitchell has shown, ${ }^{2}$ Galileo had invented a rude thermometer or thermoscope, and as early as 1600 Kiepler had used pulse-counting to time his astronomic observations. Later, Galileo conceived the idca of using his own pulse to test the synchronous character of a pendulum's vibrations, which led him to the converse proposition of measuring the rate and variation of the pulse by a pendulum, much as a metronome is used to check the tempo of music. These ideas were appropriated and utilized in a remarkable way by the celebrated Paduan professor, Santorio Santorio (1561-1636), usually called Sanctorius. In his commentary on the first book of the canon of Avicenna (Venice, 1625), Sanctorius describes a clinical thermometer ${ }^{3}$ and a pulsilogium, or pulsc-clock, of his own devising, inventions which soon passed into the limbo of forgotten things for nearly a hundred years. Sanctorius was also the clever inventor of instruments for extracting stones from the bladder and

1 See C. Binz: Deutsche med. Wochenschr., Leipz. u. Berl., 1898, xxiv, 640; and J. J. Walsh: Old-Time Makers of Medicine, New York, 1912, pp. $336-348$.

2 See s. Weir Mitehell: The Early History of Instrumental Precision in Medieine, New Haven, 1892 , p. 10 et seq.

${ }^{3}$ Drebbel is usually regarled as the inventor of the air thermometer, Gilileo, of the spirit thermometer, and Roemer, of the mercurial thermometer. 
foreign bodies from the ear, as also a trocar, a cannula, and a hygroscope. His medical fame today is best associated with the fact that he founded the physiology of metabolism through his experiments and data upon what he called the "insensible perspiration" of the body. The frontispiece plate in later editions of his Ars de statica medicina (1614), representing the famous Paduan seated in his steelyard chair, in act to weigh himself for a metabolism experiment after a meal, is a familiar human document in the annals of medical illustration.

The physical theory of vision, which might be styled the ground-bass of ophthalmology, owes its development mainly to the work of great astronomers and physicists. The Ad Vitellionem, Paralipomena, of the astronomer Kepler (Frankfort, 1604 ), contains a treatise on vision and the human eye in which is shown for the first time how the retina is essential to sight, the part the lens plays in refraction, and that the convergence of luminous rays before reaching the retina is the cause of myopia. In the Dioptrica of René Descartes (1637) the eye is compared to a camera obscura, and its accommodation is shown to be due to changes in the form of the lens. It was Edme Mariotte (died 1684) who proved that a luminous eye is due to reflection of light, and discovered the blind spot in the retina (1668). A remarkable

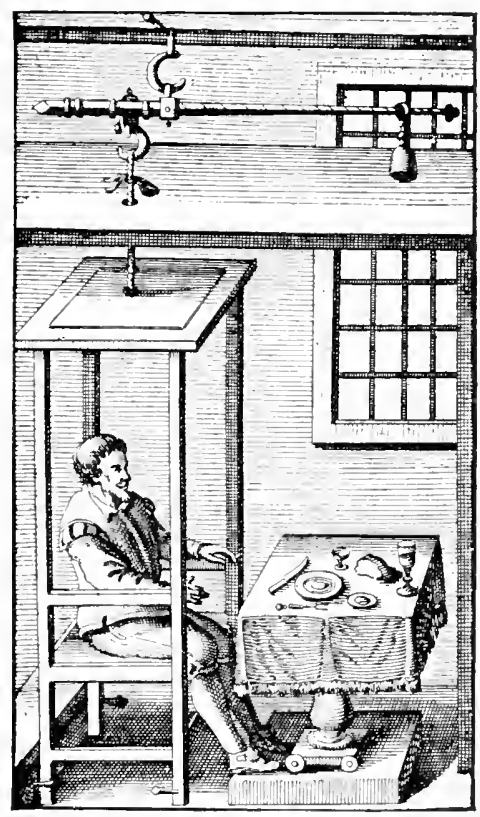

Sanctorius on the Steelyard. (From his Ars de statica medicina, Leyden, 1711.) pioneer in physiologic optics was the Jesuit astronomer Christoph Scheiner (died 1650), of Vienna. In 1587 Aranzi had demonstrated the reversal of the image projected on the retina in cattle, and had shown the lateral entry of the optic nerve. In his Oculus (Mühldorf, 1619) Scheiner gave an ingenious demonstration of how images fall on the human retina, noticed the changes in curvature of the lens during accommodation, and illustrated accommodation and refraction by the pin-hole test which bears his name.

The founder of the Iatrochemical School was the Belgian mys- 
tic Jain Baptiste van Helmont (157--11.th), who, hefore he

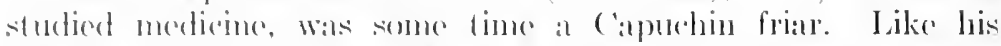

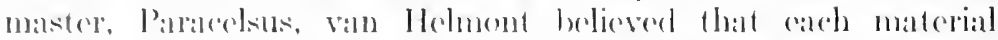

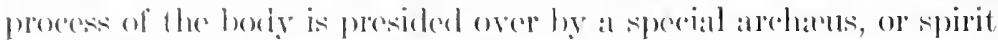
(which lo ealls Bliss), and that these physiologice processes are in themselves purely ahemiend, heing due in each ease to the ageney of a special ferment (or (ats). Fach (bas is an instrument in the hands of its speciat B Bas, while the batler are presided over by a sonsory-motive soul (amima sensitiva motivague), whieh van Helmont locates in the pit of the stomach, since a blow in that region destroys conscionsness. Ho was the first to recognize the physiologic importance of ferments and gases, partienlarly of carbonic

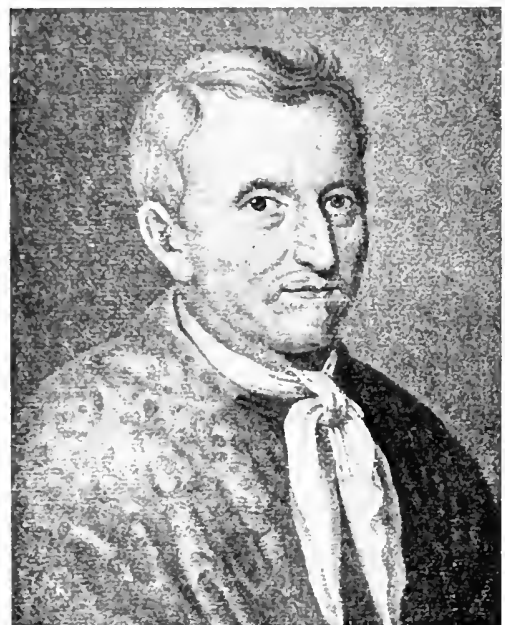

Jean Baptiste van Helmont (1577-1644). acid, which he deseribed as gas sylestre, and his knowledge of the bile, the gastric juice, and the acids of the stomach was eonsiderable. He gives a fair accomnt of the nature of wound infection in the jargon of his time, and had some notion of immunity and possible immune sera (Osler). His elaims to the discovery of carbon dioxid $\left(\mathrm{CO}_{2}\right)$ are somewhat vitiated by the fact that he regarded this "gas sylvestre," formed in vinous fermentation, as identical with the gas in the Grotto del Cane in Italy, and with the dunste, or deadly vapor of burning charcoal, the former of which is $\mathrm{CO}_{2}$, the

latter arbon monoxid (CO). Van Helmont introduced the gravimetric idea in the analysis of urine, and actually weighed a number of twenty-four-hour specimens, but drew no deductions of value from his measurements.

Physiological chemistry was divested of most of the fantastic trappings which van Helmont gave it by the Leyden professor, Franciscus de le Boë, or Sylvius (1614-72), and his pupils, Willis, de Graaf, Stensen, and Swammerdam. Sylvius, who did for Harrey's ideas what Paré had done for those of Vesalius, has been described by Sir Michael Foster as an expositor, rather than an investigator, of science, but even as a teacher, and there were none greater in his time, he was wonderfully fertile in original ideas about the function of the ductless glands, acidosis, the thermal 
and tactile senses, and other things of moment today. He was the first to distinguish between conglomerate and conglobate glands, but his relation to the Sylvian fissure, as described in his Disputationes medice (1663), is obseure. He regarded digestion as a chemical fermentation, and recognized the importance of the saliva and the pancreatic juice. His best service to medicine was that he took a firm stand upon the ultimate identity of organic and inorganic processes in chemistry, and that, in lis little infirmary of twelve beds at Leyden, he was one of the first to introduce ward instruction in medical education.

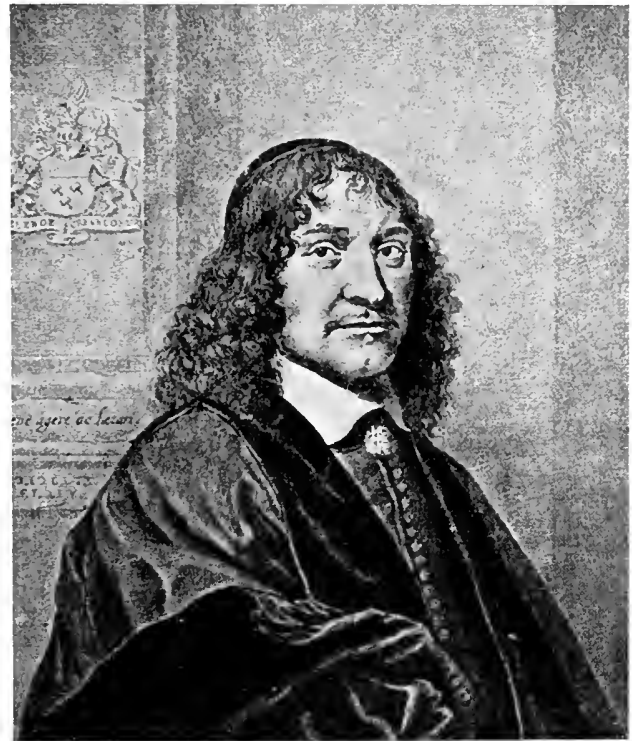

Franeiseus Sylvius (1614-72).

The Dutch followers of Sylvius, Stephan Blankaart and others, reeommended enormous quantities of the newly imported novelties, tea and coffee, as panaceas for acidity and blood-purifiers. The universities of Jena and Wittenberg espoused his doetrines, and Daniel Sennert, at Wittenberg, was one of his warmest adherents. In Paris, Vieussens, who was the first to make chemieal examinations of the blood, was his only follower. The Paris Faeulty and Gui Patin eondemned his system as the "noureauté impertinente du sièele."

The leading English exponent of chemiatry was Thomas Willis (1621-75), a Wiltshire farmer's son, who graduated from Christ Church College in 1639, was Sedleian Professor of Natural Philosophy at Oxford in 1660, and, moving to London in 1666, acquired 
the largest fashionable praction of his day. Willis's "Cerebri Anatome" (lobit), in the preparation of which he was greatly indebted to Richard Lower and to Sir ('hristopher Mren (who ilhustrated it), wats the most complete and aremate aceount of the nervous system which had hitherto appoured. It contains the chassifuation of the corehral nerves, which held the field up to the time of soemmerring, the first aeseription of the eleventh cranial (spinal aceessory) nerve or "nerve of Willis," and of the hexagonal network of arteries at the base of the brain which is called by his name. His reasoning about the physiology of the nervous system was, in many respects, erroneons and obscure, and this obfuscation

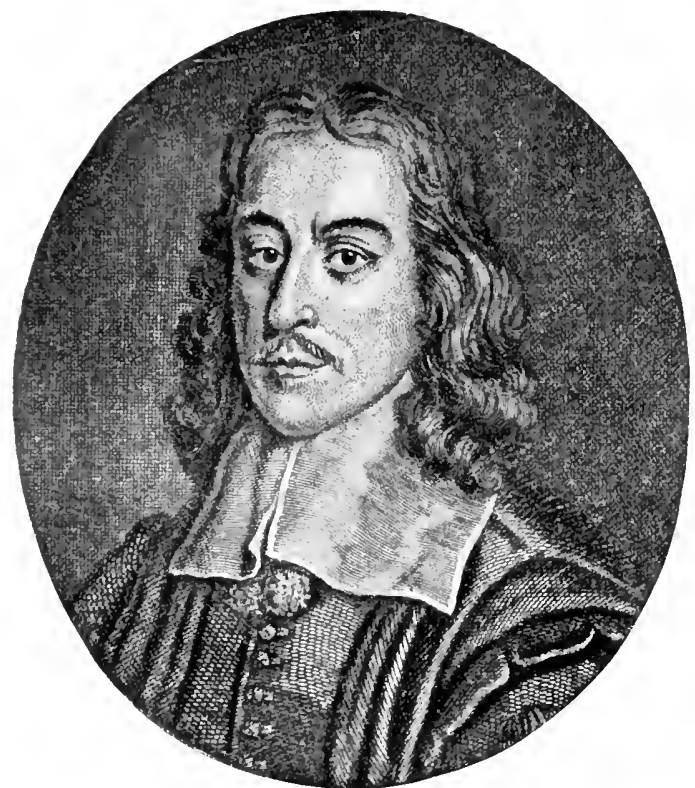

Thomas Willis (1621-75).

has caused some writers, Sir Michacl Foster, for instance, to overlook his just merits as a clinician. Willis was, like Syclenham, Heberden, and Bright, a remarkable example of the capacity of the English physicians for close, careful clinical observation. He made the best qualitative cxamination of the urine that was possible in his time, and was the first to notice the characteristic sweetish taste of diabetic urine, thus establishing the basic principle for the diagnosis between diabetes mellitus and the insipid form. In his London Practice of Physic $\left(1685^{1}\right)$ he deseribed 
the Erb-Goldflam symptom-complex (myasthenia gravis), and in his De febribus, he gave the first account of epidemic typhoid fever as it occurred in the troops of the Parliamentary Wars $\left(1643^{1}\right)$. He was also the first to describe and name puerperal fever. His works on nervous diseases $\left(1667^{2}\right)$ and on hysteria $\left(1670^{3}\right)$ are justly esteemed for their many striking clinical pictures, of which his description of dementia paralytica is perhaps the most important. A good example of his talent for locating and isolating important facts is his observation of a deaf woman who could hear only when a drum was beating. This phenomenon is known in modern otology as paracusis (or hyperacusis) Willisii, the test for paracutic hearing being made in the clinics by placing a vibrating tuning-fork on the head of a deaf patient or by means of the "noise machine" recently devised by the Viennese otologist, Robert Bárány. Willis's Pharmaceutice rationalis (1674) gives a valuable epitome of the materia medica of his time. ${ }^{4}$

Regner de Graaf (164173), of Schoonhaven, Holland, was the first to study the pancreas and its secretions before the time of Claude Bernard. In his disputation on the nature and use of the pancreatic juice $\left(1664^{5}\right)$, he describes

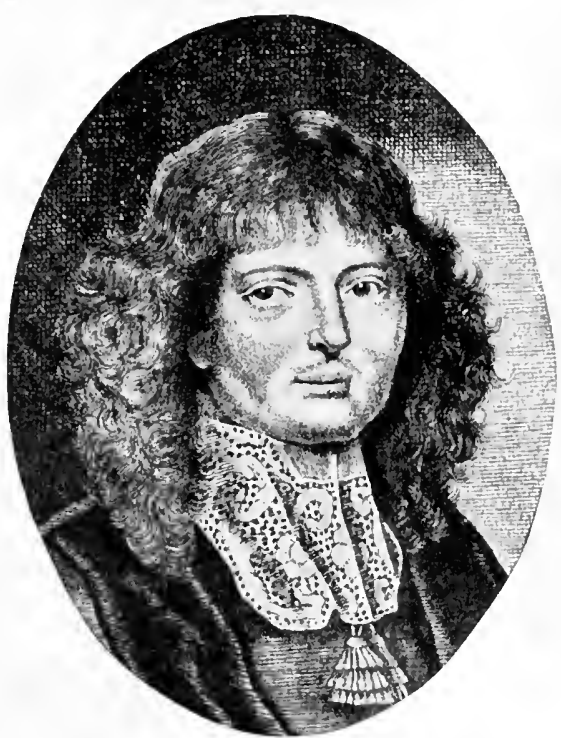

Regner de Graaf (1641-73). his method of collecting

the secretion by means of a temporary pancreatic fistula, noting the small quantity of the juice secreted and its acid character. The monograph is embellished with a picture of the dog employed, showing receptacles depending from a parotid and a pancreatic fistula. De Graaf also employed an artificial biliary fistula to

\footnotetext{
${ }^{1}$ De febribus, London, $1659,171 \mathrm{et} \mathrm{seq.}$

2 Pathologiæ cerebri et nervosi generis specimen, Oxford, 1667.

${ }^{3}$ Adfectionum quæ dicuntur hysterice, etc., Leyden, 1670.

${ }^{4}$ The second part has been praised by Osler (Practice of Medicine, Sth ed., 1912 , p. 119) for its description of whooping-cough.
}

${ }^{5}$ De Graaf: Disp. med. de natura et usu sueci pancreatici, Leyden, 1664. 
mollect the hile, in which he was precerled, howerer, by Malpighi.

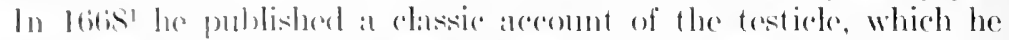
described as made up of small tabes folded up into lobules. This work also contalins an essay on the wse of alysters, which were then anting into fishion. In 1672 appeared his work on the ovaly, containing the first aceount of the structures which Haller called,

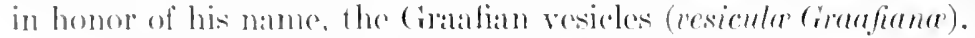

A pominent (icmmon physiologist of this period was Johann Bohn (16.t0-171!), of Leipzig, who experimented upon the decapitatod from $\left(16866^{2}\right)$ in an ontirely modern spirit, decharing the reflex phenomena to be entirely matcrial, as algainst the current view of "vital spirits" in the nerve-fluid. He showed that the panceatie juice is not acid and that the nerves do not contain a "nervejuice." As professor of anatomy (1668) and city physician (1691) at Loiprig, then famous for the medico-legal decisions of its faculty, Bohn malle his mark in forensic medicine, particularly by his treatise on lethal wounds (1689).

Important researches in the physiology of digestion were made by the swiss anatomists Peyer and Brunner.

The name of Johann Comrad Peyer (1653-1712), of Schaffhatuen, Switzerland, will always be associated with the lesions of Perer's patches in trphoid fever, although he held that these glands, which he discovered in $1677,{ }^{3}$ were not conglobate or lymphatic. as we now know then, but conglomerate, secreting, as he believed, a digestive juice. He gives an interesting eut of the Peyer glands in the small intestine and the solitary follicles in the large intestine. He also wrote on the physiology of rumination (.Merycologin, 16is5).

Joham Conrad Brunner (1653-1727), of Diessenhofen, Switzerland, cliscovered Brumner's glands in the duodenum of dogs and man in 1672, publishing his results in 1687.4 He believed that they secreted a juice similar to that of the pancreas. He also made experimental excisions of the spleen and panereas in the dog in $1683,{ }^{5}$ keeping the animal alive. with normal digestion, for some time after. In one of these excisions he found that the dog had extreme thirst and polyuria, which would seem to be a pioncer experiment on the internal secretions of the pancreas.

Niels Stensen (1648-86), or Steno, of Copenhagen, was, like

\footnotetext{
1 De Graaf: De virorum organis generationi inservientibus, Leyden, 1668.

2Bohn: Circulus anatomico-physiologicus, Leipzig, 1686, 460. Cited by Neuburger.

${ }^{3}$ Pever: Exercitatio anat. med. de glandulis intestinorum earumque usu et affectionibus. Schaffhatusen, $167 \%$.

${ }^{4}$ Brunner: De glandulis in duodeno intestino detectis, Heidelberg, 1687.

${ }^{5}$ Experimenta nova circa pancreas, Amsterdam, 1682.
} 
Athanasius Kircher, a physician-priest, and, also like him, a man of wonderful versatility. He was at once a great anatomist, physiologist, geologist, and theologian, and became Bishop of Titiopolis some time after his conversion from the Lutheran to the Catholic faith in 1667. In anatomy, his name is permanently associated with the excretory duct of the parotid gland (Steno's (luct), which he discovered in the sheep in $1661 . .^{1}$ In the same year he investigated the glands of the eye and, in $1664,{ }^{2}$ came his observations on muscles and glands in which he recognizes the muscular nature of the heart. His Paris discourse on the anatomy of

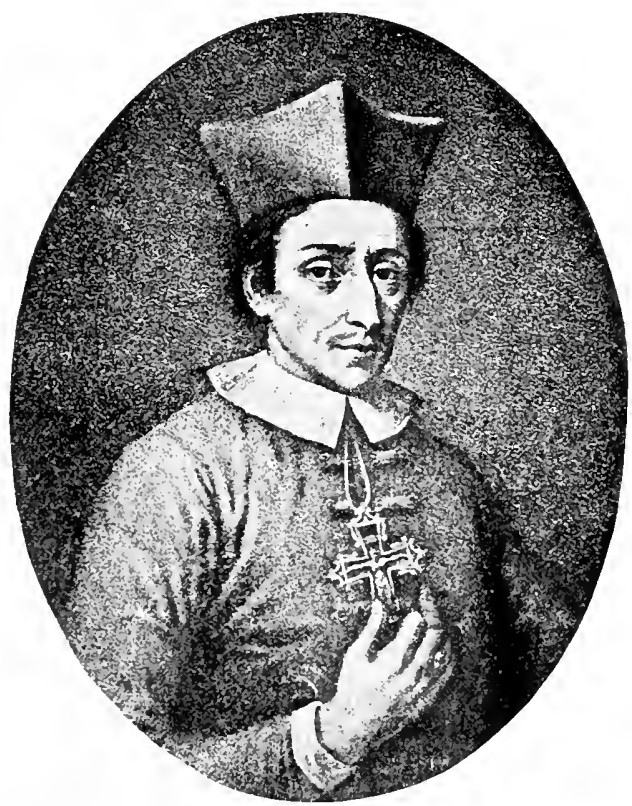

Niels Stensen $(164 S-86)$.

the brain $\left(1669^{3}\right)$ contains much acute criticism of the physiologic errors of his time, particularly those of Willis, who located common sense in the corpora striata, imagination in the corpus callosum, and memory in the cortical substance. Stensen's further studies on the physiology of muscles $\left(1667^{4}\right)$ treat the subject from a

1 Steno: Observationes anatomice, Leyden, 1662.

2 De musculis et glandulis observationum speeimen, Copenhagen, 1664.

${ }^{3}$ Discours sur l'anatomie du cerveau, Paris, 1669.

${ }^{4}$ Elementorum myologiæ specimen, seu musculi descriptio geometrica, Florence, 1667. 
purely mechanical and mathematical standpoint, regarding the individuat museles as parallelepipeds, and opposing the view entertaned hy Borelli that the incerase in size of a muscle is due to the intlux of hypothetic juices. Stensen was also one of the louding founders of geology. In 1883, a bust over his tomb, in the Basilieal sinn lorenzo in Florence, was receted and unveiled by geologists of all nations. His treatise, De solido intra solidum (ibig), contains, after Aricomma and Fracastorius, the most important work on the production of strata, fossils, and other geologic formations. He was led to geology by the dissection of the head of a dog-fish, the tecth of which made it clear to him that the "glossopetre" found in 'luscany were in reality fossil teeth. The story of Stensen's conversion to Catholicism by a sister of the faith, and of his devotion of the better half of his short life to the furthering of its eause alone, is one of the romantic episodes of human history.

Francis Glisson (1597-1677), of Rampisham in Dorsetshire, wats a graduate of Cambridge and Regius Professor of Physic in that Lniversity for some forty years. He was also one of the founders of the Royal Society and president of the Royal Coltege of ]hysicians in 1667-69. As anatomist, physiologist, and pathologist, Cilisson was highly praised by Haller and Virchow, and his name is famous for three important things: He gave the original and classic account of infantile rickets, with an early note of Barlow's disease $\left(1650^{1}\right)$, he gave the first accurate description of the (apsule of the liver investing the portal vein (Glisson's capsule) and its blood-supply $\left(1654^{2}\right)$, and employed suspension in spinal deformities (1660). Before Halter, he introduced the concept of "irritability" as a specific-property of all human tissues $\left(1677^{3}\right)$. Cilison's view of this property was, however, purely metaphysical, bound up with the current notions about "vital spirits," and, in consequence, it had no effect upon the physiology of his time.

The most brilliant outcome of Harvey's experimental method was in the clearing up of the obscure matter of the physiology of respiration, which, up to the time of Lavoisier, was entirely the work of English scientists. Before Harvey's day, men still believer, with Galen, that the object of respiration was to cool the ficry heart, the purpose of the chest movements being to introduce air for generating vital spirits by the pulmonary vein, and to get

${ }^{1}$ Glisson: De rachitide sive morbo puerili qui vulgo the rickets dicitur, tractatus, London, 1650. The earlier work of Daniel Whistler: De morbo puerili Anglorum (1654) is without originality and was probably based upon information gained from Glisson (Norman Moore).

2 Anatomia hepatis, London, 1654.

${ }^{3}$ De ventrieulo et intestinis, London, 1677 . 
rid of the heart's smoky vapors by the same channel. This Galenic notion was not a mere piece of symbolism, as in Riehard Crashaw's poem on St. Teresa (The Flaming Heart), but was part and parcel of actual belief about the physies of the circulation. "Before Harvey's time," says Allbutt, "respiration was regarded not as a means of combustion but of refrigeration. How man became such a fiery dragon was the puzzle." Harvey's demonstration showed that the blood is changed from venous to arterial in the lungs, but beyond that point, as even Pepys has recorded in his Diary, no one could tell how or why we breathe. ${ }^{1}$ The suceessive steps in what Sir Clifford Allbutt calls "the pathetic quest for oxygen" were as follows: First, the distinguished ehemist Robert Boyle (162791) made experiments with flames and animals in vacuo (1660), demonstrating that air is necessary for life as well as for combustion.2 Next, Robert Hooke (1635-1703), in 1667, ${ }^{3}$ showed, by blowing a bellows briskly over the open thorax of a $\log$, that artificial respiration can keep the animal alive without any movement of either chest or lungs. This experiment, which had also been performed by Vesalius, proved that the essential feature of respiration is not in its intrinsic movements, but in eertain blood ehanges in the lungs. The next step was made by Richard Lower, of Cornwall (1631-91), an able physiologist and suecessful practitioner, who was the first to perform direct transfusion of blood from one animal to another (February, 166.5 $)$, and who, with Sehneider, overthrew the old Galenie idea (even upheld by Veslius) that the nasal secretions originate in the pituitary body $\left(1672^{5}\right)$. About $1669^{6}$ Lower injected dark venous blood into the nsufflated lungs, and concluded that its consequent bright color

1 "But what among other fine discourse pleased me most was Sir G. Ent ibout Respiration; that it is not to this day known or coneluded among physiians, nor to be done either, how the action is managed by nature, or for what lse it is," Pepys' Diary, Mynors Bright's erl., London, 1900, v, 191.

${ }^{2}$ R. Boyle: Nova experimenta physico-mechanica de vi aëris elastica, Rotterdam, 1669 .

${ }^{3}$ R. Hooke: "A supply of fresh air necessary for life," Phil. Tr., 1667, jond., 1700 , iii, 66.

${ }^{4}$ R. Lower: "A method of transfusing blood," Phil. Tr., 1666, Lond., 700, iii, 226-232. Denys of Paris was the first to transfuse in man (June 15, 667), after which Lower performed the operation on Arthur Coga, before the Royal Society (November 23, 1667). The ease of Innoeent VIII $(1492)$ is robably apocryphat. (See Jour. Am. Med. Assoc., Chicago, 1914, 1xii, 553; 33.)

${ }^{5}$ C. V. Schneider: De eatarrhis, Wittenberg, 1660-62. R. Lower: "Disertatio de origine catarrhi in qua ostenditur illum non provenire a enrobro," $\mathrm{n}$ his Traetatus de corde, London, edition of $1680,163-175$. This discovery ocalized catarrh in the air-passages and did away with the endless recipes for "purging the brain" (Neuburger).

${ }^{6}$ R. Lower: Tractatus de corde, London, 1669. 
was due to the fact that it hat absorbed some of the air passing through the lungs. Finally John Mayow (1643-79), another Cornishman, demonst rated, in a series of convincing experiments, that the dark venous blood is changed to bright red by taking up a certain ingredicnt in this air which, as being a constituent of nitre $\left(\mathrm{KNO}_{3}\right)$, he termed the igneo-acirial particles or nitro-aërial spirit of air. Mayow was thus, in a sense, very close to the actual discovery of oxygen, and he fully grasped the idea that the object of breathing is simply to cause an interchange of gases between the air and the blood, the former giving up its nitro-aërial spirit (oxy-

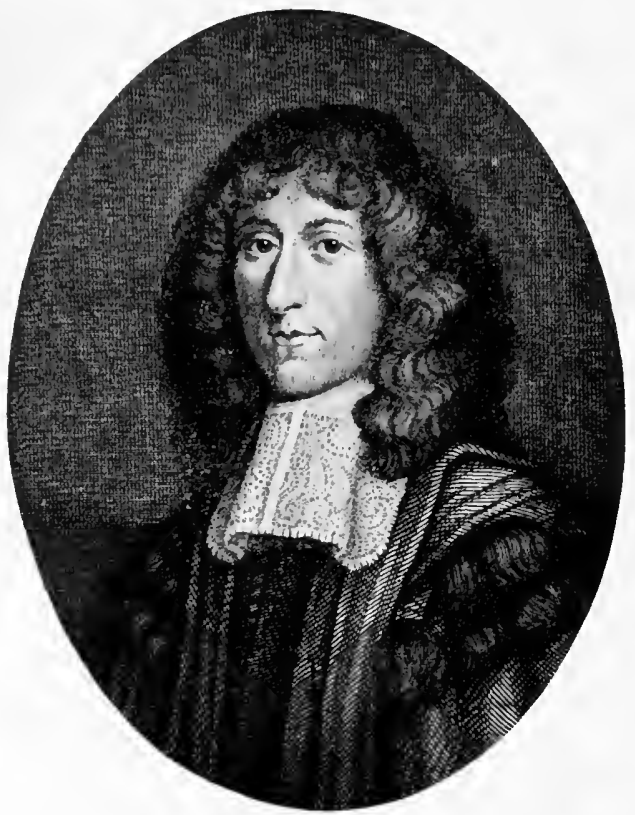

John Mayow (1643-79).

gen) and taking away vapors engendered by the blood. He saw that the maternal blood supplies the fetus not only with food, but with oxygen ("nitro-aër"), and was the first to locate the seat of animal heat in the muscles, an idea which fell into abeyance until Helmholt $z$ demonstrated it anew in 1845 . He also discovered the double articulation of the ribs with the spine, and discussed the function of the intercostal muscles in an entirely modern spirit. Mayow was a chemist and physiologist of true genius, and his Tractatus Quinque (1668) deservedly ranks today with the very best of the English medical classies. Professor Gotch has shown 
how his ideas were disregarded and discredited through the errors in a garbled English abstract of his Latin text, which some literary hack had made for the Royal society. ${ }^{1}$

In the latter half of the seventeenth century, internal medicine took an entirely new turn in the work of one of its greatest figures, Thomas Sydenham (1624-89), of Winford Eagle, the reviver of the Hippocratic methods of observation and experience, who ennobled the practice of physie through those qualities of piety, good humor, and good sense, which Edlmund Burke declared to be the genius of the English race. Educated at Oxford and Montpellier, but afterward a Puritan captain of horse in the civil wars, a "trooper turned physician," as he was called, Sydenham's relation to medicine was that of a man of action. A typical Saxon, by no means devoid of nil admirari, yet rich in the Saxon's special gift of manly independence and "saving common sense," he stood apart from all the medical theorizing and scientific experimentation of his time, disregarded all his predecessors save Hippocrates, and knew nothing whatever of Vesalius, Harvey, Malpighi, or Mayow. His four favorite books were Hippocrates, Cicero, Bacon, and Don Quixote, and his per-

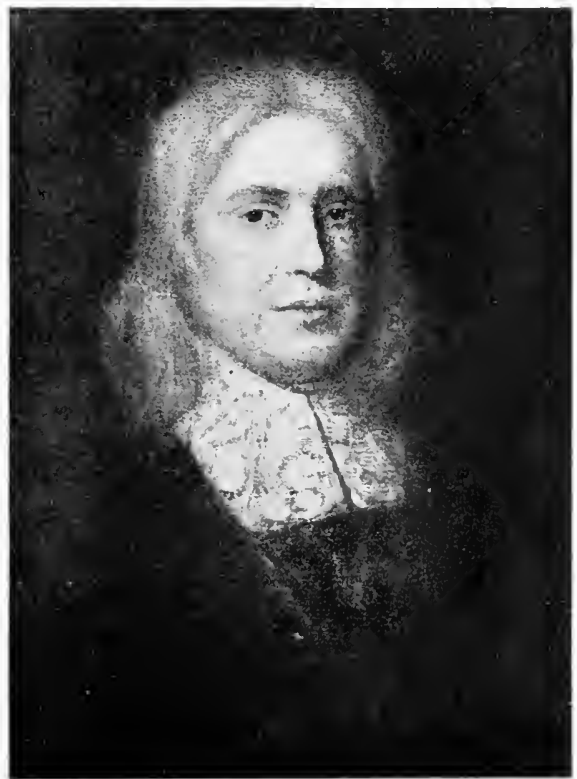

Thomas Sydenhiam (1624-89). (From a painting by Mary Beale.) sonal attitude toward his contemporaries was indifferent or scornful. This narrowness and aloofness cost him dear, for he complained bitterly of the neglect and opposition of his own profession, yet it was the very secret of his success as an internist. His theory of medicine was simple. The human mind is limited and fallible, and to it final causes must remain inscrutable. Scientific theories are, therefore, of little

${ }^{1}$ Francis Goteh: Two Oxford Phywiologists, Oxford, 1908, pp. 35-38. See, also, the brilliant chapters on the physiology of respiration in Sir Michael Foster's "Lectures on the History of Physiology," Cambridge, 1901. 174-199; $224-254$. 
value to the practitioner since, at the bedside, he must rely upon his powers of observation and his fund of experience. Sydenham regarded disease as a developmontal process, rumning a regular comrse, with a matural history of its own. Bach discase belonged to a cortan dofinito species, which could be deseribed and elassified as a botanist does plants.' Pathology for him was summed up in the Hippocratic theory of concoction of the humors of the body and the subsequent discharge of the materies morbi. Hippocrates was his pattern, and more than any other medical man he resembles the Father of Medicine in his mode of portraying disease and his dignified ethical regard for his patients, holding himself "answerable to cod" for their care and, himself a martyr to stone and gout, a fellow-sufferer along with them. This power of imaginative sympathy, a trait not usually found in the self-centered Saxon, is prominent in Sydenham's portrait as painted by Mary Beale, representing a Puritan in bearing, like Cromwell or Milton, yet a beautiful face withal, the fine brow, melaneholy eye, and sensitive mouth revealing a nature stoical rather than harsh, sad rather than sour, as of a Puritan under protest.

Sydenham's theory of "epidemic constitutions," or genius cpidemicus, maintains that contagious diseases are influenced by cosmic or atmospherie influences which may change their type, that they may spring from miasms from the bowels of the earth, that they may have long periods of evolution and seasonal variations, and that some diseases may be mere variants or sub-varieties of others. ${ }^{2}$ Some features were revived in von Pettenkofer's theory of the "soil" (Boden) and "soil-water," and the best part of it survives in Pasteur's theory of the origin of epidemies from strengthening or weakening of viruses by environmental conditions. Sydenham's studies in the geography and meteorology of epidemic diseases and the rhythmic periodicity of their recurrence ${ }^{3}$ make him, with Hippocrates and Baillou, one of the main founders of epidemiology. Studies of the relation of discase to the weather, a matter of comment even in the diaries of Pepys, Evelyn and Swift, continued to be made even up to the time of Bright. The elinical reputation of Syclenham rests to-day upon his firsthand accounts of diseases, such as the malarial fevers of his time,

1. "Primo expedit, ut morbi omnes ad definitas ac certas species revocentur,

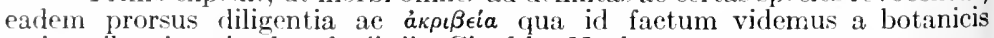
scriptoribus in suis phytologiis." Cited by Neuburger.

2 See, M. Greenwood: Proc. Roy. Soc. Med. (Sect. Epidem), 1919, xii, 55-76; F. G. Crookshank: Ibid., 1920, xiii, 159-184; and Sir. H. Rolleston: Jour. Am. Med. Ass., Chieago, 1920, lxxiv, 1495-1497.

${ }^{3}$ For the mathematical theory of periodicity see Sir Ronald Ross, Proc. Roy. Soc., Lond., 1916, ser. A, xeii, 204-230, and the eurves in A. Magelssen's article, "Genius epidemieus," Janus, Amst., 1906, xi, 561-575. 
gout, scarlatina, measles, bronchopneumonia (peripmeumonia veru), and plenropnemonitis (peripneumonia motha), dysentery, chorea, and hysteria. His troatise on gout $\left(1683^{1}\right)$ is asteemed his misterwork. In 1672 he deseribed the articular and musenlar pains of dysentery, and, in 1675, gave a full account of scarlatina as it prevailed in Lonton (1661-75), separating the disease from measles and identifying it by its present name. The Dissertatio Epistolaris (1682) contains his classic account of hysteria; and his differentiation of chorea minor is to be found in his Schedula Monitoria (1686). In therapeuties, Sydenham popularized the use of Peruvian bark and was the innovator of fresh air in sick-rooms, horseback riding for consumptives, cooling draughts in small-pox, steel tonics in ehlorosis, and the liquid opiate which bears his name. His prescriptions consisted largely of vegetable simples, and he avoided the filthy ingredients recommended, even in the London Pharmacopoia of his time. He was an extensive but not an intensive blood-letter, applying venesection in almost every disease known to him, but with diseretion. His Processus integri (1692), eontaining his therapeutic seheme, was the vade meeum of the English practitioner for more than a century, and an Oxford enthusiast is said to have committed it to memory. The influence of Sydenham lasted unto the advent of the Tienna Sehool and beyond it.

A remarkable follower and protégé of Sydenham was Walter Harris (1647-1732), of Gloueester, physician-in-ordinary to Charles II and William III. His treatise on acute diseases in infants (1689), remarkable for some prevision of the doctrine of acidosis, was reprinted and translated many times and held the field until the time of Underwood (1784).

A group of important monographs which deserve mention in connection with Sydenham's work eomprises Tobias Cober's Observationes castrenses (1606), noting the relation between typhus fever (morbus IIungaricus) and bediculosis; the De mirabili strumas sanandi (1609) of André du Laurens, an arly historic record of the King's Evil, in which the contagionsness of serofula s maintained (struma rontagiosus morbus est); Spieghel's extensive account of nalarial fever (De semitertiana, 1624); Daniel Sennert's treatises on seurvy

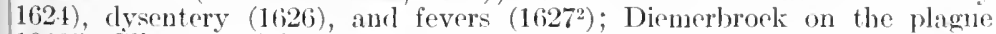
$\left.1646^{3}\right)$, Cilisson's original aeeount of rickets $\left(1650^{4}\right)$. Thuillier's experimental

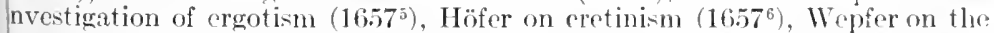
temorrhagie nature of apoplexy $\left(1658^{7}\right)$, Solleysel's account of the transmission

1 Tractatus de porlagrat et hydrope, London, 1683.

${ }^{2}$ Sennert: De febribus, Leyden, 1627.

${ }^{3}$ Diemerbroek: De peste, Arnheim, 1646.

${ }^{4}$ Glisson: De rachitide, London, 1650.

5 Thuillier: J. dl. ş̧avans, Paris, 1676 , iv, 79.

${ }^{6}$ Höfer: Hereules medieus, Vienna, 1657, p. 43.

7 Wepfer: Observationes anatomicx ex cardaveribus eorum quos sustulit poplexia, Schaffhausen, 1658 . 


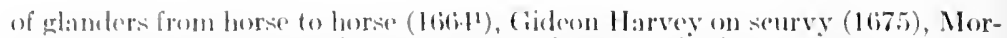

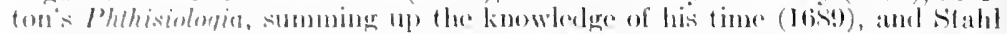

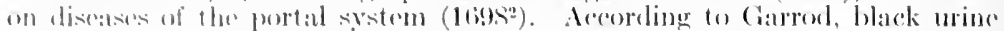

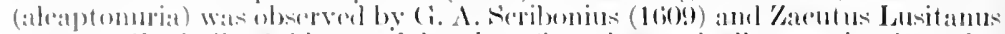

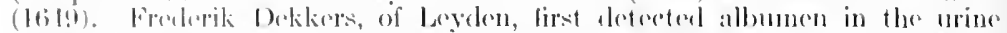

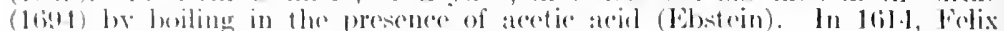
Platter (initi-tilit) reported the first known case of drath from hypertrophy

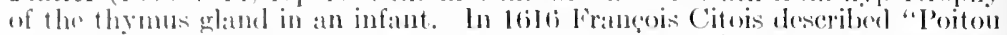
colie," which long afterward was foumd to he leal-colic. Beriberi was first describul, from liast Indian eases, by the Dutch physicians, daced, Bontius

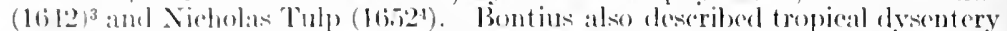
in dival. Yalws (bubess) wats derecribed by William P'iso, in his De medicina Bromiliensi $\left(16 \mathrm{~s}^{5}\right)$. Sir John Floyer's 'Treatise on Asthma (169S) gives a pestmorem of puhmonary cmphysema, and assigns as the callec of spatsmodie aschma "al cont racture of the museular fibers of the bronchi." "The Memoirs of the Eatl of Clarendon (10:32) contain a ease of angina pectoris. In this group we may also include Folix Plat ter's Proxis modice (1602-\$), containing the first attempt at a systematie classification of diseases, the Semelchetum of Theophite Bonct (1679), a collection of all the postmortems of the sixteenth and sevent eenth ("enturies, Walter Ilarris's book on diseases of children (16896), the perdiatric treatise (16977) of John Pechey (1655-1716), and the treatises on melie"al jurisprudenee by lortunato Fedeli $\left(1602^{8}\right)$, Rodericus à Cast ro $\left(1614^{3}\right)$,

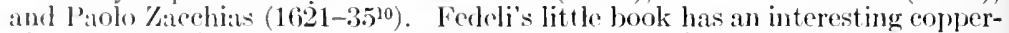
plate frontispeies, in which the attestation of virginity and time of delivery, the jurisprudenee of poisoning, lethal wounds, hereditary disease, torture, monsters, and the formation of the fetus are ammsingly "foatured," showing the interest which these subjects had accuired; and Paolo Zacchias (15841659). who was protomedicus of Rome, physicim to Popes Innocent $X$ and Alexander Yll, is replete with medico-legal information, partieularly on wounds of the eye and the jurisprudenee of insanity, of which he gives an execllent clasification. An important work on the medico-legal relations of surgery was published in 1654"1 by Nicolas de Blegny (1652-1722), who also founded the first merlical journal (1679 ${ }^{12}$ ) and made the first eity directory (1684). Medical jurisprudence was not stulierl in a critical spirit before the seventeentl century, and up to this time medieal ctlies and jurisprudence were simply regarted as phases of state medicine. Ciermany made many contributions to forensic medicine and medieal ethies in this period, such as Ludwig Hoernigk's Politia merliea (163\$13). Paul Ammam, on lethal wounds (169014), Gottfricd Welseh, on lethal wounds (1660) and plural births (166715), Melehior Sebiz, on the rigns of virginity $\left(1630^{16}\right)$, and Johann Bohn on lethal wounds

1 de solleysel: Le parfait maresehal, Paris, 1664.

2 Stahl: De vena portæ, porta malorum, 1698.

${ }^{3}$ Bontius: De medicina Indorum, Leyden, 1642, 115-120.

${ }^{4}$ Tuln: Observationes mediex, Amsterdam, 1652, 300-305.

${ }^{5}$ See E. W. Gudger: Science, N. Y., 1911, n. s., xxxiii, 42 S.

${ }^{6}$ Harris: De morbis acutis infantum, London, 1689.

7Peehey: General Treatise of the Disease of Infants [etc.], London, 1697.

${ }^{8}$ Fedeli: De relationibus medicorum, Palermo, 1602.

${ }^{9}$ à Castro: Medicus politicus, Hamburg, 1614.

${ }^{10}$ Zacehias: Quaestiones medico-legales, Rome, 1621-35.

11 de Blegny: La doctrine des rapports de ehirurgie, Lyons, 1684.

12 Nouvelles découvertes sur toutes les parties rle la médecine, Paris, 1679-81.

${ }^{13}$ von Hoernigk: Politia merlica, Frankfurt, 1638.

${ }^{14}$ Ammann: Praxis vulnerum lethalium, Frankfurt, 1690.

${ }^{15}$ Welsch: Vulnerum lethalium judicium, 1660; and De gemellis et partu numeriori, 1667 .

16 Sebiz: De notis virginitatis, 1630. 
(16\$91). The "Medieus Peceans" of thasver Fritseh (Nurembere, 1689) is an early eontribution to modieal ethics. The most important medice-legal eontribution of the eentury wats undoubtedly swammerdam's diseovery that the fotal lungs will float on water after respiration $\left(1667^{2}\right)$, which was first put to a practical proof by Johamn Schrever in the ease of a fiftern-y car-old peasant girl aecused of infunticide $\left(1681^{3}\right)$, the sinking of the infant's lungs seeuring acquittal. The Metoposcopia of Ophthalmoscopia (1615) of Samuel Fuehs $(1555-1630)$ is an illustrated treatise on physiognomy and the estimation of eharacter by the eyes, not unlike Carrlan's or Lavater's.

Intravenous injection of drugs (1656) and transfusion of alien blood (1665-67) had their scientific origins in the seventeenth century.

Sir Christopher Wren (1632-1723), assisted by Boyle and Wilkins, first injected opium and eroeus metallorum into the veins of degs in 1656 , which experiment wats repeated by Camolo Fracassato in 1655. J. D. Major (1662), Caspar seotus (16iti), Elsholtz (Clysmate nora, 16055) made the first suecessful intravenous injoetions in man. Major published his Chirurgia infusoria at Kiet in 1667. Priority in transufsion has been elaimed for Franresen Folli (1654), but the first authenticated reeords are those of R. Lower (1665-67) and R. Coga (1667). Transfusion is mentioned in Pepys' Diary (November 1.t, $\left.1666^{4}\right)$.

To English medicine belongs the first book on vital statistics, the Natural and Political Observations. upon the Bills of Mortality (London, 1662) of John Graunt. The Hebrews and the Romans had, no doubt, taken the census and comted troops, but Ciraunt was the first to notice, from the bills of mortality, that more boys are born than girls, and that the population can be estimated from an accurate death-rate, thus making the first step in the application of mathematical methors to the interpretation of statisties. He describes how the parish clerk delegated women as "seatrehers" to find out who was deat or about to die. In the absence of rompulsory notification of births and deaths, these fanlty bills of mortality were necessarily valueless. His book was followed, in 1687, by the Essays on Political Arithmetic of Sir William Petty (1623-87), who took the first census of Ireland. The English astronomer, Edmund Halley (1656-1752) employed the Breslan tables of births and funerals to estimate mortality-rates and "to ascertain the price of anmuties upon lives."

In 1672 the Welsh physician, Charles Clemont, published a work with the Hippocratic title, "On the Airs, Waters, and Plaees of Englane," in which he

${ }^{1}$ Bohn: De remuntiatione vulnerum, Leipzig, 1659.

2Swammertam: Tractatus phys.-anat.-med. de respiratione veque pulmonum, Leyden, 1667 .

${ }^{3}$ Schrever: Erörterung und Frläuterung dor Frage: Ob es rin gewis: Zeichen (ete.), Zeit z, 1690.

${ }^{4}$ J. M. Forteseue-Brickdale (Oxford thesis): Guy's Ilosp. Gaz., Lond., 1904, lvii, 15-80. D. I. Marht: Jour. An. Med. Assoe, Chirago, 1916, lxvi, \$56-860. Nlso ibid., 1914, lkii, $147 ; 222$. 
plotted of the medical topography of the country ats Daniel Drake did long after for the Mlississippi Valler. The mineral waters of lingland were studied by a large mumber of seventerenth econtury physicians, motably bdmond Deane

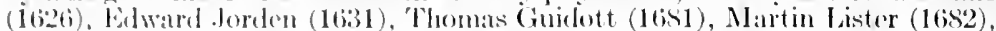
Sir l'atrick 1)un (165i3), Sir .olm Floger (An luquiry into the Right Use of the Ilot. ('old and Temprerate baths in England, 1697), and in Nohemiah (irew's study of lipsom llells (169)'s).

The first Lomfon Phamateoperia was published in 161s, having been preceded by these of Valerius (Corlus (15.60), Brice Batuderom (1588), Libavius (Hit)i), Jean de Renou (I615), and other city pharmacoperits of the sixteenth century." It patsied through many erlitions, all of which were disfigured by the retention of the usual vilo and lunsavory ingredients, which were not thrown ont mntil Willi:m Ilebeden made an onslanght npon these superstitions in 17.5. 'The Pharmaneopera lomelinensis was tramslated into linglish in 1649 by the fammo herbalist and quacksalyer, Nicholas Culpeper. Other English l'harmatepexias of the time were Philomen Holland's Latin translation from the Freneh of B:tuderon (16339), Sishuon's New London Dispensatory (1678), and skipton's Pharmacoprea Butcuma (16ss), compiled from preseriptions of William Bate, physician in ordinary to Charles I, Cromwell, and Charles II. ${ }^{3}$ Of continental pharmacopoxias, ${ }^{4}$ we may mention those of Minderer (1621), l'oterie (162:2). Sehröder (16-11), Ruland (16.14), Zwelfor of Augsburg (1652), Jïngken (1677), Nicolas Lémery (1697), Hadrian à Mynsicht (1697), and C. F. Pamlini's Heilsame Dreckapothele (1696), the title of which anply symbolizes the tendeney of many sevententh century preseriptions.

The most inuortant contribution of the seventeenth contury to veterinary medicine was Jacrutes do sollevsel's demonstration of the transmission of glinulers from horse to horse (16itit). Andrew snape, on The Anatomy of an Horse, was jublished in London in 16S6, and various French works on farriery appeared, in particular, Francini's translation of Carlo Ruini (1607), Boamgrand $(1619,1646)$, and de Bouvray (1660). The first Cierman work on veterinary medicine was the Bellerophon of Winter von Adlersflügel (16685).

In comparison with the extensive development of anatomy in the seventeenth century, its literature of surgery scems meager.

Among the Itatians, we find no surgeons commensurate in rank with those of the three centuries preceding, and the only names deserving of mention are those of Cesare Magati (1579-1647), who followed Parri in holrling that gunshot wounds are not poisonous, and taught, in theory at least, the simple expectant treatment of wounds by means of bandages moistened with plain water; and Pietro de Marchetti (15\$9-1673), Professor at Padua, whose "Observationum medico-chirurgicarum sylloge" (Padua, 1664) resembles the Consilia and the collections of Benivieni, Amatus Lusitanus, and Peter Forest, containing many strange ease-histories and valuable surgical observations. Giuseppe Zambeccari, a pupil of Redi, was a pioneer in experimental surgery. He made suceesful experimental excisions of the spleen, kidneys, gall-bladder, panereas, and of bits of the liver and intestines. On one (log he performed four successful experimental operations in succession $\left(\right.$ Neuburger $\left.^{6}\right)$. The gigantic surgical anthology (Thesaurus Chirurgice) of Peter Tffenbach (1610) de-

1 These dat a about mineral baths are given by llanderson in his translation of Bass's IIistory of Medicine, New York, 1s\$9, p. 54t.

2 All mentioned by Baas, op. cit., pp. 436, 437, 516, 547.

3 Baas: Op. cil., foot note to p. 547.

${ }^{4}$ Baas: Op. cit., p. 547. Seherer: Literatura pharmacopoarum, Leipzig, 1822, and Tsehirch: Pharmakognosie, Jeipzig, 1910, i, 2. Abt.

${ }^{5}$ Baas, p. 543.

${ }^{6}$ Neuburger: Med.-chir. Centrahll, Vienna, 1896, xxxi, 368. 
serves mention, although all the authors contained in it are of the sixteenth century.

In France, owing to disputes of the Paris Faculty with st. Come, and the decree uniting the surgeons and barbers into one guild, there was little surgieal writing of note. The French treatises of the period are forgotten. Jarques de Beaulieu or Frère Jacques (1651-1719), a strolling incisor, introfluced the literal operation for stone (1697), which was much improved by Rau in Holland. Nicolas de Blegny (1652-1722) invented the elastic truss, described in bis treatise on hernia (1676), and wrote on surgical jurisprudence (1684). The surgical treatise of Vauguion (1696) mentions the tourniquet, which was introduced by Morel (1674) and was successfully applied in ligating the fenoral artery at the Hotel Dieu, in 16ss. A quiz-eonmend by Gabriel Le Clere (La chirurgie complete, 1692), which passed through 18 editions, mentions the vitriol buttons used at the Hôtel Dieu for ehecking hemorrhage, and the mode of manual compression (twenty-four hours at a stret(h).

The leading Geman surgeons of the period were Fabry of Hilden, Scultetus, and the famous army surgeom Pummann.

Wilhelm Fabry, ${ }^{1}$ of Hilden (1560-1624), called Fabricius Hildanus. whose statue was unveiled at Hilden near Düsseldorf is usually regarded as the "Father of German Surgery." Having a good classic education, he was strongly conservative in theory, supporting the views of the ancients, but in practice a bold and skilful operator, inventing

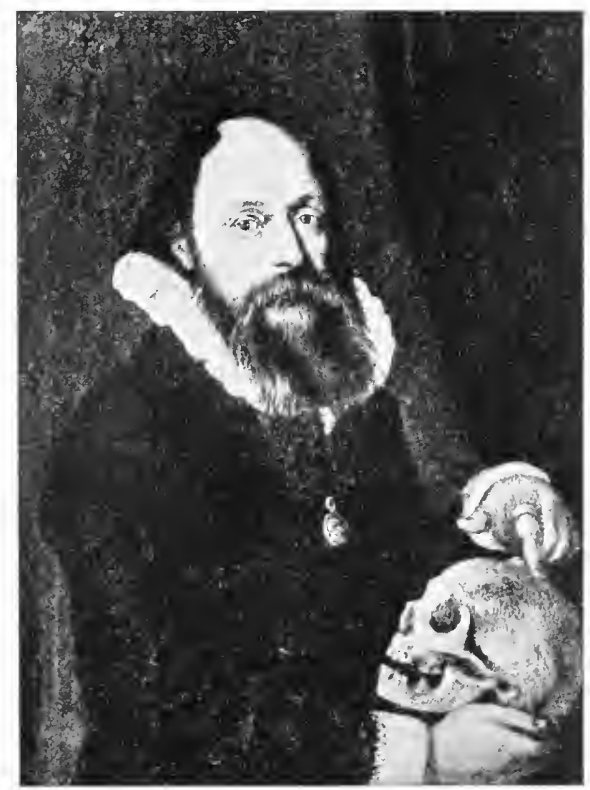

Wilheln Fabry, of Hilden (1560-1624). many new instruments. In his monograph on gangrene (Cologne, $1593^{2}$ ) he was the first to recommend amputation above the discased part, and is said to have been the first to amputate the thigh. In shutting off the circulation before amputation, he improvised a kind of tourniquet by means of a ligature tightened by a stick of wood. He also wrote a treatise on lithotomy (Basel, 1626), but his most important work is his "Century of Surgical Cases" (1606-46), the best rollection

1 The name is sometimes given in German as "Fabriz," but Sulhoff regards "Fabry" as the genitive of Faber, or Sehmialt (Fehmitz), a rommon family name in the Rhineland (München. merl. Woehensehr., 1910, lvii, 1401).

${ }^{2}$ De gangrano et sphacelo, Cologne, 1593. 
of ease-records of the time. He showed that head injuries may atuse insanity, extracted an iron splinter from the eye with a matguet, explored the anditory camal with a speculum of his invention, and described the first field-chest of drugs for army use, bascel upon that introduced by Moritz of Nassan in 1612. In 16i5, the Brandenburg amy surgeon, danus Abraham a Gehema $(16+5-1700)$, anthor of a little manual for medieal oflicers in the fich $\left(1689^{\mathrm{I}}\right)$ reeommended that these chests be supplied, ats a matter of ronrse, by the govermment instead of at the expense of the officers, as fomerly. Falny of Hilden was a reactionary in his use of the eautery, and, like most surgeons of the day, he was a believer in the weatpon-silve, which was applied to the weapon instead of the wound.

Ilis contemporary, Johann Sehultes (1595-1645), called Scultetus, is fanous, like Mbueasis and Paré before him, as one of the great illustrators of surgery and surgical instrunents. Ilis Armamentarium chirurgicum. $(\mathrm{Ulm}$, 16.5.3) gives 11. al grood side-light on the operations of the time through its interesting plates, representing such procedures as amputation of the breast, reduction of dislocations, passiage of sounds, foreeps-delivery, ete.

Mattherts: Gottfried Purmann (1649-1711) was at surgeon in the Brandenburg arny in 1675 , and acquired great skill and eourage through his pillarto-pert operating in the field. With Fabry of Hilden, he is held in the highest estrem by the German historians of to-rlay, beause he regarded anatomy as the true bisis of the surgeon's knowledge. Ile seems to have performed most of the operations known or proposed in his time, from trephining ( 40 cases), transfusion, aneurysm, and bronchotomy, to suturing wounds of the intestines. He left miny different works, one of the most interesting of which is "Fifty Strange and "Wonderful Cures of Gunshot Wounds" (16932). Needless to siy, he was a believer in the weapon-salve and the sympathetic powder for healing wound at a distance. Another important relie of the Thirty Years' War is the Wedicina Militaris of Raimund Minderer (Augsburg, 1620). No less than 24 books on contagious diseases in armies were published in this period (Heizmann). Among pioneer operations of the German surgeons in the seventeenth eentury may be mentioned the gastrotomies of Florian Matthis (1602) and Daniel schwabe (1635), Isaae Minnius' open seetion of the sternomastoid for torticollis (1641), the partial resection of the jaw by Acoluthus of Breslau in 1693, and Schonkoff's "ovariotomy" in 1685. At this time we may judge laparotomy to have been common enough, since plates in Roonhuyze (1663) and Vöter's Nilwifery (1679) give a very plausible representation of the procedure.

The Several Chirurgicall Treatises (1672) of the Royalist surgeon, Richard Wiseman (1622-76), is the leading work of a man who played the same part in the English surgery of his day that Sydenham dicl in the practice of medicine. Wiseman was a skilful operator, amputated above the diseased part, employed primary amputation in gunshot wounds of joints, and was the first to describe tuberculosis of the joints as "tumor albus." He also gave the authentic account of "King's Evil." In his treatise on gonor-

1 Gehema: Der wohlversuchte Feld-Medicus, Rostock, 1689.

${ }^{2}$ Purmann: Fünfig sonder- und wunderbare Sehusswundkuren, Frankfurt, 1693 . 
rhea he mentions the first case of external urethrotomy for stricture, which he performed with Edward Molins in 1652. The first case of amputation by means of a flap is recorded in the Triumphal Chariot of Turpentine (1679), by James Yonge (1646-1721). Stephen Bradwell's Helps in suddain accidents (1633) is the first book on first aid.

Seventeenth century obstetrics finds expression in the works of Mauriceau, de la Motte, Portal, van Deventer, Roonhuyze, and the midwives Louise Bourgeois, who attended Marie de Medici through her" six labors, Justine Siegemundin, "Court Midwife to the Electorate of Brandenburg," whose treatise of 1690 met with great opposition because it was written in the German language, and the perhaps mythical Jane Sharp, whose Compleat Miduife's Companion was first published in London in 1671. Of these writers, François Mauriceau (16371709), of Paris, is in some respects the leading represcntative of the obstetric knowledge of his time, and his work on the diseases of preguant and puerperal women $\left(1668^{1}\right)$, illustrated with exquisite copper plates, was a sort of eanon of the art in its time, giving a good account of the conduct of normal labor, the employment of version, and the manage-

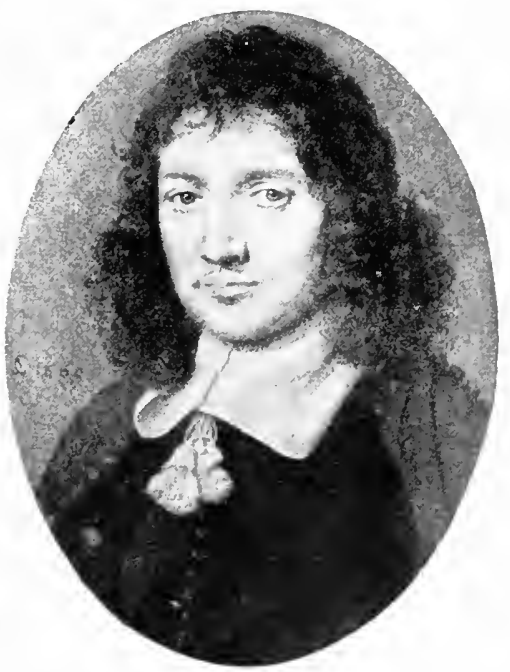

Richard Wiseman (1622-76). ment of placenta pravia. He

was the first to correct the ancient view that the pelvic bones are separated in nomal labor, and that the amniotic discharge is an accumulation of menstrual blood or milk; he was also the first to refer to tubal pregnancy, difficult labor from involvement of the umbilical cord, and epidemic puerperal fever. His book also gives an account of the author's adventure with the colebrated Hugh Chamberlen, of the Huguenot clan who sueceeded in kecping their invention of an obstetric forceps a family secret for nearly two hundred years. ${ }^{2}$

\footnotetext{
1 Mauriceau: Traité des maladies des femmes grosses (etc.), Paris, 16ith.

${ }^{2}$ The forceps was invented by Peter Chamberlen, sr., before 163.34 (Doran); with it, Hugh Chamberlen failed to deliver a rachitic dwarf confided to him by Mauriceau.
} 
Patul Portal (died 1703), of Montpollier, wrote an olstedric treatise in losi, in which he tanght that version ean be done by one foot and that face presentations usually rum a normal (o)

I far more important work is the Nomm Lumen of Hendrik van Deventer (1651-172.1), which, although printed in 1701, properly bolongs to the serenteenth century. Van Deventer, a native of Holland, was at first a goldsmith, hut turned to medicine at serentorn, and after studying at (iromingen, mactised obstetries and orthopedies in his native city, The Hague, until his death.

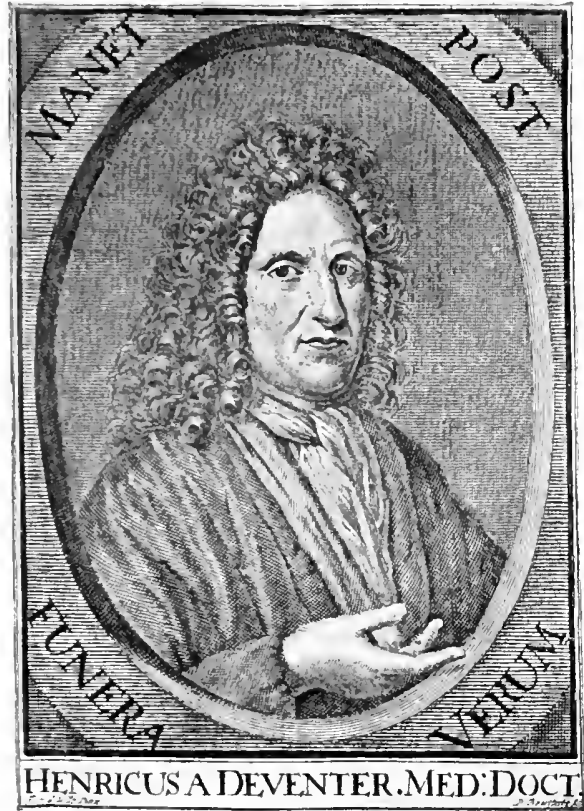

Hendrik van Deventer (1651-1724). He has been rightly called the father of modern midwifery, for his book, with its interesting plates, gives the first accurate description of the pelvis and its deformities, and the effect of the latter in complicating labor. At the same time it is a pioneer work in the delineation of deformities of the spine. There was nothing quite like it until "Das enge Becken" of Michaëlis was published onc hundred andfifty years later.

\section{Hendrik van Roon-} huyze (1625?- ) was a champion of Cesarean section, which he seems to have performed several times with sucecss, and his Heellionstige Aanmerkkingen (1663) has been described as the first work on operative gynecology in the modern sense. It is illustrated with unique copper plates, showing his mode of incision in Cesarean section, and contains case reports of extra-uterine pregnancy and rupture of the uterus. Roonhuyze was otherwise a skilful operator, excising tumors, treating wounds of the head without trephining, and performing operations for wry-neck and harelip. Stromeyer says he was the first to practise orthopedic surgery. As Dr. Howard Kelly points out, he first

${ }^{1}$ Portal: La pratique des accouchemens, Paris, 1685. 
proposed a scientific operation for vesicovaginal fistula, the features of which were exposure of the fistula by a retracting speculum, with the patient in the lithotomy position, marginal denudation, exclusive of the bladder-wall, and approximation of the clemuded edges of the fistula by means of quills fastened by silk threads. ${ }^{1}$ He is not to be confused with his som, Rogier van Roonhuyze, to whom the elder Hugh Chamberlen is said to have sold the secret of his obstetric forceps about $1693 .^{2}$

Roonhuyze and Deventer did much to improve the status and education of midwives in Holland, in which they wore followed by the former's successors in Amsterdam, Frederik Ruysch, and by Cornelis Solingen (1641-87).

A work which compares with Uffenbach's Thesomerus Chirurgion in size and shape is the huge Hebammenbueh of Gottfried Welsch (1652), eonsisting of nearly 2000 pages of translations with commentaries, of the works of Mereurio, Pinaus, and Louise Bourgeois. A gynecologie treatise of the period was L'hydre féminine by Augustin Corrade (Nevers, 1634). The Callipadia of the Abbé Claude Quillet (1656) denounced eonventional marriages and was, in some sort, a pioneer work in elgenies.

The methods of deaf-mute instruction practised by the Benedictine monk Pedro Ponce de Leon (1520-\$4) were preserved in the treatise of Juan Pablo Bonet $\left(1620^{3}\right)$, who had suceessfully taught the deaf brother of his patron, the constable of Castile. Sir Keneln Digby met Bonet at Madrid and bore witness to the success of his methods. After this, the subject beeame popular in England and Italy. Giovanni Bonifario had published his Art of Signs (L'Arte de cenni) at Vicenza in 1616. English treatises on deaf-mute instruetion were published by John Bulwer (1644-84), by John Vallis (16161703), Savilian professor of inathematies at Oxfort (16525), William Holder $\left(1669^{6}\right)$, and George Dalgarno, of Aberdeen $\left(1661-80^{7}\right)$. In 1692 Johann Conrad Ammann (1669-1724) published his ingenious method, "Siurdus Loquens," which was reprinted in 1700.

Daniel Leclerc (1652-1728), of Geneva, wrote the first large history of medicine (1696), a work which was translated into English, and is still appreciated. Of medical dictionaries published in this period, the most remarkable were the posthumous glossary of Hippocratic terms by Guillaume Baillou (Definitionum. medicinalium liber, 1639), the Quastiones iatro-philologice of Gabriel Naudé (1647), the Latin-German pharmaceutical lexicon

${ }^{1}$ H. A. Kelly: Tr. Am. Gynace. Soe, Phila., 1912, xxxvii, pp. S-10.

2 Fassbender: Geschichte der Gelourtshïlfe, Jena, 1906, 224. A. Geijl (Janus, Amst., 1906, xi, 253; 292) is of opinion that the Roonhuyzens and Ruysch knew of the forceps in 1670 .

${ }^{3}$ Bonet: Reduecion de las letras y artes para enseñar á hablar á los mutos, Madrid, 1620.

${ }^{4}$ J. Bulwer: Chirologia, London, 1644; Philocophus, London, 1648.

5 J. Wallis: De Joquela, London, 1652.

${ }^{6}$ W. Holder: Elements of Speech, London, 1669.

${ }^{7}$ G. Dalgarno: Ars signorum, London, 1661; Didascalacophus, Oxford, 1690. For an account of early writings on deaf-mutism, see F. De Land: Volta Rev., Wash., 1920, xxii. 391-421. 
of Friedrich Mïller (1601), the etymological lexica of François Thevenin (1669), and J. B. Callard de la Ducquelie (1673), the Prollomus of J. I. I Immemann (1672) and the Greek and latin lexical of Bartolommeo ('astelli (1607) and Stephan Blancaard (1679), which passed through many editions.

There was no printing press in the North American colonies hefore the year 1639, when one was set up at Cambridge, Massachusets, its first pliblication being the Bay-State Psalm-Book of 1640. The only medieal publication of the New England colonists in the soventeenth century was the Brief Rule to Guide the Common P'cople of New England how to Order themseles and theirs in the Small Poclis or Measels (Boston, 1677'), by Dr. Thomas Thacher (1620-78), an Englishman who settled in New England in 1635, and in 1669 became pastor of the Old South Church, at the same time practising medieine with success. He was a good Hebrew and Arabic scholar, and wrote a Hebrew lexicon and a catechism, which are like the "Brief Rule" in that each of them oecupies, as Handerson slyly observes, "only a single sheet of paper."

\section{CULTURAL AND SOCIAL ASPECTS OF SEVENTEENTH CENTURY MEDICINE}

The age of the rise of England and Holland was a time of spiritual and intellectual uplift, and the effect of the continued battle for freedom of thought was to make it a period of individual scientific endeavor rather than of concerted advancement of science. The stirring events of this age-the burning of Bruno (1600), the Thirty Years' War, the Fronde, the English Revolution, the embarkation of the Pilgrims, the anathemas hurled at Spinoza, the suicide of Uriel Acosta-all go to show that the superior men of the time felt themselves "in the presence of high causes." Although the wars of the Fronde riveted the bonds of monarehy and ecelesiasticism upon France, and although Germany was ruined by the Thirty Years' War, yet England and Holland were free, and the barbarities of feudalism became tempered down into real governmental activities, largely from the growing interest in the study and application of the law. From the time of the perhaps legendary discovery of Justinian's Pandects at Ravenna, about 1135, there had been a gradual attempt to regulate national and eivil government, as well as the intercourse of nations, by the Roman law, and this was brought to a foews through the labors of the two greatest jurists of the period, Hugo Grotius (1583-1645), of Delft, Holland, and Samuel von Pufendorf (1632-94), of Chem-

${ }^{1}$ Reprinted by H. E. Handerson in Janus, Amst., 1s99, iv, 540-547. 
nitz, Saxony. With better legal regulations and restrictions, the social status of the physician was correspondingly improved, although the surgeon was still under the ban, unless needed in wartime. In Germany, the physician proper was styled medicus purus, and often held definite official positions, such as physician in ordinary to a potentate (medicus ordinarius), state or (ity physician (physicus), or plague doetor (medicus pestilentiarius), all at high salaries; while army surgeons were alled Foldscheerer because they had to shave the officers. The general run of surgeons were still roughly classed with the horde of barbers, bathkeepers, executioners, and vagrant momntebanks.

The condition of medicine was further improved by the anbitions of princes to found new universities, and by the introduction of two new factors of great moment, viz., the scientific society and periodic literature.

The sorenteenth century marks the rise of many fanmons Dutch and (irrmanic universities, notably Harderwijk (1600), Ciiessen (1607), Groningen (1614), Rinteln (1621), Dorpat (1632), Ltrecht (163i), Alk, (1640), Bimberg (164s), Herborn (1654), Duisburg (1655), Kind (1665), Luml (16666), lnnsbruck (1672), and Hille (1694). But for exnturies the universities har been like Joubert's typieal bourgeris, the peaceful, idle, and self-satisfied posseswor's of what they had, transmitters of lifeless tradition and strongholds of conservattism. The best thinkers and scient ists had long since been penetrated with the eonvietion that the work done in miversities was valuedess and had as tittle to do with them as possible. Hence arose the necessity for some organizerl plan for fostering experimental researeh, bringing seicntific men together and keeping them in fouch with one another by means of publications. This haven of research and experiment, dreamed of by Baeon in his House of stolomon, was found in the scientifie society. ${ }^{1}$ The idea of scientific societies originated in Italy. Porta's seeret Arademy at Naples (1560), was follower by the Academy of the Lynxes (Acrademia dei Lincei), which was foumded at Rome, August $17,160 \hat{3}$, by Marquis Federigo Cesi, its device being a lynx rending a Cerberus with its elaws. This at first consisted of a closed eoryuraltion of four members, who met to disensi new experiments, mathemalical problems, and "the ornaments of elegant literature and philology, whicln, like a graceful garment, adorned the whole body of seience." Although it eneountered much opposition from the Chureh, it lived to include Galileo as one of its members, and still survives, publishing handsome transactions in cluirto. In 1657 , a similar soriety, called the Arearleniat del Cimento (Acadrmy of Fxperiment), was establisberl at Florenee. In 1645 an "Invisible (college," similar to Porta's Secret Acarlemy, was founded in London by Ilatk, Ilarflieb, Boyle, Wren, Coddard, and others, and, after combining with an Oxford "Philosophical society," opened its first jomnal book on November 28, 1660, and on July 15, 1662. Wat chatrtered by Chatrles II ats the Roval soedety of London. It began to publish its world-renowned "Philosophieal Transactions" in 1665. These soon reached such a high level of merit as to include many important works of Leewwenhoek, Malpighi, and other great names. 'Thic' Dublin Philosophieal Soeiety was established in 1684, with sir William Ponty as first president, and, after some rieissitudes, was reorganized at 'Trinity College in 1693. Richelisu, in France, foundert the famous Aradounic Fran-

${ }^{1}$ For the best aleonut of this matter in English, see "The Roter of the Scientifie Societies in the Seventeenth Century, "by Martha Orenstein (-13ronfenbrenner), New York, 1913. 
catise at Parts in 163.5, with the object of improving the French language and

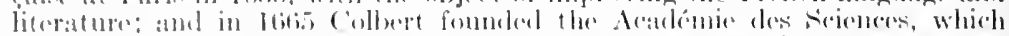

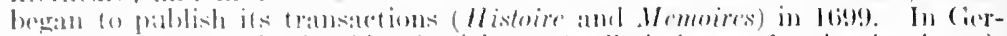

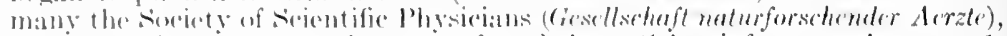

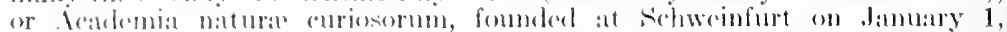

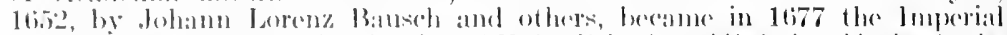

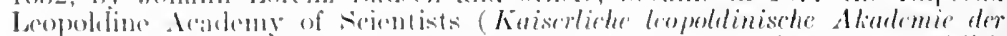

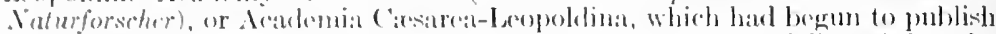
its "Mlisedlanea" or liphemerides in 1670. These were followed by the den meder Mafnionsian, edited by Thomas Batholinus (Copenhagen, 16717!), and the Acta eruditorum (Leipgig, 1652-1745). Detached periodical literature had, meanwhile, taken an inderendent comrer. The Acta Diuma of the ancient Romans, brief bulletins of battles, weetions, games, and other happenings, and the Chinese Peking Geazte, founded in the seventh century $\mathrm{A}$. D., and still enrrent, precerded everything rlse of this kind. The seventerinth century newspaper lerived from the fugitive "news-letters," originally written out in long hand for wealthy battrons, and the eonserfuent formation of "intelligenec ofliess," with himed staffs of rerks, as deseribed in Ben Jonson's enomedy, "The staple of News" (1625). Following the Venetian gazzetice, coranti or

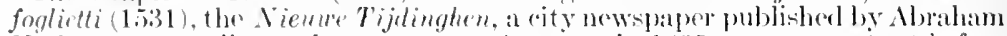
Verhoeven, was licensed to appear at Antwerp in 1605 (no copy extant before 1616), to be followel, in turn, by the first (ierman newepapess, the Fromlifurter Journal, founded by Eenolph Enmed in 1615, and the Frantifurter Oberpost-

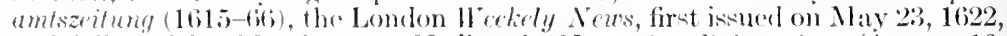
and followed by Marchamont Nedham's Mereurius Britomicus (August 16, 1643), the (iazette de Frenese, issuet at Paris by the physician Theophraste Renandot on May 30, 10:31, and, in Ameriea, the solitary number one of the Publisk Oceurenes, andited by Benjamin Harris, and published at Boston Suptember 25, 1690. Entirely distinet from newspapers or periodieals proper were such political bulletins" as the sooteh Diumel of Occurents (1513-75), Janeon's Hereurius Ciallo-belgieus (1587-94), the Diurnals of the English Parliament (1641-2) or Marchamont Nodham's Mercurius Britamieus (1643-6). The pedigree of the scientific periedical is out of the seientific soejety by the newpaper. The new tendency was represented in science by the Journal des Sccomuns of Paris (Jantary 5, 1665) and, in medicine, by the Nourdles Décoururtess sur Toutes les Parlics de la Védecine of Nieolas de Blegny (Paris, 1679s1). usually regarded as the first medical periodical in the vernaeular. Its popularity is evidenced by its translation into German as Monatliche neuraffuete Aimerchungen (Hamburg, 1680). It was translated into Latin, and eontinued by Therophile Bonet as the Zotiacus medieo-gallieus (Geneva, 16808.5). The abortive Journal de IIédecine (1681-85) of the abbé J. P. de la Rocque was continued (1686) by Clande Brunet, who also edited a monthly Progrès do la . Mederine (1695-17091). The first English medical journal was the Medirina curiosa (June 17-Oetober 23, 1654).

De Blegny was also the author of a series of satirical sketches of his contemporaries which, published as the Mercure sam (1684), beame the original of subsequent "city directories." 2 Theophraste Renaudot was the originator of pawn-shops and intelligence offiess. When we reflect that a postal service did not exist on the eontinent of Enrope before the year $1516{ }^{3}$ the value of these seientific soeieties, periodicals, and directories for the more rapiul dissemination of knowledge will at once appear.

1 Sildhoff: Nïnchen. med. Wochenschr., 1903, 1, 45.5.

2 The first being the "Almanac des addresses de Paris," 1691.

${ }^{3}$ Narco Polo describes an extensive courier service among the Chinese of his time, and Louis XI, in 1464, established an official service of mounted messengers (cheraucheurs en poste) in France, but the first mounted postal service for purely public use was established between Vienna and Brussels in 1516 by Franz von Thurn und Taxis. 
The great centers of medical education in the seventeenth century were Leyden, Paris, and Montpellier. At Leyden were Sylvius, Ruyseh, Nuck, and Bidloo; van Deventer and Cornelis Solingen were at The Hague; Roonhuyze and Swammerklam at Amsterdam; Duverney, Vieussens, Pierre ISionis, Mauricean, Jules Clément, and Paul Portal at Puris; Giorgio Baglivi at Padua, and no less than Syclenham was a pupil of Charles Barbeirac at Montpellier. In Germany, however, medicine had little chance until after the Peace of Westphalia (1648), and even after that time many original seientific mvestigations all over Europe were made by practising physicians detached from universities. It is not without significance that the huge output of brilliant work in anatomy and physiology followed directly upon the close of the Thirty Years' War.

In 1633, as Baas reeords, Ingolstadt had only 3 students; in 1647, 2; but 16 in 1648; while Strasburg had but 13 students during the entire period $1612-$ 31,4 in 1632-48, and 6 in 1649-99. German medical instruction in this perior was, moreover, along the old medieval, scholastic lines, a mere blind following of Galen and the Arabians, in opposition to the folk-medicine of Paracelsus. A lively teapot-tempest was stirred up by Thomasius in 1685, when he attempted to emulate the example of Paracelsus by lecturing in the German language, and the same prejudiee was even eneountered by sehönlein in $18+0$. Syclenham, Citisson, and the Swiss physician, Theodere Turquet re: Mayerne, were the leading exponents of the berlside study of disease in England, but, on the continent, the true clinical method, introduced in Leyden as carly as 1591 by Jan van Heurne (Heurnius'), was taught only by syjvius, and perhaps by Barbeirac at Montpellier. The usual method of teaching internal meedicine was to read off a perfunctory lecture in Latin, followed by a number of preseriptions which were variously Galenical, Spagyrical, Iatromathematical, Iatrochemical or Hermetic, and which the students copied.

Botanic gardens were establisherl at Heidelberg before 1600, Ciessen (1605), Strassburg (1620), Oxfort (1621), Jenat (1629), Tpsala (1657), Chelsea (1673), Berlin (1679), Eflinburgh (16.0), ant Amsterdam (1652).

Dissecting as a means of teaching anatomy was more frequent in Italy, Holland, and France than in Germany or Fngland. In the latter country, the material was usually obtained by graverobbing. In Germany, dissections, longo intervallo, were in the nature of civic events attended by festivities. When Rolfink began to have two annual dissections upon executed criminals at Jena in 1629 , the practice was held in holy horror by the peatsantry, who watched newly made graves lest they be "Rolfinked." A skeleton for teaching purposes was a rarity, and although there were anatomic theaters in most of the continental cities in course of time, there was none in Edinburgh until 1697. The latter, however, became the starting-point of the Edinburgh ascendancy in anatomic teaching under the Monro dynasty. In France, Vieussens is said to have made as many as 500 dissections alone.

1 J. E. Kroon: Janus, Amst., 1912, xvii, 443-447. 
The popularity and frequency of dissecting in Holland are sufficiently evidenced in the canvases of the great Dutch artists of the time. The earliest known of these is the "Anatomie" of Dr. Scbastian Feberts hy Arend Picterse (1603), in the Amsterdam (iallery, representing 28 physicians, with high ruffed collars and Vindrlie beards, gathered around the demonstrator, who is about to insert the salpel in the cadaver before him. Another" "An"ntomic" hy "Thomas de Keyser (1619), also in the Amsterdam eollection, represents the same physician quizzically tickling the ribs of a hilarions skeleton, to the ammsement of five of his friends. A superb document is the canvas of van Mierevelt in the Delft Hospital (1617), representing a body with exposed viscera, surrounded by Dr. van der Neer and 17 other figures, with all the accessories of dissecting. Rembrandt's famous Anatomy of Dr. Tulp (1632) at The Hague is suffieiently well known, and the same great master of realistic painting has, in the Ansterdam Gallery, a remarkable unfinished study of a foreshortened cadaver (1656), recombling Mantegna's pieture of the Dead Christ, and styled the Anatomie of Dr. Jolnan Deyman. The finest of all these "Anatomies" are Adriaen Backer's, in the Ansterdam Gallery (1670), representing a dissection by Frederik Ruyseh, and Johan van Ncek's picture of the same master, demonstrating the viscera of an infant to five physicians, whilst a child toys with an infantile skeleton in the eorner. As we survey the strong, valid faces of these Duteh physicians, richly elad in silk or velvet gowns, or jerkins with high ruffed collars, ${ }^{1}$ we get no bad idea of the dignity of the profession in the seventeenth century. In the Rembrandt pictures, two Anatomies of Frederik Ruysch, and in Nicholaes Maes' painting of the chiefs of the Surgeons' Guild (Ansterdam, 1680), the ruffed collars have already become Geneva bands. In Rembrandt's Doctor Tulp, as in Greenbury's "Anatomy" of Sir ('harles Scarborough (1649) in the Barbers' Hall, Iondon, the short, lace-edged collar, which was evidently a token of wealth or worldly place, is in evidence. ${ }^{2}$ An etehing representing the Anatomical Theater at Leyden, of date 1610, shows a circular inclosure affording mere fence-rail accommodations for seats, the separate tiers of which are interspersed with stuffed birds, skeletons of animals, and human skeletons (one on horseback) bearing placards adorned with appropriate mortuary inseriptions. These skeletons and inseriptions were also a feature of Ruysch's famous anatomic museum at Leyden, which was purchased by Peter the Great in

1 These ruffed collars are also worn by the lady-patronesses of the Leper Hospital, in Werner van Valckert's painting of 1620 (Holländer, p. \$9).

${ }^{2}$ For reproductions and full descriptions of all these pictures see Eugen Holländer, Die Medizin in der klassischen Malerei, Stuttgart, 1903, pp. 34-60. 
1717 for 30,000 florins (about $\$ 75,000$ ), and is still in a fair state of preservation in the Anatomical Museum of the Imperial Acadeny of Sciences at Petrograd. A second collection, which Ruysch afterward made, was, on the authority of Hyrtl, scattered and destroyed after his death.

As the great Renaissance physicians had commonly followed botany or zoölogy as speeial lines of investigation, so we find the physician of the seventeenth century distingnishing himself as a mathematician and astronomer, a physicist, a microseopist, or a chemist. In miversity teaching, the most extraordinary versatility was sometimes displayed, Meibom, for instance, presiding over philosophy, philology, areheology, and geometry, as well as

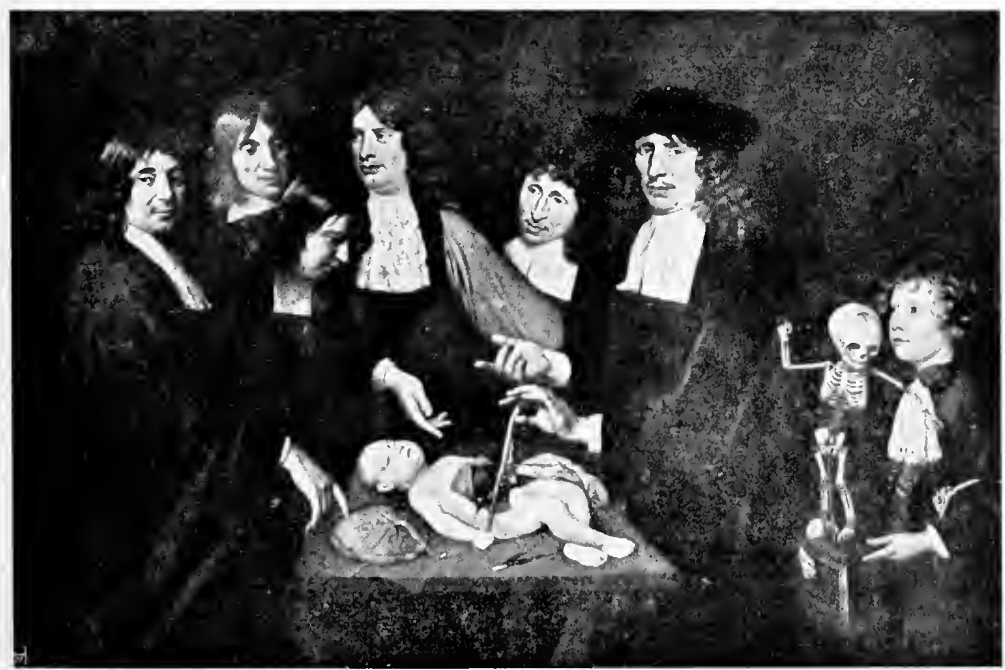

Anatomy of Dr. Frederik Ruysch by Johan van Neck (1683) (Amsterdam Museum), Hanfstaengl, Munich.

medicine (Baas). The polyhistorian Hermann Conring taught in all the four faculties. In physies, the work of Descartes, Kepler, Sanctorius, Hooke, Borelli, and Scheiner has been mentioned, and of physician-chemists we need refer only to van Helnont, who first used the term "gas," and knew the properties of hydrogen, earbon dioxide, and sulphur dioxide; Leenwenhoek and Redi, who were the first food chemists; Boyle, who first defined chemical "elements," founded analytic chemistry, and discovered that the pressure of a gas is proportional to its density (Boyle's law); John Mayow, who all but discovered oxygen; Minderer, who discovered ammonium acetate (spiritus Mindereri); Nicolas Lémery (16451715), who discovered iron in the blood; and Thomas Willis, 
who discovered the swoetish taste of diabetic urine. Johann Rudolph Glauber (160).-8s), of ('arstadt, whose bust was used as a chemist's sign for notrly two hundred yours, discovered sodium sulphate (Clauber's sult), mate sulphate of copper, arsenic chloride, and zinc chlorike, distilled ammonia from bones, and obtained hydrochloric acid by distilling sulphuric acid with soasilt: investigited probligneous acid (acetum lignorum), did much for the dhemistry of wines and spirits, and published a valuable encyelopedial of chemicul procedures. He often sold "secrets" to manufacturers, was alcused of solling the same secret several times, or of selling secerets which would not work, and his great seceret, which he expresty declined to sell or publish, was the Alkahest, or Eniversal solvent. Ilence Oliver Cromwell said "This CHauber is an arrant knave"; but Glauber was easily the greatest analytic chemist of his time, and those of his calling who have had their discoveries stolen by their assistants have loarned to appreciate his camny sense in liceping his business to himself. The secretive Cilumber is particularly interesting, because he stands between the scientific chemists, like Boyle or Marrow, and those who deliberatcly followed alchemy. Although the pretended making of gold and silver and other magie practices was opposed by the Chureh in the famous bulls, "sipondent poriter" (1317) and "Super illius speculie" (1326) of John XXI, ${ }^{1}$ alchemy became an intensive eult of extraordinary magnitude in the sixteenth and seventeenth centuries, beeause it appealed particularly to the lust of money, the lowe of life, and the corresponding fear of death. For the philosopher"s stone, otherwise known as "the quintessence" or "grand magistery" was not only supposed to transmute the baser metals into gold, make precious stones and a universal solvent, but also conferred perfect health and length of days. It was deseribed by all who claimed to lave seen it as of a reddish luster. Raymond Lully called it a carbuncle; Paracelsus likened it to a ruby; Berigard fe Pisa, to a wild poppy with the smell of heated sea-salt; van Helmont, to siffron with the luster of glass (Thorpe ${ }^{2}$ ). The choral symphony in praise of its capacity for maintaining health resembled the testimonials of "Vin Mariani" and other nostrums of our time.

${ }^{1}$ For the Latin text of which, see: Walsh: The Popes and science, New Fork, $190<,+1+-416$.

2 The Alkahest, the name of Paracelsus' Universal Solvent, which could be prepared by the stone, was supposed to be derived from the Latin alkaliest, from the German all Gitist (all gas), or Alles ist (it is all), but the ehemist Johann Kunkel (1630-1704), who pointed out these derivations, said its true name was Alles Lügen ist (It's all a lie); for "if it dissolved everything, no ressel could contain it." Sir E. Thorpe, History of Chemistry, London \& New York, $1909, \mathrm{i}, 46-56,81$. 
From the universal solvent it was but a step to a universal remedy, like that of Butler's French quack, who

And called his receipt a general specific."

The effect of alchemy upon the medicine of the sixteenth and seventeenth centuries had been to create a number of offshoots of the Paracelsian or Spagyric School, which were variously termed Hermetic, Cabalistic, Zoroastrian, or Rosicrucian, according to the individual penchant for the doetrines of Hermes Trismegistus (the Egyptian Thoth), the Hebraic "oral tradition" or Cabala, the traditional "living word" (Zendavesta) of the Persian Zoroaster (Nietzsche's Zarathustra), or the eult of the mythical Christian Rosencreutz. The doctrine of the Rosicrucians emanated from three books of mystic and alchemistic jargon, which were published during the years 1614-16 and called the Fama Fraternitatis, the ('onfessio Fraternitatis, and the Chymical Marriage of Christian Rosenereutz. The supposititions author traveled in the East (as usual), where he learned necromaney, alchemy, and philosophy. Ipon his return, he imparted the new knowledge to seven associates, forming the Brethren of the Rosy Cross, who were to follow science and to communicate their results to one another, to render free assistance to the sick poor, and to have no distinctive tokens of their cult except the letters "C. R." It goes without saying that they could manufacture gold, if so inclined, but, like the Spiritualists and Theosophists of our own time, disdained to make any practical use of their superior knowledge, which, they admitted, was obtained by direci, illumination from God. It was subsequently discovered that the three basic texts of the Rosicrucian cult were written, not by Rosenereutz, but by the Württemberg pastor, Johann Valentin Andreas (1586-16it), who perpetrated this solemn piece of mystification in the same spirit in which Meinhold wrote Sidonia the Sorceress. All the "six follies of science," viz., circle squaring, multiplication of the cube (fourth dimensional space or spiritism), perpetual motion (Cornelius Drebbel), judicial astrology, alchemy, and magic were rampant in seventeenth century medicine, and most of them were subjected to keenest ridieule by Butler, the arch satirist of his age. Prominent figures in Butler's II udibras were Ralph, the Judicial Astrologer, who presumably purged and let blood by the signs of the zodiac, and was otherwise

"For profound And solid lying much renowned." 
And sidrophel, the Rosicmedin and voterinarian

\footnotetext{
"lin whom :ill prople, f:tr and ne:ar, ()n deep importances repair

When brass or pewter hap to stray,

And linen slinks out of the way:
}

When rattle foel indisposition

And need the opinion of phyisician."

The dupes of astmologic physicians of this type were ridienled in congrese's Lore for Lore (1695), in the rharacter of "Foresight an illitelate old follow, peovish and passive, superstitions, amel potending to understand Astrologre, Palmistry, Physiognomy, (Hnons, Dreams, de." : and Dr. Johnsom, in his criticism of this play, assures us that "the chalacter of Foresight was then commom. Dryelen calculated nativities; both ( 'romwell and King IVillam han thoir lucky days; and shaftestury himself, though he had no religion, was sald to regard predictions." But the tendency was by no means onfined to the learned laity. Kepler is said to have ast a horosone for Wallenstrin. Minderer of spritus . Hindereri) advised the plague doctors to repeat the Twenty-second Psalm "rery time they approached a patient. just as the old saxon Leecheloms urged the application of holy water and the intoning of Psalms LI. LXVII, and the Athanasian creol over cattle afflicted with plemopnemonia." That able alinician. Daniel sennert, helieved in witehelaft and pacts with the devil. The affar of the Lancashire Witehes, which was elramatized hy Thomas Heywool, goes to show that, long after Weyer's time. popple were still redulous about the stigmata of inculis and sucenti (hysteric ecchymoses), witebes marks (ancsthetic patches), demoniac possession, and other pantominic phases of hystropepilepsy ((Mmerol $\left.{ }^{3}\right)$. Sebastian Wirdig favored diviningrods and magie. (ioclenius and Fabricius Hildanus were patrons of the wapon-salve. and, in 16:s, the Eniversity of Montpellier heard sir Fenelm 1)ighy's colebrated discourse on the sympathetic powder, which Iadame de sévigné pronounced "a perfectly divine remedy" (January 28, 168.5). Digby, an Eebelmenseh in his way. first leaped into promineno as a corsair in the Levantine seafight conmemorated in Ben Jonson's droll couplet:

Witness his action done at scanderoon

Lpon his birthday, the eleventh of Jume.

1 Johnson: Lives of the Poets, sub rore Congreve.

2 Cockayne: saxon Leechdoms, i, $3 \$ 9$.

${ }^{3}$.J. A. Ormerod: St. Barth. Hosp. Jour., Lond., 1913, xx, 91-97. 
Wealthy and courted, in spite of his father's imprisonment for treason, he dabbled in polities, religion, and science, got a hearing, although, according to Lady Fanshawe, "he enlarged somewhat more in extraordinary stories than might be averred," and wrote a unique autobiography. The sympathetic powder, his special hobby, consisted, it is said, of nothing more thath green vitriol, first dissolved in water and afterward recrystallized or calcined in the sun. The Duke of Buckingham testified that Sir Kenelm had healed his secretary of a gangrenous wound by simply soaking the bloody bandage in a solution of the powder. Digby elaimed to have got the secret remedy from a Carmelite monk in Florence, and attributed its potency to the fact that the sun's rays extracted the spirits of the blood and the vitriol, while, at the same time, the heat of the wound eaused the healing principle thus produced to be attracted to it by means of a current of air-a sort of wireless therapy. Quite as amusing are the superstitions of the sympathetic or magnetic cure of wounds and the healing of disease by "stroking." The former originated with Paracelsus, and was exploited in 1608 by Rudolph (ioclenius, one of his followers, in the tract, De magnetiea euratione mulneris, while sympathetic medicine was the subject of a treatise by Sylvester Rattray (1658) and of a collective Theatrum sympatheticum (1662). The treatment consisted in anointing the weapon which had inflicted the wound with the unguentum armarium, of the patient's blood and human fat, the wound itself being wrapped in wet lint. This doctrine was supported by Fabry of Hilden, Robert Fludd the Rosicrucian, and van Helmont, who attributed the cure to animal magnetism. The clergy held that the weapon cure was wrought by magic and the devil, and their view was set forth by William Foster in Hoplocrisma Spongus, or a Sponge to Wipe axay the Werpon-Salue (1631). Robert Fludd (1619), van Helmont (1621), Kircher, in Magnes (1643), and Willimm Maxwell (1679) were the early theorists about animal magnetism, which was carried into practice by Valentine Greatrakes (Greatorex) (1628-66), one of Cromwell's soldiers in Ireland, who achieved an enormous reputation in his "cures" of disease by" laying on of hands (stroking) and the cure of serofula with carrot poultices. The treatment of scrofula was, however, the special prerogative of royalty. The King's Evil, or morbus regius, has latterly been made the subject of an exhaustive and scholitry monograph by Dr. Raymond (rawfurd (1911), and the results of his original investigations of the medieval sources are briefly ats follows:

The personal power of healing, in the first instance, always an at tribute of the gods, became, by natural ascociation of ideas, a divine right of kings, and 


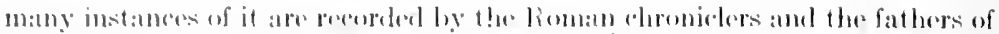

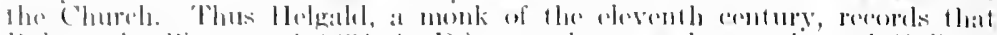

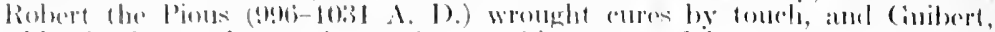

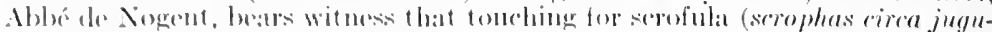

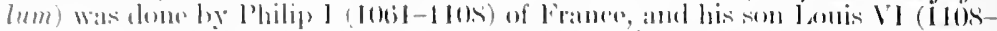

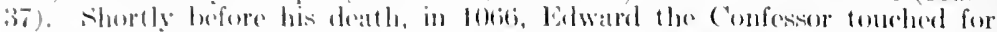

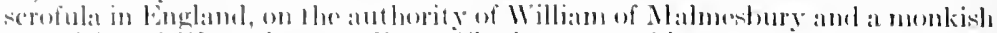

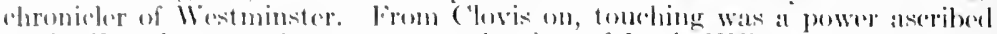

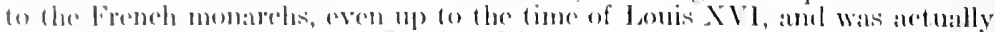

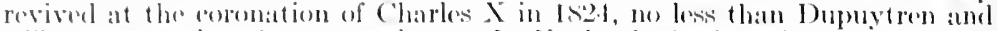

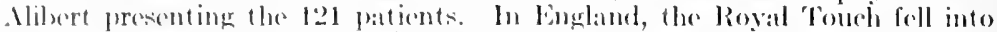
disuse among the Nolman lings after the ('onfessor, but was revived by

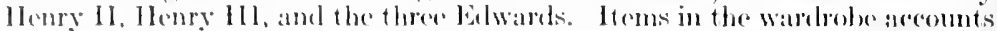
of the latter show the paymont of alus to the serofulous poor. After Richarel II's time, there jis emplete silenee in the chronicles until 1462 , whon Henry lll revivel the royal prerogative with an rlaborate ritual, and, in 1465 , the minting of a special eoin, the gold Angel, as a touchpiece. 'The coremonial with the use of tomehpieces, and of medals as tickets of atmission, ${ }^{1}$ were features of all subseguent reigns to the time of William of Orange, who troated the practice cavalierly; but (2ueen Amme revived it, "ven touching Dr. Johnson (without success). The exiled stuarts "over the water" also upheld it, but it was pratetionlly discarded hy George 1.

It was in the serenteentli entury that the practice of the Royal Touch reached its height. Richard Wiseman, onc of the ahlest surgeons of the time, wrote the classic aceount of the King's levil, in which he bears ample witness to the healing power of Charles 1I. Shakespoare, in the time of James I (1607), describes (Macbeth, Art IT, se. 3) how-

\section{"strangaly-visited people,}

All swoh and ulesois, pitiful to the eye,

The mere clespair of surgery, he eures;

Hanging a golden stamp about their necks, Put on with holy praycrs."

The Royal Touch was not even subjected to ridienle in the Pseudodoxia Ejpidemica: or Enquivies into Vulgar and Common Errors (1646) of Sir Thomas Browne (1605-82), the old Norwich physiclan, whose delightful writings-Religio Medici (1643), Urn Burial (1658), and the rest-belong to literature proper, in the most exquisite sense. The Religio Medici, with its quaint and original modes of expression, is an attempt to reconcile scientific skepticism with faith. The Vulgar Errors, while nominally a critical onslaught upon superstition, displays the same delightful whimsicality through its author's rechutous attitude toward many of the things he set out to rirlicule.

Thus while the medical science of the seventeenth century was making rapid stricles forward, its popular medicine was already in process of retrogression to the excesses of the Byzantine Period, which bears out our main thesis, that the folk-ways of medicine are inevitably the same and independent of time and place and

${ }^{2}$ For this phase of the subject, see the learnel and illuminating monograph of Helen Farquhar on Royal (harities, London, 1919 (Brit. Numismat. Jour., xii-xiii). 


\section{circumstance. This can be easily verified by a glance at the materia medica of the period.}

The first edition of the London Pharmacopaia, published in 161s, contains some 1960 remedies, of which 1025 were simples, 91 animal, 271 vegotable. Among these were worms, lozenges of driod vipers, foxes' lungs (for asthma), powders of precious stones, oil of brieks, oil of ants, oil of wolves, and butter made in May (for ointments). Among the 932 compounds, many of which had the names of their Greek and Arabian originators attached, were vegetable syrups, compound senna powder, Neapolitan (blue) ointment, Vigo's plaster (compounded of vipers' flesh, with live frogs and worms), and the edebrated antidote of Mattioli, marle up of about 230 ingredients, including the multifarious mithridate (confectio Damocratis) and the theriaea Andromachi. The Pharmacopoia of 1650 contains cochineal, antimonial wine, the red and white mereurial preeipitates, moss from the skull of a vietim of violent death, and Gaseovne's powder, eompounded of bezoar, amber, pearls, erabs' eyes, coral, and black tops of erabs' elaws. In the Pharmaeopoia of 1677 the names of the Greeks and Arabians disappear, showing that their influence had also declined, while jalap, einehona bark, burnt alum, digitalis, benzoin, balsams of eopaiba and tolu, steel tonies, and Irish whisky (aqua vite II ibernorum sive usquebaugh) make their appearance for the first time, as also human urine, so highly recommended by Madame de Sévigné (June 13, 165:15). Annong the queer remedies eontained in the three London Pharmacopocias of the period were the bloorl, fat, bile, viscera, bones, bone-marrow, claws, teeth, hoofs, horns, sexual organs, eggs, and exereta of animals of all sorts; bee-glue, cock'scomb, euttlefish, fur, feathers, hair, isinglass, human perspiration, saliva of a fasting man, human placenta, raw silk, spider-webs, sponge, sea-shell, cast-off snake's skin, scorpions, swallow's nests, wood-lice, and the triangular Wormian bone from the juncture of the sigittal and lambdoid sutures of the skull of an exeeuted criminal (ossiculum antiepilepticum Paracelsi2). The Chinese materia medica itself could go no further than this toward demonstrating that the folk-mind is stationary or discontinuous. Yet Ninderer preseribed oil of spiders and earthworms for plague, Robert Boyle reeommender album Gracum as a homely but experienced remely for dysenterv, Nieolas Iémerv, cat-ointment ane! oil of puppies boiled with earthworms, Mattioli, oil of smorpions, and P'aracelsus, human ordure (Zebethum ofcidentale). (ilauber alone, in an important treatise on salts $\left(16.5 \mathrm{~s}^{3}\right)$, urged the employment of ehemical preparations in lieu of animal excreta. Old Nicholas Culpeper, the areh herbalist and quacksalver of the time, indulged in a vast amount of scurrilous raillery at the expense of the Lonton Pharmacopxias of 1618 and 1650 , but, exeept for his herb-lore, be was himself only the credulous astrologer deseribed by Nertham, as "a frowsy-headed coxcomb" who hard "gallimawfried the Apotheearies' Book into nonsense" in his aim to "monopolize to himself all the knavery and cozenage that ever an apothecary's slop was eapable of."

In Germany, Rivinus published a 'ensure of oflicinal remedies (1701), rejecting as worthless the poisons, parts of animals, perishable and inert substances, adulterated, substitutod, faultily prepared or imaginary remelies and ineongruous or ineompatible mixtures.

Another eurious feature of seventeenth eentury therapy was the large number of private or proprietary preparations. Prominent among these nostrums were the Sicot's P'ills (irana Angeliea), compounded by Patrick Anderson ( 16353 ) of aloes, jalap, gamboge, amb anise (the molern pilular aloes et myrrhise), which were, arcording to Wootton, sucessfully patenter down to

1 She was also a warm advorate of viper meat, to "temper, purify, and refresh the blood," and gosip claimed that sir Konelm Dighy poisoned his wife with too frequent doses of viper's wine, given in aid of preserving her gext looks.

2A. C. Wootton: Chronicles of I'harmaey, Isondon, 1910, vol. ii, pl). 2-31.

${ }^{3}$ Glauber: Tractatus de natura salium, 16.58. 


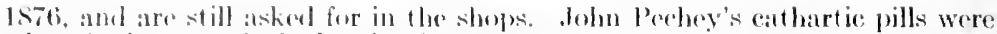

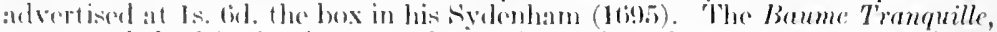
compounded of herls, hy one of the c:tpuchins of the lomvre, was highly

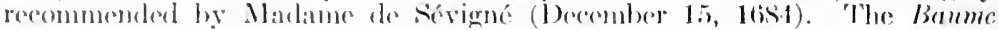
Fiorememe another herbal tincture of the time, is still featureal in the fronch

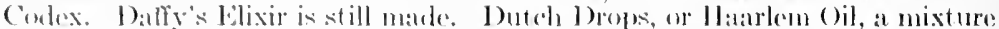
of oil of turpentine with of here ingerlients, has bern used sinee 1672 ats at "medieamentum" or routiue preventive of disestes. Clateles l] gave anywhere from

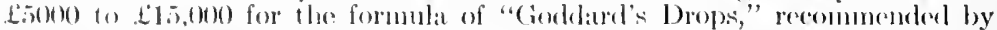
Fydenham, and sold to have beren made of raw silk. Carmelite water (erun de Wrlise des ('arme's), an atomatic cordiat, malde at the pharmaley of the Bare-

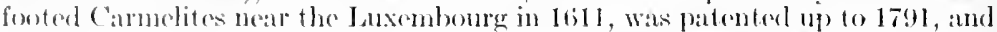

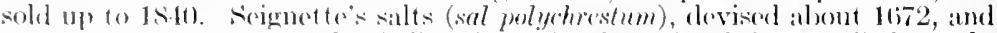
as seret up to 17:31, Were Rochedle silts. The formula of the so-ealled frankfurt pills, a popmlar laxitive of alors and rhomm, also rallod Beyor's pills or pilule andelice, was transmitfed by the inventor, boham Ilartimann Boyer

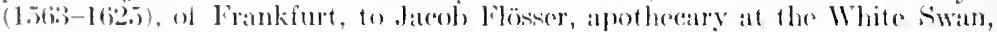
in 1.20, and transmitterl, in succession, to other apothecaries unt il late in the cighterenth entury. 'The pills of a figurative J)r. Immanucl ("Cod with us") of Nurembere, were in use about 10i3s as a cure-ill, espeedilly when the platgue was provalent." Singleton's Ciolden bye Ointment is deseribed in Wooton's Chronicles as the oblest privateremedy sold in bingland, and is still proprictary.

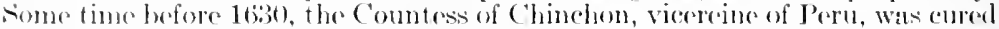
of malurial forer at Lima, hy administration of cinchona bark, which hatl long bern known to the Jeruvian Indians, and was brought to burope by the Jusuts in 16:32, amd later by Juan de Vigo. No other event, says Nouburger, did so much to upset the eirrent sehool systems of melicine as the rliscovery of Jesurts' bark. Ramazzini said that einclona did for medicine what gumpowdor had done for was. The faet that it rapidly eured a protracted intermitent forer. for which the older remedios had been employed for monthe at a time

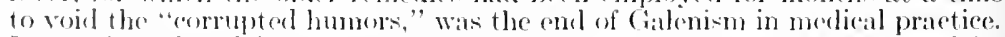
It was jutrodued into English practice by Fydenbam and Morton, and its use enablecl them to rlifferentiate malarial fover from other folmile infections and Torti to separate the perniejous forms which do not yicld to it. Ipecac wats first mentioned as igperaya by a lortuguese friar in l'urehas' Pilgrimes

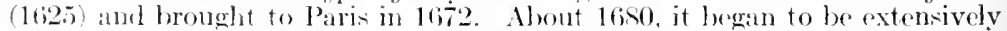
proseribed as a seceret remedy for elysentery by Helvetius, and, at the instance of Jouis XIV. the seerot was tried out and purchased by the Freneh govermment for $20,0(0)$ franes in 16ss. The drug has sinee had its ups and downs prior to the introduetion of enetine (1910). Antimony had an extratorlinary vogue in the soventeenth eentury through the faet that tartar emetic लurial Jomic XIV of a dangerous illness in 165\%. Tartar emetic was furst deseribed by Arrian Mynsicht in 1631, and may havo been identieal with the Earl

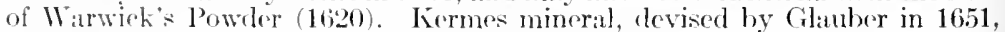
was a seeret for whjeh Louis XIV paid a high figure in 1720 , under the guise of poudre des Chartess. Antimony eups (pocula rmetica) were in eommon use in Germiny, but disappeared toward the end of the century. ${ }^{3}$ In 1646 , Athanasius Kireher deseribed another kind of wooden cup, sent him by the Jesuits in Mexion, which would color water poured inte it a deep blue, eapable of chameleon-like fluoresenee. This was the eclebrated ligmum nephriticum, first noted by Nieolas Monardes (1565) and Francisco Hernandes (1577) as a remarkable diuretic for renal and dropsieal troubles. Caspar Bauhin described a similar aup in 16.50 and, in 1663, Robert Boyle made a eareful investigation of the color phenomena. In 1915, W. E. Safford showed that ligmum nephriticum is obtained from two speeies, viz., Eyswhardtia polystacha, the palo dulce

$1 \mathrm{IV}$. Ftricker: Janus, Breslau, 1847 , ii, 397-399.

2H. Áchöppler: Arch. f. Giesch. 1. Merl., Leipz., 1911-12, v, 446-449; $1912-13$, vi, 232

3 These remedies are all deseribed at longth in Wootton's "Chronicles of Pharmacy," London, 1910, pessim. 
of Mexieo, which Boyle examined, and Pterocarpus indica, a large Philippine tree, from which Kircher's and Baubin's cups were probably made. In the seventeenth century these eups were esteened as gifts fit for royalty. ${ }^{1}$ The moxa, whieh Sydenham thought identical with the $\dot{\omega} \mu o$ d introdued into European practice as a remely for the gout by IInmam Buschoff, a Batavian clergyman, in 1674 , and recommended as a cure-all by Gehema $\left(162^{2}\right)$.

Professional poisoning, as bad ats that described in Livy and Cicero, was particularly l'ampant in Italy and France. Much of sixteenth and seventeenth century poisoning was, no doubt, intestinal obstruetion, extra-uterine pregnancy, appendieitis, or what not. But the oljects in the Musée de Cluny ${ }^{3}$ and other data indicate that it was an ambition of the time

To earry pure death in an earring, a casket,

A signet, a fam-mount, a filigree basket,

and the scene in Swinburne's "Queen Mother," in which Catherine de' Medici poisons her clown with a pair of gloves, is probably not exaggerated. Such an Italian poisoner was Exili, who left Rome for Paris, with a record of 150 eases against him, and came in contact with Sainte Croix, the paramour of the deplaved Marquise de Brinvilliers. From Exili, sainte Croix is said to have learned of the subtle compound with which his nistress disposed of her father, two brothers, and many unfortunate patients in hospital. She was eaught up with by a love-making detective, tried, and humg in 1676. The white powder she employed defied all analysis. The affair led to a fashionalle epidemie of secret poisoning, against which Louis XIV instituted the colebrated "Chambre Ardente." This was a kind of "third-degree" tribunal, and, through its official grillings, the female fortune-tellers, La 1 oisin and La Vigourenx, with their poudre de succession, were exposed and brought to justice. Arsenic was probably the toxic principle of the Acpla Tofana or Aquetta di Napoli of Teofania di Adlamo, a diabolic female who, in 1709, owned to having poisoned over 600 persons with it, and was subsequently imprisoned or strangled.

Apothecaries' bills were exeeptionally high in the seventeenth eentury, and the cost of medieines was often exploited by physieians and wurgeons as an exense for running up their charges. In Germany, the eity dipthelen were of imposing architecture, the facade being sometimes omamented with stone figures of great physicians of the past, as in those found at Hannover by Hermann Peters and at Lemgo by Amold Klebs. ${ }^{4}$ In London, Bueklorsbury

1 Safford: Ann. Rep. Smithson. Inst., 1915, Wish., 1916, 272-29s, 7 pl.

${ }^{2}$ For the history of the moxa, see Reichert: Deutsches Arch. f. Gerch. dl. Med., Leipz., 1879 , ii, $45 ; 145$.

${ }^{3}$ For a description of these see L. Courtarlon: Aseulape, Paris, 1912, ii, $185-192$.

${ }^{4} \mathrm{H}$. Peters: Die Heilkunst in der Starlt Hannover, IIannover, 1901. A. C. Klebs: Areh. f. Geseh. d. Naturw., Leipz., 1914-15, v, 102-107, 2 pl. 


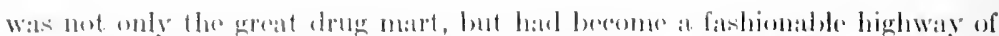

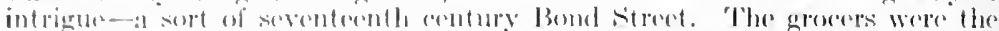

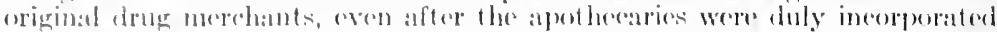

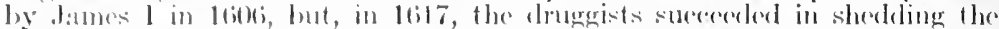

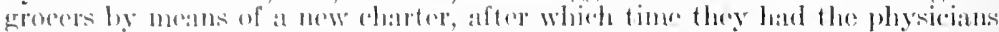
against them. "The reason of this was that the alpotheraries sot uje as practi-

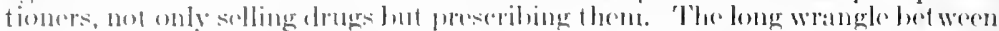

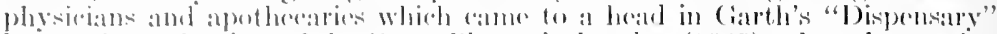
hegan about the time of the (imeat l'lagere in Iomelon (16itis), when the apothecaries made goxh in public atimation ly staying at their posts, while the

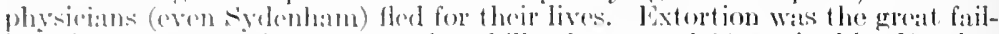

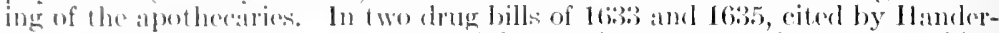

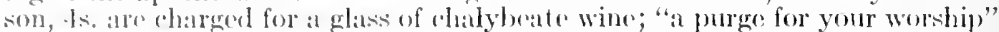

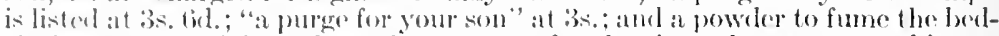
clothes at ls. Iligh as these dhitrges were for the time, they are as nothing to

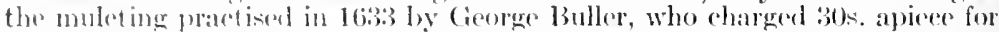
pills and E:37 10k, tho boxful. In the roign of Jandes 1, the College of Pliysicians

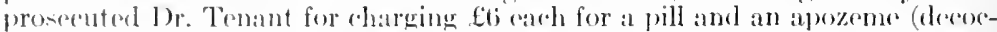
tion), and l'itt, in 170:3, stated that apothearios had been known to make between $f 150$ and $e^{3}: 20$ ont of a single ease, and that their preseription eharges were at least to pere (ent. more than the shop) priess. At this time the average Lomdon physedin's fee was abont half a soveroign, while the apotheraries in ordinary to Charles I and Charles II got $\mathcal{E} 40$ and f72 por amoun respectively: In $16 \mathrm{si}^{*}$, the Colloge of l'hysiovan bound their follows and licentiates to treat the sick poor of London ind its submrbs froe of charge, which strained the situation still further, and, in 1696, 5i3 influential physicians sulseclibed filo each to establish dispensaries for supplying drugs to the poor at cost priee. War was now joinod not only between physicians and apothecaries, but an internecine wringle broke out anong the dispensurians and anti-clispensarians, the latter being, of course, favorel by the apotheearies. A lively bout of seurrilons pampliloteering cosued, and in 1699 Garth published The Dispensary, a satirical poem in the meter of ['ope, urging the injustice of the dilemma foreed wpon the physieians "to eheat as tradesmen or to fail as fools." It was deseribed by Dr. Johmson as "on the side of charity against the intrigues of interest, and of regular learning against lieentious usurpation of medical authority." Pope also had a slil) at

Morlern potheearies, taught the art

By doctor's bills to play the doetor's part,

Bold in the practice of mistaken rules.

But, in spite of the support of the men of letters, the physicians were in the end beaten by the apotheearies, for a test case against an apotheeary who had excerled his license, which was brought to trial in 1703 , and at first decided in the physicians' favor, was subsequently reversed in a higher eourt. After this time, the English apotheearies became practitioners to all intents and purposes, and then began to nake war upon those of their number who did not come up to certain standards of their own devising. They were upheld in this, as we shall sec, in 1815 and until 1856 .

\section{In the seventeenth century, the control of the trade routes and} the drug marts passed into the hands of the Dutch and the English.

In the sixteenth century Holland hat already acquired eomplete control of the carrying trade between notthern and southern Europe, as also of the supply of timber, tar, and wheat; but the sceret of the sea route to the Fast Indies had been jealonsly guarded by the Portuguese. In 1595-6, Jan van Linschoten, who had served in the Portuguese Indian fleet, jublished an account of his travels in the Far East, which gave much of the lesired information. Many brisk sea-fights ensued, until even the Molnceas fell into the hands of Iolland. Torrents of blond were shed for the "apparently inoffensive elove," which today is mainly of value in seasoning piekles and preserves or to conceal 
the odor of a drunkard's breath. As Motley said, "The workd's destiny sermed to have almost become dependent upon the growth of a part icular grillyflower." To get complete control of the clove, the Duteh extirpated it from the Molueas and introduced the tree into Amboyna (Flindiger and lianbury). 'To momopolize Myristica fragrans, the somer of nutmegs and mace, they inmersed the kernels in milk of lime for three months, to prevent propagation outsile the Banda Islands, and kept the entire nutmeg erop in stock at Amsterdam for sixteen years (Linton). 'Tavernier tells how they nonopolized the cinnamon of Ceylon. The English did not sucered in gaining a foothold in the drug marts until late, and for a long time their supplies were obtained by the capture of Portuguese and Dutch vessels. The capture of Ormuz (16:2) and the massacre of the british at Amboyna (1623), the subject of Dryclen's play, are features of their elash with the Diteh. Their surest hold was destined to be in the peninsula of Hindustan. The British East ludia Company was chartered on 1)ecember 31, 1600, and a permanent station was established on the Malabir eoast in 1612.1

The extent to which exotic Eastern and Ameriean drugs were introfluced is evideneed in the remarkable series of pharmacologic tracts publisherl in London during 1672-95 and attributed in part to John Pechey of Gloncestershire. Nolucea nuts, ginseng, Angola seod, ipecacuanha, casmmur root, Malabar nuts, Barbado seeds, Bermula berries, Vanilla beans, salep, Colombo woor, Maldive nuts, lignum nephriticum, Blatta bizantina, Bengala beans, Perigua, Mexico seeds, Cylonian plant and cassiny are among these simples." The supposititious author is not to be confused with John Pechey (1605-1716) of London, the translator of Sydenham (1696).

The purchasing power of money in the seventeenth century is said to have been some seven or eight times what it is now, and, with this ratio in mind, we may gain some idea of the compensation and income of the physician and surgeon of the time.

The salary of a physician in ordinary was $£ 100$ annually, but Turquet de Mayerne got $£ 400$, with an annuity of $\mathfrak{E} 200$ settled upon his wife. While the average fee of the English physician was, as statel, about 10s. (worth about \$35 today), we find Richard Mlead (1673-1754) charging a guinea a lit le later and a half a guinea for coffeee-house practice. Harvev. who was not a successful practitioner, left an estate of $\$ 20,000$. The annual salary of the Professor of Physic in the University of Cambridge in 1626 was $£ 40$.

An old bill of 1665 gives $12 \mathrm{~s}$. as the fee for a twenty-mile visit; another,

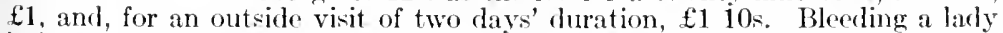
in bed cost $10 \mathrm{~s}$., as against 2. 6d. for a man. A postmortem cost $3 \mathrm{~s} .4 \mathrm{~d}^{3}{ }^{3}$

Thomas Arthur, a physician of Limerick, Ireland, although prevented by religious prejudice from practising among the wealthy, made an average income of about $£ 250$, or the equivalent of about $\$ 7000$ today (Walsh). His fee for the management of a case of gonorrhea (1619) was $£ 2$ in advance, and, for a putrid sore throat, Ss. The Professor of Physic in the Tniversity of Cambricke got $£ 40$ per annum in 1626. In Germany the tariff was fixed hy the ordinances of Hesse (1616), Frankfort on the Main (1668), and Prussia (1685). According to the Frankfort ordinance, an office visit was worth 40 pfennige (about 7.5 cents today), a house visit 1.35 marks, a night visit 1.70 marks, and a consultation one gold gulden (about \$12.50). Foreigners were charged half as much again, and the wealthy pairl what they liked. The family physician (Hausarzi) received a lump sum annually, as high as 100 marks in one ease, fur attendance on a Bavarian eountess (Baas). $\bar{A}$ rity physician got over 500

${ }^{1}$ See Tschireh: Pharmakognosie, Leipz., 1910, ii, and Linton: Jour. Am. Pharm. Assoc., 1916, v, 473; 574 .

2 See Index Catalogue, S. G. O., 1. s., x, 594-595.

${ }^{3}$ See Brit. Med. Jour., London, 1870, ii, 169. 


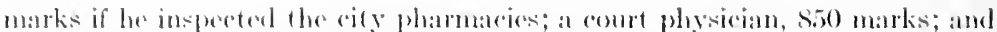

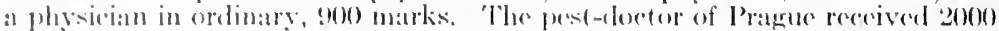

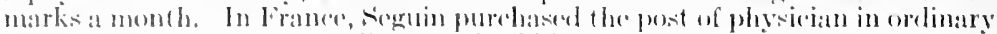

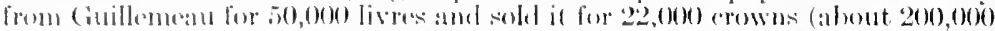

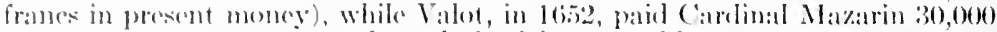
rowns for the bateant post of royal physedan. Bunkle states that the average French doweros fee was as low as that of an binglish farrior. Areording to the

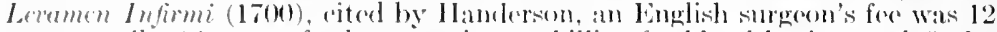

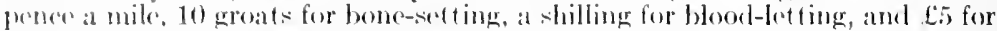
amputation; a licensed physiejan got a uoble or anged (6s. sd.), although he might demamel to, a gratuate in physie los., though they commonly demanded 20. livohard Wiseman got 1500 as surgeon in ordinary in lobil, and de

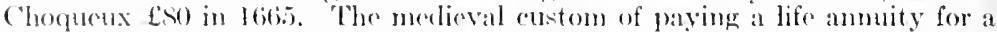

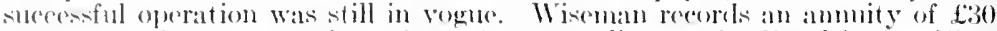
jor anmum from one patient (l'ower). Aceording to the lrankfort tariff of litis, a fierman barber surgeon got $10 \frac{1}{2}$ marks for setting a broken arm (20 marks, if wo bones were broken), 30.55 marks for a dislowation of the (1howor kneo-joint, or lialf as much if the result was poor. A surgeon charged 31 marks for amplutating an arm, 41 marks for a leg, 51 marks for a lithotomy, or half prixe if the pationt died. Herniotomy was rated at 51 marks, and cataract operation 17 marks for one eye, or 25 inarks for both. Areorling to Bats's tabulation of the pay of army surgeons in Mark Brandonlurg, a company surgeon got!about 11 to 15 mairks montly in the infantry, and in the cavalry 11.40 marks in 1639), and 27 in 1655. A regimental surgeon got 30 marks in 16i3s, 15 marks in 1639, 27 marks in 165is, and 52.80 marks in 1685. During 16i35-s5 the surgeon of the exiled French mousefuetaires got 90 marks monthly. The pay of a Saxon Freldseheerer in 1613 was 333 marks a month. It is interesting to note that, during the Thirty Years War, and after, the Feldseheerer was at oner regimental surgeon, barber, and standard-bearer (Fährich ${ }^{1}$ ). In England, unler the Commonwealth in 16.50, army surgeons at the northern posts got 6s. Sil. pre diem and $\mathfrak{E 1 5}$ for horses and medicme chests, if mounted. An English naval surgeon got $\mathfrak{E} 8$ 1s. for one hundred and seventy-five days' serviees in 1653 and \pm 1614 s. for fifty-one days serviees in 1654.

The alluninistration of military medicine during the seventeenth century was a continuation of the methods established at the siege of Metz (15.52). Find medieal officers (modici puri) were scaree. The armies of custavus Adolphus had apparently no regular regimental or company" surgeons, but he prohibitel pillage, lovoting looted goods to "the next hospital," and the (nemy"s womdel were collected and sent to aity hospitals. In the French and English amies regimental hosplitals and company infirmaries were the vogue. Richelicu established the first stationary (base) hospital under a chirurgien-major at Pignerol, 70 miles from the front, in 1630 . In 1666 , the enginerer Vauban clesignated plaees for hospitals in all the captured towns fortified by him. A retreat for superannuated soldiers was established at Horeford by sir Thomas Coningsty in 1614, and the Imolides (Paris) was finally opened in 1676. Permanent general hospitals for soldiers were opened at Chelsea (England), in 1682, at Kilmainham (Jrcland) in 1693, and the sailor's hospital at Greenwich in 1695 . The melical personnel of the period was of a higher order, including sueh men as llarvey, Wiseman, Gehema, Purmann and Minderer. In the armies of the Elector of Brandenburg, each regiment had a staff physician and a find barber, and in $16 x+$, the Saxon army acrouired a chicef surgeon on the staft of the gencral, with field barber and field apothecary, all with the ramk of ensign. At the siege of Rochelle (1627), Pichelieu assigned a personnel of civilian assistants (usually Jesuits and cooks) to the ficld hospitals, and provided for a crule ambulance personnel in an ordinanee of 1638 . In 1667 , Lours XIV held a conference with the surgeons Turbière, Bienaise and Gayant on increasing the medieal personnel, with the result that at the battle of Seneffe (167t), 230 army surgeons were available, with nursing personnel and abundant material for the care of the wounded. ${ }^{2}$

1 see A. Köhler: Arch. f. klin. Chir., Berl., 1914, cv, 780-783.

${ }^{2}$ C. L. Heizmann: Ann. Med. History, N. Y., 1917-18, i, 287-294. 
The long, tight-waisted justaucorps coats, the first distinetive uniform of the army surgeon, appear in this era, and are figured in Purmann and Heister.

The old-time strife and rivalry which, as we have seen, had always existed between the physicians, surgeons, and barbers, continued with unabated fervor in the seventeenth century. After the incorporation of the English barbers and surgeons in one company in 1540, the former continued to be a thorn in the side of the latter, and the surgeons did not succeed in getting rid of them until 1745. Meanwhile, this united Company of Barber Surgeons were permitted to have public dissections in their own hall, but nowhere else, and the cause of their education was further advanced by the Arris (1643) and Gale (1698) foundations for public dissections and lectures. In France, the medical profession had consisted for centuries of an aristocracy of physicians, a petite bourgeoisie of clerical barber-surgeons, and a proletariate of laic barbers or outeast surgeons (barbitonsores), all hating and despising one another and adhering to rigid easte distinctions. When, after the foundation of the College de St. Côme, the surgeon was in a manner assimilated to the status of the physician, he began to put on airs like the latter, wearing the square cap and long robe, substituting the device of three boxes of ointment upon his guild-banner for the traditional three basins, arrogating to himself the right to examine the barbers, and insisting that his apprentices be "gr:mmarian-clerks." By the seventeenth century, the physician had become a sterile perdant and coxeomb, red-heeled, long-robed, big-wigged, square-bonneted, pompous and disdainful in manner, making a vain parade of his Latin, and, instead of studying and caring for his patients, tried to overawe them by long tirades of technical drivel, which only conecaled his ignorance of what he supposed to be their diseases. Among themselves, the physicians were narrowly jealous of their rights and privileges, regarding their fraternity as a closed corporation, yet eternally wrangling about fantastic theories of disease and current modes of treatment. The lay barber, although an outcast and an outlaw, was, in some respects, the most worthy of all three, since he was driven to study nature at first hand. He showed little submission or respect toward his rivals, and ont of his clan had come Franco and Paré. Thus, while the barbers were crowding the surgeons who, in servile imitation of the physicians, harl formed a syndicate against then, the physicians themselves maintained a supereilious, Malvolio-like attitude towatr both. Physicians, as Forgue says, ${ }^{1}$ would sonetimes join with the batrbers in an aristocrat-socialist combine against the surgeons, although sometimes favoring the surgeons' vows of precedence over

${ }^{1}$ E. Forgue: Montpellier méd., 1911, xxxii, 601; xxxiii, s. 
the barbers, while bathere and surgeons would again solidify as a unit andinst the doretors. The result of all this intrigne and limmoil wats that the hathers finally eatne into their own though the royal

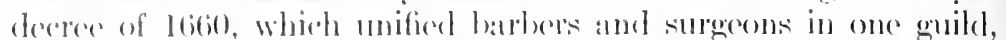
but of herwiso reducol them to the lamblolest status and dew down upon them the eostupled wath of the physicians. The arious isolation and sterile inceflecioncy of the Fronch internists of the serenternth antury ane strikingly revealed in the letters of Guy Patin (1601-72), Dom of the P'aris Faculty, who regarded the

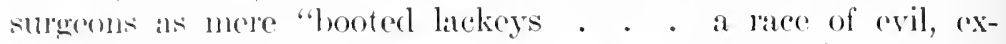
tratrant coxeombs who wear mustaches and flomish razors." In 16si, howrver, an event oceurred which Michelet has deened "more inportant than the work of Pare." Louis XIV suffered, it secms, from a fistula in ano, which, after remaining ololurate to the exhibition of all mamer of ointments and cmbrocations, was sucessfully healed by operation at the hands of the royal surgeon, Filix. The latter received for his trouble a farm, 300,000 livres, three times more than the honorarium of the royal physician, and Was cunoblod, becoming the Seigneur de Stains. Félix was succecded by Mareschal, and to Mareschal is due the elevation of the French sirgeon's social condition in the eighteenth century. Louis XIV influeneed French medicine in three curious ways: His attack of typhoid fever (1657) gave an immense vogue to the use of antimony; his anal fistula (1686) brought about the rehabilitation of French surcery; and the fact that his mistress was attended by Clement, the royal acconcheur, in 1663, did much to further the cause of male midwifery. ${ }^{1}$

The best sidelight on the pedantic formalism and complacent ineptitude of the French internist of the period is afforded in the pensive mockery of Molière (1622-73). The great dramatist had no use whatever for the medical profession, whose ridienlous side early excited his derision and against whom he seems to have cherished a lasting grudge, partly because of their inability to do any thing for his own malarly (consumption), and partly beeause he believed that they had killed his only son and one of his bosom friends with their eternal antimony. No less than five of his printed comedies abound in pungent raillery and light-barbed sareasm, directed with unerring skill against the tribe of doetors.

The tendeney is exhibited in his very earliest farees, such as Le Doeteur Amoureux, Les Trois Doeteurs Rivaux, La Jalousie de Barbouille, Le Hédecin Volant. In Le Védecin Volont, S'ganarelle, the valet, eleverly mimics the pedantries of the Paris Faculty. In L'Amour Médecin we have an inimitable

${ }^{-1}$ His ordinary physicians were d'Aquin, a ereature of Mme. de Montespan, and Fagon, who displaced the latter at the instance of Mme. de Maintenon. See P. Eloy: Fagon, Archiâtre du Grand Roi, Paris diss., 1918, No. 72. 
burlesque of professional consultations and discussions among five physician of clifferent types, one of the points brought out being the relitiver nirrits of the old-fashioned byiseopal mule and the new-fangled horse as a motans of transportation. In the second act a st rolling drug-ventor chants the virtuess of the popular opiate, omiétan. In Le Médecin Malgré Lui, Siganarello is again impresiod, by dint of drubbing, into playing the part of doetor, and, having a glib tongue, acquits himself exeeeding wedl. In Monsieur de Poreraugnar, two phycicians, who have been bribed to pronounce the latter insane, hold at solemm eonsultation de lunatico inquirendo over the pursy provineial, and their long scholastie tirarles seem exaetly in the spirit of the times. But the height of medieal satire in Molière is achieved in his last great work, Le Maldude Imaginaire, of which the central figure, Argan, the hypochondriae, forever drugging his imaginary ailments, is of the type portrayed by Butler in The Mcelieine Taker. The first act discloses Argan grumbling over his apotherary's aerounts, the principal sourees of medical revenue in those days. In order to have a physician at beck and eall about his household, he is desirous of marrying his daughter, Angélique, to Thomas Diafoirus, a dense young morlieal erarduate who is a gool mateh, as matches go, but by no means the young laty's choice. To out wit this design, Toinette, the maid, disguises as a doetor, and through a elever stratagem succeeds in making Argan relent his purpose, as well as in restoring him to health and sanity. In the meantime, however, he is fairly bullied off the stage by M. Purgon, an irate member of the Faculty, who terrorizes him with the prospect of bradypepsia, dyspepsia, apepsiat, lintery, dysentery, dropsy, and general decline. The doetors defeated, the intrigue is resolverl by persuading Argan to beeome a physician himself. Then follows what is perhaps the choicest bit of merlieal satire ever penned, the intermezzoballet, a joyous burlesque of those ceremonies of medical graduation whieh John Locke described in his French diary. The French routine of medieal examination and graduation in this period was portentous in length and pomp, and our description is taken from the admirable aecount by Mauriee Raynaud. ${ }^{2}$ The unfortunate eandidate, drilled almost to extinetion in the scholastic régime of the "naturals," anatomy and physiology, the "non-naturak," hygiene and dieteties, and the "contra-naturals," pathology and therapenties, without any bedside teaching whatever, was put through his paces every two years by a long string of examinations and argumentation of theses which lasted a week. The latter disputations usually began at 5 or $6 \mathrm{~A}$. $\mathrm{N}$.. lasting until unid-day, and woe to the luekless candiclate who ennld not cope with the fire of absuril questions which were rained upon him. If he came throngh all this successfully and his name was one of those drawn by lot from the fateful urn, he beeame a licentiate for graduation. Hereupon the licentiates and bachelors proceeded in solemn array to request the presence of all prominent and influential personages at the graduation ceremonies, the special feature of which was the Dean, the paranymph of the old Greek marriage ritual, who inducted the newly fledged licentiate into a sort of mystic union with the Faculty. At 5 in the morning of the momentous day, a preparatory session was held to determine questions of precedence, which were again decided by the urn. At 10, the hall was opened to visitors, the lists were proclaimed, and the successful candidates fell upon their knees to receive the apostolic benedietion. The chancellor then proposed a question of religious or literary character to the candiclate, which the latter immediately took up. This completed, the assembly procected in a borly to the cathedral to thank the Holy Virgin for her good offices. Then followed, after an interval of six weeks or longer, the doetorate, the object of which was to induet the eandiclate into the sinetuiry of the Faculty, as the licentiate had introduced him to the publie. After at close inquiry into his moral character the candiclate was first ulmitterl to the Vesperie, which consisted in a solemn, intimate presidential discourse on the

${ }^{1}$ M. Raynaud: La médecine au temps de Molière, Paris, 1862. Even in the fifteenth century, it was customary for the regents of the Paris Ficulty to have the recreation of a midwinter virit to the pulblie baths, followed by a supper, all at the expense of the bachelors. (E. Wickerseimer: Gazette des eaux, Paris, 1914, lvii, 751.) 
dignify and importance of the medieal profession, followed by the discussion of :mother thesis, with sperehes. Acullemire full-dress visits to the regents of the Faterty oremped the next few days. (On the final day the camdidate was sworn to the three articles of melieal faith, viz., to obey all haws and observe

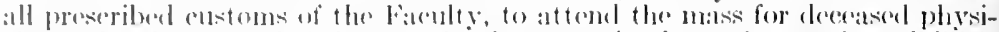

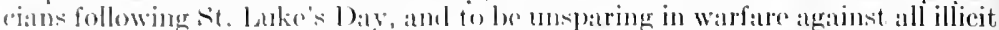
fratetitiners. The eandidate having taken oath to this in the single word,

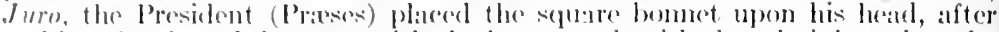
making the sign of the eross with the latter, and, with the administ ration of a slight talp or acoldele, the doetor in embryo wat born into the work. He immediately antered into his rights and privileges by proposing a thesis to be disensecel by ane of the physicians present, after which he delivered a florid, perfunctorv discourse of thianks and pratise. On the st. Martin's day following, ho presterl at the acte pastillate, il general dischission of at thesis of his own cheosing, and on the fellowing day his natme was inceribed on the registers as a junior for the next ten years.' "This lengthy eeremony, which was set off "Serywher by innumerable dinners, supper's, and bancuets of old-time timensiens, forms the substance of Moliere's immortal ballet. At the start, the Pripses burlesques, in moek Latin, the solemn discourso of the Vesperie. The first doct or then propounds the nice question: Why does opium produce sleep? To which the candidate replies

Quia cest in eo

Virtus dormitiva,

an be greeted by the obligato ehorus:

Bene, bene, bene, bene respondere,

Dignus, dignus est intrare

In nost ro docto corpore.

The eandidate is then plied with questions as to his probable line of treatment in a string of diseases, for each of which he advanees the incontestable merits of the elyster, the lancet, and the purge-

\section{Clysterium donare, \\ Postea seignare \\ Ensuita purgare,}

followel by the constantly reiterated "Bene, bene." The famous Juro is then alministered, and after the Præses has conferred the bonnet, the eandidate delivers a flowery diseourse, full of servile praises of his benefactors. The ballet dosc: with festal danes and cheers, the physicians, surgeons, and apothecaries filing out solemnly at the end.

The good-humored character of Molière's satire, and the apparent indifference with which it was received by the medical profesion of his time and country, indicate that there was plenty of human nature in the French physician of the seventeenth century, in spite of his innocuous pedantry and sterile fanaticism. Across the Pyrenees we find the same conditions, if we may trust the spanish romances of the picaresco type, and the medical scenes in Le Sage's Gil Blas, which, although published in 1715, is pure seventecnth century in its characters and local color. The droll consultation in the third chapter of its fourth book, in which Doctors Andros and Oquetos agree that the trouble in Don Vincent's

1 These data have been taken from Naurice Raynaul's delightful study, La medecine au lemps de Molière. Paris, 1862. Frank Baker, on The Faeulty of Paris in the Sesenteenth Century, Now York Med. Jour., 1913, xeviii, pp. 115-121, gives an attractive presentation of the subjeet in English. 
case is "a mutiny of the humors," is fairly typical, the patient losing his life through the consequences of their dispute whether the Hippocratic expression rimrarmis meant a fermentation or a concoction of these humors. Then there is the slap at the "fellows in this town calling themselves physicians, who drag their degraded persons at the Currus Triumphalis Antimonii, or . . . Cart's Tail of Antimony, apostates from the faith of Paracelsus, idolaters of filthy kermes"; and the side-light on the use of the seton afforded in the case of Dame Jacinta: "Though a little stricken in

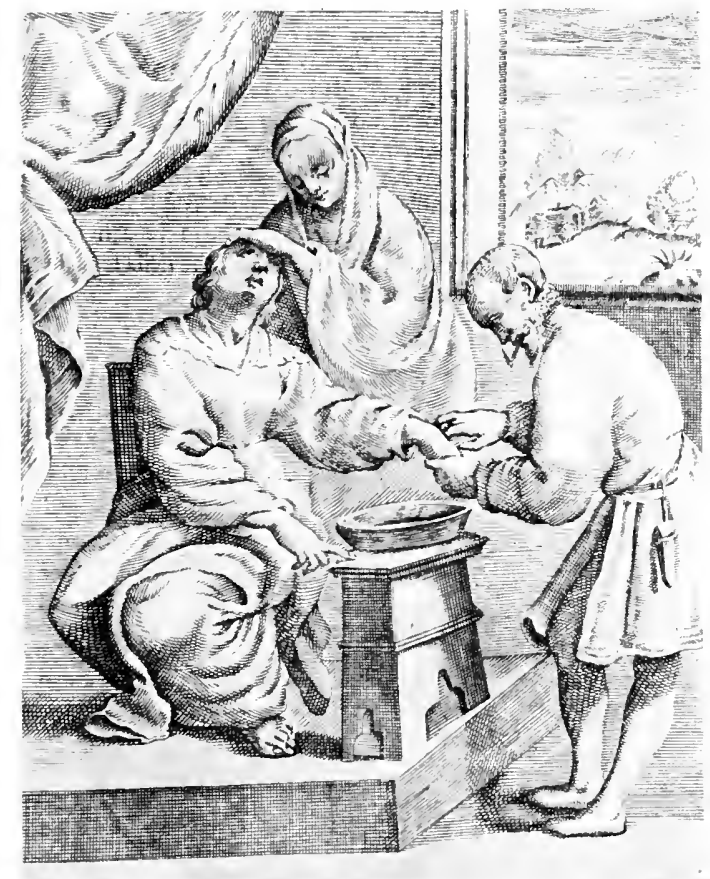

Blood-letting in the seventeenth century. (From Malfi's Il Barbiere, 1626.)

years," she cherished her bloom by depletions and "doses of all powerful jelly . . ." but "what perhaps contributed most to the freshness of this everlasting flower was an issue in each leg, of which I shoukd never have known but for that blab Inesilla." But the medical interest of Gil Bliss centers in the figure of Dr. Silngrado, "the tall, withered, wan executioner of the sisters three," whose name has, in fact, become a symbol for the kind of intensive blood-letting which was rife in the seventeenth century. Silngrado's procedure of reducing the old canon to death's door in less 
than two days by drawing off is good porringers of blood, with abundant dremelhes of warm water, may be paralleled by the actual experiences rited hy Guy Patin, who bled his wife 12 times for a fluxion in the chest, his son 20 times for a continued fever, himself 7 tines for a cold in the head, while his friends, M. Mantel and M. Comsinot, bed 36 and bit tincs in a fever and a roumatism respectively. It is now known that the rationale of this extraordinary therapy (in able-bodied people) lay in the copious drafts of water which were given with it, acting as a kind of blood-washing in the evacuation of peceant humors. In Italy, where the funetions of the physician and surgeon had never been entirely separated, intensive blood-letting had continued in vogue since the days of Botallo. The technic of the practice had become highly specialized, as we see in the handsome copper-plates of such books as Malfi's Il Barbiere (1626). Costly bleeding-glasses of Venetian type were handed down in familics as heirlooms. In Germany, perhaps for some temperamental reason, the degree of blood-letting seems to have been less intense, ${ }^{1}$ although the practice was otherwise frequent enough, being a common detail in the numerous pictures of bathing scenes. At these bathing resorts it was required to spend one hundred and twenty-four hours in the water as a cure, with frequent cupping and venesection, set off by the consumption of enormous quantities of food. Immorality was frequent, and the bath-keeper, plying his trade as a minor surgeon, is an index of the low status of the art in the Germanic countries, where Fabry of Hilden was almost the only educated surgeon. The Cicrman barbers were permitted to let hlood, set broken bones, treat wounds and syphilis, but were not allowed to purge. Some of them went on voyages to the East Indies, or on whaling expeditions to Greenland, to learn what they could. During the Thirty Years' War and after, many doctors and drug-sellers in the Germanic countries were vagrants. ${ }^{2}$ Toward the end of the century we find another queer substitute for the surgeon proper, namely, the headsman or executioner. That the ceremonies of medical graduation in seventeenth century Cermany were as long and as expensive as those ridiculed by Molière is evidenced by an edict of the Elector of Bradenburg (1683), in which, to save the students' purses, banqueting was cut down to a single supper, limited to ten courses. "Ladies" and confectionery were exchuded. In the ease of needy students, the sumptuary features could be limited to the simple announcement of the candidate's graduation in the auditorium (at half price), the distribution of gloves and the convivium

1 On this point, see France méd., Paris, 1912, lis, 365.

2 Sce C. Stichler: Arch. f. Gesch. d. Med., Leipz., 190s-9, ii, 2\$5-300. 
being omitted, unless the student saw fit to invite a few profescors to a modest repast, at discretion (Baas). Although medical students have always borne a hard reputation for pranlis and horseplay, the social custons of the Cierman students, their hazing and "pennalism," were coarse and barbaric beyond belief. As in France, the junior student was a mere bee jaune, that is, a novice or aspirant, and treated as such. The lower strata of the profession were made up of all sorts of strolling quacks-toothdrawers, uroscopists, magicians, rope-daneers, chiropodists, crystalgazers - who were also common in the Low Countries, and a favorite theme of the Dutch and Flemish artists. Of the many pictures of vagabond dentists, the best are the spirited canvases of the Flemish artist Theodore Rombouts in the Prado at Madrid, and, among the Dutchmen, those of Gerard Honthorst (Dresden Gallery), Gerard Dou (Louvre, Dresden, and Schwerin Galleries), Adriaen Brouwer (Cassel Museum and Lichtenstein Gallery, Vienna), and the younger Teniers (Cassel and Dresten). All these tootli-drawers have costumes evidently designed to make the bravest showing consistent with their means, some of them highly fantastic, with fur-trimmed robes and Oriental turbans. The current methods of venesection are well represented by the younger Teniers (Musée du Draguignan), Frans van Mieris (Vienna), in the fainting woman by Eylon van der Neer, and in the Death of Seneca by Rubens, both in the Old Pinakothek at Munich. The pedicurists, or corn-cutters, were a favorite subject of such men as David Teniers, Jr. (Cassel, Budapest, Madrid), and Adriaen Brouwer (Pinakothek, Prado, Schönborn Gallery, Vienna). Venesection in the forehead and the fastening of a seton in the arm or the back are favorite subjects of Adriaen Bronwer. The strangest of the Low Country itinerants were the quacks who pretended to cut stones from the head for the relief of insanity, idliocy, or other mental disorders. In the sixteenth and seventeenth centuries it was a common byword to deseribe a person mentally mbalanced as having "a stone in his head." The therapentic imposture consisted in making a superficial incision in the scalp, and palming a stone or stones, which were cast into a convenient basket at stated intervals during the patient's struggles. The trick seems to have been a very old one, and some of its representations in art, such as those of van Bosch in Amsterdam, Jan Sanders in the Prado, or the etching of Pieter Breughel, Sr., in the Amsterdam ('abinet, go back to the fifteenth and sixteenth centuries. The most connie specimens of seventeenth century work in this field are the stonedrawers of Frans Hals, Jr., and Jan Steen in the Musie Boijnans at Rotterdam. The latter represents a quack incising the occipitil region of a screaming fool who is tied in a chair, while an old womsn 
holds the pail into which a giggling lad in the rear tosses the supposititions stomes, onc by one. A red chalk drawing of the younger Tenicrs shows a quack, with feathered turban and sword, operting the head of a stoical patient, who sits with folded arms and compressed lips. Physicians of a higher grade are to be seen in the many Dutch pictures of watep-asting. Uroseopy is a feature of nearly all the Dutch pietures of the doctor's visit and was sometimes employed even in the diagnosis of chastity. A solemm consideration of the appearance of the patient's urine seems to have

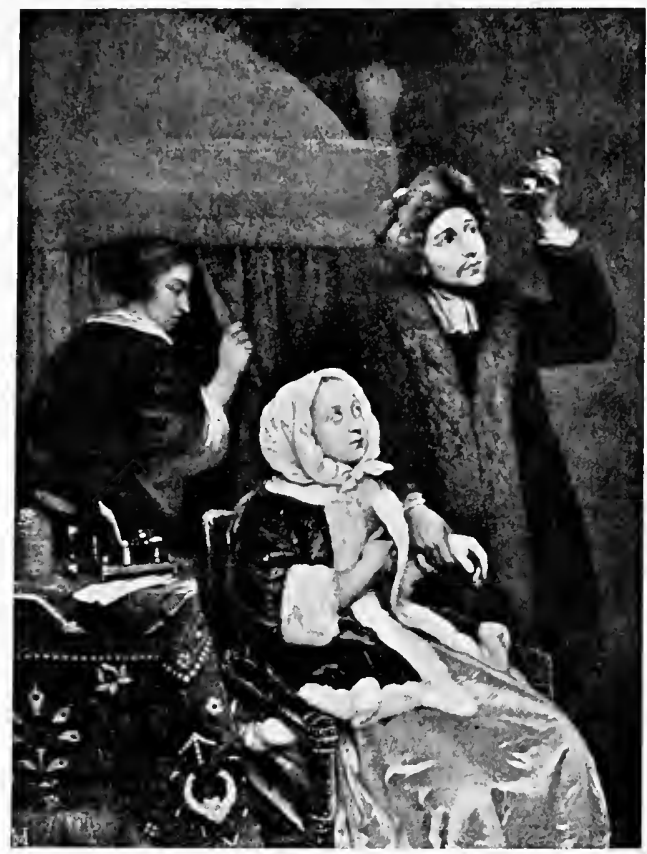

Mal (l'Amour, by Gerard Dou. (Buckingham Palace.) Hanfstaengl, Munich.

been the favorite procedure in cases of the so-called minne pyn or mal d'amour, that is, the chlorosis of love-sick young women. To this theme Jan Steen devoted no less than nine eanvases, Frans van Mieris, four, and Cabriel Metsu, two. In these pictures, the fur-trimmed jackets and rich gowns of the women indicate the wealthier class, the attending physicians being correspondingly. dressed in black velvet robes or doublet and hose, with flat bonnets or bell-erowned hats, aceording to their social or religious affiliations. The representation of the pallor and feverish discontent of 
the greensick, lovelorn maidens is very life-like, particularly in the fine canvas of Gabriel Metsu in the Preyer Collection at Vienna. The clou of this group of paintings is undoubtedly the Mal d'A mour of Gerard Dou (Buckingham Palace), a charming picture, representing a handsome young doctor, in fur-trimmed pelisse and fur cap, earnestly scanning a urine flask, while he feels the pulse of a pretty meisje, whose upturned face reveals the all-important fact that her interest in his personality is in excess of her confidence in his professional skill.'

The seventeenth century marks the rude beginnings of two new phases of national medicine-the Russian and the American.

In the fifteenth century Ivan III (1468-1505), the first Russian muler to bear the title of Czar, invited foreign physicians to settle in Moscow, with the not very alluring prospect of having their throats eut if they failed to cure. Under the reign of Ivan IV (1533-84), called the Terrible, many English physicians came to Moscow by invitation and some of these also acted as ambassadors or diplomatists. One of them founded an Apteka, or drug-store, in 1581. Under the Romanoff dynasty (1613-45), there was a great influx of adventurous foreigners which, through the encouragement of Peter the Great and Catherine, continued well into the eighteenth century. These undoubtedly did a great deal to stimulate an interest in medicine, although, like the Grecks in Rome, they were eyed with suspicion by the natives, who were always ready to sack their houses in popular uprisings. Upon their arrival, the foreign physicians took an oath of office, pledging themselves not to use poisonous drugs, and, after an audience with the Czar, were loaded with rich presents, money, provender, horses, and sometimes even acquired an estate of from 30 to 40 "souls." The first native Russian physician was Peter V. Postnikoff, who was sent to Italy to study medicine by Czar Peter and graduated at Padua in 1694. ${ }^{2}$ The Russian therapeutic superstitions of the time were identical with those we have found in other countries. There was the same elaborated polypharmacy, including extracts made from insects and parts of animals, and not even the critique of Ambroise Pare had dispelled the belief in the efficacy of the unicorn's horn, for three specimens of which 100,000 roubles $(\$ 30,000)$ were offered in 165.5. Drugs were, however, imported from Germany and Holland, botanic gardens were started, and, in 1671 . a brief account of native Russian simples was drawn up, "a sort of miniature Siberian pharmacopoia," based upon information

1 For a fuller account of all these pietures, with reproductions, sec Eugen Holländer, "Die Modizin in der klassisehen Malerej," Stuttgart, 1903.

${ }^{2}$ L. Stieda: Janus, Anst., 1903, viii, 178-189. 
gathered from the pasants by the siberian royerods, or military governors. Ender the Romanofts a Ministry of Modical Mffairs was foumbot, also a central store (Apteka) for the distribution of drugs to the followers of the Moseow conte A later Aptekit, of larger soope, which dispensed dings to soldiers and civilians and looked after the prevention of infectious diseases, was the nucleus of the abovementioned Aptekarski Prikaz (Ministry of Medical Attars), the starting-point of the patriarehal public health service of linsiar."

Among the foreign physicians wlo visited Russia was John Tratescant, a Fleming, who jommeyed to Archangel with Sir Dudley Digges in 1618, and made a unique collection of natural history specimens, coins, medals, and other objects of virtu, which became in time the present Ashmolean Museum at Oxford.

The new-world settlements of Jamestown, Virginia, in 1607, Plymouth Colony in 1620, and the New Netherlands in 1623, naturally drew to them a number of European physicians who, as in Russia, were active agents in advancing the interests of legitimate medicine in the colonies. Prominent among these were Dr. Lawrence Bohun, who became Physician Ceneral of Virginia in 1611, Dr. John Pot, the first physician to reside permanently in Virginia, and elected temporary governor of the state in 1628, Herman Van den Boogaerdt, the first phrsician of New Amsterdam, Dr. Johannes Ia Montagne, a Huguenot, who was councillor of Wilhelm Kieft, Direetor General of the New Netherlands, Dr. Samuel Fuller, who came over in the Mayflower and practised in New England until his death in 1633, and Dr. John Winthrop, $\mathrm{J}_{\mathrm{r}}$., who was the first governor of Connecticut (Handerson). One of these emigrint physicians, Thomas Thacher, was, as we have seen, the author of the first and only medical publication printed in the North American colonies in the seventeenth century (1677). Meanwhile, higher edueation had a definite start with the foundation and endowment of Harvard College in 1636-38, and of the College of William and Mary (Williamsburg, Virginia) in 1693; the native-born students and practitioners soon acquired the habit of going to Leyden, Oxford, or Paris to complete their medical courses. The practice of physic was often combined with the preaching of the gospel. Giles Firmin, who, prior to 1647 , delivered the first course in anatomy in New England, was one of these clerical physicians, and his probable scheme of treatment and instruction has been outlined in the witty imaginative sketch of Oliver Wendell Holmes. ${ }^{2}$ His anatomy he got from Vesalius,

1 For further details, see the article on Russian medicine in Lancet, Lond., 1897 , ii, $354-361$.

2 O. W. Holmes: Medical Essays, Boston, 1883, 27S-283. 
Paré, Fallopius, and Spigelius; his internal medicine was a mixture of the Greeks, Fernchus, van Helmont, and Sir Kenchn Dighy; his pathology was mythology.

"His pharmacopecia consisted mainly of simples, such as the venerable" 'Herball' of Gerard deseribes and figures in abounding affluence. St. Johun's wort and Clown's All-heal, with Spurge and Fennel, Saffron and Parsley, Eleler and Snake-root, with opium in some form, and roasted rbubarb and the four Great Cold Seeds, and the two Resins, of which it used to be said that whatever the Tacamahaca has not eured, the Caranna will, with the more familiar Scammony and Jalap and Black Hellebore, marle up a good part of his probable list of remedies. He would have ordered Iron now and then, and possibly an occasional dose of Antimony. He would perhaps have had a rheumatic patient wrapped in the skin of a wolf or wild cat, and in case of a malignant fever with 'purples' or petechix or of an obstinate king's evil, he might have prescribed a certain black powrler, which had been made by calcining toads in an earthen pot. . . . Barbeyrac and his scholar Sydenham had not yet cleansed the Pharmacopoia of its perilous stuff, but there is no doubt that the more sensible physicians of that day knew well enough that a good honest herb-tea which amused the patient and his nurses was all that was required to carry him through all common disorders."

Two features of American medicine in the colonial period are especially worthy of note. First, the half-fledged youth, who studied with some physician under indentures of apprenticeship received actual bedside instruction from the start, and, although scrving as sweep and stable-boy to his master, was still learning how to bleed and cup, to prepare drugs and apply them. Second, under primitive, frontier conditions, the medieval antagonism between the physician and surgeon soon disappeared, for the necessary and sufficient reason that, white midwifery was in the hands of women, the open-country or backwoods doctor was liable to be called upon in any emergency, and, thrown upon his own resources, soon learned to enlarge such native skill as he had in bone-setting, treatment of arrow and gunshot wounds, reducing hernias and the like. Before 1769, according to Toner, the term "Doctor" was not even employed in the colonies. As Handerson says, "Many of these apprentices doubtless proved as successful physicians (and success is the usual test of merit) as some of their more fortunate colleagues who boasted an M.D. of Leyden, Aberdeen, or Cambridge and slew their patients secundum artem." We may agree with the same authority that, from this period on, American medicine acquired that eminently practical tendency which has been its chief merit and of which we have no reason whatever to feel ashamed. That the profession soon developed a certain esprit de corps is evident in that we find no records of strolling lithotomists, cataract-conchers, or other quacks among them, that the names of no New England physicians are connected with the scan-

${ }^{1}$ Baas: History of Medicine, New York, 1889, 582. 
dal of Sildem IVitcheraft (1692), and that we find records of the latter griving service to the sick poor for a remittance of taxes. such modical legislation as the colonies hanl in this period was, as in the colle Hammurabi, mainly concerned with the monentous question of foes.

As early ats 1630 , the Assembly of Virginia passed an act provieling that thome who hat served apprenticeships as surgeons and apothecaries should reopive five shillings a visit and university graduates ten. Doetors' bills were usually paid, however, with sueh articles of barter as corn (in New England), tobiceo (at the south), or wampum (among the Indjans), and they soon be(ame so exorbitant that, in 1t33s and 1t339, the Assemblies of Maryland and Virginia passed laws to moderate them. In 16.19, the Massachusetts colony passes a law restrieting the pratice of medicine, surgery, and midwifery to such persolss as might be judged competent by "some of the wisest and gravest," or most skilful in the same art, with the additional consent of the patient. A similar law was passed in New York in 1665, and in 1699 an act to prevent the spread of infeetious discanes became a law in Massachuset ts.

The first hospital in the New World was oreeted by Cortez in the eity of Mexieo in 1524. In [639, a Hotel Dien was established in Canada by the Duehoses d'Aguiton, and ultimately located in Quehee. The Montreal IIoted Dim wals established in 164t, and the Ceneral Ylospital of Quebee in 1693. The first hospital in what in now the United states was established on Manhattan Island in 1 titi3.

In the seventeenth century, as one of its poets sings, "Devouring Famine, Plagne and War," those primal causes of human miscry, were everywhere rampant. The mortality from wars and epidemic diseases was as great as in the Middle Ages.

The bubonic plague, while it did not sweep all Europe as formerly, struck with terrifie foree in some places. The Great Ilague of London (166.5) earried away 69,000; the Vienna visitation of $1679,70,000$; that of Prague (1681), 83,000; while the Italian epidemic of 1630 numbered 80,000 victims in Milan and over 500,000 in the Venetian Republic. In the opinion of Hateser, these losses, together with the Candian war, contributed materially to the downfall of Veniee. whose great fleets onee held "the gorgeous East in fee." The earliest visitations were those in Russia (1601-03), in which Moseow lost 127,000 souts from pest and famine. Through the ecntury, England (1603-65), Franee (160s-t8s). The Netherlands (1625-80), Italy (1630-91), Denmark (1654), (iermany (1656-\$2), Sweden (1657), Switzerland (1667-68), and Spain (1677-s1) were all severely ravaged. As in the sixteenth eentury, the loeal epidemies were commemorated in coins and medak, some of which were used as amulets, while others, highly ornate, betokened the freeing of a city from the pest. (Of these we may mention the Thuringian silver pennies of 1600 , 1602, and 1611; the pest-dollars (of Wittenberg type) of 1619, the coins and medals struek off in memory of the epidemies incident to the 'Thirty Years' IVar at Lrbino (1631), Veniee (1631), Breslau (1631), Ingolstadt (1634), Frankfort on the Main (1635), Munich (1ti37), and the relies of the later visitations at Vienna (1679), Leipzig (1680), Wüurzburg (1681), Erfurt (1683), and Magdeburg (1683). All these have been described in detail by Pfeiffer and Ruland (Pestilentia in nummis, 1852). Famine, always in the train of war and plague, was commemorated in the Annona medals, in praise of the Papal regulation of the price of eorn, which were struek off in honor of Popes Clement X (1671-73) and Alexander VII] (1690); and in the medals relating to inundation in Hamburg (1655), to the plague of grasshoppers in Silesia and Thuringia (1693), hard times in the German Empire (1694), and humger and cold in Holland (169S). The intense popular animosity against the corn pedlars and factors, whose 
thrifty extortions were not unnaturally confused with the unthrift of had harvesting as a cause of human misery, is strikingly shown in the curious Kornjudenmedaillen. ${ }^{1}$ Silesian medals of this type were struck off in 1694-95 and again copied in the eighteenth century. Besides grasshoppers and pollars, comets were still regarded with superstitious awe as "Cod's postillions" (Gottespostillione), harbingers of war, pestilence and famine, although shakespeare had said

"When beggars die there are no comets seen,"

and the astronomer von Littrow has latterly shown that there is no probable connection between the hundreds of comets known and the slightest possible variation in the atmosphere. There were comet medals for the years 161s, 1677,1680 , and 1686 , but the appearance of Halley's comet in 1682 was distinguished by the great English astronomer's calculation that it would reappear in 1758 . With the verification of this predietion, it was pereeived that comets are, after all, like any other periodie phenomenon in nature, and the comet theory of rlisease disappears from medical history after 1758.2

State and eity ordinances against the plague were many, and, while providing for speeial hospitals, attendance, and sanitary inspeetion, were sometimes extremely narrow and severe. On August 25, 1683, Colbert, minister to Louis XIV, issued sanitary regulations for the whole of France, giving absolute power to the Boarl of Health and quarantine station at Marseilles. Not only were plagne-stricken houses burned to the ground, aftel the wise old Mosaic method, but persons suspected of spreading the plague by smearing its virus about were put to torture and death. A striking instance is afforded in an episode of the great plague of Milan in 1630, as deseribed by the novelist, Alessandro Manzoni, ${ }^{3}$ and latterly in the valuable paper of Dr. Robert Fletcher. ${ }^{4}$ On the morning of June 1, 1630, Guglichmo Piazza, a commissioner of health of Milan, was seen going down the street, writing from an ink-horn at his belt, and wiping his probably ink-stainel fingers against the walls of houses. Being accused by the ignorant women of the neighborhood of smearing the houses with deadly ointments, he was, upon motion of the council, haled to torture. The latter barbarity, a survival of the ordeal of feudal times, had an elaborate ceremonial, preseribed by legal corle, in which the accused was stripped, shaved to the scalp, and purged before going through his misery; and, if he survived the atrocities inflicted upon his borly three times, God was supposed to have intervened in a miracle. The unhappy Piazza stood for two applications of this hideous rite, but yielding to the "third degree" stiggestions of his tormentors, finally stated that he had obtained a poisonous ointment from a barber named Mora. The latter, upon being apprehended, yielded to the first application of torture, and though both unfortunates recanted more than once, the clamors of the superstitious populace against them were such that, upon sentence, they were torn with red-hot pineers, had their right hands cut off, their bones broken, were stretched on the wheel, and, after six hours, burned. Their ashes wore then thrown into the river, their possessions sold, the house of the crime razed to the ground, and its site converted into a sort of Aceldama by the ereetion of a "column of infamy" (colonna d'infamia). This was less than three centuries ago.

The physieians delegated to treat the plague wore a strange prophylactic garb, consisting of a long red or black gown of smooth material, of ten Noroceo or Cordovan leather, with leather gauntlets, leather masks having glass-

${ }^{1}$ The obverse of these famine medals eommonly displayed a sorry looking pedlar, weighted down by a sack of corn which a devil is engaged in puncturing. The other side bore a bushel measure, on the inner surface of which was inscribed (in German) the verse of P'roverbs $(\mathrm{x} 1,26)$ : "He that withloldeth corn, the people shall eurse him," the outer surface reading: "But blessing shall be upon the bead of him that selleth it."

${ }^{2}$ Pfeiffer and Ruland: Pestilentia in nummis, Tübingen, 18\$2, p. 19.

3 Manzoni: Storia della colonna infame, 1840.

${ }^{4}$ R. Fletcher: Johns Hopkins Hosp. Bull., Balt., 1895, ix, 175-180. 
eovered opunings for the ryo ame a long lwak or snout, filled with antisepties or fumbants, for the mose. In his hand the pest-doetor eatricel al wand to feel tho pulse. In spito of this comio operax make-1up, he was a highly esterened

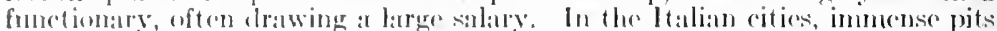
for burving the deat hat sometimes to be dug, the apperilori of summoners geing hofore, ringing a bedl notifying the pueple to hring out their elead, the momalli attruling to the mattre, and the commisseri reporting upon the cases and supervising the whole. Sometimes the rude common graves becane filled

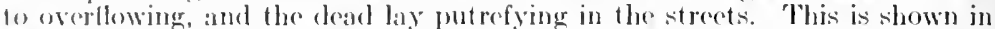
Miceo Nindata's picture of the Pest in Naples (16isti), in which the Piazza del Meroato is soch swarming with deat and dying berlies which tle monalti are struggling to remove, under dircetion of simdry physicians on looridanck, while, jn the hearems, (iod with a drawn sword appears, apparently yielding to the entreaties of the Virgin. In "lhe Plague of the Philistines" by Nicolas Poussin (1593-l66ii) (Lemve), rats are represonted in the batekground.1 Natlaniel Hodges, in his "Iodmologia" (London, 1672), describes how, during the Cireat Plague of 1665 , rodents and reptiles were seen to cone out of their holes to die in the opere, and Danicl Dofoe, in his fictitions "Journal of the Plagne Year" (1722), asserts that a purposoful war our rats and mice, as spreaders of pest, was made during the samo rpidemice (sticker'2).

Leprosy had so completely died out by the and of the sixteonth century that, in 1656 and 1602, bouis $\times 1 \mathrm{~V}$ was able to abolish the lazar-holses and devote their endownents to charity and general hospital eonstruction. Relies of the disease in art are preserved in Rubens' pajnting of Sit. Martin (Windsor (astle) and Mlurillo's st. Elizabeth in the Prado. Syphilis had also ceased to be epidemie, and was treated by mercurial fumigation and inunction at the hands of the barber-surgeons. It hroke out in Boston, Massachusetts, in 1646, sixtern years after the foundation of the city ${ }^{3}$ beyond the illustrated books, such as stephen blunkart, and the views of Sydenham, who regared it as a modified West-Afriean yaws, the seventecnth eentury literature of lues is not important. Next to the plague, the typhus and typhoid fevers, which were often vaguely described as "pest," had the highest mortality, especially in comneetion with the miseries engendered by the Thirty Years' 11 ar. Dysentery and scurvy also added their quota, and so great was the mortality oceasioned by all these that, according to the Exeirlium Germania (cited by Harser), "ono rould wander for ten miles without seeing a soul, scirce a cow, (m) an oecasional old man or ehild. or a pajr of old women. In every village, there are houses filled with dead bodjes and earrion; men, women, ehildren, srvants, horses, swinc, cows, and oxen lyjug pell-mell together, throttled by plague and hunger, devoured by wolves, dogs, crows, and ravens, for want of dreent burial." Adrl to this the sexulal atroeitjes of soldiery, as depieted in Cirmmelshausen. ${ }^{4}$ In the eities, typhus fever was earefully studied by such olscrvers as Stahl and Friedrich Hoffmann in Halle, or Schröekh in Augsburg. In England. Willis deseribed the typhojd epjdemie anong the Parliamentary tronps at the siege of Prading in the damp spring of 1643 . Typhoid pneumonia was prevalent in Italy $(1602-12,1633,1696)$, as deseribed by Codronehi and others. Hochstäter deseribed an Augsburg rpidemje of 1624 , and Switzorland was visited in 16.52, 165.5 (Lake Geneva), and 1694-95. Malarial fever was pandemie in the years $1657-69$ and $1677-95$ (Haeser). The English epidemies were described by Willis, Morton, and Sydenham, Morley and Lueas Schacht, the Italian by Cavallari (1602) and Borelli (1661), the Duteh by sivius (1677) and Fanojs (1669), the French by Chirac (1694). The severe Italian epidemie of 1690-95 was described by Ramazzini and Lancisi. Dysentery was epidemic throughout the countries ravaged by the 'Thirty Years' War, notably Germany, Holland, and France (1623-25), and it reinvided Germany

I G. Stjeker: Janus, Amst., 1S9S, iii, 13S.

2 Stieker: Die Pest, Giessen, 190s, i, 178

3 Packard: History of Medieine in the United States, Phila.. 1901, 39.

${ }^{4}$ H. J. C. von Grimmelshausen: Der abentäuerliche Simplicius Simplicissimus, 1668 . 
in 1666 and the North in 1676-79. The English epirlemies of 1668-72 were described by Morton and Srdenham. During the period 1583-1610, diphtheria was eonfined to spain. In the latter year it broke out in ltaly, where it was again epidemic in 1618-30) and 1650, while Spain was revisited in 1630, 1650 , and 1666 . Cases oceurred at Roxbury, Massichusetts, in 1 (i59 (Jaeobi). An cpidemic of anthrax (1617) is deseribed by Athanasius kireher in his Serutinium pestis (i, 9). There were many epiclemies of ergotism in the Sologne $(1630-94)$, in various parts of Germany (1645-93), and in switzerland $(1650,1674)$. Scurvy oceurred at the siege of Breda (1625), at Nurembers (1631), and at Augsburg (1632). Influenza was common through the century, both in the old world and the new. Crookshank believes that the lethargic encephalitis at Copenhag(u) (1657), described by Bartholin, the English febrile epidemic of 1661 deseribed by Willis as affeeting "brains and nervous stocks," the "comatose fever" of Sydenham (1673-5), and a ease of encephalitis lethargica deseribed by Albreeht of Hideshem (1695), were all manifestations of influenza. It was first reporterl in Ameriea in 1647.1 Yellow fever appeared at New York in 1668, in Boston (1691-93) and Charleston, South Carolina, in 1699 , but did not reach the old work until the following century. Of the exanthemata, small-pox was pandemic in Europe in 1614, epidemic in England during 1666-75, while in New England scattered outbreaks oecurred all through the century, the disease reaching Pennsylvania in 1661, and Charleston, S. C., in 1699. The most important acrounts were those of Sydenham. The first accounts of unmistakable scarlatina were those of Miehael Doering (1625-8) and Daniel Sennert (1628), but the disorder beeame generally known through the deseriptions of Sydenham (1676) and Morton $\left(1692^{2}\right)$. Sydenbam first clearly differentiated it from the "morbilli," in which the others had elassed it. Measles, rubella, and "the purples" (miliary fever) were usually grouped together and not sharply defincd. Puerperal septicemia was first defined and differentiated by Willis in 1660. ${ }^{3}$ Infantil (2 enjunetivitis was first reported in America in $165 \mathrm{~S}(\mathrm{Jacobi})$. Infantile mortality in this period was high. In Restoration England, sometimes half the births were wiped out by disease and two-fifths of the total deaths were of those under two vears. In the hot summers of $1669-71,2000$ babies died of diarrhea in eight or ten weeks. The dense London population had swarmed to the raterside and the alleys of Wapping, Lambeth, Whitechapel, and spitalfiekd, living in filthy, overerowded tenements. ${ }^{5}$ The unfortumate newborn child was salterl, after the old Galenje teaching, eneased in tight swaddling elothes, and allowed no exereise beyond a few minutes dandling in the open air. Later, it learned to walk by means of a walking-chair or leadling-st rings. Eezema and diseharges from unwashed ears were looked upon as part of the scheme of nature (Walter Harris, 1689), and artificial feeding, in lieu of wet-nursing, was not known. Pechey (1697) recommended weaning at the appearanee of the milk teeth and on the inerease of the spring or autumn moon, and to overcome the child's dislike for new foorls, the mother's nipples were smeared with aloes or wormwood. ${ }^{6}$ In France, through the humanitarian efforts of St. Vincent de Paul (died 1660), small asylums for helpless infants were started learling to the establishment of the Hôpital des enfans trouvés at Paris (1641) by Louis XIII. 414.

1 A. Jacobi: Jahrb. f. Kinderh., Stuttgart, 1913 (Baginky Festschrift),

${ }^{2}$ See Paul Richter's history of searlatina (Areh. f. Ceseh. l. Med., Leipz., $1907-8, i, 161-204)$, which eorreets the errors made by Haeser.

${ }^{3}$ De febribus, 1660, ch. xvi.

${ }^{4}$ Op. cit., 413.

${ }^{5}$ Traill and Mann: Social England, London, 1903, iv, 647. Cited by Forsyth.

${ }^{6}$ Forsyth: Proc. Roy. Soc. Med., Lond., 1910-11, iv, pt. 1, Sect. Dis. Child., 116-120. 
The seventeonth contury, as we have seen, was the age par excellence of medical delineations in oil paintings. Velasquez, the groatest portrait paintrer of all time. devoted some twelve canvases to the representation of aretinoid or hychocephalic dwarfs, four to court fooks, and three to idiots. Of these, the Prado contains ten, inchuling the hychrocephalic Don Siebastian de Morra, El Primo, the achombloplasic and rachitic specimens in Jas Meninas, the buffoons of "silly Billy" type, and those wonderful figurations of idiocy, El Niño de Vallecas and the strabismic El Bobo de coria. Riberia has a remarkable pieture of unilateral paralysis in a boy (Vomma (iallery), showing the characteristic deformity in arm and leg. A hand-bill carried by the lad, boaring the insoription Da mihi elimosinam propter amorem Dei, shows that the speech center is also affected. The lanne, the halt, the blind, and various phases of malingering (les gueux contrefaits) are well represented in the etchings and engravings of Jacques Callot (1592-1635). Pieter Bromghel the older represented the dincing mania, parades of eripples, blind men, and other crotespues in his etchings and paintings. A clisorder of the pituitary may be inferred in the obese, quasi-myxedematous girl of Juan Careño de Miranda in the Prado. Rubens depicted a microcephalic dwarf in his painting of C'ount Thomas Arundol and wife (Old Pinakothek, Munich). His "Death of Seneca" and his erayon studies of muscular anatomy have already been mentioned. Van Dyck depicted leprosy in "St. Martin dividing his cloak" (Windsor Castle). With the exception of his "Tobias healing his father" of eataract, Rembrandt adhered rigidly to the normal, even in his etehings, in which he depicted every physiologic action of the human body. ${ }^{1}$ We have mentioned the success of the Dutch painters in representing chlorosis (febris amatoria), and in the same class belong Gabriel Metsu's Feverish ('hild (Steengracht Gallery, The Hague), Gerard Dou's Dropsical Woman (Louvre), and Frans van Mieris' Physician with a Melancholic Patient (Vienna Ciallery). A remarkable painting by Simon Vouet, in the possession of Professor W. A. Fremnd, of Berlin, represents a case of suppurative osteomyelitis in a woman whose handsome appearance is in sharp contrast with her repulsive looking limb. The Dutch paintings of scenes of medical consultation and urine inspection are, for costumes and accessories, the finest in existence, in particular those of Gerard Dou in the Hermitage (Petrograd) and Vienna Ciallery, Adriaen van Ostade and Gerard Terborch in the Old Museum at Berlin, the elder Teniers in the Uffizi (Florence), Crabriel Metsu in the Hermitage, Frans van

${ }^{1}$ Rovinsky Collection, Petrograd, 1890. 
Mieris in the old Pinakothek (Munich), and Teniers' village physicians in the Brussels and Carlsuhe Cialleries.' Returning to the normal, it is worthy of remark that Rubens excelled atl other artists in conveying the charm of healthy infints and children. His handling of this thene in oil reminds us of what Swinburne says about Andrea del Sarto's "round-limbed habies in red-chatk outline, with full-blown laughter in their mouths and eyes; such flowers of flesh and live fruits of man as only a great love and liking for new-born children could have helped him to render."'

${ }^{1}$ For reproductions of these pictures, see Eugen Holländer, Die Medizin in der klaswischen Malerei, Stuttgart, 1903.

${ }^{2}$ A. C. Swinburne: Essays and Studies, London, 1575, p. 356. 


\section{THE EIGHTEENTH CENTURY: THE AGE OF THEORIES AND SYSTEMS}

Tule best work of the seventecnth century, whether of Shakespeare or Moliere, Rembrandt or Velasquez, Spinoza or Newton, Harvey or Leenwenlogek, was either conceived from some deep soure of original inspiration or else sprang from a fresh, näve wonderment over the newly reveated marvels of nature, as when old Pepres dectared hinsself "with chite" to see any new or stramge thing. ${ }^{1}$ The noble sacrifices of the heroes and martyrs of the preceding contury hat borne rich fruit in science as well ats a great gain for spiritual and intellectual frecelom. It was natural that the period preceeling the outhurst of pelitical revolution should be as a hull before an approaching tempest, and indecd things vecred firr to the opposite extreme of exaggeruted sobricty and apparent content with the old order of things. Tedious and platitudinous philosophizing (upon a priori grounds) was the fashion, even as a device to justify the immoralities of the period. In the literature of France, at least, there is sometimes an undertone which seems to tell of the coming change:

The day that darms in fire will end in storms,

Even though the noon be ealm-

but, in the end, cverything tended toward formalism, and every theory, however idcalistic, soon hardened into a rational, methodistic "srstem." In this regard, the most characteristic figures of the age- Kant and Rousseau, Voltaire and Hume, Swedenborg and Wesley, Linneus and Buffon, Racine and Pope-speak for themselves. Even the music of Mozart, Haydn, and Ciluck, although in sheer beauty like something Cireek strayed out of place and time, seems of precise and formal cut if compared with the sublime polyphony of Palestrina or the splendor in infinite detail of that seventeenth century giant Bach; while Händed is absolutely scluare-toed, silver-buckled, and periwigged in style. The best scientific work of the period was still in physies and chemistry, as witness the names of Lagrange and Laplace, Cavendish and Priestley, Scheele and Lavoisier, Galvani and Volta, Franklin

'The Orbis pictus of Amos Comenius (1657), which so delighted the childhood of Goethe, was a characteristic production of the seventeenth century, designed to make Latin easy for schoolboys through the illustrations. 
and Count Rumford, Fahrenheit, Celsius, and Réaumur, Watt, Fulton, and Stephenson. For medieine, aside from the work of a few original spirits like Morgagni, Hales, the Hunters, Wolff, and Jenner, it was essentially an age of theorists and system-makers. Linnæus established the vogue of dassification in medicine as well as his own seience and seems to have set the pace everywhere. In this respect, eighteenth century medieine is as dull and sobersided as that of the Arabic period. We see the great theorists of the time, as Emerson has described the gods, each sitting apart

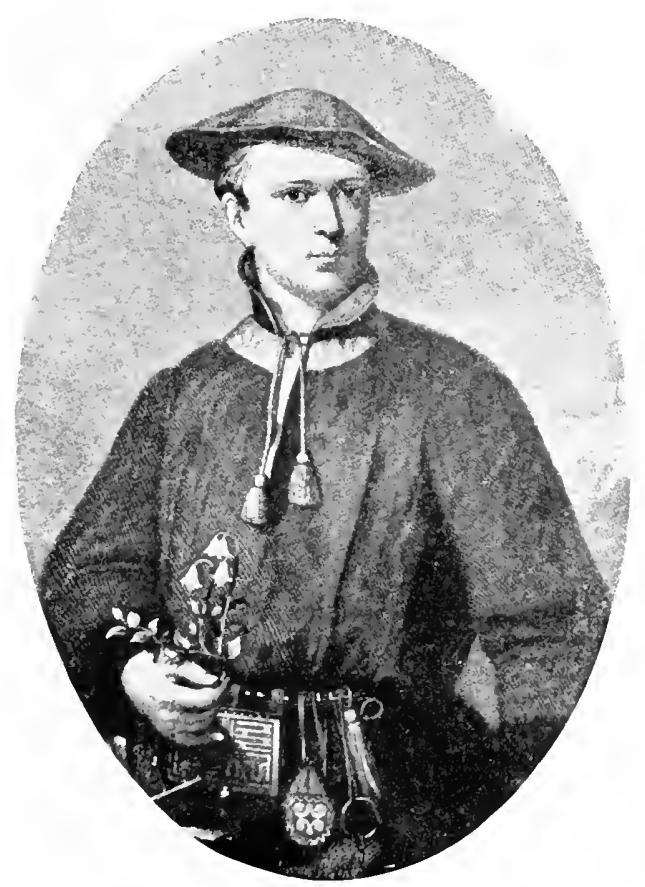

Carl von Limé (Linnatus) (1707-7s).

in his own sphere, "beckoning up to their thrones," yet somehow Hippocrates and Sydenham, Vesalins and Harvey, Celsus and Paré seem nearer and nore accessible to moderns than Stahl or Barthez, Borden or Boerhaave, Brown or Reil.

The great Swedish botanist, Carl von Linne (1707-78), or Linnæus, was himself a physieian, having studied medicine in order to win the hand of a wealthy practitioner's daughter, the father declining to consent to the match unless his prospective sonin-law became a doctor. Linneus gave the most concise descrip- 
tions of plants and animals in all natmral history, and originated the binomial nomenclature in seienese, oblling each definite natural objert he a erenerie or family name and a specific or griven name, and classifying matu himself as $/ /$ omo supiens in the oreler of primates. Ho bolievol, howerer, in the fixity of specoses (mulla species

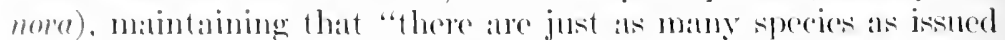
in pairs from the ('reator's hatuls" and no more. His first work, the systema Nature (1735), consisting of twolve folio pages rontaning his classification of plants, animals, and mincrals, beano so popular that it passed thromgh twelve editions in his lifetime. Specific names were first employed by Limmans in his sipecies Plantarm (1753), for plants, and in the tenth edition of the System Nature (1758), for animals. The latter is, in conseguence, the most highly prized of all the editions of his great work.

The medieal writings of Linnars include his matelia medica (1794-52) and his schene of nosology (Genere morbormm, 1763). He had some notion of water-borne malarial fever and of the parasitic origin of disease. Hektoen silys he gave good descriptions of embolism, hemicrania, and aphasia (1742).

Linnams based his classification of plants upon characters delived from the stamens and pistils (the sexual organs of the flower), and his system, which exaggerated the importance of the flower at the expense of the whole plant, and which Linnæus himself admitted to be a faulty but convenient mode of indexing things, was called the "Sexual System." It dominated European botany for more than a century, and was further expanded by Michacl Adanson (1727-1806), a physician of Aix in Provence, whose Familles des plantes (Paris, 1763) comprised an arrangement of genera in 58 families; and by Antoine Laurent de Jussien (1748-1836) of Lyons. Jussien was the nephew of Bernard de Jussieu, a botanist who had applied the Linnxan system in arranging the plants in the Royal Garden of the Trianon, and when young Jussien became demonstrator at the Jardin des Plantes, he was called upon to arrange the flora in this garden. He adopted a natural system of one hundred orders arranged in fifteen classes, harking back to the basic prineiples suggested by Ray-Acotyledones, Monocotyledones, Dicotyledones-further subdividing the litter according to the petals. His prineipal work is his Genera Plantarum (Paris, 1789), which was the source of authority until the Geneva botanist de Candolle introduced a morphologie system, ${ }^{1}$ based upon the form and development of the organs of plants as opposed to their

1.A.P. de Candolle: Regni vegetabilis systema naturale, Paris, 1818-21; Also his "Prodromus," Paris, 1824-73; and his "Organographie végétale," Paris, 1827. 
physiologie functions. All these systens exerted a profound influence upon medieal men in their attempts to classify discase, and the system of de Candolle, as we shall see, was the basis of the curious arrangements of pathologic phenomena which were made by Schönlein, Canstatt, Fuchs, Rokitansky, and other members of the German "Natural History School" in the early part of the nineteenth century.

The ludicrous side of the eighteenth century mania for sterile, dry-as-dust classifications of everything in nature or out of it was keenly felt by Goethe, the ablest plant morphologist of his time, and his sentiments are voieed in the expressive lines in his Faust:

Grau, alter Freund, ist alle Theorie,

Und grün des Lebens goldener Baum.

We may dispose of the medical votaries of "gray theory" at once. First of all, Georg Ernst Stahl (1660-1734), of Ansbach, Bavaria, a stiff-necked bigoted pietist of excellent eharacter, got himself into hot water with scientists and theologians alike by revamping van Helmont's idea of a "sensitive soul" as the source of all vital phenomena. The Stahlian "animism" (1737) is the ancient doetrine of the identity of soul and life-force (quars), the modern "vital principle," the Bergsonian élan vital. The body is only a passive machine, developed and guided by an immortal soul. As the Stahlian soul acted directly, without the intervention of archri or ferments, its author maintained that both anatomy and chemistry are useless in medieine. Disease to him was a disturbance of vital functions eaused by misdirected activities of the soul. Altered tonus and plethora (vascular aiony) make up the rest of his pathology. He even doubted the efficacy of drugs like opium or quinine, and was so far behind his time that he still recommended cast ration in hernia. Plethora he relieved by copious blood-letting and balsamie pills. He was fond of the siggestive effect of "sccret" remedies. His eonception of "life" was apparently identical with Imlac's definition of immortality in "Rasselas"- "a natural power of perpetual duration as a conseguence of exemption from putrefaction." As Stahl regarded all this in the light of a divine revelation, we cannot wonder that he sank into abject melancholia toward the end of his days. Apart from his treatise on plethora as a cause of discase $\left(1698^{1}\right)$, which has won even the commendation of Virchow, and his original aceount of lacrimal fistula $\left(1702^{2}\right)$, he left little of value, and even his own generation grew weary of him. The tendeney to confuse what the

1Stahl: De vena portie porta malorum, Halle, 1698.

2 Stahl: De fistula lachrymali, Halle, 1702. 
poet ealls "the sublime and irmefutalle passion of belief" with the purposes of soientific investigation is, incleed, one of the sadelest things in the history of medieine. And stahl was a well-meaning reactionary in still another direction-in his fake theory of combustion which threw hack the progress of chemistry for a hundred yoars. An excellent laboratory investigator, he assumed that whon a houly" hurms it is "dephlogisticated," that is, gives off a hypothetic substance, "phlogiston," although Mayow before him (as Black and Laroisier after him) had shown experimentally that a burning substance gans rather hatu loses in weight.

As a reation against the empty formalism of the eighteenth rentury, the animism of Stahl is of considerable importance to the anthropologist and the psychiatrist. In 1871, E. B. Tylor deliberately employed the Stahlian concept to explain the psychology of printive man. As an advocate of psychotherapy, Stahl is a comnecting link between the present and the past. He observed some of the remarkable effects of the mind upon the body, and his theory of the distraught psyche as a causa causans of disease contains the germ of Fremlian doetrine.

The principal follower of Stahl was François Boissier de la ('roix de Fauvages (1706-67), who considered the soul the cause of the mechinnism of the body, but is better remembered by his $\mathrm{No}$ sologia methodica (1768), which illustrates the taxonomic mania in a most hudicrous way. Sauvages endeavored to classify dis(ases as if they were specimens in natural history, subdividing them into 10 classes, with as many as 295 genera and 2400 species. ${ }^{1}$

The "animism" of Stahl became finally merged into the vitalism of the "four B's," Bordeu, Barthez, Bichat, and Bouchutto find a more recent avatar in the tedious "entelechies" of Driesch. Eighteenth century vitalism assumed a specially modern form in the "Bildungstrieb" of Johann Fricdrich Blumenbach (17521840), which argues an innate impulse in living ereatures toward self-clevelopment and reproduction. A great deal of theorizing in the eighteenth century was bound up with the Glisson-Haller doetrine of irritability as a speeific property of living tissues. William Cullen (1710-90), a lucid spirit of attractive character, sought to remove some of the difficulties the theory eneountered by considering muscle as a continuation of nerve and regarding life itself as simply a function of nervous energy. In this way, our modern phrase, "nerve force," became a substitute for the old Galenic "animal spirits," and, even today, when a doctor refers to some undetermined pathologic eondition as "probably nervous," he is

1 The other botanie classifiers of disease in the eighteenth century were Rudolph August Vogel, Sagar, Cullen, MacBride, Daniel, and Plouquet (Wunderlich). 
unconsciously harking back to Cullen. Upon this sort of reasoning still another theoretic element was superimposed-the ancient Methodistic doctrine of the strictum et laxum of Asclepiades. Friedrich Hoffmann (1660-1742), of Halle, assumed a mysterious, ether-like fluid acting through the nervous system upon the muscles, keeping them in a state of partial tonic contraction, and also keeping the humors of the body in the motion necessary for life. Acute diseases should, therefore, be due to a spasmodic condition, chronic diseases to atony. Besides spasm and atony, Hoffmann admitted humoral changes and faulty excretions as eauses of cliscase, the four to be relieved by seclatives, tonies, alteratives, and evacuants respectively. He revived the use of mineral baths. In Sir Clifford Allbutt's view, Hoffmann was the greatest of the iatromechanists and the first to perceive that "pathology is an aspect of physiology."1 He left an original description of chlorosis (1730), and was one of the first to describe rubella (1740).

The Asclepiadean Methodism was pushed to an absurd and yet most logical limit by the celebrated John Brown (1735-882). "The disputatious and disreputable Brown," as Allbutt styles him, was a coarse man of low habits, whom Cullen had taken up and launched, but who, like Colombo, Borelli, and other ingrates of medicine, turned against his quiet teacher with the plebeian's usual tactics of reviling his intellectual betters in order to exalt, himself. Yet the Brumonian theory, as it was called, actually held the attention of Europe for a quarter-century, and, as late as 1802, a rixa, or students' brawl, between Brumonians and non-Brunonians at the University of Göttingen lasted two whole clays and had finally to be put down by a troop of Hanoverian horse. As far as it went, the theory was absolutely consistent and complete in all its parts. Brown regarded living tissues as "excitable" in lien of the Hallerian "irritability," and life itself as non-existent, except as a resultant of the action of external stimuli upon an organized body. Diseases are then "sthenic" or "asthenic," according as the vital condition or "excitement" is increased or diminished. The essentials of diagnosis are simply whether a disease is constitutional or local, sthenic or asthenic, and in what clegree, and the treatment consists in either stimulating or depressing the given condition. To this end opium, and, of course, alcohol, were Brown's favorite agents. Hippocrates said that no knowledge of the brain can tell us how wine will act upon any particular individual, and Brown proceeded to apply this experinental idea in propria persona to elueidate his theory, using suc-

1 Allbutt: Brit. Med. Jour., Lond., 1900, ii, 1850.

${ }^{2}$ Brown: Elementa medieinæ, $17 \$ 0$. 
ressive doses of five glaseses at a time. Abmse of opium and alcohol eventully killod him. His methoul gamed little support in France and Emeland, hut Rush took it up in Ameria, Rasori, Moscati, Breral and others in Italy, and in Ciemany, after (hristoph (iirtanner's plagiarisms of 1790 had bern exposed and the "Elemonta modicinar," transkated by M. A. Weikand, Brown eame into his own. The book hypnotized cren Peter Frank and Röschlauh and was greeted by a flood of pamphlets and salvos of praise. Although his errors were pointed out hy Humbolelt and IIufeland, Brown had the unique distinction of polarizing the Cierman profesion. His therapentic ideas, Bas asserts, destroyed more people than the French Revolution and the Napoleonic wars comhined, nor will we dispute the same historian's pronouncement that he was "morally deserving of the severest condemnation."

Another ludicrous phase of theoret ie medieine in the cighteenth century was the so-called "doctrine of the infarctus" of Johann Kïmpf, the supposititious causa causans of most human ills being simply fecal impaction. This fine theory, of course, foll in with the vogue of clysters, then fashionable, the memory of which is preserved in Molière and in the indescribable fantasies of the artists of the period.

The leading physician of the age was the founder of the "Eclectic School," Hermann Boerhaave (1668-1738), who is especially remarkable through his pupils, Haller, Gaub, Cullen, Pringle, and the leaders of the "Old Vienna School," van Swieten and de Haen. At first a follower of Spinoza, Boerhaave was educated along the broadest lines, but while he was the leading practitioner of his time, he is now principally remembered as a great teacher and especially as a chemist. His Elementa chemia (Leyclen, 1732) was easily the best book on the subject all through the eighteenth century. In medicine, as Allbutt says, he made no experiments, and "seems to have contented himself with hashing up the partial truths and the entire errors of his time." An examination of his Aphorismi (Leyden, 1709), which at once suggests his reputation as the "Batavian Hippocrates" (the sedulous de Haen aping Galen as commentator of the great man), will also suggest that this reputation has evaporated very considerably of recent years. Baas (a good (ritic) says that many of his Delphic ntterances seem today "ambiguous rather than profound," while his maxim, sim-

1 Allbutt: Op.cit.. p. 1s.50. The only experiment eredited to Boerhase is his attempt to ascertain the effect of extreme heat upon animals. He had his pupils, Prevoost and Fahrenheit, put a rog and a cat in an oven heated up to $63^{\circ}$ C.; it was found that they died in twenty-eight minutes, while a sparrow, under the same conditions, lasted seren minutes. This, surely, is a kind of experimentation that we could get along just as well without. 
plex sigillum veri, "was never manifested in his treatment," and "his prescriptions were less effective than his personal appearance." Yet his writings had an enomous reputation in their day, and his Institutiones (1708) were translated even into Turkish and Arabic. ${ }^{1}$ He first gave a special course of lectures on ophthalmology (1708). The ancedotes about his fame reaching to China and his capacity for making monarchs wait only go to show that his influence was largely one of personality, a personality which was kindly, dignified, and unassuming. Bocrhaave was perhaps the earliest of the great physicians who have loved music and frequently assembled performers at his house. As a clinician, he is credited with

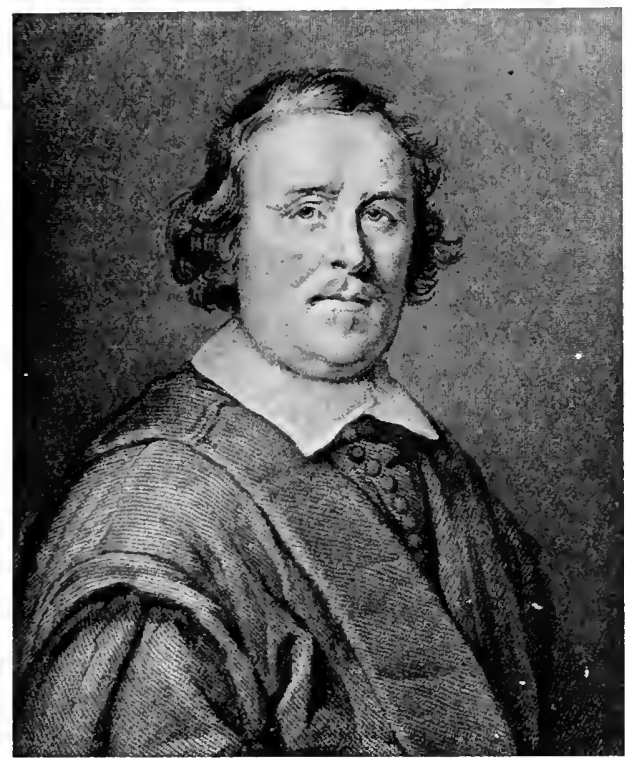

Hermann Boerhave (1668-1738).

being the first to describe rupture of the esophagus and the auralike pain which precedes hydrophobia. It is said that he was the first to establish the site of pleurisy exclusively in the pleura, and to prove that small-pox is spread exclusively by contagion. He used the Fahrenheit thermometer in his clinic and the practice was kept up by his pupils, van Swieten and de Haen. His seientific reputation today rests largely upon the idea of "affinity"

${ }^{1}$ See C. E. Daniëls: Janus, Leyden, 1912, xvii, 295-312, 2 pl. For van Swieten's shorthand notes on Boerhaave's lectures, which give some idea of his mode of speaking in Latin, see E. C. van Leersum, Janus, 1912, xvii, 145-152. 
between substanes which he introluced into ehemistry, together with an improved method of making vinegar (1732).

The theories just reviewed, with the single exeption of Hoffmann's perhaps, are not entitled to the respect which we aceord to the ideas of an Asclepiades, a van Helmont, or a Syclenham, for it is just these eighteenth century men who have given currency to the notion, so active in the lay mind, that the progress of medicine itself is only a "succession of forgotten theories." Far abler work was done by a very different group, the systematists, and we may now approach, with all due reverence, the greatest systematist

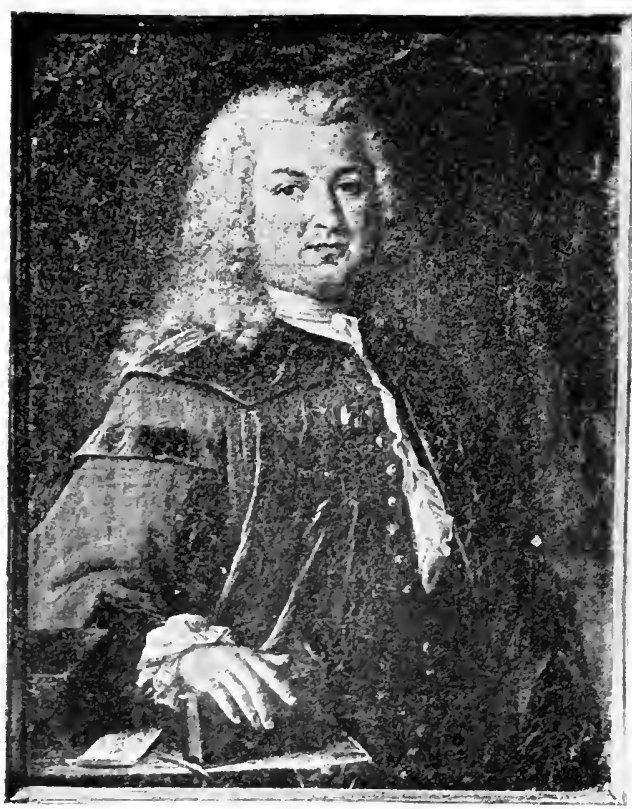

Albrecht von Haller (170S-77). (From an oil-painting by Studer.)

after Galen, and one of the most imposing figures in all medical history, Albrecht von Haller (1708-77), the master physiologist of his time. Haller came out of the old bourgeois aristocracy of Bern, Switzerland, and was an infant prodigy, writing Latin verses and a Chaldee grammar at ten, and at sixteen, worsting his senior, Professor Coschwitz, in the latter's contention that the lingual vein was a salivary duct $\left(1725^{1}\right)$. After graduating at Leyden, having for his teachers men like Boerhaave, Albinus, Winslow, and

${ }^{1}$ A. von Haller: Experimenta et dubia circa ductum salivalem novum Coschwizianum, Leyden, 1727. 
(in mathematics) John Bernouilli, his fame as a poet and botanist soon drew him away from his native city to the newly estallished university at Göttingen, where he remained for seventeen years, teaching all branches of medicine, establishing botanic gardens and churches, writing some 13,000 scientific papers, and incidentally doing his best experimental work. In 1753, at the age of fortyfive, he was seized with an attack of Heimueh, and retired to Bern for the rest of his days, leading a life of most varied activity as public health officer and savant, with a touch of "Lord High Everything Else." He was equally eminent as anatomist, physiologist, and botanist, wrote poems and historic novels, carried on perhaps the most gigantic correspondence in the history of science, and was the principal founder of medical and scientific bibliography, his patient, arduous labors in this field being marvels in their kind.' In anatomic illustration, he did much for the establishment of the norm of the blood-vessels and the viscera. His Icones anatomice is authoritative for accurate study of these and other structures (Choulant). The Hallerianum at Bern is a symbol of his chief title to fame as the founder of recent physiology, the forerunner of Johannes Mïller, Claude Bernard, and (arl Ludwig. His greatest single contribution to the subject is his laboratory demonstration of Cilisson's hypothesis that irritability (i.e., contractility), $e . g$. , in an excised muscle, is the specific immanent property of all muscular tissues, and that sensibility is an exclusive property of nervous tissue or of tissues supplied with nerve. This classic research, based upon 567 experiments, of which he himself performed 190, was mate at Göttingen in 1757, where he also laid the foundation for his Elementa physiologice corporis humani (Lausanne, 1759-66). Of this great work, Sir Michael Foster says truly that to open it is to pass into modem times. Read Profescor Kronecker's "Haller redivivus"3 and see how many apparently" "new" discoveries of modern observers had already been aceounted for by this great master and are now forgotten, doubtless berause humanity does not take kindly to the theorist on his pedestal. They include a reassertion of the myogenic theory of the heart's action (1736), a recognition of the use of bile in the rligestion of fats (1736), and the first experimental injections of putricl matter into the living body (1760). Akin to the French Eneyclopedists in his

${ }^{1}$ Bibliothera botaniea, Zürich, 1771-72; Bibliotheca anatomica, Zürich, 1774-77; Bibliothesa chirurgiea, Bern, 1774-77; Bibliotheca medicina praetica, Basel, $1766-78$.

2 "De partibus corporis humani sonsibilibus et irritabilibus," in Comment. Soe. reg. Cottinga (1752), 1753, ii, 114-214.

${ }^{3}$ Mitth. d. naturf. Gesellsch. in Bern (1902), 1903, No. 1519-1550, pp). 203-226. 
grasp of detail. Haller was the hest historian of medienel after

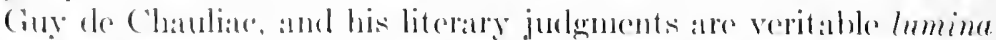
sententiarm. In emberologr, he was something of a reactionary, and sucossfully wothlanketed the rorrect ideas of Wolff, as will appest. Ho locetured amel woto on surgery, and made a superb bibliography of the subjoet, - lut never performed sun operation in his life. In private life, Haller was modest, sensible, kindly, and charitable, and- laue trait - not af raid to affirm his ignorance when he combl not explain a phenomenon. But he was complacent as to his infallibility about what he professed to know, did not like to have it guestioned, and so left no school of followers behind him. To his contemporaries he seemed a "rir gloriosus," living apart on a high eminence: but he was probably not the "pursy, play'd-out Philistine" of some of his portrats. As a youth he was singularly finc-looking. In the history of German literature, Haller hats a substantial, honorable place. His lersuch schweizerischer fiedichte (1732) Was the subject of the famous literary (quarrel between Bodnel and Gottsehed as to the relative merits of the natural and the artificial in poetry. His poem, Die Alpen (1729), first drew attention to the glorions beanties of Swiss mountain seenery, and its influence may be seen in Klopstock, in Sehiller, and even in Colerielge. By sone irony of fate Haller, the poet, is now chicfly rememhered by the following commonplare expression of bourgeois sentiment:

Ins Innre der Natur dringt kein ersehaffener Geist,

Zı glïcklich, wann sie noch die ässure Schale weist.

Of Nature's inmost heart no human mind ean tell,

Happy, indeed, is he who knows its outer shell-

which so excited the derision of Goethe. ${ }^{3}$

With Haller, the systematist, we may class the works of a group of very original men, beginning with the De morbis artificium diatriba (Modena, 1700) of Bernardino Ramazzini (16331714), which opened up an entirely new department of modern medicine, the diseases and hygiene of occupations. Ramazzini was the first after Paracelsus to call attention to such conditions as stone-mason's and miner's phthisis (pneumonokoniosis), the vertigo and sciatica of potters, the eye-troubles of gilders, printers, and other oceupations. He was a good epidemiologist, having described the outbreak of lathyrism at Modena in 1690, the malarial epiclemic's of the region and the Parluan cattle-plague of

${ }^{1}$ Haller: Methodus studii medici, Amsterdam, 1751.

2 Bibliotheca ehirurgiea, Bern, 1774-75.

${ }^{3}$ The lines occur in Haller's apostrophe to Newton, which, of course, stirred the ill-will of Goethe, on account of his own opposition to Newton's theory of eolors. 
1712. Like all the clinicians of his time, he made observations of the weather (Ephemerides barometrice, 1710). Italy hats done eponymic honor to his memory in the medical periodical which bears his name.

"The Divine Order" $\left(1742^{1}\right)$ of the old Prussian army chaplain, Johann Peter Süssmilch (1707-77), is an epoch-making work in the development of vital and medical statistics, bringing together many data of capital importance in public hygiene, life insurance, and national polity. Although the old theologian's view is entirely teleologic, basing everything upon a divine order in nature,

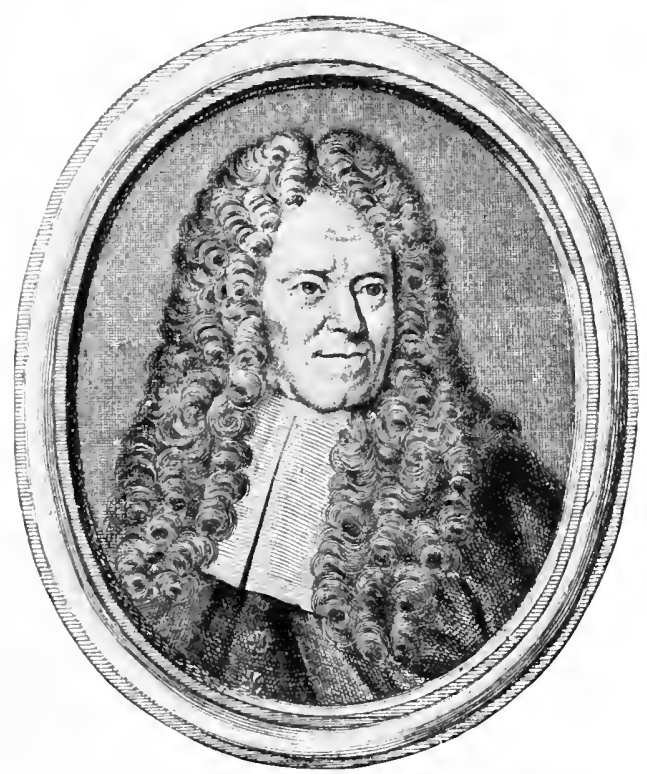

Bernardino Ramazzini (1633-1714).

and although the English statist, John Graunt, had long before noticed (1662) that the population can be estimated from an accurate death-rate, yet the importance of Suissmilch to medical men is of a higher order than the mere casting up of figures. He it was who insisted upon the moral and political significance of statisties and affirmed that the true wealth of any nation consists in an industrious, healthy native population, and not merely in material and financial resources. The intelligent application of

${ }^{1}$ J. P. Süssmilch: Die göttliehe Ordnung in denen Veränderungen des mensehlichen Geschlechts, Berlin, 1742. 
this humane, boat-minded principlo is the secret of the indust rial and military power of the mighty (ieman buphe tolay.

In eomnection with the name of Sïssmileh three other famous systematists may be mentioned, viz., Joham Friedrich Blumenbach (1752-1840), of Gottingen, and l'ielel ('imper, the founders of anthropology and craniology, and Iohamn Peter Frank, the founder of public hygiene. Although Bhumenbach's thesis, "On the Native Varieties of the Human Race" (1776'), was preceded by the essays of Bernier (16S4) and limmeus (1735), yet it may fairly be considered the starting-point in modern ethnology, sinee he bases his classification upon the shape of the skull and the facial

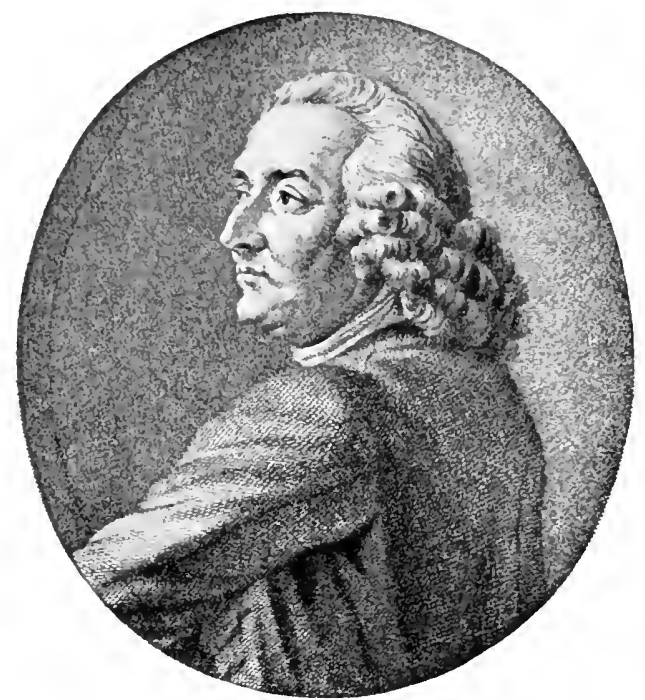

Pieter Camper (1722-89).

configuration, as well as the color of the skin. In describing his large collection of crania, in an atlas of 70 plates $\left(1790-1820^{2}\right)$, he used the vertical aspect from above downward as a norm in classifieation, but beeause a female Georgian skull was the most symmetric, he introduced the unfortunate term, "Caucasian," to represent the Aryan race. He is also remembered by the clivus Blumenbachii in the pons. Blumenbach was followed by the learned Pieter Camper (1722-89), an artist in training, who illus-

\footnotetext{
${ }^{1}$ Blumenbach: De generis humani varietate nativa, Göttingen, 1776.

2 Another valuable atlas of skulls is to be found in Eduard Sandifort's description of the Leyden Museum of Anatomy (1793-1835).
} 
trated his own works and introduced the "facial angle" as a criterion of race (1760). Camper was Albinus' great rival in anatomic illustration. He painted in oil, aquatint, and pastel, made clrawings in chalk and India ink, practised etching and mezzotint, and even made marble busts.

He discovered the processus vaginalis of the peritoneum, the fibrous strueture of the lens, and made eapital topographic studies of the $a \mathrm{rm}$, the pelvis, and the inguinal eanal. His comparative researehes on the Cetacea, his studies of facial expression of the passions, and his Icones herniarum (1779), published by Soemmerring, in 1801, are all works of great value. His treatise on the best form of shoes (1781), an important contribution to the physiology of loeomotion, was reprinted in English translation as late as 1871. Camper, one of the most versatile of men, also introdueed a pessiary and a correct

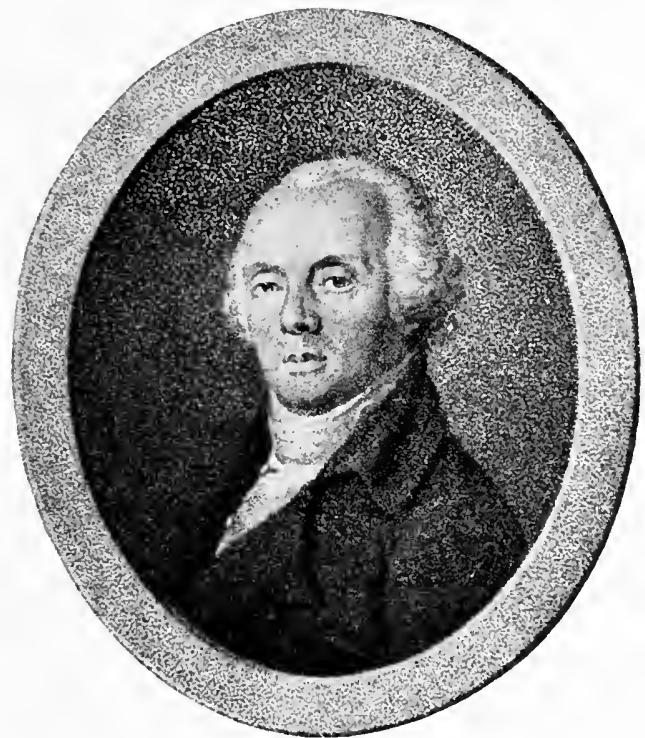

Johann Peter Frank (1745-1S21).

mode of using the vectis, practised symphysiotomy on animals, was a promoter of inoculation, leetured to erowded audiences on legal medicine, and was the first to open a surgical polyclinic (Groningen, 1764).

A rare and happy mixture of German thoroughness with French intelligence was Johann Peter Frank (1745-1821), of Rotalben (Palatinate), the four volumes of whose "Complete System of Medical Polity" (System einer vollständigen medicinischen Polizey), published at Mannheim in 1777-88 by Schwann, the printer of Schiller's "Robbers," are the very foundation of modern public hygiene, and a noble monument of a life-long devotion to humanity. The author was a poor waif, almost cast adrift at a street 
door, who made himself one of the greatest teachers and practitoncers of his timn hy his own industry. Ho was the first physician 10 signalize the importanee of diseases of the spinal corel (1792), defined diabetes insipidus (179-1), and wote an important treatise on therapentics $\left(1792-1821^{2}\right)$. His great work on public hygiene, as corering the whole subject of man's life "from the woml, to the tomb" - sewolage, water-supply, even sehool-hygicne, sexual hygiene, and suitable benches and meals for the children, as well as the idcal of a scientific "medical police"- really leaves little for Peflenkofer and the moderns. In the preventive medicine of the

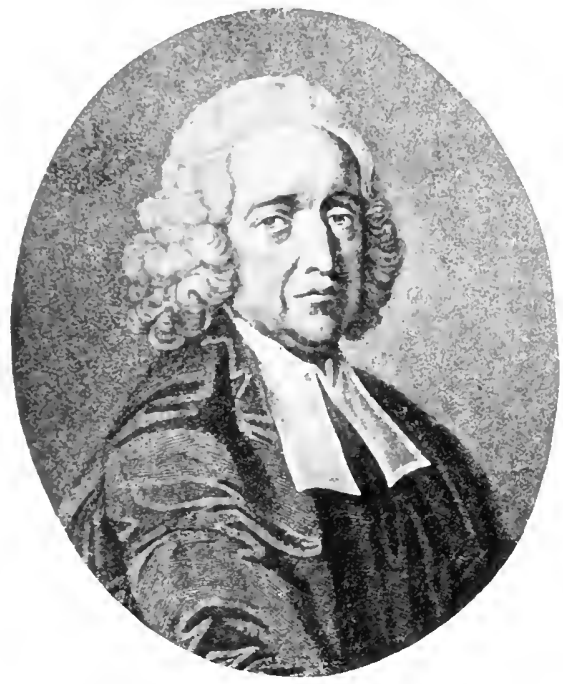

Stephen Hales (1677-1761). future, the mame of Frank will loom largel with meanings, fol he was himself a true modern.

After Haller, the principal landmark of eighteenth century physiology is 111 doubtedly the Statical Essays (1731-33) of Stephen Hales (1677-1761), an Fnglish clergyman of inventive genius, who cnriched practical science in many ways, particularly as the originator of artificial ventilation (1743). In the first part of these essays, Hales investigates the movement of sap in plants. The second part, entitled Hamadynamics (1733), contains his most important work, on the mechanical relations of blood-pressure, marking the first real advance in the physiology of the circulation between Harvey and Poiscuille. By fastening a long glass tube inside a horse's artery Hales devised the first manometer or tonometer, with the aid of which he made quantitative estimates of the blood-pressure, the capacity of the heart, and the velocity of the blood-current, which in tendency are essentially modern.

The physiology of digestion was materially advanced by the experiments of René-A.-F. de Réaumur ${ }^{3}$ (1683-1757) upon a

1 Frank: "De vertebralis columnæ in morbis dignitate," in his Delect. opusc. med., Ticini, 1792, xi, 1-50.

2 "De curandis hominum morbis epitome," Vienna, 1792-1821.

${ }^{3}$ The inventor of the 80 degrees thermometer. 
pet kite, in which he succeeded in isclating the gastric juice and demonstrating its solvent effect npon foods $\left(1752^{1}\right)$. These results were very ably confirmed and extended by the work of the Abbate Lazaro Spallanzani (1729-99), of Seandiano, Italy, an investigator of singular power. Spallanzani diseovered the digestive power of saliva, and reaffirmed the solvent property of the gastrice juice, ${ }^{2}$ showing that it will act ontside the body, and that it camot only prevent putrefaction, but will inhibit it when once begun. He failed, however, to recognize the acid character of the gastric juice, a point which was to be brought out by the American physiologist Young. In 1768, ${ }^{3}$ Spallanzani founded the doctrine of the regeneration of the spinal, cord through his discovery of its new growth during regeneration of the tail in the lizard. He also showed that the sexual posture in the frog is maintained as a spinal reflex after decapitation or after section of the two brachial nerves, fore and aft $\left(1768^{4}\right)$. He made important investigations of the respiratory exchanges in warm- and cold-blooded animals, ${ }^{5}$ showing that hibernating animals can live comfortably for a time in carbon dioxide gas, where ordinary warm-blooded creatures die at once; that cold-blooded animals can live in hydrogen and continue to give off $\mathrm{CO}_{2}$; and, most important of all, that living tissues, excised from a freshly killed animal, take up oxygen and even give off $\mathrm{CO}_{2}$ in an atmosphere of air or hydrogen or nitrogen. His experiments on the bat proved that it is very slightly dependent on vision, so that its known deficiency in visual purple (Kühne) may be due to disuse. A most important investigation of Spallanzani's bore upon the doctrine of spontaneous generation.

In 1748, John Turberville Needham (1713-81), an English Catholic priest in residence on the eontinent, published eertain experiments on boiled meatjuiees, inelosed in vials and sealed with mastie, the subsequent presence of micro-organisms in these liquids teading him to the conelusion that they were produced by spontaneous generation. Spallanzani refuted all this by using glass flasks with slender neeks, which could be hermetieally sealed in flame, immersing them in boiling water prior to the test; and he also overthrew Needham's subsequent objection to the boiling feature by showing that exposure of the sealed fluids to the air again would renew the presumable germinative or "vegetative force" in the liquids, which, Needham maintained, had been destroyed by the flame. Finally, Spallanzani was, with Réammur, Trembley, and Bonnet, one of the pioneers of experimental morphology in the strictly modern sense. Réaumur, in 1712 , produced regenerations of the

1 Réaumur: "Sur la digestion des oiseaux," Mém. Acad. roy. d. sc., 1752, Paris, $1756,266-307$.

${ }^{2}$ Spallanzani: Della digestione degli animali, in his: Fisica animale, Venice, 1782 , vol. i, $1-312$, ii, $1-83$.

${ }^{3}$ Prodromi sulla riproduzione animale: Riproduzione della coda del girino, Modena, 1768.

${ }^{4}$ Ibid.

${ }^{5}$ See the memoirs on respiration in his colleeted works. 
elaws and scales of lobsters and crabs.' In 17.10-14, ${ }^{2}$ Nbraham Trembley ent hydrats into several pieces, produring new incliviluals, and got at third generat tion by cutting the the latter. In this he was followed by Bonnet, ${ }^{3}$ who experimented on fresh-water worms (1741-li)), by Ilenry liaker, who followed in) Trembley's work on polyps (17431), and by Spallamzani, who produced reugenerations of the heats, tails, limbs, and tent acles of earthworms, tad-poles, sal:unamlers, and snatik (17685). These experinents were not taken up again until the mul of the ninctecuth century, but they contain all the essentials of the molern work of Romx, Driesch, Morgan, Isob, and others.

An English physiologist, whose work was long forgot ten but has now come to the front on accomt of its essential importance, is

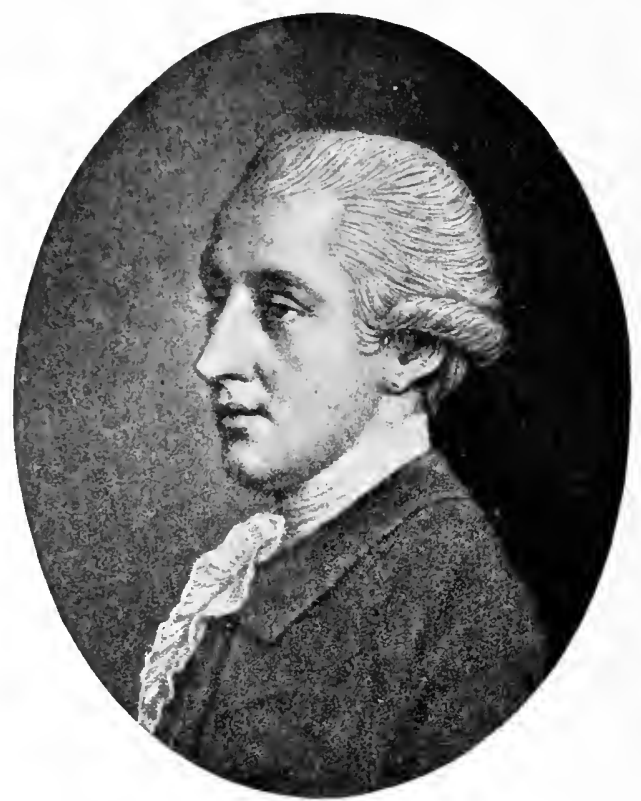

William Hewson, F.R.S. (1739-74).

William Hewson (1739-74), of Hexham, Northumberland. Hewson was a pupil of the Hunters, and John Hunter left him in charge of his dissecting-room when he went abroad with the army. He afterward went into partnership with William Hunter in anatomic

${ }^{1}$ Réaumur: Mém. de l'Acad. de sc., Paris, 1712, 223-242, 1 pl.

2 Trembley: Mémoires pour servir à l'histoire d'un genre de polypes d'eau douce, Leyden, 1744.

${ }^{3}$ Bonnet: Traité d'insectologie, pt. 2, Paris, 1745.

${ }^{4}$ Baker: An Attempt towards a Natural History of the Polype, London, 1743. 1829.

${ }^{5}$ Spallanzani: Prodromo di un'opera sopra le riproduzioni animali, Milan, 
teathing, sharing his profits, and later assisting him at the school in Great Windmill street from 1769 on. When Hewson married, Willam Hunter, who seems to have had a natural aversion to Benedicts, abruptly broke off the partnership, much to Hewson's pecuniary disadvantage. He soon retrieved himself, however, having made his reputation through his Royal Society memoir on the lymphaties, which got him the Copley medal in 1769 and the honor of F.R.S. in 1770. Hewson's discovery of the existence of lacteal and lymphatic vessels in birds, reptiles, and fishes was estecmed of capital importance in its day, because the two Hunters maintained that absorption is an exclusive function of the lymphatics, against which it was objected that there are animals which have noither lacteals nor lymphatics. Magendie's demonstration that the blood-vessels have an absorbent function of course threw this phase of Hewson's work into the background, and present interest is centered on his Experimental Inquiry into the Propertics of the Blood (1771). This work, a fine example of the experimental method taught by the Hunters, establishes the essential features of the coagulation of the blood in an entirely modern spirit. Before Hewson's time, coagulation was ascribed to the supposed cooling off of the blood, to the fact that it had ceased to move, or to the idea that its corpuseles had solidified into rouleaux. Hewson showed that when the coagulation of the blood is delayed, as by cold, neutral salts, or otherwise, a coagulable plasma can be separated from the corpuscles and skimmed off the surface, and that this plasma contains an insoluble substance which can be preeipitated and removed at a temperature a little over $50^{\circ} \mathrm{C}$. ( $10-$ agulation, in Hewson's view, was due to the formation in the plasma of this insoluble substance, which he called "coagulable lymph," and which we now know to be fibrinogen. Hewson's experiments were soon forgotten, even after Andrew Buchanan had shown, in 1845, that a substance can be extracted from the lymphatic glands, the buffy coat of the blood, and other tissues, which will coagulate not only blood, but serous fluids not in thenselves coagulable. The modern discovery that fibrinogen is a nucleoproteid, and that in coagulation it is converted into fibrin, threw the work of Hewson into stronger relief. He also made the important observation that air is contained in the pleura in pnemnothorax (1767), and was one of the first to perform the operation of paracentesis, although in this he was preceded by Monro secundus. Hewson, a man of genius, died of a dissection wound in 1774.

William Cumberland Cruikshank (1745-1800), of Edinburgh, who succeded Hewson as William Hunter's assistant, gave the latter such satisfaction that he was made a partner in the Great Windmill Street School, which, after Hunter's death, he took 
charge of, in conjunction with Matthew Baillic. ('ruikshank inrestigatod the remion and regencration of divided nerves (1776 $\left.{ }^{1}\right)$, the passige of the impreguated ovem thromgh the liallopian tube (17-52). the physology of absorption (1778-86), and in his tixperiments L pon the Insensible Perspiration of the II Iman Body (17Ts) he demonstrated that the skin rives off carbon elioxide, ats well as the lungs. His Anatomy of the Absorbing Tessels of the II mman Body (ITS6) embodies the results of his labors with William Hunter. ${ }^{3}$ In 1797, he demonstrated allouminura in dropsical fevers. C'ruikshank had a large practice, turning his private office into a public dispensary for the poor on oreasion, which won

him the warm regard of his

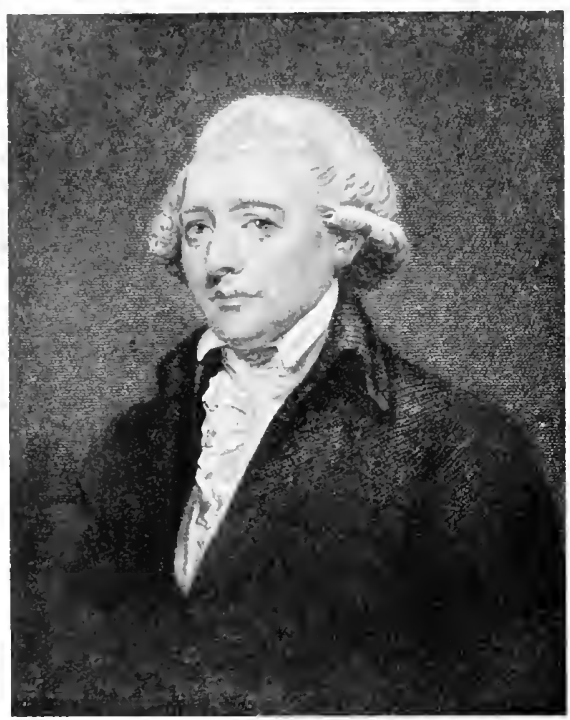

William C. Cruikshank (1745-1800). fricud, Dr. Jolnson, whom he treated in his last illness and who describod him, in the reot tish phrase, as "a sweet-hlooded man."

Robert Whytt (171466), of Edinburgh, a pupil of Nonro primus, (heselden, Winslow, Bocrhaave, and Albinus, is memorable for his work on the physiology and pathology of the nervous system. In his memoir On the Vital and Other Imoluntary Motions of Animals (Edinburgh, $1750)$, he demonstrated for the first time that the integrity of the spinal cord as a whole is not necessary for reflex action, and that the preservation of only a small fragment of it will suffice for this purpose. He also discovered that destruction of one of the anterior corpora quadrigemina will abolish reflex contraction of the pupils to light (Whytt's reflex, 1768 ), and was one of the first to notice the phenomena of spinal shock. In all these observations he was moved to discard the

${ }^{1}$ Phil. Tr., Lond., 1795, lxxxv, 177-189, 1 pl.

2 Ibid., 1797, lxxxvii, 197-214, 1 pl.

${ }^{3}$ Hunter was accustomed to say that the anatomy of the lymphatic system was developed by himself, his brother John, Hewson, and Cruikshank.

${ }^{4} \mathrm{By}$ the addition of corrosive sublimate and nitric acid or by boiling (Erich Ebstein). 
current hypothesis of Stahl that a "rational soul" is the cause of involuntary movements. In his Observations on the Dropsy in the Brain (1768) Whytt first described tuberculous meningitis in children, and his book, On Nervous, Hypochondriacal, or Hysterical Diseases (1761), was an important contribution to neurology in its day.

The cerebrospinal fluid was discovered in 1774 by Domenico Cotugno (1736-1822), who also demonstrated albumen in the urine by boiling (1764), seventy years after Frederik Dekker (1694), and described sciatica $(1770)$.

Electrophysiology had its origin in the epoch-making experiments on muscle-nerve preparations, summarized in $1792^{1} \mathrm{by}$ Luigi Galvani (1737-98) of Bologna. Animal electricity had been observed in the torpedo by John Walsh in 1773, and in John Hunter's studies of other electric fishes, but Galvani's discovery of the electric properties of excised tissues, which he happened upon in his laboratory by sheer accident, is the starting-point of modern work. It was followed up, with rare skill and insight, by Alessandro Volta (1745-1827), professor at Pavia (1778$\left.1819^{2}\right)$, in his "Letters on Animal Electricity" (1792). Volta divided conductors of electricity into metallie and liquid (cleetrolysis), devised the famous Voltaic pile (1799), and showed that a muscle can be thrown into continuous (tetanic) contraction by successive electric stimulations.

Meanwhile Benjamin Franklin, Kratzenstein, Schaeffer (1752), G. F. Rössler (electric bath, 1768), Manduyt (1777), William Henly (1779), and many others were already utilizing electricity in the treatment of disease. Statie machines were installed in the Middlesex Hospital in 1767, in St. Bartholomew's in 1777, and in St. Thomas's about 1799. An old print, of date 1799, showing the administration of static electricity to a patient, hangs on the walls of the Eleetrical Department of St. Bartholomew's.

The introduction of the galvanie method of stimulation harl no immediate effect upon physiologic research. As Langley points out, all the norves of the body were held to originate in the brain, which was regarded as the sole source of nervous influence, acting by means of "animal spirits" seeretrif from the blood and passing from the brain into the nerves. The present sympathetie or autonomic chain was ealled the "intercostal nerve," the cerehral origin of which was eontested by Pourfoir du Petit (1727) on anatomic grounds; but although Whytt (1751-65) attempted to rationalize current conerepts and Haller (1752) established his famous doetrine that sensibility is confined to nerves and irritability (eontractility) to muscle, the theory that all nervons power proceeds from the brain continued to hold the field and the true functions of the vegetative nervous system and of struetures made of involuntary muscle were not understood. ${ }^{3}$

${ }^{1}$ Galvani: De viribus electricitatis in motu musculari, Modena, 1792.

${ }^{2}$ A statue of Volta was erected in the Athenirum of the Eniversity of Pavia in 1878 .

3 J. N. Langley: Jour. Physiol., Lond., 1916, 1, 225-258. 
The Abbate Felice Fontana (1730-1803) was the author of a treatise on the venom of the viper $\left(1767^{1}\right)$, which wats the startingpoint of the modern investigation of serpent venoms.

But porhaps the best pice of physiologic work in the eighteenth century was the completion of the molern theory of respiration, which tumed upon the discovery of the different gases in the atmosphere, viz., cathon dioxide by Black (1757), hydrogen by Cavendish (1766), nitrogen by Rutherford (1772), oxygen by Priestley and Schocle (1751), and Lavoisier (1755). The great Scot tish rhemist Joseph Black (1728-99) is known to physicists

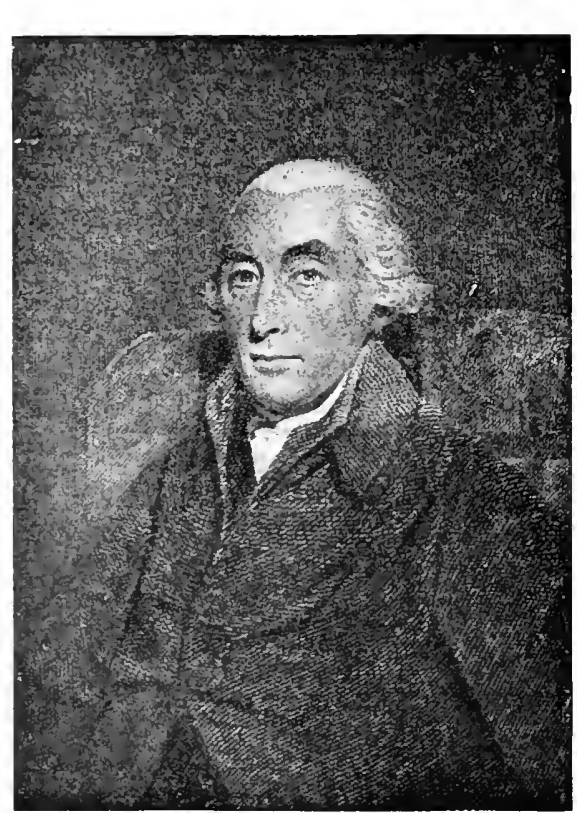

Joseph Black (172s-99). for his original definitions of "specific heat" and "capacity for heat" and for his subtle criterion of "latent heat" - that the temperature of a body and the amount of heat it possesses are two entirely different things. In his Dissertatio de humore acido a cibo orto (1754) he made a distinction equally important for chemistry and physiology. Chemists of Black's day, following Stahl, believed that when lime is heated it gains phlogiston, and whlen quicklime is slaked it loses phlogiston. Black's experiments exploded Stahl's theory by showing that, in reality, quickened lime loses something $\left(\mathrm{CaCO}_{3}=\right.$ $\left.\mathrm{CaO}+\mathrm{CO}_{2}\right)$, and quicklime, when slaked, gains something $\left(\mathrm{CaO}+\mathrm{H}_{2} \mathrm{O}=\mathrm{Ca}(\mathrm{OH})_{2}\right)$. He also noted that the gas or "fixed air" given off by quickened lime and alkalis is also present in expired air, and is physiologically irrespirable, although not necessarily toxic. 'Thus Black had again isolated the carbonic acid gas which van Helmont had, over a hundred years before, noted in fermentation as gas sylvestre. A few steps further and he would have arrived at the conclusion of the whole matter. Joseph Priestley (1733-1804) had the truth in

\footnotetext{
${ }^{1}$ Fontana: Ricerche fisiche sopra il veleno della vipera, Lueca, 1767.
} 
his grasp when he isolated oxygen $\left(1772^{1}\right)$ and saw that vegetating plants renew vitiated air, but being a confirmed Stahlian, he only made matters worse by seeing respiration as "the phlogistication of dephlogisticated air." It was reserved for the genius of AntoineLaurent Lavoisier (1743-94) to discover the true nature of the interchange of gases in the lungs, and to demolish the phlogiston theory by his introduction of quantitative relations in ehenistry. As Sir Michael Foster maintains, "he and he alone discovered oxygen" $\left(1775^{2}\right)$, for Mayow, Priestley, and Seheele had only isolated it. Priestley, deceived by the specious label, "phlogiston," had explained the facts of respiration in an inverted order. But Lavoisier proved that inspired air is converted into Black's "fixed air," the nitrogen or "azote" (which he also discovered) alone remaining unchanged. Further, in conjunction with the astronomer Laplace (1780$85^{3}$ ), he demonstrated that respiration is in every way the analogue of combustion, the ehemical products being carbon dioxide and water. But Lavoisier, whose life was tost to science through the fanatieism of the French Revolutionists, had adopted the erroneous theory that the oxidation of carbon and hydrogen takes place in the tubutes of the lungs.

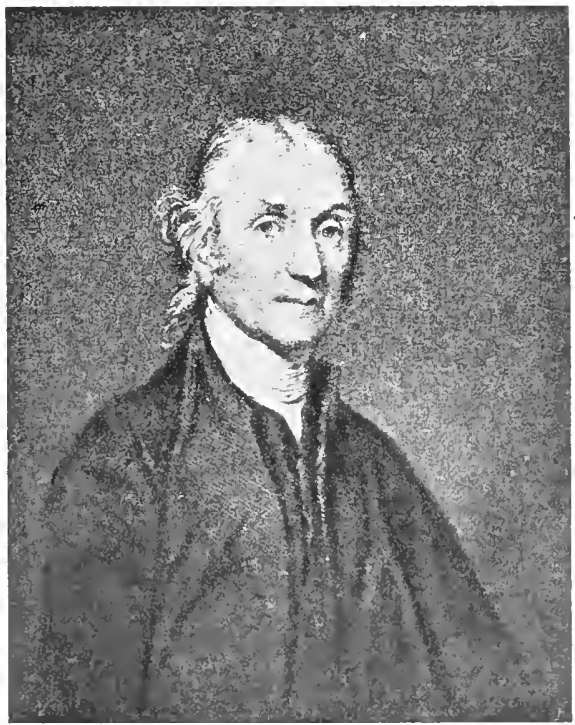

Joseph Priestley (1733-1804). This was corrected in 1791

by Lagrange, the author of the Mécanique analylique, who maintained, through his pupil Hassenfratz, ${ }^{4}$ that the dissolved oxygen of the inspired air slowly takes up earbon and hydrogen from the tissues as the blood courses through them. The finishing tonch was added when Gustav Magnus, in 1837,5 showed, with the aid of a

1 Priestley: Observations on Different Kinds of Air, Phil. 'Tr., Lond., 1772 , Ixii, 147-264, 1 pl.

${ }^{2}$ Lavoisier: Hist. Acad. roy. (l, se., 1775, I'aris, 1778, pp. 520-526.

${ }^{3}$ Ibid., 1780, Paris, 1784, 355-40S.

${ }^{4}$ Hassenfrątz: Ann. d. chim., Paris, 1791, ix, 261-274.

5 Magnus: Ann. d. Phys. u. Chem., Leipz., 1837, xli, 583-606. 
Siprengel's atr-pump, that venous and arteriat blood both contain oxygen as woll as ( 0 , domomstrathe- what ('ruikshank toward the end of his life had partly elucidated-that all the tissues respire in the sense of assinilating oxyecn and giving up $\mathrm{CO}_{2}$. Thus the development of the physiology of respiration, from Borelli to Magmus, was almost exchusively the work of three mathematicians, two physicists, and five chemists.

The discovery of oxyen had a singular effeet upon medical practice. Lomic Jurine, Lonis Odier, l'aseal Joseph Ferro, G. C. Reich, J. B. T. Banmés, sammel Latham Mitchell, and other physicians were carricel away by their imaginations to the extent of attributing diseases either to

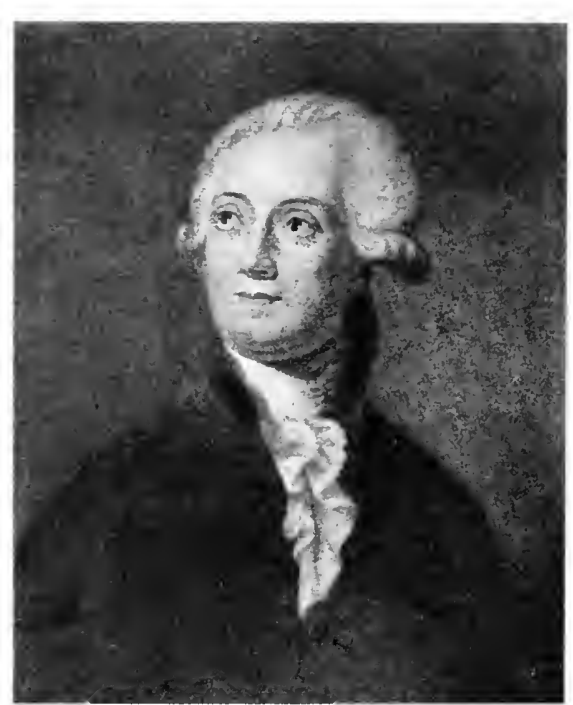

Antoine-Laurent Lavoisier (1743-94.) lack or excess of oxygen, or to some finc-spun modifications of this theory, too numerous and complex to be mentioned here. Of this group, the most memorable perhaps was Thomats Beddoes (1760)-1S08), of Shiffnal, Shropshire, who discovered Humplurey Dary. In 1798 ho fomoled the Pnematic Institute at Clifton for the treatment of disease by inhalation. The apparatus was construeterl by no less than James Watt, who invented the gasometer (1790), and, as Beddoes' assistant, Davy discovered the anesthetic properties of nitrous oxide in 1799. The essitys by Berldoes and Watt "On Factitions Airs" (1794-96) advanee the important therapeutic concept of treating certain diseases by placing the patient in a "factitious atmosphere," which has since found such a definite vindication in the open-air treatment of phthisis and the modern surgery of the chest. Beddoes' general plan of treating respiratory troubles by inhalations of different gases is now standardized as aërotherapy or pneumotherapy. The plan of Beddoes and Watt was revived by Louis Wald(nburg in his apparatus for differential pneumotherapy (1S73) and the subject has been further extended hy the labors of Demarquay (1866), J. Solis Cohen (1867-76), Paul Bert (1878), M. J. Oertel (1856), P. L. Tissier, and others.'

The great center of anatomic teaching in the seventeenth century was Leyden; at the beginning of the eighteenth century, Paris. The rise of Edinburgh as a center of medical teaching was due to the following train of cireumstances. In 1700, John Monro, a Seotch army surgeon of good family, settled in Edinburgh, and, knowing of the superiority of continental training in medicine,

1 See Neuburger: Einleitung, 108, and Syst. Physiol. Therap. (ed. S. Solis Cohen), 1903, x, passim. 
conceived the idea of starting a medical school in the northern calpital, mainly out of a great affection for his only son, Alexander, whom he desired to leave well established in this world. In accordance with this plan, young Alexander Monro received a careful medical education at London, Paris, and Leyden, becoming a warm friend of Cheselden and Boerhaave, and, on returning to Edinburgh in 1719, was duly examined and qualified by the surgeon's Guild, and, in 1720, on recommendation of the Town Council, was elected professor of anatomy in the newly established miversity at the age of twenty-two. Being a teacher of marked ability, his courses were soon followed by enthusiastic students in large numbers, the roster climbing from 57 , in 1720 , to 182 , in 1749 , this stcarly arithmetic progression heing interrupted only by the Rebellion of ' 45 . Alexander Momro followed his father's plan for his own son, and the latter extended the same policy to the grandson, both of whom were also named Aleximder, so that the three Monros, primus, secundus, and tertius, as they were called, hold the chair of anatomy at Edinburgh in uninterrupted sucoession, like some entailed estate, for a period of one hundred and twenty-six

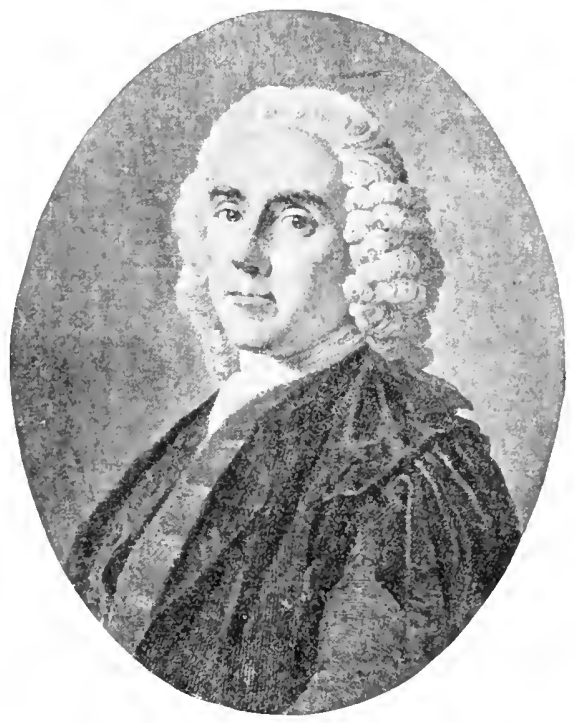

Alexanrler Momro primus (1697-1767). yeals $(1720-1846)$. The

men of the Monro dynasty were, all of them, original characters of unusual attainments, authors of many valuable works, morbid on the subject of controversy, it is true, but in every way worthy of the confidence placed in them by their fellow-townsmen. During the period 1720-90, some 12,800 students were taught by Monro primus and secundus alone, and it was largely due to them that Edinburgh became the great center of medical teaching that it was in the "last century."

Anatomie research in this period did not attain the britlianey it had in the preeeding eentury, nearly every year of which was distinguished by some new diseovery. Many of the best anatomists of the eighteenth century, such at Cheselden, Pott, the Monros, the Hunters, Desault, Scarpa, were so-ealled surgeon-anatomists, and the studies of the time were mainly topographic 
and icomographice. Surgical anatomy, in fart, bugins poprerly with the writ-

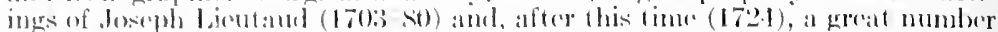

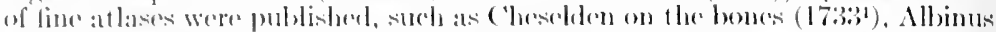

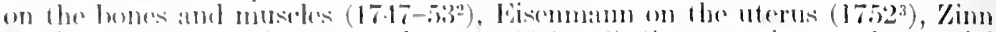

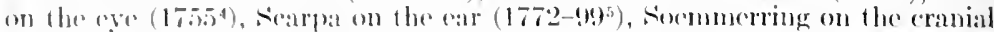

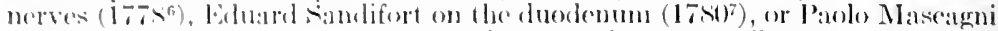
on the lymphaties (175-s). These and many others were all gat hered together

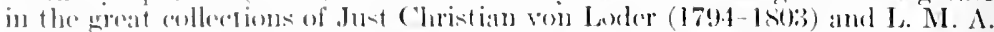

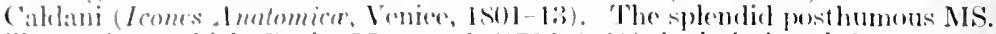
illustrations which Paolo Mascagni (1752-1815) had designed for a great, andomic atlas were cutpusted fo his prosector, Franceseo Antommarehi (Nipoleon s physedian at Ft. Holena). for publication, and were issucel by him insumptuets style in Is19. and axain, in 1821 and $1823-32$, by others whem the

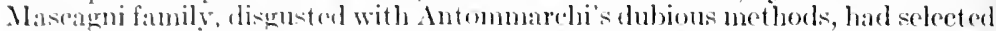
iss erlitors. Anfommanchi subsequenty plagiarizod a number of Mascagui's plates in a work purperting to be his own. The surgeons Pierre Dionis and William Cheselden wreto anstomic text-books which were both of them popular in their day, but probably the best all-round treatise on the subject between Fesalius and lidehat was the Exposition anatomique (1723) of the Danish racher Jakob Benignus Winslow (16i(i9-17(i0)), a pupil of Duverney, who did mole to comblense and systematize what was known, especially in regard to such matters as the origin, insertion. and nomenelature of the different museles. lJis work was the authoritative text-book for nearly a century. 'There was a fair showing of those specializel investigations of physiologie inport which adied so mueh luster to seventeenth eentury anatomy. Duverney's work on the car (16s;) was very ably supplemented by the investigations of Valsalva (170.1) and Cotugno (1774), and with these miy be montioned the monographs of Cowper on the urethral glands $\left(170^{9}\right)$, of Abraham Vater on the ampulla of the bile-duet $\left(17200^{0}\right)$, of Lieberkibh on the intestinal glands, ${ }^{11}$ of James Donglas on the peritoneum (173012), of the elder Meckel (1748 ${ }^{13}$ ) and Wrisberg $\left(177^{14}\right)$ on the vagus nerve, of Kinn on the ciliary ligaments $\left(1753^{15}\right)$, and the varied researches of simtorini $\left(1724^{16}\right)$.

1 Cheselelen: Osteographia, London, 1733. 1747.

2 B. S. Albinus: Tabule sceleti et musculorum corporis humani, Leyden, 1752.

${ }^{3}$ G. H. Eisenmann: Tabule anatomice quatuor uteri (etc.), Strassburg,

4 J. G. Zinn: Descriptio anatomica oculi humani, Göttingen, 1755.

${ }^{5}$ A. Scarpa: De structura fenestræ rotundx auris et te tympano, Modena, 17.2. De aulitu et olfactu, Pavia, 1789. De penitiorum ossium structura, Leipzig, 1799.

${ }^{6}$ Soemmerring: De basi encephali et originibus nervorum cranio egredientiun, Göttingen, 1778.

7 E. Sandifort: Tabulæ intestini duodeni, Levden, 1780 .

${ }^{8}$ P. Mascagni: Vasorum lymphaticorum corporis humana historia et iconographia, Niena, 1787 .

9 W.. Cowper: Glandularum quarundam, nuper detectarum . . descriptio, London, 1702.

${ }^{10}$ A. Vater: Diss. anat. qua norum bilis diverticulum circa orificium ductus choledochi (ote.), Wittenberg, 1720).

11 J. N. Lieberkihhn: De fabrica et actione villorum intestinorum tenuium hominis, Leyden, 174i).

$12 \mathrm{~J}$. Douglas: A description of the peritonaum, London, 1730.

13 J. F. Meckel: De quinto pare nervorum cerebri, Göttingen, 1748.

${ }^{14} \mathrm{H}$. A. Wrisberg: Observationes anatomica de quinto pare nervorum encephak, Götingen, 1777 .

15 J. G. Zinn: De ligamentis ciliaribus, Göttingen, 1753.

${ }^{16}$ G. D. Santorini: Observationes anatomica, Venice, 1724. 
Toward the end of the century, Samuel Thomas von Soemmerring (1755-1830), a native of Thorn, Western Prussia, wrote a monumental treatise on anatomy (1791-96), which was reissued nearly half a century later by Rudolf Wagner, Henle, and others.'

He made most important researches on the brain, the eye (macula lutea, 1791), the ear, nose, and throat, hernia, the anthropology of the negro (17852.), and the injurious effects of eorsets $\left(1793^{3}\right)$, but is now best remembered for his remarkable aceurney in anatomic illustration and by his classification of the eranial nerves $\left(177 \$^{4}\right)$, which eventually superseded that of Willis. Soemmerring was himself a good artist and trained Christian Koeck to make anattomic drawings under his direction (Choulant). He followed Albinus in fidedity

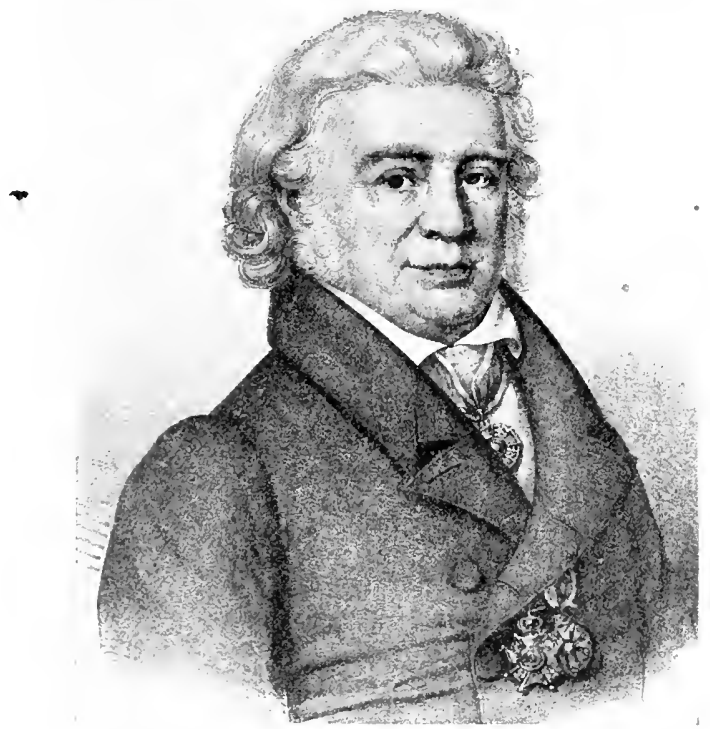

Samuel Thomas von Soemmerring (1755-1830).

to nature and the quest of the "anatomie norm." His devotion to the " $\Lambda$ ttic perfection" of his master is seen in his plates of the brain and cranial nerves (1791-99), the embryo (1799), the eye (1801), the ear (1808), the tongue (1808), the nose (1809), and partienliarly in the exquisitely exceuted skeleton of a girl of Mainz (1797), which was designed to be a companion-piece to the male skeleton of Albinus (1747). Soemmerring was also one of the inventors of the electric telegraph (1809).

${ }^{1} \mathrm{~S}$. T. von Soemmerring: Voum Baue des mensehlichen Körpers, Frankfort on the Main, 1791-96. 1784.

2 Ueber die körperliche Versehiedenheit des Negers vom Europäer, Cassel,

${ }^{3}$ Ueber die Wirkung der Sehnürbrüste, with copper-plate, Berlin, 1793.

${ }^{4}$ De basi eneephali et originibus nervorum cranio egredientium libri quinque, Göttingen, 1778 . 
A remarkinhlo fandy of Prossian anatomists were the Meckels, father, som, and two gramblans.

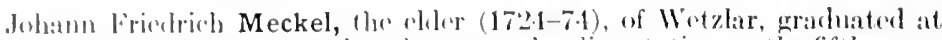
Giotlingen with his ahere-ment ioned moteworthy dissertation on the fifth nerve

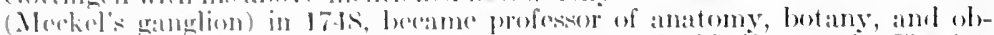
stetries at Berlin in 1751, and was the lirst teateder of nidwifery at the Charite. Ho was the first to deseribe llo sulmaxillary ganglion (1748), and mate important investigations of the nerve-supply of the fares (1751) and the terminat viseral filaments of the veins and lymphaties (I772). His son, Philipp lered-

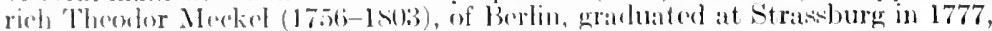
with an important disisertation on the internal war, was professor of anatomy and surgery at Halle in 1759, and editor of the Nowes Archie der praktisshen

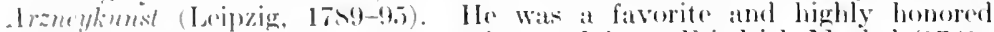

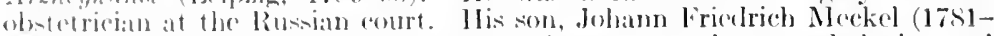
15.33), of Halle, ("alled the younger Meckel, was an eminent pathologist, and the greatest combarative anitomist in (iermany before Johannes Müller. lle has been eallew the Gorman Cuvier. His most inportant works are his treatioes on pathologic anatomy (1\$12-1s), normal human anatomy (1815), his attats of 33 plates representing hmman abnormities $(1817-26)$, and his great system of comparative antomy (1521-30), in which he sots forth the view that the develogment of the higher animals is an epitome of the ancest ral stages which preceded it. II translated Wolfe's monegraph on the development of the intestines in 14l2, and is memorable as the discoverer of the Meckel divertienhmon of the intestines. His younger brother, August Albrecht Meekel (179015:9), of llalle, breame professor of antitomy and forensic medicine at Born in 1521 , and wats a sperialist in the latter branch.

The starting-point of modern embryology was the Theoria Cimerationis (1759) of Caspar Friedrich Wolff (1733-94), of Berlin, onc of the most original spirits of his time, who is eponymically remembered by his discovery of the Wolffian bodies. Wolff revived Harvey's doctrine of epigenesis or gradual building up of parts. and took a firm stand against the current theory that the embryo is already preformed and encased in the ovary (emboite$m e n t)$ : but his negation of germinal continuity and the opposition of Haller prevented his evolutionary ideas from gaining any ground until 1812, when the younger Meckel translated his great monograph on the levelopment of the intestines in the chick (1768-69), one of the acknowledged alasics of embryology. While the plates and the argument of the Theoria Cenerationis (1759) are far inferior to Malpighi's work, Wolff surpassed bimself in the memoir of 1768, described by von Baer as "the greatest masterpiece of scientific observation that we possess." Wolff's view, that the organs are formed from "leaf-like (blastodermic) layers," comes as near as possible to the germ-layer theory of von Baer himself. In 1767 , from investigations of the buds of eabbages, beans, and other plants, Wolff arrived at the conclusion that "all parts of the plant except the stem are modified leaves."

This conchusion was reached independently by Johann Wolfgang von Goethe (1749-1332), in his essay on plant metamorphosis (17901), in which he 1790.

${ }^{1}$ Goethe: Versuch die Metamorphose der Pflanzen zu erklären, Gotha, 
argued deductively the fundamental unity of leaf, flower, and fruit, and the descent of all plants from an arehetypal form (Urpflanze). Like more recent botanists, he was unable to deeide whether the direction of evolution was from folinge-leaf to reproductive leaf, or vice eersa, and he was painfully surprised when schiller observed, "This is not an observation, it is an idlea." The great poet was, however, one of the pioneers of evolution, the first to we the term "morphology," and the diseoverer of the intermaxillary bone (1786). Independently of Oken (1790), he stated the theory that the skull is made up of modified vertebre, and, before Savigny, he saw that the jaws of inseets were modified limbs. In conneetion with Goethe's botanie work, a passing mention should be made of Christian Konrad Sprengel (1750-1816), the old Prussian pastor who was thrown out of his rectorate at Spandau beeause he neglected his congregation for botany, and whose "Newly Discovered Seeret of Nature" (1793) was brought to the front by Darwin. Sprengel pointed out that the colored markings, shapes, nectar, ete., of plants are adaptations to secure cross-fertilizations by insects, and that the latter process is the rule, not the exception. The teleologic signifieance of eross-fertilization was afterward proved by Herbert, Gärtner, and others, and utilized by Darwin. Other forerunners of Darwin were the naturalist Buffon (1707-88), whose Histoire Naturelle (1749-1804), although a popular deseriptive work, containerl many casual denials of the fixity of species and a veiled suggestion of a possible common ancestor for horse and ass, ape and man; and Erasmus Darwin (17311802), whose Loves of the Plants (1789) and Zoönomia (1794) emphasized the gradual evolution of complex organisms from simple primorlial forms, the struggle for existence in animals and plants, sexual selection, protective mimicry, and the indireet influence of environment in producing transformations which may morlify species.

Perhaps the greatest comparative anatomist of the eighteenth century was Felix Vicq d'Azyr (1748-94), permanent seeretary of the Paris Aeademy of Medicine, whose studies of the flexor and extensor museles of man and animals, and the morphology of the brain, the voeal cords, and the strueture of birds and quadripeds, were the best of the period.

The best specimens of anatomic illustration in the eighteenth century show the gradual passage from the copper-plate, through the "taille-douce" to the steel-plate period, as seen in such splendid folios as Cheselden's Osteographia (1733). Haller's Icones anatomica (1743-56), or William Hunter's Anatomia uteri humani gravidi (1774), and the masterpieces of Haller, Santorini, Abinus, Soemmerring, and Scarpa.

The six beautiful plates of pregnancy and parturition made by Riemsdijk for Charles Nicholas Jenty (175s), of London, are rare examples of mezzotint, which was seldom used in medieal illustration.2 ${ }^{2}$ Colored copper-plates were introduced in the eighteenth eentury by Jieques-Christophe Le Blon (16671741), who left only one anatomic specimen of his handiwork, a lit tle plate of the genital organs made for the 1719 edition of Cockburn's treatise on gonorrhea, now execedingly rare. It was followed by the beautiful six anatomic plates which his pupil, Jan Ladmiral (1698-1773), made for Albinus, Ruysch, and others (1736-41), by the eopper-plates in red and black of his pupil, Robert (1750), and by the many pieturesque atlases of his asistant, JacobFabian Gautier d'Agoty $(1717-\dot{\delta} 6)$, a layman whose colored mezzotints are often of striking artistic power, but too grandiose and showy in their temdeney for the ultimate purposes of anatomic illustration. The flamboyant technique, as Choulant pounts out, is not suitable for firlelity and delieaey of detail. Gautier delighted particularly in rendering the graceful physieal habitus of

1 Goethe: Ueber den Zwischenkiefer des Mensehen und der Thiere.

Sova Aeta Acad. Leopold-Carol., Halle, 1831, xv.

2 See J. G. de Lint, Janus, Amst., 1916, xxi, 129-135, 4 pl. 
the Parisionne of the eighternth erontury, fombliar in the many engravings of

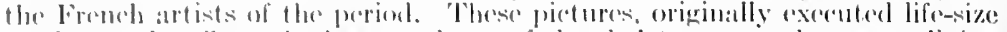

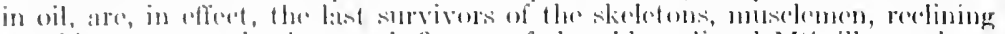

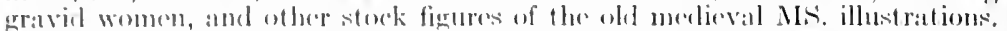
finwol simply as obl-pantiugs, the life-sized (iantire pands, sold in Puris in

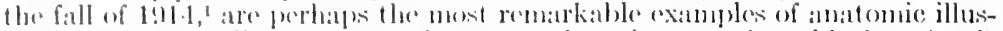

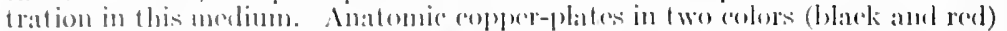

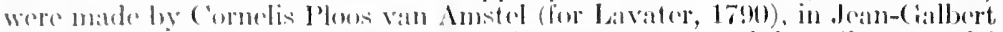

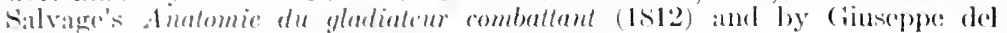
Merlico $(1,11)$.

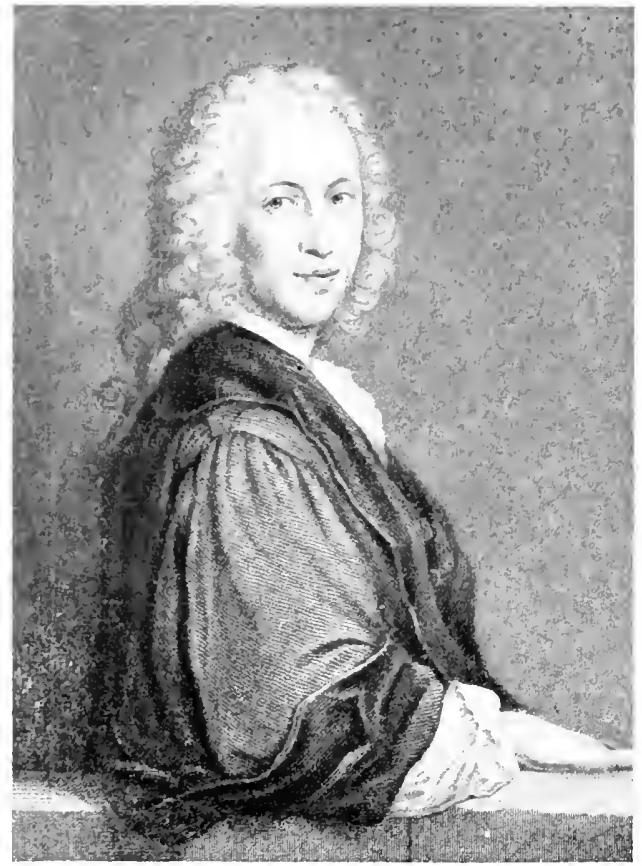

Bernhard Siegfried Albinus (1697-1770).

One of the greatest anatomic illustrators of his time was Bernhard Siegfried Albinus (1697-1770), of Frankfort on the Oder, who had studied uncler Bidloo, Bocrhaave, and Duverney, and held the chairs of anatomy and surgery (1718) and medicine (1745) at the University of Leyden. Albinus edited the works of Harvey, Vesalius, Fabricius, and Eustachius, and his atlases of the bones $(1726,1753)$, the muscles (1734), the veins and arteries of the intestines (1736), the fetal bones (1737), the skeleton and skeletal muscles $(1747,1762)$, the gravid uterus (1749), are all justly renowned for their beauty and accuracy of illustration and for the elegant style of the accompanying text.

${ }^{1}$ For cuts of whieh, sec Laneet, Lond., 1914, i, 557. 
Under Albinus' direction, the artist Jan Wandelaer established a new anatomic norm in ilhstration, founded upon the closest scientific observation. In this regard, both the seientifie and artistic anatomy of the period beeame, as Choulant says, truly Althinian, as seen in the statuette éeorehés of Fischer (1754). Albinus was also held to be an incomparable lecturer, and was a master of the art of anatomic injection. In opposition to Althinus, Pieter Camper (1722-59), who made his own drawings, mantained that anatomic subjects should not be represented in perspective, as had been the custom from Vesilius to Haller, but arehitecturatly, $i$. e., not as if seen from a particular angle, but as if the axes of vision struck each part of the object from the sume distance. This mode of orthographic projection had been used by Leonardo in some of his drawings. It oceasioned bitter controversy between Camper and Albinus.

Of all medical men who have illustrated their own books, probably none have ever exhibited such striking artistic talent as that brilliant Venetian, Antonio Scarpa (1747-1832). In appearance like the routhful Napoleon, Scarpa was a virtuoso in the most varied sense, a great anatomist and surgeon, equally skilled as orthopedist and ophthalmologist, an irreproachable Latinist, a master of sarcasm, yet a most attractive teacher, and a draughtsman of the first order. He himself trained Faustino Anderloni to execute the copper-engravings from his drawings (choulant). In anatomy he is remembered for his discovery of the membranous labyrinth, the nasopalatine nerve, and the triangle in the thigh which bears his name; he was the first to regard arteriosclerosis as a lesion of the inner coats of the arteries, and, in 1832, described (rubito-digital neuralgia (Weir Mitchell's causalgia); he wrote important treatises on hernia and eve diseases, and originated the procedure of iridodialysis; he made a shoe for club-foot which is still the model for orthopedists; but his greatest work is undoubtedly the magnificent Tabule Netrologice (Pavia, 1794), which gives the first proper delineation of the nerves of the heart. Executed with the force of genius, and irreproachable in accuracy of detail, Scarpa's illustrations are the crown and flower of achievement in anatomic pen-drawing, while Anderloni's wonderful copperplates of the same are comparable in brio with the work of sharp, the Drevets, and other masters of the best period of line-engraving.

In Great Britain anatomic study received a mighty impulse from the teaching of the brothers Hunter, and the name of William Hunter is inseparably connected with the advancement of obstetrics. During the eighteenth century, the care of labor eases began to pass from the midwife proper to the trained male obstetrician. Peter Chamberlen attended Queen Henrietta Maria in a miscarriage in 1628. In Paris, the pace for this was already set during the preceling century through the eircumstance that le sieur Boucher was called upon to attend La Vallière, mistress of the "Grand Monarque," in her first confinement in 1663, and in 1670 , Julien Clément attended Mime. de Montespan at the birth of the 
Due de Matine, afteiwats dedivering the Damphine (1682). Clément received the title of "aleoucheme" for his troubled whereupon, in due comrse, male midwifery hereme the fashion among the great ladies of the eourt. In 1692 , Hugh (hamberlen delivered the futme (gueen Anne. Progress in this matter was, of course, slow, and when a rertain obstetrieian told boseph II that the Viemnese women were too modest to have men as midwives, that moral monareh replied, with fitting irony: Utinam non essent adeo

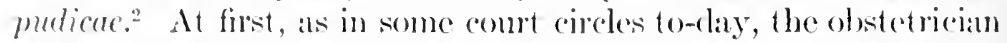
simply supervised or "assisted at" the conduct of labor among

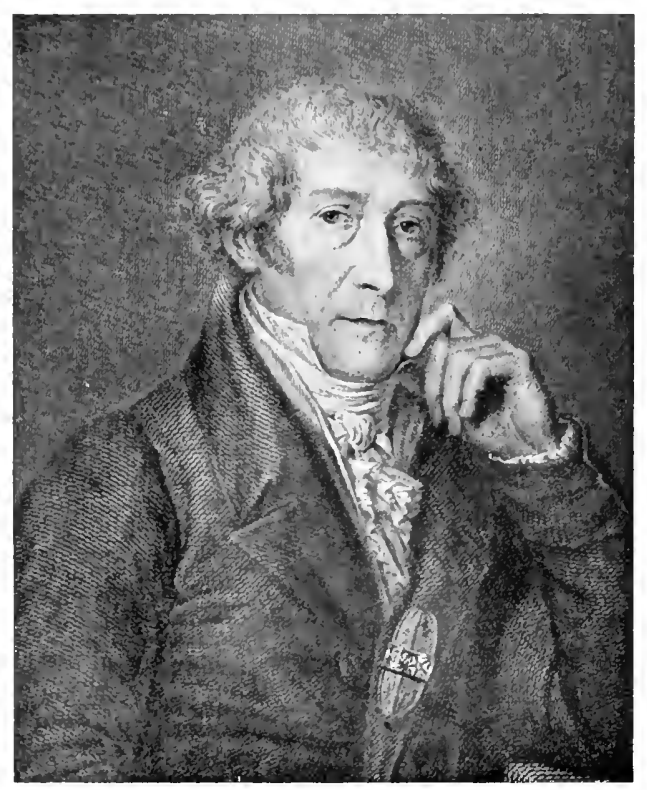

Antonio Scarpa (1747-1832).

those who could afford his services; but as soon as women began to permit physicians to examine the parts as well as deliver them, inductive knowledge of the complex details of midwifery began to make rapid strides. In London this change was principally due to the teaching and influcnce of two Lanarkshire men, William Smellie, and his pupil, William Hunter, to sir Fielding Ould in

1 See Alban Doran: Jour. Obst. and Gynæc. Brit. Emp., Lond., 1915, xxvii, 15s-159.

2 "Woukl they were not modest to that extent." (Cited by Moll.) Perhaps the Emperor was thinking of the advice which van Swieten gave to his father. 
Dublin and to Charles White in Manchester. On the continent, the cause of male midwifery was upheld by Röderer in Göttingen, Camper in Amsterdam, Baudelocque and Levret in Paris, Boër in Vienna, and Saxtorph in Copenhagen.

William Smellie (1697-1763), the friend and teacher of Smollett, learned his obstetries in Paris, and, settling in London in 1739, conceived the idea of teaching the subject at his own house, using a leather-covered manikin supported by actual bones, and charging three guineas for the course. In spite of his uncultivated bearing and the bitter opposition of Mrs. Nihell, the Haymarket midwife, who called him "a great horse godmother of a he-midwife," he acquired a large practice, and to him William Hunter came as resident pupil in 1741. Smellie introduced the steel-lock forceps in 1744 and the curved and double-curved forceps (1751-53). Smellie's Midwifery (1752) was the first book to lay down safe rules for using the forceps and for differentiating contracted from normal pelves by actual measurement. It was deemed

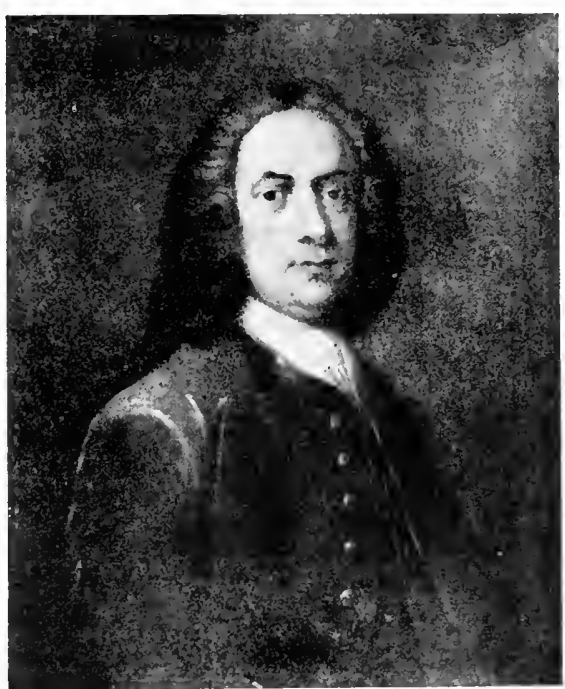

William Smellie (1697-1763). worthy of the honor of a special reprint by the Sydenham Society in 1876-78. Smellie's "Set of Anatomical Tables" (1754) are entirely obstetric.

In 1767 John Harvie, who married Smellie's nicee and suceeeded to his lecture room in 1759 , published a pamphlet in which the advantages of external manual expression of the placenta over traction or internal manipulation are clearly stated, nearly ninety years before Credé (18541). The same idea was gradually conveyed by the Dublin obstetricians Edward Foster (1781), William Dease (1753), Joseph Clarke (1817), Robert Collins (1835), A. H. MeClintoek and S. L. Hardy (1StS), and, although not known outside of Ireland, beeame an established mode of procedure there-the "Dublin method.",

$1 \mathrm{~J}$. Harvie: Practical Directions, shewing a method of preserving the Perinceum in birth and delivering the Placenta without violenee, London, 1767, pp. $45-48$.

2 See H. Jellett: Tr. Roy. Acad. Merl. Ireland, Dublin, 1899-1900, xviii, 305-316; and T. P. C. Kirkpatrick: Jour. Obst. and Gynac. Brit. Empire, London, 1915, xxvii, 1-7. 


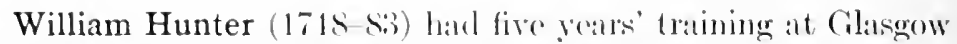
Eniversity and theo as a pupt of cullon's, and followed the example of his lomdon fouchers, sindlie and l)ouglass, hy giving, in 17.46, a compse of private loetures on disserting, operative sur-

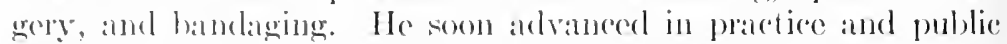

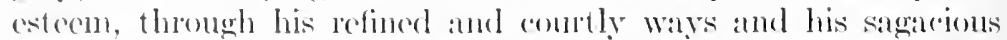
disposition, and oventually hecame the leading olstetrician and consultant of londom. In 1768 , he built the famous anatomice theatel and nusem in Circat Windmill stroct, where the best

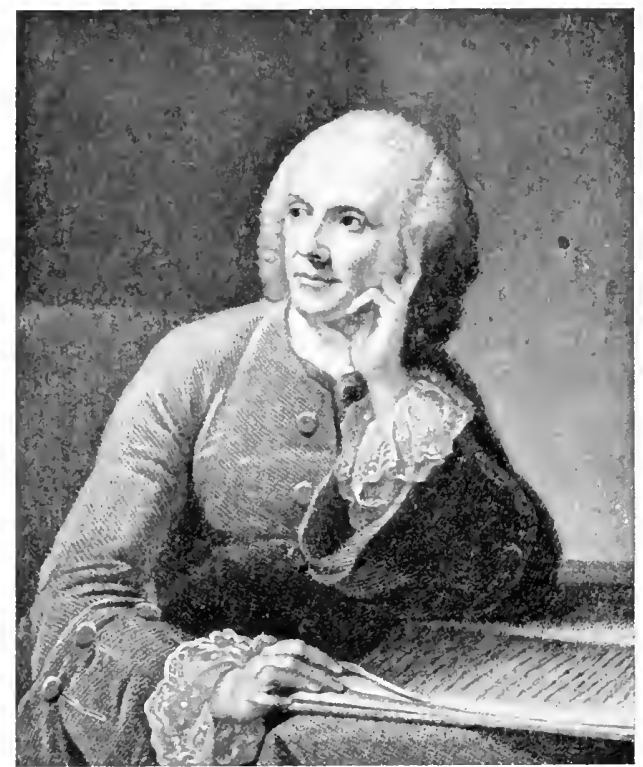

William Hunter (1718-83).

British anatomists and surgeons of the period, including his brother John, were trained. Here he labored with ardor to the end of his days, and few men have shown such austere devotion to science. We may contrast his noble gift of a museum worth $£ 100,000$ to the eity of (ilasgow with the Seotch tenacity of purpose and the self-clenying stoicism of his private life, as summed up in the terse phrases of Stephen Paget: "He never married; he had no country house; he looks, in his portraits, a fastidious, fine gentleman; but he worked till he dropped and he lectured when he was dying." In relation to his colleagues, William Hunter was a jealous, sensitive, thin-blooded, high-strung man, who embittered his own life by needless eontroversy with eontempora- 
ries whom he easily overshadowed. His greatest work is his atlas of the pregnant uterus (London, 1774), the only medieal publication of the celebrated Baskerville Press, illustrated by Riemsdijk at an enormous expense to the anthor, and representing the labor of thirty years. His special discovery of the "decidua reflexa" and the separate maternal and fetal circulation, in which his brother had a part, is the foundation of modern knowleclge of placental anatomy. William Hunter also wrote papers of pernanent value on old dislocations of the shoulders (17621), symphysiotomy $\left(1778^{2}\right)$, the jurisprudence of infanticide $\left(1783^{3}\right)$, and the history of anatomy $\left(1784^{4}\right)$. He was the first to describe arteriovenous aneurysm $\left(1761^{5}\right)$ and retroversion of the uterus $\left(1770^{6}\right)$, and one of the first to recommend the tapping of ovarian cysts $\left(1757^{7}\right)$; but, unlike Smellie, he opposed the use of the forceps, and sometimes exhibited his own instrument, covered with rust, in evidence of the fact that he never wed it.

The obstetric treatise of the Manchester surgeon, Chartes White (London, 1773), stands out in its time as a pioneer work in aseptic midwifery.

The mechanism of labor was first considered by Deventer (1701), by Sir Fielding Ould (1710-89), of I)ublin, in his "Treatise on Midwifery" of 1742, and later by Smellie, André Leveet, J. J. Fried, J. G. Roederer, Pieter Camper, C. J. Berger, Mathias Raxtorph and Jens Bang. ${ }^{8}$

Prominent continental obstetricians of speeial note were Jean Palfyn (1649-1730), who reinvented or reintroduced the forceps (mains de fer) in $1720^{9}$; Guillaume Mauquest de La Motte (1665-1737), who extended the use of podalic version to head presentations (1721); Pirter Cimper (1722-89), who first proposed symphysotomy, and Jean léne sigalult, who first perforned it successfully upon Mme. Sinfehot in 1777; Jean Louis Batudelocrpue, sr.

${ }^{1}$ W. Hunter: Med. Obs. \& Inquiries, Lomd., 1762, ii, 373-381.

2 "Reflections on dividing the Symphysis of the Ossa Pubis." Published as a supplement to the second edition of J. Vaughan's "Cases and Observattions on the Hydrophobia," London, 1778.

3 "On the uncertainty of the signs of murder in the ease of bastard chitdren," in Med. Obs. \& Inquiries, 1778-83, Lond., 1784, vi, 266-290.

${ }^{4}$ Two Introduetory Lectures, London, 1784.

${ }^{5}$ Med. Obs. \& Inquiries, Lond., 1753-57, i, 340; 1762, ii, 390.

${ }^{6}$ Med. Obs. \& Inquiries, Lond., 1771, iv, 409; 1776, v, 388.

${ }^{7}$ Med. Obs. \& Inquiries (1757-61), Lond., 1762, ii, 44, 45.

8 See E. Ingerslev: Arch. f. Geseh. d. Med., Leipz., 1908-9, ii, 141-18s.

9 The instrument was figured by Heister in 1724. Dusere's double-jointed forceps was exhibited in Edinburgh in 1733. Curved foreeps were introduced by Pugh (1740), Levret (1747), Smellie (1751-53). Many others followed. For further details about the history of the forceps in the eighteenth ecintury, see Alban Doran's papers in Jour. Obst. and Ciynec. Brit. Empire, Lond., 1912 , xxii, $119 ; 203: 1913$, xxiii, $3 ; 65$ : xxiv, $1 ; 197: 1915$, xxvii, 154 . The latter entry (1915) gives a good chronology of the history of the forceps. 
(1746-1S10), who insented a bulvimeter and advaned the knowledge of the

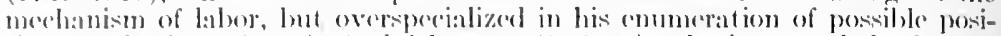
tims of the fotus (1751); Andre leveret (1703-s0), who imporeded the foreeps and extended its use (17.75); Carl Calspar siebold (1736-1807), who performed the first symphysotomy in (iermany (176); and Lateds Johamn Bocer (1751-

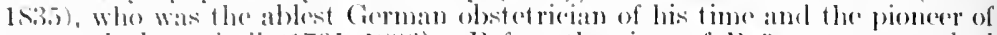
"natural olstetries" (179)1-1st86). Before the time of boër, pregnatuey had

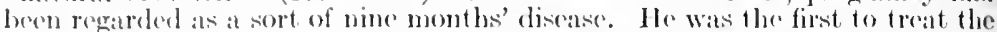
condition ats a physiologic process, and was a forerumner of Ramsbotham in tilting against "niddlesome midwifery." To Mamriesau, l'ortal, and Mauquest the lat Notte is due the improvement of obstetrie diagnosis by digital rexpleration, thestandardization of version and its indieat ions, the substitution of a rational expectant proeedhre for bungling instrmmentation, and the study of eontricted pelsers.

Operative gynecology, as an independent specialty, had no real existence before the first half of the nineternth ecutury. Of stray contributions in the eighternth eentury, we may mention Robert Houstoun's treatment of an "villian dropsy (1701), hy taplung the eyst (otymologically an "ovariotomy," but in no sense an exeision of the ovary); William Itunter's proposal of excision for oviluan eyst in 1757 , and his description of retroversion of the uterus (1770); Sigavilt's symphysiotomy (1777); Matthew Baillic's deseription of dermode eysts of the ovary (1759), and Soemmerring's essay on the injurious effects of corsets (1793). Georg Ernst Stahl (1660-1734) wrote a lengthy monograph on the diseases of spinsters in 1724, and Jean Astrue (165t-1766) achieved a six-volume treatise on diseases of women in 1761-65.

Cp to the time of John Hunter, surgery was entirely in French hands, and Paris was the only place where the subject could be properly studied. In Germany, as a consequence of the great setback of the Thirty Years' War, general surgery was practised mainly by the executioner and the barber (Chirurgus), or else by the wandering incisors, couchers, and bone-setters, while the army surgeon was called a Feldscherer, because it was his duty to shave the officers. Even with such talent as that of Heister, von Sicbold, and Richter, the art had no real status before the time of Frederick the Great. In England there were only two clinical surgeons of first rank before Hunter's time, William Cheselden and Percival Pott. The whole period before Hunter was one of enterprise in respect of new amputations, excisions, or other improvements in operative technic, most of which are associated with French names.

As early as 1673 , Picre Dionis (died 1718) was giving courses on operative surgery on the cadaver, and his treatises on anatomy (1690) and surgery (1707) were, both of them, standard works for half a century, and translated even into Chinese. Dionis' Cours d'opérations is now valued for its aneedotes and pictures of the surgery of the day, in particular the story of the wandering lithotomist, Frère Jacques, who began as a bungling experimenter and became a masterthrough his study of anatomy.

Jean-Louis Petit (1674-1750), of Paris, the leading French surgeon of the ealry eighteenth centnry, was the inventor of the screw-tourniquet, gave the first account of softening of the bones 
and of the formation of clots in wounded arteries, and made improvements in amputations and herniotomy. He was the first to open the mastoid process, an operation which he describes in his posthumous surgical treatise. ${ }^{1}$ Petit's pupil, Dominique Anel (1628-1725), of Toulouse, is remembered by his operation for lacrimal fistula (1712), and by the fact that, like Guillemean in the sixteenth century, he treated a traumatic aneurysm by single ligature (1710) before John Hunter's time. Pierre Brasdor (172197 ) is also remembered for his suggestion that aneurysms be treated by distal ligation, which was made an accomplished fact by Wardrop in 1828 .

Picrre-Joscph Desault (1744-95), the teacher of Bichat, was the founder of an important surgical periodieal, the Journal de Chirurgic (1791-92), did mueh to improve the treatment of fractures, and developed the technic of ligating blood-vessels for aneurysms." Nicholas André (1658-1742) coined the term "orthopeclies" in his treatise of 1741 , and was the first to describe infraorthital neurulgia (1756). The real originator of surgical orthopedies was, however, Jean-André Venel (1740-91), of Cieneva, Switzerland, who, in 1780, founded the first orthopedie institute at Orbe, Canton de Taud, where he achieved many successful results. He was the author of monographs on the treatment of forcign bodies lodged in the esophagus (1769), and on the correction of lateral curvatures and torsion of the spine by mechanical devices (1788). Spinal braces were introduced by Heister (1700), Levischer (1761-68), Portal (1767), Schmidt (1794), and Kohler (1795). Jean-Pierre David (1737-84), a Rouen surgeon, in his essay on the effects of movement and rest in surgical diseases (1779) gave a capital deseription of spinal deformity from caries, with autopsies, contemporaneously with Pott and wrote on necrosis of bone (1782). The name of François Chopart (1743-95) of Paris, is associated with his method of amputating the foot (1792), and that of P. F. Moreau with the carliest exeisions of the elbow $\left(1786-94^{3}\right)$.

The leading ferman surgeons of the age were Lorenz Heister (1683-1758), who made the first post-mortem section of appenlicitis (1711), introduced the term "tracheotomy" (17184), and whose Chirurgie (Nuremberg, 1718) is of unusual historic interest on account of its instructive illustrations, and August Gottlieb

1 J. L. Petit: Traité de mal. chir., Paris, 1774, pp. 153, 160.

${ }^{2}$ P. J. Desault: Euvres chirurgicales, Paris, 1801, 553-580.

${ }^{3}$ P. F. Moreau: Observations pratiques relatives a la résection des articlations affectées de carie, Paris thesis, an. xi (1803).

${ }^{4}$ E. Ebstein: Virchow's Arch., Berl., 1920, cexxvi, 96-99. 
Richter (17.12-1812), who wrote a gool history of surgery (17821S(0), which he left uncompleted, odited an important surgical journal (Chirumgische Bibliothel, 1771-96), and wrote a troatise on heruia $\left(1777-79^{1}\right)$, which is still an acknowledged chassic. With Richter's book on hernia may be gromped the important works on the sime subject by Percival Pott (1756), Antonio de Cimbernat (1793), Pieter Camper (1S01), and Antonio Scarpa (1809).

Johann Clric Bilguer (1720-96), one of Frederick the Great's surgeons general, was the author of a monograph De amputatione membromum rarissime administranda aut quasi abroganda (1761),

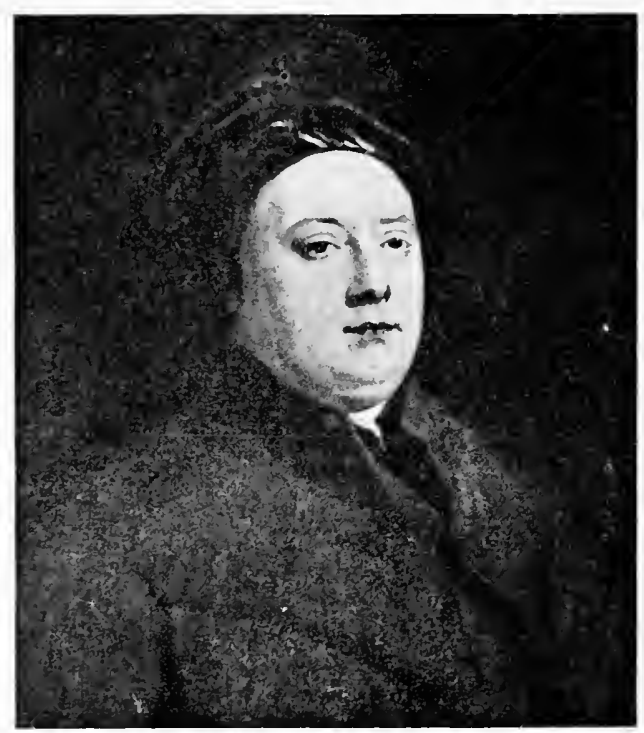

William Cheselden (16S5-1752).

which was translated into French by Tissot in 1764 , and is indeed the most important plea for conservative surgery of the joints before the time of Fergusson, Brodie, and Syme.

Of English surgeons before the time of Hunter, we may consider the names of Cheselden, and his pupil, Sharp, Charles White, of Manchester, and Percival Pott.

William Cheselden (1688-1752), of Somerby, Leicestershire, a pupil of Cowper's, became surgeon to St. Thomas's Hospital in 1718. On publishing his "Treatise on a High Operation for

${ }^{1}$ Richter: Abhandlung von den Brüchen, Göttingen, 1777-79. 
Stone" in 1723, he was assailed with violent abuse by John Douglass, on the score of alleged plagiarism from the latter's Lithotomia Douglassiana (1720). Cheselden accordingly dropped the procedure he had described, and went on to modify the method of Frère Jaeques into a "lateral operation for stone," which he performed March 27, 1727, and which has hardly been improved upon since. In 1728 he introduced a new operation for artificial pupil, consisting of a simple iridotomy with a needle.' His anatomy (1713) was popular in its day, and his atlas of osteology (1733), illustrated by Van der Gucht, is a work of permanent value. Cheselden was a genial, kincl-hearted, versatile man, not unlike Hogarth in appearance. He was a patron of boxing and a good draftsman; prepared the plans for Old Putney Bridge and the Surgeon's Hall in the Old Bailey, and assisted Van der Gucht in sketching bones for his Osteographia under the camera obscura. He was perhaps the most rapid of all the pre-anesthetic operators, performing a lithotomy in fifty-four seconds, which equals or outpaces the time record of even a Langenbeck or a Pirogoff. His social and professional status is embalmed in Pope's couplet:

"I'll do what Mead and Cheselden advise,

To keep these limbs and to preserve those eyes."

Charles White (1728-1813), of Manchester, one of the pionecrs of aseptic midwifery (1773), first excised the head of the humerus in 1768,2 gave the first account of "white swelling," or phlegmasia alba dolens $\left(17 S 4^{3}\right)$, and introduced the method of reduring dislocations of the shoulder by means of the heel in the axilla. De Quincer called him "the most eminent surgeon by much in the North of England."

Percival Pott (1714-88), of London, was surgeon at St. Bartholomew's Hospital from 1744-87, having, in his own words, served it "man and boy for half a century." Through a fall in the street, he sustained the particular fracture of the fibula which bears his name, and, taking up authorship while confined to his bed, he began to produce in rapid succession such masterpieces as his treatises on hernia (1756), head injuries (1760), hydrocele (1762), fistula in ano (1765), fractures and dislocations (1768), and, above all, the epoch-making pamphlet on palsy from spinal deformity (caries) (1779), which was contemporaneous with the more conplete account contained in the prize essay of Jean-Pierre David

1 W. Cheselden: Plil. Tr., Iond., 172S, xxxvi, 447.

${ }^{2}$ C. White: Phil. Tr., Lond., 1769, lix, 39-46, 1 pl. v, $50-57$.

${ }^{3}$ White: An inquiry [etc.], Warrington, 1784; also London M. J., 1785, 
$\left.(177)^{\prime}\right)$. Towated the ond of the century Pott had the largest

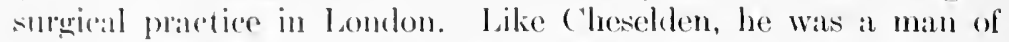
kindly, oharitable nature, and his lectures drew many foreign pupils to st. Bartholomew's.

All the operators before Hunter's time were clinical surgeons, of the stamp of Patré or Richard Wiseman, and knew nothing of pathology. Even long after the publication of Morgagni's great work (1761), the latter scionce had no real existence. For eximple, the first ase of localized appendicitis to be operated on wats reported by Mestivier in $1759,{ }^{2}$ and the pathologic appearances

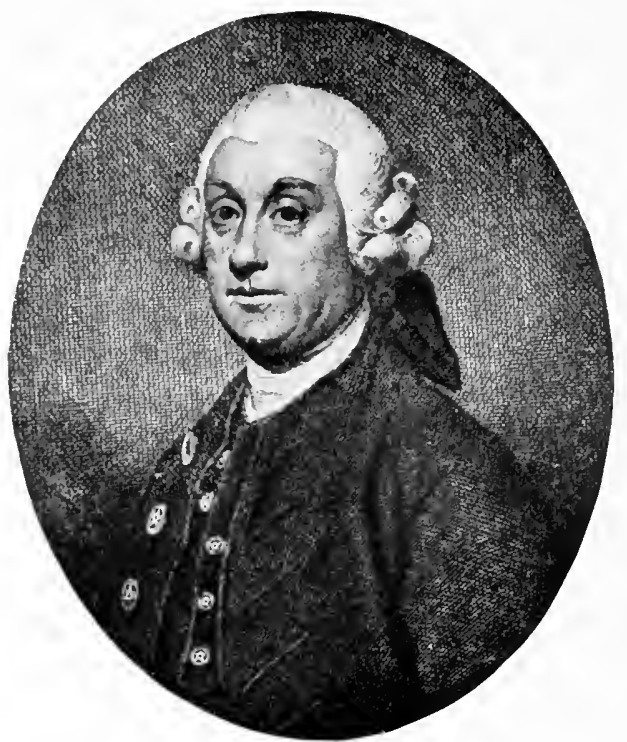

Pereival Pott (1714-8S).

clearly described in the autopsy, yet it made no impression upon practice whatever.

With the advent of John Hunter (1728-93), surgery ceased to be regarded as a mere technical mode of treatment, and began to take its place as a branch of scientific medicine, firmly grounded

${ }^{1}$ David: Dissertation sur les effets du mouvement et du repos dans les maladies chirurgieales, 1779. Although spinal caries is now termed "Pott's disease," Pott dirl not describe the disease or its tuberculous nature, but only the deformity and the sequela of the latter. The tubereulous nature of gibbous spine, found in Egyptian mummies by Elliot Smith, had been surnised by Hippoerates (Disloeations, \$41), eonfirmed by Galen, revived by J. Z. Platner (1744) and was finally established by Delpeeh (1816).

2 See Howard A. Kelly: Les débuts de l'histoire de l'appendicite en France, Presse médicale, Paris, 1903, 437-441. 
in physiology and pathology. Hunter came up to London in 1748 , a raw, uncouth Scotch lad, fonder of taverns and theater galleries than of book-learning. He was taken in hand by his

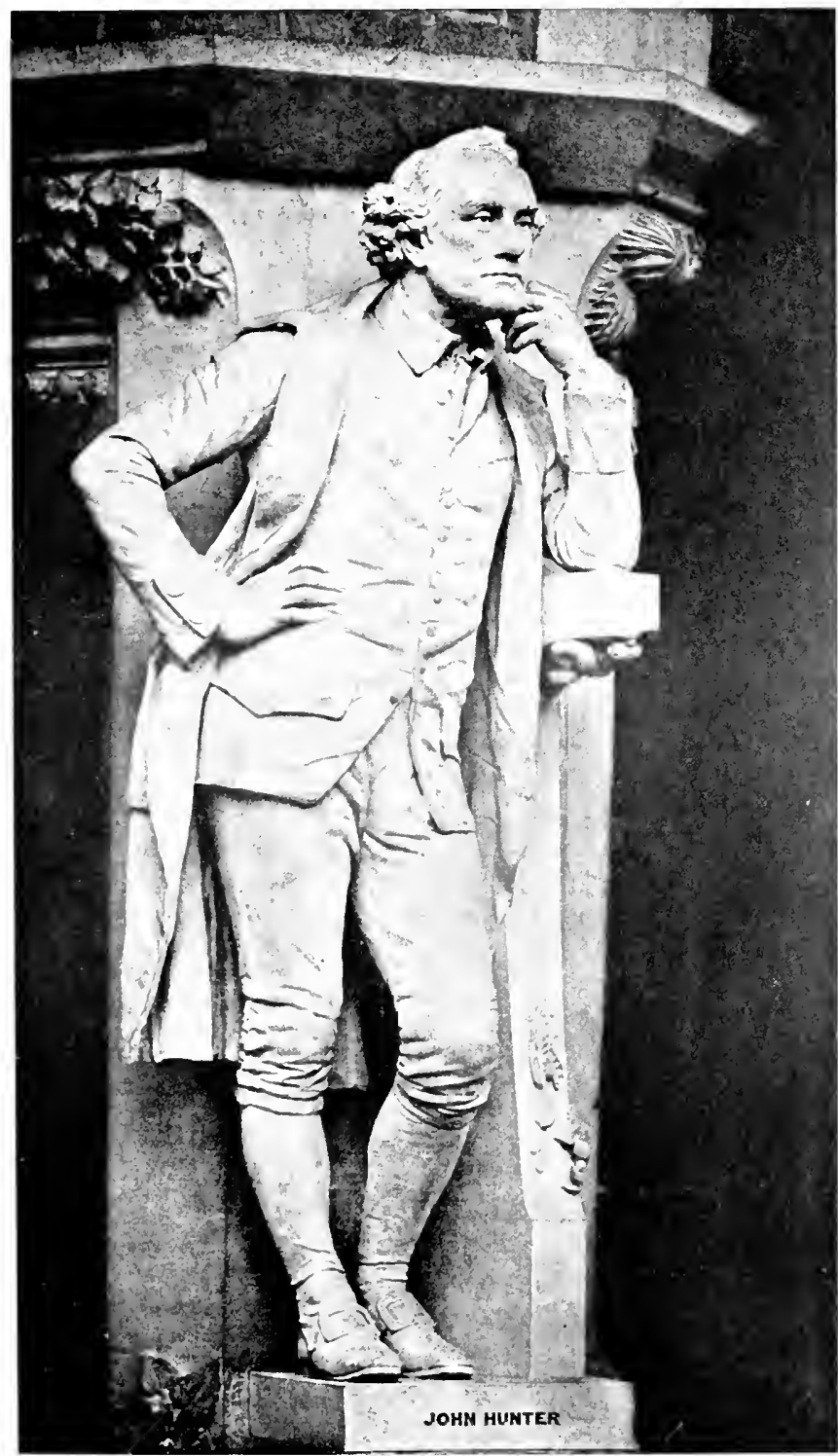

Statue of John Hunter (The Museums, Oxford). (Courtesy of Professor William Stirling, Manchester, England.) 
hother, the refined and arenmplisherd William, and put at dissecting. Hrere he soon found himself, and, at a year's end, was traching antatomy on his own alcount and following surgery under Cheselden and l'ott. Aftre some expericnee as staff surgeon with the expodition to Belle Isto (176i), where he gained his unique knowledge of gumshot womnds, he settled down in Iondon to a life of ardent original investigation, diversified by extensive surgical practice and a commanding influence as a teacher. In persomality. Inunter was very like Ruskin's description of Carlylea Northern god struck hy lightning-in other worrls, a Norse or Saxon sicot crossed by Coltic emotionalism and whimsicality. His nature was kindly and generous, though outwardly rude and repolling, and, if crossed or thwarted, he was apt to paw the air like a restless, high-spirited horse. Late in life, for some private or personal reason, he picked a public quarel with the brother who had formed him and made a man of him, basing the dissension upon a quibhle about priority entirely unworthy of so great an investigator. Yet three years later he lived to mourn this brother's death in tears. Of a piece with this was the pathos of John Hunter's own end. Being a vietim of angina pectoris, he had said: "My life is in the hands of any rascal who chooses to annoy and tease me," and so it fell out. He was something of a scornful Ishmaelite among his professional eolleagues, and being contradicted by one of these in a public discussion, was overtaken by the fatal malady and led out of the room. In a few minutes, the strong, imperious man had passed away. Many years after his death, his brotherin-law, Sir Everard Home, consigned himself to oblivion by burning Hunter's manuscripts after using them as the groundwork for sundry Croonian lectures and other alleged scientific contributions of his own devising. As Hunter was a composite character, so his work was many-sided, and we sense its magnitude not merely in his writings, many of which were destroyed, but in the great museum of orer 13,000 specinens which he collected; and by the influence of such pupils as Jenner, Astley Cooper, Abernethy, C'line, Clift, Parkinson, Blizard, Home, Alanson, Wright Post, and Physick. He deseribed the ramifications of the olfactory nerve in the nose; the arterial supply of the gravid uterus, and discovered the lacrimal ducts in man and many features of the lymphatic system. His permanent position in seience is based mpon the fact that he was the founder of experimental and surgical pathology and a pioneer in comparative physiology and experimental morphology. As the phlogiston-chemistry of his day was sadly mudlled, he was fortunate in knowing nothing about it. He got up no daborate experiments, and his mode of guestioning nature has been justly praised for its simplicity. Thus he demonstrated the 
arrest of digestion in hibernation by passing bits of meat down the throat of lizards kept in cool winter quarters. His observations of the collateral capillary circulation in the antlers of deer in Richmond Park led to his method of treating aneurysms. His studies on the repair of tendons began with an accident he sustained while dancing. He aecidentally inoculated himself with lues, and purposely delayed treatment in order to study the disease in his own person. As a surgical pathologist, he described shock, phlebitis, pyemia, and intussuseeption, and made epoch-making studies of inflammation, gunshot wounds, and the surgieal diseases of the vascular system. He differentiated elearly between hard (Hunterian) chincre and the chancroid ulcer, but his auto-inoculation seems to have confused gonor'rea ${ }^{1}$ with syphilis, a confusion which obtained until the time of Rieord. He introduced artificial feeding by means of a flexible tube passed into the stomach $\left(1790^{2}\right)$ and invented an apparatus for foreed respiration (1793). His greatest innovation in surgery was the establishment of the principle that aneurysms due to arterial clisease should be tied high up in the healthy tissues by a single ligatuie $\left(1786^{3}\right)$, which displaced the old Antyllus method of securing the aneurysm between two ligatures and evacuating its contents. The novel feature was not the single ligature, which had already been employed by Guillemeau (1594) and Anel (1710), but the sound pathologic reasoning upon which its use was based. Not eredited in Hunter's day, it has since saved "thousands of limbs and lives." As a biologist, Hunter dissected and described over 500 different speeies of animals, but, unlike many modern systematists, declined to publish any monographs on a single animal, aiming to connect morphology with physiology by studying the relation between structure and function. He held that the blood is alive, that strueture is the ultimate expression of function, and not vice versa, that abnormities are an expression of "arrested development," and that the embryo in cach successive stage of its existence resembles the completed form of some order lower than itself, leading to the basic principle of eomparative physiology, that the functional activities of the lower forms of life are, as it were, simplifieations of those in the higher. In all this, Hunter was sound and modern. His defective oducattion erops out in his various referenees to the fluid parts of the body as sentient beings, endowed with consciousness, and in such expressions as "the irritation of imperfection," "the stimulus of death," "the blood's consciousness of its being a useful part of the

1 See J. Le Petit: Historique du chanere mou. Paris diss. No. 94, 191:3.

2 Tr. Soc. Improvement Med. \& Chir. Knowledge, Lond., 1793, i, 1\$2-18s.

${ }^{3}$ Ibid., i, 138-181; 1800 , ii, 235-256. 
bodr." Phrases like these not only outvitalize the vitalists, but indiate Hunter's complete innoranee or wilful distegand of the work of his predecessors. In his dispute with the Nbbate Spallanzani about digestion he was hopelessy at fault. Mis reasoning about phlobitis and pyemia was wrong, since he regarded the former condition as the anse of thrombosis, a theory which was demolished by Virehow in 1856. But, when all is said, Hunter remains one of the great all-round biologists like Haller and Johanmes Müller, and, with Pare and Lister, one of the three greatest surgeons of all time. Only a passing reference can be macle to his observations on vital heat in animals and vegetables, fotal smallpos, free martins, superfetation, electric fishes, postmortem diestion of the stomach, and his experiments on pathologic inoculations and on regeneration and transplantation of tismes, in which he is, in some sort, a forerunner of the experimental morphologists and extra-vital tissue-growers of our own time. His four masterpieces are the Natural IIstory of the Human Teeth (1771); the treatise On Venereal Disease (1786); the Observations on Certain Parts of the Animal Geconomy (1786); and the Treatise on the Blood, Inflammation and Gun Shot Wounds (1794). Hunter was the first to study the teeth in a scientific mamner, and the first to recommend complete removal of the pulp in filling them. He introduced the classes cuspids, bicuspids, molars and incisors, enlarged upon dental malocclusion, and devised appliances for correcting the condition. His work was preceded by a French and a German classic, Pierre Fauchard's Le Chirmgien Dentiste (172S), and Philipp Pfaff's Abhandlung von den Zähnen (1756), these three books being the most important in the history of dentistry. The second edition of Fauchard's work (1746) contains (pp. 275-277) the first account of pyorrhoea alveolaris, familiarly called Riggs's disease, after the American dentist, John M. Pigess, who, in $1876,{ }^{1}$ introduced the modern heroic treatment of the condition by scraping the teeth to the roots. Fauchard was also the first to employ orthodontal procedure in the treatment of malocelusion.

Hunter's immediate successor in London was his devoted pupil, John Abernethy (1764-1S31), who constituted himself a sort of champion of his master's physiologic theories, which he dramatized in the lecture room by his poetic imagination and vigorous style of delivery. Abernethy was the first to ligate the external iliac artery for aneurysm (1796), an operation which he performed four times, twice with success.? He ligated the common carotid

1 J. M. Piggs: Penn. J. Dent. Sc., Phila., 1si6, iii, 99-104.

2J. Abernethy: Surgical Observations, London, 1809, 234-292. 
for hemorrhage in 1798, and improved the treatment of lumbar abscesses by incision, admitting as little air as possible. He also described an anomaly of the viscera which is not unlike the Eck fistula $\left(1793^{1}\right)$. He believed that local diseases are either of constitutional origin or due to digestive disturbanees, and, in practice, treated nearly everything by ealomel and blue-mass. Although kind-hearted and generous at bottom, he affeeted a brusque, downright manner with his patients on the ground that masterful

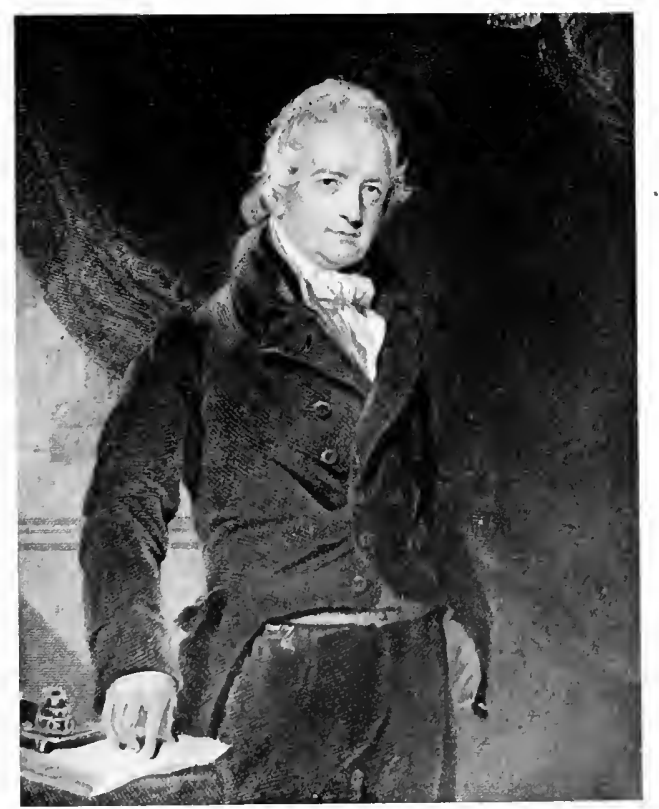

John Abernethy (1764-1831).

rudeness wins confidence, where amiability might suggest weakness and so dininish respect.

Of pioneer operations by American surgeons in the eighteenth century, a passing notice may be taken of an amputation of the shoulder-joint by John Warren, of Boston, in 1781, three eases of laparotomy for extra-uterine pregnancy by John Bard, of New Jersey, in 1759,2 and by William Baynham, of Virginia, in 1791 and $1799^{3}$; and 'Wright Post's operation for femoral aneurysm by the Hunterian method in 1796.4

1 J. Abernethy: Phil. Tr., Lond., 1793, 59-6s, 2 pl.

${ }^{2}$ Bard: Med. Obs. \& Inq., 1757-61, Lond., 1762, ii, 369-372.

${ }^{3}$ Baynham: New York Med. \& Phil. Rev., 1809, i, 160-172.

${ }^{4}$ Post: Am. Med. \& Iliil. Reg., N. Y., 1814, iv, 452. 
The surgery of the eye received an important uplift in 1752 at the hands of lacques Daviel $(169)(j-1762)$, the originator of the modern tratment of ("ataract by extraction of the lens. In the early part of the century Brisscau (1706) and Mâtle-Ian (1707) had brought out the important fact that true catalact is, in effect, a rloudling and hadening of the lens. In a postmortem of 1692 , Misître--Jan had indeed proved that the opaque lens is cataract, but before $1700-7$ it had been regaleded as a sort of skin or pellich. immediately inside the capsule. Daviel was a Norman by birth. After studying surgery with an uncle at Ronen, and showing his courage and humanity in fighting the plague at Toulon and Marseilles, he settled in Paris in 1746, where he soon succeeded in

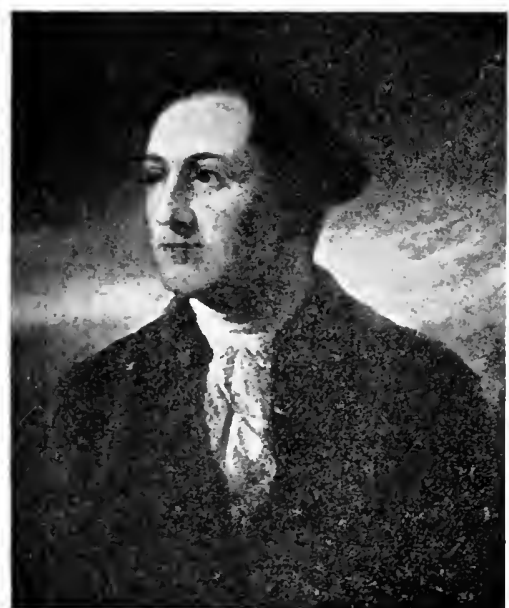

William Baynham $(1749 \sim 1 \$ 14)$. (Courtesy of Dr. Philip s. Roy, Washington, D. C.). surgical practice, being appointed eye surgeon to Louis XV in 1749. In 1752 he sent to the Royal Academy of Surgery his only literary production, the memoir on the cure of eaturact by extraction of the crystalline lens, giving statistics of 100 successful operations out of $115 . \mathrm{By}$ 1756 he had a record of 434 extractions, with only 50 failures, and from that time on his method became a permanent part of ophthalmic procedure, the principal modification being the addition of iridectomy by von Craefe. ${ }^{2}$

Other ophthalmic contributions of note were Sylvester O'Halloran's treatise on glaucoma $(1750)$, Georg Ern-t Stahl's original description of lacrimal fistula $\left(1702^{3}\right)$, Heberden's account of nyctalopia or night-blindness $\left(1767^{4}\right)$. John Dalton's account of color-blindness $\left(1794^{5}\right)$, and Joseph Beer's innovation of irilectomy (1798).

Of equal rank with Daviel in ophthalmology was Thomas Young (1773-1829), of Milverton, England, a Quaker physician

1 J. Daviel: "Sur une nouvelle methode de guérir la cataracte par l'extraction du cristallin" in: Mém. Acarl. roy. de chir., Paris, 1753, ii, 337-354.

${ }^{2}$ Even in the employment of iridectomy, Daviel was a pioneer, as is shown in his letter to Haller (J. de méd., chir., pharm. [etc.], Paris, 1762, xvi, 245251).

${ }^{3}$ Stahl: De fistula lachrymali, Halle, 1702.

${ }^{4}$ Heberden: Med. Tr. Coll. Phys., Lond., 3. ed., 1785, i, 60: 1806-13, iv, 56.

${ }^{5}$ Dalton: Mem. Lit. \& Phil. Soc., Manchester, 1798, v, pt. 1, 28-45. 
and one of the greatest men of science of all time. Learning Latin and many Oriental languages at an early age, he began to study medicine in 1792 under John Hunter, Matthew Baillie, and William Cruikshank, graduated at Göttingen in 1796, took his M.B. and M.D. at Cambridge in 1803 and 1808, and practised in London from 1799 to 1814 . Young was thus the most highly educated physician of his time, and held many scientific positions of honor. Tscherning calls him "the father of physiologic optics," and Helmholtz, "one of the most clear-sighted men who ever lived."

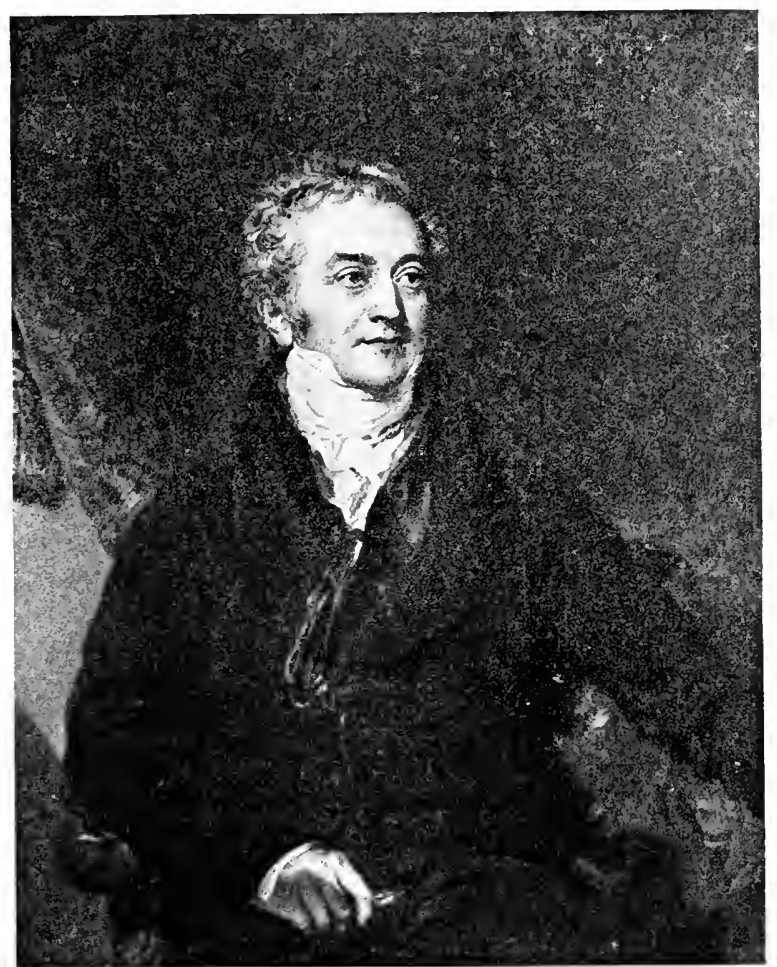

Thomas Young (1773-1829).

In 1792 he read to the Royal Society his paper showing that visual accommodation of the eye at different distances is due to change of curvature in the crystalline lens, ${ }^{1}$ which, however, he erroneously attributed to some muscular structure in the latter. In his memoir, On the Mechanism of the Eye $\left(1801^{2}\right)$, he gave the first description of astigmatism, with measurenents and optical constants. He also stated the now famous Young-Helunholtz theory that color vision is due to retinal structures corresponding to red, green,

1 Young: Phil. Tr., Lond., 1793, 169-181, 1 pl.

2 Ibid., 1801, xci, 23-8S, 5 pl. 
and violet, color-blindness bring defieient response of these to normat stimuli. In his Croomian lecture of lisos, he eloarly staterl the haw governing the flow

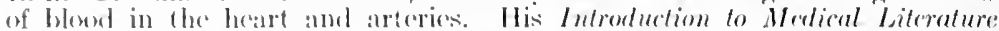

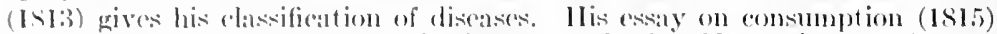

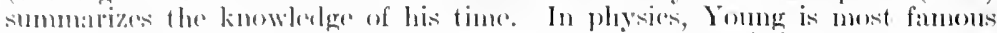
ats the anthor of the watro theory of light (1St) -103$)$, that it is due to undulatous of the other. In 1 sols, he showed its applieation to crystalline refraetion and dispersion phenomena, which lad to the Fresinel theory of doutse refraction (IN2) and the Ilemboltz theory of dispersion for absorbent media. He intemlueed the mexlern physical concepts of "energy" and "work done," showing that they are proportional to aeh other, and in lisot he statrel the theory of capillary attracetion, founded upon the doct rine of energy, which was inderemdently alvianerel by laplace in 1805. 110 atso defined the "modulus of alsticity" (Voung's modulus); regarded heat as the "mechanical vilorafions of particles larger and stronger than those of light"; and his theory of tides (1s1:3) is said to have explained more tidal phenomena than any other hypothesis before the time of Airy. Loung was atso an aecomplished Figytolourist, one of the earliest decipherers of hioroglyphics (losetta Stone), and his discovery that the demotic eharacters are not alphabetic but symbols derived from hieroglyphs and that the latter are not words but phonetic signs, was soon adoptri hy Champollion. His extraordinary versatility is also evidenced in his reports on ship-building, gas-lighting, standardization of the seconds pendulum and the imperial gallon, Jongitude, and lifo insurance.

Young was fond of dancing and good society, but was not regarded as a successful practitioner because he studied symptoms too elosely, although his treatment was admitted to be effective. In person, he was probably the handsomest of all the great physicians. His fine open countenance was of classic contour, expressing great kindliness and good will, and with that sign of the mathematic mind which the old French poet has also esteemed a criterion of beauty-

$$
\text { "Eyes wide apart and keen of sight."1 }
$$

In 1749 the philowpher Denis Diderot (1713-S4) publisher his "Lettres sur les avengles,"showing how the blind survive in the struggle for life by supreme adaptability of their four remaining sonses, and suggesting the possibility of teaching them to read and write by the sense of touch. For this he was thrown into the Bastile for three months. Rousseau visited him in prison and is said to have suggested a system of embossed printing for the 1,lind. In the eighteenth ecntury, blind beggars were so numerous that they often fought and jostled for standing room in plaees where they were likely to receive alms. At the annual fairs it was customary to utilize the blind, lecked out with asses' ears, peacocks' tails, and pasteboard spectacles, as objects of amusement. In 1771, Valentin Hauy (1745-1822), vounger brother of the celebrated mineralogist, saw a burlesque coneert of this kind, greeted day after day by the eoarse guffaws of the vulgar. Deeply affected by the pitiful spectacle, he resolved in his heart to teach the blind to read, write, and play musie. In 17.5, he founded the Institut nationale des jeunes areugles and began the first printing for the blind in raised eharacters. By 17\$6. he was able to make a good exlibition of the suecess of his pupils before Louis XVI and his court, and in the same year pubished his Essai sur l'éducation des aveugles. This was the crigin of modern methods of teaching and caring for the blind.

Otology was very materially advanced in the eighteenth century.

${ }^{1}$ François Villon, Swinburne's translation. 
Among the contributions of capital importance were the studies of the strueture and physiology of the ear by Valsalva $\left(1717^{3}\right)$, Scarpa $\left(1772-89^{2}\right)$, and Cotugno $\left(17 \% 4^{3}\right)$, and the morphologic essays of Geoffroy $\left(1778^{4}\right)$ and Comparetti $\left(1789^{5}\right)$. The existence of an elastic fluid in the labyrinth and its rôle in the transmission of sound was noted, even before Cotugno, by 'Theodor Pyl in 174:2 (Neuburgor ${ }^{6}$ ). Catheterization of the Eustachian tube was first attempted by the French postmaster Guyot in $1724^{7}$ and subsequently performed by Archibald Cleland in 1741.8 Eli, a strolling quack, is creclited with the first perforation of the tympanic membrane for cleafness $\left(1760^{\circ}\right)$, and, in 1755, Jonathan Wathen had treated catarrhal deafness by means of injections into the Eustachian tube through a catheter inserted in the nose. ${ }^{10}$

More important still, the mastoid process was opened for the first time in the history of surgery by Jean-Louis Petit in $1736^{11}$ with subsequent successful eases, by the Prussian army surgeon Jasser in 1776,12 by J. G. H. Fielitz, ${ }^{13}$ and A. F. Löffler, ${ }^{14}$ and by the Danish surgeon Alexander Kölpin in $1796 .^{15}$

Inspired by the suceesses of Rodriguez Pereira, the pioneer of deaf-mute instruction in France, the Abbé Charles-Michacl de l'Épée (1712-89), founded the first sehool for deaf-mutes in Paris (1755), maintained at his own expense, and published many writings on the subject, the most important being his treatise of $1784 .{ }^{16}$ He got much from Bonet (1620) and Amman (1692), and may have acquired some of his manual alphabet from Pereira, but the main feature of his hitherto uuparalleled suceess was his intense and lifelong devotion to his pupils, living among them, identifying himself with them, and sparing himself no trouble and expense for their maintenance. In 1838 a monument was ereeted over his grave in the chureh of St. Roch. His unfinished dietionary of deaf and dumb signs is said to have been completed by his successor, the Abbé Cucurron Sicard (1742-1822), who succeeded far better in training the minds of deaf-mutes. The earliest advoeate of education of the cleaf in Ameriea was Francis Green (1742-1809), of Boston, Massachusetts, who published the treatise Vox oculis subjccta (London, 1783), and translated the Abbé de l'Épée's letters.

The salient features of clinical medicine in the eighteenth century were the introduction of postmortem sections, of new

1 Valsalva: De amre humana tractatus, Utrecht, 1717

scarpa: De structura fenestix rotunda auris, Mutina, 1772; and his: Anatomica disquisitiones de auditu et olfactu, Ticini, 1789.

${ }^{3}$ Cotugno: De aquaduetibus auris humanx internæ, Vienna, 1774.

${ }^{4}$ Cieoffrey: Dissertations sur l'organe de l'ouie, Amsterdam, 1778.

${ }^{5}$ Comparetti: Observationes anatomies de aure interna comparata, Padua, $17 \$ 9$.

${ }^{6}$ Pyl: Dissertatio merliea de auditu, Greifswald, 1742. (See M. Neuburger, Janus, Amst., 1896-7, i, 380.)

${ }^{7}$ Guyot: Hist. Acad. roy. d. sc., 1724, Paris, 1726, 37.

${ }^{8}$ Cleland: Phil. Tr., 1732-41, London, 1747, ix, 124, 1 p.

${ }^{9}$ A. Politzer: Gesch. der Ohrenheilk., Stuttgart, 1907, i, 336.

10 Wathen: Phil. Tr., 1755, Lond., 1756, xlix, 213-222, 1 pl.

1 Petit: Traité d. mal. chir., Paris, 1774, 153; 160.

12 Jasser: In Schmucker's Vermischte chirurgische Schriften, Berlin, 1752, vol. iii, pp. 113-125.

${ }^{13}$ Chir. Biblioth. (Richter), Gïtingen, 17s.5, viii, 524; 17 SS, ix, 5.5.

14 Ibid., $1790, x, 613$.

15 See Schmiegelow: Ztschr. f. Ohronhoilk. Wi(sb., 1913, lxviii, 5i)-59.

${ }^{16} \mathrm{C}$. M. de l'Épée: La véritable manière d'instruire les sourds et mucts. Paris, 1784. 
methods of precision in diannosis, and of preventive inoculation, none of which, howerer, were much appreciated until the following century. In the year 1761 there were published two works which have exerted a profound influenee moon the medicine of our own period, viz., the Inentum Nomm of Anenbrugerer and the 1) Sedibus ot Causis Morborum of Morgangi.

Lcopold Auenbrugger (1722-1809), a Styrian by birth, be(ame physician-in-chice to the Hospital of the Holy Trinity at Vienna in 1751, and there he tested and tried out the value of the discovery which afterward made him famous. His little book is the fust record of the use of immediate percussion of the chest in diagnosis, based upon observation verified by postmortem experiences and experiment. Our anthor's first proposition is that

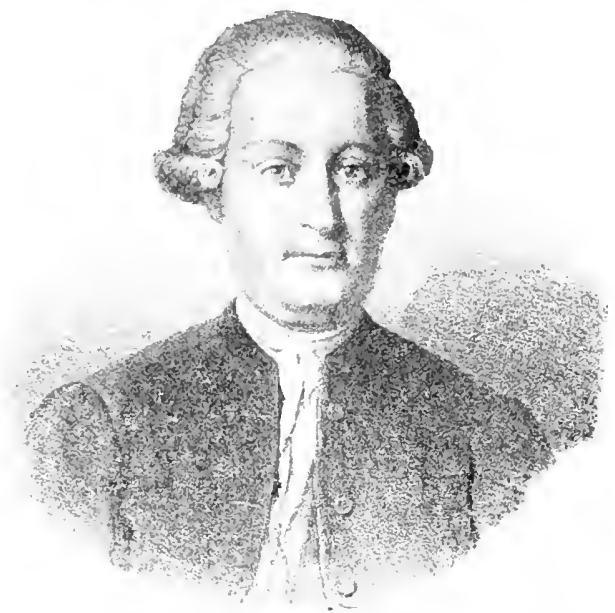

Leopold Auenbrugger, Edler von Aumbrugy (1722-1809).

the chest of a healthy subject sounds, when struck, like a clothrovered drum. He then proceeds to outline his special method of eliciting information by striking the chest gently with the points of the fingers brought together (stretched out straight and afterward flexed), the patient holding his breath; a muffled sound or one of higher pitch than usual indicating the presumable site of a diseased condition. He ascertained the sounds produced by tapping over fluids injected into the chest of a cadaver, localized pectoral fremitus, and carried his findings over into bedside practice, including treatment by thoracentesis. This great discovery was slighted and even snubbed by de Haen, Sprengel, Vogel, Baldinger, and other contemporary writers, Peter Frank gave it but frosty commendation, and only Haller, Stoll and Lud- 
wig were friendly in Auenbrugger's lifetime. The work remainerl unnoticed until Corvisart took it up in 1808, one year before its author's death. Although Corvisart might easily have revamped the idea of percussion as his own discovery, he says with fine feeling that he would not sacrifice the name of Auenbrugger to personal vanity: "It is he and the beautiful invention which of right belongs to him that I wish to recall to life." Auenbrugger himiclf was too well poised and serene by nature to worry about his posthumous reputation. Grave, genial, inflexibly honest, unassuming and charitable, loving science for its own sake, writing the libretto of a little opera ${ }^{1}$ for the delectation of Maria Theresa, and modestly waiving her request that he repeat the experiment on the ground that "one was enough," caring more for the society of his beautiful wife, good music, and Gemüthlichlieit generally than for any notoriety, he is, indeed, a noble example of the substantial worth and charm of old-fashioned German character at its very best. ${ }^{2}$

Giovanni Battista Morgagni (1682-1771), of Forli, a pupil of Valsalva and later a professor at Padua (1715-71), published the results of his life-work in his seventy-ninth year. It consists of 5 books of letters, 70 in number, written in an engagingly communicative manner, and constituting the true foundation of modern pathologic anatomy, in that, for the first time, the records of postmortem findings are brought into correlation with clinical records on a grand scale. As Virchow ${ }^{3}$ said, he introduced the "anatomical concept" into medieal practice. In the preface, Morgagni modestly disavows any special claim to originality, and gives due credit to the works of his predecessors, such as the Sepulchretum of Bonet, which contains all the known postmortems up to 1679 . But while others, like Benivieni, Vesalius, or Bonetus, may have looked at diseased viscera in the dead body with some intelligence, it was by the vast scope of his work and his many deseriptions of new forms of disease that Morgagni made pathology a genuine branch of modern science, even if the seed sown, as Sir Clifford Allbutt contends, fell "upon hard and sterile ground."

Morgagni gave the first deseription of eerebral gummata and disease of the mitral valve; early aceounts of syphilitic ancurysm, aeute yellow at rophy of the liver and tubereulosis of the kidney, and the first reeorded ease of leartbloek (Stokes-Adams disease ${ }^{4}$ ); idlentified the clinical features of pnoumoniir

${ }^{1}$ It was ealled "The Chimney Sweep" (Der Rauchfangkehrer). (Composed by Salieri.)

${ }^{2}$ For Dr. Weir Mitchell's beautiful tribute to Auenbrugger, see Tr. Cong. Am. Phys. 1891, New Haven, 1892, ii, 180, 181.

${ }^{3}$ Virchow: Morgagni und der anatomisehe Gedanke, 1894.

'De Sedibus, Venice, 1761, i, 70. Cited by Sir William Osler. 
with solidifiestion of the lungs, emphasized the extreme importanee of visecral syphilis, and was the first to show that intrateranial smppmation is really at secpuel of diseharge from the ear, a phenomenon wheh "ven Valsallva had conceiver the other way aromel. Norgagni also deseribed what is now known als "Mlorgagnian cataract," and he proved, in many autopses, the Valsalva dietmon that the exrebral lesion in apoplexy is on the opposite side from the rewulting paralysis. 'The De sedibus abolished humoral concepts in pathology for a long period of time.

A worthy follower of Morgagni was Matthew Baillie (17611523), who, like Sncllie, Cullen, and the Hunters, was a native

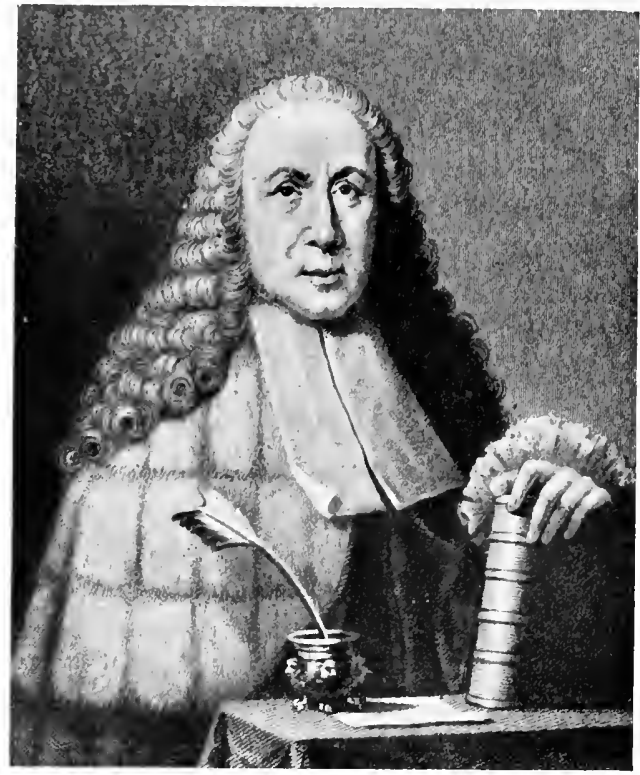

Giovanni Battista Morgagni (1682-1771).

of Lanarkshire, Frotland. He received a good classic education at Balliol College, was advised by his uncle, William Hunter, to study medicine, and, in due course, became a pupil and houseintimate at Winchill Street. He was physician to George III, and is said to have ruined his health by devoting sixteen hours a clay to his extensive practice. Baillie's Morbid Anatomy (London, 1793), illustrated with beautiful copper-plates by William Clift, John Hunter's famulus, differs from Morgagni's work in that it is the first attempt to treat pathology as a subject in and for itself, describing the morbid appearances of each organ in systematic succession, as in a modern text-book. In each instance the autopsy is correlated with a full case-history, and the author secms

${ }^{1}$ E. Ebstein: Deutsche Ztschr. f. Nervenheilk., Loipz., 1914, liii, 130-136. 
to have grasped the idea that postmortem appearances are only end-results, although such results "may then become again the cause of many symptoms." He wisely limited his descriptions, as a rule, to such naked-eye appearances as he actually understood-those in the brain and the viscera-and he did not attempt to deal with the nerves or the spinal cord.

Baillie described transposition of the viseera, ${ }^{1}$ hydrosalpinx, and dermoid cysts of the ovary ${ }^{2}$; gave the first accurate definitions of eirrhosis of the liver and of "bepatization" of the lungs in pneumonia; distinguished renal eysts from renal hydatids; deseribed endocarditis, gastrie ulcer, and the ulceration

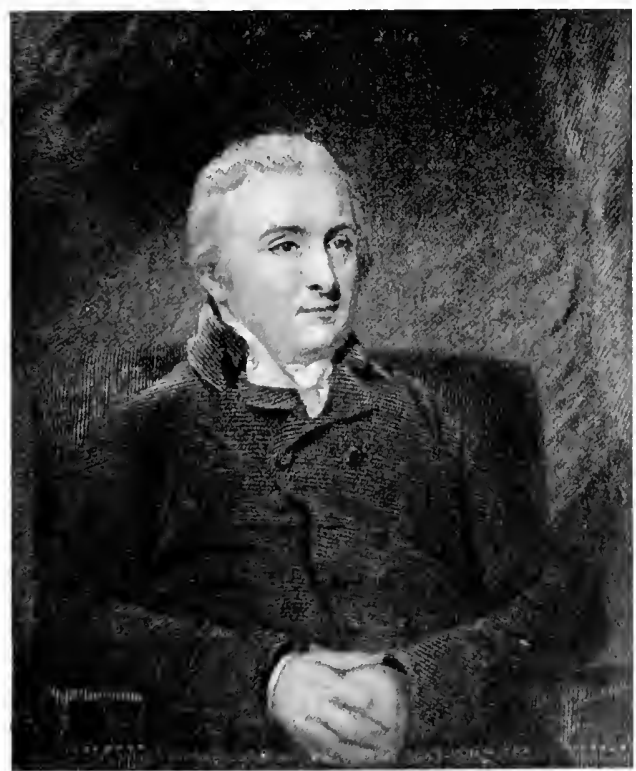

Matthew Baillie (1761-1823). (From the painting by John Hoppner.)

of Pever's patches in typhoid fever (without understanding the latter); and showed that death from "polypus of the heart" is really dhe to a clot of fibrin, and that pulsation of the abdominal aorta is not necessarily a sign of internal disease. In his sceond edition (1797) he mentions rhenmatisn of the heart, to which Piteairn first called attention in his leetures of 1788.

In consultation, Baillie had the same gift of clear, concise expression which distinguished his writings. He was the last inheritor of the "Ciold-headed Cane," and his bust is in Westminster Abbey.

${ }^{1}$ Baillie: Phil. Tr., Lond., 17\&s, lxxvii, 350-363.

${ }^{2}$ London Mcd. Jour., 1789, x, 322-332. 
The Hallerian deetrine of irritability was carried over into pathology by

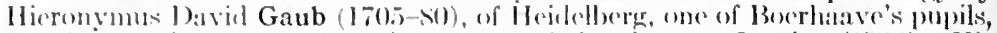

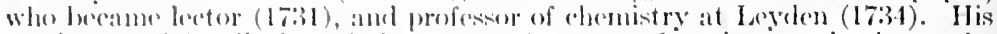
Institutes of Merlical l'athology (17.51), was a favorite text-book on the continent for a long time. Ilo envisaged irritability as a pathologie ineroase of vital pewer and alpplied this concent to disease. This dicl great hirm, as his hook, which passed through many editions and transhations, wats in the hands of all students, to most of whoin Morgangin and Matthew Baillie were unkmown. (atub was more of a dhemist tham a medical matn. Ilis best work is his treatise on preseriptions $\left(1739^{2}\right)$.

During the righternth entury there were some noteworthy attempts to employ instruments of precision in diagnosis. In 1707 . Sir . John Floyer (1619-1734), of Staffordshire, published his Physician's Pulse Watch, which records the first effort in a century to revive the forgot ten lore of Galileo, Kepler, and Sanetorius. loyer, in IIaller's phrase, "broke the jee," in that he tried to get the pulse-rate by timing its boats with a watch, which ran for exactly one minute. Ho tabulated his results, but his work was neglereter or its intention even vitiated by a revival of the old (ialenic doetrine of specific pulses, $i$. e., a special pulse for every disease. Of the pulse lore of the eighteenth century, Dr. Weir Mitcholl, the historian of instrumental precision in medicine, says: "It is observation going minutely mad; a whole Lilliput of symptoms; an exasperating waste of human intelligence," and he arkls that "it was not until a later day, and under the influence of the great Dublin school, that the familiar figure of the doctor, watch in hand, came to be commonplace."

The clinical thermometry dreamed of by Sanctorius, and contetted with by Boerhave, Haller, and de Haen, was revived in the classic Essays and Observations (1740) of Ceorge Martine $(1702-41)$, of Scotland, which is the only scientific treatment of the subject before the time of Wunderlich. Martine's ideas were carricd into practice in the Medical Reports (1798) of James Currie (1756-1805), another sicot, the editor and biographer of Robert Burns, who, after an adventurous experience in America, attained eminence as a practitioner in Liverpool. Long before Brand of sitettin, ('urrie used cold baths in typhoid fever and checked up his results with the clinical thermometer. He used sea-water, as a rule, pouring it over the pationt's body and making the dounlues colder and more frequent, the higher the temperature, as measured by the themomoter. Dr. S. Weir Mitchell saw "absolute genius" in ('urrie's hook, which, like those of Floyer and Martine, was neglected, if not soon forgotten.

${ }^{1}$ Gaub: Institutiones pathologiæ medicinalis, Leyden, 1758.

${ }^{2}$ Gaub: Libellus de methorlo concinnandi formulas medicamentorum, Leyden, 1739. 
In Germany, the use of the eold paek in exanthematous fevers was revived by the Silesian Sigmund Hahn $\left(166^{2}-174^{2}\right)$ and his sons, particularly, in the Psyehroluposia veterum renovata (1738) of Johann sigmund Hahn (1696-1773), which, as late as 1S9S, was reissued in a sixth edition by Wilhelm Winternitz (1835-1917).

One of the ablest clinicians of his time was William Withering (1741-99), of Shropshire, England, memorable as the pioneer in the correct use of digitalis. An Edinburgh graduate of 1766, afterward enjoying a large and lucrative practice at Birmingham, Withering was not only an admirable observer of the English

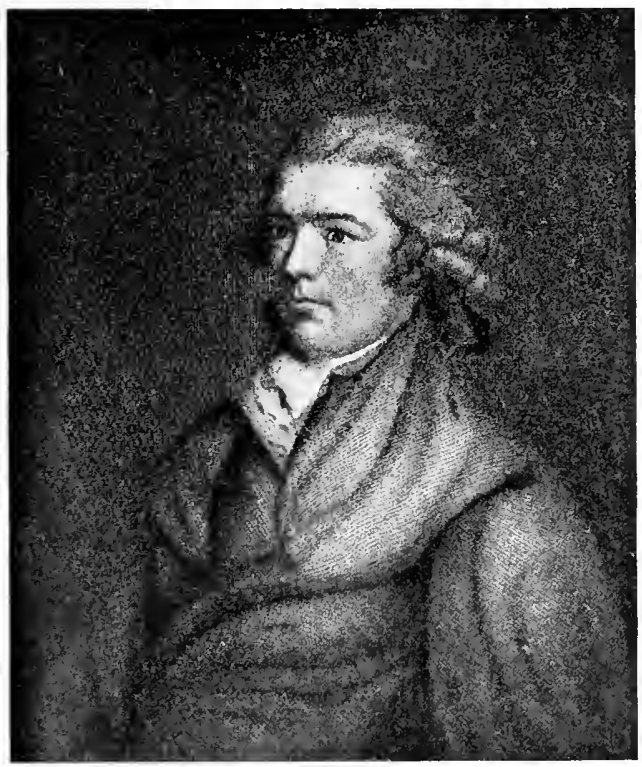

James Currie (17506-1805).

school, but a man of unusual versatility. He described the epidemies of scarlatina and searlatinal sore throat in 1771 and 1778 , and in 1793 recommended an admirable modern treatment for phthisis. He was one of the greatest of medical botanists, wittily called "the flower of physicians," and his Botanical Arrangement of all the Vegetables (1776) is esteemed his masterpiece. He also made analyses of minerals and mineral waters, was an opponent of phlogiston, a member of the famous "Lunar Society," a climatologist, a breeder of dogs and eattle, and solaced his leisure hours with the flute and harpsichord. In 1776 Withering learned from an old grandame in Shropshire that foxglove was good for dropsy. He immediately set about trying it in heart diseases, afterward 
recemmending its use where he comld, and hy 1783 it was introdured into the Edinhmegh Phamanoporia. His views were sup)ported by cullen and fieredy opposed by Letsom." II Account of the Fox-ylore (17S5), a phambeological classice, wats incidentally a protest against the abuses of digitalis, which wowe aboaly ereep)ing in. In Withering's time, dropsy was regarded as a primary discase, and he did not know of the distinction between caldiate and remal dropsy, which was afterward made by Bright. He was disappointed to find that "cerebral dropsy" (hychocephatus) and oviuim (eystic) dropsy did not yield to the drug. Withering was

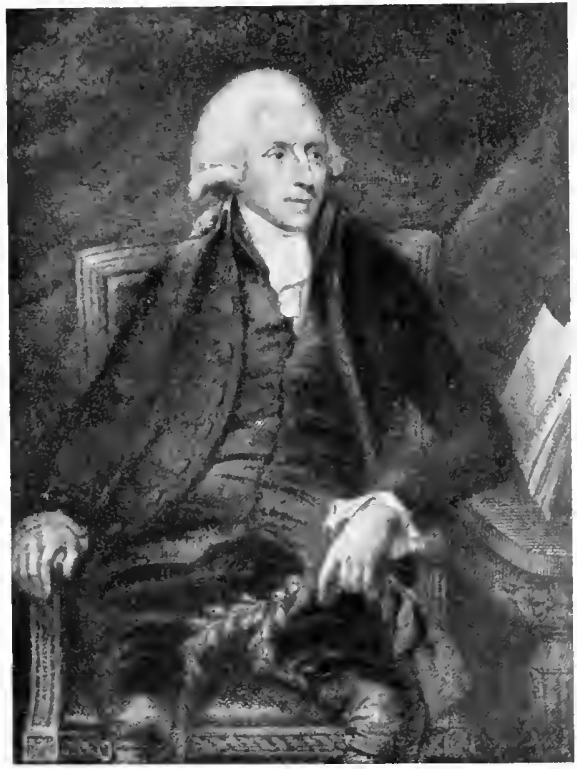

William Withering (1741-99). (From a painting by C. F. Breda.)

buried in the old church at Edghaston, and the fox-glove adorns the monument over his grave.

Among the English chinical teachers of the eighteenth century there is no name more justly and highly esteemed than that of Willian Cullen (1712-90). A pupil of Monro primus, he was instrumental in founding the medical school of Glasgow in 1744, and, during his long life, held the chairs of medicine and chemistry at both Glasgow and Edinburgh. He was one of the first to give clinical or infirmary lectures in Great Britain, and his lectures were the first ever given in the vernacular instead of Latin (1757). Having a mind of philosophic bent, he was probably greater as an

1 G. Foy: Med. Press \& Circ., Lond., 1915, cli, 39. 
inspiring teacher than as a clinician, and was noted for his kindness' in assisting needy students. Although he introduced sonre new remedies into practice, Sir William Hamilton was not far from right when he said that "Cullen did not add a single new fact to medical science." The basis of his teaching was to the effect that every organic phenomenon arose from nerve force or its disorders. Fever, for example, was caused by diminished cerebral power from external injury. His Symopsis nosologice methodice (1769), which divides diseases into fevers, neuroses, eachexias, and local disorders, even including gout among the neuroses, and differentiating thirtyfour varieties of chronic rhemmatism, is now forgotten, although it made his reputation; but his "First Lines of the Practice of Physic" (1776-94) was for years authoritative on medical practiec, even among the pioneers and "forty-niners" in the Far West.

The names of many English physicians of Queen Anne's time, such as Radcliffe, Mead, Garth, Arbuthnot, Sloane, and Blackmore, have a literary and social, rather than a scientifie, interest.

A typical practitioner

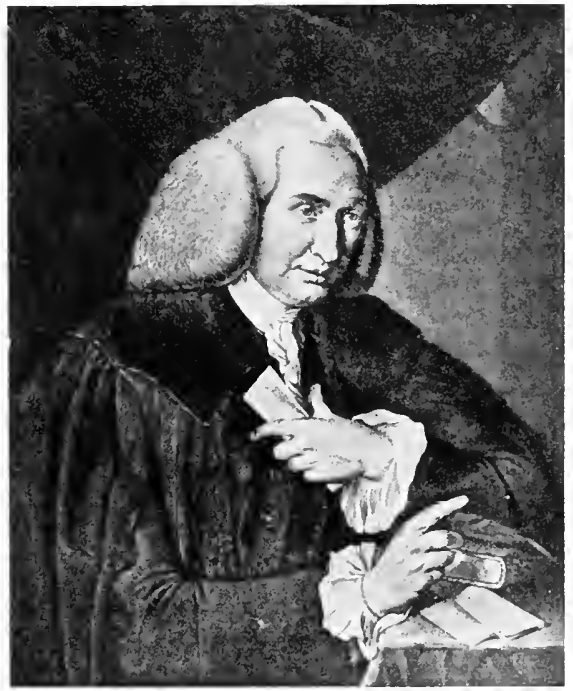

William Cullen (1712-90). of the period, whose lifetime eovered nearly the whole century, was the distinguished IVil-' liam Heberden (1710-1801), of London, Socmmerring's "medieus vere Hippocratieus," whom Dr. Johnson ealled "ultimus Romanorum, the last of our great physicians." A Cambridge graduate of superior attainments, Heberden was esteemed as one of the finest Greek and Hebrew scholars of his time, and he resembles the elassic writers in his careful portrayals of disease. His Commentaries (1802), written in Latin, are the result of a lifetime of conscientious note-taking, and contain his original deseriptions of varicella $\left(1767^{1}\right)$, angina pectoris $\left(1768^{2}\right)$, and the nodules in the fingers

'Heberden: "On the chicken-pox," Med. Tr. Coll. Phys. Lond., 1767. 3. ed., 1785, i, 427-436.

2 Ibid., 1768-70, ii, 59-67. 
which oceur in arthritis deformans (1802), a disease which was clearly differentiated by Haygarth in 1805." Heberden also described "night-blindness, or nyetalopia" (17672). As Sir Dyce Duckworth points out, ${ }^{3}$ Heberden's Commentaries are rich in the subtle notation of such clinical minutiae as the diminished liability to diphtheria after adolesence, the lightning flashes before the eyes in hemicrania, or the tendency of phthisis to rebate in pregnaney, but not after it. An actual case of angina pectoris was described in the memoirs of the Earl of Clarendon (1632) in the person of his own father, but it was Heberden's elassic account that put the disease upon a scientific basis, and his work was soon

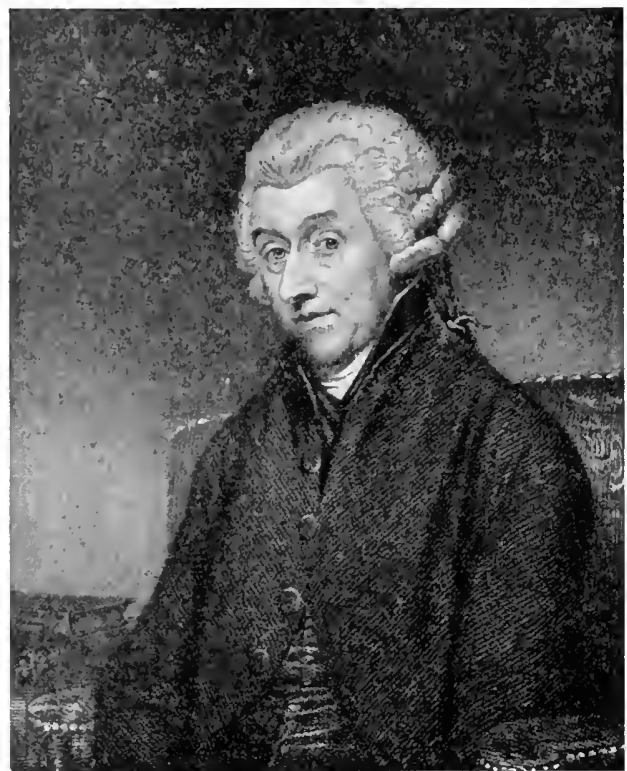

William Heberden (1710-1801).

confirmed by the observations of Parry (1799) and Edward Jenner. In his Essay on Mithridatium and Theriaca (1745), Heberden did a most important service to therapentics by dispelling current superstitions about thesc curious concoctions, and banishing them forever from the pharmacopocia. This little book is one of the shining monuments of medical scholarship.

William Heberden, Jr. (1767-1854), son of the above, was also

${ }^{1}$ Heberden: Commentarii, London, 1802, Cap. 28. p. 130. Haygarth: A clinical history of acute rheumatism, London, 1805, 158 (Arnold Klebs).

${ }^{2}$ Med. Tr. Coll. Phys. Lond., 3d ed., 1785, i, 60; 1806-13, iv, 56.

${ }^{3}$ St. Bartholomew's Hosp. Rep., 1910, Lond., 1911, xlvi, 1-12. 
an able classical scholar, and author of a Latin Epitome of pediatrics (1804, Englished in 1805), which is of such superlative excellence and brevity that it might well be attributed to the elder master.

A group of men who resembled Heberden in character, if not in learning, were Fothergill, Lettsom, and Parry.

John Fothergill (1712-80), of Carr End, Yorkshire, a Quaker pupil of Monro primus, became a very successful and wealthy London practitioner, was noted for his generous philanthropies, his magnificent botanic garden, his splendid collections of shells, insects, and drawings, which after his death fell into the hands

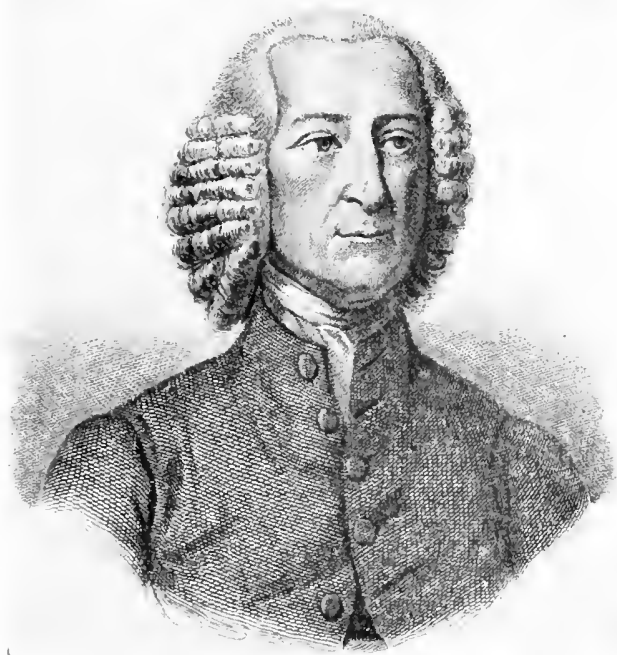

John Fothergill (1712-80).

of his friend, William Hunter. He was a true follower of Syclenham, in his "Observations on the Weather" and Diseases of Iondon" (1751-54), and his original descriptions of diphtheritic sore throat (1748) and facial neuralgia (1773). Fothergill was a warm friend of the American colonies. He advorated the repeal of the Stamp Act in 1765, collaborated with Franklin in a plan for reconeiliation with the nother-country in 1774, and played an important part in the founding of the Pennsylvania Hospital.

John Coakley Lettsom (1744-1815), of Iittle Vandyke (Virgin Islands), also a Quaker, and, like Fothergill, lavish in expenditure and munificent in philanthropy, was one of the original founders of the Medical Society of London, which commemorates 
his mame, with Fothergill's, in the lettsomian and Fothergillian lecture foundations. Lettsom was a prolifie writer on such subjects as offectis of stuffy air (1772), substitutes for wheaten breal (1774), teal, (hhlorosis in boarding-schools (1795), effects of hard drinking (1791), and the like, but his only contribution of value to modern medicine is his original account of alcoholism, which is incidentally the first palper on the drug hatbit. $\left(1789^{1}\right)$. He wrote inn admirable History of the Origin of Medicine (1778), with interesting illust rations.

(alch) Hillier Parry (1755-1S22), a highly esteemed practitioner of Bath, who, like Heberden, accuired a lifelong habit of taking

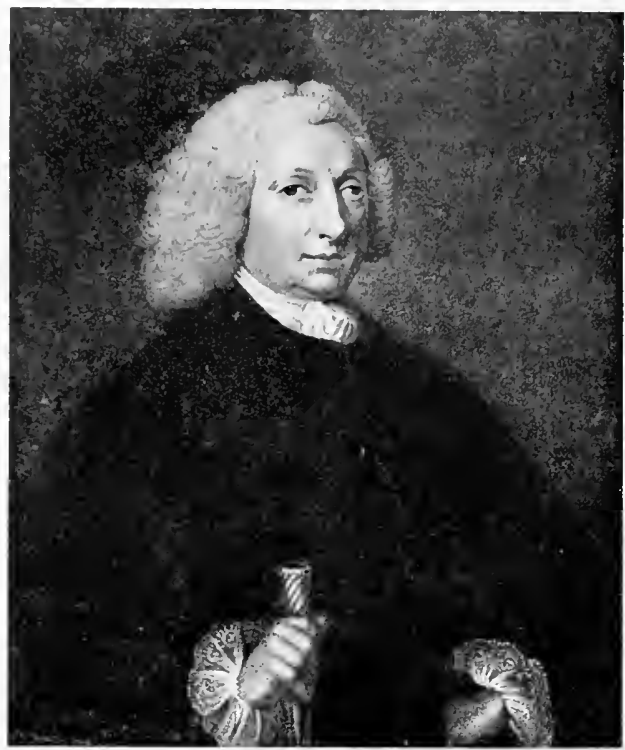

John Huxham (1692-1768).

notes, described the first recorded cases of facial hemiatrophy $\left(1814^{2}\right)$, and of congenital idiopathic dilatation of the colon (1825), and, in 1786, left an account of exophthalmic goiter ${ }^{3}$ so complete and original that it more justly entitles him to the honor of its discovery than either Flajani (1800), Graves (1835), or Basedow (1840).

The work of these men illustrates the eminently practical tendencies of English physicians since the time of Sydenham, and, as

${ }^{1}$ Lettsom: Mem. Med. Soc. Lond., 1779-87, i, 12S-165.

2 Parry: Collected Works, London, 1S25, i, 47S-480.

${ }^{3}$ Ibid., iii, 111-128. 
careful, common-sense olservers, studying their patients' symptoms rather than books, they were true followers of the master. The same thing may be said of two physicians of a more provincial stamp, Huxham and Baker. John Huxham (1692-1768), of Totnes, Devon, one of Boerhaave's pupils who had studied Hippocrates in the original, made meterologic observations like Fothergill's, won the Copley medal for his essay on antimony (1755), and in his Essay on Fevers (1755) gave careful and original observations of many infectious diseases, differentiating, in particular, between the "putrid malignant" and the "slow nervous" fevers, that is, between typhus and typhoid. Huxham devised the familiar tincture of cinchona bark with which his name is associated, and in 1747 recommended that 1200 sailors of Arlmiral Martin's fleet, who had been disabled by seurvy, be put upon a vegetable diet. ${ }^{1}$ In his essay on malignant sore throat (1757), he was the first to olserve the paralysis of the soft palate which attends diphtheria, although he confused the latter with searlatina. In 1739 he described Devonshire colice from cider-drinking), without, however, ascertaining its true cause. This cause was discovered in $1767^{3}$ by Sir George Baker (1722-1809), another Devonshire man, who noticed that the cider-time colic, endemic in Devon, was connected with large pieces of lead used in the vats and cider presses, which were not so employed in other comnties of England. He completed his chain of induction by extracting lead from the Devonshire cider, and proving that none could be found in the cider of Herefordshire. Although he was denomnced from the pulpit as a "faithless son of Devon" for his pains, yot, in course of time, the colic disappeared from the county and Baker extended his investigations of lead-poisoning to iron pipes, glized earthenware, and the linings of iron vessels. Public service of the same high character was rendered by Sir John Pringle (1707-82), the founder of modern military medicine and the originator of the Red Cross idea. Pringle, a Seotch pupil of Bocrhate and Albinus, and a friend of van Swieten's, was a surgeon on the rontinent in the mid-century wars, and surgeon general of the English army from 1742 to 1758 . In his "Observations on the Diseases of the Army" (London, 17.52) he lays down the true principles of military sanitation, especially in regard to the ventilation of hospital wards. Both Pringle and Stephen Hales were instrumental in securing better ventilation for those confined in ships, jails, barracks, and mines. Pringle was also a pioneer of the antiseptic:

1 See his "De seorbuto," Venice, 1766.

${ }^{2}$ De morbo colico Damnoniensi, London, 1739.

${ }^{3}$ Baker: An essay concerning the cause of the endemial colic of Devonshire, London, 1767 . 
idea; gave a good description of typhus fever; showed that jail fever and hospital fever are one and the same; correlated the different forms of dysentery, and named influenza. As he relates, it was about the time of the battle of Dettingen (1743) that the Earl of Stair made the historic suggestion that the nilitary hospitals of both the Fronch and the English sides stiould be regarded as neutral and immune from attack.

"But the Earl of Stair, my late illustrious patron, being sensible of this hardship, when the army was eneamped at Aschaffenburg, proposed to the Duke of Noailles, of whose humanity he was well assured, that the hospitals on both sides should be considered as sanctuaries for the sick, and mutually

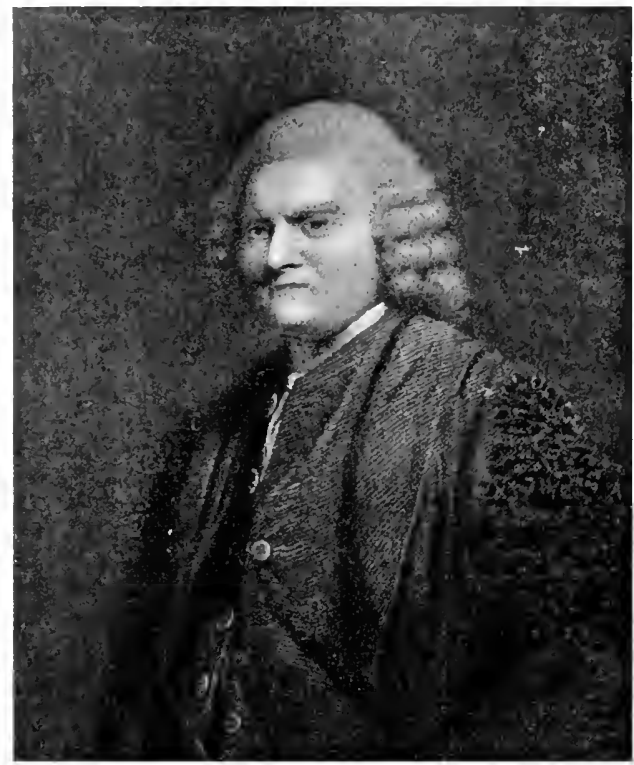

Sir John Pringle $(1707-82)$.

protected. This was readily agreed to by the French General, who took the first opportunity to show a particular regard for his engagement. . . . This agreement was strictly observed on both sides all that eampaign; and though it has been sinee neglected, yet we may hope that on future oceasions the contending parties will make it a precedent."1

The rule remained loosely in force until it was put upon an absolute basis through Henri Dunant, in the Geneva Convention in 1864 .

1 Pringle: Observations on the Diseases of the Army, London, 1752, preface, pp. viii-ix. 
In connection with Pringle's work in military medicine mention should be made of van Swieten's monograph on camp diseases (17581), the sterling Economical and medical observations on military hospitals and eamp diseases (1764) of Richard Brocklesby (1722-97), Hugues Ravaton's Chirurgie d'armée (1768), de Meyserey's La médecinc d'armée (1754), Jean Colombier's C'ode de médecine militaire (1772), and Jourdain le Comte's La santé de Mars (1790). Thomas Diekson Reide's View of Discascs of the Army (1793) and Robert Jackson's Scheme of Metical Arrangement for Armies (1798). Prominent contributions to naval medicine were James Lind's essay on the hygiene of sailors (1757), and Thomas 'Trotter's Medicina nautica (1797-1803).

James Lind (1716-94), a native of Scotlind, who was surgeon in the Royal Navy (1739-48) and became physician to the Royal Naval Hospital at Haslar (1758-83), four years after its foundation (1754), was the founder of naval hygiene in England. His fame rests upon three epoch-making treatises, those on scurvy (1754), naval hygiene (1757), and tropical medicine (1768).

Scurvy became an all-important subject at this time through its ravages among the sailors of Lord Anson's expedition of 1740 ( 75 per ecnt. of the total complement of men). 'The Chamnel Fleet harl 2400 eases after a ten-weeks' cruise in 1779, and Lind had met with 350 cases in a ten-weeks' voyage. He points out that orange and lemon juice had been employed by the Duteh (Ronssius, 1564) in the voyages of Sir Richard Hawkins (1593), and Commodore James Lancaster (1600), after which it had been recommended in John Woodall's Surgeon's Mate (1636, p. 165). Huxham, as we have seen, reeommended a vegetable diet in 1747 . Lind, in his treatise of 1754 , even urged the use of preserved orange and lemon juice. Through his influence, Arlmiral Watson employed lemon juice in 1757, and Sir Gilbert Blane (1749-1834) cured an outbreak in 28 ships of the line in 1782 by means of fresh lemons, limes and oranges, also recommending lime juice in his Observations on the Diseases of Seamen (1785). Through the powerful influence of Blane, an admiralty order enjoining the use of lemon juice was at length issued in 1795, after which seurvy disappeared from the Navy as if by magie. Earl spencer could not find a single ease at Haslar in $1797^{\circ}$ (Roileston). Lind also studied jail (typhus) fever, recommending destruction of the infective agent in clothing by great heat; introduced regular uniforms, powdered foods, and portable soups into the Navy; recommended that the sick in tropical ports should be kept on "hospital ships," and devised a method of distilling sea water for drinking purposes (1761-62). His contemporary, Trotter, who also wrote on seurvy (1786), says that "Lind stands alone in the Navy" as "the father of nautical medicine." ${ }_{2}$

Perhaps the most important English statist of the period was Jolm Heysham (1753-1 834 ), of Lancaster, who commenced practice at Carlisle in 1778, where he founded its first poor-law dispensary, described jail-fever there in 17.81, and, in 1779-8s, made those statistical observations of births, marriages, diseases, and deaths which became the basis of the celebrated "Carlisle Tables" of the actuary, Joshua Milne (1816).

The epoch-making reforms of John Howard (1726-90) in relation to the management of the prisons, hospitals, and lazarettos

1 van Swieten: Kurze Beschreibung und Heilungsart der Krankheiten welche am öftesten in dem Feldlager beobachtet werden, Vienna, 1758.

${ }^{2}$ H. D. Rolleston: Jour. Roy. Naval Med. Serv., Lond., 1915, i, 181-190. 
of Europe $\left(1777-899^{1}\right)$ had much to do with the suppression of that vermin-carried discase, typhus fover.

The work of Johann Conrad Amman (1669)-1724), on the edueation of deaf-mutes $\left(1692^{2}-1700^{2}\right)$. the cofforts of the Abbe dre l'epee $(1712-90)$ to get an alphabet of communication for the deaf and dumb (177/3), the work of Valentin Hang (1745-1522) in educating the blind (175.5), and Pestalozzi's work in the ciuse of popular enlueation $(17 \mathrm{S1}-1 \mathrm{~s}(03)$, are remarkable foutures of serein medicine in this period. In 17st, C. C. Cinmer showed the possibility of vencreal infection from a common drinking-cup. ${ }^{4}$

There was little of value in the clinical medicine of France in the eighteenth century. Its principal representative, Theo-

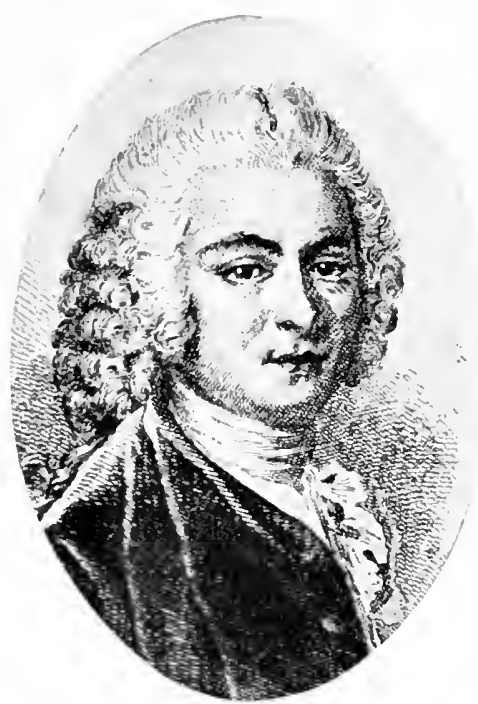

Théophile de Bordeu (1722-76). phile de Bordeu (1722-76), the founder of the Vitalistic School of Montpellier, is now rementbered as a theorist pure and simple. He graduated at Montpellier in 1794,.was director of the baths in the Pyrenees, but spent the greater part of his life in Paris, where he held a high reputation in spite of his wrangles with the Faculty. Like most medical leaders of his time, Bordeu maintained a rigid, dogmatic "system," which was not unlike that of van Helmont.

He held that the organs of the body, with their several functions, are federated with and dependent upon each other, but presided over and regulated by the stomach, the heart, and the brain, which he ealled the "Tripod of Life." Next in importance were the nerves and the glands, the former eentralizing the different functions of the borly, and eonsequently governing the secretions of the latter. Each separate part of the boty harl a vita propria, and the brain as many areas as there were organs governed by it-a foreshadowing of localization. Borleu first stated the doctrine that not only each gland, but each organ of the body, is the workshop of a spreifie substance or secretion, which passes into the blood, and upon these the integration of the

${ }^{1}$ Howarl: The State of the Prisons in England and Wales, Warrington, 1777 ; and his "An Account of the Principal Lazarettos in Europe," Warrington, 1789 .

2 Amman: Surdus lorpuens, Amsterdam, 1692; reprinted, 1700.

${ }^{3}$ De l'Êpée: Institution des sourds et muets par la voie des signes méthodiques, Paris, 1776.

${ }^{4}$ C. G. Gruner: Der gemeinsehaftliche Keleh, Jena, 1785; Die venerische Ansteckung durch gemeinschaftliche Trinkgeschirre, Jena, 1787. 
body as a whole depends. Thus Borleu, as Neuburger has shown, ${ }^{1}$ was very close upon the modern theory of the internal secretions and "hormonic e(puilil)rium," but, as he made no experiments, his ideas ean be regarded as only theoretic. Disease he regarded as passing through the stages of irritation, coetion, and crisis, dependent upon the glandular and other seeretions of the blood. In consequence, he classified diseases, not aceording to their elinical or pathologic manifestations, but arbitrarily as cachcxias. Of these he unrolled an extraordinary list, corresponding to the different organs and seeretions, as bilious, mueous, albuminous, fatty, splenic, seminal, urinary, stercoral, perspiratory, and so on, with an equally complex classification of the pulse as eritical, non-critical, simple critical, eompound eritical, nasal, tracheal, gastrie, renal, uterine, seminal, etc. The most interesting part of his theory is his observation of the effects of the testicular and ovarian seeretions upon the organism. He regarded the aura seminalis of the sexual seeretions as giving a "male (or fenale) tonality" to the organism, "setting the seal upon the animalism of the individual," and, in effeet, "the particular stimulus of the machine (novum quoddam impetum faciens)." In this connection, he made elever studies of the obesity, retiring disposition, and other characteristies of eumuehs, eapons, and spayed animals, suggesting some phases of the modern "pluriglandular syndromes."

Bordeu's successor, Paul-Joseph Barthez (1734-1806), of Montpellier, who was successively a theologian, physician, soldier, editor, lawyer (even a counselor of justice), philosopher, and again a physician, is memorable for his introduction of the term "vital principle" (vitalis agens) to denote the cause of the phenomena in the living body. The vitalism of Borden and Barthez underwent a third transformation in the nimeteenth century as the "seminal vitalisn" of Bouchut.

The rise of the Old Vienna School, under Gerhard van Swieten (1700-72), of Leyden, was a feature of the ascendancy of Austria under Maria Theresa and Joseph II. Van Swieten, who was in special favor with the Empress, did much to advance Austrian medicine and created the world-famed Vienna clinic after the Leyden pattern. As prefect of the Imperial Library at Vienna, which he raised to the first rank, he had great influence upon the advancement of higher and medical edueation by his reorganization of the University. He took the censorship of prohibited books away from the Jesuits, and his stenographic notes, with the characteristic "damnatur" and "Nil mali inveni" have been preservel." He was also a great friend of the poor. As army surgeon, he wrote

${ }^{1}$ M. Neuburger in Janus, Amst., 1903, viii, 26-32; and Wien. klin. Wochensehr., 1911, xxiv, 1367. Neuburger eites the following from Bordeu's "Analyse médicinale du sang" (1774): "J'en eonclus que le sang roule toujours dans son sein des extraits de toutes les parties organiques. . ehriem (des organes) aussi sert de foyer et de laboratoire à une humeur particulière qu'il renvoie dans le sang après l'avoir pléparée sans son sein, après lui awir donné son caractère radical," pp. 943, 948.

2 See Sitzungsb. d. k. Akad. d. Wissenseh. in Wien, Phil.-hist. Cl., 1877, lxxxiv, $3 \$ 7$ et seq.; and Janus, Amst., 1906, xi, 3\$1; 446; 501; 5\$\$ (E.C. van Leersum). Haller is said to have disliked van Swieten because he suspected him of tabooing his poens in Austria. 
an important work upon the hygiene of troops in camp (1758). As a clinician, he noted such things as the aura in hydrophobia, the occurrence of symmetric gangrene in spinal affections, used the Fahronheit thermometer, was instrmmental in bringing about the internal use of corrosive sublimate (liquor Swietenii) in syphilis and loft a commentary upon the aphorisms of Boerhaave $(17+1-76)$, which oceupied him for over thirty years.

Besilles vin Swieten, the Vienna group included such prominent figures as the quarrelsome, pragmatic Anton de Haen (1704-76), of 'The Hague, the rabid defender of belief in witeheraft, who wrote at treatise on hospital therapenties in 15 volumes (1758-69), maintained the supremacy of elinical experience over physiologie experimentation, used the thermometer at the bedside, first noted that there is an elevation of temperature in the algicl stage of ague, and cmployed electrotherapy; the bureaucratic Anton Stoerck (1731$1803)$, of swabia, who was the greait chmmpion of emeties and did some careful work in pharmacology and toxicology, notably his investigations of hemlock $(1760-61)$, stramonium, hyoscyamus, and aconite (1762), colchicum (1763), and pulsatilla (1771); the epidemiologist, Maximitian Stoll (1742-87), of Swabia, who followed Sydenham in metcorologic studies of the "genius epidemicus," influenecd even Bretonneau in therapenties, wrote woll upon medical othics, and brought the old Vienna school to its high-water mark; Marcus Anton von Plenciz, sr. (1705-86), who, in his tract on scirlatina $\left(1762^{1}\right)$, alvanced the idea of a contagium animatum, with a special sminium rerminosum for each discase; the dermatologist, Joseph Jacob von Plenck $(1732-1507)$, who followed the method of Limnous in classifying diseases of the skin $\left(1776^{2}\right)$; Johann Valentin von Hildenbrand (1763-1818), who had some inklings of the difference between typhus and typhoid fevers $\left(1810^{3}\right)$; and, above all, the sterling figures of Auenbrugger and Frank.

The leading practitioners in Germany were Stahl, Hoffmann, Kïmpf, Werlhof, Zimmermann, Wichmann, Senckenberg, Reil, and Heim. Of these, Paul Gottlieb Werlhof (1699-1767), of Helmstädt, court physician at Hannover, was a great friend of Haller, and, like him, wrote poems in the German language and medical works in Latin. He is now remembered by his original description of purpura hæmorrhagica, or morbus maculosus Werlhofii $\left(1735^{4}\right)$.

The snobbish Johann Georg Zimmermann (1728-95), of Brugg, Switzerland, a practitioner of great repute, who succeeded Werlhof as ordinarius at Hannover, was the author of an important monograph on "Epidemic Dysentery in the Year 1765,"5 and of the famous "Treatise on Solitude," which so tickled the sentimental palates of our grandfathers.

${ }^{1}$ Plenciz: Tractatus III de scarlatina.

2 Plenck: Doctrina de morbis cutaneis, Vienna, 1776.

${ }^{3}$ Hildenbrand: Ueber den ansteckenden Typhus, Vienna, 1810.

${ }^{4}$ Werlhof: Opera omnia, Hannover, 1775, ii, 615-636. (Dissertation published at Brunswick, 1735.)

${ }^{5}$ J. G. Zimmermann: Von der Ruhr unter dem Volke im Jahr 1765, Zürich, 1767. 
Johann Ernst Wichmann (1740-1802), a contemporary of Werlhof's at Hannover, is notable for his monograph on scabies $\left(1786^{1}\right)$; and Joham Christian Senckenberg (1702-72), for his public-spirited endowment of the Senckenberg Foundation at Frankfort on the Main.

Johann Christian Reil (1759-1813), of Eastern Frisia, professor of medicine at Halle (1787) and Berlin (1810), was the original editor of the Archiv für die Physiologie (Halle, 1795-1815), the first periodical to be devoted to the science. It eventually passed into the elder Meckel's hands, and became in the course of time the epoch-making Müller's Archiv (1834-58).

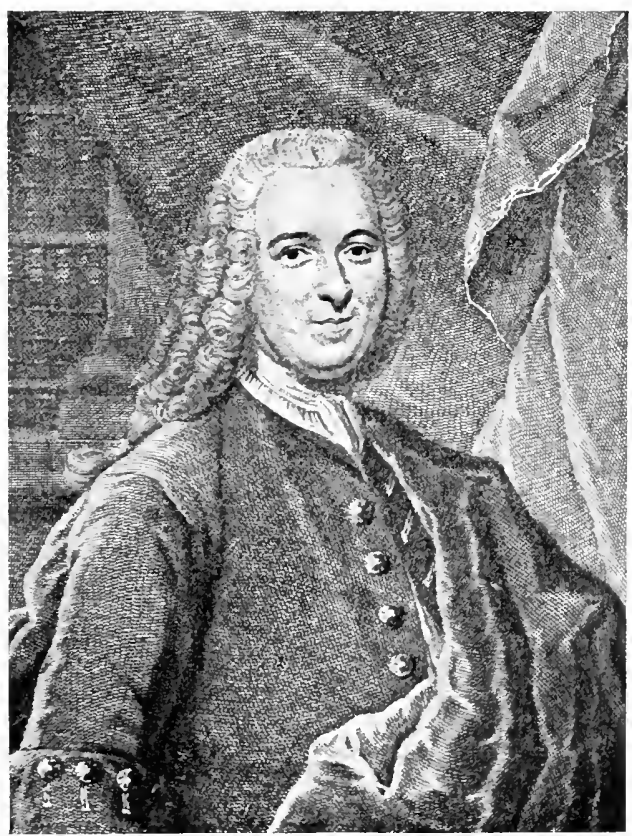

Paul Gottlieb Werlhof (1699-1767).

Reil is memorable for his work on the histology of the crystalline lens (1794), in which he employer ehenical reagents for his investigation of the strueture of nerve-fibers (1796), his figuration of the maeula lutea and its postmortem appearanee (1797), his deseription of the "island of Reil" in the brain $\left(1809^{2}\right)$, and for his "Rhapsodies" on the psyehie treatment of the insane $\left(1803^{3}\right)$. He founded the first journal of psychiatry (Magazin fiü psychische Heilkunde, $1805-6)$, which was suceeded by his Beyträge (1808-12) and was followed by the Zcitschrift jür psychische Acrztc (1818-22) of his pupil, C. F.

1 Wichmann: Aetiologie der Krätze, Hannover, 1786.

${ }^{2}$ Reil: Areh. f. Physiol., Halle a. S., 1809, ix, 136; 195.

${ }^{3}$ Reil: Rhapsodicen (ete.), Halle, 1803. 
Nasse. His theory of nervous action is summed up in his essay on the lifeforee $\left.(179)^{1}\right)$, in which the autonomy of cerobral funetion is established, vital foree, the subjective expresion of the ehemical interaction of body substances, is dofined as the specifie function of organic matter, and irritability is not only recoguized as a specifie property of tisisues (Hallor), lut is regarded, in Cilisson's original sense, as the principal manifestation of life, or matter in motion. Reil hat some notion of motabolism and even of internal secretions (Nenburger). In his clinie he practisol surgery, obstetries, and ophthalunology, as woll as internal medieine. Towarel the end of his life, he lost himself in the vagaries of the Nature Philosoplyy Sehool. A statue was ereeted to his memory in 1915.

Ernst Ludwig Heim (1747-1834), a wealthy, witty, very honest, and very independent practitioner of Berlin, is said to have introduced Jennerian vaccination into that city in 1798 , and as "der alte Heim," is remembered for his many sharp sayings.

Christian Wilhelm Hufeland (1762-1836), of Langensalza, professor at Jena (1793) and Berlin (1800), was one of the great philanthropic physicians who are true friends of the human race. At Weimar (1783-93), he was the friend and physician of Goethe, Schiller and Herder, and did much to correct popular misconceptions about Mesmerism, Brunonianism, phrenology, and other current fancies. He was one of the first to espouse the cause of Jenner and took the keenest interest in combatting smallpox and cholera.

He deseribed the typhoid and typhus epidemies of 1806-7 and 1813 respetively, and wrote much on popular medieine, in particular his treatise on long life (Makrobiotik, 1796) and his Encheiridion medicum (1836). He is now best remembered as one of the great pioneers of medieal journalism in the eighteenth eentury. He edited four different periodieals, the most important of which was "Hufeland's Journal" in 82 volumes (Journal der praktischen Arzneikunde, 1795-1836).

Simon-André Tissot (1728-97), the famous practitioner of Lausanne, was one of the leading propagandists of variolation (1754), wrote considerable treatises on epilepsy (1770) and nervous discases (1782), and became widely known through his popular writings on onanism (1760), the hygiene of literary men (1766), and the diseases of men of the world (1770). His best known achievement in this kind was the Avis au peuple sur la santé (1760), a tract on popular medicine which ran through ten editions in less than six years, and was translated into every European language.

Théodore Tronchin (1709-81), of Geneva, Boerhaave's favorite pupil, Voltaire's favorite physician, and one of the wealthiest and most fashionable practitioners of his time, is remembered by his compilation De colica Pictomum (1757), in which he showed that "Poitou colic" was caused by water poisoned from passing through the gutters of lead roofs. He introduced inoculation into Holland (1748), Switzerland (1749), and France (1756), having 20,000 successful coses to his credit : and was a pioncer of the open-

${ }^{1}$ Reil: Von der Lebenskraft, Areh. f. d. Physiol., Halle, 1795, i, S-162. 
air cult, of psychotherapy, and of suspension in spinal curvature (1756).

The greatest Italian clinician of the period was Giovanni Maria Lancisi (1655-1720), of Rome, who was physician to scveral popes, one of whom (Clement XI) placed in his hands the forgotten 47 copper plates of Eustachius, executed in 1552, which Lancisi edited with marginal notes and published, with a title page vignette by Pier Leone Ghezzi, in 1714.

Lancisi was a great epidemiologist. He described the cpidemies of influenza in 1709-10, of cattle-plague in 1713, ant of malurial fever in 1715. His great treatise on swamp fevers $\left(1717^{1}\right)$, while stating the doctrine of miasms, shows a clear insight into the theory of contagion and the possibility of transmission by mosquitors (Culices), of which he gives a naturalist's aceount. Ho was the author of two works of eapital importanee on surden death $\left(1707^{2}\right)$ and on aneurysm $\left(1738^{3}\right)$. In the first work he notes hypertrophy and dilatation of the heart as causes of suflen death, first describes valvular vegetations and gives a classification of cardiac diseases. In the second he notes the frecuency of eardiac aneurysm, distinguishes between aneurysmal eavitics with thin and thick walk, and notes heredity, syphilis, asthma, palpitation, violent emotions, and exeesses as prominent causes. He was also the first to describe curdiac syphilis.

Francesco Torti (1658-1741), professor at Modena, and a good pharmacologist, wrote an important treatise on the pernicious malarial fevers $\left(1712^{4}\right)$, which practically introduced the employment of cinchona bark into Italian practice and introduced the term mal aria.

Pellagra was originally described by Ciaspar (asal (1691-1759), a Spanish physician, in a book written by him in 1735, but not published until $1762 .^{5}$ At court, ('asal met François Thićry, who, from what he had seen or heard of Casal's deseription, published an account of the disease in $175.5,{ }^{6}$ antedating him in priority of publication, but not of first-hand description. Both Casal and Thiéry called the new discase "rose sickness" (mal de la rosa). In $1771^{7}$ Francesco Frapolli, an Italian physician, published a careful account of pellagra, in which he gave the malarly its present name.

Connected with the history of internal medicine on the conti-

${ }^{1}$ Laneisi: De noxiis paludum effuviis, Rome, 1717.

${ }^{2}$ Lancisi: De subitaneis mortis, Rome, 1707. Written on aceount of the fright of the Roman population at the number of sudden deaths in 1706 .

${ }^{3}$ Lancisi: De motu cordis et ancurysmatibus, Naples, 1738. 1712.

${ }^{4}$ Torti: Therapentiee specialis ad febres quasdam perniciosas, Modeua, 1762:

${ }^{5}$ Casal: Historia natural y mediea de el prineipado de Asturias, Madrid,

${ }^{6}$ Thiéry: Jour. de mél., chir. et pharm., Paris, 1755, ii, 337-346.

${ }^{7}$ Frapolli: Animadversiones in morbum, vulgo pelagram, Milan, 1771. 
nont is the revival of Athanasius Kircher's hypnotic idea, under the guise of “animal magnetism," by Franz Anton Mesmer (17341S15), of Itznang, Switzerland. Mesmer's graduating dissertation hat boon upon the subject of the influence of the planets on man (1771), and, in experimenting with the mannet, he got the idca that a similar power is possessed by the hmman hand. Attompting to pratioce mesmerism in Vicma, his private séances were investigated by one of Maria Thoresa's "commissions," and he was compelled to leave the city inside of twenty-four hours. Arriving in Paris in 177s, after some failures at Spat, he at length gained a foothold, and in a very short time he was maling a great deal of money by his hypnotic séances. In these he appeared clad in a lilac suit, playing upon a harmonica, touching his patjents with a wand, staring into their eyes, and attending them in a private chamber in case of a "crisis." A prominent feature of the mesmeric treatment was a number of so-called magnetic tubs, or buguets, containing a mixtum compositum of hydrogen sulphide and other ingredients, and provided with iron conductors from which depended a ring for purposes of contact with the patients, who stood around the tubs, joining hands. Being investigated by another committee, Xesmer was again driven from the ficld, and, after the Revolution, dropped out of sight. His book, containing his ideas on mesmerism, was published in $1779 .^{1} \mathrm{Al}$ though the subject did not gain a scientifie foothold until the time of Braid, mesmerism, like Lavater's ideas on physiognomy $\left(1772^{2}\right)$, attracted a great deal of public and private notice and was exploited in various mystic forms by Charles d'Eslon, a pupil of Mesmer's, the brothers Purségur, Lavater, the novelist Justinus Kemer, and by Baron Karl von Reichenbach, whose concept of "odic force" still survives in the ouija-boards and odic telephones of the present time. Somnambulism (witness Bellini's opera) and ventriloquism (witness Brockden Brown's Wieland) began to have their vogue also, and in the "wonder-cures" of the exorcist Joseph Gassner and the necromancer Schröpfer, the magic merlicine of primitive man began to loom large again. In London, Mesmer's charlatanry cropped out in the notorious "Temple of Health" (1780) of the quack James Graham, in the ministrations of which Emma Lxon, the future Lady Hamilton, played a prominent choreographic part.

With all its lack of instrumental precision, the internal medieine of the eighteenth century, as a whole, was far superior to its surgery, beeause the systematic tendencies of the age led to the composition of specialized text-books, the introduction of new drugs, and the aceurate description of many new forms

1 Mesmer: Mémoire sur la découverte du magnétisme animal, Geneva and Paris, 1779.

2 Joh. Caspar Lavater: Von der Physiognomik, Leipzig, 1772. 
of disease. Among these isolated clinical discoveries we may mention Friedrich Hoffmann's deseriptions of ehlorosis $\left.(1730)^{1}\right)$ and rubella $\left(1740^{2}\right)$; Freke's ease of myositis ossifieans progressiva $\left(1736^{3}\right)$; Fothergill's areounts of diphtheria $\left(1745^{4}\right)$; facial neuralgia $\left(1773^{5}\right)$, and siek headache $\left(1754^{6}\right)$; J. Z Platner on the tuberculous nature of gibbous spine ${ }^{7}$; Nieolas André on infraorbital neuralgia $\left(1756^{8}\right)$; the deseription of pellagra or "mal de la rosi" by François 'Thiéry $\left(1755^{9}\right)$, William Hunter on arteriovenous aneurysm $\left(1757^{10}\right)$; Tronchin on lead colic (175711); Mestivier's operated ease of appendicitis $\left(1759^{12}\right)$; Robert Hamilton on orehitis in mumps $\left(1761^{13}\right)$; Heberden on varicella $\left(1767^{14}\right)$ and angina pectoris $\left(1765^{15}\right)$; Robert Whyt t's elinical pieture of tuberculous meningitis $\left(176 \mathrm{~s}^{16}\right)$; Rutty's account of relapsing fever $\left(1770^{17}\right)$; Cotugno on seiatica (177018); van Swieten on the paralytic type of rabies (1771); Rouelle's diseovery of urea (1773); J. W. Tiehy's Observations of sediments in febrile urine (1774); Werlhof on purpura hamorrhagiea $\left(1775^{19}\right)$; Matthew Dobson's proof that the sweetness of the urine and blood-serum in diabetes is due to sugar $\left(1776^{20}\right)$; Bylon and Benjamin Rush on dengue (177980); Pott on pressure paralysis from spinal caries (177921); the yeast test for sugar in diabetic urine by Francis Home $\left(1780^{22}\right)$ and Johann Peter Frank (1791); Lettsom on the drug habit and aleoholism $\left(1786 j^{23}\right)$; Parry on exophthalmie goiter $\left(1786^{24}\right)$; Hezekiah Beardsley's ease of eongenital hypertrophic stenosis of the pylorus $\left(1785^{25}\right)$; Soemmerring's case of achondroplasia $\left(1791^{26}\right)$; Charles Stewart's deseription of paroxysmal hematuria (179427); Wollaston's diseovery of urates in gouty joints $\left(1797^{28}\right)$; Nikolaus Friedreich's deseription

${ }^{1} \mathrm{~F}$. Hoffmann: De genuina ehlorosis indole, 1730.

${ }^{2}$ Opera omnia, Geneva, 174 s, ii, 63.

${ }^{3}$ J. Freke: Phil. Tr., 1732-44, Lond., 1747, ix, 252.

${ }^{4}$ J. Fothergill: An aceount of the sore throat, London, 1748.

${ }^{5}$ Med. Obs. Soe. Phys., Lond., 1771-76, v, 129-142.

${ }^{6}$ Med. Obs. \& Inquiries, Lond., 17S4, vi, 103-137.

${ }^{7}$ J. Z. Plitner: De iis, qui ex tubereulis gibberosi fiunt, Leipzig, 1744 , with plate by Schönemann. 1756 .

${ }^{8}$ N. André: Observations pratiques sur les maladies de l'urétre, Paris,

${ }^{9}$ F. Thiéry: J. de méd., ehir. et pharm., Paris, 1755, ii, 336-346.

${ }^{10} \mathrm{~W}$. Hunter: Med. Obs. \& Inquiries, Lond., 1757, i, 340.

11 T. Tronehin: De colica Pietonum, Geneva, 1757.

${ }^{12}$ Mestivier: J. de mél., ehir. et pharm., 1759, x, 441.

${ }_{13} \mathrm{Tr}$. Roy. Soc. Edinb. (1773), 1790, ii, pt. 2, 59-72.

${ }^{14}$ Heberden: Med. Tr. Coll. Phys., Loml., 3. erl., 175.5, i, 427-436.

${ }^{15}$ Heberden: Med. Tr. Coll. Phys., Lond., 1768-70, ii, 58-67.

${ }^{16}$ Whytt: Observations on the Dropsy in the Brain, Elinburgh, 1768.

${ }^{17}$ Rutty: A chronological history (etc.), London, 1770.

${ }^{18}$ Cotugno: De ischiarle nervosa, Vienna, 1770.

19 Werthof: Opera omnia, Hannover, 1775, ii, (615-636.

${ }^{20}$ Dobson: Med. Obs. \& Inq., Lond., 1776, v, 298-316.

${ }^{21}$ Pott: Remarks on that kind of palsy (ete.), Iondon, 1779.

${ }^{22}$ F. Home: Clinieal Experiments, Edinburgh, 17s0.

${ }^{23}$ Lettsom: Mem. Med. Soc. Lond., 1779-87, i, 128-165.

${ }^{24}$ Parry's works, London, 1825 , ii, 111.

${ }^{25}$ Beardsley: Cases \& Obs. Med. Soe., New Haven County, 17s8, 81-84.

${ }^{26}$ Soemmerring: Abbildungen . . e einiger Missgeburten, Mainz, 1791. 30 , pl. xi.

${ }^{27}$ Stewart: Med. Comment., Ellinb., 1794, Dec. II, ix, 332.

${ }^{28}$ Wollaston: Phil. Tr., Lond., 1797, lxxxvii, 356-400. 
of peripheral facial paralyis (17971); and John Haslam's deseription of gencral paralrsis $\left(179 \AA^{2}\right)$. Besides this brilliant array of original work, which would honor any century, there were many andmirible treatises or text-books on special branches of interual medieine, such as $A$ strue (1736), (iirtamner

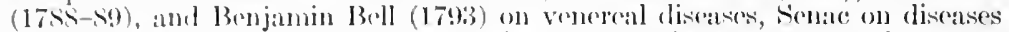
of the heart (17.19), Ploneiz on seirlatina (1762), Zimmermann on dysentery (1767), lind on tropieal discases (1765), Millar on asthuma and whooping-cough

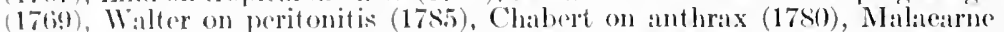
(175) and Foléré (1792) on eretinism and goiter, and John lablo on the sueress of meat diet in diabetes (1797), Benjamin Martin in A New Theory of Consumptions (Lomblon, 1720) discolsses palratitic microörganisms as the caluse of phthisis. ${ }^{3}$ The transmission of yaws hy flies was noted by Edward Bancroft $\left(1769^{4}\right)$. There was a great increase in the literature bearing on the diseases of children, as evidenced in the poediat rie treatioss of William Cadegan (17.5), Nils Rosén von Rosenstein (1752), (ieorge Armstrong (1767), Me llin (1753) and Michacl Enderwood (17S4), which contains the first account of infantile poliomyelitis. Sir John Flover wrote the first treatise on diseases of old age (Medicina gerocomiea, 1724). (iout and seurvy were favorite subjects of the linglish prictitioners of the period, notably George Cheyne (1720) and Cadogan (176t) on the former, Lind (1753) and 'Thomas Trot ter (1785) on the latter. of all these special monographs, the best was unepestionably the treatise of Robert Willan (1757-1812) (n diseakes of the skin (1796-1808), which marks an epoch in the history of dermatology, but belongs escentially to the modern period. Of original contributions to descriptive dermatology, we may mention John Machin's observation of jolnthyosis hystrix in the Lambert family (17335), which was followod through suecessive generations by Henry Baker $\left(1755^{6}\right)$, and Tilesius (18027); the observation of seleroderma in Curzin's elinic at Naples by Willian and Robert Watson $\left(1754^{8}\right)$; Wichmann on the parasitic origin of scabies $\left(1786^{9}\right)$, and Sir Everard Home's description of cutaneous horns (hyperkeratosis) in 1791.10 The subject of medical jurisprudence was carefully systematized in the eighteenth century, and the leaders in this field were the Ciermans, who were the first to found profesorships of forensie merlicine and turned out the most important treatjses. The earliest of these was the Corms juris medieo-legale of Miehael Bernhard Valentini (1657-1729), published in 1722, a huge storehouse of wellarranged facts. It was followed in 1723 by the Institutiones of Hermann Frielrich Teichmever (1655-1746), which was for a loug time the stanclard authority, and, in 1736-47, by the System of Nlichael Alberti (1682-1757) of IIalle, a six-volume work, not unlike Valentini's in seope and thoroughness. In France, Antoine Loujs (1723-92) was the pioneer in applying medical knowlelge to eourt-room practice. He wrote an important memoir on hanging, with reforence to the differential signs of murder and suicide in cases of hanging $(1763)$, and, in his discussion of the celebrated Villebranche case (1764), he ridiculed the possibility of extremely protracted pregnancy, endeavoring to set the time-limits of normal gestation, which, under the Code Napoleon, were finally fixed at three hundred days, as in the Roman laws of

${ }^{1}$ Friedrejch: Med. ehir. Ztg., Salzburg, 1798, i, 415.

${ }^{2}$ Haslam: Observations on insanity, London, 1798.

${ }^{3}$ See C. Singer: Janus, Amst., 1911, xvi, S1-98.

${ }^{4}$ Bancroft: Essay on the Natural History of Guiana, London, 1769, 38.5. Cited by E. W. Gudger.

${ }^{5}$ Machin: Phil. Tr., Lond., 1733, xxxvii, 299-301, $1 \mathrm{pl}$.

${ }^{6}$ Baker: Phil. Tr., Lond., 1755, xlix, pt. 1, 21-24.

`Tilesius: Ausführliche Beschreibung . . . der beiden sog. Stachelsehweinmenschen, Altenburg, 1802.

8 Watson: Phil. Tr., Lond., 1754, xlviii, 579-587.

${ }^{9}$ Wichmann: Aetiologie der Krätze, Hannover, 1786.

${ }^{10}$ Home: Phil. Tr., Lond., 1791, lxxxii, 95-105. 
the Twelve Tables. Fodéré's great treatise on legal melieine (179s) belongs to the modern period of the science. The first English work was the Elements of Samuce Farr (17SS), but William Hunter's essay on the signs of murder in bastard children (1783) is probably the most important English contribution in the eighteenth century.

As in the seventeenth century, forensic medicine was still coneerned with many questions properly belonging to state medicine and public hygiene. Medical ethics was treated in Friedrich Hoffmann's Medicus politiens (173s) in Johamn Wilhelm Baumer's Fundamenta politiea mediea (1777), and by Stoll.

Medical history was systematically treated in the works of Freind $1725-$ $27)$, J. H. Schulze (172s), J. C. Lettsom (177s), B]umenbich (1786), J. C. G. Ackermann (1792), and Kurt Sprengel (1792-180:3). Of these, John Freind (1675-1725), of Croton, Northamptonshire, who was highly educated at $0 \mathrm{x}-$ ford in the humanities and in medicine, and delivered the Ashmolan leetures on ehemistry in 1704, was an intellectual light of considerable prominener in his day. Ite accompanicd the Earl of Peterborough on his Spanish eampaign of 170.5 , as physician to the English forces, and subsequently mixing in politics as a partisan, was committed to the Tower on the charge of high treason in March, 1922-23; but was soon released through the good offices of Mead, and became physician to Queen Caroline in 1727. During his short imprisonment he planned his IVistory of Physick from the Time of Galen to the Beginning of the Sixtenth Century (London, 1725-26), (ledicated to Mlead, and intended as a continuation of Leclere. This is usually regarded as the best English work on the period of which it treats, although, as sir Clifford Albutt says, the author "spread his net too widely" and produced a general survey "from the time of Galen," where he might have done better by confining himself to English medicine in detail.

The greatest medical historian of the eighteenth century was the eminent Pomeranian botanist Kurt Polykarp Sprengel (1766-1833), whose work, al-o translated into French and Itilian, has been the great source-book for facts and footnotes for all subsequent investigators. Although sprengel's uneompromising vitalism makes him an unfair eritic of the seventeenth century scientists, his history is still a marvel of solid learning and contains a valuable chronology. He also wrote a series of medieo-historical essays (Beyträge, 1794-96), and a history of surgical operations (1S05-19). Harily inferior to Sprengel as original investigators were such men as Johann Karl Wilhelm Möhsen (1722-95), of Berlin, who investigated the medieal MS. in the loyal Library there (1746-47); also the medical portraits (1771), medieal medals (1772-73), the earliest important contribution to nedical numismaties, and wrote a learned history of seience in Mark Brandenburg (1781); Christian Gottfried Gruner (1744-1815), a prolifie writer on the history of diseases (Morborum antiquitates, 1774), in particular, syphilis (1793) and sweating sickness (1S47); the army surgeon Ernst Gottfried Baldinger (173S-1S()4), biographer of his contenporaries (1768), of Haller (1778), and Tode (1778), a sturdy organizer, who poured many learned essays into his Magazin für Aerzte (1795-99); Johann Ileinrich Eder (1687-1744), author of the earliest German work on the subject (1728) and the first to attempt photography; Philipp Gabriel Hensler (1733-1805), historian of syphilis (1783-89) and leprosy (1790); Christoph Girtanner (1760-1800), another historian of syphilis (1783-59): August Friedrich Hecker (1763-1811), editor of many periodicals, and Antoine Portal (1742-1832), author of a seven-volume history of anatomy and surgery (1770-73). Haller's 1751 edition of the Wethodus Studii Medici of Boerhate is an introduction to medical literature similar to that compiled by Thomas Young more than half a century later, and is romarkable for those sententious eritical apercus for which IIaller is so justly famous. The arrliest periodicals devoted to the history of medicine were $F$. Aglietti's Giornale per servire alla storia ragionata della medicina di questa secolo (Venice, 1783-95), and P. L. Wittwer's Archin für die Geschichte der Arzncykunde (Nuremberis, 1790).

1 Sprengel: Versuch einer pragmatischen Geschichte der Medicin. Halle 1792-1S03. 
In an age in which medien-historical studies were so assiduously cultivated, medical lexicography becames effertively sperialized. 'The exegesis of Greck molicisl terms by J. (i. Ilobenstreit (1751), the glossiry of Erotian, Galen and Herodotus of J. G. liranz (17SO), the lexieat of Latin-French terms by E. Col. F. do Villars (17.11) and of Jatin-firman by (i. Matharus (17.48) and C. L. H. Knackstedt (1754-5) follow the old Renassance lines. Dietionaries of special terms abounded, notably those of anitomy by Peras (1753), P. 'Tarin (1753), J. F. Dufieu (1760) and F. Vica d'Azyr (1786) of surgery by A. F. T'. Levacher de la Feutrie (1767), Antoine Louis (1772), and P. Francois (1773), of drugs by Nicolas Lemery (1714), and Julliot (1758), of prognosis (1770) and semeiology (1777) by Michel du Tennetar. 'The principal medieal dietionaries in English are those of John Quincy (1719), Robert James (1743) and Robert Hooper (179S.

An important three-volume treatise on medical geography was published by Leonhard Ludwig Finke (1747-1828) in 1792-95.1 The Observations

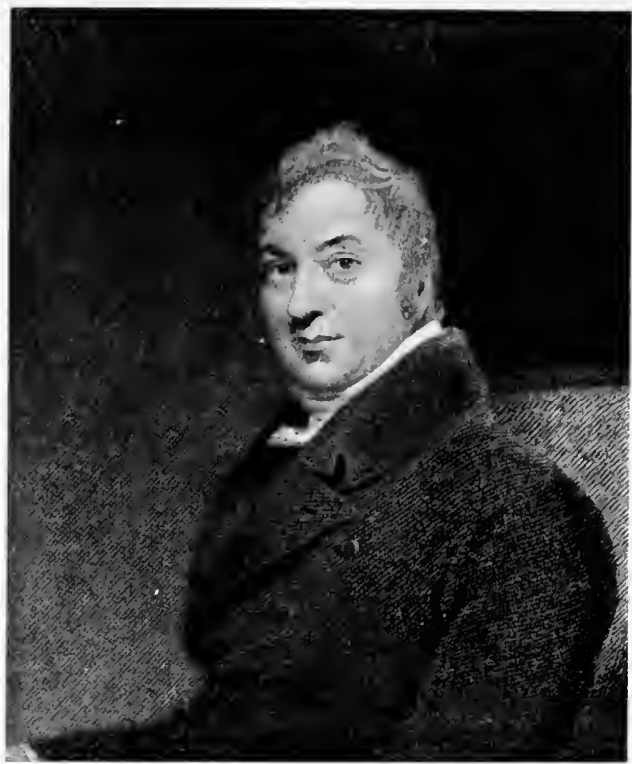

Edward Jenner (1749-1\$23). (From the painting by Sir Thomas Lawrence.)

on epidemical diseases in Minorea (1751) of Cieorge Cleghorn (1716-89), still useful to practitioners in the island, contains many post-mortems, and clarifies obscurities in the Hipperatic books, particularly as to the modifieation of acute and chronic diseases by concurrent malarial fever.

Toward the end of the century came one of the greatest triumphs in the history of medicine-the successful introduction of preventive inoculation by Edward Jenner (1749-1823), son of a Gloucestershire clergyman, who, in 1770, became a friend and pupil of John Hunter's, and helped him a good deal in his experi-

${ }^{1}$ L. L. Finke: Versuch einer allgemeinen mediciniseh-praktischen Geographie, Leipzig, 1792-95. 
ments. It had long been a countryside tradition in (iloucestershire that dairy-maids who had contracted cow-pox through milking did not take simallpox, and similar observations had been noted in Germany and Fance. On learning of this fact from a milkmaid, Jenner early conceived the idea of applying it on a grand seale in the prevention of the disease. On communicating his project to Hunter, the latter gave him the characteristic advice: "Don't think, try; be patient, be aceurate." On returning to his home at Berkeley he began to eollect his observations in 1778, and on May 14, 1796, performed his first vaccination upon a country boy, James Phipps, using matter from the arm of the milkmaid, Sarah Nelmes, who had contracted cow-pox in the usual way. The experiment was then put to the test, by inoculating Phipps with smallpox virus on July 1st, and the immunization proved successful. By 1798 he had 23 cases, which he emborlied in his work, $A n$ Inquiry into the Causes and Effects of the Variola Vaccina, a thin quarto with four colored plates, printed in 1798, and dedicated to Parry of Bath. This book establishes his main thesis that a vaccination with cow-pox matter protects from smallpox, and was followed, during the years 1799-1806, by five successive pamphlets, recording his subsequent experiments and improvements in technic up to the stage of recommending ivory points as the best vectors in inoculation. Jenner's work was rapidly taken up on the continent and in America; good statisties began to pour in, in less than a year's time, and, by 1800 , as many as 6000 people had been vaccinated. In 1802 and 1807, Parliament voted grants amounting $10 £ 20,000$ to Jenner in aid of prosecuting his experiments. At the same time he met with bitter opposition from jealous contemporaries, like Ingen-Housz, Woodville, anel Pearson, who either claimed priority or acted upon the parliamentary principle that the duty of the opposition is to oppose.

The mere irlea of inoculation is apparently as old as the hills. Human inoeulation of variolous virus is said to be mentionerl in the Atharval Verda (Bats) and eertainly in the Flos of the Sehool of Salerno, amr was known to most Oriental peoples. The idea was introdueed into England by 'Timoni's and Pilarini's eommunications to the Roval Soeiety in 1713-16, and was af torward taken up by sir Hans Sloane (1717). On Mareh 1s, 1718, Iarly Mary Wortley Montigu had her three-year-old son inoenlatefl in Turkey, anel her five-year-old daughter was inoenlated in England in April, 1721. During the sixth epielemic of smallpox in Boston, Massichusetts, Zabdiel Boylstom (1679-1766) courageously inoeulated his son and two negro slaves on Jume 26,1721 , and had inowalated 244 persens before its elose, exeiting great opposition and even threats of hanging. In the Boston epidemie of 1752,2109 were inoculated, and nearly 20,000 in England, under Daniel sutton in 176.4-6.5. ${ }^{1}$

1 See Reginald H. Fitz, on Zabeliel Boylston in Bull. Johns ILopkins Hospital, Balt., 1911. xxii, 315-327, and A. C. Klebs: Ibrid., 1913, xxiv, 69-83, passim. Inoculation was a eommon preventive measure in Americal , huring the War of the Revolution. 
Apart from the huge eighteenth ecutury literature on inoculation, one of the most important items of which is the propessal of preventive inoculations

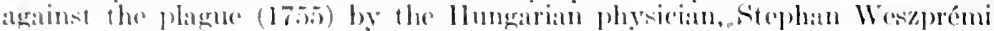

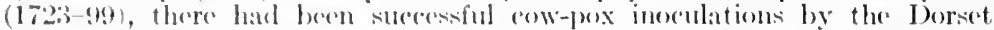
farmer, Banj:min desty, in 177.1-89, and by Plett of Holstein in 1791. All these efforts were, howerer, "is an arrow shot in the air or a sword-stroke in the wither."

The merit of Jenner's work rests upon the fact that, like Harvey, he started out with the hope of making his thesis a permanent working principle in science, based upon experimental demonstration, and he sucereeded to the extent of carrying his inoculations sucessfully through several generations in the body, and, above all, in overeoming the popular aversion to vaccination. In short, Jemer transformed a local country tradition into a viable prophylactic principle, and, although he was preceded by really scientifuc experts in inoculation (variolation), his reputation in his own field is fairly safe from the priority-mongers. Faults of diffuseness and lack of skill in marshaling facts have been imputed anainst the Impuiry, but, on the whole, it remains an unimpeachable record of careful scientific work, the effeet of which is seen to-day in the rapid strides that preventive medicine is making and in the results of compulsory vaccination in Prussia and Holland, where the mortality curve of smallpox approaches zero as its limit. Striking, indeed, was the relative immunity of the German Army of the Franco-Prussian War in 1870-71, in which the unvaccinated French prisoners lost 1963 out of 14,178 eases of smallpox, while the Cicmans, who had been revaccinated within two years, had 4835 cases and 278 deaths (Myrdacz). Kitasato's statisties of vaccination in the Russo-Japanese War (1911') show that, with smallpox endemic in Japan, there were only 362 cases and 35 deaths in an army of over a million soldiers. Jenner's monograph of 1798 has loomed into especial prominence of late through the fact that it contains an early reference and a clear explanation of anaphylaxis or allergy. In case 4 he notes that inoculations of variolous matter in a woman who had had cow-pox thirty-one years before produced a palish red effloreseence of the skin, which he regards as almost a criterion of whether the infection will be received or not, attributing the phenomenon to the dynamic effect of a permanent change in the blood during life." In the later years of his life Jemner lived in London, of which eity he was made an honorary citizen. He died there of apoplexy in 1823, and his momument, erected in 1858, is in Trafalgar Square.

${ }^{1}$ Cited by Osler in his Principles and Practice of Medieine, eighth edition, New York, 1912, p. 330.

2 Jenner: Inquiry, 1798, footnote to p. 13, cited by L. Hektoen in Jour. Am. Med. Ass., Chieago, 1912, Iviii, foot note to p. $108 \overline{7}$. 
In personality Jenner was the typieal English eountry gentleman, blond, blue-eyed, of handsome figure. A well-known aceount deseribes him ready for a mount, in blue coat, nankeen ridingbrecehes, and top-boots, with whip and silver spurs. He was a bird-fancier, played the flute and violin, botanized, and wrote clever verses, of which the "Address to a Robin" and the "Signs of Rain," rodolent of the English countryside, deserve a place in any anthology of minor poets. Jenner's kindness of heart is seen in his regard for his first vaccination patient, James Phipps, for whom he built a cottage, planting the roses in the garden with his own hands. Like Newton, Harvey, Sydenham, Darwin, and Lister, he is one of the great men of purely saxon genius, a happy combination of rare common sense with extreme simplicity of mind and character.

In Germany, Jenner's work was immediately taken up about 1798-99 by Hugo von Wreden, G. F. Ballhorn, and C. F. Stromeyer in Hannover, by Heim and Brenner in Berlin (1800), by A. H. MacDonald in Altona (1800), by Hirt in Saxony, and by Jean de Carro and Paseal Ferro in Austrial (1799), de Carro being also the first to introduce Jennerian vaceination in to Asiat. Pind and Thouret in France, Vrancken in Holland, Demanet in Brigium, saceo in Italy, Heinrich Callisen in Denmark, Amar and others in spain, were among the earliest promoters of the practice, which reached India and Mexico in 1802. In the Inited states, the Harvard professor of medicine, Benjamin Waterhouse (1754-1846) make the first vaccinations upon his four children in July, 1800, ${ }^{1}$ proeuring his virus from Dr. Haygarth of Bath, England. He was speedily followed by Crawford and smith in Baltimore, James Jackson in Boston, David Ilosack in New York, and John Redman Coxe in Philadelphia. The first Vaceine Institute was organizerl in Baltimore by James smith in 1802 and a national Vaccine Ageney was established by Congress under his direction in 1813. Waterhouse said that, before the introduetion of vaceination, the fear of smallpox compelled the Now Englanders, "the most democratical people on the face of the earth," to cndure "restrictions of liberty such as no absolute monarch could have enforced."' The early American tracts of the colonial pamphloteers on inoculation, such as Benjamin Colnuan (1721-22), Isaac Greenwood (1721), Cotton Mather (1722), William Douglass (1722-30), Zabdiet Boykston (1726), Adam Thomson (1750), Nathanad Williams (1752), Lauchlin MaeLeane (1756), Benjamin Franklin (1759), John Morgan (1776), and Benjamin Rush (1781), with the Waterhouse pamphlets on vareination $(1800-02)$, are now among the rarest and nost highly prized of medieal curiosities.

There was no American medical literature to speak of until long after the Ameriean Revolution. The first medical hook to be published on the North American continent was printed by the Spaniards in the eity of Mexico in 1570, and the first medical school was founcled by them in 1578. Thacher's Brief Rule (Boston, 1677) was the only medical publication of the New England Colonies in the seventeenth century.

"In the "Columbian Sentinel" of Mareb 12, 1799, Waterhouse refers to vaceination in down-East phrase, as "Something curious in the medical line."

2 Cited by Dock. 
"At the commencement of the Revolutionary War," says Billings, "we" hat one modical book by an Ameriean anthor, three reprints, and about twenty panphlets"; and of the book in gunestion, John Jones's Plain, Concise, Practical Remarks on the 'Treatment of Hounds and Fractures (New York, 1775), he goes on to sily that "it is simply a eompilation from Ranby, lott, and others, and eontains but one original observation."' 'The book contains, however, an appendix on camp) and military howpitals, and was of great use to the young military and navil surgeons of the Revolution, for whom it was priniarily designed, being, in fact, the first American book on military medicine. Jones was a skilful lithotomist and was remembered by Benjamin Franklin in his will for a suecessful performance of the operation. Of pamplulet literature, there were some now curious eolonial productions on the various anginas and eruptive fevers of the time by Joln Walton (17:32), Cadwallader Colden (1735), William Douglass (angina uleuseulosa, 1736), and Jabez Fiteh (1736) and the tracts on inoculation, already mentioned. The early inaugural dissertations of the students Elmer, Potts, and Tilton at the University of Pennylvania in 1771, the latter a product of the celebrated Bradford Press, are now only colleetors' curiosities, and the same thing applies to the oration Antiqua novum orbem decet medico-philosophica, delivered at Williamsburg, Virginia. June 12, 1782, by Jean-François Coste (1741-1819), medieal director of the Freneh forees in America, published at Leyden in 1783 and dedieated to Washington. Better than these are the essays on yellow fever by John Bard, Colden (1743), Mitehell (1741), John Lining (1753), and William Currie $(1792)$; and, more important still, the clinical studies of Thomas Cartwalader (170S-79) of Philadelphia on the West-Indian dry-gripes (lead-poisoning), which was printed by Benjamin Franklin at Philadelphia in 1745; John Bard on malignant pleurisy (1749), and the essay of Famuel Bard (17421821) on diphtheria or "angina suffocativa" (1771), which is spoken of by Osler as "an American classic of the first rank." The Cases and Observations of the Medical Socicty of New Haven County, founded in 1784, contains the first recorded cave of congenital hypertrophic stenosis of the pylorus (17882) by Hezekiah Beardsley (1748-90), of Southington, Connecticut, which Osler rescued (in Lessing's sense of the term) by reprinting it in $1903 .{ }^{3}$ The history and geography of yellow fever in the United States were treated of by William Currie (1792) and Noah Webster (1796-99), and the work of Matthew Carey $(1760-1839)$ on the Philatelphia epidemic of yellow fever in 1793 stands with that of Benjamin Rush as the most graphic, realistic, and complete account of the disease that had yet appeared. ${ }^{4}$

Some good botanic works were printed abroad, notably a first account of senega and its uses by John Tennent, of Virginia, in 1736, John Clayton's Flora Firginica (Leyden, 1739), probably the first work on Ameriean botany; An Expcrimental Inquiry into the Properties of Opium, by John Leigh of Virginia (Edinburgh, 1786), which gained the Harveian prize in 1785; and the still more interesting Materia medica Americana (Erlangen, 1787) of the old Anspach-Bayreuth surgeon, Johann David Schoepf (1752-1800), who eame out to America with the Hessian troops in 1777 , remained over after the war, and recorded his experiences in his Travels in the Confederation (1788), which was translated and published in Philadelphia in 1911. The first pharmacopceia to be printed in Ameriea, a pamphlet of 32 pages, was prepared by Dr. William Brown, of Virginia, who succeded Rush as Physician General of the Middle Department. It was designed for use in the Continental army and was issued anonymously from the military hospital at Lititz, Pa., in $177 \mathrm{~S}$

I J. S. Billings in "A Century of American Medicine," Philadelphia, 1876, J. 293.

2 Beardsley: Loc, cit., pp. 81-84.

${ }^{3}$ Arch. Pediat., N. Y., 1903, xx, 355-357.

4 Charles Brockden Brown's novel of Arthur Mervyn contains another interesting account of this epidemic. 
(Handerson ${ }^{1}$ ). The first Ameriean eontributions on medieal education, medical ethies, and medical history were written by John Morgan (176i5), Sanuel Bard (1769), and Peter Middleton (1769) respeetively.

The War of the Revolution was the making of medicine in this country, and it was in the nature of things that it should bring to the front the three leading American physicians of the time, Morgan, Shippen and Rush. The war found us in a state of "unpreparedness," with nothing of military, still less of medical, organization. Every one was on the fighting line, and there was little time for building hospitals, making instruments, or obtaining drugs. After drafting the Declaration, the ablest members of the Continental Congress were called, like every one else, to immediate and pressing duties in their several states; and Congress itself became, by all accounts, a feeble, bungling, almost impotent thing, accomplishing very little in aid of the medical administration of the war, in some respects the most important feature of all. As Mumford says, there was but one man who was found "steadfast, patient, imperturbable," and that was Washington." All honor belongs to the two army surgeons who were associated with him and who did so much for the organization of American medical education, John Morgan and William Shippen. Besides these, only brief mention can be made of other physicians, many of whom played a noble and self-sacrificing part, such as John and Joseph Warren of Massachusetts, the latter serving in the ranks and losing his life at Bunker Hill; Benjamin Church, the first Surgeon General of the American Army; Hugh Mercer, of Virginia, who was killed at Princeton in 1777; James Thacher, the first American medical biographer, whose Military Journal (Boston, 1827) gives a picturesque account of the struggle and perhaps the best wordpicture of the personality of Washington; and James Tilton, whose "Observations on Military Hospitals" (Wilmington, 1813) is a contribution of permanent value to his subject.

John Morgan (1735-89), a native of Philadelphia, was a student of John Redman's, served as surgeon in the French wars, and graduated at Edinburgh in 1762 , where he was trained by such masters as William Hunter, the Monros, Cullen and Whytt. Returning to his native eity in 1765 , he published, in the same year, his "Discourse upon the Institution of Medical Schools in America," which files the first brief for adequate medical education in

${ }^{1}$ Pharmacopoia simpliciorum et efficiarum in usum Nosocomi militaris ad Exercitum Federatum Ameriea Civitatum, Philadelphia, Styner \& Cyst (1778). A copy is in the Surgeon General's Library. Handerson gives a facsimile of the title-page of the second edition (1781) in his translation of Bass, p. 820.

${ }^{2}$ J. G. Mumford: A Narrative of Medicine in Aneriea, Philadelphia, 1903, p. 122 . 
this country and eommemorates the organization, at the College of Philadelphiar (founded in 17.40), of the Medical Department of the University of Pennsvlyania, of which Morgan was, with Shippen, the principal founder and in which he held the first chair of pratetice of medicine. In 1775, Congress appointed Morgan "Director Ciencral and Physician in Chief" of the American Army, to suceed Church. He entered upon his duties with vigor, insisting upon rigorous examinations for medical officers and subordinating the regimental surgeons to the hospital ehiefs, but the enmity of his subilterns and the shiftiness of politicians led to his unjust disnissal by Congress in 1777 and Shippen was appointed in his place.

Morgan thereupon pub-

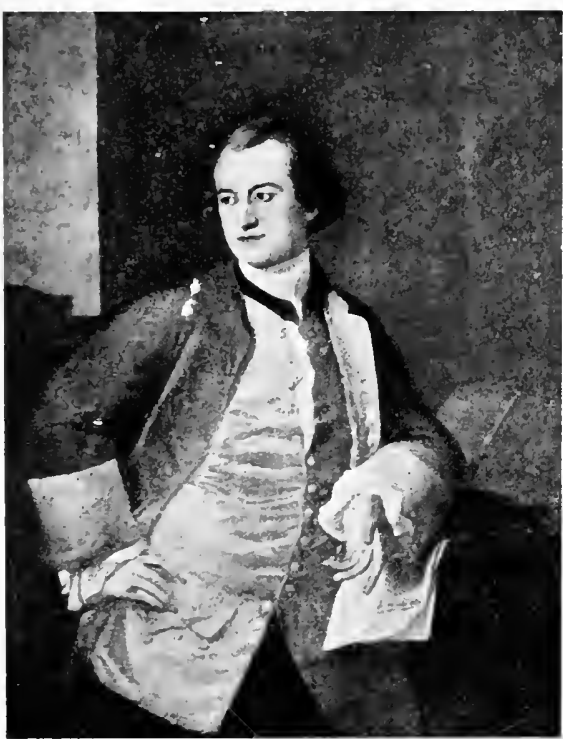

John Morgan (1735-89). lished his spirited Vindication (1777), in which he ably defends himself, with all loyalty to the cause and his great chief, demanding at the same time a court of inquiry. After two years' deliberation, the latter met and honorably acquitted him of all the charges in 1779. Broken in spirit, poor, and injured in health, Morgan retired to private practice and died twelve years later.

William Shippen, Jr. (1736-1808), of Philadelphia, who suceeeded Morgan as Surgeon General in 1777, was also an Edinburgh graduat (1761), coming under the Hunters, Cullen and Monro secundus. Returning to America in 1762, he began to give private and public instruction in anatomy and obstetries, and was, indeed, the first publie teacher of obstetries in this country, where he greatly advaneed the cause of male midwifery. In 1765 he collaborated with Morgan in organizing the Medical Department of the University of Pennsylvania, in which he was, at the same time, appointed professor of anatomy and surgery. Upon his accession to the surgeon-generaley in 1777 , Shippen, who was more practical, less sensitive, better off in worldly wisdom than Morgan was none the less court-martialed on grave charges in 1780 , but secured acquittal. He resigned in 1781 , to devote his 
entire attention to medical teaching, which he had kept up intermittently during his period of military service. With this his fame is associated, for he left no literary contributions of moment, ${ }^{2}$ but he was the second in seven generations of American physicians bearing his name.

Benjamin Rush (1745-1813), of Penmsylvania, was of English Quaker stock and a graduate of Princeton (1760) and Edirburgh (1768), his graduating thesis in medicine being De coctione ciborum in ventriculo. In 1769 he was elected professor of chemistry in the College of Philadelphia and sueceeded Morgan as professor

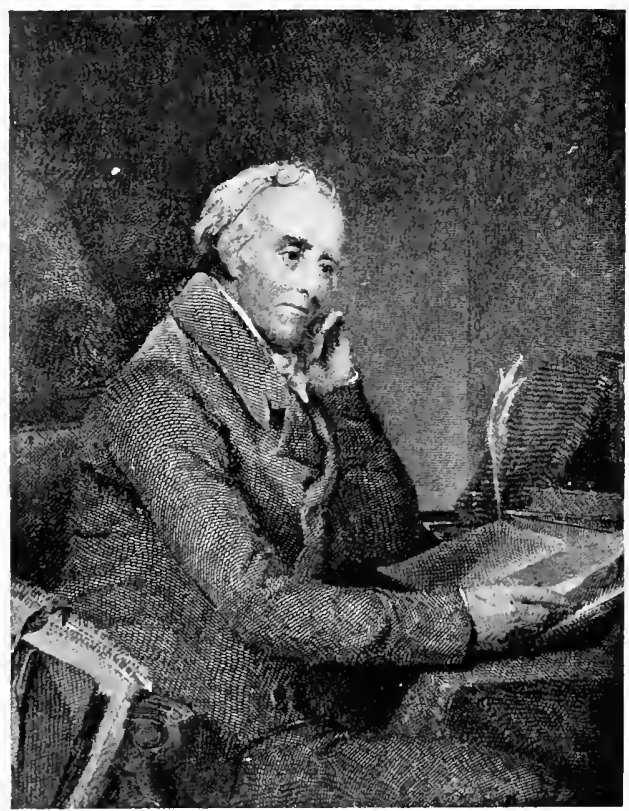

Benjamin Rush (1745-1813).

of practice in the same institution in 1789, attaining the chair of institutes of medicine, when the latter was merged into the University of Pennsylvania in 1791. He was also physician to the Pennsylvania Hospital (1783-1813), the ehief founder of the Philadelphia Dispensary (the first in this eountry) in 1786, and Treasurer of the United States Mint (1799-1813). Rush was a man of highly original mind, well read, well trained in his profession, an attractive, straightforward teacher, of wide human interests, sometimes

1 Shippen's graduating dissertation at Edinburgh, "De placentæ cum utero nexa" $(1761)$ is now only of bibliographie interest. 
wrong-headed as well as strong-headed. A signer of the Declaration and sometime surgeon gencral for the Middle Department under Shippen (1776-78), he deserted Washington at Valley Forge to join the infamous "Conway (abal" against the latter's "Fabian policy." As a modical theorist, he opposed Cullen's solidism and his claborate rassification of diseases for a mociified Brunonianism. His own therapentice sehente was upon the most arbitrary hasis. Ho looked upon inflammation as the effect rather than the cause of discase, and in regard to his statement that "Medicine is my wife and science my mistress," Dr. Holmes has added the caustic comment: "I do not think that the breach of the seventh commandment 'an be shown to have been of advantage to the legitimate owner of his affections." A typieal cighteenth century theorist, and a man whose social propagandism against war, slavery, alcoholism, and the death penalty was perhaps not entirely dissociated from a personal interest in increasing his practice, Rush was easily the ablest American clinician of his time, and his writings and reputation won him golden opinions abroad. Lettsom called him the American Sydenham, where effusive but more uncritical compatriots had dubbed him the Hippoerates of Pennsylvania, and he was the recipient of a dianond and various medals from royalty. He belongs to the sehool of Sydenham in his adherence to bloodletting and in his careful accounts of the discases under his observation. Of these, he described cholera infantum in 1773; he was the first, after Bylon, of Java (1779), to describe dengue (1780'), and perhaps the first to note the thermal fever oceasioned by drinking cold water when overheated. His monograph on insanity (1812) has been pronounced by Mills' to be, with that of Isaac Ray, the only systematic American treatise on the subject before the year 1883. His account of the Philadelphia epidemic of yellow fever in 1793 is only approached by that of Matthew Carey for its realism. In fighting this epidemic, Rush played a distinguished part, breaking down his health by treating 100 to 150 patients a lay, and incurring eivic and professional hatred through insisting that the disease was not imported from without but arose de novo in the city. His scheme of treatment was the exhibition of large doses of calomel and jalap, copious blood-letting, low diet, low temperature in the sick-room, and abundant hydrotherapy, within and without. As a blood-letter, Rush has been likened to Sangrado, but he saved many patients and, when sick, as he thought, of yelow fever, consistently submitted to his own line of treatment.

${ }^{1}$ Rush: Medieal Observations and Inquiries, Phila., 1789, v, 104-121.

${ }^{2}$ C. K. Mills: Benjamin Rush and Ameriean Psyehiatry, 1856. Cited by Mumford. 
Apart from his elinieal memoirs, Rush wrote a valuable pamphlet on the hygiene of troops (1777), and his papers on the diseases of North Ameriean Indians (1774) and their viees (1798), with his aceount of the German inhabitants of Pennsylvania (1798), are perhaps the earliest American contributions to anthropology. The original bent of his mind is shown in his inquiries into the effects of ardent spirits on the mind, the cure of diseases by the extraction of deeayed teeth, and the effeet of arsenie in eancer. Like Shippen and Physick, Rush was a well-featured man of aquiline profile, suggesting native shrewdness and penetration.

The name of Benjamin Franklin (1706-90), of Boston, is intimately conneeted with Ameriean medicine through his invention of bifoeal lenses $\left(1784^{\mathrm{I}}\right)$ and a flexible catheter, his treatment of nervous diseases by eleetrieity (Franklinism), his letters on leadpoisoning, and his observations on gout, the heat of the blood, sleep, deafness, nyctalopia, the infeetive nature of colds, infeetion from dead bodies, death-rate in infants, and medical edueation. He was the prineipal founder and the first president of the Pennsylvania Hospital (1751), of which he wrote a history, by request, printed at his own press in 1754. Of special bibliographic interest are his Dialogue with the Gout and his pamphlet on inoculation in smallpox (London, 1759), which was aceompanied by William Heberden's chirections for performing the operation.

Thomas Cadwalader (1708-79), of Philadelphia, a pupil of Cheselden, was a pioneer of inoculation (1730), a founder of the Philadelphia Library (1731) and its direetor (1731-39), and the first to teach anatomy by dissections in the city (1730-31).

His Essay on the West-India Dry-Gripes, printed by Benjamin Franklin in 1745, and sometimes wrongly catalogued as an "Essay on the Iliac Pission,"'2 is an aecount of lead colie and lead palsy from the habitual use of Jamaica rum distilled through leaden pipes. It contains his autopsy of a ease of mollities ossium (1742), and ranks with the essays of Huxham (1739), Tronchin (1757), Bordeu (1761-63) and Baker (1767) as one of the elassic accounts of lead poisoning in the eighteenth century.

Apart from the work of Morgan, Rush, and Shippen, the writings of the colonial pamphleteers on inoeulation, the clinical observations of Cadwalader, Samuel Bard, Beardsley, Rush, and Carey, and the pioneer exploits in pelvie and vaseular surgery by John Bard, William Baynham, and Wright Post, most of the produetions of American medicine in this period, although of a respectable character, are aside from the main eurrent of scientifie progress. As Sainte Beuve said to Matthew Arnold about Lamar-

${ }^{1}$ In his letter to Whately of London, 1785 .

${ }^{2}$ See C. W. Dulles: Med. Library \& Histor. Jour., Brooklyn, 1903, i, 181-184. 
tine's poems, they are "important to us," in the sense of having a definite local and historic interest.

\section{CULTURAL AND SOCIAL ASPECTS OF EIGHTEENTH CENTURY MEDICINE}

The rise of Prussia and Russia and the American and Freneh revolutions are perhaps the only historie events which exerted much influence upon the condition of medicine in the eighteenth century, and then only in relation to the development of surgery. The tendencies of the age were artificial and theoretic rather than sincere or realistic. 'This periwigged period is conceded to have been the "Golden Age," alike of the suceessful practitioner and the successful quack. The reason of this is to be sought in the stationary condition of society prior to the French Revolution, which kept all oceupations in a definite groove; so that the internist or physician proper was in every sense of the word a family doctor (Hausarzt), who was given a voluntary annual honorarium for his continuous services during the year, thus relieving him of the necessity of competing with his fellow practitioners or of struggling for his existence beyond a certain point. Nearly every one of the great physicians of the time stood on a pedestal all his own, and many of these, as Weleh has said, "let it be known" that they were in possession of private or secret remedies which were superior to all others. Practice was inherited from father to son or passed on to favorite pupils, and, in this way, a certain elegant leisure was acquired by the well-to-do members of the profession, giving them exceptional opportunities for the acquisition of culture. Haller, William Hunter, Searpa, Heberden, and Thomas Young vield to none in scholarship and variety of attainments. Arbuthnot, Garth, and other physicians of Queen Anne's reign were coffee-house intimates of the wits and poets of the period. ${ }^{1}$ Lessing had studied medicine. Goldsmith and Schiller were medical graduates; and such men of letters as Garth, Arbuthnot, Blackmore, Akenside, Haller, Zimmermann, and Werlhof were practitioner's. There is plenty of evidence that the social status of the eighteenth century physician was, if anything, better than it is now. In some countries he wore a sword, his color was the

${ }^{1}$ Every reader of Pope will recall his grateful tribute to Arbuthnot:

"Friend to my life; (which did you not prolong,

The world had wanted many an idle song),

The muse but serv'd to ease some friend, not wife,

To help me through this long disease, my life,

To seeonil, Arbuthnot! thy art and eare,

And teach the being you preserved to bear." 
"austere scarlet," and people commonly took off their hats to him, even when he bore a muff, to preserve his delicacy of touch in diagnosis. In England, the fashionable physician wore a powdered wig, a handsome coat of red satin or brocade, short breeches, stockings and buckled shoes, a three-cornered hat, and bore a goldheaded cane. Werlhof, at Hannover, on the occasion of his second marriage, wore a violet velvet coat. Toward the end of the seventeenth century, ruffled collars gave place to Geneva bands, an appropriate symbol of the clerical origin of the medical profession. The summit of its grandeur, in costume at least, is to be seen in the

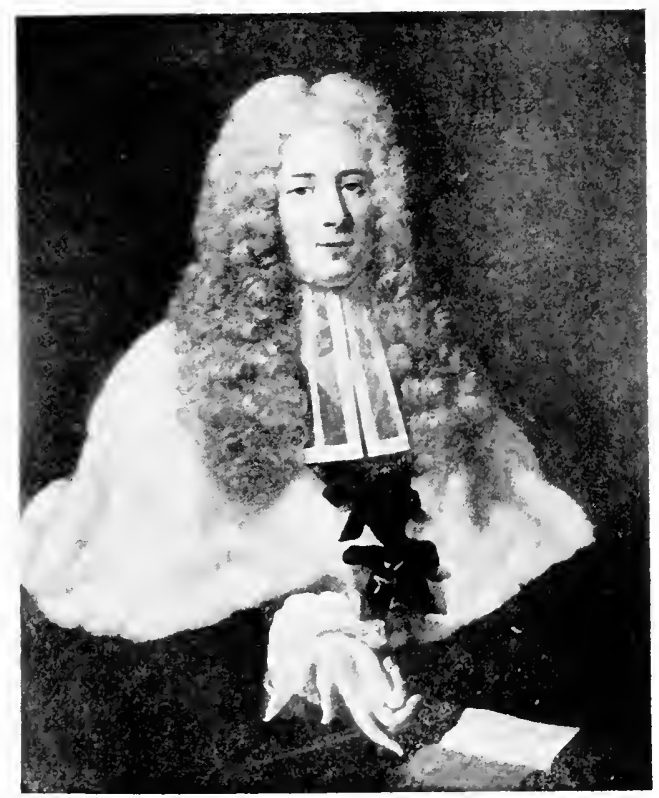

Hyacinthe-Théodore Baron père (1710-58), Dean of the Paris Medieal Faculty, 1730-34. (Courtesy of M. Noé Legrand, Paris, from his "Les Collections Artistiques de la Faculté de Médecine de Paris," 1911.)

portrait of the elder Baron, the pleasant-faced dean of the Paris Faculty (1730-34), which is reproduced in the beatiful album of its artistic collections published in 1911. ${ }^{1}$ The handsome dean wears a long, carefully curled wig, an ermine cape, a delicate, transparent rabat in place of the stiff Geneva band, a red ecclesiastic cope (the "regal dalmatic") with lace ruffles at the sleeves, and, over his breast, a decoration suspended by a long black ribbon.

${ }^{1}$ Les collections artistiques de la Faculté de médecine de Paris. Inventaire raisonné par Noé Legrand et L. Landouzy, Paris, 1911. 
Solemn clegance could go no further. Careless elegance as well as political sympathies were sometimes evinced in the loosely knotted "Steenkirk tie."

Exeept in caricature, the art of the eighteenth century throws little light upon the status of the medieal profession. Reynolds and Gainsborough, Fragonard and Waticau, are unusually reticent about medicine in their canvases, although a few portraits of physicians were, of course, painted by Racburn and others, with Sir Joshua's great portrait of John Hunter at the head of the list.

IIogarth's "Company of Undertakers" (1736), with the legend, Et plurima mortis imago, represents twolve hard-featured individuals, all bewigged and armed with gold-headed eanes, who are supposed to represent Spot Ward, the

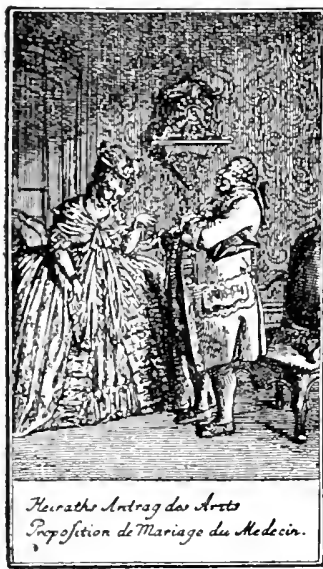

A proposal of marriage. Etching by Daniel Chodowiecki (1726-1801). Chevalier Taylor, Madame Mapp) (in a zany's eoat of many colors), and other quacks of the period. Hogarth also made two pictures of Maria Toft's miraculous birth of rabbits, a celebrated imposture of the eighteenth century and has various broad or slanting allusions to prostitution, pregnaney, alcoholism, and insanity in his copper-plates, including the quack with the syphilitic girl in Mariage à la Mode (Plate III). His "Pool of Bethesda" (St. Bartholomew's Hospital) has representations of lameness, rickets, consumption, psoriasis. and other diseases (Norman Noore). Gillray and Rowlandson, those masters of the coarse and grotesque, indulged their animal spirits abundantly at the expense of medicine, but their plates belong mostly to the Georgian period. Those on The Dying Patient, or the Doetor's Last Fee (Rowlandson, 1786), Transplantation of 'Teeth (Rowlandson, 1787), The Gout (Gillray, 1799), The Midwife (Rowlandson, 1800), and Metallic Tractors (Gillray, 1S01), are all true eighteenth century in implication. Animal magnetisn, vaceination. elysters, Macassar oil, men-midwives, metallie tractors, phrenology, and other foibles of the period were all abundantly caricatured in the fugitive anonymous plates of the time. That prolific Danzig artist. Daniel Chodowiecki, the illustrator of the Zopfzeit, has some clever etchings of German interiors, representing inoculation, animal magnetism, dissecting, fashionable physicians (Modedoctoren), miraculous healers (Wunderdoctoren), Frederick the Great having a vein opened, a sick person receiving extreme unetion, an absurd proposal of marriage by a corpulent physician to an equally stout patient, and a plate showing Prussian police in the act of ordering patients to the Charite. Dr. Leonard Mark has noted that the various etchings and mezzotints of one Richard Diekinson, a shoe-cleaner and ginger-breadseller of Searborough Spa, afford striking representations of the aeromegalic facies, made over two hundred years ago $\left(1725-26^{2}\right)$. Boucher's cartoon of the orviétan-vendor (1736) was reproduced in Gobelin tapestry. The excellence of Tiepolo's dwarfs has been emphasized by Chareot. A clever painting by Pietro Longhi represents an Italian apotheeary shop of the period.

1 So called from the disordered condition of rich cravats at the battle of Steinkirk (1692). After this event, the studiously disarranged Itie became fashionable in France, and, if we may trust the Restoration dramatists, even in England. Sce Vanbrugh's Relapse, aet 1, sc. 3, and Scott's Rob Roy, ch. xxxi.

${ }^{2}$ L. Mark: Lancet, Lond., 1914, ii, 1412 (with cuts). 
In the secular literature of the eighteenth century the physician was especially satirized by Smollett. (Count Fathom), Sterne (I)r. Slop), and Le Sage (Gil Blas). In Smollett's Count Fathom the adventurous knave takes it into his head to enroll himself among "the sons of Pæan," and his experiences give an amusing purview of the "solemnities of dress and address," the trade tricks (being called out of church or riding aimlessly about in a chariot) which were resorted to even by practitioners of better repute.

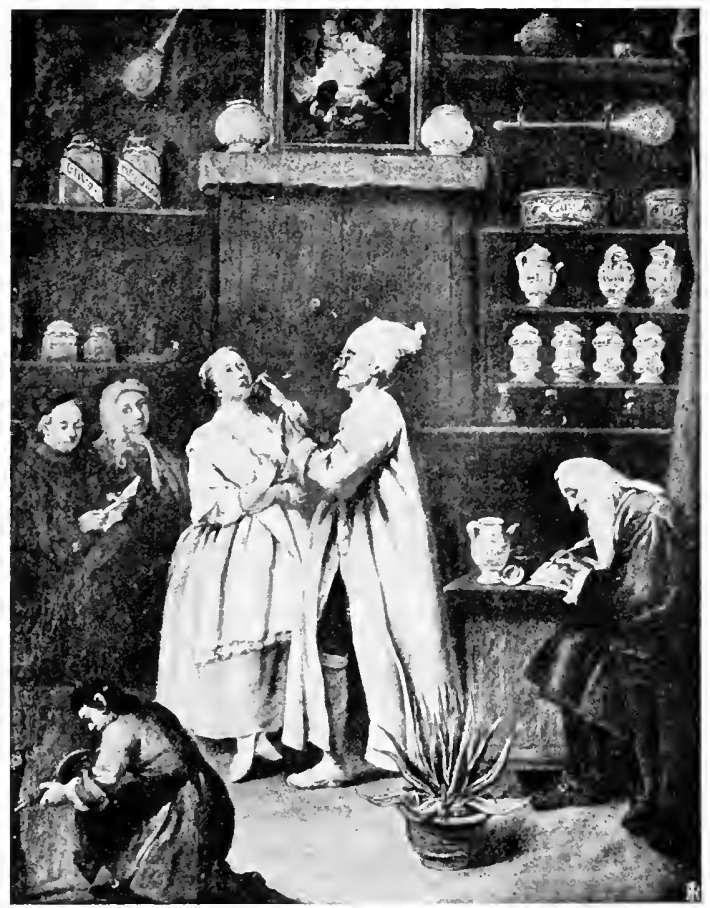

The Apothecary, by Pietro Longhi (1702-85). (Italian interior of the eighteenth eentury.)

The capable Huxham, a butcher's son, who first praetised among non-conformists and afterward went over to the Established Church, often had himself summoned ont of conventicle at stated intervals, whereupon he would gallop through the town to create the impression of an extensive practice. He usually stalked about in a scarlet coat, flourishing a gold-headed cane, a footman bearing his gloves at a respectful distance. Le Sage throws much light upon medicine in Spain, where blood-letting and eathartics were almost the only known remedies, where cleaning the streets of 
oftal was opposed for a fantastic reason, where there was not a single apotherary for oyer half a contury, and whele, as bate as

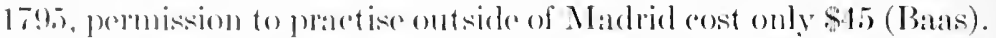
The ignominions position of the army surgeon in (iermany after the time of Federiele the (ireat is alluded to in the early writings amel porms of sedhiller.' In Roderick Random, Smollett describes

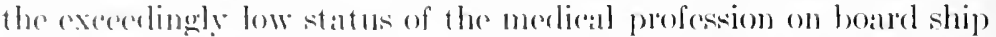
and the bumbugerery and corruption which attended the competitivo examinations for the position of surgeon's mate. His picture of X. Iallemint, the shabhy, nimble-shilling apothecary, is equally significant. In an age in which easte distinctions were on an ironrelal basis (witness the French Rovolution), it is obvious that the inposing dess and manners of the mpper-elatss physicians should lend themedres readily to indation at the hands of mocrupulous impostors. The eighteonth century was the age par excellence of suleoessful guateks, and it only vields to the nineteenth century in respect of those patented or secret preparations of which the poet Crabloe, the satirist of culacks, laments:

"From the poor man's pay"

The nostrum takes no trifling part away."

Quackery, if not universal, wats at least, in Thoreau's phrase, "muiversally successful." Rolling stones, like Cagliostro, and Mesmer, managed to ply their trade for a long while withont interruption. ('asinova paid a decorous visit to Haller at Bern, and his stay with the great man was supposed to be not so much "the homage which vice pays to virtue" as a manifestation of genuine estrem, for Casanova not only affected to enjoy the commerce of the learned, but had written Latin dissertations or had some one write them for him. In England, there was a long line of successful medical charlatans of both sexes. The earliest of these was Sir William Read, who started out as a tailor, but in 1694 set up in the strand as an oculist, having hired some one to write a book on eye diceases under his name and a Cirub Street poet to praise him in verse. His success in this specialty attracted the attention of Queen Anne, whose bad eyesight made her an easy victim of such impostors, and, gaining her grood graces, be was actually knighted, subsequently heroming oculist to George I. He frequented the society of Swift and the other coffee-house wits, who made fun of him while accepting his lavish hospitality, and he is even mentioned in the spectator (September 1, November 27, 1712). Other quack oculists of importance in their day were Dr. Crant (who was also patronized by Queen Anne), Thomas Woolhouse, oculist

${ }^{1}$ For a goot aceount of Schiller's medical eareer, see M. Neuburger, Wien. klin. Wochensehr., 1905, xviii, $485-497$. 
to James II and William III, who is said to have proposed iridectomy in 1711, before (heselden, and the Chevalier Taylor. The latter, the son of a female apothecary of Norwich, had actually worked with Cheselden at St. Thomas's and had invented a cataract needle and other instruments, but, failing of suceess in London, decided for the adventurous career of a roving oculist. It has been remarked that even Daviel, in the early part of his career, did practically the same thing, trumpeting his praises abroad after the fashion of the wandering eye-eouchers of the Middle Ages, but with this difference that Daviel was really a great ophthalnie surgeon in the making, where Taylor was only a clever buffoon.' Clad in black, with a long flowing wig, possessed of a good address and undonbtedly of some skill in eye surgery, Taylor went abont, lecturing like a mountebank at a fair, expressing himself in queer sentences with inverted syntax, in imitation of Latin, which style he called "true Ciceronian." He numbered even Cibbon and Händel among his patients, but did not impose upon Horace Walpole or Dr. Johnson. The latter says of him (Boswell, 1779): "Taylor was the most ignorant man I ever knew, but sprightly: Ward, the dullest. Taylor challenged me once to talk Latin with him [laughing]. I quoted some of Horace, which he took to be a part of my own speech. He said a few words well enongh." The Ward to whom Dr. Johnson refers was Joshua Ward, another famous quack, also known as "Spot" Ward, on aceount of a claret mark on one side of his face. Ward was originally a drysalter who had tried polities withont success, but soon made his fortune by the sale of antimonial pills and drops, a "liquid sweat," a "dropsy purging powder," and other nost rums. General Churehill constituted himself press-agent for Warl's pills. Ward's "essenee for headache" and "Ward's paste" (for fistula and piles) afterward appeared in the Pharmacopocia as compound camphor liniment and eonfection of pepper. He won the absolute confidence of George II by reducing a disloeated thumb with a sharp wrench, after which he was given a room in Whitehall and liberally patronized by the great, numbering ('hesterfield, Walpole, and Cibbon among his patients. He was specially exempted from the penalties of the Parliamentary Act of 1748 , restricting the practice of medicine, and, in his will, had the impudence to request burial in Westminster Abbey. Pope has embalmed him in a couplet:

"Of lite, without the least pretenee to skill,

Warl's grown a famerl physician by at pill."

1 Taylor's writings, transtated into many languages, eontain many things in advance of his time, $e$. $g$. the first delineation of conieal cormeal after that of Duddell (in 1736). See G. Coats: Roy. Lond. Ophth. Hosp. Rep., 1:15, xx, $1-92$. 
Famoms female impostors of the poriod were Mrs. Mapp, a

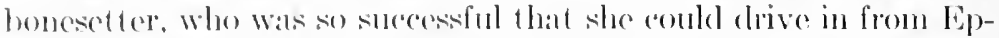
som in a distiot and four, with gorgeossty liveried servants, and Jostuna Stevens, a wilow, who, in 1739), actually suceoeded in having her romedy for stone purehased pro bono publico by Act of Parliament. Her philanthropy went to the extent of agrecing to part with this vatuable recipe for $\mathscr{L} 5000$, but even a titled subscription list could not raise this sum in the first instance, and powrerul influence was brought to bear upon Parlianent, even Chesclen, Sharp, and Cassar Hawkins vouching for her merits. The recipe was published in the London Gizette of June 19, 1739, and furned out to be a set of mixtures of eggeshells, garden-snails, swines' (resses, soap, and such regetable ingredients as burdock sceds, hips, and haws. In each one of her certified "cures," the stone was found in the bladder after death.

Of secret or proprietary medicines patented in England, Timothy Byfield's sal olesum rolatile (1711) was the first to take advantage of the old Statute of Monopolies of 1624. It wats followed by Stoughton's Great Cordial Elixir (1712). Betton's British Oils (1742), John IIroper's Female Pills (1743), and at long list of other nostrums, down to Ching's Worm Lozenges (1792) and Della Lena's Powder of Mars (1799). The Duke of Portland's Powder is menttioned in Fielling's Voyage to Lisbon (1755). The most famous of these were the antimonial fever powder (1747) and analeptic pills (1794) of Dr. Robert James, a physieian of solid ability, who wrote a bulky Dietionary of Medicine inel a Pharmacopoia Universalis, and was an esteemed friend of Dr. Johnson. The original James's powder was, in the opinion of Christison, more effective than its antimonial substitute in the Pharnacopoeia. The eau medicinale de Husson, a secret remedy for gout, probably contained colchicum (introduced by Stoerek in 176:3). "T'uscora Rice," for consumption, was the first Americin patent medicine (1711).

Among the therapentic fads of the time were quassia-cups, saffron drops, purging sugar-plums, anodyne necklaces for pregmant women and tecthing ehildren, Macassar oil (for the hair), and the metallic or magnetic tractors patented by Elisha Perkins of Connecticut in 1798. These were compass-like contrivances, with one blunt-pointed and one sharp-pointed arm, made of combinations of copper, zine, and gold, or iron, silver, and platinum. Cures were effected by stroking, and their principle of action was supposed to be analogous to that of galvanism or animal magnetism. Perkins's tractors had a remarkable vogue in England, were abundantly satirized in the colored prints and pamphlets like "A Terrible Tractoration," until John Haygarth, a Bath physieian, showed that similar cures could be effected with wooden tractors, whence it was perceived that they were due to imagination. Electricity and animal magnetism were used as a special mode of appealing to the baser passions by James Graham of Edinburgh, who was the coryphrus of "celestial beds" for re- 
juvenating senility. Ciraham was a man of handsome physique, aquiline features, and pontifical manner, who hat half stuclied medicine and picked up some knowledge of electricity from hearing about Franklin's experiments in America. His "Temple of Health," opened in London in 1780, consisted of a sumptuously appointed apartment, with all the implications and accessories of a strictly Oriental interior, including mysterious perfumes, soft music, and bacchantic poses. The entrance fee was six guineas and, in a plain-spoken lecture which "tickled the ears of the groundlings," immediate conception was guaranteed to the childless for a $£ 50$ banknote. The fraud clid not last long, and when the crash came, in 1782, Graham was driven to preach mud-baths (fangotherapy), evincing his sincerity by remaining in them for hours at a time each day. "Half knave, half enthusiast," as Robert Southey called him, he did not profit by his hygienic theories, and died at an early age. More respectable and hardly to be elassed among quacks, pure and simple, were the "Whitworth doetors," otherwise the Taylor brothers, two village farmers who took up human ailments, buying Glauber's salts by the ton, and dispensing it in proportion, bleeding the poor free of charge on Sunday mornings, setting broken bones and treating eancers, apparently with some show of success. Although the elder Taylor cared more for horse-doctoring than for human patients, Whitworth was erowded with the visiting siek, who were treated strictly as they came, without preference or deference for rank. Even royalty had to taste the same rustic independence. The "Whitworth red bottle" and "Whitworth drops" were famous a century ago. When John Hunter asked Taylor the composition of one of his ointments, he replied, "No Jack, that's not a fair question. I'll send you as much of it as you like, but I won't tell you what it's made of.",

Toward the close of the century, a Mr. and Mrs. Loutherbourg acquired an enormous following by reviving the old method of Valentine Greatrakes of curing disease by touch, in other words, faith cure. They were besieged by great crowds of patients whom they professed to treat gratis, declining to take any fee whatever, but it was discovered that they were in collusion with rertain agents who sold their "free" tickets for whatever they could get. Dr. Katterfelto, another sharp practitioner, traveled about the north of England in a van drawn by six horses, containing a number of black cats and attended by many outriders in gay liveries.

'For further information about the English (puacks of the eighteentl) century see the admirable quackery number of the British Medical Journal for May 27, 1911 (vol. i, 1264-1274); Wootton's Chronicles of Pharmacy, Lond., 1910 , vol. ii, 203-219, and the separate biographic notices in Leslie Stephen. 
Dr. Mrershach, in spite of Icttsom's opposition, continued to make a larere inconne ont of fashionable people. On the continent, Villars had rnormous suceess with a five-frane nostrum of niter and water, and Ailhand, whose powders are salid to have destroyed as many people as Napoleon's campaigns, though he was put out of business by Tissot in his Avis au Peuple (1803), had already attained to three baronies and was known as the Baron de Castelet. Johann Christoph Ludemann (1685-1757), of Harburg, practised astrology and uroscopy in Amsterdam up to the end of his life. His success was largely due to a female companion, who, like the Wise Woman in Heywood's comedy, played the part of informant and procuress. ${ }^{2}$

In Farquhar's Recruiting Offeer (act iv, se. 3), there is a scene in which Sergeant Kite whiles away his time by passing himself off as a conjurer. Assuming the power of precliction, he tells a butcher that, from his skill in swinging the cleaver, he will some day become surgeon general of the army. This was at the beginning of the century, and, only a little while before, the witty and discolute Earl of Rochester is said to have diverted himself by hiring a stall on Tower Hill, where he practised as a quack doctor, delivering himself of truly Paracelsian tirades, ${ }^{3}$ and selling cosmetics and remedies for female complaints. It is obvious that the great army of adventurers, carcl-sharpers, quacks, and other financial crooks who flomished in the eighteenth century succeeded, then as now, by the kind of assurance which the Germans call imponiren. They clared to be themselves with a vast amount of swagger and with the trait of clever brutality which is always an asset among rogues. Yet the same aplomb was noticeable in more honorable branches of activity, and, as Jeaffreson says, "the physician, the divine, the lawyer, the parliament-man, the country gentleman, the author by profession-all had peculiarities of style, costume, speech, or intonation, by which they were well pleased that they should be recognized. . . . The barrister's smirk, the physician's unctuous smiles, the pedagogue's frown, did not originate in a mean desire to be taken for something of higher mark and esteem than they really were." 4 Indeed, Thomas Sergeant Perry maintains that the uneasy sense of inferiority and concern about the opinion of others which is snobbery first made its appearance in literature in the episode of Mrs. Tibbs in Goldsmith's "Citizen of the World" $\left(1762^{5}\right)$. The professional jealousy

1 J. C. Jeaffreson: A Book about Doctors, New York, 1861, 101-114.

2 J. G. de Lint: Janus, Leyden, 1913, xviii, 165-196.

${ }^{3}$ For an amusing speech by Rochester, see Wootton's Chronieles of Pharmacy, London, 1910, ii, 204-205. ${ }^{4}$ Jeaffreson: Op. cit., 83.

${ }^{5}$ T. S. Perry: The Evolution of the Snob, Boston, 1887, pp. 57-60. 
and rancor which obtained among some members of the profession can be sensed in the virulent character of their medical controversies, which form such a large segment of eighteenth century pamphleteering. On Decenter 28, 1750, Drs. John Williams and Parker Bennet, of Jamaica, having become involved in a wrangle about their respective views on bilious fever, eame to blows, and, the next day, proceeded to a desperate hand-to-hand combat with swords and pistols, which ended fatally for both. ${ }^{1}$ It is said that Joham Peter Frank was so disgusted with the behavior of doctors in consultation that he advised the ealling in of the police on all such oeeasions (Jacobi). In 1799, the Medical and Chirurgical Faculty of Maryland imposed a fine of ten dollars upon any member guilty of disorderly conduct in its meetings, with orders to eject him, if neeessary $\left(\right.$ Cordell $\left.^{2}\right)$. But these eases are hardly typical. The general tendeney of the age was toward sobriety, urbanity, extremely artificial manners, and the control of the body by the mind. The eighteenth century physician of better type was in position to make large sums of money without using his profession as a trade and enjoyed social and cultural advantages far above the average. Let us glance for a moment at some of the fashionable London practitioners of the period. In England, Garth was the idol of the Whigs, Arbuthnot, of the Tories. Sir Samuel Garth (1661-1719) was the only physician who belonged to the famous Kit-Kat Club, and, while making a name for himself in literature and taking an occasional hand in politics, had no mean success as a practitioner. John Arbuthnot ("Martimus S'criblemes") (1667-1735), the author of "The History of John Bull," was the friend and familiar of Pope and Fwift and eventually became physician to Queen Anne. Sir Richarcl Blackmore ( -1729), although a total failure as a poet, was accounted one of the most suceessful men in the medical profession, the oracle of the wealthy, whom he emulated-in "style." Sir Hans Sloane (1660-1753), the first physician to be made a baronet, enjoyed the highest scientific and professional reputation, was a founder and later seeretary and president of the Royal Society, and his musem and library, after his death, became the nucleus of the present British Museim collections. John Radcliffe (1650-1729), although of humble origin, was appointed physician to Princess Anne of Demmark, which position he lost through his arrogant demeanor. He had financial luck from the start, commeneing practice about the time that Richard Lower was losing ground, and was making more than twenty guineas a day at the end of his first year. He was a Jacobite, and,

${ }^{1}$ J. Williams and P. Bennet: Essays on bilious fever, London, 1752.

${ }^{2}$ Cited by G. Wythe Cook: The history of medical othies, New York Med. Jour., 1915, ci, 140; 205. 
saly Jeaffreson, "comtrived hy his shrewd humor, arrogant sim-

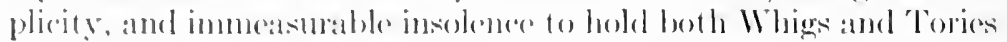
in his grasp). The two bactions of the aristodracy bowed before him." His disposition was somewhat somed hy the fand that he had hoon one jilted and onee rejoeted in a proposal of mamiage, yet, though he pertended to be miserly, he was forpuently generous with his moner. Aftre liberally providing for his relatives in his will, he loft funds to Oxford for the present foundations known as the Radeliffe Jibrary, the Radeliffe Infirmary, the Radeliffe (obscrvatory, and the Radeliffe Travelling ledlowship. Toward the rlose of his life, he took a fancy to young Richard Mead (167:3175t), who flattrod his vanity and so inherited his practice. "Noad, I love you," said Radeliffe, "and I'll tell you a sure secret fo make vou a fortune- nse all mankind ill." Mead was a complete contrast to his predecessor-a a seholar where Radeliffe was ignorant of books, courtly and polished whore Radcliffo was crude and overbearing. "Dr. Mead," said Dr. Johnsom, "lived more in the broad sunshine of lifo than almost any man." Through Radeliffe's influence, he was summoned to the death-hed of Quoen Anne, and he becime the most prosperous practitioner of his time, making in one year as much as $\mathfrak{E} 7000$. Epon moving into liad(diffe's house in Bloomsbury Square, he inherited the lat ter's famous gold-hearled eane, which passed successively through the hands of Askew, Pitcairn, and Baille, and is now in the Library of the Royal College of Physicians. Mead afterward moved into a handsome establishment in Ormond Street and liverl to be eighty-one. After him came such men as Heberden, Lettsom, Fothergill, Parry, and the Hunters.

On the continent we find Werlhof, eourt physieian at Ilannover, and, after the battle of Dettingen (June 27, 1743), physieian in ordinary to George II. He was suceeded by Zinmermann and Wichmann, who, says Baas, flourished a barber's bowl before he entered the gymnasium. In Leyden, Boerhave was preëminent; in Ifalle, Stahl ant Hoffmann, and later Reil; in Berlin, Heim; in Jena, Hufeland; in Vienna, van Swieten and de Haën; in Paris, Théophile de Bordeu; in Modena, Torti; at Pavia, Borsieri de Kanilfeld and Peter Frank; in Grneva, Tronchin; and in Lausanne, Tissot.

All these physicians were fortunate above the average, and one characteristic seems common to most of them. As they were not specially exposed to commercial competition and the petty human traits it brings forth, they could afford to be charitable in the best sense. No other single group of physicians was probably so generous to the poor. Take, for example, this little note which Garth scribbled to Sir Hans Sloane:

"Dear Sir Hans:

"If you ean recommend this miserable slut to be fluxed, you'll do an act of charity for, dear sir,

\footnotetext{
"Your obed" sert $^{\mathrm{t}}$
} "Sl Garth." 
or this of John Hunter to his brother William:

"Dear Brother:

"The bearer is very desirous of having your opinion. I do not know his ease. He has no money, and you don't want any, so that you are well mot.

"Ever yours, "Jolin Hunter."

Rough kindness this, yet it shows a degree of fraternal confidence between physicians which seldom exists to-day, and toward the humble poor the sentiment of Empedocles:

"Thou art my friend, to thee All knowledge that I have, All skill I wield are free."

That this sentiment was reeiprocated by the mass of mankind we need no better evidence than the experience of Jemner, or the extraordinary popularity of such books as Tissot's Avis au Peuple or Hufeland's Makrobiotik.

One of the kindest and most liberal of the eighteenth century physicians was Richard Brocklesby, who, in 1788, gave Edmund Burke $£ 1000$ with an offer to repeat the gift "every year until your merit is rewarded as it ought to be at court" ; who encouraged Young and who offered to settle $£ 100$ a year upon Dr. Johnson for life. Boswell records that "a grateful tear" gathered in Johnson's eye, "as he spoke of this in a faltering tone." In 1792, Benjamin Thomson, Count Rumford (1753-1814), of Woburn, Mass., established the People's Soup Kitehens at Munich, with provision for warm meals for school children, the first venture of this kind.

Another sidle-light on the social status of eighteenth eentury physicians is afforded by the ineomes they made and the fees some of them reeeived. The guinea came into eurreney in Restoration Englind in 1660, and this afforded an opportunity to raise the doetor's fee from a noble or angel to this sum, a fee which has persisted even to our day, although the guinea ceased to be coined in 1813 (Power). Mearl eommonly charged a guinea as an offiee fee, two guineas or more for a visit to pationts in good standing, and, like Rarlcliffe, be wrote half-guinea preseriptions for the apothecaries while sitting in his coffee-house, without seeing the patient. His average ineome was bet ween $£ 5000$ and $£ 6000$ per annum, which had a purchasing power of over three times its value in modern money. Nead attended to Freind's practice when the latter went into polities, and handed him 11,400 guineas as the amount collected Radeliffe's consultation fee at Bow was 5 guineis. Later on, we find Fothergill making $£ 5000$ at year and Lettsom $£ 12,000$. Batas considers 3000 to 4000 marks ( $\$ 2250$ to $\$ 3000$ in present value) as a medioere eighteenth century ineome in a eity of size, and he states that, in 1782, Heim, in Borlin, got 4200 marks from 784 patients, 6600 marks from 383 patients in 1784 , 26,400 marks from 1000 patients in 1790 , and by 180.5 , his annual ineome had gone up to 36,000 marks. Orräls, in Moseow, was making 90,000 marks in a short time. ${ }^{2}$ The phenomenal fee of the period was that aequired by 'Thomas Dimslale for inoculating Catherine of Russia and her son, viz., $\$ 50,000$, with

1 Baas: Op. cit., pp. 745, 751, 763. 
$\$ 10,000$ mdelitional for traveling exponses, a pension of $\$ 2500$ for life, and the

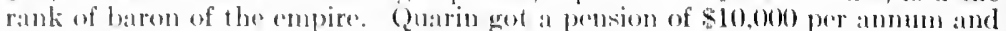

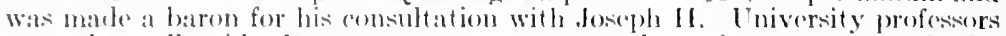

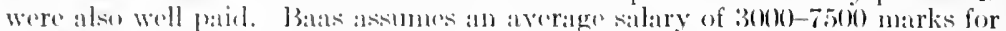
tho North Cierman miversitius. but points out that the cost of comfortable living was about foon marks anmially in llannover and 7500 in borlin. De

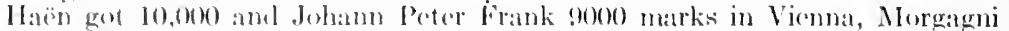

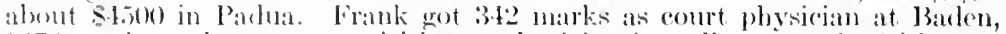
1:370 marks and many perpulsities as physiedan in ordinary to the bishop of

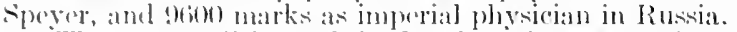

"Three new elitions of the Lomblon Pharmateoperiat were issued during the eighteruth century, ach of them characterized by changes which show the status of therapeutics ame the gradual advance of phammeology. 'The fomrth l'hammapria (1721), adited by sir llans sloine, drops many of the old srrups and watels, but refains theriac, the extracts of exereda and other animal porducts, and introduess stramonium, gamboge, Focale cormutum,

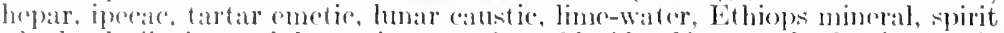
of sal volatile, iron sulphate, tincture of prerchloride of irom, and other inorganic preparations. The fifth Loudon Jharmaceporia (17.16), reviserl by Miead, Hebereles, levind, and others, professes to condemn the old astrologic and folk remodics, and while it drops human fat, spider-welss, moss from human skulls, mivorn's horn, virgin's milk, bowes from the stag's heart, and the like, still retains mithridate, theriac, erabs eves, wood-lice, peark, bezoars, vipers, coral, ete. sirups and medieated waters diminish in number, but there are many new timctures, including those of valorian and carlamoms. Cilauber's salts, sweet spirits of niter, syrup of squils, liquor putassar, and potassium aretate are addol. One your before this phamacoporia was printed, William IIberden published his famous essay, Antitheriaka (1745), in which he showert that the bedief in the eflicacy of therise and mithridate was based upon a tissur of absumlitios, sinee the artial formula for theriae found in the anbinet of Mithridates after his death called for 20 leaves of rue, 1 grain of salt, 2 nuts, and 2 driel figs, a striking contrast to the long-winded reeipes for its eomposition which had bees imagined by later authorities.2 Heberden sucessfully ridieuled these nostrums out of existence, but it was too late to make any changes in the Phamacopocia of 1746 . The effect of his destructive eriticism appears to advantage in the sixth Phammeopocia (17ss), in which practically all the animal materia mediea has disa]peared, alone with theriac and mithidate; while among the new drugs and eompounds added are aconite, arnica, castor oil, colombo, eascarilla, kino, quassia, magnesia, senega, simaruba, ether, tartrate of iron, oxile of zine, Dover's powder, Hoffmann's anodrne, Huxham's tineture, James' powder, spiritus Mindereri, sarsaparilla decoctions, compound tincture of benzoin, extract of ehamomile, tineture of opium, and "tinctura opii camphorata" (paregorie). Of these, kino and catechu were introduced by Fothergill, colombo by Gaub, quassia by Danicl Rolander, senega by John 'Tennent of Virginia. Dover's powder was introduced by the famous buceaneer physician, Thomas Dover (1600-1742), who was onee in residence with sydenham, and, in 1709, reseued Alexander Salkirk (Robinson Crusoe) from the islaud of Juan Fernandes. Dover's formula for his "diaphoretic powder" is given in his "Ancient Plyysician's Legacy to His Country" (1732). Digitalis was introduced by William Withering in 178.5 , but did not appear in the London Pharmacopoia until 1809. Stocrek of Vienna made carcful studies of conium, stramonium, hyoscyamus, colehicum, pulsatilla, clematis, and recommended their use (1760-71). Thomas Fowler introdueed his solution of arsenic in 1786. Compound licorice powder was the in-

I Wootton: Op. cit., ii, yp. 65-6i.

2 Most remarkable of these was the complex therinque céleste of Strassburg, the formula of which, as given by Mare Mapp (1695), was repeated in the Strassburg pharmscopocias of 1725 and 1757 and eharmingly represented, as a lay-out in colors, in an advertisement of the Strassburg druggist Stroehlin (174). See E. Wickersheimer: La thériaque céleste, Paris, 1920. 


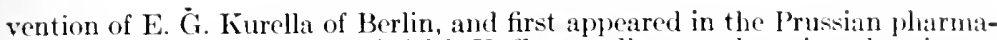
copowa in 1799. In 1724, Friedrich Hoffmann discovered a mineral spring at Seidlitz, Bohemia, which owed its medicinal properties to a combination of magnesium and sodium sulphates; but of "Scidlitz powders" only the name remains attached to the present formula, which was patented by the liond Street chemist Savory in 1815. Many physicians of the eighteenth century, including Hoffmann, Stahl, Sloane, and Mead, made money by selling preparations with secret formulas, and a token of the popular faith in drugs was the large-sized medicine spoon which often formed part of a bride's dowry. In this period, both physicians and surgeons compounded and dispensed their own remedies, and, as the practitioners themselves were usually "fimily doetors," their incidental charges were made for their prescriptions and not for their visits. This largely accounts for the terribly long-winded preseriptions which aboumd in the eighteenth century, and, as Billings remarks, the surgeons "kept on preseribing and using their oils, ointments, plasters, vulnerary drinks, rte.," for similar reasons. ${ }^{1}$ That English clergrmen dabbled in therapeutics is plain from the lueubrations of Bishop Berkeley on the virtues of tar-water (1720-48) and John Wesley's Primitive Physick (1747).

Execpt in France, the status of surgery, during the greater part of the eighteenth century, was exceelingly low. The French surgeon owed the improvement in his social condition to the fistula of Jouis XIV and its suceessful treatment by Félix, which made the latter, and his suecessor, Mareschal, royal surgeons. In 1724, Mareschal obtained from Louis XV the creation of fire chairs of surgical instruetion at st. ('ome. The Paris Faeulty immediately went into revolt and, in spite of the ling's order, make a public demonstration against St. ('ome." Decked out in their scholastic robes, the physidians, headed by the dean of the Faculty, preceded by a beadle and an usher, marched to St. Côme in solemn arlay, in spite of the hitter cold weather, the snow and sharp sleet, which made their red robes ahmost unrecognizable. Cheering one another on with cries and oaths and followed by a great crowd of people, they at length ranged themselves in a long line against the wall, while the dean presented himsolf at the door of the College accompanied by the only anatomist of the Faculty, who stood behind him holding a skeleton. Cries and imprecattions, knocks, and threats to break down the door, were only greeted by the jeers of the students from within, and, when an usher tried to make himself heard in the matter of what the surgeons owed to the physicians, the people suddenly turned against these formalities, which they had once respected like a religion. and drove the doctors away without regard for their furs and costly raiment. Two steps more put the surgeons on a social and scientific level with the doctors, viz., the foundation of the Academy of Surgery, the first session of which was held on December 18 ,

IJ. S. Billings: The History and Literature of Surgery (in Dennis's "System"), New York, 1895, i, 70.

2 E. Forgue: Montpellier méd., 1911, xxxiii, 10, 11. 
1731 , and the ordinaner of Ionis $X V^{\prime}$ (17.13), delivering the surgrons from forther association with barbers and wig-makers, who

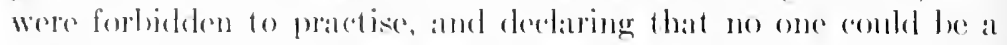
makel in surerery whout being a matser of the ats. 'This was

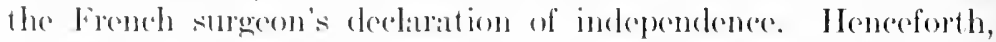
he was a lotered man, prepared for his life-work by a special scientific alucation. The King was inspired to make this wise moxe by La Peyronie, the eminent Montpellier surgen, who, with Maresohal, had fommed the Acadomy of Surgery and, in fact, devoted his cutire fortune to the alvancement of his beloved art.

In addition to Mareschal's five surgieal professorships of 1724, La Peronie fommled a sixth at his own expense, with an assistant to each professor, and also obtained four chairs of surgery for Montpellier, laying upon each inrumbent the olligation of lecturing on obstetries to both surgeons and midwives. In his will, he left a legacy of anmual prizes in surgery, his two houses in the Cirande Rue, and 100,000 franes to buikd the amphitheater of St. Conme, now the Bonrse and the Chamber of Commeree. It was doe to La Peyrnie that Paris became the surgieal enter of the world in the eighteenth eentury.

During the French Revolution, the 18 medical faculties and 15 medical colleges of France were abolished by vote in 1792 , and along with them the Société roygle de médecine (founded 1776) and the Acartemie de chimurgie (1731). This was modified in 1794, by the creation of Écoles de santé, the title of "health officer" (offecier de santé) being substituted for that of "doetor." All distinction between phrsieians and surgeons as separate guilds or rliques was broken down, and practice was thrown open to everybody who coutd pay for a license. Hospital internes, externes, physicians, and "ordinary professors" were appointed by competitive trials (concours), and medieal societies became Sociétés libres de médecine. The Écoles de santé were created to supply the urgent need for military surgeons for the armies of the Republie, and the schools at Paris, Montpellier, and Strassburg were, in reality, schools of military medicine. It was soon found that this chaotic scheme was fatal to further progress, and under the Consulate, the medieal and surgical faculties were restorel (180304), with the revival of examinations and diplomas. The concours were finally abolished by the Bourbons after $1821 .^{1}$

In eighteenth century England, there were no surgeons of first rank before the time of Pott and Cheselden, Hunter and Abernethy.

${ }^{1}$ Baas: Op. cit., pp. 749, 760, 774. For a specimen "examination" of 1\$03, with the illiterate answers given, see E. Wiekersheimer: Paris méd., 1912-13, suppl., 749-751. 
On June 24, 1745, through the good offices of Mr. Ranby, serjeant surgeon to the king, the surgeons were formally separated from the barbers as the "Masters, Governors, and Commonalty of the Art and the Seienee of Surgeons of London," and it was declared to be a penal offense for any one to pratetise surgery in London or within a radius of seven miles from it, without being duly examined and liecnsed by ten of their number. In getting rid of the barbors, the surgeons left them the hall, library, and plate, only appropriating to themselves the Arris and Gale endowments. By 1790, the company of surgeons had a loeal habitation, but Mr. Gumning, the master, reminded then that "Your theater is without lectures, your library room, without books, is converted into an office for your clerk, and your committee room is beeome his parlor."1 In 1800 the Corporation of Surgeons was rechartered by George III as the present Roval College of Surgeons of London, and, in 1813, this body beeame the Royal College of Surgeons of England. Cheselden began to lecture at st. Thomas's Ilospital about 1720, Pott at St. Bartholomew's in 1763, and there had been some haphazard lecturing on anatomy in the latter institution from the vear 1734 on. The London Hespital began to take in students in 1742 , and was fully organized in 1785 . When Guy's Hospital was opened to students in 1769 , it was agreed that all surgeons of the hospital should lecture on their subject now and then. In those days "students went for their anatomy to Windmill Street, for their midwifery to Queen Street, and for their "Chymistry, Materia Mediea and Practice of Physie' to that new home of other delightsLeicester square." The fees were $\mathfrak{E}^{300}$ for one year's dressing under a surgeon and $£ 25$ for "walking the hospital" (Charles ${ }^{2}$. Surgieal teaching in Edinburgh began vaguely with the Monro dynasty, whose whole concern was anatomy. The only Erlinburgh surgeons of prominenee were Benjamin and John Bell. The latter's unfortunate passion for controversy kept him out of the Royal Infirmary and thus deprived students of the only surgeon who could have taught them properly. In Ireland, the guild of barber's ehartered by Henry VI in 1446 was combined with the surgeons by the eharters of Elizabeth (1572) and James II (1687), but they began to break asunder in 1745, and in 1784 the surgeons were given their own autonomy through the ereation of the Royal College of Surgeons in Ireland. Through a bequest of Sir Patriek Dun (1704), president of the College of Physieians in Ireland, medieal and surgical teaching was begun in Dublin in 1714.

In Germany, there was little advancement of the surgeons' status before the time of Frederick the Great. Heister's illustrated treatise, printed in the vernacular (1743), was, it is true, the most popular surgical work in the eighteenth century, but Haller lectured and wrote on the subject without having performed an operation in his life, and there was no adequate teaching until Richter began to lecture at Göttingen in 1766 and von Siebold at Würzburg in 1769. Surgical practice was mainly in the hands of the barber, the executioner, and the strolling bone-setters, cataract-couchers, herniotomists and lithotomists, of whom the famous Dr. Eysenbarth was the type. In Goethe's Autobiography, the barber who shaved his father is styled der gute Chirurgus. Even Theden, Surgeon General of the Prussian Army, was once a barber. The barber's apprentice was usually an illiterate lad, practically a servant in the household, advertised for as a bond slave if he ran

${ }^{1}$ Cited by Billings, op. cit., p. 83. xvi, 59.

2 J. A. M. Charles: Univ. Durham Coll. Med. Gaz., Newcastle, 1916, 
away. Superstitious beliof in chatus and magic prevailed, and the executioner was believed to have a compact with the devil, power to deal with discascs atused by witheraft, and, from his oceasional duty of broking bones upon the whed, he was credited with a special talent for setting fractures and diskocations. Judicial torture was, in fact, still very common in the cighteenth ecntury, and approved of for instance, by Maria Theresa. 'Even Frederick the Cireat, in 17.4, allowed the Prussian executioners to treat wounds, ulerers, and fractures on the ground that, if competent, they were better for the mucalred masses than bungling surecons or no surgeons at all." Indeed, owing to the great need for competent surecons in the Prussian Army, the Theatrum Anatomicum at Berlin (foumded in 1713) was expanded in 1724 to inchucle a Collegium medico-chirurgicum, and the Charité Hospital at Berlin was founded, in 1727, by Friedrich Wilhelm 1 to furnish clinical instruction to the students at the Collegium. But Frederick the Geat, in his silesian campaigns, still found his army sadly defieient in surgeons, and not only sent medical caclets to Paris and Strassburg to complete their surgical education, but, in 1743, engatged 12 French surgcons, with assistants, to look after his troops. The Prussian Army surgeon of the day was ranked above a drummer and beneath a chaplain. Being a harber's apprentice, he had to shave the officers, and if he proved delinquent in line of duty, he conkl be beaten with sticks at their instance. The generul ignorance and incompetence of these amy surgeons gave so much dissatisfaction that, in 1785 , uncler Surgeon General Coopelse, the Collegium Medico-Chirurgieum was converted into a MedicoChirurgieal Pepinière, devoted exclusively to the aducation of army surgeons and retaining its connection with the Charité. This institution was also known as the Friedrich-Wilhelms Institut and, since 1895 , has been ealled the Kaiser-Wilhelms Alademie.

The learling Prussian Army surgeons of this period were Holtzendorf, the first surgeon general (1716); Sehmueker, who left some valuable collections of surgical eases (17-4-\$2); Bilguer, who filed the first brief for a conservative attitude toward amputation (1761); Theden, who was an early advocate of methodical bandaging, and Göreke, who reorganized the Prussian Army medical department. In October, 1510 , the University of Berlin was opened

${ }^{1}$ Her eorlifieation of laws, the Constitutio criminalis Theresiana (1768), was as iron-clarl in this respeet as the earlier cole of tort ure of Guazzini (1612), and while the practice was abolished by Frederick in Prussia in 1740-54, and in Saxony in 1770 , it was not until $17 \% 6$ that Maria Theresa consented to do away with it. Austria owes this advance to the humanitarian writings and efforts of Ferdinand von Leber and Joseph von Sonnenfels. See Max Neuburger: Wien. klin. Wochenschr., 1909, xxii, 1075-1078, and H. Schneickert: Arch. f. Krim.-Anthrop., Leipz., 1907, xxvii, 341-345.

${ }^{2}$ For the surgical status of the executioner in the eighteenth century, see K. Caröe, Janus, Amst., 1897-8, ii, 309-312. 
with such men as Hufeland, Reil, Ernst Horn, Rudolphi, and the elder Graefe in the medical faculty, and here many of the young army surgeons of the Pepiniere, inclurling Helmholtz, were clucated. In 1745 a similar Collegium metico-chirurgitum was established at Dresden, and in 1785, under Joseph II, the Medico-Chirurgical Academy or Josephinum was founded at Vienna, in charge of Brambilla, for instruction in military medicine, with permunent military hospitals at Prague, Budapest, Brünn, and other cities. The pupils at the Josephinmm, like those in Berlin, were usually barbers or sous of poor oflicials, but these institutions undoubtedly did most to elevate the status of surgery in Prussia, Saxony, and Austria. The Vienna school of ophthalmology was established, under royal patronage, by Michel Barth, in 1773.

In Russia, Peter the Great, who visited Boerhave and Ruysch, tried to nationalize medicine, and to this end built the first hospital and medical school in Russia (eopied from the Greenwich Hospital) in 1707. Being of wood, this structure was often burned down and as often rebuilt, in spite of the grumbling of the ecclesiastics who "had to find the funds." There were 50 pupils in 1712 , but the constant disputes between Synod and Senate about finanees led to the neglect of the hospital, and it gradually fell into ruins. In 1754, under Elizabeth, it passed into the hands of the Military Collegium, the War Department of the period. The students were clad in a caftan or long cloak, a camisole, and breeches. There was much brawling and drunkenness among them, they were often subjected to imprisonment or beating with the knout, and from various side-lights upon this period in literature and painting, some of them may have answered to the thumb-nail sketch of the Russian poet:

"Buried in his cravat, his coat reaching down to his heels,

Heavily mustached, with a dull look and a falsetto voice."

Peter the Great opened the St. Petersburg Admiralty Hospital in 1716, and, in 1717, the Dry Land Hospital, which was relutilt in 1733. In 1799, the Russian Army Aledieal Aeademy was founded, and the ancient hospital and medical school beeame the purely military institution which it is to-day. In 1763, the seventeenth century Aptela became a Collegium medicum under an "Archiater," the first of these being a Scotchman, Robert Erskine, who wats also "Leib-medik" of Peter the Great.

A prominent feature of the bureaucratic machinery founded by Czar Peter was the institution of the "tchins" in 1722, consisting of a series of grades of nobility conferred upon the tchinorniks, or public servants, a very complicated scheme of degrees of gentility and precedence. Under this system, still in vogue, medical men may rise to almost any rank.'

The ardministration of military medicine beeame, in the eighteenth century, a funetion of government. Limited periods of enlistment, strongly ardvocated by the Maréchal de Saxe in 1732, were earried ont in England (threeyear periods) in 1755 , and permanently adopted by Venice (1766) and in the

${ }^{1}$ Lancet, Lond., 1897, ii, 354-361. 
British Army in 1755. Molinal examination of recruits was carried out in

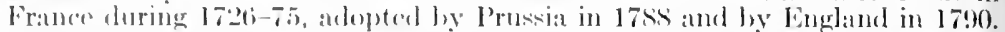
Regular government harracks for toons were substituted for billeting and their hyerenic refunements were discussod by all writers on the art of war and military mediene, atsere also the alothing, rationing and food-supplies of

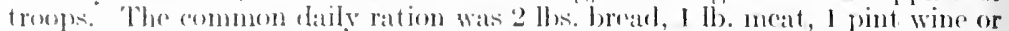
2 pints here. In 17!9!), this issole was made at the rxpense of the French governument and not ont of the soldier's pay. Army hospitals wero put under military regulation by the french in 17 stand by the English in 1762 . Sehools of military modicine, such as tho P'russian l'opinière (1755) or the Austrian

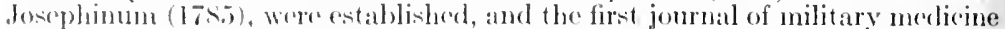

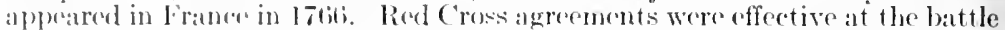
of Dettingen $(17-1: 3)$ and the Bridge of Lodi (1796i). At the Berlin exposition of military molicine in 1914, five precursors of the Eeneva Convention, between 17.3 am 1N6.1, were plateareled. In 1748, the British Army had flying, fixerl and convalesernt hosputals. Disposition of the wounderl, even in Mar]borourch's time, boing like that at the siege of Mlety (1552), attempts were mate to devise plans for evaluation which would not interfere with military movements. Thrse came to a remarkable focus at the battle of fontenoy ( May 11, 17.5), where, as Heizmann says, the wounded were treated on the front line by reginental surgeons, then collected at ambulance stations, where capital operations were performed and to which the walking wounded came, and finally transferyed to gencral hospitals in near citics, or to cities further batek, when these beeame overerowled." Yot cluring the Seven Years' War (17iti-63), due to Fredrick's methods of flank and frontal attack in close order, and of volley firing at close range, rescue of the wounded during a battle was impossible.

Among the important scientific societies of the eentury were the Royal academies at Berlin (1700), Göttingen (1751), and Munich (1759); there were founded also the Paris Acadinie de chirurgie (1731) and the medical societies of Edinburgh (17:37), London (1773), Paris (1776), the Physical Socicty of (iny's Hospital (1771), the Socicty for Improvement of Medieal Kinowledge (1752), the Society for Inprovement of Medical and Surgical Knowledge (17 8.3), both of which publiched transactions. the Lyeeum Nedicum Lonlinense (1785), the Abernethian Society (London, 1795), and the Royal College of Surgeons at London (1S00). "An exclusive "MIedical Society" of seven members (1752), dominated by Willian Hunter, published six volumes of valuable "Melical Observations and Enquiries." Of medical libraries Lancisi founded the Biblioteca Laneisiana at Rome (1711), and in 1733. the Faculty of Merlicine of Paris, which possessed only 32 books, acquired from Franģois Picoté de Bćlestre, some 2273 volumes, the nucleus of its present splendirl eollection, the largest in the motern workl. ${ }^{2}$ Similar eollections by sir Hans sloane and John Radeliffe were the origins of the Library of the British Museum and the Radrliffe Camera at Oxford. The earliest of the medical periodicals of the eighteenth eentury was Der patriotische Medicus (Hamburg, 1724-26), which was followed by about s0 others, of which 55 were Cierman, 3 French, 4 English, and 1 American. It is in the files of many of these forgotten periodicals, Sudhoff thinks, that the unwritten cultural hist ory of eighteenth century merlicine is to be found. ${ }^{3}$

The prineipal advanees made in medical education in the eighteenth century were in anatomy and elinical molicine. Before the time of John Hunter, surgery was well taught only at Paris; before the time of the Nonros, anatomy flourished prineipally on the continent. Berlin and Strassburg seem to have hal the best opportinities for obtaining material for dissection. A

1 C. L. Heizmann: Ann. Merl. History, N. Y., 1917-1S, i, 294-300.

${ }^{2}$ For its history, see A. Chéreau: Notice sur lorigine de la Bibliothìque de la Faculté de médecine de Paris, Paris, 1878.

${ }^{3}$ For further details, see the histories of medical libraries and medieal journalism by the present writer in Stedman's Reference Handbook, N. Y., $1915, \mathrm{v}, 706 ; 901$. 
Theatrum anatomicum was founded at Borlin in 1713 , was specially favored by medical legislation, and, by 1786 , was supplied with some 200 dead bodies of suicides and worklouse paupers. It was much frequented by forcignors. In Strassburg, under Salzmann, there were daily discetions and thrier werkly demonstrations as early as 1708 , and he is said to have had 30 eadavers in 1725 , and 60 in 1760, afforling opportunities even for surgical work on the caldurer. At Tübingen, however, Ilaller, the student, did most of his dissecting on dogs, and, in Paris, he had to flee for his life for body-snatehing. At Leyden, Albinus got only one eadaver a year and Fredrich Hoffmann, at Halle, only 20 bodies in twenty-four years. In Prague, there were only three dissections during the period 1692-1712; in Vienna, there was hardly a dissection as late as 1741 , although an anatomic theatre had been opened in 1718. In Great Britain chairs of anatomy were established at Edinburgh (1705), Cambridge (1707), Glasgow (1718), Oxford ("lecturer on anatomy," 1750), Dublin (1785), and the four carlavers allotted to the Company of Surgeons (1540) and the College of Physicians (1565) had been increased by Charles II to six. The first professor of the subjeet was Robert Elliot, who assumed his Edimburgh chair in 1705 , at an annual salary of $£ 15$, and resigned in favor of Monro primus in 1720. The matriculation tiekets and certifieates of attendance at Erlinburgh in the early days were written or printed upon the backs of orelinary playing cards. The ticket of Ralph Ashet on, of Philadelphia, to the seeond course of anatomy in 1758 , is made out upon the back of a deuce of spades (Packard1). Even under the Monro dynasty, instruetion was very rudimentary, the whole demonstration being done upon a single eadaver, while the vessels and nerves were studied in a fetus and surgical operations taught upon a dog. The dissecting rooms of the time, as depicted in old engravings, were unwholisome places. Jesse Foot reealled five lecturers on anatomy who had died of "putrid myasma" from foul cadavers furnished by the resurrection men. John Bell,2 in his reply to Ciregory's diatribes, gives some grim details of bungling, incompetent surgery as a result of anatomie ignorance. In one operation for stone (1SOS) the patient was kept in intense suffering for over thirty minutes, and, even then, the stone could not be ext racted, although the normal time limit for a lithotomy in those pre-anesthetic lays was about five minutes, and Cheselden usually did it in three. In Italy, before the time of Searpa, Foliee Fontana's wax preparations ${ }^{3}$ were used in lieu of eadavers for teaching purposes, and in Spain, unt il the middle of the century, there was no anatomic teaching at all.

With sueh a great leader as Linnous, it was natural that hotany should have been extensively cultivated in this period. In England, Fothergill, Cruikshank, and others had private botanie garlens of their own. Iew Gardens was established is a royal preserve about 1730, and a Physie Garden was added to it in 1759 , with William Aiton, and later, Sir Joseph Banks, as managers. Other gardens were established at St. Petersburg (1713), Virnna (1754), Cambridge (1762), Marlrid (1763), St. Vincent (1764), Coimbra (1773), Calcutta (17S6), Sydney (17SS); and the garden of the Roval Dublin Soeisty at Glasnevin was opened about 1796 . It is said that there were about 1600 botanie garlens in Europe at the end of the eighteenth eentury. The interest in botany in the New Morld is sufficiently evileneed by the generic names Claytoria, Cotlenia, Kuhnia, Carlenia, Mitehella, Bigelowia, Marshallia, Burtonia, ete, which were bestowed mon colonial plants by Linnaus and others in honor of American botanists (II. A. Iolly $\mathrm{y}^{4}$ ).

1 Packard: History of Medicine in the United States, Philadelphia, 190I, plate opposite p. $15 \mathrm{~s}$.

2 John Bell: Letters on Professional Character and Manners, Edinburgh, 1810, рр. $590-592$.

${ }^{3}$ The Musenm of the Ahbate Felice Fontana (1730-1803) was the most famous anatomie collection of its lind in the eighteenth eentury, containing over 1500 preparations in wax, many of them made after Maseagni's pripirations. These still exist, "beautiful to look at, but inaecurate and of little scientific vilue" (J. S. Billings).

${ }^{4}$ H. A. Kelly: Jour. Am. Med. Ass., Chieago, 1911, lviii, 437-411. 
Exerpt at leyden, there was no clinical instruction on the continent until 17.5., whon an ambulatory clinic was established at Prague, which lasted

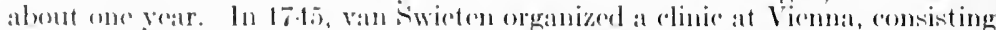
of twelve beds at the Bürgerspital, in charge of do llä̈n, who publiched elinioal reports of the work. The example was followed by Borsieri de Kanilfeld at P'avia in 1760, at P'ague under von Plenciz in 1781, at Göttingen under frank in 17st, at dena under Hufoland about 1793. Bodside instruetion was reint roduecel inte lirane by Desbois de Rochefort in 1780. In England, chairs of clinieal molicine were established at Eslinburer in 17.11, at Oxford in 1780 , :med, about 175. Cullen began to lecture on medicine in English instead of Latin. The linglish phrsieian, no doubt, got a greal deal of his early clinical knowlodgr from his association with a patron or preceptor, as wo have seen in the ease of Nead, who inherited his praetiee from Radediffe. 'The special feature of molern English clinical instruction, the hospital medieal school, had its beginnings in such institutions as (iuy's llospital (1723), the Edinburgh llowital (1736), or the Meath IJospital (Dublin, 1756), and attained a definite status at the London IIospital Medieal Sehool (1785), and at St. Bartholomew"s under Abernethy (1790). Private instruetion, such as that of sunellie in olstetries, C'ullen in internal medieine,., Black in chemistry, or the Hunters in anatemy, surgery, and obstetries, was the feature of the period. The private modieal scheol of Sir William Blizard and Naclaurm beeane, in 1785, the Ionden I Iespital Medieal school. On June 14, 1710, the School of Physic in Trinity College, Dublin, was founded by a grant for a chemical laboratery and anatomic theater, and on lebruary 22, 1711, Thomas Molyneux was chosen profesisor of physic. The seope of this sehool was further enlarged by the act. of 1755 and 1800 , and, in 1825 it aequired a new set of buildings, which made the roforms of (iraves and Stokes possible. Private instruetion in midwifery was first given by (irégoire, Sr., in Paris in 1720, but, in 1797, there was a school for midwives at the Maternité under Baudelocque. Obstetric instruction was first given at strassburg in $172 \mathrm{~s}$, followed by a sehool for midwives in 1737 , and at Vienna in 1748. The first German institution for the instruetion of male ob-tetricians was founded under Röderer at Göttingen in 1751, to be followed by schools for midwives and obstetricians at Berlin (1751), at Tühingen (1759), at Berne, under Venel (1782), at Cassel about 1760, at Jena (17SS), at Marburg (1790), and at Würzluse under von Siebeld (1778-99). In Eclinburgh, instruction for miclwives was given ly Joseph Gibson in 1726. in England by John Maubray (1724), and Richard Manningham (1736), in Dublin by Bartholomew Mosse (1746) and, his successor, Sir Fielding Ould (17.59). Xlosse's private lying-in hospital at Dublin, opened Mareh 15, 1745, was the first institution of the kind in the Inited lingelom. In 1751, Mosse, a surgeon and obstetrician of philanthropic turn, began the construetion of the Rotunda IJospital. Dublin, which was opened on Deeember 8, 1757. Chairs of midwifery were established at Edinburgh (1739), at Dublin (1743), and at (ilargow (1815). The British Lving-in Hospital was founded in 1749, the City of London Lying-in Hospital in 1750, the Queen Charlotte Hospital in 1752, and an obstetrie polyclinie was opened at Meath Hospital (Dublin) by Fleury in 1763. In Italy, sehools for midwives were opened at Piedmont (1728), Padua (1769), and Rome (17S6). Beclside instruetion in pediatries was introdueed by Rosenstein (Stoekholm) in 1760 (Jaeobi). In 1795 Trommsdorff established a Chemieo-Pharmaceutieal lnstitute at Erfurt, which raised pharmaey to the dignity of a seience. Medical history was taught at the Paris Faeulty by Goulin $(1795-99)$ and Cabanis $(1799-1808)$, but the ehair was abolisherl ip to 1S1s, when it was again oecupied by Moreau de la Sarthe $\left(1 \mathrm{~S} 18-22^{1}\right)$.

Many new hospitals were built in the eighteenth eentury, but, in respect of eleanliness and administration, these institutions sank to the lowest level known in the history of medicine. The prinejpal London hospitals were the Westminster (1719), Guy's (1725), St. Gorge's (1733), the London (1740), the Virddlesex (1745), and the Small-pox Hospital (17.46), and there were provineial hospitals at York (1710), Salisbury (1716), Cambrilge (1719), Bristol

${ }^{1}$ L. Hahn: Janus, Amst., 1899, iv, 26. 
(1735), Windsor (1736), Nortlaupton (1743), Exeter (1745), Worester (1745), Neweastle (1751), Manehester (1753), Chester (1755), Leeds (1767), Stafford (1769), Oxford (1770), Leicester (1771). Norwieh (1771), Birmingham (1778), Nottingham (1752), Canterloury (1793), and Stafford (1797). In Fiotland hospitals were founded at Edinbirgh (Royal Infirmary, 1729) (1736), Aberdeen (1739), Dumfries (1775), Montrose (1780), Cilasgow (1794), and Dundee (1795); in Ireland, at Cork (1720-22), Limerick (1759), and Brolfast (1797), while the earliest of the Dublin hospitals were the Jervis Strect (1726), Steevens's (1733), Mereer's (1734), and the Meath Hospital (1756). The Royal Sea-Bathing Infirmary for Serofula, a new departure in the treatment of surgical tubereulosis, was opened at Margate in 1791. Children's hospitals were founded at London by George Armstrong (1769), and at Vienna by J. J. Mastalier and L. A. Gölis (1787). The Charite at Berlin (1710), the Albergo dei poveri at Naples (1751), the Allgemeines Krankenhaus at Vienna (1784), the Necker (1779), Coehin (1780), Beaujon (1785), and St. Antoine (1795) at Paris were among the larger hospitals founded on the continent. To Catherine 11. Moseow owed the Catherine, Pavlovski, and Golitzin Hospitals, an insane asylum and a foundling asylum (1764); St. Petersburg the Obukhovski Hospital (1784), a Foundling Hospital (1770), and a "Seeret Hospital" for venereal diseases (1763), the linen of which was marked "Discretion."

In 1788, Jacobus-René Tenon published a series of memoirs on the hospitals of Paris, ${ }^{1}$ containing his famous description of the old Hôtel Dieu, which was at that time a veritable hotbed of disease. There were some 1220 beds, the most of which contained from four to six patients, and about 486 beds for single patients. The larger halls contained over 800 patients crowded on pallets, or often lying about miserably on heaps of straw, which was in vile condition. Acute contagious diseases were often in close relation to mild cases, vermin and filth abounded, and the ventilation was often so abominable that the attendants and inspectors would not enter in the morning without a sponge dipped in vinegar held to their faces. Septic fevers and other contagia were the rule; the average mortality was about 20 per cent., and recovery from surgical operations was, in the nature of things, a rarity. The same thing was true of the Allgemeines Krankenhaus of Vienna, the Moscow Hospital, and many other institutions of size, and it was not until John Howard had made his exhaustive studies of the eondition of European hospitals, prisons and lazarettos (1777-89), and Tenon had published his report, that any attempts at reforms were made. Baas says that, in Frankfurt an Main and other cities, "even physicians declined hospital service as equivalent to a sentence of death." Under Louis XVI and Joseph II, reforms were finally made in Paris and Vienna, with a very creditable and significant reduction of mortality. One result of Tenon's report was the foundation of the present Hoppital des enfants malades, at the time, the largest children's hospital in Europe. When the C'zar Paul came to the throne, he was so horrified with the condition of the Moseow Hospital that he ordered its reconstruction in 1797,

1 Tenon: Mémoires sur les hôpitaux de Paris, Paris, $178 s$. 
with the result that the new Moseow Hospital, with aecommodations for 12S0 pationts, was amploted in 1802. But hospitals remaincel notorious for uncleanliness and general danger to life well into the nineteonth eentury, and many persons alive to-day (am resall the horror in which they were held. "The mal angel of purity and clounliness was floronec Nightingale, and there was no such thing as surgical cleanliness before the timo of I.ister.

Bad as was the management of hospitals, the treatment of the insane was ren worse. They were either ahained or anged when housod, or, if hammless, were allowed to rum at large, the T'om o' Bedlans of England or the wizards and warlocks of Seotland (tochice in (amphell's poem). The earliest insane asylums in the northern countries wore St. Luke's in I.ondon (1751), the Quaker Asvhum near Vork (1792), and the Vorrenthurm, or "Ianatics' Tower" (1784), onc of the show places of old Viemna, where, as in ancient Bedlam, the public were allowed to view the insane, like animals in a menagerie, on payment of a small fee. The latter institution was described by Richand Bright in 1815 as a fanciful, four-story edifice having the extemal appearance of a large round tower, but, on the inside, consisting of a hollow cirele in the center of which a quadrangular building arose, joined to the circle by each of its corners. The inclosed structure afforded residence for the keepers and surgeons. The cireular part contained three hundred patients, "whose condition," says Bright, "is far from being as comfortable as in many of the establishments for the insane which I have visited." It was not closed until 1853. Mönkemoiller's rescarches on German psychiatry in the eighteenth century. hased on the records of Hanoverian asylums at celle and alsewhere, confirm what Reil wrote of German asylums in his "Rhapsodies" of 1803, and go to show that the theoretic part of the soience in this period was nebulous philosophic speculation, insanity being still attributed to yellow and black bile or to heat in the dog days, while symptoms like exaggerated self-estecm, jealousy, enry, sloth, self-abuse, etc., were regarded as causes. The cases treated were all of the dangerous, unmanageable, or suicidal type, and no hope of recovery was held out. There was an extensive exhibition of drugs and unconditional belief in their effieacy. A case that did not react to drugs was regarded as hopeless. Melancholia was treated by opimm pills, excited states by camphor, pruritus by diaphoresis, and a mysterious power was

I Bright: Travels . . . through Lower Hungary, Edinburgh, 1s18, 87,88 .

2Mönkemöller: Zur Geschichte der Psychiatrie in Hannover, Halle, 1903. Also: Allg. Ztschr. f. Psychiat., Berl., 1902, lix, 193-210. Also: Psychiat.neurol. Wochenschr., Halle, 1911-12, xiii, 211;220; 232. 
ascribed to helladonna: if it failed, everything failed. Other remedies were a mixture of honey and vinegar, a decoction of "Quadenwurzel," large doses of lukewarm water, or, if this failed, "that panacea of psychiatry, tartarus tartarisatus." The costly aqua benedicta Rolandi, with three stout ruffians to administer it, a mustard plaster on the head, venesection at the forehead and both thumbs, clysters, and plasters of Spanish fly, were other resources. Barbarities were kept in the background, but the harsh methods of medieval times were none the less prevalent. A melancholic woman was treated with a volley of oaths and a douche of cold water as she lay in bed. If purgatives and emeties failed with violent patients, they came in for many hard knocks, with a régime of bolts and chains to inspire fear. A sensitive, self-conscious patient was confined in a cold, damp, gloony, mephitic cell, fed on perpetual hard bread, and otherwise treated as a criminal. The diet-soup, wam beer, a few vegetables and salad -was of the cheapest. There were some attempts at open-door treatment, such as putting the patients to mind geese, sending them to the mineral baths at Meyenburg and Pyrmont, or sending them as harvest hands to Holland (Hollandgeherei). Marriage was also recommended as a cure.

The Quaker retreat, founded by William Tuke in 1794 at York, England, was the first attempt at humane treatment of the insane before the time of Pinel.

In Emile (1762), Jean-Jaeques Rousseau made tis famous protest against the divinclination of Frenseh mothers to nurse their own children, is a comres of weakness to the nation. At this time, the rate of infantile mortality was appalting. During 1771-77, of 31,951 children admitted to the Paris Foundling Hospital, 25,476 (SO) per eent.) died before completing the first year, as against 7601 cust of 15,10)t during 1520-22. At the Dublin Foundling Asylum, during 1775-96, only 45 survived out of 10,272 (99.6 per eent. mortility). Sir Hans sloane stated that the ratio of mortality of dry-nursed to breast-fed infants wats as three to one, and, in the early nineteenth century, Marshall Hall said that seven in ten dry-nursed ehilden died. At the British Lying-in Hospital compukory feeding at the mother's breast lowered the mortality 60 per eent. The hired wet-nurse had her palmiest period at the end of the eighteenth century, ustally getting 25 guineas a year or 10 a quarter, and in order to nake money in this way, young unmarried women cleliberately harl illegitimate ehildren who were destinesl to die through baby-farming or in the foundling bespitals. In England the wet-nurse became a tyrant in the hodsehold until she was put out of business by the nursing bottle. In France, the evil grew apace and added to the depopulation eatsed by the Revolution and the Napoleonic wars. The earliest substitute for mother's milk was waterpap, marle of boiled bread or baked flour meristened. To this pamada, Lisbon sugar was sometimes adked. 'Then followed French bread, Uxbridger rolls, turtle-doves, and small beer. With elear insight, Michael I'nderwood (1784) recommenderf boiled cow's milk diluted with barley-water, and added rice, tapioea, and semolina to the semi-solid foods. He curtaited the period of suekling to a twelvemonth, int roduced Mrs. Relf's nipple-shich, and suggested a speeial diet for infants in sickness and fever. Thus artificial infant feeding had its origin in the eighteenth century. In the early nineteenth eentury, the term of weaning was less than a year, but the attempit to regulate it wat given 
up in favor of subsompent mised fording. Oafumcil, cowslip foa, boiled barley

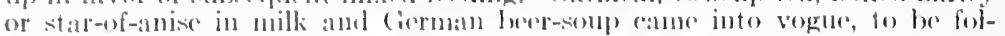

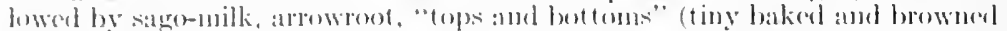

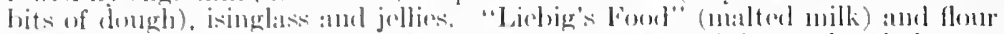

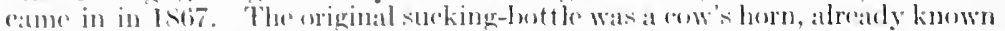

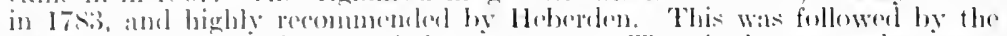

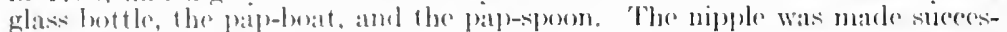
sively of parchument and leather, sponge, heofer's teats kept in spirit, woed and imelia-rubber. M. I)abo's biberon eame in with the Paris bxposition (1567), ame, in Istig, (. H. F. Routh introduced a simpler form, which underwent the llsulal inprovenulls.

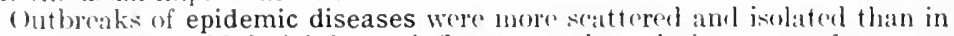
formorer centuries. Malarial fruer, influcmza, and scarlatinal were often fintdomite; smallpox, diphtheria, and whooping-eough were widely diffused, but plague. syphilis, crestisn were fal less malignant, and with the return of

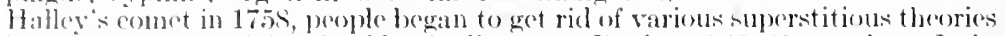
in regillel to the origin of epidemine diseases. During 1702-0), southern Italy wats visted by a series of eartheuakes (deseribed by baglivi) which destroyed some 20,000 lives, and the winter of the year 170 ( $)-09$ was beset with such intense rold that ren leniee was iecbound. Lancisi said that this winter was as fatal to life as the pest, and the general destruction of vogetation and consequent shortening of the food-supply brought on famine, discases of eattle, and rrotism. Inundations and fluetuations of heat and cold were followed by epidemics of malarial and typhus fevers in the first quarter of the century, and during 17:20-50 these gave place to diphtheria and the exanthemata. At the beginning of the econtury the principal focus of the plague was in 'Turkey and the Danube region; by 1703 , it was devastating the Ekraine, whence, through the war of Charles XII with Rusia, it gradually spread to the I3altic Sica and the seandinavian conntries. Danzig sustaincel a mortality of 32,599 from January 5 to Deeember 7,1709 , and I'russia and Lithuania lost 283,733 during 1709-10. The epidenic suddenty disappeared after a hurricane which swept over all Europe on February 27, 1714 ; but it was again introduced, this time in the south of Franee, levastating Provence during 1720-22. It was again prevalent along the Danube and in the Ukraine (1734), and, in 1743, eost Messina (ricily) 30,000 lives. The most severe epidemic was that at Moscow in $1770-71$, in which the total mortality was 52,000 out of a population of 230.000. This epidemic was cheched through the prophylactic measures of ()räus, but matters were further complicated by the outbreak of a revolution. In England, Richard Mead's Diseourse on the plague (1720) effeeted the humane sanitary reform of isolating plague patients outside the city limits, instead of ineareerating them in their own houses. Typhus or eamp fever was, of course, especially prevalent during all the wars of the century, in particular the long contest between Frederick the Great and Maria Theresa (1740-4s), the Seven Years' War $(1756-63)$, and the French Revolution (1759-99), with the events preceding it. One Prusian outbreak of typtius (1757) was describud by the statistician Süssmileh. who was one of Frederiek's army chaplains. Typhus was particularly fatal at Prague (1742), around Mainz (1760), and, as "famine fever," in Ireland (1740), where a failure of the potato crop cost 80,000 lives, in Saxony (1778), and Italy (1783). Malarial fever and lysentery also played havoe in camps and were clearly defined and distinguished in the careful observations of Pringle. In 1774, on recommendation of John Howard, Alexander Popham (1729-1810), M. P. for Taunton, introduced his celebrated bill for the prevention of the gaol distemper, an admirable bit of sanitary legislation, the provisions of which were, howerer, largely evaled. Typhus and typhoid fevers were, of course, confused, and were variously termed "putrid," "gastric," or "nervous," Baglivi described typhoid as "mesenteric fever"; Huxham, during the Plymouth epilemic of 1737 , clearly distinguished between "putrid" (febris putrida) or typhus, and "slow nervous fever" (febris neriosa lenta) or typhoid fever.

${ }^{1}$ Forsyth: Proc. Roy. Sor. Med., Lond., 1910-11, iv, Sect. Dis. Child., 121-141. H. Brüning: Arch. f. Gesch. 1. Med., Leipz., 1907-8, i, 326-328. 
During the heary epidemie of typhoid fever at Göttingen in 1757-63, a careful account of the disease was published, in 1762 , by Johann Cieorg Rocderer, professor at the (iöt tingen clinie, and his assistant IV agler, who male auterkies of the eases.. The intestinal lesions were carcfully noted, but the authers regarded the disease as identical with intermittent fever and dysentrry. P'erhaps for this very reason the unique monograph was soon forgotten, although Cotugno is said to have nade similar postmortem observations in Italy. The old theory of epidemic constitutions was still in the aseendant, and Fitoll of Vienna thought that the discases of "bilious" type, which had been prevalent since 1760 , began to take on a "putrid" character" about 1779-52, a view which mon much consideration in Germany and Italy. Sitoll regarded nearly all ferers and inflammatory discases as "gastro-filions," with emeties as the standard remedy. Malarial fever was spread by inundations, pollution of streams, and the unsanitary condition of streets and sewers. The Italian epidemic of 1715 was described by Lancisi and Baglivi. Dysentery was widely prevalent on the continent throughout the century, and a clasisic description of the Swiss epidemic in the cantons of Bern and Thurgan was published by Zimmermann in 1762. Scarlatina was common, and, from 1776 on, spead over both hemispheres. The monograph of Pleneiz (1762) ascribes the disease to a contagium animatum. It was still confused with measles, which also cansed a high mortality in the French and Cierman cities and in Brazil (1749). Experimental inoculations of measles were made by Francis Home in 1759. There were several pandemics of influenza in both the old worlel and the new. Lancisi described the influenzal epidemic of 1709-10. In 1712 , epidemics occurred at Tïbingen (Schlafkrankit) and at Turin, whieh, as deseribed by Camerarius and Ciuidetti, were probably identical with the encephalitis lethargica, deseribed at Vienna by von Economo in 1917. A similar outbreak oceurrel at Tübingen in 1729. A Swedish epidemic of 1757-8, with the same symptoms, was attributed by Rothmann, a pupil of Linnaus, to radish seeds in threshed grain, and called Raphania. The first ease of botulism was deseribed in Germany in 1755 (Crookshank ${ }^{2}$ ). Diphtheria, yellow fever, whooping-cough, and ppidemic pnemonia were wide-spread; croup and erysipelas were oceasionally epidenic. The term "yellow fever" was first employed by Griffith Hughes in his "Natural History of Barbadoes" (1750). Puerperal fever was often confused with "miliary" or sweating fever (Schueissfriesel). Smallpox was so common everywhere that it was taken for granted and only the heavier epidemies were recorded, e. g., in Paris (1719), Sweden (1749-65), Vienna (1763, 1767), Tuscany (1764), and London (1760, 1770). It was especially destructive in the East Indies (1770-71), and among the Indians of the new world (Hacer). The great success of Jemmerian vaccination has obseured the early history of the other preventive measure which it eventually displaced, viz., inoculation of human virus or variolation. Dr. Arnold C. Flobs, in his interesting study of variolation, ${ }^{3}$ divides its history into an introductory poriod $(1713-21)$, a period of stagnation $(1727-46)$, a second revival $(1746-64)$, and a scientifie and experimental period (1764-9s). The practice was introdued into Europe by Emanuel Thmoni and l'ilarini, who published aceounts of it in 1713 and 1716 respectively. Timoni'sdaughter was inoculated in 1717 , and the juoculation of the childen of Lardy Wortley Montagu followed (17 1 s-21). In the latter year, Boylston began to inoeulate in Boston. Massachusets, and, by 1752 , had 2124 inoculations, with 30 deaths, while in Charleston, South Carolina, Kirkpatrick hat inoeulated between $S(0)$ and 1000 in 1743 , with only $s$ deaths. Attenuation of the virus was attempted by passing it through several human subjects (Kirkpatrick's arm-to-arm methord), by dilution with water, or by ehoosing the virus at the crude or unripe stage. "13y $172 \mathrm{~s}$ there had been s97 inoculations in linglanel and Sootland, with 17 draths. In 1760 , Robert and Daniol sutton introducoul

1 These findings were chatlenged by Murchison.

${ }^{2}$ F. G. Crookshank: Proc. Roy, Soc. Med., Lond., 1919, Sect. Hist. Med., 11-15.

${ }^{3}$ A. C. Klebs: Die Variolation im achtzehnten Jahrhundert, Giessen, 1914. 
inoculation by puncture, with diototis prepanation, and has some 30,000 cascs, with albunt f por cont. mortality, whilo in Paris, Angedo (iatti, of Pisa, was given permission to inoculato by the seientific method of preparatory treatment and pumeture incrulations in 1769. (iatti mantanod that smallpox is ratused lyg the introduction of a living specific vims, atablole of reproducing itsolf. l'rior to this, the gleat danger of inoculation had beren the large anomet of virus used and the extensive somes, which tended to make the subject a veritable smallpox earrier. The sulecess of the suttons and catti was such that in $176 x$, at the instance of Voltare, Catherine of Rusia permitted herself and the (irand Duke Paul to bo inoculated by Dimsdale, and, in the same your, lugen Homsz inoculated threa of the imperial family of Austria after joreliminary experiments upen 200 children of the Viemese suburbs. In 1770), George Motherhy was inowulating at liöngsberg, but, by 1774, Bonjamin Jesty had performed his first vaceination. The subsequent suecess of Jenner's experiments soon swept inoculation from the fiedd, although it had wedl-nigh attained the status of a morlern preventive injertion. The suceess of vaccination was due to its relative harmlessness, there being little mortality and no posibility of convection of the disease by the vaccinated person. In England, variolation was declared a felony by Act of Parliament in 1840.

The leaders in the literature of American medicine in the colonial and revolutionary period have already been referred to, and, until after the Revolution, there was little arlvance upon the seventeenth century.

I3ofor" 1s(0) there were five good medical schools established, viz., those of the Lniversity of Pennsylvania (1765), ling's College, New York (1767), which, in 1792, became the Medical Faculty of Columbia College, IIarvard University (1762), the College of Philadelphia (1790), and the Medieal Sohool of Dartmouth College (1798). In 1720, a diploma conveying an honorary medical degree was conferred upon Danjel Turner, at Yale College. The first American to graduate in medicine abroad was John Moultric, of South Carolina (1749). The first medieal diploma to be awarded after a course of study in Ameriea was that given to John Areher at the University of Pennsylvania in 17is. It is now in the library of the Mledical and Chirurgical Ifaculty of Maryland. There were 63 American medical graduates at Edinburgh during $1758-88$ (1'ackardi1). Medical societies were organized in Boston (1735-41), New York City (1749); Philadelphia (1765-81), again in New York City (about 1769), Philadolphia (American Medical Society, 1773), Boston (1780), New Haven County (1784), and state medieal societies in New Jersey (1766), Massachusetts (1781), South Carolina (1789), Delaware (1789), New Hampshire (1791). Connecticut (1792), and Maryland (179s). Of these, the Massachusets Medical Society (17S1), the College of Physicians of Philadelphia (17.5), and the Medical and Chirurgieal Faeulty of Maryland (1789, incorporatel 1799), are remarkable for solid performance as well as for ancient lineage and rontinuous deseent. The societies of New Jersey $\left(1766^{2}\right)$, Massachusets $(1790)$, and the College of Physieians of Philadelphia (1793) issued transactions and, in $178 \mathrm{~s}$, the Modical Soriety of New Haven County, Conneetirut (instituted 1784), published a thin little volume of Cases and Obserzations containing, among other good papers, Hezekiah Beardsley's "Case of a ccirrhus in the pylorus of an infant." The first medical periodicals of the period were the Medical Repository of New York (1797-1824), (edited by Samuel L. Mitehill, Elihu H. Smith, and Edward Miller, a single number of a translation of the Journal de médecine militaire of Paris (1790), and John Redman Coxe's Philadelphia Medical Museum (1804). These had all been

${ }^{1}$ Packard: Hist ory of Medicine in the United States, Philadelphia, 1901, pp. $156 ; 160-161$.

2 The transactions of the Medical Society of New Jersey for 1766-1859 remained in MS. until 1875 , when they were printed in one volume. 
preceded by the Mercurio volante (October 17, 1772), the earliest Mexican medical periodical, edited by Josef lgnacio Bartolochi. The Memoirs of the American Academy of Arts and sciences were begun in Boston in 1755. 'The hospitals of the early period were the Pennsylvania llospital of Philadelphia, organized in 1751, and opened in a permanent building in December, 1756, the Philadelphia Dispensary (1786), the New York Dispensary (organized 1791), incorporated 1795, and the New York Ilospital, which was begun in 1773 , destroyed by fire in 1775 , and not rebuilt until 1791 . The original of Bellevue Hospital was a large room for patients in the lublic Workbouse of New York City (erected in 1736). Dr. John Van Buren was the first medical officer, at $\mathfrak{E 1 0 0}$ a vear. A new building was put up on the present site of Bellevue in 1796, and here a new almshouse and hospital was opened on April 28,1816 . A fever hospital was added in 1825 , a new wing in 1855 , and the first ambulance service in the world was established here in 1869. The first lying-in hospital was Shippen's private institution of 1762 , and the first insane hospital, the Eastern Lumatic Asylum at Williamsburgh, Virginia, which was chartered in 1772 and opened in 1773. The first American botanic garden was established by John Bartram at Philadelphia in 1725, and the first museum of natural history at Charleston, S.C., in 1773. Medical libraries wre foumeded in the Pennsylvania Hospital (1762), the New York Hospital (1776), and the College of Physicians of Philadelphia (1788), the latter being now one of the finest in the country. The favorite text-books of the period were Albinns, Cowper, Cheselden, Monro, and Winslow in anatomy, Haller's linst Lines of Physiology, Boerhaave and van Swieten on internal medicine, Heister's surgery, Simellie's midwifery, and, of course, Sydentam, Huxham, Pott, and other well-known autljors. There was strong prejudice against dissecting, and material was usually obtained by body-snatching. There was little study of physiology or pathology, but surgery was ably taught by such men as John Jones, William Shippen, Jr., Thomas Bond, John Warren, Richard Bayley, and Wright Post. Obstetric cases were usually handled by midwives, and the first male obstetricians were pupils of Sinellie and Willian Hunter. William Shippen, Jr., first lectured on the subject in Philadelphia in 1762 There were a few strolling dentists anel oculists here and there, but, with the exception of Perkins's tractors, we hear little of quackery in the colonial period, for the simple reason that no very rich harvest was held out to it: practitioners. Witch-doctoring, in the sense of averting malign influence, was, however, still conmon among the Germans of southeastern Pennsylvania. It is said that the expense account of General Washington for October, 1797. shows that he paid his employee, Christopher, \$25 for a visit to a German hex- and herb-doctor at Lebunom, Pa., to secure treatment for hychophobia, which probably consisted of an infusion of rad chickweed or pimpernet." Thr" Long IViden Friend of George Hohman (1819), a Germain redemptioner who eame over in 1799 , is the authoritative compilation of the folktore of hexdoetoring. It is made up of brobal remedies, acostic chames, and pious invocations, like those in Aetius and Alexander Trallianus. Acts to regulats the practice of medicine and surgery were passed in New York City (1760) and New Jersey (1772), a special orkinanes for midwives in New York City (1716), quarantine acts in Pennsylvania (1700), Nassachusetts (1701). Virginia (1722), New York (17.58), and other States, and a general quarantine act by Congress on February 23, 1799. The earliest Camadian molic "al laws were the "Quebec Ordinanee" of 1788, "To Prevent Persons practising Physic and Surgery" in Lower Canada; and the Newark (Cpper Canadia) "Act to Regulate the Practice of Physic and Surgery" (179.5), which was variously modified as time went on.

1 "Bellevue: A Short History of Bellevue Hospital," New York, 1915.

${ }^{2}$ Burdick: Dietet. \& Hyg. Gaz., N. Y., 1912, xxviii, 423-426. See, also, J. N. Bertolet: Phila. Month. Med. Jonr., 1899, i, 730-732. 


\section{THE NINETEENTH CENTURY: THE BEGINNINGS OF ORGANIZED ADVANCEMENT OF SCIENCE}

Ix the evolution of modern medicine, as in the development of pure soience of which it was a part, three factors secm of especial moment. First of all, the great industrial or social-elemocratic movement of civilized mankind, which, following alose mpon the political revolutions in America and France, intensified the feeling for intellectual and moral liberty and uphed the new idea of the dignity and importance of all kinds of human labor, as exemplified in Tapoleon's famous device: "The tools to those who can handle them" (La carrière ouverte aux talens). Some immediate corollaries of this proposition were the removal of the civil disabilities oppresing the Jews, and the opening out to talented womankind of oecupations and modes of thought which had hitherto been closed to them. Second, the publication of such works as Helmholtz's Conservation of Energy (1847) and Darwin's Origin of siperies (1859) dicl away forever with many of the silly anthropomorphisms and appeals to human coneeit which have always hampered the true advancement of medicine in the past. Third, as an inevitable consequence, physies, chemistry, and biology came to he studied as objective laboratory seienees, dissociated from the usual subjective human prepossessions. Harlly any one to-day doubts the theorem sustained by Emile Littre that the real advancement of biological and medical seience has nothing to do with theological dogma or metaphysical speculation, but simply depends upon collateral improvements in physical and chemical procedure. Medicine owes much to the great mathematicians and physicists of the serenteenth and eighteenth centuries, who developed the theory of vision and amost the whole physiology of respiration. In the nimeteenth century, the extension of the three fundamental branches of pure science has not been surpassed in variety by the work of any preceding age.

Of modern mathematicians, we need only mention tlue names of Euler, Gauss, Riemann, Jacobi, Abel, Weierstrass, Caylev, Sylvester; of physieists, Young, Carnot, Fourier, Kirchhoff, Clausius, Helmholtz, Ohm, Maxwell, Lord Kelvin, Boltzmann, Gibbs, J. J. Thomson, Edison, Tesla, Arrhenius; of chemists, Dalton, Dunas, Chevreuil, Berzelius, Liebig, Wöhler, Berthollet, Mendelejeff, Ostwald, van't Hoff, Ramsay, Rutherford, anrl the Curies.

The physical principle of Conservation of Energy was demonstrated by Robert Maver (a phrsician of Heilbronn) and James Prescot Joule in 1842 , and applied to the whole field of elemistry and physies by Helmholtz in 1847. 
The principle of Dissipation of Energy was first stated by Sadi Carnot in 1824, developed by Clatusius (1550) and Lord Kelvin (1852), and applied to all physical and chemical phenomena by the Yale profesor, Willard (ibbs, in $1872-78$. The generalization of (Gibls is now seen to be so complete and far-reaching as to make engineering, geology, biology, melieine, and every other phatse of seienee that deals with states of substance, a branch of ehemistry. The inmediate eonsequence of the same generalization was the development of the new seience of physical ehemistry by Ostwald, Le Chatellier, van't Hoff, Roozeboom, and the chemists of the Dutch school. In physical or thermorlynamic chemistry, all changes of substance are treated as rigid eonsequences of the laws of dynamies.

In 1859, Kirchhoff and Bunsen devised spectrum analysis. Faraday (1S21-54) and Maxwell (1865) worked out the whole theory of electricity and electromagnetism, upon which followed such practical consequences as cleetrie lighting, heating, and motor power, telephonic communication, and the realization of wireless telegraphy by Hertz (1887) and Marconi (1895). The Roentgen rays were discovered in 1895, and the Curies isolated rudium chloride in 1898. Among physicians, Thomas Young deseribed astigmatism in 1801, stated the wave theory of light in 1802 , and the surface tension theory of capillarity in 1805; John Dalton stated the chemical law of multiple proportions (1S02) and the atomic theory (1S03); William Hyde Wollaston investigated the pathological chemistry of calculi (1797-1809), suggested stercochemistry (180S), showed that gas explosions will not pass throngh a small tube (1S14), which led to Sir Humphry Davy's safety lamp (1815) and invented the camera lueida (1807); Helmholtz invented the ophthalmoscope and the ophthalmometer in 1850, the teleostereoseope in 1857, and elaborated the theories of vision (1853-67) and of tonal perception (1856-63). Another physician, William Charles Wells $(1757-1817)$, a native of Charleston, S. C., developed the theory of dew and dew-point in 1814. Photography was developed by Niepce (is14), Daguerre (1839), Draper (1840), and Fox Talbot (1840). Amici (1S12), Chevalier (1S20), and Joseph Jackson Lister (1S30) devised the improved achromatic lenses of the compound mieroseope to which Amici laxd given the idea of water-immersion and Chevalier the compound objective, Purkinje stereopticon effeets and reagents, and E. Abbe the modern illuminating apparatus, apochromatic objective, oil immersion, and compensiting ocular (1856).

It will be seen, from the dates of these discoveries, that the modern scientific movement did not attain its full stride until woll after the midclle of the century. The medicine of the early half was, with a few noble exceptions, only part and pareel of the stationary theorizing of the preceding age. Up to the year 1850 and well beyond it most of the advancements in medicine were made by the French. After the publication of Virehow's "Cellular Pathology" (1858), German medieine began to gain its ascendaney. The descriptions of new forms of discase, and the discoveries of anesthesia (1847) and antiseptic surgery (1867), were the special achievements of the Anglo-saxon race.

On the continent of Europe, Immanuel Kant, who pointed out the limitations of thought and the subjective character of human observation, had little effect upon medical theories, but the socalled "Nature Philosophy" of Schelling, which aimed to establish the subjective and objective identity of all things, and the system of Hegel, which, like evolution to-day, regarded every thing as in a state of becoming something else (Werden), excrted a very 
baneful effect upon Corman medieine by diverting mental atetivity away from the investigation of enerete facts into the realum of fanciful speculation. The "therapentic nihilism" formulated by Skoda put a recided limitation upon Austrian medieine, and, in Fince and Italy, a valst deal of energy, and even of human life, Was wasted orer the doctrines of Broussais and Rasori. It took a long time to demonstrate that the advancement of internal medicine as a science can never be accomplished by hugging some pet theory out of a regard for its author's personality, but only through the performance of a vast amount of chemical, physical, and biolog-

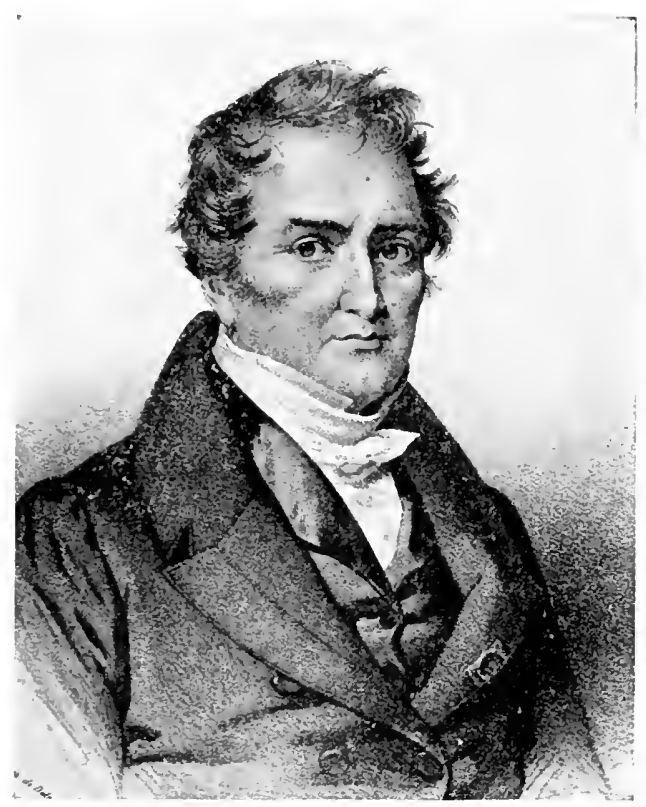

François-Joseph-Victor Broussais (1772-1838).

ical research by thousands of willing workers. The first step in this direction was taken by Broussais, who did away with metaphysical conceptions of disease only to substitute something worse.

François-Joseph-Victor Broussais (1772-1838), the son of a Breton physician, had sworn at troops as a sergeant in the Republican Army in 1792, had swung a cutlass as a privateersman in 1798 , and, after graduating in medicine in 1803, served for three years as an army surgeon in Napoleon's campaigns. He carried his rough schooling into his medical teaching, in which his methods were Napoleonic and his therapeutics sanguinary. Broussais 
modified the Brunonian theory by saying that life depends upon irritation, but, in particular, upon heat, which excites the chemical processes in the body. Disease, however, depends upon loealized irritation of some viscus or organ, $e . y$. , the heart, or, above all, the stomach and intestines. Specific morbid poisons, such as the syphilitic virus, were to Broussais non-existent. The only merit in his reasoning was that he substituted the diseased organ for the hazy concept "fever" as the all-important factor, the foyer de maladie. To describe a group of symptoms as a "clinical entity" and label it with a name was to Broussais a fictive process (ontology). Gastro-enteritis he thought the "basis of all pathology," as Cullen thought nearly everything a neurosis or Cruveilhier a phlebitis. Nature had no healing power and it was necessary to abort clisease by active measures. To this end, he adopted a powerful antiphlogistic or weakening régime, the main features of which were to deprive the patient of his proper food and to leech him all over his body. As many as 10 to 50 leeches were applied at once, even 5 to 8 being prescribed in cases of extreme debility. Of the scarcity of leeches in Broussais' time, Baas records that "in the year 1833 alone 41,500,000 leeches were imported into France, and only nine or ten million exported. Yet in 1824-25 two or three million were sufficient to supply all demands." As he approached his dotage, which Dr. Holmes has so humorously described, Broussais, a vieux militaire by training, scolded, bullied, and wrangled with the vigor of Paracelsus, and although his follower, Bouillatud, was moved to let even greater torrents of blood, students began gradually to edge away from him, until his theories were finally exploded by the good sense and temperate judgment of the clinician Chomel and the statistical inductions of his pupil Louis. Broussais' doctrine of irritation was taken up in Germany by Roeschlaub, and oceasioned a pale temporary reflex in the writings of Benjamin Travers, Pridgin Teale, and other English physicians of the period, who ascribed many diseases to "spinal irritation." In Italy, about 1807, Giovanni Rasori, in his clinic at Milan, began to revamp the Asclepiadean theory of constricted and relaxed conditions (which Brown had ealled sthenie and asthenic and Hoffman tonic and atonic) by considering diseases as states of stimulus or contra-stimulus. Diagnosis of these conditions was effected by means of venesections which were supposed to turn out beneficially in over-stimulated conditions or vice versa. Overstimulus was then opposed by sedatives, opium, and copious

${ }^{1}$ Max Neuburger says that the supposed gastric origin of most diseases (gastricism) had been long before advaneed by 'Tissot, Grant, Finke, and Stoll. (Puschmann Handbuch, Jena, 1903, ii, 96.) 
hood-letting; contrastimulus hy huge doses of gamboge, aconite, iperase, mux romitea, and the like. 'This method, which did as much batm as that of Bromssatis, had to run its comse, and, like the litter, eventmally died out.

The arhitriry doctrines of Broussais were finally overthrown by lierre-( harles-Alexandre Louis (1787-1872), the founder of medical, as distinguished from vital, statisties. After passing six years in liussia, where his despair over the impotence of medicine in a diphtheria epidemic convinced him of the necessity of deeper study, he returned to Paris to complete his medieal education, and,

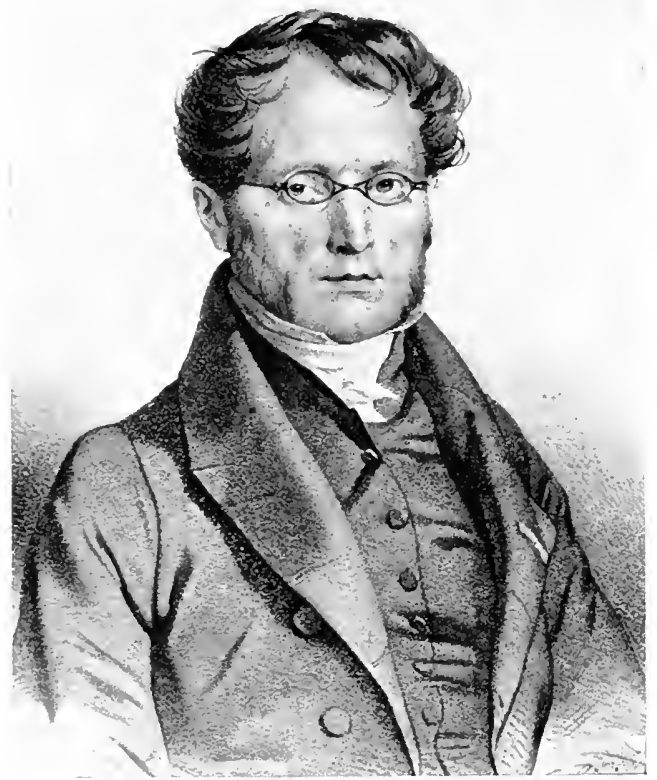

Pierre-Charles-Alexandre Louis (17\$7-1872).

entering Chomel's elinic, devoted the rest of his life to teaching, combined with incessant dissecting and hospital practice. His principal works are his researches on phthisis $\left(1825^{1}\right)$, based upon 358 discections and 1960 clinical cases, and pointing out the frequeney of tubercle in the apex of the lung; his work on typhoid fever $\left(1829^{2}\right)$, which gare the disease its present name (fière

${ }^{1}$ Louis: Recherches anatomico-physiologiques sur la phthisie, Paris, 1825.

2 Recherches . . sur la maladie connue sous les noms de gastroentérite (etc.), Paris, 1829. 
typhö̈de), and his polemies against Broussais (18351), which finally demolished the latter's "system," and, by a statistical proof that blood-letting is of little value in pnemonia, did away with its abuse in that disease. Louis thought that the fallacies of an a priori theory, like that of Broussais, ean easily be brought out and thrown into relief by good statisties ${ }^{2}$ and that the latter can sometimes be used as an instrument of precision in cases where proper experimental methods are wanting. Although Gavarret wrote a treatise on statistics in which therapentic problems were especially considered $\left(1810^{3}\right)$, the idea met with no special support in Louis' lifetime; but it has since proved its own worth in testing etiologic and hereditary data or the value of different therapeutic methods, especially through the great increase in medical periodicals, with corresponding improvements in bibliography and census-taking, which, of course, furnish the materials for good statistics. Its value was shown by Fournier and Erb in demonstrating the causal nexus between tabes, paresis, and syphilis; and by others, in testing the value of hydrotherapy in typhoid, of antitoxin in diphtheria, of operative intervention in appendicitis and other abdominal or pelvie diseases, or in trying out new drugs, such as "606." Louis was the first, after Floyer, to use the watch in timing the pulse, in which he was followed by the clinicians of the Irish, English, and American schools. Through his American pupils, Holmes, Gerhard, the Jacksons, the Shattucks, and others, he exerted a powerful influence upon the advancement of medical science in the Eastern United States. The strong stand which Louis took in favor of facts and figures as against the sterile theorizing of the past appealed especially to the keen, practical eommon sense of these northern physicians.

The most distinguished and important internist of the early French school was Réné-Théophile-Hyacinthe Laënnec (17811826), a native of Quimper (Brittany), who, like Bichat, was a regimental surgeon in the Revolution, and was also, like him, an early victim of phthisis. He was physician to the Hôpital Beaujon in 1806 and to the Hôpital Necker in 1816. Laënnec made his name immortal by his invention of the stethoscope in 1819 (at first only a cylinder of paper in his hands), and by the publication of the two successive editions of his Traité de l'auscultation médiate in 1819 and 1823. This work placed its author among the greatest clinicians of all ages, and, unlike Auenbrugger's, was immediately

1 Recherches sur les effets de la saignée (ete.), Paris, 1835.

2 The use of statisties in medical investigations was first suggested by the astronomer Laplace. To establish his own results, Louis made over 5000 postmortems (Neuburger, op. cit., p. 139).

${ }^{3}$ Gavarret: Prineipes généraux de statistique, Paris, 1810. 
taken up and translated everywhere. It is the foundation stone of modern knowledge of discases of the ehest and their diagnosis by mediate exploration. In the first edition (1819), Laënnee pursucs the analytic method, giving the different signs elicited by percussion and anscultation, with the corresponding anatomic Josions (he was an expert pathologist). In the second edition (1523), the process is turned about and the method is synthetic, ach disease being described in detail in respect of diagnosis, bathology, and (most intelligent) treatment, so that this edition is, in effect, the most important tratise on diseases of the thoracic

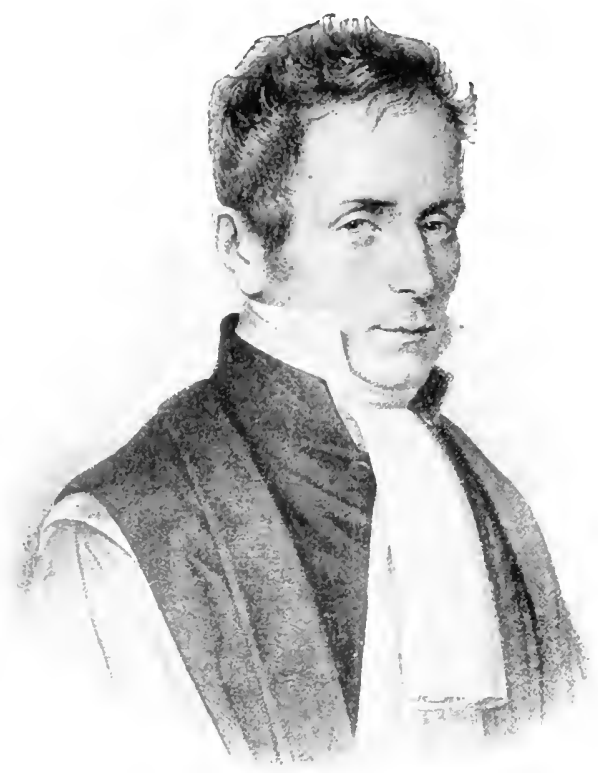

Réné-Théophile-Hyacinthe Laënnee (1781-1826).

organs that was ever written. Laënnec not only put the diagnostie sounds of cardiac and pulmonary disease upon a reliable basis, but was the first to deseribe and differentiate bronchiectasis (first noted by his assistant Cayol in 1808), pneumothorax, hemorrhagic pleurisy, gangrene, and emphysema of the lungs, cesophagitis, and that form of cirrhosis of the liver which is now termed "chronic, diffuse, interstitial hepatitis." He left masterly descriptions of bronchitis, peritonitis, and pneumonia, with a full aceount

1 For the history of our knowledge of the heart sounds before and after Laënnec, see G. Joseph, Janus, Gotha, 1853, ii, 1; 345; 565. 
of the pathologic appearances, and his accounts of pulmonary gangrene and emphysema needed only the retouching of Rokitansky's microscope to make the pictures classic. Laënnec was also the first to discover and deseribe the "anatomic tubercle" or postmortem wart, ${ }^{1}$ which McCall Anderson, in 1879, showed to be identical with lupus verrucosus; and he was the originator of such terms as "xgophony," "pectoriloquy," the sonorous and sibilant "râles," and other well-recognized signs of moment in the exploration of the chest. Personally, he was a slight, nervous, aquiline figure, of generous, tolerant, unaffected nature and refined feelings. Like Auenbrugger, he was modest about his work and eared more for his proficiency in horseback ricling than for fame. A statue, erected to his memory in 1868 , stands in the. Place Saint-Corentin, Quimper.

Among the prominent French internists contemporary with Louis and Laënnec were Bayle, Bretonneau, Bouillaud, Corvisart, Pinel, Andral, Piorry, Rayer, and Ricord.

Gaspard-Laurent Bayle (1774-1816), of Vernet in Provence, a Paris graduate of 1801, made his mark in pathology by his original description of the coarse characters of tuberele, and its

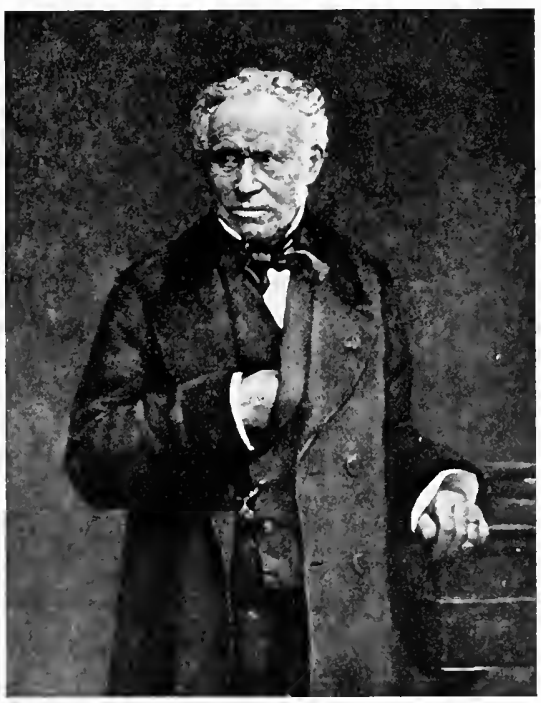

Pierre Bretonneau (1771-1\$62). (From the painting by Noreau of Tours.) identity with the pulmonary, granular, and other varieties of tuberculosis (1803), which he expanded in his Recherches sur la phthisie pulmonaire (1810), the basis of Laënnee's and of subsequent work.

Pierre Bretonneau (1771-1862), of Tours, wrote important monographs on the contagion of "dothienenteritis" or typhoid fever $\left(1819-29^{2}\right)$, on diphtheria $\left(1826^{3}\right)$, giving the disease it. present name; and, on July 1, 1825, performed the first successful

1 Also noted by Sir Samuel Wilks as "verruca necrogenica," in 1862.

${ }^{2}$ Bretonneau: Arch. gén. de méd., Paris, 1829, xxi, 57-78.

${ }^{3}$ Des inflammations spéciales du tissu muqueux et en particulier de la diphthérite, Paris, 1826. 
tracheotomy in cromp.' He locited and understood the typhoid lesions in Peyer's patches as early as 1820, predicted that typhoid would some diy be differentiated from typhus (1828), and, in 15is, elearly stated the doetrine of speeificity (germ-theory) in disase." His correspondence with his pupils Velpean and Trousseau is the most interesting collection of medical letters since Guy Patin.

Jean-13aptiste Bouillaud (1796-1881), of Angonlêne, although it furious blood-letter, was one of the ablest diagnosticians of his time. He was the first to point out that aphasia is correlated with

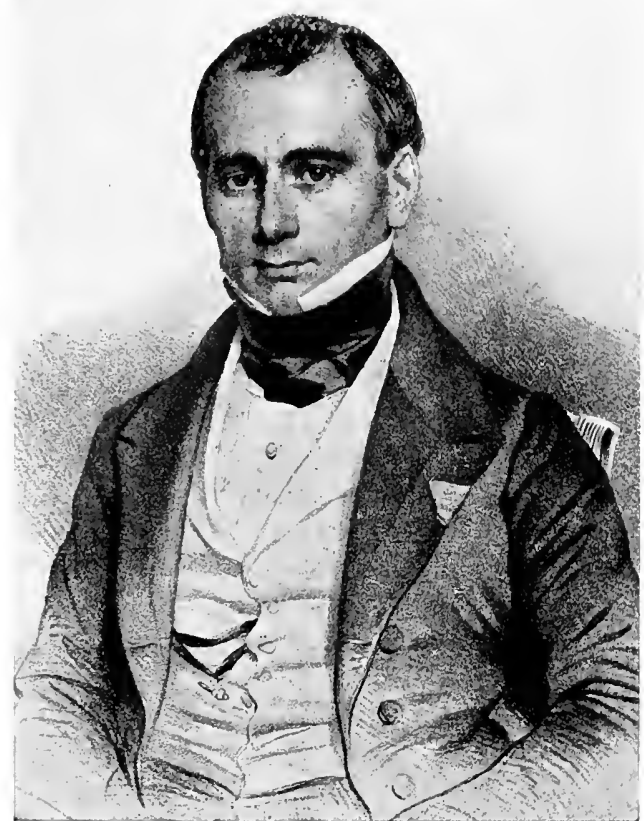

Jean-Baptiste Bouillaud (1796-1881).

a lesion in the anterior lobes of the brain $\left(1825^{3}\right)$ and he established a "law of coincidence" between the occurrence of heart disease and acute articular rheumatism $\left(1836^{4}\right)$. These researehes were further extended in his important clinieal treatise on articular

1 Bretonneau. Des inflammations spéciales (etc.), Paris, 1826, 300-338.

${ }^{2}$ For these references see Paul Triaire: Bretonneau et ses correspondants, Paris, 1892, i, 303; ii, 593.

${ }^{3}$ Arch. gén. de méd., Paris, 1825, viii, 25-45.

${ }^{4}$ Bouillaud: Nouvelles recherches sur le rhumatisme articulaire (etc.), Paris, 1836. 
rheumatism of $1840 .{ }^{1}$ Regarding fever as the effect of endocarditis and of inflammation of the intima of the blood-ressels, he farored pitilessly rapid bleeding "coup sur coup."

Jean-Nicolas Corvisart (1755-1821), Napoleon's favorite physician, and the teacher of Bayle, Bretonneau, Dupuytren, Laënnec, and Cuvier, is now remembered chiefly through his revival of Auenbrugger's work on pereussion (1808), a previous translation of which had already been made by Rosière de la Chassagne (1770), but forgotten. Corvisart's Essay on the Discases and Organic Lesions of the Heart and the Great Vessels (1806), the most important French treatise on cardiac disease after Senac's,

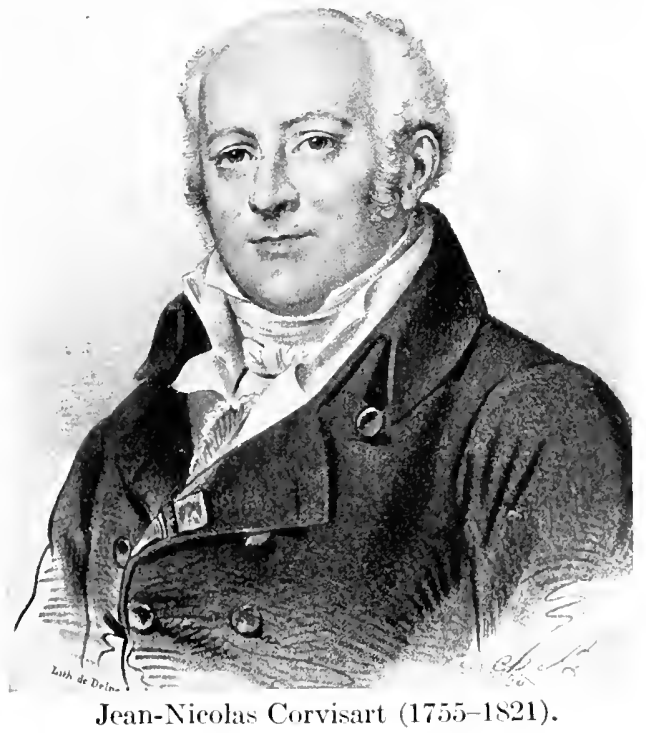

was reprinted in 1818, with some simplifications and improvements of Auenlurugger's method.

The noble-minded Philippe Pinel (1745-1826), of Saint-Paul (Tarn), stands high in medical history as the first to treat the insane in a humane manner. At the risk of his own life and liberty, he initiated the reforms of striking off their chains, placing them in hospitals under lenient physicians, and doing awa with the abuses of drugging and blood-letting to which they were subjected. In this regard he is the real founder of the modern "open-door"

1 Traité clinique du rhumatisme articulaire, Paris, 1840. 
school of psychiatry, although his classifications of insanity and discase are now formotten. His Traité médico-philosophique sur l'alienation mentule (1S01) is one of the most important of medical classics, and it was followed by such psychiatric milestones as Reil's Rhapsodies on the Psychic Treatment of Insanity (1803), Heimroth:s books on insanity (1S1S), the jurisprudence of insanity (1825), and the psychology of lying (183.'); ('almeil on general paralysis of the insane $\left(1826^{2}\right)$; Prichard's Treatise on Insanity, containing the first description of moral insanity (1835); Esquirol's great work (18383), Falret's original description of circular

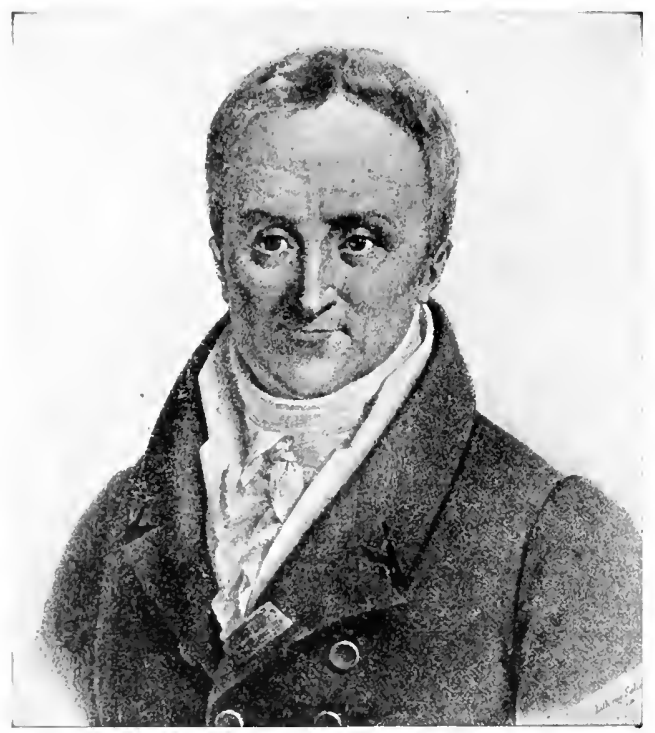

Philippe Pinel (1745-1826).

insanity $\left(18533^{4}\right)$, and John Conolly on The Treatment of the Insane without Mechanical Restraints (1850).

Gabriel Andral (1797-1876), of Paris, was a clear, methodic, analytic spirit who opposed all scholastic eccentricity and fanaticism, edited the works of Iaënnec, joined hands with Louis in his propaganda against blood-letting, favored cold baths in typhoid and other fevers, and is to be especially remembered as the first

1 J. C. A. Heinroth: Die Lüge, Leipzig, 1834.

${ }^{2}$ L.-F. Calmeil: De la paralysie générale (etc.), Paris, 1 s26.

3 J.-E. D. Eequirol: Des maladies mentales, 2 vols. and atlas, Paris, 1838.

${ }^{4}$ J.-P. Falret: Bull. Aead. de méd., Paris, 1553-4, xix, 352-400. 
to urge a chemical examination of the blood in morbid conditions $\left(1843^{1}\right)$.

His Clinique médicale (1829-33) was the first work of the kind marle famous by Trousseau, Dieulafoy, and others, in which a series of medieal cases is employed as a means of establishing the data of internal medieine. In Andral's work, the elinical pietures of the development of morbid processis's were masterly. His ehemical studies of the blood (witl Gavarret), the only thing of the kind after Hunter and Hewson, led him to the conelusion that there are primary blood diseases, a phase of humoral pathology which was again to be revived by Ehrlich.

\section{Pierre-Adolphe Pi-} orry (1794-1879), of Poitiers, was the inventor of the pleximeter (1826) and the pioneer of mediate percussion (1828*2). He wrote much, including a treatise on pleximetry (1860), and, althoingh a "poet," affected an exaggerated and pedantic nomenclature, employing such high-sounding terms as "cardiodysneuria," "hypersplenotrophy," and so forth.

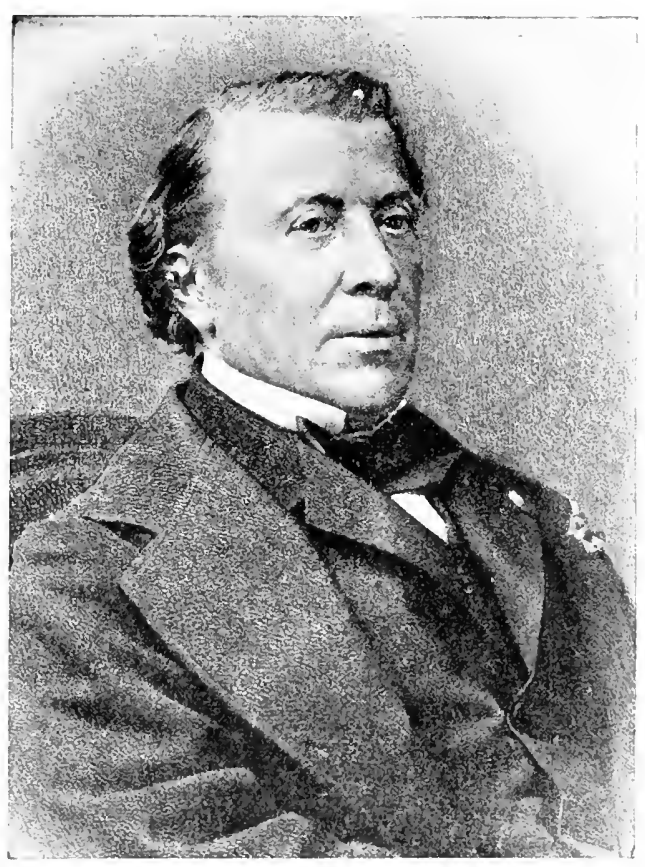

Philippe Rieord (1799-1889).

Pierre-François-Olive Rayer (1793-1867), of Calvarlos, was the author of a number of works of capital importance, including his treatise on skin diseases, with atlas (1826-27), his classic monograph on glanders and farry in man $\left(1837^{3}\right)$, his threc-volume treatise on diseases of the kidney, with atlas (1837-41), which marks an epoch in the development of the subject, and his memoir on endemic hematuria (1839).

Philippe Ricord (1799-1SS9), born of French parents in Baltimore, Md., and a graduate of the Paris Faculty, was the greatest authority on venereal diseases after John Hunter. His treatice

1 Andral: Essai d'hématologie pathologique, Paris, 1843.

2 Piorry: De la pereussion médiate, Paris, 1 s2s.

${ }^{3}$ Rayer: De la morve et du farein chez l'homme, Paris, 1837. 
on the subject (1838) is memorable in the history of medicine for overthrowing IIuntor's erroneous ideas as to the identity of gonorrhea and syphitis (250) inoculations), establishing the antonomy of these discases $(1831-37)$.

He divided lues into its primary, secondary, and tert iary stages, described vaginil, uterine, and urethral chancres, and noted the rarity of rejufection, and

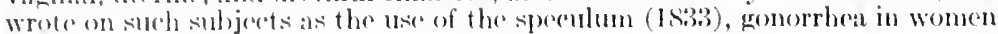
(1834), rpidiclymit is (1839), gonorrheal conjunctivit is (1842).

Rirord is redited with a vast number of risky bons mots and ancedotes (Ricordiana) relating to his specialty. Dr. Oliver Wendell Holnes styled him "the Voltaine of pelvic literature-a skeptic as to the morality of the race in general, who would have submitted Diana to treatment with his mineral specifies, and ordered a course of bluc pills for the vestal virgins."

Morlem dermatology derives from the work of Willan, and his pupil Bateman, as continued and carried forward by the French and the New Vienna schools. Robort Willan (1757-1812), “ Yorkshire Quaker who had studied the pathologic work of Matthew Batllie to advantage, did much to clear up the nature of eczema and lupms, and divided cutaneous discases, according to their ohjective appearances, into eight classes: the papular, squamous, exanthematous, bullous, vesicular, pustular, tubercular, and macular. By collating all the Cireek, Latin, and Arabic terms, he established a definite classic nomenclature. His classification, which was awarded the Fothergillian gold medal in 1790, was the starting-point of modern dermatology, and is still more or less in use. Willan's great work On Cutameous Diseases (1796-1808), published in parts, was left unfinished at his death, and was completed hy Bateman. It contains original descriptions and figurations of prurigo, pityriasis, and ichthyosis, while psoliasis (the Biblical "leprosy" of Gehazi and Naaman), sycosis, tinea versicolor, lupus, and impetigo are more clearly defined and differentiated. Osler says that the first case of Henoch's purpura (with visceral symptoms) is here described. Willan also defined erythema iris as a species of his original genus "iris" (herpes iris), and separated out the forms of eczema due to external irritation (eczena solare, impetiginodes, rubrum, mercuriale). He gave a clearer description of the "urticaria tuberosa" described by Frank in 1792. This part of his work is included in the Delineations of Cutoneous Diseases, an at las of 72 colored plates published in 1817 by Thomas Bateman (1778-1821), of Whitby, Yorkshire. Bateman was the first to describe lichen urticatus, molluscum contagiosum, and ecthyma, which Willan had clepicted as "phlyzacia."

${ }^{1}$ Ricord: Traité pratique des maladies vénériennes, Paris, 1838. 
Eethyma terebrans or "pemphigus gangrenosa" was first deseribed by Whitley Stokes of Dublin (1807'), and xamthoma by Addison and Gull $\left(1851^{2}\right)$.

The founder of the modern French sehool of dermatologyt wis Jean-Louis Alibert (1768-1837), of Villefranche de l'Aveyron, Dr. Hohmes" "jolly old Baron Alibert, whom I remember so well in his broad brimmed hat, worn a little jauntily on one side, ealling out to the students in the court-yard of the Hoppital St. Louis, Enfans de la méthode naturelle, êtes-ious tous ici?" This "natural method" of classifying diseases was, in fact, the passion of Alibert's life. A pieture of his "family tree" of dermatoses, standing grim and solitary in the foreground of a barren, uninviting landscape, forms the initial plate of his prineipal work. ${ }^{3}$ Alibert was the first to deseribe myeosis fungoides (pian fungö̈de) in 1806 and keloid (cancroöde) in 1810 (later as "keloide" or "kclis") (1835). He also described, as "pustule d'Alep" (18294), the endemic ulcer which has lately become so important in connection with the LeishmanDonovan bodies, and introduced many new terms, such as "syphilides," "dermatoses," "dermatolysis," ete. Un visuel et un artiste, as Sabouraud has styled him, Alibert prided himself upon the fact that he was the first to employ the painter's palette and the burin in the delineation of skin diseases. In his clinieal lectures he was at pains to visualize everything to his pupils by long, personal, cireumstantial ease-histories, like those of Joln Bell. In his efforts to make these pieturescue, he sometimes pushed the devices of rhetoric to a ludicrous and pompous extreme. Alibert's family tree was discarded by his pupil Biett for the system of Willan, and the ideas of Bietf were further extended hy Rayer (1826) and by Cazenave and schedel (1828), who made the first dassification of skin diseases upon an anatomie basis, $e . g$. , inflammations, hypertrophies, disorders of secretion and sensation, hemorrhagie manifestations, ete. This classification was the forerummer of the seeond phase of modern dermatology, the pathologie or histologic period inaugurated by von Hebra and his followers, which will be considered in connection with the New Vienna School.

Laënnec's teaching had an immediate outcome in Creat Britain in the brilliant elinieal work of two physicians of the Irish school. The founters of the Dublin school were John Cheyne

1 W. Stokes: Dublin Med. and Phys, Essays, 1807-8, i, 146-153.

2 Guy's Hosp. Rep., Lond., 1851, 2. s., vii, 265.

3 Alibert: Monographie des dermatoses, Paris, 1S42, vol. i, plate opposite p. 1 .

${ }^{4}$ Ibid.: Rev. méd. franç. et étrang., Paris, 1529, iii, 62-71. 
(1777-1836), who described acute hyolrocephalus (1808') and ('herno-stokes respiration (18IS"); Abraham Colles (1773-1843), who stated "Colles' liw": and Robert Adams (1791-1875), who loft rlaside aceounts of essential heart-block $\left(1826^{3}\right)$ and rhenmatic rout $\left(1857^{4}\right)$. ()ther important members of this school Here Corrigan (of "Corrigan's pulse"), William Wallace (179)11837), who introlued the use of potassium iodide in syphilis (1836), and Francis Rynd (1801-61), who first employed hypo(lemic injections by a gravity devioe (of his invention) for the re-

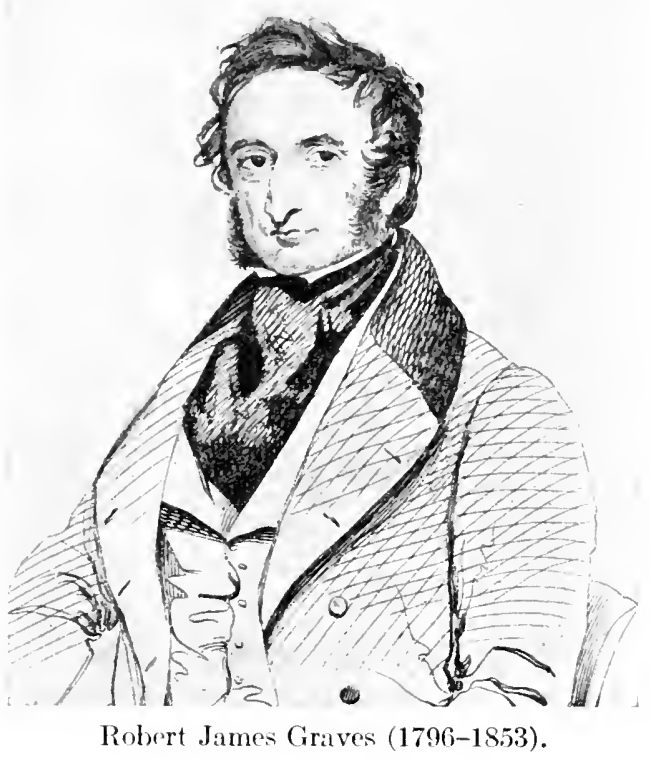

lief of pain $\left(1815-61^{5}\right)$. The true leaders of the Dublin school, however, were Graves and Stokes.

Roloert James Graves (1796-1853), the son of a Dublin clergyman, took his medical clegree in 1818, and, while making the usual

${ }^{1}$ Cheyne: An essay on hydroeephalus acutus, Edinburgh, 1808.

${ }^{2}$ Cheyne: Dublin Hosp. Rep., 1S18, ii, 216. See, also, "The case of the Honourable Colonel Townshend" in George Cheyne's "English Malady" (London, 1733, 209-212).

${ }^{3}$ Adams: Dublin Hosp. Rep., 1\$27, iv, 396.

${ }^{4}$ Adans: Treatise on rheumatic gout, London, 1857.

${ }^{5}$ Rynd: Dublin M. Press, 1845, xiii, 165; and deseription of instrument in Dublin Quart. Jour. Med. Sc.. 1561, xxxii, 13. For a full account of Rynd's invention see Pfender, Wash. Med. Ann., 1912, x, 346-359. 
continental tour, had such adventurous experiences as being arrested as a Geman spy in Austria on aceount of his fluency as a linguist, and of successfully putting down a mutiny on board ship during a storm in the Mediterranean, afterward assuming command and saving the vessel through his pluck. Returning to Dublin in 1821, he beeame chief physician to the Meath Hospital and one of the founders of the Park Street School of Medicine. Here he immediately went in for the videst reforms, introducing the continental methods of clinical teaching, such as making his advanced students handle and report on clinical eases, and suppressing the maltreatment and abuse which hospital patients had to endure from the roughspoken Irish M.D.'s of the day. Tall, dark, and distingué, Graves had a warm heart, in spite of his sareastic speech, and once even did a stint of literary work for a poor student. His Clinical Lectures (1848), which Trousseaul read and re-read with highest admiration, introduced many novelties, such as the "pin-hole pupil," timing the pulse by the watch, and discarding the old lowering or antiphlogistic treatment of fevers. He requested that the phrase "He fed fevers" should be

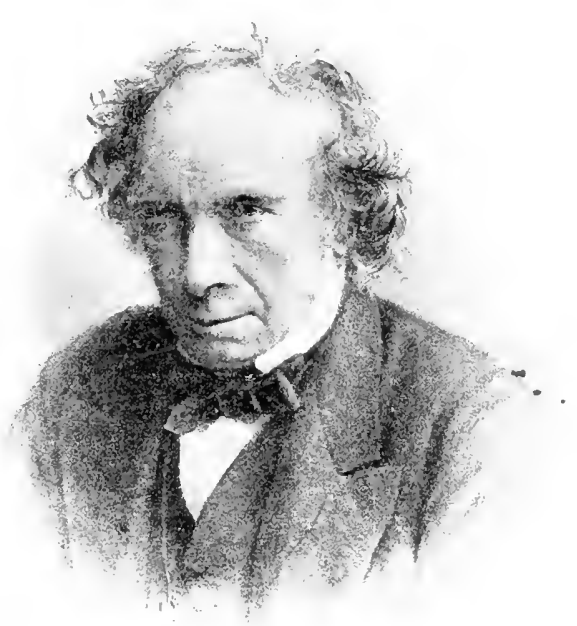

William Stokes (1S04-78).

his epitaph. Graves also left early aceounts of angionenrotic edema, scleroderma and erythromelalgia (1843-8), and, in 1835, he published a description of exophthalnic goiter so admirable that the disease still goes by his name. ${ }^{1}$

William Stokes (1804-78), Graves's colleague at Meath Hospital, was the son of Whitley Stokes, Regius Professor of Medicine at Dublin, and succeeded his father in this position in 1815. As early as 1825 he put himself on record as a diseiple of Laënnec by the publication of his "Introduction to the Use of the Stethoscope." During the Dublin epidemic of typhus fever in 1826, he worked hard for the poor, and had an attack of the disease hinself in 1827.

${ }^{1}$ Graves: London Med. \& Surg. Jour., 1S35, vii, pt. 2, pp. 516, 517. 
He reported the first casc of cholera in the Dublin epidemic of 1832 , and, in 1846, pulnlisherl his colebrated aceount of the stokesAdims disease. His tratises on discases of the rhest (18:37) and discases of the heart and arorta (1854) won him lasting fame. He wits one of the fow physicians who ever received the Prussian order "pour le mérite."

Sil Dominic John Corrigan (1802-80), who described the "famine fever" of 1847 , also wrote upon discases of the heart, and, in 1832, published an original description of insufliciency of the aortic valve (with a superb plate) which is accepted as the classic account of the disease, ${ }^{2}$ although the latter had becn carlicr noted hy Cowper (1705), Vieussens (1715), and Hodgkin (1829). Corrigan was the first to throw into relicf the characteristic receding or "water-hammer" pulse in aortic regurgitation (Corrigan's puls( ), and suggested that a flagging heart may be stimulated by tapping the precordial region with a hot spoon (Corrigan's hammor). He also noted the "cerebral breathing" of typhus and the cxpansile pulsation of aneurysm (Corrigan's sign), and described cirrhosis of the lungs or fibroid phthisis, which, like aortic incompetency, sometimes goes by his name.

The English clinicians of the early nineteenth century assimilated the ideas of Laënnec and Bichat in their practice, and, like Heberden, Parry, Fothergill, and Huxham, showed themselves true followers of Sydenham in their descriptions of disease. Of special importance is the clinical and pathologic work which was done by the long line of brilliant workers at Gur's Hospital-the "great men of Cuyy's." Of these, Richard Bright (1789-1858), of Bristol, had studied under Astley Cooper and Jameś Currie, and was physician at Guy's for twenty-three years (1820-43), where he worked for six hours a day in the wards and postmortem room, besides lecturing on materia medica and clinical medicine. His experience was further widened by extensive continental travel, in the course of which he came to know and admire Johann Peter Frank. He was the leading consultant of London in his day. His Reports of Merlical Cases (1827), containing his original description of essential nephritis, with its epoch-making distinction between cardiac and renal dropsy, at once established his reputation all over Furope. White clouds in the urine had been noticed even by Hippocrates ${ }^{3}$; Saliceto, the Italian surgeon, had pointed out the association of dropsy, scanty urine, and hardened kidneys

1Stokes: Dublin Quart. Jour. Med. Sc., 1846, ii, 73-85.

${ }^{2}$ Corrigan: Edinb. Meel. \& Surg. Jour., 1832, xxxvii, 225-245, 1 pl. (Hodgkin: London Med. Gaz., 1528-29, iii, 433-443).

${ }^{3}$ For instance, in the case of Thasus, wife of Philinus, in Epidemic Diseases, Book I, §13, Case iv. 
(durities in renibus) in $1476^{1}$; and the correlation between dropsy and albuminous urine had been established by William Charles Wells $\left(1811^{2}\right)$ and John Blackall $\left(1813^{3}\right)$; but Bright was the first to connect these symptoms with the peculiar inflammation of the kidneys which he found in so many postmortems, and his epochmaking synthesis soon made its way everywhere, on account of its immense importance in medical practice. ${ }^{4}$ In work of this kind, he is one of the greatest of modern pathologists, and as an original

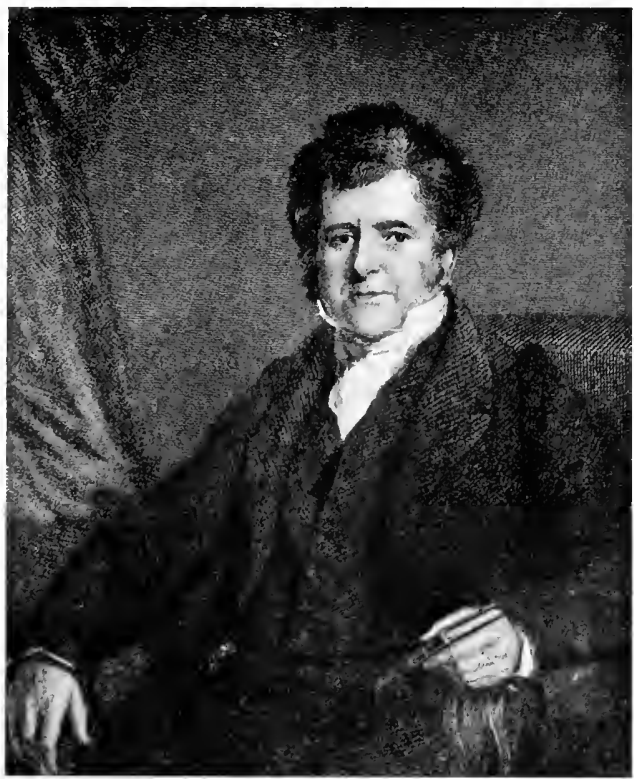

Richard Bright (1789-1S58).

delineator of disease, he ranks next to Laënnec. "Bright could not theorize," says his biographer, Wilks, "but he could see, and we are struck with astonishment at his powers of observation, as he photographed pictures of discase for the study of posterity."

1 "Signa duritiei in renibus sunt, quid minoratur quantitas urinæ, et quod est gravitas renum et spina cum aliquo dolore; et incipit venter inflari post tempus et fit hydropieus seeundum dies. Et ut plurimum fit talis durities post apostema calidum in renibus et post febrem ejus." Saliceto: Liber in scientia medicinali, 1476 , eh. 140 .

2 Wells: Tr. Soc. Improve. Med. \& Chir. Knowledge, 1804-12, Lond., 1812, iii, 194-240.

${ }^{3}$ Blackall: Observations on the nature and eure of dropsies, London, 1813.

${ }^{4}$ For the history of Bright's disease (1827-47), see C. P. Falck, Janus, Breslau, 1S4S, iii, 133; 456. 
He advaneed no special views of pathology and affixed no particular labels to his many descriptions of morbid states, but he collected an extrordinary number of facts and knew how to use them. Thus, he gave original accomnts of pancreatic diabetes and pancreatic steatorrhea ( $\left.1832^{1}\right)$, acute yellow atrophy of the liver $\left(1836^{2}\right)$, unilateral convulsions or Jacksonian epilepsy $\left(1836^{3}\right)$, and "status lymphaticus" (1838"), which, had they been tagged with appropriate names, would hase been better known before our day. His Medical Reports contain aceurate accounts of such novelties as scarlatinal otitis, otitic abscess of the brain, laryngeal phthisis, pressure paralyses, the cerebral hemiplegias, the hysteric

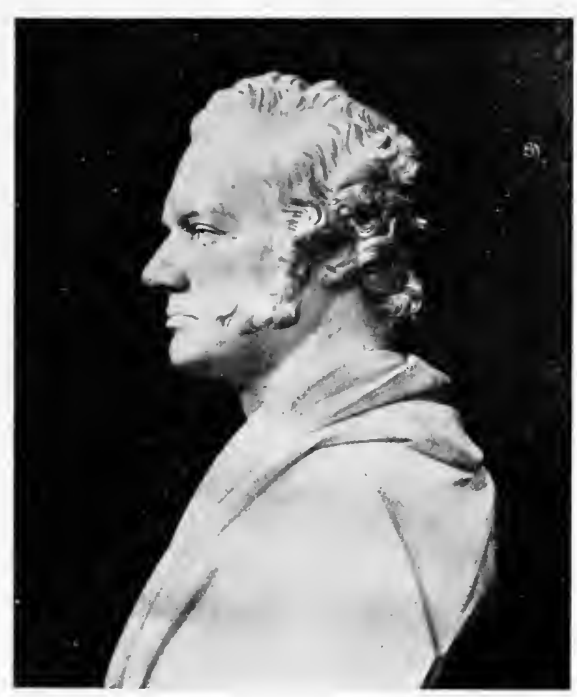

Thomas Addison (1793-1860). (Courtesy of Dr. Herbert L. Eason, Guy's Hospital, London.) equivalents of disease, and striking plates of the pathologic appearances in $t y-$ phoid fever, nephritis, acute yellow atrophy of the liver, and cerebral disease. Sir Samuel Wilks further records that he was one of the first, if not the first, to describe pigmentation of the brain in melanemia, condensation of the lung in whooping-cough, small echinococci in the interior of hydatid cysts, and the bruit of the heart in chorea. Bright was a capable and accomplished artist, a collector and connoisseur of engravings, and his early volume of Hungarian travels is illustrated with charming pictures drawn by himself. This great physician was also an able botanist and geologist, and personally a simple, unprejudiced, truth-loving man.

Thomas Addison (1793-1860), of Longbenton, North Cumberland, Bright's colleague at Guy's, was more the brilliant pathologic lecturer and diagnostician than the successful practitioner. On account of a haughty, repellent manner which, on his own show-

${ }^{1}$ Bright: Med. Chir. Tr., Lond., 1832-33, xviii, 1-56.

${ }^{2}$ Guy's Hosp. Rep., Lond., 1836, i, 36-40.

${ }^{3}$ Ibid., 604-637.

'Ibid., 1S3s, iii, 437. 
ing, concealed excessive shyness and sensibility, he never had a large practice and lived almost entirely for his pupils and hospital work. He attached so little importance to drugging that (it is said) he sometimes forgot to prescribe; yet "Addison's pill," of calomel, digitalis, and squills, for hepatic dropsy in syphilis, is still used. He was also the first to employ static electricity in the treatment of spasmodic and convulsive diseases (1837), and, in collaboration with John Morgan, wrote the first book in English on the action of poisons on the living body (1829). In 1849, Addison read a paper before the South London Medical Society, ${ }^{1}$ in which he described pernicious anemia (twenty years before Biermer) and disease of the suprarenal capsules (melasma suprarenale). These clinical notations were afterward expanded at full length in his great monograph On the Constitutional and Local Effects of Disease of the Suprarenal Capsules (London, 1855). This book was regarded merely as a scientific curiosity in Addison's time, but it is now recognized as of epoch-making importance, since, in connection with the physiologic work of Claude Bernard, it inaugurated the study of the diseases of the ductless glands and of those

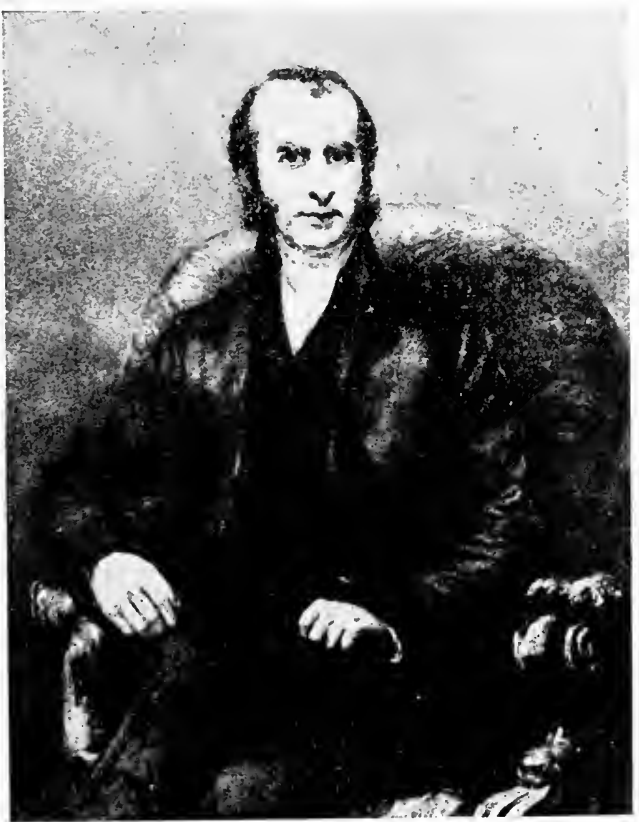

Thomas Hodgkin (179S-1866). disturbances of chemical equilibrium known as "pluriglandular syndromes." It was Trousseau who first proposed to call the suprarenal syndrome "Addison's disease." In 1851, Addison and Sir William Gull described the skin disease "vitiligoidea," now known as xanthoma. "Addison's keloid" is a circumscribed form of scleroderma.

The pathologist Thomas Hodgkin (1798-1866), of Tottenham, England, a member of the Society of Friends, always wearing 
their characteristic dress, was a plilanthropist and reformer by nature and was driven away from Guy's, says Wilks, by his cecentrie inclependence of spirit. His reputation rests upon his original description of that simulaneous enlatgement of the spleen and lymphatic glands or lymphadenoma (1832') which, as he himsolf records, was valgucly outlined by Malpighi in 1665, and which Wilks, in 1S65, called "Hodgkin's disease." He also wrote an account of insufficiency of the aortic valve $\left(1829^{2}\right)$, which antedated Corrigan's classic paper by three years. His essay on medieal oducation (1823) is an interesting contribution, and his Lectures on the Morbid Anatomy of the Serous and Mucous Membranes (1836-40) is one of the ealliest English treatises on pathology. Being generous to his patients and careless about collecting fees, Hodgkin gradually foll out of practice and devoted the rest of his life to various philinthropies. He died at Joppa, while traveling in the East with Sir Moses Montefiore, who erected the momment over his grave.

Probably the greatest of all illustrators of gross pathology was Sir Robert Carswell (1793-1857), of Paisley, Scotland, an Aberdeen graduate of 1826 , who became professor of pathology at University College, London (1828). From a wonderful series of 2000 water-color drawings of diseased structures (1828-31) came his Illustrations of the Elementary Forms of Disease (1837), a folio of colored plates, drawn and set upon the stone by himself, which has never been surpassed.

Among eminent English clinicians of the early period were Parkinson, Wells, Hodgson, and Hope.

James Parkinson (1755-1824), of London, one of John Hunter's pupils, is remembered to-day by his unique and classic description of paralysis agitans or "Parkinson's disease" $\left(1817^{3}\right)$, and by the fact that he reported the first ease of appendicitis in English $\left(1812^{4}\right)$, this ease being also the first in which perforation was recognized as the eause of death (H. A. Kelly). Parkinson was a radical, a reformer and political agitator, sometimes in hot water with the government, and what little is known of his life is almost entirely due to the recent interesting researches of $\mathrm{L}$. C. Rowntree $\left(1912^{5}\right)$. He wrote political and controversial pamphlets, a number of small treatises on domestic medicine, and a good book on medical education (The Hospital Pupil, 1800); but his most im-

1 Med. Chir. Tr., Lond., 1832, xvii, 68-114.

${ }^{2}$ London M. Gaz., 1828-29, iii, 433-443.

${ }^{3}$ Parkinson: An Essay on the Shaking Palsy, London, 1817.

${ }^{4}$ Med. Chir. Tr., Lond., 1812, iii, 57.

${ }^{5}$ Rowntree: Bull. Johns Hopkins Hosp., Balt., 1912, xxiii, 33-45. 
portant contributions outside of medieine are his works on fossil remains (1804-22). An able geologist and palreontologist, he is memorable, with Avicenna, Fraeastorius, Stensen, Hutton, Wollaston, Owen, and Huxley as one of the medieal men who have contributed something of permanent value to these scienees.

William Charles Wells (1757-1817) was born in South Carolina, but his people being Tories in the Revolutionary period, he must be accounted, by his own choice, a British subject. Wells was a highly original observer, both in medicine and physies, his most important contribution to the latter science being his well-known Essay on Dew (1814). He deseribed the albuminous urine of dropsy in $1811^{1}$, and, in 1810 , published perhaps the earliest elinical report on the cardiae complications of rheumatism. ${ }^{2}$ His essay's on vision (1793-1814) eontain many observations of the highest originality.

Joseph Hodgson (1788-1869), of Birmingham, a successful lithotomist, wrote an important Treatise on Diseases of the Arteries and Veins (1815), in which he gave the first description of aneurysmal dilatation of the aortic arch, which the French writers eall maladie d'Hodgson. This book is a wonderful storebouse of knowledge on the subject of vascular disease, and contains a great many valuable historic data about aneurysms and the early ligations of important arteries. In conneetion with it, we may mention Allan Burns's "Observations" on Heart Disease $(1809)$.

James Hope (1S01-41), of Stockfort (Cheshire), an Edinburgh graduate (1825), afterward associated with St. Cieorge's Hospital, did much for our knowledge of heart-murmurs, aneurysm and valvular disease, summarized in his treatise on Diseases of the Heart and Great Tessels (1831). In 1833-4, he produced an at las of plates of anatomy, drawn by himself, which was, however, surpassed by that of Carswell (1837).

The most important English treatice on the practice of medicine in the first half of the nineteenth century was the "lectures on the Principles and Practice of Physic," published in 1843 by Sir Thomas Watson (1792-1882). For more than a quarter century, this work continued to pass through many editions and enjoyed a well-deserved popularity on aceount of its author's attractive and elegant style and his clear prescntation of his subject.

The treatise on practice by Bright and Addison, of which only the first

1 Wells: Tr. Soc. Improve. Med. and Chir. Knowledge, 1১04-12, Lond., 1812 , iii, $194-240$.

I Ibid., 372-112. 
volume was ever published $(1800)$, is a strietly seientifie production, in which the phenomena of disease are treated in rigid catcogories, as in a work on mathematical physies. It is remarkable for its frankly agnostie spirit in regard to otseure phenemenal, sueh as the nature of ferer. Most of the text is said to have been written by Addison.

Other chinical treatises of the perjod, now almost forgotten, were Seudamore on grout (1s16). Thackrah on the blood (1819), Sir Charles Hastings on inflammation of the lungs (1520), sir James Clark on phthisis (1835), Franeis sibson on position of the internal organs (1844). Golding Bird on urinary deposits (1845), and the works of James Hope (1s32), Peter Mere Latham (1845), Alison (1845), and Chevers (1851) on heart disease.

A prominent feature of English medicine in this period was the publication of admirable sistems and encyclopedias of medicine, such as those of Forbes (1\$33-35), Todd (1S35-59), Tweedie (1S40), South (1S47), and Reynolds (1866-79). These, with Panckoueke's sixt y-volume Dietionnaire des

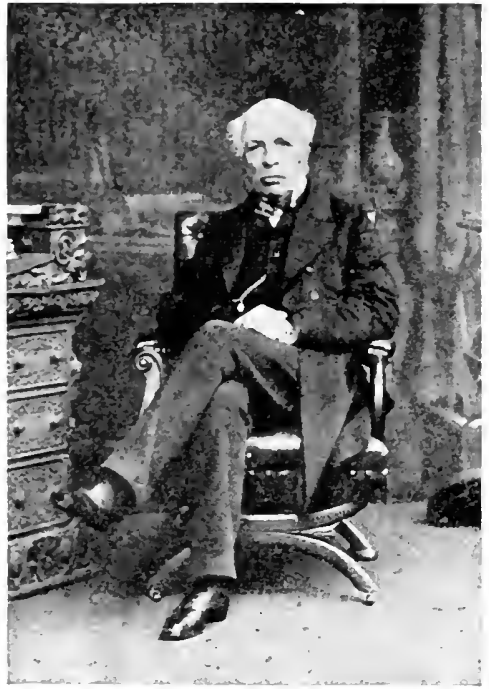

Sir Thomas Watson (1792-18\$2). sciences médicales (1S12-22) and the fort v-one volume Encyclopedie of Dechambre (1834-46'), were the forerunners of such later works as Quain's Dietionary of Medieine and the systems of Ziemssen, Eulenburg, Allbutt, and Osler. A remarkable compiler of the day was James Copland (1791$1870)$, of the Orkney Islands, a "polyhistorian" of the type ridiculed in Germany, who made his living by hack work, and whose "Dictionary of Practieal Medicine" (1834-59) consists of 3509 double column pages, all written by himself. Norman Moore likens it to the Continens of Rhazes, adding that our own generation leaves it, "its undisturbed on the shelves as the Continent itself." As president of the Pathologieal Society of London, Copland exeited many a ehuckle of derision when he claimed various modern discoveries as his own.

A most important feature of British medicine in the nineteenth century was the work of the Anglo-Indian surgeons. The East India Company was chartered by Queen Elizabeth in 1600 and established its first trading station in 1612. Even in the early days, two surgeons, Gabriel Boughton, who, in 1645. was sent from Sirat to the eourt of Shah Jahan at Agra, and William Hamilton, who accompanief the mission to Delli in 1714-17, were both of them instrumental in securing trading concessions and charters for the eompany, learling up to the establishment of the three great centers at Bombay, Caleutta, and Madras; but it was not until well after Clive's victory at Plassey in 1757 that we sce the Indian Medical Service playing much of a part in colonial and tropical merlicine. It was formally eonstituterl as such on Jan-

1 The seventeenth eentury eneyclopedias of medicine were really anthologies. The modern idea of dictionary eompilations originated in sueh works as the Konversations-Lexika of Hübner (1704) and Brockhaus (1796-1S08), the eneyelopedias of Ephraim Chambers (172s), Diderot (1751-72), and Voltaire (Dictionnaire philosophique, 1764), and the Encyclopædia Britannica (1768-71). For a good list of early medical encyclopedias, see Brit. Med. Jour., London, $1913, \mathrm{i}, 725$. 
uary 1, 1764. The earliest treatise on tropieal medieine was, in fact, published in 1768 by James Lind (1716-94), whose important work was followed in due course by an imposing array of books on the Indian climate and diseases, notably those of John Peter Wade (1791-93), William Hunter (1804), Sir James Annesley (1825), Willian Twining (1832), Nir James Ranald Martin (1841), Allan W ebb (1848), and Charles Morehearl (1856), not to omit Goodeve's perennial little treatise on tropical pediatrics (1844). Aside from the development of tropieal medicine, the organization of hospitals, of medieal education, of public hygiene, and other administrative duties connected with the buikding up of the Indian Empire, the most important achievements of these army surgeons were their remarkable first-hand accounts of heat stroke (those of Green, Barclay, Longmore et al., being among the closest to fact that we have), the descriptions of various forms of snake-bite, of native nodes of poisoning, and of the properties of far eastern drugs, the many contributions to Indian botany, zoölogy, geology, and ethnography, the original aceounts of cholera, beri-beri, seurvy, dysentery, leprosy, and filarial elephantiasis, and the introduction of such novelties as mesmeric anesthesia, the British Army bamboo splint, and the Hindu method of traching surgieal incision upon plants, or the reintroduction of the use of ipecac in dysentery by Surgeon-Major E. S. Docker in 15.58.

The literary organ of the Indian Medical Service at this time was the India Journal of Medical Science (1834-45), which was edited up to 1842 by Frederick Corbyn. The earlier volumes contain interesting engravings of some of the medical nabobs of the period.

Two of the Anglo-Indian surgeons will always hold a high place in the history of serpent venoms, viz., Patrick Russell (1727-1805), of Braidshaw, Scotlind, whose Account of Indian Serpents (four volumes, 1796-1809) was the earliest venture in the field, containing the original description of the celebrated Russell's viper (Daboin Russellii); and Sir Joseph Fayrer (18241907), who played a spirited part in the Mutiny, and whose Thanatophidia of India $(1572)$ is one of the great classics of zoology, describing all the venomous snakes of the Indian Peninsula, with magnificent life-size plates from drawings by Hindu pupils in the Covernment Sehool of Art in Caleutta; and original experiments on the venoms, which were, however, preceled by the early work of the Abbé Fontana and Weir Mitchell (1870). The greatest of the AngloIndian zoölogists was Thomas Caverhill Jerden, whose aceounts of the hirds (1844-64) and manmals (1854) are famous. Among the many botanic works were William Roxburgh's Plants of the Coromandel Coast (1795-1819) and Flora Indica (1820-24), Nathaniel IVallich's Tentamen Flora $N^{\top}$ cpalensis (1824-26) and Plante Asiatien Rariores (1530-32), Robert Wight's Icones Plantarum India Orientalis, six volumes with over 2000 plates (18.35-53), William Griffith's Icones Plantarum Asiaticorm (1847-51), and Thomson and Hooker's Flora Indica (1855). Important original monographs on tropical diseases were John Peter Wate on ferre and drsentery (1791-93), John MacPherion's Annals of Cholera (1839), Edward II are on the freatment of remittent fever and dysentery (1847), N. C. MacNamara's Il istory of A siatic Cholera (1S76), and the original investigations of Henry Vandyke Carter, (1831-97) on mycetoma (1874), leprosy, and elephantiasis (1874) and spirillosis (1852), and of Leonard Rogers on Indian frvers (1S97-1908), and dysenteries (1913). Beri-beri had already been described in the seventeenth rentury by Bontius $(16+2)$ and Tulp $(16.52)$, but the treatice of John Grant Maleohinom (1535) will always be accounted the elasic source of recent knowledge of the lisease. The treatise on tropieal pediatrics by Froderick Corbyn (1S28) and Henry Iturry Goodeve (1844) were new departures, and the latter (mjoyed a popularity of nearly fifty yoars standing. Some of the Indian surgeons, who loft the service early, attained distinction in other fiolds of activity, lotably Murchison, Esdaile, Playfair, whose midwifory passed through nine ditions (1576-95), Ireland, momorable for his witings on insanity, and Edvard Joln Waring (1819-91), who compiled the first official Indian pharmaopoeia (186S), a bilingual work on Bazar Medicines (1S60), also a Hallorike Bibliotheca Therapeutica (1S78), and afterward did good service in public ygiene. 
Charles Murchison (1830-79), born in Jamaica of Scoteh parentage, ontered the Bengal army in 1853, and published a treatise on the climate and diseases of Burmah in 1855. Returning to England, he becane a prominent physician at the London Fever Hospital (1S56-70) and St. Thomas's Hospital (1871-79), in connection with his wonderful special knowledge of fevers; and, in 1S73, he was presented with a testimonial by the residents of West London for tracing an epidemic of typhoid to a polluted milk supply. He was noted for his solid accuracy, promptitude, and decision in diagnosis, and alt hough he opposed the bacterial theory of infection, his Treatise on the Contimued Fevers of Cireat Britain (1862) is as important a work for England as Drake's Diseases of the Mississippi Valley is for the Inited States. Murchison translated Frerichs' book on discases of the liver in 1861 and wrote a number of important monographs on the same subject himself. Like his famous brother, he was an able geologist.

The name of Esdaile, of the Indian Medical Service, is prominently associated with the history of hypnotism, particularly of hypnotic anesthesia in surgical operations. After the time of Mesmer, hypnotism was only a peg for arrant charlatanry. The great pioneer of scientific hypnosis was James Braid (1795-1861), a surgeon of Fifeshire, Scotland, who settled in Manchester and beeame attracted to the subject of animal nagnetism about $18+1$. Braid at first believed that the phenomena produced by professional mesmerists were due to "collusion and illusion"; but he soon became convinced, upon experimentation, that there can be a genuine self-indueed slecp brought about by al fixed stare at a bright inanimate ohject (Braidism). The importance of Braid's work is that he proved that the mesmeric influence is entirely subjective or personal, and that no fluid or other influence passes from the operator to the patient. This subjective trance he called neurohypnotism or hypnosis (1842), and his important treatise on the subject was entitled Neurypnology, or the Rationale of Nerrous slcep (1St3). Braid's idleas met with violent opposition, especially from the professional mesmerists, who wished to keep their exhibits upon it miraculous basis, but his ideas were taken up by Azam, Broca, Chareot, Liébeault, Bernheim, and became the true starting-point of the French school. ${ }^{1}$ Hypnotism was first used in surgical operations by John Elliotson (1791-1868²), a professor of practice in the Lniversity of London and president of the Royal Medical and Chirurgical Society, who, in 1843, published a pamphlet describing Numerous Cases of Surgical Opera-

1 Wilhelm Prever translated Braid's complete works into German in $18 s 2$.

2 To whom Thackeray dedicated his "Pendennis." 
tions without Pain in the Mesmeric State. Dispute about this led to his resignation from his various offices. A far more impressive record was made by James Esdaile (1808-59), of Montrose, Scotland, who, in 1845 , began to try hypnotism in operating on Hindu conviets. He performed over 100 such operations with suecess, having been put to a serere test by the Deputy Governor of Bengal, and eventually had a record of 261 painless operations with a mortality of 5.5 per cent., which he described in his book, "Mesmerism in India" (1846). On returning to Scotland, Esdaile found that, except in disease, the self-contained Europeans differed from the impressionable, neurotic Hindus in not being specially susceptible to the hypnotic trance.

German medicine, in the first half of the nineteenth century, labored under the disadvantage of being split up into schools. Exhausted by the Nipoleonie wars, and existing mainly as a set of petty principalities, with only a vague racial and political solidarity, the German people had to endure a long period of brutal military régime, as a natural sequel of the previous struggłe against foreign invasion. In consequence, the best minds of the time were driven into various idealistic mockes of thought, a fermentation which came to a head in the Revolution of 1848 . Brunonianism, Mesmerism, and the various phases of "magical medicine" which followed in its train, had prepared the ground for the wildest kind of speculation. During this period of idcalism, the favorite philosophers were Schelling, Fichte, and Hegel. Clinical medicine was dominated by the fanciful reveries of the Nature-Philosophy School, of which Schelling hinself was, indeed, the founder. Its principal spirit was the Bavarian naturalist, Lorenz Oken (17791851), editor of the journal Isis and a founder of the first German Congress of Naturalists and Physicians (1822), in whom great originality of thought went hand in hand with much ineptitude. He accepted and expanded Goethe's vertebrate theory of the skull (in 1806), regarcled the flesh as a conglomeration of infusoria (cells), and glorified the male element in nature to the extent of declaring that "Ideally every child should be a boy." Other members of the school, such as Döllinger, Görres, Treviranus, and Steffens, drifted into a maze of incomprehensible jargon and fanciful distinctions as to the real and the ideal, identity, imponderables, polarities, irritability, metamorphosis, and the like. Hard upon the Nature-Philosophy School followed the Natural History School, which aimed to name and classify diseases after a rigid system, as in botany or zoölogy. It was succeeded by the rational or physiologic teaching of Roser and Wunderlich, Henle and Pfenfer, the forerunners of the scientific movement of German medicine, which was headed by the pupils of its prime mover, Johannes Müller. 
Apart from these, many struyed into such devious by-paths as Phrenology, Homoropathy, Rademacherism, Bammscheidtism, Hydropathy, Odic Foree, Animal Magnetism, and other narrow and exclusive ways of conceiving the facts of medicine. The tendency of all these hole-and-corner schools was toward wholesale contempt for the scientific achievements of men like Bichat and Magendie, Lännec and Louis, or the practical sense of such clinical workers as Bright, Stokes, or Graves; and this tendency reached the limit of exaggeration in the doctrines of the New Vienna School, as stated by Skoda, Hamernijk, and Dietl. Skoda said that while we can diagnose and describe disease, we dare not expect by any means to cure it. Dietl, in an oft-quoted utterance of 1851, announced that a physician must be judged, not by the suceess of his treat-

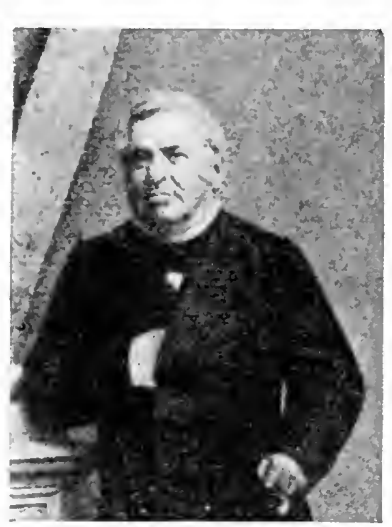

Johann Lucas Sichönlein $(1793-1864)$. ment but by the extent of his knowledge: "As long as medicine is art, it will not be science. As long as there are successful physicians there will be no scientifie physicians." These ingenious paradoxes, which amounted virtually to a plea of impotence, made up the "therapeutic nihilism" of the New Vienna School. The Revolution of 1848 dissipated the silly doctrines of the Nature-Philosophy School into space, but the New Viema School died hard, and Rokitansky had to be overthrown by Virchow, and Semmelweis had to sacrifice his life in proving his thesis before German medicine could finally emerge from the Happy Valley of speculation to gain the tableland of reality. ${ }^{1}$

The first to break away from the jargon of the Nature-Philosophy School was Johann Lucas Schönlein (1793-1864), of Bamberg, the founder of the so-called Natural History School, the ambition of which was, as we have said, to study medicine as descriptive botany and zoölogy are studied. Schönlein, his pupil, Carl Canstatt, and Conrad Heinrich Fuchs, all of them inspired by de Candolle's classification of plants, proceeded to make arbitrary classifications of disease, based, in each case, upon a very hazy fundamentum divisionis, not unlike those of Boissier de Sauvages in the eighteenth century. Schönlein, in particular, indulged in such whimsies as forcing gangrene of the uterus into the class

1 For a brilliant and effeetive exposition of the intellectual follies of this period see Dr. A. Jacobi's aceount of his student day's in Germany, in New Fork Med. Jour., 1901, lxxiii, 617-623. 
"nemrophlogoses" and cholera into the catarrhs. In his progress from Würzburg to Zürich and Berlin, he passed through all three of the developmental phases of the Natural History School, the parasitic, the nosologic, and the scientific. ${ }^{1}$ The real merits of Schönlein, however, are of a different order. In his clinic at the Charité, in Berlin, he was the first to lecture on medieine in German instead of Latin (1840), and was the founder of modern elinical teaching in Germany, introducing examinations of the blood and urine, chemical analysis, auscultation, percussion and microscopic investigations. He wrote little, ${ }^{2}$ his only contributions of importance being his observation of triple phosphates in the excreta of typhoid fever (1836), his description of peliosis rheumatica (Schönlein's discase) in $1837,{ }^{3}$ his discovery of the parasitic cause of favus (achorion Schönleinii) in $1839,{ }^{4}$ and his proposal of the terms "typhus abdominalis" and "typhus exanthematicus" to differentiate these discases (1839), and of the term "hemophilia" for the hemorrhagic diathesis. Schönlein was a man of peculiar character. During his later years in Berlin he often affected the eccentricities of a rechuse, denying hinself to patients when it suited his whim, and otherwise treating them with the "godlike coarseness" of demeanor (göttliche Grobheits) which was then the vogue. His scientific abilities have been ably set forth in the well-known eulogy of Virchow $\left(1865^{6}\right)$, but he seemed, alike to the delicate perception of Fanny Hensel and the plain common sense of Augustin Prichard, something of a boor.

Schönlein's pupil, Carl Friedrich Canstatt (1807-50), of Ratisbon, wrote a sterling text-book on practice, absolutely free from metaphysical dogma, which, says Ja col)i," was the "Bible of Cielman medicine" until it was superseded by Niemeyer, as the latter was, in due course, by Strimpell.

The scientific movement in modern German medicine was started and kept in pace mainly through the medium of four important periodicals which stood out for exact investigation and exerted great influence upon the younger spirits in the speculative

1 Neuburger. (Puschmann Handbuch, ii, 145.)

${ }^{2}$ As to eertain submerged writings of Sehönlein, see E. Ebstein: Arch. f. Geseh. d. Med., Leipz., 1911-12, v, 419-452.

3 Sehönlein: Allg. u. spee. Path. u. Therap., Herisau, 1837, ii, 1848.

${ }^{4}$ Miiller's Arch., Berlin, 1839, \&2, 1 pl. (A contribution of only 20 lines.)

${ }^{5}$ The Homeric phrase oeeurs for the first time in Friedrich Schlegel's celebrated romance of "Lueinde." Virehow gives one (perhaps apoeryphal) instanee of Sehönlein's rudeness. The latter was onee consulted by an elderly physieian, who, disconeerted by his brusque manner, pointed to his gray hairs. Schönlein retorted: Auch dic Escl sind grau!

${ }^{6}$ Virchow: Gerläehtnissredle auf Lueas Sehönlein, Berlin, 1865.

7 Jacobi: Op. cit., p. 622. 
period, viz., Müller's Archir für Amatomie, Physiologie und wissenschuftliche Uedicin (15:3t), Ilonle and P'foufor's Zeitschrift für retionelle Medicin (1811-69), Roser and Wunderlich's Archiv für physiologische Heilkunde (1842-59), and Virchow's Archir fiur pathologische Anatomic (1S17-1913). Of these able editors, Mialler, Henle, and Virchow were the leaders in Germany of eomparattive, histologic, and pathologic anatomy respectively, and Mïller, in particular, Was the greatest Geman physiologist of his time. Wunderlich was perhaps the most original clinician.

Carl Reinhold August Wunderlich (1815-77), of Wïrttemberg, gladnated at Tübingen in 1837 and taught medicine there until 1850, when he sueceeded to Oppolzer's chair at Leipzig (1850-77).

He deseribed renal apoplexy

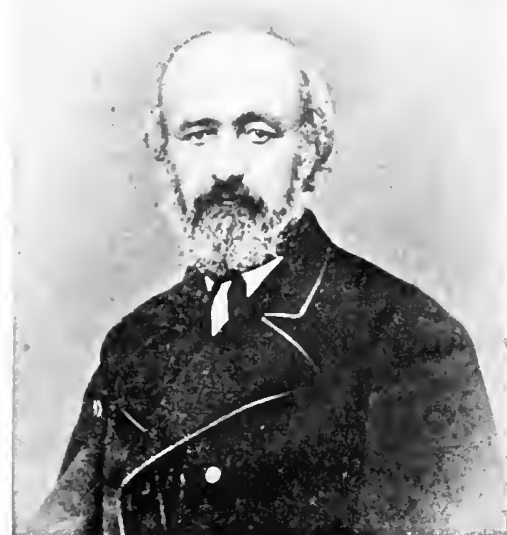

Carl R. A. Wunderlich (1815-77). (By kind permission of Frau Geheimrat Franz Hofmann-ITunderlich, Leipzig.) (1856), wrote a good treatise on practice (1858) and an excellent history of medicine (1859), but his masterpiece is undoubtedly his tratise on the relations of animal heat in disease $\left(1868^{1}\right)$, which is the very foundation of our present clinical themometry. Before Wunderlich's time, Reil and others had written five-volume treatises on fever as a disease. About 1850, Clausius, Helmholtz, and Sir William Thomson had worked out the mathematical relations of the laws governing heat-transformations, and, in 1849, Thomson (Lord Kelvin) had established his "absolute scale of temperature," without which no thermometers coukl be reliable. Upon this hint, Wunderlich made many careful observations of temperature in disease, tabulating his results, and, after the true significance of the thermal changes in the body were better understood, thermometry became a recognized feature in clinieal diagnosis, and new studies were made of fever and other pathologic problems in which the idea of temperature is involved. Before the time of Clausius, heat (caloric) was still regarded by many as a material substance, an idea which threw back the progress of medicine as much as did its parent and fore1868.

1 Wunderlich: Das Verhalten der Eigenwärme in Krankheiten, Leipzig, 
runner, the phlogiston theory of Stahl. ${ }^{1}$ By utilizing the advanced thermodynamic knowledge of his time, Wunderlich made his book a permanent seientific classic. He found fever a disease and left it a symptom.

Josef Skoda (1805-81), of Pilsen, Bohemia, was the leading clinician of the New Vienna School and the exponent of its therapeutic nihilism. He was the first medical teacher in Vienna to lecture in German (1847), and talight nearly all his life in the Allgemeines Krankenhaus. His principal contribution to medicine is his treatise on pereussion and auscultation $\left(1839^{2}\right)$, in which he attempts to classify the different sounds in the chest by categories, ranged according to musical pitch and tonality, and alternating from full to hollow, elear to dull, tympanitic to muffled, high to deep. Skoda's resonance, the drum-like sound heard in pneumonia and pericardial effusion, is a permanent part of modern diagnosis. Although little was known of the physies of sound in Skocla's time, his acoustic refinements were, in some respects, an im-

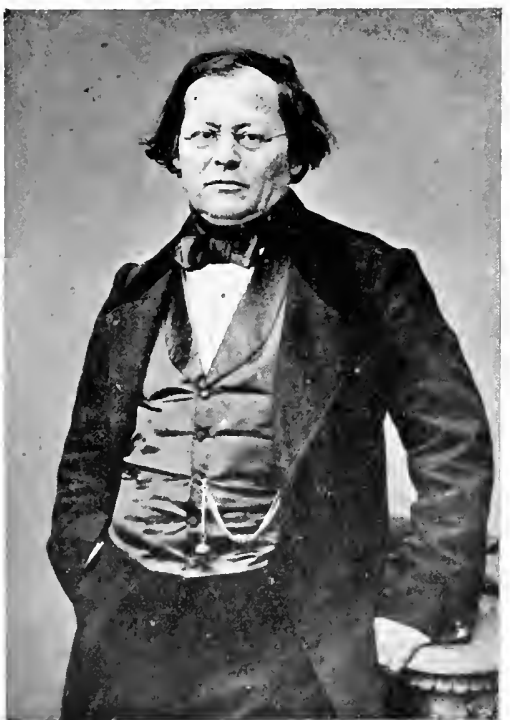

Josef Skorda (1805-81). (Collection of A. C. Klebs.) provement upon the loose descriptive terms used by the French elinicians of the period, so wittily exemplified in the "Stethoscope Song" of Dr. Holmes:

"The bruit de rape and the bruit de scir

And the bruit de diable are all combined;

How happy Boullaud would be,

If he a case like this could find."

None the less, so effective an expression as Laënnec's "xgophony" still means a great deal to the ear of the modern practi-

${ }^{1}$ It is now charitably supposed that when Stahl and his followers maintained that if a body unilergoes eombustion, it gives off something (becomes "dephlogisticated"), they were elumsily groping in the direction of Carnot's principle that "Heat cannot flow from a colder to a warmer body." Even as late as 1865, we find such an able engineer as the hard-hetded Rankine still believing that heat is an indestructible substance.

2 Skoda: Abhandlung über Perkussion und Auskultation, Vienna, 1839. 
tioner. In recent times, skodals work has found further clathorafion in the romplicated instruments with Hehmboltz resonators which some clinicians use to amalyze the sommls of the chest for teabhing pmposes. Skoda was a whimsical, top-heavy old bachelor, who, as Bats rolates, put up with quece clothes all his life for foar of offending his tailor (a personal friend), yet onee sled a dergrman to ohtain payment of a fee. ${ }^{1}$ He looked upou his patients as objects of investigation merely, and, whon it came to treatment, said, with a shrug: Ach, das ist ja alles eins! This sot a bad eximple. The humane or psychic side of medical treatment was entirely ignored, and a diagnosis confirned by a post-

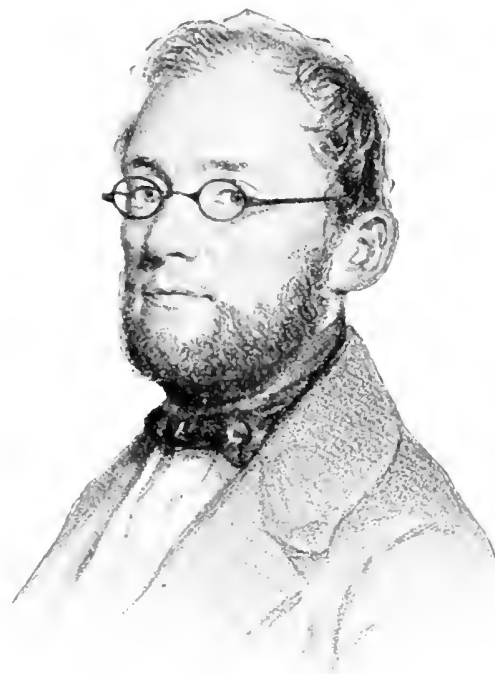

Carl Rokitansky (1804-78).

mortem came to be a sort of shibboletl, in Vienna, and snap-diagnoses (Schnell-Diagnosen) the fashion, even among practitioners, who could not have differentiated the pitel and tonality of a heart-sound from a band of music.

Carl Rokitansky (180178), Skoda's colleague, was also a Bohemian, but a man of different type, genial and massuming, where Skoda was pragmatic and pedantie; a graceful and witty writer, where Skoda was dry and dull. His Viennese bonhomie is sensed in his jest about his four sons, two of whom were physicians, the other two singers: Die Einen heilen, die Anderen heulen. Rokitansky did an enormous amount of pathologie work, and, it is said, had the disposal of between 1500 and 1800 eadavers annually. He made over 30,000 postmortems in his life. He was the first to detect bacteria in the lesions of malignant endoearditis, and to differentiate between lobar and lobular pneumonia, as also between Bright's disease and Speckniere (Tirchow's amyloid degeneration of the kidney). He first deseribed acute dilatation of the stomach (1812), left a elassic account of the pathologie appearances in acute yellow atrophy of the liver, giving the disease its present name (1843); deseribed and defined the bronchitic and

${ }^{1}$ Baas: Op. cit., footnote to p. 954 . 
pulmonary complications of typhoid as bronchotyphus and pneumotyphus; and completed Laënrec's picture of emphysena of the lungs by describing the microscopic appearances of the same. In obstetries and orthopedies, he is memorable as the first to describe the spondylolisthetic deformities $\left(1839^{1}\right)$. The value of the first edition of Rokitansky's treatise on pathologic anatomy (1842$46^{2}$ ) was seriously impaired by his doctrine of "crases" and "stases," in which chemical states of substance were actually conceived of as being susceptible to "disease," and which was mercilessly chaffed out of existence by Virchow $\left(1846^{3}\right)$. The latter intimated that Rokitansky was in reality an adherent of the Natural History School, since he employ ed a bizarre terminology to describe things of which he had no ken, his chemical hypotheses of tissue changes being susceptible of a simpler and more purely mechanical explanation, while his attempt to revamp the ancient drivel about solidism and humoralism was a monstrous anachronism (ein ungeheurer Anachronismus). Virchow knew more chemistry than Rokitansky, but he cordially admitted that in picturing what was actually before him on the postmortem table his jolly Viennese rival was the ablest descriptive pathologist of his time. It is said that when Rokitansky read Virchow's criticism, he could never bring himself to look at his unfortunate first edition again. Rokitansky's finest productions are unquestionably his monograph on diseases of the arteries $\left(1852^{4}\right)$, illustrated with 23 folio plates; and his great memoir on defects in the septum of the heart $\left(1875^{5}\right)$, the result of fourteen years' labor, giving his transposition theory of the deviation of the aortic septum. These works have been the subject of deep study by modern pathologists, in comection with the English classic (1866) of Thomas Bevill Peacock (1812-82) on malformations of the human heart (1866), and the later memoir of Maude Abbott (1908).

Johannes von Oppolzer (1808-71), also a Bohemian, was a clear-headed, extremely competent practitioner who steered clear of all haphazard theorizing, and, as professor at Leipzig, did much to popularize the Viennese immovations in Germany. He was noted for his quickness in offhand diagnosis. Hamernijk of Prague and Dietl of Cracow were the extremists in therapentic nihilism,

${ }^{1}$ Rokitansky: Med. Jahrb. des österreiehischen Staates, Vienna, 1\$39, xix, $41 ; 195$.

${ }^{2}$ Rokitansky: Handbuch der pathologisehen Anatomie, Vienna, 1842-16.

${ }^{3}$ Virehow: Kritik des Rokitansky'sehen Handbuchs der pathologischen Anatomie, Med.-Ztg. (Verein f. Heilk. in Preussen), Berl., 1846, xv, Lit. Beilage, Nos. 49,50 , pp. $237,243$.

${ }^{4}$ Rokitansky: Ueber einige ler wichtigsten Krankheiten der Arterien, Denksehr. d. k. Akarl. d. Wissenseh., Vienna, 1852, iv, 1-72.

${ }^{5}$ Die Defekte der Scheidewände des Herzens, Vienna, 1875. 
and the latter is now remembered only by the painful symptoms in floating kidney (D)ictl's arises), attributable to a kink in the ureters or lenal vessels, which he described in $186 t$.

Pertatps the most brilliant mame of the New Vienna Sehool, after skodis and Rokitansky's, was that of Ferdinand von Hebra (1Sli-S()), of Brïmn in Moravia, a pupil of both these masters, and the founder of the histologic school of dermatology, the second phase in its modern development. Hebra's classification of skin discases $\left(1855^{1}\right)$ was hased upon their pathologic anatomy, and

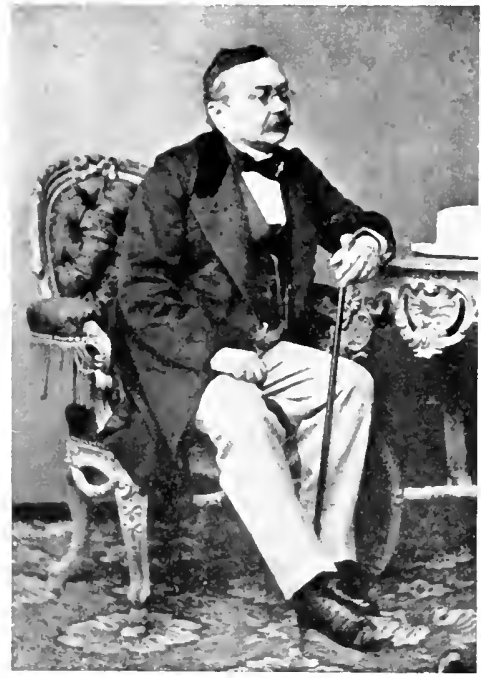

Ferdinand von Hebra (1816-80). (Boston Medieal Library.) while complieated and artificial, lacking the simplicity of Willan's, it opened ont new lines of investigation, in which his pupils, Kinposi, Nenmann and Pick, played a prominent part. Hebra rexarded most entalleous disorders as purcly local, and, from this viewpoint, devised many offective modes of treatuent. Yot, as a chimpion of nihilistic therapy, he is said to have followed Skodis in feigning treatment in some cases in order to demonstrate to his own satisfaction that they could get well of thensivles. Hehra revived the use of mercurials in syphilis and gave the classic accounts of lichen exsudativus ruber $\left(1857^{2}\right)$ and eczena marginatum $\left(1860^{3}\right)$. He also did much to clear up obseure points in classification and nomenclature, and was the first to describe impetigo herpetiformis $\left(1872^{4}\right)$, although the final account of the latter disease was completed by his son-in-law, Kaposi, in 1S57.5 Hebra's clinic was one of the most popular in Vienna, on account of his genial, offhand style of lecturing, and his keen, often sareasitic, humor.

${ }^{1} \mathrm{~F}$, von Hebra: Versuch einer anf pathologischer Anatomie gegründeten Eintheilung der Hautkrankheiten, Ztschr. d. k. k. Gesellsch. d. Aerzte zu Wien., 1845. i, 34; 142;211.

${ }^{2}$ Allg. Wien. med. Ztg., 1857, ii, 95.

${ }^{3}$ Handb. d. spec. Path. u. Therap. (Virchow), 1860, iii, 1. Abth., pp. $316-363$.

${ }^{4}$ Wien. med. Wochensehr., 1872, xxii, 1197-1201.

${ }^{5}$ Kaposi: Vrtljschr. f. Dermat., Vienna, 18s7, xiv, 273-296, 5 pl. 
The greatest single achievement of the New Vienna School was the determination of the true cause and prophylaxis of puerperal fever. In the eighteenth century, Charles White, of Manchester, England, had enlarged upon the advantages of scrupulous cleanliness in these eases, and on February 13, 1S t3, Oliver Wendell Holmes (1809-94) read to the Boston Society for Medical Improvement his paper On the Contagiousness of Puerperal Fever, ${ }^{1}$ in which he amnounced that women in childbed should never be attended by physicians who have been conducting postmortem sections or cases of puerperal fever; that the latter disease mav he conveyed in this manner from patient to patient, cven from a case of erysipelas; and that washing the hands in calcium chloride and changing the clothes after leaving a puerperal fever ease was held to be a preventive moasure. Holmes's essay stirred up violent opposition on the part of the Philadelphia obstetrieians, Hodge and Meigs, and, in 1855 , he returned to the charge in his monograph on "Puerperal Fever as a Private Pestilence," in which he reiterated his views and stated that one "Senderein" had lessened the mortality of puerperal fever by disinfecting the hands with chloride of lime and the nailbrush. This Senderein was

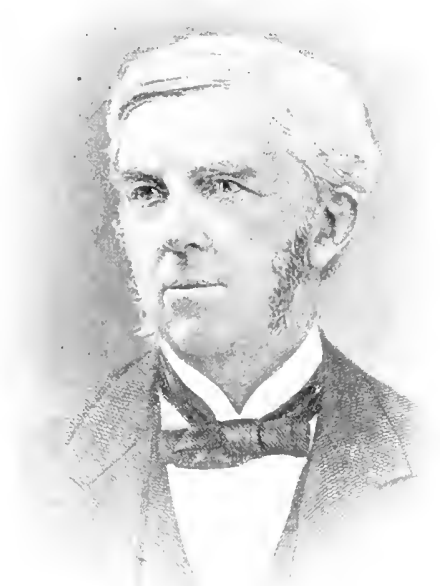

Oliver Wendell Holmes (1809-94).

\section{Ignaz Philipp Semmelweis}

(1818-65), a Hungarian pupil of Skoda's and Rokitankky's who, in 1846, had become an assistant in the first olstetric wall of the Allgemeines Krankenhalls in Viemna. This watrl had acquired such a high mortality in puerperal cases that women begged in tears not to be taken into it. Semmelweis hatd noticed that the first ward differed from the second (which had a lower mortality-rate) in that students came into it directly from the dissecting-room for instruction, often making vaginal examinations with inclean hands, while in the second ward, devoted to the instruction of midwives, much greater attention was paid to personal cleanliness. With this ider in mind, he also made a careful study of

${ }^{1}$ Holmes: N. Engl. Quart. Jour. Ned, and Surg., Bost., 1s+2-13, i, $503-530$. 
the antopsies in the fatal pmeperal cases. In 18.7, Kolletsehka,

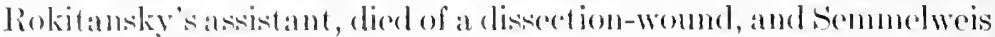
was present at the postmortem. As he stood beside the borly of his former instructor, he noticed that the pathohogieal appearances were the same as in the mufortmate puerperae of the first wated, and he now had his chan of evideneremplete. He immediately instituted such precantions in the handling of habor cases that the montality curve sank from 9.92 to 3.8 per ent. In the following year he had a mortality as low as 1.27 per cent., ame all through the simple expedient of washing the hands in a calcium chloricle solu-

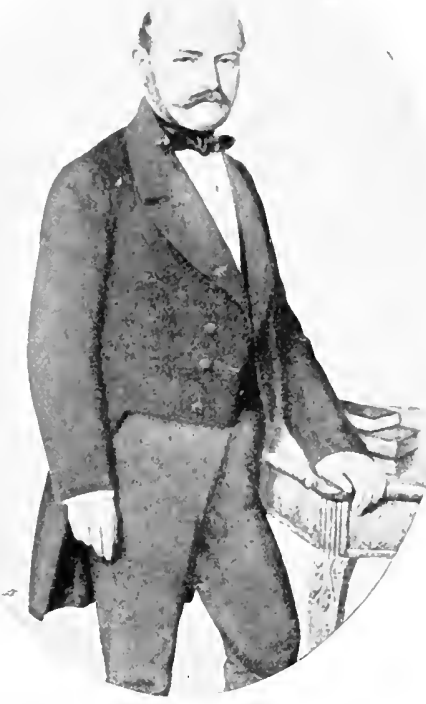

Ignaz Philipp Semmelweis (1818-65). tion in connection with pregnaney and the conduct of labor. Semmolweis is thus the true pioneer of antisepsis in obstetries, and while Holmes antrolated him in some details by five years, the superiority of his work over that of his predecessor lies not only in the stiff fight he put up for his icleas, but in the all-important fact that he recognized puerperal fever as a blood-poisoning or septicemia $\left(1847-49^{1}\right)$. Like Holmes, he met with fierce opposition, and while Rokitansky, Hebra, Michaelis, and, to his lasting honor, Skoda stood by him, he was persecuted by Scanzoni, Carl Braun, and the orthodox obstetricians of the day. Disgusted, he suddenly left Vienna for Budapest, where he became in due course professor of obstetries at the University (1855) and published his immortal treatise on "The Cause, Concept, and Prophylaxis of Puerperal Fever" $\left(1861^{2}\right)$, as well as his seathing "Open Letters to Sundry Professors of Obstetries" (1861). But his sensitive nature was not

1 Semmelweis' original communication is entitled "Höchst wichtige Erfahrungen über die Aetiologie der in Gebäranstalten epidemischen Puerperalfieber," Ztsehr. d. k. k. Gesellseh. d. Aerzte in Wien, 1S47-48, iv, pt. 2, $242 ; 1849, \mathrm{v}, 64$.

2Semmelweis: Die Aetiologie, der Begriff und die Prophylaxis des Kindbettfiebers, Budapest and Vienna, 1861. 
equal to the strain of violent controversy, and brooding over his wrongs brought on insanity and death. He is one of medicine's martyrs and, in the future, will be one of its far-shining names, for every child-bearing woman owes something to him.

Medicine is also indebted to the New Vienna School for the introduction of laryngoscopy and rhinoscopy.

The dentist's mouth mirror appears to have been long known and is mentioned by Celsus (lib. vii, eap. xif, 1) as "specillum." Various oral specula had also been employed, the most important being that deseribed by the obstetrician André Levret in 1743,1 and the "light conductor" of Philipp Bozzini (1773-1S09) of Mainz, in which the idea of illumination and reffection by mirrors was utilized $\left(180^{2}\right)$. On March 1s, $18299^{3}$ at rude "glottiscope" was exhibited to the Hunterian Soeiety of London by Benjamin Babington (17941866), of Guy's Hospital, and, in 1S37, the Scotch surgeon, Robert Liston, described his mode of exploring the larynx." These efforts passed unnotieri, however, and the modern laryngoseope eame to be invented by Minuel Garcia (1S05-1906), a Spanish singing teacher in London, who sent an account of his instrument to the Royial Socjety in 185.5. ${ }^{5}$ Three years later, his method of examining the throat was made a permanent part of laryngology by Johann Nepomuk Czermak (1S2S-73), of Bohemia, and his colleague, the Viennese neurologist, Ludwig Türck (1810-6s), both publishing their initial communications in the same year (Czermak, March 27, Tïrek, Jume 26, $\left.1858^{6}\right)$. Separate treatises on laryngosopy by the same witers appeared in 1S60, and, about the same time, Czermak devised a method of exploring the nose and nasopharynx by means of small mirrors $\left(1559-60^{7}\right)$. Türck wrote an important treatise on diseases of the larynx, with atlas $\left(1866^{8}\right)$, and was an able neurologist, his studies on the sonsible cutaneous areas of the separate spinal nerves (1856-68) being classic. He was also the first to note the correlation of retinal hemorrhage with tumors of the brain $\left(1853^{9}\right)$.

Other prominent members of the New Vienna School were Josef Hyrtl, the great anatomist, the physiologist Ernst von Brücke, the ophthalmologists Beer, Arlt, Stellwag von Carion, and Jaeger von Jaxtthal, Adam Politzer the otologist, the clinicians Bamberger, Winternitz, and Nothnagel, and the neurologists Meynert, Benedikt, and Ritter von Rittershain. Virehow was almost the only German spirit of his time who appreciated Bichat and Magen-

${ }^{1}$ Levret: Mercure de France, Paris, 1743, p. 2434.

${ }^{2}$ Bozzini: Der Liehtleiter, Weimar, 18()$\overline{7}$.

${ }^{3}$ Babington: London Med. Gaz., 1829, iii, 55.5.

${ }^{4}$ Liston: Practical Surgery, London, 1837, p. 350.

${ }^{5}$ Garcia: Proc. Roy. Soc., Lond., 1854-55, vii, 399-410.

${ }^{6}$ Czermak: Wien. med. Wochensehr., 185\$, viii, 196. Türck: Ztschr. d. k. k. Gesellsch. d. Aerzte zu Wien, 1858, xjv, 401; 1859, xv, 817. Czermak: Sitzungsb. d. k. Akad. d. Wissenseh. Math.-naturw. Cl., Vienna, 185s, xxix, 557-584. For a more detailed history of laryngoseopy, see the article of Louis Elsberg in Phila. Med. Times, 1873-4, iv, 129-134.

${ }^{7}$ Czermak: Wien. med. Wochenschr., 1S59, ix, 51S; 1860, x, 257.

${ }^{8}$ Türck: Klinik der Krankheiten des Kehlkopfes und der Luftröhre, Vienna, 1866 .

${ }^{9}$ Türck: Ztschr. d. k. k. Gesellsch. d. Aerzte zu Wien, 18533, ix, pt. 1, 214-218. 
die, Bright and Addison, and it was latgely due to the eminently practical tendeney of these phesiedans of the New Viemna sehool - most of them stass-that Cierman medicine finally arossed the laubion.

(One other prominent feature of (ieman medicine in the early part of the nineteonth contury has yet to be mentioned, namely, the rise of homeopathy, which, in point of time, is really one of the many isolated theoretic systems of the preceding contury. Its fombler, Samuel ("hristian Fredrich Habnemann (1755-1843), of Meissen, took his degree at Erlangen in 1779, and toward the cnd of the century, as the result of certain experiments, some of them made mon his own person, began to formulate those theories which characterize his system. These are, first, a revival of the old Paracelsian doctrine of signature, namely, that diseases or srmptoms of discases are curable by those particular drugs which produce similar pathologic effects upon the body (simitia similibus curantur); second, that the lymamic effect of drugs is heightened by giving them in infinitesimally small doses, which are to be obtained by carrying dilution or trituration to an extreme limit; third, the notion that most chronic diseases are only a manifestation of suppressed itch or "Psora." These doctrines were emhodied in his Organon der rationellen Heilliunde (1810), and found wide areeptance, especially in the New World.

The difference between Hahnemann and Paracelsus was, as Neuburger says, that Hahnemann directed his areana, not against the eauses of disease, but against simptoms or groups of symptoms. Honce his therapeutie method is not at true isotherapy, nor were the isopathic systems which followed it quite the same thing as treatment by sera, vaceines, bacterins, hormones, and inimal extracts. Anong the later off hoots of homeopathy was the system of Johamn Gottfried Rardemacher (1772-1Si50), in which pathologie processes and findings were ignored, diseases being diagnosed and classified as. "universal" or "organie," from the effect of remerlies upon then. The natural ehild of this sytem was the sehonl of "speeificists," which rejeeted the fantastic "universal remedies" of Pademacher for the rloetrine of the specific relation of eartain remedies to definite pills of the body. This system, which is strongly suggestive of Ehrlich, was favorably regarded by Virchow. It was but natural that this aimless theorizing should finally droindle and fade into a colorless, footless "eclectirism." The impotenee of erlepticism was sufficiently manifested in the floods of turgid verbovity and fustiun inspired by the cholera rpirlemie of 1S.31-37.2 Neuburger says that the masterpieces of Skorla and Rokitansky were greeted with frigid silence, "a silenee that speaks volumes."

The extreme popularity of Hahnemann's doctrines is probably due to the fact that they lessened the seale of dosage of drugs in practice. He was, in fact, the introducer of the small dlose. Other-

I The isopathy (arqualia arqualibus) of G. F. Müller, proposed the treatment of scabies by psorin, twnia by teniin, dental faries by odontonekrosin, phthisis by phthisin ( $i$. e. phthisical sputa, as originally proposed by Robert Flurd), liver diseases by hepatin, ete.

${ }^{2}$ Neuburger: Puschmann-Handbueh, Jena, 1903, ii, 125-129. 
wise his system is but an offshoot of eighteenth century theorizing. He died a millionaire in Paris in 1843.

Of the earlier American clinicians, those who dicl the most original work were Otto, the dackisons, North, the cleler Mitchell, Ware, Gicrhard, and Drake.

John ('onrad Otto (1774-1844), born at Woodbridge, New Jerser, of Ciemlan-American stock, took his medical degree at the University of Pennsylvania in 1796, succeeded Benjamin Rush at the Philadelphia Dispensary in 1813, and taught clinical medicine at the Pennsylvania Hospital for twenty-one years. He played an active part in the cholera epidemic of 1833 , and is especially remembered by his paper on hemophilia (is03ㄴ), an investigation of a family of "bleeders," which was the first account of the condition in literature.

James Jackson (17771868), of Boston, a pupil-apprentice of Edwald Augustus Holyoke (1797-8) and later a dresser at st. Thomas's hospital and a student of Astley Cooper's, was the first physician to the Massachusetts Cieneral Hospital (1810), wrote an early text-book on practice

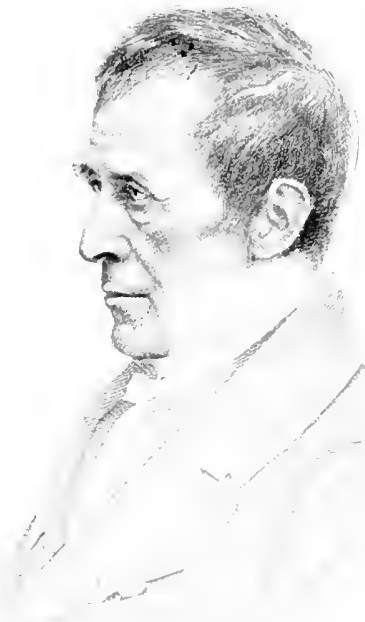

James Jackson (1777-1stis). (Boston Medical Library.) (1S25), and was widely read in

his attractive Letters to a Young Physician (1855). He left one of the earliest accomnts of alcoholic neuritis, which he described as "arthrodynia à potu" (1822\%), outlining the mental symptoms, and his report on typhoid fever $\left(183 \mathrm{~S}^{3}\right)$ played a great part in putting the disease upon a definite basis in this country.

Jackson's son, James Jackson, Jr. (1810-34), whose early death robbed American medicine of one of Louis' most promising pupils, left a valuable memoir on the cholera epidemic of 1832 and first described the prolonged expiratory sound as an important diagnostic sign of incipient phthisis $\left(1833^{4}\right)$.

1 J. C. Otto: Med. Repository, New York, 1803, vi, 1-4.

${ }^{2}$ J. Jackson: New Engl. Jour. Med. and Surg., Bost., 1\$22, ii, 3.5I.

${ }^{3}$ J. Jackson: Report founded on the cases of typhoid fever, Boston, 1838 .

${ }^{4}$ Communieated to the Société médieale d'observation de I'aris in 1833. 
Elisha North (1771-1843), of Goshen, Connecticut, was a pioneer in Jennerian vaceination $(1800)$, established the first eye infirmary in the United States at New London (1817), and, in 1811, published the first book on cerchrospinal meningitis ("spotted fever"), in which he recommends the use of the clinical thermometer. North's book was preceded by the graduating dissertation of Nathan Fitrong, Jr. (Hartford, 1S10).

John Kearsley Mitchell (1798-1858), of Virginia, was educated in Scotland, graduated from the University of Pennsylvania in 1819, and after making three sea voyages as a ship's surgeon, commeneed practice in Philadelphia, where he became eminent as an internist, neurologist,

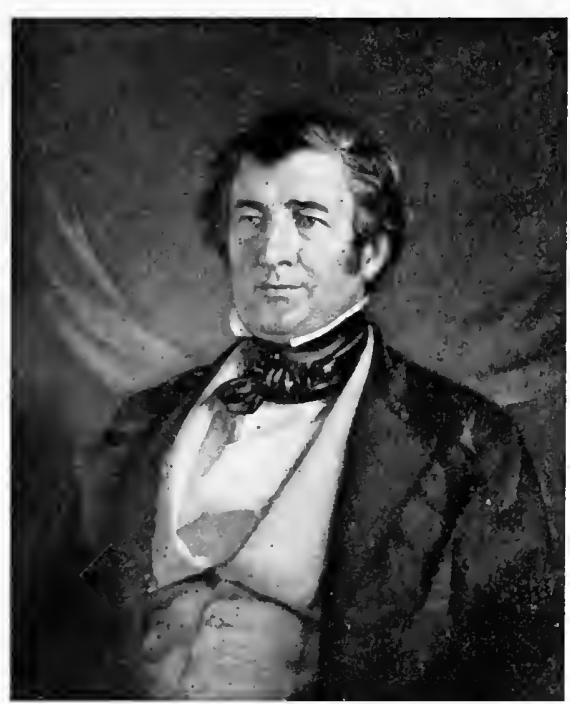

John Kearsley Mitchell (1798-1858). and teacher. The volume of monographs collected after his death by his distinguished son (1859') reveals an originality of mind far above the average, and, like the latter, he was talented in poetry and fiction as well. He wrote ably and suggestively on mesmerism, osmosis, liquefaction, and solidifieation of carbonic acid gas and ligature of limbs in spastic conditions, and he was the first to deseribe the neurotic spinal arthropathics $\left(1831^{2}\right)$, which have since been developed by Charcot, Bechtereff, Strümpell and Marie. His essay On the Cryptogamous Origin of Malarious and Epidemic Fevers (1S49) files the first brief for the parasitic etiology of disease on a priori grounds-a rigorous, logieal argument which, as pure theory goes, ranks with Henle's essay on miasms and contagia (1840).

John Ware (1795-1S64), of Hingham, Massachusetts, a Harvard graduate, who was professor of practice at Harvard from 1832 to 1858 , wrote an important monograph on eroup $\left(1842^{3}\right)$, and his 1859.

1 J. K. Mitehell: Five Essays, edited by S. Weir Mitchell, Philadelphia,

${ }^{2}$ Am. Jour. Med. Sc., Phila., 1831, viii, 55-64. 1842.

${ }^{3}$ Ware: "Contributions to the History and Diagnosis of Croup," Boston, 
exhaustive study of delirium tremens $\left(1831^{1}\right)$ is, in connection with the earlier paper of Thomas Sutton (1813), the classic account of this neurosis.

Jacob Bigelow (1787-1879), of Massachusetts, was one of the greatest of American botanists, the three volumes of his "American Medical Botany" (1817-20), illustrated with 60 plates and 6000 colored engravings, technieally devised by himself, being a work of international reputation, and, in Ameriea, approached only by the writings of Barton, Raffinesque, Porcher, and Asa Gray. Bigelow was visiting physician to the Massachusetts General Hospital, professor of materia mediea at Harvard, and a great medical reformer. During the cholera epidemie of 1832 his wise sanitary rulings limited the mortality in Boston to 100 , as against 3000 in New York City. His diseourse On Self-limited Diseases (1835) exerted a powerful influence upon medieal practice in the United States, and, in the words of Dr. Holmes, did "more than any other work or essay in our own language to reseue the practice of medicine from the slavery to the drugging system which was a part of the inheritance of the profession." In 1855 Bigelow published an anonymous volume of clever poetical travesties entitled "Eolopoesis."

William Wood Gerhard (1809-72), born in Philadelphia, of German extraction, was perhaps the most brilliant American pupil of Louis. He was resiclent physician to the Pennsylvania Hospital (1834-68), taught the institutes of medicine at the Cniversity of Pennsylvania (1838-72), and was much beloved in his native city for his geniality and kindliness. He investigated the endermic applieation of medicines (1830), deseribed (with Pennock) the cholera epidemic at Paris in 1832, and wrote interesting papers on smallpox $\left(1832^{2}\right)$ and pneumonia $\left(1834^{3}\right)$ in ehildren. His treatise on cliscases of the chest (1842) was the most authoritative American work on the subject before the time of Flint. He left two contributions of enduring value, his monograph on tubereulous meningit is in children $\left(1833^{4}\right)$, the first accurate clinical study of the disease, and his paper on differential diagnosis of typhus and typhoid fevers $\left(1837^{5}\right)$, which, in the United States at least, definitely settled the elinical and pathologic status of the two affeetions. Isolated observers, like Willis in $1643,{ }^{6}$ Huxham in $1737,{ }^{7}$

1 Ware: Med. Commmicat. Mass. Med. Soe., Bost., 1830-36, v, 136-194.

${ }^{2}$ Gerhard: Am. Jour. Med. Sc., Phila., 1832, xi, 368-40s.

${ }^{3}$ Ibid., 1834, xiv, 32s; $1 \$ 34-335, \mathrm{xv}, \mathrm{s}$.

${ }^{4}$ Gerhard: Am. Jour. Med. Sc., Phila., 1833, xiii, 313-359.

${ }^{5}$ Gerhard: Ibrid., 1837, xx, 289-322.

${ }^{6}$ Willis: De febribus, 16.59, ch. xiv, xvii.

${ }^{7}$ Huxham: Essay on Fevers, 175i). 


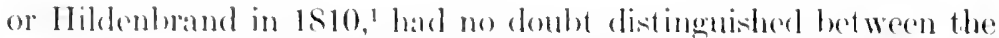
two disestese to their own sattisfartion; but the subject remained in a hazy state mutil the lime of (ierhasd, for even lomis' masterpiece of 1829 took no rognizander of typhus fover, and British pratetitioners, with the posible exeeption of $\mathrm{A}$. P. Stewart $\left(1840^{2}\right)$ or

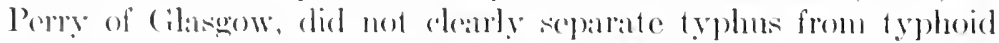
until sir William . Inner pointed the way in 1849. ${ }^{3}$

The ereatest physician of the West, and one of the most picturesclue figures in Americ:an medicine, was Daniel Drake (1785-1852), who was the first after Hippocrates and Sydenham to do much

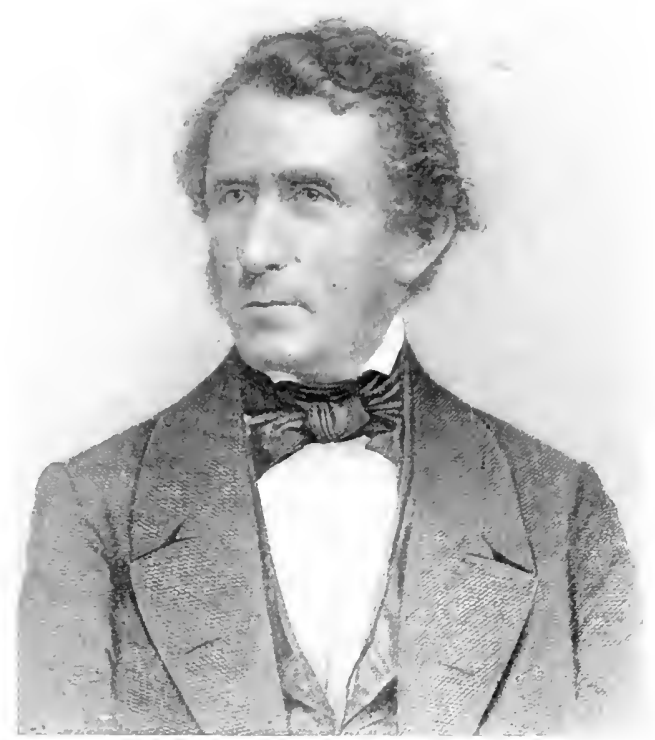

Daniel Drake (178.5-1852).

for medical geography, and has a unique position of his own in relation to the topography of disease. He was born in New Jersey in abject poverty, was reared in a log-cabin among the Kentucky pioneers, and the story of his struggles to gain an education, self-aided and single-handed, his rise to the height of his profession in the face of almost every obstacle, is a fine example of what honest ability can accomplish if persistent. A pupil of William

${ }^{1} \mathrm{~J} . \mathrm{V}$. von Hildenbrand: Ueber den ansteckenden Typhus, Vienna, 1810.

2 Stewart: Erlinb. Med. \& Surg. Jour., 1840, liv, 289-369.

${ }^{3}$ Sir WV. Jenner: Med.-Chir. Tr., Lond., 1849-50, xxxiii, 23-12. 
Goforth, the pioneer of Jennerian vaecination in the West, his diplonil, made ont in the latter's handwiting, was the first to be issued west of the Alleghanies. Although in practice, Drake did not complete his medical edueation until 1815 , when he received an academic degree at the University of Pennsylvania. He was one of Osler's "peripatetic physicians," constantly moving from place to place in aid of the eause of medical education, "ever at war with man" (for his nature was combative), and apparently dissatisfied with every condition he met. He changed his loeality as a teacher no less than seven times during his life, and two important medieal faculties, the Medical C'ollege of Ohio (1821) and the Medieal Department of Cineinmati College (1835), were founded by him. In the hatter venture he had as associates some of the best American teachers of his day, inchuding Samuel I). Gross and Willard Parker. Drake was atso the founder of the Western Journal of the Medical and Physical Sciences (1827-38), the most important medical periodical of the West in its time. It contains his celebrated essays on Medical Education, which were reprinted in 1832 , and are, far and away, the most important contributions ever made to the subject in this country. They are written in a style which, for clarity and beauty is, even to-day, a perfect model of what such writing should be. In 1841 Drake published one of the first accounts in hiterature on the local disorder known as "the trembles," or milk sickness." He also described epidemie cholera as it appeared in Cincinnati in 1832, and wrote a number of papers on the evils of city life (1831), mesmerism (1844), moral defects in medieal students (1847), and an entertaining posthumous work on Pioneer Life in Kentucliy (1870); but his erowning achievenent was the great work on the Diseases of the Interior V'alley of North America (1850-54), the result of thirty years' labor, based largely upon personal observation made during extensive travel. The first volume is a wonderful enevclopedia of the topography, hydrography, climate, and meteorology, plants and animals, population (including diet, habitat, and oecupations), of the Mississippi Valley. The seeond volume, not published until after his death, treats of the autummal malarial and other fevers, yellow fever, typhus fever, the exanthemata, and the unchassified "phlogistic fevers," in relation to topographic, meteorologic, and sociologie features. There was nothing like this book in literature, unless it might be Hippoerates on Airs, Waters, and Places, and even Hippocrates made no attempt to map out or triangulate the geographic locale of disease. In its practical intention I)rake's

${ }^{1}$ Early accounts were those of Thomas Barbee, in "Notices Concerning Cineinnat" (1809), and by Alexander Telford and Arthur Stewart in Med. Repository, N. Y., 1812, xv, 92-94. 
book bolongs in the class described hy Billings as distinctively and peculiarly Anerican, "in subject, mode of treatment, and stye of composition." When Alfeal stille reported upon it to the Ameri(an Medical Assodiation in 1850, Drake was greeted with proJonged and thunderous demonstrations of enthusiasm and applause, such as hatd soldom been aceorded to any physician before. "He covered his face with his hands and wopt like a child." In connection with Drake's masterpiece, two of his earlier pampindets should not be forgotten, for they are among the rarest of Amori(anil. The first, a pamphlet on the Climate and Diseases of C'incinnati (1810), was the germ of the greater work; the second, his Nerrative of the Rise and Fall of the Medical College of Ohio (1822), is one of the choicest bits of medical humor in existence. Drake, as described by (iross, was a tall, commanding figure, simple and dignified in manner. "He was always well dressed, and around his neck he had a long gohd watch-chain, which rested looscly upon his rest." As a lecturer he had a splendid voice, and was possessed of fiery eloquence, causing him at times to sway to and fro like a tree in a storm. He was gentle, fond of children, hating coarseness, and had a genume poetic side, writing very creditable verses. Yet, although he practically created decent medical teaching in (incinnati, he was subjected to many snubs and insults by snobs who affected to look down upon his origin and early chances. He assigned as a reason for not going to Europe that he did not wish to meet physicians who might phume themselves upon possessing greater advantages than himself, and said, with pathetic feeling, "I think too much of my country to place myself in so awkwarl a position."

Other prominent Ameriean physicians of the early period were George Baeon Woor (1797-1879) and Franklin Bache (1792-1864), of Philadelphia who collaborated in the huge "Dispensatory of the United States" (1833), which ran through 17 editions; Alonzo Clark (1807-87), of New York, who introduced the opium treatment of peritonitis (185.5\%); Elisha Bartlett (180455), of Rhode Island, John Y. Bassett (1805-81), Osler's "Alabama student," and samuel Henry Diekson (1798-1872), of South Carolina, a trio of elegant and attractive medical stylists and litterateurs; that belligerent Celt, Charles Caldwell (1772-1853), of North Carolina, who founded two medical schools in the West, and whose Autobiography (1855) is a remarkable diatribe, sureharged with venom and raneor; Robley Dunglison (179S-1S69), of Kes-

1 J. S. Billings, in "A Century of Amerifan Merdicine," Philadelphia, 1876, p. 314. Dr. Billings was the first to emphasize the importance of Drake in American medicine. The latter has since been made the subject of an elaborate and excellent biography by Dr. Otto Juettner of Cineinnati (Daniel Drake and his Followers, Cincinnati, Harvey Publ. Co., 1909), which gives a detailed account of Western medicine in the early days, and should be read by all who wish to understand the conditions of the time. 1855.

2 Clark: On the treatment of puerperal peritonitis by large doses of opium, 
wick, England, who eompiled an excellent medical dictionary (18:33) and wrote an amazing array of text-books on nearly every subject except surgery; David Hosack (1769-1835), in his day the best known practitioner in Niw Tork City, and editor of the American Medical and Philosophical Pingister (1S10-14), in which work he was assisted by John Wakefiedd Francis (17 1S61), a German-American physieian who eame to enjoy something of Hosack's popularity in New York, was an attractive teacher and writer and something of a medieal Macenas in the city; Nathaniel Chapman (1780-185\%), of Virginia, a prominent teacher of clinical nodicine at the University of Ponn-ylvania, who, in 1820, with Matthew Carey, founded the Philadelphia Joimal of the Medical and Physical Scicnecs, which, in 1S27, under the guidanco of Siac Hays (1796-1879), beeame the American Joumat of the Medical Scinces (Hays' Journal); Theodorie Romeyn Beck (1791-1S55), of New York, whose Elemerts of Medical Jurisprudence (1823) was easily the best American work on the subject in its day, rumning through 10 editions and many translations; and Isaac Ray (1807-51), of Beverly, Massachusetts, who wrote the first treatise on the medieal jurisprudence of insanity (1838), a solid, well-written book which is still of value.

Of isolated diseoveries in internal medicine in the first half of the nineteenth century, we may mention the original deseription of "kondee," or sleeping sickness, in the African travels of Thomas Winterbottom (1S031); the first accounts of cerebrospinal meningitis by Gaspard Vieusselu $(1746-$ 1S14) at Geneva $\left(1805^{2}\right)$, and by L. Damielsson and E. Mann at Medfied, Massachusetts $\left(1806^{3}\right)$; Charles Badham's little monograph on bronehitis. to which he gave the name (1S084); Allan Burns on endoeardit is $\left(1809^{5}\right)$; William Charles Wells on theumatism of the heart $\left(1812^{6}\right)$; Romberg's thesis on achondroplasia (18177); John Clarke's aceount of laryngismus stridulus and tetany in children (1S158); John Bostock on hay-fever (1S199); Louyer-Villermay's elassic paper on appendieitis $\left(1824^{10}\right)$; Kopp's deseription of "asthma thymicum" and "thymus-death" (183011); Lobstein's account of fragility of the bones, or osteopsathyrosis (18:3312), John Badham's elinical description of infantile paralysis (1835 $\left.5^{13}\right)$; Carl Arblph Basedow's important paper on exophthalmic goiter, giving the three elassic symptoms or "Mlerseburg trial" $\left(1840^{14}\right)$; Nohr' ease of tumor of the pituitary body with obesity $\left(1840^{15}\right)$;

I Winterbottom: An Aceount of the Native Africans, London, 1803 , vol. ii, pp. $29-31$.

2 Vieusseux: Jour. de méd., ehir., pharm., ete., Paris, 1805, xi, 163-182.

${ }^{3}$ Danielsson and Mann: Med. \& Agric. Register, Bost., 1806.

${ }^{4}$ Badlam: Observations on the Inflammatory Affections of the Mueous Membrane of the Bronehix, London, 1808.

${ }^{5}$ Burns: Observations on Some of the Most Frequent and Inumertant Diseases of the Heart, Edinburgh, 1809.

${ }^{6}$ Mells: Tr. Soc. Improve. Marl. \& Chir. Knowledge, 1s04-10, Lond., 1812, iii, 373-412.

7 M. II. Romberg: De rachitide eongenita, Berlin, 1817.

${ }^{8} \mathrm{~J}$. Clarke: Commentaries on some of the most important diseases of children, Lond., 1S15, pp. $86-97$.

${ }^{9}$ Bostock: Med.-Chir. Tr., Lond., 1\$19, x, 161-165.

${ }^{10}$ Lonyer-Villermay: Arch. gén. de mérl, Paris, 1824, v, $246-250$.

11.J. Kopp: Denkwïrdigkeiten in dor ärztliehen Praxis, Frankfurt a. M., $1830, \mathrm{i}, 1 ; 36 \mathrm{~S}$.

12 Lobstein: Traité de l'anat. path., Paris, 1833, ii, 204-212.

13 Badham: London Med. Giz., 1835-36, xvii, 215. First described by Michael Underwood (17S4).

${ }^{14}$ Basedow: Wehnschr. f. 1. ges. Heilk., Berl., 1840, vi, 197; 220.

${ }^{5}$ Mlohr: Wehnschr. f. d. ges. Ileilk., Berl., 1s40, vi, 56,5-571. 
Jakoh Heine's monorraph on infantik poliomyelitis (1s41) ; Ilonry Burton's

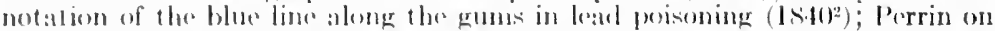

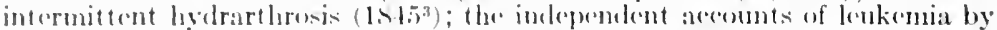
Virehow and John Hughes Bamett (1845); and ('urling's note of the eon-

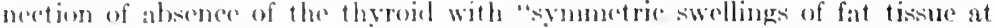
the sides of the neck rommened with defeetive eerebral development," or

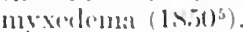

The neurologic discoweries of the period will be considered later.

The carliest nincteenth century exponent of anatomy and of scientifie medieine in France was Marie-François-Xavier Bichat $(1771-1802)$, the creator of descriptive anatomy. The son of a plysician, the farorite pupil, assistant, and houschold intimate of the surgeon Desault, and sometime an army surgeon in the French

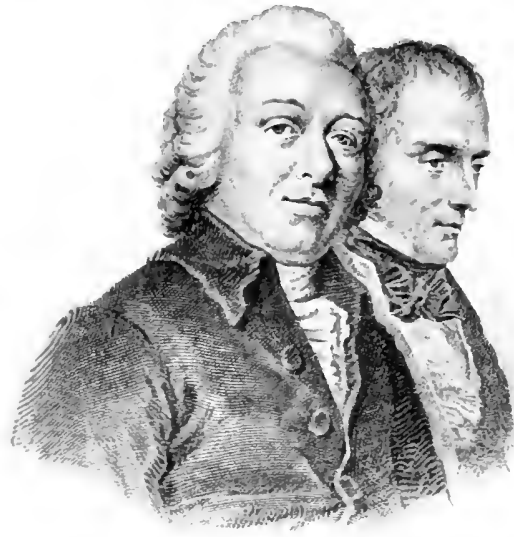

Desault (1744-95) and Bichat (1771-1802).

Revolution, Bichat soon developed from a lighthearted, rollicking, happy-go-lucky student into a successful surgeon and a master-worker in the science which sustained onc of its gravest losses by his early doath. His Traité des membranes (1799-1800), his five-volune Anatomie descriptive (1801-3), and his work on general anatomy applied to physiology and medicine (1802) opened out an entirely new field for anatomists, that of a detailed description of the parts and tissues of the body in health and disease. Before Bichat's time, such text-books as those of the Monros were woefully rudimentary in spots and said next to nothing about the detailed anatomy of the nerves and viscera; while teaching by dissection, as Robert Knox has recorded, was on the most rough-and-ready basis. Bichat was a forerunner of Henle and the histologists, dividing the tissues into 21 (non-microscopic)

'Heine: Beobachtungen über Lähmungszustände der untern Extremitäten und deren Behandlung, stuttgart, 1840.

${ }^{2}$ Burton: Med.-Chir. Tr., Lond., 1840, xxiii, 63-79.

${ }^{3}$ Perrin: Jour. de méd., Paris, 1845, ii. 82 . Union méd., Paris, 1878, 3, s. $\mathrm{xxy}, 821$.

"Virehow: "Weisses Blut," in Neue Notizen a. d. Geb. d. Nat. u. Heilk., Weimar, 1845, xxv, 151-155. Bennett: Edinb. Med. \& Surg. Jour., 1845, lxiv, 413-423.

${ }^{5}$ Curling: Med.-Chir. Tr., Lond., 1850, xxxiii, 303. 
varieties, which he treated as indivisible parts, like the elements in chemistry, each tissue having its own particular kind of sensibility and contractility (propriétés vitales). He was profoundly influenced by Bordeu, and, like Hunter, he regarded disease as an alteration of vital properties or principles. His error was to assign a specific vital property, a different mode of vitalism, to each tissue. This physiologic doctrine, now obsolete, is summed up in his famous and fallacious definition of life as "the sum of the forces that resist death," which, as has been often observed, ${ }^{2}$ is only a question-begging truism in the form of a reversible equation, in fact, a simple case of arguing in a circle.

In connection with Bichat's work may be mentioned the splendid atlas Anatomie de l'homme (Paris, 1821-31), by JulesGermain Cloquet (1790-1883), consisting of five volumes illustrated with 300 folio plates; and the diseovery of the third corpuscles or blood-platelets by Alexandre Donné (1801-78) in $1842 .^{3}$

Bichat's ideas were carried into pathology by Jean Cruveilhier (1791-1873), of Limoges, a pupil of Dupuytren's, who gave the first description (with plates) of disseminated sclerosis and left an early deseription of progressive muscular atrophy of the AranDuchenne type (Cruveilhier's palsy), but, like Hunter before him, was led to the erroneous deduetion that pyemia is the result of phlebitis, pushing his theory, indeed, to the extent of asserting that "Phlebitis dominates all pathology." Cruveilhier's atlases of pathology (1842) are among the most splendidly illustrated books on the subject. He did not use the microscope, and his errors were afterward corrected, as we shall see, by Virchow.

Sir Charles Bell (1774-1842), the leading British anatomist of the period, is now more celebrated as a physiologist and neurologist. The son of a Scotch Episcopal clergyman, he was a brother of John Bell, the well-known surgeon, who opened a private school of anatomy at Edinburgh in 1790. Both the Bells had an uncommon artistie gift, and Charles, in particular, illustrated his System of Dissections (1798), his Engravings of the Brain and

1 Bichat: Recherehes sur la vie et la mort, Paris, an viii $(1800)$, p. 1 .

${ }^{2}$ For example, in the inaugural dissertation of Dr. Abraham Jacobi (Cogitationes de vita rerum naturalium, Cologne, 1851, p. 24): "Prioribus iam temporibus Bichat alio morlo vitam definire conatus est. Vitam igitur qualitatum et actionum materix morte resistentium, eomplexum noninat. Sed hae num definitio est? num aliud est, quam cireulus? Statin interrogandum erit, quidnam sit mors, et quod solum respondere poteristis, id erit, mortem absentiam esse vita. Mors, constitut a notione vit $a$, vita negatione definienda est, non vice versa."

${ }^{3}$ Donné: Compt. rent. Acad. d. sc., Paris, 1842, xiv, 366-368. pl. 5 .

${ }^{4}$ Cruveilhier: Anatomie pathologique, Paris, 1835-42, ii, livraison xxxviii, 
Nerrous System (1802), and his Bridgewalde treatise on the hand (15:33) with expuisite sketches. Coming up to Isondon in 1804, he began traching anatomy in his own house and later at Great Windmill strect. He also lectured to artists, his "Anatomy of Expression" (1806) being the result of these studies. 'Through his ardent derotion to private investigation, he never acquired the practice he had hoped for in London, and eventually aceepted the chair of surgery at Edinburgh in 1836. In 1811, Bell published A Veu Idea of the Anatomy of the Brain and Nerrous. System, which contains the following sentence: "On laying bare the roots

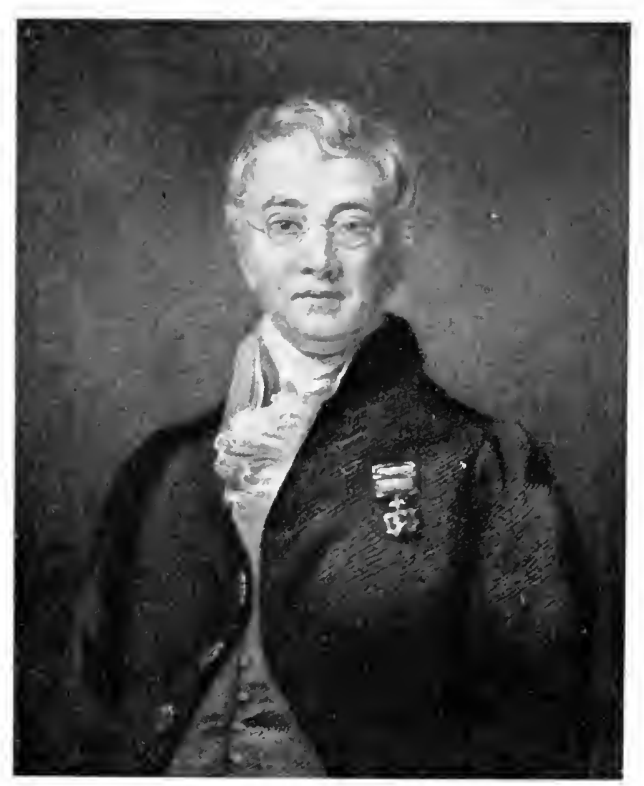

Sir Charles Bell (1774-1842).

of the spinal nerves, I found that I could cut across the posterior fasciculus of nerves which took its origin from the posterior portion of the spinal marrow without convulsing the muscles of the back, but that, on touching the anterior fasciculus with the point of the knife, the muscles of the back were inmediately convulsed." This is the first experimental reference to the functions of the spinal nerve-roots in literature, but Bell vitiated the effects of his discovery, to some extent, by holding fast to the old theory that all nerves are sensory, classifying them as "sensible and insensible," and, in reality, he demonstrated clearly the functions of the anterior roots only. An anatomist by training, his subsequent dis- 
coveries were all, in his own phrase, "deductions from anatomy," largely, no doubt, on account of his dislike of vivisection, and he failed to understand the true bearings of the experiment he had made or to interpret it correctly. The conclusive experimental proof that the anterior roots are motor, the posterior sensory, was made by Magendie upon a litter of eight puppies and published in $1822,{ }^{1}$ and confirmed by Johammes Müller in the frog in 1831.2 In 1826 Bell himself (in a letter of January 9th) had acquired a clear idea of the difference between sensory and motor nerves. In 1829 he demonstrated that the fifth cranial nerve is sensorymotor: discovered "Bell's nerve"; also the motor nerve of the face (portio dura of the seventh nerve), lesion of which causes facial paralysis (Bell's palsy). These discoveries are incorporated in his book on the nervous system (1830), which also contains early cases of pseudohypertrophic paralysis and "Thomsen's disease." Bell was a genial, unaffected, kind-hearted man, with a captivating twinkle behind his eye-glasses, a bit of a dandy in attire. He was much lionized during his London life, and in 1829 was knighted for his physiologic discoveries by the enthusiastic Lord Brougham. He was an able surgeon, and attended the wounded after Colunna and Waterloo, making interesting sketches of what he saw.

The ablest supporter of Bichat's ideas in Great Britain was the Scotch anatomist, Robert Knox (1791-1862), who was the first to teach general anatomy from the descriptive, histologic, and comparative angles, and attracted Edinburgh students in great numbers by his dramatic style of delivery and his showy appearance in the lecture-room. At this time, there were no public regulations to supply dissecting material for teaching purposes, and the needs of the large anatomy classes were met by surreptitious methods. Body-snatching and even murder were rife. On the twenty-ninth of November, 1827, the dead body of an old man who owed $\mathfrak{E}$ to his landlord, William Hare, was sold by Hare to Knox for $\mathfrak{E}$ 10s., to recoup the debt, and this stroke of business led Hare and his associate Burke to the idea of smothering their lodgers, or any other unfortunates who fell into their hands, as a money-making asset. The victim was first intoxicated, and then suffocated by closing the hands tightly over the nose and mouth ("Burking"). sixteen bodies were secured in this way and sold before the crime was detected, and the last body was found in Knox's rooms. All Edinburgh went wild on the instant, and Knox was mobbed by the horrified populace, vituperated by press and pulpit, and threatenod

1 Magendie: Jour. de physiol. expér., Paris, 1822, ii, 276-279.

${ }^{2}$ Müller: Froriep's Notiz a. d. Geb. d. Nat. u. ILeilk., Weimar, 1831, xxx, $113 ; 129$. The experiment was further confirmed in fish by Wagner (1846) and Stannius (1849), and in birds by Panizza (1834) and Schiff (1858). 
with hanging. The fact that "I)aft Jamie," a harmless imbecile of the "Old Town," and the vohuptuous figure of "a beantiful lats" had heon among those vietimized and dissected, added greater fuel to the flames. Knox, a man of powerful physique and self-possessed character, braved the clamor, made bold to outface his opponents, and eventually defended himself in writing, but he was never popular afterward; his only adherents were his faithful pupils, and he eventually lost his hold, leading a wandering existence until his death.' This sensational and entirely discreditable episode led at least to one good reform, Lord IVarburton's Anatomy Aet of 1832 (2d and 3d William IV, cap. 75), which provided that all unclaimed bodies should, under proper conditions, go to the medical sehools. Knox was an able and interesting writer on artistic anatomy and natural history, and his fragment on The Races of Man (1850), although full of eccentric views, is one of the most original and readable contributions ever made to anthropology. It was highly praised by Emerson.

An interesting work on artistic anatomy, which may be mentioned in connection with Knox, is the "Anatomical Studies of the Bones and Muscles for the Use of Artists" (London, 1883), which were engraved from the posthumous drawings of John Flaxman (1755-1836) by Henry Landseer.

The leading comparative anatomists of the early nineteentl century were Lamarck, Cuvier, Owen, and Agassiz. Of these, Jean-Baptiste Lamarck (1744-1829), who gave up soldiering for medieine, medicine for botany, and botany for zoölogy, once famous for his Natural History of Invertebrates (1815-22), is now best remembered by his Philosophie Zoölogique (1809). In this he appears as a great pioneer of evolution, in his theory that variations are produced by the effects of use and disuse upon organs, by response to external stimuli, and by the direct inheritance of these acquired characters. Like Galen and Hunter, Lamarck believed that structure follows function (La fonction fait l'organe), and although his theory of the heredity of acquired characters is now hotly contested, he is still regarded as one of the greatest of philosophic biologists.

Georges Cuvier (1769-1\$32), whom Lamarek helped and who afterward

${ }^{1}$ Of the odium whieh Knox incurred from the Burking incirlent. it may be said that, while he was technically guiltless, the aversion of his fellow-townsmen was not entirely without foundation, since they knew that the bodies of poor people were liable to be spirited away by "sham mourners" at funerals and other devices of the "Resurreetionists," while the showy, sensational methods of the lecturer himself were not strictly in accord with the best modern taste as to the dignity of medieal teaching. Dissection and vivisection, to be respectable and scientific, should always be private and under proper legal restrictions. Even the public dissections depieted on the title-pages of Vesalius and Columbus reek a little too much of the Barnum's show-bill for modern taste, and a blood-pressure experiment demonstrated on a vivisected animal to a public audience, hardly any of whom understand its bearings, can best be judged in the light of the "Law" of Hippocrates: "Those things which are sacred are to be imparted only to sacred persons; and it is not lawful to impart them to the profane until they have been initiated into the mysteries of the science." 
turned against him, who once overshadowed him, but is now regarded as his inferior, had, as Flomrens said, "l'esprit raste." His great works on eomparative anatomy (1801-05), on the fossil bones of Paris (1812), on the structure of fishes (1S2S), and on the animal kingdom (1836-49) are on the most extencled scale. He was the founder of vertebrate paleontology, first stated the theory of morpholegic types (vertebrate, molluscan, articulate, radiate), the doctrine of the structural correlation of parts of an organism, and the catastrophe theory of geologic formations. But he believed in spontancous generation, the fixity of species, and the preformation of the embryo.

Sir Richard Owen (1804-92), of Lancaster, England, a pupil of Abernethy's, and the associate and son-in-law of John Hunter's secretary, William Clift, edited Hunter's posthumous works, and began his studies in morphology with his great Catalogue of the Physiologieal Series of Comparative Anatomy (1833-10) in Hunter's collection. His Anatomy and Physiology of the I'crtebrates (1866-68) was pronounced by Flower to rank next to Cuvier's Comparative Anatomy in scope. In $1840-45$, he published the Odontography, a monumental treatise on the morphology of the teeth of living animals, illustrated with 150 plates. In paleontology, his monographs on British fossil mammals, birds, and reptiles (1846-84), extinct mammals of Australia (1877), and extinct wingless birds of New Zealand (1879), are of the highest importance. He described the Archaepteryx, the oldest known bird, the Apteryx, Notornis, and Dinornis, the latter elass including the dodo and the giant moa. He was also the first to deseribe the Trichina spiralis $\left(1835^{1}\right)$, but he classified the spermatozoa as internal parasites under "Entozoa." Owen was one of the early workers with the microscope in England, a founder and charter member of the Royal Microscopic Society, and an aceomplished violoncellist and chess-player. He

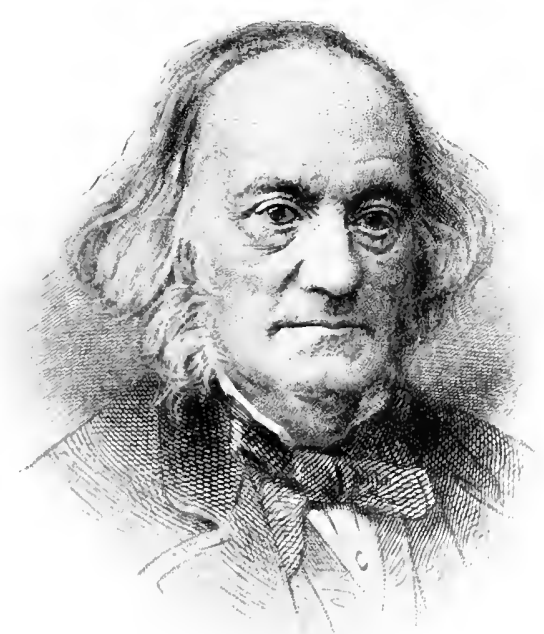

Sir Richard Owen (1804-92). was Hunterian professor at

the Royal College of Surgeons (1836-56), and suprerintendent of the Natural History Departinent of the British Museum (1856-83). In 1843 he introduced the well-known distinction between serial homologies (organs of similar structure and development) and morphologic analogies (different organs of similar function). He followed Goethe and Oken in upholding the vertebrate theory of the skull, ${ }^{2}$ and while admitting variation of speeies through an innate tendency to deviate from an ancestral arehetype, was an opponent of Darwinism, but being worsted by Huxley in two important controversies, he eventually went over to it. After Owen's death, Huxley wrote an appreciative study of his work.

Louis Agassiz (1807-73), of Mottier, Switzerland, settled in Cambridge,

1 Owen: Tr. Zoöl. Soc., Lond., 1835, i, 315-324. Śee, also, IIilton: London Med. Gaz., 1833 , xi, 605.

${ }^{2}$ Owen: On the Archetype and Homologies of the Vertebrate Skeleton, London, 1848. 
Mass, in 1sft, and his Contributions to the Natural History of the United states $(1857-62)$ is of esperall interest to Americans. Ilis Lowell Institute lectures on comparation embryology (1sili), followed by those of Jeffries Wy-

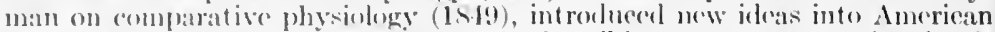

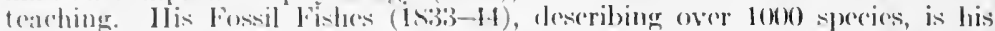
masterpiecer, althomgla his empririeal classification by scales is now discarded.

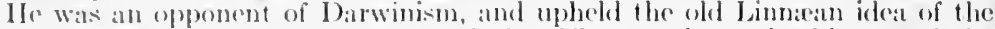
fixity of speries; also the Rerapitulation 'Theory, that "the history" of the individual is but the "pitomized hist ory of the race."

The pionecrs of American anatomy in the first half of the cenlury were Wistar, Horner, (iodman, and Morton.

Casper Wistar (1760-1818), born in Philadelphia of Cieman extraction, tamght anatomy at the Eniversity of Pemssyania from 1791-1S18, and his "System of Anatomy" (1S11-14), now forgotten, was the earliest

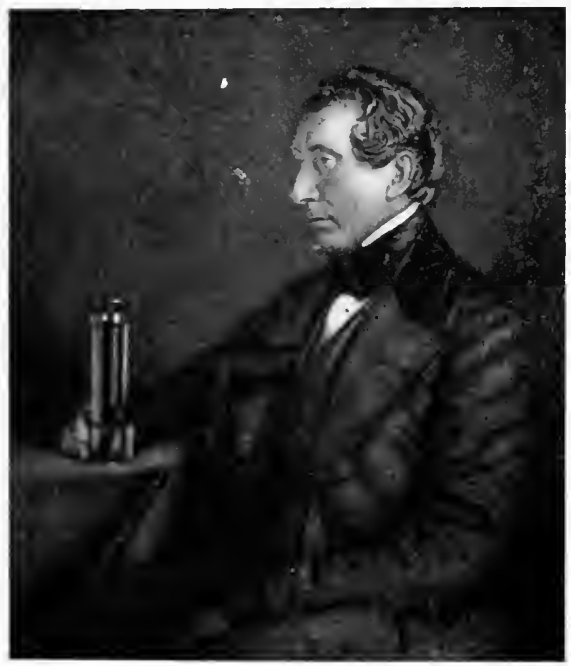

Willian Edmonds Horner (1793-1853). tieatise on the subject published in this country. His description of the ethmoid bone was praised by Soemmerring, and his memory survives in the wistaria vine, which was named after him; in the still popular "Wistar parties" of old time, weekly literary gatherings at which he was a cultured and amiable lost, and in the present Wistar Institute of Anatomy and Biology in Philadelphia (1892).

William Edmonds Horner (1793-1853), of Warrenton, Virginia, studied medicine at Edinburgh and Philadelphia, and after serving as army surgeon in the war of 1812 , settled in the latter city, where he became prosector to Wistar, Dorsey, and Phrsick, eventually succeeding the latter as professor of anatomy in the University of Pennsylvania in 1831, his successor being Joseph Leidy. Horner discovered the tensor tarsi muscle (Horner's muscle) supplying the lacrimal apparatus $\left(1824^{1}\right)$, and investigated the odoriferous axillary glands in the negro, the muscular tube of the rectum, and the membranes of the larymx. He performed and described important surgical operations, particularly on the eye, and published treatises on anatomy (1826) and

${ }^{1}$ Horner: Phila. Jour. Med. and Phys. Sc., 1824, viii, 70. 
pathology (1829). In $1834^{1}$ he published an important palper showing that the rice-water discharges in Asiatic cholera consist of epithelitum stripped from the small intestine.

John D. Godman (1794-1830), of Ammapolis, Maryland, an anatomist of great talent, could not realize what was in himself, because, as Gross puts it, "poverty literally pursued him from the cradle to the grave." Orphaned in infancy, friendless, cheated out of his inheritance by fraud, by turns a printer's apprentice and a sailor, he succeded in gaining a medical education through a noble perseverance, attracted the kindly notice of Daniel Drake, who gave him a chair in surgery, and became editor of the shortlived II estern Quarterly Reporter of Medical, Singical, and Natural Science (1822-23), the first medical journal to be printed west of the Alleghanies. His life was one of grinding toil, his lectures were popular, but never remmerative, and he was an carly victim of phthisis; but he produced three works of importance and originality-his treatise on the fascia (1824), his Contributions to Physiological and Pathological Anatomy (1S25), and his American Tatural History (1826).

Samuel George Morton (1799-1851), of Philadelphia, a graduate of the Eniversity of Edinburgh, published an elaborate trat ise on general and microscopic anatomy in 1849 , but he is now best remembered as craniologist, paleontologist, and phthisiographer. His Crania Americana (1839) and Crania Egyptiaca (1844) are fine atlases, among the earliest of their kind, of permanent value and reputation. His book on organic remains (1834) is said to be the starting-point of all systematic study of American fossils. His Illustrations of Pulmonary Consumption (18:34) is of great value as summing up the knowledge of his time. He believed that the races of mankind are of diverse origin, and his essay on hybridity (1S47) demonstrated the fertility of hybrids, both which views made him a target for controversial abuse and theological hatred.

Among the earlier American works on zoölogy and morphology are Thomas Say's ('rustace of the E'nited States (1817-18) and American Entomology (1824-28), Richard Harlan's Faune Americana (1825), ( iodman's work on Forth Ameriean mammals (1526). Audubon's Birds of America (1527), Isaac Lea's Fresh Water Mussels (1s29), Nuttall's (mnithology of the I'niled states and Canada (182:3-34), Holbrook's North Anerican IIerpetology (183640), De Kaly's Zoölogy of New York (1846-49), and Audubon and Bachmann's Quadrupeds of North America (1846-54).

In Germany, the development of anatomy and physiology went hand in hand, and the ablest of the carlier morphologists and histologists-Nï̈ller, Schleiden, Schwann, Henle, Remak-were also,

${ }^{1}$ Horner: Am. Jour. Med. Sc., Phila., 1834, xv, 545; 1835, xvi, 58; 277, 2 pl. 
in the best sense of the tem, physiologists. The founder of scientifie medieine in (iermany was, inderel, Johannes Müller (1801-58), of Cohlenz, who was also the greatest (icman physiologist of his time, and, like llaller amel John Hunter, one of the great all-round medical naturalists. Ho was equally ominent in biology, comparative morphology, physiologic (chemistry, psyohology, and pathology, and thromgh his best pupils-the histologists Schwam, Henle, Kölliker, and Vireluow, the physiologists I Du Bois Reymond, Helnholtz and briicke, most of whom followed the sane trend-we may trace the malin corrents of modem (iemann medicine. Mübler's

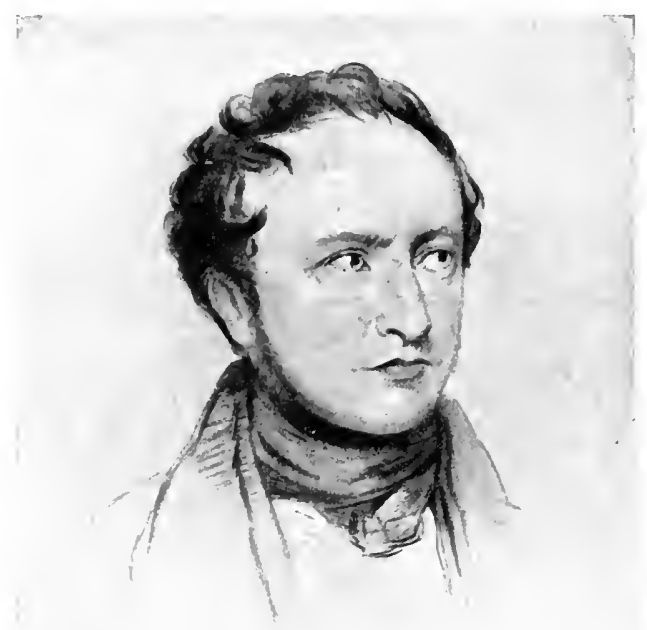

Johannes Müller (1801-58). (From a ehalk drawing in the Surgeon General's Libratry.)

Handbuch der Physiologie des Wenschen (1834-40) resembles Haller's great treatisc as a rich mine of novel facts and original ideas, and introluces two new elements into physiology - the comparative and the psychologic. His principal contributions to the science were his investigation of specific nerve energies $\left(1826^{1}\right)$, his explanation of the color sensations ("pressure-phosphenes") produced by pressure on the retina $\left(1826^{2}\right)$, his experimental proof

1 "Ceber die fantastischen Gesichtserscheinungen," Coblenz, 1826; and Zur vergleichenden Physiologie des Gesichtssinnes, Leipzig, 1826.

2 Zur vergleichenden Physiologie des Gesichtssinnes, p. 73. 
(in the frog) of the Bell-Magendie law of the spinal nerve-roots $\left(1831^{1}\right)$, his discovery of the lymph-hearts in the frog $\left(1832^{2}\right)$, his law of the eceentric projection of sensations from the peripheral sense organs to other nerve-terminals (18:33), his experiments on the vocal cords and the voice $\left(1835-57^{3}\right)$, his theory of color contrast $\left(1837^{4}\right)$, his isolation of chondrin and glutin $\left(1837^{5}\right)$, his demonstration of the function of the bristle cells of the internal ear $\left(1840^{6}\right)$, and his examination of the slimy secretions of the clubcells of the myxinoid fishes $\left(1845^{7}\right)$. His broadest generalization, the Law of Specific Nerve-energies, ${ }^{8}$ which mantains that each sense organ, when stimulated, gives rise to its own peculiar sensations and no other, has since been extended far beyond its author's original intention, in the idea that each nerve-fiber, as well as each organ or nerve, has its specific sensations, differing in degree if not in kind under stimulation. As a morphologist, Müller made investigations of the first rank on the structural relations of the myxinoid and ganoid fishes (1834-44), the Plagiostoma (with Jacob Henle in 1838-41), and the echinoderms (1846-52). In embryology, his name is associated with the discovery of the Müllerian duet $\left(1825^{\circ}\right)$. As a histologist, he worked out the whole finer anatomy of the glandukar and eartilaginous tissues $\left(1830^{10}\right)$, grouped the connective tissues, and thus cleared the ground for the cell theory of his pupil, Schwann. In pathology, as in histology, he was one of the first to use the microscope, particularly in his monmmental work on tumors $\left(1838^{11}\right)$, and he introduced the idea that fever is a nervous reflex (1840). In 1841 he described the parasitic disease now recognized as psorospermosis. ${ }^{12}$ In 1834 he founded the journal everywhere known as Müller's Archiv, which was contimued after his death by His, Reichert and Du Bois Reymond, and later by His and Waldeyer, Engelmamn and Rubner. As containing a host of classic contributions, it has exerted a profound influence upon the advaneement of seientific

${ }^{1}$ Notizen a. d. Gebiete d. Natur. u. Heilk., Weimar, 1831, xxx, 113; 129.

${ }^{2}$ Phil. Tr. Lond., 1833, pt. 1, 89-94.

${ }^{3}$ Handb. d. Physiol., Coblenz, 1840, ii, 184-222.

${ }^{4}$ Handb. d. Physiol., 1840, ii, 372.

${ }^{5}$ Ann. d. Pharm., Heidelb., 1837, xvi, 277-282.

${ }^{6}$ Handb. d. Physiol., 1840, ii.

'Untersuchungen über die Eingeweide der Fisehe, Berlin, 1845, p. 11.

${ }^{8}$ Handb. d. Physiol., 1840, ii, 258.

${ }^{9}$ Nova acta Acad. Nat. Curios., Bonn, 1825, pt. ii, 565-672, 6 pl.

${ }^{10}$ De glandularum secernentium struetura penitiori, Leipzig, 1830.

${ }^{11}$ Ueber den feinern Bau und die Formen der krankhaften Geschwülste, Berlin, 1838.

${ }^{12}$ Müller's Arch., Berl., 1841, 477-496, 1 pl. 
modicine. Like every great investigator who has approached his subject from the broadest angle, Müller made a fow mistakes. Following Hewson, Mascagni, and the Hunters, he maintaned that absorption is the special and exclusive function of the lymphat ies, although Mancudie, in 18:36, had shown that the blood-vesieds also possess this power. As late as 1840 he held that respiration in the fetus is effected not (as John Mayow had shown in 1674) by the placenta, but by a special juice or plasmat secreted in the materual blood. In 1840 Müllel stated that no one could rver hope to measule the velocity of a nervous impulse. Ten yeirs later his pupil, Helmholtz, had dome so. Temperamentally, he was a mystic, and, by the same token, a vitalist in theory. He believed that there is something in vital processes which does not admit of a mechanical or a

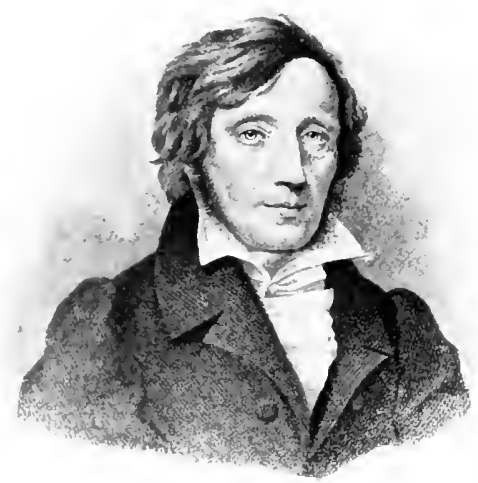

Carl Ernst von Baer (1792-1876). (From an engraving in the surgeon General's Library.)

After Müller's time, the main trend of German anatomy was along histologic and functional lines, and this new departure turned upon three important factors-the foundation of modern embryology by von Baer (1827-28), the improvement of the achromatic mieroscope by Joseph Jackson Lister in 1830, and the development of the eell theory by Schleiden and Sehwann (1838-39).

Carl Ernst von Baer (1792-1876), the father of the new embryology, was a native of Esthland, in the Baltic Sea provinces of Russia, and was successively professor at Dorpat, Königsberg, and St. Petersburg. The special service of von Baer was that, where his predecessors had only studied the chick, he made embryology a comparative science, established the modern theory of the germlayers, and the beginnings of histogenesis, organogenesis, and morphogenesis. 
Caspar Friedrich Wolff, in 1768, hat alleady been close upon the germlayer concept wher he saw that the intestines are produced by the folding in and rolling together of "leaf-like" embryonic layers. In $1817^{1}$ Christian Pander (1793-1865), assisted by von Baer, in his observations upon the chick, extended the number of these layers to three. Von Baer, in his great work on the development of animals (1528-342), showed, from comparative studies of all kinds, that these leaf-like layers are not true tissues of the developing organism, but the germs or germ-layers from which the alimentary canal, the nervouts system and its other parts are unfolded, disappearing as the latter are contpleted. He recognized four layers in all, from the fact that the millle layer is made of two sheets: but this double layer was afterward shown to be a singl. structure by Robert Remak, who first defined the three categories, ectoderm, endoderm, and mesoderm (1845).

The supreme merit of von Baer's work lies in the wonderful patience shown in working out, as Minot puts it, "almost as fully" as was possible at this time, the genesis of all the principal organs from the germ-layers, instinctively getting at the truth as only a great genius could have done." This was in the trying early dilys of the modern microscope, and the clear and beautifully accurate results obtained, from sections cut without the aid of a microtome, have set the pace for all subsequent work, down to the reeent phase of tracing the embryonic cell-lineage in minutest detail. Von Baer discovered the mammalian ovum in $1827,{ }^{3}$ and, at the same time, the ehorda dorsalis or notochord. From his exhaustive studies in comparative embryology, he was led to classify animal into four groups, viz., Vertebrata, Articulata, Mollusea, and Radiata, which makes him, with Cuvier, the founder of moderu morphology (Haeckel). Von Baer went to Russia in 1834, and devoted the rest of his life to investigating the physical geography and anthropology of that country. In coöperation with Rudolf Wagner, he was instrumental in calling together the first Congress of Anthropologists in 1861. He was of a deeply religious nature, and his autobiography, privately printed in 1864 , gives an interesting account of his experiences.

Contemporaneous with von Baer, was Wagner's discovery of the germiral spot (1835), Purkinje's characterization of the formative substance ("protoplasm") of the embryo (1839), Schwann on respiration in the embryonic: chick (1834), Reichert on the viseeral arches in vertebrata (1837), Bischoff on the development of the rabbit (1848) and the guinea-pig (1852); but the latterday embryology of von Kölliker, His, Haeckel, Balfour, Hertwig, and Minot is part and parcel of the doctrine of the nucleated cell.

The development of the cell-theory, one of the fundamental principles of modern science, was almost entirely the work of botanists. In the seventeenth century, Robert Hooke (1665), Mal-

1 Pander: Diss. sistens historiam netamorphoseos (quam ovum ineubatum prioribus quinque diebus subit, Würzburg, 1817.

${ }^{2}$ Ueber Entwickelungsgeschichte der Thiere, Königsberg, 182\$-34.

${ }^{3}$ De ovi mammalium et hominis genesi, Leipzig, 1827. 
pighi (1675), and Nehemiah Grew (1682) had noticed the cellular ravities in cork and green plants. In 1831 the cell-nucleds was discovered by the botanist Robert Brown (1773-1858), who also discovered the process of generation in plants by means of pollen. The cell nucloolus was discovered by Cabriel Valentin in 1836. The signifienne of the nucleus in vegetable histology was first emphasized by the Hamburer botanist, Matthias Jacob Schleiden (1S()4-81), who, after studying law and medicine, became professor of botany at Jena, Dorpat, and Frankfort on the Main. In his important paper on Phylogenesis (18381) Schleiden saw and proved that plant tissues are nude up of and developed from groups of colls, of which he recognized the nueleus (or

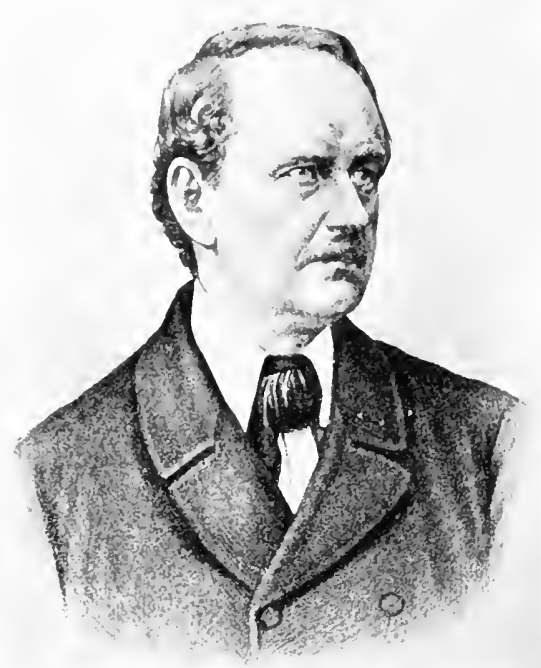

Matthias Jacob Schleiden (1804-81). "'ytoblast") as the important feature; but he held that young cells originate spontaneously from the $\mathrm{cy}^{-}$ toblast, which he thought to be encased in the solid cell wall. He regarded the young cell as resting upon and expanding over the eytoblast like a watch-crystal over a watch, an idea which became known as the "watch-glass theory" (Uhrglastheorie). Thus, he regarded cell reproduction as cndogenous (free internal formation) instead of by division, and the cell wall as a solid structure instead of a semipermeable membrane. But Schleiden was a true physiologie botanist withal, entertaining a lively contempt for the mere herbarium collector, and his Grundzüge $\left(1842-43^{2}\right)$ is perhaps the most important landmark in the modern history of the seience. He was keen at controversy and, lawyer-like, did not hesitate to indulge in personalities to put his adversaries in a corner. A friendly after-dinner conversation between Schleiden and Schwann, who in the meantime had discovered nueleated cells in the animal tissues, led the latter to look for cells in all the tissues he knew of and to formulate

1 “Beiträge zur Phytogenese," Müller's Arch., Berl., 1838, 137-176, 2 pl.

${ }^{2}$ Grundzüge der wissenschaftlichen Botanik, Leipzig, 1842-43. 
the most important generalization in the science of morphology, viz., the principle of structural similarity in animal and vegetable tissues: "There is one universal principle of development for the elementary parts of organisms, however different, and that principle is the formation of the cells." To Schleiden's concept of the cytoblast, Schwann added the "cytoblastema" or matrix of cell development, analogous to the mother liquor from which crystals spring. This, as Virchow pointed out, was a tacit acceptance of "spontaneous generation," the very thing which Schwann afterward did so much to overthrow.

Theodor Schwann (1810-82), born at Neuss near Diisseldorf, was a pupil of Müller's at Bonn and the latter's prosector at Berlin. After the publication of his classic on the cell theory in $1839,{ }^{1}$ he was called to the University of Louvain, and, in 1848, became professor of anatomy and physiology at Liège. A most careful and accurate investigator, he discovered the sheath of the axis-cylinder of nerves, which goes by his name $\left(1838^{2}\right)$, and the striped muscle in the upper part of the esophagus $\left(1837^{3}\right)$. His inaugural dissertation $\left(1834^{4}\right)$ showed that air is necessary for the devclopment of the embryo; and, applying the same idea to

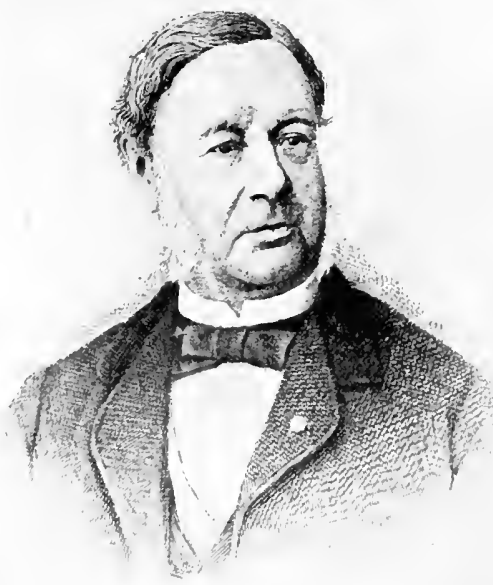

Theodor Sehwann (1810-82). the problem of spontaneous generation, he was able to prove, in 1836,5 that putrefaction is produced by living bodies, which are themselves destroyed if the surrounding air be heated or vitiated. In $1837,{ }^{6}$ about the same time as Cagniard Latom, he discovered the organic nature of

1 Mikroskopische Entersuchungen über die Tebereinstimmung in ler Struktur und dem Wachsthum der Thiere und Pftanzen, Berlin, 1839.

2 Froriep's Neue Notizen, Weimar, 1838, v, 228, and Schwann's book on the cell-theory.

3 Joh. Müller: Handbuch d. Physiologie, Coblenz, 1840, ii, 36.

${ }^{4}$ De necessitate aëris atmospharici ad evolutionem pulli in ovo incubato, Berlin, 1 s34.

${ }^{5}$ Ann. d. Physik u. Chemie, Leipz., 1S37, xli, 1S4-193. 9-1ร.

${ }^{6}$ Mitth. a. d. Verhandl. d. Gesellsch. naturf. Freunde zu Berlin, 1837, ii, 
reast, and showed that the yeast-plant eauses fermentation which atu be suppressed by heating the colture-medium and sterilizing the surromeling air by heat. As a physiologist, he discovered pepsin in 1835,', showing its power to change nondiftusible albumens into peptomes; and, in 1841,2 domonstrated, by means of an artificial biliary fistula in a dog, that bile is absolutely escential to digestion. He was the first to investigate the laws of muscular contraction by physical and mathematical methork, in his (lassic experiment, demonstrating that the tension of a contracting muscle varies with its length (18373). In personality, schwamn was an amiable, mopretentious nature, sonewhat below the middle height, with an open, pleasant, genial countenance, not unlike that of Claude Bernard. He is said to have visited Iondon twice without making himself known to any one. He was a devout (atholic, submitting the mamuscript of his work on the cell theory to the Bishop of Malines for approval before publication, but he did not hesitate to rleclase the Lonise Latean affair an arrant imposture. During the last forty years of his academic life be seems to have done little scientific work, and Profossor Ray Lankester records that "to sit with him in front of a "afe' in the pleasant streets of Louvain and hear him discourse on the progress of histology and the germ theory of disease" was "a pleasure no less startling than that which could be conferred by one risen from the clead."

Following upon the researches of Schleiden and Schwann, cells were discovered which had not a cell wall, but merely what physicists call a "surface of discontinuity" in relation to the surrounding medium; and it was found that the nucleus is contained, not in the cell wall, as Schleiden had supposed, but in the ground substance of the cell itself. From this time on, the nature and significance of this fundamental substance became the main object of investigation. In 1835, the French zoologist Felix Dujardin (1S01-60) had described and defined it in the protozoa as "sarcode."4 Schleiden, in his paper of 1838, had noted it in plants and regarded it as a gum. Purkinje was the first to employ the term "protoplasm," applying it to the germinal ground substance of the embryo (1839). In 1846-51, the botanist Hugo von Mohl (1805-72), of Stuttgart, described part of the contents of the vegetable cell (just under the cell-membrane) as "protoplasm,"5 and

1 Müller's Archiv, Berl., 1\$36, 90-114.

2 Ibid., 1844, 127-159.

${ }^{3}$ Described in Müller's "Physiologie," 1840, ii, 59-62.

${ }^{4}$ Dujarlin: Ann. d. sc. nat. (zoöl.), Paris, 1835, iv, 343-376.

${ }^{5}$ Von Mohl: Botan. Ztg., 1846, iv, 337; 353; 369; 385. 
the chemical nature of the same was investigated by a Swiss botanist, Carl Nägeli (1817-91) in 1862-63. ${ }^{1}$ Ferdinand Cohn (182898), of Breslau, eminent for his work in bacteriology, declired, after a study of the protococcus, that animal and vegetable protoplasm are analogous, if not identical, substances $\left(1850-53^{2}\right)$. Heinrich Anton de Bary (1831-88), a Frankfort botanist, showed this identity further in his work on the myxomycetes $\left(1859^{3}\right)$. In the meantime (1858), Virchow had already amnounced the continuity of cell development and its importance in pathology. Finally, Max Schultze, in $1861,{ }^{4}$ showed that the likeness between animal and vegetable protoplasm is not only structural and chemical, but also physiologic. Thus the cell gradually came to be recognized as the structural and physiological unit in all living organisms, whether animals or plants, simple or complex, embryonic or adult, healthy or diseased, while, in our own time, the cellnucleus is regarded as the chemical "center of oxidation" and the chromosome as the transmitter of inherited characters.

It was in this way that anatomic studies came to be more and more histologic or microscopie, and the "seats and eauses" of disease itself to be referred to the cellular elements in the body and the unicellular organisms attacking them.

The importance of the cell theory is immediately sensed in the work of Jacob Henle (1809-85), the greatest German histologist of his time and one of the greatest anatomists of all time. Born of Jewish parents at Fürth, near Nuremberg, Henle was one of Johannes Müller's favorite pupils, one of his prosectors at Berlin, and later professor of anatomy at Zürich (1810), Heidelberg (1814), and Göttingen (1852-85). Henle did many important things for medical science. In his classic researches of $1836-37^{5}$ he was the founder of modern knowledge of the epithelial tissues of the body. He first described the epithelia of the skin and intestines, defined columnar and ciliated epithelium, and pointed out that this tissue constitutes the true lining membrane of all free surfaces of the body and the inner lining of its tubes and cavities. In $1840^{6}$ he demonstrated the presence of smooth muscle in the middle or endothelial coat of the smaller arteries, a discovery which was the starting-

1 Nägedi: Sitzungsb. d. k. Jayrer. Akad. d. Wissensch., München, 1862, ii, $280 ; 1863, \mathrm{i}, 161,483 ; 1863 ;$ ii, 119 .

${ }^{2}$ Cohn: Zur Naturgesehichte des Protococeus pluvialis, Breslau, 1850, and Untersuchungen über die Entwieklungsgeschichte der mikroskopischen Algen und Pilzen, Bonn, 1853.

${ }^{3}$ de Bary: Die Mycetozoen, Leipzig, 18.59.

${ }^{4}$ Schultze: Müller's Arch., Berl., 1861, 1-27.

${ }^{5}$ Symbole ad anatomiam villorum intestinalium imprimis eorum epithelii et vasorum lacteorum, Berlin, $18: 37$.

"In his "Allgemeine Anatomie," Leipzig, 1841, pp. 510, 690. 
point of the present physiological theory of the vasomotor mechanism. Ho also discovered the axtermal sphincter (striated musce) of the bladder, the central chylons vessels, the intermal root-sheath of the lair, the Inenle tubutes in the kidney (1862') and gave the first accurate accomt of the histology of the cornea and of the morphology and development of the larymx. He first pointed out many important structures in the brain, notably the relations of the hippocampus, and the vestigial chatracter of the posterior bohe of the pituitary body. Altogether, the histological discoveries of Henle take rank with the anatomical discoveries of Vesalius. As a morphologist, he collaborated with Müller in his monograph on

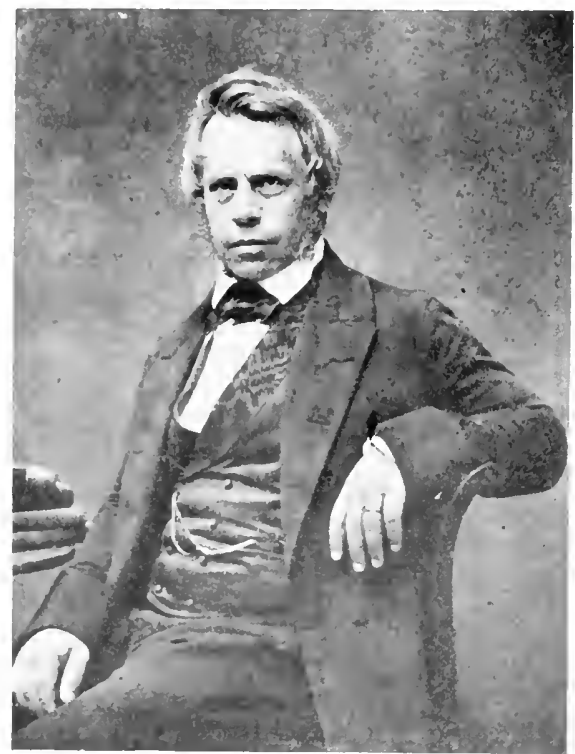

Jacob Henle (1809-85). the plagiostomes (183841), and described the electrice fish Narcine, and the annelid Enchytrieus. In pathology he was, with his friend Pfenfer, the founder of the celebrated Zeitsehrift für rationelle Medizin (1842 -69), which exerted a powerful influence upon the advancement of German medicine and contains some of the best monograplis of the period. His essay "On Miasms and Contagia" $\left(1840^{3}\right)$ contains the first clear statement of the idea of a contagium animatum. His essay on fevers ${ }^{4}$ elaborates Müller's idea that fever is only a symptom, occasioned by disturbances in the eentral nervons system. In his "Hand Book of Rational Pathology" (1846-535) he maintains that the physician's duty is to prevent and cure disease; that discase is a deviation from normal physiologic processes; death the cessation of metabolism; and the hypothesis of a vital foree, "just as good or as weak as that

${ }^{1}$ Contained in his "Handbuch der systematisschen Anatomie," 1862, ii, $300-305$.

2 These discoveries are to be found in Henle's two treatises on anatomy.

${ }^{3}$ In his "Pathologische Untersuchungen," Berlin, 1840, pp. 1-\$2.

${ }^{4}$ Ibid., $206-274$.

${ }^{5}$ Handbuch der rationellen Pathologie, Braunschweig, 1846-53. 
of electric attraction or gravitation." In practical medicine, he first connected the catarrhs and exanthemata with inflammation (1838), pointed out the preponderance of left-sided varicocele and the relation of left-sided intercostal neuralgias to the hemiazygos vein, and first showed the significance of urinary casts in renal disease (1844). Of Henle's two books on anatomy, the earlier Allgemeine Anatomie (1841) was, in reality, the first treatise upon microscopic histology, and marks a great advance upon Bichat in that the tissues are considered in their developmental and functional, as well as their structural, relations. The classification of the tissues is the simplest and best ever made, and the book contains an arlmirable history of microscopy and histology, as also some of Henle's most important discoveries. The later "Hand Book of Systematic Anatomy" (1866-71') is an exhaustive threevolume treatise of the highest scientific order. It contains the first logical account and nomenclature of the axes and planes of the body, the terminology is greatly simplified and the sections on the ligaments, the muscles, the viscera, and the vascular and nervous systems are of epoch-making importance. The illustrations of this work, made with Henle's own hand, are, as he puts it, architectural rather than diagrammatic, in that only so much of a structure is given in light and shade as is necessary for its comprehension, while the idea of plan and elevation is freely resorted to. As a lecturer, Henle was vivid and inspiring, making his own drawings with his crayon as he went along, and winning love and admiration by his sincerity and charm. He was not only a skilful artist, but something of a poet, and an accomplished musician, beginning with the violin and eventually learning to play both viola and violoncello, so that he might take any part at need in an impromptu string quartet. The experiences of his life, his peripatetic career as student and professor, the romantic circumstances of his first marriage, his friendships with such men as Humboldt, Gustav Magnus, and Felix Mendelssohn, make an interesting narrative.

Robert Remak (1815-65), of Posen, also of Jewish descent, was an assistant of Schönlein's at the Charité, and apart from his reputation as a microscopist, did a number of important things in other directions. In histology he is memorable for his discovery of the non-medullated nerve-fibers (fibers of Remak) in 1838, and of the ganglionic cells in the sinus venosus of the frog's heart

1 Handbuch der systematischen Anatomie des Menschen, Braunschweig. $1866-71$.

${ }^{2}$ Remak: Observationes anatomica et microscopica de systematis nervosi struetura, Berlin, 1838. 


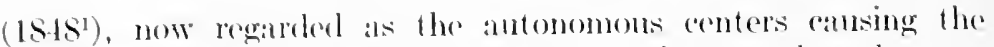
heart-luat. Ho was one of the first to point out that the proliferation of rells to form tissues is a acomplished by adl clivision (15.52: and not, as Schlodelen and schwamn had supposed, hy ondogenoms fomation. Ho simplified von Bacr's classification of the germ-layers, as we have seon $\left(1551^{3}\right)$. In 18t2, in schönlein's rlinic, he produced farms axperimentally, in propria persona, separating the fungus from the genus Öblim, and calling it Acho-

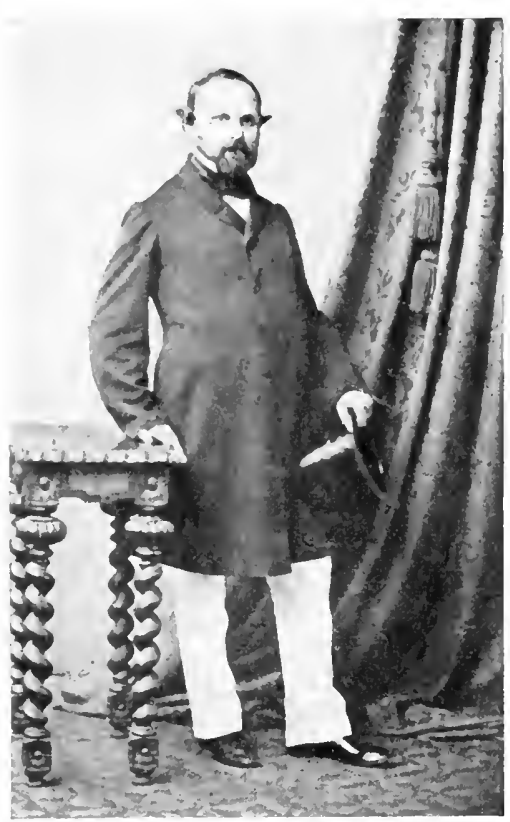

Robert Remak (1815-65). rion Schönleini, after the master $\left(1845^{-1}\right)$. He was the first to (lescribe ascending nemritis (1861), and he was, with Ad(lison and Duchenne of Boulogne, one of the pioneers of olectrotherapy, substituting the anlvanic for the induced current $\left(1856^{5}\right)$.

Another important pioneer in the use of the miscroseope was Johamnes Evangelista Purkinje (1787-1869), of Bohemia, who was also a physiologist of genius. He began life as a teacher, having previously taken orders, but graduated in medicine at Pragie in 1819, his inangural dissertation being an important work on subjective visual phenomena, ${ }^{6}$ which won for him the friendship and protection of Goethe. It was perhaps through Goethe's influence that Purkinje was appointed professor of physiology and pathology at the University of Breslau in 1823. At Breslau, he was at first coldly received, on account of the current prejudice against Slavs, which he soon lived down, winning every one over by his

1 Müller's Archiv, Berl., 1S48, 139.

I Ibid., 1852, 47-57.

${ }^{3}$ Untersuchungen über die Entwickelung des Wirbelthiereies, Berlin, 1851.

${ }^{4}$ Remak: Diagnostische und pathogenetische Untersuchungen, Berlin, 1845, pp. $196 ; 205 ; 208$. $155 \mathrm{~s}$.

${ }^{5}$ Remak: Galvanotherapie der Nerven- und Muskelkrankheiten, Berlin,

${ }^{6}$ Beiträge zur Kenntniss des Sehens in subjectiver Hinsicht, Prague, 1819. 
superior knowledge and urbane demeanor. Purkinje remained at Breskau until 1850, when he was ealled to the chair of physiology at Prague. During his Brestau period he did some important work for the development of German science which is frequently overlooked. He was the founder of laboratory training in connection with German university teaching. In 1824 he started a physiologic laborat ory in his own house, and the work done by the master and his pupils proved to be of such high character that the Prussian government finally erected a Physiological Institute for him at Breslau in 1842. As in the case of Carl Ludwig, many dissertations of Purkinje's pupils represent the ideas of the great physiologist himself.

As a microscopist, Purkinje was the first to use the microtome, Canada balsam, glacial acetic acid, potassium bichromate, and the Drummond lime light (1839). In 18251 he deseribel the germinal vesicle in the embryo, and he was the first histologist to employ the term protoplasm, which he applied to the embryonie ground substance in $1839 .^{2}$ He discovered the sudoriferous glands of the skin with their excretory ducts $\left(1 \times 33^{3}\right)$, the pear-shaped ganglionic (Purkinje) cells in the cerebellum $\left(1837^{4}\right)$, the lumen of the axis-cylinder of nerves, ${ }^{5}$ and the ganglionie bodies in the brain. ${ }^{6}$ In $1834-35$ he wrote

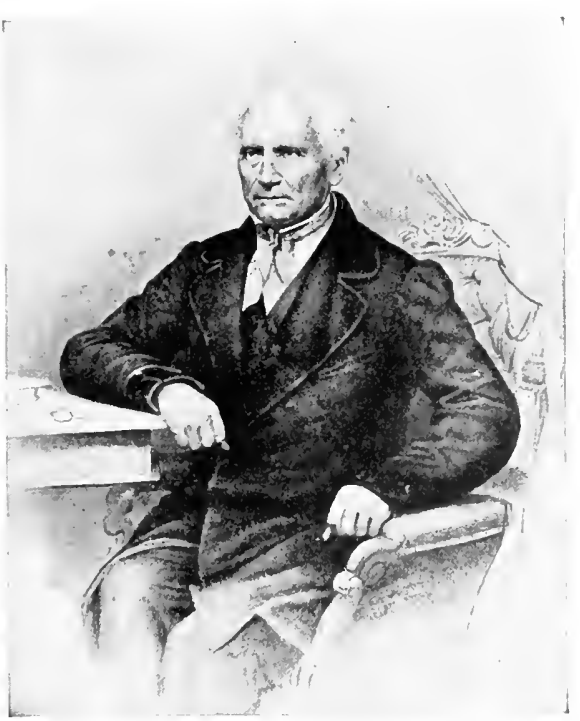

Johannes Evangelista Purkinje (17\&7-18699). (with Gabried Valentin ${ }^{7}$ ) his famous essay on ciliary epithelial motion; deseribed the "Purkinje fibers" of

1 Symbola ad ovi avium historiam ante inenbationem, Brestau, 1825.

2 Uebersieht d. Arb. u. Veränd. rl. sehles. Gesellseh. f. vaterl. Kultur, 1839, Brestau, 1840 , p. 82. Akso, De formatione granulosa in nervis aliisque partibus organismi animalis, student's dissertation by Joseph Roscnthal, Breslau, 1839.

3 In student's dissertation, "De epidermide humana," by Adolph Wendt, Breslau, $18: 33$.

${ }^{4}$ Ber. ü. d. Versamml. deutsch. Naturf. u. Aerzte, 1837, Prague, 1s3s, xy. 1so, plate, Fig. 1s.

${ }^{5}$ Ibirl., 177.

${ }^{6}$ Ibid., 17s-179.

7 Müller's Arch., Berl., 1834, 391-400. Alio "De phanomeno generali ef fundamentali motus vibratori continmi in membranis tum externis tum internis animalium plurimorum et superiorum et inferiorum ordinum obvii. Breslau, 1835. 


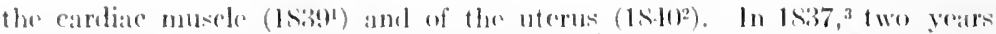

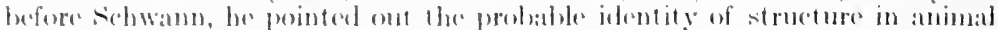
and plant colls amb ho also antolated the latter hy two yoas in his work on

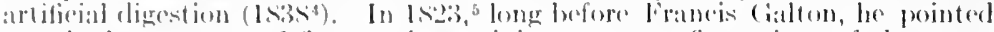
ont the importanes of fingerments, giving aremate figmations of the same, and he also moted that draf-multes ean hear threngh the bones of the skull. Ho was an inportant pionere in the description of most of the subjoctive vis-

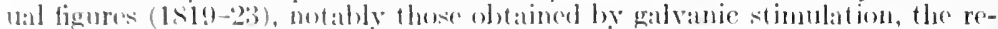

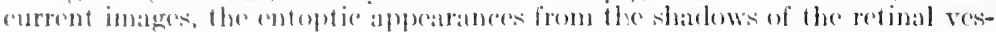
sals, the dependence of hrightness of color upon intensity of light, the choroidal figure, the rosettes of light produced hy the use of digitalis, and the poroliar radiations following the instillation of frelladomnat l'urkinjo was also the first formploy the topus "enchyma" for the basic substance of glands, "eambium" for the sime thing in plants, and "protoplasm" for the gromud substanec of

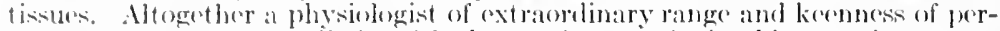
ecplion, he was further distinguished as a pharmacologist, his experiments on the action of eamplabr, opium, folladomna, stramonium, and turpentine having iren mato noon himself $\left(1529^{6}\right)$.

In relation to clinical medicine, Purkinje was the first to study the vertigo and rolling of the eyes produced by rotating the erect body in a vertical axis $\left(1820-25^{7}\right)$, and, although he did not conneet the phenomenon with the semieircular canals, his description is the starting-point of modern work on vestibular and cerebellar nystagmus.

After Henle's time, perhaps the most distinguished histologist of the early period was Albert von Kölliker (1817-1905), a Swiss who had heard Johannes Müller's lectures at Berlin, graduated at Heidelberg in 1842, and was Henle's prosector at Zürich in 1843. He became professor of anatomy at Zürich an 1846, and, the following year, received a call to Würzburg, where he remained for the rest of his active life. Kölliker was a follower of pure science and was equally remarkable in comparative embryology, histology, and morphology. In his monograph on the development of invertebrates $\left(1813^{4}\right)$ he was one of the first to apply Schwann's

${ }^{1}$ In student's discertation by Bogislaus Palicki: De musculari cordis struetura, Breslau, 1839.

2In student's dissertation by Wilhelm Kasper: De structura fibrosa uteri nongravirli, Breslau, 1840.

${ }^{3}$ Ber. d. Versamml. deutsch. Naturf. u. Acrzte, Prague, 1837, 175.

"Purkinje and Pappenheim: Ueber künstliche Verdauung, Müller's Arch., Berl., 183\&, 1-1.

${ }^{5}$ Commentatio de examine physiologico organi visus et systematis eutanei, Breslau, 1823. In this Purkinje describes the three entoptic images of a flame placed in front of the eye in a dark room.

${ }^{6}$ Neue Breslau. Sanml. a. d. Geb. d. Heilk., 1829, i, 423-444.

7 "Beiträge zur Kenntniss des Schwindels aus heautognostischen Daten," Med. Jahrb., Vienna, 1820, vi, 79-125, and Rust's Mag. f. d. ges. Heilk., Berl., 1825, xxiii, 284-310. See, also, the student's dissertation "De cerebri lasi ad motum voluntarium relatione, eertacue vertiginis direetione ex eertis cerebri regionibus læsis pendente," by Heinrich Carl Krause, Breslau, 1824.

${ }^{8}$ Müller's Arch., Berlin, 1843, 68-141. 
cell-theory to descriptive embryology, treating the ovum as a single cell and its segmentation as normal cell division only.

In 1847 he first demonstrated the true development of the spermatezoa, showing that they are not extraneous bodies, but originate in the testieular cells and fertilize the ovum. He was the author of the first work on eonparative embryology $\left(1861^{2}\right)$, which embodies his important study of the relation of the vertebrate notochord to the adult spine and skull. In histology, he was the first to isolate smooth musele $\left(1846-48^{3}\right)$, confirming Henle's discovery of the latter in the walls of blood-vessels; and he demonstrated the relation of the nerve-cell to medullated nerve-fiber (18s9-94). He also eonfirmed Sbarpey's theory of ossification and growth of bone $(1860)$ and Corti's discoveries on the finer anatomy of the ear. Kölliker's "Mieroscopic Anatomy" (1850-54t) and "Hand Book of Human Histology" (18525) were the first formal text-books on the subject and the fifth edition of the latter was so enlarged by an added weath of material as to be, in effect, a new book, the second volume literally creating the seience of the comparative histology of the eentral nervous system in vertebrated animals. Minot says that "he knew more by direct personal observation of the mieroseopic strueture of animals than any one else who has ever lived." In physiology, he applied Matteneci's "rheoscopic frog" effeet to the heart. (1855) and first investigated "veratrinized musele" (1856). In zoölogy, Kölliker's name will always be assoeiated with the Cephalopoda, the Coelenterata, the Gregarinidie, Rhodope, Aetinophrys, and other animals investigated by him. In 1849 he founded, with von Siebold, the "Zeitschrift für wissenschaftliche Zoologie," the leading German

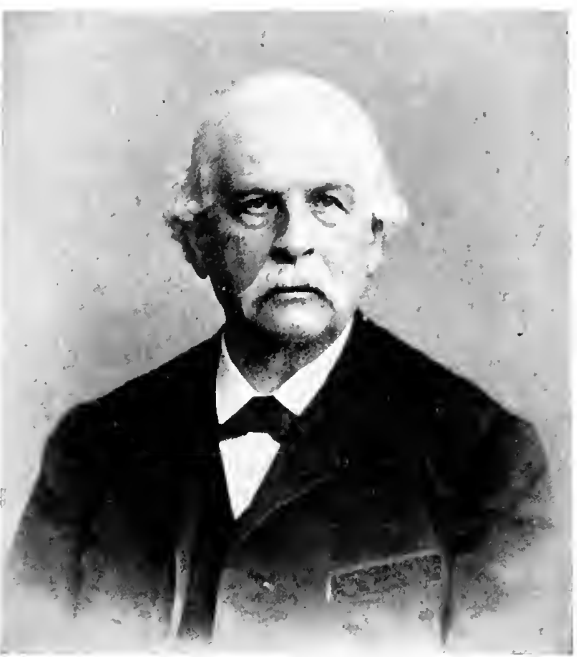

Albert von Kölliker (1817-1905). organ of the scienee, which ho edited for balf a century. Kölliker was not only unrivaled in his notations of fact, but was also an able theorist and in arlvanee of his time. Although ignorant of Mendel's work, he rejeeted the theory of natural seleetion in favor of saltattory or spontaneous variations (mutations); he regarded the eell nucleus as the transmitter of hereditary characters, and his theory of the mechanism of the male generative process $\left(186 i 3^{6}\right)$ was eonfirmed by Eekhard. In 1862 he rediscovered the branched muscle plates in the heart which Leeuwenhoek had seen two hundred years before. ${ }^{7}$

${ }^{1}$ Nene Denksehr. d. allg. sehweiz. Gosellsch. f. d. ges. Naturwissonseh., Zürich, 1847, viii.

${ }^{2}$ Entwicklungsgeschichte des Mensehen und der Thiere, Leipzig, 1861.

${ }^{3}$ Mittb. d. naturf. Gesellseh. in Zürieh, 1847, i, 18-2s, and Ztsehr. f. wissensch. Zoöl., Leipz., 184s, i, 4s-87, 4 pl.

${ }^{4}$ Mikroskopische Anatomie, Leipzig, 1850-54.

${ }^{5}$ Handbuch der Gewebelehre des Mensehen, Leipzig, 1852.

${ }^{6}$ Würzb. naturw, Ztsehr. (Sitzungsb., 1863), 1864, v, p. v.

${ }^{7}$ Proc. Roy. Soc., Lond., 1862-63, xii, 65-84. 
Presonally, von Kölliker Was a strong, grive, handsone, dignified figume, a reoteran of pure serence, whose prodigions industry was rewarded hy a patent of nobility from the Bavarian government and the Prussian order "pour le mirite." like his great predecessor, von Bater, he left an interesting atulobiography (1899).

The first and greatest teacher of toposraphic and regiomal anatomy in the nincteenth contury was Josef Hyrtl (1810-94), of the Now Vienna fohool, who was bom at Eisenstarlt, in Hungary. His father, a musician in Comnt Esterhay's band, had played an oboe under Haydn, and Hyrtl, himself a chorister in his youth,

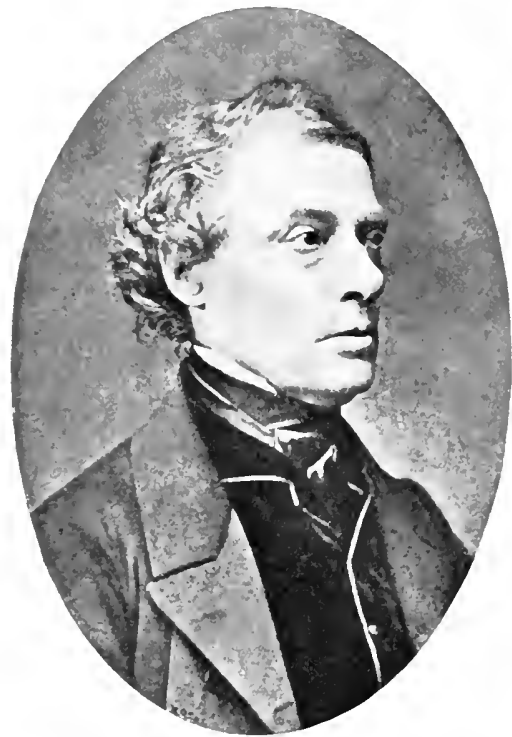

Josef Hyrtl (1810-94). (Courtesy of Captain Henry J. Nichols, I. S. Army.) character. Hyrtl did not go in for merging his seience into histology, like Henle, but kept up the straight Vesalian tradition of teaching gross or regional anatomy, and, for once, he suceceded, both as writer and lecturer, in making a dry subject piquant as well as interesting. Zuckerkandl said: "He spoke like Cicero and wrote like Heine." He made no great discoveries, and, as an independent investigator, he is not anywhere in Henle's elass, but is to be regarded rather as the mapproachable teacher and technician and one of the greatest of medical philologists, a man to whom written and spoken Latin were as his mother tongue. His famous Lehrbuch (1846) passed through twenty-two editions, was 
translated into most languages, and has been pronounced by von Bardeleben to be the least soporific of all scientific treatises. Before reaching its twenticth edition (1889), it had no illustrations, the deficiency being largely supplied by Hyrtl's clear, beantiful, straightforward style, closing immediately with the subject in hand, and his wealth of historie and cultural allusions. Following the example of the French surgeons, Hyrtl published, in 1847, the first topographic anatomy in the German language, which, despite its lack of illustrations, is doubly fascinating by reason of the same extraordinary display of historic and philologic knowledge. Hyrtl's manual of dissecting, published in 1860, is a classic of the same rank with Virchow's book on postmortem sections, and his Corrosions-Anatomie (1873) is a permanent memento of his unique skill in making anatomic preparations. These, the wonder and admiration of Europe, included his unrivaled collection of fish skeletons, all prepared by himself; his models of the human and vertebrate ear; his microseopic slides and the corroded preparations (his own invention), consisting of injections of the blood-supplies of the different organs and regions, with the adjacent parts eaten away by acids, to show the finest ramifieations. His favorite fields of investigation were, in fact, the vascular and osscous systems. He discovered the portal vein of the suprarenal capsules, the branchial veins of fishes, the origin of the coronary arteries (1854), and made a collection of hearts devoid of blood-supply (gefäslose Herzen). Everything he did was stamped with originality and self-will. He once had the Laokoön represented as a life-sized skeletal group in support of his belief that bodily grace and poise depend, in the last analysis, upon bony structure. He opposed Brieke's theory of the autonomy of the heart with such harsh personalities that there came to be a Hyrt faction and a Bräcke faction in Vienna. Hyrtl had known the bitterness of poverty in his youth, but when he came into his own, and he was accomted wealthy as physicians go, his charity and humanity knew no bounds. Generous to a fault with his money, he endowed churches, orphanages, miversitics, with the same innate kindliness and liberality which prompted him to cheer his students at their work by his engaging presence and witty sallies. Nothing delighted him more than to lavish praise upon the work of a younger man, and in this unique regard he is like Müller and Ludwig, Virchow and Pasteur, those incomparable teachers of youth. Having filled his chair for thirty years, he resigned it voluntarily in 1874, in order to escape the (to him) humiliating experience of being pensioned off at seventy, retiring to a hermit-

${ }^{1}$ Hyrtl: Handbuch der topographischen Anatomie, Vienna, 1847. 


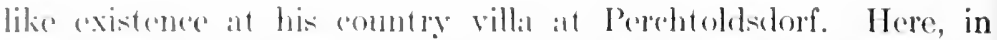
the socedety of his enentle, poetic wife, he produced his three mas-

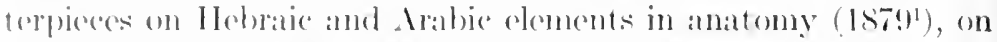

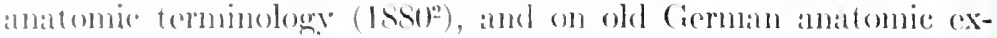

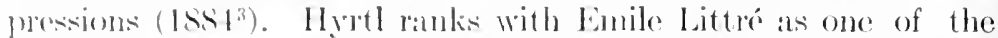
eroutest of modern medical seholats, and these hooks show him at his best in a fiold which was his veryom. Ilis dochining years were choded by a phase of pessimism that belied his rhecerful, kindly nature.t

The gromp of investigators just considered includes a munhrer of nen who, under the influence of those great morphologists, John Hunter and Iolammes Mïller, approached physiologic problesns larely from the point of view of structure. Müller and his pupil shwann employed both physical and chemical procedures in (xperimentation, but, after Mïller's time, physiologic investigation proceeded along 1 wo broadly divergent lines. The physieal school, which aimed at murely mechanical modes of experimentation and interpretation, includes such names ats Flourens, Poisenille. Marshall Hall, the brothers Weber, Brücke, Carl Iudwig, du Bois Reymond, and Helmholtz. The chemical school, the followers of Liebig and Wöhler, was represented by Schwann, Peamont, Tiedemann, Gmelin, Pettenkofer, and attained its highest development in the epoch-making work of Claude Bernard and Pasterur.

The pioneel of experimental physiology in France was François Magendie (1783-1855), of Borleaux, who, like Müller, employed hoth physical and chemical procedure in his investigations, and was incidentally the modern founder of experimental pharmacology. Lnlike Bichat, Magendie had not the slightest use for vitalistic or other theories, but regarded medicine as "a science in the making" (une science a faire) and songht to explain everything in terms of physics and chemistry. Pathology he was fain to regard as "the physiology of the sick man." Physiology he sought to advance by closer revision of the facts. He compared himself to a rag-picker (chiffonier), who wanders through the domain of science collecting whatever he finds. This expressive phrase sums up the hard limitations which Magendie put upon himself or which existed in his own mind. He discovered only isolated facts, did not try to conneet them with one another by any special hy-

${ }^{1}$ Hyrtl: Das Arabische und Hebräische in der Anatomie, Vienna, 1879.

2 Onomatologia anatomiea, Vienna, 1860.

${ }^{3}$ Die alten deutschen Kunstworte der Anatomie, Vienna, $18 s 4$.

"See, "Fin Brsuch bei Hyrtl," in Wien. med. Woehensehr., 1894, xliv, 1406. Contrast this with the jolly discourse of 1880 (Las Culebras) in Allg. Wien. med. Ztg., $1880, \mathrm{xxv}, 521$. 
potheses, and so arrived at no important generalizations. As the ardent protagonist of experimentation on living animals he is, of course, the particular aversion of the anti-vivisectionists, and there is no doubt that many of his experiments were without aim and necdlessly cruel. But, before his time, physiology was made up of what Claude Bernard called rêteries systematiques, and it is the special distinction of Magendie to have headed the recent line of illustrious laboratory experimenters from Bernard himself to Parloff, Loeb, and Ehrlich. Magendie was the founder of the first

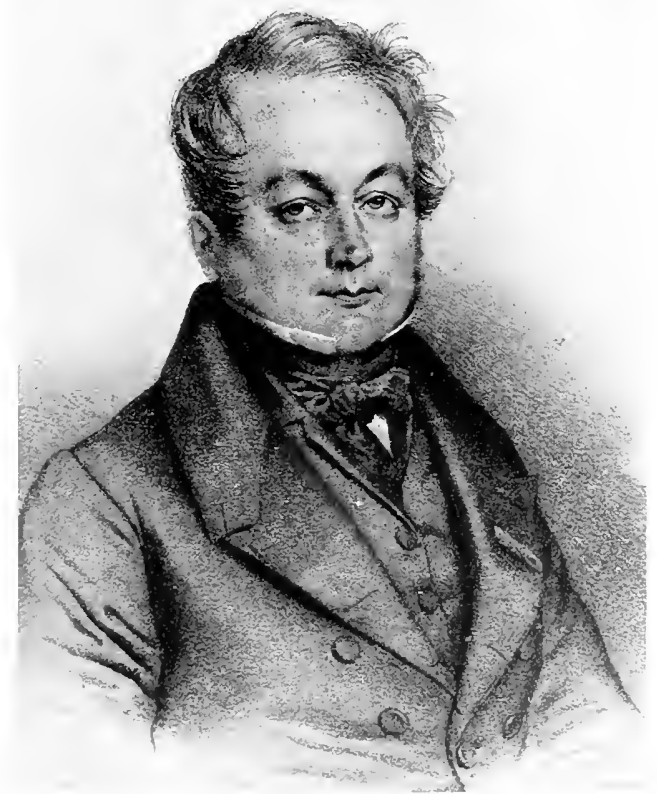

François Magendie (1783-185i5).

periodical devoted exchusively to physiology, the Journal de physiologie expérimentale (Paris, 1821-31).

His greatest contribution to the seience was his experimental proof (on a litter of puppies) of the truth of Bell's law, that the anterion roots of the spinal nerves are motor, the posterior sensory, in function (1522). Through his bold vivisecting and lueid reasoning he arrived at at much elearer conception of these functions than Bell; and, in adjusting the two claims, it seems proper to assign to Betl priority of discovery and demonstration in reference to the anterior roots, to Magendic priority of conclusive flemonstration and interpretation of the functions of both motor and sensory roots. Magendie also made important investigations of the mechanism of deghtition and

${ }^{1}$ Magendie: Jour. de physiol. expér., Paris, 1852, ii, 276-279. 
voniting (1s1:3); of the effects of exeision or section of the eerebellum $\left(15^{2} 25^{2}\right)$, and of the "circus meremente" (monuerment de menege) obtained by lesion of the optic thalamus. Ife demenstrated that the pumping power of the heart is the main e'atuse of the blowh-flow in the veins, that ehemieal dilferenees between the bloed and the lymph will cause osmosis through the vessel walls,

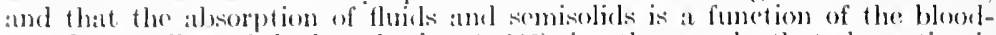
risscels ats well as of the lymphaties $\left(1821^{3}\right)$; in other words, that alsorption is not a specific vital property of the lymphaties, but only imbihition by vaseutar tissues. With Poisenille, he was one of the first to moties that arterial hlowelpresiure rises with expiration, and his experiments on the eireulation clemon-trated the absurdity of the ancient idea of "points of election" in bloorlletting, sinere the effects of venesection are the same at any site.

Magendie's investigations in pharmacology int roduced bromine, iodine compounds, and such alkaloids as strychnine (showing its antion on the spinal cord in paralysis), morphine, veratrine, brucine, piperine, and cmotine into medical practice (18214). In experimental pathology, he induced Gaspard to repeat Haller's experiment of injecting putrid matter into the veins $\left(1822^{5}\right)$. His proof that secondary or subsequent injections of egg-albumen cause doath in rabbits tolerant to an initial injection was the first experiment in anaphylaxis or supersensitization of the tissues $\left(18.39^{6}\right)$, a phenomenon which Edward Jenner had already observed in variolous inoculations in 1798 .

The most important French physiologists between Magendie and ('laude Bermard are Legallois, Flourens, and Poiseuille.

Julien-Jean-C'ésar Legallois (1770-1814), a Breton who took part in the French Revolution, was some time in hiding for his political affiliations, and, after studying at the Ecole de santé, rereived his medical degree in 1801. He was one of the earliest of the experimental physiologists, and his procedure was cruder and more brutal than Magendie's.

He marle such experiments as investigating the effect of submersion upon newly born animals or the temperature relations of brainless animals subjected to artificial respiration. In $1812^{7}$ he showed that bilateral section of the vagus nerve may produce fatal bronchopneumonia, and he greatly extended the observation of Robert Whyt $(\mathbf{1 7 5 0 )}$ that absolute integrity of the spinal cord is not neeessary for the maintenance of the reflex functions. ${ }^{8}$ His discovery that a lesion of a small ciremmscribed area of the medulla inhibits breathing $\left(1811^{9}\right)$ was the first attempt to localize the center of respiration and was afterward completed by the work of Flourens. Legallois is principally remembered today by his Expériences sur le principe de la vie (1S12), in which

1 Mémoire sur le vomissement, Paris, 1813.

2 Jour. de physiol. expér., Paris, $1825, \mathrm{v}, 399$.

${ }^{3}$ Ibid., 1S21, i, 1-31.

${ }^{4}$ Formulaire (etc.), Paris, 1821.

5 Jour. de physiol. expér., Paris, 1822, ii, 1-45; 1824, iv, 1-69.

"In his "Lectures on the Blood," Phila., 1839, 244-249.

${ }^{7}$ Legallois: Expérienees sur le principe de la vie, Paris, 1812.

8 (Euvres, Paris, 1830, i, p. 135.

${ }^{9}$ Ibid., j, p. 248 . Expériences (etc.), Paris, 1S12, p. 37. 
he was the first, after Borelli, to revive the neurogenie theory of the heart's action. He maintained that the motor power of the heart is a principle or fores contained throughout the spinal eord, and transmitted to the heart by the branches of the sympathetic nerve. This was soon shown to be erroneous, but the neurogenic theory was further fortified by Robert Remak's diseovery of intrinsie nerve-ganglia in the heart (1S44), and held its own until the revival of the myogenie theory by Gaskell and Engelmann.

Marie-Jean-Pierre Flourens (1794-1867) is memorable as the discoverer of the nœud vital, or "vital node," the bilateral center of respiration in the medulla oblongata, a lesion of which causes asphyxia $\left(1837^{\mathrm{I}}\right)$. Although the exact situation and extent of this vital spot have been in dispute down to the present time, the crucial feature of Flourens' experiment has never been set aside.

In $1822-24^{2}$ he made his classic observations on the effeets of removal of the cerebrum and cerebellum in pigeons, showing the absolute maintenance of reflexes with loss of ecrebration and volition in the former case and the disturbanee of equilibrium in the latter. These important experiments demonstrated that the brain is the organ of thought and of will power, while the cerebellum presides over the coördination of bodily movements, although Flourens denied the possibility of any cortical loealization of funetions. In $1828^{3}$ Flonrens announced that a lesion of the semicireular eanals in the internal ear will eause motor ineoördination and loss of equilibrium, seetion of an individual canal produeing rotatory motion around an axis at right angles to the plane of cleavage. From the analogy of these phenomena

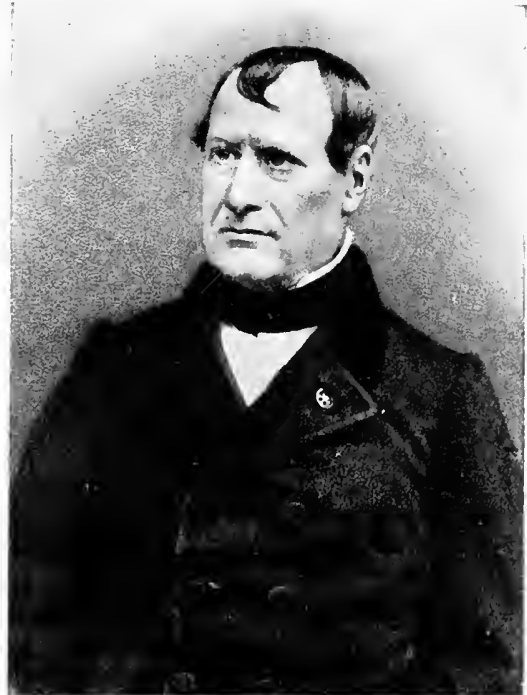

Marie-Jean-Pierre Flourens (1794-1867). with the effects of a deep lesion in the eerebellum, Flourens inferred that both organs have to do with coörlination of movement. Thus, where Purkinje had described only a presumable visual nystagmus, Flourens loeated the existenee of a true erebellar and labyrinthine vertigo. His results were eonfirmed physiologically by Vulpian, Goltz, Cyon, Ferrier; on the elinical side by Ménière; and have been ably elucidated, both surgically and elinically, by Robert Bárány as "vestibular nystagmus."

Jean-Léonard-Marie Poiseuille (1799-1869), of Paris, a medical graduate of 1828, was the first experimenter between Stephen

${ }^{1}$ Recherches expérimentales, Paris, 2, éd., 1s42, p. 204. Compt.-rend. Iead. d. sc., Paris, 1858, xlvii, 803; 1859, xlviii, 1136.

${ }^{2}$ Arch. gén. de niél., Paris, 1823, ii, 344, 351; 1825, viii, 422-426; and Recherches expérimentales, Paris, 1824.

${ }^{3}$ Mém. Aead. d. sc., Paris, 1828, ix, 45j-477. 
Halls and Card Iondwig to make any real advande in the physiology of the dirculation. Ilis name is permanently associated with the study of blood-pursine and the viscosity of the blood.

Starting from Hades's original bleol-pressure experiment of 1733, Poisewille improver upon it by sulstituting a mereury manometer for the inconvenient long tube, connection with the artery beang established by means of a hollow lead tip filled with potassium carbonate to prevent coagulation. This wats peisenille's hemolynamometer (182\$1), with which he showed that the bleod-presisure rises and falls on expiration and inspiration, and measured the dearee of arterial dilatation (about of of the nomal) at each heart-beat. To this instrument Carl Luclwig, in 1847,2 adeded a float, and, ats Professor Stirling silys, "had the genius to caluse this float to write on a recording cylinder, and thus at one eoup gave us the kymograph, or wave-writer, and the applieation of the graphic methol to physiology." With these improvements, the seienee of hlood-presure (hemodynamies) became a definite part of recent medicine. Poisenille's other great contribution to physiology was an investigation in mathematifal physies, namely, on the flow and ontflow of linguids in caprillary tubes $\left(1 \$ 40^{3}\right)$. Ile found that the average volocity of capillary flow varies directly with the seetional area of the tube, the grarde of pressure, and the visesity or stickiness of the moving fluid; also that the quantity of outflow is inverwe as the length of the tube and directly proportional to the fourth power of its diameter, the pressure gradient, and the viscosity coeflicient $\left(Q=\frac{D^{4} P^{\prime}}{L}\right)$, whenee, for unit length, diameter, and pressure, the viscosity coefficient can be computed from the following formula: $V=\frac{\mathrm{QL}}{\mathrm{D}^{4} \mathrm{P}}$.

This important equation is the mathematical expression of "Poisenille's law," which, in recent times, has become fundamental in estimating the viscosity of the blood. The instrument used for the purpose (viseosimeter) was also invented by Poisenille, and his name now stands, with those of Harvey, Hales, and Lurlwig, as one of the founders of hemodynamies.

In applying the methods of laboratory physics to physiologic problens remarkable work was done by the brothers Weber, of Wittenberg. Of these, Ernst Heinrich Weber (1795-1878) was professor of anatomy and physiology at Leipzig (1821-66) up to the time of Carl Ludwig's advent, and afterward held the chair of anatomy there until 1871, when he was suceeeled by Wilhelm His. He made an event in medical history by his discovery of the inhibitory power of the vagus nerve in $1845,{ }^{4}$ a find which threw

1 This instrument in described in Poiseuille's graduating dissertation: "Rerherches sur la force du cour aortique," Paris, 182s.

2 Lulwig: Areh. f. Anat., Physiol. u. wissensch. Med., Berl., 1847, 261.

${ }^{3}$ Poiseuille: Compt. rend. Acall. rl. sc., Paris, 1840, xi, 961; 1041; 1841, xii, 12;1 1843 , xvi, 60.

${ }_{4}^{4}$ The discovery was communicated by the Webers to the Congress of Italian freientists at Naples in 1 s.5 ("Experimenta quibus probata nervos vagos rotatione machina galvano-manguetica irritatos, motum cordis retardare et adeo intereipere," in Omodri's Ann. univ. de med., Milan, 1845, 3 s., xx, 227 ). It was afterward published at length in Wagner's Handwörterbuch der Physologie, 1846 , iii, $45-51$. 
much light upon such problems as the motion of the heart, the nature of fever, and the like. His original experiment, made with his brother, Eduard Friedrich Weber (1806-71), consisted in bringing the heart to a standstill by placing one pole of an electromagnetic apparatus in the nostril of a frog, the other on a cross-section of the cord at the level of the fourth vertebra. The field of inhibition was then localized to a region between the optic lobes and the calamus scriptorius, the vagi were found to be the channels of communication, and the results were extended to warm-blooded animals. Although the Webers at first thought that stimulation

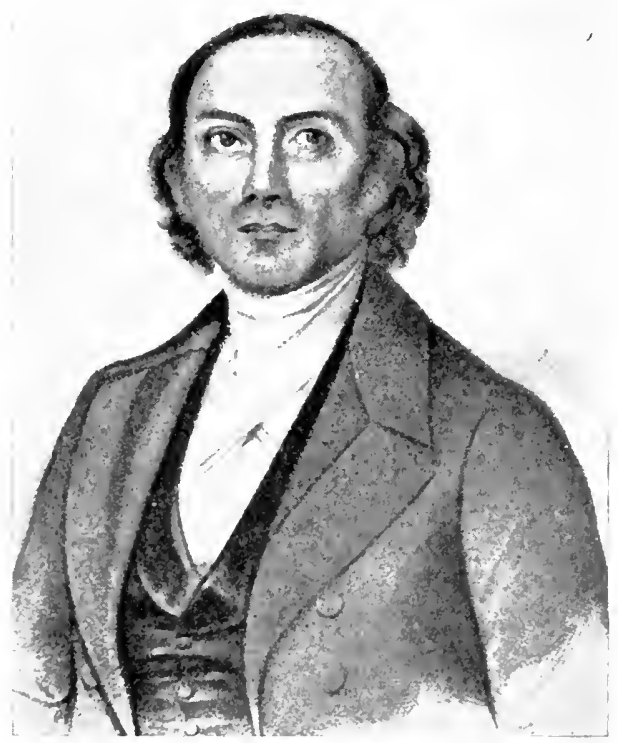

Ernst Heinrich Weber (1795-187S).

of both vagi was necessary for inhibition, and although Ludwig and Schmiedeberg afterward showed that the vagus contains accelerator as woll as inhibitory fibers (1870-71), the original proof remains unshaken as one of the great monuments of physiologic discovery. Ernst Heinrich Weber and Eduart Friedrich Weber also collaborated in the famous Hellenlehre or Hydrodynamies of Wave-Motion (1825), in which the velocity of the pulse-wave was measured for the first time and it was shown that it is delayed $\frac{1}{6}$ " to $\frac{1}{7}^{\prime \prime}$ in transmission, thus overthrowing Bichat's theory that the pulse is synchronous in all the arteries. In 18.37 these two 
Hothers again did rever work together in measuring and comparing the velocity of the hlood and lymph eorpuseles in the capil-

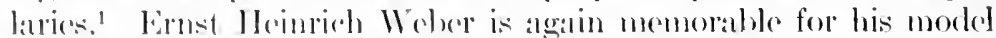
to illustrate the hydrolynamies of the aireulation $\left(18.50^{2}\right)$, but the eoping-stone of his single aldhevement is moloulotedly his great work on loneh and tomperature somse (Der Tastsinn und das Gemeingrähl, 1st(i), which was the stating-point of the experimental psorhophysies of Foehner and Wundt. Johannes Müllor, while assigning to ateh sonse organ its proper, paticular functions, did not admit the existence of any "common sensation" (such as pain or malaise) apart from the sonse of touch. Weber was the first to show that this common sonsation can be analyzed into its viscelal and muscular components, and these separated from the tactile sensations. He boldly alpplied the idlea of measurement to such phomomena as sonsations of pain, heat, pressure, smell; noted that the threshold of painful sensation is also the threshold of nerve-injury, and stated the generalization known as Weber's law, viz., that intensity of sensation is not directly proportional to the degree of stimulus, but depends upon its mode of applieation. A given stimulus is less pereeptible when added to a larger stimulus than fo a smaller one; in other words, when the sensation increases in arithmetic progression, the stimulus must vary by geometric progression. Fechner afterwarl expresed this idea by saying that intensity of sensation varies with the logarithm of the stimulus (Weber-Fechner law), since the curve produced is a logarithmic curve.

A third brother of the Weber family was the celebrated electrician, Wilhelm Eduard Weber (1804-91), who was professor of physics at (iöttingen all his active life (1831-91), constructed the first electromagnetic telegraph in 1833, made an atlas of the earth's magnetism (1840), and further distinguished himself by his important work in electric measurements. He collaborated with Eduard Friedrich Weber in the well-known classic on the mechanics of the human locomotor system (Mechanik der menschlichen Gehuerkzeuge, 1836), the most important study of the time on the physiology of motion and locomotion and the mechanism of the joints.

A remarkable all-round physiologist and anatomist was Ernst Wilhelm von Brücke (1819-92), of Berlin, who, in 1849, became professor of physiology at Vienna, where he was associated with the New Vienna School for the rest of his life.

1 Müller's Arch., Berl., 1837, 267-272. 186.

2 Ber. ü. d. Verhandl. d. k. sächs. Gesellsch. d. Wissensch., Leipz., 1850, 
His investigation covered all branches of the subject, including the luminosity of the eye in animals (1845), phoneties (1856-62), the semilunar valves (1555), and artistie anatomy (1892), the latter one of the most at tractive books ever written on the subject. He was the first to hold that normal urine may contain sugar (1858), and he introduced the emulsion test for fatty acid (1870).

The leading English exponent of physical experimentation in the early period was Marshall Hall (1790-1857), of Nottingham, whose Royal Society memoir on The Reflex Function of the Medulla Oblongata and Medulla Spinalis (1833 ${ }^{1}$ ) established the difference between volitional action and unconscious reflexes.

The idea that peripheral impulses can be reflected outwardly from the nerve cen-

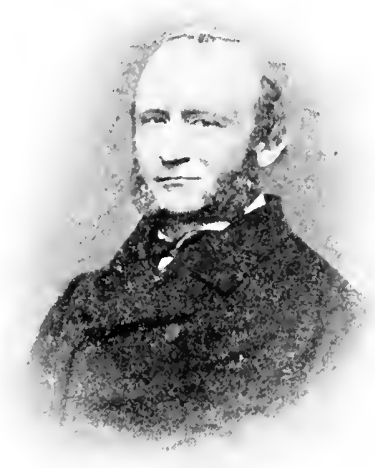

Ernst Wilhelm von Brücke $(1819-92)$. ters connected with the brain, without relation to consciousness, had originally been suggested by Deseartes in 1644 in his diseussion of the batting of the eyes upon a threatened blow. Robert Boyle had noted that a viper, three days after decapitation, still wriggles upon being pricked. Johann Bohn had discussed the reflex movements of the deeapitated frog as "a material phenomenon" (1686). Stephen Hales hat shown that the movements of the decapitated frog are nullified when the spinal cord is destroyed. Robert Whytt, of Edinburgh, showed that destruetion of the anterior optic lobe abolishes the contraction of the pupil to light (Whytt's reflex), and that a mere fragment of the spinal cord will suffice for the production of reflex movements. But most of these observers helieved that reflex phenomena are bound up with sensation and ideation. The Bell-Magendie experiment (1811-22) was a great step forward and the discovery of the respiration eenter by Legallois (1826) and Flourens (1837) threw further light upon the problem.

Independently of these last, and in apparent ignorance of the work of his predecessors, Marshall Hall showed that strychnine convulsions cease upon destruetion of the spinal cord, that reflexes are more readily produced by stimulating the nerve-endings than the nerves themselves, and that there is a reflex contraction of sphineter museles.

It was Hall's work that gave "reflex action" a permanent place in physiology, although he did not realize, as Sherrington and others have pointed out, that volitional and reflex processes can pass from one to the other and that many nervous phenomena lie between the two extremes. He thought that the chief merit of his work lay in the discovery of special reflex paths dissociated from sensation and volition, an idea which was borne out by R. D. Grainger's discovery that the gray matter in the cord and its afferent roots is the true medium of reflex action (1837).

1 Hall: Phil. Tr., Lond., 1833, 635-665. 
William Sharpey (1S(2)-So), of Arbroath, Siotland, who was all his lifo a prominent teacher of physiology at Lniversity College, Lomelon (1S36-7.1), is momorable for his papers on cilia and ciliary motion (1S:30-361), and for his discovery of the "fibers of Sharpey" (1846"). Molem English physiology owes its origins to Huxley and to Sharpey, who was the teacher of the Cambridge and Oxford profosors, Michael Foster and Burdon-Sanderson. Sharpey, says Foster, was "the only pure physiologist in England; . . the only man of the time who devoted all his life to physiology." In describing Ludwig's work on blood-pressure curves to his stu-

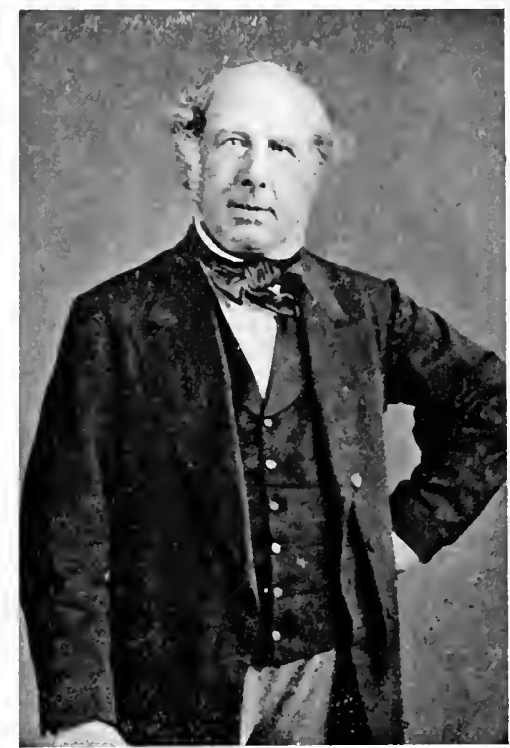

William Sharpey (1802-80). (Boston Medical Library.)

dents, he would sometimes use his old cylinder hat as a kymographion.

Sir William Bowman (1816-92), of Cheshire, England, eminent as physiologist and ophthalmic surgeon, discovered and described striated muscle $\left(1840-41^{3}\right)$, basement membranes (1842), the ciliary

1 Sharpey: Edinb. Med. and Surg. Jour., 1830, xxxiv, 113-122, and Todd's Cycloperlia, London, 1835-36, i. clxiii.

2.. Sharpey: in Jones Quain's Anatomy, 5. ed., Lond., 1846, ii, pp. cxxxii-

${ }^{3}$ Bowman: "On the Minute Structure and Movements of Voluntary Muscle," Phil. Tr., Lond., 1840, 457-501, 4 pl.; 1841, 69-73, the drawings by Bowman himself 
region of the eyeball (1847). To Bowman is due the seientific treatment of lacrimal diseases. In $1842,{ }^{1}$ he stated his theory of the urinary secretion that, as the tubes and their plexus of eapillaries are probably the parts concerned in the secretion of the basie principles of the urine (the urea, lithic acid, ete.), the Malpighian bodies might be an apparatus destined to separate the watery portion from the blood.

The chemical tendeney in modern experimental physiology, which led up to the magnificent work of Claude Bernard and

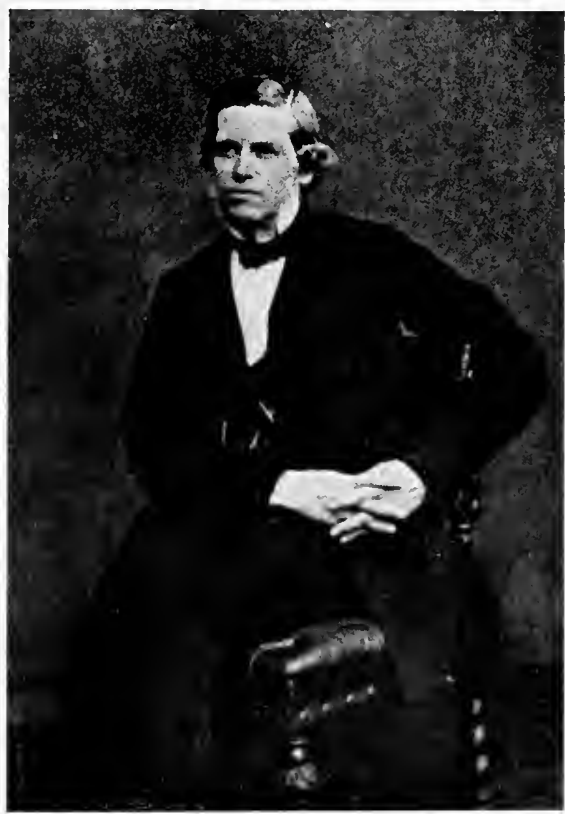

Sir William Bowman (1816-92).

Pasteur, was initiated by Liebig and Wöhler in Germany, and by Dumas and Chevreuil in France.

Justus von Liebig (1803-73), of Darmstadt, a pupil of GayLussac, was the founder of agricultural chemistry, one of the principal founders of physiological chemistry and the chemistry of the earbon compounds, and the originator of laboratory teaching in chemical science. Liebig's laboratory, established at Giessen in 1826, was the first institution of the kind to be connected with university teaching, and, bare and simple as its appointments, was soon thronged with enthusiastic, hard-working students. Here

${ }^{1}$ Phil. Tr., Lond., 1841-2, 57-80. 
liebig made his famous investigations of eyanides, eyanates, amides, aldehydes, henzoyls, henzontes, organic acids, and chemiab fertilizers of soils, and here he fommded Lielig's Annalen (183274), the leading literary organ of chemistry during his lifetime.

Liebig's most inportant contributions to medicine were his discoveries of hippurie atcid (Poggendorff's Ann., 1529), ehloral and chloroform (1831'), his studies of uric aceid eompounds, his mode of estimating urea (18532), and his important work on fats, blood, bile, and meat juice (Liet)ig's extract). His book on "Organic Chemistry in its Applications to l'hysiology" and Pathology" (18423) was the first formal treatise on the subject, introducing the coneept of "metabolism" (Stoffucchsel). His Familiar luet ters on Chemistry (1S44) did more than any other work to popularize that seienee.

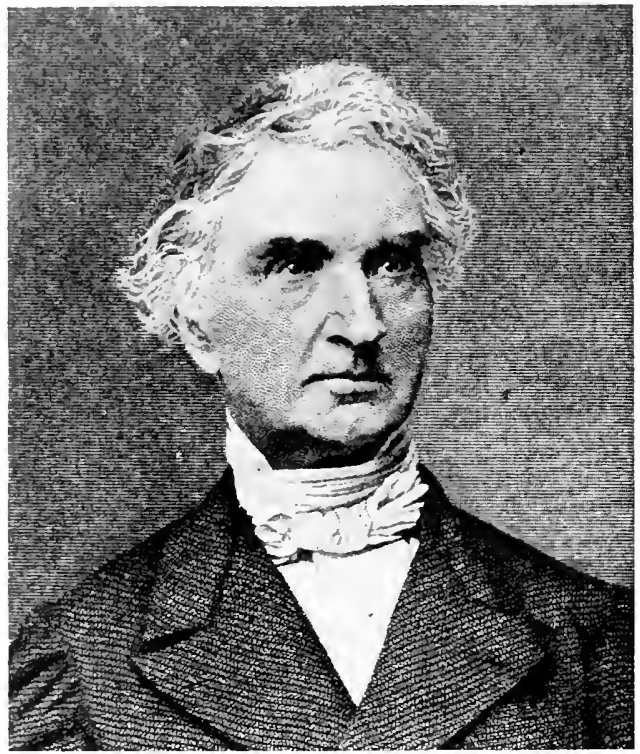

Justus von Liebig (1803-73).

Liebig's investigations of fermentation and putrefaction were vitiated by his purely materialistic view of these phenomena, as based upon his theory of catalysis. He defined catalysis as the

${ }^{1}$ Ann. d. Pharm., Lemgo and Heidelb., 1832, i, 182-230. Chloroform was discovered independently in the same year by Soubeiran (Ann. de ehim., Paris, 1831, xlviii, 113-157), and by Samuel Guthrie, M.D. (17S2-184S), of Bloomfield, Mass. (Am. Jour. Arts and Sc., 1S31, xxi, 64; xxii, 105), at Jewettsville, near Sackett's Harbor, N. Y., where he hit upon the modern method of making ehloroform by distilling aleohol with chlorinated lime.

${ }^{2}$ Ann. d. Pharm., Lemgo and Heidelb., 1853, lxxxv, 2\$9-328.

${ }^{3}$ Die organische Chemie in ihrer Anwendung auf Physiologie und Pathologie, Braunsehweig, 1842. Sebwann introduced the phrase "metabolie phenomena" in 1839 (Fraser Harris). 
tuning-fork power of a system of molecules to set up sympathetie vibrations in another system, producing chemical change, and he affected only contempt or disbelief in regard to such vital ageneies as bacteria or living ferments. He believed that fermentation and putrefaction are only physical disturbances of equilibrium which can be communicated by contact to other bodies. He refused to believe that yeast is alive and declined to look through a microscope. When, after long and bitter controversy, Liebig saw that his materialism had been refuted by Pasteur, he rehctantly stated that he had only attempted to assign a chemical cause for a chemical phenomenon. Yet Liebig was otherwise an uncompromising vitalist. Lord Kelvin relates that when he once asked the great chemist if he believed that a leaf or a flower could be formed or could be made to grow by chemical forces, Liebig replied: "I would more readily believe that a book on ehemistry or on botany could grow out of dead matter by chenical processes."

Friedrich Wöhler (1800-82), of Eschersheim, Hesse-Nassau, was associated with Liebig in his investigations of uric acid, the cyanogen compounds, and the oil of bitter almonds, the artificial synthesis of sugar, morphine and saliein, and himself made many important discoveries, two of which were epoch-making in the history of physiology. In 1828, Wöhler succeeded in effecting an artificial synthesis of urea $^{2}$ by heating ammonium cyanate, accorting to the equation: $\mathrm{NH}_{4} \mathrm{CNO}=\mathrm{CO}\left(\mathrm{NH}_{2}\right)_{2}$. This was the first time that an organic substance had ever been built up artificially from the constituents of an inorganic substance, without any intervention of vital processes, and it soon became clear that there is no essential difference between the structural chemistry of life and that of inanimate nature. This discovery led to a brilliant line of synthetic work, of which the highest point has so far been attained by Emil Fischer. In 1824 Wöhler made, and in 1842 confirmed, a discovery which became the starting-point of the modern chemistry of metabolism, viz., that the benzoic acid taken in with the food appears as hippuric acid in the urine." 'This at once did away with the idea, current in Wöhler's time, that while plants can synthetize their complex materials, animals have to receive their constituent substances already synthetized from

${ }^{1}$ Lord Kelvin: Popular Lectures, London, 1S94, ii, foot-note to p. 464.

2 Wöhler: Ueber künstliche Bildung des Harnstoffs, Ann. d. Phys. u. Chem., Leipzig, 1828, xii, 253-256.

3 Wöhler: Ann. d. Phys, u. Chem., Leipz., 1\$42, Ivi, 63\$-641. One year before this, Alexander Cre, of Edinburgh, had pointed out that benzoie acid is changed to hippurie in the body (Provincial Med. ant surg. Jour., London, 1841, ii, 317). Wöhler's original experiment was given in 'Tiedemann's Ztschr. f. Physiol., 1824, i, 142, but his views were not definite until after Liebig's diseovery of hippurie acid in 1829. 
plants or other animals. Other modes of animal synthesis, such as those of urie ateid from ammonimm arbonate or of ghucose from glyeogen in the liver, weresoon discovered and the problem of building up attificial foods from clementary materials had its inception here. Lichig and Wöhler were, in fact, the inaugurators of what von Noordon alls the qualitative period of metabolism exporinents.

Among the earlier chemical investigations of importance to medicine were Sertïrner's isolation of morphine (1S061); Wollaston's investigation of cystin

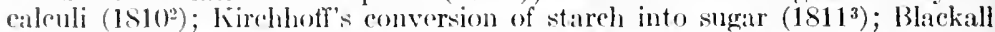
and Wells on albumen in the urine (1812-14); the isolation of strychnine $\left(11^{4}\right)$, brucine $(1819)$, quinine, ${ }^{5}$ and veratrine $\left(1 s^{2} 2\right)$ by Caventou and Pelletier; Alexander Marcet's investigation of black urine $\left(1822^{6}\right)$; Dutrochet's work on endosmosis and exosmess $\left(1 \$ 27-35^{7}\right)$; Geiger and Hesse's isolation of atropine $\left(1333^{8}\right) ; F$. Rose's biuret test for albumen $\left(18: 33^{9}\right)$; the investigations of Cagniard Latour ${ }^{10}$ and sichwann on yeast eclls and vineus formentation $(1837-38)$; the preof of Bouchardat and Peliget that the sugar of diabetic urine is grape-sugar (1838'1); Trommer's test for grape-sugar in the urine (Mitscherlich, 1841); Pettenkofer's test for bile (184412); Hermann von Fehling's quantitative test for sugar in the urine (1848 $\left.{ }^{13}\right)$; Henry Bence Jones's discovery of a special protrid (albumose) in the urine of patients with softening of the bones (myelopathic albunosuria, 184814); Adolf Strecker's investigations of ox bile (is $48-49^{15}$ ): Millon's diserevery of a special reagent for proteids $\left(1849^{16}\right)$. The chemistry of the urine derived a strong impetus from the brilliant work of Joham florian Heller (1s13-71), of the New Vienna School, it pupil of Liebig and Wobler who devised the ring test for albumen (184t ${ }^{17}$ ), the eaustic potash tests for sugar in the urine (1s1418), was the first to notice the retention of chlorides in pneumonic urine $\left(1847^{19}\right)$, introduced the eatustic potash test for blood in the urine (1.5.520), invented the ureometer for estimat-

1 Sertürner: J. d. Pharm., Leipz, 1\$06, xiv, 47: 1811, xx, 99.

2 Wollaston: Phil. Tr., Lond., 1810, 223-230.

${ }^{3}$ Kirchhoff: Jour. f. Chrm. u. Physik, Nuremb., 1815, xiv, 389-398.

${ }^{4}$ Caventou and Pelletier: J. 1. pharm., Paris, 1819, v, 142-177.

Ann. de chim. et physe, Paris, 1\$20, xv, 289; 337.

${ }^{6}$ Mareet: Merl.-Chir. Tr., Lond., 1822-23, xii, $37-45$.

${ }^{7}$ Dutrochet: Ann. fechim. ef phys., l'aris, 1827-35, vols. 35, 37, 49, 52, 60 . 44.

s Geiger and Hexse: Ann. d. Pharm., Lemgo and Heidelb., 1833, v, 43; vi,

${ }^{9}$ Rose: Poggendorff's Ann., Lripz., 1833, xxviii, 132.

10 Cagniard Latour: Ann. dr chim. et physe, Paris, 1838, lxviii, 206-22I.

11 Péligot: Ann, de chim. ot pharm., Paris, 1\$38, lxvi, 140.

${ }_{12}$ Pettenkofer: Ann. d. Chem. 1. Pharm., Heidelb., 1844, lii, 90-96.

${ }^{13}$ Fehling: Areh. f. d. physiol. Heilk., Stuttg., 1848, vii, 64-73.

${ }^{14}$ Benee Jones: Phil. Tr.. Loml., 1sts, 5.5-62.

15 Strecker: Ann. l. Chem. u. Pharm., Heidelb., 1848, 1xv, 1; Ixvii, 1: $1849, \mathrm{lxx}, 149$.

${ }^{16}$ Nillon: Compt.-rend. Acad. d. sc.. Paris, 1849, xxviii, 40-42.

${ }_{17}$ Heller's Arch. f. Physiol. u. path. Chem., Vienna, 1844, i, 192-199.

${ }^{18}$ Ibid., 1844, i, 212; 292.

${ }^{19}$ Ibid., 1847, iv, 522-525.

${ }^{20}$ Heller: Ztschr. cl. k. k. Gesellsch. 1. Aerzte zu Wien, 1858, n. F., i, 751. L. Teichmann gave an earlier test for hæmin in Ztschr. f. rat. Med., Heidelb., 1853, iii, 375-388 (Erich Ebstein). 
ing specific gravity (1848), and wrote a famous elassic on urinary eoneretions $\left(18\left(60^{1}\right)\right.$. Great impetus was given to chemical investigation in France by the work of Jean-Baptiste Dumas (1S00-84), who isolated nethyl aleohol, (siablished the quantitative analysis of air and water, studied the ehemical changes in the development of the chick, and (with Coindet) showed the value of iofine treatment in goiter $\left(1820^{2}\right)$. Michel-Eugène Chevreul (1757-1859) investigated the sugar in diabetic urine $\left(1815^{3}\right)$, and made an important study of animal fats (1823). In England, Thomas Graham (1805-69), of Cilasgow, did work of capital importanee in modern plyysiology by his discovery of the laws governing diffusion of gases $\left(1829-31^{4}\right)$, his investigation of osmotic force $\left(18.54^{5}\right)$, and his method of separating animal and other fluiels by dialysis, introducing the distinction between colloid and erystalloid substances $\left(1861^{6}\right)$. Grabam's definition of osmosis as "the conversion of chemieal affinity into mechanieal power" still remains the most scientifie ever made, as borne out by recent investigations of semi-permeable membranes.

The most important advance made by chemical investigation in the early period was in the physiology of digestion. The first work in this field, in order of time, is "An Experimental Inquiry into the Principles of Nutrition and the Digestive Process" (1803), by John R. Young, of Maryland, being his graduating thesis at the Eniversity of Pennsylvania. The labors of the earlier physiologists on digestion-Van Hehnont, Sylvins, Borelli-were to a great extent impaired by their theories of innate heat and vital spirits, and, as William Hunter derisively remarked, they were fain to regard the stomach as a mill, a fermenting vat, or a stewpan.

In the ejghteenth century, Réaumur isolated the gastrie juiee and demonstrated its solvent effect upon foods (1752). Siallanzani confirmed the fact of its solvent and antiseptic character (1782), and thus did away with the various views of coneoction, putrefaetion, trituration, and fermentation in favor of a chemical theory of solution; but he failed to recognize that the solvent action of the gastric juice is due to its acility. Young took up his work at thin point and, by experiments made upon bull-fross, snakes, and "ven in popria persona, showed that the solvent principle of the gastrie juice is an acil, turning litmus paper red and softening bones into a pulp, and that this acid does not arise from any vinous or other fermentation in the stomach, but is part of the normal gastric seeretion.

He arrived at the important deduction, demonstrated in our own time by Pavloff, that the flow of gastric juice and of saliva are associated and synchronous, but he wrongty inferred that the acid principle of the stomach is phosphoric acid. In 1824 William Prout (1785-1850), an English chemist, was able to prove, by careful titration and distillation, that the acid of the gastric juice

1 Heller: Die Harneoncretionen, Vienna, 1860.

2Coindet: Ann, de, ehim. et phys., Paris, 1820, xv, 49-59.

${ }^{3}$ Chevreul: Ann. de chimice, l'aris, 1815, xev, 319.

${ }^{4}$ Graham: Quart. Jour. Sc., Lond., 1829, ii, 74-83; Phil. Magr., Lond., 1833, ii, $175-190$.

${ }^{5}$ Phil. Tr., Lond., 1854, exliv, 177-22S.

${ }^{6}$ Ibid., 1861, cli, 183-224. 
is free hydrochloric acid. 'This result was soon confirmed by other rhemists, notably in the classic monograph on "Digestion, Experimontally Considered" (1826-272), by Friedrich Tiedemann (17811S(i1), of Cassd, and Leopold Gmelin (1785-1853), of Göttingen. In this work (imelin's nitric acid test for the bile-pigments in chyle, blood-serum, and urine is given (preface, p. $11^{3}$ ), the limited quantity of the gastric secretion is pointed out, and it is shown that the saliva contains a sulphocyanate, and the pancreatic secretion a principle which tums red with chlorine water. This prineiple (tryptophan) was afterward shown by (laude Bernard to be a

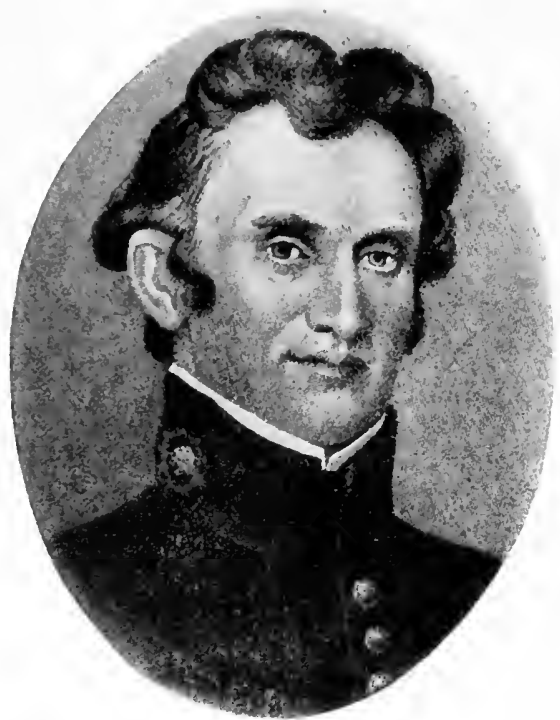

William Beaumont (1785-1853). (Courtesy of Dr. Jesse S. Myer, St. Louis.) by-product of pancreatic digestion and not a true constituent of the pancreatic juice.

In 1833 William Beaumont (1785-1853), of Connecticut, a surgeon in the United States Army, published his famous "Experiments and Observations" on an accidental gastric fistula in the Canadian halfbreed, Alexis St. Martin, which threw so much light upon the nature of the gastric juice, the process of digestion in the stomach, and the early stages of gastritis. As far back as 1664, Regner De Graaf had published his account of artificial salivary and pancreatic juice in a $\log$, giving a picture of the dog; and there were earlier cases of gastric fistulæ; but Beaumont was the first to study digestion and the movements of the stomach in situ $\left(1825^{4}\right)$. He began by carefully reviewing the work of his

${ }^{1}$ Prout: Phil. Tr., Lond., 1824, 45-49.

2 Tiedemann and Gmelin: Die Verdauung nach Versuchen, Heidelberg and Leipzig, 1826-27.

${ }^{3}$ Erich Ebstein (Ztschr. f. Urol., Lcipz., 1915, ix, 283) points out that Gmelin's nitric acid test for bile was employed about forty years before (November, 1757) by Franceseo Marabelli, a pupil of Johann Peter Frank, and apothecary to the hospital at Pavia (Atti d. Accas. d. sc. di Siena, 1794, vii, 224-232). Marabelli's scattered essays (Leipzig, 1795) also contain analyses of dropsical fluid (1791), diabetic urine (1792), and of maize (1787) and various fruits and drugs.

${ }^{4}$ Med. Recorder, Phila., 1825, viii, 14: 840: 1826, ix, 94. 
predecessors in a fair-minded spirit; gave an aceurate description of the normal and pathologic appearances of the gastric mucous membrane in life, and the movements of the stomach up to the completion of digestion; showed that the gastrie juice is secrefed only when food is present and that mechanical irritation of the mucous membrane produces congestion, but only a limited local secretion of gastric juice, thus foreshadowing the results of Pavloff, and overthrowing the doetrine of Magendic that the gastric secretion is continual. Beammont's experiments on the effect of gastric juice upon different foods and the relative digestive values of the latter are the foundation of modern dietetic tables and scales; and his chemical examination of the gastric juice led him to the conclusion that it contains free hydrochloric acid plus some other active ehemical substance, which Theodor Schwann, in 1835, proved to be pepsin. This was the most important work on the physiology of gastric digestion before the time of Pavloff, and the difficulties under which the experimenter completed his labor's, first begun at an isolated military post in the primeval forests of Michigan, and completed only by dint of following up his patient, and bringing him nearly 2000 miles to Plattsburgh Barracks, N. Y., make his experience one of the romantic episodes in the history of medicine. "Every physician who preseribes for digestive disorders," says Vaughan, "and every patient who is benefited by such a prescription, owes gratitude to the memory of William Beaumont, who. in 1825, on the island of Mackinaw, began his studies of digestion, which he pursued with labor and skill for the benefit of mankind." He was the true leader and pioncer of experimental physiology in our country. ${ }^{1}$

Early nineteenth century surgery was mainly a continuation of the surgery of the eighteenth century, with this difference, that the center of gravity had shifted from Paris to London, as a result of the mighty influence of Hunter's teaching, and of the evil efferts of the fanatical prohibitions of $1792-93$, which abolished medical faculties and societies in France. Many bold operative fouts were performed in this period, plastic surgery was revived, most of the larger arteries were successfully ligated, American and Russian surgery came into existence, but of general operating within the cranium, joints, abdomen, and female pelvis, or in isolated organs like the eye and ear, there was no sign until well after the year 1867.

The leading surgeons of the pre-Listerian period were the Bells, Cooper, Colles, Brodie, Liston, Syme, and Fergusson in Great Brit-

${ }^{1}$ For a very complete and interesting aleount of Beaumont and his work, see the "Iife and Letters of William Beatumont," by the late Jesse s. Myer (1873-1913), with an introduction by sir William Osler, St. Louis, C. V. Mosby Co., 1912. 
ain: lanley, Dupuytren, Lisfrane, Dolpech, Velpeau, Malgaigne, and Nolaton in France; the older langenbeck, Dieffenbach, the deder cirace, and Stromeyer in Cormany; Pirogoff in Russia; Physick, Post, Mott, the Warrens, and Mcl)owell in America.

'The hrothers John and Charles Bell were leading figures among the bondon and Edinburgh surgeons of their day, but the fane of vir ('harles Bell now rests latrgely upon his discoveries in anatomy, physiology, and pathology. John Bell (1763-1820), of Edinburgh, lrolongs, in part, to an earlier period, but his great works upon smrgical anatomy exerted a powerful influence upon the men of a later time, and ho was, with Desault and John Hunter, a founder of the modern surgery of the vascular system. He himself had ticel the common carotid and the posterior branch of the intermal iliare suceresfully, and was the first to ligate the gluteal artery. Jike his brother Charles, John Bell was an artist of talent, one of the great medical men who have illustrated their own books. His Anatomy of the Human Body (1793-1803) was an important work in its time, afterward reissued with original plates drawn hy sil (harles Bell (1811); and his Engravings, illustrating the different parts and organs of the body (1794-1804), the drawings and almost all the etchings and engravings being his own, is one of the milestones in the history of anatomic delineation. 'The third volume, dealing with the brain, nerves, sense organs, and viscera (1804), is almost entirely the work of Sir Charles. John Bell's most enduring contributions to surgery are his Discourses on the Nature and Cure of Hounds (1795), the second of which is a valuable historic discussion of the surgery of the arteries; and his monumental Principles of Surgery (1981-1807), embellished with beautiful original engravings and full of unique historical and rlinieal matter relating to the ligation of the great vesels, fractures, trephining, tumors and lithotomy, of which he gives a detailed history, occupving 248 pages. The writings of John Bell are characterized by great sincerity and depth of feeling. He took his profession with a fine ethical seriousness, which, given his combative temperament, often involved him in hot and bitter controversy. He railed at the mistakes of Benjamin Bell and Monro secundus, which dic! not increase his popularity. He was kept out of practice in the Royal Infirmary through the machinations of James Gregory, who assailed him in a bulky volume under the now-forgotten psendonym of "Jonathan Dawplucker." Toward the end of his life, broken in health by a fall from a horse, John Bell went to Italy to die, leaving an enduring memento of his visit in his posthumous Observations on Italy (1825), one of the

1 See his "Principles of Surgery," 1801, vol. i, pp. 421-426. 
best books of travel ever written by a physician. This work is again remarkable for beautiful original drawings, some of which exhibit a feeling for the details of Italian architecture akin to that of Piranesi.

Sir Astley Paston Cooper (1768-1841), of Norfolk, a pupil of John Hunter's, was the most popular surgeon in London during the first quarter of the century. A clergyman's son, he was something like Iunter in his youthful pranks, and became demonstrator of anatomy of St. Thomas's Hospital at the age of twenty-one (1789), and surgeon at Guy's Hospital in 1800 . He was one of the

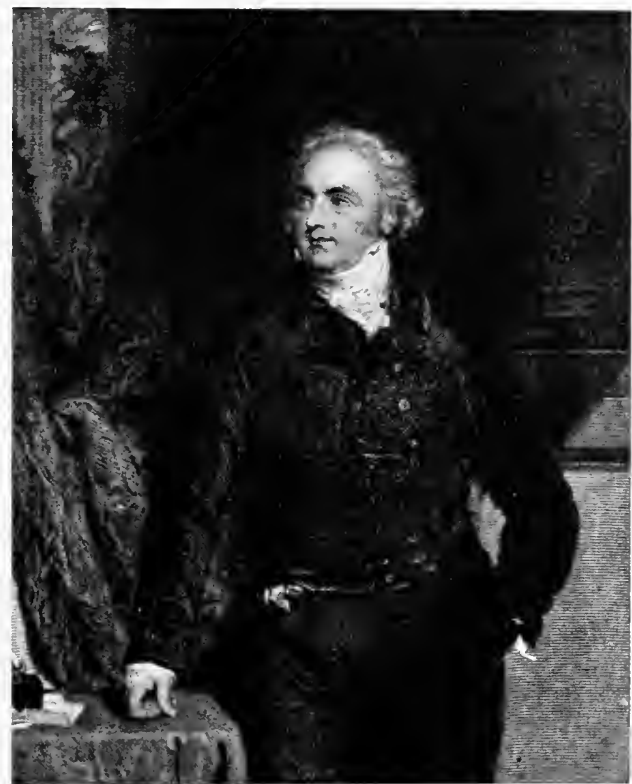

Sir Astley Paston Cooper, Bart. (1768-1841).

pioneers in the surgery of the vaseular system, in experimental surgery, and in the surgery of the ear. In 1808 he successfully ligated the common carotid and the external iliac arteries for aneurysms, making postmortem dissections of his cases in $1821^{1}$ and $1826^{2}$ respectively, and in 1817 came his celebrated feat of ligating the abdominal aorta. ${ }^{3}$ Valentine Mott has left an interesting account of his attempt to tie the subclavian in 1809." Bell

1 Bell: Guy's Hosp. Rep., Lond., 1836, i, 53-58, 1 pl.

${ }^{2}$ Ibid., 43-52, 2 pl.

${ }^{3}$ Cooper \& Travers' "Surgical Essays," London, 1818, pt. 1, 101-130, 2 pl.

4 Med. Repository, N. Y., 1809-10, xiii, 331-334. 
also mato experimental limations of the arteries and nerves in dogs.' In ls:2 he amputated at the hip-joint. His Royal Socioty memoir, on perforating the tympanic membane for deafness resulting from obstruction of the bustathim tube in 20 ("ases $\left(1801^{2}\right)$, ganed him the copley Mredal in 1802, and a slight eperation performed on (icorer IV, in 1820, was followerl by his baronetey. Cooper's profesifonal life was thus one lomg trail of suceess, which eam be sonsol in the comormoms number of engravings which were made of his likeness. "No surgeon, before or since," satys Bettany, "has filled so litue a slatee in the public eye." Although his early inrome was very small, his wifo's fortune made his circumstances easy. Yet fow medical men have ever worked so hard and so incessantly. He dissected every day of his life, even when traveling, paying large fees and liberal douceurs to the body-snatehers. With these, his experiences were such that he once stated before a House of ('ommons committee that "there was no person, what"ver his worldly place, whom he could not dissect if he would." His diily course of life was to rise at six, dissect until cight, breakfast on 1 wo hot rolls and tea, see poor patients until nine, attend to his regular consulting practice until one, when he would drive rapidly to Guy's Hospital to visit the wards; at two he lectured on anatomy at St. Thomas's Hospital, after which he went through the dissecting-rooms with the students and visited or operated on private patients until seven; he would then bolt his limner, snatoh forty winks of sleep, and start out again for a possible clinical lecture, with another round of visits intil midnight. He dictated whatever he wrote while in his carriage. He read little, but managed to absorb the best ('urrent knowledge, and his books on Hemia (1804-07), Injuries of the Joints (1822), Diseases of the Testis (1830), and the Anatomy of the Thymus Gland (1832) are still remembered, as also Cooper's fascia, Cooper's hernia, and other eponyms. Cooper was one of the first surgieal teachers to substitute practical demonstrations over an actual case for the old didactic theory-mongering of the past; and one of his best achievements was the large number of capable and spirited young surgeons he formed through contact with himself. In personality, he was no pedant or Philistine, but "courteous-eyed, erect and slim," the tall, handsome, engaging figure of Sir Thomas Lawrence's portrait, with a lively, expressive comtenance, cheeks aglow with color, a clear voice and chnckling laugh, and, in spite of his quick, imperious temper, idolized by the students, who followed his clinics in enthusiastic throngs. As an operator, he was unaffected, elegant,

1 Guy's Hosp. Rep., Lond., 1s36, i, 457; 654.

${ }^{2}$ Phil. Tr., Lond., 1801, 435-450, 1 pl. 
rapid but unhurried, thorough, masterful, "all ease, all kindness to the patients, and equally solicitous that nothing should be hidden from the observation of the pupils." He attributed his professional success to his uniform and unfailing courtesy to rich and poor alike, as well as to his zeal and industry, "but for this I take no credit, as it was given to me from above." Few men have so fully realized the truth of the poet's device, "We receive but what we give," in the possession of a cheerful, manly, and generous disposition.

Charles Aston Key (1793-1849), of Southwark, one of ('ooper's juniors at Cuy's, successfully ligated the external iliac artery for femoral aneurysm in $1822,{ }^{1}$ and the subclavian for axillary aneurysm in 1823.' He also tied the carotid in 1830 and introduced such improvements as the use of the straight staff in lithotomy (1824) and the principle of dividing the stricture outsicle the sac in strangulated hernia (1833). Jike Cooper, he was a swift, neat operator and a popular teacher, smart in attire, but, unlike his ehief, condescending, over-clictatorial, and self-important in manner.

Benjamin Travers (1783 -1858), of London, another of Cooper's pupils, collabo-

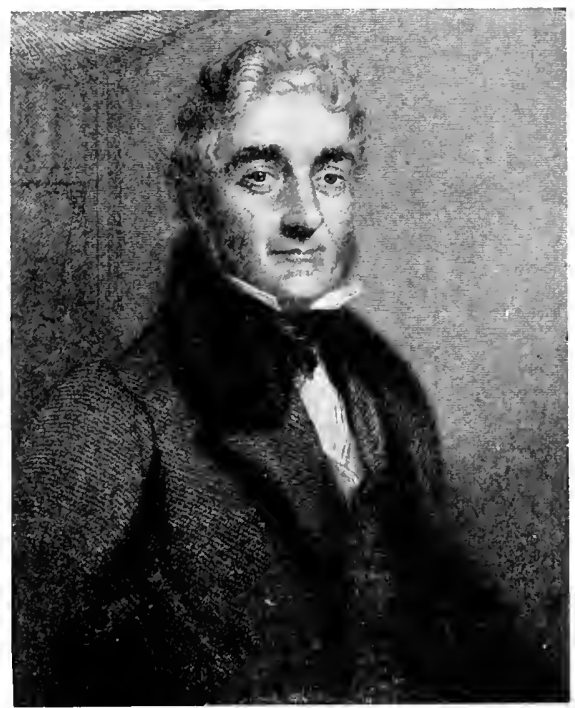

Benjamin Trivers (1783-1\$:5). rated with the latter in the valuable Surgical Essays (181S-19), to which he contributed a noteworthy paper on wounds of the veins. In 1809 he successfully ligated the common earotid artery in a case of aneurysm by anastomosis in the orbit. ${ }^{3}$ He was one of those who followed Broussais in regarding constitutional irritation as a cause of disease, particularly in the nervous system (1824-34). His specialty was ophthalmology, in which field he introdueed the use of mercury in non-specific iritis and wrote the best systematic treatise on diseases of the eye of his time (1820).

${ }^{1}$ Key: Guy's Hosp. Rep., Lond., 1836, i, 68-70.

2 Med.-Chir. Tr., Lond., 1s23-27, xiii, 1-11.

3 Travers: Med.-Chir. Tr., Lond., 1817, ii, 1-16. 
Ahrahim Colles (1773-1843), of Dulblin, professor of surgery in that city for thirty-two years (1804-36), wats the leading Irish surgeon of his dary. He tied the subelavian artery twice (1811-15'), and was the first to tie it within the sealeni (1816). He is said to have been the first man in Europe to tie the imnominate successfully." Ho wrote treatises on surgical anatomy (1811) and on surgery (1st4-15), but his most important works are his original description of fracture of the carpal end of the ratlius or "Colles" fracture" $\left(1814^{3}\right)$, and his Practical Observations on the Venereal

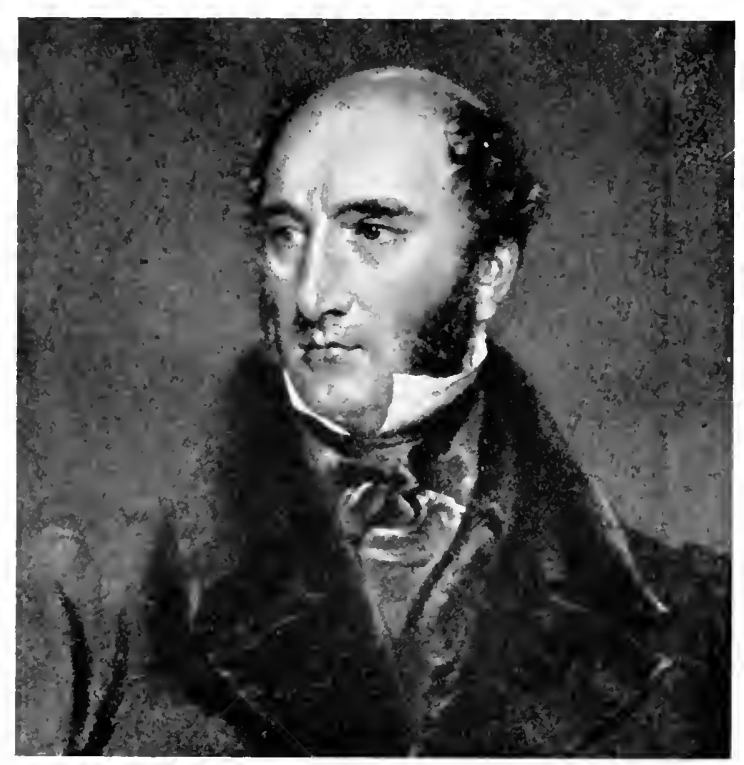

Robert Liston (1791-1847).

Disease (1837), in which he states "Colles' law," rolating to the supposed immunity which a healthy mother accuires in bearing a syphilitic child.

Robert Liston (1794-1847), of scotland, was an Edinburgh graduate who became professor of clinical surgery in University College, London, in 1834. Like the Bells and Astley Cooper, he was a fine anatomist, keeping up his dissections all his life, and this helped to make him one of the most brilliant and skilful operators of his time, excelling in emergency cases which called for swiftness

\footnotetext{
${ }^{1}$ Colles: Edinb. Med. and Surg. Jour., 1815, xi, 1-25.

${ }^{2} \mathrm{I}$ have been unable to verify this statement, which is made in all biographies of Colles.

${ }^{3}$ Edinb. Med. and Surg. Jour., 1814, x, 182-186.
} 
of decision and originality of procerlure. He introduced many novelties, sueh as his popular mode of flap-amputation, his shoe for club-foot, and his devices for redueing disloeations and crushing and eutting for stone. He was especially successful in plastic operations. In 1836 he suceessfully excised the upper jaw, and, in $1837,{ }^{1}$ he described his method of laryngoseopy, in which he was one of the early pioneers. His most important works were his Elements of Surgery (1831) and his Practical Surgery (1837), which passed through many editions and still contain things of

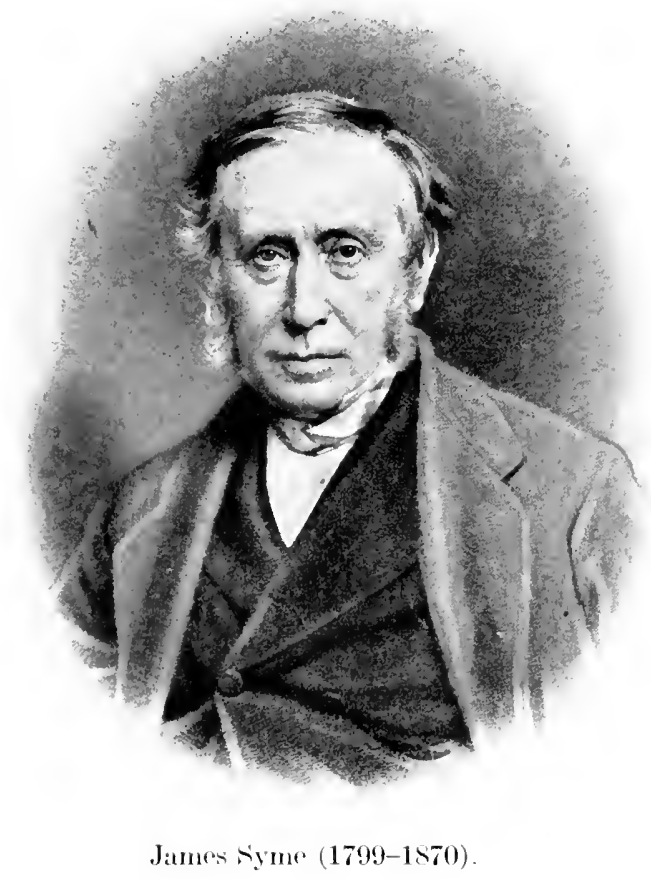

permanent value. Liston was of ten rough, abrupt, and contentious in public relations, but kind and charitable to the poor, soft and gentle in the sick-room. He was possessed of such Hereulean strength that he conld amputate a thigh with the aid of only one assistant, while compressing the artery with his left hand and doing all the sawing and eutting with his right.

James Syme (1799-1870), of Edinburgh, was a cousin of Liston's and taught anatomy with the latter in 1822. Having quarreled with his partner, he could get no appointment in the Royal Infirm-

1 In his "Practical Surgery," London, 1837, p. 350. 
ary until 1S33. But when liston went down to Loudon in $18: 31$, he

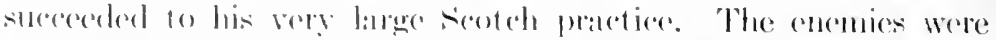

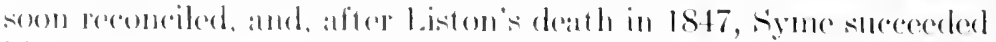
him in Iondom, hom not liking the postion, momed to Edinburgh. symes most important antribution to surgery is his work on ampmtations and axeisons. In his Excision of Diseased Joints (1S:31) he was the first to show that excision is mstlilly preforable to ampmattion, and the adoption of this new principle is due to

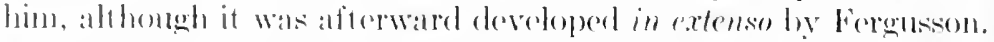
Ho made his first there slueressful axeisions of the allowe-joint in $1828-29.9^{1}$ ( ful case of anmputation at the ankle-joint (Syme's amputation) of which he described right asses in his Compributions to the Pathology! and Prastice of Surgery (1847). In 1864 he published his

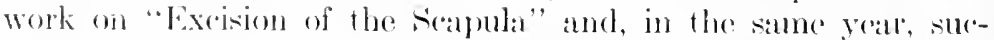

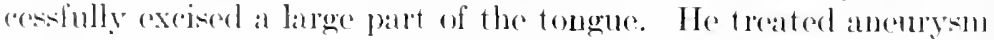
by tying the aldery above and below and incising the tmmor, performing this operation for carotid and iliac ancurysus in 1857 ,

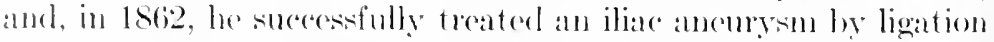
of the common, externat, and intemal iliac atteries. ${ }^{3}$ Fyme was a genial, happy, evon-tempored man who "never wasted a wold, now a drop of ink, nor a drop of blood," pet a broad-minded, liberal spirit withal, weleoming all smegeal innovations of value. He was, with Pirogoff, perhaps the first Europoun surgeon to adopt ether anesthesia (1847), and, in 1868, he was the first to woleome the antiseptic method of his hest and grantest pupil, his son-in-law, Lord Lister.

Sir William Fergusson (1808-77), of Prestonpans, Seotland, was the fomder of conservative surgery, that is, of the preservation of farts of the body which were needlessly sacrificed by earlier operattors. Bufore Fergusion's time, demuled bones, diseased or painful (evon nemotio) joints, were regarded as a sufficient reason for amputation. Ho held it to be "a grand thing when by prescience "ven the tip of a thumb (atu be saved." Fergusson was a pupil and prosector of Robret Knox, and soon hecame surgeon to the Edinburgh Royal Dispensiry (18:31) and the Royal Infirmary (1839); but syme's huge practice drove him to London where, after slow progress, he eventually at tained the summit. He was one of the first in scotland to tie the subclavian artery, and his progress in substituting excisions for amputation was rapid. He excised the head of the femmr for incurable hip clisease (1845), the scapula, in

1 Syme: Edlinb. Med. and Surg. Jour., 1829, xxxi, 256-266.

${ }^{2}$ Lond. and Edinb. Month. Jour. Med. Sc., 1843, iii, 93-96.

${ }^{3}$ Proc. Roy. Med. and Chir. Soc., Lond., 1862, iv, 114-116. 
place of the interscapular-thoracic amputation (1847), and the knee-joint (1850). Between 1828 and 186 the had operated 400 times for harelip, with only three failures, and 134 times for eleftpalate, with 129 suceessful cases. In lithotomy, he proceeded with such lightning speed and skill that some one artvisod al prospeetive visitor at his clinic to "look out sharp, for if you only wink, you'll miss the operation altogether." Yet he carefully planned every detail in advance, silently working out each step as he went along, even to the bandaging. He wrote a siystem of Prectical s'uryery

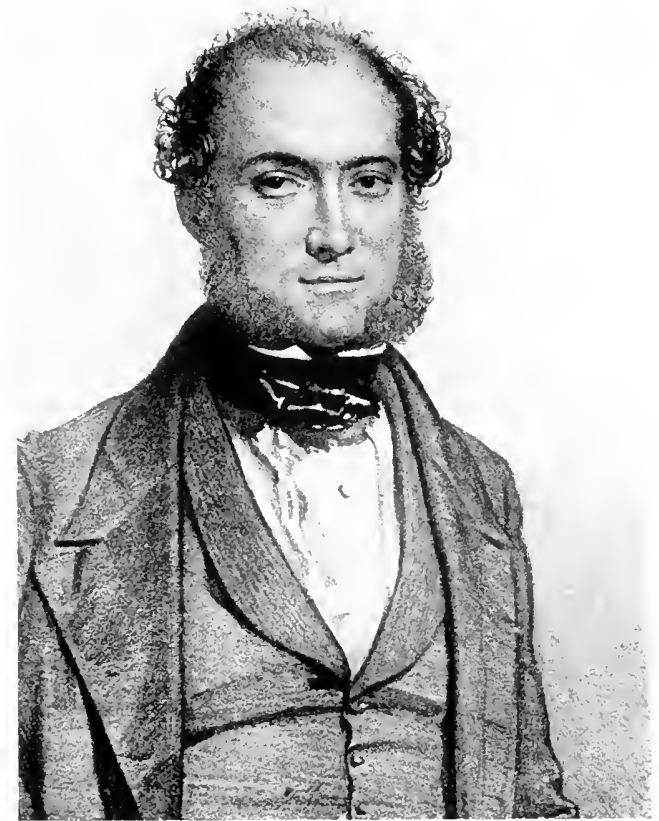

Sir William Fergusson (180S-7T).

(1842), and his Progress of Anatomy and Singery During the Present Century (1867) is a historic work of permanent value. He was an indifferent lecturer and is said to have had a poor bedside manner, but he fascinated his patients and was adored by the children. He was highly accomplished, a good violinist, an inventor of many surgical instruments, so expert in carpentry and metal work that he conld devise any necessiry apparatus out of hand, an enthusiast at fly-fishing and in dancing Scotch reels. He was noted for his great generosity and hospitality to struggling authors, dramatists, and medieal students. 
Sir Benjamin (ollins Brodie (178:3-18ti2) was the son of a Wiltshire clereromam who was deserneled from a Jacohite exile in England. He was a pupil of Sir leverand Home, lectured at Great Windmill streed (1805-12), and was subsecuently assistant surgeon, and later full sureren, at St. Coorge's Hospital (ISOS-40). Bcing profommlly influcneed by Bichat, he at first devoted himsedf to physiologic experimentation, producing fom papers, important in their day, on the influence of the brain on the action of the heart $\left(1810^{1}\right)$, the effects

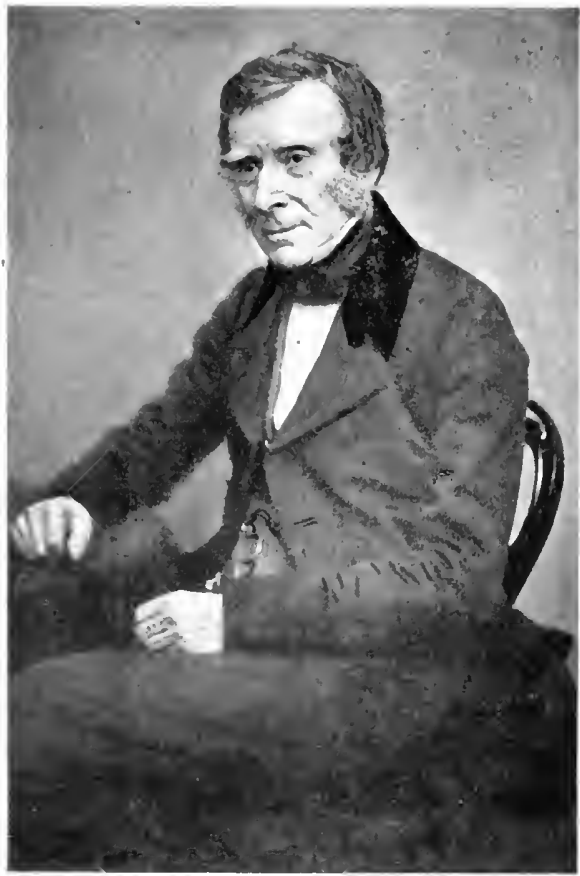

Sir Benjamin Collins Brodie (1783-1862). of certain vegetable poisons $\left(1811^{2}\right)$, the influence of the nervous system on the ploduction of animal heat $\left(1812^{3}\right)$, and the influence of the pnemogatstrie on the secretions of the stomach $\left(1814^{4}\right)$. In these researches, the first two of which gained him the Copley Medal (1811), he used the woorala poison which had just been hought from Guiana. In 1819 he published his dassic treatise $O n$ the Pathology and Surgery of Diseases of the Joints, his most important work, (learly describing the different articular diseases and differentiating the local lesions from the hysteric and nemalgic forms. He was a pioneer in subcutaneous surgery, performing his first operation on a case of varicose veins in 1814, and made many improvements in surgical instruments and appliances. He was the acknowledged head of the medieal profession in London for over thirty years, his incone often averaging $£ 10,000$ annually, and largely made up of guinea fees at that. He did not regard operative intervention as the

${ }^{1}$ Brodie: Phil. Tr., 1811, 36-4S.

2 Ibid., 1S11, 17S-20S: 1S12, 205-227.

${ }^{3}$ Ibid., 1812, 373-393.

${ }^{4}$ Ibid., 1814, 102-106. 
highest part of surgery, and "his vocation was more to heal limbs than to remove them." Brodie had been all his life assisted by influential friends and family connections, but he held high places, such as the presidency of the Royal College of Surgeons, with dignity, grace, and the kind of tactful self-effacement which aims to stimulate and bring out the ideas of other men. He seems to have been "servile to none, deferential to none," standing on an equal footing of friendliness and confidence with the poor in hospital or his titled intimates at Holland House or Windsor Castle. "I hear you are ill," he once wrote to an almost unknown student; "no one will take better care of you than I; come to my country house till you are well,"

making the student remain with him two months.

Here may be mentioned two other surgeons of the Scoteh group-Lizars and Wardrop.

John Lizars (17831860), of Edinburgh, a pupil of John Bell's, was originally a naval surgeon, but became professor of surgery to the College of Surgeons in his native city in 1831. He was one of the first to remove the lower jaw, but he is now best remembered as the follower of MeDowell (his fellow-

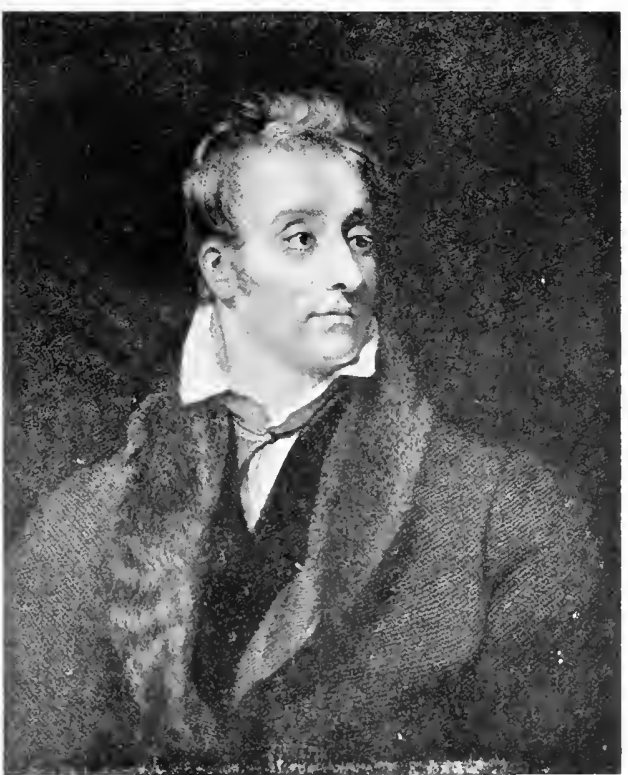

James Wardrop) (17s2-1s69). pupil) in ovariotomy (1825), and by his System of Anatomical Plates (1825), at stuperb) scries of 110 colored illustrations in folio, made largely from his own dissections.

James Wardrop (1782-1869), of Scotland, an Edinburgh graduate who settled in London in 1809 , is now best remembered by his Essays on the Morbid Anatomy of the Human Eye (1808), at book of importance in its day, and by his method of treating aneurysm by ligating on the distal side of the tumor, which was first suggested by Brasdor in the eighteenth century. Wardiop performed this operation twice with suceess on the carotid artery 
(1S(09) and once on the subelavian in a case of innominate anenrysm $\left(1827^{2}\right)$. A emrious side of Warelrop is that he stood in the way of his own sucoess and estranged his colleagues through his acrimonions and abusive papers in the Laneet of 1826-27, and through the famous Interepted Letters, in the same jommal for 1834 , in wheh he foisted off more personal abuse by using the leading names of the London profesion as stalking-horses.

Other prominent English surgeons during the pre-antiseptic period were William Hey (1736-1S19), of leeds, who first described infant ile hernia (1764), internal derangement of the kner-joint (1782-18013), fungus hamatodes, and devised a useful saw for operating in fractures of the skull (ISO)3), and whose "Practical Observations on Surgery" (1803) passed through three editions; Woward Alanson (17.77-1823), of Newton, Lancashire, a pupil of Joln Hunter's, who was the first seientifje surgeon of Liverpool in his period, published at valuable treatise on amputation (1779), and displayed wonderful insight in his rulings about absolute cleanliness and proper ventilation in hospital wards; dllan liurns (17\$1-1813), of (ilasgow, who wrote an important work on the siurgical Anatomy of the Head and Neck (1811), and first described the falciform proess of the fascial lata in relation to femoral hornia; Samuel Cooper (17S()-1S48), whose Surgical Dictionury (1809) was the first thoroughgoing work of its kind to be published, passing through eight editions; Joseph Constantine Carpue (1764-1848), who was a pioneer in clectrotherapy (1S0:33), revived the Hindu method of rhineplasty (1S16), and wrote a valuable History of the High Opwration for Stone (1819); John Flint South (1797-1882), the historian of (arly lititish surgery, who translated Chelius, and whose posthumous manuseript of a IIistory of the Craft of Sturgery in England was edited and published by D'Arey Power in 18s6; O'bryen Bellingham (1805-57), whose book on the treatinent of aneurysm by compression (1847) preserves his natne and fame in comnection with the procedure; Thomas Pridgin Teate (1801-fis), of lueds, menorable for his treatise on abrlominal hernia (1846), his method of amputation by a long and short rectangular flap (185S), and for his attempt to apply the Broussais doetrino of irritation to the nervous system (1829); Sir William Lawrenee (1783-1867) and Sir William Bowman (1816(12), who did much to advance the surgery of the eye; Sir William Wilde (1S15$76)$, of Castlerea, lretand, one of the pioneers of aural surgery (1843-5:3) and rerebral surgery (Wilde's incision), who also discovered prehistoric lake dwellings on the Irish erannogs (1839) before Keller; William Henry Porter (17901861), who wrote an important work on the surgieal pathology of the larynx anrl trachea (1826); and John Hilton (1804-78), of Guy's Hospital, whose Rest and P'ain (1863) is one of the permanent elassics of surgery. Robert Chessher (1750-1831), an estimable surgeon of Hinckley, Leicestershire, achieved a great reputation through his double inclined-plane to support fractured legs, his apparatus for weak spines and for massage of contractures. He is mentioned in Grorge Eliot's Middlemarch "MIr. Chessher and his irons"). Joseph Fox, in his Natural IIistory of the IIuman Tecth (1803), gave the first explicit directions for correcting dental irregularities, which were in use for nearly half a century (Weinberger).

Of isolated operations and operative procedures by English surgeons of the period we may mention the interscapular-thoracic amputation (excision of arm, scapula and clavicle), which was first performed by Ralph Cuming of the Royal Navy in $1808^{4}$; Anthony White's exrision of the head of the femur

${ }^{1}$ Med.-Chir. Tr., Lond., 1825, xiii, 217-226.

${ }^{2}$ Lancet, Lond., 1827 , xii, 471; 601; 798: $1827-8, i, 408$. 1803.

3 J. C. Carpue: An Introduction to Electricity and Galvanism, London,

4 Cuming: Lond. Med. Gaz., 1829-30, v, 273. 
for hip disease (1S221); the first English eases of gastrostomy (1858-592) hy John Cooper Forster (1824-96), of Guy's IIospital; Pridgin 'Teale's method of amputation by a long and a short rectangular flap (1Sis); Richard Carden's single flap amputation $\left(1864^{3}\right)$; and four sucessful cases of ligation of the $(2 x-$

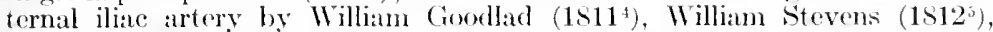
John Simith Soden $\left(1 S 16^{6}\right)$, and T. Cole (1S17 ). In Stevens' ease, the patient lived ten years, the parts being disiected eight years later $\left(18300^{8}\right)$ by sir Richand Owen. The first successul ligation of the common earotid artery appears to have been performed by David Fleming, surgeon of H. M. S. Tonnant, in Oetolyer, $1803 .^{9}$

The leading English military surgeon of the time was Cieorge James Guthrie (1785-1856), of London, who bad served in America and in the Napoleonic wars. At Waterloo, Guthrie successfully amputated the hip-joint ${ }^{10}$ and ligated the peroneal artery $\left(1815^{\mathrm{ij}}\right)$. His most important work is his Treatise on Gunshot Wounds of the Extremities requiring Amputation (1815), which was epochmaking and ran through six editions. Guthrie was also a skilled ophthalmic surgeon and left two important works on artificial pupil (1823) and the surgery of the eye (1812). He was the stepfather of Margaret (iordon, of Carlyle's "Reminiseences." 12

Dominique-Jean Larrey (1766-1842), the greatest French military surgeon of his time, also served in the Napoleonic wars. In his will, Napoleon left 100,000 francs to "Larrey, the most virtnous man I have ever known." Larrey was one of the first to amputate at the bip-joint $\left(1803^{13}\right)$, performing the operation twice with success. He was surgeon-in-chief to the crande Armée, taking part in 60 battles and 400 engagements. He was three times wounded, performed as many ats 200 imputations in twenty-four hours at Borodino, was the inventor of the celebrated "flying. ambulances," and sometime professor at the École de médecine militaire at Val-rle-Grâce, which was founded in 1796. He was the originator of "first aid to the wounded," in the ultrit-modern sense, taking hold, with his hundreds of ambulances, directly a

1 White: Lancet, Lond., 1849, i, 324.

${ }^{2}$ Forster: Guy's Hosp. Rep., Iond., 185s, 3. s., iv, 13: 1859, v, 1.

${ }^{3}$ Carden: Brit. M. J., Lond., 1864, i, 416-421.

${ }^{4}$ Goodlarl: Edinb. Med. and Surg. Jour., 1812, viii, 32-39.

${ }^{5}$ Stevens: Med.-Chir. Tr., Lond., 1814, v, 422-434.

${ }^{6}$ Soden: Ibid., 1816, vii, 536-540.

7 Cole: London Med. Repository, 1820, xiii, 369-375.

8 Owen: Med.-Chir. Tr., London, 1830, xvi, 219-325.

${ }^{9}$ Fleming: Med.-Chir. Jour. and Rev., Lond., 1817, iii, 1-4.

${ }^{10}$ In his Treatise on Gunshot Wounds, second efl., London, 1520, 332-3340.

${ }^{11}$ Guthrie: Med.-Chir. Tr., Lond., 1816, vii, 3330-337.

${ }^{12}$ For an interesting aceount of him, see R. C. Archibsld: "Carlyte's First Love," London, 1910, 53-61.

${ }^{13}$ Larrey: Mém. de elir. mil., P’aris, 1s12, ii, 180-195. 
battle was joined and not after it. Lilie Ambroüse Paré, he was adored by his comrales in arms for his good nature, comrage, and lmmanity. His most interesting work is contained in the four volumes of his "Mcmoirs of Military Medicine" (1812-17), which contains the first aceount of "trench foot" (1812, iii, 60). In a memoir published at ( $a$ ino in 1802 , he was the first to point out the

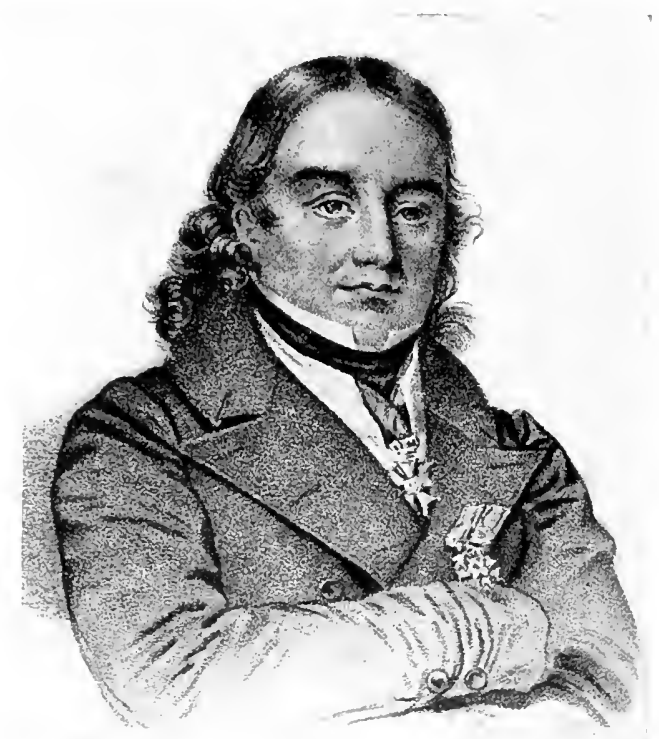

Dominique-Jean Larrey (1766-1842).

contagious nature of Egyptian ophthalmia or granular conjunctivitis.

The ablest and best trained French surgeon of his time was Cinillaume Dupuytren (1777-1835), who was at once a shrewd diagnostician, an operator of unrivaled aplomb, a wonderful clinical teacher, and a good experimental physiologist and pathologist. Dupuytren rose from poverty and fought his way up, and his achierements are sometimes overlooked on account of the meanness of his character. In 1808 he became one of the staff at the Hôtel Dieu, and on September 9, 1814, he was appointed surgeonin-chief. Here his lectures and his extensive practice soon made him the leading surgeon of France, and he died a millionaire and a baron of the Empire. His clinies drew crowds of students from all countries, and he turned out many brilliant pupils. He had an immense practice, about 10,000 patients annually outside his hospital work. 
He was the first to excise the lower jaw (18121) and to treat aneurysm suecessfully by conpression $\left(181 \mathrm{~s}^{2}\right)$; was the first to treat wry-neck by subcutaneous section of the sternomastoid muscle $\left(1822^{3}\right)$, ant performed many feats in vascular surgery, such as the successful ligation of the external iliac $\left(1815^{4}\right)$ and two ligations of the subclavian $\left(1819-29^{5}\right)$. He also substituted ligation for amputation in fractures complicated by aneurysm (1815), devised an original method of treating artificial anus by means of a compressing enterotome of his invention (1S286), but his most encluring title to morlern fame is in the field of surgical pathology. His original descriptions of fracture of the lower end of the fibula (Dupuytren's fracture, 18197), congenital dislocation of the hip-joint $\left(1826^{8}\right)$, and retraction of the fingers from affection of the palmar aponeurosis, for which he devised an operation $\left(1832^{9}\right)$, are his greatest works. He also described fractures on chiletren (1811), vaginit is in maidens

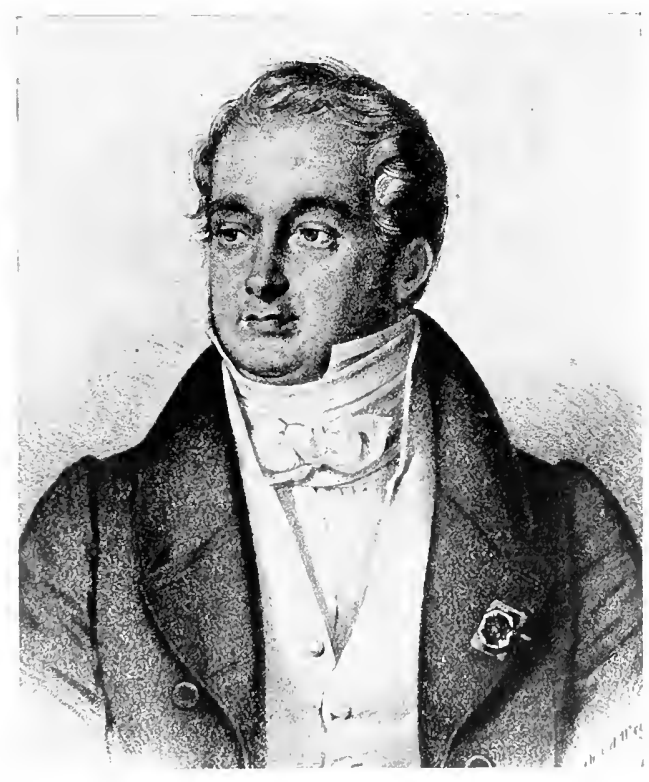

Guillaume Dupuytren (1776-1835).

(1527), variese ancurysms (1829), and sul)luxation of the wrist for radius curvus, afterward known as Madelung's deformity. His memoirs ( In $_{\text {Injuries }}$

1 Dupuytren: Leçons orales, Paris, 1839, ii, 421-453.

${ }^{2}$ Bull. Fac, de néd. de Paris, 1818, vi, 242.

${ }^{3}$ Described in Dupuytren: Leçons orales, Paris, 1839, iii, 45.)-461, and in Charles Averill's "Short Treatise on Operative surgery," London, 1823, 61-64. The operation was repeated by Bouvier (1S36) and J. Guérin (1837).

${ }^{4}$ Pepert. gén. d'anat et de physiol. path., Paris, 1\$26, ii, 230-250.

${ }^{5}$ Edinb. Med. and Surg. Jour., 1819, xv, 476, and Arch. gén. de méd., Paris, 1829, 7. s., xx, 566-573.

${ }^{6}$ Mén. Acad. de méd., Paris, 1828, i, 259-316, 3 pl.

7 Annuaire méd.-chir. d. bôp. de Paris, 1819, i, 1-212.

${ }^{8}$ Repert. gén. d'anat. et de physiol. path., Paris, 1826, ii, \$2-93.

${ }^{9} \mathrm{~J}$. univ. et hebd. de méd. et de chir. prat., Paris, 1832, 2. s., v, 348-365. 
and Discises of the Bones and on of here phases of surgieal pathology were

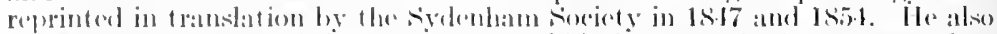

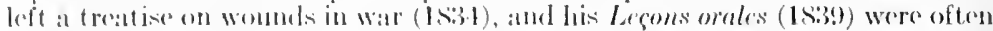

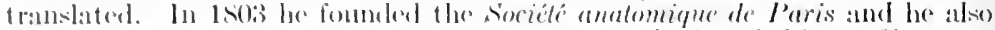

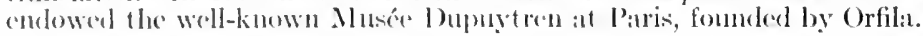

Dupurtren was the type of man whom grinding poverty in fouth, perhaps also some youthful disappointment in love, had made overambitions and overbearing. Ho had the ntmost sangfroid and solf-control, cren when a patient had died on the table hefore him. His personality was olympian. In Palis, he was regiarded as "nobody's friend," because he tolerated no rivals, and perseruted and intrigued against those who, like Dumoril or Velfeau, aspired to that eminence, even pursuing them with vindietive hatrod. He was cold, hard, contemptuous, unscrupulous, and overbearing, and more respected than boloved. Percy called him the first of surgeons and the least of men. Lisfrane dubbed him "the hrigand of the Hôtel Dieu." Yet his fame was such that, when ho visited Italy, he was treated en prince.

Alexis Boyer (1757-1833), a pupil of Desault and surgeon at the Charité (vern after the Revolution, wrote a treatise on diseases of the bones (1803), but wats best known by his treatise on surgieal discases (1814-26), a huge compilation in 11 volumes, defined by Malgaigne as "a summary of the works and opinions of the French Academy of Surgery." Boyer, like llippocrates and Delpech, noted that caries of the spine is oceasioned by "le vicc scrofule ux."

Jaeques Lisfranc (1790-1S47), surgeon at La Pitié, levised many n'w operations, in particular his partial amputation of the foot at the tarsometatarsal articulation (Lisfrane's amputation, 1S152), his methods of disarticulating the shoulder-joint (1815), of excision of the rectum, of lithotomy in women, anil of amputation of the cervix uteri. He was little admired for lis many aspersions of his colleagues.

Philihert-Joseph Roux (1750-1854), a pupil and friend of Biehat, was surgeon at the Charité in 1S10, and succeeded Dupuytren at the Hôtel Dieu in 15.35 . He was the first French teacher to give a definite course of lectures (1812). He was a pioneer in plastic surgery, performing the first staphylorrhaphy in 1519 (described in detail in his memoir of $1825^{3}$ ), and the first suture of the ruptured female perineum $\left(1532^{4}\right)$.

Jarques-Mathieu Delpech (1777-1832), of Toulouse, graduated in Montpellier (1801) and, in 1812, beeame professor of surgery there. He was the pioneer of orthopedic surgery in France, his principal work being De l'orthomorphie (1828). On May 9, 1816, he performed, for the first time, a subeutaneous section of the tendo Achillis for club-foot, the object being to exclude the air and obtain union by first intention. This operation, hitherto

1 Boyer: Traité des malarlies chirurgicales, Paris, 1S14, ii, 492.

2 Lisfranc: Nouvelle méthode opératoire (etc.), Paris, 1815.

${ }^{3}$ Roux: Arch. gén. de méd., Paris, 1825, vii, 516-538.

${ }^{4}$ Roux: Gaz. méd. de Paris, 1834, 2. s., ii, 17-22.

${ }^{5}$ In his Clin. ehir. de Montpellier, 1823, i, 147-231, pl. x. 
done by the open method, was twice repeated by Stromeyer in 1821-22. Delpech was also one of the first after Hippocrates to point out that Pott's disease (spinal caries) is tubercular in nature $\left(1816^{1}\right)$. He erected a large orthopedic institute at Montpellier, and, one morning, while on the way to it in his carriage, he and his coachman were shot and killed by a vindictive patient, who thought that an operation for varicocele had rendered him unfit for marriage.

Alfred-Armand-Louis-Marie Velpeau (1795-1867), a pupil of Bretonneau's, originally a blacksmith's son who hat once been

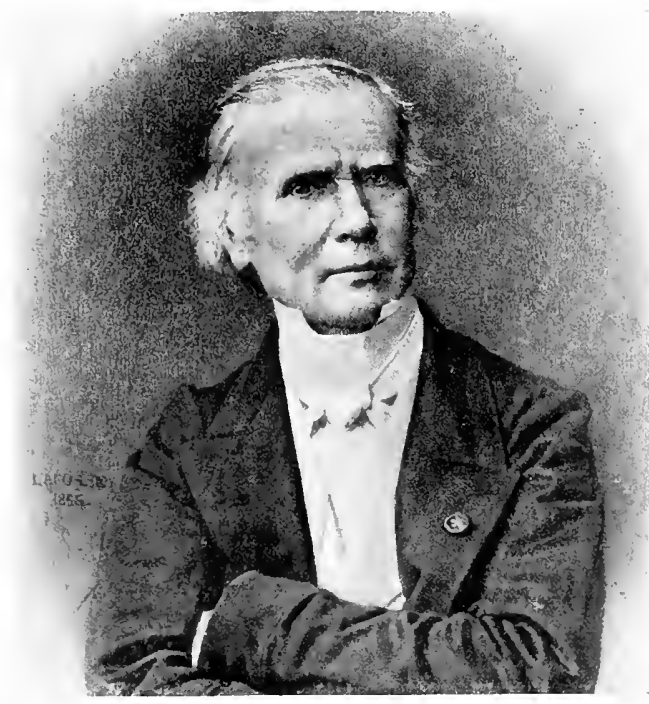

Alired-Armancl-Louis-Marie Velpeau (1795-1867).

apprenticed to his father's trade, was surgeon to the Hoppital st. Antoine (1828-30), La Pitié (1830-34), the Charité (1834-177), and professor of clinical surgery at the Paris Faculty (1834-67). He was not a scientific surgeon, but a strong, capable, hard-working teacher and operator, of whom Oliver Wendell Holmes said that "a good sound head over a pair of wooden shoes is a good de:al better than a wooden head belonging to an owner who cases his feet in calf-skin." His principal works are his Treatise on Surgical Anatomy (1823), the first detailed work of its kind, his threevolume treatise on operative surgery, with atlas (1832), important for its historic data, and once edited in translation by Valentine

${ }^{1}$ Delpech: Précis élémentaire des maladies réputées chiruraricales, Paris, 1816, iii, 629; 63S, et seq. Also: De l'orthomorphie, Paris, 1S2S, i, 241-251. 
Mott (1S47), and his great treatise on Discases of the Breast $\left(1554^{1}\right)$, the most important work on the suhject in its time.

Joseph-Flancois Malgaigne (1806-(65), the som of a French health officer, is described by Billings as "the greatest surgical historian and critic whom the world has yet seen," and he is, with Petrecuin, the most able writer on the surgery of the Hippocratic period. He served in the Napoleonic wars, wrote important works on operative surgery (1834), experinental surgery (1838), fractures and distocations (1847-55), and odited the anthentic modern edi-

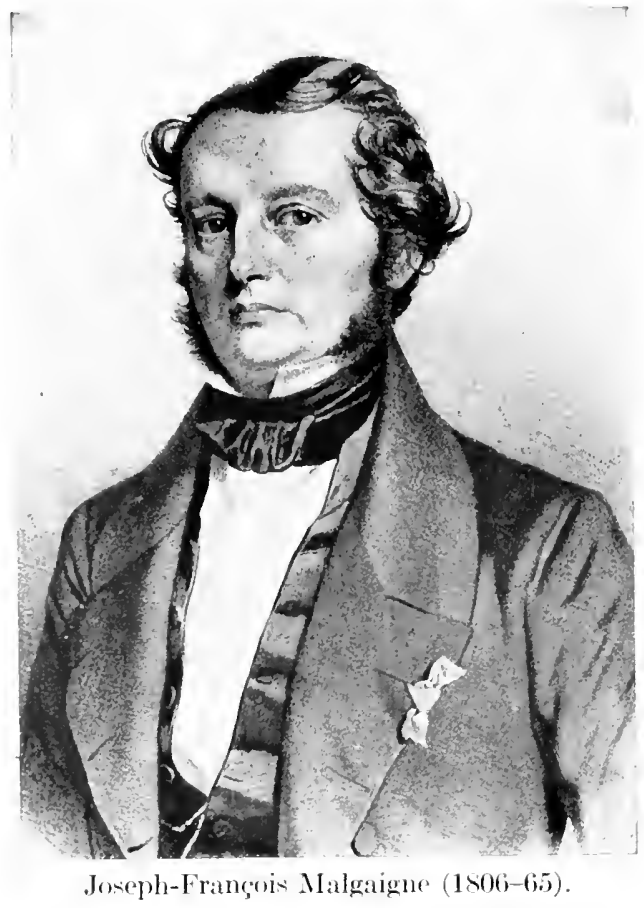

tion of Ambroise Paré, with a fine biography of the latter (1840). Malgajgne's Mamuel de médecine opératoire (1834) passed through seven editions and five translations, one of them Arabic. In practical surgery his name is associated with the hooks of his invention used in treating fracture of the patella, but he is perhaps best remembered by the critical and historical discourses which Billings classes "among the most delightful reading in surgical literature."

1 Velpeau: Traité des maladies du sein, Paris, 1854. 
Auguste Nélaton (1807-73), of Paris, who presided with Malgaigne at the Hôpital St. Louis, held the same unapproachable rank as an operator and teacher which Dupuytren had attained at an earlier period, but in personality he was the logical opposite of his self-seeking predecessor. He was modest, quiet, helpful, and friendly, generous to the unfortunate-in short, a gentleman. He invented a bullet-probe (first used in Caribaldi's case) and a valuable flexible rubber catheter (1860), and improved the treatment of nasopharyngeal tumors. In gynecology he is memorable as the first to describe pelvic (retro-uterine) hematocele (15.51-52), and

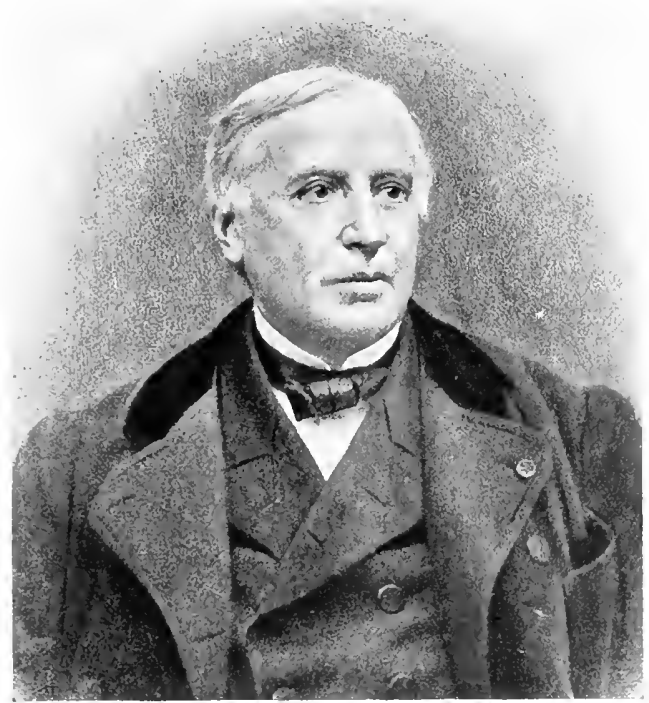

Auguste Nélaton $(1807-73)$.

he did most to establish ovariotomy in France. His principal work is his Eléments de pathologie chirurgicale (1S4t-59).

Paul Broca (1824-80), who was, in suecession, surgeon at st. Antoine, Ia Pitié, the Hôpital des Cliniques, and the Hôpital Necker, was the founder of the modern surgery of the brain and also of the modern French school of anthropology. In $1861^{1}$ he discovered that the third left frontal convolution of the brain is the center of articulate speech, a point which is now disputed, but which, in the first instance, undoubtedly led to mapping out the different centers of the brain for surgieal operations. Broca wat, in fact, the first to trephine for a cerebral abseess diagnosed by his

1 Broca: Bull. Soc, d'anthrop, de Paris, 1s61, ii, 235-23s, and Bull. Soc. anat, de Paris, 1861 , xxxvi, 330; 395. 
theory of localization of function. In conncetion with his disrovery, he introduced the term aphemia or "motor aphasia"

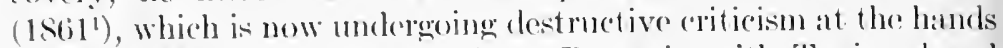
of Picrre Marie, In anthropology, Brocal is, with Topinard and Quatrefages, the erreatest name of modern France. He originated the modern methods of determining the rat io of the dimensions of the brain to those of the skull (craniometry), and to this end devised the oceipital crochet, a craniograph, and a goniometer, and

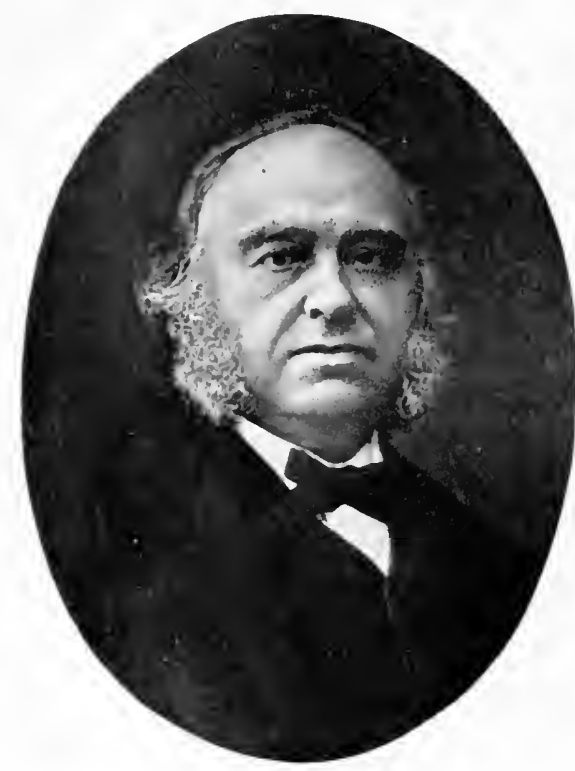

Paul Broca (1824-80). did much to standiurlize the measurements of bones and the classification of colors of the hair and skin. He opposed the theory that the different races were originally developed from several separate pairs of species, in his law of "eugenesis," which maintains that the different varieties of the genus Homo are, and always have been, fertile with each other. This drove the "polygenists" to their last resort, diversity of language. Broca is also credited with the aphorism: "I woutd rather bea transformed ape than a degenerate son of Ailam."

Among the isolated French eontributions of importance are Richerand's resection of the fifth and sixth ribs (1818); the introduction of lithotrity by Leroy d'Étiolles (1822), Civiale (1824), and Heurteloup (182431); Beclard's excision of the parotid $\left(1823^{2}\right)$; Gensoul's incision of the upper jiw (1826); Lembert's method of enterorrhaphy $\left(1826^{3}\right)$; Maisonneuve's hair ('atheter $\left(1845^{4}\right)$; Sédillot's introduction of gastrostomy, which he performed for the first time on November 13, 1S49 and Lallemant's method of autoplasty (1856).

Plaster-of-Paris bandages were introduced by Anthonius Mathijsen (1505-78), of Brabant, in 1852, and popularized by J. H. P. van de Loo.

${ }^{1}$ Broca: Bull. Soc. d'anthrop. de Paris, 1\$61, ii, 235-236, and Bull. Soc. anat, do Paris, 1S61, xxxvi, 332.

2 Béclard: Arch. gén. de méd., Paris, 1824, iv, 60-66.

${ }^{3}$ Lembert: Repert. gén. d'anat. "t physiol. path., Paris, 1S26, ii, 100$107,1 \mathrm{pl}$.

${ }_{4}^{4}$ Maisonneuve: Compt. rend. Acad. d. se., Paris, 1845, xx, 70-72.

5 Sédillot: Gaz. méd. de Strasbourg, 1849, ix, 366-377.

${ }^{6}$ Pravaz: Compt. rend. Acall d. se., Paris, 1853, xxxvi, 88-90. 
Among the prominent German surgeons of the period were Vincenz von Kern (1760-1829), professor at Vienna (180;-24), who simplified wound-dressings by using bandages moistened with plain water (first proposed by C'esare Magati in 1616) as a substitute for the salves and plasters then in vogue; Christian Lurlwig Mursinna (1744-1823), who was successively weaver, bath-keeper, barber's apprentice, and surgeon general of the Prussian Army (1787-1809); Conrad Joham Martin Langenbeck (1776-1851), professor of anatomy and surgery at Göttingen and surgeon general of the Hannoverian Army (1814), who devised the operation of iridocleisis for artificial pupil (1817), and attained such supreme

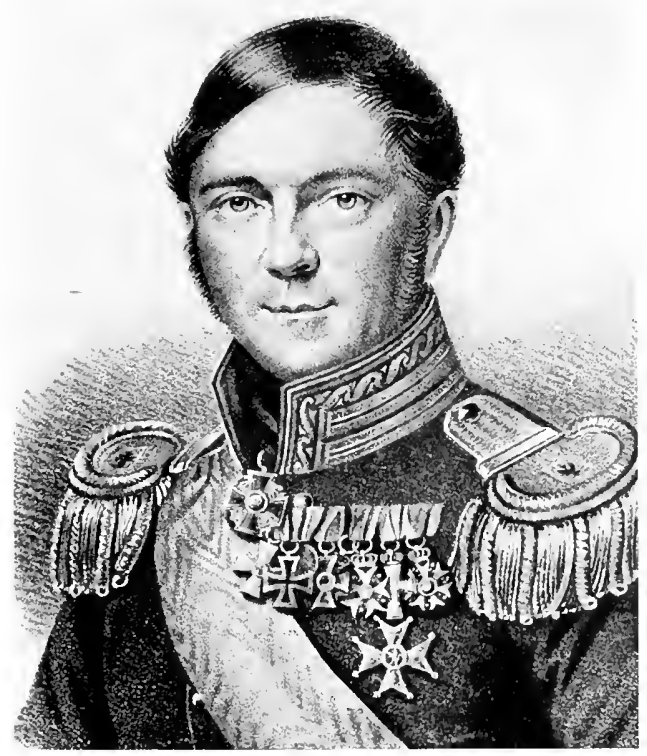

Carl Ferdinand von Graefe (1787-1840).

swiftness in operating that he is said to have amputated a shoulder while a colleague present was taking a pinch of smuff; and Max Joseph von Chelius (1794-1876), whose "Handbueh der Chirurgie" (1822-23) was the standard text-book in Germany until the middle of the century, and who, according to Baas, was "the only professor in Heidelberg who kept a carriage." The most important German surgeons before 1850 were Dieffenbach, the elder von Graefe, the younger Stromeyer, Langenbeck, and Custav Simon.

Carl Ferdinand von Graefe (1787-1840), of Warsaw, was one of the surgeons general in the German struggle for independence 
(1St;-15), having previously been profesior of surgery at the Eniversity of Berlin in 1810, resunning this position after the wirl. He was the founder of modern plastic surgery, devising the operation for congenital cleft-palate in $1816 .{ }^{1}$ In 1818 he introduced rhinoplasty (simultaneously with Bünger) and blepharoplisty (simulaneously with Dzondi). In the same year, he improvel the technic of Cesarean section and excised the lower jaw for the first time in Germany. He was also the first German surweon to ligate the innominate artery (1822), his pationt living sixty-eight days." His "Thinoplastik" (1818) was the first hand-

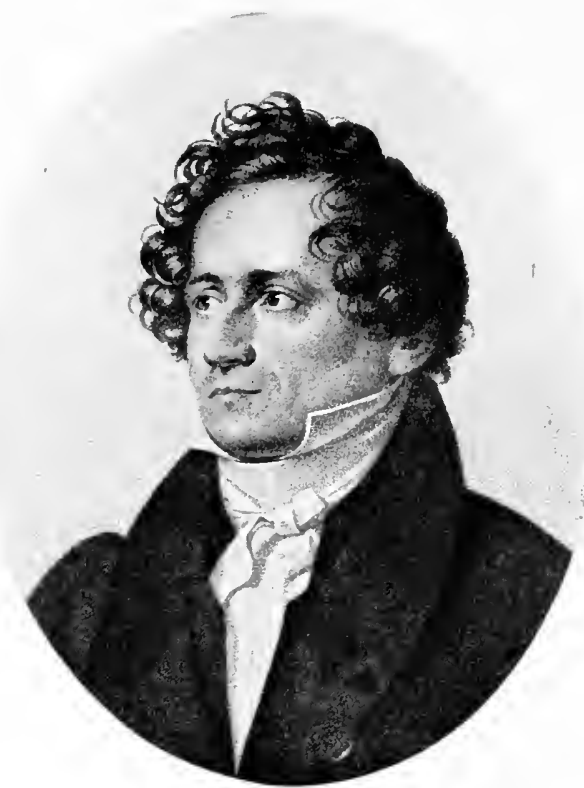

Johann Friedrich Dieffenbach (1792-1847).

ling of the theme of artificial nose-making after Tagliacozzi (1575) and Carpue (1816).

Johann Friedrich Dieffenbach (1792-1847), of Königsberg, also fought (as a rifleman) in the Cierman war for independence. His floctor's dissertation at Würzburg (1822), on regeneration and transplantation of tissucs, already shows his leaning toward plastic surgery. ${ }^{3}$ He was surgeon at the Charité (Berlin) in 1829, and, in

${ }^{1}$ von Graefe: Jour. f. Chir. u. Augenheilk., Berlin, 1S20, i, 1-54, 2 pl.

${ }^{2}$ London Med. and Phys. Jour., 1823, xlix, 475. 1822 .

${ }^{3}$ Dieffenbach: Nonnulla de regeneratione et transplantatione, Würzburg, 
1840, suceeded von Graefe as professor at the university. In 1829, following Stromeyer's proposal, he first treated strabismus by severing the tendons of the eye muscles (with suecess ${ }^{1}$ ).

This suceess perhaps led him to attempt the erroneous procedure of subcutaneous division of the lingual museles for stammering $\left(1841^{2}\right)$, which produeed many untoward results in his patients; but he got wonderful results in tenotomy, skin-grafting, and orthopedie surgery, and was a pioneer in transplantations and experimental surgery on animals, which were first essayed by John Hunter and Giuseppe Baronio $\left(1804^{3}\right)$. He wrote on treatment of urethral stricture by incision (1826); transfusion of blood (1828), bandaging (1829), nursing (1832), treatment of preternatural anus (1834), and urethral fistula (1836), and a great treative on operative surgery $\left(1845-48^{4}\right)$. He also made a brave attempt to treat vesicovaginal fistula by every known method, and left a elassic aceount of the sufferings entailed by the condition (1845).

Dieffenbach was a genial, humane, attractive man, and an admirable teacher, upholding the highest idleals of his profession. He maintained that the surgeon should be a many-sided Odysseus, full of native invention and resourees not to be found in books. All great surgeons, he says, are, or ought to be, clear thinkers, and therefore good writers.

Georg Friedrich Loulis Stromeyer (1804-76), of Hannover, professor at Erlangen, Munich, Freiburg, and Kiel,

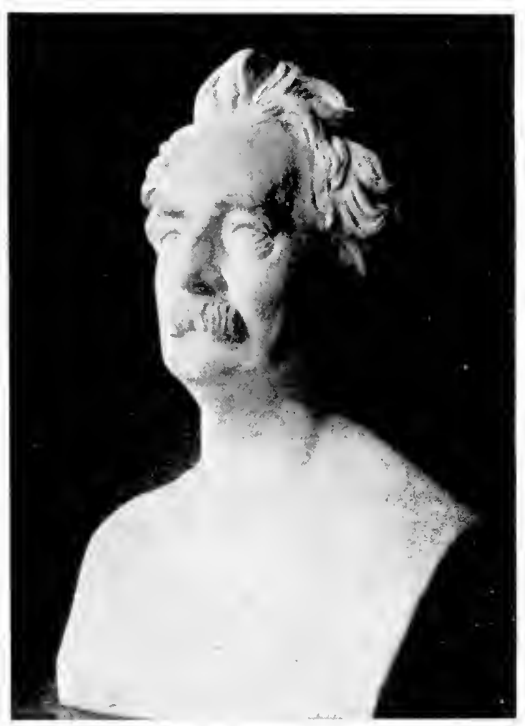

Georg Friedrich Louis Stromeyer $(1804-76)$. (New York Academy of Medicine.) and successively surgeon general of the Sehleswig-Holstein and Hannoverian armies, was the father of modern military surgery in Germany. He greatly extended the fields of conservative surgery of the joints and subeutaneous surgery. Stromever performed his first subeutaneous section of the tendo Achillis in $1831,{ }^{5}$ fifteen years after Delpech (1816), but if Delpech was the diseoverer, Stromeyer developed the field. He practically ereated the modern surgery

${ }^{1}$ Ueber das Sehielen, ete., Berlin, 1842.

${ }^{2}$ Die Heilung des Stotterns (ete.), Berlin, 1841.

${ }^{3} \mathrm{G}$. Baronio: Degli innesti animali, Milan, 1804.

4 Dieffenbach: Die operative Chirurgie, Leipzig, 1845-48.

${ }^{5}$ Stromeyer: Mag. f. d. ges. Heilk., Berl., 1833, xxxix, 195-218. 
of the locomotor system by applying subentaneous tenotomy to all deformitios of the body depending upon muscular defocts. He is one of the founders of orthopedies in recent times. His methods were introdued into England by Little, who established the Royal Orthopedic Hospital in London (1837), and published a standard Ireatise on deformities (1S53). Stromeyer's Maxims of WarSurgery (1S55) made an epoch in German military medicine. He Was a poet and wrote an attractive autobiography.

Bernhard von Langenbeck (1S10-87), the nephew of Conrad, succeded J)icfernbach at Berlin in 1847, and became the greatest

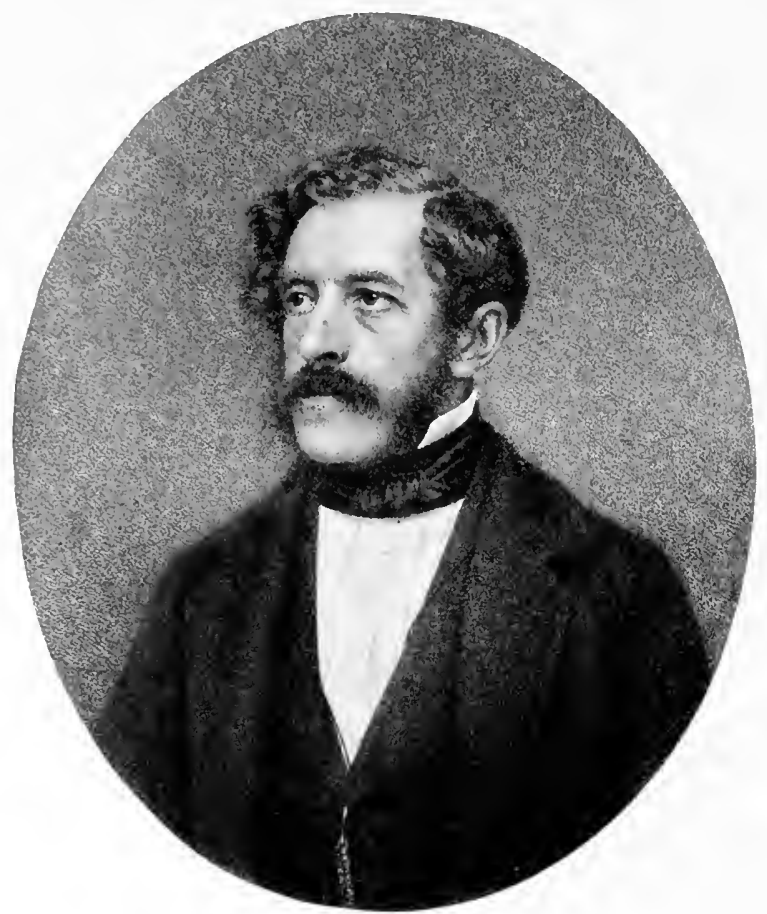

Bernhard von Langenberk (1810-87).

chinical surgeon and teacher of his day in Germany, having trained nearly every prominent operator up to the present time. In 1861 he started the Archiv für linische Chirurgie (known as Langenbeck's Archiv), and founded the German Society of Surgery, both of which have exerted a profound influence ever since. He has 21 operations credited to his name, of which the most important are his methods of excising the ankle, knee, hip, wrist, elbow, shoulder, and lower jaw, and of plastic surgery of the lip, palate, and nose. 
Gustav Simon (1824-76), of Darmstadt, professor at Rostock (1861) and Heidelherg (1867), was a highly original operator and the author of admirable monographs on the treatment of vesicovaginal fistula (1854), the excision of the spleen (1857'), on plastic surgery $\left(1868^{2}\right)$, and the surgery of the kidneys $\left(1871-76^{3}\right)$. He was the first in Europe to excise the kidney $\left(1869^{4}\right)$, but killed his second patient hy sepsis from a digital exploration on the twentyfirst day after the operation. The fatal result in Paul von Bruns'

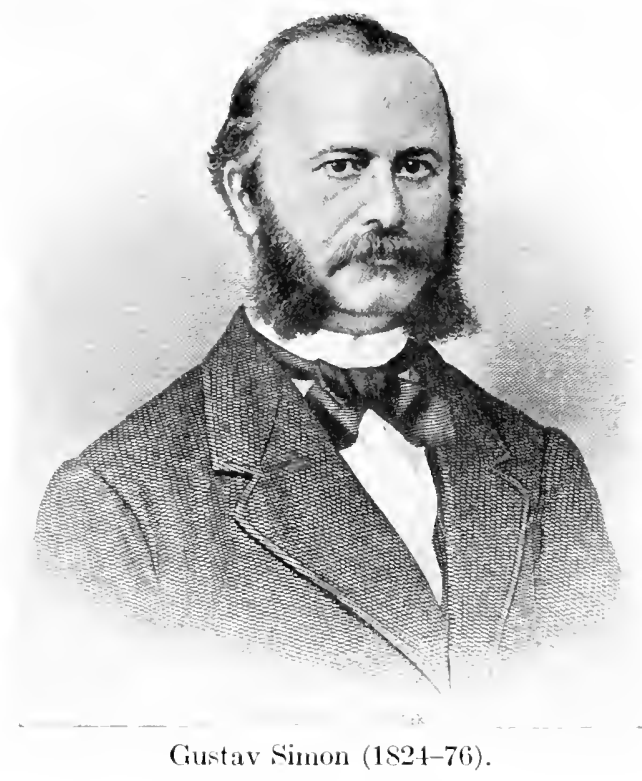

case of 1878 made an end of nephrectomy until antisepsis was firmly established.

Albrecht 'Theodor von Middeldorpf (1824-68), of Breslau, performed the first operations for gastric fistula (1859) and esophageal tumor, was a pioneer in the use of the galvanocautery (1854), and made important contributions on fractures and dislocations.

The greatest of Russian surgeons, and one of the greatest military surgeons of all time, was Nikolai Ivanovich Pirogoff

1 Simon: Die Exstirpation der Milz am Mensehen, Giessen, 1857.

2 Beiträge zur plastisehen Chirurgie, Prague, 1868.

${ }^{3}$ Chirurgie der Nieren, Erlangen, 1871-76.

${ }^{4}$ Deutsche Klinik, Berl., 1870, xxii, 137. 
(1S10-\$1), who, like Pare and Hunter, had a remarkable career of self-elevelopment. Ciaduating in 1832, he studied for two years at Berlin and foittingen, where he was disgusted with the small attention paid to anatomy. Langenbeck was, in his estimation, the only man who was well informed on the subject. Upon returning to Russia, he taught at Dorpat for five years, and, in 1840 , was appointed professor of surgery at the Medico-Chirurgical Academy at St. Petersburg. In his forty-five years of service here he introduced many important reforms, among others the teaching of applied topographic anatomy, for the first time in Russia, to which end

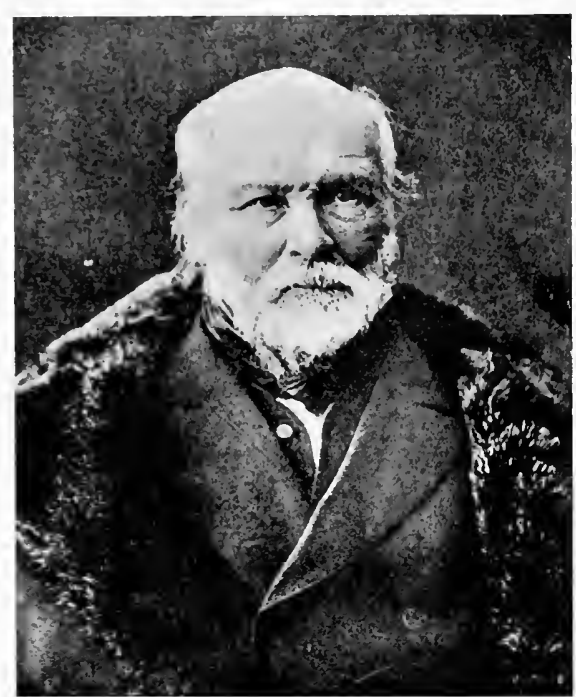

Nikolai Ivanovich Pirogoff (1810-81). he invited Hyrtl's pupil, Gruber, from Vienna. He made 11,000 postmortems, among them 800 of cholera victims in 1848 . He saw a great deal of military surwery, serving in the field during the camprigns in the Caucasus (1847) and the (rinea (1854), and also reported ipon the Franco-Prussian and Russo-'Turkish campaigns. $\mathrm{He}$ served fourtcen months in and around Sebastopol, and, in trenches and tents, witnessed all the horrors of pycmia, hospital gangrene, erysipelas, and purulent edema. Here he got himself into hot water with the governmental authorities

by his sharp criticism of the bad management of the campaign, his attempts at segregation and other improvements, and was forced to resign his professorship. His experiences with sepsis led him to define war as a "traumatic epidemic." Through the aid of the Grand Duchess Helena Pavlovna, he introduced female nursing of the wounded in the Crimea, and, all his life, he was a warm advocate of freedom and higher education for women. In 1847 he was already using ether anesthesia in his surgical practice. ${ }^{1}$ He devoted his latter days to advaneing the cause of medical education in his native country, in which he was again subjected to bitter enmity and persecution at the hands of the official and military

${ }^{1}$ Pirogoff: Recherches pratiques et physiologiques sur l'éthérisation, St. Petersburg, 1817 . 
tchinovniks. Pirogoff is, in the esteem of cultivated Russians, the most important figure in their medical history. He is noted for his method of complete osteoplastic amputation of the foot $\left(18.54^{1}\right)$; for his great atlas of 220 plates $\left(1851-54^{2}\right)$, in which frozen sections were first utilized on a grand seale in anatomic illustration ${ }^{3}$; and for his treatise on military surgery $\left(1864^{4}\right)$, in which he holds large hospitals responsible for the spread of epidemic diseases and recommends small, barrack-like pavilions, such as were suggested by his Crimean experiences. In speed, dexterity, and strength of hand, Pirogoff, the operator, was like those Slavic virtuosi of music whose execution is the astonishment of our times. The usual portraits of the great surgeon in his old age represent a broadbrowed, serious face of venerable aspect, strongly resembling two other great Russians, Glinka and Turgenieff. In relation to his country, we may apply to him the exquisite tribute which Henry James paid to the latter: "His large nature was filled with the love of justice but he was also of the stuff of which glories are made."

American surgery in the pre-Listerian period was distinguished principally by a great deal of bold operating on the vascular and osseous systems, by the foundation of modern operative gynecology at the

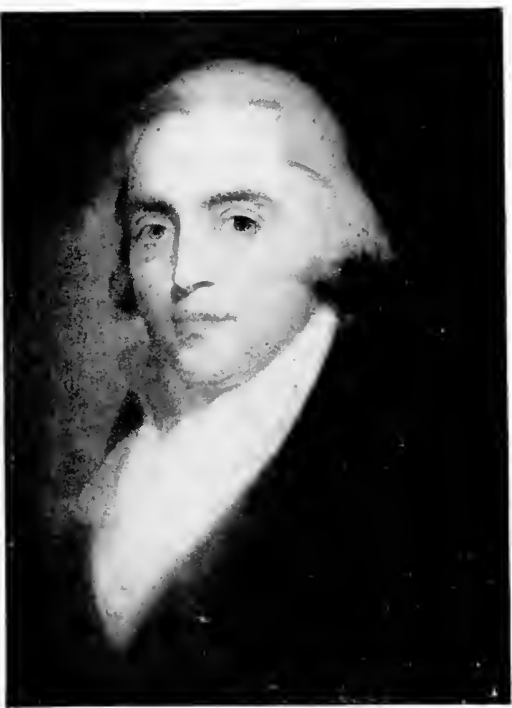

Philip Syng Physick (1768-1837). From an oil-painting by Thomas Sully. (Surgeon General's Library.) hands of McDowell and Sims, and by the permanent introduction of surgical anesthesia. Its leading representatives in this period were Physick, the two Warrens, Post, Mott, Gibson, the two Smiths, Willard Parker, McDowell, and Sims.

Philip Syng Physick (1768-1837), of Philadelphia, a pupil of

1 Voyenno Med. Jour., St. Petersburg, 1854, lxiii, 2. sect., \$3-100.

2 Anatome topographica sectionibus per corpus humanum congelatum triplice direetione duct is illust rata, St. Petersburg, 1851-54.

${ }^{3}$ Frozen sections in anatomy were first used by Pieter de Riemer (17601831) in his "Afbeeldingen" (The Hague, 1818) and later by E. Weber (1S36) and Huschke (1844).

${ }^{4}$ Pirogoff: Grundzüge der allgemeinen Kriegsehirurgie, Leipzig, 1864. 
John Hunter's, and sometimes ealled the Father of American Surgery, was an Edinburgh graduate of 1792 , surgeon to the Pennsytvania Hospital in 1794, and professor of surgery in the University of Pennsylvania (1805-1S). He wrote nothing of consequenceall his teaching was preserved in the treatise on surgery of his nephew, John Syng Dorsey (1813).

He is now remembered principally by eertain procedures of importance in their day, such as the introduction of absorbable kid and buckskin ligatures $\left(11^{1}\right)$, the use of the seton in ununited fracture $\left(1822^{2}\right)$, an operation for artificial anus $\left(1826^{3}\right)$, the advocation of rest in hip)-joint disease $\left(1830^{4}\right)$, and the invention of the tonsillotome $\left(1828^{5}\right)$. His modification of Desault's splint for fracture of the femur is still in use. He seems to have been the first to describe diverticula of the rectum $\left(1836^{6}\right)$, and he was the first American to wash out the stomach with a syringe and tube in a case of poisoning $\left(1802^{7}\right)$.

John Warren (1753-1815), of Roxbury, Massachusetts, rendered distinguished army service in the Revolution and was founder and the first professor of anatomy and surgery of the Harvard Medical School (1783). He was seventh president of the Massachusetts Medical Society, an office which he held until his death (1804-15). He amputated at the shoulder-joint in $1781,{ }^{8}$ and excised the parotid gland in $1804 .^{9}$ His son, John Collins Warren (1778-1856), of Boston, was a pupil of Astley Cooper and Dupuytren, and succeeded to his father's professorship in 1815 . He was a pioneer in the excision of bones and joints, such as the hyoid (1804) and the elbow (1834), introduced the operation of staphylorrhaphy for fissure of the soft palate in $1828,{ }^{10}$ and was the first in this country to operate for strangulated hernia. He was the founder of the Massachusetts General Hospital (1811) and of the Warren Museum, and he practically introduced ether anesthesia in surgery (1847). His prineipal work is his Surgical Observations on Tumors (1837).

Nathan Smith (1762-1829), of Rehoboth, Massachusetts, a medical graduate of Harvard (1790), studied also in the Scotch and English schools, commenced practice at Cornish, N. H., and

${ }^{1}$ Physick: Eclect. Repertory, Phila., 1816, vi, 389.

${ }^{2}$ Phila. Jour. Med. and Phys. Sc., 1822, v, 116-118.

${ }^{3}$ Ibid., 1826, xiii, 199-202.

${ }^{4}$ Am. Jour. Med. Sc., Phila., 1830, vii, 299-308, 1 pl.

'Itid., 1828, ii, 116.

${ }^{6}$ Am. Cycl. Pract. Med. and Surg,, Phila., 1836, ii, 123-136.

${ }^{7}$ Eclect. Repcrtory, Phila., 1812-13, iii, 111; 381. Matthews: Med. Recorder, Phila., 1826, ix, 825-827. Physick acknowledges the priority of Monro secundus in the invention of a similar instrument (1767).

8 Warren: Boston Med. and Surg. Jour., 1839, xx, 210.

${ }^{9}$ In J. C. Warren: Surgical observations on tumors, Boston, 1S37, p. 287.

${ }^{10} \mathrm{Am}$. Jour. Med. Sc., Phila., 1s28, iii, 1-3, $1 \mathrm{pl}$. 
in 1798 became a professor in Dartmouth College, filling, as O. W. Holnes said, not a chair, but "a whole settee of professorships," viz., anatony, surgery, chemistry, and practice.

For fourteen years Smith labored at building up the Dartmouth school, when, in 1821, he was asked to establish a medical department at Yale, with the same multifarious duties. This accomplished, in the faee of many obstacles, he did a similar good turn for Bowdoin College (1820) and later for the University of Vermont. He was more the great orginizer and teacher than a writer on medicine, but his essay on typhus fever (1824) and his observations on necrosis (1827) are still memorable. An able and successful operator, particularly in lithotomy, he performed the second ovariotomy in the United States (July 25, 1821), amputated at the knee-joint (1825), and did the first staphylorrhaphy.

The pioneer surgeon of the middle West was Daniel Brainerd (1812-66), of New York, a graduate of Jefferson Medical College (1812-66), who settled in Chicago in 1835, secured a charter for Rush Medieal College (1837), which, after some Parisian study, he organized in 1843 , occupying the chair of surgery until his death. He invented the bone-drill, and made several good contributions to surgery, notably a prize essay of 1854 on a new method of treating fractures and deformities.

Wright Post (1766-1822), of Long Island, N. Y., was the first in America to ligate the femoral artery successfully (for popliteal aneurysm) according to John Hunter's method $\left(1796^{1}\right)$, and the second to ligate the external iliac sucessfully $\left(1814^{2}\right)$, having been preceded by Dorsey in $1811 .^{3}$ Post was also the first surgeon to tie the primitive carotid in its continuity with sucess $\left(1813^{4}\right)$, an operation which he sucessfully repeated in $1816,{ }^{5}$ and the subclavian artery was first successfully ligated outside the sealeni by him in $1817 .^{6}$

Valentine Mott (1785-1865), of Long Island, was a pupil of Astley Cooper, and, like him, a great pioneer in vascular surgery. The innominate artery was ligated for the first time in the history of surgery by Mott in 1818. the first successful operation being that of Smyth, of New Orleans, in 1864.

In addition, Mott has to his eredit the remarkable reeord of successfully ligating the common iliac at its origin $\left(1827^{8}\right)$, the carotid for subclavian an-

' Post: Am. Med. and Phil. Register, N. Y., 1814, iv, 452.

${ }^{2}$ Post: Ibid., 1813-14, iv, 443-153. Also in: Med. Repository, N. Y., 1815 , n. s., ii, $196-199$.

${ }^{3}$ Dorsey: Eclect. Repertory, Phili., 1811, ii, 111-115.

${ }^{4}$ Post: Am. Med. and Phil. Register, N. Y., 1S14, iv, 366-377

${ }^{5}$ Post: Med. Repository, N. Y., 1\$17, n. s., iii, 412.

${ }^{6}$ Post: Tr. Phys. Med. Soc., N. Y., 1S17, i, 387-394.

${ }^{7}$ Mott: Med. and Surg. Register, N. Y., 1818, i, 9-54.

${ }^{8}$ Phila. Jour. Med. and Phys. Sc., 1827, xiv, 176-181. 
("urysm (1529), the rarotid for anastomosing aneurysu in a three-months'

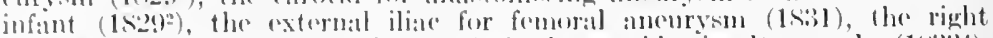

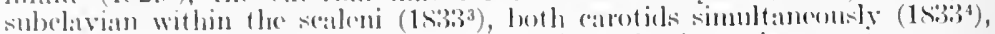
and the right internal ilial $\left(1 \$ 37^{5}\right)$. Besides the innominate antery, salys

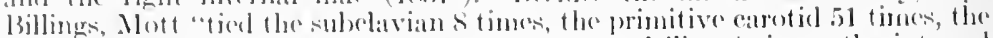

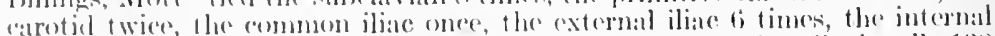
iliac wiee, the fomoral 57 times, and the pupliteal to times"-in all, 138 ligations of the great vessels for anourysm. Mott was also a boll and successful operator on the benes and joints. He excised the right sicle of the

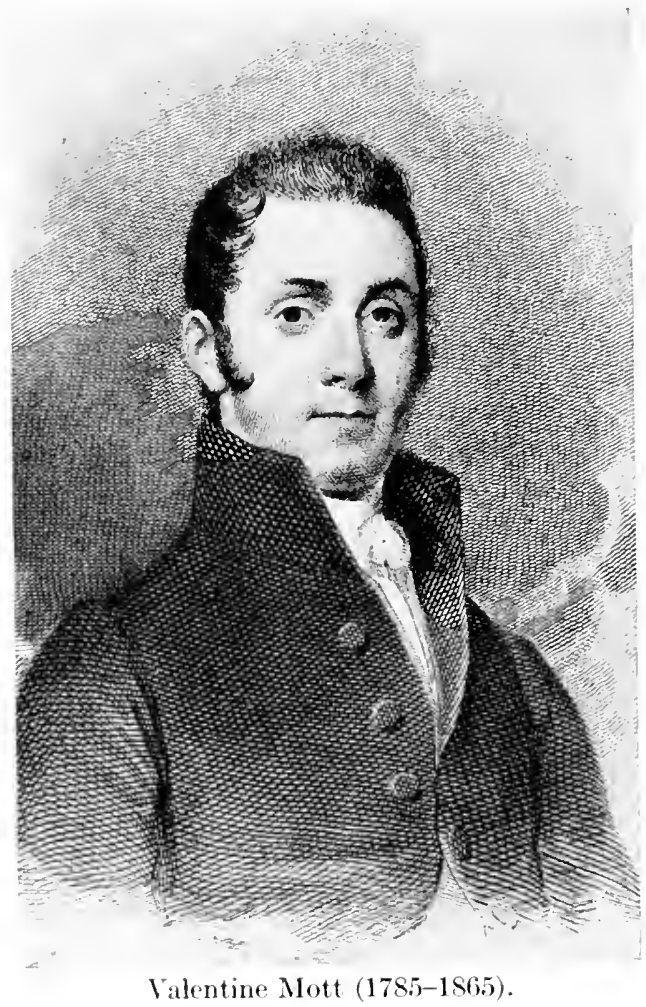

lower jaw, after tying the carotid artery, in $1821^{6}$; successfully amputated at the hip-joint in $1824^{7}$; excised the left clavicle for osteosarcoma in $1828,{ }^{8}$

1 Am. Jour. Med. Sc., Phila., 1829, v, 297; 1830, vi, 532.

2 Ibid., 1829, v, 255; 1830 , vii, 271.

${ }^{3}$ Ibid., 1831, viii, 393-397.

${ }^{4}$ Ibrid., 1833, xii, 354.

5 Ibid., 1837, $\mathrm{xx}, 13-15$.

${ }^{6}$ New York Med. and Phys. Jour., 1822, i, 385.

7 Phila. Jour. Med. and Phys. Sc., 1827, xjy, 101-104.

8 Mott: Am. Jour. Marl. Sce, Phila., 182s, iii, 100-108. 
and removed a large fibrous growth from the nostril by dividing the nasal and maxillary bones $\left(15+1^{1}\right)$.

In connection with the work of l'ost and Mott, it is proper to montion here some other early ligations of arteries by American surgeons in thes sume field. The primitive earotid artery was suecessully ligated for primary hemorrhage by Mason Fiteh Cogswell (1761-15:30), of Connecticut, in 180:3, ${ }^{2}$ and, for secomblary hemorrhage by Amos 'Twitchell (17\$1-1850), of New Hampshire, in 1807.3 eight months prior to Nir Astley Cooper's ease. Both primitive carotids were first sucesssully tied in continuty, within a month's interval, by James Macgill, of Marylanel, in $1823,{ }^{4}$ to be followed by Reuben 1). Mlussey in 1827 and Mott in 1833. The primitive and internal carotids wore first simultaneonsly tied by (iurdon Buck $(1807-77)$, of New York City, in $1845^{5}$; and John Mlurray Carnochan (1S17-S7), of Savannah, Georgia, ligated the carotid on both sides for elephantiasis in $1867 .{ }^{6}$ Carnochan was also the first to rxcise the superior maxillary nerve (inchuding Meckel's ganglon) for facial neuralgia (18587). John Kearny Rodgers (1793-1851), of New York City, a pupil of IVright Post, was the first to tie the lelt subelavian artery within the scaleni for aneurysm $\left(1845^{8}\right)$, but with fatal result, the first successful case being that of Professor $\mathbb{W}^{5}$. S. Halsted, of Johns Hopkins, in $1892 .{ }^{9}$ William Gibson (17SS-1S6S), of Baltimore, Maryland, was the first American surgeon to tie the rommon iliae artery $\left(1812^{10}\right)$. In the preceding year, John syng Dorsey (17S3-1818) had suecessfully tied the external iliac, ${ }^{11}$ to be followed by Post (1S14), Horatio Gates Jameson (1S212), and Edward Peace (184113). The internal iliae was successfully tied by S. Pomeroy White in 182714; the femoral, by Henry M. Onderdomk (181315); David L. Robers (1824), and Carnochan (1851); the gluteal artery, by John B. Davilge, of Baltimore, and George McClellan, of Philadelphia; the arta, for the first time after vir Astley Cooper, by Hunter MeGuire in $1868 .{ }^{16}$ In addition, Gurdon Buck (1807-77), of New York, suecessfully ligated the femoral, pofmela, external and common iline arteries for femoral aneurysm in 185877; Willard Parker (1800-84), of Francistown, N. Y., ligated the left subclavian inside the sealenus, together with the common carotid and vertebral arteries, for subelavian aneurysm in 1864,18 the patient dying on the forty-second lay; and Andrew Woods Snyth (1833), of New Orleans, first successfully ligated the innominate artery, together with the common carotid, and subsequently the right vertebral, for 360 .

1 Mott: Am. Jour. Med. Sce., Phila., 1842, n. s., iii, 257; 1843, v, s7.

${ }^{2}$ Cogswell: New Engl. Jour. Med. and Surg., Bost., 1824, xiii, 357-

3 'Twitehell: New Engl. Quart. Jour. Med. and Surg., Bost., 1842-43, i, $158-193$.

${ }^{4}$ Macgill: New York Med. and Phys. Jour., 1825, iv, 576.

${ }^{5}$ Buek: New York Merl. Times, 1855-56, v, 37-12.

${ }^{6}$ Carnochan: Am. Jour. Med. Sc., Phila., 1S67, n. s., liv, 109-115.

${ }^{7}$ Carnochan: Ibid., 185s, n. s., xxxv, 134-143.

8 Rorlgers: Am. Jour. Med. Sc., Phila., 1846, n. s., ix, 541.

${ }^{9}$ Halsted: Johns Hopkins Hosp. Bull., Balt., 1892, iii, 93.

${ }^{10}$ Gibson: Am. Med. Recorder, Phila., 1820, iii, 1s.j-193, 2 pl.

11 Dorsey: Ecleet. Repertory, Phila., 1S11, ii, 111-115.

12 Jameson: Am. Med. Recorder, Phila., 1S22, v, 119-124.

13 Peace: Med. Exam., Phila., 1842, n. s., i, 225-22s.

14 White: Am. Jour. Med. Sc., Phila., 1827, i, 304-306.

15 Onderdonk: Am. Med. and Phil. Register, N. Y., 1S14, iv, 176.

${ }^{16}$ McGuire: Am. Jour. Med. Se., Phila., 1S6S, n. s., lvi, 415-419.

${ }^{17}$ Buck: New York Med. Jour., 18:5, 3 s., v, 30.j-311.

18 Parker: Am. Jour. Med. Sc., Phila., 1\$64, n. ‥ xlvii, 562. 
subelavian aneurysm in $186.4,^{1}$ exhibiting his patient alive in 1869 , the specimen being now in the L. S. Army Medieal Musemm.

Of early American operations upon the bones and joints, we may montion the first amputation of the hip-joint in the United States, by Walter Brashear $(1760-1860)$, of Maryland, in 1s06"; the sucessful excision of part of the lower jaw, by William Itenry Deadrick (1773-1sis), of Winchester, Va., in 18103; the first suecessful excision of the elavicle, by Charles MeCreary (1785-1826), of Kintucky, in 1s13"; the excision of the superior maxilli, by I Ioratio Gates

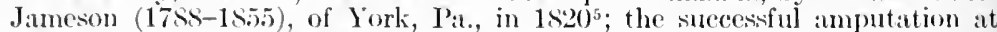
the elbow-joint, by James Mamn, U.S. Army, in $1821^{6}$; an exeision of the fifth and sixth ribs, with a portion of gangrenous lung, by Milton Antony (17S91839), of Georgia $\left(1821^{7}\right)$; excision of nearly the whole of both upper jaws, by Darvid L. Rogers, of New York, in $1824^{8}$; amputation at the knee-joint, by Nathan Smith (1762-1S29), of Massachusetts, in 1824; osteotomy for ankylosis of the hip-joint, by John Rhea Barton (179.1-1871), of Lancuster, Pa., in $1826^{10}$; successful wiring of an ununited fracture of the humerus (182711), by J. K. Rodgers (1793-1851), of New York City; excision of the cocevx, by Josiah Clark Nott (1804-73), of Columbia, S. C., in 183212; excision of the elbow-joint, by John Collins Warren (1778-1856), of Massachusetts, in 183413; the interseapular-thoracic amputation, by Dixi Crosby (1801-73), of New Hampshire, in $1836^{14}$; and, in two stages, by Reuben Dimond Musiey (181882), of New Hampshire, in 1831-3715; excision of the olecranon process, by Gurdon Buck (1807-77), of New York City, in 184216; the Fergusson operation for fissure of the hard and soft palates, by Jonathan Mason Warren (1811-67), of Boston, in $1842^{17}$; S. D. Gross's amputation at the ankle-joint in 1851' Bigelow's exeision of the hip-joint $\left(185^{2} 2^{19}\right)$; exsection of the ulna $\left(1853^{20}\right.$, ) the radius (185.21), and the os ealeis (185722), by John Murray Carnochan (1817-

1 Smyth: Am. Jour. Med. Sc., Phila., 1866, n. s., lii, 280-282. (Exhibition of living patient.) New Orleans Jour. Merl., 1869, xxii, 464-469. Repeated by J. Lewtas, of Murdan Hospital, Punjab (Brit. Med. Jour., Lond., 1889, ii, 312 ).

${ }^{2}$ Brashear: Tr. Kentucky Med. Soc., 1852, Frankfort, 1853, ii, 265.

${ }^{3}$ Deadrick: Am. Med. Recorder, Phila., 1823, vi, 516.

${ }^{4}$ McCreary: Tr. Kentucky Med. Soc., 1852, Frankfort, 1S53, ii, 276.

5 Jameson: Am. Med."Recorder, Phila., 1821, iv, 221-230, 1 pl.

${ }^{6}$ Mann: Med. Repository, New York, 1822, n. s., vii, pp. 17-19.

${ }^{7}$ Antony: Phila. Jour. Med. and Phys. Sc., 1823, vi, 108-117, 1 pl.

${ }^{8}$ Rogers: New York Med. and Phys. Jour., 1824, iii, 301-303.

${ }^{9}$ Smith: Am. Med. Rev. and Jour., Phila., 1825, ii, 370.

${ }^{10}$ Barton: North Amer. Med. and Surg. Jour., 1826, iii, 279-292; 400, 1 pl.

${ }^{11}$ Rodgers: New York Med. and Phys. Jour., 1827, vi, 521-523.

12 Nott: New Orleans Med. Jour., 1844-45, i, 58-60. p. 69 .

${ }^{13}$ J. C. Warren: In Hodges's (J. M.) Excision of Joints, Boston, 1861,

${ }^{14}$ Crosby: Med. Record, N. Y., 1S75, x, 753-755. (Crosby was preceded by the English naval surgeon, Ralph Cuming, in 1808.)

${ }^{15}$ Mussey: Am. Jour. Med. Sc., Phila., 1837, xxi, 390-394.

${ }^{16}$ Buck: Ibid., 1843, n. s., v, 297-301.

I7 J. M. Warren: New Engl. Quart. Jour. Med. and Surg., Bost., 1842-43, i, 538-547.

${ }^{18}$ Gross: cited on p. 457 of Am. Jour. Med. Sc., Phila., 1S76, n. s., lxxi.

${ }^{19}$ Bigelow: Am. Jour. Med. Sc., Phila., 1852, xxiv, 90.

${ }^{20}$ Carnochan: Am. Med. Monthly, N. Y., 1854, i, 180-1S8.

${ }^{21}$ Carnochan: Am. Jour. Med. Sc., Phila., 1868, n. s., xxxv, 363-370.

${ }^{22}$ Carnochan: Am. Med. Gaz., N. Y., 1857, viii, 321-323. 
S7), of Savannah, Ga., and Sayre's resection of the hip for ankylosis (185.51). In 1836 Paul Fitzsinmons Eve (1806-77), of Georgia, removed a large fibrous polyp from the base of the cranium, ${ }^{2}$ and, in 1850, William Detmold (1808-94) opened the lateral sinus of the brain for abseess, ${ }^{3}$ the report of which operation Virchow treated with scornful skeptieism. Carmochan's three eases of excision of the fifth nerve for neuralgia $\left(1858^{4}\right)$ were followed by the ingenioms and sucessful method of Joseph Pancoast (180.5-82), of New Jersey, in 1872, 5 who was also the first to perform a suecessful plastic operation for exstrophy of the bladder in February, 1858. ${ }^{6}$ This operation was repeated with suceess upon the female bladder by Daniel Ayres, of Brooklyn, N. Y., in November, 1858.7 Cystotomy for inflammation and rupture of the bladder was first performed $\left(1846-54^{8}\right)$ by Willard Parker (1800-84), of Francistown, N. Y., who was also the first, after Hancock, of London (1848), to operate for appendieitis $\left(1864^{9}\right)$, and tied the subelavian artery five times. In lithotomy, Benjamin Winslow Dudley (17S5-1S70) was especially successful, having performed this operation 225 times with scaree a death. Next to Dudley, Physick is said to have cut for stone oftener than any other Ameriean surgeon, and his removal of over a thousand caleuli from Chief Justice Marshall is a famous early case. The kidney was first exeised (before Gustav Simon) by Erastus Bradley Wolcott (1804-80), of Benton, N. Y., in 1861.10 John Stough Bobbs (1809-70), of Pennsylvania German deseent, was the first to perform cholecystotomy for gall-stones (186811), in which he was followed by Marion Sims $\left(187 \mathrm{~S}^{12}\right)$. Among the special procedures introduced by American surgeons in this period are Nathan Smith's method of treating necrosis of bones

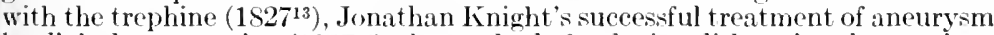
by digital compression $\left(1 S 47^{14}\right)$, the methor of redueing dislocat ions by manipulation, without weights or pulleys, introduced by William W. Reid, of Rochester, New York, in his classic papers of $1851-55,15$ based upon dissections and experiments; the treatment of fractures of the femur by Nathan Ryno Smith's anterior splint $\left(1860^{16}\right)$, and by the weight and pulley apparatus of Gurdon Buck (Buck's extension, 1861 ${ }^{17}$ ).

The Civil War in the United States (1861-65) brought forth the remarkable Medical and Surgical History of the War of the Rebellion (1870-88), by Joseph Janvier Woodward, Charles Smart, George A. Otis, and David L. Huntington, a splendid eollection of ease listories and pathologic reports, embellished with fine plates, and, altogether, a work that is unique in the an-

1 Sayre: New York Jour. Med., 18.55, n. s., xiv, 70-\$2.

${ }^{2}$ Eve: South. Med. and Surg. Jour., Augusta, 1836-37, i, 78-80.

${ }^{3}$ Detmold: Am. Jour. Med. Sc., Phila., 1850, xix, \$6-95.

${ }^{4}$ Carnochan: Am. Jour. Med. Sc., Phila., 1858, n. s., xxxv, 134-143.

${ }^{5}$ Pancoast: Phila. Med. Times, 1871-72, ii, 285-287.

${ }^{6}$ Pancoast: North Am. Med.-Chir. Rev., Phila., 1859, iii, p. 710 (bracketed case, reported by S. D. Gross).

7 Ayres: Am. Med. Gaz., N. Y., 1859, x, \$1-89, 2 pl.

${ }^{8}$ Parker: New York Jour. Med., 1851, n. s., vii, \$3-86. Also, Tr. Med. Soc., N. Y., 1867, 345-349.

${ }^{9}$ Parker: Med. Ree., New York, 1867, ii, 25-27.

${ }^{10}$ Wolcott: Med. and Surg. Reporter, Phili., 1861-62, vii, 126.

${ }^{11}$ Bobbs: Tr. Med. Soc. Indiana, 1S68, 68-73.

12 Sims: Richmond and Louisville Merl. Jour., 1878, xxvi, 1-21.

${ }^{13}$ N. Smith: Phila. Month. Jour. Med., 1\$27, i, 11; 66.

${ }^{14}$ Knight: Boston Med. and Surg. Jour., 184S, xxxviii, 293-296.

${ }^{15}$ Reid: Buffalo Med. Jour., 1851-52, vii, 129-143.

${ }^{16}$ N. R. Smith: Maryland and Virginia Med. and Surg. Jour., 1860, xiv, $1 ; 177$.

${ }^{17}$ Buck: Bull. New York Acad. Med., 1860-62, i, 181-188. 
nals of military medicint. It wats the subjeet of enthusiastic praise by Vir-

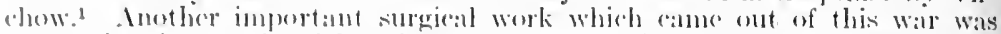
the study of "(iunsher lounds and Ohher lujuries of Nerves" (Istif) hy s.

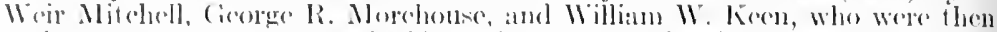
aleting as army surgeons at the 'Turner's Lame llospital in Philatelphia. This luok was the first full-dength study of the tramat ie neuroses, int ronlueing the use of maksige in these cases, and was the stanting-peint of Nitchetl's subse-

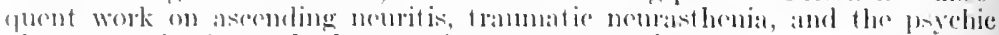
phenomena in those who have modergone amputation."

The only steressul amputation at the hip-joint during the Civil War was performed in a case of gunshot injury by Edwad shiphen, of Philadelphia. ${ }^{3}$

The carly history of the introluction of ether anesthesia in America has been the subject of rabid controversy, but the principal fats may be briefly stated as follows: The use of the soporific (lranght of Dioscorides and the soporific sponge of the Salemitans was unknown to Paré and died out in the seventeenth rentury, but it was sometimes eustomary for early nineteenth century surgeons to intoxicate the patient with alcohol or opium in eases recpuiring complete muscular relaxation, such as reduction of dislocations, ligations of large arteries, or operation for hernia. Hypnotism was also employed, and even suggestion, as where Dupuytren induced a convenient fainting spell by a brutal remark. In March, 1842, Dr. Crawford Williamson Long (1815-78), of Daniclsville, Ga., a graduate of the University of Pennsylvania (1839), having previously noted some aceidental anest hetic effects of ether, removed a small cystic tumor from the back of the neck of a pattient under its influence, and subsequently used it in other eases (1842-43), which have been amply certified and vouched for by resident physicians of his locality. ${ }^{4}$ But Long published no reports of his results, and, as Welch has admirably said, "we cannot assign to him any influence upon the historical development of our knowledge of surgical anesthesia or any share in its introduction to the world at large." Long had no one to take up and expand his work, as Lizars did for MeDowell's. In 1800 Sir Humphry Davy (1788-1829), of Penzance, England, experimented upon himself with nitrous oxide, and stated that "it may probably be used with advantage in surgical operations in which no great effusion of blood takes place." In 1844 Horace Wells $(1815-48)$, a dentist of Hartford, Connecticut, began to use nitrous oxide in dentistry, communicating his results to his friend and former partner, William Thomas Green Morton (1819-68), of Charlton,

1 Virchow: Dic Fortschritte der Kriegsheilkunde, Berlin, 1S74, p. 7.

2 Mitchell: Injuries to Nerves and their Consequences, Philadelphia, 1 s72.

${ }^{3}$ Surgeon Gencral's Office: Circular No. 7, Washington, 1567.

${ }^{4}$ The original documents in support of Long's claim have been effectively brought together by Dr. H. H. Young in Bull. Johns Hopkins Hosp., Balt., $1896-97$, viii, $174-184$. 
Massachusetts; but a fatal case caused Wells to withdraw from practice, and he eventually put an end to his life. Morton had, in the meantime, been studying medicine, having for his preceptor Dr. Charles 'T. Jackson, a chemist of ability, who pointed out to him the anesthetic effects of chloric ether, which he proceeded to apply in filling a tooth in July, 1844. Becoming interested, Morton pushed his inquiries further and subsequently learned from Jackson that sulphuric ether is also an anesthetic, whereupon he applied it at once in extracting a deeply rooted bicuspid tooth from one of his patients. Morton then visited Dr. John Collins Warren, of the Massachusetts General Hospital, and persuaded him to give the new anesthetic a trial in surgical procedure, without, however, disclosing the name of the drug. The operation took place at the hospital on October 16, 1846, the ease being a "congenital but superficial, vascular tumor, just below the jaw, on the left side of the neck." The tumor was dissected out by Warren in five minutes, and, as the patient came back to consciousness, he exclaimed, "Gentlemen, this is no humbug." The next day a large fatty tumor of the shoulder was removed by Hayward, with Morton as anesthetist, and again with success. On November 18, 1846, the discovery was announced to the world in a paper by Henry $J$. Bigelow, published in the Boston Medical and Surgical Journal. It was largely due to the high eharacter and repute of such men as Warren and Bigelow that ether anesthesia was taken up all over the world and became a permanent part of operative surgery, for Morton tried to patent the drug as "letheon" $\left(1846^{2}\right)$, squabbling with Jackson about their respective legal rights, and not announeing it as sulphuric ether until $1847 .{ }^{3}$ In the meanwhile, Robert Liston had amputated a thigh under ether in December, 1846; Syme took it up in Edinburgh (1847), and Pirogoff wrote a little manual on etherization (1847), based upon his Crimean experiences. The terms "anesthesia" and "anesthetic" were proposed by Oliver Wendell Holmes. On January 19, 1847, Sir James Young Simpson (1811-70), professor of obstetries at Edinburgh, used ether in midwifery practice for the first time in Great Britain, but on November 4, 1847, he was led to substitute chloroform, the discovery of Liebig, Guthrie, and Soubeiran, and was so much impressed with its advantages over ether in obstetric work that he published his results a week later. ${ }^{4}$ The effeet of these discoveries upon medieine and surgery was remarkable in many ways. First

${ }^{1}$ Boston Med. and Surg. Jour., 1846-47, xxxy, 309; 379.

2 T. W. Morton: Circular, Morton's letheon, Boston, 1846.

${ }^{3}$ Morton: Remarks on the proper mode of administering sulpliurie ether, etc., Boston, 1847.

${ }^{4}$ Sir J. Y. Simpson: Account of a new anesthetic agent, Edinburgl, $1 \leqslant 17$. 
of all, the surgeon, who, in pre-anesthet ic days, had to rush through an operation at lightning speed and ander great disadvantages oceasioned by the strugerles and distress of the patient, conld now take his time and therefore perform many new operations impossible nuder the old conclitions.' 'The days of sleight-of-hand feats were over, and the presticligitations of a Cheselden, a Iangenbeck, a Fergusson, or a Pirogoff gave place to careful, deliberate procedure. Again, a fow whiffs of chloroform enabled the lying-in woman to confront the ficree pangs of labor with greater case and security, and the obstetrician was able to work under the same advantages as the surgeon. Both surgeon and obstetrician specialized at need, as operative gynecologists, while laboratory workers in physiologr and other branches of experimental medicine could have no further misgivings about the sufferings of vivisected animals. In these ficlds ancsthesia was, in the memorable phrase of Weir Mitrhell, the "Death of Pain."

Operative gynecology, which had no special existence before the beginning of the nineteenth century, was largely the creation of a number of surgeons from the Southern States, and, as has been sugested, had its origin in the attempt to repair the crrors and omissions of hackwoods obstetries. In the eighteenth century, we find William Baynham (1749-1814), of Virginia, operated twice with success for extra-uterine pregnancy (1790-992), and, in the early part of the nineteenth, John King, of Edisto Island, South Carolina, performed a remarkable operation for abdominal pregnancy in $1816,{ }^{3}$ saving both mother and child by cutting through the walls of the vagina and applying the forceps, with abdominal pressure exerted upon the fetus from above. He afterward expanded his observations in a thin volume of 176 pages, published at Norwich, England, in 1818, entitled "An Analysis of the Subject of Extra-nterine Foctation, and of the Retroversion of the Gravid Uterus," the first book on the subject. The founders of operative grnecology were MeDowell and Sims.

Ephraim McDowell (1771-1830), of Virginia, was a pupil of John Bell, of Edinburgh, in 1793-94, and, through Bell's eloquent

1 "When I was a boy, surgeons operating upon the quick were pitted one against the other like runners on time. He was the best surgeon, both for patient and onlooker, who broke the three-minutes record in an amputation or a lithotomy. What place could there be in record-breaking operations for the fiddle-faddle of antiseptie preeautions? The obvious boon of immunity from pain, precious as it was, when we look beyond the individual, was less than the boon of time. With anestheties ended slapdash surgery; anesthesia, gave time for the theories of Pasteur and Lister to be adopted in practice." Sir Clifford Allbutt, Johns Hopkins Hosp. Bull., Balt., 189S, ix, p. 281.

2 Baynham: New York Med. and Phil. Rev., 1809, i, 160-170.

${ }^{3}$ King: Med. Repository, N. Y., 1817, n. s., iii, 3SS-394. 
teaching, was early impressed with the sad and hopeless fate of women afflicted with ovarian disease. In 1795 , he settled in the village of Danville, Kentucky, then one of the outposts of civilization, and soon became known as a skilful and successful surgeon, especially in lithotomy, which he performed 22 times in succession without losing a case. In 1)ecember, 1809, he performed his first ovariotomy upon Mrs. Crawford, a woman of forty-seven, who afterward lived to be seventy-eight. MeDowell reported this case with two others in April, 1817, 1 following these with a report of two more cases in $1819 .^{2}$ He performed the operation 13 times in his life, with a record of $S$ recoveries. Although he may have been preceded by Weyer's swineherd of the sixteenth century, and by the partial operation (tapping of cyst) by Houstoum, of Edinburgh, in 1701, yet one swallow does not make a summer, and ovariotomy had no. existence in surgical practice before McDowell produced his results and put it upon a permanent basis. He had sent a manuscript copy of his first paper to his old preceptor, John Bell, who was then ending his days in Italy and never saw it. It came, however, into the hands of Bell's pupil, John Lizars (17871860), of Edinburgh, who took up McDowell's work

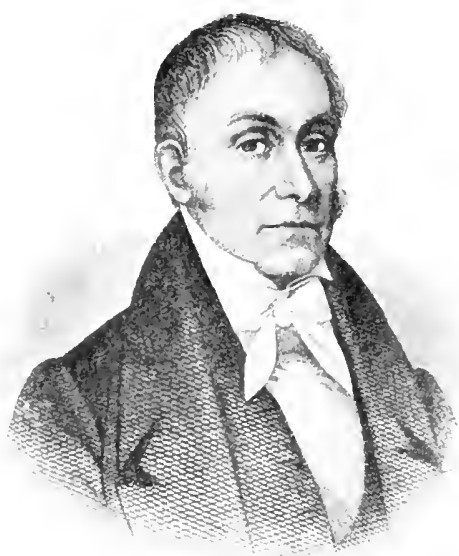

Ephraim MeDowell (1771-1830). with interest, publishing his results in his Observations on Extraction of Diseased Ovaria (1825), the next important contribution to the subject.

In the meantime, Dr. Nathan Smith had performed an ovariotomy at, Norwieh, Vermont, in July, $1821,{ }^{3}$ in ignorance of MeDowell's work, which was destined to reeeive its greatest impetus at the hands of the brothers, Joln

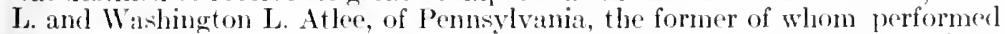
the operation 78 times, with 64 recoveries (1S43-83), and the latter 387 times (1844-78). Ovariotomy was firmly established in English surgery through the admirable labors of Charles Clay (1801-93), of Manchester, and sir sirener Wells (1818-97), of London. Benedikt Stilling did an ovariotomy by the extraperitoneal route in 1837 . The introluction of ovariotomy in Franee was 244.

${ }^{1}$ McDowell: Eclect. Repertory and Analyt. Rev., Phila., 1817, viii, 242-

${ }^{2}$ MeDowell: Ibid., 1819, ix, 546-553.

${ }^{3}$ Smith: Am. Med. Recorder, Phila., 1822, v, 124-126. 


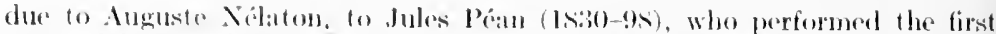
suecessful operation in Paris (ISti-1), and to the Alsatian surgeon Eugine Koeberté (1S゙L-1915), who performed his first ovariotomies on June 2 and Septrmber 29$), 18(i 2.1$

Before the time of Sims, mueh important work of a seattered charaeter was done in Europe and Ameriea, notibly Osiander's s' cases of excision of the portio for eancer (1,0)1-8"2), C. J. M. Laingenberek's vaginal hysterectomy for caneer (15133), which wats followed by the cases of J. N. Siuter (1522) and J.-C.-A. Récamier (1829); Ritgen's case of gistro-elyt tootomy (1521 operation for ruptured perineum $\left(1834^{5}\right)$; Willian Camploll's "Nemoir on Extra-uterine Gestation" (1840); Recamier's invention of the speculum plein et brisé $\left(1842^{6}\right)$, the simultaneous invention of speeial uterine sounds, in 1843 , by lluguier, of P'aris, Kiwisch, of Praguc, and sir James Young Simpson (is11-70), of Edinburgh; Heath's abdominal seetion for fibroids (1843), Bennett's treatise on Inflammation of the C'erus (1S45); C. D. Meigs' Females and their Diseases (1819); 'Tilt on Orarian Inflammetion (1850); Nélaton's description of pelvic henatecele $\left(1851-52^{8}\right)$; Emil Noeggeratlis operation of epicystotomy $\left(1853^{9}\right)$, and Daniel Ayres's plastic operation for congenital exstrophy of the fentale bladder $\left(1859^{10}\right)$. In 1836 , Miehaëlis, of Kiet, reported the eeletrated case of Frau Adametz, ujon whom four Cesarean sections had been suecessively performed, his own operation being as successful as the rest"1 ; and, in Ameriea, John Lambert Richmond performed the first Cesirean section at Newtown, Ohio, on April 22, 1827.22 François Prevost (1764-1842), of Donaldsonville, Louisiana, performed the operation four times prior to 1832,13 with three successful cases; and William Gibson, of Baltimore, performed the Cesarean operation twiee with suceess upon the same patient $\left(1835-38^{14}\right)$, who lived for fifty years after her first experience. Myomectomy for fibroid tumors of the uterus was performed twice with success by Washington L. Atlee in $1844,{ }^{15}$ and by Walter Burnham, of Lowell, Massachusetts, in $1853,{ }^{16}$ and, in the same year $\left(1853^{17}\right)$, Gilman Kimball (1804-92), of Lowell, Massachusetts, first performed this operation with deliberate intention. Eugène Koeberlé, the pioneer of hysterectomy and morcellement of tumors, exeised the uterus for uterine fibroma on Mareh 14 and April 20, 1863, excised the uterus and adnexa for tumor in 1869, and per-

I Toeberlé: Mém. Acad. de méd., Paris, 1862-63, xxvi, 371-172, 6 pl.

2Osiander: Göttingen gelehrte Anz., 1808, 130; 1816, 16.

${ }^{3}$ Langenbeck: N. Biblioth. f. d. Chir., Hannover, 1817, i, st. 3, 557.

${ }^{4}$ Ritgen: Heidelberg. klin. Ann., 1825, i. 263-277.

${ }^{5}$ Roux: Gaz. méd. de Paris, 1834, 2. s., ii, 17-22.

${ }^{6}$ Réeamier: Bull. Aead. de méd., Paris, 1842-43, viii, 661-668.

7 Simpson: London and Edinb. Monthly Jour. Med. Se., 1843, iii, 547; 701; 1009: 1844, iv, 208.

s Nélaton: Gaz. d. hôp., Paris, 1851, 3. s., iii, 573; 581; 1852, iv, 54; 66.

${ }^{9}$ Noeggerath: New York Merl. Jour., 1853, 3. s., iv, 9-24.

${ }^{10}$ Ayres: Am. Med. Gaz., N. Y., 1859, x, 81-89, 2 pl.

II Michä̈lis: Mitth. a. d. Geb. d. Med. (ete.), Altoona, 1836, iv, 7.-S. Hft., 1). 60 .

12 Richmond: West. Jour. Ned. \& Phys. Se., Cinein., 1830, iii, 485-489.

${ }^{13}$ Prevost: Am. Jour. Med. Se., Phila., 1535, vi, 347. (See Harris: New Orleans Med. \& Surg. Jour., 1878-79, n. s., vi, 935-937.)

${ }^{24}$ Gibson: Am. Jour. Med. Se., Phila, 1835, xvi, 351; xvii, 264: 1838, xxii, 13: 1885, n. s.. xe, 422.

15 Atlee: The Surgical Treatment of Certain Fibrous Tumors of the Uterus, New York, 1853.

${ }^{16}$ Burnham: Nelson's Am. Laneet. Plattsburgh, N. Y., 1853, vii, 147.

${ }^{17}$ Kimball: Boston Med. and Surg. Jour., 1855, lii, 249-255. 
formed his first myomectomy in 1878. He had many disputes with Jules Pran as to priority in the invention and use of the hemostatic forceps. Beforr the time of Sims and Koeberle, operations upon the uterus had been attempted here and there, but the various procedures had fallen into disrepute through íailure (exitus lethalis).

Prior to the year 1852, the stumbling-block of gynecology was the relief of vesicovaginal fistula. Many surgeons, from the time of Paré onward, had attempted to operate for this condition, with no better result than to entail an additional amount of suffering and inconvenience upon their unfortunate patients.

Roonhuyze (1672) and Fatio (1752) left admirable accounts of their operative nethods, but no reports of suecessful eases. Dieffenbach left a elassical aceount of the wretehed plight of the women upon whom all his wonderful resoures were tried in vain (1S45). Jobert de Lamballe had witten a whole treatise upon female fistulæ $\left(1852^{1}\right)$, but his autoplastic operation par glissement had only resulted in repeated failures and the death of many of his patients. Six successful operations for the condition had been reporter in Ameriea by John Peter Mettauel (1787-1875), of Virginia ${ }^{2}$ (1838-47); others by George Hayward (1791-1863), of Boston, in $1839^{3}$; by Joseph Paneoust, of Philadelphia, in $1847 ;^{4}$ and, in France, by Maisonneuve $\left(1845^{5}\right)$.

The whole matter was changed, as Kelly says, "almost with a magic wand" by James Marion Sims (1813-83), of South Carolina. A graduate of Jefferson Medical College, Philadelphia (1835), Sims settled in Alabama, where he soon became known as a capable and original surgeon, operating sucessfully for abscess of the liver in 1835, and removing both the upper and the lower jaw in 1837. In 1845 , he was called to see a country woman who had sustained a displacement of the uterus from a fall from a horse. In making a digital examination to correct the displacement, he hit upon the peculiar lateral posture (Sims' position), and was led to the invention of the special curved speculum, which were to be the particular factors of his success in operating for vesicovaginal fistula. To the Sims position and the Sims speculum, which enabled the operator to see the condition "as no man had ever seen it before," he added a special suture of silver wire, to avoid sepsis, and a catheter for emptying the bladder while the fistula was healing. With these four coefficients, Sims perfected his operation for repairing this almost irremediable condition, and published his

1 A.-J. Jobert de Lamballe: Traité des fistules vésico-utérines, vésicoutéro-vaginales (ete.), Paris, 1852.

2 Mettauer: Boston Med. and Surg. Jour., 1840, xxii, 154. Also, Am. Jour. Med. Se., Phila., 1847, n. s., xiv, 117-121.

${ }^{3}$ Hayward: Am. Jour. Med. Se, Phila., 1839, xxiv, 2s3-2ss.

${ }^{4}$ Pancoast: Med. Examiner, Philiı., 1847, n. s., iii, 272-274; 1851, vii, $650-6.56$

${ }^{5}$ Maisonneuve: Clinique chirurgicale, Paris, 1848 , vii, 660 et seq. 
paper in 1S52. ${ }^{1}$ It areated a profound impression, and, in 1854, ${ }^{2}$ was followed hy a monograph of Gustav Simon, suggesting a method of miting the edges of the fistula by means of double sutures. Fims removed to New York in 1853, and, in 185.5, established the state Hospital for Women, which soon became the center of the best gynccological work of the time. Visiting Europe in 1S61, sims porformed his fistula operation with great éclat before Nélaton, V'elpean, Larrey, and other surgical leaders, and was soon in request all over Europe as an operator in discases of

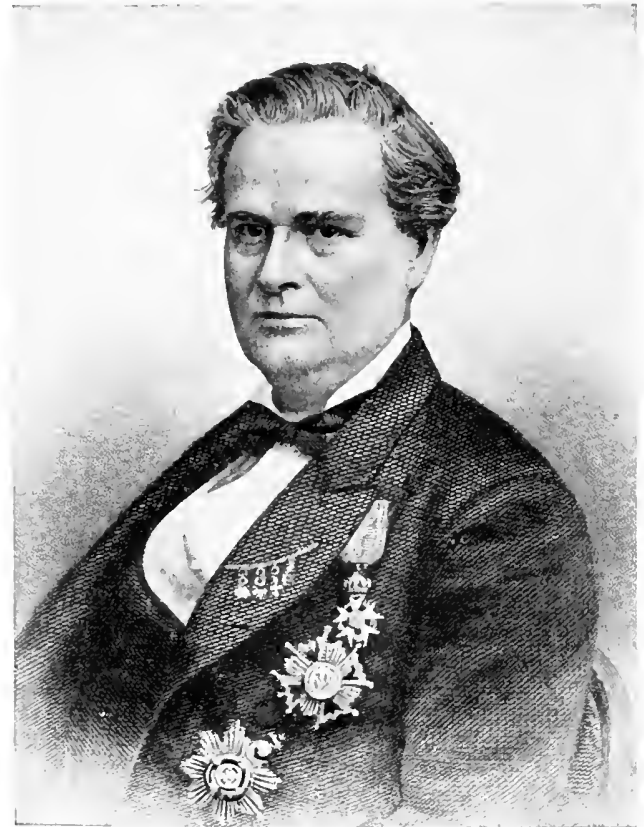

James Marion Sims (1813-83).

women. His Clinical Notes on Uterine Surgery (1866) was translated into German, and Robert Olshausen and August Martin have borne testimony to the high esteem in which Sims was held in that country. ${ }^{3}$ Among his other important contributions were his methods of amputating the cervix uteri $(1861)^{4}$, his description

1 Sims: Am. Jour. Med. Sc., Phila., 1852, n. s., xxiii, 59-\$2.

2 Simon: Ueber die Heilung der Blasen-Scheidenfisteln, Giessen, 1854.

${ }^{3}$ Olshausen: Ueber Marion Sims und seine Verdienste um die Chirurgie, Berlin, 1897. Martin: Ztschr. f. Geburtsh. u. Gynäk., Stuttgart, 1913, lxxiii, 946-948.

${ }^{4}$ Sims: Tr. Med. Soc. New York, Albany, 1861, 367-371. 
of the condition "vaginismus" (18611), his operation of cholecystotomy (1878), and his great paper on "The careful aseptic invasion of the peritoneal cavity for the arrest of hemorrhage, the suture of intestinal wounds, and the cleansing of the peritoneal cavity, and for all intraperitoneal conditions" $\left(1881^{3}\right)$. Sims, a kind-hearted but impulsive man, was one of the most original and gifted of American surgeons. A statue, erected to his memory in 1894 by European and American admirers, is in Bryant Park, New York City.

In the Womm's Hospital in New York, Sims was assisted by Thomas Addis Emmet (1828-1919), a native of Virginia, who, under his training, became a great master of the plastic surgery of the perineum, the vagina, the cervix uteri, and the bladder. As Kelly says, he "caught Sims' idea at once, acquired his methods, and improved upon them, and did more than any other surgeon to teach the members of the profession in this country how to do these operations."

Emmet's principal contributions were his papers on the treatment of dysmenorrhet and sterility resulting from anteflexion of the uterus $\left(1865^{4}\right)$, on the surgieal treatment of laecrations of the eervix uteri $\left(1869-74^{5}\right)$, his monograph on vesieovaginal and reetovaginal fistula $\left(1868^{6}\right)$, and his papers on vaginal eystotomy $\left(187^{7}\right)$ and the plastie surgery of the perineum $\left(182^{8}\right)$. He also wrote a treatise on gymecology (1879) and an entertaining autobiography (1905).

Sims' work was further extended by Nathan Bozeman (18251905), of Alabama, who did many successful operations on vesical and fecal fistulx in women, paying special attention to the complication of pyelitis, which he treated by catheterizing the ureter through a vesicovaginal opening (1887-889).

In the group of Southern gynecologists may be included Prevost, of Donaldsonville, Louisiana, and William Gibson, of Maryland, both pioneers in Cesarean section, and Josiah Clark Nott (1804-73), of South Carolina, who, in 1844, described the condition which Sir James Y. Simpson, in 1861, called "coceygodynia."10

1 Sims: Tr. Obst. Soc. Lond., 1861, iii, 356-36i7.

${ }^{2}$ Sims: Richmond and Louisvillo Med. Jour., 1\$78, xxvi, 1-21.

${ }^{3}$ Sims: Brit. Med. Jour., Lond., 1881, ii, 925; 971; 1882, i, 18. ; 222; $260 ; 302$.

${ }^{4}$ Emmet: New York Med. Jour., 1865, i, 205-219.

${ }^{5}$ Am. J. Obst., New York, 1868-699, i, 3399-362; 1874-7.), vii, 442-4.56.

${ }^{6}$ New York, 1868.

${ }^{7}$ Am. Pract., Louisville, 1872, v, 6.5-92.

${ }^{8}$ Tr. Am. Gynee. Soe., 18\$2, N. Y., 18\$4, viii, 198-216.

${ }^{9}$ Bozeman: Tr. Internat. Med. Cong., Wash., 1887, ii, 514-55s; and Am. Jour. Med. Sc., Phila., 1888, n. s., xev, 225; 368.

${ }^{10}$ Nott: New Orleans MIed. Jour., 1844-45, i, 58-60. Simpson: Med. Times and Gaz., Lond., 1861, i, 317. 
Nott was also one of the first to sugrest the "mosquito theory" in referenee to the transmission of yellow fever (1848), and wrote a number of works on ethnology.

Theodore Gaillard Thomas (1831-1903), of Edisto Island, South Carolina, like Marion Sims, practised in New York. In 1868, he published a treatise on diseases of women, which was esteemed the best that had yet appeared, ${ }^{2}$ and was translated into French, German, Italian, Spanish, and Chinesc. In 1870, Thomas revired Ritgen's operation of gastro-elytrotony as a substitute for Cesarean section, ${ }^{3}$ and in the same year was the first to perform vaginal ovariotomy. ${ }^{4}$

Robert Battey (1828-95), of Augusta, Georgia, a graduate of the Jefferson Medical College of Philadelphia, was the first to suggest the operation of oophorectomy, or excision of the uterine appendages, for such non-ovarian conditions as painful menstruation and neuroses. This operation was first performed by him on August 17, 1872.5 "Battey's operation" was afterward applied in the treatment of uterine nyomata by E. H. Trenholne $\left(1876^{6}\right)$, to other pelvie conditions by Alfred Hegar (1830-1914) in Cicrmany, and Lawson Tait in England, and has more reeently acquired a definite phrsiological significance in connection with modern work on the chemical eorrelation of the internal secretions.

The advancement of scientific medicine in the second half of the nineteenth century was characterized by the introduction of a biological or evolutionary view of morphology and physiology, out of which eame the sciences of cellular pathology, bacteriology, and parasitology, new modes of seeing disease and its causes, which harl in them the germ of novel methods of treatment by means of sera and vaceines. The discoveries of Pasteur led immediately to Listerian or antiseptic surgery, with its remarkable applieations in such regions as the abdomen, the brain, the joints, the thorax, and special sense organs, and its great extension in operative gynecology. Creat improvements in medical edueation, public hygiene, and military medicine followed upon these developments in due course, and were further helped out by the great increase in the number and quality of seientifie periodicals and through the growth of rapid means of national and international communication by railway, steamship, telegraph, and eable. In this way,

1 Nott: New (Orleans Med. Jour., 1848, iv, 563; 601.

2 Thomas: A Practieal Treatise on the Diseases of Women, Phila., 1868.

${ }^{3}$ Thomas: Am. Jour. Obst., N. Y., 1870, iii, 125-139.

${ }^{4}$ Thomas: Am. Jour. Med. Sc., Phila., 1870, n. s., lix, 387-390.

${ }^{5}$ Battey: Atlanta Med. and Surg. Jour., 1872-73, x, 321-339.

${ }^{6}$ Disputed by Lawson Tait, who elaimed priority in an alleged case of 1872. See Trenholme: Med. News, Phila., 1886, xlix, 530. 
specialties like ophthalmology, otology, laryngology, orthopedies, dentistry, and veterinary medicine became something more than mere names.

The immense growth of general biology in our time was principally due to the evolutionary theories of Charles Robert Darwin (1809-82), of Shrewsbury, England, a Cambridge graduate, whose bent toward natural history was set by his boyhood interest in botany and his five years' eruise as naturalist on H.M.S. Beagle (1831-36), an experience which rendered him an expert geologist and zoölogist. Although an invalid for the rest of his life, Darwin labored for twenty years before publishing his great work On the Origin of Species by Means of Natural Selection (1859), perhaps the most wonderful piece of synthesis in the history of science. This theory was arrived at independently. by Alfred Russel Wallace (1822-1913) in 1858 , although Darwin's priority dates back to 1838 . Both Darwin and Wallace owed much to the Essay on the Principle of Population published by the English clergyman, Thomas Robert Malthus, in 1798. Darwin's extraordinary marshaling of facts, in evidence of the survival of the fittest by natural selection in the struggle for existence, had

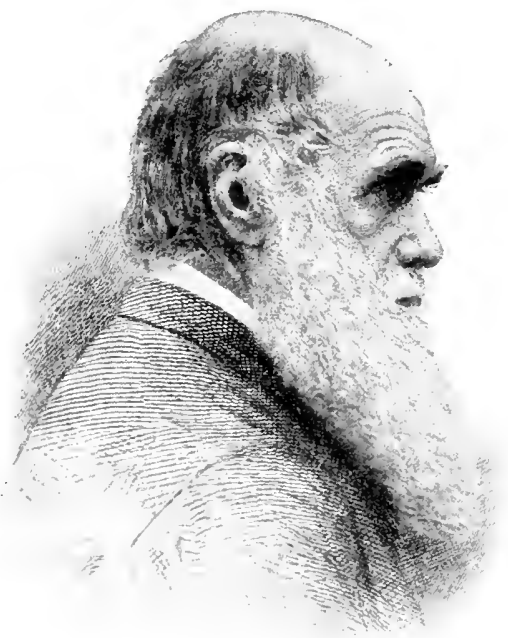

Charles Robert Ditrwin (1809-82). the same far-reaching influence upon biological speculation that the discoveries of ( $\mathrm{o}-$ pernicus had upon astronomy. It dispensed with the ancient Linnzan concept of the fixity of species, that animals and plants were originally ereated as we find them today, and the ghostly metaphysical abstractions which were invoked to "explain" why this should be. It created the sciences of comparative physiology and pathology, by pointing to the close struetural and functional relationship between human tissues and those of animals and plants. And though the idea of evolution was known to the Cirecks and was more or less definitely outlined by Bacon, Buffon, Erasmus Darwin, Goethe, Lamarek, Lyell, and Herbert Spencer, it became the salient fact of modern science through Darwin's work. The 
applieation of the idea of continuous devolopment in The Descent of $M a n$ (1S71) made an and of the anthropocentric theory that the universe was created for man. It began to be pereeived that there is a rude and noble dignity in the story of man's painful evolution from the lower forms of life, even as Darwin's picture of the struggle for existence illuminat ed the true causes of human misery as never before. 'That there are flaws and gaps in Darwin's hypotheses; that he did not take sufficient account of those spontancous aceidental variations or mutations which, as Mendel and De Vries have indicated, may also originate speeies; that his theory of sexual selection is not borne out by the facts; that many speeifie characters in animals and plants are not true survival values, is all elear enough now. But it should not be forgotten that Darwin himself regarded natural seleetion "as the main, but not the exclusive, means of modification," and that a true specific character is a survival value only in regard to its possessor's essential enviromment, and not in respect of some accidental enemy. Darwin's essay on The Variation of Animals and Plants under Domestication (1868) is now mainly memorable for his attempt to explain the mechanism of inheritance by "pangenesis," or the transportation of gemmules from all parts of the organism to the ovum, to insure their reproduction, which has found an avatar in Starling's theory of the hormones. The great monograph on "The Expression of the Emotions in Man and Animals" (1873) ranks with the contemporaneous work of Duchenne of Boulogne (1862), and the theory of evolution itself is the starting-point of comparative psychology. The investigations in botany and geology, the monographs on Climbing Plants (1875), Cross and Self-Fertilization (1876), Power of Movement in Plants (1880), Formation of Vegetable Mould (1881), Coral Reefs (1842), and Volcanic Islands (1844), can only be mentioned. Much harm has been done to Darwin's reputation among shallow-minded people through the attempt of the half-insane Nictzsche and his school to carry the idea of "war down the weak" into actual ethics. This contravenes the true intent of the Darwinian theory, which shows why nature is pitiless, but did not say that man should be. Over against these misinterpreters should be set the grave, selfpossessed, entirely human figure of Darwin himself. Bearing in mind the magnificent sincerity of his work, his fame is safe enough from inexpensive caviling.

Darwin's work was popularized and extended in the philosophic writings of Herbert Spencer (1820-1903), whose "Principles of Biology" (1866-67), "Principles of Psychology" (1871), and "Descriptive Sociology" (1873-81) are all of a high order of merit; by Alfred Russel Wallace, whose "Geographical Distribution of Animals" (1876) is his best work; and by Huxley and Haeckel. 
Thomas Henry Huxley (1825-95), of Ealing, England, was a medieal graduate of the London University (1S45) who became a surgeon in the Royal Navy. As with Darwin, his interest in biology was awakened by a sca voyage, a five years' cruise on H.M.S. Rattlesnake (1846-50). Prior to this experience he had already discovered the layer of eells in the root-sheath of hair which goes by his name $\left(1845^{1}\right)$, and upon his return he made many important contributions to marine zoölogy, in recognition of which he became Fellow and gold-medallist of the Royal Society (1851-52). Resigning from the navy, he became lecturer on natural history at the Royal School of Mines, and introduced the idea of teaching morphology by means of a series of typical animals, as norms of their species, which afterward became the feature of Huxley and Martin's Elementary Biology (1875). He applied evolution to paleontology, in his extended studies of fossil fishes, crocodiles, and other vertebrata, and in his work on the ancestry of the horse. His Croonian Lectures on the theory of the vertebrate skull (18.58) overthrew Owen's conecpt of an arehetype in favor of a morphologic type, an assemblage of features com-

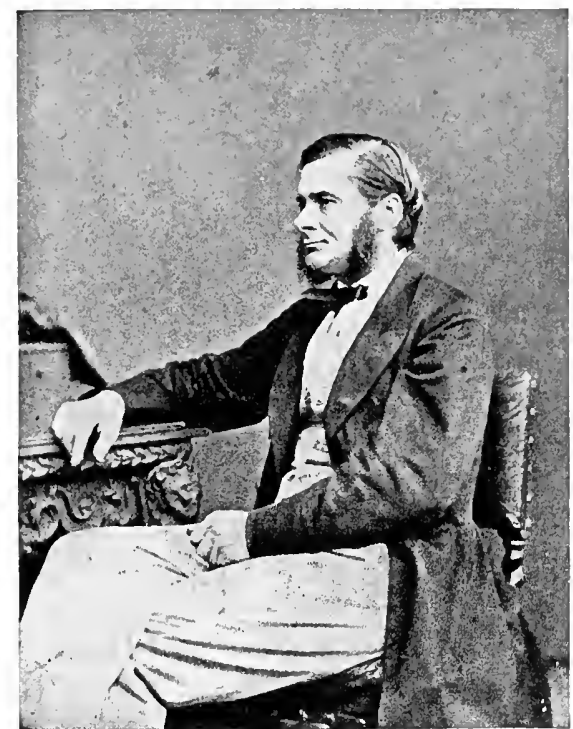

Thomas Henry Huxley (1825-95). mon to all its class, as in a composite photograph. With this may be bracketed Huxley's important lectures on the craniology of birds (1867). In $1861^{2}$ he demonstrated the inaceuracy of another contention of Owen's, relating to the supposed backward projection of the cavities of the brain into the posterior horn and the hippocampus minor, as a specific character in man. The essays on the Comparative Anatomy of Man and the Higher Apes (1859-62), and On Evidence as to Man's Place in Nature (1863), reveal the follower of Darwin, of whose idea Huxley was indeed

${ }^{1}$ Lond. Med. Gaz., 1845, n. s., i, 1340.

${ }^{2}$ Nat. Hist. Rev., Lond., 1861, 67-84. Proc. Zoöl. Soc., Lond., 1S61, $247-260$. 
the ablest modem interpreter. A master of vigorous English, he wote sevoral volumes of essilys, which are among the most delightful of modern contributions to popular science; and his texthooks on physiology (1866), which passed thromgh 30 editions, on vertebrate and invertebrate anatomy (1871-77), and on physiography (1877) are little masterpieces of their kind. Huxley defined himself as one who cared more for freedom of thought than for the mere advancement of science, and this is the interest of his personality. Vigorous and resolute in form and features, a stalWart, masculine-minded man who ruined his health by sedentary labors, he was, in the circmustances of his marriage, as in his cham-

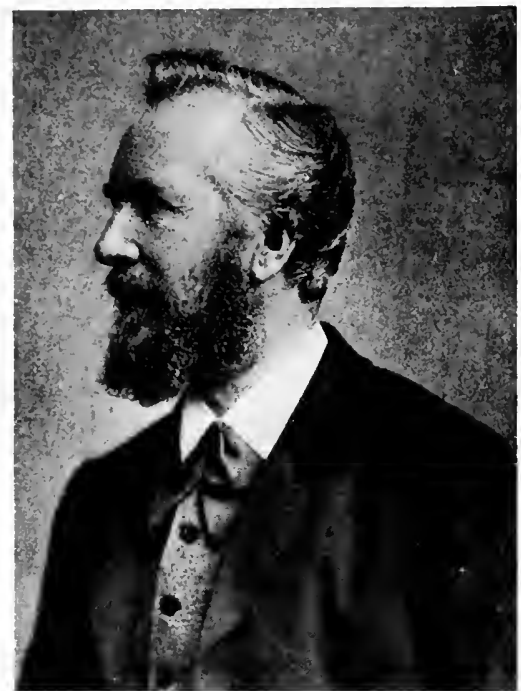

Ernst Haeckel (1834-1919). pionship of Darwinism or his Napoleonic warfare on theologians, a romantic, like Vesalius. No man ever fought more bravely and openly for truth and honesty, for the right of people to think and express their own thoughts. No man ever admitted his own errors more readily or was more generous to a fallen adversary. His conviction that "there is no alleviation for the sufferings of mankind except veracity of thought and action and the resolute facing of the world as it is, when the garment of make-believe by which pions hands have hidden its uglier features is stripped off," is the final justification of Darwinism and sounds the keynote of the social medicine of the future.

Ernst Haeckel (1834-1919), of Jena, a great morphologist, carried Darwinism into Germany, where the opposition of Virchow created the necessity for such a defender. ${ }^{1}$ Haeckel's greatest work is his Generelle Morphologie (1866), in which organisms and the forms of organic structures are considered and classified in relation to serial homology, heredity, and evolution. In 1868, appeared his "Natural History of Creation"; in 187t, the Anthropogenie, a great treatise on human embryology; and, in 1884, his

${ }^{1}$ It is said that Fritz Müller was the first German to support the Darwinian theory ("Für Darwin," 1864), Haeckel the second (1866), and Wiesmann the third (1868). 
monograph on the Gastrax Theory, which regards the two-layered gastrula as the ancestral form of all multicellular animals. These were all contributions of the most effective kind, the result of years of patient investigation. Haeckel's popular writings inclucle his delightful letters of Fast Indian travel and such uncritical works as The Riddle of the Universe. In the latter, he combines an ironclad materialism, like that of the French Encyclopadists, with the notion that aggregations of molecules have souls (Plastidul-Seelen), which was ridiculed by Virchow. In his lifetime Hacckel, the sage of Jena, was highly revered among scientific men, and looked up to as one of the greatest of fighters for freedom in thought and teaching. His Phyletic Musem at Jena is said to be the most wonderful collection of serial illustrations of evolution and development in the world.

The problem of heredity was attacked in four different waty by Mendel, Hering, Galton, and Weismann.

Gregor Mendel (1822-84), abbot of the Augustinian monastery at Brinnu, Austria, discovered the mathematical law governing the dominant and recessive characters in hybrids (1866-67), the application of which belongs to the twentieth century.

Ewald Hering (1834-1918), a Saxon professor, is the author of the psychophysical theory (1870) that facultative memory, the automatic power of protoplasm to do what it has done before, is the distinetive property of all living matter. The transmission and reproduction of parental characters are supposed to be the result of the organism's unconscious memory of the past, the mechanism being, in Hering's view, the persistence of wave motions of molecules. This idea was also advanced by Haeckel (Perigenesis of Plastidules) and by Samuel Butler (1835-1902), of Langar, England, who translated Hering's essay and applied the doctrine in his polemies against Darwinism.

Sir Francis Galton (1822-1911), a cousin of Darwin's, began to investigate hereelity experimentally in 1871 . His observations upon the inheritanee of transfused blood in rabbits, of tricolored spots on the coat of Bassett hounds, of stature and other characters in human families, led him to reject the Lamarckian theory of the inheritanee of acquired chararters as well is the Darwinian Pangenesis. In his book on Natural Inheritance (18s9), he procceds, by statistical induction, to the Law of Filial Regression, which asserts that the offspring of parents unusual in height, talent, ef e., regress to the average of the stock; also to the Law of Ancestral Inheritance, in virtue of which each parent eontributes one-fourth $\left[(1 / 2)^{2}\right]$ of the total inheritanee, each of the four grandparents one-sixteenth $\left[(1 / 2)^{4}\right]$, each of the eight great-grandparent: $\frac{1}{12}=(1 / 2)^{6}$, while, in general, the ancestors in $n$ degrees removerl contribute $(1 / 2)^{2 n}$ each. The latter theorem has been confirmed, with slight mathematieal changes, by the biometrie methods of Karl Pearson. Galton's work on Finger-prints (1892) is the first eontribution of importance after Purkinje. II introduced the doctrine of engenics (a term of his coinage), founded the Eugenies Laboratory in Jondon (1904), and, with Pearson and Weldon, founded Biometrika (1901), a journal for the study of biologie problems by alvaneed statistical metheds.

An important extension of evolutionary theory is the idea of the unbroken continuity or immortality of the gern-plasin, which was elaborated by August Weismann (1834-1914), of Frankfort on the Main, between 1893 and 1904. The general idea of eontinuity of growth and development by direct "ell-lineage was already inherent in Virchow's cell-theory. Owen, in his pilper on Parthenogenesis (1849), distinguished between edls forming the body and germ-cells. Hacckel emphasized the idea of continuous descent all through 
his Generelle Morphologie (1s6i). Jaeger coincel the phrase "continuity of the germ protoplasma" in 1s7s, and the capacity of the lat ter for transmitting hereditary qualitios was elrarly stated by Nusibam in 1875. Wrismam insisted on the continuity of desent in dinicellular organisms, and, in tracing the gradual evolution of multicellular organisms from these, pointed out that the complex orginism, male up of boxly-e(els, is only the vehiche of the germcells. The germ-plasm, a complex structure contained in the muclei of these reproductive eells, is the parent of the germ-cells of the suecerding generation, securing a relative immortality for the species, although individuals die out. "The union of the two ererms or "amphinixis" is the principal agent in evolution. Weismann mantaned that variation is produced by sexual selection, and latterly by a nutritional selection among the components of the germplasm (germinal selection). He held that the germ-plasm in the sex-cells is to be found in the chromosomes (idants) and predicted the "reduetion division" (by onc-half) in the maturation of the sex-cells and the "equation divisions" or equal division of the chromosomes. Il is assumption that the determinants in the chromosomes are arranged in a linear series has been confirmed by $\mathrm{T}$. H. Mlorgan. Another feature of Weismann's theory is his experimental proof that acquired charaeters are not directly transmitted. This apparent overthrow of the Lamarckian theory has caused much cont roversy, but the balance of experimental evidence seems in favor of Weismann. If true, the Weismann theory is of far-reaching social significance, since it seems probable that moral qualities eannot be transmitted to children, but have to be acquired, in each case, by intensive early training.

Another outgrowth of biologic and cvolutionary thinking was the nineteenth-century science of anthropology. With nothing to start with but the meagre data in Hippocrates, Herodotus, Tacitus (Germania) and the carly travellers, it was built up by the labors of such men as Darwin, Huxley, Lyell, Spencer, Prichard, and Tylor in England; in France, by Broca, who invented some 27 craniometric and cranioscopic instruments; in Germany, by Virchow, who was an expert in craniology, and took the whole field of anthropology for his province; in Italy, by Cesare Lombroso, who developed the study of the criminal and the morbid side of the man of genius. Anthropological societies were founded in Paris (by Broca) in 1859, in London in 1863 , in Madrid in 1865, in Berlin in 1868, in Vienna in 1870, in Italy in 1871, and in Washington, D. C., in 1879. Physical anthropology was developed through the craniological investigations of Broca and Virchow, the treatises of Paul Topinard, Quatrefages' studies of fossil and savage men (1861) and pygmies (1887), Virchow's statistics on the physical anthropology of the Germans (1876), the books on genius and insanity (1S64) and criminal man (L'uomo delinquente, 1876) and criminal anthropology by Cesare Lombroso (1836-1909), Adolf Bastian's theory of "elemental ideas" (1881), the RatzelSmith theory of the geographic diffusion of ethnic culture by convection (1SS2-1915), Alphonse Bertillon's method of identifying criminals by sclected measurements (Bertillonage, 1886), and Francis Galton's simpler mode of identification by finger-prints (1892), which superseded Bertillonage in England in 1900. Ethnological socicties had been founded in Paris (1839), New York (1842), and London (1844), and the principal monuments of the science are the monographs of Prichard (1813), Pickering (1848), Knox (1850), Latham (1850-59), Nott and Glidelon (1857), Waitz (1859-72), Herbert Spencer (1873-81), Friedrich Müller (1873), Peschel (1873), Ratzel (1855-88), Haddon (1894-1909), Achelis (1896), and Ripley (1900). In the field of ethnic craniology, we may mention Morton's albums of American and Egyptian skulls $(1839-44)$, the Crania ethnica of de Quatrefages and Hamy (1872-82), Rütimeyer and His on Swiss skulls (1864), the albums of Finnish and Swedish skulls (1878-1900) by Gustaf Magnus Retzius (1842-1919) and Virchow's "Crania ethnica Americana" (1892). The subject was carried into a singular excess of detail in Sergi's polysyllabic subdivisions of racial types of skulls, and in Aurel von Török's Systcmatic Craniometry (1890), with its 5000 proposed measurements of a single skull. Medical anthropology, yet in its infancy, has for its basic data such finds as Dupuytren's radius curvus, Hutch- 
inson's teeth, Manouvrier's sincipital-T, the sabre-shaped tibia, the graphic representation of disease and deformity in art, and such interesting recent developments as the studies of Sir Mare Arnand Ruffer (1\$59-1917) on yalaeopathology (1909-14), the investigation of the clinieal significance of the seaphoid seapula by Wiltiam W. Graves (1910-20), the study of discase in autochthons, of ethnic incidence and racial equation in disease; and the applieation of the Binet-Simon tests to determine the mental age of children, adults and soldiers (R. M. Yerkes, 1917-1S). Military anthropometry on a large scale is exemplified in such measurements as those condueted by J. H. Baxter and liobert Fleteher on U. S. troops in the Civil War (1875), by Rodolfo Livi on the Italian army (1896) and by Albert G. Love and Charles B. Davenport on our drafted troops in the European War (1919-20). Ethnie jsychology was developed by Andrew Lang (18S4-1901), Adolf Bastian (1886$90)$, Alired Fouillée (1903), Wilhelm Windt (1904), and in such monographs as those of the Torres Straits Experlition (1898). Other phases of comparative ethnology are the studies of Pitt-Rivers on technology (1S60-75), Sir Henry Maine on Ancient Law (1S61), J. J. Bachofen on the Matriarchate (Das Mutterrecht, 1S61), F. MacLennan on Primitive Marriage (1865), Sir Edward Burnett Tylor (1832-1917) on Primitive Culture (1871), L. H. Morgan on s'ystems of Consanguinity (1871), Herbert Speneer on Deseriptive Soeiology (1873-81), William Blick (1853) and Max Bartels (1893) on medieal folk-lore, J. G. Frazer on Totemism (1857), Totemism and Exogamy (1910), and The Golden Bough (1890-1913), Westermarck on IIuman Marriage (1891), Alfred C. Haddon on Evolution in Art (1895), Edwin Sydney Hartland on Primitive Paternity (1910), and W. I. Thomas on Social Origins (1909). The exeavations of bones and flint implements by M. Boucher de Perthes at Abbeville, during $1805-47$, the later unearthing of similar finds in the Devonshire eaves, the exploration of lake-dwelling remains in the Irish crannogs by Sir William Wilde (1839), and of the Swiss Pfahlbauten by Ferdinand Keller (1853-54), led to extensive and intensive study of these prehistoric objects all over the world. The results were systematized in Gabriel de Mortillet's classic, Le Préhistorique (1883), and carried forward by Sir John Evans in England, Virchow in Germany, Piette in France, and Holmes in America. The diseovery of the prehistoric skull and skeletal remains at Neanderthal in 15.56 , which Virchow pronounced diseased, Broca normal, and Huxley human but ape-like, led Huxley to his famous assignment of man's place in nature as "more nearly allied to the higher apes than the latter are to the lower" (1860). "The subsequent eranial finds at Spy (1886), Irrapina (1889), Heidelberg (1907), Le Moustier (1908), La Chapelle aux Saints (1909), and Sussex (1912), and Eugène Dubois' discovery, in Java, of the teeth, ealvarium, and femur of the Pithecanthropus erectus (1S91), which he regarded as a sort of "missing link" between the anthropoid apes and man, only added fuel to the ensuing controversy which is bound up with the question of the single or diverse origin of the human speeies. In general, man is now classed, where Linnaus left him in 1735, with the Simida. The unity of the human species has been maintained by Linnæus, Buffon, Prichard, Sir William Lawrence, Broea, the English anthropologists and the followers of Hacckel, 'while the multiple or polygenist theory has been favored largely by those Germans who have followed the somewhat official leadership of Virehow.

After the labors of such masters as Bichat, Bell, Henle, and Hyrtl, there was little to be added to the subject of descriptive human anatomy and most investigation in this field became merged into morphology and histology.

Splenclid atlases of gross or macroscopic anatomy were published, sueh as those of the Bells, Cloquet (1821-31), Werner Spalteholz (1904), Carl 'Tolilt (1896-1900), Sir William MacEwen's Atlas of Head Seetions (1893), and the albums of John C. Dalton (1885), the younger Retzius (1896) and Carl Wernicke (1897-1904) on the brain. Frozen sections, introduced by Pieter de 
Ricmer (1760-1831) in 1s1s, wrore utilized in P'irogoff's epoch-making Ana-

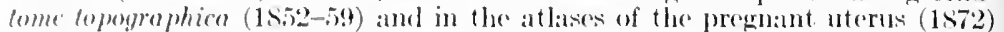
and of normal topographie anatomy (1872) by Christian Wilhelm Brame (1N31-92). Among the many excellent treatises on topographical and surgieal anatemy were these of Volpean (1525-26), Hyrtl (18.17), Malgaigne (1859), J. H. Power Anatemy of the Arteries, 1863), C. Heitzmann (1870), N. Rüh-

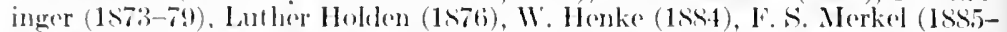

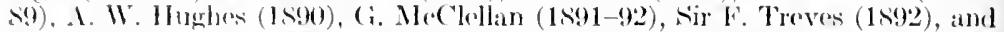
li. von Bardelethen (1s9). Artistic anatomy was ably trated by John folasman (1s33). Robert Knox (1852), Aathias Duval (is81), the physiologists, I'aul Richer (1s90) and brnst Wilhelm Brücke (1891); and, by direct photography from the nude, in the elifferent works of Carl Heinrieh Strat $z$, the motion. piefures of Ealweard Atuybrige (1901), and the splendid treatise of 1856 by Julius Kollmann (18:34-1918). Treatives on gross anatomy were published by Jones Quain (1520), Erasmus Wilson (1840), M-P.-C. Sapley (1850-64), II. (iray (1sis9), C. Gegenbaur (1S83). J. Testut (1859-91), K. von Bardoleben (1s96), J. Sobotta (1904), A. Van Gehuchten (1906-09), and the coöperative treatises edited by D. J. Cumningham (1902) and the Americans, F. H. Gerrish (1s99) and (i. A. Piersol (1911). Special treatises of great use and value were the manuals of dissecting of Luther Holden (1850) and Hyrtl (1860), llolden's Ostenlogy (1855), D. N. Eisendrath's Clinical Anatomy (1903), J. F. Barker's Laboratory Mamual (1904), the Applied Anatomy (1910) of Gwyllym George Davis (1558-1918) and the Cross-section Anatomy of A. C. Eycleshymer and D. N. Scho'maker (1911). The history of amatomy was taken up by Hyrtl, Linox, Robert von Toply (1S98), the history of anatomic methods by William II. Keen (1852), the history of anatomie illustration by Ludwig Choulant (1\$52), translated by Mortimer Frank (1920), and the history of plastie anatomy by Mathias Duval and Edouard Cuyer (1S9S). There were isolated diseoveries in plenty, such as the island of Reil (1809), Clarke's columns (1851), Broea's convolution (1861), Aucrbach's plexus (1862), Bigelow's demontration of the Y-ligament (1S69), or Waldeyer's ring (1S84). Perhaps the nost important of these was the deseription of the parathyroid glands by the Swedish anatomist, Ivar Sandström, in 1879.

The leading German anatomist of recent times is Wilhelm Waldeyer (1836-1921), of Hehlen, Brunswick, a pupil of Henle, professor at Berlin (1883), who made important researches on the development of cancer (1S67-72), retroperitoneal hernia (1868), ovary and ovum (1870), the topographical relations of the pregnant uterus (1886), pelvic viscera (1892) and pelvis (1899), and the neuron theory (1891), to which he gave the name. He first described the open ring of lymphoid tissue formed by the faucial, lingual, and pharyngeal tonsils (1884), which is now regarded as a prominent portal of infection. Waldeyer also referred the lymphatic constitution to persistence of the thymus gland.

Karl von Bardeleben (1849-1918), of Ciessen, a graduate of Berlin (1871), assistant to His at Leipzig (1871-2), prosector to (iustav Schwalbe at Jena (1873-88), and professor extraordinarius at Jena (1889-1918), was the author of a topographical atlas (1894), a manual of dissecting (1896), a Lehrbuch (1906), edited a great Handbuch der Anatomie (1896-1915), and made many special inrestigations in the skeletal, muscular and vascular systems.

${ }^{1}$ Wakleyer: Deutsche med. Wochenschr., Leipz. and Berl., 1S54, x, 313. 
He was for thirty years the general secretary and leading spirit of the Anatomische Gesellschaft (founded 1886).

English anatomy sustained a grave loss in the early death of Henry Gray (1825-61), who gai ned the triennial prizes of the Royal College of Surgeons and the Royal Society by his memoirs on the optic nerves (1849) and the spleen (1853), and whose anatomic treatise (1858), recently adapted to the B. N. A. terminology by E. A. Spitzka (1913), has been the standard text-book of English-

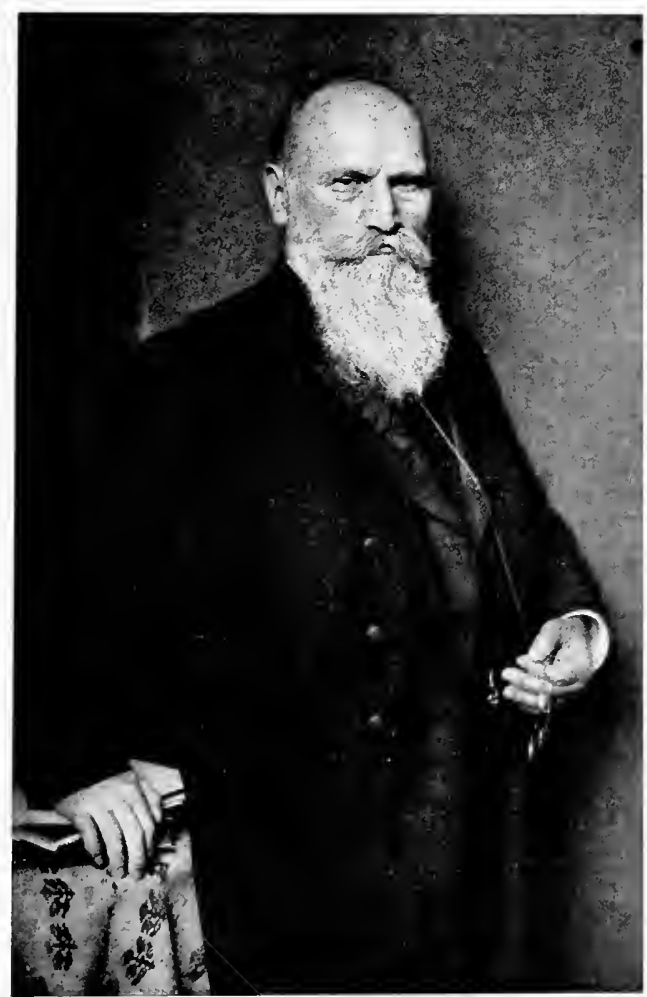

Wilhem Waldeyer (1S36-1921). (Berlin Photographic Company.)

speaking students for over half a century. The superb drawing: by $H$. Vandyke Carter have, most of them, been retained in the latest edition.

John Goodsir (1814-67), of Anstruther, Fifeshire, sueceeded to the chair of Monro tertius at Edinburgh (1845), and did much to lift anatomic teaching from the disrepute into which it had fallen through the latter's incompetenee. Coodsir's Anatomical and Pathological Observations (1845) contain the germinal idea of the 
cell-theory of Virchow, who dedicated his Cellular Pathology to him. Goodsir also discovered the sarcinae ventriculi (1865).

Sir William Turner (1832-1916), of Lancaster, England, became Coodsir's assistant (1854) and successor (1867) at Edinburgh, where he made its anatomic school the foremost and the largest in Great Britain. Remarkably sagacious and exceeding wise, he became president of the Council (1S98-1905) and ultimately principal of the University (1903). As teacher, investigator, and

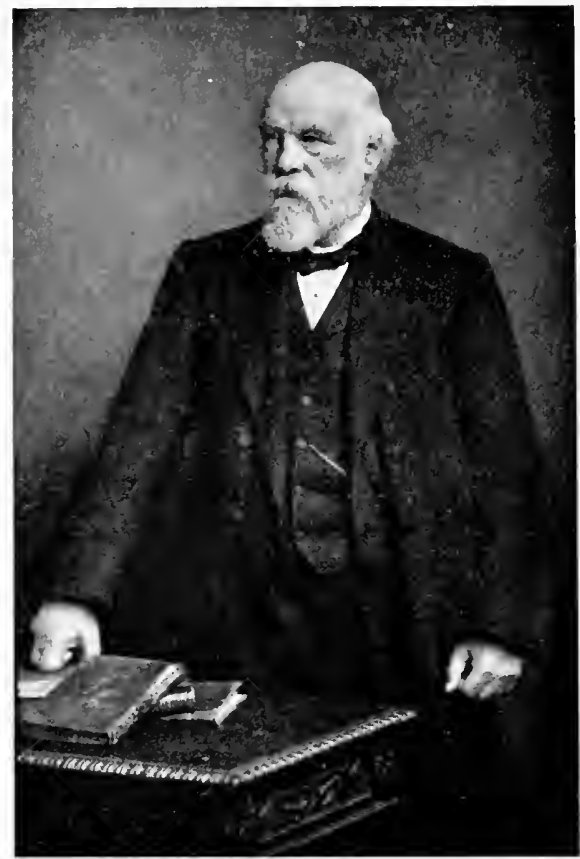

Sir William Turner (1832-1916). (Elliot and Fry, London.)

administrator, Turner was a tower of strength, sometimes grim and pawky in his humors, but big, jovial, kind-hearted au fond.

He made able contributions on placentation in the Cetacea (1870-89), comparative anatomy of the placenta (1S75-76), Indian craniology (1899), Scottish anthropology (1915), craniocerebral topography, and wrote the history of anatomy in the Encyclopædia Britannica (1875), the best monograph on the subject in English.

Sir Arthur Keith, Hunterian professor at the Royal College of Surgeons, discovered (with Flack), the sino-auricular node in the heart (1907) and has written with ability on the anthropoid apes (1896), human embryology and morphology (1901), and the antiquity of man (1914). 
Joseph Leidy (1823-91), of Philadelphia, who succeded Horner as professor of anatony at the University of Pennsylvania, was the leading American anatomist of his time, and a biologist of the type of Hunter and Müller, doing important work in botany, zoölogy, mineralogy, and paleontology, as well as in comparative and human anatomy. He was our greatest descriptive naturalist. His Fresh Water Rhizopods of North America (1879) is one of our biological classics. He made valuable researches on the comparative anatomy of the liver (1848), the bones, trichinosis in hogs, etc., and his Elementary Treatise on Human Anatomy (1861, revised 1889 ) has a special interest in that it was illustrated by himself.

He was the first to find Trichina spiralis in hogs $\left(1846^{1}\right)$, discovered the bacterial flora of the intestines $\left(1819^{2}\right)$, macle the first experiment in transplanting malignant tumors $\left(1851^{3}\right)$, and, in 1859 , found the hookworm in the eat, and suggested that it might aloo be found in man as a cause of pernicious anemia. ${ }^{4}$ As army surgeon during the Civil War, he performed some 60 autopsies, and, in the hospital wards, he surmised that flies may be trunsmitters of wound infection. ${ }^{5} \mathrm{He}$ was the first to separate out the parusitic anebre $(1579)$. The discoveries in his Resfarches in IIelminthology and Parasitology, edited by his nephew, Joseph Leidy, Jr., in 1904, would suffiee to make a reputation in themselves. He was the founder of vertebrate paleon-

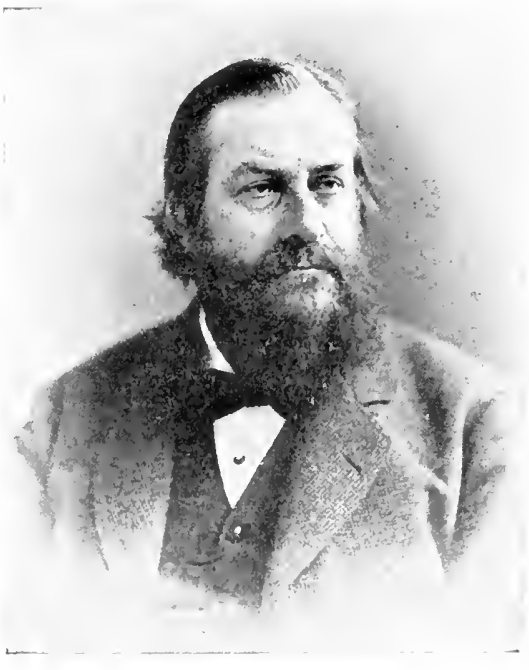

Joseph Leirly (1S23-91).

tology in America, and his great memoirs of $1869^{6}$ and $1873^{7}$ upon extinet fossils have never been surpassed. Like Gerhard and Gross, Leidy was a fine type of the Ameriean physieian of German origin, as modest and unassuming as he was learned and versatile.

Oliver Wendell Holmes (1809-94), of Boston, whose work on puerperal fever has been mentioned, was Parkman professor of anatomy at the Harvard Medical School (1847-82), and resembleil

${ }^{1}$ Leidy: Proc. Aearl. Nat. Sce, Phila., 1S46, iii, 107.

${ }^{2}$ Ibid., 184S-49, iv, 22:-233.

${ }^{3}$ Ibid., 1851, v, 212.

${ }_{4}^{4}$ Tr. Coll. Phys., Phila., 1856, 3. s., viii, 441-443.

${ }^{5}$ Proc. Acad. Nat. Se., Phila., 1871, xxiii, 297.

${ }^{6}$ Leidy: Jour. Acarl. Nat. Sc., Phila., 1S69, 2. s., vii, 1-472.

${ }^{7}$ Rep. U. S. Geol. Survey, 1873 , i. 
Hyrtl in his skill in making a dry subject interesting through his liveliness and wit. He made no discoveries of importance, but he wrote many elever medical poems, and his "Medieal Essays" (1883) was easily the most important American book dealing with medical history in its day.

Prominent among the comparative anatomists of the transition period were Gegenbaur and Wiedorsheim. Carl Gegenbaur (1826-1903), a native of Wiarburg and a follow-student of flaeckel's, established the point that comparative morphology, and not embryology, is the true eriterion for determining the relation of homologies or pedigrees of organs (phylogeny), thus bringing the matter of the genealogy of organs back to Owen's original eonecpt. In recent tincs, a large number of facts in cormoboration of Owen's theory were prenluered, but many others which showed that similar struetures may arise in different ways. At present, embryology is studied as a phase of morphology. Ciegenbaur also gave the coup de grace to the vertebrate theory of the skull (Coethe-(Owen), by showing that, in the embryo, there are a large number of head segments corresponding to the branchial clefts and the eranial nerves; that, in the lowest order of fishes, the head, instead of being composed of vertehrat, is ansegmented, while in the higher, many eranial bones arise from the skin. In 1861, Gegenbaur demonstrated that the ovum of every vertebrate is a single cell. His prineipal works are lis Comparative Anatomy of Vertebrates (1S64-72), his Elements of Comparative Anatomy (1870), and his Text-book of Human Anatomy (1883). He was editor of the Morphologisches Jahrbuch (1875-1902), and professor of anatomy at Heidelberg, where he hat many Amerjean pupils.

Robert Wiedersheim (1848- ), professor of anatomy at Freiburg, was the author of important works on the Comparative Anatomy of Vertebrates (1582-53) and The Structure of Man as an Evidence of his Past (1857).

After the time of Schleiden, Schwamn, and Henle, the study of the finer or microscopic anatomy of the tissues beeame the word of ambition. Histologieal investigation was rapidly improved by the introduction of new staining methods, microtomy, and other technical procedures. Purkinje, as we have seen, had a microtome and used Canada balsam, glacial acetic acid, and potassium bichromate. but these things were not generally known, and the common procedure was to examine the tissues in the fresh state, sliced by a razor between layers of vegetable pith. Hardening of the tissues in alcohol eame long after. In 1847, Joseph von Gerlach, sr. (1820-96), of Mainz, began to inject capillaries with a transparent mixture of earmine, ammonia, and gelatine; and, by 1855 , he was employing carmine as a nuclear stain for the tissues. Virchow did practically all his work with earmine. Gerlach was also a pioneer in the use of aniline and gold chloride, and, after his time, differential staining became rapidly specialized. The microtome was definitely introduced by Wilhelm His in 1866, but was not perfected until about 1875 , after which it became an important labor-saving device.

The master worker in histology was Max Schultze (182.5-74), of Freiburg, who was professor of anatomy at Halle (1854-59), 
and, succeeding Helmholtz at Bonn in 1559, became director of the Anatomical Institute there in 1872.

Schultze introdueed the dilute chromie acid solution, the osmic acid stain, iodated serum as a preservative, and invented the heatable object-stand. An important contributor to marine zoölogy, in his studies of the Turbellaria (1S4S-51), the Polythalimia (1S54-56), and the embryology of Petromyzon (1856), he marle an epoch in histology by his great monographs on the nerveendings of the sense organs, in particuliur, the internal ear (18581), the nose

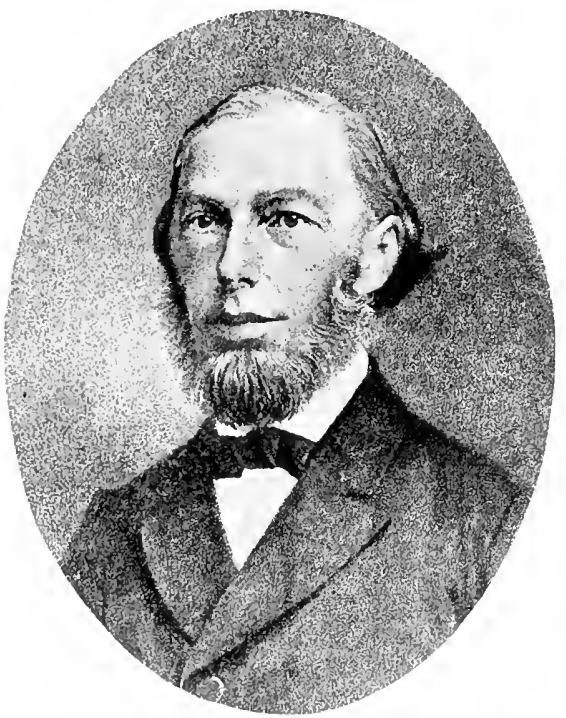

Max Schultze $(1825-74)$.

$\left(1863^{2}\right)$, and the retina $\left(1866^{3}\right)$. In 186.5, he founded the Archio für mitroskopische Antomie, which he edited until his death. Sehultze had a lasting influence upon the eell theory through his essay of $1861,{ }^{4}$ in which, contemporaneously with Brücke, he defined the true eell ats a clump of nucleaterl protoplasm, thus cmphasizing the point which Leydig had made in 1856. that the eell membrane, even in the ovum, is a seeontlary physico-ehemica, formation, probably due to surface-tension condensation of the cell contentsi In his memoir on the protoplasm of rhizopods and plant eells $\left(1863^{5}\right)$, Schultze definitely introduced the term protoplasm, and showed that it is practicatly identieal in all living eells. In 1863 he gave the most aceurate contemporary aecount of the furrowing and segmentation of tho frog's egg. ${ }^{6}$

Schultze was a striking, keen-eyed investigator, an aceomplished draftsman, and a friend of music, devoting his leisure hours to the violin.

'Schultze: Müller's Areh., Berl., 1858, 343-3\$1.

${ }^{2}$ Abhandl. d. naturf. Geselkeh. zu Halle, 1863, vii, 1-100.

${ }^{3}$ Zur Anatomie und Physiologio der Retina, Bonn, 1866.

${ }^{4}$ Arch. f. Anat., Physiol. u. wissensch. Med., Leipz., 1861, 1-27.

${ }^{5}$ Das Protoplasma der Rhizopoden und der Pflanzenzellen, Leipzig, 1863.

${ }^{6}$ De ovorum ranarum segmentatione, Bonn, 1863. 
The next most important step in the cell doctrine was taken by Walther Flemming (1843-1905), of Schwerin, professor at Prague (1873-76) and Kiel (1876-1905), whose important monograph, Zellsubstanz, Kern- und Zelltheilung (1882), gives the classic account of ecll division and karyokinesis. Some phases of the latter process had been observed by Virchow and Sehneisler, and Heitzmann had noted (1873) that all protoplasm is a continuous network the gramular appearance of which is only optical. Flemming's memoir put the whole matter in a new light. He worked out the phenomena of muclear division, as erystallized in his aphorism "Ommis mucleus e mucleo"; and showed that protoplasm is a complex structure, made up of an active, contractile, net-like material,

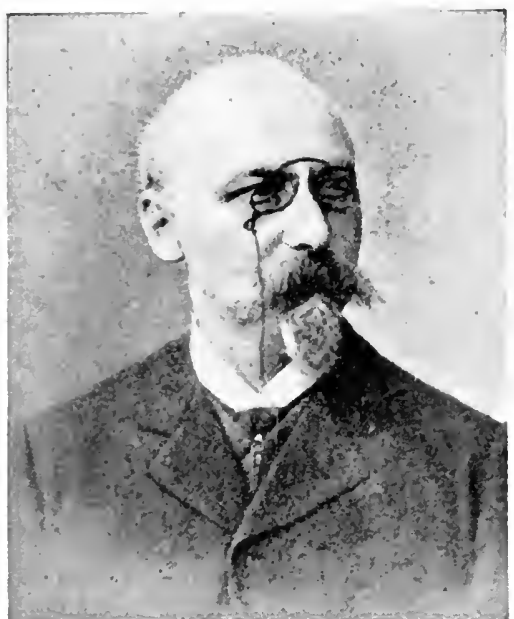

Walter Flemming (1843-1905). and an inert, semifluid, inter-reticular substance, which, from their behavior toward various stains, he called chromatin and achromatin, respectively. Histologists hold this to be the most important work on the cell after Schwann's and Virchow's.

Many important discoveries and innovations in histology were made in this period, such as Alfonso Corti's investigations of the mammalian coehlea (rorls of Corti, 18511), Virchow's diseovery of the neuroglia $\left(1854^{2}\right)$, Wilhelm His' investigations of the strueture of the lymphatic glands (Leipzig, 1861) and lymphatic vessels (1S63), Willy Kü̈hne's memoir on the peripheral end-organs of the motor nerves (Leipzig, 1862), Deiters' memoir on the brain and spinal cord in man and mammals (Brunswick, 1865), the islands of Langerhans $\left(1869^{3}\right)$, F. S. Merkel's deseription of the taetile corpuseles in the papillse of the skin (1875), Ranvier's investigations on the histology of the nervous system (norles of Ranvier, 187S), Ehrlieh's investigations of the leukoeytes (is804), and his intravital (methylene-blue) stain for nerve substance $\left(1 \$ \$ 6^{5}\right)$, and Camillo Golgi's epoch-making work on the nervous system $\left(1873-86^{6}\right)$. The third elements of the blood, the so-ealled blood plaques or platelets, were first noticed by Alexander Donné

1 Corti: Ztschr. f. wissensch. Zoöl., Leipz., 1851, iii, 109-169.

${ }^{2}$ Virehow: Arch. f. path. Anat., Berl., 1854, vii, 135-138.

${ }^{3}$ Paul Langerhans: Berlin dissertation, 1869.

${ }^{4}$ Ehrlieh: Ztsehr. f. klin. Med., Berl., 1879-80, i, 553-560.

${ }^{5}$ Ehrlich: Deutsche med. Wochenschr., Leipz. and Berl., 18\$6, xii, 49-52.

${ }^{6}$ Colgi: Sulla fina anatomia degli organi centrali del sistema nervoso, Milan, 1886. 
(1S01-7St) in 1842, afterward by Max Schultze, and more fully deseribed by Sir William Osler $\left(1873^{2}\right)$ and Giulio Bizzozero $\left(1883^{3}\right)$.

One of the most eminent of modern histologists was Magnus Gustav Retzius (1842-1919), a graduate of Lund (1871) and professor of histology at the Karolingska Institut (1877-1900), who investigated the organ of hearing in bony fishes (1S72) and vertebrates (1851-4), also the macroseopic anatomy of the human brain (1896), published remarkable albums of Finnish and Swedish skulls (1S9S-9), and a series of splendid histological studies in folio (1890-1914).

Toward the elose of the nineteenth century, the storm center of histologie controversy was the neuron theory, the doctrine of the physiologic autonomy of the nerve-cell and its branches. The cell theory seemed adequate to account for this as far as the nerve-cell itself was concerned, but the great stumbling-block was the origin and true significance of the far more abundint nerve-fibers, whieh harl always been rescribed as detached formations, separate. from the cells. In 1850, Augustus Volney Waller (1816-70), of Faversham, England, showed that if the glossopharyngeal and hypoglossal nerves be severed, the outer segment, containing the axis-cylinders cut off from the cells, will undergo degeneration, while the central stump will remain relatively intact for a long period of time. "This "law of Wallerian degeneration" indicated that the nerve-fibers are simply prolongations of the cells from which, as Waller maintained, they receive their nourislmment. The classical researches of Deiters $\left(1865^{5}\right)$ showed that each nerve-cell has an axis-cylinder or nerve-fiber process growing from it, and a number of protoplasmic processes or dendrons, wbich branch into dendrites, forming arborizations. The material continuity of the nervo-fibers with the terminal arborizations was demonstrated by Gerlach's gold chloride stain in 1871, and later the use of carmine with Weigert's mordant showed the eontinuity of the nerve-body with the axis-cylinder. In $1883^{6} \mathrm{Ca}^{\mathrm{a}}$ millo Golgi (1844- ), of Pavia, applied his silver nitrate stain of $1873^{7}$ to the central nervous system, and strikingly demonstrated the existence of multipolar nerve-eells, having long and short axis-cylinder processes (Golgi cells) with the arborization of denilrites. In $1856,{ }^{8}$ Wilhelm His showed how the nerve-cell develops from a columnar epiblastic cell into a neuroblast by thrusting out a pseudopodium, which beeomes the axis-cylinder, the polar pseudoporlia remaining protoplasmic and becoming the dendrites. Progress was now rapid. Forel, in 1S87, confirmed the work of His on the pathologie side by studying experimental degenerations. A loost of investigations by von Kölliker (Switzerland), von Lenhossék (Hungary), the younger Retzius (Sweden), $A$. Van Geluchten (1861-1914) (Belgium), and the eminent Spanish bistologist, Santiago Ramon y Cajal (1852- ) greatly extended the knowlerlge of those terminal arberizations in the brain anfl eord, which Obersteiner likened to an espalier growth and Ramon y Cajal to the network of lianas and mosses in a. tropieal forest. Many new staining methods were introduced, in particular, that of Bethe, who marle Ehrlich's intravital (methylene-blue) stain a permanent one by arlding ammonium molyblate, and thus clearly demonstrated the continuity of the cell-borly and axis-cylinder $\left(1895^{9}\right)$. The neurofibrill:e,

1 Donué: Compt. rend. Acad. 1. sc., Paris, 1842, xiv, 366-368.

${ }^{2}$ Osler: Proc. Roy. Soc., Lond., 1873-74, xxii, 391-398.

${ }^{3}$ Bizzozero: Di un nuovo elemento morfologieo del sangue, Milan, 1883.

${ }^{4}$ Waller: Phil. Tr., Lond., 1850, 423-430.

${ }^{5}$ Otto F. C. Deiters: Untersuchungen über Gehirn und Rüiekenmark (ctc.), Brunswick, 1865.

${ }^{6}$ Golgi: Riv. sper. di freniat., Reggio-Emilia, 1882 , viii, 16.5; 361 : 18\$3, $\mathrm{x}, 1 ; 161 ; 385$ : $1885, \mathrm{xi}, 72 ; 193$.

${ }^{7}$ Golgi: Gazz. med. ital. lombard., Milano, 1s73, 6. s., vi, 244-246, 1 pl.

${ }^{8}$ His: Abhandl. d. math.-phys. KI. d. k. sächs. Akarl. d. Wissenseh., cipz., 1887, xiii, 477-513, $1 \mathrm{pl}$.

${ }^{9}$ Albrecht Bethe: Arch. f. mikr. Anat., Bonn, 1894-95, xliv, 579-622. 
which Max sichultzo hat seen in the dectrio lobe of the torpedo in 1852 , were beatutifully hrought out in violet hy the gold rhloride stain of the Ilumgarian,

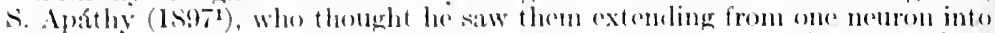
another. This was, howrere, confuted by the rematiable staining mothods of

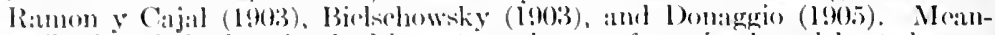

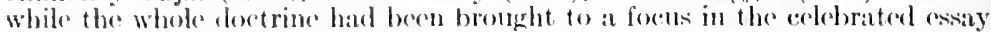
of 1 ilholm Waldeyer $\left(1591^{2}\right)$, which atfirmed that the norvous system is made I1p of cpiblatio colls or netrons, anch consisting of a coll-body with two sets of processes, an axon (axis-celiuder) having offerent (collulifugal) functions and one or more dendrites with afferent (cellulipetal) functions. Upon these comentlose nemrons the functional activity of the nervous system depends, the nervelibers boing nowise independent, but axonic and dendritje out growths. In Amerioa, the whole subjoct was ably and aritically expomeled in the troation of lewellys F. Barker $\left(1899^{3}\right)$, who has dealt particularly with the controversies which raged down to the year 190.4. Implicit in the nemron foretrine itself is the basie idea of the autonomy of its units, viz., that the brinehes of the netrons are eonfiguous, but not continuous, transmitting sensitions and jumpulses by contact alone. But Gerlach bolieved that the sensorium commune is mald ip of a continuous network (rete mirabile); Apathy, Held, and Bethe upheld the notion of a continuum of neurofibrillae, Henson, the concept of a system of intercellular bridges, Franz Nissl (1s60-1919), the theory that the gray matter (nervëse Graut) is the condueting modium, Held and Bethe that nerve-fibers can be formed by a fusion of ecrtain cells (pluricellular loetrine). In battling over these views, many able investigators wandered away from actual facts into journalistic pettifogging. The eonelusion of the whole matter was reached in a series of beanitful and convineing experiuments by Ross Granville Harrison (1870- ), who eventually demonstrated the ameboid outerowth of the nerve-fibers from the cell in an extravital culture $\left(1910^{5}\right)$. Thus, by purely physical and ehemical mothods, the whole nervots system was finally brought under the ecll doctrine of Sichwann and Virchow.

By the close of the nineteenth century, embryology had become a highly complex science, its main developments being along such $d_{a t}$ ths as the investigation of the origin of tissues, the morphology and pathology of the embryo as a whole, the signifieance of maturation and fertilization of the ovmm, the tracing of cell lineage (crtogenesis), the study of embryology in the light of evolution (Recapitulation Theory), the structural relations of the placenta, and the beginnings of experimental embryology.

Highest among contemporary names, perhaps, stands that of Wilhelm His (18:31-1904), of Basel, Switzerland, who did the best work of his time on the origin of tissnes and the serial and morphologieal study of the embryonic and adult organism. As Bichat dealt with the coarser aspects of tissues, Henle and Köliker with their microscopic appearances in health, Virchow with the same in

${ }^{1}$ Apáthy: Mitth. a. d. zoöl. Station zu Neapel, 1897, xii, 495-748.

2 Waldeyer: Deutsche med. Woehenschr., Leipz. and Berl., 1891, xvii, $1241 ; 1267 ; 1257 ; 1331 ; 1352$. 1899.

${ }^{3}$ Barker: The Nervous System and its Constituent Neurons, New York,

${ }^{4}$ Franz Nissl: München. med. Wochenschr., 1909, xlv, 98\&; 1023; 1060.

${ }^{5}$ Harrison: J. Exper. Zoöl., Phila., 1910, jx, 7\$4-\$46, 3 pl. 
disease, so the name of His will always be associated with the science of their origins (histogenesis). His came of a distinguished Basel family, and apart from the advantages derived from his parentage, his education was of the very best, his teachers being Johamnes Müller, Robert Remak, Virchow, and Kö̈lliker. Professor of anatomy at Basel from 1857 to 1872 , he was, through the influence of Carl Ludwig, appointed in the latter year to the same chair at Leipzig where he remained for the rest of his life.

His earlier studies were on such themes as the normal and pathologifal histology of the cornea (1853-56), the strueture of the thymus gland (15.59-6i1), the histology of the lymphatie glands (1861) and the limphatic vessels $(1862-63)$, the latter illustrated with univaled plates. In 1865 he published his great academie program, "On the Tissue-layers and Spaces of the Body," introducing at new classification of tissues as a guide in embryological researeh. It contains a sympathetic alpreciation of Bichat, a defense of his elasifirition as being related to the germlayers, and points ont that all the serous spaces arise in the mesoderm and are lined with the special membrane which lis eatled endothelial. His monograth on the embryology of the chick appeared in 1868 , and during 18S()-85 his famous inatomie menschlicher Embryonen, in which, from carefully selected s]wimens, the human cimbryo was studied as a whole for the first time. In 1886, His astablished, by ambryot logiral invostigation, the fact that the axis-eylinder is a process of the nerverecell. In 1900, he introduced his eoncepts of the leeithoblast and angioblast (the Arelage of the blood

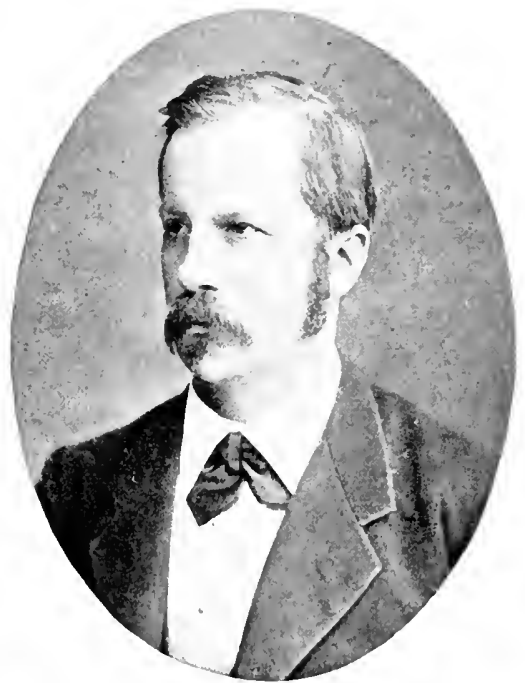

Wilhelm llis (1831-1904). (Comptest of Miss Davina Wattrson.) and eapilliries).

In the meantime he had been approaching his subject from a larger angle. A beautiful draughtsman and a skilful photographer from boyhood up, his am in teaching was to visualize everything to his pupils by moans of microphotography, lantern-sides, models, and his own unrivaled drawings, and he was able to utilize the advantages given him at Leipzig in a most remarkable way. In 1866 , he invented a microtome which he gradually inproved, and, from the serial sections so obtained, he conceived the idea of a graphic reconstruction of the embryo in two and three dimensions (1868), the former process being attained by means of the "cmbryograph" (his invention), the latter by the 
models of his assistant li. J. Steger, and afterward, by the device, invented by Born, of drawing the sections upon wax plates and setting them in juxtaposition. These serial sections, all from the same embryo, soon obviated the errors made by comparing chance sections of embryos of different sizes and ages. The HisSteger models, now seen in all anatomical musemus, are permanent memorials of his success in demonstrating morphological relations in three-dimensional space. This is especially true of his Präparate zum Situs viscerum (1878), which included models of the female pelvic viseera. In 1874, he published Unsere Köperform, which argues that the form of an organism is due to such mechanical offects as the migrations of cels, tissues and organs, although a mechanical causation of cell glowth is denied. While not the same thing as developmental mechanics, this idea may be said to have led up to it. His was one of the founders of the Anatomische Gesellschaft, and in 1895 he drew up its report on the revision of anatomieal nomenclature (B. N. A.), which, it is said, reduced current anatomical terms by about eighty per cent. This was presented in English dress by Lewellys F. Barker in 1907. In 1876, His founded the Zeitschrift für Anatomie und Entwicklungsgeschichte, which, in 1877, became merged into the old Müllerdu Bois Reymond Archiv, His and Braune editing the Anatomische Abteilung (1877-1903). The great Anatomisehes Institut at Leipzig was construeted under the direction of His, and opened April 26, 1875. He was also one of the founders of the Archiv für Anthropologic (1876), and his interest in the subject is evidenced in the monograph on Swiss crania which he made with Rütimeyer in 1864 , his studies of the Rhætian population (1864), of the skeletons belonging to Vesalius and Platter (1879), of the development of human and animal physiognomies (1892), and his identification of the remains of Johann Sebastian Bach (1895). The latter were found in a coffin in the yard of the old Johanniskirehe and, by comparative measurements and averages taken from other cadavers, His enabled the sculptor Seffner to construct a bust in elay which was at once recognizable as a counterfeit presentment of the great seventeenth century composer. Unlike his colleague, Ludwig, His founded no school, believing that it is best for the student to go his own way and follow his own bent. His work on the anatomy of the human embryo has been carried forward to a unique conelusion by his pupils, Franz Keibel and Franklin P. Mall (1910-12).

The problem of the dynamies of the maturation, fertilization, and segmentation of the ovum, which had remained insoluble sinee Harvey's time, was worked out in the following way: In $1826,{ }^{1}$ Prévost and Dumas first de-

${ }^{1}$ Prévost and Dumas: Ann. d. sc. nat., Paris, 1827, xii, 415-143. 
seribed the segmentation of the frog's egg. The mammalian ovum was discovered by von Baer in 1827, and was shown to be unicellular in every vertebrate by Gegenbatur in 1861 . The spermatozoa, discovered by llamen in 1677 , were shown, in a filtration experiment of Spallanzani's, to be essential to fertilization $(1786)$, and their cellular origin was demonstrated by Kölliker in 1841. In 1865, Schweigger-Seidel and La Valette St. George provel that the spermatozoon is a cell possessing a nucleus and cytoplasm. ${ }^{1}$ Its union with the ovum was first observed (in the rabbit) by Martin Barry in 1843. Virchow clearly stated that the ovmm is derived, in continuous line of deseent, from preёxisting fertilized ova (1853). In 1875, Oscar Hertwig demonstrated that the spermatozoon enters the ovum and that fertilization is acconplished by the union of the male and female pronuclei so formed. ${ }^{2}$ Huxley conceived that, "regarded as a mass of moleeules, the entire organism may be compared to a web of which the warp is derived from the female and the woof from the male" (1878). The polar bodies, given off by the ripe ovum, were shown to be formed by division of its nuclens by Bütschli in 1875, and by Fol in 1876 . In 1880 , the splitting of chromosomes in the cell-nucleus (karyokinesis) was discovered by Flemming; and in 1883, Van Beneden discovered that the associated male and female pronuclei in the fertilized egg each contain half as many chromosomes as the normal body cells in the same species. Weismann believed that the object of this was to keep the number of ehromosomes constant in the given species. Theodor Boveri ( -1916) defined the splitting of the chromosomes as a definite act of reproduction (1SSS), and he showed that there are two varieties of Ascaris megalocephala which differ only in the number of chromosomes. In 1875, Flemming discovered a minute body in the ovum of the Anodon, usually lying out ide the mucleus and often paired. This was discovered independently by Elouard Van Beneden in 1876 , and was termed the centrosome by Boveri in 1888. The centrosome was soon found to be common to many other cells of the body and to unicellular organisms, and came to be regarded as the special organ of cell division, the "dynamic center" of the cell. Boveri supposed it to be the specific organ of fertilization in the spermatozoon, initiating mitosis by its own division, or, as Wilson once put it, "the web is to be sought in the chromatic substance of the nuclei," while "the centrosome is the weaver at the loom." While the latter point has not been entirely substantiated, the study of the reduetion of the chromosomes has led to an exact comprehension of oögenesis and spermattogenesis (Oscar Hertwig, 1890), and latterly to the elucidation of the part they play in heredity and the determination of sex by McClung, Morgan, Wilson, Miss Stevens, and others.

The science of the germ-layers was founded by von Baer (1828-34) and Robert Remak (1845). In 1849, Huxley showed that the embryonic epiblast (ectoderm) and hypoblast (endoderm) can be assimilated to the two layers of cells which make up the body of the adult Hydra. This was regarded as a great alvance at the time, but later investigation has shown that the developments from the germ-layers in different animals are by no means constant; that the mesoderm may originate from either ectoderm or endoderm, and that many organs can be traced back to certain predestined cells, rather than to cell-layers. Cell lineage or cytogenesis has therefore become a subject of ardent investigation, and, since the initial labors of Blochmann (1882), most of this work has been done in America. In such finely illustrated monographs as those of Charles Otis Whitman on the embryology of Clepsine (1878), Fdinund B. Wilson on Nereis (1892), C. A. Kofoid on Limax (1895), Frank R. Lillie on the Unionidx (1895), H. S. Jennings on Asplanchna (1896), W. E. Castle on Ciona (1896), and E. G. Conklin on Crepidula (1897), the germ layers have been traced out, cell by cell, from the beginning of segmentation, and it has been shown that there is nothing constant about the development of the mesoderm and its derivatives.

${ }^{1}$ F. Schweigger-Seidel: Arch. f. mikr. Anat., Bonn, 1865, i, 309-335.

${ }^{2}$ O. Hertwig: Morph. Jahrb., Leipz., 1875-6, i, 347-434, 4 pl. 
The net result of the vast amomut of embryological investigation, up to the your lSs1, was summed up in the master-work of Fancis Manland Balfour (1S51-82), of Elinburgh, whose tragie death rohbed serence of one of its brightest, most attractive and most promising spirits. Af cambrilge, Balfour came molde the influenes of Michadel Foster, and from that master he acepuired his interest in ambryologr, collabolating with him in the well-known Elements (187t), which was the standard text-book of its time in English and Anerican schools. In 1873, Balfour went to sturly uncker Anton Dohm at the Naples Zoölogical Station, and here he made an important research upon the embryology of Elasmobranch fishes, ${ }^{1}$ which was particularly strong in regard to the early stages of the ormm and cmbryo, the development of the kidneys, and the origin of the spinal nerves. In the meantime, Balfour had been appointed fellow and lecturer on animal morphology at Cambriclge, and was soon attracting large classes of enthusiastic pupils. In 18S0-81, appeared his great Treatise on Comparative Embryology, which is not only indispensable as a digest of all that was known up to that time, but, as cmbodying the work of himself and pupils, is the most compact and lucid exposition of the science which has ret appeared. Foster describes it as brushing away many cobwebs and mooted points "with a firm but courtcous sweep." In acknowledgment of the value of this work, Balfour was made profescor of animal morphology at Cambridge in 1882, but he was not, to enjoy the fruits of his labors. Taking up Alpine climbing to improve his health, he attempted, in July, 1882, to make an ascension of a virgin peak and was never seen alive again. His body and that of his guide were found at the bottom of a chasm a day later. Balfour was described by Foster as a keen, quick observer and logician, a high-minded, fascinating, and very able man. Had he lived, he would undoubtedly have been one of the topmost figures of modern science. Locy says that "the speculations contained in the papers of the rank and file of embryological workers for more than two decades, and often fondly believerl to be novel, were for the most part anticipated by Balfour, and were also better expressed, with hetter qualifications."

The close resemblanee between the early stages of the embryo in different animals harl been noticed by Meckel and Oken. Von Baer is said to have admitted that he could not distinguish between three unlabeled embryos of a bird, a reptile and a mammal before him. Agassiz, in his Essay on Classification (1559), stated that the developmental phases of all living animals correspond to the morphological changes in their fossil suecessors throughout geological time. Fritz Müllor, in 1863, showerl that the larval stages of erustaceans ean be interpreted as a recapitulation of the evolution of the race. Kovalevsky, in 1866, showed that the early stages of Amphioxus (the lowest vertebrate),

${ }^{1}$ Balfour: Jour. Anat. and Physiol., Lond., 1876-8, passim. 
and of the invertebrate order of Tunieata are identieal. He also demonstrated that all animals pass through the so-ealled gastrula stage, which led IIaeclid to his (iastraea Theory (1S\$1), viz., that the two-hayered gastrula is the an:1logue of the hypothetic ancestral form of all multicellular animals (gastrata). Hacekel's biogenetic law asserts that the developmental history of the individual (ontogeny) tends to recapitulate the developmental history of the rarial type (phylogeny). The most critical and eonservative statements of the $R e-$ capitulation Theory are those of von Baer and Balfour. Von Baer's "laws" asselt that the resemblance of early embryonic stages in different vertebrates is limital to a eertain short period at whieh the embryo in question not only differs, in special class features, from all other embryos, but has alrearly beguin to put on generic and speeific characters of its own. Balfour pointed out that the recurrenee of certain ancestral eharaeters, such as the fish-like branchial clefts and the two-chambered heart in the frog, inclieate that these "wrere functional in the larva of the ereature after they eeased to have any importanee. in the alult." The De Vries theory, that species ean originate by sulden jumps or mutations, has ereated a great spirit of antagonism to the old Darwinian idea of the slow, gradual evolution of species through accidental variations, although it is perfectly possible that both processes may eoexist in the scheme of nature. In any ease, the reapitulation doctrine is now regarled as a mere literary analogy or formal interpretation, as something read inte the facts of comparative embryology by htman prepossessions. Concerning the hypothetical family tree of the vertebrata through the Anphioxus, the Innelida, the worms of Sagitta type, the spiclers, limulus and the Echinoderms, Driesch quotes the seathing remark of du Bois Reymond that "phylogeny of this sort is of about as much seientifie value as are the pedigrees of the heroes of Homer."

Among the important embryologieal researches of the century may be mentioned Wilhelm Waldeyer's studies on the ovary and ovum, including his diseovery of the germinal epithelium (1870), Felotiard Van Beneden ( 1916) on the early development of the mammalian ovmm (1575) and the history of the germinal vesicle and embryonie nuelens (1876), the work of Alexander Agassiz (1835-1910) on the ledimolerms (1872-83) and the Ctenophora; the diseovery of the atro-ventricular buntle of the heart by Wilhelm His, Jr. (1893), Johannes Sobotta on the formation of the "(olpus luteum (1S96), Alfred Schaper on the earliest phases of differentiation in the central nervous system (1897), the work of Florence Sabin on the lymphatics, and the important investigations of George: Howarel parker on the evolution of the norvous system.

Of Americans, William Keith Brooks (1S4s-196s), of Cleveland, ()hio, professor at the Johns Hopkins University (1S7(j-19) S), is memorable for his monographs on the oyster (1891), the genus salpa (1893), which corrected the carlier views entertained as to its "alternation of generations," the stomattopoda of the Challenger expedition, the genera Lucifer and Macrura, and his books on Pangenesis (1877), Heredity (1883), and The Foundations of Zoölog!! (1899). He founded the Chesapeake Zoölogieal Laboratory (1S7S), and was a fascinating, inspiring teacher, especially through his mmsually boatutiful drawings.

Charles Otis Whitman (1842-1910), of Woodstock, Maine, profosior of zoology in the University of Chieago (1892), fomded the Jourral of Morphology (18S7) and the Biologieal Bulletin (1S99), and is memorable for his papers on the embryology of Clepsine (1S7s) and the inalequacy of the cell theory of development (1895).

Franklin Paine Mall (1862-1917), of Bolle Plaine, lowa, professor of anatomy at the Johns 1 lopkins University, a pupil of His and Carl Lumlwig, did good work on the physiology of the eircilation under the latter, and is known for his important investigations on monsters, the pathology of (arly humam embryos (1899-1908), and the struetural unit of the liver (1905). II robliborated with Franz Keibel in the valual,le. Manual of IImman Embryoloy!y (191012), the best modern work of its kinel.

Charles Sedgwick Minot (1852-1914), of INest Roxbury, Massarbusetts, professor of embryology and comparative anatomy at Harvard University, was 
the author of an important treatise on $/ /$ uman Embryology (1892), which introduced many novel theories, also of a Bibliography of Vertebrate Embryology (1593), and a Laborutory Text-book of Embryology (1903). He inverted two different kinds of automatie microtomes, and is widely known for his original investigations, partienlarly those on the origin and strueture of the plicent: (1891). IIis Age, Grouth, and Death (1908) states the "law of cytomorphosis," in virtue of which these processes result from the steady change of protoplasm into more highly differentiated forms.

Thomas Hunt Morgan (1866-_ ), of Lexington, lientucky, professor of experimental zoölogy at Columbia College (1901), wrote the first treatise on experimental embryology in English (1897), has made many important investigations in embryology and the mechanism of heredity, and is the anthor of outstanding monographs on Regeneration (1901), Erolution and Adaptation (1903), Experimental Zoölogy (1907), Hercdity and Sex (1913) and the Mechanism of Mendelion IIeredity (1915).

George Iloward Parker (1S64- ), of Philadelphia, professor of zoölogy at IIarvird Lniversity (1906), is the anthor of important researches on the survival of primitive types of neuromuseular mechanism in the higher vertebrates, summarized in his work on The Elcmentary Nertous System. He discovered that differentiation of muscle preecles differentiation of the nervous system in the lower multicallular animals, which accords with Galen's law that st ructure follows function.

Experimental embryology is a branch of experimental morphology or developmental mechanics (Entwicklungsmechanik), a phrase introduced by Wilhelm Roux (1850- ), of Halle, who may be regarded as the founder of the seience. Roux was a pupil of Virchow and Iiaeckel, and his bent was already shown in his graduating dissertation (Jena, 1878), which dealt with the hydrodynamie eonditions governing the formation of the lumina of branching blood-vessels. In 1894, he founded the Archiv für Entuicklungsmechanik, the principal organ of his seience to date. Most of the early work in experimental embryology was done upon the frog's egg, as being the easiest to ohtain. The first step was taken by the physiologist Eduarl Pfluger (1S29-1910), who, in 1852-83, made a number of experiments on cross-fertilization with different species of the frog. In 1883, Pftïger made a series of still more important experiments upon the effect of gravity upon the development of the egg, showing that the initial planes of eleavage will be vertical and the development normal, no matter how the egg is placed. In 1884, Born showed that gravity brings about a slow rearrangement of the contents of a rotated egg, aceording to their specific gravity. In the same year, Roux demonstrated that eggs whirled in a centrifugal machine do not differ in development from the normal controls. Pflüger, in 1S54, showed that compression of the unsegmented egg between two planes of glass modifies the planes of cleavage according to the direction of pressure. Later, in 1892. Hans Driesch (1S67- ) showed that continued pressure applied to an Echinus egg can produce a flat plate of 16 or 32 cells, which will proceed to normal development in three dimensions, direetly the pressure is removed. In 18S8, Roux published his celcbrated experiment of killing one of the two initial blastomeres with a hot needle, producing a typical half-embryo. This led to the Roux-iWeismann hypothesis of mosaic or qualitative development, which assumes that the center of formative ehanges is the complex structure of the nucleus, the sifting of the differential eharacters in the danghter eells being purely qualitative. Driesch, however, found, in 1891 , that if the two blastomeres could be separated and set free by shaking, the segmentation in each would go on unilaterally up to the blastula stage, after which the open side of the latter would close over, resulting in a fully developed but small-sized embryo. Thomas Hunt Morgan (1866- ), by rotating the surviving blastomere in Roux's hotneedle experiment, so that the white pole was turned upward, produced a whole embryo of half size (1894), showing that the completed development was due to a rearrangement of the contents; and Schultze, in 1894, produced double monsters by inverting a fertilized frog's egg between two glass plates, so that the dark pole of the egg came uppermost. In 1895, Driesch and Morgan, by cutting off a piece of the protoplasm of a etenophore egg, prior to segmentation, 
without damaging the nucleus, produced the same half-embryo which ordinarily results from isolating the blastomeres of this egg. In 1s\$9, Boveri had succerded in fertilizing a non-nueleated piece of sea-urehin egg with the sperm of another species, producing an organism destitute of maternal characteristics. Later, Jacques Loeb produced the fatherless sea-urchin and fatherless frog. All this indicated that the protoplasm, rather than the nucleus, is the prineipal agent in the production and regulation of form (morphogenesis). Horbst pointed out (IS94-1901) that the formative and directive stimuli are usually external in plants and internal in animals. From a number of faets of this order, including the many novel experiments upon regeneration in adult marine hydroids by Loeb, Morgan, Miss Bickford, and others, Drieseh was led to formulate his quantitative theory of cell-rivision, viz., that the "prospective value" of any embryonic cell is simply a function of its location; and that protoplasm is a "polar bilateral structure," capable of regulating its development symmetrieally in any of the three dimensions of space, also a "harmonious equipotential system," having the same poteney for development in all its parts. From the totipotency of protoplasm, Driesch argued that its functions ean never be explained mechanically, since a machine, the smallest part of which is identical in structure and functional capacity with the whole machine itself, is unthinkable. The same sharp distinetion which is made in mechanies and patent law between a "tool" and a "machine" is, therefore, to be observed between a machine and a living organism or substance, since the former is always a clumsy imitation of the latter, and never vice versa. If this point were constantly observed by biologists, the superfine vitalism of Driesch would soon dwindle into a truism, for the eminent morphologist has latterly invoked, as a substitute for the medieval vital principles, the old Aristotelian "entelechies," which is again, only a petitio principii. Drieseh has given up experimentation to philosophize in the Cloud-Cuekoo-Land of "harmonious equipotential systems," but his quantitative theory of the development of the ovum had the advantage of being identical with the "epigenesis" of Wolff and von Baer, while Roux's "mosaic theory" is only a modified form of the old "preformation" hypothesis of Bonnet and Haller. Roux, having become enmeshed in these difficulties, devoted a great deal of labor to the task of extricating himself by means of "sage provisos, sub-intents and saving clauses." Thus, two of the ablest experimental morphologists of recent times have lapsed into scientific inactivity through the effect of their own theories.

The masters of physiology in the second half of the nineteenth century were Helmholtz, Claude Bernard, and Carl Ludwig. In the second rank come du Bois Reymond, Brücke, Goltz, Pflüger, Brown-Séquard, and, among the physiological chemists, Willy Kühne, Hoppe-Seyler, Salkowski, and Kossel. About the middle of the century, the physical principles of the Conservation, Transformation, and Dissipation of Energy came into prominence, and we may begin with the great mathematician and physician who made these an essential part of physiological theory.

Hermann von Helmholtz (1821-94), of Potsdam, was of mingled German, English, and French extraction, and was educated as a surgeon for the Prussian army. At the University of Berlin, he came under Johannes Müller and Gustav Magnus, and met such younger men as Virchow, du Bois Reymond, Brücke, Kirchhoff and Clausius. His inaugural dissertation dealt with the origin of nerve-fibers from cells in the ganglia of leeches and crabs, which he had observed with a rudimentary compound mieroscope (1842). During his barrack life at Potsdam he published his 
rssuy, Ueber die Erhaltumg der Kraft (1817), which established his reputation, although, at first, appreciated only by the mathematfician Jicohi. In 18.19, Itehuholtz was appointed profesiog of physiology and pathology at Königsborex, subseruently oceupying the chairs of anatomy and physiology at Bom (1855-58), physiology at Hejdelbereg (1858-71), and physies at Berlin (1871-94).

"The essay on lue Conservation of Energy established the first law of thermolynamies, viz., that all modes of emergy, as beat, light, electricity, and all cheminal phemomenas, are capable of transformation from one to the other but otherwise indestructible and imposible of creation. This had actually been

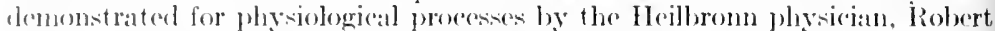
Mayer, and, for plyosial plenomena, by James Preseot .Jonle, in Iste, but II lmbloltz gave it miversal applica-

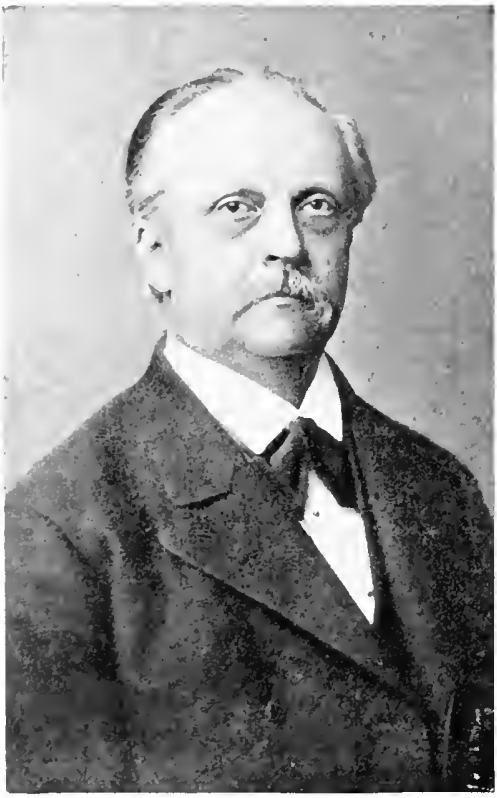

tion. buring the years $15.50-52$, (callsins and Lord Kelvin astablished the second law of thermodymanies, which asierets that omrergy, in all its nodes, is eontinually flowing or tonding to flow from states of concentration to phases of dissipation and never otherwise. 'This was applied to all physical and chomieal phemomena by one of Helmholtz's pupils, the Yale professor, Willard (iibbs (1872-78), of whose work Helmbeltz wote an appreciativestudy in 1852. That the museles are the main somres of animal heat was demonstrated by 11 (s) in isolated preparations in $1818,{ }^{1}$ and, in $15.50-52,{ }^{2}$ he measured the velocity of the nervous impulse with tha pendulum-myograph of his invention. His invention of the ophthalmoseope, in 1851,3 marle ophthalmology an exact science, and it was followed by his phakoseope and ophthahmometer (18.52). With the latter, he was able to determine the optical constants and explain the mechanism of accommodation (1854), particularly the part played by the lins. His great Handbook of Physiological Opties (185667 ) is a permanent elatsic, containing his revival of the Young theory of

color vision, which he regarded is a Hermann von Helmholtz (1\$21-94). -precial arise of Miiller's law of specific nerve energies. The Tonempfindungen (1St33) shows thr same wonderful sweep and mastery, revealing, at the same time, the aceomplished musieian. Never has the subject of acoustics been so exhaustively dealt with, exeept, perhaps, in Lord Rayleigh's treatise. Among other things which eannot be recorded here, Helmholtz also made an injportant study of the mechanism of the tympanum and ossicles of the middle ear (1869), which rid much to elucidate the phenomenon of audition. After assuming the

1 Arch. f. Anat, Physiol. u. wissensch. Med., Berl., 1848, 144-164.

I Ibid., 1850, 71; 276: 1S52, 199. See, also, E. Ebstein: Janus, Amst., 1906 , xi, 322 .

${ }^{3}$ Beschreibung eines Augen-Spiegels zur Untersuchung der Netzhaut im lebenden Auge, Berlin, 1851. 
chair of physies at Berlin and bereming director of the Physico-Technical Institute at Charlot tenburg in $18 \times 7$, he drooted the rest of his life to the field in which his true genius lay and in which ho was only equaled, in modern times, by such men as Clerk Maxwell and Loml Kelvin. In mathematical physics, Helmholtz made contributions of the first rank to the principles of dynamies, hydrodynamics, thermodymamics, and electrodynamics. He investigated the spin or vortex motion of an ideal, frictionless fluid (1858-73), he introlueed thr idea of the conveetion of electricity by noving material systems, and, in his Faraday lecture of 1881 , stated his bolief that the ehenical atoms are, in their ultimate nature, eleetric. Independently of Cibbs, he defined the "free (available) (nergy" of a chemical system as the difference between its total (intrinsic) ('nergy and its molecular (unavailable) energy; and he was the first to introduce the idea that the "hidden motions" of material bodies are those of cyclie systems with reversible eircular motions (as in the gyroscope or the governor of a steam-engin( ), in other words, rotational stresses in the ether or "whirls of" cnergy." "The Cibbs-Helmboltz equation, which assorts that the eleetromotive force of a galvanic cell (the actual work it can do) is equal to its free energy per electro-ehemical equivalent of decomposition, is now one of the basic priticiples of physical and physiological chemistry, eontaining, as Nornst says, "all that the laws of thermodynamics can teacli concerning chemieal processes." It was in Helmholtz's laboratory that Rowland investigated the properties of at moving body charged with eleetricity, so important in colloidal chemistry, and that Hertz discovered the electric (Hertzian) waves, which led to wirelesis tclegraphy.

Yet, although he stood at the summit of the highest department of human thought, Helmholtz never forgot that he was a physician. "Medicine," he said, with pride, "was once the intellectual home in which I grew up; and even the cmigrant best understands and is best understood by his native land." He even made a little contribution to medical practice, the application of quinine sulphate to the nasal mucous membrane in hay-fever $\left(1869^{1}\right)$. As a lecturer on "popular science," Helmholtz was approached only by Huxley, Tyndall, and Ernst Mach. His writings in this field have an elevation and dignity, a genial command of vast resources, which is peculiarly his own. In them one senses the personal nobility of the scientifie gentleman. Hehmholtz was of middle height, a man of extremely scrious, dignified mamner, his head of Gocthean proportions, with fine, carnest eyes. With the sincere, he was absolutely sincere and helpful. With shallow or trivial persons, he was apt to invest himself with "the sulstle ether of potential disapprobation," which, as some have testified, made them feel as if they were dealing with the fourth dimension of space. He had the northern tendeney toward the impersonal, and this was manifested even in his attitude toward religion. As to his ultimate views of the great questions of life, death, and immortality, Helmholtz was inscrutable and gave no sign. And, in this regard, his impersonal contributions to mathematical and physiological science are a true expression of his strong and dignified character.

${ }^{1}$ Ueber das Heufieber, Arch. f. path. Anat, Berl., 1869, xlvi, 100-102. 
Emil du Bois Reymond (1SIS-96i), of Berlin, the fombler of modern electrophysiology, was of Fronch extration, and he wote in German with the elarity and precision commonly associated with the French language and literature. Like Helmboltz, he was one of Johannes Müller's pupils, and succeded the latter as professor of physiology at Berlin in 1858, holding the chair for the rest of his life. Hede he added a new luster to the Berlin Faculty, turning out many fine pupils, and supervising the construction of the paliatial Physiological Institute (opened November 6, 1877), the best equipped laboratory of its kind in the world. The studies of du Bois Reymond relate almost entirely to the physiology of those muscle-nerve preparations which he did so much to introduce into

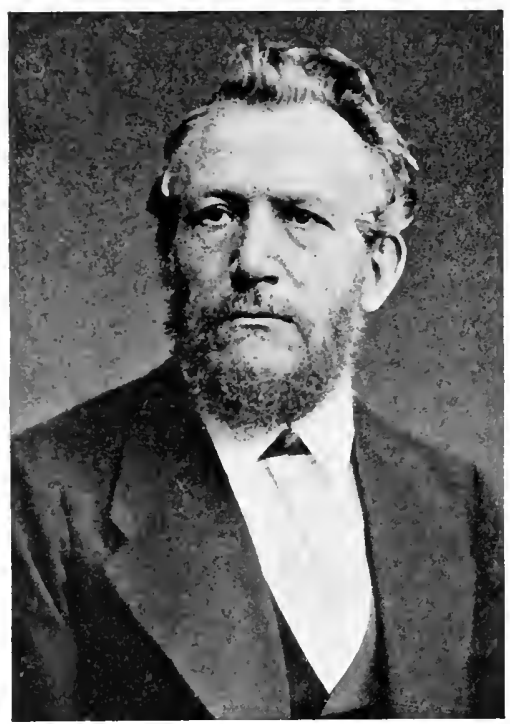

Emil du Bois Reymond (1818-96). laboratory experimentation, and his numerous investigations were twice printed in collective form-in 1848-60 and 185:3. After the discovery of muscular electricity hy Galvani, and of physiological tetanus by Volta, in 1792, there was little done in electrophysiology beyond the introduction of the astatic galvanometer by Lcopoldo Nobili (1784-1834), of Florence (1S25); and the bricf investigations of Stefano Marianini (1790-1866), and of Carlo Mattenced (1811-68), who introduced the word "tetanize" (1838), and first denonstrated the "rheoscopic frog" effect, viz., that the muscle of a muscle-nerve preparation will contract if its nerve be laid across another contracting muscle (18+2 $)$. Du Bois Reymond introduced faradic stimulation by means of the interrupted (makeand-brak) current from the special induction coil which is called after him (1849), made a thoroughgoing investigation of physiological tetanus, and was the first to describe and define electrotonus (1843), representing both conditions graphically by means of algebraic curves.

In 1843 he discovered that there is a difference of potential between the cut end of an excised muscle or nerve and the uninjured end, producing a cur-

1 Matteucci: Compt. rend. Acad. d. sc., Paris, 1842, iv, 797. 
rent which ean be demonstrated with a galvanometer, by closing the circuit. Ile wrongly inferred that this difference of potential exists in normat uncut muscle, but Hermann has since shown that it is due to chemical changes in an injured end. Since du Bois Reymond's time, a tetanic condition of injurerl or minjured musele has been regarded as the summation of individual responses evoked by rapidly succedling stimuli. He showed that tetanized muscle? yields an acid, resting musele a neutral, reaction; that stimulation with it constant current has no effect upon nerve, and stated the "law of stinmulation," in virtue of which the excitation of nerve depends, not upon the intensity of the eurrent, but upon the rapidity of its variation or upon maximum variations in unit time. He believed that the "currents of rest" and other electric phenomena which he found in muscle, nerve, and the glands, were due to elcetromotive molecules of prismatic form, arranged in series end to end, unbroken eircuits being maintained by the fact that these tissues are all moist, conductors. He applied the same reasoning to the organs of electric fishes, which he was the first to sturly in detail, and he summed up his view by stating that electrophysiological stimulation is mercly a phase of electrolysis.

During his long life, du Bois Reymond wrote many faseinating essays and many fine biographieal memoirs, in partieular, his seientific studies of the French materialists, Voltaire, La Mettrie, Diderot, Maupertuis; and of Johannes Müller and Helmholtz, the latter being the standard sourees of information in regard to their achievements. These lectures are written with great verve and esprit, displaying wide culture, but are more loaded with erudition than those of Helmholtz. Two have attracted especial attentionthose on the Limits of Natural Scienee (1872) and the "Seven World-Riddles" (1880), in which their author professes a rigid denial of final causes in regard to such problems as the nature of force and matter, the origin of motion, the origin of life, the purposeful character of natural phenomena, the origin of sensation, thought, and speech, and the freedom of the will, summing up his view in the oft-quoted phrases, Ignorabimus, Dubitemus. In person, du Bois Reymond was a man of middle height, of ruddy countenance and energetic features, strong and athletie, with fiery glance and lively gestures. He left two sons, both of whom became well-known physicians.

The example of Helmholtz and du Bois Reymond gave an atded interest to the study of the physiology of muscle and nerve, and the special advanes that was made was in the int roduction of new instrumental procedures. Many of these, such as the cosine lever, the myotonograph, and the improved thermor pile, were introduced by Arlolf Fick (1829-1901), of Cassel, a pupil of Ludwig's, who wrote two important works on medical physies $\left(1856^{1}\right)$ and on mechanical work and heat-production during muscular activity $\left(1852^{2}\right)$. The method of obtaining myograms, introduced by Selowann (1537) and IIelmholt\% (1850) was vastly improved by Etienne-Jules Marey (1830-1904), of Paris, who showed that, in order to avoid the errors from inertia and other calses, it is best to have at very light writing style for the tambour (1860). Invostigation was akso materially aided by such instruments as d'Arsonval's galvanometer, Lippmann's eapillary electrometer, Fick's tension writer (1882), the ingenions

1 Fick: Die medizinische Physik, Brannschwrig, 1856.

${ }^{2}$ Fick: Mechanische Arbeit und Wärmeentwicklung bei der Muskelthïtigkeit, Leipzig, $18 \$ 2$. 
iuprovements of the Seandinavian, Magnus Blix, for synchronous records of isemefric and isolonic corves (1s92), Bernstrin's differential rheotome (1S90), Mosso's ergograph (1S:9(1), for the study of voluntary museular eontractions in man, and his myotenometer (1s:4i). Photograply wis effectively comployed hy Nir John Burdon Sanderson (JS28-1905) am l by Julius Bernstein (1839) $1917)$ in measuring the time relations of the periogl of latent stimulation of murede, which they reduend from the figures Helmheltz gave to about 0.0035"." Bernstein, one of du Buis Revmond's best pupils, has also done important werk upon the thermolymanies of muscular contration (1902-0s). 'The effoct of veratrine upon museular contraction "reratrinized muscle") wats

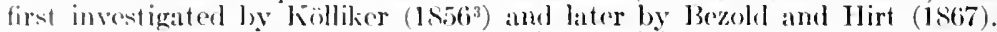

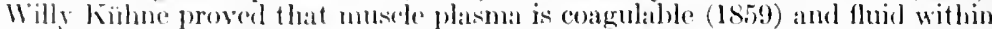
the living fiber (1563). Ludimar Ilormann investigated muscular metabo-

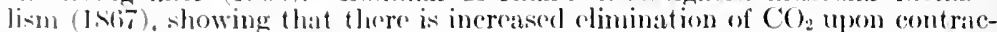
tiem. Ingelo Mosso (1\$4t-1910), of Turin, investigated museular fatigue with the ergograph (1890-914), and, by injeetion experinents with the bioced of a fatigued animal, indieated that fatigue is due to a toxie product of muscular contraction $\left(1890^{5}\right)$. Auguste

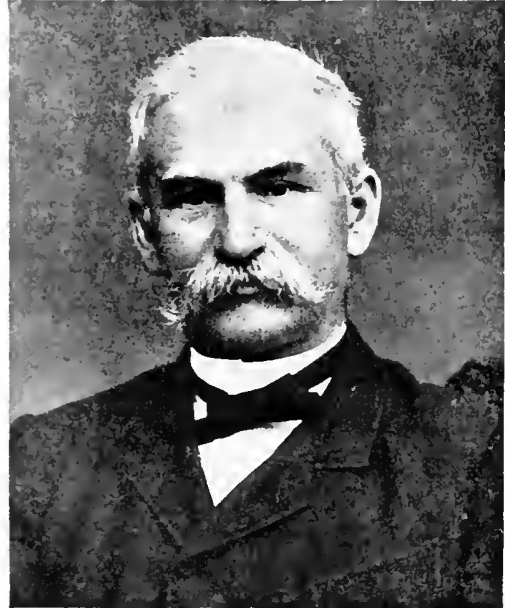

Hugo Kronecker (1839-1914). Chauveau (1827-1917) investigated the heal and energy relations of museular work (1891), and Theodor Willıclu Engelmann (1843-1909), the meehanies and thermodynamies of muscular contraction, illust rating his theory by an artificial muscle made of a violin-string. Some of the best work on muscle was done in ('arl Ludwig's laboratory, in partieular, H. P. Bowdit ch's demonstration of the staircase phenomenon (Trepre) in smooth (heart) inusele $\left(1871^{6}\right)$, von Kiries upon the effect of tension upon the response of muscle to stimuli (1S80), and the work of Kroneeker.

\section{Hugo Kronecker (1839-} 1914), of Liegnitz, Silesia, a pupil of Helmholtz, Wundt, Kïhne, Traube and Ludwig, and professor of physiology at Bern (1885-1914), has especially distinguished himself by his work on fatigue and recovery of striped muscle $\left(1871^{7}\right)$, his proof that heart muscle cannot be tetanized $\left(1874^{5}\right)$, his investigation of the mechanism of degluti-

${ }^{1}$ Moșo: Arch. ital. de biol., Turin, 1890, xiii, 124-141.

2Sanderson: Jour. Phyriol., Lond., 1895, xviii, 146. Bernstein: Arch. f. d. ges. Physiol., Bonn., 1897, lxvii, 207.

${ }^{3}$ Kölliker: Virchow's Arch., Berl., 1856, x, 257-272.

4 Mosso: La fatica, Milan, 1891.

${ }_{5}$ Tr. Internat. Med. Cong., 1890, Berl., 1891, ii, 2. Abth., 13.

${ }^{6}$ Bowditch: Ber. d. k. säehs. Gesellsch. d. Wissensch., Leipz., 1871, xxiii, 6.52-659.

' Kronecker: Arb. a. d. physiol. Anst. zu Leipz., 1871, 177-266.

${ }^{8}$ Kronecker: Ludwig Festschrift, Leipz., 1874, pt. 1, pp. clxxiii-cciv. 
tion (with S. J. Meltzer, 1880-83), his inventions of the phrenograph, the thermo-esthesiometer, the graduated incluetion coil, the frog-heart manometer, and a perfusion-camnula, his studies of reflex action, animal heat, innervation of respiration, and many other things of importance. The classic experiments of Bowditeh and Kronecker on heart-muscle have led to the principle that the heart's motto is "all or none," i. e., no matter what the stimulus, it will either contract to the fullest extent possible or not at all. Kronecker also investigated the importance of inorganic salts for the heart-beat, the rationale of transfusion, and the physiology of mountain sickness. He directed and assisted von Basch in the first sphygmomanometric studies on human beings, and was instrumental in the foundation of Mosso's Monte Rosa Institute in the High Alps, of the Hallerianum at Berne, and of the Institut Marey at Paris. He was the soul of Ludwig's laboratory and a lifelong promoter of cordial relations among scientific men (Meltzer). His American pupils include Meltzer, Stanley Hall, Cushing, Mills, and H. C. Wood, jr.

The mechanics of locomotion was first investigated by the Weber brothers (1836), later by Samuel Haughton (1873), and along rigid mathematieal lines by Christian Withelm Braune and Ot to Fischer (1891-95). The idea of invest igating loeomotion by serial (cinemat ographic) pietures was first suggested by the astronomer Janssen, who observed the transit of Venus in this way (is78). The method was perfected and utilized by E. J. Marey (Le mourement, 1894) and by Eadweard Muybridge in his atlases of animals and of the nude human figure in notion (1899-1901).

After du Bois Reymond, the most interesting investigations upon the physiology of nerve were the discovery of the inhibitory power of the vagus nerve by the Weber brothers (1845); Helmholtz's measurement of the velocit $y$ of the nerve eurrent (1850-52), which was avowedly suggested by du Boin Revmond's work; Eduard Pflüger's monograph on electrotonus (1859), in which he first stated the famous laws governing the make and break stimulation of nerve with the galvanic eurent; the early work on the "exeito-seeretory system," of Henry Fraser Campbell of Crorgia (1857), the Ritter-Rollet phenomenon (1876); Angelo Mosso's investigations of the movements of the brain (1876), his instrument for studying the eerobral pulsations and counting the duration and degree of a sensation transmitted to the brain from without $\left(1876^{1}\right)$, which won him the prize of the Aceademia dei lineei; the studies of mechanical irritation of nerve by Rudolf Heidenhain (1S5s), Robert Tigerstedt (1S80), and von Texküll ("nerve-shaker," 1895); Paul Ciritzuer on the effect of chemical stimulation (1\$93); the investigations of Matgnus Blix upon the specific energies of the cutaneous nerves (1S54-85), of Alfred Coldseheider upon the temperature nerves (1S\$4-85), and of Inenry Head upon the effects of injury and seetion of peripheral nerves and the mechanism of sensation and cerebration ${ }^{2}(1905-18)$. Head's war studies have resulted in the discovery of the "mass reftex," a diffuse and massive response to stimuli, a primitive defensive reaction against pain, which had seemingly remained dormant until thrown into relief by "shell-shock" and the grosi injuries to the spinal eord characteristic of the recent war.

1 Mosso: Areh. per le se. med., Turin, 1876-7, i, 252-256.

${ }^{2}$ H. Head and G. Riddoch: Brain, London. 1918, xl, 217-231. 
()ne of the most important experiments was the demonstrattion of the indefat igability of nowe (1S9)(0) by Henry Pickering Bowditch (1S40-1911), of Boston, Massuchusetts, who founded the first plysiological laboratory in the United States (1871), made the first investigation of the Treppe in heart muscle (1871), showed that delphine will make the heart beat rhythmioally (1871), was a pionecr in investigating the growth of children (1877-90), and did important work upon reënforecunent of the knee-jerk (1890).

Bowditeh's proof that norve eannot be tired out was aceomplished by paralyzing the motor nerve-endings in the muscle, to climinate the latter, and

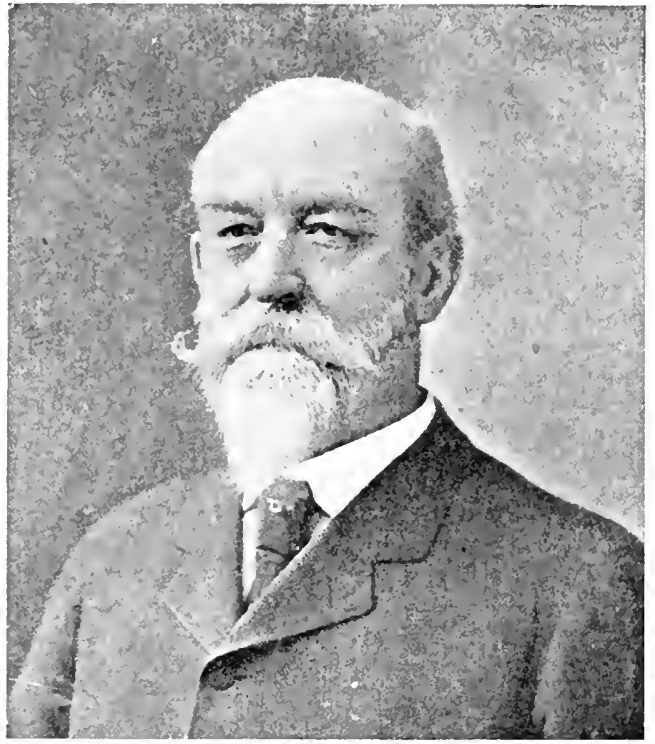

Henry Pickering Bowditeh (1840-1911).

stimulating the nerve at intervals, under artificial respiration, until the effect of the drug wore off, when it was seen, from the muscular twitchings, that, in spite of the prolonged excitation, the nerve had responded and still responded to the stimulus. Bernstein (1877) and Wedensky (1884) varied the experiment by blocking off the nerve from the muscle by means of a galvanic current (Wedensky effect ${ }^{2}$ ), and Masehek, in 1887, blocked the nerve by local application of ether vapor to a part between the stimulaterl region and the muscle, the nerve still responding after twelve hours' excitation.

Thus the initial experiment of Bowditch led in time to the idea of anesthetie blocking of the nerve-trunks by Crile and Cushing, which is one of the fundamental principles of recent surgery.

${ }^{1}$ Bowditch: Arch. f. Physiol., Leipz., 1890, 505-508.

${ }^{2}$ Wedensky: Centralbl. f. d. med. Wissensch., Berl., 1S\$4, xxii, 65-68. 
The whole subject of muscle-nerve preparations was exhaustively treated in the Electrophysiologie (1895) of Wilhelm Biedermann (1854- ), and du Bois Reymond's studies upon electrical fishes were continued by Gustav Theodor Fritseh (1887-90), Karl Schönlein, and the late Francis Goteh (1887-95). 'The chemical side of nervous activity has been investigated by William D. Halliburton (London, 1901), A. B. Macallum, and Menten (1906).

The starting-point of the neuron theory was the epoch-making experiment of Augustus Volney Waller (1816-70), of Elverton Farm, Kent. He showed that when a nerve is eut, the distal stump (the axis-cylinders, severed from the nerve-cells) will soon degenerate, while the proximal stmmp remains relatively intact (1850), from which he inferred that the nerve-cells nourish the nerve-fibers. By the same method Waller showed that, if an anterior spinal nerve-root is severed, the degenerative changes indicate that the nutritive centers of the motor fibers must lie in the spinal cord, while, in the ease of section of the posterior (sensory) roots, they are seen to lie in the posterior root ganghia. These experiments won for Waller the Montyon Prize of the French Academy of Sciences (2000 franes) in 1856, and they have been repeatedly confirmed by the observations of the histologists who worked on the neuron theory. Some important observations on old amputations, made by the late William Howslrip Dickinson (1832-1913), of Brighton, England, in 1865, demonstrated that the proximal stump of a severed nerve eventually undergoes atrophy. ${ }^{1}$

The theory that the functions of the brain can be localized in the cereliral cortex was introduced in somewhat fantastic form by Franz Joseph Gall (17.571828) as organology or eranioscopy, and by his pupil, Jobann Carpar Spurzheim $(1776-1832)$, as phrenology, their joint researches appearing as a fourvolume treatise, with atlas, in $1810-19 .{ }^{2}$ This contained many really important additions to cerebril anatomy and also the theory that the brain is a bundle of some twenty-seven (later 37) separate "organs," presiding over the different moral, sextual, and intellectual traits of the individual, their size being proportional to the preponderance of these traits and manifested on the surface of the skull as protuberances. Gall's theory drove him out of Vienna, but two medals were struck off in his honor in Berlin, and, like Hahnemann, he died rich in Paris. Spurzheim's propagandism led to the formation of secret plirenological societies and phrenological journals in Creat Britain and the United States. The theory attracted the favorable notice of Goethe, who shrewilly pointed out that the secret of its hold upon the popular mind lay in the fact that it dealt with particulars rather than general propositions; in other words, the folk-mind, even in fashionable people, was not unnaturally preoceupied with the various cranial "bumps" which located the speeific amativeness, combativeness, philoprogenitiveness, etc., of the person in question. EXploited by quacks and charlatans, phrenology soon became an object of derision among scientific men.

${ }^{1}$ Dickinson: Jour. Anat. \& Physiol., Lond., 1869, iii, 88-96, 1 pl.

${ }^{2}$ Gall and Spurzheim: Anatomie et physiologie du systime nerveux, Paris, 1810-19. 
The first real advance, after the experiments of Flomens and learallois, was also the most important one, vi\%, the work of (iustaly Fritsch (1835-91) and Finard Hitzig (1838-1907), (stab)lishing the olectrie excitability of the hrain (1870'), which hat been domber sine the time of lifourens. Motor aphasia from injuries or lexions in the region of the third left frontal (Brocas's) convolu-

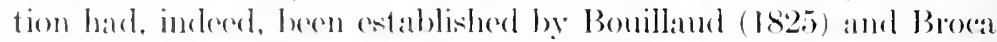
(1861), and localized, eppleptiform spasms from dofinite cereboral lesions had fren deseribed by Richard Bright (18:36) and Hughlings dackison (1575); lut the experiments of Fritseh and Hiteig upon the dog sorain wre the first to show that lowal bodily movements and romvulsions an be produced by stimulation of dofinite aroas in the brain, always identical in different animats of the same

species, and that, per contra,

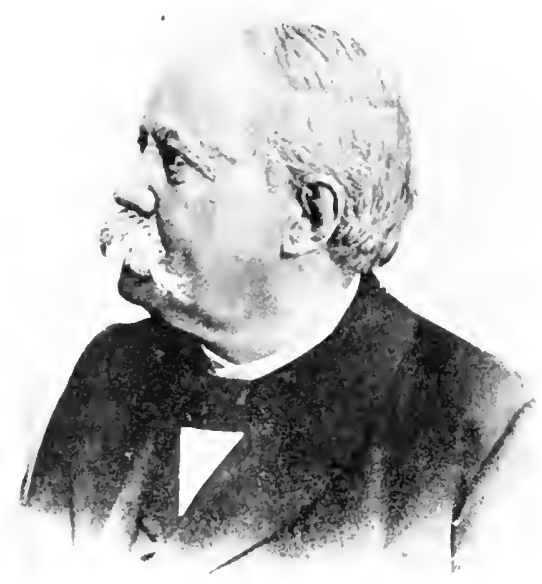

Friedrich Lcopold Goltz (1834-1902). removal of these alress will produce paralysis or loss of fimction of the romesponding parts of the body. These olservations were verified and equatly axtended by the work of Sir David Ferrier (1843- ), upon manmals, birds, foogs, fishes, and other (reatures (1872-76 $\left.6^{2}\right)$; and the subsequent recharting of the areas.

Horsley and Schäfer (1884SS) and Borevor and Horsley (1Sist-9.4) have tenderl to eonfirm Ferrier's inforenee that the motor area of the ecrebral cortex is around the central sulens of Rolando. 'The special motor and sensory, as well as the "silent" or inexcitable, arras wore mapped out by the Jabors of Flechsig (1576), Munk (1877-89), Bechtereff (1S87), Francois Franck (1SS7), Gurden (eollected in 1Ss9), Hensehen (1S90-94), and Monakow (189192), while the subject was most carefully considered on the clinical and pathologie side by Chareot and Pitres (1s95).

The subject of the total functions of the cerebral hemispheres and the spinal cord will always be associated with the name of Friedrich Leopold Goltz (1834-1902), of Posen, one of Helmholtz's pupils, who became professor of physiology at Halle (1870-72)

${ }^{1}$ Fritseh and Hitzig: Arch. f. Anat., Physiol. u. wissench. Med., Berl., $1870,300-332$.

2 Ferrier: West Riding Lun. Asyl. Rep., Lond., 1872, iij. Functions of the Brain, London, 1876. 
and Strassburg (1872-1902). Goltz did important work upon cardiac pressure, the mechanism of shock (Klopfersuch, 1862 $)$, and the functions of the semicircular canals (1870), but his most telling experiments were those upon the effect of excision of the brain and spinal cold in the frog $\left(1869-72^{2}\right)$ and the dog (1874$\left.96^{3}\right)$. He showed how the decerebrated or "spinal" frog will hop, swim, jump ont of boiling water, rroak like the frogs in Aristophanes, and adjust itself mechanically to every stimulation, but will otherwise sit like a nummy and, though surrounded with food, die of starvation, because it is a spinal machine, devoid of volition, memory, or intelligence; how, if the optic thatami remain intact, the animal will show some intelligence in regard to its own nutrition and sexual instinct, and how ablation of the cerebral hemispheres in the dog is followed by restless movements, unintelligent response to stimuli, and inability to feed itself of to swallow. Similar experiments had atready been made upon fish, pigeons, and smaller mammals by Rolando, Flourens, Longet, and Vulpian, but no one ever described the phenomena so carefully and graphically as Coltz, who brought out the important fact that the effects of decerebration are the more profound, the higher the animal, as evideneed by amentia in man. The other experiment (excising the spinal eord) hat to be performed with the greatest delieacy and care if the animal was to live; and Goltz's datat showed that, under these conditions, the muscles supplied by spinal norves are totally paralyzed, with a complete loss of sensation in the corresponding parts, the viscera and blood-vessels lose theil tone, the power of adaptability to temperature and other envirommontal changes is lessened, and perspiration abolished, although pregnancy, labor, and lavetation an oceur. Goltz's exposition of tho "spinal" animal as a boanless mechanism which, in Bernard Shaw's phrase, "blumders into death," and of the animal deprived of its spinal cort as a conscions intelligenee with lessened power of coördination and adaptation, initiated much of the work of recent times upon the complex reflexes of the body.

While du Verney had successfully excised the erebrum and exrebellum (1697), the earliest investigation of the ereveledlar functions was Rolancles Saggio of 1809 . This was followed by Flomene' elassical experiments on the pigeon $(1822)$ and those of Lueiani upon the dege (1852-91), which bronght out the ataxie ineoördination. Experimental excisions of fractional parts were made by a host of observers, from Rolando and Magendie on. Rolande likened the cerebellum to the Voltaie pile, in that it augments and reänforess the voluntary movements initiaterl by the cerebrum, a view which was reiterated and emphasized by Weir Mitehell (1869). Flourens introduced the ide:a of

1 Goltz: Königsb. med. Jahrb., 1s6i2, iii, 271-274.

${ }^{2}$ Goltz: Beitrïge zur Lehre von den Functionen der Nerveneentren des Frosches, Berlin, 1869; and Arch. f. l. ges. Physiol., Bonn, 1s72, v, 53.

${ }^{3}$ Goltz: Ibid., 1874, viii, 460; 1892, li, 460; 1896, lxiii, 362 . 
nervou coördination, which was again emphasized by John Call Dalton (1s61).

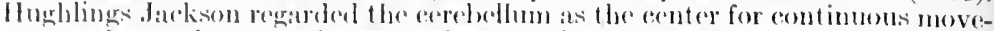
ments, the cerebrums as the center for changing movernents. The effect of ex-

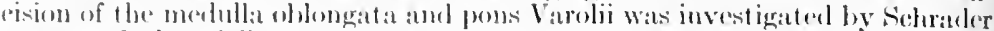

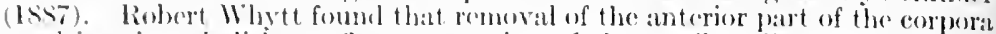
(puadrigemina atolisbes reflex eontratetion of the pupil to light (17ts), Jvan Miehailovied setelyonof thought it contained an inhibitory anter for the spinal reflexes (1Sti3), and (hatrles s. Sherrington showed that a comfition of "decorebrate rigidity" obtains upon complete transection (1s96-97). "The redation of the optie thatamus to oppositr-sided sensation, especially in the rye, wats notod simultaneously by Panizza and Joseph swan (1856), and bronght out, on the elinieal and pathologic sirle, in an important postmortem by IInghlings dackson (1si5). The sympathetie system was investigat ed by liriedried Wilhelm Bidder (1s10-94) and Alfred Vilhelm Volkmam (1800-77), who showed that it is largely made up of small, medullated fibers originating from the sympathetic and spinal ganglia $\left(1842^{2}\right)$; by Clanle Bernard, BrownSécpuard, Waller, and lidge, who demonstrated the effeet of section and stimmlation of the cervieal sympathetic $(1 \$ 52-53)$; by Köliker (1sis) and other modern histologists, who studied the strueture of sympathetie colls by improved staining methods; by W. II. Gaskell, who studied viseeral and vascular innervation (1886); by J. N. Langdey, who studied reflexes from sympathetic ganglia $\left(1894^{3}\right)$ and defined the "autonomic system" (1900); and batterly by IIenry Ifeat. Of speeial nerves, the vagus was investigated by the Webers (1845), Schmiedeberg (1871), and (iaskell (1852), the nerves of the heart and chorda tympani hy Carl Ludwig, the vasoconstrietors and viesodilators by Claude lisernard (1858), the dilator nerves of the peripheral vesseds by Carl Ludwig (1s66), the intestinal plexuses by Auerbach and Mlessner (186i2), the secretory and trophie norves of glands by Heidenhain (1878), the temperature nerves (1854) and nerves of entaneous sensation (1855) by Alfred Coldscheider, the distributory fibers of the eranial nerves by Vulpian (1\$85), the crector meehanism by Eekhard (1863) and Gaskel] (1887), the end-organ of the eighth nerve by Julius Ewald (1892), the pilomotor nerves by J. N. Langley (1893), and the nerve-endings for painful sensations by Max von Frey (1896).

The modern concept of reflex action was an outgrowth of the cell theory, with its most important corollary, the neuron theory; for it was through the labors of the different histologists and experimenters who worked on the latter, from Deiters to Harrison, that the complex paths for transmitting impulses from nerve-cell to nerve-eell were traced out and their morphological continuity demonstrated. The initial data were the Bell-Magendie law of the spinal nerve-roots, the law of Wallerian degeneration of nervefibers after section, and Goltz's work on the effects of the exeision of large segments of the central nervous system. Türck's investigations of the cutaneous distribution of the separate pairs of spinal nerves (1858-68) were of eapital importance, as also the discovery of the cerehral inhibition of spinal reflexes by Setchenoff $\left(1863^{4}\right)$, and the investigation of such loealized reflexes as the knee-

${ }^{1}$ Jackson: London Hosp. Rep., 1875, viii.

2 Bidder and Volkmann: Die Selbstständigkeit des Nervensystems, Leipzig. 1842.

${ }^{3}$ J. N. Langdey: Jour. Physiol., Lond, 1894, xvi, 410-440.

${ }^{4}$ I. M. Setehenoff: Physiologisehe Sturlien über die Hemmungsmechanismen für die Reflexthätigkeit des Rückenmarks im Gehirn des Frosches, Berlin, 1863. 
jerk or the mechanism of deglutition. Under the neuron theory, the simple reflex mechanism of external stimulus, afferent path, nerve-center, and efferent path became converted into a "reflex arc," requiring a sensory nemron centered in the ganglia of the posterior spinal roots or the cranial nerves and a motor neuron in the anterior horn of the cord or in the motor nucleus of a cranial nerve. Even this complex was soon perceived to be only an abstraction, since an isolated system of nerve-cells, functionating apart, is unthinkable. It became elear that most reflexes are compounded or coördinated, and that the nervous system functionates as a whole. This idea was specially developed by Charles Scott Sherrington, who did a large amount of experimental work on all phases of the subject. Sherrington was the first to investigate the phenomena of "decerebrate rigidity" produced by transection between the corpora quadrigemina and the thalamus opticus (1896$\left.98^{1}\right)$, and of "reciprocal innervation" and reciprocal inhibition, in virtue of which antagonistic museles, e.g., flexors and extensors, when under reflex stimulation, are so related that excitation of one center is simultaneous with inhibition of the other $\left(1893-98^{2}\right)$. Sherrington expanded the theoretical concept of the "synapse," the separating surface which Foster postulated to exist between two neurons or their terminations, to complete the circuit in the reflex are; and he did much to develop the knowledge of reënforcement and antagonism in simple and compound reflexes and of coördination in successive (chain) reflexes. The whole trend of his teaching is to the effect that a reflex action is seldom an isolated phenomenon, but one in which several reflex ares are concerned, so that the true function of the nervous system is to integrate the organism, in the sense of giving it an individuality which is not possessed by a mere collection of cells or organs. ${ }^{3}$ No one has handled this abstruse subject with more ability than Sherrington, and, in connection with his work, it is proper to mention the important experiments of Erb and Westphal (1875), Jendrassik (1885), Weir Mitchell and Morris J. Lewis (1886), Lombard (1889), Bowditch and Warren (1890), on reënforcement and inhibition of the knee-jerk, of Sigmund Exner on reënforcement (Bahnung) of reflexes (1882), of Jacques Loeb on "chain-reflexes" (1899), and of Pavloff on conditional reflexes (1912).

Experimental psychology began in Ernst Heinrich Weber's laboratory, and its modern phases are principally the work of Lotze, Fechner, and Wundt,

${ }^{1}$ C. S. Sherrington: Proc. Roy. Soc. Lond., 1896, $\mathrm{lx}, 415$; and Jour. Physiol., Lond., 1898, xxii, 379.

${ }^{2}$ Proc. Roy. Soc. Lond., 1892-3, lii, 556-564. 1906.

${ }^{3}$ Sherrington: The Integrative Action of the Nervous System, New York, 
Rondelph Hermann Lotze (1S17-S1), of Batutzen, a medieal graduate who went orer the metaphysies and philosophy, was the atuthor of many important works on anslytic psychology, in particiliar his Medicinische Psyshologie, or Psychology of the sonl (1552). He was a pionere in the investigation of space

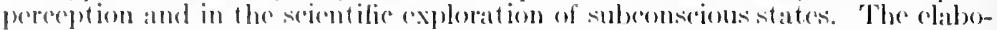
rate analyties of Jung and the fereudian seheol are foreshatewed in such works as J. C. I. Heinroth's treatise on lying (1s:34), in which the coneept of "pather-

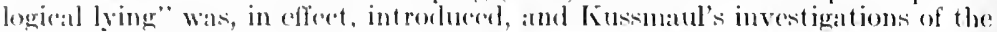
paychic life of the newborm ehild (1859).

Gistav 'Theodor Fechner (1s01-87), professor of physies at Leipzig (1\$3975), who did much experimental and editorial work in physies and chemist ry, wis perhapes the birst af er Weber to apply mathemat ieal physies to the physiciogy of sensation, and wrote the first treatise on pryehophysies (1860) $)$. He made extended experimental studies of cutaneous sensation and muscular sense, for example, his record of 24,576 separate judgments of weights; he pointed ont the personal or egotistie nature of painful sensation, he followed Wrober in his investigations of the threshold limits of sensition, and stated Weber's law in its molern form. In 1 s3s he first investigated the color phenemenat produced by rotating disks with black and white sectors, and mention can only be made of such eptieal novelties as his "side-window experiment" and his "paradoxieal experiment."

Withelu Wundt (1832-1920), of Neckarau, Baten, was professor of physiology at IIcidelberg (186.4), Zürich (1S74), and Leipzig (1875) and founded the Institute for Experimental Psychology in the latter city (1S7s). Ho wrote a text-book of phrsiology (1865), and three enduring memoirs on muscular motion $\left(1858^{2}\right)$, sensory pereeption $\left(1862^{3}\right)$, and the mechanies of the nerves and nervecenters $\left(1871-76^{4}\right)$, which were the foundation of his fut ure work. The first of these is memorable for the famous "isotonic eurves" produced by musele under continuous and constant (amounting to continual) exeitation, which, as Burdon Sanderson says, have been eopied into every text-book. It also contains valuable researches on museular aetion under drugs and after transection of the nerves and spinal eord. The book on the nervous mechanism deals with such matters as reaction time and reffex time through the spinal corl and ganglia, and muscle sense. Wundt's contributions to peychology proper are a long list, and include his Elements of Physiological Psychology $\left(184^{5}\right)$. Logie (1880-83), Ethies (1886), and Comparative Psychology (1904106). In $18 s 3$ he founded the Philosophische Studien, a serial devoted to experimental pevehology and epistemology.

Other noteworthy contributions to psychology are the measurenent of the velocity of the visyehie inpulse by Donders (18697), the monographs of Duchenne (1862) and Darwin (1873) on the expression of the passions and cmotions, stanley Hall's study of Laura Bridgman (18798) and his book work on Ailoleserence (1904). Angelo Mosso's book on foar (La paura, 1sst), the work of ( $\mathrm{x}$. J. Romanes, Jacques Loeb, C. Lloyd Morgan, H. S. Jennings (Brhaviour of the Lourer Organisms, 1906), Robert M. Yerkes (The Dancing Hows, 1907), and ot hers on comparative peychology, of J. MeKeen Catteli, Hugo Miunsterberg, J. Mark Baldwin and others on experimental psychology, and of Krafft-Ehing, Haveloek Ellis, and Freud on morbid sexual psychology.

${ }^{1}$ Fechner: Elemente der Psyehophysik, Leipzig, 1860.

2 Wundt: Die Lehre von der Muskelbewegung, Brunwsick, 1858.

${ }^{3}$ Beiträge zur Theorie von der Sinneswal rnelmmung, Leipzig, 1562.

4 Intersuchungen zur Mechanik der Nerven und Nervencentren, Erlangen, $1571-76$.

${ }^{5}$ Grundzüge der physiologischen Psychologie, Leipzig, 1873-74.

${ }^{6}$ Tölkerpsychologic, Leipzig, 1904-10.

'Donders: Arch. f. Anat., Physiol. u. wissensch. Med., Leipz., 1868, $65 \overline{7}-681$.

${ }^{8}$ Hlall: Mind, Lond., 1879, iv, 149-172. 
Much of our knowledge of the digestive and vasomotor systems was developed by Claude Bernard (1813-78), the greatest physiologist of modern France, who was born in the village of Saint-Julien (Rhône), where his father was one of the many vinegrowers and wine-makers of this region. A chorister and pupil of the Jesuits of the college at Villefranche, young Bernard was driven by straightened family circumstances to become a pharmacist's assistant at Lyons. Sharing the romantic aspirations of the youth of his time, he turned his attention to literature and wrote "La Rose du Rhône," a vaudeville comedy, which was produced with some success, and "Arthur de Bretagne," a five-act tragedy which

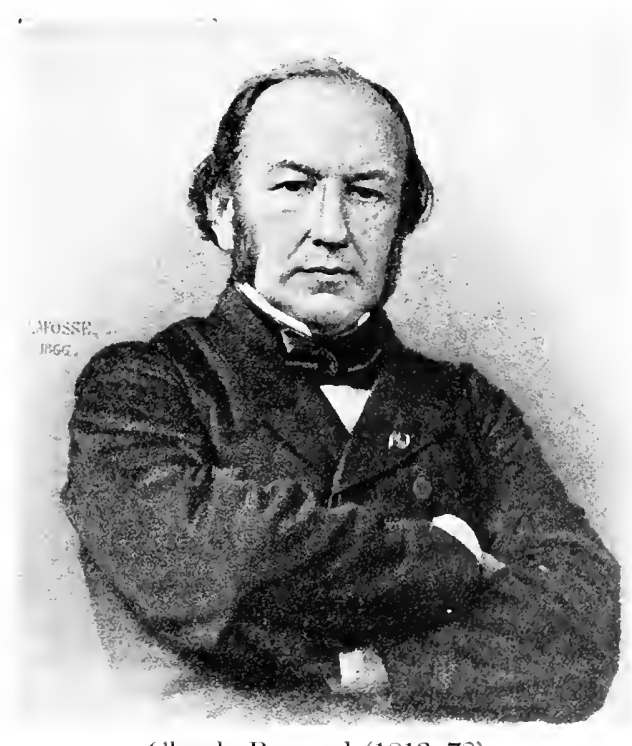

('laude Burnatrd (1813-7s).

was long afterward handsomely printed (1886). With the latter n hand, he went up to Paris to consult the critic Saint-Mare Girardin, who saw the merits of his work ats a dramatic poet, but hrewdly advised him to study medicine as a surer meatns of raining a livelihood. This advice was the turning-point in Berard's career, for it brought him into close contact with Magendie, vho directed his genius into its proper channels. Nagendie, after hree or four demonstrations of Bernard's superb talents, ancounced, with characteristic generosity, "You are a better" man han I." As compared with Magendie, who often experimented it haphazard, like one groping in the dark. Bermard's attitude tovard scientific investigation is best summed up in his own words: 
"Put off your imagination, as you take off your overeoat, when you enter the baboratory; lut put it on algaii, as you do your overcoat, when you leave the laboratory. Before the experiment and betwen whiles, let your imagination wralp you round; put it right away from you during the experiment itself lest it hindor vour obscrving power."

All of Bernard's greatest discoveries were based upon accidentally discovered facts, which he used as clues to larger results through his wonderful power of thinking physiologically. It came to be said of him that he was no mere physiologic experimenter, but "physiology itself." Like Migendie and Johannes Mïller, he made his how to "vitalism," but he gave it the widest possible berth. Where Magendic had left medicine "une science a faire," Bernard boldly advanced to the position that the chief aim of physiologic experimentation is to throw light upon morbid conditions. He is the founder of experimental medicine, or the artificial production of disease by means of chemical and physical manipulation.

In 1843 , he discovered that canc-sugar, when injected into the veins, appears in the urine, but not if treated with gastric juice prior to the injection. This was the starting-point of his investigation of the glycogenic function of the liver. He arrived at this by the aeeidental discovery of sugar in the hepatic vein of a dog fed upon sugar, whence he proceeded to experiment with a $\operatorname{dog}^{2}$ fed upon meat, with the same results, and published his papers in 1848-50. By 1557 he had, through a number of ingenious experiments, established the ghycogenic function of the liver upon a permanent basis, and had succeeded in isolating glyeogen. ${ }^{3}$ The fact that this substance could be obtained, scen as such and experimented with was more potent even than Wöhler's work in establishing the fact that the animal body ean build up ehemieal substances as well as break them down. Furthermore, Bernard made it clear that the glycogenie funetion of the liver is in the nature of an "internal secretion," a term which he first introduced. "This," says Foster, "at one blow, destroyed the then dominant eonception that the animal body was to be regarded as a bundle of organs, each with its appropriate functions." In 1849, Bernard marle his celebrated diseovery that a puncture (piquere) of the fourth ventricle of the brain in dogs produces temporary diabetes. ${ }^{4}$ Equally important for the physiology of the digestive system was his work on the pancreatic juice $\left(1549-56^{5}\right)$. $\mathrm{L}_{\mathrm{p}}$ to the time of Bernard, gastric digestion was the whole of digestive physiology. Eberle, in 1834, suggested that the panereatic juice emulsifies fats, and Valentin, in 1844, showed that it acts upon starch, but this was all that had been done and even this was not generally known. Bernard eleared up the whole subject. He showed that "gastric digestion is only a preparatory act," that the pancreatic juice emulsifies the fatty foods passing through the intestines, splitting them up into fatty acids and glycerin; and he demonstrated its power of converting starch into sugar and its solvent action upon the proteids undissolved by the stomach. Bernard put the experi-

1 "Ce n'est pas un grand physiologiste: e'est la physiologie même." J.B. Dumas.

${ }^{2}$ Bernard: Compt. rencl. Aeal. d. sc., Paris, 1848, xxvii, 514; 1850, xxi, 571. Areh. gén. de méd., Par., 1848, 4. s., xviii, 303-319.

${ }^{3}$ Ibid., 1S55, xli, 461-469; 1857, xliv, 578, 1325.

${ }^{4}$ Compt. rend. Soc. de biol., 1849, Paris, 1850, i, 60.

${ }^{5}$ Areh. gén. de méd., Paris, 1849, i, 60-61. Compt. rend. Acad. d. sc., Paris, 1849, xxviii, 249-253; 1856, suppl., 379-563, 9 pl. 
mental pancreatic fistula upon a working basis. His third great achicvement was his exposition of the vasomotor mechanism (1851-531). In 1840, IIente, as we have seen, demonstrated the existence of smooth musele in the endothelium of the smaller arteries; and, in 1846, Fölliker showed that such involuntary museles are mate up of small, spindle-shaped eells. The term "vasomotor" was first employed by Benedikt Stitling, in 1840, as a hypothetic designation of the nerve filaments supplying the blood-vessels. Bernard started out with the idea that the nervous system sets up ehemieal changes producing animal heat. On dividing a rabbit's cervical sympathetie nerve (15.51), he found, instead of the expected fall in temperature, a sensible rise $\left(4^{\circ}-6^{\circ} \mathrm{C}\right.$.) and a marked inerease in vascularity of the ear, but he left it an open question whether the congestion was the eause or the effect of the increased temperature. In August, 1852,2 Brown-Sécuard, then residing in Ameriea, showed that galvanism applied to the superior part of the divided sympathetic really causes contraction of the blood-vesseds and a fall of the temperature on that side, whenee he inferred that the effect of section of the sympathetie was to paralyze and dilate the blood-vessels. Bernald performed the same experiment independently, in November, 1852, and similar results were obtained by Waller and Budge, in 1853. In 1853, Bernard shut off the cirenlation in the ear by ligating two of its veins, and, finding the same rise of temperature upon section of the sympathetie, argued that the latter controls the temperature relations, a view which he held to the end of his life. In 1858 , he demonstrated that the sympathetic is the constrictor nerve and the ehorda tympani the dilator of the blood-vessels. The diseovery of vasodilator and vasoconstrictor nerves ${ }^{3}$ eompletes his work on the eireulation. Among his lesser achievements are his experiments with curare $\left(1850-56^{4}\right)$, in which, by paralyzing the nerve, he demonstrated the independent exeitability of musele, thus giving the classieal proof of Haller's doetrine of speeifie irritability; his investigations of carbon monoxide poison (1853-585), showing that it displaces the oxygen in the red blood-corpuseles; and his studies of the "paralytie seeretions" oceasioned by section of ghandular nerves $\left(1864^{6}\right)$. In the Army Medieal Museum at Washington may be seen the historie table upon which Magendie and Bernard performed their experiments.

During the later years of his life Bernard expounded and extended his doctrines by means of courses of lectures at the Collège de France and the Sorbonne, in particular those on experimental physiology (1855), the effect of poisonous substances and drugs (1857), the physiology and pathology of the nervous system (1858), the liquids of the organism (1859), experimental pathology (1872), anesthetics and asphyxia (1875), and operative physiology (1879). The last of these reveal the unapproachable master in the technique of experimental procedure, and all of them the acemplished man of letters, who began his carcer as a poet and dramatist. Scattered through his writings are many luminous aphorisms which are to medicine what the "Pensées" of Vauvenargues and Joubert are to literature, in that they deal, as never before, with the high

${ }^{1}$ Compt. rend. Soe de biol., Paris, 1851, xxxiii, 163; 1852, xxxiv, 472; xxv, 168; 1853, xxxvi, 378.

2 Brown-Séquard: Med. Exam., Phila., 1852, viii, 4\$1-504.

${ }^{3}$ Compt. rend. Acad. d. se., Paris, 1858, xlviii, 245; 393.

${ }^{4}$ Compt. rend. Acad. d. sc., Paris, 1850 , xxxi, 533; 1856, xliii, $\$ 25$.

${ }^{5}$ Compt. rend. Acad, d. se., 1858, xlvii, 393.

6 J. de l'anat. et physiol., Paris, 1564, i, 507-513. 
(alling, the honorable ands and aspirations of the seientifie physician. In the ourly days, Bemand was looked upon askance as a mere vivisector of animals, and he relates that he owed mote immmity from perserntion to an acodental frondship with a policecommissoner, in whese district he was afterwald areful to piteh his tent. For the same reason, he was not happy in his married life, even his danghters becoming estringed from him through his wife, who had no sympathy with his genius, and was soured by the falet that he dicl not become a suceessful practitioner. But homors (anne in due course. A special chair of general physiology was created for him at the Sorbonne during Matgendie's

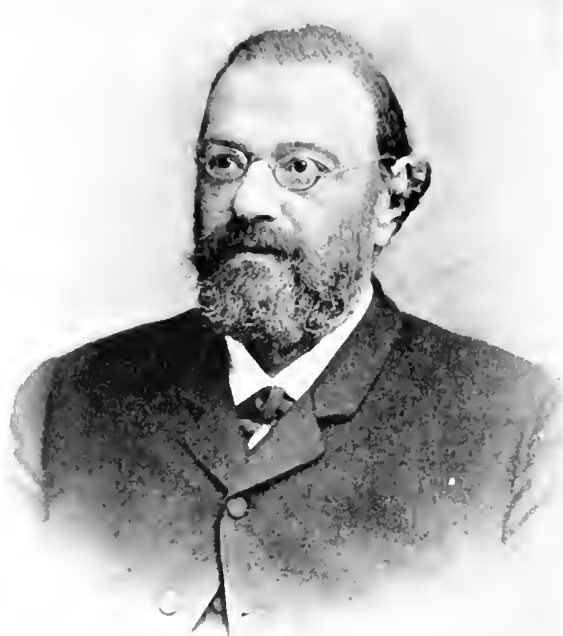

Willy Kühne (1837-1990). (Boston Merlical Library.) lifetime; and, in 1855, he suceoceled the latter as full professor of physiology at the collège rle France, and was admitted to the Académie Française in 1868. Napoleon HI was so fascinated with his pelsonality that he gave him two fine laboratories at the Sorbonne and the Muséum d'Histoire Naturelle, and made him a senator in 1869. Among his friends were Duruy, Gambetta, Pasteur, Rayer, Davaine, St. Claire Deville, Berthelot and Renan, who succeeder to his fauteuil in the French Academy. Claude Bernard was tall and imposing in presence, with a noble brow and a countenance expressing depth of thought and kindliness of feeling. "As he walked the streets, passers-by might be hearel to say, 'I wonder who that is? He must be sone distinguished man.'"

Of Bernard's pupils, Willy Kühne (1837-1900), of Hamburg, professor of physiology at Ansterdam (1868-71) and Heidelberg (1871-1900), is memorable for his investigation of the peripheral end-organs of the motor nerves (1862), of hemoglobin (1865), of the digestion of proteids by the pancreatic juice $\left(1867^{1}\right)$, of the proteolytic enzyme in the pancreas, which he called trypsin

${ }^{1}$ Kühne: Virchow's Arch., Berl., 1s67, xxxxi, 130-174. 
$\left(1876^{1}\right)$, of the cleavage of the albumens in gastric and tryptic digestion (1S772), of rhodopsin, or "visual purple," and the "chromophanes" of the retina $\left(1877^{3}\right)$; of the electrical storms in a muscle stimulated under pressure, and its power to excite another muscle compressed with it $\left(1888^{4}\right)$, and particularly the remarkable series of chemical studies of the intermediate products of peptic and intestinal digestion which he carried on with his pupil, Russell Henry Chittenden (1856- ), of New Haven, Connecticut, many new substances being isolated and named for the first time by these investigators (1883-885). Kühne was a man of infinite resource in experimentation, notably in his "optograms," or photographs made directly on an excised retina, and his use of pancreatic ferments as a reagent in histology.

Paul Bert (1830-86), of Auxrre, Bernard's favorite pupil and his suecessor at the Sorbonne (1S68), spoiled a brilliant scientific earecr by mixing in politics. He was fierecly ratlical and anticlerical, and, being sent by Giambet ta as consul general to Tonkin in 1856, died there of dysontery shortly after. He discovered an un:malyzed substance in the mammary gland (1879), but his best work was La Pression Burometrique' (1S7s), a bundli of seattered essays dealing with the gases of the bloorl, eaision disease, and particularly with the toxic effects of oxygen at high pressure. In prosecuting these experiments, Burt indlueed three balloonists to make a high ascension, armed with bags of oxygen, and only one survivel the attempt. The theory of the glyeogenie function was formally opposerl by Frederiek William Pavy (1829-1911), whose work will be considered in relation to internal medicine.

In connection with the work of Bernard, we may follow the modern developments of the physiology of digestion, of metabolism, and of the ductless glands.

The elassical deseription of the meehmism of the act of deglutition was given by Magendic (18176), who deseribed the three stages in the passage of food through the mouth, pharymx, and esophagus. He thought that the principal coeflicients of the motor power were the constrictor museles of the pharynx, but it was afterward shown by Hugo Kronecker (1839-1914), of Bern, and Simmucl James Meltzer (185)1-192i) that the swallowing reflex is a eomplex coördinated meehanism, depending mainly upon the mylohyoid and hyoglossal muscles $\left(1880-83^{7}\right)$. The escent iat reftex character of the act was demonstrated in 1876 by Angelo Mosso (1s4ti-1910). of Turin, who showed that, even after section or ligation of the esophagus, the peristaltic wave from the pharrnx will, in time, be taken up on the lower side of the gap by means of the nerve-

1 Verhandl. d. naturh.-med. Ver. zu IIeiklelb., 1574-77, n. F., i, 194; 233. 2 Ibid., 236. 155.

${ }^{3}$ Untersuch. a. (1. physiol. Inst., IIrilelb., 1877, i, 15; 105; 109; 119 ;

${ }^{4}$ Ztschr. f. Biol., Munich, 18s8, xxiv, 383-422.

${ }^{5}$ Kühne and Chittenden: Zeitschr. f. Biol., Munich, 1S83, xix, 160: 1884, $\mathrm{xx}, 11 ; 1856$, xxii, 409;423; 1858, xxv, 35s.

${ }^{6}$ Magendie: Précis élémentaire de physiologie, Paris, 1\$17, ii, is-67.

7 Kronecker and Meltzer: Arch. f. Physiol., Leipz., 1s80, 299: 446; 1883, Suppl.-Brl., 328. 
supply and pass to the stomath, white seetion of the nerves will abolish the reffex eompletely. 'The morements of the stomach were first studied in silu by William Bosumont. and more acenrately by Walter Bradford Camnon ${ }^{2}$

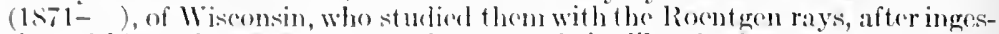
tion of hismuth (1s9s). 'That the stomach is, like the heart, an antematic motor mechanism, independently of the nervous meehanism which adjusts its

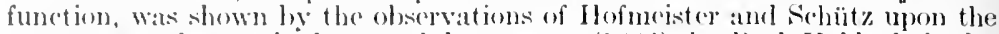
moxements of an excisid stemateh kept warm (1SS6); by Rud. Ilcidenhain; by II. 13. Cammon, at llarvard (1906), who proved that the gastrie movements amel seeretions continue unabaterl after section of the extrinsie fibers of the vagus and splanchnie nerves; and latterly in the "visceral organism" which Alexis Carrel has kept alive in an extravital culture-medium (1912). Cannon has also studied the mochanies of digestion in surgieal conditions and aiter surgical operations (1905-9). The mochanism of vomiting was first described by Magendie (1813), who thought that the sole agent was the contraction of the abiominal numeles. Later investigations have shown that he was only half right, the aet being a complieated reflex in which the walls of the stomach play an equal part. After the time of Prout and Beaumont, it was contended by Clatude Bernard and Barreswil, Lehmann, and others, that the free acid of the gastrie juice was, in reality, lactic acid, but this was finally set at rest by the laborious :malyses of Bidder and Schmidt (1552), which proved that normally the gastrie juiec always contains hydroehlorie acid in exeess. Brüeke $(1 s-i 2)$ and ofhers had shown, however, that during earbohydrate digestion, stareh can be converted directly into laetic acid in the stomach, probably through the action of the lactic acid bacillus. The hydrochloric acid in the stomach was shown by Toit (1869) and Cahn (1856) to be derived from the chlorides in the blood-plasma. In regard to the mechanism of its formation, the different theories advanced by Maly, Gamgee, and others are still sub judice. The histologic changes in the gastric glands during secretion were studied by Heidenhain (1S78), and intravitally by J. N. Langley (1850). The stages of "onversion of proteids into peptones in the stomach were first described by Meissner (1559-62), and more exhaustively and finally by Willy Kïhne (IST).

The movements of the intestines rere studied by Carl Ludwig (1861 ${ }^{3}$, who deseribel the swaying motions (Pendelbewegungen) between the intervals of peristalsis; by W. B. Cannon, who observed the latter by means of the Roentgen rays $\left(1902^{4}\right)$, and by Bayliss and Starling, who deseribed peristalsis as a reflex through the intrinsic ganglia $\left(1899^{5}\right)$. That the peristaltic wave is in one direction and due to some drfinite arrangement in the intestinal walls was proved by Franklin P. Mlall, who cut out a picee of the gut and reversed it in silu, producing intestinal obstruetion from aecumulation of food above the section $\left(1 s 96^{6}\right)$. In 1912-13, Roger Clénard marle einematographic studies of the intestinal movements, normally and under the action of purgatives, by isolating the entire tract, exeised from a rabbit, and keeping it active in a constant perfusion of Locke's solution.7 The intrinsic nerve plexuses were described by Auerbach and Meissner. Pflüger, in $1857,{ }^{8}$ showed that stimulation

${ }^{1}$ Mosso, in Molesehott's Untersuch. z. Naturlehre (etc.), Frankf., 1S76; xi, $331-349$.

${ }^{2}$ Cannon: Am. Jour. Physiol., Bost., 1S98, i, 359-382.

${ }^{3}$ Ludwig: Lehrbueh der Physiologie, 2. Aufl., 1861, ii, 615.

${ }^{4}$ Cannon: Am. Jour. Physiol., Bost., 1901-2, vi, 251-277. Also, "The Mechanical Factors of Digestion," London, 1911.

${ }^{6}$ W. M. Bayliss and E. H. Starling: Jour. Physiol., Lond., 1S99, xxiv, 99.

'Mall: Johns Hopkins Hosp. Rep., Balt., 1896, i, 93.

7 Glénart: Les mouvements de l'intestin en circulation artificielle, Paris thesis (Faculté des sciences), 1913.

${ }^{8}$ Pflüger: Ueber das Hemmungsnervensystem für die peristaltischen Bewegungen der Gedärme, Berlin, 1857. 
of the splanchnic nerves inhibits the intestinal movements. The net result of investigation goes to show that the intestines, like the stomach, are an automatic mechanism which is regulated by, but not dependent upon, the extrinsie, nerves. Similar conclusions in regard to the rectal functions have been reached through the experiments of Goltz upon dogs deprived of the spinal cord (1s74), and the skiagraphic observations of Hertz (1907). In 1895, it was shown, by G. H. F. Nuttall and H. Thierfelder, that hoalthy animal life and perfect digestion are possible without the presence of bacteria in the alimentary canal. Harvey Cushing showed that, above and below the ileum, the intestines are relatively free from bacteria, and that the intestinal tract can be sterilized by fasting (Welch-Festschrift, 1900). Our knowledge of the chemistry and histology of intestinal absorption is largely due to the work of Kiuhne (1877), Heidenhain (1SSS-94), and Pavloff and his pupils (1897). What we know of the functions of the liver and pancreas will always be associated with the great name of Clande Bernard. His pupil, Willy Kiuhne, as we have seen, worked jut the cleavage changes of the proteins in the stomach and intestines, but, jefore him, Purkinje and Pappenheim had noticed the proteolytic power ff pancreatic extracts (1836), and Lucien Corvisart, in a long series of reiearches $\left(1857-63^{1}\right)$, had shown that proteids are converted by the pancreatic uice into the ordinary digestive products, at the temperature of the body, nd in alkaline, acid, or neutral media. This corrected the error of Clatide 3ernard, who supposed that pancreatic proteolysis cannot take place without he previous action of bile. The sugar-forming ferments of the salivary glands nd panereas were investigated by the pathologist, Julius Cohnheim $\left(18\left(3^{2}\right)\right.$. 'tyalin was isolated by Mialhe (is453), trypsin by Kïhne $\left(1876^{4}\right)$. The deivatives of bile were studied by Thénard (1809), Gmelin (1826), Plattner, who rst obtained "crystallized bile" (1844), and particularly by Adolf Streeker 1822-71), who showed that Plattner's erystals were a mixture of the sodium lts of glycocholic and taurocholic acids, which, treated with acids, yield the mino-acids, glveocoll and taurine, with clıolic acid as a common product $\left(848-49^{5}\right)$. Bilirubin was firt isolated by Heintz (18.51); biliverdin, by erzelius (1840), who confused it with chlorophyll, and by Valentiner, who rst obtained it in erystalline form (1859). Urobilin was discovered in the rine by Max Jaffé (1840-1911) in 186S. Austin Flint, Jr. (1836-1915), in 362 , elaimed that cholesterin is removed from the blood by the liver and scharged from the body as stercorin, but Naunyn and his pupils have asimed it to be a product of the gall-blarder and duets and not of the liverlls (1892). The common bile-tests were introduced by Gmelin (1S26), ttenkofer (1S44), Ottomar Rosenbach (1876), and Paul Ehrlich (1S83).

Recent knowledge of the relation of the nervous system to the livary, gastric, and pancreatic secretions is mainly due to the ork of the physiologists of the Russian school, in particular Ivan etrovich Pavloff (1849- ), of the Ryazan Government, who, 1904, was awarded the Nobel prize for his investigations. ${ }^{6}$ pupil of Heidenhain and Ludwig, he became director of the istitute for Experimental Medicine at Petrograd in 1890. The

${ }^{1}$ L. Corvisart: Collection de mémoires sur une fonction peu eonnue du neréas, Paris, $1857-63$.

${ }^{2}$ Cohnheim: Arch. f. path. Anat., Berl., 1863, xxviii, 241-253.

${ }^{3}$ Mialhe: Compt. rend. Aead. d. se., Paris, 1845, xx, 654; 1483.

${ }^{4}$ Kühne: Verhandl. d. naturh.-med. Ver. zu Heidelb., 1876, n. F., i, 190.

${ }^{5}$ Strecker: Ann. d. Chem. u. Pharm., Heidelb., 1848, lxw, 1; lxvii, 1: 19, lxx, 149 .

"Collected in his "Le travail des glandes digestives" (Russian text, St. Itersburg, 1897. French translation, Paris, 1901). 
suceess of Pavloff's experinents was mainly due to certain improvements which he and his pupils made in the operative production of gastric and pancreatie fistulae.

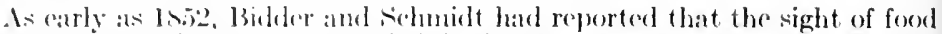
will produce a copious flow of gas rice juice in at gatst rostomized dog, and Richet, in Ists, hand obtamed a similar offect in a patient who haul to be fod through a gastric fistula, on aceosunt of a strictured esophlagus. Iledentain failed to obtain this result in a fistulized dog, whonee it wats inferred that he had in some way damaged the merve comnetions in preparing his fistula (1880). Pavkofi improved the Jleidenhain fistulat by kerping the nerve-supply intact, and so standaridzed it for molern proedere. In addition, he severed the dog's esophagus in such wise that swallowed food might be discharged at the upper oprening, and unswallowed food ingested into the stomach at the lower. Three sets of experiments were then pesibile: The llog might be allowed merely to see or smell the food, at barmeride feast which Pavloff ralled "psychieal fording"; or, the ani-

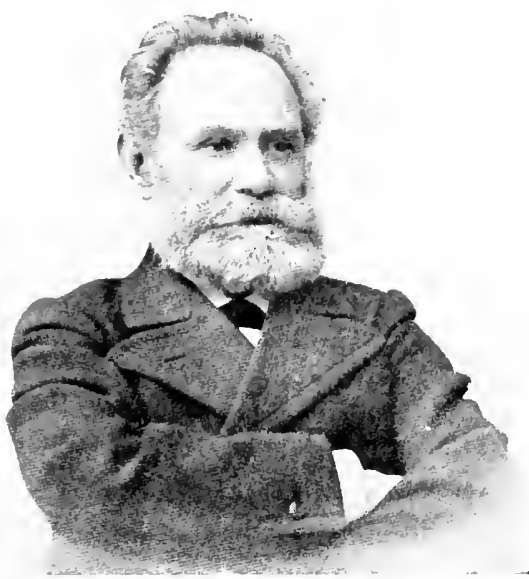
mal might rhew the fond which passed throngh the esophlageal opening. constituting a sham meal (Scheinfütlerung); or, a true foeding might be obtained by introdueing the food through the lower stoma of the esophagus. In the first two instances, the (ffect of smoll, sight, tast', chewing, and swallowing was such that al enpious and eontinual gastric secretion-as much as 700 c.c. in five or six hours - was obtained withont the int roduetion of any food into the stomach. Pavloff ealled this effect a "psyehical secretion." He next showed that severing the splanchnic nerves does not affeet the phenomenon, but section of both vagi will abolish the reflex secre-

Ivan Petrovich Pivloff (1849- ). tion, and direct stimulation of the peripheral ends of the cut vagi will, after a short interval, produce it again. This proved that the gastric seeretion is regulated hy the vagus. Inder the third eondition set by Pavloff, mere mechanical stimulation of the stomach by the introluction of food through the esophageal opening, while the dog is asleep or inattentive, does not neeessarily stimulate secretion, contrary to received opinion. Chischin, Pavloff's pupil, found that, when the prychieal stimuli are shut off in this way, the amount of secretion varies with the kind of food, being positive for meats and peptones generally, and negative for other substances, which, when eaten, might eause a psychical secretion $\left(1 \$ 94^{1}\right)$. By means of a special panereatie fistula, Pavloff was able to indieate that the seseretory fibers of the pancreas are in the vagus nerve. In 1\$95, Dolinsky found that the introduction of acids into the duodenum eauses a flow of pinereatie juice, from which it is inferred that the acid in the gastrie juice sets up this secretion, probably through the production of the hormone which Bayliss and Starling eall seeretin (1902). Chepovalnikoff, another Pavloff pupil, diseovered that panereatie juice from a fistula acquires a powerful solvent aetion on proteids from contaet with the duodenal mem- 
brane or its extract, and the latter Pavloff assumed to contain a special enzyue, "enterokinase," which activates the panereatic juice (1S99'). In his later work on "conditional reflexes" (1912), $i$. e., on the effect of speeifie sensory or psyehie stimuli on reflex actions, Pavloff showed that a musical note, a bright color, : strong odlor, or a skin stimulus will, if associated with the sight of food, avilil of itself to cause salivation, but that the flow of saliva at the sound of a given note will cease if the note be raised or lowered even by a quarter-tone.

The scientific study of metabolism has been divided by von Noorden into three stages: First, the qualitative period, inaugurated by Liebig and Wöhler, in which the end-products of animal metabolism and the conditions of their formation were determined. Seeond, the quantitative period of von Voit and von Pettenkofer, in which food values were carefully studied in dietetic tables and the balanee of nutrition determined, after which the thermodynamic relations of metabolic processes were calculated in terms of heat and energy units. Third, the recent era of the study of the intermediate products of metabolism, which is again qualitative, but already in process of becoming quantitative. The earlier experiments were concerned mainly with urinalysis and measurement of intake and output; now they are coneentrated upon interpretation of tissue activities in terms of calorimetry and respiratory metabolism or gas interehange (Du Bois). The initial experiments in metabolism were all quantitative, viz.,. Sanctorius' efforts to measure his own "insensible perspiration" on the steelyard, and the attempt of Lavoisier and Laplace to establish an equation between the quantity of heat formed in the body of a mammal and that formed in a burning candle, assuming the quantities of carbon dioxide formed to be identical in both cases. The latter has been signalized by Jacques Loeb as the foundation of seientific biology. All of Lavoisier's work on the exchange of gases in the lungs belongs, in fact, to the subject of metabolism, in the strict modern sense.

During the early periorl, Magendie was the first to emphasize the imporance of the nitrogenous substances in the organism. Prout dlividerl foorl-stuffs nto the saccharine, oily, and albuminous, from the faet that milk, nature's eady-made perfect food, is marle up of these ingredients. Next came the work of Liebig and Wöhler on urea and uric-acid compounds, in particular Wöhler's intheses of urea (1S2S) and hippuric acid (1S42). Liebig was the first to lassify the organic food-stuffs and the processes of nutrition (1S12). He held hat oxygen is the principal chemical coeffecient in living processes, that museuar work is dlone at the expense of albumen, that fat ean be formed in the borly rom albumen or sugar, and, like Claude Bernard, he believed that food-stuffs a ave to be ehanged into physiologic albumen before they can be utilized in he body. The embryologist Theodor Ludwig Wilholm Bischoff $(1807-1882)$, of Hannover, was the first to demonstrate the presenee of free CO, and oxygen n the blood (1837), studied the urea as a measure of metaholism (1842), and

1N. P. Chepovalnikoff: St. Petersburg diswertation, 1899.

${ }^{2}$ J. Locb: The Mechanistic Conception of Life, Chicago, 1912, pp. 4, 5. 
(with Voit) the laws of nutrition and inanition in carnivora (1860). The Alsatian chemist, Boussing:ult, first attemperel to tabutate the metalbolie intake and output in different :mimals (Is:35-10), and (with D) monas) defined an anintal

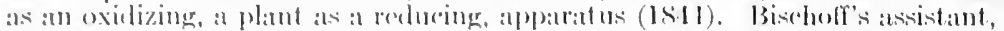
Carl von Voit (IS3I-19)S), of Amberge, madre nany intoresting studies on dieteties, particularly in his Ifamdboek of the Physiology of Motaboliom in Nutrition (ISSI), which introduend new methods of deternining the intake

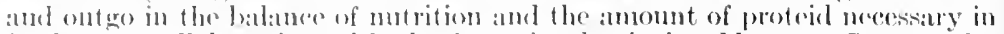
fords. In collaboration with the Bararian hygienist, Max von Pettenkofer (1s1s-1901). Voit first citinated the amounts of proteins, fat, or catbohydrates broken dewn in the bouly (from the total nitrogen and $\mathrm{CO}_{2}$ (dimiuated) by moans of at sperial respiration alpparatas, comstructed at the expense of King Maximilian of Balvaria (1Sti1), which wats further daberated and impoved by

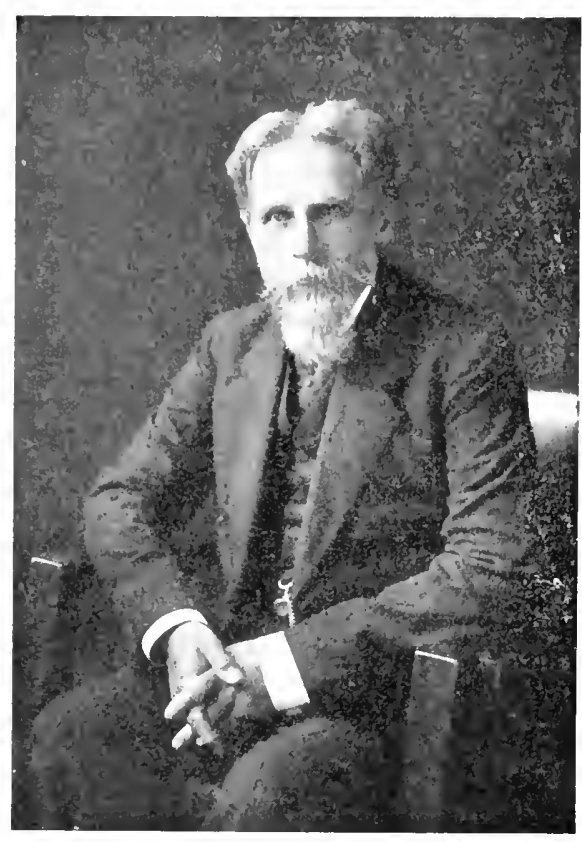

Max Rubner (1S51- ). Voit himself. 'These two investigators alsodemonstrated that fats are formed from the forol motricls $(1862-81)$, but, later, this view was not exclusively held to, "ren by Voit (1s86i), and wats abochlutely denied by Pflügor (1892). Voit distinguished between organized or tissue-proteids and unorganized or cireulating proteids (18s1), and held that the food carbohydrates ami proteidiare dirently consumen in the body (1SS1), in opposit ion to the Iiebig-Bornard-Pflüger hypothesis, that they have first to be chimged into body-substance. Petrenkofer introduced the well-known test for bile (1844), and a new mothod of estimating the $\mathrm{CO}_{2}$ in the air. The estimate of the nitrogen content in metabolism was rendered relatively easy by the methol introduced by J. Kjeldahl in 1883.

Max Rubner (1854-

), of Munich, a pupil of Ludwig and Voit, professor of hygiene and director of the Hygienic Institute at Berlin (1891), discovered that the metabolism is proportional to the surface area of the body (1883), that the specific dynamic action of foods on metabolism is greatest for protein and least for carbohydrates (1902), and was one of the first to investigate metabolic changes in terms of heat and energy units by means of the calorimeter, or by using the animal body as a calorimeter (1891).

The heat relations of the body were first investigated by Lavoisier and Laplace (1780), Crawford (17SS), and Scharling (1849), who used ice, water, and air calorimeters respectively. Since the time of Voit and l'ettenkofer, these investigations have been improved by such instruments as d'Arsonval's 
differential air calorimeter (1886), and the respiration ealorimeters of Atwater and Rosa (1897), Atwater and Benediet (1905), H. B. Williams (1912), Riche and söderstrom (Sage calorimeter, 1913). With this apparatus, the hrot production of the body can be measured rirectly and also indirectly by calculating it from the respiratory (uutient (liters $\mathrm{O}$ consumed into liters $\mathrm{CO}_{2}$ prowlued and the nitrogen output in the urine, one method serving as a cherk upon the other. The vilue of quantitative work by improved means has been esperially shown in such researches as those of Nathan Zuntz (1847-1920) on the blood gases and respiratory metabolism, Pavy and Molesehott on dieteties, Loewy (1890), Edsall and Neans (1914-15) on the effeet of drugs on heat production, Atwater and Langworthy on the balance of nutrition (1s9s), Max Rubner on the energeties of nutrition $(1902), \mathrm{R}$. 11. Chittenden on the minimum nutritive requirements of the body in relation to its eapacity for work and nitrogenous e(puiblorium (1904), F. G. Benedict on the influence of inanition of metabolism (1907), Carpenter and Murlin on metabolism in women before and after childbirth (1911), and Graham Lusk on animal calorimetry (1912-15). In 1s99, Magnus Levy and Falk demonstrated that metaboliom is high in childhood and low in old age. Metabolism in infancy has Jeen studied by Howland (1911), Benediet and Talbot (1914), and others. These results, supplemented by the studies of E. F. Du Bois on boy scouts (1915-16), show that motabolism is very low in the newborn, 50 per eent. above the adult level at the end of the first year, rising to at maximum in the unexplored period between two and six years, after which it falls rapidly up to the age of twonty, with a much slower decrease thereafter (Du Bois). The sturly of metabolism in disease is obtained by comparing the heat prorluetion of the pationt at complete rest some fourteen hours after the last meal (basal metabolism) with the normal controls. The extreme variations in the latter have been ladgely obviated by the iulproved "linear formula" of Delafield Du Bois for ealculating the surface areat of the body (1915), to which the metabolism of individuals between twenty and fifty is proportional. This formula gives a normal average basal metabolism of 39.7 ealories per squase meter. Friedrich Mïller" first noted the striking inerease of metabolism in exophthalmic goiter (1893). Magnus Levy found the gaseous interchanges very high in Graves' disease $(1895-7)$, very low in myxedema (1904), which results have been amply confirmed, partieularly by the work of E. F. Du bois with the Sage calorimeter $(1915-16)$. The abnormal heat production elucidates the semeiology of the disease and has important dietetie bearings. That the inerease of metabolism in typhoid fever is proportional to the lise in temperature has bern slown by many investigators. The effert of the starvation factor las been abolished by the high calory diet of shaffer and Coleman (1909), The respiratory motabolism in the different anemias has been studied by Magnus Levy (1906), Mever and Du Bois (1916), and others. The latter observers (with Peabody) have investigated metabolism in eardio-renal disease (1916). Grafe found an increase in caneer, and only a moderate increase in low-grade fevers (1904). Varying results in pituitary discase, notably a slight rise of heat production in acromegaly, have been obtained by lalta (1913), Du Bois (1914), and Means $\left(1915^{\mathrm{i}}\right)$. The pathology and treatment of diabetes have been rendered a purely chemical problem through such advances as Petters' discovery of acrotone in rliabetie urine (1857); the work of Kusmanl on acetonemia (1871); of Starlelmann (1883), Külz (1S84-\$7), Ninkowski (1S84), and Magnus-L('vy (1899-1909) on $\beta$-oxybutyric acid in relation to diabetic coma, von Mering's experimental production of diabetes by exhibition of phlorizin (18s6); the dietetic studies of Carl von Noorden (1895-1911), the important and extensive studies of Graham Lusk (189S-1915), F. G. Benediet and Joslin (191()-15), and the effects of the fasting treatment of F. M. Allen (1915). Jusk's original observation that a completely diabetic patient will excrete not only all the ingested carbohydrate, but the sugar equivalent of half the protein molecule (1906), has been confirmed by Allen and Du Bois (1916). 'The true metaberlic: relations of uric acid, first isolated from the urine by Sebeele (1776) and found in gouty and urinary concretions by Wollaston (1797), have been at matter of

${ }^{1}$ See E. F. Du Bois: Am. Jour. Mel. Sc., Phila., 1916, cli, 781-799. 
kon eontroversy. Important lambmarks in its history are Mareet's diseovery of xamthin (1sig); Strecker's demonstration of the sane in the urine (15:57); Lessel's prowf that xanthin hatses are therivatives of the mine (1879); the

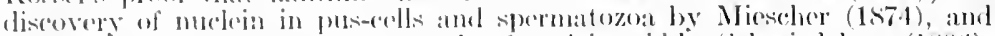

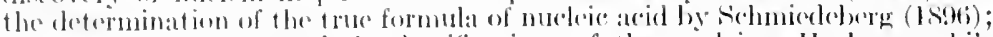

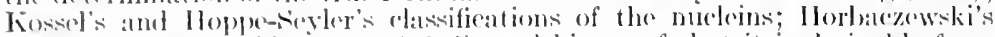
synthesis of ure acid in vitro (1Ss2), and his proof that it is derivable from nuclein (1sis); Minkomski's discovery that a dien of xamthin bases will incerase mric-acid exeretion (1sisi), and that, in birds, the latter is synthetized in the livere through the influence of lactie acid (1ss6); and Emil Fischer's family tree of gont, based upon the idtea that urie acid and the xatuthin bases have a common purin-nueleus (1595). The redation of the liver to metalbolism was stutiod to advantage through a method introduced by the Russian physiologist, Nikolai Vladimirovich Eck (1847- ) in 1877. This consisted in establishing a permanent communication between the portal voin and the inferior vena cava (Eek's fistula), abolishing the portal eirculation by ligation of the portal vein, so that ligation of the hepatie artery under these conditions is equivalent to excising or exeluding the liver.

The name of Rudolph Heidenhain (1834-97), professor of physiology at Breslau (1859- ) , is int imately associated with the interpretation of all secretory phenomena as intracellular, rather than mechanieal, processes.

He investigated the histologic changes in the eells eoncerned in the secrotion of waliva, milk, the gastric and intestinal juices, and the panereatic ferments, and opposed Ludwig's filtration theory of the formation of lymph and urine on the same grounds, deseribing lymph as a secretion from the cells forming the walls of the eapillaries, and urine as a product of the renal glomeruli, so far as water and inorganie salts are concerned, urea and uric aeid being regarded as seeretions of the epithelial cells in the convoluted tubes. Most of these theories are contained in his memoir on seeretions in Hermann's Handbuch der Physiologie $(1850, v)$. He also investigated the action of poisons on the nerves of the sibmaxillary gland (1872), the trophic and secretory fibers of the secretory nerves $(1878)$, and the phenomena of intestinal absorption (188894). Cnder du Bois Reymond, he began his studies of the mechanies, metabolism, and heat prorluction of muscular activity (1S64), leading to the construction of a "tetanomotor." With Bürger, he made some experimental investigations in hypnotism, but his most striking work was undoubtedly his method of staining the kidney-cells by the injection of indigo-carmin into the blool, which, whatever his hypotheses, shows him to have been an investigator of great power.

The beginnings of the theory of ductless glands and internal secretions, especially in relation to metabolism, were Claude Bernard's work on glycogen (1848-57), the pancreatic functions (1849$56)$, his fourth ventricle piqûre, Addison's description of the suprarenal syndrome (1849-56), and the experiments of Brown-Séquard and Schiff.

Charles-Edouard Brown-Séquard (1817-94), a native of Mauritius. was the son of an American father and a French mother, but his life-work was mainly associated with French medicine.

He led a roving existence, posting from one country to another at intervals, and, whether in London, Paris, or New York, he could have attained almost any eminence by eontinuous effort. Ho suceeeded Claude Bernard as professor of experimental medicine in the Collège de France in 1878 , and he 
was successively a professor in the Harvard and Paris medical faculties. In 1852, he confirmed Bermarl's work on the sympathetic. Previous to this he had made his mark by his experimental transections and hemisections of the spinal eord (1849); his description of hemiplegia with erosed anesthesia $\left(1850^{1}\right)$ of whieh he gave an incorrect physiological explanation; his investigations of the associated pains of viseeral disease (18.57); the elfert of tropical heat on the temperature of the body (1659); the "tremospasm" feature of the" knee-jerk (1858); the experimental production of epilepsy (1869-70); the experimental profuction of vasomotor changes in the pulmonary circulation (1S72); and the vasodilator effect produced by beat stimulation of the eerebral cortex (1897). He is, with Claude Bernard, the principal founder of the doetrine of the internal secretions, through his experimental production of an exagerater Addison's diseate in animals by excision of the suprarenal capsules (15.56-5) $\left.55^{2}\right)$, his use of the testicular and other organic juices as remedics $\left(1859-91^{3}\right)$, his theory that the kilney has an internal secretion $\left(1892^{4}\right)$, and his treatment of acromegaly by animal extracts $\left(1593^{5}\right)$. He was frounder and editor of the Journal de la physiologie de l'homme et des animaux (1S.58-63), and, with Chareot and Vulpian, of tho Archives de physiologie normale ot pathologique (1S6S-94).

\section{Moritz Schiff (1823-} 96), of Frankfort on the Main, a pupil of Magendie and Longet, was professor of comparative anatomy at Bern (1854-63), and of physiology at Florence, Italy $(1863-76)$, and Cieneva $(1876-96)$. He was a zoölogist by training, at-

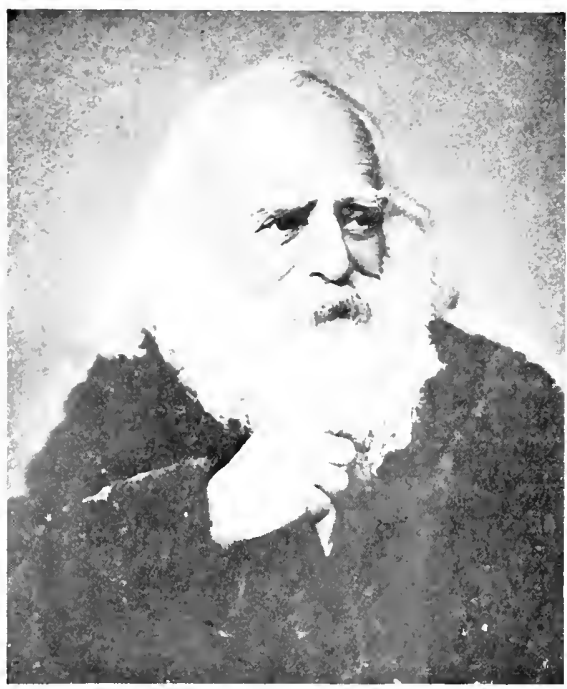

Moritz Sehiff (1S23-96). taining particular eminence in ornithology, and there are few aspects of physiology which he did not investigate.

Schiff's work was characterized by great originality in the minutiac of experimental procelure, displaying an almost prophetic insight into many things of present moment. He liked to cross sworks with eontemporary theorists, and the fact that he sometimes abandoned his own theories, or that some of them have been abandoned by others, has tended to obsenere his very solid merits. Thus, in 1849, he took the somewhat arbitrary standpoint that the vagus is the motor, rather than the inhibitory, nerve of the heat, from his

1 Brown-śécyuard: Compt. ronel. Soc. de biol., 1S.50, Paris, 15.51, ii, 70-73.

2 Compt. rend. Aead. d. se., Paris, 1856, xiii, pt. 2, 422; 512. Jour. de la physiol. de l'tomme, Paris, 185s, i, 160-173.

${ }^{3}$ Arch. de physiol. norm. ot path., Paris, 1Ss9, 5. s., i, 739; 1890, ii, 201; $443 ; 646 ; 1891$, iii, 746.

${ }^{4}$ Arch. de physiol. norm ot path., Paris, 1892, 5. s., v, 775-7s6.

5 Compt. rend. Soc. de biol., Paris, 1893, xlv, 527. 
results on stimulation of the treminal unotor fibers, which anticipated the dis-

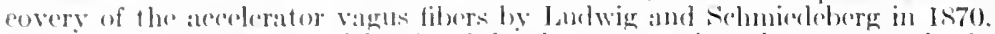
Ho notied that the ventricke of a dying heart sometimes beats more stowly

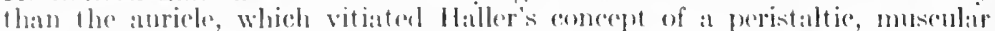
was pasing from the groat veins through the heart to the aortat unt il (iaskell showed the phenomenom to be a simple case of bluck. He believed that the localized "inliopathice" muscular contrations at the outset of rigor mortis are duc to a special chemical stimulus (homone) formed at doath. In Isiti, he made experiments which foreshatowed the existence of the vasodilator nerves discovered by Bernarel in 1sis. In 1867, in anticipation of Jatoff's pupils, ho noted that the reflex flow of salivat in a flog with a parotid fistula varies with the methods and substances employed in stimulation. He wats one of the earliest to study the effects of removal of the expelbellum, hemiseetion of the cord, and transection of the eereloral peduncles and spinal nerveroots (185s); he was the first to motier the effeet of exeitation of the eerebral eortex upon the cireulation; first deseribet the vasoconstrictor function of the great aurieular

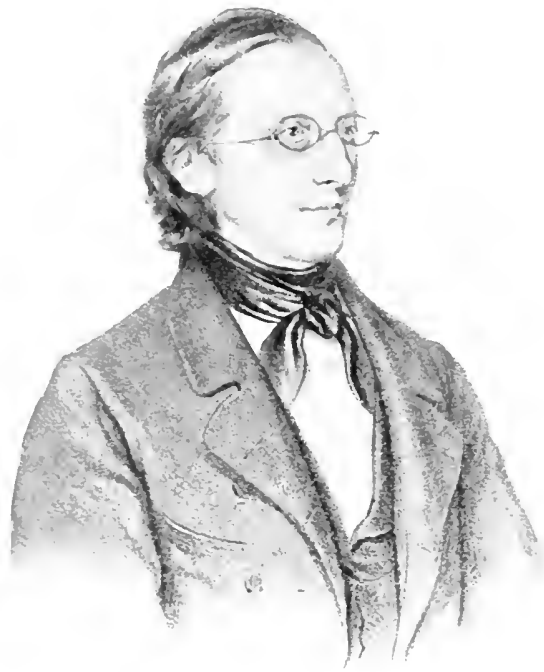

Carl Ludwig (1816-95). nerve and the inhibitory offect of section of the small superficial petrosid upon reflex salivary seeretion: and first regurded the Rolandic area as sensory, although he later abandoned this view. His epoch-making experiments on the effects of excision of the thyroid in logs, their prevention by thyroid grafts and by the injection or ingestion of thyroid juices (18.56-841), which will be deseribed under twentieth century medicine, make him a pioneer of the doctrine of internal secretions and a prophet of thyroidtherapy. To this field belong also his experiments on artificial diabetes $(1556)$ and the relation of the nervous system to its production (1859).

"More than to any one else since the time of Harvey," says Sir Lauder Brunton, "do we owe our present knowledge of the circulation to Carl Iudwig.

Like the great architects of the Middle Ages, who built the wonderful eathedrals, which we all admire, and whose builder's name no man knows, Ludwig has been content to sink his own name in his anxiety for the progress of his work, and in his desire to aid his pupils." Carl Ludwig (1816-95) was a native of Witzenhausen, Hesse, a Marburg graduate (1840), professor of anatomy at the latter university (1846-49), professor of anatomy and physiology at Zürich (1849-55), professor of physiology and zoölogy in the Josephinum at Vienna (1855-64), and finally professor of physi-

1 Schiff: Intersuehungen über die Zuckerbildung in der Leber, Würzburg, 1\$59, pp. 61-63. Rev. méd. de la suisse Rom., Geneva, 18s4, iv, 6.5-75. 
ology at Leipzig (1865-95), where he founded the Physiological Institute in which so mueh of his work was done. Ludwig was perhaps the greatest teacher of physiology who ever lived. He had over 200 pupils of all nationalities, and most of the younger generation of investigators in his science were trained by him. Beyond a text-book of physiology (1852-56), two inaugural addresses on the mechanism of urinary secretion (1843) and on blood-pressure (1865), and a few minor essays, he did but little independent writing. Most of his important discoveries were published under the names of his pupils, some of whom, von Kries tells us, merely sat on the window-sill, while Ludwig and his faithful assistant, Salvenmoser, did all the work. He had a wonderful eapacity for selecting themes which would make the pupil find himself. His object was to form capable investigators, while earrying out his own ideas, and, to this end, he always mapped out the experimental problem himself, including its technieal details, and usually wrote out the final draft of the paper also.'

His principal contributions to physiology are the introduction of the graphic method (1847), with new instruments, like the kymograph, blood-pump, and Stromuhr; perfusion of exeised organs (1865-67), his theories of the mechanism of urinary secretion and lymph-formation, his discovery of the innervation of the salivary glands, and his many exeursions into the physiology of the cireulation. Nearly all these things were done before Ludwig came to Leipzig.

To the Marburg period belongs the mechanieal theory of the secretion of urine by osmosis. In $1842,{ }^{2}$ Sir William Bowman, in rleseribing the eapsule around the glomeruli and the urinary tubules, advaneed the theory that the proximal prineiples of the urine are secreted in solid form from the epithelium of the venous tubules, solution being effected by water discharged from the glomerulus. Ludwig's theory $\left(1813-44^{3}\right)$ starts with the idea that the seeretion of urine depends upon the beating of the heart, the blood-pressure causing the urinary constituents to pass from the blood through the capillary walls as a dilute liquid, which becomes eoneentrated, as it passes through the tubules, by osmosis of water to the more concentrated lymph outside. Bowman and Heidenhain treated the glomerular epithelium as a seereting gland. Ludwig regarded it as a passive filter. Lulwig's theory has been aceepted by most physiologists, although strong objections to it have been made by Heidenhain ${ }^{4}$

1 These monographs were published simultaneously, under the pupils' names, in the "Berichte" of the Saxon Acarlemy of Sciences, and in the famous Arbeiten aus der physiologischen Ansialt zu Leipzig (1866-77), but, after 1877, in dı Bois Reymont's Archiv. They cover every aspeet of the subject exeept the physiology of the brain, and reveal, at every turn, the master experimenter, the man of infinite resource in investigation.

2 Bowman: Phil. Tr., Lond., 18 $42,57-80$.

${ }^{3}$ Ludwig: Beiträge zur Lehre vom Mechanismus der Harnsecretion, Marburg, 1S43, and Wagner's Handwörterb. d. Physiol., 1844, ii, 637.

${ }^{4}$ Heidenhain: Arch. f. path. Anat., Berl., 1866, xxxv, 158. 


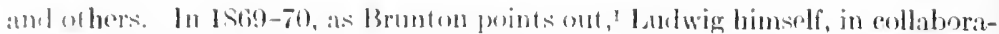
tion with his pupil. Nstimesiteh, performed an experiment which foreed him to molify his views sementat." "This eonsisted in divieling the medultat in the neck of a dog, ratling the blexd-pressure to fall, amel stopping the urinary se-

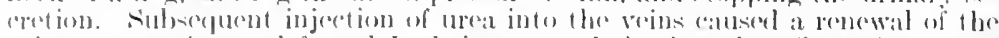

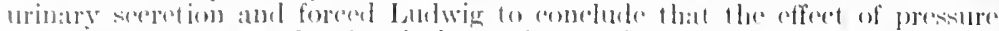

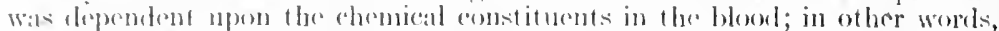
upon osmosis through as selective, semipermeable membrane. In 1817 , Luth-

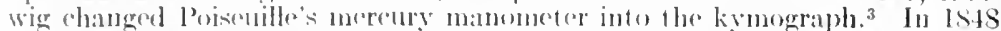

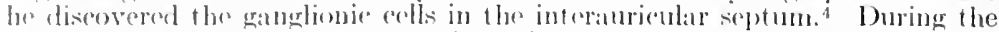

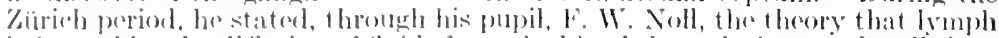
is formed by the dilfusion of thrits from the blosed through the vesied walle into the surromiding tissues, the motor power being the capillary blood-pmessure

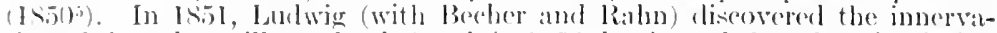
tion of the submaxillary ghand ${ }^{6}$ and, in list), he showed that the stimulation of the sympathete nerve will eallse seeretion by the submaxillary gland.? During the Viennese period, his pupil, Lothar Mleyer, investigated the gaters of the blood (15.5-58); Cloetta diservered inosite, taurin, fencin, and urie aceid in the animal boyly (15is); and Ludwig himself collaborated with the phrsicist stephan in a hydrolynamie investigation of the pressure exerted by flowing water in a plane perpendieular to its direction (1858). In 186.4, he sturfied, with Thiry, the effeet of the spinal cord upon the blood eurrent, ${ }^{8}$ and his Leipzier inaturural address (1865) introdueed the idea of keeping excised portions of an organism (überlebende Organe) active by an artifieial cireulation or "perfusion." During the Leipzig period, research wats varied, but the main object of study was the hast and the cireulation. Thus, in 18156 , we find him, with Elie ron Cyon, investigating the effect of temperature on heart-theat, and in the same year he diseoverel the depressor nerve of the heart, and the "nervi crigenten" of the peripheral vessels $\left(1866^{\circ}\right)$. With Dogiel, he invented the Stromuh for measuring the amount of blood passing in unit time (1S66-10); in 1Stis, with'the same pupil, he found, upon auscultating the heart after ligation of the vena cava, pulmonary artery and vein, and aorta, that the first (systolie) sound is not of valvular origin entirely, but is partly produced by the eardiac muscle. ${ }^{11}$ In 1\$69-70, Lauder Brunton and O. Sehmiedeberg began to study the effeets of drugs upon the circulation; and in 1871 , Schmierleberge traeed the aceelerator fibers of the vague norve in the dog. ${ }^{2}$ In 1571 , 1I. P. Bowditch, experimenting with an exeised heart and a frog manometer, showed that the heart muscle always gives a maximal contraction or none at all ("all or nothing"); and Kronecker, investigating fatigue and recovery of muscle, showed that heart musele eannot be tetanizerl. In 1871-73, Ludwig, with Dittmar, was the first to localize a vasomotor center (in the medulla blongat $\left.a^{13}\right)$. With M(rso, he made plethysmographic studies on the blood-

'Brunton: Proc. Roy. Soc. Med., Lond., 1912, v, Therap. Sect., 139-151.

${ }^{2}$ C. Ustimovitch: Arb. a. d. physiol. Anst. zu Leipz., 1870, v, 217. 302.

${ }^{3}$ Ludwig: Arch. f. Anat., Physiol. u, wissensch. Med., Berl., 1847, 241-

${ }^{4}$ Ludwig: Müller's Areh., Berl., 1848, 139-143, 1 pl.

${ }^{5}$ Ludwig and Noll: Zeitschr. f. rat. Med., Heidelb., 1850, ix, 52.

${ }^{6}$ Ludwig, Becher and Rahn: Ibid., 1851, n. F, i, 22.5-292.

7 Aceording to his pupil, Czermak.

"Ludwig and Thiry: Sitzungsb. d. k. Akard. d. Wissensch., Med.-naturw. Cl., Vienna, 186-4, xlix, 2. Abth., 421-4.54.

${ }^{9}$ Ludwig's Arbeiten (1S66), Leipz., 1867, i, 12\$-149.

${ }^{10}$ Ibid., ii, 196-271.

${ }^{11}$ Ber. d. k. sächs. Gesellsch. d. Wissenseh., Leipz., 1868, xx, 89.

${ }^{12}$ Ludwig and Schmierdeberg: Ibid., 1S71, xxiii, 148-170.

${ }^{13}$ Ludwig and Dittmar: Ber. d. k. sächs. Gesellsch. d. Wissensch., Leipz., 1S71, 135; 1573, 460. 
ressels of the excised kilney (1Sit); with von Kries, he measured the bloodpressure in the eapillaries (18751); with Sehmidt-Mülhoim, he began to experiment with the injection of prptones into the blood $\left(1880^{\circ}\right)$; in 1853 , Wooldridge made his important studies on the chemistry of coagulation of the blood, and in 1SS4, Conrad Compertz investigated the arrangement of muscular fibers in the heart. Other important investigations from Ludwig's laboratory were his monograph on the lymphaties (with schweigger-soidel, 1572-743); introducing the puncture methor of injection in histology; Flechsig's investigations of medullated nerve-fibers (1876); Ludwig's study of the digestion of proteids after excision or exclusion of the stomach (with Ogata, 18834), and Bowditels's proof of the non-fatigability of nerve (1890).

The titles listed give but a faint idea of the immense amount of valuable work done in the Leipzig laboratory, where not a few students, as Burdon Sanderson tells us, "for the first time in their lives came into personal relation with a man who was utterly free

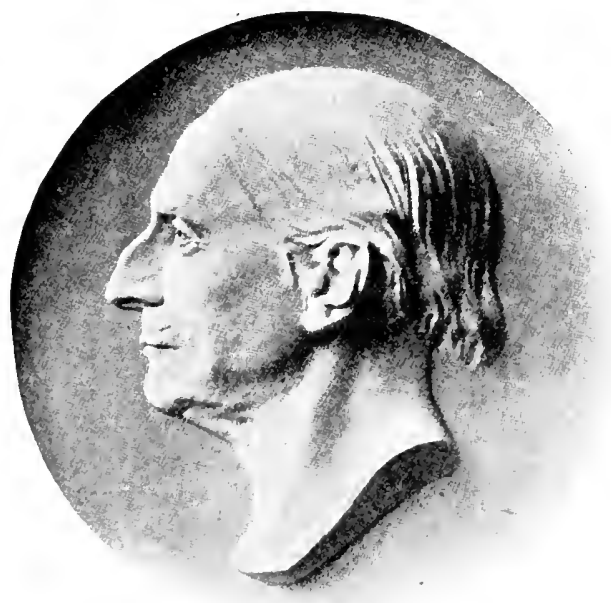

Carl Ludwig (medallion). (Courtesy of Profosoor William Stirling, Manehester, Englind.)

from selfish aims and vilin ambitions, who was scrupulously conscientious in all that he said and did, who was what he seemed to be and seemed what he was, and who had no other aim than the advancement of his science." "All who met Ludwig," says Kronecker, "came under the influence of his enchanting personality." He lived with his pupils in a "schöne Cemeinsamlieit," and was, indeed, in some respects, the personification of Browning's hawknosed, high-cheek-boned, blue-eyed German professor, absolutely

${ }^{1}$ Von Kries: Ibid., 1875, 148.

2 Arch. f. Physiol., Leipz., 1880, 33.

${ }^{3}$ Die Lymphgefässe der.Faseien und Sehnen, Leipz., 1872.

${ }^{4}$ Ludwig and Ogata: Areh. f. Anat. u. Physiol., Leipz., 1883, $\$ 9$. 
sincere and unpretentions, and, however rigorous and exact in mothod, captivating every one by his warmth of heat, his genial sympathy, and the simplicity of his life and aims. Indwig was a splendid draftsman, and his mind was of the purely plastic kind, which visualizes everything as a material phenomenon. For this reason, he had little use for mathematies, psychology, or any of the sciences which reposc mpon a metaphysical basis. He was devoted to music, however, a great patron of the Gewandhaus eoncerts, and he often had chamber music at his house. The cham of his persomality has been admirably conveyed in the reminiscences of his old pupils, Kronecker, von Kries, Burdon Sanderson, and William Stirling.

The innervation of the heart was investigated by Ilenle (1S41); by Friedrieh Bidder, who diseovered the ginglionic cells at the junction of the aurieles and ventricles $\left(1852^{1}\right)$; by Albert von Bezold, who demonstrited the areelerator nerves of the heart and their origin in the spinal eord (1862); and by Walter Iolbrook Gaskell, who showed that the innervation of the heart is the same in eold-blooded and warm-blooded animals, and that the vagus nerve weakens the heart as well as slows it (1852-84). A striking experiment upon the heart-beat was made by IIermann Stannius (1808-83), of Hamburg, who, by placing a ligature at the junction of the auricle and the sinus venosus, brought the heart to a standstill, while a second ligature, applied to the aurieulo-ventrieular groove, eaused the ventricle to beat again $\left(1852^{2}\right)$. In the early days of the neurogenie theory of the heart's action, the effeet of the Stannius ligaitures was supposed to be due to inhibition of the ganglia of Bidder and Remak, but the subject took on a new light with the discovery of the auriculoventrieular bundle of His. The pulse was specialy studied by Etienne-Jules Marey (1830-1904), who invented the splnygmograph, although the graphic method in pulse-examination harl already been introduced by Karl Vierordt (1855). Other studies of the pulse were made by Landois, von Kries, and von Frey. Blood-pressure was especially investigated in Alfred Wilhelm Volkmann's Die Homodynamik nach Versuchen (1850), by Ludwig Traube (1818$76)$. who first deseribed the rhythmic variations in the tone of the vasoconstrictor eenter (Traube-Hering waves) in 1865, and by Roy and Adami (1892).

Coagulation of the blood was investigated by Andrew Buchanan, who extracted the fibrin ferment (1845); and by Alexander Sehmidt (1831-94), who gave it its name, but supposed that coagulation was due to the combination of fibrinogen and serum-globulin. This error was corrected by Olof Hammarsten (1841- ), who showed that coagulation is accomplished by splitting up of the fibrinogen into fibrin and other substances (1875).

Some of the best modern work on the circulation came from the Cambridge School of Physiologists, who were all pupils of Sir Michael Foster (1836-1907). On Huxley's recommendation, Foster became prrelector of physiology at Cambridge in 1870 , succecling to the professorship created in 1883. Here, after a tour of the German laboratories with Sharpey, he made an epoch in teaching that was only excelled by Ludwig's, and through an unrivaled group of pupils in all branches of biological science-

${ }^{1}$ Bidder: Müller's Areh., Berl., 1852, 163-177.

2 Stannius: Ibid., 8.5-100. 
Balfour (embryology), Iiversidge (chemistry), Milnes Marshall (zoölogy), Sidgwick (animal morphology), Ray (pathology), Francis Darwin (vegetable morphology), Vines (experimental botany) - apart from the physiological group. Foster collaborated with Balfour in "Elements of Embryology" (1874), with J. N. Langley in a book of practical physiology (1876), and in the same year produced his own Text-Book of Physiology, which passed through seven editions and was translated into German, Italian, and Russian. To medical history he contributed his beautiful memoir of Claude Bernard (1899) and the superb Lane Lectures on the History of Physiology (1900). His own experimental work was entirely on the heart, in particular his observations on the snail's heart (1859), that any part, separated from the rest will beat rhythmically, and that the heartbeat must be a specific property of general cardiac tissue and not the result of any localized mechanism. Foster's talents as an organizer gradually drew him into an incessant round of public activities, and with his entry into Parliament his scientific work ended and he lived forward in his pupils.

Foster's pupils include

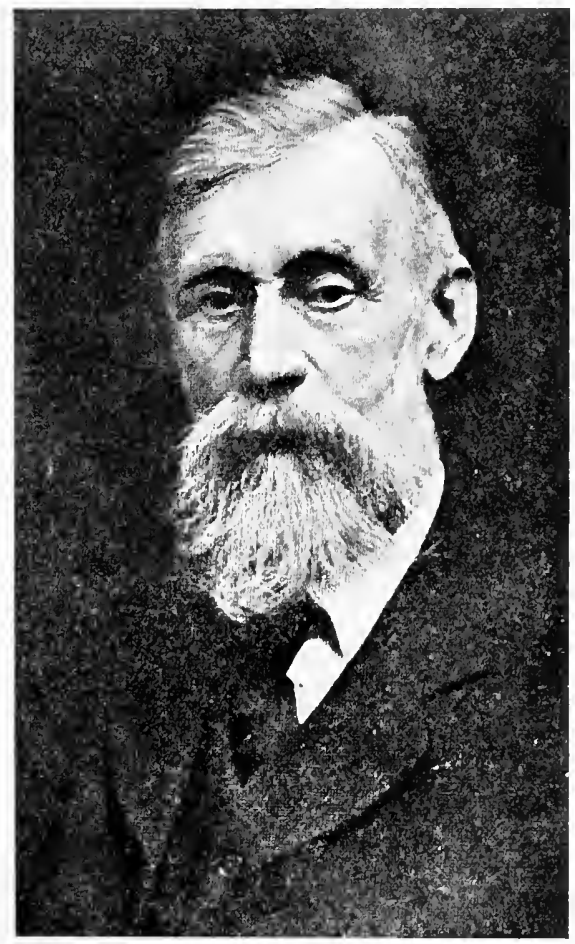

Sir Michael Foster (1836-1907). the embryologist Balfour, Gaskell and Langley, Sherrington, Henry Head, and Charles Scot Roy (1854-97), of Arbroath, Scotland, who invented many unique nstruments, made important researches on the renal circulation with Cohnheim), on the extensibility and elasticity of blood-vessels, liscovered an automatic rhythmic tomus in the mammalian spleen, levised a successful preventive inoculation against a cattle disease n Argentina, and achieved a great memoir on the mammalian leart (1892) with John George Adami (1862- ) ), of Manchester, Ingland, another Foster pupil who is eminent as the leading 
bathologist of Canada, and anthor of important works on cancer, heredity, classitieation of tmmors, and widely known text-hooks on pathology (190S-12). Among other Foster pupils, A. C. Dew Smith, a man of wealth, financed the Journal of Physiology, founded by Foster in 1STS, and estat)lished the Cambridge Seientifie Instrument Company, which made the latoratory appatatus.

Hemry Newell Martin (1848-96), of Newry, Ireland, mofessor of biology at the Johns Hopkins University (1876-93), carried Foster"s methods of teaching into the United states, collaborated with Inxley in his "Elementary Biology" (1875), devised (with

II. T. Selowick) a method of

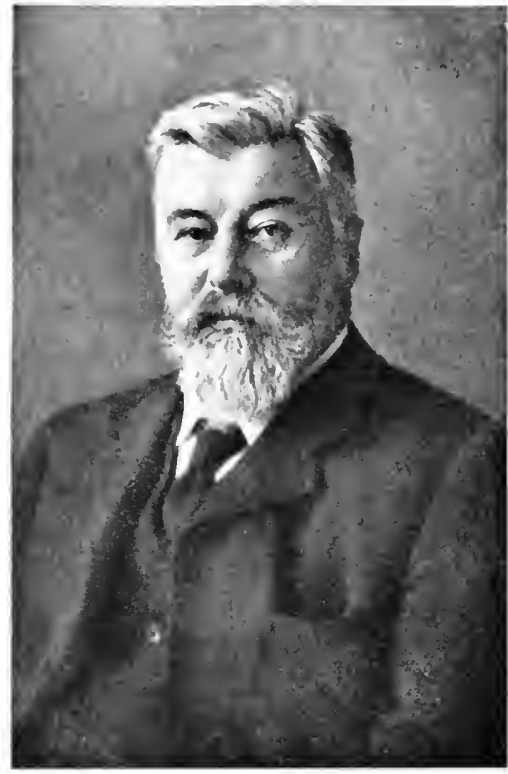

Walter Holbrook Gaskell (1847-1914). isolating the manmalian heart for experimentation (1880), studied the effect of variations of hlood-pressure and temperature upon the rate of beat of the mammalian heart (1S8283). Martin's pupil and suecessor, William Henry Howell $(1860-)$ ), of Baltimore, Maryland, has investigated such problems as the accelerating effect of increased venous pressure on the heart (1881), the life-history of the bloodcorpuscles (1890), blood-serum deprived of proteids as an improvement on Ringer's solution (1893), and the rôle of the "hommones," antithrombin and thromboplastin, in the coagulation of the blood (1911).

Frederick Gowland Hopkins, prielector in biochemistry at Trinity College, devised a well-known method of estimating uric acid in the urine (1892), analyzed tryptophan, and was the earliest to recognize the significance of vitamines in his observation that a diet lacking in the amino-acids, arginine and histidine, or composed of only 5 simple amino-acids of the 18 composing protein, will fail to maintain life. Joseph Barcroft (1872), of Newry, Ireland, wrote an important memoir on the respiratory function of the blood (1914).

Walter Holbrook Gaskell (1847-1914), perhaps Foster's greatest pupil, did the most important work on the heart after Ludwig, and laid the histologic foundations of the modern study of the autonomic nervous system. 
During his Cambridge period, Gaskell worked for a while in Ludwig's laboratory (15i4) and produeed an important paper on the vasomotor nerves of striated muscle $\left(1877^{1}\right)$. In 1881, he produced his great memoir on the musculature and innervation of the heart, ${ }^{2}$ in which it is shown that the motor influences from the nerve ganglia in the simus venosus influence the rhythm (rate and force) of the heart but do not originate its movements or beat, which are due to the automatic rhythmic contractile power of the heartmuscle itself and to the peristaltic contraction wave which proceeds from sinus venosus to bulbus arteriosis and from musele-fiber to muscle-fiber. Following Romanes' experiments upon the bell of Medusa (1S75 $)$ the zigzag ineisions of Gaskell and Engelmann upon extra-vital hearts and isolated strips of heart muscle, containing no nerve tissue, demonstrated the continuity of rhythmic wave. Gaskell showed it to be reversible by stimulating the vent ricle after the second Stannius ligature, proving that the normal peristaltic wave could not have proceeded from the cardiac ganglia. Gaskell introduced the term "heart-block" (from an expression of Romanes) and produced it experimentally, as also fibrillation of the heart and the two-, three-, and four-time gallops of the clinies. These, with the effects of the Stannius ligatures, and Schiff's observation that the vent ricle of a dying heart beats slower than the auricle, he showed to be simple cases of block. He was the first to investigate the electrical condition of the heart with a galvanometer. Schmicdeberg's observation that stimulation of the vagus after administration of nirotine will hasten the heart (1S71), he showed to be a simple case of nicotining the pre-ganglionic inhibitory fibers of the vagus, the switchboard effect across the synapse being abolished, and the post-ganglionic accelerator fibers being unaffected by the poison. Thus the true function of the vagus is not inhibitory, but quiescent, integrative, regulative, the nerve aeting as whip and bridle, spur and snuffle. In $1886^{4}$ Gaskell produced another vast research on the comparative histology of the nervesupply of the vascular and visceral ssytems, mapping out a large part of what Langley more clearly defined as

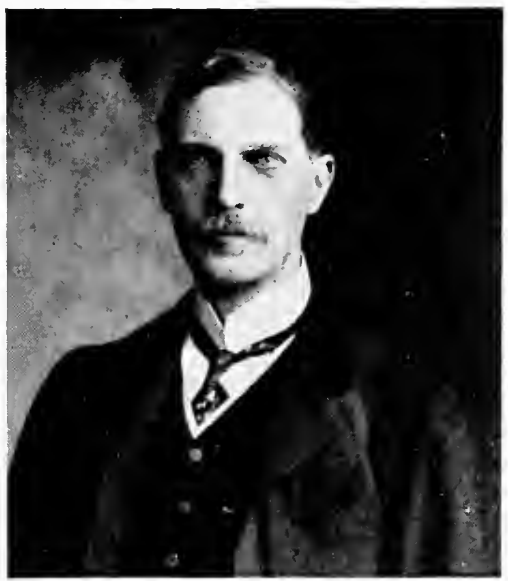

John Newport Langley. the autonomic or self-governing system. The sympathetic fibers were shown to originate only from the thoracic and lumbar regions of the cord.. In 1893, he showed that chloroform lowers blood-pressure by acting directly upon the heart and not on the vasomotor center. ${ }^{5}$ The rest of his life was devoted to his theory that the central canal of the nervous system was originally the lumen of a primitive gut $\left(190 \mathrm{~S}^{6}\right)$. His posthumous memoir on The Involuntary Nervous System (1916) sums up his lifework.

John Newport Langley, who succeeded Foster as professor of physiology at Cambridge, made important investigations of the

${ }^{1}$ Gaskelt: Proc. Roy. Soe. Lond., 1876-7, xxv, 439-145.

${ }^{2}$ Phil. Tr., Lond., 1882, elxxiii, 933-1033.

${ }^{3}$ Romanes: Phil. Tr., Lond., 1875, elxvi, 269.

${ }^{4}$ Jour. Physiol., Lond., 1886, vii, 1-80.

${ }^{5}$ Laneet, Lond., 1893 , i, 386.

${ }^{6}$ Gaskell: The Origin of Vertebrates, London, 1908. 
coll changes in pancreatic secretion, on the liver fat, the salivary and galstrie secretions, and in 1889 (with W. L. Dickinson ${ }^{1}$ ) he showed that upon painting a sympat betic nerve ganglion (Foster's synapse) with nicotine, the passiage of nerrouls impulses across it will bo blocked. This was followed hy a brilliant series of experiments," which overthew many current conceptions in regard to the involuntary nervous system, showing that the visceral (oro-inal) srstem is different in origin from the sympathetic and leading to the classification of the sympathetic and cranio-sacral systems of spinal nerves as "autonomics" for the redistribution of all efferent impulses which do not terminate in striped or voluntary muscle.

The art of keeping animal tissues active extravitally was introdueed by (arl Ladwig in his perfusion experiments, and was perfected by sydney Ringer (1835-1910), of Norwich, England, who showed that a frog's heart can be kept beating for long periods of time in a mixture of the chlorides of sodium, potassium, and calcium. This was afterward shown to be equally true of the mammalian heart. ${ }^{3}$ Ringer's work showed the importance of the calcium salts in maintaining tissue activity, and "Ringer's solution," so wiclely used in physiological experiments, was the culturemedium in which Carrel latterly grew his "visceral organism."

Among Americans who have worked on the circulation are Howell, William Townsend Porter (1862- ), of Plymouth, Ohio, professor of comparative physiology at Harvard University (1906), who helped to found and financed the American Journal of Physiology (1898-1915), and is author of a very practieal laboratory manual (1900), and of researches on the growth of children (1893-96), the coronary arteries (1893-96), etc.; Henry Serrall (1855- ), of Winchester, Va., one of Newell Martin's pupils, later professor of medicine in the University of Colorado (1911); Russell Burton-Opitz (1875- ), of Fort Wayne, Ind., who studied the viscosity of the blood (1914), and George Neil Stewart (1860- ), of London, Canada, professor of experimental medicine in the Western Reserve University of Cleveland, Ohio (1907), author of a mannal of physiology (1896) and of valuable studies from the $H$. K. Cushing Laboratory.

Among French physiologists Charles Richet (1850- ), of Paris, professor of physiology in the Paris Faculty, introduced the term "anaphylaxis" (1909), and is known for his researches on the gastric juice (1878), the diuretic action of milk and all sugars (1881), the modalities of muscular contraction (1882-3), regula-

${ }^{1}$ Langley and Dickinson: Proc. Roy. Soc. Lond., 1859, xlvi, 423: 1890, xlvii, 379 .

${ }^{2}$ See Langley: Lancet, Lond., 1919, i, 951.

${ }^{3}$ Ringer: Jour. Physiol., Lond., 1880-87, iii-vii, passim. 
tion of animal heat by polypnoca (1884-93), his therapentic innovations of hematotherapy (1888), chloralose (1893), deprivation of chlorides in epilepsy (1900), and zomotherapy (1900), and his dictionary of physiology $(1895-1907)$.

Eugène Gley (1857- ), of Epinal, professor of physiology in the Paris Faculty (1889), demonstrated the existence of iorline in the thyroid gland and the blood, and has done valuable work on the heart muscle (1888), the coagulation of the blood, the effect of drugs, the internal secretions and the pathology of the thyroid gland.

The most important work on respiration was done by Eduard F. W. Pflüger (1829-1910), of Hanau-am-Main, a pupil of Johannes Müller and du Bois Reymond, who succecded Helmholtz as professor of physiology at Bomn in 1859, and held the chair the rest of his life. Under Pflüger, the new Institute of Physiology at Bonn was opened in 1878, and in 1868 he founded the famous Archiv für die gesamte Physiologie (Pflüger's Archiv), which ran through 130 volumes under his direction, and became the most popular journal of physiology in Germany.

Pflüger early made his nark as a master investigator by his monograplo on electrotome (18591). By his experiments in elossing species (1853) he became the founder of experimental embryology. In his work on metabolism he (p)posed the view of Voit that organized (tissue) proteid, in order to undrergo metabolism, must first be converted into unorganized (cireulating) proteid, maintaining just the opposite view, viz., that proteids ean never undergo metabolism or assinilation exeept in the organized or stationary forns; in other words, that proteid metabolion cannot take place until the material is built up into protoplasm. Ho adopted as a criterion for a proteid the capacity to naintain life and to enter into the composition of protoplasm, which would, of course, exclude the polypeptides, proteoses, protamins, and the poisonous roteids. Pflüger also made laborious researches to prove that glyeogen rloes ot originate from protein material, and, like Pavy, he was forerel to surrenter is position toward the end of his life. The most effective work of Pfliger and is pupils is the proof that the essential seat of respiration is not in the blood, ut in the tissues. This was accomplished in his important memoirs on the asometry of the blood $\left(1 \$ 66^{2}\right)$, on the cause of dyspnea, apnea, and the mechnism of respiration $\left(1, s^{3} S^{3}\right)$, on the origin and rationale of the oxidative procss in the animal organism $\left(1872^{4}\right)$, and on the heat production and oxilation f living matter $\left(1878^{5}\right)$. He proved his thesis by showing that frogs, the blool f which had been entirely replaeed by normal salt solution, gave off just as uch carbon rlioxide and took in just as much oxygen as normal control anitals. ${ }^{6}$ He invented new physiologieal instruments, such as the improved ercurial gas-pump (1865), the lung catheter (1872), the aerotonometer $872)$, and the pneumonometer $(1882)$. 359.

1 Pflüger: Untersuchungen über die Physiologie des Elcetrotonus, Berlin,

2 Centralbl. f. d. med. Wissensch., Berl., 1s66, iv, 305-30s.

${ }^{3}$ Arch. f. d. ges. Physiol., Bonn., 1868, i, 61-106.

${ }^{4}$ Ibid., 1872, vi, 43; 190.

5 Ibid., 1878, xviii, 247-380.

${ }^{6}$ Ibid., 1875, x, 251-367. 
Pflügrer was of a combative disposition, fond of arguing for the salie of argument, and actually bedieving that science is advanced by vigorous controversy. This has been held to explain his somewhat unseasonable and ill-advised attacks on the neuron theory and on the work of Emil Fischer. He seems to have led the uneventful life of a man devoted exclusively to scientific rescareh, and it is said that he spent his last dars in bed, correcting the proof-sheets of papers sent to his Archiv.

Latoisier, as we have seen, showed that respiration and combustion are analogous, and that both are essentially an oxidation with water and carbon diexide as by-products (1771-80). Hassenfratz showed that the oxygen of the inspired air, being dissolved in the blood, takes up carbon and hydrogen from the tiswles. The fact of tissue respiration was demonstrated by Gustav Magnus in 1837, who ext racted oxygen and earbon dioxide from both arterial and venous blood by means of a mereurial pump, from which he inferred that these gases are simply dissolved in the blood. Lothar Mleyer, working in Lurlwig's laboratory in 1857 , obtained these results by the more refined method of heating the blood to extract the gases, and arriverl at similar conclusions. Liebig, however, had pointed out, in 1S51, that the hlood gases were probably in loose combination with some unknown substance, and this substance Hoppe-Sevler subsequently obtained in erystalline form as hemoglobin (1862-64). The discovery of Sir George Gabriel Stokes that oxygen ean be removerl from hemoglobin by redueing agents proved that the latter is the agent of combination (1864). The combining agency of the earbon dioxide is still obscure. The extraction of gases from the blood has been further refined by means of the inproved mereurial gas-punps of Ludwig and Setehenoff (1S59), Pflüger (1\$65), Grehant, and Leonard Hill (1895). The other gas of the blood, nitrogen, was shown to be in a state of simple solution by Lothar Meyer (1857), Pflüger (1864-68), and Paul Bert (187S). The spirometer was invented by John Hutchinson of Neweastle-on-Tyne in 1844. ${ }^{1}$ The difficult subject of the metabolism in respiration was investigated by Pettenkofer and Voit (1S63), Zuntz (1880), Atwater and Rosa (1899), and Atwater and Benediet (1905). Angelo Mosso introduced the coneept acapnia (1897) and studied the physiology of apnoea in man (1903), at Monte Rosa (1897) and at his Institute on the Colle d'Olen (1908), he studied the physiology of respiration at altitudes above the snow line. The proof of Paul Bert that high altitude symptoms are due to imperfect oxygenation of the blood $(1878)$ was apparently contravened by Mosso's acapnia theory (defieieney of $\mathrm{CO}_{2}$ in the blood), but was finally reestablisherl by E. Rippstein's experiments in Kronecker's laboratory (1917) and $\mathrm{br}$ subsequent work on oxygen requirements of aviators.

The action of the intercostal muscles in respiration was first investigated by Haller, and, in geometrie manner, by G. E. Hamberger (1748). The lat ter's view was confirmed experimentally by Henry Newell Martin and Edward M. Hartwell at the Johns Hopkins Lniversity (1879). The aetion of the vagus on respiration was first investigated by Isidor Posenthal (1864), who showed that section of both vagi is always followed by deeper, slower breathing, while the amount of air taken in in unit time is the same as before. He held that the vagus entains two sets of fibers-one to contract the diaphragm, the other to relax it. In 1868, Ewald Hering and Breuer showed, by alternate closure of the trachea at the end of inspiration and expiration, that the mechanism of breathing is automatic and self-regulative, the distention and contraction of the lungs being, in themselves, a normal stimulus of the vagi, the effeet which Rosenthal had obtained by stimulation of the rlivided nerve.

${ }^{1}$ Hutchinson: Lancet, Lond., 1844, i, 390; 567. Also, Med.-Chir. Tr., Lond., 1845-6, xxix, 234-238, giving three cuts of the spirometer. 
In $1889,{ }^{1}$ Henry Head, of London, working in Hering's laboratory at Prague, earried these experiments much further by such novel means as freezing the nerve or etherizing it inside a rubber tube, and the sum of his investigations is that the vagus acts like the governor of a steam engine in economizing the energies of respiration, preventing the center in the medulla from wearing itself out. This was shown by section of the vagi, which produced a condition of "spendthrift aetivity" in the respiratory center.

Normally, each inspiration stimulates the fibers which eventually inhibit it, and, at each expiration, the collapse of the lungs stimulates the inspiratory fibers, thus keeping up a steady automatic rate of respiration, which is largely due to the inhibitory fibers in the vagus. Head, the present editor of "Briain," has also done most important work on the cutaneous distribution of pain and tenderness in visceral disease (1893-96:), showing that the segmentation of the cutaneous areas affeeted by the different viseera (Heal's zones) corresponds strikingly with those belonging to the root ganglia of the spinal nerves. With A. W. Campbell, he showed that herpes zoster is a hemorrharie inflammation of the posterior ierve-roots and the homologous ranial ganglia $\left(1900^{3}\right)$. In April, $1903,{ }^{4}$ he submitted to the unique xperiment of division of his own eft radial and external eutaneous zerves, in order to study the loss and restoration of sensation, which ed to a new elassification of the ensory paths.

His subsequent studies (1905$\left.8^{5}\right)$ cover the whole mechanism if sensation from the peripheral terves inward to the brain includ-

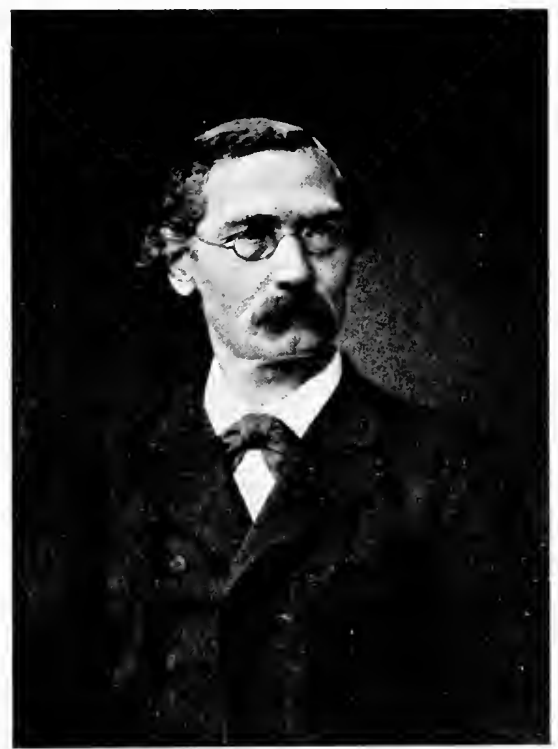

Felix Hoppe-Seyler (1825-95). nig the elassification of peripheral

fferent fibers as to sensation, the grouping of afferent impulses within the ord, the "mass reflex" on eomplete section of the eord, the termination of seendary paths of sensation in the optie thalamus, and the limitations of sensaion when these impulses are redistributerf to the eortex.

The ventilatory functions of the diaphragm have been investigated by tharles F. Hoover (1865- ), of Clevelind, Ohio (1913-17).

Even before Pflüger, respiration of the tissues had been careally investigated by Felix Hoppe-Seyler (1825-95), of Freiburg

${ }^{1}$ Head: J. Physiol., Lond., 1889, x, 1; 279.

${ }^{2}$ Brain: Lond., 1893, xvi, 1: 1894, xvii, 339: 1896, xix, 153.

${ }^{3}$ Ibid., 1900, xxiii, 353-523, 17 pl.

${ }^{4}$ Ibid., 1908, xxxi, 323-450.

${ }^{5}$ H. Head (et al.): Studies in Neurology, London, 1920. 
(Saxony), who is the groatest physiological chemist between Liebig and Emil Fischer. Hoppe-seyler studied under the three Webers, Skoda, and Virchow, was Virchow's assistant in the Pathological Institute at Berlin (1856-64), professor of applied chemistry at 'Tübingen (1S(it-72), and professor of physiological chenistry at Strasshurg (1872-95). He was founder of the Zeitschift fïr physiologische Chemie (1877-95); also the author of a handbook of chemical analysis applied to physiology and pathology (1858), and an epoch-making treat ise on physiological chemistry (1877-81).

In 1854, he male investigations of the physies of pereusion and ansentation, eorrecting eertain errors of skoda, and he also did some important work in inorganic chemistry and mineralogy. He is particularly remembered by his studies on the blood (1757-91), of which he made analyses for over thirty years. He first obtained hemoglobin in crystalline form, deseribed the speetrum of oxybemoglobin (1S62), first ascertained the formulas of hemin, hematin, and hematoporphyrin (186i3), discovered hemochromogen and methemoglobin (1S61), and showed that hemoglobin is loosely combined with oxygen, but cannot be separated from carbon dioxide. He also made studies in netabolism, and construetel an apparatus for measuring gaseous interchanges. He was the first to observe the appearanee of gas in the blood following a sharp and sudden fall of the atmospheric pressure. His investigations of pus and of pathological transurlates led to the discovery of nuclein by his pupil Miescher, and of paranuclein by Lubavin. He first obtained lecithin in the pure state, and introduced the term "protcids." He investigated the chemistry of cartilage, and, in his laboratory, glycosamin was discovered by Ledilerhose (1876) and chitosan by himself. He made important analyses of milk, bile, and urine, investigated the chemical products of fermentation, especially in yeast, and his sturly of chlorophyll was the starting-point of Ehrlich's work on the dymamies of the cell periphery. Personally, he seems to have been an attractive man, of happy, genial disposition.

Of his many pupils, Albrecht Kossel (1853- ) ), of Rostock, professor of physiology at Marburg (1892-1901) and at Heidelberg (1901- ), is to be remembered for his important work on the chemistry of the cell and its meleus (1882-96), on nucleinic acid (1893), on albuminoids (1898), for the discovery of adenin, thymin, thymic acid, histidin, and agmatin, for his elassification of the proteids, his studies of the fundamental units (Bausteine), of the protein moleeule, and of the substitution products of albuminoids. He made important investigations in the chemistry of metabolism, and received the Nobel prize for medicine in 1910.

Ernst Salkowski (1844- ) , of Königsberg, professor of medical chemistry at Berlin (1874), author of a treatise on the urine (with W. Leube) and a laboratory manual of physiological and pathological chemistry (1893), made the important discoveries of pathological excretion of phenol (1876), pentosuria (1892-5), peptonuria (1897), a quantitative test for oxaluria (1899), employed the antiseptic properties of chloroform in studying fermentation (1888), used his discovery of phytosterin in vegetable fat in detecting adulteration of animal fat, and made memorable investigations 
in digestion, the oxidizing power of the blood, putrefaction, and urinary chemistry.

The physiological chemistry of the nineteenth century was rich in the discovery of new compounds, notably in the analysis and formulation of the decomposition products of proteids at the hands of Paul Sehützcuborger and others. After Kirehboff had effected the hydrolysis of stareh by diastase in 1815 , Braconnot, in 1820 , first hydrolyzed proteins by acids and diseovered glycin, the simplest form of proteid.

Of the amino-aeid constituents of proteins (Kossel's Bausteine), eystin was found in calculi by Wollaston (1810), and shown to be a deeomposition product of protein by K. A. H. Mörner (1899), tyrosin was diseovered by liebig (1S46), glycocoll (1848) and alanin (1S49) by Strecker, serin by Cramer (1865), phenylalanin by sehulze (1879), histidin by Kossel (1896), while tryptophau was named as a hypothetieal product by Neumeister (1890), and isolated by Gowland Hopkins (1902). Leuein was diseovered in putrefying ehense hy Proust (181S), and named by Braconnot $(1820)$. Both leuein and tyrosin were found in the pancreas after death by Virchow (1853), and in the living body by the elinician Frerichs (1855). Glutamie acid was obtained by Rithausen (1866) and Krentzer (1871), aspartic acid by Radziejewski and Salkowski (1873), ornithin by Jaffé (1877), arginin by Schulze and Steiger (1886), lysin by Drechsel (1859), prolin by Willstätter $(1900)$ and Emil Fischer (1901), diaminobut yric acid (1901), oxyprolin (1902), serin (1902) and valin (1906), by Emil Fiseber (1901-102), isoleuein by $\mathrm{F}$. Ehrlich (1903), norleucine by Abderhalden and Weil (1913).

The effect of animal enzymes on proteirls was sturlied by Willy Küuhne, Kossel, Drechsel, and others, and Schulze studied the effeet of vegetable enzymes. Drechsel diseovered that the protein molecule eontains di- as well as mono-amino aeids, and these were investigaterl by Kossel, Kutscher, and Emil Fischer. In 1881,

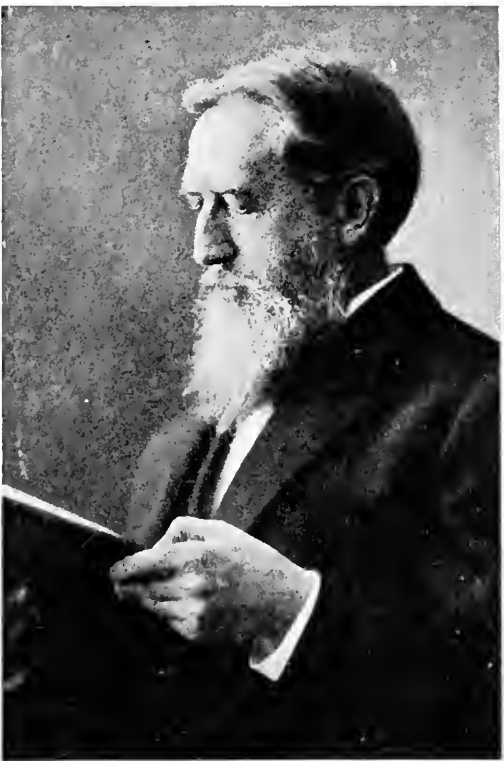

Ernst Salkowski (1844- ). Schmiedeberg extracted histozyne, at

ferment which will disintegrate or synthetize hippuric acid. The nueleins were investigated by Worm Müller (1873) and Miescher (1874); the nucle if acids by Kossel (1893), Altmann (1889), Abderhalden, and Sehittenhelm (1906); the albuminoids by Kiossel (1898), Drechsel (1891), and Abderhalden (1905). 3-oxybutyrie aeid was isolated by Eduard Küulz (1884-87), and investigalerd in relation to diabetes by Ernst Stadelmann (1883) and Adolf Magnu-Levy (18:191909). Acetone was disecovered in diabetic urine by Wilhelm Petters (1857), atud nvestigated by Carl Gerhardt (1865), Rudolf von Jaksch (1885), and, in the blood, hy Adolf Kussmaul (1874). Nax Jaffé (1841-1911) diseovered urobilin n the intestinal eontents (1871) and indiean in the urine (1877). Lhrlich ntroduced his diazo-reaction in 1852 , and cryoseopy of the urine was int roduesd y Sandor Koránvi in 1894. Myclopathie albumosuria (proteinuria) was lescribed by Ilenry Benee. Jones in 1848; aeetonuria and diaceturia by von aksch (1885), and pentosuria by Ernst Salkowski (1895). The tests of Johann Kjeldahl for estimation of nitrogen in organic matter (1883), of Otto Folin for 
rstimating urea and urie acid, of (iowland IJopkins for urea, of liranz. Soxhlet fer fats in milk, hatro all proved of grout practical value. 'The ptomains wore

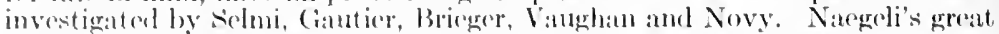
nemoir on the starehes (15.1), chassifying some 200, was followed by the re-

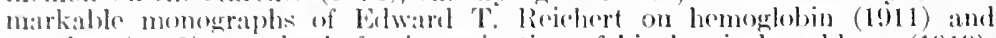
starches (1915) at a basis for investigation of biochemical problens (19)19). The theory of the apen earbon chain and the elosed benzene ring was stated

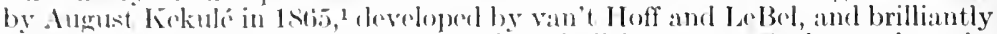
applied to the structural theory of chlorophyll hy Hoppe-seyler, and to the "side-chain" theor"y of immunity by Paul Ehrlich.

Physical chemistry was male available for physiology through the labors of suli Carnot (1824), Robert Mayer (1S42), Lord Kolvin (15.5-52), Helmholtz (1st7), Clatsius (1Sist), Ilillarel (iibbs (1872-78), van't IIoff (1857), Arrlonins (1ss7). Ostwald, anel the ehemists of the Duteb sehool. Its laws were applied to the physiology of muscles by Julius Bernstein (1902-08), to the (pucstion of surface tension by Isidor Traube (1910-11) and Macallum (1910-11), and to various biological problems by Jacques Loeb. 'The theory of osmosis and of semi-permeable membranes was investigated by Dut rochet $(1827-35)$. Graham (1854-61), Moritz Traube (1867), Willard (iibbs (1576), van't Hoff and Arrhenius (1si7), anel II. J. Hamburger (1902-04), and eolloids were studied by Graham, siedentopf, and /sigmondy.

Anost every great teacher of the subject has written a treatise on physiologr. To the early periol belong those of Mtagendie (1816-17), H. Mayo (1527), Joh. Miiller (1S34-10), Rudolf Wagner (1S38-12), W. 13. Cirpenter (1S42), G. Valent in $(1814,184(i)$, the many editions of Senbouse Kirkes' IIandbook (1S48), F. C. Domlers (1550), F. A. Longet (1850), and Wagner's IIandwörtrbuch (1S12-53). In the second balf of the century, we have those of Card Ludwie (15i)2-56), J. C. Dalton (1859), W. Wundt (1865), T. H. Iuxley (1S6(j), Anstin Flint, J'. (1s66-7t), Sir Michael Foster (1877), L. Landois (1879-80), W. Stirling (1885), A. D. Waller (1891), E. If. Starling (1892), Max Verworn (149,j), G. N. Stewart (1896), Robert Tigerstedt (1S98), L. Luciani (1895-1903), W. H. Howell (1905), M. Duval and E. Gley (1906), H. Zwaardemaker (1910), M. von Frey (1911), and Russell Burton-Opitz (1920). Foster's book is a masterpiece. The "Textbook" edited by sir Erwarl 1 . Sehäfer on the cooperative plan (London, 1898), is remarkable for its wonderful assemblage of historieal data, in respeet of which it has been likened to llaller's great "Elementa" of 1757-66. The treatise of the late Luigi Luciani (18401919). Englished in 1911-17, is also valuable for its historical quality. Of American treatises, that of William H. Howell (1905) is incomparably the best, on aecount of its elean-eut, heid presentation of what is known. The recent treatise of 11 . M. Bayliss (1916) is eoncejvel from the viewpoint of physical elemistry.

The rise of modern medicine is inseparably connected with the name of Rudolf Virchow (1821-1902), the founder of cellular pathology. A native of schievelbein in Pomerania, Virchow graduated at Berlin in 1843, became Froriep's prosector at the Charité in 1845, full prosector in 1846, and, in 1817, founded the Archiv für pathologische Anatomie, known everywhere as Virchow's Archiv. His first paper in this periodical artvanced the idea that an unproved hypothesis of any kind is a very leaky bot tom for practical medicine to sail or trade upon, and scouted the notion that any one man is infallible in respect of judgment or knowledge. It is one of the strongest manifestos of the modern spirit in recent medicine. In

${ }^{1}$ For the history of benzol, see A. F. Hollemann: Janus, Amst., 1915, xx, $459-188$. 
1848, Virehow was sent by the Prussian government to investigate the epidemic of typhus or "famine" fever then maing_among the weavers of Upper Silesia. His exhaustive account of what he saw reminds us of the piling up of horrors in Cerhart Hauptmann's social drama of "Die Weber," and his recommendations included not only hygienic measures and a large charity for these unfortunates, but filed an actual brief for democracy and freedom ("rolle und unumschränkte Demokratie . . . Bildung mit ihren Töchtern, Freiheit und Wohlstand"). This bold pronouncement, along with the tendencies of his semipolitical periodieal, Die medizinische Reform (1848-9), soon got Virchow into trouble with the governmental authorities, and, in 1849 , he was deprived of his prosectorship, obtaining, at the same time, through the offices of the obstetrician Scanzoni, the chair of pathologic anatomy at Würzburg. Seven years later, after making a brilliant record as lecturer and teacher, he was asked to come back to Berlin upon honorable terms, and, in 1856, was duly installed as professor of pathology at that University, at the same time assuming the directorship of the Pathologieal Institute, which had been erected for him. Here he entered upon at career of almost unparalleled activity in many directions. Ho was a man of wide rulture and deepest hmman interests, and

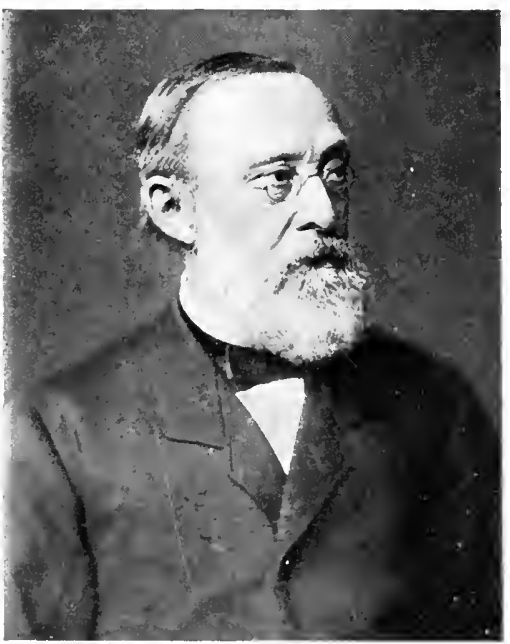

Rudolf Virchow (1\$21-1902). (Courtesy of Dr. (irorge N. Kober.) he soon became known every-

where as anatomist and pathologist, epidemiologist and sanitarian, anthropologist and archeologist, editor and teacher, social reformer and "old parliamentary hand." He joined the Prussian Lower House in 1862, and from 1880 until 1893 he served in the Reichstag as a faithful and reliable representative of the rights of the people. During the Franco-Prussian War, he organized the Prussian Ambulance Corps and superintended the ereetion of the army hospital on the Tempelhof. He hat much to do with securing a good sewage system for Berlin, and, as president of many different, societies, he became easily the most influential medical personality in the Prussian capital. As he grew older, honors eame to him from all quarters, and, in 1899, he dedicated the Pathological 
Mluseum, to which he gave his private collection of 23,066 preparations, each of which had been prepared, labeled, and placed upon the shelves by his own hand. On his eightieth birthday he recoived a purse of 50,000 marks from his Cierman colleagues, in aid of the Virchow Institute, with a unique gold medal from the Emperor, and shortly bofore his death he saw the completion of the splendid municipal hospital in Berlin (January 15, 1902) which is now called hy his name.

Virchow derived the inspiration for his life-work from Johannes Miiller, and what he aceomplished was in every way worthy of his great teacher. In pathology, he had only Morgagni as a possible competitor hefore him and no one after him. His CellularPathologie (1858) set in motion a new way of looking at the body as "a cell-state in which every cell is a citizen," (lisease being "merely a conflict of citizens in this state, brought about by the action of externat forces." Virchow's aphorism, "Omnis cellula e cellula," means that cell development is not discontinuous (as Schleiden and Schwann had supposed), and that there are no speeifie cells in disease, but only modifications of physiologic types. In other words, "A new growth of cells presupposes already existing cells." This morphologie view is the basis of his work on tumors (1863-67'), which treats of these formations as physiologieally independent new-growths of either histioid or cellular structure. The two most prominent errors in the cellular pathology were the theories that the cell-contents are the controlling feature of the whole organism, and that there can be no diapedesis of blood-cells, which was afterward disproved by Cohnheim.

Virchow was the first to observe and define leukocytosis, and in 1845 , simultaneously with the clinical record of John Hughes Bennett, he deseribed leukemia as "white blood." " In 1846, he separated pyemia from septicemia, and between the years 1846 and 1856 created the doctrine of embolism, ${ }^{3}$ his greatest single achievement in pathology, and one which is, in every sense, his very own. Before Virchow, as we have seen, both John Hunter and Cruveillier saw thrombosis as a sequel of phlebitis, with the latter as the prime factor in pyemia also. Virchow revolutionized existing knowledge by showing that a thrombus is the primary essential condition in phlebitis. His studies of embolism were based upon experiment, and he was the first to recognize the cerebral and pulmonary varieties. In 1856 , he demonstrated the embolic nature of the arterial plugs in malignant endocarditis, and attributed the condition to parasites. As a parasitologist, he also did good work on trichinosis (1859-70), and discovered the sarcinic and aspergillic forms of mycosis in the lungs and bronchial tubes. He also pointed out the true relationship between lupus and tuberculosis, introduced new pathological concepts like agenesia, heteropopia, ochronosis, and first described leontiasis ossea, hematoma of the dura mater,

1 Virchow: Die krankhaften Geschwülste, Berlin, 1863-67.

${ }^{2}$ Froriep's Neue Notizen a. d. Geb. d. Nat. u. Heilk., Weimar, 1845, xxxvi, $151-155$.

${ }^{3}$ Beitr. z. exper. Path. (Traube), Berl., 1846, ii, 227-380, and Virchow: Ges. Abhandl., Frankf. a. M., 1856, 219-732. 
the aortic hypoplasia with eontraetod heart in chlorotic maidens (1872) and spina bifida occulta (1875). In 1861, he gave the name "arthrit is cleformans". to rheumatic gout. In listology, he made two important discoveries-the neuroglia $\left(1 S+6^{1}\right)$ and the special lymphatie sheaths of the colebral arteries (1851). He made hundreds of eontributions to anthropology (his special hobby), from the great atlas of "Crania Ethnica Americana," prepared "in memory of Columbus and the Diseovery of America" (1892), to well-known papers upon racial characters and abnormities, anthropometry, physical anthropology of the Germans, prehistorie finds, prehistorie syphilis, tattooing, and relies of the Trojan War. To medieal history he contributed valuable monographs on the leprosoria and other hospitals in the Midllle Ages, biographical studies of Morgagni, Johannes Müller, and Schönlein, and he was the first to write upon medicine in relation to the fine arts $\left(1861^{2}\right)$, but his tiny contribution was far surpassed in the same year by the exluaustive monograph of K. F. H. Marx, in which nearly all the important pietures relating to medicine are already elassified and listed. ${ }^{3}$

Personally, Virchow was a small, elastie, professorial figure, with snappy, black eyes, quick in mind and body, with a touch of the Slav, something of a martinet in the morgue or leeture-room, often transfixing inattention or ineompetence with a flash of sarcasm. Yet he was generous, whole-souled, and broad-minded withal, and none who "made good" were ever lost from sight or memory. In extreme old age, Virchow, always "liberal in polities," beeame "reactionary in science"; but love of truth, generosity in word and deed, were the essence of his youth and mature manhood. All his life he had been keen and ardent in controversy. He began his eareer by giving Rokitansky's theory of "crases" a wholesale slashing, with the result that the Viennese pathologist withdrew all reference to the matter from the second edition of his book and never afterward referred to it again. Yet there is no finer tribute in literature to the best features of Rokitansky's work than Virchow's. Then eame his disputes with Hughes Bennett about leukemia, and his destruction of the Cruveilhier dogma that phlebitis is the whole of pathology. At the same time, he was cheerfully encouraging Cohnheim to combat the Virchow hypothesis of the non-migration of blood-cells. Believing that the nervous system is not the eenter of life and does not control the nutrition of peripheral parts, Virehow deelined to see anything in Chareot's ataxic joint symptoms but a simple local lesion. He believed in the duality of tubereulosis. He opposed the Darwinian theory; and the new views of Koch and Behring about toxins and antitoxins were hardly aceeptable to one who had obliterated the humoral pathology. The peculiarities of the Neanderthal skull were wrongly attributed by Virchow to the effects

${ }^{1}$ Arch. f. path. Anat., Berl., 1854, vi, 135-138.

${ }^{2}$ Virchow's Areh., Berl., 1861, xxii, 190-192.

${ }^{3}$ Marx: Ueber die Beziehungen der darstellenden Kunst zur Heilkunst. Abhandl. d. k. Gesellsch. d. Wissensch. zu Göttingen, 1861-2, x, 3-74. 
of disease. An accidental shelling of the Muséum d'histoire naturelle in Paris, during the war of $1870-71$, led Quatrefages to write an indignant panphlet stating that the Prussians were not a Germanic, but a barbaric, destructive Mongol race. This stirred Virchow's patriotism to the extent of instigating a colossal public census of the color of the hair and eyes in $6,000,000$ German schoolchildren, the solemn ofticial character of which frightened some of the children out of their wits. The sight of a copy of Grimmelshausen's "Simplicissimus" is said to have cansed him the same indignation that Wordsworth experienced when he saw the first line of Keats's "Ode to a Grecian Uru." These vagaries may be

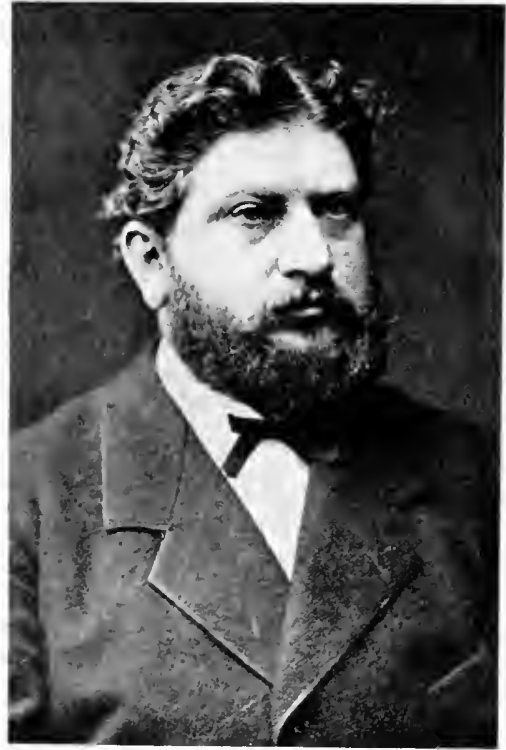

Julius Cohnheim (1839-84). (Collection of A. C. Klebs.) set of by the generosity of his touching defense of Pasteur, his discriminating tribute to the American Army Medical Department, or the laurel-wreaths of praise which he has laid upon the tombs of so many of his predecessors and contemporaries. Above all, he was, in respect of civic courage, an ideal modern man. He did not believe in a characterless, stockjobbing bourgeoisie, but warmly espoused the cause of those who labor for the common good of all. His lifelong championship of the rights of inclustrial humanity, valiantly upheld in the very stronghold of the Prussian military government, hows the kind of fiber he was made of.

Of Virchow's pupils; the most eminent was Julius Cohnheim (1839-84), of Demmin, Pomerania, who, after serving as a Prussian army surgeon in the Austrian War (1864-65), became an assistant in the Pathological Institute, and was subsequently professor of pathologr at Kiel (1868-72), Breslay (1872-78), and Leipzig (1878-84). Under Willy Kühne, Cohnheim made an important investigation on the sugar-forming ferments $\left(1863^{1}\right)$, but his inaugural dissertation on the inflammation of serous membranes (1861) marks his bent as a pioneer in experimental histology and pathology.

${ }^{1}$ Arch. f. path. Anat. (etc.), Berl., 1S63, xxvii, 241-253. 
He introduced the method of freezing fresh preparations in microseopical work, investigated the nerve-endings in muscle by means of silver salts (1863-65), discovered the mosaic ficlds in cross-sections of muscle which bratr his name (1865), and first used gold salts, with brilliant results, in his studlies of the sensory nerve-endings in the cornea (1S67). His monographs on inflammation and suppuration $(1567-731)$ revolutionized pathology, showing, in direet opposition to the teaching of Virchow, that the essential feature of inflammation is the passage of white blood-cells through the walls of the capillaries, and that pus and pus-cells are formed in this way from the blood. Diapedesis had already been described by Addison (Goulstonian lectures, 1849), but Cohnheim's experiments traced the direct migration of the stained leukoeytes to a center of inflammation in the cornea. Valuabe papers on venous stasis (1S67) and on the relation of the terminal arteries to embolic processes (1872) followed.

The summit of Cohnhein's experimental achievement was his successful inoculation of tuberculosis in the anterior chamber of the eye of the rablit $\left(1877^{2}\right)$, which Weigert wittily described as a demonstration "in oculo ad oculos." Two years before, Robert Koch had demonstrated his cultures of anthrax bacillus, and Cohnheim made the prophetic statement that Koch woukd surpass all others in this field. The last years of Cohnheim's life were clouded by severe complications of gout, an old enemy, and his brilliant career was cut short at the early age of forty-five. He is described

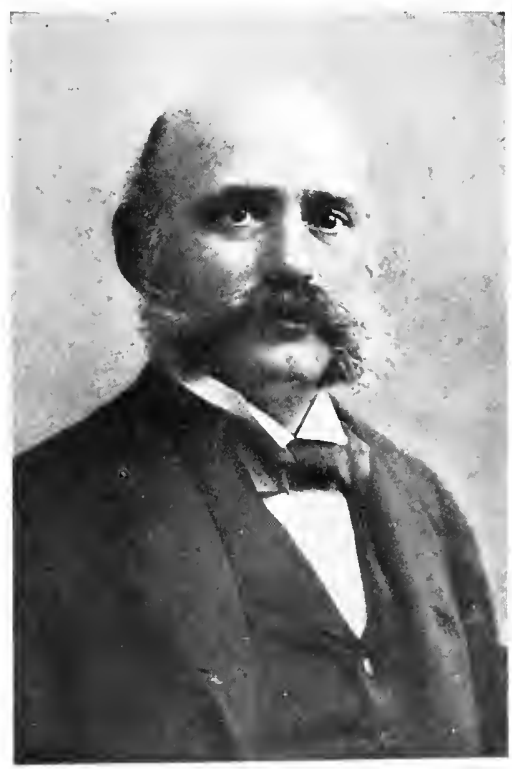

Carl Weigert (184,-1904). as a man of robust, cheerful, energetic disposition, swift and sure of speech, with great powers of wit and sareasm. Among his pupils were Heidenhain, Litten, Lichtheim, Welch, Ehrlich, Neisser, and Weigert at Breslau, and, at Leipzig, Roy and Councilman.

Carl Weigert (1845-1904), of Münsterber'g, Silesia, is memorable for his investigations of the pathological anatony of smatlpox $\left(1874-75^{3}\right)$, and Bright's disease $\left(1879^{4}\right)$, and by the fact that

1 Neue Untersuchungen über die Entziindung, Berlin, 1873.

2 Die Tuberkulose vom Standpunkt der Infectionslehre, Leipzig, 1580.

${ }^{3}$ Weigert: Anatomische Beiträge zur Lehre von den Pocken, Breslau, $1874-75$.

${ }^{4}$ Samml. klin. Vorträge, Loipz., 1879, Nos. 162, 163 (Innere Med., No. $55,1411-1460)$. 
he was the first to stain bacteria (187 1'), in which he later hat great success with anilin colors $\left(1855^{2}\right)$. He introduced many improvements in the differential staining of the nervous system, notably with acid fuchsin (1852). He also made investigations of the neuroglia (IS90-95), and of coagulation-necrosis (1880), described tuberculosis of the voins (1882), and stated the well-known quantitative "law" that the amount of repair in an injured tissue is always in excess of what is needed.

Among the special pathologieal sturlies of the period were those of Ludwig Traube (1855), 1lermann Senator (1873), Carl ven Liebermeister (1875), and Ernst von Leyden (1870-79) on the pathology of fever, Peter Lutwig P'anum (1520)-85) on the experimental pathology of embolism (1863-(i)1), Thomas Bevill Peaceck on malformations of the human heart (1S66), Carl Thiersch on phosphoric neerosis of bones (1867). Wilhelm Waldeyer on the development of caneer $(1867-72), F, D$. von Recklinghatusen on adenomyoma and neurofibroma (1S52), Paul Cirawitz on the origin of renal tumors from suprarenal tissues (1854), Julius Wolff on the law of transformation in bones (1892), Paul Ehrlich and Adolf Lazarus on anemia (1898). Among Americans, William Pepper (1813-9S), deseribed the changes in the bone-marrow in pernicious anemi: (1875), William Henry Welch (1850- ) investigated acute edema of the lungs (1877) and embolism and thrombosis (1899), Reginald Heber Fitz (1843-1913), gave conelusive demonstrations of the pathology of perforating infl:mmation of the vermiform appendix (1886), hemorrhagic panereatitis with fat necrosis (1859), and deseribed intrapleural lipoma of the mediastinum; Francis Delafield ( -1915), of New York, author of a handbook of pathology (1572), Studies in Pathological Anatomy (1878-91), and (with T. Mitchell Prudden) of a text-book of pathology (1855), which passed through ten editions, made special studies of the pathological histology of nephritis and pneumonia; Martin H. Fischer (1879- ), of Cincinnati, has matle experiment:l studies of edema (1910) and nephritis (1912). The studies of Ehrlich, Peyton Rous, W. S. Lazarus Barlow, Maud Slye, E. E. Tyzzer, and others on cancer are of great interest.

Following the eighteenth-century works of Astruc (1743), Gaub (1758), Morgagni (1761), Matthew Baillie (1791), and Kurt Sprengel (1795-97), pathology was the subject of special treatises by Carl Friedrich Burdach (1808), J. W. H. Conradi (1811), A.-F. Chomel (1817), E. D. A. Bartels (1819), J. C. C. F. M. Lobstein (1829-33), Herbert Mayo (1836), and Thomas Hodgkin (1836-40). The first exhaustive treatise on pathology in English was that of Samuel David Gross (Boston, 1839), which was followed by the treatises of Rokitankky (1S42-46), Jacob Henle (1846-51), Alfred Stillé (1848), Salvatore De Renzi (1856), Virchow (1858), Samuel Wilks (1859), P. Uhle and E. Wagner (1862), Eduard Rindfleiseh (1867-69), Victor Cornil and L. Ranvier (1869-76), T. H. Green (1871), F. V. Birch-Hirschfeld (1S76), Cohnheim (187780), Ernst Ziegler (1881), Sinus Woodhead (1883), Henri Hallopeau (1884), Francis Delafield and T. Mitchell Prudden (1885), Edwin Klebs (1887), D. J. Hamilton (1889-94), V. V. Podwyssotsky (1891-94), Anton Weichselbaum (1592), Otto Bollinger (1S96-97), Alfred Stengel (189S), Harvey R. Gaylord and Ludwig Aschoff (1901), Ludwig Hektoen and David Riesman (1901-02), Guido Banti (1905-07), and John George Adami (1908-12). Noteworthy atlases of pathological illustration are those of Johann Friedrich Meckel (181726), Jean Cruveilhier (1829-42), Alexander Auvert (1856), F. A. Thierfelder (1872-81), The Sydenham Society (1877-1906), Alfred Kast and Theodor Rumpel (1892-97), and Paul Grawitz (1893). Important works on experi-

${ }^{1}$ Centralbl, f. d. med. Wissensch., Berl., 1S71, ix, 609-611.

${ }^{2}$ Jahresb. d. schles. Gesellsch. f, vaterl. Cultur, 1875, Bresl., 1s76, liii, 229. 
mental pathology are those of Ludwig Traube (1871-78), Claude Bernard (1872), Salomon Stricker (1877), Vietor Pasehutin (1855), and P'aul Ehrlich (1909); and the monographs of August Hirseh (1860-64), Andrew Dafidson (1892), and Frank G. Clemow (1903) on geographieal pathology, John William Ballantyne on fetal pathology (1902-4), F. B. Matlory and J. H. Wright on pathological technic (1897) deserve mention.

The founders of bacteriology were Louis Pasteur and Robert Koch, the former being also the pioneer of the modern theory of preventive inoculation against disease, while to the latter we owe the development of the correct theory of specific infectious diseases.

Before the time of Pasteur, Leeuwenhoek had seen protozoa (1675) and bacteria (1687) under the miscroscope. Agostino Bassi (1773-1856) showed that silkworm disease is due to the presence of mieroörganisms (1836), John Goodsir deseribed sareina in the stomach (1812), Casimir Davaine the mieroöorganisms of anthrax (1865), and Ferdinand Cohn the morphological and botanieal characters of bacteria (1870). Before the time of Koch, Kircher (1658), Pleneiz (1762), and Henle (1840) had announced the theory of a contagium animatum, Hermann Klencke had shown that tubereulosis may be transmitted by cow's milk (1846), Jean-Antoine Villemin (1827-92) had demonstrated that the tubercular virus is speeifie and inoculable, in a series of masterly experiments (1868) which were confirmed by the further investigations of Edwin Klebs (1873), L.-A. Thaon and J.-J. Grancher (1873), and Julius Cohnheim (1880).

\section{Louis Pasteur (1822-95)} was born at Dôle (Jura), where

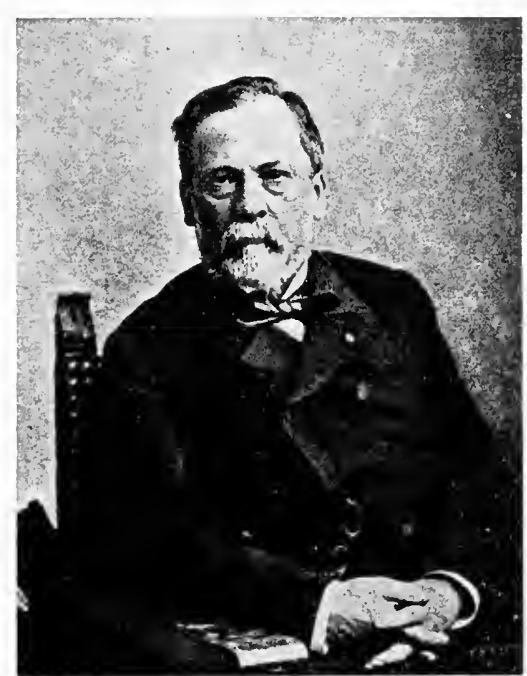

Louis Pasteur (1822-9.5). his father, one of Napoleon's old soldiers, was a local tanner. As a youth, Pasteur was remarkably good at portrait sketching, but was otherwise only a aarmless, enthusiastic fisherman. Awakening to the call of duty, 1e went to study at Besançon, where he aequired his interest in hemistry, and graduated at the Ecole normale at Paris in 1847. Ifter this he was successively professor of physics at the Lyceum it Dijon (1848), professor of chemistry (1852-54) at the University if Strassburg, dean and professor of chemistry in the Faculty of iciences at Lille (1854-57), director of scientific studies at the icole normale at Paris (1857-63), professor of geology and chemitry at the Ecole des beaux-arts (1863-67), professor of chemistry $t$ the Sorbonne (1867-89), and director of the Institut Pasteur 
(18s9-95). As set forth in the inscriptions on the arches over his tomb, Pastem is memorable for his work on molecular dyssymmetry (1S4S), feruentation (1857), spontaneous generation (1862), diseases of wine (1863), discases of silkworms (1865), microörganisms in heer (1S71), vimlent diseases (anthrax, chicken cholera) (1875), and preventive vaceinations (1880), particularly of hydrophobia (1SS5).

The first of these, his chassie investigations of the conversion of dextrotartarie acid into the inaretive forms (racemic and mesotartarie acids), and his discovery of the splitting up of racemic acid into right-and left-handed tartaric acid by means of optieally active substances, gained him the Rumford medal of the lioval society (155i), and undeubtedly led to the work of vin't Hoff and la Bel on stereochemistry or chemistry in space. They also led Pasteur to the study of ferments and mieroörganisms through his initial expriment of indueing fermentation in racemic acid by means of albumen, (ansing the destruction of the dextro-rotatory product by fermentative nueroorgunisms. From this he proceeded to those studies of beer yeasts and lactic-acid fermentation which resulted in the discovery of lactic-acid baeteria, and confuted the errors which I iebig and even 1 lelmholtz had made in regard to the significanee of fermentation. He next discovered the anaerobic character of the bacteria of butyrie fermentation, introducing the concepts of ä̈robism and anaërobism. A eomparion of flasks of yeast in nutrient media, one of which had been sterilizerl, demonstrated the rôle of mieroörganisms in changing atmospherie oxygen into earbon dioxide (1861). His dispute with louchet about spontaneous generation was obseured by the fact that Pouchet's hay infusion was more diffienlt to sterilize than the yeast infusion employed by Pasteur, but the latter prevailed in his contention, ${ }^{1}$ winning a prize and nembership in the Acarlemy of Seienees. About this time, he discovered that the pellicle so necessary to the formation of vinegar from wine consists of minute, rod-like mieroörganisms (Mycoderma aceti). The investigation of aeetie fermentation ${ }^{2}$ confuted Liebig's meehanieal theory of the latter process, and led l'asteur to study the eauses detrimental to the three great industries of his country, those of wine, silk, and wool. In 1867 , the wine industry of France was worth $500,000,000$ franes to the nation, and this gain was due to Pasteur's diseovery that the aging of wine by mieroörganisms can be prevented by partial heat sterilization (Pasteurization) at a temperature of $55^{\circ}$ to $60^{\circ} \mathrm{C}$. without an alteration of the taste or bouquet of the vintage (1863-65). This process is now applied to all perishable foods, and is of inestimable importance in the nutrition of infants. In 1849, the silkworm industry of France began to be crippled by the disease pébrine. By 1S61, the annual revenue from this source had sunk from $130,000,000$ to $8,000,000$ francs, and enormous sums were spent in importing healthy silkworm eggs from Spain, Italy, and Japan. The mulberry plantations in the Cevennes were abandoned, and the state was petitioned, in 1865 , to remedy the evil. In a little house near Alais Pasteur and his assistants worked for five years on an apparently insoluble problem, and even after he had discovered the cause and prevention of pébrine there came his burst of despair: "Il y a deux maladies!" The second disease. flacherie, was conquered in time, ${ }^{3}$ but at a terrible cost, the death of one of his daughters and the worry incident to harsh eritieism of his failures bringing on a severe attack of paralysis. Even his pleasure in such tokens of recognition as a degree of M.D. from Bonn, a prize from the Austrian government, membership in the Royal Society, and a nomination as senator, was spoiled by the outbreak of the Franco-Prussian War. He returned the Bonn diploma and

${ }^{1}$ Compt. rend. Acad. d. se., Paris, 1860, 1, 303; 849; li, 348; 675: 1864, Iviii, 21: 1S65, lxi, 1091.

${ }^{2}$ Etudes sur le vin, Paris, 1866.

3 Etudes sur les maladies des vers a soie, Paris, 1870. 
took up the study of the spoiling of beer by microörganisms, anain showing the artvantages of Pasteurization. ${ }^{1}$ About this time, his definition of a formont as "a living form which originates from a germ," was contested in a prosthumous essay of Claude Bernard's, ${ }^{2}$ but, in 1874 , Lister had sent him thr colebrated letter acknowledging the value of his work in relation to antiseptic surgery. Thus Pasteur was gradually transformed from a chmist to a molical man, particularly in his mode of attacking the problem of infectious diseases. In his studies on anthrax he was preceded by Davaine, who discovered the bacillus and showed that the virulence of the disease was in proportion to the number of bacteria present (1550-65); by Klebs, who indieated that anthrax virus is non-filterable, since the filtrate will not produce the licease (1S71), and by Koch, who first cultivated pure cultures of anthrax bacilli, described their full life-history and their relation to the disease (1877). Pasteur confirmed Koch's results, and disposed of the controversial question of a separate virus by carrying the bacilli through a hundred generations and producing anthrax from the term of the series. ${ }^{3}$ At the same time, he discovered, with Joubert and Chamberland, the bacillus of malignant edema (vibrion septique), the first find of an anaërobic microörganism of a pathogenic character; and he showed the relation of animal heat to bacterial virulence. As he cared nothing for the morphological aspects of bacteriology, it is sometimes forgotten that he' discovered the Staphylococcus pyogenes in boils as "microbe en amas de grains," and the Streptococcus pyogenes in puerperal septicemia as "mierobe en chapelet de grains" (1S7S-94). His discovery of preventive inoculation wats flue to the accidental fact that virulent cultures of chicken cholera virus, during a vacation from the laboratory, became sterile or inactive, and, when injected, were found to act as preventive vaceines against a subsequent injection of a virulent character. The attenuated virus could be carried through several generations and still maintain its immunizing property. In 1S\$1, he succeeled in producing a vaccine against anthrax, injection of which lowered the mortality-rate to 1 per rent. in sheep and to 0.34 per cent. in horned cattis. Experiments with the viruses of anthrax, chicken cholera, and swine measles (nomget des pores) brought out the princiole that the pathogenic properties of a virus can be attenuated or heightened by sucessive passiges through the bodies of appropriate animals, and led to one of the most luminous thoughts in the history of seience-that the origin or extinction of infectious discase in the past (svphilis, for instance) may be simply due to the strengthening or weakening of its virus by external conditions, or in some such way as the above. This principle was apjlicel with success against anthrax at the sheep-folds near Chartres, and in preventive vaccinations against hydrophobia, the eulture-medium being the spinal marrow of the infected animal. Pasteur's first patient was Joseph Mrister, an Alsatian boy, bitten all over by a rabid dog, who was treated with snecess in July, 188.5. Shortly afterward, the Pasteur Institute was opened, and special institutes for hydrophobia inoculations were foumderl all over the world. If(re Pasteur labored almost to the end of his life, with such brilliant pupils as Metchnikoff, Roux, Yersin, Calmette, Chantemesse, Chambirlaus, and Pottevin. With Ch. Chamberland, he devisod the coldorated filter whieh is called after him, while Emile Roux did ppoch-making weirk on the diphtheria antitoxin, Metchnikotf on phagocytosis and the lacticacid bacillus. Alexalure Yersin on the plague bacillus, Albert Calmette on preventive inoculations against snake-bites.

Pasteur's last years were crowded with honors from all parts of the world, and, after his death, an appropriate mausoleum for his

1 Études sur la bière, Paris, 1876.

2 Bernard: Rev. scient, Paris, 1879, xv, 49-56.

${ }^{3}$ Compt. rend. Acad. d. sc., Paris, 1880, xci, 86; 455; 697; 18s1, xeii, 209.

${ }^{4}$ Ibid., 1880, xe, 1033-1044.

${ }^{5}$ Compt … L tearl. d. sc., Par., 1885, ci, 765: 1856, cii, 459; \$3.5; riii, 
remains, copied from the tomb of Galla Placidia at Ravenna, was built in the Pasteur Institute by his family. Deeply religions, intensely serious, endowed with a mind the quality of which Roux has compared to the action of a blow-pipe flame, Pasteur was a sensitif, who suffered unduly, in his ife, from the capt ious cavillings of lesser men. His return of the diploma from the genial Rhineland University of Bomn ean be excused only by his child-like, highstrung devotion to his native land. Literary snobbery has descanted sufliciently upon his "peasant origin," but the man himself was a gentleman of the type deseribed by Wordsworth and Cardinal Newman, one who never infliets wanton or needless pain upon others. His sympathy with the sufferings of dumb animals was of a kind which, said Roux, might have seemed comic had it

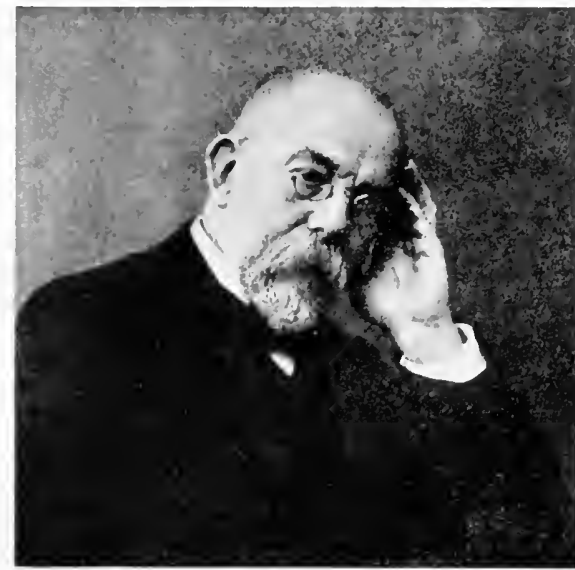

Robert Koch (1843-1910). (Courtesy of Captain Henry J. Nichols, U.S. Army.) not been touching. We have the testimony of his pupils as to his power of establishing an immediate sympathetic relation between himself and any one sincerely interested in his work, and his sympathies extended, cirele-wise, as in Fmerson's parable, from the intimate group of his family and pupils, to embrace the people (even the animals) of his native land and the entire human race. ${ }^{1}$ His humanity was of that rare and noble kind which, in Fmerson's words, "approves itself no mortal, but a native of the deeps of absolute and inextinguishable being."

Robert Koch (1843-1910), of Klausthal, Hannover, was educated in the gymnasium of his native town, and took his medical degree at Göttingen (1866), where he was profoundly influenced by the teachings of Jacob Henle, whose theory of contagion (1840) may have started Koch upon his life-work in seience. After serving in the Franco-Prussian War, he became district physician (Kreisphysicus) at Wollstein, where he varied the monotony of long journeyings over rough country roads by private microscopic

1 The writer once had the privilege of hearing an account of Pasteur in which these quilities were very strikingly set forth by one of his pupils. 
studies. He began with anthrax, and, in April, 1876, wrote to the eminent botanist Ferdinand Cohn at Breslau to the effect that he had worked out the complete life-history and sporulation of the anthrax bacillus. About a week later, at Cohn's invitation, he gave a three-day demonstration of his culture methods and results at the Botanical Institute (Breslau), in the presence of Cohn, Weigert, Auerbach, Traube, Cohnheim, and others. The latter declared that Koch's was the greatest bacteriological discoverv yet made, and Cohn immediately published his paper in his Beiträge (July 1S76 $6^{1}$ ). This memoir demonstrated that the anthrax bacillus is the cause of the disease, and that a pure culture grown through several generations outside the body can produce it in various animals. Koch's results were violently opposed by Paul Bert, but completely confirmed by Pasteur. In November, 1877, Koch published his methods of fixing and drying bacterial films on cover-slips, of staining them with Weigert's anilin dyes, of staining flagella, and of photographing bacteria for identification and comparison. $^{2}$ In 1878 appeared his great memoir on the etiology of traumatic infectious diseases, ${ }^{3}$ in which the bacteria of six different kinds of surgical infection are described, with the pathological findings, each micrö̈rganism breeding true through many generations in vitro or in animals. These three memoirs clevated Koch to the front rank in medical seience, and, through Cohnheim's influence, he was appointed to a vacaney in the Imperial Health Department (Kaiserliches Gesundheitsamt), with Löffler and Gaffky as assistants, in 1880. Here, in 1881, he produced his important paper upon the method of obtaining pure cultures of organisms by spreading liquid gelatin with meat infusion upon glass plates, forming a solid coagulum. When Koch demonstrated his plate cultures at the International Medical Congress in London, Pasteur is said to have rushed forward with the exclamation: C'est un grand progrès! and so it proved. The year 1882 was marked by the diseovery of the tubercle bacillus by special culture and staining methods. This paper ${ }^{5}$ contains the first statement of "Koch's postulates," establishing the pathogenic character of a given microörganism, which had already been pl.

${ }^{1}$ Cohn's Beitr. z. Morphol. d. Pflanzen, Bresl., 1876-7, ii, 277-310, 1

2 Ibid., 399-434, 3 pl.

${ }^{3}$ Untersuchungen über die Aetiologie der Wundinfektionskrankheiten, Berlin, 157s.

${ }^{4}$ Mitth. a. d. kaiserl. Gesundheitsamte, Berl., 1881, i, 1-4S, 14 pl.

${ }^{5}$ Berl. klin. Wochensehr., 1882, xxi, 221-230. The bacillus was probably seen, though not positively identified in a eausal relation, by Aufreeht (1881) and Baumgarten (1882). 
adumbrated by Henle' and Edwin Klebs. ${ }^{2}$ About the same time, lioch and his assistants introduced steam sterilization by dry heat. In 1S83, Foch, at the head of the German Cholera Conmission, visited Egypt and India, diseovered the cholera vibrio, ${ }^{3}$ its transmission ly drinking-water, food, and clothing, and incidentally found the microörgamisms of Egyptian ophthalmia or infectious conjunctivitis (Koch-lWeeks bateillus, 18834), for which results he received a donation of 100,000 marks from the Prussian state. In 1SS5, he was appointed professol of hygiene and bacteriology at the University of Berlin, where his laboratories were erowded with hright pupils from all over the world, anong whom were Gafflky, Löffler, Pfeiffer, Welch, and Kitasato.

At the tenth International Meelieal Congress at Berlin, in 1890, Koch ammonecd his belief that he had found a remedy for tuberculosis. The introchetion of tubereulin, ${ }^{5}$ his one mistake, in that it was prematurely considered, was hailed all over the world as an event of the groutest scientific moment, and honors and felicitations of all kinds were showered upon its discoverer. Although he himself had limited his claims to the possible cure of carly catses of phthisis, the great hopes which had been entertained of the remedy were not realized in time, and the mumber of failures and fatal eases impaired the confielenee of the profession, but abated little of Koch's great reputation, especially after the cliseovery that tuberculin is the most reliable means of diagnosis. In 1s91, the Institute for Infectious Diseases was founded in Berlin, and remained under his direction intil he resigned in 1904, in favor of his pupil Gaffky. In 1892, his ideas were applied in fighting the cholera epidemic at Hamburg, and in 1893 he wrote an important paper on waterborne epidemics, showing how they may be largely prevented by proper filtrittion. ${ }^{6}$ In 1896, he investigated Rinderpest in south Africa at the recquest of the English government, devised a method of preventive inoculation, and mats valuable studies of Texas fever, blaekwater fever, tropical malaria, surre, and plague. ${ }^{7}$ In 1897 , he produced his new tubereulin ( $T$. R.), and in 1S95 he investigated malarial fever in 1taly. At the London Tubereulosis Congresu (1900) he announced bis view that the bacilli of bovine and human tubereulosis, which harl been separated and studied by Theobald Smith in 1594, are not idlentical, claiming that there is little danger of transmission of the bovine type to man. These views were reiterated at the Washington Congress of 1908 , and on both oecasions aroused violent controversy, the general trend of opinion at present being provisionally in favor of Koch. In 1902, he stuchiol lihodesian red-water fever (Küstenfieber), horse-sickness, trypanosomiasis, and recurrent fever in German East Africa, and, in the same year, establisherl methors of controlling typhoid which have been adopted almost everywhere.

'Henle: Pathologisehe Untersuchungen, Berlin, 1840, 43.

${ }^{2}$ Klebs: Amtl. Bor. (l. 50. Versamml. deutsch. Naturf. u. Aerzte, München, $187 \pi, 49$, at bottom.

${ }^{3}$ Deutsche med. Wochenschr., Berl., 1854, x, 725-72S.

${ }^{4}$ Wien. mod. Wochenschr., 18\$3, xxxiii, 1550; also described by John E. Weeks, in Arch. Ophthal., N. Y., 1\$\$6, xv, 441-451.

${ }^{5}$ Deutsche med. Wochenschr., Leipz. u. Berl., 1890, xvi, 1029: 1S91, xvii, $101 ; 11$ s9.

${ }^{6}$ Ztschr. f. Hyg. u. Infektionskr., Leipz., 1893, xiv, 393-426.

${ }^{7}$ Reiseberichte über Rintlerpest (etc.), Berlin, 1898. 
Koch received the Nobel Prize in 1905, and, in 1906, visited Africa again, at the head of the Sleeping Sickness Commission, introducing atoxyl for the treatment of the disease. Although he was honored by a membership in the Prussian Academy of Seiences and the title of Excellenz, he was not happy in the later years of his life. Certain changes in his domestic arrangements estranged many of his friends, and subjected him to harsh criticism, which he bore with stoicism and dignity, but which told upon him in the end. He died of heart-failure on May 27, 1910, at the age of sixty-seven. His body was cremated at his own request, and his ashes deposited in the Institute which he had founded. In appearance, Koch was a typical German savant of Prussian cast, in character dignified, modest, and fairminded, altogether one of the greatest men of science that his country has produced.

Edwin Klebs (18341913), of Königsberg, Prussia, one of the earlier assistants of Virchow at Berlin (1861-66), who became professol of pathology at Bern (1866), Würzburg (1871), Prague (1873), Zürich (1852), and Chicago (Rush Medical College, 1896), is, with Pasteur, perhaps the most important precursor in the bac-

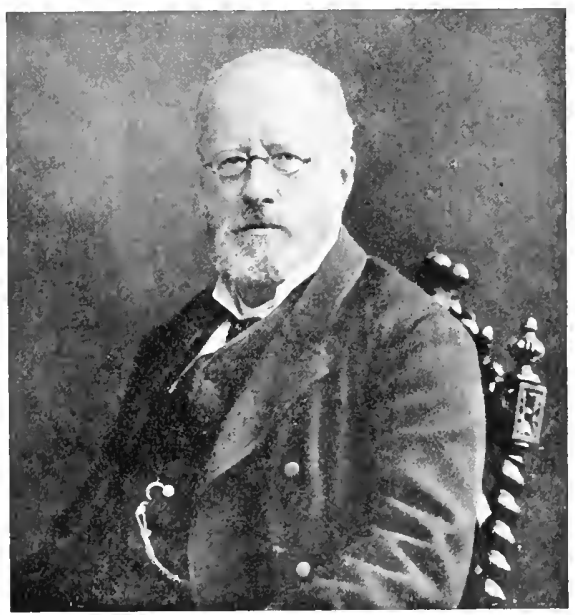

Edwin Kilebs (1834-1913). (Nurgeon-General's Libriary.) terial theory of infection; indeed, clid most to win the pathologists over to this view. $\mathrm{He}$ saw the typhoid bacillus before Eberth $\left(1881^{1}\right)$, the diphtheria bacillus before Löffler (1883\%), made solid cultures of bacteria, and investigated the pathology of traumatic infections before Koch $\left(1871^{3}\right)$; the priority of his inoculations of syphilis in monkeys was recognized by Metchnikoff $\left(1878^{4}\right)$, and, in his ex-

${ }^{1}$ Klebs: Arch. f. exper. Path. u. Pharmakol., Leipzig, 18so, xii, 231: 1881, xiii, 381,3 pl.

${ }^{2}$ Verhandl. d. Cong. f. innere Med., Wiesbaden, 1883, 139-174.

${ }^{3}$ Cor.-Bl. f. sehweiz. Aerzte, Bern, 1871, i, 241-246.

4 Areh. f. exper. Path. u. Pharmakol., Leipzig, 1878-79, x, 161-221, 4 col. pl. 
periments on anthrax (1871) and ofher discases, he was one of the first to experinent with the filtrates of bitcterial cultures. Ile wrote wo text-hooks on pathology (1869-76, 1887-89), monoeraphs on bacteriology im relation to gunshot wounds, based npon his experiences in the Franco-Prussian War (1872), on tumors (IST), and gigantism (1884), matde many investigations on tuberculosis, and he was, with Gerlach, the first to produce bovine infection or l'erlsucht by foceling with milk (187:32). In his studies of gumshot wounds, he showed that the filtrate of the wound-discharges is non-infections, whence he reasoned that trammatic septicemia is of bacterial origin. In 1870, he recognized hemorrhagic pancreatitis as a cautse of sudden death, and in 1876, he produced valvular disease of the heart experimentally. He investigited the genesis of endocarditis (1878), and his studies of malarial fever (with Tommasi ('rudeli, 1879) were translated for the Sydenham Society. He experimented with various products for the treatment of tubereulosis, and was the first to experiment with the therapentic possibilities of the tubercle bacilli of coldblooded animals (1900). The original discoveries of Klebs, "so often (as Osler says) a pioneer," had great heuristic value in their day, and undoubtedly stimulated Koch and others in their work.

Friedrich Löffler (1852-1915), of Frankfort on the Oder, was for many years a Prussian army surgeon, and eventually became professor of hygiene at Greifswald (1888). He discovered the bacteria of erysipelas in swine $\left(1882-83^{3}\right)$, and glanders $\left(1882^{4}\right)$; established the causal relation of the diphtheria bacillus $\left(1884^{5}\right)$, differentiating it from the organisms causing the discase in doves and calves; eradieated the field-mouse plague in Thessaly by means of the Bacillus typhi murium (1892); and, in his investigations of the foot-and-mouth discase $\left(1899^{6}\right)$, he was able to prove experimentally that the latter is caused by a filterable virus, thus establishing this concept and introducing a preventive inoculation against the disease (1899). He wrote an admirable history of bacteriology (1887), still unfinished.

Cieorg Gaffky (1850-1918), of Hannover, also a Prussian army surgeon, became associated with Koch in Berlin, and, after filling the chair of hygienc at Giessen (1888) for several years, suceeded Koch as director of the Hrgienie Institute. He made important studies of experimental septicemia (1881), cholera, and anthrax,

\footnotetext{
${ }^{1}$ Cor--BI. f. schweiz. Aerzte, Bern, 1871, i, 279. (Nachschrift).

2 Arch. f. exper. Path. u. Pharmakol., Leipzig, 1873, i, 163-180.

${ }^{3}$ Löffler: Arb. a. d. k. Gesundheitsamte, Berlin, 1885, i, 46-55.

${ }^{4}$ Deutsche med. Wochenschr., Leipzig u. Berlin, 18s2, viii, 407.

${ }^{5}$ Mitth. a. d. k. Gesundheitsamte, Berlin, 1884, ii, 451-499.

${ }^{6}$ Centralbl. f. Bakteriol., 1. Abt., Jena, 1898, xxiii, 371-391.
} 
and is a well-recognized morlern authority on infeetious diseases and public hygiene.

The work of these men lod to a wonderful output of epoch-making discoveries in bacteriology and parasitology, which constitute one of the chief glories of nineteenth century medicine. 'These are the establishment of the eatsal relations of the bacteria of leprosy in 1571-4 by Armater Ilansen (1S+1-1912), of gonorrhea in 1879 hy Albert Neissel (1855-1916), of typhoid fever by Carl Joseph Eberth $(1880)$, of lobar pneumonia by Pasteur (Iscos1), Cieorge Miller Stepnberg (1SS(-81), Albert Fränkel (1SS4), and Cirl Friedlander (1S83), of glanders by Friedrich Jöffer (18S2-86), of ervipulas by Friedrich Fehloisen (1883), of swine erysipelas by Löfther (1S82-80), of diphtheria by Elwin Klobs (1853) and Friedrich Löffler (1853-84), of cholera nostras by Dittmar Finkler and J. Prior (1SSt), of tetanus by Arthur Nicolaier (1854), of Bacillus eoli infection by Theodor Exeherich (1856), of Mialta fever by Sir David Bruce (18S7), of cerebrospinal meningitis by Anton Weichsedbatum (1887), of fibrinous pnemmonia hy Nicolaus Gamaleia (1885), of chancroid by Auguste Duerey (1889), of influmza by Richard lefeiffer (1892), of Bacilus aërogenes infection by William Henry Weleh and George H. F. Nuttall (1892), of bubonic plague by shibamiro Kitasato and A. Tersin (1894), of dysentery by Isagiyoi Shiga (1597), of bovine peripnemmonia by Elmond Nocard and Emile Roux (1898), of whooping-cough by Jules Bordet and Oetave Gengou (1906'), of typhus fever by Harry Plotz (1915). The microorganisms of the surgical and puerperal infections were diseovered and investigated by Pasteur (1878-9), Koch (1875), Gaffky (1851), and Welch (1\$92). Toxins were first isolated and named (tvphotoxine and tetanine) by Ludvig Brieger in 1SS5. The baetericidal effeet of blood-serum was rliscovered by Hans Buchner (1S89), bacteriolysis by Richard Pfeiffer (1894), bacterial hemolysis by Jules Bordet (1898). L. Landois, in 1875, made the important discovery that animal sermm will hemolyze human blood. The subsequent diseoveries of Maragliano (1892), Landsteiner (1901), and Eisenbero (1901), that the sera of diseased and even of normal, donors, will hemolyze alien blood, have revolutionized the whole subject of transfusion. Anaplivlaxis was oliscovered by Elward Jenner (1798) and lrancois Magendie (1839), and investigated by simon Flexner (1894), C. Riohet and Herieourt (18!9-1903), Theobadk simith (190)3), Rosenate and Anderson (1906), and von lirquet (1907). Bacterial agglutination was diseovered by Max Ciruber and Fornand Widal (1896). Opsonins were investigated by Denys and Leelef (1898) and by Wright and Douglas (1903). Parasitology was greatly advanced by surh monumental treatises as those of K. A. Rudolphi on entozoa (1SGs-10), C. F. H. Küchemmeister on cestodes (1853) and parasites in man (18.5.), Carl Theodor von Siebold on tenia and hydatils (1554), Casimir Davaine on entozoa in man and animals (1860), Thomas Speneer Cobbold on entozoa (1S64), Rudolf Leuckart (1822-98) on human parasites (1867), and Raphael Blanchard on medical zoölogy $(1886-90)$. ( ) parasites proflueing disease, that of favus was diseovered by sehönlein (1839), of psorospermosis liv Johannes Mïller (1S+1), of tinea favosa (alopeeia) by David Griby (1S+1-44), of anchylostomiasis by Angelo Dubini (1843), of recurrent fever by Otto Ohremoin (1573), of malarial fever by Alphonse Laveran (1880), of parasitie hemoptysis (paragonomiasis) by Erwin Baelz (18s0), of 'Texas fever (piroplasmosis) by Theobald smith (18s92). The parasite of aspergillosis was diseovered and deseribed by Bennett in 1842, that of actinomyeosis in man by von Iangenbeck (1S4s) and James Israel (187s), that in cattle by Otto Bollinger (Is76), the identity of both being established by Emil Ponfick (ISt1-19)13) in 1 that of Nocardiosis by Edmond Nocard (1s8s-93), that of blastomveosis by Thomas Casper Gilchrist (1896), and that of sporotrichosis by Benjamin $R$.

1 For bibliographical referenees to these diseoveries son Imlex Catalogue, Surgeon General's Library, 1912, 2. series, xvii, pp. 135-137.

${ }^{2}$ Ibid., pp. 13s, 139. 
Silhenck (1s9s). The two latter diseoverios were mank in the Johns Hopkins Ilospitil.

The theory that mosplites an transmit malarial ferer was indionted eren in the sanskit subruta, and the same theory was advaneel for vellow fever

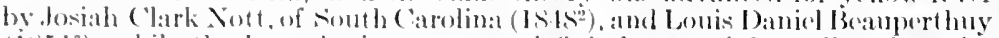

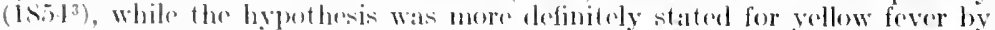

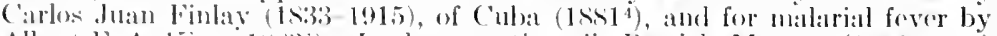

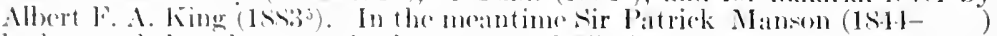
had proved that the mospuito is a vector of filatial sanguinis hominis (1879 $9^{6}$, and the phasmodium of malarial fever had been diseovered by Mphonse Laveran (1st.)- ), a French army surgeon, in 18 so.? These hemocetozoa were aceratedy described by lettore Marchiafava and Angelo Colli (1sis.5), and it was shown by ('amillo (iolgi (1st. - ), the histologist, that malarial paroxysms arr coincident with sporulation of parasites (188t), and that the paracite of (flatatan fever differs from that of tertian (1\$s9). In 1889, Marchiafarat and celli shwerl that the organisms of the pernicious and the tertian and quartan forms are different: 13. Grasis and k. Feletti studied the parasites in

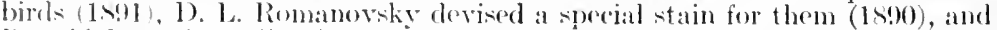
Ronald Ross, in India, demomstrated the infeetion of birds by meatns of the

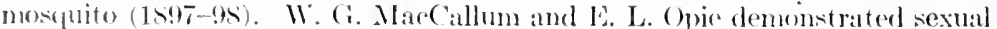
conjugation in the flagellated forms (18!97-9s'), and Cirassi and A. Bignami showed that the parasites develop only in the Anophedes monequito (1s99). Intracorpuscular conjugation in the parasite as a callse of latency and relatpse was demonstrated by (Charles $\mathrm{F}$. (Taig (1907), also the possjhility of malariat carriers. That flies ean transmit disase is one of the most ancient of folkintuitions, implicit in the flea- and fly-amulets of the ancient Eayptians, in the erlindrereal of Nergal, the Mesopotamian god of disease and darkness, in Piorpont Alorgan's collection, in the IBiblical roforences to the "plague of flies" visited upon the Egyptians and the iatromantic power aseribed to Beelzebub, the Fly-god 2 Kings 1, 2-6) and in Pliny's ironical recipe of ashes of flies for alopecia, (xix, 34), sine these represented the gorl Mviagros or Mviodes, who drove flies away, to the romfort of the bald. Ambroinse Paré noticed that flies are lisease-rarriers at the hattle of St. Quentin (155), Joseph Leidy ealled attention to the fact in his hospital work during the Civil War (1861-65), A. Raimbert demonitrated the transmission of anthrax by flies (1869), (i. E. Nieholas, R. X., noticel that flies and cholera appeared and disappeared together on board ship during the Levantine epidemic of 1850 (1873), and their ageney in the transmission of eholera was demonstrated by (i. Tizzoni and $\mathrm{I}$. Cattani $(1>66)$; the life-listory of the fly was investigated by $A$. T. Packard (15-7) and L. O. Howard (1909); Battista Cirassi howed that flies can carry the eggs of intestinal worms (1853). Angele, Celli showed that they may transmit nubereulesis (1sss), and that the bacilli of anthrax, tuberenlosis, and typheid fever retain their virulenee and reproductive power after passing through the intestines of flies $\left(18 s^{8}\right)$. In $1892,{ }^{9}$ George NI. Kober emphasized the importance of flies as disease-transmitters and, in his report on typhoid fever in the Distriet of Columbia (1595), definitely located them as such, in eonnection with a houscepidemic of typhoid from box-privies. In Circular No. 1,

1 sir H. A. Blake: J. Ceylon Braneh, Brit. Med. Ar., Colombo, 1905, ii, 9.

2 Nott: New Orleans .I. \& s. J., 1s4s, iv, 563; 601 .

${ }^{3}$ Gaz. offic. de Cumana, 185t, No. 57 .

${ }^{4}$ Finlay: An. r. Acad. de aien. merl. de lit Habana, 1ss1-2, xพiii, $147-169$.

${ }^{5}$ King: Pop. Se. Month., N. Y., 18\$3, xxiii, 644-65.5.

${ }^{6}$ Manson: J. Linnæan Soe., Lond., 1879, xiv, 304-311.

7 Laveran: Compt. rend. Arad. d. se., Paris, 1850, xciii, 627.

${ }^{8}$ A. Colli: Boll. d. Soe lancisiana d. osp. di Roma, 1S8S, viii, 5-8.

${ }^{9}$ G. M. Kober: Rep. Health Offieer D. C., Wash., 1895, 258; 260; 266; $270 ; 280 ; 281$. 
Surgeon General's Office (April 25, 1s98), George M. Sternberg brought out the same point, and the report of Valter Reed, V. C. Vaughan and W. O. Shakespeare on the typhoid in the Spanish-Ameriean Wir (1898) settles the matter by induetive proof. ${ }^{1}$

About 1890, Pasteur's theory of attenuated viruses was extended to the science of toxins and antitoxins by Emil von Behring (1854-1917), a Prussian army surgeon who became professor of hygiene at Halle (1894) and Marburg (1895). In his studies on chicken cholera, Pastem had already noticed the pathogenic effects of a clear filtrate on the specific organism, and, in 1885, his pupils, Roux and Yersin, got the same results from diphtheria filtrates. ${ }^{2}$ Hans Buchner, in 1889, had established the bactericidal effect of blood-serum. While working in Koch's Institute with Kitasato, Behring demonstrated that the serum of animals immunized against attenuated diphtheria toxins can be used as a preventive or therapentic inoculation against diphtheria in other ani mals, through a specific neutratization of the toxin of the disease $\left(1890-93^{4}\right)$. After trying ont the remedy in man, Behring began to produce it upon a grand scale (1894), and it soon became recognized as the specific treatment for diphtheria. The success of diphtheria anti-

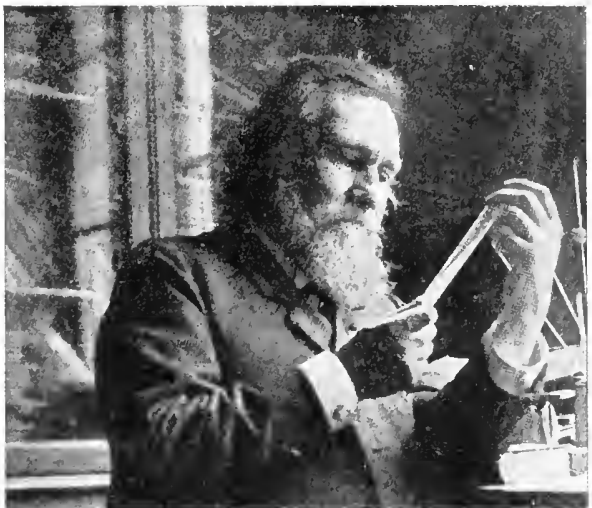

Elie Metchnikoff (1S45-1916). toxin led to many attempts to treat other specific infections by immune sera, but, except in the case of tetanus and serpent-poisoning, these have not been uniformly successful. Neanwhile the subject of immunity was developed on the solidist or cellular side by Elie. Metchnikoff (1845-1916), the eminent Russian biologist, who, in his studies of Daphmia (1884), showed how ameboid cells in the connective tissues and the blood engulf solid particles and bacteria, destroying bacteria by absorbing them (phagocytosis).

1 For references to fly-transmission see the exhaustive history of $\mathrm{H}$. G. Beyer: New York Med. Jour., 1910, xei, 677-685.

2 Ann. de l'Inst. Pasteur, Paris, 18s, ii, 629; 18\$9, iii, 273.

${ }^{3}$ Buchner: Centralbl. f. Bakteriol., Jena, 18\$9, v, \$17; vi, 1.

4 Behring: Deutsche med. Wochensehr., Leipz. and Berl., 1890, xvi, $1113 ; 1145 ; 1 S 93$, xix, $389 ; 415$. 


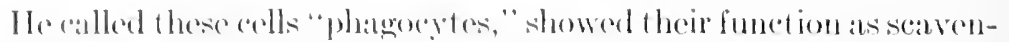
eners, developed the doetrine of inflammation as the effect of the heremination of swams of phigereytes to the site of injury by "hemiotaxis amel uphedel the solidist theory of immunity or phatgo"ytosis. This theory, in the hands of sir Ahoroth llright and

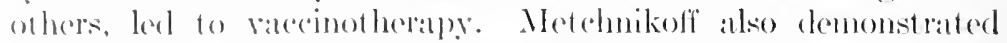
that Peifler's phemomenon (hateloriolysis) an take place in vito $\left.(189.5)^{1}\right)$; wh Roux, he showed that the higher apes ean be inorulated with syphilis (1903-12), atnel his theories of the offert

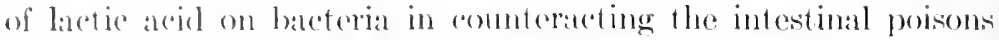
and prolonging life (1906) have attrated much attention. His best works are those on the comparative pathology of inflammation (18,02), on immunity in infoctious discases (1901) and on "the Nature of Man" (1903), which gives his views on intestinal antointoxication. He received the Nobel price in 1908.

Sir Alumoth Edward Wright (1861- ), of Dublin, Ireland, professor of pathology in the Army Medical school at Netley (1892-1902), was the first to point out the role of calcium salts in the coagulation of the blood (1891) and devised a coagulometer for estimating coagulation-time. He made typhoid vaccination practicable (1896-7), having inoculated over 3000 soldiers in India (1898-1900), and the entire British forees in the South African War. Through this work, he originated general vaceinotherapy $(1902-7)$, with the superadded feature of measuring the protective substances in the blood by means of the opsonic index (1903). He is the anthor of treatises on anti-typhoid inoculation (1901) and immunization (1909), and during the European War has investigated wound infection.

Fernand Widal (1862- ), a native of Algiers and professor in the Paris Faculty, collaborated with Chantemesse in his early work on preventive vaceinations against typhoid fever (1888), made his mark by his discovery of bacterial agglutination and its application in the diannosis of typhoid (1896), and described noncongenital hemolytic jaundice (i907).

Bacteriology and pathology have been specially advanced in America by William Henry Welch (1850- ), of Norfolk, Con-

I Ann. de I'Inst. Pasteur, Paris, 1895, ix, 433-461, 1 pl.

2Ibid., 1903, xvii, s09; 1904 , xviii, 1 . The experimental inoculability of syphilis was demonstrated, contrary to the views of Ricord, by Julius Bettinger $(1802-87$ ) in anonymous protoeds presented to the Society of Physicians of the Palatinate in September, 185.) (Acrztl. Int.-131., München, 1856, iii, 426-425). Bettinger carefully kept the authorship of these human inoculations a secret all his life. His findtings were subsequently unearthed by Erich Hoffmann (Deutsehe med. Worhenschr., 1906, xxxii, 497) and the identity of the "anonymus Palatinus" also established (Dermat. Ztschr., Berl., 1912, xix, 1013: 1913, xx, 220). 
necticut, a pupil of Cohnheim's, who became professor of pathology at the Bellevue Hospital Medical College (1879-8t) and at the Johns Hopkins University (1884), where he has turned out a long line of worthy pupils. Welch investigated acute edema of the lungs in Cohnheim's laboratory (1877), discovered the Staphylocoecus epidermidis albus and its relation to wound infection $\left(1892^{1}\right)$, also the Bacillus aërogenes capsulatus $\left(1892^{2}\right)$, grouping the diseases caused by it $\left(1900^{3}\right)$. He also made important studies of embolism and thrombosis, and, with Flexner, demonstrated the pathological changes produced by experimental injection of the toxins of diphtheria $\left(1891-92^{4}\right)$, simultaneously with von Behring.

Simon Flexner (1S63- ), of Louisville, Kentucky, Now director of the Rockefeller Institute for Medical Research (1903), has distinguished himself by his work on terminal infections, his experimental work on venoms (1901), and the etiology and therapy of cercbrospinal meningitis (1909) and infantile poliomyelitis (1910-13).

Victor Clarence Vaughan (1851- ), of Mount Airy, Missouri, professor of hygiene and director of the Hygienic Laboratory at the University of Michigan (1887-1909), was the earliest after Panum (1856) and Selmi (1878) to investigate the poisonous alkaloids and proteins, in particular tyrotoxicon (1885), ptomaines and leucomaines (with F. G. Novy, 1888), the bacterial proteids or cellular toxins (1891-1913), and the protein split products (1913). In 1896, he found the poison-producing bacillus in ice-cream and cheese.

His general theory is that bacteria are not plants, but particulate, specific proteins (nucleo-proteins), that all true proteins contain a poisonous molecular nucleus, that the pathogenicity of bacteria depend upon their reproductive power or mass-action within the body, that specific infeetious diseases result from parental protein digestion, that protein sensitization and bacterial immunity are identical, that vaccines are protein sensitizers, but toxin immunity and bacterial immunity are radically different, since the protein poison is not specific but common to all proteins, and these elaborate no antibodies, but, through their secondary groups, develop specific proteolytic ferments capable of digesting the protein which created them.

Vaughan's colleague, Frederick George Novy (1864- ), of Chicago, professor of bacteriology at Ann Arbor (1902), collaborated with him in his book on ptomaines and leucomaines (1888), has made culture investigations of the trypanosomes, and (with Knapp) discovered the special spirochete of the American variety of relapsing fever (1906).

${ }^{1}$ Welch: Tr. Cong. Am. Phys. \& Surg., New Haven, 1892, ii, 1-28.

2 Johns Hopkins Hosp. Bull., Balt., 1892, iii, 81-91, with G. H. F. Nuttall.

${ }^{3}$ Ibid., 1900, xi, $185-204$.

${ }^{4}$ Ibid., 1891, ii, 107; 1892, iii, 17. 
Ludvig Hektoen (1S63- ), of Westby, Wisconsin, professor of pathology in Rush Medical College, Chicago (1895), and director of the John MeCormick Institute for Infectious Diseases (1902), is one of the most eminent pathologists and bacteriologists in our country. He lias done much valuable work in experimental medicine, notably on vascular changes in tuberculous meningitis (1896), blastomyeosis and sporotrichosis (1899-1907), experimental baeillary cirrhosis of the liver (1901), blood-cultures during life (1903), experimental measles (1905-19), phagocytosis (1905-8) and antibodies (1909-18). He first pointed out the possible danger from iso-agglutination in transfusion of blood (1907). He was the teacher of many of the promising younger people, notably Ricketts, H. G. Wells, Rosenow, Irons, and Alice Hamilton.

George H. F. Nuttall (1862- ), of San Francisco, professor of biology at the University of Cambridge (1906), editor and founder of the Journal of Hygiene (1901) and of Parasitology (1908), first stummarized the rôle of insects, arachnids, and myriapods as transmitters of bacterial and parasitic diseases (1899), and his monograph on Blood Immunity and Blood Relationship (1904) establishes the identification of different kinds of blood by the precipitin test.

Hans Zinsser (1878- ), of New York, professor of bacteriology in Leland Stanford (1910-13) and Columbia Universities (1913), who made a brilliant record in medico-military administration on the Western Front, is the author of sterling text-books on bacteriology (1911) and infection (1914) and of experimental researches on the Treponema pallidum.

Theobald Smith (1859- ), of Albany, New York, professor of comparative pathology in Harvard University (1896), has been one of the pioneers in the theory of infectious diseases. In 1886 , working with D. E. Salmon, he demonstrated that immunity from hog cholera can be secured by injection of the filtered products of the specifie organisms. This was the first experiment in immunization, and was soon followed by the work of Behring, Roux, and others. Smith's demonstration of the parasite of Texas fever (Pyrosoma bigeminum) (1889'), and his work (with F. L. Kilborne) in tracing its transmission by the cattle tick (Boöphilus bovis), was a great advance in the science of protozoan discase (1893). He also demonstrated anaphylaxis from the bacterial products of diphtheria prior to 1903, a discovery which Ehrlich ealled the "Theobald Smith phenomenon." He made the first elear differentiation between the bovine and human types of tubercle bacilli $\left(1898^{2}\right)$, his work having been substantiated by Koch,

1. Smith: Med. News, Phila., 1889, lv, 689-693.

${ }^{2}$ J. Exper. Ned., N. Y., 1898, iii, 451-511. 
Spengler, and others, and has made many other discoveries in bacteriology, notably the first observation of pleomorphism in Dacteria.

While Pasteur was investigating fermentation and putrefaction, the foundations of the most important application of this work were being laid by Joseph Lister, a young. English surgeon who was destined to make his art a science in the same sense in which the mathematician Cayley defined bookkeeping as a perfect science. Lord Lister (1827-1912), the last and greatest of the interesting line of English Quaker physicians, was born at Upton, Essex (April 5th). His father, Joseph Jackson Lister, a London wine merchant, who devoted his leisure homrs to the study of opties, was, in a sense, the founder of modern microscopy through his epochmaking improvements in the achromatic lenses of the instrument (1830), and his special bent was not without its influence upon his son. After graduating in medicine from the University of London in 1852 , Joseph Lister produced a number of papers on the histology of muscle, illustrated by drawings which are rare and delicate examples of the talent which so many great physicians

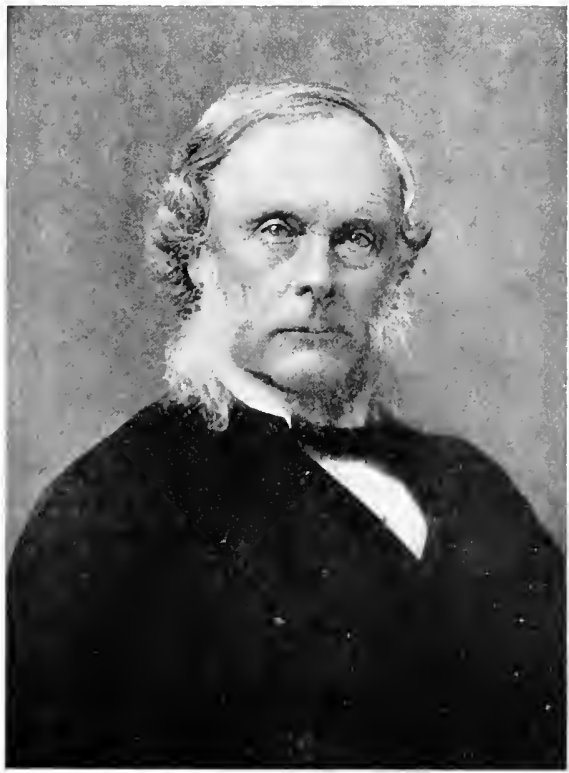

Lord Lister (1827-1912). have displayed in illustrating their own works. 'Two of Lister's teachers, William Sharpey and Thomas Graham, were Scots, and it was upon their advice that he went up to Edinburgh to follow surgery under Syme, who made him his house surgeon in 18.54 , and whose eldest daughter afterward became Lister's wife. In 1860, Lister became professor of surgery in the University of Glasgow, and it was during the latter years of his residence there that his greatest contribution to the science was made. Meanwhile, he had verified Kölliker's observation that the contractile tissues of the iris consist of smooth muscle $\left(1852^{1}\right)$; he had over-

${ }^{1}$ Lister: Quart. Jour. Micr. Sc., Lond., 1S53, i, p. S et seq. 


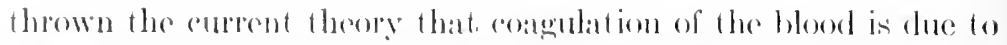

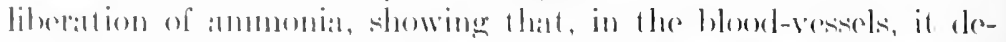

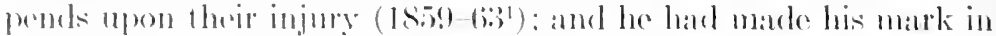

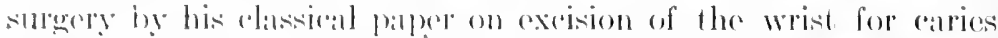

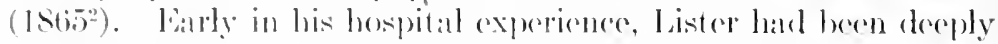
impressed with the high mortality from such surgical pests ats septicomia, pyomia, cresipelas, fotants, and hosplat gangrene. In his own stat isties of amplation (1S61-66), he found t5 per eent. of fatal casces, althomgh he had comstantly employed symes methols of kerping the wound elean by silver wire sutures, drainage, frequent rhanger of dressings, and serupulous deanliness. These were the days of "laudable pus," yet Lister had alleady begun to think of the old Hippocratic healing by fust intention as the surgeon's ideal. Noticing that the latter, when attainable, was always discoriated from putrefaction, his attention was aceidentally drawn to Pasteur's work, and, immoliately grasping its tendeney, he set ont definitely to prevent the development of microörganisms in womuls. Perceiving that Pasteur's heat sterilizations would avail nothing here, he turned to chemical antisepties, and, after trying out chloricle of zine and the sulphites, he hit, by lucky chance, upon carbolic acid, which had been cmployed, a short while before, in the disinfection of sewage at Carlisle." On August 12, 1865, he employed it in a case of compound fracture with complete success, and, in 1867 , published the results of two years' work in two papers, the second of which bears the significant title, On the Antiseptic Principle in the Practice of Surgery. The criticisms which were heaped upon his paper turned upon such non-essentials as the question of priority in the use of carbolic acid, or the character of Lister's dressings, which, complex at the start, were only accictental features of the great surgical principle with which they were confused. Lndisturhed by these attacks, Lister proceeded to derelop his thesis in the broadest and most scientific manner by original investigation of lactic-acid fermentation, of the relation of bacteria to inflammation, and of the antiseptic healing of wounds. All his life, he labored constantly to improve his dressings, from the carlier devices of putty, block tin, layers of oiled silk or gauze, and the carbolic acid spray, to his later experiments with the double cranides of mercury and zine and his great innovation of catgut

${ }^{1}$ Edinb. Med. Jour., 18.59-60, $r$ 536-540; and Croonian lecture, Proc. Roy. Soc., Lond., 1\$62-3, xii, 5s\$0-611.

2 Lancet: Lond., 1S65, i, 308; 335; 362.

3 This substance had alrearly been recommended by Francois-Jules Lemaire, a French ehemist, in 1\$60, but Lister had heard of neither Lemaire nor semmelweis.

${ }^{4}$ Lancet, Lond., 1867 , ii, $95 ; 353,665$. 
ligatures in the surgery of the vaseular system $\left(1880^{1}\right)$. He boldly applied the antiseptic principle to such conditions as abscesses in the spine and the joints, excision of the knee-joint (1878), oporations on the breast (1881), fracture of the patella (1883), and all manner of operations on the locomotor system, doing as much to extend the domain of surgery as any man of his time. Modern surgery, it is true, has become almost entirely aseptic, in the sense of discarding strong antiseptics in the dressing of wounds, bnt in both the Listerian ideal of avoiding sepsis remains the same. In 1869, Lister sueceeded Syme at Edinburgh, and, in 1877, accepted the chair of surgery at Kings College, Lomdon, retiring from prac'tice in 1896 , before which time his fame had beeome international. He was president of the Royal Society during 1895-1900, received his baroneter in 1883, and was the first medical man to be raised to the peerage (1S97). In France, his irleas were defended by J.-MI. Lucas-Championnicre (1813-1913), who pointed out that asepsis, he Listerian ideal, must always be preceded by antisepsis, and ven heat sterilization is, in the truest sense, antiseptic. This was he weak point of Lawson Tait's argument against Listerism, for the Birmingham gynecologist, who denied that bacteria are pathogenic, ould not admit that his own marvelous success in ovariotomy was lue to those housewifely antisepties, soap and hot water. ${ }^{2}$ Koeberle vashed and scrubbed his own instruments personally, afterward reating them in an alcohol flame. Von Bergmann gradually nerged the eorrosive sublimate method into steam sterilization 1886) and general asepsis (1891). The military applications of ntisepsis, which Lister suggested in $1870,{ }^{3}$ were not taken up until ite in the Franco-Prussian War, but his methods were soon rasped by von Volkmann, Thierseh, Mikulicz, and others, and his bur through Germany, in 1875, was in the nature of a triumphal rogress. Upon hearing of Semmelweis, in 1883, Lister generously eelared him to be his forermmer; and, in the olstetrieian's hands, isterism is now the main safeguard of the woman in childhed. o Listerism are due all modern developments of the surgery of re hollow cavities of the body, including the (ranium, chest, abomen, the joints, and the male and female pelvic viscera. At asteur's jubilee, in 1892, Lister paid a feeling tribute to the man hose work he had been first to appreeiate. As an operator, Lister as not brilliant, but deliberate and eareful, aiming, like Kocherr day, to make the recovery of his patient a mathematieal cer-

${ }^{1}$ Tr. Clin. Soe, Lond., 1sso-81, xiv, pp. xliii-lxiii.

${ }^{2}$ The cavillings of von Bruns ("Fort mit dem s'proy!"), Tait, and Bantock 1) ve, in the end. proved to be of little moment, so far as the generic idea of : gieal eleanliness is coneerned.

${ }^{3}$ Brit. Med. Jour., Lond., 1870, ii. 243. 
tainty. His Quakel solniety, his sovere and amstere ideals, were not the trats that make for rapid and showy suceess. His progress was slow; he left no school; but, bofore be died, the entire guild of surereons "lived in his mild and magnificent eye." When his hody was had at rest in Westminister, England had huried her greatest suremen.

The character of Listel was one of rare unblity. As the Quaker is the Puritan transposel into a softer and more wrateful key, so his nature had those elements of sweetness which proverbially can conc only out of strength,

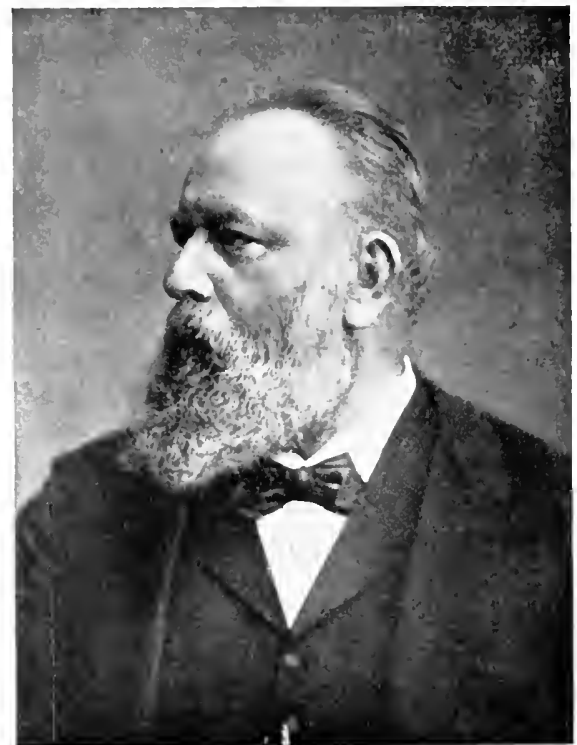

Theodor Billroth (1829-94). and no praise of him is more touching than that of one of the Scottish clergymen after his death:

"Of Joseph Lister's winsome personality, those speak most warmly who knew him best. It was his gentleness, above all, that made lim greater. His very presenee was a spiritual foree. Clear-e'yed and pure of soul, he cherivined from carliest days that love of truth which guided him to the end. His noble passion for humanity extinguished all thoughts of self and personal fame, impelling him along that path which he steadfastly pursued till he found the seeret of his search, and bestowed on the worlı probably the greatest boon which science has been able to win for the physieal life of mankind. Yet greater than his greatest achievement was the man himself, and the final secret of his greatness was that serene simplicity which was his most distinguished characteristic. . . . His was the grave and thonghtful courtesy which bespoke the Christian gentleman and the earnest lover of his kind. Hence we are not surprised to learn how he stirred enthusiasm and moved men to reverence, how he gained such love and affection as rarely fall to a seientifie teacher. Behind his acknowledged mastery of his science, his grave and noble faee, marked by soft lines of tranquil thought, revealed a soul of singular beauty and sweetness, of high integrity and stainles honour. That sueh a man, dowered with God's gift of genius, should rise to lof $t y$ heights and achieve great things was inevitable." - Rev. Wallace Williamson: Memorial Discourse, Edinburgh, February, 1912.)

Of the surgeons of Lister's time, who developed his ideas in new fields, perhaps the first place belongs to Theodor Billroth (1829-94), the pioneer of visceral surgery. Born on the island of Rügen, a Berlin graduate of 1852 , Billroth became an assistant in Langenbeck's clinic, and subsequently professor of surgery at Zürich 
(1860-67) and Vienna (1867-94). Billroth was early interested in wound infections, and, in his "coccobacteria septica," he had undoubtedly grasped the causal idea, but regarded one generic group of bacteria as the cause of a whole family of affections. He wrote an admirable volume of lectures on surgical pathology and therapeutics $\left(1863^{1}\right)$, which was transkited into almost every modern language, but he is especially remembered as the surgeon of the alimentary tract. In 1872 , he made the first resection of the esophagus, ${ }^{2}$ and, in 1881, the first resection of the pylorus for eancer, which was successful. ${ }^{3}$ He also made the first complete excision of the larvnx $\left(1873^{4}\right)$, is said to have been the first to perform the "interilio-abdominal amputation" (18915), and did a large number of intestinal resections and enterorrhaphies $\left(1878-83^{6}\right)$. All these operations upon the gastro-intestinal tract did much to elucidate the pathology of those regions, as being, in Naunyn's phrase, "auopsies in vivo." Billroth was a man of charming, genial personlity, with a strong artistic bent, delicately revealed in the few ipecimens of verse and music which he left, and in his delightful Briefe, in some sort, a memorial of his life-long friendship with he great North German composer, Johannes Brahms.

Billroth's most prominent pupils were Mikulicz, Czerny, Völfler, and Gersuny, all Slavs, and von Eiselsberg, an Austrian.

Johann von Mikulicz-Radecki (1850-1905), of Czernowitz, 'oland, who was Billroth's assistant 11 to 1881, and professor of urgery at Königsberg (1857) and Breslau (1890), did much to mprove antiseptic methods, introduced the present modes of sploring the esophagus and the stomach $\left(1881^{7}\right)$, first treated nneer of the esophagus by resection and plastic transplantation $886^{8}$ ), introduced lateral pharyngotomy in excising malignant mors of the tonsillar region $\left(1886^{\circ}\right)$, described symmetrical inmmmation of the laerimal and salivary glands, Mikuliez's disease $\left.892^{10}\right)$, greatly extended the operative surgery of the stomach and le joints, and collaborated in an atlas (1892) and a treatise (1898)

${ }^{1}$ Billroth: Die allgemeine ehirurgisehe Pathologie und Therapie, Berlin, 63.

${ }^{2}$ Areh. f. klin. Chir., Berl., 1872 , xiii, (55-69, 1 pl.

${ }^{3}$ Wien. med. Woehenschr., 18s1, xxxi, 162-165.

${ }^{4}$ Arch. f. klin. Chir., Berl., 1874, xvii, 343-356, 1 pl.

${ }^{5}$ Billroth did not report upon an unsuccessful operation, said to have been 1 formed about 1891, so that, by the law of priority, eredit is given to Mathieu oulity, who published the first paper in Lyon méd., 1894, 1xxv, 507-510.

${ }^{6}$ Zeitschr. f. Heilk., Prague, 1884, v, 83-108.

7 Mikulicz: Wien. med. Presse, 18\$1, xiii, 1405 et seq.

${ }^{8}$ Prag. med. Wochenschr., 18\$6, ix, 93.

${ }^{9}$ Przegl. lek., Krakow, 1886, xxv, 173.

${ }^{10}$ Billroth Festschrift (Beiträge zur Chirurgie), Stuttg., 1892, 610-630, $1 \mathrm{pl}$. 
in discases of the month. Itr was ome of the first to wear gloves on operative work, hut the atton gloves he used were soon superserloct hy those of rublere, introducod hy Halsted in baltimore

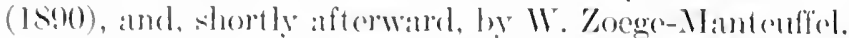

Vincenz Czerny (1812-19)(i), of Trantemau, Bohemia, profossor of surgery at Froilume (1S7) and Hoidellorg (1887), introduced the enucleation of sulperitoneal uterine fibmoids by the vaginal route (ISS1 ${ }^{1}$ ), and extended Billroth's work on the carision of the lanson, the esophagus, the kidneys, and general viseral surgery. His latter daly were devoted to cancer rescareh, culminating in the opening of the Hoidelberg samariterhaus (1906) under his direction.

Anton Wölfler (18is()-1917), of Kopezen, Bolsemia, professor of surgery at (iraz (1886) and Prague (1895), introduced gastroenterostomy $\left(1 S S 1^{2}\right)$, and devoted special attention to the surgical treatment of goiter $(1887-91)$.

Robert Gersuny (1841- ), of Teplitz, Bohemia, who sucreeded Billroth as director of the Rudolfmerhaus (1S94), is now bost remembered for the introduction of prothetic paraffin injections (1900).

Larl Thiersch (1822-95), of Munich, one of Stromeyer's pupils, who became professor of surgery at Erlangen (1854) and Leipzig (1S87). was a great pioncer of Iisterism, and through his studies of epithelial caneer $\left(1865^{3}\right)$, phosphoric necrosis of the jaws $\left(1867^{4}\right)$, the healing of wounds $\left(1867^{5}\right)$, and his improvenent in skin-grafting $\left(1 S{ }^{6} 4^{6}\right)$, was a prominent contributor to surgical pathology.

Richard von Volkmann (1830-89), of Leipzig, son of the wellknown Halle physiologist, and professor of surgery in the latter city (1867-89), also did much to introduce antisepsis during the Franco-Prussian War, was the first to excise the rectum for cancer $\left(1 \delta 7 \delta^{7}\right)$, described the so-called ischemic contractures or paralyses $\left(1881^{\circ}\right)$, and cancer in paraffin-workers, and founded the well-known Sammlung lilinischer Torträge (1870), which contains some of the nost valuable monographs of recent times. He was a man of aristocratic appearance, a poet ("Richard Leander"), and his "Dreams by French Firesides"' is a charming book.

1 Czerny: Wien. meel. Wochenschr., 18\$1, xxxi, 501; 525.

2 Wölffer: Centralbl. f. Chir., Leipz., 1s81, viii, 705-708.

${ }^{3}$ Thierseh: Der Epithelialkrebs, Leipzig, 1865.

${ }^{4}$ Thiersch: De maxillarum necrosi phosphorica, Leipzig, 1867.

${ }^{5}$ Handb. d. allg. u. spez. Chir. (Pitha-Billroth), 1867, i, 2. Abth., No. 3.

${ }^{6}$ Verhandl. d. deutsch. Gesellseh. f. Chir., Berl., 1874, iii, 69-75.

'Volkmann: Samml. klin. Vortr., Leipz., 1s7s, No. 131 (Chir. No. 42), $1113-1125$.

${ }^{8}$ Centralbl. f. Chir., Leipz., 18s1, viii, s01-803.

${ }^{9}$ Träumereien an französisehen Kaminen, Leipzig, 1871. 
Friedrich von Esmarch (1823-1908), of Tönning, SchleswigHolstein, a pupil of Stromeyer and Langenbeck, who became professor of Kiel (1857-99), was a great military surgeon, having served through the campaigns of 1848-50, 1864-66, and 1870-71. He is most memorable for his introduction of the first-aid bandage on the battle-field (1869-701), and for standardizing surgieal hemostasis by the "Esmarch bandage" (18732). He did much to improve the status of military surgery through his contributions on resection after gimshot wounds (1851), the proper locale for field hospitals and bandaging stations (1861), surgical technics (1871), first aid to the wounded (1875), and on first aid in accidents (1882).

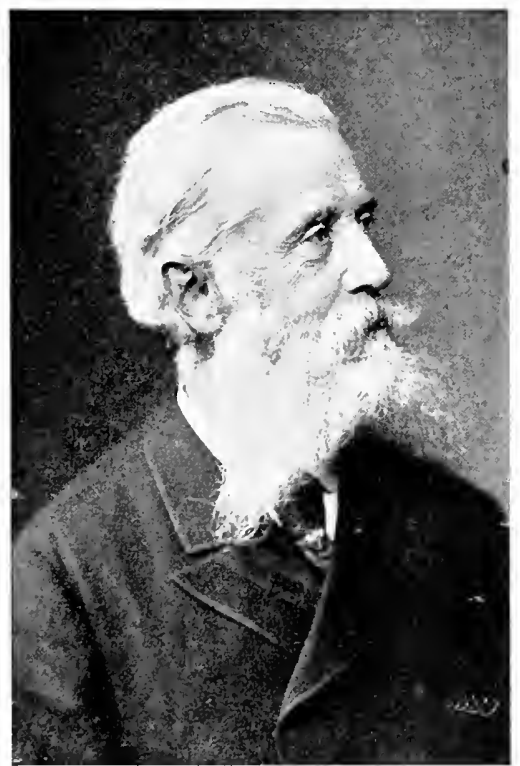

Friedrich von Emarch (1\$23-190\$). (Collection of A. C. Klebs.)

He was the pioneer and founder of the so-called Samariterwesen, or military nursing, in Germany, and, through his marriage with royal princess, became the uncle of the present emperor.

Ernst von Bergmann (1836-1907), of Riga, Russia, grarluated t Dorpat in 1860 , served in the Prussian army in the wars of $18666^{\circ}$ nd 1870-71, and on the Russian side in the war of 1877-78, after hich he became a prominent figure in German medicine. He was alled to the chair at Würzburg in 1878, and succeeded Langenbeck $t$ Berlin (1882), where he remained for the rest of his life.

${ }^{1}$ Esmarch: Der erste Verband auf dem Sehlachtfelde, Kiel, 1869.

${ }^{2}$ Samml. klin. Vortr., Leipz., 1873, No. 58 (Chir. Ne. 19), 373-384. 
Ho greatly advancerl cranial surgery in his momoirs on head injuries

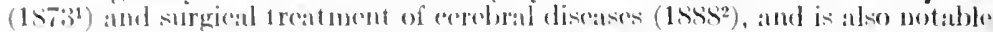
for his werks on fattre embolism (ls(ii), the surgery of the joints (1S72-7S),

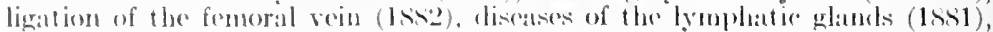

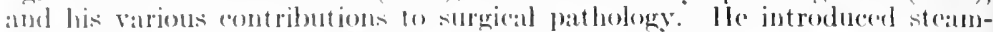
stcrilization in surgery (18vti), and erentually male his own procedure aseptic

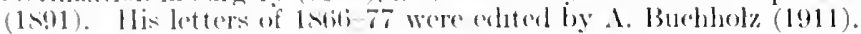

Ernst Julius Gurlt (182:)-99), of Berlin, where be became professor in 1862, took part in all the Cicman wats of the period,

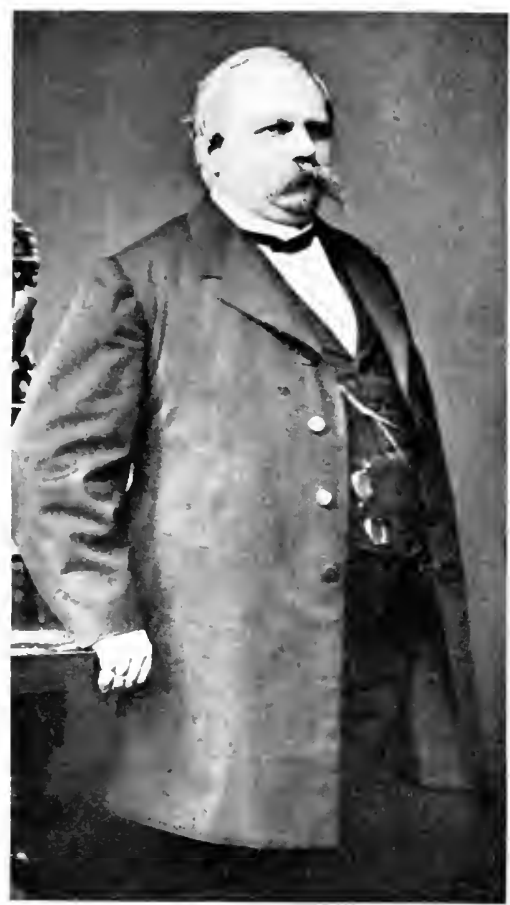

Ernst Julius Gurlt (1825-99). (Courtesy of Dr. (George M. Kober.)

wrote with ability on a great variety of themes, and holds a Jigh place in medical literature as the historian of surgery par excellence. He was one of the most learned surgeons of his time, and his Geschichte der Chirurgie (1898), dealing with the history of the subject down to the Renaissance period, is to surgery what Hacser is to medicine, unrivaled for scholarship, exhaustive treatmont, and accurate bibliography. It is a work which stands quite apart as one of the greatest monuments of Cierman thoroughness.

In orthopedics, especial distinetion was at tained by the Heine family, all of whom were expert mechanicians, in partieular Jacob von Heine (1799-1s79), of Cannstatt, who first deseribed polionyelitic deformities (1s40) and wrote an importunt treatioe on disfocations (18.42), Gustay simon (1868), Adolf Lorenz (1854- ), of Weidenau, Silesia, who int roduced the bloodless method of reducing congenital dislocations of the hip-joint by foreible manipulation, Julius Wolff (18361902 of West Prussia, author of a great monograph on the law governing the pathological transformations of bones (1892), and Albert Hoffa (1859-1908), who introduced a well-known operation for congenital hip dslocations (1590), and was founder and editor of the Zeitschrift für orthopädische ('hirurgie (1891).

Of original operations by Germian surgeons of the nineteenth eentury, we may mention those of the first nephropexy by Eugen Hahn (18s1), the first excision of the gall-bladder by Carl Langenbueh (1882), the first colostomy by Karl Maydl (1Ssi), thoracotomy for empyema by Ernst Küister (18s9),

${ }^{1}$ Bergmann: Handb. d. allg. u. spez. Chir. (Pitha-Billroth), Erlangen, 1873, iii, 1. Abth., 1. Abschn.

${ }^{2}$ Die chirurgische Behandlung bei Hirnkrankheiten, Berlin, 1888. 
resection of the reetum by Paul Kraske (1s91), exeision of the Gasserian ganglion by Fedor Krause (1893), and excision of the stomach by Carl sehliatter (1897). The introduction of the eystosepe $(157-78)$ by Max Nitze (18451906 ) vastly improved the surgery of the bladder.

Of the French surgeons of the period, Aristide-Auguste Verneuil (1823-95), of Paris, who held many hospital appointments and trained many good pupils, made no original discoveries, but is remembered by such procedures as foreipressure in hemorrhage (1875), dry bandaging, treatment of abseesses with iodoform, and by the Revue de chirurgie (1881), of which he was one of the founders and editors. He wrote no large monographs, and his works are all contained in the six volumes of his Memoires de chirurgie (1877$88)$.

Edouard Nicaise (1838-96), surgeon at the Laënnec Hospital (1880-96), was, like Malgaigne, especially learned in the history of his subject, issued superb modern editions of Guy de Chauliae (1890), Henri de Mondeville (1893), and Pierre Franco (1895), and wrote many fascinating essays.

Just Lucas-Championnière (1843-1913), who before his grarluation $(1570)$ entered Lister's service at Glasgow, did most for the establishment of antisepsis in France. He wrote a Manuel de chimurgie antiseptique (1876), and, as a pupil of Broca, did much for trephining, also for the surgery of the osseous system generally.

Félix Guyon (1831-1920), a native of the Island of Rémion, professor of genito-minary surgery at the Paris Faculty (1890), was one of the great teachers of this specialty in his time, and his linies at Necker were followed by students from all over the world. His lectures on genito-urinary diseases (1851) and surgical diseases of the bladder and the prostate (1888) are his most important rorks. Bigelow's litholapaxy was perfected by Thomson and by tuyon, who was succeeled, and perhaps surpassed, by his briliant pupil, Joaquin Albarran (1860-1912), another exotic, born at fagua la Grande, Cuba, who was twice a gold medalist of the Paris Paculty (1888-89), and professeur agrégé in 1892, and, in his short ife, became a star of the first magnitude as a teacher and through is many valuable innovations in the diagnosis of intrapelvic conitions by the urine. His works on exploration of the renal funcions (1905) and surgery of the urinary passages (1909) are his lasterpieces.

Other French surgeons of note were Charles Sedillot (1S04-83), who prerrmed the first gastrostomy (1849); Paul Berger (1845-) , who wrote 1 exhaustive monograpb on the interseapulo-thoracic amputation (1856): Lathieu Jaboulay, who first deseribed the inter-ilio-abelominal amputation 894), and wrote an authoritative monograph on the surgery of the symparetie system and of the thyroid gland (1900), in which he was assoeiaterl with 
Antonin Poncet (1s[9-1643); Edmond Delormo (1St7- ), who int roduced the operation of decortication of the lunge for chronic ampyema (1s9.1-1901);

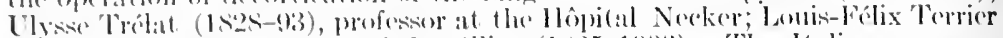

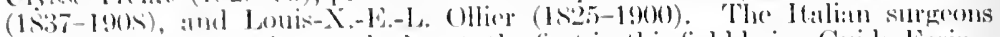
didsome bold operating on the heart, the first in this fold being Guide Farina, who sutured the right rentricle on dune s, isgti. The forst successful suture of the heart wats done hy L. Jehn at leankfort on the Main in 1596.2 Cardiolysis was proposed by Brature in 1902. Of the Swiss surgeons, JacepuesLonis keverdin (1s.2- ) and Theodor Kocher are memorable for their operations on the thyroid gland, and August socin (1\$37-99) for his work in military surgery $(1 \times-2)$ and surgionl diseases of the prostate (1575).

Sir James Paget (1S14-99), of Crout Yamonth, England, graduated from st. Bartholomew's Hospital, with which he was

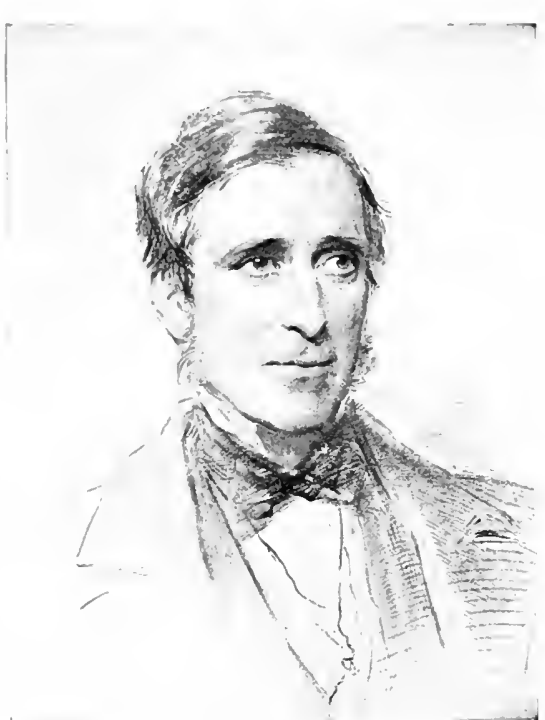

Sir James Paget (1814-99). (From a Portrait by George Richmond.) all his life associated, and was serjount surgeon to the Queen, receiving his baronetey in 1871. A warm friend of Virchow, Paget was, like Brodie, a great surgical pathologist, his best works being his Lectures on Tumours (1851), Surgical Pathology (1863), Clinical Lectures and Essays (1875), the catalogue of the Pathological Museum of the Royal College of Surgeons (1882), of which he was president (1875), and his original descriptions of eczema of the nipple, with subsequent mammary cancer $\left(1874^{3}\right)$, and the trophic disorder, osteitis deformans $\left(1877-82^{4}\right)$. He also made an early note of erythromelalgia (Weir Mitchell's (lisease), and his life-work illustrates how the surgeon proper can be a good clinical observer.

Sir Jonathan Hutchinson (1828-1913), of Selby, Yorkshire, also a St. Bartholomew's man, surgeon to the London Hospital (185983), and professor of surgery at the Royal College of Surgeons

1 Farina: Bull. d. r. Acrad. di med di Roma, 1S96-7, xxiii, 248.

${ }^{2}$ L. Rehn: Arch. f. klin, Chir., Berl., 1907, lxxxiii, 723-778; Rehn's case was alive when he wrote this paper, ten and one-half years after the operation had been performed.

${ }^{3}$ Paget: St. Barth. Hosp. Rep., Lond., 1874, x, 87-89.

${ }^{4}$ Mled.-Chir. Tr., Lond., 1s76-7, lx, 37; 18s1-2, lxv, 225. 
(1879-83), was also an able surgical pathologist, and is especially nemorable for his description of the notched, peg-shaped incisor teeth (Hutehinson's teeth) in eongenital syphilis $\left(1861^{1}\right)$, of varicella gangrenosa (1852*) and other skin diseases, and for his views of the causation of leprosy, which he attributed to eating fish. His name is further associated with the eponyms "Hutchinson's facies" in ophthahmoplegia, "Hutchinson's mask" in tabes, the uncqual pupils in meningeal henorrhage, and "Hutchinson's triad" (interstitial keratitis, notehed teeth, labylinthine disease) in syphilis, of which he saw over a million cases. His Archires of Suryery (1889-99) consist of ten volumes, issued in periodical form, the entire contents written by himself, forming a great storchouse of original observations on disease, which will sone day be studied like the works of John Hunter.

Hugh Owen Thomas (1834-91), a gifted orthopedist, of Liverpool, wrote much on fractures and deformities (1876-90), invented the extension splint which proved so valuable during the World War, devised the method of treating delayed union of fractures by passive congestion ("lamming the circulation"), later revived by Bier, and did much for the after-treatment of motor-nerve injuries.

Sir William MacEwen (1848- ), of Rothesay, Scotland, professor of surgery at the University of Glasgow (1892), is motable for his methods of osteotony for genu valgum (1881), radical cure of oblique inguinal hermia (1887), treatment of aneurysm by acupuncture (1890), and his monograph on Pyogenic Infective Diseases of the Brain (1893), which sums up his brilliant work on the surgery of the brain and spimal cord.

Sir William MacCormac (1836-1901), of Belfast, Ireland, saw a great deal of military surgery in the Franco-Prussian and TurcoServian wars, and early applied Listerian principles with success to the surgery of the joints and the abdomen, particularly in his pioneer operations for intraperitoncal rupture of the blatder $\left(1886^{3}\right)$.

Sir Vietor Horsley (1857-1916), of Kensington, Englant, wats a pioneer in experimental and neurological surgery, particularly in is operations on the ductless glands (188t-86), the brain (188630), and in his imitial operation for a tumor of the spinal cord diagnosed by Gowers, 18884), after which, as ('ushing says, "certain neurologists began to do their own surgery."

${ }^{1}$ Hutchinson: Brit. Med. Jour., Lond., 1 \$61, i, 515-519.

2 Med.-Chir. Tr., Lond., 1ss1-2, lxw, pp. i-ii.

${ }^{3}$ MacCormac: Lancet, Lond., 1s86, ii, 1118-1122.

${ }^{4}$ Sir W. R. Gowers and Horsley: Med. Chir. Tr., Lond., 1857-8, Ixxi, $77-430$. 
Horsley produed artifucial myxedema in the monkey by thyroidectomy (1sis). Wis one of the carliest operators for hypophyseal timors, and standarelized the operations of laminertomy, eraniotomy, and intradural division of

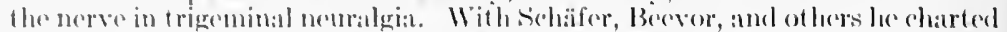

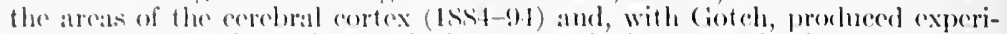
mental degenerations of the sipinal tracts and of currents in the cord (1891). His sulggestion that numaling would stamp out rabies proverl effective, and under his inspiration, l. C. Wooldridge made those experiments on saline blood congulation which led to the use of the normal salt solution.

Horsley, who came of a family of artists, was a man of aggressive, chivalrous temperament, and with a mind intensely alive. In politics he was dogmatic, self-centered, sometimes inconsistent, with no notion of compromise.

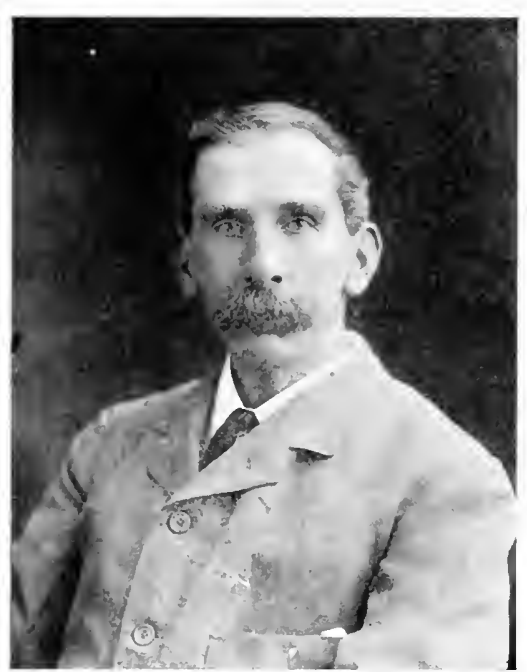

Sir Victor Horsley (1857-1916). IIis opposition to the use of alcohol and tobacco was hased upon isolated observations and experiences, and, although peremptory with his nurses, he was yet ardent for womansuffrage. He died for his country, having served in Egypt and Gallipoli, succumbing to heat-stroke in Mesopotamia.

Sir Frederick Treves (18.53- ), of Dorchester, Fngland, is widely known for his works on surgical anatomy (1853), intestinal obstruction (1SS4), appendicitis, and peritonitis, his System of Surgery (1895), and (with Lang) a very valuable dictionary of German medical terms (1890). He played an important part in the Transval War, has written some charming travel sketches, and performed the operation upon King Edward VII in 1902.

Two American surgeons whose life-work extended over into the Listerian period were Bigclow and Gross.

Henry Jacob Bigelow (1816-90), of Boston, Massachusetts, who became surgeon to the Massachusetts General Hospital (1846) and professor of surgery in the Harvard Medical School, was the leading surgeon of New England during his life-time. He was the first to excise the hip-joint in America (18.52'), and, in his monograph on dislocation and fracture of the hip $\left(1869^{2}\right)$, he first de-

1 Bigelow: Am. Jour. Med. Sc., Phila., 1552, xxiv, 90.

2 The Mechanism of Dislocation and Fracture of the Hip, Phila., 1869. 
scribed the meehanism of the iliofemoral or Y-ligament, emphasizing its importance in reducing dislocation by the flexion method. He also introduced the surgical procedure of litholapaxy or lithotrity for rapid evacuation of vesical calculus $\left(1878^{1}\right)$.

Samuel David Gross (1805-84), of Easton, Pennsylvania, professor of surgery at Louisville, Ky. (1840-56), and at the Jefferson Medical College, Philadelphia (1856-82), was the greatest American surgeon of his time. He wrote the first exhaustive treatise on pathological anatomy in English $\left(1839^{2}\right)$, which passed through three editions and was highly thonght of, even by Virchow. He also wrote an authoritative treatise on diseases of the genito-urinary organs (1851), containing the first account of the distribution of urinary calculus; the first systematic treatise on foreign bodies in the air-passages (1S.54), and an inportant two-volume system of surgery (1859), all these works being extensively illustrated. Gross invented many new instruments, made original experinents 1 pon the effects of manual strangulation (1836) and wounds of the intestines (1843) in animals, disscreted and deseribed specimens of

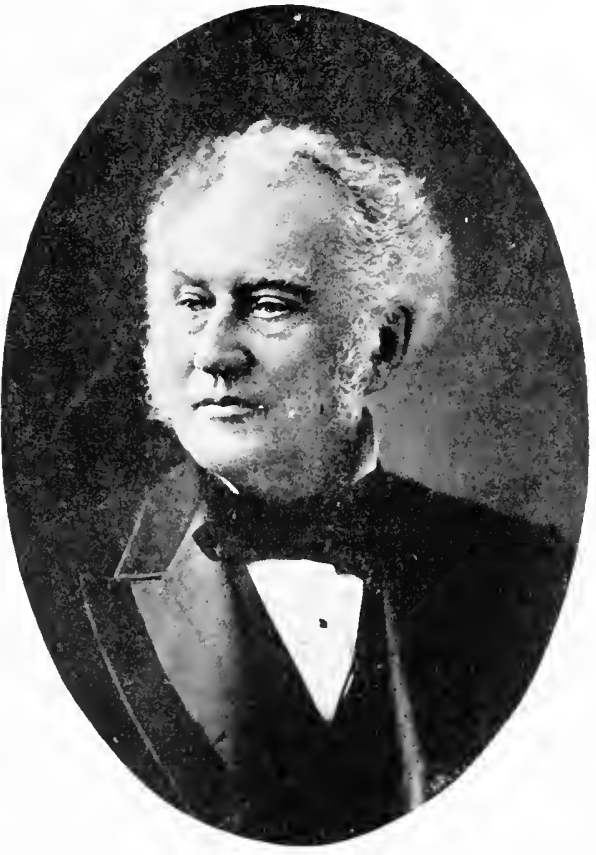

Samuel David Gross (1805-84). molar pregnancy (1839), introduced deep stitches in wounds of the abdominal wall, performed laparotomy for rupture of the bladder, myotomy for wryneck (1873), and first described prostatorrhea (1860). He knew the literature of his subject well, and his histories of Kentucky surgery (1851) and of American surgery down to the year 1876 are authoritative and accurate monographs. His biographies of Drake, McDowell, John Hunter, Richter, Paré, Mott, and others

1 Bigelow: Am. Jour. Med. Sc., Phila., 1s7s, lxxy, 117-134.

${ }^{2}$ Gross: Elements of Pathological Anatomy, Boston, $1 \$ 39$. 
alre all attractive realing. (iross was a strong personality a stalwalt figme, with a hoututiful, henignant eomntenance. His works were crowned, as the inseription of his funcral urn reads, by "the milk-mhite tlower of a stainlest life." His statue stands by the Army Medical Mnsenm, Mashington, D). ('. Me was the gheatest of the (iomman- Imerican physicians.

Millian Williams Keen (18:37

), of Philadolphia, professor of surery at the Jefferson Meclical colloge (I889-1907), is the anthor of an important work on the surgical complications and secpucls of typhoid forer (1s9s), and has been a brilliant and skilful operator, partidulary in discases of the brain. He diel much for lincar" andotomy (1891) and the inter-ilio-abdominal operation (1904). He is well known by his Amcrican Text-book (1899-1903) and his sistem of surger (1905-21), which are probably the best American works of their kind. Anong his historical essars, his Early History of Practical Amatomy (1870) is most valuable for its acruracy and thoromghness.

Christian Fenger (1840-1902), of ('hicago, was the first teacher of pathology in the Nidclle West, and did notable work on cancer of the stomach, hasal hernia of the brain, the ball-valve action of floating gall-stones, and, as a pioneer surgeon, in the operative approaches to brain abscesses, the ureters, and the bile-rlucts.

Nicholas Senn (1841-1909), of Buclus, switzerland, settled in the Inited States in 1852, graduated from the Chicago Medical ('ollege (1868), and became professor of surgery at the Rush Medical College of that city. Semn was a highly trained, scientific, surgeon, who nade valuable experimental contributions to the study of air cmbolism (1885), the surgery of the pancreas (1886), gunshot wounds, and intestinal anastomosis, in which he introduced the use of rlecalcified bone-plates. He was, in fact, a great master of intestinal surgery, especially in the treatment of appendicitis. He devised a method of retecting intestinal perforation by means of inflation with hydrogen gas (1885), and was the first to use the Roentgen rays in the treatment of leukemia (1903). Senn played an important part in the Spanish-American War, founded the Association of Military Surgeons of the United States (1891), and, at his rleath, left a fine collection of medical books to the Newberry Librarr, and other handsome bequests to the city of his adoption.

Other prominent American surgeons of the Listerian period are D. Hayes Agnew (1818-92), of Philadelphia, professor of surgery at the Cniversity of Pemsylvania, who was prominent in the case of President Garfield, and one of the few surgeons who practised medicine and surgery together; John Thompson Hodgen (1826-82), of Kentucky, who devised many instruments and apparatus, in particular, his wire suspension splints for fracture of 
the femur and forearm, which are still in use; Henry Orlando Marey (18:37- ), of Otis, Massachusetts, who introduced antiseptic ligatures in the radieal cure of hernia (1878), and wrote important treatises on hernia (1889) and the surgery of the perineum (1889); Robert Fulton Weir (1838- ), of New York, who has done much in visceral and articular surgery; (harles MeBurney (1845-1913), of Roxbury, Massachusetts, who discovered "MeBurney's point" as a sign for operative intervention in appendicitis (1889); Lewis Atterbury Stimson (1814-1917), of Paterson, N. J., author of treatises on fractures and dislocations (1899), operative surgery (1900), and of improvements in gynecological surgery; Lewis Stephen Pilcher (1845- ), of Adrian, Michigan, editor of Annals of Surgery (1885); Robert Abbe (1851- ), of New York (ity, who introdueed catgut rings in intestinal anastomosis and suturing (1892); Frank Hartley (1856-1913), of Washington, who originated intracranial nemrectomy of the seeond and third divisions of the fifth nerve for facial neuralgia (1892); George Michael Edebohls (1853-1908), of New York, who introduced the operation of renal decapsulation in the treatment of chronic nephritis and puerperal eclampsia (1901); Ceorge Ryerson Fowler (1848-1906), who first performed thoracoplasty (1893); Arpad G. Gerster (1848- ), of Kassa, Hungary, author of an early treatise on ascptic and antiseptic surgery (1888); Roswell Park (1852-1914), of Pomfret, Comecticut, prominent in connection with President MeKinley's ease, and author of a text-book of surgery (1896) and an attractive history of medieine (1897); Robert T. Morris (1857- ), of Seymour, Connecticut, author of many technical improvements and original ideas; William B. Coley (1862- ), of Westport, Connecticut, who introduced the treatment of inoperagle sarcoma with the mixed toxins of erysipelas and Bacillus prodigiosus (1891-1911), and the brothers, Charles Horace and William James Mayo, of Minnesota, authors of many accepted improvements in visceral surgery, whose genius for method and system at their hospital at Rochester, Minn., has made Listerian surgery almost as reliable a science as bookkeeping.

Prominent in orthopedie and plastic surgery were Frank Hastings Hamilton (1813-86), of Wilmington, Vermont, who was a pioneer in skin-grafting for uleers (1854), and wrote an important treatise on fractures and dislocations (1860); and Louis Albert Sayre (1820-1900), of New Jersey, "who performed the second excision of the hip-joint in America (1855) and introduced the method of suspension in a plaster-of-Paris Jacket for Pott's disease (1877).

The gynecology of the post-Listerian period was, in the main, a brilliant development of the operative principles which had been stablished by MeDowell, Sims, Emmett, and Battey in America, 
Kocberle in France, Custay Simon in Germany, and Sir Thomas Spencer Wells (1S1S-97) in Englund. The latter, one of the greatest of the ovariotomists, was a native of Saint Albans, Hertfordshire, a pupil of Stokes and (iraves in Dublin, and of Travers in London, Ifter serving seven years as surgeon in the Royal Nary (1St1-4S), including an experience in the Crimean War, he settled in london, and, in 18.58, performed his first suceessful ovariotomy, which was followed hy a large number of favorable experiences with the same operation. Phenomenal luck attended all his improvements in technic, and, in a few years, he was known

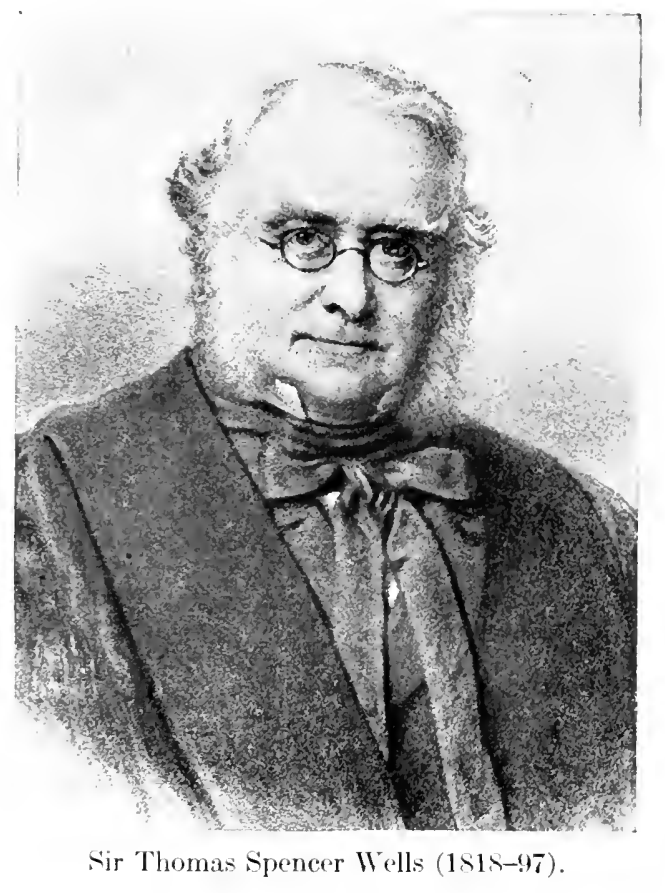

to his colleagues and sought by patients all over the world as an absolutely safe operator in ovarian conditions. His work was summed up in his treatise on Diseases of the Ovaries (1865-72). He was professor of surgery and pathological anatomy and president of the Royal College of Surgeons, and surgeon to the Queen's houschold, receiving his baronetcy in 1883.

A grnecologist of wider scope and even greater success was Robert Lawson Tait (1845-99), of Edinburgh, who settled in Birmingham in 1871, and made that eity another Mecea for female patients seeking operative relief. Tait's suceess in operating, as 
judged by his statistics, was marvelous. He rolled up ovariotomies ${ }^{1}$ and other abdominal sections by the thousands, with scarce a death, yet, strange to say, he was a violent and even truculent opponent of Lister, declining to see any causal relation between bacteria and disease, and pointing, with exiggerated scorn, to the fact that he never used any antiseptic precautions in his operations beyond simple cleanliness. The secret of his success was undoubtedly his wonderful skill, plus the use of warm or boiled water to flush out the abdomen, which was, of course, asepsis.

Tait performed the first successful operation for ruptured tubal pregnancy (January 17 , $1883)$, was the first to work out the pathology and treatment of pelvic hematocele, and, in his Lectures on these subjects $\left(18 S^{2}\right)$, he points out that the first authoritative treatise on extra-uterine pregnancy was written by John S. Parry (1S4376), of Philarlelphia (1876). In 1879 Tait excised the normal ovaries, ${ }^{3}$ along the lines laid down by Battey (1872-73), but elaimed that in none of his cases were the uterine appendages normal. This, with the similar operation of Alfred Hegar (1830) -1914) in 1s77, teveloped, says Kelly, "the whole feld of pelvic operations for diseases of the organs other than gross ovarian und fibroid tumors." "The peri-uterine phlegmons of Emnet and Thomas became recogized as tubal inflammations

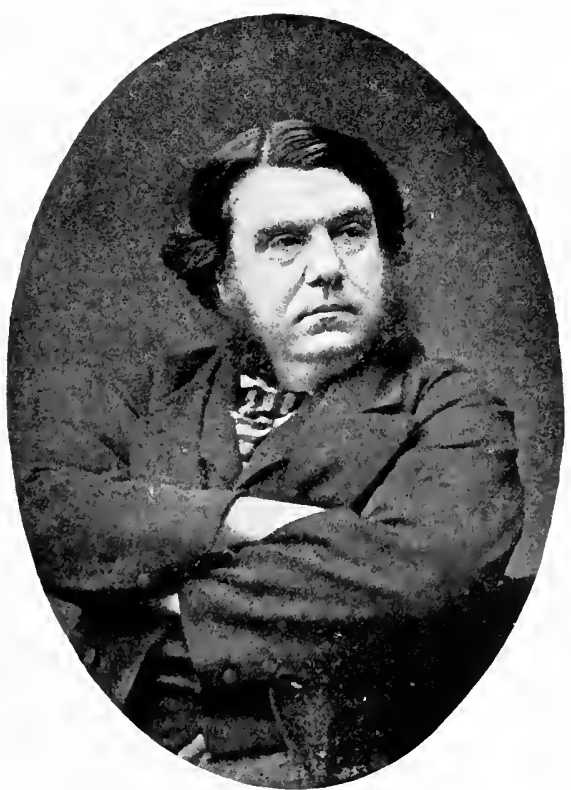

Robert Lawson Tait (1845-99). and abscesses." In 1879, Tait performed choleeystotomy, excision of hydrosalpinx and pyosalpinx, introluced his flap-splitting operation on the perineum, and his methods of dilating he cervix and of replaeing the inverted uterus. In 1SS0, he introdued sepatotomy, and, in 1851, he devised the special operation for excision of the terine appendages by securing the pedicle with a silk ligature, tied by means

1 Tait performed his first ovariotomy, July 29, 1868; removed an ovary or abseess, February 2, 1S72; excised the uterine appenclages to arrest the rowth of a bleeding myoma, August 1, 1s72; performed his first hystercetomy or myoma in 1873, removed a hematosalpinx, June 21, 1876; performed his rst eholeeystotony, and removed his first pyosalpinx and hydrosalpinx, in 879; and dirl a successful operation for ruptured tubal pregniney, Januiry 7,1883 .

2'Tait: Leetures on Ectopic Pregnaney and Pelvic Hamatocele, Birlingham, $18 s 8$.

${ }^{3}$ Brit. Med. Jour., Lond., 1s\$1, j, 766. 
of his invention, the "Staffordshere knot." Ils method of "flap-splitting" in plast je repair of the perinem was a valuable innovation $\left(1879^{2}\right)$, but it wats not taken up in Americal for a long time.

Tait left interesting summuries of conclusions from his operative statisties, treatises on discases of the ovaties (1873) and diseases of women (1579-89), and highly original essats on ralpe and other subjects connected with nedieal jurisprudence. In all these productions, ho is a forcible, effective, freguently coarse, but always amusing, writer.

() frouninent innovations in operative gynecology, we mity mention the different mellows of expising or emelesting uterine tumors introblued by Eugine Koeberló (1861), August d]artin (1876), Jiarl Sehrö̈ler (1878-81), and Vinernz ("zerny (1sis); of exeising the utcrus, by Wilhelm Nexander

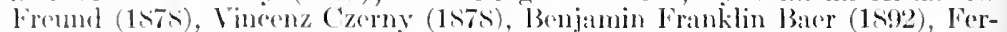
nand Ilenrotin (1s92), Jean-Louis Faure (1897) and by brnst Wertheim (1)6t-1920) in 1900, the improvements in myomestomy liy Ifenry O. Marcy (1S51), Joseph Price (1856), Lewis A. Stimson (1S59), Joweph R. Eastman (1sv9), William M. Polk (1S59), Florian Krug (1s94); of treating uterine displacements, by James Alexander Adams and William Alexinder (1S82), Jobert Olshausen (1886), Howard A. Kelly (18s7), and George Michael lickebhls (1901). The introduction of the standard hemostatie foreeps by Eugène Koeberlé (1865), his methods of liberating adhesions, of morcellement in enucleating fibroids (1865), of constrieting the pedicle in ovarian cysts (pédicule perdu), of pelvic drainage, were all great advances in operative technicule. The surgieal posture (elevation of the pelvis) introctuced by Friedriel Trendelenburg (1890) was another valuable device. The technic of Cesarean section was improved by Ferdinand Adolph Kehrer (18s2), particularly by Max Sïnger (1582), by Edoarlo Porro (1876), who first performel Cesarean sextion with excision of the uterus and adnexa (1876), and by Alfred Dührssen, who introduced the vaginal operation (1898). Excision of the vagina was introduced in 1895 by Robert Olshausen (1835-1915), the plastie reformation of the vagina by Alwin Kirl Mackenrodt (1S96), and a flap operation for atresia of the vagina by George Henry Noble (1900). Crsarean section in puerperal convulsions was introduced by Tjalling Halbertsma (1859). Pubiotomy as a substitute for symphysiotomy is associated with the name of Leonardo Gigli (1902). Extri-uterine pregnaney was studied by John S. Parry (1876); Lawson Tait, who performed the first successful tubal operation (1S83), by Richard Werth (1850-1919) in 1S57, Joseph Eastman (158s) Joseph Price (1853-1911) in 1890, John Clarence Vebster (1892), and B. J. Kouwer, who first deseribed ovarian pregnaney (1897). Nuch of the history of gyneeology up to recent times has been deseribed by Priestley as a siries of "erazes," a tendency to follow prevailing fashions. First of all came the uterine displacement craze, when Ciraily Hewitt in England, Velpeau in Franee, Hodge in Ameriea, ehampioned the cause of the pessary for the treatment of baekache or pelvic pain, and every gyneeologist felt himself called upon to invent one or to modify some one else's; the unfortunate uterus all the while being, as Allbutt says, either "impaled on a stem or perehed on a twig." The pelvie cellulitis eraze had its origin in the fact that, in 1857, Gustave Bernutz found a case of peri-uterine abseess due to inflammation of the pelvic cellular tissue, after which Bernutz and Goupil published their famous memoir on pelvic cellulitis (1862). This view of pelvic pathology was widely taken up until Gaillard Thomas exploded it in 1850, by showing that much of alleged cellulitis is really peritonitis, and that the former con-

1 Brit. Med. Jour., Lond., 18\$1, i, 766.

${ }^{2}$ Obst. Jour. Gr. Brit., Lond., 1s79-80, vii, 585-58s. Brit. Gynæc. Jour., Lond., 18\$7-\$, iii, 366: 1892, vii, 195. 
dition is rare in virgins. In like manner oöphorectomy, elitoridectomy, inflammation of the os and cervix uteri, excision of the uterus and its appendinges, operations for extra-uterine pregnaney, and Cesarean section all had their day, according to the dictates of fashion. Meanwhile very substantial work was done on the pathological side by C. A. Ruge and Johann Veit (1852-1917), who described erosions of the eervix uteri (1877), by A. J. Skene on the paraurethral glands (1850), by August Breisky on kraurosis vulva (1855), by Max Sïnger on decidual sareona of the uterus and other decidual tumors (1859-93), by J. Whitridge Williams on papillary cystoma of the ovary (1s91) and deciduoma malignum (1895), by Thomas $S$. Cullen on hydrosalpinx (1895), euncer of the uterus (1900), adenomyoma of the uterus (1908), and diseases of the umbilicis (1916), and by Georg Winter on gynecological diagnosis (1S96). The importance of latent gonorrhea in women was first emphasized in 1872 by Emil Noeggerath (1\$27-95), the general subject developed by Ernst voin Bumm (1SS5), Max Sänger (1859), and the uterine and vesical phatses (18956) by Ernst Wertheim. The treatment of uterine tumors by galvanism was introduced by Ephraim Cutter in 1874 and faradization was first employer by Georges Apostoli in $1854 .^{1}$

Samuel Jean Pozzi (1846-1918), of Paris, a highly skilled general surgeon, author of many papers on anatomy and abnormities, and deviser of many technical procedures, did most to make gynecology a going concern in France.

\section{Howard Atwood Kelly (1858-_ ), of Philadelphia, ${ }^{2}$ professor} of gynecology in the University of Pennsylvania (1885) and the Iohns Hopkins University (1889), who founded the Kensington Hospital in Philadelphia (1883), is a recognized leader of his science n America.

He was a pioneer in the use of eocaine anesthesia (1.584), in the treatment $f$ retroflexion of the uterus by suspension (1887), in the introduction of the perations of nephro-ureterectomy, nephro-uretero-cystectomy, vertical biection of the uterus in hystereetomy, bisetion of fibroid or ovarian tumors, orizontal bisection of the cervix for tumors and inflammation, and ideal apendicectomy; the procedures of aëroseopic examination of the bladıer and theterization of the ureters, exploration of the rectum and sigmoid flexure, iagnosis of ureteral and renal calculi by wax-tipped bougies, diagnosis of hyconephrosis by injection and measurement of the capacity of the renal pelvis, perating on the kidney by the superior lumbar triangle, treatment of maligint tumors by radium, and various improvements in the treatment of vesicotginal fistula. ${ }^{3}$ He is the inventor of the Kelly parl, new rectal and vesical recula, and his Operative Gynecology (1898) and Medical Gynecology (1908), th illustrated with Max Brödel's drawings, are full of improvements in his ience which have made these books among the best American treatises of the ne.

Kelly is also known by his valuable historical contributions on pnotism, American gynecology, appendicitis, vesico-vaginal fisla, medical botanists, medical illustration, and American merjal biography (1912, 2d ed., 1920). His Stereo-Clinic (1910-13)

${ }^{1}$ For bibliographical references to modern gyneeology, see Index Cata1 : ue, Surgeon General's Library, 1912, 2. series, xvii, 163-166.

${ }^{2}$ Born at Camden, New Jersey.

${ }^{3}$ For references, see the bibliography of Kelly by Miss Minnic W. Blogg i Bull. Johns Hopkins Hosp., Balt., 1919, xxx, 293-302. 
is a permanent photographic record of recent surgical procedures.

The tendency of recent grnecology to become merged into general abdominal surgery has been wittily signalized by Dr. Kelly as follows:

"The vital question which now affects gynecology is this, is she destined to live : spinster all her days? For we see her on one hand eourted by her obstetrieal ancestor, who sceks to draw her onee more into an unholy, unfruitful alliance, destined to rob her of virility, to be rocked into innoenous desuetude for the rest of her days in the obstetric cratle, sucking the withered ancestral finger in the vain hope of nourishment (with apology for mixed metaphor). On the other hand, we see her wooed by a vigorous, manly suitor, General surgery, seeking to allure her from her autonony into his own house, under his own name, obliterating her identity."

Although antisepsis, and even asepsis, had been introduced into obstetrics before the time of Lister, the principle did not begin to take hold until surgeon and obstetrician alike began to cleanse their hands in carbolic or bichloride solutions. The first to employ the carbolic solution in obstetrics was Etienne Tarnier of Paris $\left(1881^{1}\right)$, the inventor of the well-known axis-traction forceps $\left(1877^{2}\right)$ and the introducer of milk-diet in pregnancy.

Important features of the pre-antiseptie period were the artifcial induction of premature labor by Carl Wenzel (1S04), the use of ergot by John Stearns, of Massachusetts (1s08), the suggestion of ehlorine water to prevent infantile conjunctivitis by Gottfried Eisenmann (1830), the establishment of the contagionsness of puerperal fever by Holmes (1843) and Semmelweis (1847-61), the first findings of atbuminous urine in eonnection with puerperal convulsions by John C. W. Lever, of Guy's Hospital (18433), Crede's Handgriff (1854), the introduction of conbined eephalie version by Marmarduke Burr Wright, of Ohio (1854), and of eombined porlalie version by Braxton Hieks in 1 S64. In the early part of the eentury, the two Freneh midwives, Mme. Boivin (17731841) and IIme. La Chapelle (1769-1821), published noteworthy treatises on obstetries (1812 and 1\$21-25). Mne. La Chapelle's book, with its statistical deductions from 40,000 labor cases, had a good deal to do with the establishment of a proper norm or canon of obstetric procedure at the time. It was followed by sueh works as those of Velpean (1829), Cazeaux (1840), and Dubois (1849) in Franee; Caspar von Siebolıl (1841), Michaëłis (1842), Kiwisch (1851), Scanzoni (1852), and Carl Braun von Fernwald (1857), Otto Spiegelberg (1858), in Germany and Austria; Fleetwood Churchill (1834) and Francis Henry Ramsbotham (1841) in England; W. P. Dewees (1824), Charles D. Meigs (1849), Hugh I. Hodge (1864), and W. T. Lusk (18\$2) in America. The best recent Ameriean treatise is that of John Whitridge Williams (1903).

Morphologieal study of the deformed pelvis and of spinal deformity in relation to difficult labor has been almost exelusively in the hands of the German obstetricians. The obliquely eontracted pelvis (Naegele pelvis) was first described by Franz Carl Naegete in 1839, ant the oblique ovoid pelvis by Carl C. T. Litzmann in 1853 , the latter variety including the coxalgic, scoliotic, and kyphoseoliotic forms. The straight narrow pelvis, due to defective de-

${ }^{1}$ Tarnier: Tr. Internat. Med. Cong., Lond., 1881, iv, 390.

2 Ann. de gynée, Paris, 1877, vii, 241-261.

${ }^{3}$ Lever: Guy's Hosp. Rep., Lond., 1843, 2. s., i, 495-517. 
velopment of the saerum, was leseribed by Robert in 1 s42. The osteomalacic pelvis was first observed by William Hunter and described by the younger Stein. The rachitio or psemlo-ostemalacie type was described by smollie, Sandifort, and the younger Stein, and named by Michacilis (1851). The spondylolisthetic polvis was deseribed by Rokitansky in 1\$39, and carefully studied by Kilian as "pelvis obtecta" (1854). Rokitansky also introrluced the term "kyphotic pelvis." Batldeleceque was the first to observe and deseribe the funnel-shaped pelvis. The spinous pelvis (polvis spinosil) was derseribed and figured by Kilian in 18.54, while Michaëlis and Litzmann first studied the flat pelvis (pelvis plana Deventeri) and its raehitic variety. Congenital eleft of the symphysis pubis was observed by Bonnet (1724) and Creve (1795), and deseribed by Litzmam (1861). All these different varieties were carefully described by Gustav Adolf Michaëlis (1798-1848) in Das enge Becten (1851) and in Die Formendes Beckens (1S61), by Carl Conrad Theodor Litzmann.

After Semmelweis, the most prominent obstetricians of modern times were Simpson, Credé, and Braxton Hicks.

Sir Janjes Young Simpson (1811-70), of Bathgate, Seotland, became professor of obstetrics at Edinburgh in 1840 , and soon acquired an enormous practice through his great ability and fascinating personality. As the first to employ chloroform in olstetrics and labor (1847), he made a great name for himself in the history of his science. He introduced iron wire sutures (1858), the long obstetric forceps, acupressure (1850-64), and many new

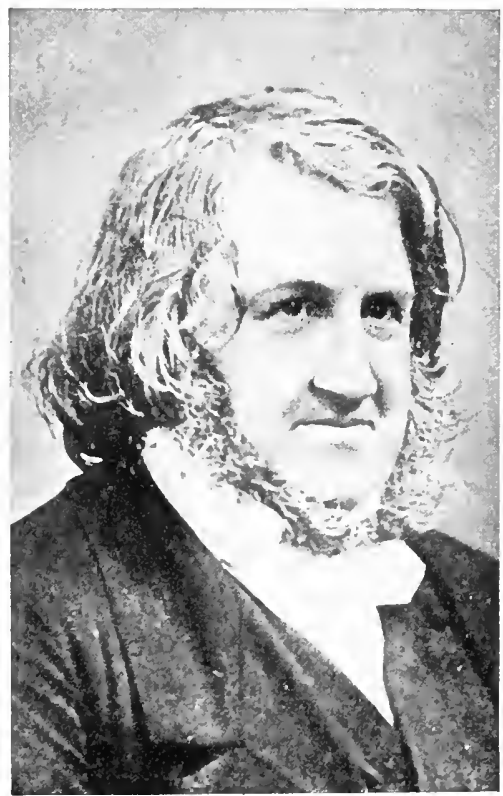

Sir James Young Simpson (1S11-70). "wrinkles" in grnecology and obstetries, such as the uterine sound (1843), the sponge tent, dilatation of the cervix uteri in diagnosis, "Simpson's pains" in uterine cancer (1863), version in deformed pelves. His memoirs on fetal pathology and hermaphroditism are noteworthy; and he also made valuable contributions to archeology and medical history, particularly on leprosy in Scotland (1841-42). He introduced village or pavilion hospitals, and, by his statistical investigations of the results of major operations (Hospitalism, 1869), did much to improve the status of hospitals. Although not without a certain touch of religious fanaticism, which may account for his somewhat blgoted opposition to Lister, he exerted a wonderful influence over his patients, and was, all in all, one of the most remarkable personalities of his time. 
Carl siegmund Franz Credé (1\$19-92), of Brolin, director of

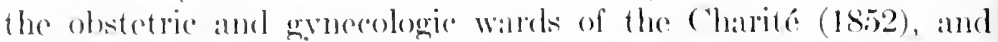

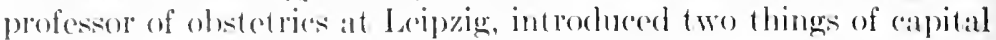
inportance in obstotric procedure-the method of removing the plarenta by oxternil manual rxplession (185t-6(0) ) and the prevention of infantile (eonorrheal) conjunctivitis by instillation of silrer nitrate solution into the ryes of the newborn $\left(188 t^{2}\right)$. He was colitor of the Momatsischrift fïr Goburtskunde (1853-69) and of the Archix für Ciynökologie (1870-92). He was an admirable teacher and a good organizer, having founcled the obstetric and

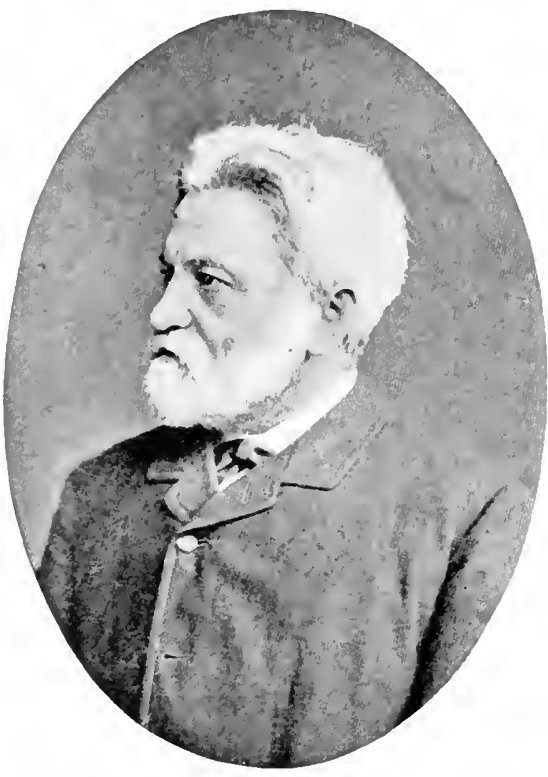

Carl siogmund Franz Credé (1\$19-92).

grnecologic polyclinic at Leipzig. The two innovations associated with his name entitle him to the permanent gratitude of mankind.

John Braxton Hicks (1825-97), of London, a famous teacher who held many honorable places, made an epoch in the history of obstetric procedure by the introduction of podalic version by combined external and internal manipulation $\left(1863^{3}\right)$, which forms a connecting link across the ages with Ambroïse Paré's famous

${ }^{1}$ Credé: Klin. Vortr. über Geburtshülfe, Berl., 1854, 599-603.

2 Die Verhütung der Augenentzündung der Neugeborenen, etc., Berlin, "18s4. Preceded by Gottfried Eisenmann's recommendation of ehlorine water in 1830 (Jacobi).

${ }^{3}$ Hicks: Tr. Obst. Soc. Lonrl. (1.63), 1S64, v, 219-259 (Appendix), 265. 
paper. Hicks's priority has been disputed in favor of Marmaduke Burr Wright, who, howrver, employed or recommended external handling in cephalic version (1854). Hicks's observations on the condition of the uterus in obstructed labor $\left(1867^{1}\right)$, and on accidental concealed hemorrhage $\left(1872^{2}\right)$, are also highly esteemed by the practitioners of his art.

In the post-antiseptie period, Adolf Cusserow (1836-1906) deseribed pernicious anenia in pregnancy (1871), Christian Wilhelm Brame (1831-92) studied pregnaney in frozen seetions (1872), Gustav Adolf Walcher (1856-

) introduced the hanging posture (IIängelage) in the conduct of normal labor (1859), Luigi Mlaria Bossi (1\$59 -1919 ) originated the induetion of premature laber by forced dilatation of the cervix (1892), Albert Döterlein (1860-1919) studied the relation of the vaginal seeretions to puerperal fever (1892), Fritz Momburg (1870-

) and F. La Torre int roduced the use of the abdominal ligature to prevent uterine hemorrhage (190S), and C. J. Gauss and Bernard Krönig (1863-191s), twilight sleep (1906$15)$.

Ophthalmology and the surgery of the eye were put upon a scientific basis mainly through the labors of three men, Helmholtz, Albrecht von Craefe, and Donders. When the ophthalmoscope was invented, von Graefe exclaimed: "Helmholtz has opened out a new world to us" (Helmholtz hat uns eine

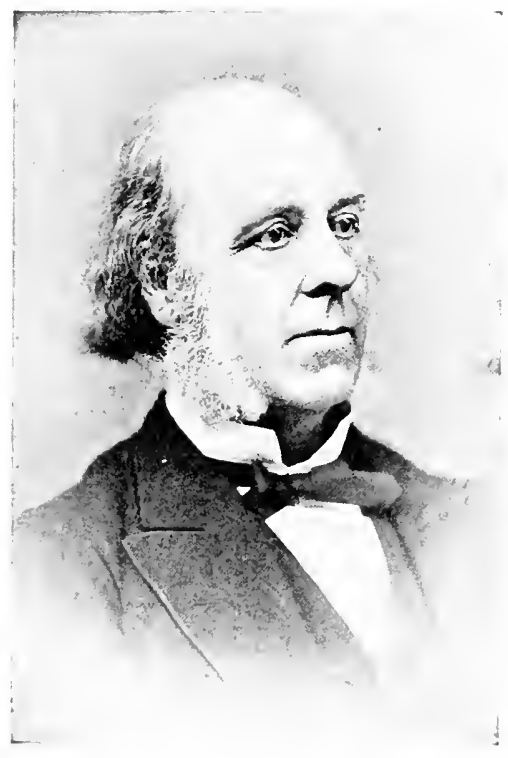

John Braxton Hicks (1825-97). (Boston Medical Library.) neve Welt erschlosen), and the usefulness of the instrument is sufficiently indicated by the fact that nearly evely prominent eye specialist of recent times has tried to add some improvement to it. Not only did it elucidate the disorders of the uveal tract, but even such obseure diseases as those of the brain, the kidneys, and the pituitary body. Bouchut, in 1893 , called the process "cerebroscopy."

Before the time of von Graefe, the infeetious forms of aranular conjunetivitis had been described by Baron Larrey (1802). John Veteh (1s07), and Jacob Christian Bendz (1855); William IIyde Wollaston hat inventerl uneriseopic speetacles (1803) and the eamera lueifla $(1807)$; Benjamin (ibson hat

${ }^{1}$ Ibid. (1867), 1s69, ix, 207-227!(Appendix), 229-239.

${ }^{2}$ Brit. Med. Jour. Lond., 1si2, i, 207. 
demonstrated that ophthatmia neonatorum is due to the vaginal sereretions

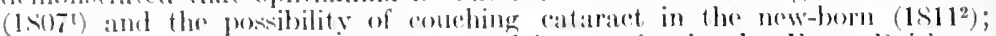

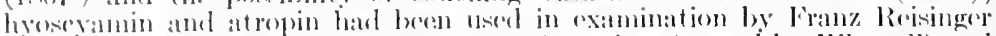

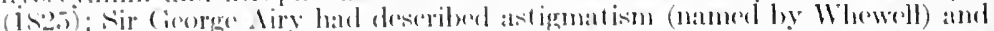

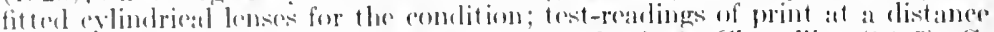

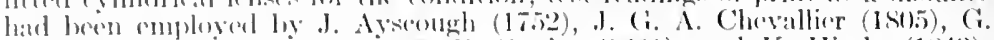

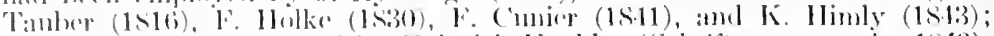

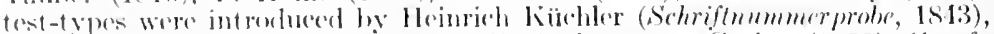

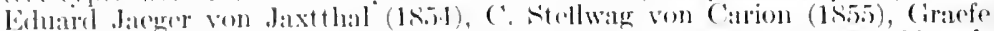

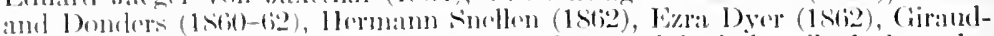

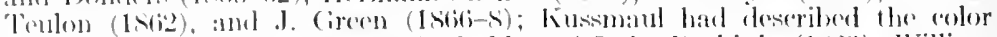
phenomena in the funclus (1s.5); J. Mery (1704), l'urkinje (152:3), Willian

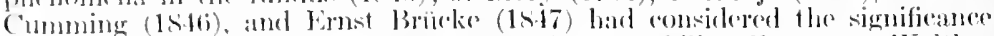
of lominosity of the eyo in vertebrates and man; Philip) Franz vom Walther

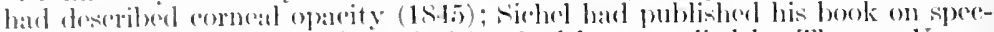

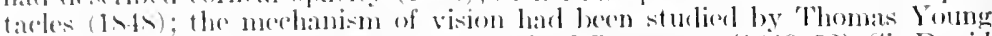

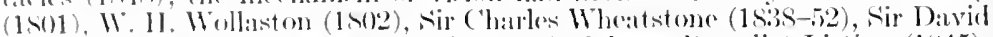

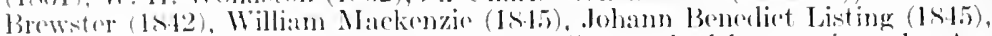
and Ildmboltz; anel good treatises on rye diseases had beren written by An-

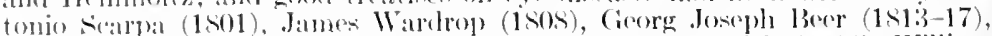

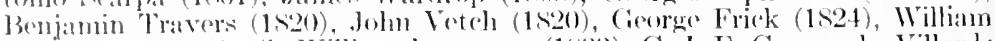

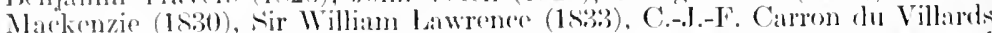
(1513), Friedrich Dugust von Ammon (1838-41), the Camadian Hemry lloward (1850), lianl Ilinly (1843). Louis-Anguste Domarres (1847), Carl Stellwag von Carjon (1,-i)-S), and Carl Foglinand von Arlt (185-6i). The surgery of the

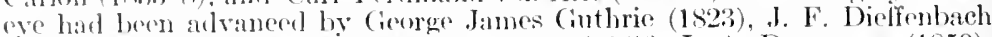
(strabismus, 1S42), Thomas Wharton Jones (1847), I.-A. Dosmarres (1850), and particularly hy vir Wilham 3owman (artificial pupil, 1852; lacrimal obstruction, 1857). In 1820). Captain Charles Barbier laid before the Aealemie des feieness a monograph on teaching the blind to read and write by a system of combinations of six elevated points, instead of embossed lines. The Barbjer six-point sytem was introdueed in Paris by Louls Braille, a blind teacher of the blind, in 1,29, and in 1836. Braille introdued his system of musieal notation for the blind. He acknowledged his indrbtedness to Barbier in the proface to his book $\left(1537^{3}\right)$. In $1845-7$, William Moon, of Brighton, England, introlueed the Roman line types which are still used, but by 1879 , the BarbierBraille vyes had become a workl-alphabet for the blind.

Albrecht von Graefe (1828-70), of Berlin, the creator of the modern surgery of the eye, and indeed the greatest of all eye surgeons, was the son of Carl Ferdinand von Craefe. After graduating in Berlin in 1847 , he was urged to specialize in ophthalmology by Arlt in Prague, and, having followed the elinies of sichel and Desmarres in Paris, the Jaegers in Viema, Bowman and Critchett in London, he soon obtained phenomenal success in his native eity, becoming professor at the Cniversity in 1857. In 1854, he founded the Archiv fur Ophthalmologie, which contains most of his important discoveries and inventions and has remained the leading organ of his specialty to date. The first volume alone contains his papers on the disorders of the oblique eye museles, the nature of glaucoma, keratoconus, mydriasis, diphtheritic conjunetivitis, and on double vision after strabismus operations.

1 Gibson: Edinb. Med. \& surg. Jour., 1807, iii, 159-161.

2 Ibid., 1811, v. 394-400.

${ }^{3}$ L. Braille: Procédé pour écrire au moyen des points, Paris, 1837. 
Von Graefe introduced the operation of iridectomy in the treatment of iritis, iridochoroiditis, and glaucoma $\left(1855-62^{1}\right)$, made the operation for strabismus viable $\left(1557^{2}\right)$, and improved the treatment of eatarict by the modified linear extraction $\left(1865-68^{3}\right)$, which reduced the loss of the eye from 10 to 2.3 per eent. He applied the ophthalmoscope to the study of the amblyopias in functional disorders with extraordinary suceess; made a brilliant diagnosis of embolism of the retinal artery as the eause of a case of sudden blindness $\left(1859^{4}\right)$, and proceeded to point out that most eases of blindness and impaired vision connected with cerebral disorders are traceable to optic neuritis rather than to paralysis of the optie nerve $\left(1860^{5}\right)$, as had been maintained before his time.

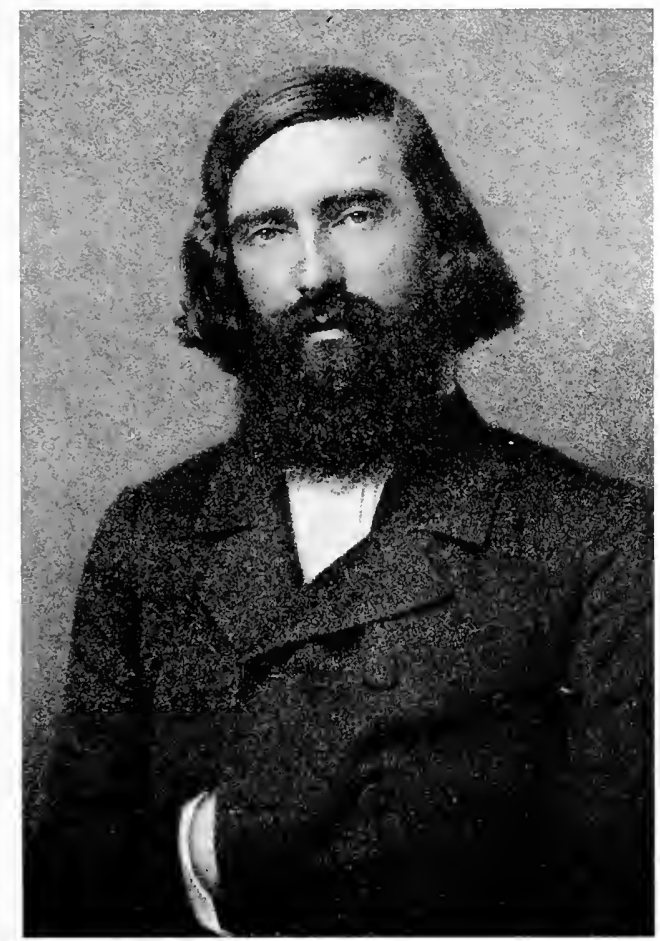

Albrecht von Graefe (1825-70).

Graefe was also the founder of modern knowledge of sympahetic ophthahmia $\left(1866^{6}\right)$ and the semeiology of ocular paralyses

${ }^{1}$ Graefe: Arch. f. Ophth., Berl., 1855-4i, ii, 2. Abth., 202: 1857, iii, 2. bth., 456: 1858, iv, 2. Abth., 127: 1862, viii, 2. Abth., 242.

${ }^{2}$ Ibid., 1857, iii, 1. Abth., 177-386.

${ }^{3}$ Ibid., 1865, xi, 3. Abth., 1: 1866, xii, 1. Abth., 150: 1868, xiv, 3. Abth., 16.

${ }^{4}$ Ibid., 1859, v, 1. Abth., 136-157.

5 Arch. f. Ophth., Berl., 1860, vii, 2. Abth., 58-71.

${ }^{6}$ Ibid., 1866, xii, 2. Abth., 149-174. 
(1Stifi), deseribed conical cornea, or "kiratoconus" (18542), and first noted the stationary condition of the upper eyclid, when the cychall is rolled up or down, in exophthalmic goiter (Cracfe's sign, 1S6. $\left.4^{3}\right)$. Ciracfes clinic hecame famous all over the worlel, and was followed, not so much by students as by practising physicians, who had come to Berlin to learn opht halmology from its greatest master. He was a man of refined, spirituel type, a Johamiskopf, as the Germans say, and his health did not long withstand the strain of such tremendous work as he aceomplished in so short a life. Ciraefe was fond of pranks and practical jokes, even after his youthful days were over, and many pun-

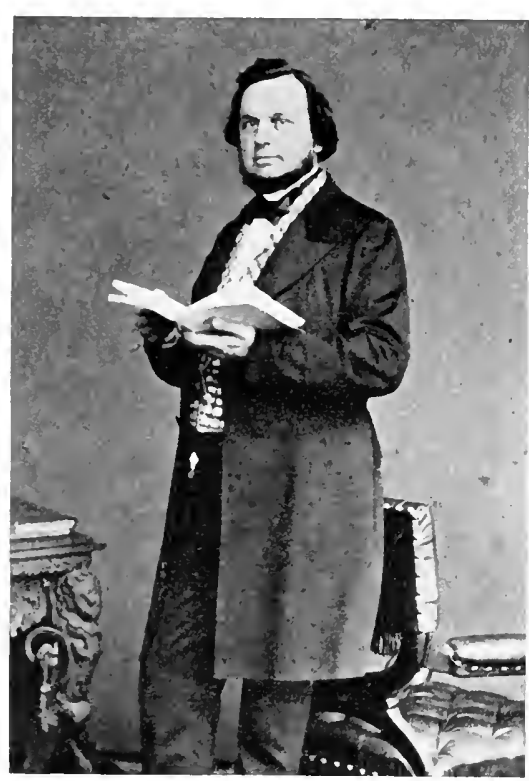

Frans Cornelis Donders (1S1S-89). gent witticisms attributed to him are still quoted and remembered.

Frans Cornclis Donders (1818-89), of Tilburg, Holland, was elncated as an army surgeon, but became a professor in the Utrecht Faculty in 1848, and, after 1862, devoted himself exchsively to ophthalmology. To this field belong his studies of the muscie volitantes (1847), the use of prismatic glasses in strabismus (18tS), the relation between convergence of visual axes and accommodation (1848), regeneration of the cornea (1848), hypermetropia (1858-60), ametropia and its sequels (1860), astigmatism (1862-3), anomalies of refraction as a cause of strabismus (1863), the invention of the ophthalmotonometer (1863), and, above all, his great work on The Anomalies of Refraction and Accommodation, which was published, not in Dutch, but in English, by the New Sydenham Society (1864). As a contribution to physiological opties, this book ranks with the labors of Helmholtz.

It contains Donders' explanation of astigmatism, his definitions of aphakia and hypermetropia, his sharp distinctions between myopia and hyper-

1 Symptomenlenre aer Augenmuskellähmungen, Berlin, 1867.

2 Areh. f. Ophth., Berl., 1854-5, i, 1. Abth., 297-306.

${ }^{3}$ Deutsehe Klinik, Berl., 1864, xvi, 158. 
metropia (as errors of refraction) and presbyopia (as senile ebange with diminished accommodation), his views of myopia as the result of exessive eonvergenee and the cause of genuine divergent strabismus, of hypermetropia as the cause of convergent stribismus, of the ciliary muscle as the only musele used in aceommodation and its action in bulging the antrior surfaes of the lens, and of asthenopia (eye-strain) as the result of anomalies of refraction, nuscular insufficieney, or astignatiom.

It has been the main source of knowledge on the improvement of clisorders of vision by speetaeles up to the time of Cullstrand. It is said that, while impatiently waiting for one of Ilelmholtz's ophthalmoseopes, Donders contrived one for himself in which the silvered miror with central perforation, now in use, was substituted for the superimposed glass plates of the Berlin master's instrument. In 18t5, Donders became editor of the Nederlandsch Lancet, and in 1851 he established the Netherlandish Hospital for Diseases of the Eyc (Nederlaudsch Gasthuis roor Oogleiden); but. his labors were not entirely confined to the eye. In 1863, he sueceeded schroeder van der Kolk as professor of physiology at Utrecht, and, in 1866, established the New Physiological Laboratory in the same city. His nost important contribution to physiology was the first measurement of the reaction time of a pstchical process (1S68 $)$. In 1845 he wrote on metabolism as the souree of heat in animals and plants, and his contributions on the physiology of speects $\left(1864-70^{2}\right)$ are of great importance. Donders was highly aceomplished, speaking English, French, and Cerman like a native, yet modest to the point of difficlence. His carlier military avocations gave him a polished tenue which, with his natural personal charm, made him known all over Europe as one of the most attractive specialists of his time.

Prominent among ron Crace's pupils wrere his nopterw Alfred Karl Graefe (1830-99), who made a rlinical analysis of disordered movements of the eye (185s), invented a special "foealization ophthahnoseope" for extracting deep-lying eysticerei, wrote a monograph on the troitment of infantile conjunctivitis hy caustics and antisepties (1SS1), and, with samiseh, editer the well-known Grate-Saemich IJandbuch der Ophthalmologie (1874-80); Julius Jacobson (182\$-89), of Konigsherg, who made a great improvenent. in the operative treatment of eatarat by his peripherat incison meler ehloroforn anesthesia (1S6i3), redueing the loss of the eye from 10 to 2 per cont., anul further improving the operation by extraetion within the (ausule (1Sis), originated the operative treatment of trachoma and trichiasis (1stis), whote a fine memoir on the work of his friond von (iracfo (185i), and rujoyed the largest consulting practice in sastern Europe, patients stroming in "yon from Russia; the brothers Alexander (1828-79) and Hermann Pagenstecher (1814), the former of whom made his niark in the history of eataract by the extraction of the tens in the closed capsule through a seleral incision (1sfiti); Edwin Theodor Saemisch (1833-1909), of Luckau, who first deseribed serpiginous ulcer of the cornea and its treatment $(1870)$ and vernal eomjunctivitis or Frïhahrskatark (1876), and alited the above-mentionol Iandbueh with

1 Arch. f. Anat., Physiol. u. wisemseh. Med., Berl., 1869, 657-681.

${ }^{2}$ De physiologic der spraakklanken, Utrecht, 1870. 
the younger Graefo; Julius Hirschberg (1S13-

), of Potsd:um, whose n:une is associated with the introduction of the clectromatgnet into ophthalmology (1S\$5), with a dictionary of ophthatmology (1857), with the editing of the Arabie texts $(1905)$, and with the most complete and seholarly history of his

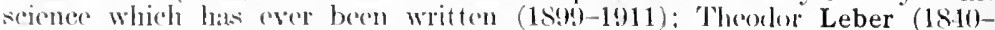
1917), whostulied the diabetie disorders of the ere (1875) and the disorders of circulation and nutrition of the rye (1576); Lidwig Laqueur (18:39-1909), who introduced the use of physentigmin in glatucoma (157i); Richard Liebreich (1830-1917), of Königsberg, who intrenluced lateral illumination in micreseopic invertigation of the living (eye (1855), and published the first at las of ophthahmoseopy (1sti:3), in which he was followed by Jaeger von Jixtthal

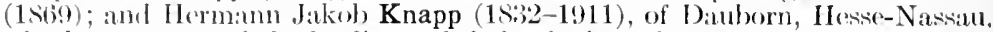
who bectune one of the leading ophthalmologists of New York City, founded the Archines of Ophthelmology and Otology (New York, 18(99), and wrote valuable memoirs on curvature of the cornea (1859) and intra-ocular tumors (1<ti9), and other sibjects.

On the didactic side, the most eminent living ophthahnoloxist is Einst Fuchs (1851- ), of Vienna, a pupil of Brüke and Billroth, Arlt's assistant (1876-80), professor of ophthalmology at Liège (1S80-S5) and Vienna (18S5), who is the anthor of important monographs on sarcoma of the uveal tract (1882), blindness (185.), and the histopathology of sympathetic ophthalmia (1905), of improvements of Jaeger's test-types (Leseproben für die Nähe, 1895), and of the outstanding German treatise on eye diseases (1889), which has passed through 12 editions and many translations, including the Japanese.

Of works relating to the normal eye we may mention Henry (iray's memoir on the optie nerves (1S49), Max Schultze's memoir on the anatomy and physiology of the retinis (1S66); the theories of vision of Helmboltz (1S67), Ewald Hering (1872-75) and Christine Ladd Franklin (1892); Willy Kühne's investigations of visual purple (1S77), and Johannes von Kries' memoir on the function of the rorls in the retina (1895). The examination of the eye was furthered by such inventions as the astigmometer (1867) of Emile Javal (1839-1907), of Paris; by the Javal-schiötz ophthalmometer (1881); by the method of retinoseopy introduced by Ferdinand Cuignet (1573), and by the keratoscope invented by A. Placirlo (1882). Color-blindness was investigated by the Swedish physiologist Alarik Frithiof Holmgren (1831-97), who introduced the wool-skein test (187t) and gave special consideration to colorblindness under railway and maritime conditions (1S78). The relation of eye-strain and astigmatism to headaches and other neurotic symptoms was first investigated by $\mathrm{s}$. Weir Mitchell (1874) and William Thomson (1879), and applied extensively to morbid psychology by George M. Gould (18ss). The work of Alexander Duane (1858- ) on aecommodation and on evolution of squint and of James Thorington (1558- ) on refraction (1916) has taught much. The relation of eye diseases to general and organic diseases of the body was especially treated by Richard Förster (1877) and in 1898 by Hermann Schmidt-Rimpler (183\$-1915), who was also, with Hermann Cohn (1S39-1906), a pioneer in the examination of the eyes of school-children. The bacteriology of the eye was especially advanced by Robert Koch, who discovered the bacilli of two different forms of Egyptian conjunctivitis (1883); by John E. Weeks, who found the same organism as the cause of "pink-eye" (1886); by Henri Parinaud (1844-1905), of Paris, who deseribed an infectious tubercular conjunetivitis transmissible from animals to man (1889), and a lacrimal pneumococcic conjunctivitis in new-born infants (1894), both associated with his name; and by Victor Morax and Theodor Axenfeld, who simultaneously described the diplobacillary form of chronic conjunctivitis 
(1596-97). In 1894, Axenfeld described in masterly style the pyemic or metastatic ophthalmia, first noted by J. IH. Meckel in 1854 . Apart from the Graefe-saemiseh Handbuch, the best modern works on ophthalnology are the monumental treatises of Ernst Fuchs (1S89, 12 ed., 1910) and Louls de Wecker (1832-1906) and Edmond Landolt (1S46- ), published 1880-89. Another good work is that of the Greek, Photinos Panas (1894), whose name is especially associated with an operation for congenital and paralytic ptosis (1S86). Besides the Americans already reforred to, we may mention IIenry Willard Williams (1\$21-1895), who introduced the treatment of iritis withont nercury (15.5) and a method of suturing the flap after cataract extraction (186t); Comelius Rea Agnew (1830-88), who described a method of operating for divergent squint (1\$66); Henry Drury Noyes (1832-1900), who first investigated retinitis in glyeosuria (1867); Lucien Howe (1848), author of The Muscles of the Eye (1907); Casey A. Wood (1856- ), editor of the Ameriean Encyclopedia of Ophthalmology (1913-21), notable for work on alcoholic amblyopia (1904) and a monograph on the fundus oculi of birds (1917); Edward Jackson (1856- ), editor of the Ameriean Journal of Ophthahmology (1898), author of a valuable work on skiascopy (1895); George L. deschweinitz (185s), author of a sterling text-book (1892), who has done?much valuable work on the toxic amblyopias (1896), and the work of E. Dyer on asthenopia (186.5); George $\mathrm{T}$. Stevens on elassification of the heterophorias $(1886)$; G. C. Savage on functions of the oblique muscles (1893), and Willitm $\mathrm{H}$. Wilmer on eye conditions in aviators (1918). Many instruments and test types have been invented, notably the electric light ophthalmoseope of II. S. Dennett, F. Buller's shield for ophthalmia neonatorum (1874), and the tangent-plane of Alexander Duane. Aside from the great work of Julius Hirseliberg (18991911), good histories of ophthalmology have been written by August Hirsch (1877), P. Pansier (1903), and Carl Horstmann (1905).

Laryngology and rhinology were specially arlvanced by the introduction of laryngoseopy by Benjamin Babington (1829), Robert Liston (1837), Manuel Gareia (1855), Ludwig Tïrek (1859-60), and Johann Czermak (1858); of rhinosiopy by Philipp Bozzini (1773-1809), in 1807, and (suecessfully) by Czemak (1859); of autoscopy of the laryns and trachea without the mirror by Alfred Irirstein (1\$6i3- ), of Berlin, in 1895, and of direet bronchoseopy by Gustay Iillian (1860- ), of Mainz, in 1s98. Laryngoseopy was introdueed in $\mathrm{N} \times \mathrm{W}$ York in 1858 by Ernest Krakowizer, of Vienna, who was the first physician in Ameriea to demonstrate the vocal cords. In 1858 also, Ephrain Cutter, of Massachusetts, devised a larvngoseope with two tubes, one for observation, one for illumination. Suspension-laryngoseopy (Schuebelaryngoskopie) was introdueed by Killian in 1912. The anatomy of the larynx and the physiology of the voice and speceh were investigated by Johannes Müller (1839), Ernst von Brücke (1856), F. C. Donders (1870), Hubert von Luschka (1873), and Carl Ludwig Merkel (Anthropophomik, 1876). MIax Schultze investigated the histology and nerve-endings of the sehneiderian membrane (1863), Emil Zuckerkandl the anatomy and pathology of the acessory sinuses (1S\$2-92), and Hendrik Zwaardemaker the physiology of smell (1895). A perfected method of photographing the larynx wits devised by Thomas Rushmore French in 1884. Important early treatises on laryngology were those of John Cheyne (1777-1836) on the Pothology of the Meimbrane of the Larynx and Bronchia (1809), William Henry Porter (1790-1Sti1) on the surgical pathology of the larynx and trachea (1826). Armand Trowssean and Hippolyte Belloc on laryngeal phthisis, chronic larvngitis, and disorders of the voice (1837), Horace Green (1802-66) on diseases of the air-passages (1846), Samuel D. Cross on forcign bodies in the air-passages (1854), Nir Morell Mackenzie on laryngeal tumors (1871). As Bryson Delavan says. ${ }^{1}$ the seiences of laryngology and rhinology were placed upon a firm literary basis through the three treatises of J. Solis Cohen (1S72), Sir Morell Mackenzie (1sio) and Francke Huntington Bosworth (1881). Intubation of the larynx in croup was

1 See his excellent historical sketch in Howard Kelly's "Cyrolopedia of American Medical Biography," Philadelphia, 1912. 


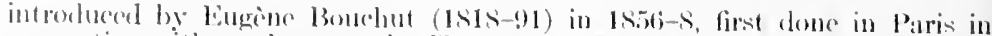

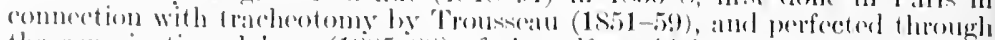

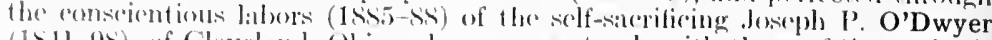

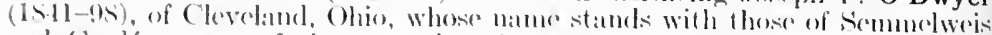
and croke as one of the great benefaletors of infant life. Horace Green

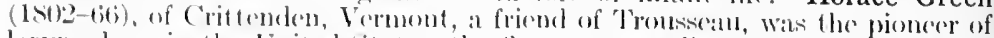
laryngoleng in the enited states, the dirst to treat diseases of the throat by local applications (Isis), the first to describe cystio and malignant lanyugeal growths (1sit-2), and the anthor of important works on cromp (1819) and the surgical treatment of polyps of the larym (15.52). In 1878, Clinton Wag-

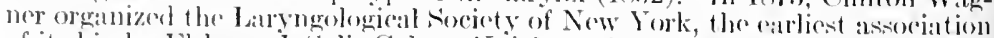

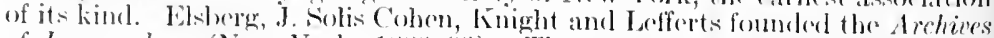

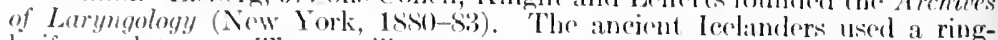
knife nvilotome. The tonsillotome was invented by P. S. Physek (1s28), and the ring-knife tomsillotome by Falnustock (15:32). Chardes llenri Ehrmann (1792-1s7s) was the first to remove a laryngeal polyp (1841); Vietor von Brums (1s12-13) fust enueleated a laryngeal polyp by the bloodlestinothod (1s62), and wis the pioned of laryngeseopic surgery (1s65); and Rudolph Foldolini (1s19-8!) first employed the galvanocautery in laryngeal surgery (1sit) and performed the first laryngeal operation through the month with external illumination (1889). Paralysis of the vocal eorels was first carefully sturliod by Carl (irduard in 1863-72. Ottomar Rosenbach, in 1s80, and later Sir Felix Semon stated the law governing the site of immolilization of the vocal cores in complete and incomplete paralysis of the recurront laryngeal nerve. The first important treatises on diseases of the nose were the Paris thris of Jacques-Louis Deschamps fils (1804) and the "Ophrésiologie" (1S21) of Hippolyte Cloquet (1787-1840), which were followed by such nose and throat treatises as those of Horace Croen (1846), Carl Seiler (1879), M. Bresgen (1881), 1. F. Ingals (1881), sil Morell Mackenzie (1880-84), C. E. Sajous (18\$5), Ottokar von Chiari (18S7), R. Voltolini (18S8), Lenox Browne (1890), and F. H. Bosworth (1890-92). In 1832, the explorer, George Catlin, mublished his classic on Mouth Breathing, based upon his observations of nasal obstruction in North American Indians. Benjamin Löwenberg was the first to consider the nature and treatment of ozena (1SS5), and Ludwig Grünwald (1863- ) the surgical treatment of nasal suppuration and disease of the ethmoid and sphenoid (1893). Ephraim Fleteher Ingals (1848-1918), of Iee Contre, Illinois, treated deflections of the nasal septum by partial excision in 18 82 , and this operation was finally perfected by Robert Krieg in 1889, Otto T. Freer in 1902, and Gustav Killian in 1904. Killian also originated the radiral operation for chronic inflammation of the frontal sinus (1903). The best histories of laryngology and rhinology are those of Louis Elsberg (1879-80), Gordon Holmes (1887), Jonathan Wright (1898, 1914), and the monumental work of $\mathrm{C}$. Chauveau on the history of diseases of the pharynx (Paris, 1901-
$\left.-06^{1}\right)$.

The foundations of otology were the catheterization of the Eustachian tubes through the mouth by Guyot (1724) and Cleland (1741), the mastoid operations of Petit (1774) and Jasser (1776), Cooper's perforation of the tympanic membrane for deafness (1800), and the monographs of Valsalva, Cotugno, scarpa, and others. The first treatise on diseases of the car was written by Jean-Mare-Gaspard Itard (1775-1838), of Oraison (Provence), in 1821, and this important work was followed by such treatises as those of Joseph 'Toynbee (1860), Anton Friedrich von Tröltsch (1866), Lawrence Turnbull (1872), Sir William B. Dalby (1873), St. John Roosa (1873), Adam Politzer (1878-82), Victor Urbantschitsch (1880), and Friedrich Bezold (1906). Max Schultze deseribed the nerve-endings in the labyrinth (1858), Helmholt $z$ the mechanies of the ossicles and membrana tympani (1869), Goltz the physiological significance of the semicircular eanals $(1870)$, the younger [Magnus Christian] Retzius wrote an important monograph on the vertebrate ear (18S4), Julius Richard

${ }^{1}$ For bibliographic references to this section see Surgeon-General's Catalogue, 1912,2 . s., xvij, pp. 171,172 . 
Ewald studied audition in birds deprived of the labyrinths, and Stanislat Stein the functions of separate parts of the labyrinth (1894). Aram Politzer (18351920), of Alberti, Hungary, was the first to obtain pietures of thr membrama tympani by illumination (1S65), which he afterward illustrated in an atlats of 14 plates and 392 pietures $\left(1896^{\circ}\right)$. The transmission of sounds through the cranial bones in diagnosis of aural diseases was first studied by Johtmn C. A. Lucare (1870), and great advanees in exploration were made by friofrich Bezold (1842-1908), of Rothenburg ob der Tauber, who gave the first clear description of mastoditis (1577), introdueed new tests for audition in deafmutism $(1896)$ and in unilateral deafness $(1597)$. Among other arlvances were the Weber and Rimné tests, Hartmann's diapasons, and Sir Franeis Galton's whistle for determining the superior limits of audition. The pionerers of aur:al surgery in the nineteenth century were Sir Astley Cooper (1S01) and Sir William Vilde (15 $43-53$ ), and after their time the most important English work on the subject was that of James Hinton (1527-75), of Guy's Hospital (1574). The modern surgery of the ear and mastoil has been mainly the work of the Germans. In 1873, Hermann Schwartze (1837-1910) and Adolph Eysell described the method of opening the mastoid by chiseling (typische Aufmeisselung). This operation was further improved hy Emanuel Zaufal (1S\$4) and Ernst Küster (18\$9), while Ludwig Stacke (1\$59-191S) introduced excision of the ossicles (1890) and greatly improved the surgery of the midllle ear (1892-97). Aural vertigo was first deseribed by Prosiper Ménière (17991862) in 1861, was again noted by Chareot as "vertigo ab aure laesa" (1S74), while the relations between nystagmus and vestibular or eerebellar disease had been noted by Purkinje and Flourens, and have been developed, in the twentieth eentury, by Robert Báriny. The authoritative history of otology by Adam Politzer is now eompleted (1907-131).

Modern dentistry, since the days of Fauchard, Pfaff and Hunter, has been largely developed by Amerieans. ${ }^{2}$ On the teehnical side, the hand mallet (E. Merrit, 1838), vulcanite artificial dentures (Charles Goodyear, jr., 1855), the rubber dam (S. C. Barnum, 1864), the use of amalgams, the Morrison and Bonwill dental engines (1S70-71), erown and bridge work (C. M. Richmoml, 1878), the use of amalgams and poreelain inlays and other devices are nearly all of American origin. The science of malocelusion and its treatment by orthodontal procedure originated with Fauchard (172S) and John Hunter (1771) and has had a lengthy and complex history culminating in the epochal work of Edwin Hartley Angle, who, sinee 1S57, has devoted over thirty years to the classification of the different modes of malocelusion, their treatment by the many technical appliances of his invention, ${ }^{3}$ the organization of a School of Orthodontia (1900) and a Society of Orthodontists (1901). Dental bacteriology, upon which aseptie and antiseptie dentistry is based, was developed by Willoughby Davton Miller (18.53-1907), an American professor in Berlin. The treatment of pyorrhea alveolaris by seraping was introdueed by John M. Riggs (1S76). Modern maxillo-faeial surgery, which made such a remarkable record in the European War, owes much to Simon P. Hullihen, James Eilmund Garretson (1828-95), Norman IV. Kingsley (1829-1913), Truman W. Brophy, Thomas Fillebrown (1836-1908), Matthew H. Cryer, John S. Marshall, Thomas L. Gilmer (1S49- ), Vilray Papin Blair (1Si1), and other Americans, and latterly to such Europein surgeons as Pierre Sebileau, A. C. Valadier and H. D. Cillies (Plastic Surgery of the Face, 1920). In England dentistry was lifted from the status of a trade to that of a seienee

1 For bibliographie referenees to this section, see Surgeon General's Catalogue, 1912, 2. s., xvii, pp. 172, 173.

2 See Dental Cosmos, Phila., 1920, Ixii, 1-73.

${ }^{3}$ E. H. Angle: Malocclusion of the Teeth, Philadolphia, 1Sst (7. ed., 1907). For the history of ortholontia, see B. W. Weinberger: Intermat. Jour. Orthodontia, St. Louis, 1916-19, passim, and for Angle's work, Ibid., 1919, $\mathrm{v}, 50 \mathrm{0}-527$. 1890.

IV. D. Miller: The Mieroörganisms of the Human Mouth, Philadelphia, 
Ly sir John Tomes (151i-95), a surgeon, who early made his mark by his studies on the histology of bone and teeth (1St9-isti), invented a pratetieable dental forcens (1539-10), wrote a woll-known s'ystem of Dental surgery (1859), Wiss one of the founders of the Odentological society (1Siti) and the Dental llespital (155s), and wis instrumental in securing passinge of the Dental Aet (1sis), for the compulsory colucation and registration of dentists.

Neither the English nor the French clinical medicine of this period had the rigorous scientific tenden'y which characterized the German. In England, pathology was little studied after the time of Bright, Hodgkin, and Addison, although the English talent for cal'oful clinical observation was amply illustrated. The brightest phase of French medieine in the second half of the nineteenth century was its neurology. With the exception of Chareot, most of

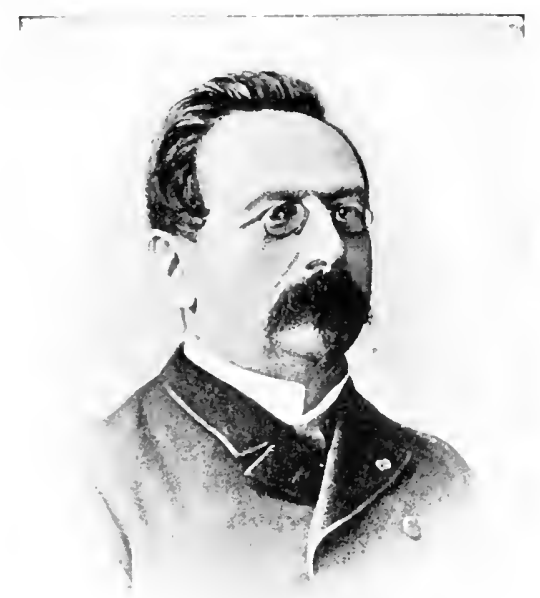

Jean-Antoine Villemin (1827-92).

the French clinicians of the time were brilliant and elegant expositors of internal medicine, as Helmholtz has described them, rather than original workers in pathology. Indeed, as we shall see, there are no professional pathologists in French medical schools, their places being supplied by physicians practising in hospitals.

In experimental medicine, Jean-Antoine Villemin (1827-92) of Prey (Vosges), a medical graduate of Strassburg (1852), and professor at Val de Grâce, achieved an undying reputation by his proof that tuberculosis is a specific infection, due to an invisible, inoculable agent and transmissible by inoculation from man to the lower animals (1865-69). Before the advent of Pasteur, these ideas could gain no credence, although Villemin did what he could 
to spread the doctrine of contagious phthisis. In 1870 , he told his aids at Val de Grâce that "the phthisical soldier is to his messurate what the glandered horse is to its yokefellow."

Of the French clinicians, Armand Trousseau (1801-67), of Tours, a pupil of Bretonneau, professor in the Paris Faculty (1850) and physician at the Hôpital St. Antoine (1839) and the Hôtel Dieu (1850), occupied about the same position in French medicine as Bright and Addison, Stokes and Graves over the Channel. He received the prize of the Academy of Medicine for his classical treatise on laryngeal phthisis (1837), was the first to perform tracheotony in Paris (18131), and was a pioneer in the introduction of thoracent esis (1843) and intubation (1851). He first described gastric vertigo and a diagnostic sign of infantile tetany, consisting of the voluntary reproduction of the paroxysms during the attack by compressing the affected parts. His Clinique médicale de l' IIôtel. Dieu (1861), which passed through three editions, contains his best work, much of which has silently taken

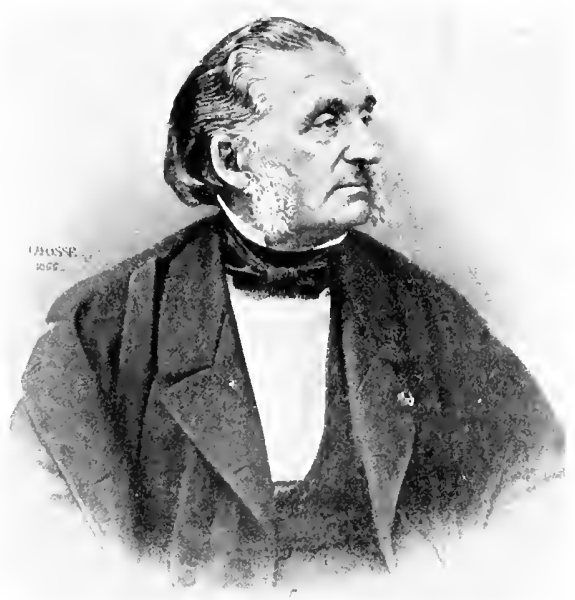

Armand Trousseau (1.801-fi7). its place in the text-books.

He was a man of big personality, a great master of clinical delineation, and a generous interpreter of the ideas of other men, particularly of the diseases described by Bretonneau, Addison, Hodgson, Corrigan, and Duchenne of Boulogne. His last mupils were Dieulafoy and Dal Costa.

Georges Dieulafoy (1839-1911), of Toulouse, who wrote the most readable French treatise on internal medicine in his day (1880$84^{2}$, and is otherwise remembered by his employment of the trocar in the treatment of pleurisy, hydatids, ete. (1869-723), was a fiery clinieal orator of the meridional type, who never bothered himself about scientific speculations, but built up a large elientile and as a wise humane physician, enjoyed the expression or exploitation

1 Jour. de conn. méd.-chir., Paris, 1833-34, i, 5; 41.

${ }^{2}$ Dieulafoy: Manuel de pathologie interne, Paris, 1880-84.

${ }^{3}$ De l'aspiration pneumatique sous-cutanée, Paris, 1870. 
of his personality in the elinies. Handsome and gaty (le bean Dienlefoy), he wats gifted with great powers of elocution and mimicry, a natural hom actor, with the gestures and intomations of an Italian tonor des gestes qui implorent ol qui caressentand ho always suceroded in posing his diagnosis in a way to excite the greatest admiration. At the bedside, Dienlafoy was ideal. $A$ physician of alert intedigenes and fascomating personality, who at latst endeavoled to make his teaching anything but clull, his passion was to show his pupils how to got good amswers by asking the right guestions, without offending or tiring the patients. The patient he hold to be entitled to the highest consideration and sympathy. He had an exedlent classical education and first attracted Trousseats's attention by helping him out with a citation from Ovid. He did good work in separating out the complications of appendicitis and other minutia. In his spirited rlinical improvisations, he excelled in coining such expressions as "le foie appendiculaire," which illustrate his virtuosity in the use of the French language, but convey nothing very definite to the mind. A tablet to his memory was set in the walls of the Amphithéâtre Trousseau in 1914.

sigismond Jaccoud (1830-1913), of Ceneva, was another prominent Paris internist, whose treatise on practice (1871) and clinical lectures (1867-88) enjoyed about the same reputation as Dieulafoy's.

Jean-Alfrel Fournier (1832-1914), of Paris, professor in the Paris Faculty, whose name is associated with the great venereal rlinic at the Hopital St. Louis, was reputed as a teacher of great power, possessed of a clear, harmonious voice, full of the finest delicacy and courtesy to patients or pupils, universally liked, and penetrating even the dullest minds by his luminous intelligence and rear, effective mode of expression. With Diday, of Lyons, Fournicr did most to develop the subject of congenital syphilis, in which he brought "order out of chaos." Practically all his life had been devoted to the study of this discase, to every phase of which he arlded something of clinical importance, as also to its soeial aspects (Syphilis et Marriage, 1890). He introduced the conrept "parasyphilis" and his statisties on the causal relation of lues to ataxia and paresis $\left(1876-94^{1}\right)$ are, with those of Erb, the most important contributions to the subject. In March, 1901, he founded the Society of Sanitary and Moral Prophylaxis. Fournier is described as a keen-eyed, close-cropped military figure, looking like an old artillery officer.

Henri Huchard (1844-1910), of Auxon (Aube), was a clinician

${ }^{1}$ Fournier: Les affections parasyphilitiques, Paris, 1894. 
of the same effective trpe. He is especially remembered for his studies in therapentics, his Traité des néroses (with Axenfold, 1883), his great monograph on disorders of the circulation (18.99), and particularly by his work on the clinical forms of arteriosclerosis (1909), which he did most to develop).

Charles-Jacques Bouchard (18:37-1915), late dean of the Paris Faculty, a masterful, dominant figure, deseribed the fulgurant pains of ataxia with (hareot (1866), was the first to call attention to autointoxication (1887) and to diseases caused by diminished nutrition (1879-80), and wrote a treatise on general pathology (1899), which was a popular students' text-book.

Among the original contributions of French elinicians are J.A. Villemin's proof of the inoeulability of tuberculosis (1568), the theses of L.-A. Than and Jaeques-Joseph Grancher (1843-1907) on the unity of phthisis (1573), Joseph Dumoutier's aecount of sleeping rickness (1stis), Paul Lorain's delincution of sexual infantilism (1871), the deseriptions of ehronic interstitial hepatitis (1874) by Georges Hayem (1841- ), of cirrhotie jammlice (1875) by Vietor-Charles Hanot (1844-96), of primary endotheliomatous hypertrophy of the spleen (1882) by Ermest Gaueher (15.5-1918), of enteroptosis. and gastroptosis by Frantz (ilénard (1855), of paralytie vertigo (kubisigari) by $\mathrm{F}$. Cerlier (1856), of primitive caneer of the panereas by Ionis Bard and Airien Pie (1888), of eymotic polyeythemia by Henri Viquez (1892); Ch. Bouchard (1857) and A. Combe (1907) on auto-intoxieation; the definition of the emeept "acetonemic vomiting" (1905) by B.-J.-A. Marfan and others; and the pediatric treatises of Charles-Miehel Billard $(1 \times 2 S-33)$; and of $F$. Rilliet and A.-C.-E. Barthez (1S3\$-43), which contains an carly aecount of poliomyelitis. Of later French pediatricians, Jarques-Joseph Grancher (1813). Jules Comby (1853-) and B.-J.-A. Marfan (1858-) are prominent as authors of treatises and monographs and editors of pediatric journals.

German clinical medicine in the second half of the nineteenth century includes such names as Frerichs, Traube, Kissmaul, Gerhardt, Ziemssen, Leyden, Senator, Naunyn, and Friedrich Müller.

Friedrich Theodor von Frerichs (1819-85), of Aurich, graduated it Göttingen in 1841, and soon achieved a reputation as an ophhalmologist, but afterward went over to seientific and internal nedicine and became one of the founders of experimental patholgy. He received his professorship at Göttingen in 1848, aftervard holding chairs at Kiel (18.50) and Breslau (1852), succeeding schölein at Berlin in 1859 . Frerichs seems to have attained the ummit of his profession in a surprisingly short while, and his ourse from Göttingen to Berlin has been likened by Naunyn to al riumphal progress. Students humg upon his lips, and his coleagues revered his wonderful precision in diagnosis. At forty, he tad already done his best work, his great monograph on digestion n Wagner's Dictionary of Physiology, his discovery of leucin and yrosin in the urine of acute yellow atrophy of the liver $\left(18.5 .5^{I}\right)$,

${ }^{1}$ Freriehs: Deutsehe Kolinik, Berl., 1855, vii, 341-343. 
his pathological studies of cirthosis of the liver, pernicious malarial ferer, and melanemia, and his books on Bright's discase (1851') and diseases of the liver $\left(1558^{2}\right)$. Yet, at Berlin, as his pupil, Namyn, tels us, Ferichs semed, at the height of his reputation, to molergo a sort of spiritual and intellectual blight. Apart from his students, of whom he had always a large following, he became sechuded, reserved, and querulous, and wrote little. The second volmme of his work on discases of the liver (1868) is said to show a

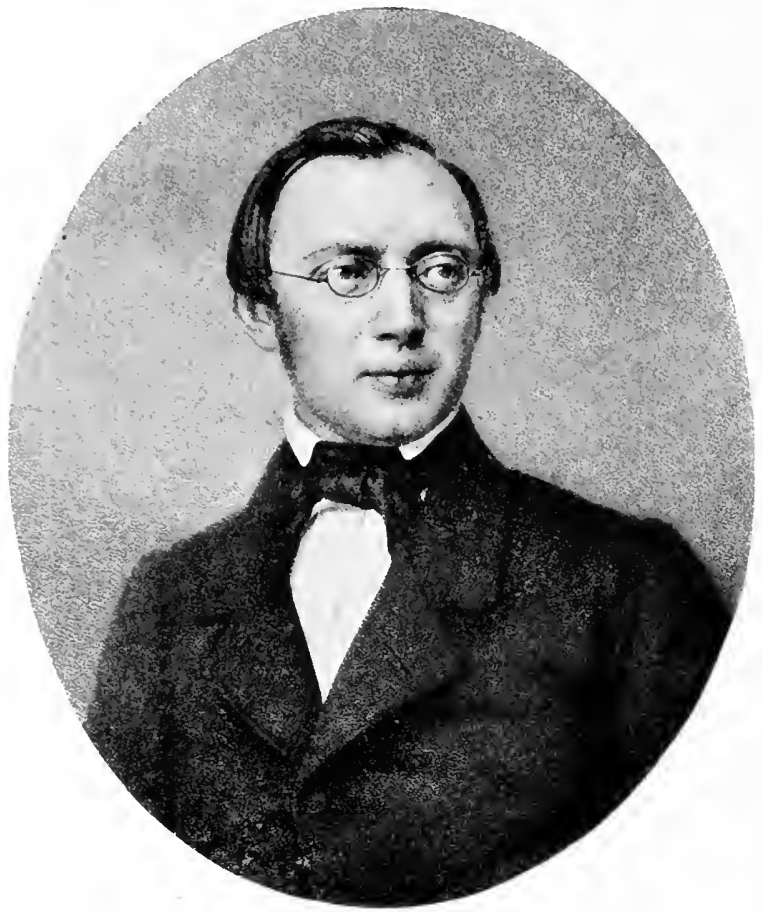

Friedrich Theodor von Frerichs (1819-85).

distinet falling off in talent, although his lectures were always highly esteemed for their beautiful coneision and aceuracy, and he enjoyed an enormous consulting practice. This change in Frerich's personality was due, Naunyn thinks, to his extreme sensitiveness to criticism; to the opposition which he encountered in Berlin, especially from his mistakes about the origin of the bile-pigments and acids; to his falling out with Traube, his colleague at the Charité, and to the aggressive enmity which he encountered at the

1 Die Bright'sche Nierenkrankheit, Braunschweig, 1851.

${ }^{2}$ K'linik der Leberkrankheiten, Braunschweig, 1858. 
hands of Virchow. So strong was Virchow's personality that even Graefe and Langenbeck lined up with him in official opposition to Frerichs, whose productiveness was soon sterilized by this professional jealousy. It was under the sympathetic influence of Leyden, who came on at the Charité in 1876 and eventually sueceeded him, that he brightened up again and produced a monograph worthy of his fame, his work on diabetes $\left(1884^{\prime}\right)$, based upon 400 cases and 55 antopsies. The elinical lectures of Frerichs, which he delivered offhand, are described by Naunyn as of classic perfection of phrase, clear and plastic in the delineation of disease, and as having a rare freshness from the number of facts drawn from his own experience. His diagnoses, which he made offhand, directly upon seeing the cases, were usually intuitive, always developed as a disturbance of physiological function, and never admitted to be wrong. Like Skoda, Frerichs was indifferent to patients, even to students, carng only for the scientific ispects of the disease itself, lthough he always condecended to outline a course of reatment, including a precription. In person he was all and ungainly, yet imposing hrough his style of delivery, which was frequently dranatic. The interests of Freichs is that he developed sei-

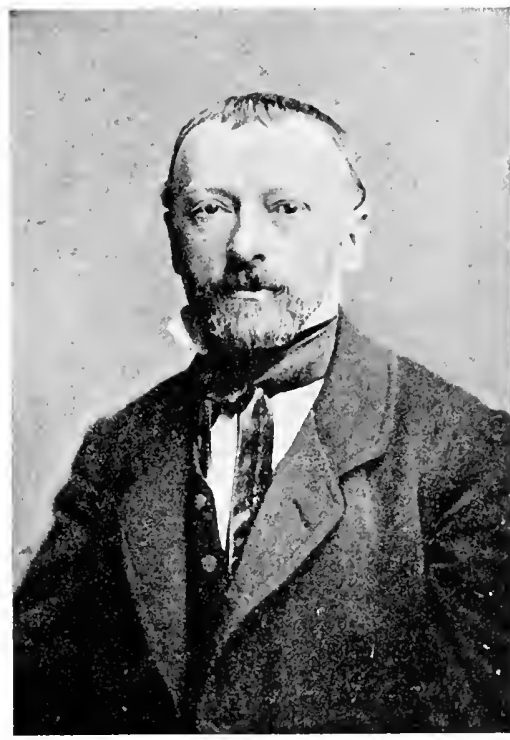

Ludwig Traube (1S18-76). " (Boston Medieal Library.) ntific clinical teaching in iermany. His pupils include some of the brightest spirits of hodern times, such men as Ehrlich, Naunyn, Leyden, and von Iering.

Ludwig Traube (1818-76), of Ratibor, Silesia, was a pupil of 'urkinje, Johannes Müller, Skodla, Rokitansky, and Schönlein, ecoming the latter's assistant in 1849 and professor at Berlin in 857. Traube early made his mark as the founder of experimental athology in Germany by his investigation of the pulmonary

IFrichs: Teber den Diabetes, Berlin, 1sst.

${ }^{2}$ See A. Boruttau: Ztsehr. f. exper. Path., Berl., 1919, xx, 144-145. 
disorders oceasioned by section of the vagus nerve (1846). This was followed by studies of suffocation (1847), crises and critical days (1850), the pathology of fever, the effeets of digitalis and other drugs, the relation of aurdiac and renal disorders, and particularly by his Gesammelte Beiträge zur experimentellen P'athologie (1S71-7S), which gave him a wide reputation. He introdueed the thermoneter in his clinic about 1850. Traube was one of the first of the Jewish physicians to receive official recognition after the events of 1848 , and his clinies at the Charite soon beeame very popular on account of his exact methods and his honest, sincere attitude toward his patients. His eomtenance, like Carlyle's or Ehrlich's, has about it that indefinable something which we associate with the honest man.

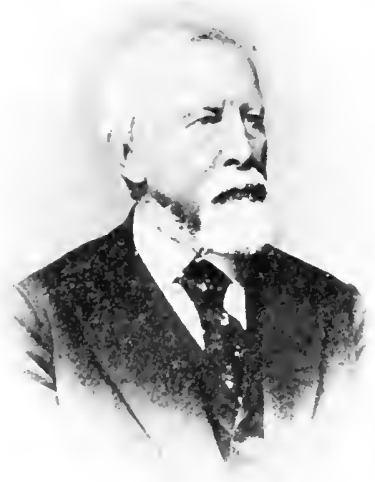

Arlolf Kussmaul (1S22-1902). His long-standing difference with Frerichs was due to the usual disputes about clinical material, of which the latter, as physician-in-chief, had the lion's share.

Adolf Kussmaul (1822-1902), of Graben, near Karlsruhe, began as an army surgeon, becoming later professor at Heidelberg (1857), Erlangen (1859), Freiburg (1863), and Strassburg (1876).

His earlier studies were upon the changes of color in the eye (1845), the effect of the circulation upon the movements of the iris (18.56), the relation between anemia and epileptiform convulsions (1857). Of greater importance were his monographs on the psychology of the new-born infant (1859), on mercurial salivation and its relation to constitutional syphilis (1861), and on disorders of speech (1877). He was the first to deseribe "periarteriitis nodosa" $\left(1866^{1}\right)$, progresive bulbar paralysis (1873), and diabetic coma with acetonemia, and the peculiar type of breathing ("air-hunger") associated with the condition $\left(1874^{2}\right)$. He added much to the knowledge of tetany and osteomyelitis. Equally brilliant were his contributions to diagnosis and therapeuties. He introduced the concept of "pulsus pararloxus" $\left(1873^{3}\right)$, was the first to diagnose mesenteric embolism in the living subject (1864), the first to attempt esophagoscopy and gastroscopy $\left(1869^{4}\right)$, the first to wash out the stomach with the stomach-tube for gastric dilatation $(1867-69)$, to treat gastric uleer with large doses of bismuth, and to employ thoracentesis $\left(1868^{5}\right)$. $484-518$.

${ }^{1}$ With Rudolf Maier: Deutsches Arch. f. klin. Med., Leipz., 1866, i,

2 Ibid., 1874, xiv, 1-46.

${ }^{3}$ Samml. klin. Vortr., Leipz., 1873, No. 54 (Innere Med., No. 62), 1637-74.

${ }^{4}$ Deutsche Ztschr. f. Chir., Leipz., 1900-1901, Iviii, 500-507, 1 pl. (Communicated by G. Killian.)

${ }^{5}$ For references to these and other contributions of Kussmaul see Deutsches Arch. f. klin. Med., Leipz., 1902, lxxiii, 1-89. 
His Jugenderinnerungen (1899) is one of the best of medical autobiographies, containing interesting sidelights on the palmy days of the New Vienna School. On Christmas day, 1893, he distributed among his friends a volume of poems, privately printed under the pseudonym "Dr. Oribasius."

Hugo von Ziemssen (1829-1902), one of Virchow's pupils, was professor of clinical medicine at Erlangen (1863), and (after serving in the Franco-Prussian War) at Munich (1874), where he directed the city hospital and founded the first clinical institute for instruction in the specialties (1877). Ziemssen was one of the great

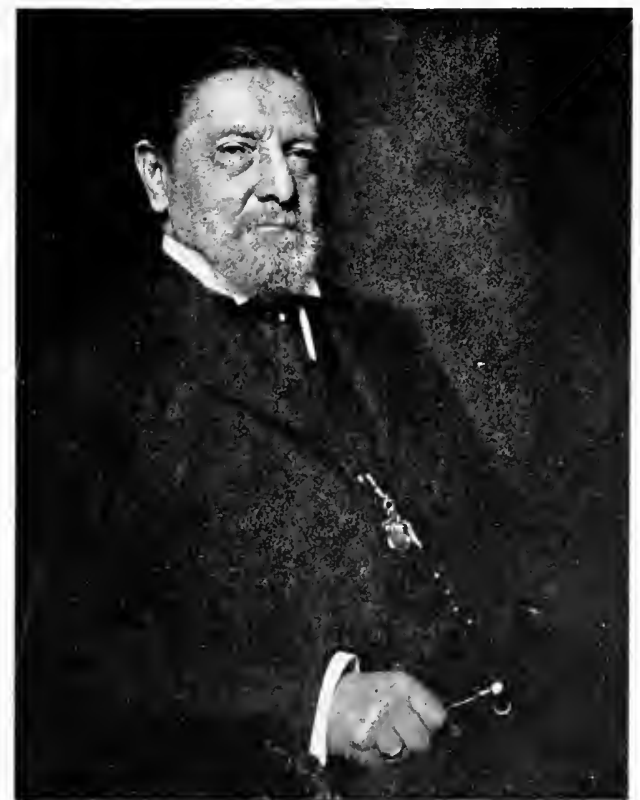

Ernst vón Leyden (1832-1910). (Berlin Photographic Company.)

medical encyclopedists, whose fame rests largely today upon his Handbook of Special Pathology and Therapeuties in seventeen volumes (1875-85). He edited handhooks of therapeuties (188084), hygiene (1882-26), and skin diseases (1883-81), and made innumerable contributions to many different subjects.

Ernst von Leyden (1832-1910), of Danzig, a pupil of Schönlein and Traube, succederl the latter at Berlin in 1876, and also sucseeded to Frerichs' clinic upon his death (1885). In 1894, he wis alled to the Russian court to treat Czar Alexander, for which he eceived a patent of nobility in 1895 . In 1879 he founded, with Frerichs, the Zeitschrift für klinische Medizin, and, in the later 
years of his life, was an active co-editor of several other joumals. He did most to promote the morement for hospitalization of phthisical paticuts in Germany.

He accpuired a great reputation in Borlin and specialized in neurology, his most fomoms work being his clinical studies of tabes dorsalis $(18633-1901)$, respiration in fever (1570), diseases of the spinal cord (1574-76), polionyctitis and neuritis (1Sso), perionlic voniting (1S\$2), and prognosis in heart discase (15s9).

Hermamn Nothnagel (1SH-1905), a pupil of Trambe and Virchow, Leyden's assistent at lö̈nigsherg (1865-68), and professor at Freibure (1872), Jena

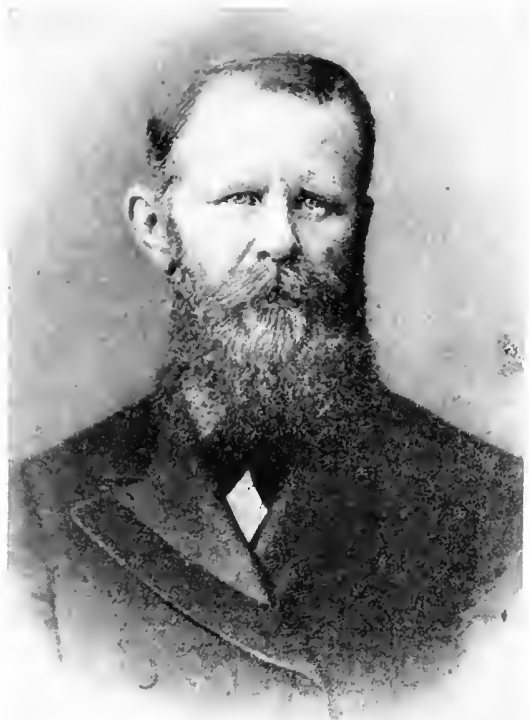

Hermann Nothnagel (1841-1905). (Boston Medical Library.) (1874), and Viemma (1882$1905)$, wrote an anthoritative treatise on therapenties (1870), made miny excellent contributions to neurology, and is especially memorable for his encyclopedic Handbook of Special Pathology and Therapeutics in 24 volumes (1894-1905). He first described universal anesthesia or absence of all sensation in the body (Seclenlähmung) in 1887. His favorite clinial themes were the riagnosis of cerebral diseases (in which ho separated disease of the optic thalamus) and diseases of the intestines and peritoneum, on which he wrote a classic monograph (1898). He was a gifted orator, an impressive lecturer, and a man of high ideals. A victim of angina pectoris, he stoically set down his own symptoms in writing just before his end. ${ }^{1}$

Hermann Senator (1834-1911), of Gnesen, Polish Prussia, a pupil of Johannes Müller, Schönlein, and Traube, became one of the director's of the Charité in 1881, and after Frerichs' death he was given a separate medical clinic and the University polyclinic (1888). He made his reputation by his investigations of the pathology of fever and its treatment (1873), diabetes (1879), albuminuria in health and disease (1852), which was translated for

${ }^{1}$ Deutsche med. Wochenschr., Leipz. \& Berl., 1905, xxxi, 1564. 
the New Sydenham Socioty (1890), and diseases of the kidneys (1896). He also deseribed infectious peripharyngeal phlegmon (1888).

Carl Gerhardt (1833-1902), of śpeyer, professor at Jena (1861), Würzburg (1872) and Berlin (1885), devoted himself mainly to internal medicine, pediatrics, and laryngology.

He made important contributions on liryngeal croup (1859), parulvis of the vocal cords (1\$63-72), laryngeal tumors (1896), syphilis of the lirymx and trachea (1898), and was the author of treatives on auseultation and percussion (1890), diseases of children (1880), and the editor of a great lanubook of pediatrics $(1577-96)$. In 1865, following Wilhelm Petters' diseovery of acetone in diabetes (1857), he introdueed his iron-chloride reaction for aceto-acetic ether in acetonemic urine.

In connection with the name of Gerhardt, we may mention, as contributors to pediatrics, Eduard Heinrich Henoch (1820-1910), of Berlin, a pupil of Schönlein and nephew of Romberg, who wrote a Clinic of Ablominal Diseases (1852-58), a masterly series of essays on children's diseases (1861-68), lectures on pediatries (1881), and described Henoch's purpura $\left(1874^{1}\right)$ and dyspeptic asthma $\left(1876^{2}\right)$; the Viennese, Alois Bednar (of Bednar's aphthx), whose treatise on diseases of infants (1850-53) is equally well known; Theodor Esche-

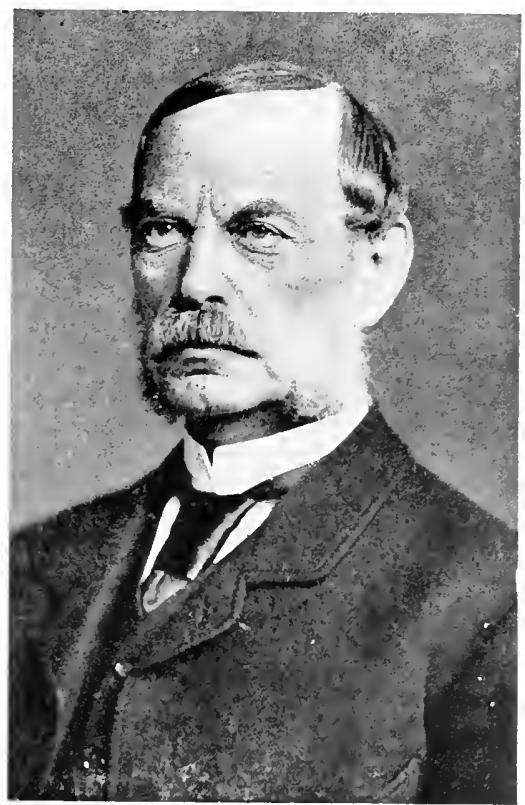

Eluard Heinrich Henoeh (1ৎ20-1910). (Collection of A. C. Klelss.) rich $(1857$ - ) , of Munich,

whose treatise on the intestinal bacteria of infants $\left(1886^{3}\right)$, contains the first account of Bacillus eoli infections; Arlolf Baginsky (1843-1918), of Berlin, author of a handbook of sehool hygiene (1876), a text-book of pediatries (1882) and many separate studies; ind the Galician, Adalbert Czerny (1863- ), who introduced he concept "exudative diathesis" (19074), and with Arthur Keller

${ }^{1}$ Henoch: Berl. klin. Wochensehr., 1874, xi, (641-643.

2Ibid., 1876, xiii, 241-243.

${ }^{3}$ Escherieh: Die Darmbakterien des Säuglings, Stuttgart, 1886.

4. Czerny: Monatschr. f. Kinderheilk., Leipz. \& Wien, 1907-8, vi, 1-9. 43 
(1906), wote a great treatise on the disorders of infantile nutrition, in which the digestive diseases of infants and childen are separated and rassified areording to metaloolie redations.

The subject of seientific infant fording, was inatgurated by Philipp Biedert (1S47- ), who wrote the first important treatise (1SSO), giving a minute classification of gastro-intestinal discases in infincy. This was followed by the treatise on the metabolism of infiucy and childhood (1S94) of Wilhehn Camerer (1S42- ), and the joint treatises on infant mutution and its disorders by Adallort 'Coeny and Arthur Keller (1906), Leo Langstein and Ludwig F. M(Y̧or (1910), Ludwig Tobles and Ci. Bessau (1914).

of recent German pediatrists, the ereatest was Leonhard Heubner (1S43- ), a pupil of Wunderlich and successor to Henoch's chair at Berlin, anthor of treatises on disorders of infant nutrition (1894), diseases of children (1903-6), and originator of the method of caloric feeding. In 1898-9, he made, with Max Rubner, the important investigations of the food requirenents of the normal and at lophie infant, which have been the basis of all subsequent work in infant metabolism. His pupil, Heinrich Finkelstein (1865- ), of Leipzig, originally a geologist, sucreeded Heubner as professor at Berlin, and in 1905-12, produced a remarkable treatise on diseases of nurslings. In 1906-10, he introduced his theory of salt and sugar intoxication (alimentary fever) as the basis of infantile nutritive disorders, with a special "albumen milk" (Eiucissmilch) to relieve the condition; in opposition to the theories of Biedert that asein is harmful, of $\mathrm{A}$. Czerny that fats are harmful, of Escherich that intestinal bacteria are harmful, of Rotch that proteids are harmful (pereentage feeding). This theory of Finkelstein, latterly abandoned in part by himself, has been the stom-center of controversy during the last deeade.

Arthur Schlossmann (1867- ), of Dresten, author of important works on infant hygiene (1907) and stall hygiene (1909), collaborated with Meinhard Pfaundler in a massive pediatric handbook (1906). In 1908-14, with H. Murschhauser, he showed the marked effect of muscular activity on heat production during the estimation of basal metabolism; and in 1913, investigated the fasting metabolism of infants.

Bernard Naunyn (1839- ), son of a burgomaster of Berlin, was Frerichs' clinical assistant for seven years, afterward professor of elinical medicine at Dorpat (1859), Bern (1872), and Königsberg (1872), finally succeeding Kussmaul at Strassburg in 1888 . With Klebs and Schmiedeberg, he founded the Archiv für experimentelle Pathologie und Pharmakologie in 1872, and, with Mikulicz, the Mittheilungen aus den Grenzgebieten der Medizin und Chir- 
urgie (1896). Of all Frerichs' pupils, Naunyn and Ehrlich have best followed the master's bent in experimental pathology and pathological chemistry. Aside from his earlier investigations of hydatids and the chemistry of the transudates, Namnyn has devoted his whole life to the study of metabolism in diabetes and in diseases of the liver and the pancreas, his most important works being his clinical study of gall-stones $\left(1892^{\mathrm{I}}\right)$ and his monograph on diabetes $\left(1898^{2}\right)$.

In the former, he introduced the new concept of "cholangitis" as an inflammation of the lining membrane of the smallest bile-duets eausing obliteration of their lumina, explaining catarrhal jaundice and syphilitic hepatitis as primary and secondary forms of infectious cholangitis anil regarding biliary calculi as the effect rather than the cause of the same disease. His treatment of the condition by drainage of the bile tract shows how the modern clinieian may think surgically as the surgeon elinically. He opposed Flint's idea that cholesterin is a specific product of the liver secretions or of metabolism. In 1S83, his pupil, E. Stadelmann, rliseovered $\beta$-oxybutyric acid and Namyn introduced the term "acidosis" "(1906) to define the metabolic condition of acid formation in diabetic coma.

When Naunyu went to Strassburg, his rigorous Prussian temperament excited a great deal of prejudice and opposition among the Alsatian population and it took him thirteen years to succeed,

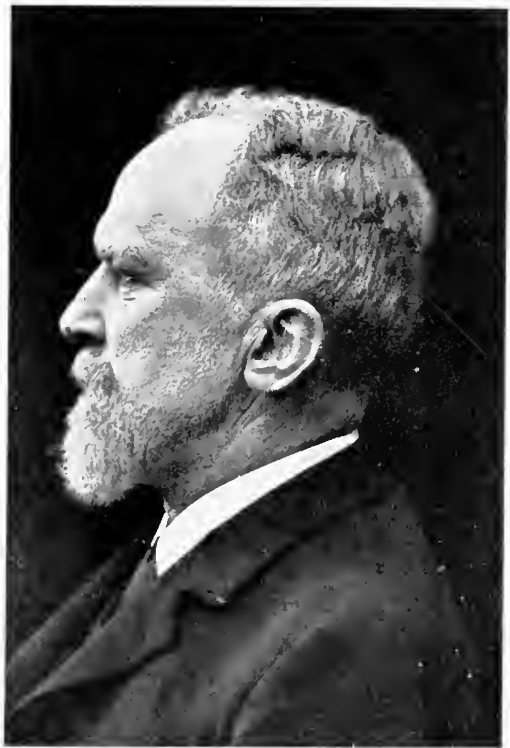

Bernard Naunyn (1S39- ). where even the suave Kuss-

maul had failed, in having the ancient city hospital (built 1718) converted into the splendid new building (1901). In spite of an attractive call to Vienna, he fought it out in Alsace, where his splendid clinical abilities, ${ }^{3}$ his stern fidelity to duty, his love of truth, his polished wit and sareasm, did not fail of recognition in the end. On the social side, he was known as a man of widest culture, especially in music. His promised antobiography, if we may judge from the fascinating fragment published in 1908, should be the most interesting book in its class.

1 Naunyn: Kilinik der Cholelithiasis, Leipzig, 1892.

${ }^{2}$ Der Diabetes mellitus, Vienna, 1898. 
Namyn's pupils number such distingushed pathologieal chenists as Ernst Stadelmann (18ij3- ), of lusterburg, who investigated the relation of 3 -oxvbutrric acid to diabetic coma (1SS3), the offect of alkalies on wotabotism (1590), deseribed pentosurial (1894), and, with M. Afanassyeff (1S83), worked out the experimental pathology of toxemie and hemolytic janndice $\left(1 \leq 91^{1}\right)$; Osear Minkowski (185s- ), of Alexoten, Russia, who deseribed conerental achohurie janndiee with splenomegaly and urobilinuria $\left(1900^{2}\right)$, studied the presenee of oxybutyrie acid in diabetic urine (1SS4), the effect of excision of the liver on metabolism (1855), and, with Joseph von Mering, the production of diabetes by excision of the pancreas (1S59-93); Max Schrader (1S60- ), who made valuable stutlies on the inhibitory center of the heart (1S86) and the eomparative physiology of the brain, and Adolf Magnus Levy (1565- ), whose name is partieularty associated with diabetic coma and its treatment (1899-1909). Namyn and his pupils did the best recent work in chemieal and experimental pathology.

Joseph von Mering (1849- ) , of Cologne, a pupil of Frerichs and Hoppe-Seyler, investigated phlorizin diabetes (1886) and collaborated with Minkowski in his experimental work on pancreatic diabetes (1889).

Carl von Noorden (1558- ) , of Bonn, professor at Frankfurt (1893) and Nothnagel's suceessor at Vienna (1906), has made important studies of albuminuria in health (1885), disorders of metabolism (1892-95), and the treatment of the same (1909). His pupils, H. Eppinger, W. Falta, and C. Rüdinger, have done much to develop the doetrine of the correlation of the internal seeretions of the ductless glands (1908-9).

Friedrich Müller (1858- ), of Augsburg, a pupil of Voit and Gerhardt, succeeded Biermer at Breslau (1890), and has held ehairs at Marburg (1892), Basel (1899), and at Munich (1902), where his elinic is now one of the most largely frequented in Europe. An able internist and neurologist, he is perhaps the most scientific teacher of internal medicine today.

Carl Anton Ewald (1845-1915), of Berlin, an assistant of Freriehs and Senator's suecessor at the Augusta Hospital (1886), is known everywhere for his great work in disorders of digestion (1879-SS), his use of intubation in exploring the contents of the stomach (1875), and his "test-breakfast," which he devised (1885) with his pupil, Ismar Boas (1858- ), of Exin, Posen, author of diseases of the stomach (1890-93) and the intestines (1899) are also highly esteemed. Boas founded the first polyclinic for gastro-intestinal diseases in Germany (Berlin, 1886). Ewald was editor of the Berliner l'inische Wochenschrift (1881-1907), librarian of the Berlin Medieal Society and an authority on forestry.

Ernst Finger (1S56- ), of Vienna; Hermann von Zeissl

1 Stadelmann: Der Icterus (etc.), Stuttgart, 1891.

2 Minkowski: Verhandl. d. Cong. f. inn. Med., Wiesb., 1900, xviii, 316. A non-congenital hemolytic icterus was described by F. Widal and P. Abrami (1907). 
(1817-84), of Zwittan, Moravia, and his son Maximilian von Zeiss (1853- ), of Vienna, have distinguished themselves in, the field of genito-urinary and venereal diseases.

Of the brilliant group of Italian elinicians and epideminlogists, Angelo Dubini first described the European hook-worm discase (1843) and electric chorea (1846); Salvatore Tommasi (1813-88), of Turin, reformed Italian medicine by making a clean sweep of the school theories of Rasori in North Italy, Bufalini in C'entral Italy, and the diathetic school of Southern Italy, in favor of a physiological interpretation of pathology; the veteran Guido Baccelli (1832-1916), of Rome, became widely known by his account of aphonic pectoriloquy in plemral effusion (Baccelli's sign, 1875), by his methorls of treating aortic aneurysm by the introduction of a coil of metal in the walls (1876) and the injection treatment of malaria with quinine (1890), syphilis with corrosive sublimate (1894), and tetanus with carbolic acid (1905); Camillo Golgi (1844-

), the eminent histologist, Corrado Tommasi-Crudeli (18341900), of Rome, a pupil of Virchow, Ettore Marchiafava (18471916), Angelo Celli (1858-1914), Bat tista Grassi (1855- ), and Amico Bignami, all made their mark by brilliant and effective work on malarial fever; Pietro Grocco (1856-1916), of Pavia, described paravertebral duhness on the opposite side in pleural effusion (Groceo's triangle, 1902); Guido Banti.described splenomegalic anemia (1898); Adelchi Negri (1876-1912) discovered the Negri bodies in hydrophobia (1903-4); Aldo Castellani found Dutton's Trypanosoma gambiense in the blood of sleeping sickness (190:3), discovered the spirochete of yaws (1905), and (with A. J. Chalmers) wrote the best modern book on tropical niedicine (1910); Edoardo Maragliano (1849- ) ), of Genoa, is memorable for his work in tuberenlosis; Ciuseppe Sanarelli for investigations of yellow fever; Giuseppe Guarnieri (1856-1918) for his work on the supposed parasites of variola and vaccinia (IS94); and as elinicians Achille De Giovanni (1837-1916), Augusto Tamburini (1S48-1919), Gaetano Rummo (1853-1917), and in neurology, Enrico Morselli.

The most prominent elinicians and pathologists at Guy's Hospital during the later period were Gull, Wilks and Hilton Fagge. Sir William Withey Gull (1816-90), of Colehester, England, graduated in medicine from the University of London (1846) and soon became associated with Guy's, where he taught medicine for the rest of his life.

He was one of the first to note the posterior spinal lesions in locomotor ataxia $\left(1856-58^{1}\right)$, described intermittent hemoglobinuria (1s6 $\left.60^{2}\right)$, myxolema

1 Gull: Guy's Hosp. Rep., Lond., 1856, 3. s., ii, 143: 1858, iv, 169.

2 Ibid., 1866, 3. s., xii, 381-392. 
$\left(1573^{1}\right)$, and, with sutton, the "arteriompillary fibrosis" in chronic nephritis (15:2:), which showed that the eonecpt "Bright's disease" is something more than a local renal affection. He also wrote upon vascular obstructions, cerebral abseess, "anowexia nervosa," factitious urticaria, and describerl, with Addison, "vitiligoidea" or xantluelsma $\left(1851-52^{3}\right)$. Ile was one of the pioneers in the use of male form in tronia (15is)) and of static clectricity in the treatmont of nervous diseases $\left(1 \mathrm{Si}^{\circ} \mathrm{2}^{4}\right)$.

He was one of the greatest practitioner's of his time, Napoleonic in appearance, witty, genial, attractive, and a beatiful lecturer. He is said to have fascinated his patients, to whose cases he gave unstinted time and pains, but, although adored by his pupils, he sometimes repelled his colleagues by his magisterial manner and his imperious temper. His clever epigrams, "Savages explain, science

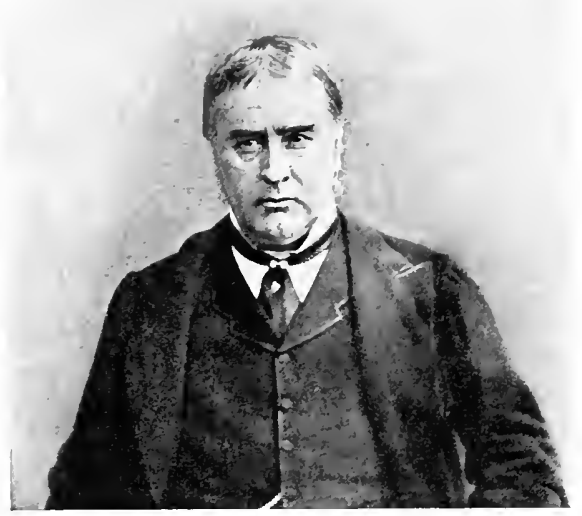

Sir William Withey Gull (1\$16-90).

investigates" and "You are a healthy man out of health," intended to soothe a troublesome hypochondriac, are often quoted. He defined a neurotic woman as "NIrs. A. multiplied by four," and to another he said, "Madame, you have a tired heart." He opposed surgical anesthesia with similar flippancies, and affected a sort of therapeutic nihilism, although he was, in reality, remarkably skilful with such drugs as he used. "The road to medical education," he said, "is through the Hunterian Museum and not through an apothecary's shop." He left a fortune of $\mathfrak{£} 344,000$, almost unprecedented in the history of medicine.

1 Tr. Clin. Soc. Lond., 1873-74, xii, 180-155.

2 Med.-Chir. Tr., Lond., 1871-72, lv, 273-326, 2 pl.

${ }^{3}$ Guy's Hosp. Rep., Lond., 1550-51, 2. s., vii, 265, 2 pl.: 1\$52-3, viii, $149,1 \mathrm{pl}$.

"Ibid., 1852-53, 2. s., viii, 81 . 
Sir Samuel Wilks (1S24-1911), of C'amberwell, England, was associated with Guy's Hospital all his life, and, in his charming Biographical Reminiscences (1911), he appears as its loyal historian, recounting the discoveries of his eolleagues with scrupulous fidelity and settling many points of priority. The writings of Wilks really gave the diseases ealled after Bright, Addison, and Hodgkin their place in English medicine.

He himself introduced the term "enteric fever," was one of the first to study viseeral syphilis (1557-631), left clear acconts of such rare conditions as osteitis deformans (1S6 $\left.\mathrm{S}^{2}\right)$, acromegaly $\left(1869^{3}\right)$, gave a classical account of alcoholic paraplegia $\left(156 \mathrm{~S}^{4}\right)$, and, as dermatologist, deseriber the "linex atrophicx" on the skin $\left(1861^{5}\right)$ and dissectingroom warts (verruce necrogenic:e), or subcutancous tuberculosis $\left(1862^{6}\right)$.

Wilks was a personality of rare kindliness and charm, deseribed by Osler as one of the handsomest men in London in his time, with "a splendid head and merry blue eyes, a man whose yea was yea and whose nay, nay." His lectures on pathological anatomy (1859, re-edited by Walter Moxon, 1875), and on diseases of the nervous system (1878) were standard sources of knowledge among English students of

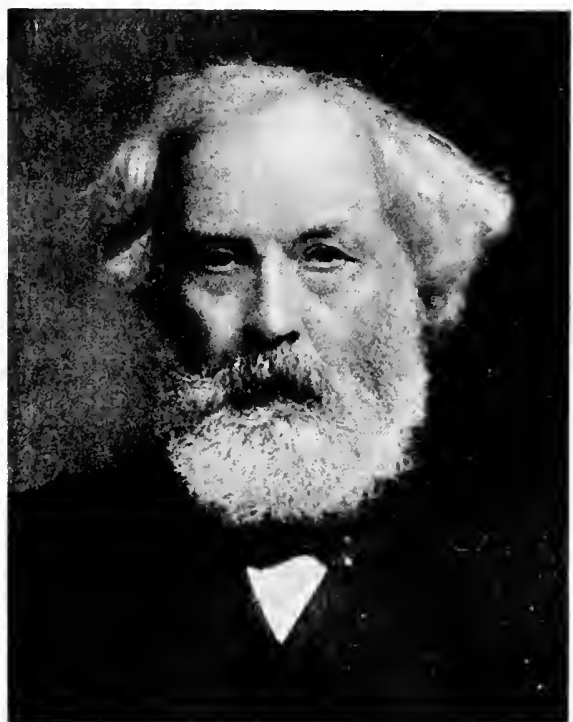

Sir Samuel Wilks (1824-1911). his time.

Charles Hilton Fagge (1838-83), of Hythe, Fngland, editor of the Cuy's Hospital Reports, was an able pathologist and clinician, an authority on heart disease, an investigator of cretinism and rickets, and an expert dermatologist. He translated Hebra for the Sydenham Society (1866-68), grouped keloid, morphea and

1 Tr. Path. Soc. Lond., 1S57-5s, ix, 55: 1860-61, xii, 216. Guy's Hosp. Rep., Lond., 1862-63, s., ix, 1-63, 4 pl.

2 Tr. Path. Soc. Lond., 1S68-69, xx, 273-277.

${ }^{3}$ Wilks: Biog. Reminiscences, London, 1911, 198.

4 Med. Times and Gaz., Lond., 1868, ii, 470.

5 Guy's Hosp. Rep., Lond., 1861, 3. s., vii, 297-301.

6 Ibid., 1862, viii, 263-265. 
spuriots leprosy under the category "scleriasis" (1867), and andve the classical description of gastromesentoric ileus (1stig), first noticed by Rokitansiy. His I'rinciples and I'ractice of Medicine (185i-8(i), which was completed hy Philip IIenry Pyo-smith 1S10-1911) and II ilks after his death, is ono of the solid books of the time.

Golding Bird (1S14-54,) of Downham, Norfolk, describol oxalmia (1842), wrote an important book on Urimary Deposits (1844), and was a pioneer in static olectrotherapy (18+1-49), which he employed with sucerss in amenorrhea.

Frederick Willinm Pavy (J S29-1911), of Wrougluton, Wiltshire, who eraduated from the Eniversity of Iondon (1850-i;3) and lectured at Guy's Hospital from 1856 to 1877 , had worked with ('latud Bernard in 1853, and clevoted his whole life to the thesis that the liver is not a storchouse of available carbohydrates.

110 started from his initial discovery that bleorl drawn from the inforior venal catat of an animal, immediately after it has been killed by a sharp blow on the head, contains no sugar; from which he inferred that the excess of sugar which Bernard obtained from the liver was entirely due to postmorten changes in that organ. Pary maintained that sugar is slecomposed and eonverted into fats and proteins in the intestines and reaches the liver only when it is in excess. By many ingenious arguments based large ly upon original experimental work, he showed that the liver does not change glyeogen into sugar during life, that oxygen does not destroy sugar in the blood, and that glycogen itself exists in the blood; but, as his knowledge of the subject arlvanced, his views unconsciously adjusted themselves to those finally held by Bernard. Gowland Hopkins records the pathetic and ironic fact that the last experiment which Payy performed indicated that more than 150 grams of dextrose per hour could be injected into the blood without appearing in the urine, which explorles the principal argument upon which he based his theory. Pavy was undoubtedly right, however, in holding that too mueh stress has been laid upon the liver as at sugar produecr. He was the first to deseribe eyclie or postural albuminuria (1855) and the typhoidal arthritis known as "Pary's joint" and is also remembered by his substitution of ammonia for caustic potash in Fehling's solution (Pary's blue fluid), which, as Pavy's pellets, was one of the first preparations to be nade in tabloid form. He had probably the largest practice in London in diabetic cases, in the treatment of which he was particularly successful, and his "Treatise on Food and Dictetics" (1874) is an index of his reputation as an investigator of metabolism.

Sir William Jenner (1815-98), of Chatham, England, professor at the University College, London, and physician to Queen Victoria, was Gull's great rival in practice, in which he was so suc-

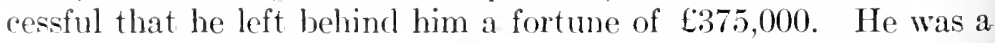
solid, able man, whose fame today rests upon the fact that, from a rigid clinical and pathological examination of thirty-six cases, he separated typhus from typhoid fever $\left(1817^{2}\right)$, although ten years later than Gerhard in America.

${ }^{1}$ Guy's Hosp. Rep., Lond., 1869, 3. s., xiv, 321-339. Tr. Path. Soc. Lond., 1875-76, xxvii, $157-160$.

2 Jenner: Month. Jour. Med. Sc., Ellinb., 1849, ix, 663-680. 
Charles West (1816-98), of Loindon, was a practitioner of obstetries, grnecologr and pediatries, whose Lectures on Diseases of Children (1S17) was the best English work of his time and wats translated into many languages, notably by Henoch into (ierman. He delivered the Limleian lectures on nervous disorders in rhildren (1S71) and was the main fomder of the Hospital for sick Children in Great Omond Street, which has now the latrgest clientèle of children in the world.

Other prominent English practitioners of the time include John Hughes Bennett (1812-75), who described leukemia (1845); Charles J. B. Williams (1805-89), who was, in his day, an authority on consumption and discases of the chest; Thomas Blizard Curling (1S11-SS), who first noted myxedema (1850); sir Alfred Baring Garrod (1S191907), who introduced the "thread test" in gout (184S$54^{1}$ ), and wrote an important. treatise on the subject (1859); William Brinton (1823-67), who described plastic linit is, $\mathrm{n}$ his work on Diseases of the Stomach (1859); Sir Thomas 3arlow (1845- ), who first lescribed infantile scurvy (Barow's (lisease, 1S76-82, and Feorge Frederick Still (1868), physician to the Great rmond Street Hospital, who leseribed arthritis deformans n children (Still's disease, $\left.896^{3}\right)$.

Sir Thomas Clifford Allbutt (1836- ), Regius Professor of hysic at the University of ('ambridge, described the histology of yphilis of the cercbral arteries (1868), gave an early description if the joint symptoms in locomotor ataxia $\left(1869^{4}\right)$, is the author f the Goulstonian lectures on the visceral neuroses (1884), the ane lectures on diseases of the heart (1896), and is the editor of useful and learned System of Medicine (1S96-99, 2d ed., 1905-11).

${ }^{1}$ Garrod: Med.-Chir. Tr., Lond., 1\$4\$, xxxi, 83: 1854, xxxvii, 49.

2 Barlow: Ibid., 1852-83, lxvi, 159-219. Early eases were deseribed by O. L. Möller (1856-60), who did not consider the pathology of the eonelition. 3 Still: Ibid., 1896-97, lxxx, 47-59.

${ }^{4}$ Allbutt: St. George's Hosp. Rep., Lond., 1868, iii, 55: 1869, iv, 259. 
His observations on the offeret of strain in producing heart disease and ancurysm (187 $\left.1^{1}\right)$ are important, in connection with the work of 1 a Costa and the "offort syndrome" of Lewis. His two-volume treatise on discases of the arteries (1915) summarizes his own original work on the circulation. His valuable contributions on medieval seience (1901) and surgery (1905), Greek medicine in Rome (1909²), and Byzantine mediebe (19133) give him a unique place anong medical historians. Few have approached him in literary style and the power to stimulate thomght.

Sir Villian Osler (1819-1919)), of Bond Houd, ('mada, Regins Professor of Medicine at the Univelsity of Oxford (1904), was profesior at his alma mater,

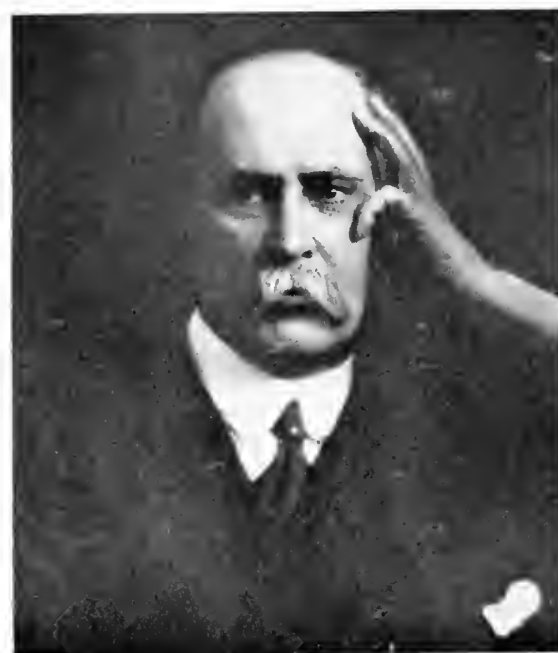

Sir William Osler (1849-1919). McGill University (187481), the University of Pennsylvania (1884-89), and at the Johns Hopkins University (1889-1904), where he did most to develop the scientific teaching of internal medicine in the hospital wards.

He was one of the earliest investigators of the blood-platelets (1873); described the viseeral complications of erythema multiforme (1895), a form of multiple telangiectasis (1901), and chronic eyanosis with poly"ythemia and enlarged spleen (1903); devoted special monogriphs to the cerebral palsies of children (1859), chorea (1894), abdominal tumors (1895), angina pectoris (1897), cancer of the stomach (1900), and has done much Filigranarbeit, such as the description of the erythematous swelling: (Osler's spots) in malignant endocarditis (1908).

Osler's Principles and Practice of Medicine (1892, 9th ed., 1920) is the best English text-book on the subject in our time. His essays on Linacre (1908), An Alabama Student (1908), Servetus (1910), and other subjects are among the most attractive of modern contributions to the history of medicine. In this field he is especially memorable for his studies of the work of the earlier American clinicians, whose modern status he has done most to

1 Allbutt: St. George's Hosp. Rep., 1871, v, 23.

${ }^{2}$ Allbutt: Brit. Med. Jour., Lond., 1909, ii, 1449; 1515; 1598.

${ }^{3}$ Allbutt: Glasgow Med. Jour., 1913, lxxx, 321; 422. 
establish. He was the editor of Modern Medicine (1910), also founder and editor of the Quarterly Journal of Hedicine (1908).

When he came to die, Osler was, in a very real sense, the greatest physician of our time. He was one of Nature's chosen. Good looks, distinetion, blithe, benignant manners, a sunbright personality, radiant with kind feeling and good will toward his fellow men, an Apollonian poise, swiftness and surety of thought and speech, every gift of the gods was his; and to these were added careful training, unsurpassed clinical ability, the widest knowledge of his subject, the deepest interest in everything human, and a serene hold upon his fellows that was as a seal set upon them. His enthusiasm for his calling was boundless. As Hare says, "Oster went into the post-mortem room with the joyous demeanour of the routhful Sophocles leading the chorus of victory after the battle of Salamis." All young English and American physicians who have ollowed the seience and art of medicine in this spirit have been "pupils of Osler." His writings have been aptly described as elonging to the true "literature of power." The less of his boy, illed in the artillery action about the Ypres salient, broke his ieart, but could not bend his resolution to front disaster "with the ourage that befits a man." At the last, he took up medical ibliography, and all but achieved his great Bibliotheca Prima, a Iallerian catalogne of his wonderful collection of historical texts. Bequeathed to his Alma Mater at McGill, it will stand as a monulent of his devotion to his profession-

"The silent organ loudest ehants,

The master's requiem."

In Osler's clinic at the Johns Hopkins, much important work as clone, such as the studies of malarial fever by W. S. Thayer nd others (1886-1902), the investigation of amebie dysentery by Filliam T. Councilman and Henri A. Lafleur (1890-91), the finclIg of the microörganisms in gonorrheal endocarditis and septimia by W. S. Thayer and George Blumer (1896), the studies of sinophilia in trichinosis by Thayer and Thomas R. Brown (18973), the demonstration of sexual conjugation in the malarial parattes by William G. MacCallum and Eugene L. Opie (1897-98), id the exhaustive study of pneumothorax by Charles P. Emerson $903)$.

Lewellys Franklin Barker (1867- ), of Norwich, Ontario, no succeeded Osler as physician-in-chief at the Johns Hopkins ospital, has done much to advance the study of anatomy in neriea by his works on the nervous system (1899) and anatomical menclature (1907), his translation of Spalteholtz's Hand Atlas 1900), and his Laboratory Manual (1904), and has added much 1 the literature of neurology and clinical pathology. In 1896, 
ho deseribed a moigue case of "circumseribed milateral and alective sensory paralysis," analogens in its bearings to the antoobservation of Henry Head, and with Frederick M. Hanes (I9)99), the eye signs in ehromic nephritis. With F. J. Sladen, he has also made interesting olinical and phamancological studies of the automomic system (1910-13) and is the anthor of an exhanstive treatise on cliannosis (1916).

William Sydney Thayer (1S61- ), of Milton, Massachusetts, professor of clinical medieine at the Johns IIopkins University, has male extensive investigations of malarial fever (1895-97) and typhoid fever (190)t), the obser-

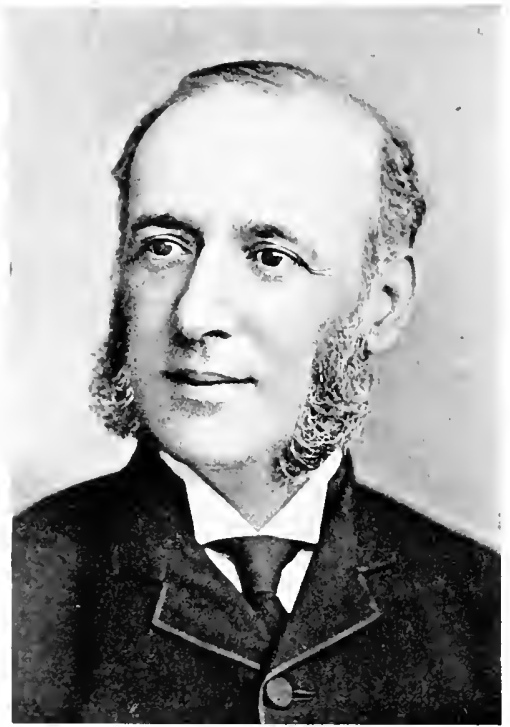

Jacob M. Da Costa (1833-1900). vations on gonorrheal endocarditis and trichinosis above roferred to, and made the first elinical notation of the thirel sound of the hoart (1908).

Of other American practitioner's, Austin Flint, Sr. (181286), of Petershim, Massachulsetts, was, in his lifetime, an authority on clinical medicine and auseultation, particularly in his treatises on practice (1866), percussion and auscultation (1876), and medical ethics (1853). His monograph on phthisis (1875) "is still of value today" (Osler). His son, Austin Flint, Jr., was an eminent physiologist.

Alfred L. Loomis (1831-95), of Bemnington, Vermont, who settled in New York City, wrote the best American text-book on Physical Diagnosis (1873), which even today is sometimes consulted.

William Pepper (1843-98), a native of Philadelphia, described the changes in the bone-marrow in pernicious anemia (1875), wrote many good papers, and edited the first large American System of Medicine (1886), but, apart from his great practice, his activities were mainly devoted to the University of Pennsylvania, of which he became provost (1881-94), and where he greatly improved the facilities for medical education.

Jacob M. Da Costa (1833-1900), of Philadelphia, the accomplished pupil of Trousseau, wrote a standard treatise on diagnosis (1864), and much upon functional diseases of the heart. He 
was perhaps the ablest clinical teacher of his time in the Eastern states, and his ideas on respiratory pereussion were adopted by Friedrich, his views on typhus by Jaccoud. He described irritable heart in soldiers (1862-71), which was also noted by Alfred Stillé (1813-1900), who played an important part in establishing the individuality of typhus and typhoid fevers (1838) and was a prominent teacher of pathology.

Nathan Smith Davis (1817-1904), of Chicago, perhaps the leading practitioner of that city in his day, was the father of the American Medical Association, and the author of a history of medical education in the United States (1851) and a much better report on the same subject (1877).

James Tyson (1841-1919), of Philadelphia, Professor of pathology (1876-89) and practice (1899-1910) in the University of Pennsylvania, was widely known for his admirable works on the cell doctrine (1870), examination of the urine (1875), physical diagnosis (1891), practice (1896), and, in particular, his monograph on Bright's disease and diabetes (1881).

Edward Gamaliel Janeway (1841-1911), of New Brunswick, New Jersey, who succeeded Flint as professor of practice at Bellevue Hospital Medical College, was the first to found an extensive whole-time consultant practice in this country. His Pathological Reports on Autopsies (1870), the record of six years of hard work at Bellevue, and his expert skill in microscopy, constituted the basis of his wonderful skill and subtlety in diagnosis. He was in every sense a great bedside physician. He was commissioner of health in New York (1875-81), secured the first hospital for contagious diseases in Manhattan and first called the attention of the profession to leukrmia (1876), the contagiousness of tubereulosis (1882) and the fever of tertiary syphilis (1898).

His son, Theodore Caldwell Janeway (1S72-1917), professor of medicine at the .Johns Hopkins Eniversity (1914-17) and author of The Clinical Study of Blood-Pressure (1904), and served with credit and distinction in the Medical Corps of the U.S. Army during the recent war, in the period preceding his mntimely death.

Frank Billings (1854- ), of Highland, Wisconsin, professor of medicine in the University of Chicago, edited Frederich Forchheimer's Therapeusis of Internal Diseases (1914), and, with E. C. Rosenow, and others, developed the doctrine of focal infection from bacteria of the streptococcus pneumococcus group ria the teeth, tonsils, and other portals (1909-16 $)$.

Henry Leopold Elsner (1857-1916), late professor of medicine at the University of Syracuse, summed up the experience of a life-

1 Billings: Focal Infection. Lane Lectures, New York, 1916. 
time in his massive treatise on prognosis (1916), almost the only important, work on the sulyject after Prosper Alpinus (1601).

Richard ('larke Cabot (IStis- ), of Brookline, Mass., author of various treatises on diagnosis (IS96-1901), was an early worker with blood-pressure profocols (1903), challenged the aceuracy of most hospital diagnoses as tested by antopsy findings, introduced the idea of teaching medicine by case-histories, as exemplified in his own treatise (1906), his "Differential Diagnosis" from 702 cases (1911-15), and in the subsequent collections of James Ciregory Mlumford (1863-1914) in surgery (1911), E. IV. 'Taylor (1917) in newlology (1911) and .John Lovett Morse in pediatries (1913).

Prominent among American specialists in gastro-enterology are John Comad Hemmeter (1864- ), who was the first to make a radiogram of the stomach

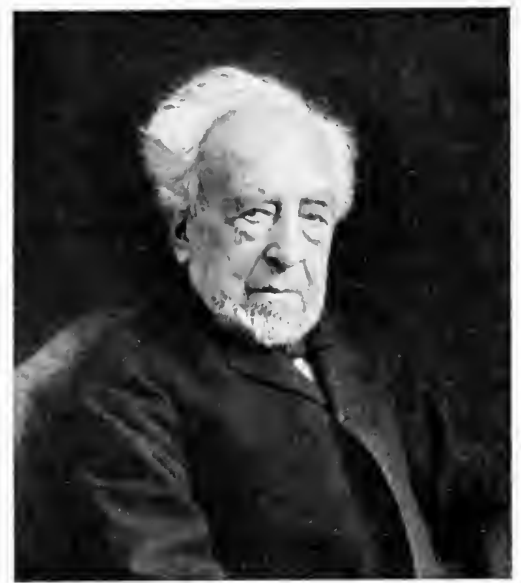

Abraham .Jacobi (1830-1919). (I89)(i), was a pioneer in duodenal intubation, and is anthor of the carliest complete Amrrican treatives on discases of the digestive organs (1896), stomach (1897) and the intestines (1901), a manual of physjology (1913) and many contributions to experimental physiology and the history of medieine; and Max Einhorn (1862-

), of Grodno, Russia, a Berlin graduate and professor in New York, who has invented many ingenious devices and instruments, such as gastro-diaphany (1887), stomachbuckets (1890), duodenal buckets (1908), and is author of well-known treatises on diseases of the stomach (1896), of the intestines (1900) and dieteties (1905).

Abraham Jacobi (1830-1919), of Hartum, Westphalia, a graduate of Bonn (1851), was held in detention for his participation in the German revolution of 1848, and settled in New York in 1853, where he became honored and revered as one of the leading praetitioners in this country and the Nestor of Ameriean pediatries, a subject which he taught in different medical sehools of New York for forty-two years. In 1857, he began lecturing on pediatrics at the College of Physicians and Surgeons, and thus "pressed the button which set the pediatric elinie in motion" (Aclams). It was due to his efforts that the New York Medieal College started the first pediatric elinie in this country (1860). He was a founder and 
editor of the American Journal of Obstetrics (1868-71), and is the author of works on disorlers of dentition (1862), infant diet (1872, 1875), diphtheria $(1876,1880)$, diseases of the thymus gland (1889), and pediatrics (1896-1903). In 1854, he made a laryngoseope of his own. In 1874, he noted that congenital lipomata are finely lobulated and unencapsulated. He played a prominent part in the advancement of American medicine, and many discourses, distinguished by quaint wit, varied learning, and true wislom (Collectanea Jacobi, 1909), including the authoritative monograph on the history of American pediatries (Baginsky-Festschrift, 1913).

Contemporaneous with Jacobi as a pioneer of pediatrics in America was the modest and unworldly Job Lewis Simith (182797), of Stafford, N. Y., whose Treatise on the Diseases of Infancy and Childhood (1869), hased upon his own clinical and pathological findings, passed through eight editions (1869-96).

Of recent American pediatrieians, John M. Keating (1852-93), of Phitadelphia, edited a Cyclopredia (1890-91), Louis Starr (1549-) of New York an American Text-Book (1894), Henry Koplik (1853- ), of New York, diseovered the spots diagnostic of measles (1S98) and published a pediatric treatise (1902). Similar treatises have been written by John Ruhräh (1905), John Lovett Morse (1911), W. G. Kerley, (1914) and others. Treatises on the neurotic disorders of chitdhood were written by Bernhard Sachs (1S95) and B. K. Rachford (1905). A transtation of the Pfaundler-Sehlossmann Mandbuch was edited by Linneus E. La Fetra in 1912, and a System of Pediatrics, edited by Isaae A. Abt (1S67- ), of Chieago, is in preparation.

Infant nutrition was first studied in a scientific manner in America by Thomas Morgan Rotch (1849-1914), of Philadelphia, a medical grathate of Harvard (1874), who held its first chair of pediatrics (1888). Perceiving that the earlier efforts of Meigs and Pepper to approximate cow's milk to mother's milk by comparative analyses failed through the specific needs of fat, sugar, or protein in different babies, he introduced the method of percentage feeding, in which these elements were employed as needed. He founded the first milk laboratory (Walker-Gordon) in Boston (1891), which was soon followed by one in London, and through his studies of substitute and percentage feeding and the necessity of surveillance of such laboratories, originated the movement for a clean milk-supply. He also established the Infants' Hospital of Boston, and wrote an important pediatric treatise (1896).

Henry Dwight Chapin (1857- ), of New York, has written treatises on infant feeding (1902) and pediatrics (1909). Chapin and Luther Emmet Holt (1855- ), of Webster, N. Y., author of treatises on infant nutrition (1894-1915) and pediatries (18971916) were the advocates of top-milk, whole milk, skimmed-milk mixtures, and other modes of home modification of milk which were followed by the eereal decoctions recommended by Jacobi and 
Chapin, and complete pastemization or boiling of the milk. Milk commissions to insure a pure supply to large towns originated with Henry Leher Coit (1554-1917). In this country, individual feeding of the individual child, according to its needs, is preferred to the Cierman method of feeding by calories in proportion to the infant's weight originated by linkelstein. In recent investigation of infant metabolism, important work has been done by Julius P'. Sedgwick (1906), John Howland (1910-16), Fitz B. Talbot and F. C. Benediet (1909-16), Bert R. Hoobler (1911-15), John R. Murlin (1910-15), Alfred F. Hess (1912-20) and many others.

Geriatrics, the earliest text of which is Sir John Floyer's Medicina (ierocomica (1724), has found modern expression in the writings of (anstatt (1839), Chareot (1881), J. M. Fothergill (1SS5), seidel $(1890)$, and the recent treatises of 1. L. Nascher (1914) and Malford W. Thewlis (1919).

Much good work has been done in America by such teachers and praetitioners as the Jacksons, the Shattuchs, the Bowditches, the Minots, James J. Putnam, R. C. Cabot (Boston); Charles L. Dana, L. E. Holt, T. Mitchell Prudden, Frank P. loster, Joseph Collins, M. Allen Starr (New York); the Nitehells, James M. Antlers, Wharton Sinkler, John Herr Musser (18561912), Alfred Stengel (Philadelphia); Eugene F. Cordell, Frank Donaldson, Thomas B. Futcher. II. B. Jacobs, Henry M. Thomas, John C. Hemmeter (Baltimore); Samuel C. Busey, W. W. Johnston, D. S. Lamb, S. S. Adams, George M. Kober, J. B. Nichols (Washington, D. C.); James B. Herriek, Frank Billings, Henry Baird Favill (Chieago); Charles F. Hoover (Cleveland); (ieorge Dock, W. J. Calvert (St. Louis), Christian Rasmus Holmes (18571920) (Cineinnati), Joseph Jones, Elmond Souchon, Arthur Washington De Roaldes (laryngology), Isadore Dyer (leprosy) (New Orleans), Henry Sewall, Walter A. Jayne, Charles D. Spivak (Denver), and, in Canada, by Robert Palmer Howard, F. J. Shepherd, James Bovell, George Ross, A. D. Blackader. Sir James Grant, J. George Adami, J. Playfair McNlurrich (anatomy), John MeCrae. D Fraser Harris, and Maude E. Abbott, to mention only a few names.

Of the many important advances in diagnostic procedure we may mention the graphic method of investigating the pulse introdueed by Karl Vierordt $(1855), A$. Stich's suggestion of the use of reflexes in diagnosis (1856), the sphygmograph of Etienne-Jules Marey (1860), the sphygmomanometers of Ritter von Basch (18S1), C. Potain (air sphygmomanometer, 1S59), Scipione Riva-Rocei (1896) and Leonard Hill (1897), the tonometer of Gustav Gaertner (1899), the introduction of esophagoscopy by Kussmaul (1S68), cystoscopv, urethroseopy, and reetoscopy by Max Nitze (1877), gastroscopy by Mikuliez (1SS1), gastrodiaphany by Max Einhorn (18S9), autoscopy of the air-passages by Alfred Kirstein (1895), direet bronehoscopy and suspension laryngoscopy by Gustav Killian (189S-1912); above all the $x$-rays by Wilhelm Conrad Roentgen (1893); Kernig's sign in eerebrospinal meningitis (1884), Henry Koplik's sign in measles (1898), Pietro Crocco's triangle in pleurisy (1902), the differentiation of pericardial pseudocirrhosis of the liver (Piek's disease) by Bamberger (1872) and Filipp Josef Pick (1834-1910) in 1896. and such phases of urinary analysis as Fehling's test for sugar (1848), Bence Jones's proteirl (1848), J. C. Faget's note of the relation between pulse and temperature in yellow fever $\left(1875^{2}\right)$, indicanuria (Max Jaffe, 1877), Salkowski's modification of the Trommer test for grape-sugar in the urine (1879), Wilhelm

1 Mixsell: Arch. Pediat., N. Y., 1916, xxxiii, 292.

2 J. C. Faget: Monographie sur le type et la specificite de la fièvre jaune, Paris and New Orleans, 1875. 
Ebstein's note of cylindruria in diabetic coma (1851), E. Legal's test for acetonuria (18S2), Ehrlich's diazo-reaction (1883), Ruldolf von Jaksch on acetonuria and diaceturia (1855), Matthew Hay's test for bilu (1sisi), F. Gowland Hopkins' mode of estimating uric acid (1593), cryoseopy, introduced by Sandor Korányi (1594), Ernst Salkowski on pentosuria (189:-95), and M. Bial's test for the same (1903), the test of Perey John Cammilge in pancreatic disease (1904), Albarran's experimental polyuria (1905), the oscillometer of V. M. Pachon (1909) for exploring ultra-sensible pulse and bleot-presenre, L. Ambard's uremic constant (1910), and the phenolphthalein test in renal disease deseribed by L. G. Rowntree and Geraghty (1910).

Modern neurology is mainly of French extraction and derives from Duchenne, of Boulogne, through Charcot and his pupils.

In the eighteenth eentury, Johamn Peter Frank had filed a speeial brief for the study of diseases of the spinal eord (1792); Fothereill had described facial neuralgia (1773): Whytt, tubereular meningitis (176s); Cotueno, seiatiea $(1770)$; Pott, pressure paralysis from spinal deformity (1779); Lettion, the drug habit and aleoholism (17S6); Nikolaus Fricdreich, facial hemiplegia (1797), and John Haslam, general paralysis (179S). In the early nineteenth century, cercbral (lropsy was described by George Cheyne (1808), delirium tremens by Thomas sutton (1813) and Joln Ware (18:31), tetany by J. Clarke (1.15), S. L. Steinhein (1\$30), and J. B. H. Dance (1832); paralywis agitans by Parkinson (1s17), softening of the brain by Rostan (1\$20), alcohelic neuritis by James Jackison (1S22), neuroma by IV. Wood (1529), and edectric clorea by Angelo Dubini (1846). Epilepsy anel spinal heniplegia have been known since the Greeks and chorea since the time of syden-

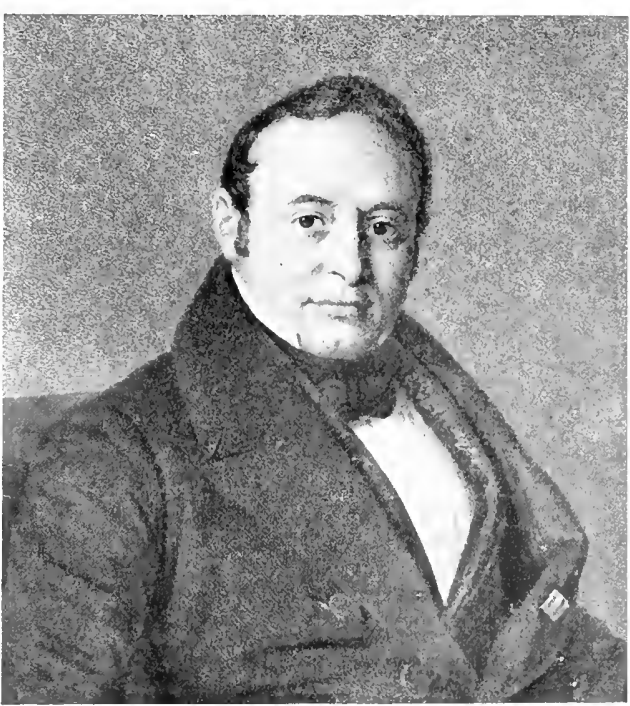

Moritz Heinrich Romberg (1795-1S73). ham. Tabes dorsalis had

been vaguely considered by Schelhammer (1691) and Brendel (1749), and was the subject of the dissertations of Emst Horn's pupils, Lowwenharil (1s17), von Weidenbach (1817, Schesmer (1819), (Gossow (1825), but these last, Max Neuburger thinks, really deal with cases of prostatic neurasthenia. Itorn's own view of the disease, faulty as to pathelogy and semeiolegy, is given in the dissertation of his son, Wilhelm von Iforn (1527). In 1844 steinthal gave a remarkably exact and complete description of the eharacteristic gait, the paresthesia, the electrie pains, the gastric and veriend crises and the amaturosis, but this was soon forgotten. ${ }^{1}$

The first real advance in the diagnosis of ataxia was made by Moritz Heinrich Romberg (1795-1873), of Meiningen, who grad-

1 Martin Steinthal: Jour. f. prakt. Heilk., Berl., ISt1, xeviii, 1. St., $1-56 ; 2$. St., 1-S4, cited by Neuburger. 
nated at Borlin in 1817 (his thesis being a classieal description of achomdroplasia), and became professor there in 1838. Mis Lehrbuch der Vervenkemlheiten (1810-16) was the first formal treat ise on nervous discases, and made an epoch by its careful collation of hitherto scattered data, its clear, precise clinical piotures and its attempt to systematize treatmont. It contans (p. 795) the wellknown "pathognomonic sign" that ataxics cannot stand with their (yes shut (Romberg's sign), and a description of "ciliary newrilgial."

Romberg's "propsedentic clinic" at. Berlin, instituted in 18:34, was much frequented for the alvantages derived from diannoses made by physical eximination.

Guillamme-Benjamin-Amand Duchenne (1806-75), who, as

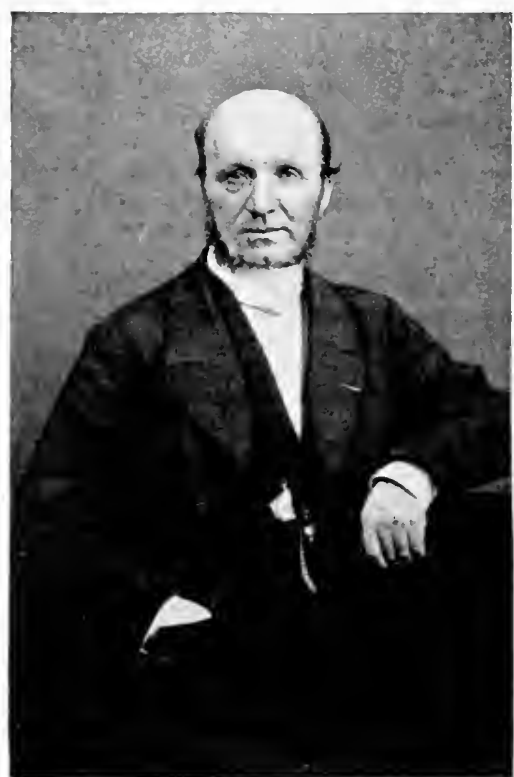

Guillaume-Benjamin-Amand Duchenne, of Boulogne (1806-75), (From a carte de visite photograph in the Surgeon-General's Library.)
Collins says, found neurology "a spuraling infant of $1 \mathrm{~m}$ known parentage which he succored to a lusty youth," was descended from a long line of seafaring people at Boulogne, and it was an inboln love of seience which prevented him from complying with his father's wish that he should become a sailor. Coming up to Paris, he studied under Laënnec, Dupuytren, Magendie and Cruveilhier, graduated in 1831, and after practising for some years in Bonlogne, settled in the eapital and devoted the rest of his life to neurology and electrophysiology. His method of prosecuting his studies was peculiar. A strange, sauntering, mariner-like figure, he haunted all the larger Parisian hospitals from day to day delving into case-histories, holding offhand arguments with the internes and physiciansin-chief, who frequently laughed at him for his pains, and following interesting cases from hospital to hospital, even at his own expense. All this was done in an unconventional and eccentric way, which at first laid him open to suspicion and exposed him to snubs, but the sincerity of the man, his transparent honesty, and 
his unselfish devotion to science for itself, soon broke down opposition, and, in the end, when his reputation was made, he was greeted everywhere with the warmest welcome. Being timid and inarticulate in relation to public speaking, he was aided by his friend, the fair-minded and generous Trousseau, who, out of fondness for Duchenne, often voiced his ideas with effect in medical societies.

Faraday discosered induced currents in 1831, and Duchenne employed these in the treatment of paralysis and other nervous disorders. He first set out to classify the electrophysiology of the entire muscular system, studying the functions of jolated muscles in relation to bodily movements, and summarizing his results in I) l'électrisation localisée (1855). Ho started with the olservation that a eurrent from two electrodes applied to the wet skin ean stimulate the museles without affecting the skin, and it was hi- brilliant application of this principle to pathological conditions that brought out so many fine points in the diagnosis of nervous disorders and made him the founder of clectrotherapy, in which he was followed by Remak, Ziemssen and Erb. His electrophysiological analysis of the mechanism of facial expression under emotion, illustrated by many striking photographs $\left(1862^{1}\right)$, is approached only by Darwin's work on the observational side. He was the first to distinguish between the different forms of lead palsy and of facial paralysis from lesions of the brain or nerves, ineluding the rheumatic and lacrimal forms. But his great field was the spinal cord. In 1840, Jacob von Heine (1800-79), of Canstatt, had described infantile paralysis as a spinal lecion, ${ }^{2}$ but in the face of his deseription, it was usually regarded as an atrophic myasthenja from inactivity. Duchenne pointed out that such a profound disorder of the locomotor system could only come from a definite lesion, which he located in the anterior horns of the spinal cord (1555), his view being afterward confirmed by Gull, Chareot, Cornil, and Vulpian. He also describerl anterior poliomyclitis in the ardult as due to at rophie lesions of the ganglion cells of the anterior horns, and his name is permanently eonnected with spinal progressive museular atrophy of the "Aran-Duchenne type" (1847-61). In 1850, F-A. Aran, of the Hôpital St. Antoine, publisher some cases of spinal progressive muscular atrophy which had been worked out by Duehenne. ${ }^{3}$ 'The latter, in his exhaustive study of the whole matter, at first regarded the disease as a prinitive alteration of the muscles, then assumed a lesion in the anterior horn of the spinal eord, finally, under pressure of enrrent opinion, returned to his original view of a primitive museular atrophy ${ }^{4}$ He deseriber the initial pseudohypertrophies in detail, but did not interpret them, as Erb dirl. The most definite thing which Duchenne described was the bulbar or glosso-labio-lingual paralysis $\left(1860^{5}\right)$, which is known by his name, as also the pseurlohypertrophic form of muscular paralysis $\left(186 \varsigma^{6}\right)$. Although the latter is simply one of the many forms of muscular dystrophy now reeognized, it was Duchenne's careful work in the hospital wards which first opened up the whole subject. In his work on locomotor ataxia, Duehenne labored under one great disadvantige. He cared little for book knowledge, and knew nothing of the work of Strinthal and Romberg, let alone the faet that Edward Stanley had deseribed divease of the posterior columns of the spinal cord in 1839 and Sir William (iull in $1856-5 \mathrm{~s}$. In

${ }^{1}$ Duchenne: Mécanisme de la physionomie humaine (ete.), Paris, 1s6z.

${ }^{2}$ Heine: Beobaclitungen übor Lähmungszustände der unteren Extremitäten (etc.), Stuttgart, 1840 .

${ }^{3}$ Aran: Arch. gén. de méd., Paris, 1850, 4. s., xxiv, 4; 172.

${ }^{4}$ Duchenne's final aeeount of the disease is given in his 1)e l'électrisation localisée, 2. éd., Paris, 1861, 437-5.57.

${ }^{5}$ Arch. gén. de méd., Paris, 1860, 5. s., xvi, 2\$3; 431.

${ }^{6}$ Ibid., 1S68, 6. s., xi, 5; 179; 305; 421; 552 . 


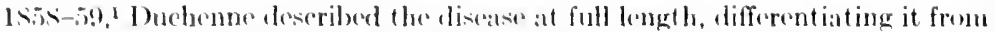

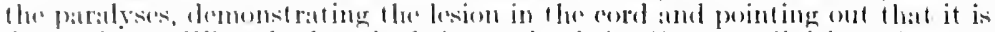

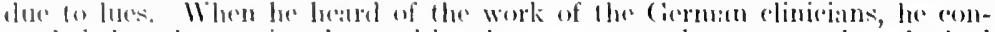
temled that the at asies observed by then were mot the same as those he had sorn, stul so obsomed his sul, jecel iil controversy.

In appearaner, Ducheme was a deep-chested, broad-shouldered, sillor-like man, whose ruddy, contented, humorons countenance hats been well preserved in the many photographs in his work on physiognomy. He was at once jolly, expansive, and absentminded. brusque yet cordial, disputatious yet tactful, and he attributed his suecess in bearding the lions of the hospitals to his combination of poise and insensitiveness. The last four years of his life were clonded by arterioselerosis of the hrain, and he died

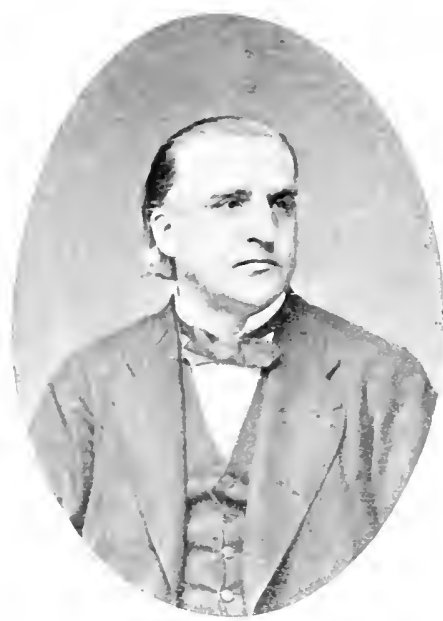

Jean-Martin Chareot (18:;-93). forgotten and unhonored, except by a corporal's guatrol of old friends at his grave; but he is, with ('harcot and Maric, one of the greatest neurologists of France. The hest account of him in English is the svimpathetic study of Joseph Collins $\left(1905^{2}\right)$.

(ontemporary with Duchenne and firr greater in the scope and scientific aceuracy of his work was Joun-Martin Charcot (1825-93), of Paris, who grarluated in 1853 with a thesis on arthritis nodosin, and in 1862 hecame plysician to the great hospital of the salpêtrière, with which his name will always be associated. IIere, from small beginnings, he created the greatest neurological clinic of modern times, which was followed by enthusiastic students from all parts of the world.

Chareot was not only a great nenrologist, but early made his mark in his lesens on senile and chronic diseases (1 $-6 ; 7$ ), diseases of the liver, the biliary passages, and the kidners (1s7 ). He left memorable deseriptions of chronic pnemonia, gout and rheumation. endocarditis, and of tubereulosis, in the dual nature of which he did not beline. He marle important physiological studies of the localization of functions in erebral flisease $(1876)$, and (with Albert Pitres) on the eortical motor centers in man (1595). The five volumes of his lessons on nervous diseases delivered at the salpêtrière (1872-93) are a good summary of his work, much of which was, as with Ludwig, eonveyed through the medium of his pupils. Thus, in 1s66, he rleseribed, with Henri

1 Areh. grén. de médl., Paris, 15.5\$, 5. s., xii, 641: 15.59, xiii, 36; 15\$; 417.

${ }^{2}$ Collins: Med. Record, N. Y., 1909, lxxiii, 50-54. 
Bouchard, miliary aneurysms, emphasizing their importance in cerebral hemorrhage; with Georges Delamarre, the gastric erises in locomotor ataxia (1866i); with Boucharl, the ataxic douleurs fulgurantes (1866); with Alexis Joffry, the lesions in museular atrophy (1869); with Pierre Marie, the peroucal form of muscular atrophy (1SS6); and his ideas on hysteria and hystromerpilepsy were set forth in the dinical studies of Richer (1579-85) and Gilles do la Tourette (1891). He defined hysterial as a psychosis superinduced by idration, the touchst one being the subject's eapacity for responding to suggestion. He considered "the phases of the major attack, the innumerable psychic and somatic manifestations, the phenomena of tansferenee on the application of metals, the sensory ehanges in hemianesthesia and hemianalgesia, the motor phenomena of contracture and spasm, the visual features, the relation of hysteria to traumatism, its frequency in the male-these and a seore of related problems" (Osler). In museular atrophy, he differentiated botween the ordinary wasting or AranDuchenne type and the rarer amyotrophic lateral selerosis (1874); and deseribed, with Marie, the progressive neural or peroneal type (1856), which was also deseribed, in a Cambridge graduating dissertation, by Howal' Henry Tooth (18S6). He differentiated the essential lesions of locomotor ataxia and deseribed both the gastric erises and the joint affeetions (Chareot's disease). He separated multiple selerosis from paralysis agitans, althongh the "intentional tremor" which he signalized as a differential sign had been noted by Bernhard Cohn in 1860. "No writer," satys Osler, "has more graphieally described the trophic troubles following spinal and cerebral disorders, particularly the acute bedsore." Like Babinski after him, Chareot regirded hypnotism as a nourotic condition, akin to, if not identical with, hysteria, and there was a long-rlrawn bat tle between the sehool of the Salpetrière and that of Naney (under Liébeanlt and Bernheim) as to the part played by suggestion, which, in the hands of the latter, some say, beeame mere brow-beating. Charcot was not deceived hy the foigning of some of his patients, and, in the end, regarded hypnotism as a doubtful therapentic measure. The soundness of his view is borne out in the molern tendency to merge the procedure into psyehotherapy. Chareot was a purely objective investigator, eared little for the special psychology of neurotic patients, and so was saved from some of the subjective exagrerations of the Fremlian school. "For purely psychological investigation," says Havelock Ellis, "he had no liking, and probably no aptitude. Any one who was privileged to observe his methods of work at the salpêtrière will easily recall the great master's towering figure; the disclainful expression, sometimes, even, it seemed, a little sour; the lofty bearing, which enthusiastic adminers called Napoloonic. The questions aclilressed to the patient were cold, distant, sometimes impatient. Charcot elearly had little faith in the value of any results so attained."

Apart from his clinical work, Chareot was an artist of talent, and the creator of the study of medical history in the graphic and plastic arts. With Paul Richer, he published two fascinating monographs on demonomania in art (1887), and on the deformed and diseased in art (1889), while many valuable studies by his pupils, Henri Meige, Richer, and others appeared in his Iconographie photographique de la Salpêtrière, begun in 1876 and contimued to the present time. Through his wife, who was a lady of wealth, Chareot lived in easy circumstances, but his clinieal genius, his keen, clear mind, his poise and dignity, would have made him a commanding figure in any station in life.

Pierre Marie (1853- ), of Paris, Chareot's ablest pupil, graduated in 1883, and became professor in the Paris Faculty in 1889. In 1886, he described, with Charcot, the peroneal type of 
muscular at rophy, ${ }^{1}$ and has made at least four original delineations of new forms of nelvous discase. These are his deseriptions of arromegaly, pointing out the pituitary lesion $\left(1880^{2}\right)$, hypertrophic puluonary osteourthropathy $\left(18900^{3}\right)$, hereditaly cerelpellar ataxia $\left(1893^{-1}\right)$, and the so-called rhizonclic spondylosis or Strünpell-Marie type of spinal arthritis deformans (18985). He has also made an assault of rlestructive eriticism upon Brocals concep)tion of aphasia, maintaining that the third left frontal eonvohtion has no special rôle in spoken language (1906), and upon the identity of the Aran-Ducheme type of muscular atrophy, which he challenges (1897). Since the

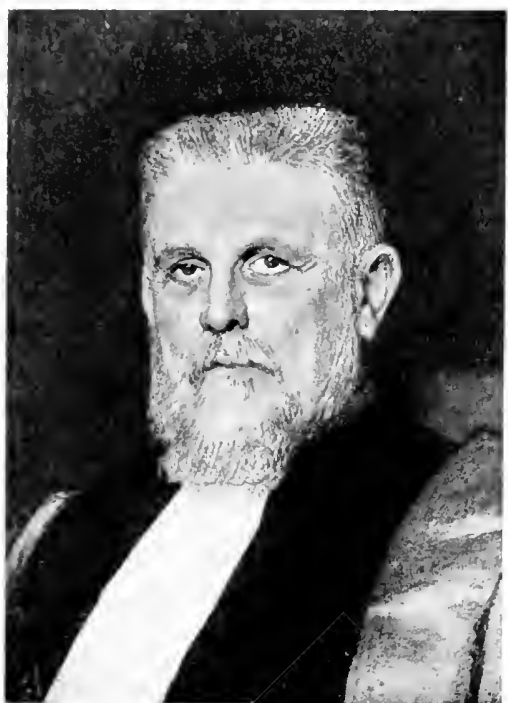

Pierre Marie (1853- ). outhreak of the European War, he has done most valuable work upon disorders of the peripheral nerves and other efects of gunshot lesions upon the nervous system.

The ablest German neurologist, after Romberg, is Wilhelm Heinrich Erb (1840), of Winnweiler, Bavaria, a pupil of Nikolatus Friedreich, who became professor at Heidelber" (1880). In 1868, Erb introduced the method of electrodiagnosis by galvanic and induction currents. He followed Duchenne in the extensive development of electrotherapy (18s2), wrote important hand-books on diseases of the cerebrospinal nerves (1874) and of the spinal cord and medulla (1876), and did much to establish the medern theory of the muscular dystrophies, which he described and classified (1891). He also described brachial palsy $\left(1874^{6}\right)$, syphilitic spinal paralysis $\left(1875^{7}\right)$, the juvenile type of muscular atrophy $\left(1884^{8}\right)$, and the so-called asthenic bulbar paral-

${ }^{1}$ Marie: Rev. de méd., Paris, 1s\$6, vi, 97-13s.

${ }^{2}$ Ibid., 1856, vi, 297-333.

3 Ibid., 1890, x, 1-36.

${ }^{4}$ Semaine méd., 1893, xiii, 444-447.

${ }^{5}$ Rev. de méd., Paris, 1898, xviii, 285-315.

${ }^{6}$ Erb: Verhandl. d. naturh.-med. Ver. zu Heidelb., 1874-77, n. F., i, $130-137$.

${ }^{7}$ Berl. klin. Wochenschr., 1875, xii, 357-359.

${ }^{8}$ Deutsches Arch. f. klin. Med., Leipz., 1883-84, xxxiv, 467-.519. 
ysis or myasthenia gravis $\left(187 \mathrm{~S}^{\mathrm{I}}\right)$, also described by Willis (1685) and by Goldflam in 1893 (Erb-Goldflam symptom-complex). Simultancously with Westphal (1875), Frb discovered the significance of the knce-jerk in locomotor ataxia ${ }^{2}$ and, with Fournier, he did most to establish a statistical causal relation between tabes and syphilis.

Other German neurologists of the period were Nikolaus Friedreich (1825-82), of Würzburg, who described hereditary ataxia $\left(1863-76^{3}\right)$ and paramyoclonus multiplex $\left(18 S 1^{4}\right)$, diseases which are sometimes eponymically confused; Carl Friedrich Otto Westphal (1833-90), of Berlin, who described agoraphobia (1871), pseudosclerosis $\left(1883^{5}\right)$, signalized the knee-jerk in diagnosis $\left(1875^{6}\right)$ and did important work in psychiatry (1892); Heinrich Quincke (1842- ), who described angioneurotic edema (18827), which had also been noted by John Laws Milton as giant urticaria (1876), and introduced lumbar puncture $\left(1895^{\circ}\right)$; Arlolf Strümpell (1853-

), of Neu-Autz, Courland, who is well known for his treatise on internal medicine (1883) and who described spondylitis deformans (1897) and pseudosclerosis of the brain (WestphalStrümpell disease); Paul Julius Möbius (1S54-1907), of Leipzig, who described dysthyroidism (1S86), infantile Kernschwund (1S92), and akinesia algera, and wrote nonographs on the physiological weak-mindedness of women (1900) and the pathology of men of genius (1889-1904); Hermann Oppenheim (1858-1919), of Berlin, who first described amyotonia congenita (1900) and "myohypertrophia kymoparalytica" (1914), and is the author of important treatises on the traumatic neuroses (1889), brain tumors (1896), cerebral syphilis (1896), myasthenic paralysis (1901) and neurology (1894), and Max Lewandowsky (1S76-1918), of Berlin, editor of a great handbook of neurology (1911), left unfinished through his death during the Creat War.

The leading English neurologists of the period were John Hughlings Jackson (1S34-1911), of Yorkshire, who did much to establish the use of the ophthalmoscope in diagnosing brain diseases (1863), made valuable studies of aphasia (1864), described

1 Arch. f. Psychiat., Berl., 1878-79, ix, 172.

2 Areh. f. Psychiat., Berl., 1875, v, 792; 803.

${ }^{3}$ Friedreich: Arch. f. path. Anat. (etc.), Borl., 1s63, xxvi, 391; xxvii, 1: 1876 , lxviii, 145 ; lxx, 140 .

${ }^{4}$ Ibid., 18s1, lxxxvi, 421-430.

${ }^{5}$ Westphal: Areh. f. Psyehiat., Berl., 1883, xir, 87; 767.

${ }^{6}$ Westphal: Ibid., 1S75, v, \$03-834.

${ }^{7}$ Quineke: Monatsh. f. prakt. Dermat., Jamb. and Lejpz., 18\$2, i, 129-131.

${ }^{8}$ Quineke: Berl. klin. Woehensehr., 1895, xxxii, 8\$9-\$91. 
mulateral convulsions or lakelsonian eprilepsy (1875'), and originated the doetrine of "levels" in the nevous system (1898);

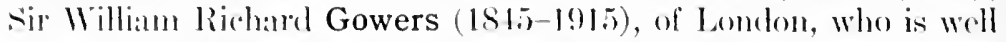
known for his tratises on discases of the spinal cond (1880), in which he described Cowers' trant, ppilepsy (18S1), discases of the brain (ISS5) and the nervous system (18S6-8), diel much to systematize existing knowledere of these conditions. His treatise on medical ophthalmology (1597), heatutifully illustrated by his own hand, was of great value in diagnosis. Ciowers did good work on

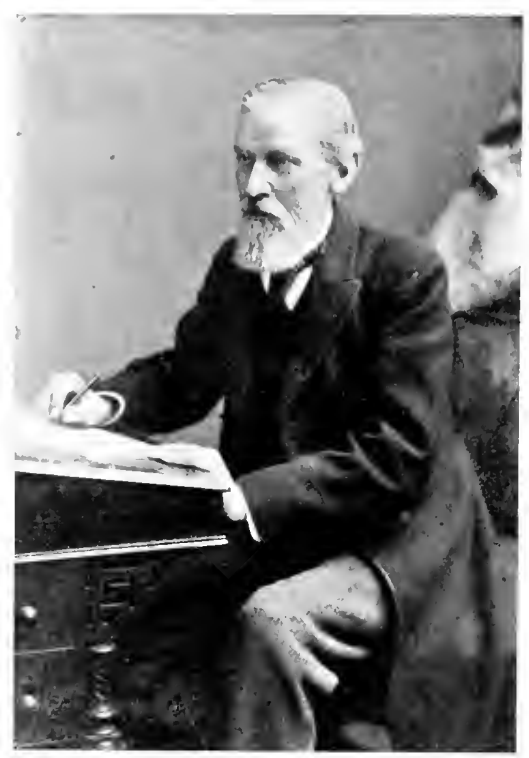

Sir William Richard Gowers (18451915). the finer anatomy of the nervous system, desiribod ataxic paraplegia, introduced the aluminum ehloride treatment of tabes and invented the hemoglobinometer (1878); Henry Charlton Bastian (1837-1915), of Truro, one of the founders of English nemology, and anthor of important books on the brain (1882), the paralyses (1886-93), aphasia (1898), and spontaneous generation (1913); Sir Victor Horsley (1857-1916), of Kensington, England, who did admirable work on the physiology of the nervous system, the functions of the luctless glands, and, with Gowers, was the first to remove a tumor of the spinal cord (1888).

In America, George Miller Beard introduced the concept of nemrasthenia or nervous exhaustion (1869), outlined by Eugene Bouchut as nervosisme (1860); George Huntington described hereditary (Huntington's) chorea (1872); William Alexander Hammond (1828-1900), once Surgeon-Cieneral in the United Stated Army, made his mark with his Physiological Memoirs (1863), described athetosis (1873), and wrote a good book on nervous diseases (1871); Francis Xavier Dercum (1856- ), of Philadelphia, described adiposis dolorosa (1882); Thomas G. Morton described metatarsalgia (1876); Bernhard Sachs (1858- ), described amaurotic family idiocy (1887-96), the ocular manifestations of which had 
been noted in 1880 by Waren Tay (Tay-Sachs discase), and wrote the first Ameriean treatise on the nervons diseases of children $(1895)$; Whaton sinkler isolated the great toe reflex (1885); William F. Mihoy, of Omaba, Nebraska, described persistent hereditary elema of the legs, or "Milroy's discase" (1892); ('harles Karsner Mills (1845- ), of Philadelphia, founded the nenrological wards in the Pennsylvania Cieneral Hospital (1877), deseribed milateral progressive asending paralysis (1900), unilateral descending patralysis (1906), and macular hemianopsia (1908).

('hristian Archibald Herter (18(65-1910), of Glenville, ('onnecticut, author of a study of experimental myelitis (1889) and a text-book on the diagnosis of nervous discases (1892), was a great promoter of scientific medicine in America. He founded the Journal of Biological ('hemistry (1905), helped to organize the American Society of Biological Chemists (1908) and the Rockefoller Institute (1901), and established the Herter lecture foundations at the Johns Hopkins and Bellevue. His monographs on chemical pathologr (1902) and on infantilism from chronic intestinal infection (1908) attracted wide attention.

Charles Loomis Dana (1852- ), of Woodstock, Vermont, author of a TextBook of Nemous Diseases and Psychiatry (1892), was,

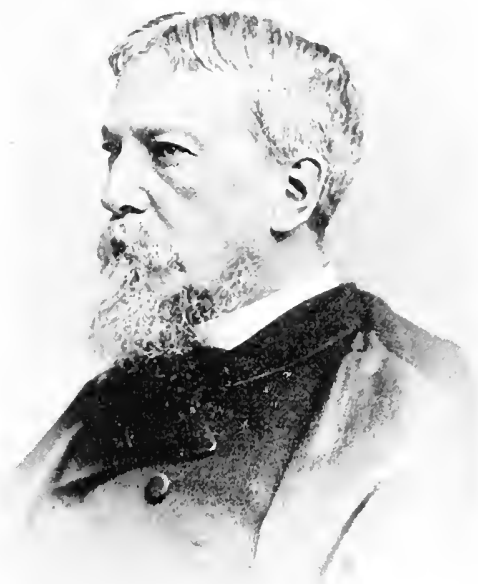
after James Jackson Putnam

Silas Woir Mitchell (1830-1914). (National Academy of Foieneer.

(18t6-1918), of Boston (1891), among the first to differentiate the primary combined scleroses, described acute transverse myelitis with perforating necrosis, lesions of the cortex in chronice myoclonias, serous meningitis ol "wet-brain," has done experimental work on the pineal gland, and proposed resection of the posterior spinal nerve-roots within the dura for pain, athetosis, and spastic paralysis, which was performed by Robert Abbe (December 31, 1888).

Silas Weir Mitchell (1830-1914), of Philatelphia, the leadling American neurologist of his time, was a graduate of the Jefferson 


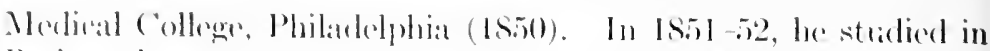
Patris and atame muler the influenere of clatude Bepmard.

In 15.89, with Hansmond, he iuvestigaterd the arrow and ordeal proisons, corrovil and vace and he was the first, after the Abbate fontanat and Boua-

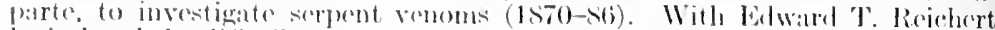

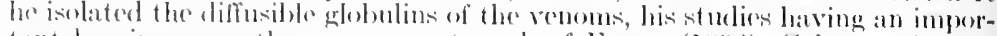

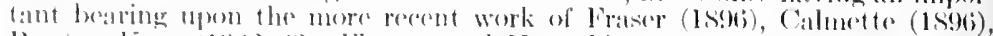

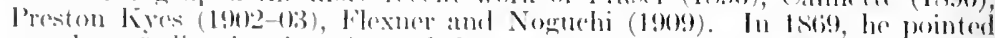

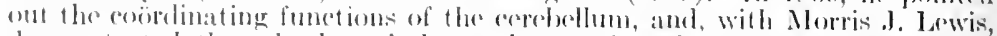
demonstrated that the kuerejerk ran be reänforedel by sensory stimulation

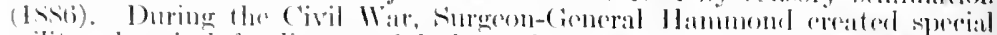
military hespitals for diseases of the heart, lungs, and nervoussestem. Mitchedl was in charge of 'Tumer's lane 1lospital, Philardphia, where he established at

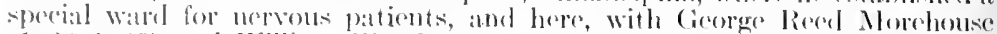
(15:9-19)(0.5) and William W. Keen, he marle those studies of gumshot and other injuries of peripheral meres (1sid) whieh were af terward expanded in his important work, on Injuries of Verese and Their ('onsequeners (1872). This book contains the earliest distinet areounts of aseremeling newritis, the treatment of ururitis by cold and splint-rests, the psychology of the amputat ad and of here data wheh have been aboorbed in the text-hooks. Nitehell was the

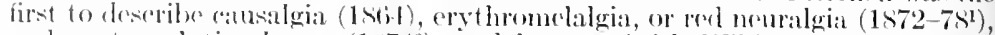
and postparalytio rhorea (187. $2^{2}$, and he was (with William Thomson) the first to (mphasize the importanere of rye-strain as a camse of hearlache (15743). In 1Si, sitehell introdued a treatment of nervous discase by prolonged rest in bed, with such adjurants as optimum feeling, massage, and cleetricity, the so-ralted "rest cure," or Wrir Mitchell treatment, which is now used rverywhere. Ilis ideas on the subjeet were summed up in his classieal monograph, Fat and Blood (1877), which has been translated into French, German, Spanish, latian, and Rusian. Nitehell was also the first to sturly the effeet of meteorological changes upon traumatic neuralgias, particularly in old amputation stumps (1S77). Ile made a large number of minor eontributions of highty original character, notably those on ailurophobia, phantom limbs, disorders of sleres, Wear and Tear (1873) and on freezing his own ulnar nerve. To the histery of modieine be contributed an aecurate history of instrumental precision (1892) and his memorials of Harvey $(1907-12)$.

In the world of lotters, as poet and novelist, Mitchell has a place near Goldsmith and Holmes, not far below Scott and Lamb, the beloved masters of what Owen Wister calls the "Iiterature of Fncouragement." In person, even in his demure choice of quaint phrases, Mitchell was himself a survival of the okl-fashioned American gentleman of colonial type. In sobriety and versatility, he was like some of the great eighteenth century physicians, in perception of the fine sicle of life he suggests Turgenieff, in sense of honor, he was like Bayard or Colonel Neweome. "Who dares draw illness as it is," he makes a physician say, yet, as Wister points out, not Balzac, Flaubert, Maupassant or Zola, "knew more of evil and sorrow and pain." The tone of his books, says Wister, "is a lesson and a tonic for an age that is sick and weak with literary perverts."

1 Amer. Jour. Med. Sce, Phila., 187S, n. s., lxxvi, 17-36.

Ibid., 1874, lxviii, 342-352.

${ }^{3}$ Med. and Surg. Reporter, Phila., 1874, xxxi, 67-71. 
Other innovations in neurology bosides those alpoady nentioned were

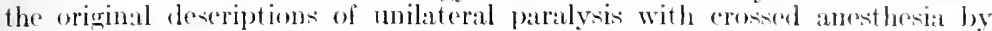

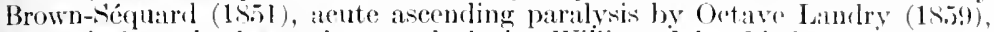
congenital ecrobral spastic paraplegia hy William John Little (Itil), sym-

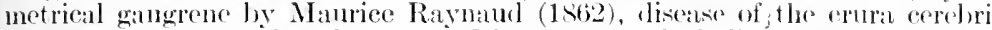
(Weber's syndrome) by Hermann Veber (1862), alcoholic paraplegia by sir Samuel Wilks (1sis), plexiform neurofibroma (Ronkennemoma) by Paul von Bruns (1s70), myotonia, deseribed in his own person, by Julius Thomsen (1S7 6 ), syringomyelia with trophic disturbances by Augustin-Mlarie Morvan (1883), impulsive tie or saltatory spasm (jumping, latah, myriachit) by (ieorges Gilles de la Tourette (1SSt), subacute combined degeneration of the spinat eoral (1SS1) by Otto beichtenstern (1si4) and Ludwig Lichtheim (1545-1915), astacilabasia by Panl Blocq (1Sxs), progresive interstitial hypertrophic neuritis of infants by Joseph-Jules Déjerine $(1819-1917)$ and Jules Sottas

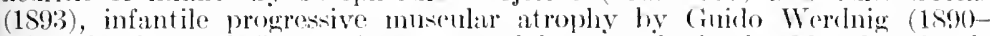
94) and Johamn Hoffmann (1s!)4), meralgia parantlestia ly Max Brornhardt and Vladimir Karlovich Roth (1s!) 5 ), and anyotonia (ongenita by Hermann Oppenheim (1900), the Gullain-Thaon syndrome (transitional erobro-spinal syphilis, 1909), and progressive lenticular degeneration by s. A. Kinmear Wilson (1912), whol, Gowers had roognized as "tetamoid chorea" (1sks) and which Frericts had also dereribed in his treative on diseases of the liver (1851). Herpes zoster was first aseribed to a lesion of the spinal ganglia by Friedrich von Bärensprung (1861-633), and was further boealized as an arute bemorrhagie inflammation of the posterior spinal and cranial ganglia by Henry Head and A. W. Campbell in 190(). Negrims and all mental distirrbances oming under the description of brain-storms or nerve-storms were leseribed yy Edward liveing in 1873 . The visoral nenposes were investigated by sir lifford Allbutt (1SS4), and the patlology of the cerebral eireulation by Leonund Hill (1S96). Aphasia, first described and loealized by Bomillaud $\left(182.5^{1}\right)$, lefined as "aphemia" by Broea (18ti1), has boen further studied by Hughlings fackson (1866), Carl Wernieke (1s74), Adolf Kissmaul (1s77), Isulwig dichtheim (185.5), and Pierve Marie (1906), who has entested the part played n aphasia by Brocats convolution, insisting that the true lesion is a lenticulat one in the jeft temporoparietal lobe (Wernieke's zone), which is also in dissute. Aphemia, anarthria, verbal amnesia, and other phases of the subject rere rlueidated by the late H. C. Bastian (1597-982), word-blindness (dysexia) was deseribed by Rudolf Berlin (1S87), and apraxia (motor asymbolia) y Hugo Karl Tiepmann $(1900)$.

After the time of Pinel and Reil the treatment of the insane vithout mechanical restraints (open-eloor method) was arlvaneed y John Conolly (18.56) and by the Tukes, of whom Daniel Hack uke (1827-95) collaborated with John Charles Bucknill in a Ianual of Psychological Medicine (1858), which played a great art in its diay. Another advocate of the no-restraint system was Vilheln Griesinger (1817-68), of Stuttgart, a pupil of Fchönlein, clinical assistant of Wunderlich, and ultimately IRombere's sucassor at Berlin (1865-67), who, apart from his work in psychiatry,

tErich Elstein points out that ases of aphasia bad been described by on Swieten (1753) and (ioethe: Wilhelm Weister, vii, ch. ti, atml IJanderjahre, , ch. 13 (1796), which had, however, been preceded by the ease of linnarus 742). Thomas Hood (Phreuol. Tr., 1822, iii) is said to have given a rase ith autopsy before Bouilland, but the lattrer, who had marle 700 by $18 t s$, will ways be credited with the classieal areonnt of the disease. Aeeording to roussean, the term "aphasia" was devised by tho celebrated Hellenist, Crisais. See Ebstem, Zeitschr. f. fl. ges. Neurol., Berl., 1913, xvii, is-61.

${ }^{2}$ Bastian: Aphasia and Other Speech Defeets, Lonclon, 1898. 
distinguished himsedf by his atrly description of hook-worm in-

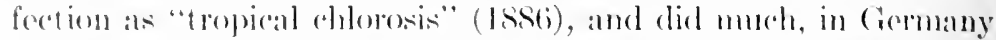
at least, to deatr up the status of typhus, typhoid, rolapsing and makatrial forers, in his momographs on infortioms discases (1857-6it). (iriesinger"s "Pathology and Therayy of Psychic Disolders" (1845)

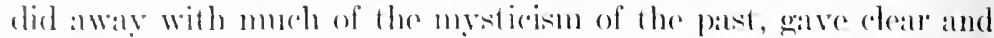
mmostakable alinical piotures based mpon rational psychological amalysis, amoded to anmoet the subject with pathologice anatomy and advocated the openterloos and the psychiatrieal clinic. Since (iriesinger"s time, the secientifie study of insinity has been maning in the hands of the (iemans.

Thoodor Meynert (18:33-92), of Dresden, profossor of nourology and psedhiatry at Vienua (1S7:3 92), exlitor of the Jahrbücher für Prychiatrie (18s?-92), mate many investigattons of the anatomy and physiology of the brain (1865-72), describerl amentia, and wroto on insanity as "Discases of the Fore-Brain" (1881).

("ul Wernicke (1S4S-1905), of Tarnowitz, Upper silesia, professor at Borlin (1855) and Broslan (1890), described sensory aphasia, incholing alexia and agraphia (1874), discases of the intermal capsule (1875), acute hemomhagie polioencephalitis (1881), and preshyophrenia $(1900)$; wrote treatises on brain diseases (18S1-83) and insanity (1894-1900), and issued a splendid atlas of the hrain $(1897-1904)$.

Fimil Kraepelin (1856- ), of Neustrelitz (Mecklenburg), professor of psychiatry at Dorpat (1SS6), Heidellorg (1890) and Imnich (1903), was the pioneer of experimental psychiatry (1896'). His Kompendium (1883) and thirty lectures on psychiatry (1901) introduced a new and simple classification of insanity, emphasizing the effective, precocions, involutional, katatonic and maniacal forms, introducing the eoncepts "dementia precox" and "manic deplessive insanity" and bringing about many simplifications by clever gromping of related varieties. Kracpelin made the classical analysis of the fatigne-('ure and the dassical investigations on the psychic effects of alcohol (1883-92), which were continued by Raymond Dorlge and Francis (x. Benedict (1915).

Paul Eugen Bleuler (1857- ), of Switzerland, has expanded Fracpelin's original concept of "dementia precox" to include a group of "schizophrenias" (1910) which imply many things not regarded by Kracpelin, in particular "autism," or the mental life of the individual which is kept apart from the outside world. Blenler also described "relative idiocy" (1914).

Adolf Meyer (1866-- ), Switzerland, professor of psychiatry at the Johns Hopkins Lniversity (1910), has also maintained

1 Kraepelin: Psychol. Arb., Leipz., 1896, i, 1-91. 
the psychogenic origin of dementia pracox, that it is functional rather than organic, but this hypothesis is somewhat shaken by the discovery that Abderhalden's forment reation is obtained in this neurosis, indicating disordered function of the sexual gonats.

Richard von Krafft-Ebing (1840-1902), of Mamnhein, a pupil of Friedreich and Griesinger, professor at Strassburg (1872), Craz (1873), and Vienna (1889), wrote the best German work on forensie psychiatry (1875), also a treatise on psychiatry based upon elinient experience (1879), and is especially known for his Psychopathia sexualis (1886), which classifies and describes the various forms of sexual inversion and perversion, especially in their medicolegal relations. Albert Moll is another writer on this theme.

Of English psychiatrists, Sir Thomas smith Clouston (18401915), late editor of the Journal of Mental Scienee, wrote a volume of clinical lectures on mental diseases (1883), and other treatises; Hemry Mandsley (1835-1918) was a prolific writer on psychologicat themes; Charles Arthur Mercier (1852-1919) is the author of a text-hook (1902), but his most valuable contributions are those on riminal responsibility (1905), conduct and its disorders (1911), rime and insanity (1911), and his historical sturlies of astrology 1914) and loper houses (1915); John Milne Bramwell (1852- ) as witten much on hypmotism; Frederick Walker Mott, editor of Archives of Neurolot!n, is the author of the C'roonian lectures on be regeneration of the neuron $(1900)$. Mention should be made of the psochiatrie treatises of the Italians F. Tanzi (1904), and . Bianchi (190.) which have been Englished; of the Ruscians P. I. Kovalerski (1892), S. S. Korsakofṭ (1893) and Y. M. Bechtereff 1908) and of the Americans, Edward (harles spitzkal (185:3), Frederick Peterson (1899), Henry J. Berkley (1900), S'tewart aton (1905) and William A. White (1909). Is superintendent of he Government Hospital for the Insane (1908), editor of the Psyhoanalytic Revicer, and author of at tratioc on mental mechanismo 1911) White has done much for recent psrchiatry. With smith ily Jelliffe (1866- ), of New Tork, eflitor and translator of any things of historic interest and value, White collaboraterl in at reatise on cliseases of the nerrous system (1915), presenting the lost adranced views. Henry Mills Hurd (1843- ), professor f psychiatry (1S\$9-1906) and superintendent of the Johns Hopkins Iospital (1859-1911), is editor of The Institutional c'ane of the nsane in the Inited States and Canada (1916), which contanis his aluable history of American psychiatry.

New methods of prychopathological investigation were introlueed by obert Sommer (1899). Psycho-andysis was int roduced by sigmumd Frend ad C. G. Jung (1893-1909). General paralysis of the insane was deseribed y John Haslam (1795) and Calmoil (1S26), moral insanity by James Cowles 


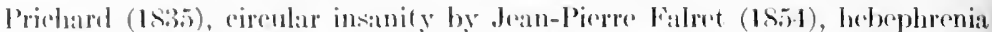

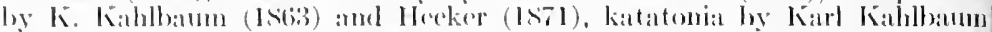

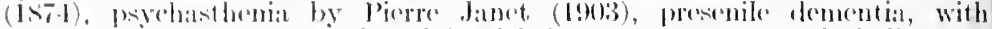
platues in (he brain (191i) by Alois Alzheimer (1s6-1-1915). Aleoholie para-

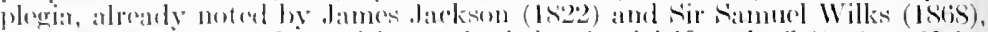

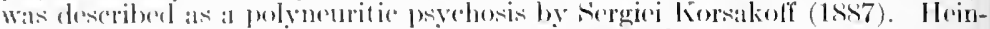

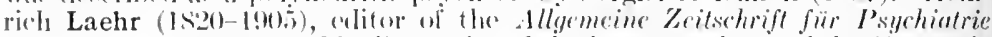
(1sis- ), mate valuable direetories of the imsane asylums of the (iermanie:

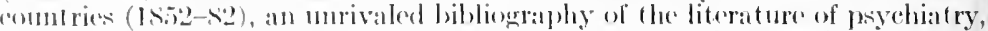

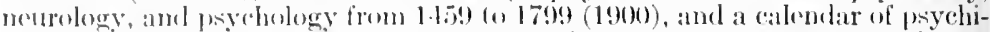
atry (1sis ) entaining, diay by day, all the important events eonnected with the history of the subject, inclinding the mart yrelogy of physicians and asylum attendanfis killorl by the homiejelal insine. Otto Mönkemöler has written wedl on the history of prowhiatry (1903-10).

The later nineteenth rentury marks the scientific or parasitic period of dermatology, in which miny entaneous discases were directly traced to microseopic organisms, especially under the leadership of Sabouraud and Umma.

llebrats work was completed and extended by lis son, Hans von Hebra (1sit- ), of Vimna, who wrote a text-book on skin diseases in relation to diseases of the antire organism (1884), deseribed rhinoscleroma (1870) and rhinophyma (ISS1), and by his pupil, the llungarian Moriz Kaposi (18:371902), who completed the elder Hebra's text-book, besides writing one of his own (1879), and deseribed pigmented sureoma of the skin (1872), diabetie dermatitis (1S76), xeroderma pigmentosum (18\$2), Iymphodermia perniciosa $(1 \times 85)$, the various forms of lichen ruber $(18 \$ 6-95)$, and ultimately put Hebra's impetigo herpetiformis upon al definite footing (1857). Isidor Noumann's treatise of 1869 was frequently translated and willely read. Dematology was also popularizel by Sir William James Erasmus Wilson (1809-84), who made :m early reputation with his Dissector's Manual (1838), Inatomist's Vademenum (1S40), and anatomieal plates, his Diserese's of the Skin (1S42), derma10logieal Atlas (1847), and his Royal College of Surgeons lectures on derinatology (1571-7s), particularly by his gift of $£ 5000$ for founding a chair of dermatology in the latter institution and the extensive collection of dermafological preparations which he inarde for the same. Wilson classified eutaneous divorder's as diseases of the true derma, of the sudoriparous and sebaceous gl:ands, the hair and follieles, and he was the first to describe dermatitis exfoliativa (1s70). The parasitic etiology of skin diseases had been introdueed by the Arabians, by Cosimo Bonono, who leseribed the parasite of seabies (16-7); by John Hunter, who gave a clinical deseription of the rlisease; by Wiehmann, of Hamburg, who estahlished its parasitic nature (1786); by schönlein, who described the achorion fungus of favus (1839); by David Grüby (1810-98), who described a contagious tinea syeosis or mentagra (porrigo decalvans or phytoalopecia), due to a fungus (1841-13), and by Carl Eichstedt, who established the relation between pityriasis versicolor and Mierosporon furfur (1846). Crüby's work received little attention until the bacteriologic and parasitologic period when it was taken up by Raymond Sabouraud (1864), of Paris, who marle extensive studies of the different varieties of trichephyton (1894), the etiology of eezema (1S99-1900), of pityriasis, and the "pellicular alopecias" (1904). Sabouraud did the best work on the myeotic riseases of the skin. In 1SS1, Thin had shown that trichophyton is distinet from orelinary fungi. Eezena marginatum of the groin and axilla (dhobie itch) has been traeed to the Epidermophyton inguinale, pityriasis versicolor to Mierosporon furfur, tropical tinea imbrieata to another ringworm fungus. Neanwhile extremely valuable work was done on the pathologieal, baeteriological, and therapeutic sile by Paul Gerson Unna (1850), of Hamburg, who was severely wounded as a volunteer in the FraneoPruscian War, and afterward founded a private elinie (1881) and a hospital 
for skin diseases (1SS4) in his native eity. He publisherl valuable works on the anatomy (1S82) and histo-pathology of the skin (1s94) and the treatment of skin cliseases (1S98), founded the Monatshefte für praktische Dermatologie (1882) and Dermatologische studien (1S86), and codited an intrernational at las (1859) and a histopathological atlas (1894) of skin diseases. Itma, a most

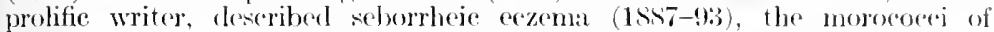
eczema (1892-97), the different coeei of favus (1892-99), phlyetarnesis streptogenes (1s95), pustulosis staphylogenes (1s96), described the pathology of leprosy (1910), and introduced ichthyol and resorein (1856), and spectially coated pills for loeal absorption in the duodenum (1884).

Among the original descriptions of skin diseases in the modern perion are those of porrigo (1864), dysidrosis (1\$73), and hydroa (18s0) by 'Tilbury Fox (1836-79), colloid milium by Ernst Wagner (186i), dermatitis exfolittiva by Erasmus Wilson (1s70), giant urtiearia (angioneurotir eflenma) by J(Jm Laws Milton (1876), angiokeratoma by Wyodhan Cottle (1877), infantile exfoliative rermatitis by Ritter von Rittershain (1S7s), neurofibroma by l: 1 . von Recklinghatusen (1852), epidermolysis bullosia by Alfred Coldscheduler (1852), varicella gangrenosa by Sir Jonathan Hutchinson (1882), xeroderma pigmentosum (1852), lymphodemia perniciosa (1855), lichen ruber moniliformis (1S\$6) by Moriz Kaposi (1\$37-1902), who also establisherl the definite status of impetigo herpetiformis (1887), lichen ruber planus (1895), and pemphigus vegetan (1S96); erythema elevatum by Julson s. Bury (1S8s), folheular psorospermosis by Jean Darjer (1859), acanthosis nigrieans by Sigmund Pollitzer and V. Janowsy (1890), angiokeratoma (1891), and porokerittosis (1893) by Vittorio Mibelli (1891), hyperkeratosis by Emilio Rexpighi (1893), benignant sareoid by Ceser Boeck (1 $\$ 999)$, chronie atrophic acrodermatitis by J. Herxheimer and Kuno Hartmann (1902), granulosis rubra nasi by Josef Jadassohn (1901), parapsoriasis by Lonis Broca (1902) and lichen nitiches by Felix Pinkus (1907). Of Amerieans, Robert William Taylor deseribed idlopathic progressive atrophy of the skin (1s76); Louis A. Duhring, dermatitis herpetiformis (18S4); Andrew Rose Robinson, lyydrocystoma (18S4); Thomas Caspar Gilehrist, blastomyeetje dermatitis (1S96); Benjamin R. Schenek, sporotrichosis (1S9S); and Jay F. Schamberg, the progressive pigmentary dromatitis which goes by his name $\left(1900-011^{1}\right)$.

The work of Magendie in experimental pharmacology was ably continued by Alexander Crum Brown and Thomas Richard Fraser, who first investigated the relation between the chemical constitution of substances and their plyssiologieal action ("anchoring the molecules") (18672), in which they were followed by Lauder Brunton and J. T. Cash (188t-92), and by Cash and W. R. Dunstan (1893). Friedrich Walter investigated the actions of arids upon the animal organism (1877), Ernst Stadehmann the action of alkalies upon metabolism (1890). Admirable text-books on maeria medica and therapeuties were written by such men as sydhey Ringer in England (1869) and H. C. Wood in America (18.4), ooth of whom aimed to establish the status of drugs on the clinical ide, while Buchheim, Schmiedeberg, and Binz in Germany, Brunon and Cushny in England, have done brilliant experimental rork on animals. The latter names have been particularly asociated with the destructive and critical pharmacodynamic's of

${ }^{1}$ For bibliographieal refereness to these diseases see Index Catalogue S. (i. O.), 1912, 2 s., xvii, $150-152$.

${ }^{2}$ Tr. Roy. Soc. Edinb., 1867-9, xxy, 151-208. 
the present time, the aim of which is to apply a rigorous sifting process to the vast numbers of alleged remedies listed in the valliols formularies and phamaneopeiats, on the principle of "Prove all things, hold fast to that which is mood." "The effect of this destrutetive criticism has not only been adnirable in reducing the gigantic vegetable materia medica of the past to reasonable proportions, hut, in the face of the huge output of coal-tar products ly: the Gorman chemists, initiated by Perkin's discovery of aniline dyes (1S.5), it became absolutely necessary. "The period of constructive pharmacologr," Cushny declares, "has scarcoly dawned" and he points out that remedies may now "be numerated in units where they were once counted

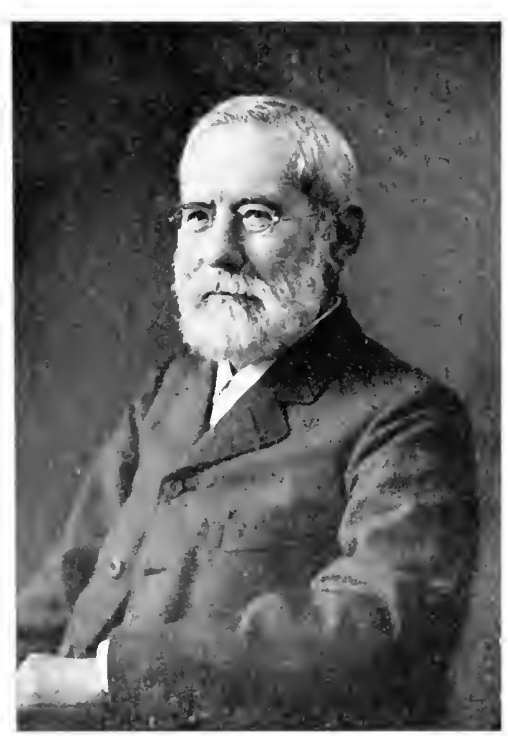
in scores." The French rlinicians Hemri Huchard and C'harles Fiessinger, for instance, have limited actual drug therapy to some 20 remedies or groups of remedies, viz.: opium, mereury, quinine, nux romica, digitalis, arsenic, phosphorus, ergot, bellaclomna, chloral, bismuth, the bromides, the hypnoties, the purgatives, the antisepties, the ancsthetics, the antipyretics, the nitrites, the sera and vaceines, the animal extracts, each of which has a specific therapentic intention. An International Conference for the unification of the formulise of heroic remedies was held at Brussels in 1902. The whole tendeney of recent Oswald Schmiedeberg (1\$3S- ). pharmacology is in the direction of simplification and specificity, but it is rightly contended by the therapeutists of the older school that human beings are not necessarily rabbits and guinea-pigs of a larger growth, since individual drugs have different effects, not only upon different animals, but upon different human beings. The only final test of the reliability of a drug is at the bedside.

The leading pharmacologists of the German school are Rudolf Buchheim (1820-79), of Bautzen, professor at Leipzig (1846), Dorpat (1849), and Giessen (1867), who published a text-book of materia medica in 1856 and investigated the action of potassium salts, of purgatives, cod-liver oil, ergot, the mydriatic alkaloids of the Solanecex, ete.; his pupil, Oswald Schmiedeberg (1838- ), 
of Courland, professor at Dorpat (1870) and Strassburg (1872), who first investigated the action of poisons on the frog's heirt (in Ludwig's laboratory, 1871), investigated hippurie acid synthesis in the kidneys $(1876)$, discovered sinistrin (1879) and histozyme (1881), determined the true formula of histamin and nucleic acid from Miescher's posthumous notes (1896), and did a great amount of critical and experimental work on muscarin (1869), ferratin (1893), digitalis and other drugs, the tendeney of which is erystallized in his well-known elements of pharmacology (1853); and Karl Binz (1832-1912), of Bernkastel, a pupil of Virchow and Freriehs and professor at Bomn (1868), where he founded the Phitrmacological Institute of the University (1869). Binz published a text-book on materia medica (1866) and lectures on pharmacology (1884), made experimental investigations of the action of quinine, alcohol, arsenie, the ethereal oils, the halogen compounds, and the anesthetics, and wrote an admirable history of anesthesia (1896). Hans Meyer (1853-

), of Insterburg, a pupil of Ludwig and Schmiedeberg, professor at Dorpat (18S1), Marburg (1882), and Vienna (1854), and E. Overton, have devoted especial attention to the part played by lipoid solvents in narcosis.

The history of pharmacy as been exhaustively presented in the works of F. A.

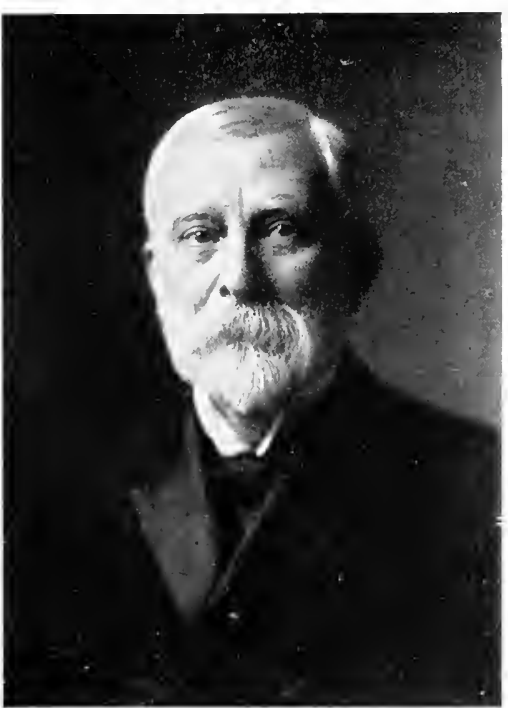

Sir Thomas Lauder Brunton (1S4t1916).

Flückiger and Daniel Hambury (Pharmacographia, 1879), Herman schelenz (1904) and A. Tschirch (Pharmacognosie, 1909-14).

Sir Thomas Lauder Brunton (1844-1916), of Roxburghshire, scotland, an Edinburgh graduate (1868), who was assistant physcian (1875-97) and full physician (1897-1904) to St. Bartholonew's, studied with Brücke, Kühne and Ludwig, and becane a naster in the application of the physiologieal findings of pharmaology to internal medicine.

From the time of his graduating dissertation on digitalis (1868), his pecial field was the action of drugs on the heart. In 1567 he ascertained that se of arterial pressure is a feature of angina pectoris and reeommended the 


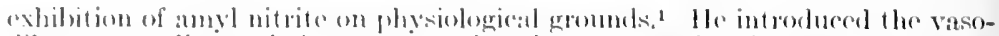
dilator remedies and, in 1sit, employed raw moat in diabotes in order to

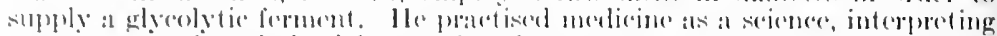

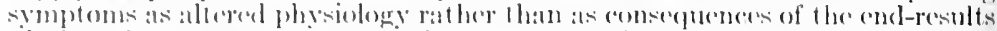
if allered structure. He served on the serond chloroform commission at

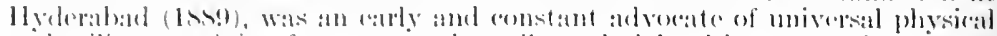

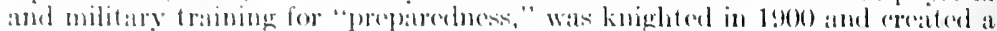
baronet in igos.

Personally Brunton was the "kindly scot," a mixtmre of sagacily and simplicity, generoms, sportsmanlike, and solf-sacrificing. Ho paid all the expenses and salaries of his pharmacological laboratory at st. Bartholomew's, was a warm personal fricul of Billings, and made princely domations to the surgeonGeneral's Libraly. His works include the well-perognized and fre-

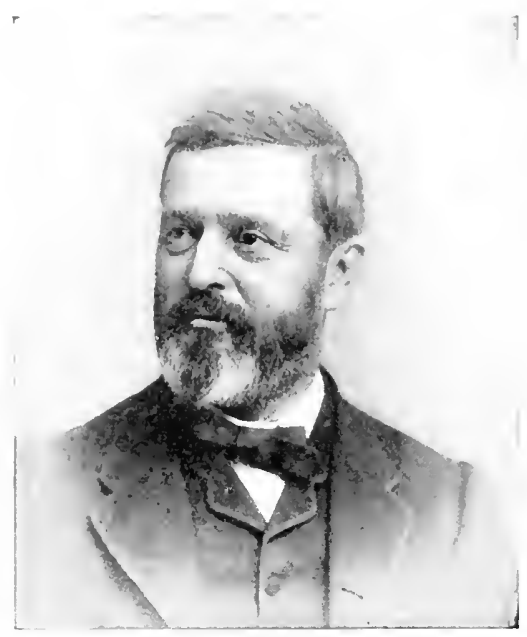

Horatio C. Wood (1S41-1920). quently transkated text-book of pharmacology and therapenties (1855), the (roonian Lectures mpon the redation between rhemical structure and physiological action (1892), the populatr Lectures on the Action of Medicines (1897), monographs on disorders of rligestion (1886), disorders of assimilation (1901), and the therapentics of the circulation (1908), and a vast mumber of individlal papers.

Sir Thomas Richarel Fraser (18+1-1920), of Calentta, India, a medical graduate of Edinburgh (1852), where he sueceeded Sir Robert Christison as professor of materia medica (1S77-1917), was one of the pioneers of experimental pharmacology through his original work on physostigmine (1863-7), strophanthus hispidus (1875-95), which he adkled to the Pharmacopoeia, and his investigations of arrow-poisons and serpent venoms.

Arthur Robertson Cushny (1866- ), of Scotland, who has been professor of pharmacology at Ann Arbor (1893-1905) and in the University of London (1905), was a pupil of Schmiedeberg, and his text-book of pharmacology and therapeutics (1899) is imbued with the spirit of his master. He has done admirable work on the effects of digitalis on heart-muscle (1912).

Horatio C. Wood (1841-1920), of Philadelphia, professor of

${ }^{1}$ Brunton: Lancet, Lond., 1867, ii, 97. 
botany (1866-76) and therapenties (1876-1907), also profecor of nervous discases (1875-1901) in the University of Pennsylvamia, made an important investigation of the pathology of sunstroke (1872), wrote a momoir on The Fresh-water Alya of North America (1872), and a pionecr treatise on therapeutics (1874), in which the effects of the vallions drugs upon man in small doses were first discussed, then of experimentation upon animals, which, with the evidence of toxicology, was made the rationale of their use in disease. This book alio contains a standard classification of drugs. Wood wrote a valuable monograph on fever (1880), investigated amyl nitrite (1871), discovered the physiological and therapentic properties of hyoscine (1885), introduced atropine to combat the fall of blood-pressure in shock, and first systematized the treatment of accidents in anesthesia (1890). He was editor of the Philedelphia Medical Times (1873-80), the Therapeutic Gazette (188490), the United States Dispensatory (1883-1907), and was author of a book on nervous diseases (1887).

Hobart Amory Hare (1862- ), of Philadelphia, professor of therapenties in the Jefferson Medieal college (1891), eclitor of the Therapeutic Gaztte (1891) and other periodicals, is author of wollknown text-books on therapeutics (1890), diagnosis (1896), and practice (1907), of monographs on mediastinal disease (1888). epilepsy (1889) and fever (1890), and is editor of a System of Therapeuties (1890-1911).

Good original work has been done by Torald Sollmann (1874), of Cleveland, Ohio, who has written a noteworthy text-book of pharmacology (1917).

John Jacob Abel (1857- ), of ('leveland, Ohio, professor of pharmacology at the Johns Hopkins University (1893), is editor of the Journal of Pharmacology and Therapeutics (1909)), first isolated epinephrin (1898) and bufagin (1911), has made valuable investigations of new substances and devised the methods of vividiffusion (1912-13) and plasmaphieresis (1914). Among his pupils, Reid Hunt is known by his studies on experimental alcoholism (1907) and the thyroid (1909), I. (i. Rowntree and J. 'T. Geraghty by their discovery of the phenolsulphonephthalein test in kidney discase (1910), David I. Macht has investigated the opium alkaloids (1915-16) and other substances. At the Johns Hopkins, also, Sammel J. (Crowe discovered that hexamethylenamin (urotropin) is excreted in the cerebrospinal fhuid (1909), which led to its extensive use in membranous diseases eaused by microörganisms.

The special action of magnesimm salts upon tetanus was inrestigated in America hy Samuel James Meltzer and John Aucr $(1905-6)$. 
Among the many new drugs introfucol in reont times are ehloral (1869)

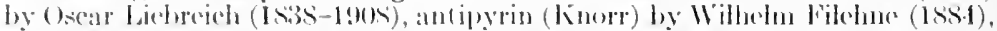

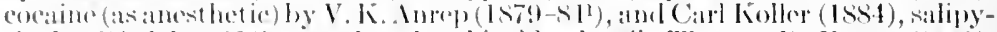

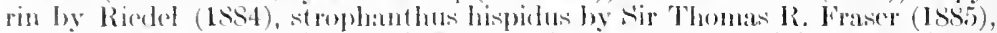

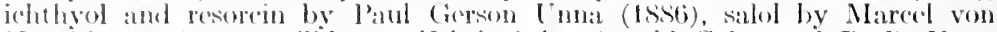

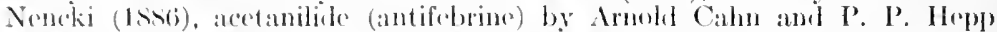

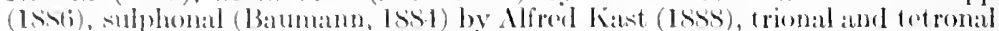

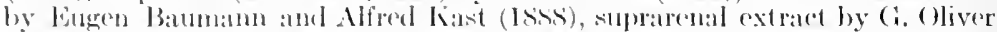

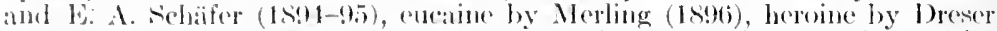

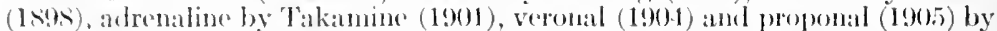

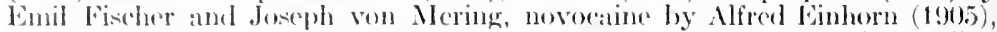
scarlet rod (Bichrichs, Is:2) by B. lischer (I9)ti), bismuth paste by linil J. Beck (190k), pantopon by llevinann sahli (1969), and salvarsan ("606") by Ehrlich $(19090)$.

Emotin, introfuced by Bardsley, of Manchester, in 1829, as a remedy for dysontery, was fonnd to be anedocidal by bifwarl B. Vedeler (1910-11) and its ne in anebic dysentery was established clinically by sir loomard Rogers $(1912)$

of other therapeutic moasures, electrotherapy was modernized by Du-

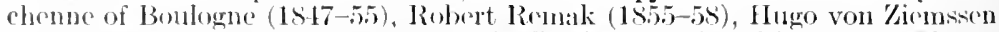
(1857), Moriz Benedikt (1865-75), and Wilhelun Heinrich lish (1582). I'hototherapy was advaneol by Nicls Ryberg Finson (1860-1904). The first definite results of the effect of galvanie clectrolysis were obtained in the troatment of urethral stricture by the sivede, Gustav Crusell (18:392), who published a monograph on galvanism in the tratment of local disorders in 1841-43. Static electricity was first employed at Guy's Hospital by Thomas Adilison, Goldine Bird, and Sir Willian Giull (1837-52); the double faradie enrrent was usal against uterine diseases and tumors by Georges Apostoli at Paris (18St); high-frepuency currents were introduced by Jaceues-Arsone d'Arsonval (1S92) and employed by $F$. Nagelsehmidt in electric tbermopenetration (diathermy) in 1906-8. Ionotharapy, suggested by Edison in 1890 , was introluced by sitéphan Leduc of Nantes in 1900. The $x$-rays, discovered by Wilhelm Conrad Roentgen in 1895 , soon became a most reliable aid in diagnosis, and, in the hands of experts, a useful therapeutic measure, as also radium. Ralium therapy, particularly ultra-penetrating radiation, which rendered its action potent for neoplasms, without damaging healthy tissues, was largely developed luring 1906-19 by Henri Dominici (1867-1919), an Englishman of Corsican descent. ${ }^{3}$

The hypodermic syringe was introduced in Europe by Franeis Rynd (1S45), Charles-Cuabriel Pravaz (1551), and Alexander Wood (is55), ancl, in America, by Fordyce Barker (1856) and George Thomson Elliott (1858). Tablet triturates for this and other purposes were invented and introduced by Robert M. Fuller, of Philadelphia, in 1878. Magendie and Gaspard revived experimental intravenous injections of drugs in 1823. G. B. Halford, of Melbourne, Australia, reintroduced Fontana's injections of ammonia in snake-bite in 18t39-73. A. S. Landerer introdueed hetol injections in phthisis (1892), Guido Baccelli injections of quinine in malarial fever (1890) and of corrosive sublimate in syphilis (1894), and injections of colloidal metals (collargol, etc.) were introduced by Benno Credé in 1901.

In 1895, Carlo Forlanini (1S17-1918) introduced the treatment of phthisis by artificial pneumothorax, which had been suggested by Carson in 1842, and was introduced in America by John B. Murphy (1898). The prineiple of employing deep alcohol injections in neuralgia was suggested by Pitres and Vaillard in 1857, and first applied by Karl Schloesser in 1903.

1 V. K. Anrep: Pflüger's Areh., Bonn, 1879, xxi, 47; Vrach, Petrograd, $1884, v, 773$.

2 G. S. Crusell: Ueber den Galvanismus als chemisehes Heilmittel gegen ötliche Krankheiten, St. Petersburg, 184l-43.

${ }^{3}$ See J. Barcat: Arch. Radiol. and Electrotherapy, Lond., 1920, xxiv, $343-3+5$. 
Hydrotherapy was popularized by Max Joseph Oertel and the Silesian farmer, Vineenz Priessnitz (1799-1551), whose cold parks and outdoor mothork were followed up by the Bavarian pastor Kneipl); by C. Munde at Ciräfonberg (1\$39); in England, by James Manby Gully at Malvern (1\$42); and, in the United Ftates, by Rissoll Thacher Trall (1844), Joel Shew, and others. Seientific hydrotherapy is especially assoriated with the names of linst Brand (1827-97), a practitioner at sitettin, who put Curro's formoten cold bath treatment of typhoid fever upon a reliable working basis (Istil63), and Wilhelm Winternitz (1835-1917), of Josefntadt, Bohrmia, professor at Vienna (18\$1), director of the hyclropathic establishment at Kaltenleutgeben, and founder of the Blatter für lilinische Hytrotherapie (1s!)(1), who wrote the best molern treatise on the subjeet (1577-80), based upon rxperimental as well as clinical investigation. Oskar Lassar in Borlin (15:3) and Simon Baruch in New fork have becen the leading propagandists for public baths within the means of the people in large cities.

In 1834 victor-Theodore Junol (1809-81) investigated the rffects of compressed and rarefied air upon the boly and its members, which he applied in therapy as "hemospasia" or giant-cupping, summarized in his treatise of 1875. This method consisted in the proluction of a fainting spell by drawing the blood from the brain to the foot, a species of blood-letting without letting blood, the revulsive effects of which were extraordinarily suceessful in various diseases.

Dietetics and regimen were arlvaneed by William Banting (1797-187S), of England, who in his Leter on Corpulence (1863), introdueed the eure of obesity by the gemeral reduction of food, inclueling the exclusion of fats and earbohydrates (1863), by Liebig, Wöhler, Boumont, Moleschott, Pavy, Pavloff, Rubner, Chittenden, and the other investigators of nutrition and metabolism, by Boss and Ewald, who introdueed test-meals in digestive disorders, by Debove, who originated forced fereling in phthisis, and latterly by Carl von Nonrden, who has made a special sturly of dietetics in disorders of motabolism and introrluced the oatmeal diet in diabetes. Fpeeial treatments of heart disease were introlued by the laryngologist Max Joseph Oertel (1835-97), of Dillingen, Bavaria, whose method eonsists in proteid diet with reduetion of liquids, free perspiration, and graduated uphill exereises (18S4) and by Theodor Schott (1552- ), who, at Natuheim, liscovered the beneficent iffeet upon weak hearts of earbonated baths (18s3) combined with slow grmmasties, rexented by the patient and resistol by the operator. The stomach-pump, for the removal of opium and other poisons (Monro secumdus) was introduced simultaneouly by Fdward Jukes and Francis Bush, two English physicians, in 1822.1 simple intubation, with lavage, for gastrie dilatation from pyloric abstruction, was introuluced by Adolf Kussmaul (1867-6!).

The seicntific applications of hypnotism wore prineipally studied by Charcot and his pupils at the Salpetriere and by the two leaders of the Naney school, Anbroise-Auguste Liébeault (1523-1904) in his Le sommeil promoné (1889) and Thérapentique suggestive (189I) and Hippolyte-Mario Bermheim (1840-1919) in De la suggestion dans l'ctat hypnotique et dans l'état de veille. (1884) and Iypmotisme, suggestion, psyrhotherapie (1891). These titles show the general tendeney away from hypnotie suggestion and toward mental and moral suasion or psychotherapy, which was implicit in Charcot's teaching. Psychotherapy was put upon a definite basis in such works as Paul Dubois' book on the moral treatment of psychoneuroses (1904), and Isolement et psychotherapie (1904) by Jean Camus and Philippe Pagniez. The treatunent of neurotic persons by moral elueation beame the word of ambition. It was applierl with ability by Rev. Elmwood Woreester and his assoerates at the Emanuel Church at Boston.

${ }^{1}$ Bush: London Med. \& Phys, Jour., 1822, xlviii, 21S-220. Jukes: Ibid., 384-389. Jukes claims priority of publieation, but does not give the soures of his antecedent paper. His priority is, however, acknowleclged by sir Astley Cooper (Laneet, Lond., 1823, i, 223), who says that Jukes originally (inployed a gum-elastic bottle for suction, the syringe having becm singgested by Bush. 


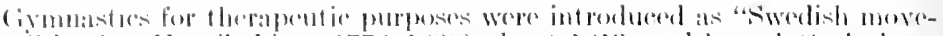

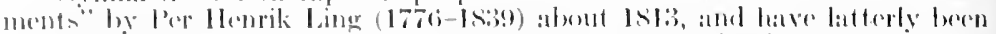

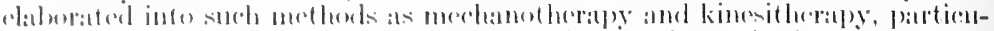

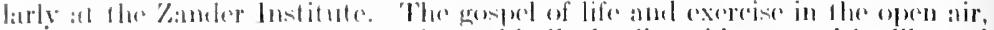

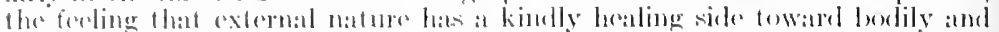

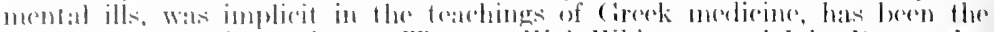

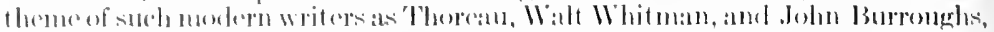

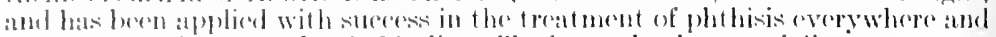

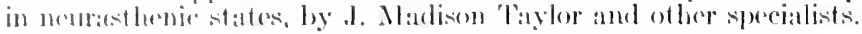

The founder of experimental hygiene was Max vou Pettenkofer (ISIS-1901). of Lichtorsheim, Bavaria, a pupil of Lichig and Bisthofl, who hecame professor of "dietetic chemistry" at Mumich in $18+7$, and professor of hy-

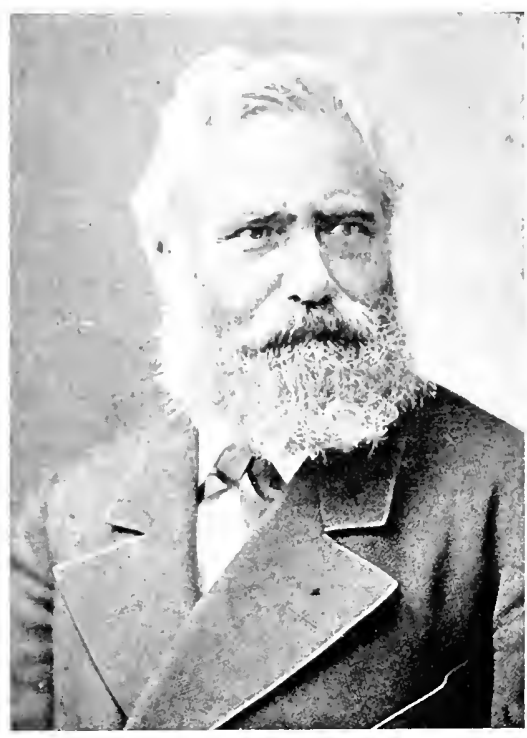

Max von Pettenkofer (1\$18-1901). (Buton Modieal Library.) giene at the same miversity (18.5.3), where, under his direction, the first Ireienic Institute was opened, in 1875. Pettenkofer's artiol work, ats we have seen, was in the field of phrsiological chemistry and motaloolism.

In $184 t$ he introlueed the wellknown test for bile acids and in 1sti3-64, with Voit, he mate his classical investigations of metabolim in respiration. He also investimated such substances as the sulphoryanates in sputum, hippurie aldid, creatin and creutinin. From 155is on he devoted much attention to the entiotrogy of cholera and typhorid fever, the sprearl of which he attributed to the eomslition of the soil and seil-water. latterly opposing the barterial theory of infection to the extent of swallowing a culture of virulent cholera bacilli at seventy-four, in order to prove his thesis. In spite of his somewhat arbitrary views, he all but ricl the city of Munich of trphoid through the introchiction of a propersystem of drainage, a subject which frequently involved him in controversy with Virehow. Pettenkof 'r's most important contributions to experimental hygiene were his method of estimating carbon dioxide in air and water (185), his investigations of the ventilation of dwelling houses (15) S). and the relation of the atmosphere to cothing, habitations and the soil. He studied the relative advantages of stove and hot air heating, showed that air can pass through the thickest masonry, and investigated the contamination of the atmo-phere from gases deep in the parth. He was ennobled in 1 ss.3. and beeame president of the Bavarian Academy of Sciences in 1859. In 1s\$2, Pettenkofer published, with Ziemssen, the Haridbuch der Hygiene, and he was one of the co-erlitors of the Zeitschrift für Biologie (156.5-\$2) and the Arrlive für Hygicne (1883-94). Experimental hygiene, as based upon the bacterial theory of infection, took a new start with the work of Koeh and his associates in the Hygienic Institute at Berlin.

Perhaps the most important of the earlier treatices on public hygiene 
after the time of Johann Peter Frank were John Roberton's "Mredieal Police"

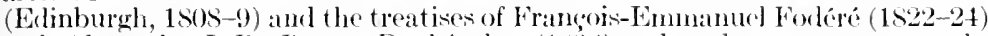
and Alexamlre-J.-I3. Parent-Duchâtelet (1836i), who also wrote an epochmaking work on prostitution in the eity of Paris (1536). David Hosack, in 1820, wrote on the medical police of New York City. In the first half of the century, the subject was extensively eultivated in France. Various treatises were written by Molard (1841), Royer-Collard (1S43), Bourlon (1st4), Michel Levy (184t-45), Briand (1845), Foy (1845), Boulin (18t6), while Parkes's Manual of 1861 set the pace for later works by L. Hirt (1576), L. Fazio (18s0-86), G. H. Rohé (1555), Max Rubner (18s5), E. Flügge (18s9), J. Uffelmann (1ss9-90), W. Pralsnitz (1592), L. Mangin (1s92), Ferdinand Hueppe (1899), A. WV. Blyth (1900), Chartes Harrington (1901), W. T. Sidgwick (1902), Josef Rambousek (1906), and M. J. Rosenau (1913). Pettenkofer's great handbook $(1862-94)$ was followed by similar coöperative works, edited by Thomas stephenson and Shirley F. Murphy (1892-94), Theroior Weyl (1s93-1901) and Tlax Rubner (1911). Industrial hygiene was advanced by sir Humphry Davy (1779-1829), who invented the well-kmown safety lamp) for coal-miners (1S15); by Charles Turner Thackrah (1795-1833), of Leeds, one of Sir Astley Cooper's pupils, who, in his treatise of 1832 , first investigated brass-founders' aute, dust diseases, ete.; by 'Tanquerel des Planches (1809-62), who wrote an important work on diseases in lead workers (15:39); by François Melier, who dealt with the hygiene of tobaceo manufacturers (1849); by A.-L.-D. Delpech, who investigated the rubber industry (1863), and, with $\mathbf{j}$. B. Hillairet, the diseases of chromium manufacturers (1809-76). In Germany, Ludwig Hirt (1S14- ) of Breslau, wrote a monumental four-volume treatise on occupational diseases (1S71-7S), which was followed by the Ifrulbücher of H. Eulenburg (1876), H. Albrecht (1894-96) and Th. Weyl (1908). In England. Sir Thomas Otiver has paid especial attention to dust diseases, miners' and live-wire aeeidents (Dangerous Trades, London, 1902), and Leonard Hill investigated caisson disease (1912) and the general evils of stuffy atmosphere. In Ameriea, the investigations and reports of Coorge M. Kober (190s-16), Frederick L. Hoffman (1909-16), John B. Andrews (1910-16), and Aliee Hanilton (1911-14) on industrial poisons, William C. Hanson on dust and fumes (1913) have proved of great value. Important monographs are those of Josephine Goldmark on industrial fatigue (1912), George M. Price on the modern factory (1914). WV. Gilman Thompson on oceupational diseases (1914), the eo-operative treatise on the same subject edited by George M. Kober and William C. Hanson (1916) and the Industrial Medicine and Surgery of Harry E. Mock (1919). Rudolf Virchow played an important part in the sanitation and sewage disposal of Berlin $(1865-73)$ and was the originator of the modern movement for the hygiene and inspection of school-children (1869), which was ably carried forward by the labors of Edwin Chatwick (1871), Hermann Ludwig Cohn (1SS7), and a host of workers. School hunches for children, first established by Count Rumford, in 1792, were revived in the Caisse des ceoles of a French battalion in Paris in 1849. These becume permanent cantines sfolaires by law in 1852 . Victor Hugo started a selıool luncheon movement at Guernsey in 1866 . In Germany, the movement began at Munich in 1876 , and by 1909 was extended to half the eities of the empire. It began in England in 1902, and in New York City on November 23, 1895. ${ }^{2}$ Dental elinics were introduced at Strassburg and Darnstadt in 1902 . 'There are now 120 in Germany. Food chemistry and the detection of adulterants was the subject of special treatises by F. C. Knapp (184S). Molesehot (1850), A. Chevallier (Dictionnaire, 1850), F. Artmann (1859), E. Reich (1860), J. König (1S7S), H. Fleek (1S52). The sanitation of hospitals was greatly forwarded in the writings of Florenee Nightingale (1859), Lord Lister (1870), Sir Douglas Galton (1893), Sir Henry Burdett (1891-93), and by the lessons gained in the construetion of sueh fine modern struetures as the Johns Hopkins Hospital in Baltimore (1889), the I Iamburg Eppentorf pavilion (1889), or the Rudolf Virehow in Berlin (1906). The hygiene of habitations and the planning of towns is a subject of recent interest among arehitects and sanitary

${ }^{1}$ New York Med. Jour., 1916, eiii, 1037. 
enginers, In Isit, Lord kidvin said that there san be no proper hygiene of

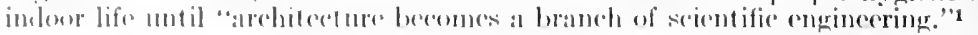

Public hygiene in lingland was sperially advanced by the reports of Sir Jimues Phillips Kay-Shuttleworth (1S01-77) on the cotion worliers of Manchester (1832), the triming of pauper children (1841) and public education (1852-42); and those of 'Thomas Southwood Smith (178S-1861) to the Poor-latw Commisioners on the physical canses of preventable sickness and mortality among the poor (1838), by the reports of sir Edwin Chadwick (1800-90), on poor-law reform (183.1-12), heallh of the laboring dasies (1812) and cometeries (1813-55); by Sir John Simon (1816-1904), whose famous Public Ilealth Report (1887) and English samitary Institutions (1890) excrted great influence upon modern developments and legislation, and by Henry Wydbore Rumsey (1809-76), who, during the last forty years of his life, by sharp criticism, telling evidence before public committees, by his recommendation of miversity degrees in state medicine (1865), and by the effect of his Essays in state medicine (1865) and on the fallacies of statisties (1875) did yeoman's service in advaneing sanitary legislation. The most important English treatise on hygiene is the manual of Ednmond Alexander Parkes (1819-76), published in 1864, in the preparation of which he was aided by Lord Sidney Herbert (1810-61), of Lea, who was Secretary for War at the outbreak of the Crimean War (1854) and chairman of the Roval Commission on the sanitary conditions of the army and of military hospitals and barracks. Lord Herbert was in frequent consultation with Parkes as to the formation of the Army Medical School at Fort Pitt, Chatham, in 1860, which was transferred to the Royal Vietoria Hospital, Netley, in 186:3. It was the friendship of Lord and Lady Herhert for Florence Nightingale which led to the latter's passage to Scutari with forty nurses to look after the soldiers in the Crimean contest. It is said that all the recommendations made by the Fouth African Royal Commission in 1901 had been made by Lord Herbert fifty-five years before. His colleague, Parkes, held the first chair of hygiene in England (at Fort Pitt, 1860), and the Parkes Museum of Hygiene was instituted in his memory, July 18, 1876, and opened on June 28, 1879. Baron Mundy, of Vienna, called Parkes "the founder and best teacher" of military hygiene in our day, the friend and benefactor of every soldicr."

The epidemiologist, William Budd (1811-80), of North Taunton, Devonshire, described by Tyndall as "a man of the highest genius," did the best English work of this time in infectious dis-

${ }^{1}$ Lord Kelvin: Popular Lectures, London, 18\$4, ii, 211. 
eases. His monograph on typhoid fever (1873) demonstrated its contagious nature and the different modes of its transmission. In 1866 he stamped out cholera in Bristol, lowering the mortality to 29 cases as against 1979 in 1849 . His famous recipe for the rinderpest epidemic of 1866 , "a poleaxe and a pit of quicklime," was ridiculed but proved to be the true one. George Budd described an atypical cirrhosis of the liver (without jaundiee) from auto-intoxication (Budd's disease) and William wrote a fiunous paper on symmetrical disease (1842). John Snow (1813-58), of York, a London medical graduate of 1844, first stated the theory that cholera is water-borne and taken into the system by the mouth (1849), in an essay which was awarded a prize of 30,000 franes by the Institute of France. During a severe London epidemic of cholera in 18.54 , he told the vestrymen of St. James that the outbreak would cease if the handle of the Broad Street Pump were removed, which proved to be the case. In 1841, he devised a sort of pulmotor for asphyxiated infants and a trocar for thoracentesis. He was a pioneer in anesthesia, having delivered the Queen by chloroform in 1853 and 1857 . The second edition of his work on cholera (1852), which contains a remarkable statement of the germ theory, cost him $£ 200$

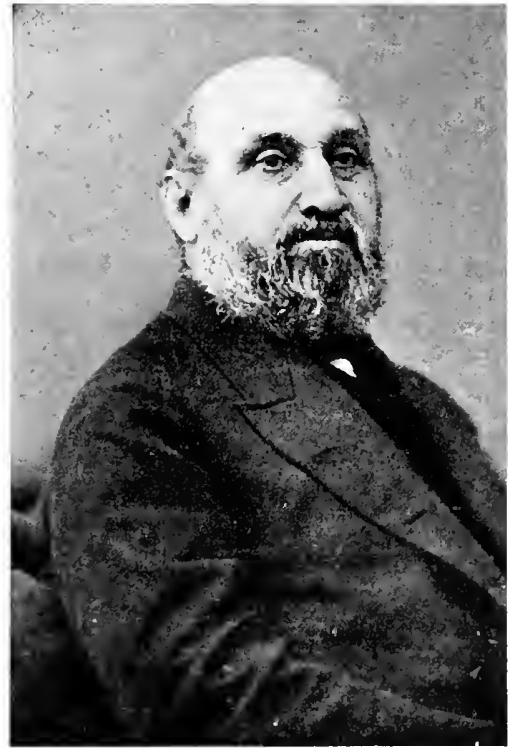

William Farr (1807-83). (Boston Merdical Library.) and netted him a few shillings.

The leading English medical statist of his time was William Farr (1807-83), of Kenley, Shropshire, who, at the instance of Chadwick, gave up medical practice to enter the Registrar General's office, in the reports of which he published his elassie let ters on the causes of death in England (1839-70). His other valuable papers were collected in the volume Yital Statistics (1885), with the exception of his important letter to the Daily News (February 17, $1866^{1}$, which contains the first statement of "Farr's law," viz., that the curve of an epidemic at first ascends rapidly, then slopes slowly

${ }^{1}$ Reprinted by J. Brownlee in Brit. Med. Jour., Lond., 1915, ii, 250-252. 
fo a maximum to fall more lapielly than it mounted. He first plotfor this rurve from the smallpox epidemic of 18.10, and from it he

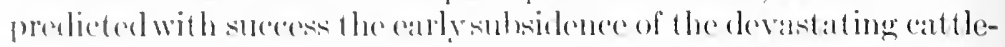

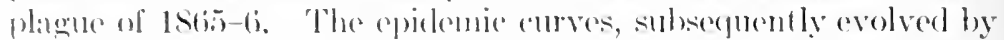

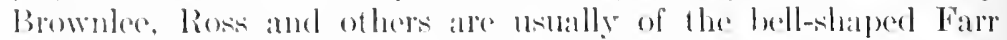

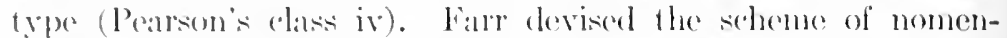
ritture and nosology of the Royal college of Physicians, which is still used in the elassifieation of medical literature and medical libraries. He elited the British Medical Almanack (1835-39), which contains his valuable medical chronology, his remarkable Essun on Prognosis (18:38) and his history of the medical profession in England (1S933).

Perhape the rarliest modern work on statistics was the famous Essay on the Principle of Population (J79S) of Thomas Robert Malthus (1766i-1834), of Guildford, England, which maintains that food-supply and birth-rate increase in arithmetiond and geometrieal ratios mespetively, so that poverty is the natural result of inereased population. It has exerted a profound influence upon the postponement of marriage and the deerease in size of families down to) the present time, although it is erroneous to deseribe methorls of preventing conception as "Malthusian," as these (originally suggested by Condorcet) were unequirocally eondemned by Malthus. Nedieal statisties were introduced by Louis (1535). The modern methods of arriving at the mortality of large eities and other data were blocked out by the Hungurian statistieian Josif ron Körös (1s73); the fallacies and other nathematieal relations of vital statisties were studied by the English writers. Henry Wyldbore Rumsey (1575) and William Farr (1555). In Ameriea, John shaw Billings (1S381913) made valuable contributions, particularly in his Cartwright Leetures (18s9) and his special reports on the United States Census. Frederick I. Hoffman has investigated the statisties of eancer (1915) and other diseases. The statistical investigations of Jaeques Bertillon (1851-1914) on the depopulation of Franer (1850-1911') have had their effect upon other countries in which a falling off of the birth-rate is noticeable. Karl Pearson's work belongs to the twentieth eentury. In Ameriea, his biometrie methods have been applied with telling effeet to vital and medieal statisties by John $\mathrm{S}$. Fulton, Charles B. Davenport and Raymond Pearl.

In the department of medical jurisprudence the treatise of FrançoisEmmanuel Fodéré (1798, 1812) was the standard source of authority in France in the early part of the eentury. In Germany, Johann Ludwig Caspar (17961S64), of B̉erlin, achieverl a wide reputation through his works on medieal statistics and state medicine (1825-35), jullicial post mortems (1851-53), and his Practical Handbook of Legal Medicine (1856), which remained, for a long time, unsurpasisel for its wealth of facts and sound judgments. The first treatises in English were written by the Amerieans, Theodric Romern Beck (1S2:3) and Iraac Ray (1839). William Augustus Guy (1810-85) was the first English writer on the subject (1844). Other American treatises of note were tho:e by Franeis Wharton and Moreton Stillé (15.5), and John Ordronaux (1S69), both of which deal with forensie medicine from the lawyer's point of view. The four-volume treatise of Witthaus and Becker (1894-96) is a comprehensive modern enevelopedia, written by many hands. Heinnoth (1825), Isaae Ray (1839), Trifft-Ebing (1875) and Charles Arthur Nereier (1890) have dealt with the jurisprudenee of insanity, Carl Ferdinand von Arlt with the medicolegal aspect of injuries of the eve (1875), MI.-J.-B. Orfila (1S13-15), Sir Robert Christion (1829), Auguste-Ambroise Tardieu (1567) and Georg Dragendorff $(1869-72)$ with toxicology, Frank Hastings Hamilton with the

1 J. Bertillon: La dépopulation de la France, Paris, 1911. 
jurisprudence of deformities after fractures (15,5), and Krafft-Ebing with sexual perversion and inversion (1Ss; 7 ). Theodore Gergere Wormeley wote a sterling work on the mierochemistry of poisoms (1s67), and Virehow's little handbook of yostmortem teclnic $(1>76)$, was the standarel in its day. In recent times, Paul Brouardel (15:37-1906), of Paris, is memorablefor a number of exhaustive monographs of value, in particular, those on death amel sulden death (189.5), hanging, strangulation, suffoeation and (lrowning (1s97) and infanticide (1897). The precipitin test (Borlet-Ublenhuth) for blowl-stains. was introduced in $1901,{ }^{1}$ and the cobra-venom reaction in insanity (MuchHoltzmiann) in 1909.2

From the time of Haller, the study of medical history has been mainly in the hands of (ierminn and French writer's.

British scholars, such as Francis Atams (1796-1\$61), of Banchory, Seotland, William Alexanuler Greenhill (1814-94), of London, the editor of fydenham, have made valuable transhations of the greater (ireck and Roman clasices; and delightful books and essays, with the genume flavor of letters, have been written by William MaeMichael (The Gold IIeaded Canc, 1527), John Brown (INore Subsecive, 185\%), J. Cordy .Jeaffreson (A Book About Doctors, 1S60), Wilks and Bettany (History of Guy's Iospital, 1892), Nir Benjamin Wari Richardson (Disciples of Esculapius, 1900), particularly by the two Regius. professors, Osler and Allbutt; yet no work on a large sallo has been at temptre] in Great Britain or America which will measure up with the performances of Haeser or Daremberg, mless it be Charles Creighton's II story of Evidemies in Britain (1894). Thomas Young's Introduction of Medieal Litcrature (1813), an unfinished history of medieine by Edward Meryon (IS61), a very readable one by Erlward 'T. Withington (1894), the studies of John Flint Sonth (1S86), Sydney Young (1890), and D'Arey Power (1899) on English surgery, Sir Clifford Allbutt's stulies of medieval science and surgery $\left.(1901-1)^{5}\right)$, J. F. Payne on Anglo-saxon medieine (1904). L. M. Griffiths on medical phitology (1905), Norman Moore on medical elueation in Great Britain (1908), Raymond Crawfurd on the King's Evil (1911), plagur and pestilence (1914), Charles A. Mercier on astrology in medicine (1914) and leper-houses (1915), Charles singer's studies on the history of contagion, microseopy and tropical medicine, and the illuminating essays of Sir William Osler are ameng the best things that lave been done in England. Ip to the present time, Aneriean contributions have been meager in extent. The best are the exsays of Joseph Meredith Toner, John Call Dalton [Cartwright leetures on the experimental method (1SS2) and his Doctrines of the Circulation (1S84)] and George. Jackson Fisher, the historical survey entitled "A Century of American Medicine" (1S76), the Medical Essays of Oliver Wendoll IIolmes (1883), Weir Mitchell's history of instrumental precision in medicine (1892) and Harvey memorials, James J. Walsh's studies of medieval medicine, the history of nursing by Mary Adelaide Nutting and Lavinia L. Dock (1907-12), John G. Curtis's stuly of Harvey (1916) and Ilenry M. Hurd's history of Ameriean psychiatry (1916). The English translation of Baas by Henry E. Handerson (1837- j, of Orange, Ohio, preserves the humorous flavor of the original and is doubly valuable for the superalded material. The earliest American histories of medicine were those of Peter Mirldleton (1769), Robley Dunglison (1s72). and the short history of Roswell Park (1897); the history of medicine in the United States has been treaterl by James Thacher (1828), Francis Ranlolph Packard (1901) and James Gregory MImmford (190.3); Jewish medicine by Sharles D. Spivak and F. T. Haneman (1904); medical folk-lore by Robert Fleteher; medical botanists and medical illustrators by Howard $\mathrm{A}$. Welly.

${ }^{1}$ Uhlenhutly: Deutsehe med. Wochensehr., Leipz. \& B(rl., 1901, xxvii, $36 ; 260$.

${ }^{2}$ Much: Centralbl. f. Bakteriol. (ete.), Beil. zn 1. Abt., Jena, 1909, xlii, $-8-50$. 
William A. Heidel's stuely of Creok compunoular theorios (1910) is a fine examplo of what philologiond stuly maye do for medical history.

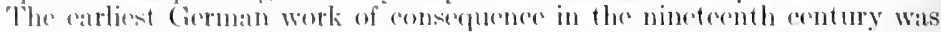
the Gischichte der Heilkunde of .I. I. K. Hecker (1795-1550) which was fol-

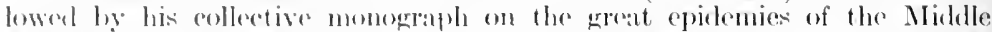
Ages (1vii)). "The most scholarly and thoroughgoing medieal history of mort-

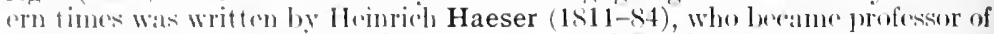

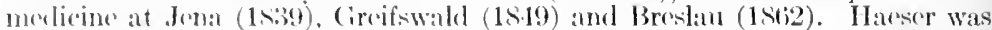
the son of a music directer at Wintar, was brought ap) in an atmospliere of sulfure and wats one of the most learned physicians of his time. Ilis carlier worlis on the history of epulemic discases (1839-11) and his Bibliothece rpidemiographica (1S.43), with the valuable ddditamenta by Johamn Gottlieb "Thiorfolder (1st3) demomstrate his takents for afose investigation. These eane to apt fruition in his Lehbuch der Geschichte der Wedicin und der Volksliramhheiten (1545), which, in its third odition (1575-82), hat become an unrivalod storehouse of knowledge, wonderfully acourate as to dates and eitations, although naturally there were a fow croms here and there. The third volume, on the history of apdemies, contains original citations of many firsthand deseriptions of disease from the old mmicipal and monkish ehronicles, a ficld in which Ilacser has hern equalled only by Sudhoff. Hacser's masterpiece was followed in Cermany by the histories of Wunderlieh (1S59), Johann Hormamn Bats (1S76), Julius Pagel (1s9s, 1901-6), and the Viennese professor, Max Neuburger (190), all of them works of solid and sterling character. Meanwhile, Russian molicine was treated hy Wilholm Michad Jichter (181317). Arabian medicine by Heinrieh Ferdinind Wüstenfold (1840), and Karl Opitz (1906), the history of syphilis by Conrad Heinrich Fuchs (1543), Julius Rosenbaum (1845), and Iwan Bloch (1901-11), Talmudic gynecology by A. II. Israels (1St5), the history of medieval leprosy by Virchow (1S60-015), Cerman medicine by Heinrieh Rohlfs (1875-82) and August Hirsch (1893), the history of therapeities (1S77) and the merlieal elinie (1889) by the Dane J. J. Petersen (1840-1912), Viennese medieine (1SS4) and the history of medieal education (1889) hy Theodor Puschmann (1814-99), Portuguese medicine by M. Lemos (1S91), 'Thibetan medicine by Heinrieh Laufer $(1900)$, cumeiform medicine hy Felix ron Oefele (1902), the history of epidemic liseases by Noah Webster $(1799,1802)$, J. A. F. Ozanam (1817-23), Alfonso Corradi (1865-86) and C. Creighton (1891-94), the history of plague and eholera by Georg Sticker (1908-12), Persian medieine by the Norwegian, Adolf Mauritz Fonahn (1910), and Jewish medicine by Julius Preuss (1911). Remarkable medical scholars were Johann Ludwig Choulant (1791-1861) of Dresien, author of sterling bibliographies (1S2S-42) and an unrivalled history of anatomical illustration (1852); Karl Friedrich Heinrich Marx (1796-1877) of Götingen, the first molern to signalize the importance of Leonarcio rla Vinci in anatomy (184S), the first to list and elassif $y^{2}$ paintings of medical interest (1861) and author of Origiues contogii (1824-2i) and of exhaustive sturlies of Horophilus (1838), Blumenbach (1840), Paraeelsus (1842), Leibnitz (1859), Conring (1872), Paullini (1S73) and Schneider (1873); Moritz Steinschneider (1817-1907), one of the greatest of medieal arehivists, who catalogued the Oriental MSS. in the Bodlcian, wrote authoritative stuclies on pseudo-epigraphic literature (1862), the Arabic sources of Constantinus Africanus (1866), Donnolo (1868), Arabian toxicology and quackery (18f66), Arabic translations from the Greek (1891) and erowned his labors with his great work on the Hebrew translations of the Middle Ages (1893); August Hirsch (1817-92), author of the monumental Handbook of historie-geographic pathology (1860-64); Gurlt, the historian of surgery; Fröhlich, the historian of military medieine; Valentin Rose (1829-1916), cataloguer of the Latin NISS. in the Royal Library at Berlin (1893-1905) and editor of Aristoteles psendepigraphicus (1S63), Anecdota grace ot graro-latina (1864-87), Vitruvius (1867-99), medieal Pliny (1575), Anthimus (1877), Cassius Felix (1879), Theodorus Priscianus (1852) and Agiclius Corboliensis (1907); Max Höfler (1S48-1915), author of a dictionary of old German medical terms (1S99). J. Berendes, the translat or of Dioscorides and Paul of Agina; and the medical philologists, Hermann Diels, Johannes llberg and Max Wellmann, now professor of medical history at Berlin (1920). 
Julius Pagel (1851-1912), a busy practitioner of Brolin, who edited Mondeville (1859-92) and Mesuc (1893), wrote a history of molieine in 1897 and issued a capital biographical lexicon $(1900)$, an eneycloperlic history of morlicine (19016), and a usoful medieal ehronology (190s). 'The work of Karl siblhoff has a high place in the twenticth entury. The ablest medical historian of linnce. was Charles-Victor Daremberg (18i7-72), of Dijon, who edited and translated Oribisius (155I-76), the Four Masters (1854), select works of Hippocrates (1543), Galen (15.54-56) and Celsus (15.59), made original investigations of Homeric medicine (1S6.5), Hindu molicine (1567), medicine between Homer and Hippoclates (1569), and wrote an admirable history of medicine (1 150 ), which is still consulted. Daremberg was a wam friend of Enile Littré (180181) of Paris, one of the greatest of modical philologists, who wats the authol of a huge dietionary of the French language (1863-72), published the finest modern edition of Ilippoerates, with parallal French translation (1\$39-fi1), also of Pliny's Natural History (1845-50), reëdited Nysten's morlical dictionary and wrote many interesting historical essays (1861-81), notahly those on Celsus, Magendie, Cuvier, Buckle, Socrates and Pascal, Gil Blis, the great epidemies, historical suicides and poisonings, the pest-carriers, spiritism and the cholera of 1832 . Other French contributions of value are the medical histories of Eugene Bouchut (1873) ant Lén Memier (1911), the sturlies ol medicine in the Latin poets by Prosper Menicre (1S58) and Elmond Dupouy (1855), Maurice Raynaud's sturly of medicine in the time of Molière (1862), Achille Chéreau's listories of French melical journalism (1867), plague in Paris (1873), Coitier (1861), Mondeville (1862), Guillotin (1873) and the library of the Paris Medical Faculty (1878), the splendid memorials of the Paris Mfedieal Faculty by Auguste Corlicu (1896) and Nó́ Lacorand (1911) Ernest Wickersheimer's study of Renaissanee medicine in France $(1905)$ and Raphael Blanchard's "Epigraphie médieate" (1909-15). The sturly of medicine in relation to art was inalugurated by Virchow (1S61), blocked out in detail by Marx (1861), placel upon its feet by the extensive work of Chareot and his pupils and continued in such Gerinan works as Hermann Peters' Der Arzt (1900), Eugen HoHänder on medicine in classical painting (1903), medical caricature and satire (1905) and molieine in the plastic arts (1912). and Robert Müllerhein on the lying-in chamber in art (1904) and li. Parkes Weber on reath in art (1910). Mesticine in aneient India was treated by ,ir Bhagvat Sin Jee (1896) and August F. R. Itoernle (1907), melicine in Mexico by Franciseo A. Flores (1S\$6-8), medieine in Upper Canarla by William Canniff (1s94). Useful biographical dietionaries of medicine are those of J. A. Dezeineris (182S-9), Bavle and Thillaye (15.55), August Hirseh and E. Gurlt (1884-8) and Pagel (1900). The notiess in the Dictionary of National Biography (1855-1912) for English physicians; and for Americin physicians, James Thacher (1\$28), S. D. Ciross (1561), W. B. Atkinson (1S78), R. F. Stone (1894), Irving A. Wation (1896) and Howard A. Kelly (1912) are indispensable. In Italy, a good history of medieine was written by lrancesco Puecinotti (1850-66), the Copenhigen manuseripts of the Sehool of Salerno were edited by salvatore 1)e Renzi (Collectio Salernitana, Naples, 1553-59) and Piero Giacosa (1901), De Renzi wrote a five-volumb history of Italian melicine (1844-8), and an exeellent history of dentistry was written by Vincenzo Gucrini (1909). Treatises on melieal geography were written by F. Schnurrer (1S13), V. Isenses (1833), Marslall (1832), C. F. Fuehs (1853), A. Mühry (1856), J. Bouctin (1857), A. Hirsch (1860-64). Aurlrew Davidion (1892) and Frank C. Clemow (1903). Latterly, Piotro Capparoni (Rome), Andrea Corsini (Florence), Modestimo del Gaizo (Naples), Cimseppe Albertotti (Padua), and Domenico Barluzzi (Siona) have done exollent work in original medien-historical investigation. The ehair of melieal history in the Paris Faculty, has bern held intermittently by Goulin (1795-9), Cabanè (1799-1S(5), Moreatu de la Furtho (1S18-22), Daremberg (1870-72), Jorain (1873-5), Parrot (1876-9), Laboulbòne (1S79-99) and Menetrier (1520). The study of medical history was introduced at Vienna by Romeo Seligmann (1833), at Berlin by Pagel, at Leipzig by Sulhoff, at Glasgow by Comrie, in Baltimore by Billings, Welch, Osler and Cordell.

Among the modern periodicals devoted to medical history are Hreker's 
Litterarische Annalen der gesemmen I1rilkunde (Borlin, 1525-35), Choulant's

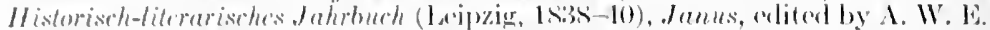

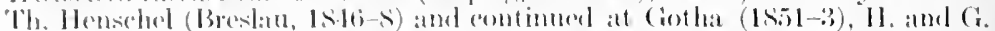

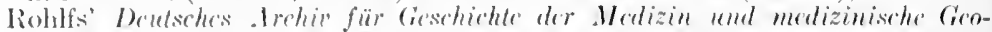

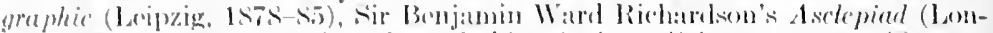

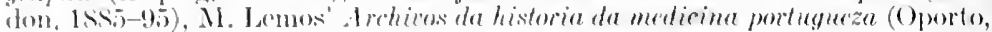

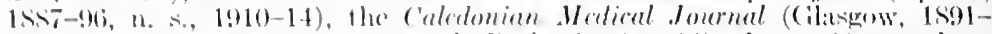

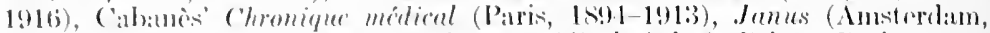
1s9(-1917), the new series of La Frane midicale (ed. A. Prieur, Paris, 1900)1914), the Abhendlungen zur Gesehichte der Medizin (Breslau, 1902-ti), the Vedical Library and Ilistorial Journal (Brooklyn and New York, 1903)-7), which had a short-lived suceessor, the Wsculepium (Brooklyn, 190s-9), and

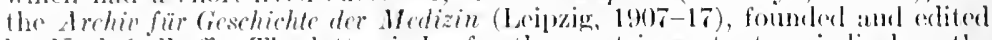
by Kirl sidlholf. The latter is by far the most important periodical on the subjert which has yet appeared, the rontents bring devoted exclusively to original researeh. Among the monograllhie serials are Sudhoff's studien zur Gesehichte der Mcdizin (Leipzig, 1907-15), 'Theodor Meyer-Steineg's .Jenaer

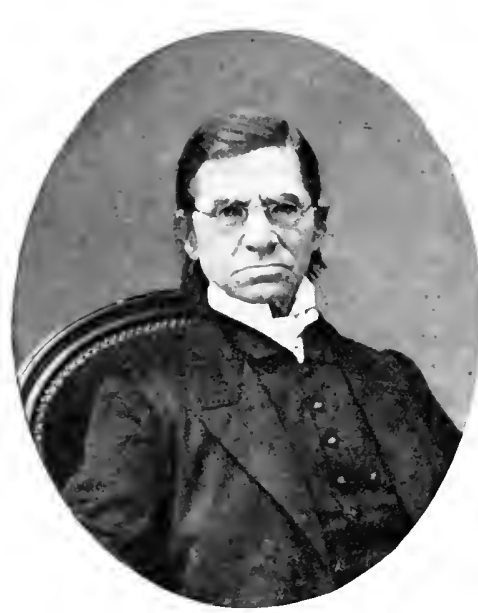

Émile Littré (1801-\$1). madizin-historische Beträge (1912and Vilholm Maar's Medicinish-historisli Smanskifter (Copenhagen, 191214). Several medieal history socenties atr now publishing transactions, in partienlatr, the Deutsole Gesellschaft fiur (ireshichteder Medizin und der Naturwisconsehaften at Loipzig (Mitteilun$g e n, 19(02-17)$, the Charaka Club, New York (Proecedings, 1902-17), the Soeiété française d'histoire de mélerine, Paris (Bulletin, 1903-14), the Societa italiana della storia eritica delle scionze mediche e naturali, Rome (Rivista, 1910-17), the Society of Medieal History of Chieago (Bulletin, 1911-17) and the Ilistorieal Section of the Royal Society of Medicine of London (Proecetings, 1912-17). The Bulletin of the Johns Hopkins Hospital (1S90-1917) is the literary organ of the Hospital Historical Club. The Annats of Medical History (1917-20), edited by Francis R. Packard, is now the leading Ameriean perioslieal of the subject. The eareful reviews in the Leipzig Mitteitungen, under the direction of Sudhoff and Siegmund Günther, afford a convenient clearing-house of all reeent medico-historical literature.

Medical lexicography in the nineteenth century made remarkable advances, both in respect of solid performance and practical utility, under the inspiration of the gigantic accomplishment of Emile Littré (1801-81), whose five-volume dietionary of the French language (1863-72) set the pace for all modern scholars. The medical dictionary of Pierre-Hubert Nysten (1810) was, in its tenth edition (1855), entirely recast and enlarged by Littré and Charles Robin (1821-85), reaching its 21st edition in 1905. Nysten was followed by a swarm of medical clictionaries in all languages, notably those of A. F. Hecker (1816-22), Robley Dunglison (1833), James Copland (1834-59), R. D. Hoblyn (1835), Otto Roth 
(1878), the New Sydenham Society (Henry Power and I. W. Sedgwick, 187S-99), Nir Richard Quain (18S2), (ieorge M. Fould (1890), J. S. Billings (1890), A. L. Ciarnier and V. Delamane (1900), L. Landouzy and F. Jayle (1902), $\mathbb{W}$. Guttmann (1902), and the Larousse médical illustré of E. (ialtier-Boissière (1912). In point of seholarship, the best medical dictionary of American origin is the four-volune work (1885-93) by Frank Pieree Foster (18411911), which was followed by a number of very practical books in flexible leather, such as those of $\mathrm{WI}$. A. N. Dorland (1900), H. WV. Cattell (1910) and Thomas L. Stedman (1911). Of dictionaries of special terms, we may specify those of Julius Hirschbere for ophthalmology (1887), Charles Richet for physiology (1895-1907), Wilhelm Roux for embryology, and the Larousse médical de guerre (Galtier-Boissière, 1917) for military medicine.

As the modern period has been the great age of medieal periodicals, so too it has been the age of medical bibliography.

In the past, Conrad Gesner dirl something of the kind as early as 1545. Haller wis the leading medieal bibliographer of the eighteenth century, and, in the nineteentl, Young (1813), Haeser (1862), Ploneruet, Forbes, Atkinson, Watts and others did gool work; but the first attempt to give in indexed author catalogure of an entire period, incluting the eontents of perierlicals, was the Medicinisches Schriftsteller-Lexion (33) volmues, 1930-45) of the Dimish surgeon, Carl Peter Callisen (1787-1866). As a complete conspestus of this merlieal literature of the last half of the eighteenth eentury and the first third of the nineteenth, this production ranks with Haller's as one of the most wonderful things ever achicved by a single man. It is invaluable for seope and aceuracy. Other works of equal value are the IIandluch der Büsherkunde (1825) of Ludrig Choulant (1791-1S61), which, in its seconrl erlition (1841), is, with the indispensable Additamenta of Julius Rosenbanm (1812), the best check list we have of the different editions of the older merlical writers. The Repertorium biblingraphisum (1S26-2s) of Ludwig Hain, with the supplements of Walter Arthur Copinger (1 $\$ 95-1902)$ and Dietrich Reichling (1905-11), has been the standard catalogue of the incmabula.

The opportunity for a unique bibliography of the entire medical literature of the world was afforded by the building up of the Library of the Surgenn-General's Office at Washington, which, at the outbreak of the Civil War, consisted of some 1000 odd volumes and became, in time, the best medical library in the work through the energy, perserverance, and ability of its principal founder, John Shaw Billings (1838-1913), a native of Indiana, who had been a distinguished army surgeon in the Civil War. In 1876, Billings published a specimen Fasciculus of a combined index catalogue of authors and subjects, arranged in a single alphabet in clictionary order, and, in 1880, he issued the first volume of the Index Calalogne of the library, in which he was assisted by Robert Fletcher (18231912), of Bristol, England. This work, the most exhanstive piece of medical bibliography ever undertaken, has now reached its hirty-seventh volume (second series, XXI), and embraces the 
contents of a medical librum of over 600,000 items. The selection of the material and the scientifie classification in the first series (1SS0-95) Wore mate by Billings; the carcful proofreading wats done by Fleteher; both classification and proofreading of the secomd series (1S96) were done by Fleteher up to the time of his death (1912). This work, and the Index Medicus, a monthly hibliography of the world's modical literature, edited in the first series (1S79-99) by Billings and Fleteher, and revived, with Fletcher as oditor-in-ehief, by the Carnegie Institution of Washington, in 1903, are known to all physicians who use medical litera-

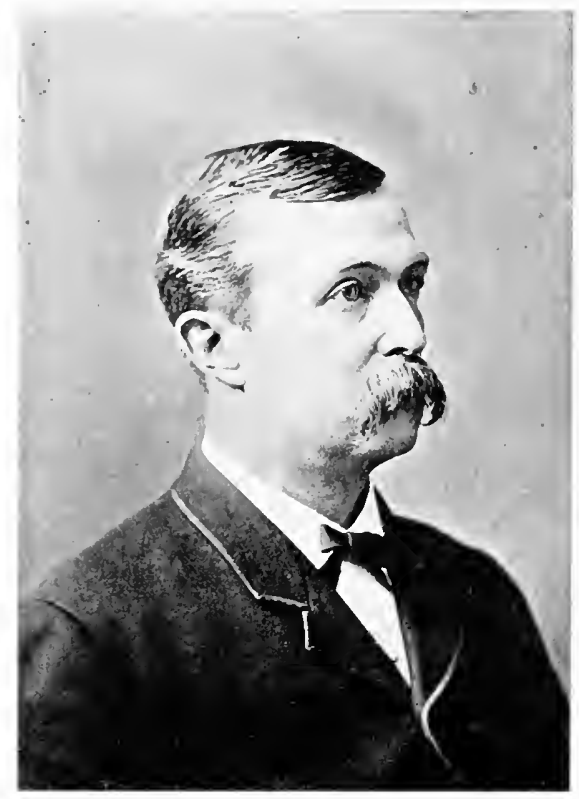

John Shaw Billings (183S-1913). (Courtesy of the National Academy of Sciences.)

ture. Apart from his talents as a medieal bibliographer, Billings was a man of all-round ability, an able operative surgeon in wartime, an authority on military medicine, public hygiene, sanitary engineering, statisties and hospital construction, the author of the most eritical account of American medical literature (1876) and the best history of surgery that has been published in English (1895) and widely known as the designer of the Johns Hopkins and other modern hospitals. Altogether, Billings did a giant's work for the advancement of American medicine. The erown of his achievement as a civil administrator was the New York Public 
Library, which he planned with his own hands and brought to its present state of efficiency. Fletcher made many admirable contributions to anthropology and medical history.

The example set by Billings in the Surgeon-General's Library and its Index Catalogue gave an enormous impetus to the growth of medical libraries in the United States, of which there are now 167 as algainst 118 in Europe. 'The three largest medical libruries in the world are the Library of the Paris Medical Faeulty (240,(000 volumes, 800,000 pamphlets), the SurgeonGeneral's Library at Washington, D. C. (238,799 volumes, 366,925 pamphlets), and the Library of the Imperial Medico-Nilitary Academy at Petrograd (180,000 volumes). The Libraty of the College of Physicians of Philadetphia (founded 1788) has 101,340 volumes and 89,807 pamphlets, the Library of the Medical and Chirurgical Faeulty of Maryland (founded 1830), 23,000 volumes, the Library of the New York Aeademy of Medicine (founded 1\$46), 100,000 volumes and 85,000 pamphlets. The Boston Medical Library, founded August 20, 1875, with Oliver Wendell Holmes as president, James R. Chardwiek and Edwin H. Brigham as lihrarians, has some $\$ 2,275$ volumes, 57,035 pamplulets, and is now directed by Dr. John W. Farlow. The Medical Library Association of the United States and Canuda (founded 1s9s) has been represented by the periodieals Medical Libraries (1898-1902), edited by Charles D. Spivak, a short-lived Bulletin (1962), The Medical Library and Historical Journal (1903-7), and the present Bulletin of the Merdical Library Association (1911) edited by John Ruhräh and Miss Marcia C. Noyes.

46 


\section{THE TWENTIETH CENTURY: THE BEGINNINGS OF ORGANIZED PREVENTIVE MEDICINE}

Priniture medicine, with its Egrptian and Oriental congeners, is essentially a phase of anthropology. Greek medicine was science in the making, with Roman medicine as an offshoot, Byzantium as a cold-storage plant, and Islam as traveling agent. 'The best side of medieval medicine was the organization of hospitals, sick nursing, medical legislation and eduction; its reactionary tendeneies are mainly of antiquarian interest. The Renaissance Period marks the birth of anatomy as a science, with a corresponding growth of surgery as a handicraft. The best of seventeenthcentury medicine was purely scientific. Eighteenth-century medicine was again retrograde in respect of system-making, but has to its credit the beginnings of pathology, refined diagnosis (Auenbrugger), experimental and physiological surgery (John Hunter), and acquires an added social interest in relation to the founding of preventive medicine (Jenner), and the extension of public hygiene (Frank). In the nineteenth century, the advancement of science was organized and scientific surgery was ereated. The interest of twenticth-century medicine is again social.

The most noticeable things about recent medicine are the growth of coopperation and international solidarity, and the fact that nearly every important advance that has been made is prophylactic, that is, comes within the scope of preventing the occurrence, the recurrence, or the spread of the discase. Listerism; the gifts to mankind of Jenner, Pasteur, Semmelweis, Credé, and O'Dwyer; the chemical and bacteriological examination of air, water, food, soils, and drugs; the purification of sewage; cremation; the hygiene of occupations and habitations; the medical inspection and care of school-children and factory children; the Binet-Simon tests; racation colonies; social surveys and settlement work; the war on the white-slave traffic; the police surveillance of perverts and criminal characters in great cities like Berlin; the Gothenburg method of regulating the liquor traffic; the revival of the old Greek ideal of athleties and personal hygiene; the displacement of the medieval ascetic view of the sexual instinct by the clear-eyed scientific view; the formation of societies for moral prophylaxis and eugenics; the proposed legal regulation of marriage and sterilization of degenerate stock; the intensive 
study of alcoholism, the drug habit, syphilis, tuberculosis, and cancer; the use of medical bibliography and statisties to get extensive information as to pathologieal conditions in space and time; the coöperation of universities, armies, public health services and private endowments in preventing tropical or parasitic diseases; international congresses; the Geneva Convention; even such things as Banting, Bertillonage, Esmarch bandlages, or sanitary towels and drinking cups, are all features of preventive medicine or medicine on a grand seale. It is evident that the misapplication of some of these prophylactic measures might lead to social slavery worse than that of feudalism, because, as Emerson said, "The race is great, the ideal fair, the men whiffling and unsure." In the hands of corrupt politicians, Johann Peter Frank's great concept of a scientific medical police might easily become a stalking horse for private vindictiveness, in the regulation of marriage, for instance. As Allbutt has wittily said: "The Greek philosopher, like the morlern socialist, would sacrifice man to the State; the priest would sacrifice man to the Chureh; the scientific evolutionist woukl sacrifice man to the race."

The tendency in all branches of recent science, even in zoölogy, sociology, therapeuties, internal medicine and surgery, has been to pass out of the deseriptive into the experimental stage. The aim of seience to predict and control phenomena is shown in the application of the equation in Mendel's law to the study of heredity, in Loeb's proof that the fertilization and development of the embryo is a chemical process, in the eonsideration of the accessory chromosome as the determinant of sex, in the conguest of such diseases as typhoid and yellow fever or hookworm infection, in the extravital cultivation and rejuvenation of tissues, in the more exact knowledge of diseases of the heart, disorders of the internal secretions, and diseases due to filterable viruses, and in the recent developments of Hunterian or physiologieal surgery.

In 1865, ${ }^{1}$ the Augustinian Monk Gregor Johann Mendel (182234), abbot of Brünn, announced the results of certain experiments on hybridization in peas in the form of a law which shed much ight upon inheritance and the origin of species. If we agree to epresent the generation of hybrids by the mathematical process of squaring, and if a represents the dominant or inchangeable haracters, and $b$ the recessive or latent characters in the parents, hen Mendel's law beeomes identical with Newton's binomial heorem: $(a+b)^{2}=a^{2}+2 a b+b^{2}$; in other words, one-half of the rogeny will breed true to the parental characters $(2 a b)$, while the

1Mendel: Versuche über Pflanzen-Hybriden, Verhandl. d. naturf. Ver. 1 Brünn (1S65), 1866, iv, 3-270. 
other half will be divided equally between offspring possessing only the dominant (a) and the recessive (b) chatraters. In subsecpunt encorations, the hybrid offspring will hroed according to Mendel's law, while the dominants and recessives will brod true to their kinds, For at last thirty-five yoas this ankgue approximation, printed in an olsene periodical, remained monoticed, but in 1900, Hlugo do Vries (1s18- ), ( . ( 'orrons, and F. T'sohormak simmlaneonsly anfirmed Mendel's results in every lesped, while, in 1s!7, francis (iallon hat arrived at a statistionl "law of heredity," hased upon his observations on the poligrees of basset

hommds. Fom his experiments with the plant (Eno-

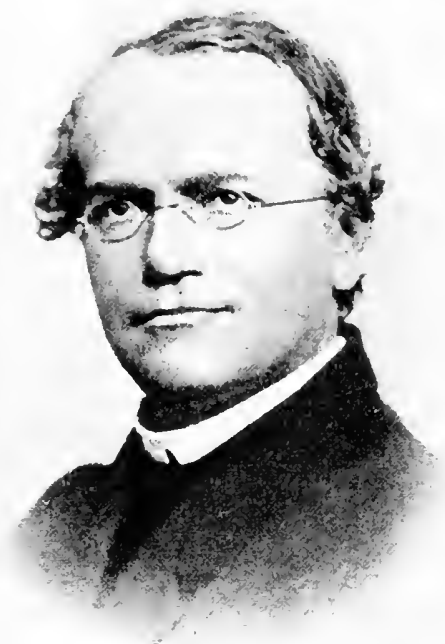

Gregor Johann Mendel (1822-18\$4). (Courtesy of Professor William Bateson. London.) which have been read into it by overzealous admirers, but no experiments to date have demonstrated that species originate by mutation alone. The trent of recent opinion is to the effect that the importance of mutation, which commonly obtains in plants only, has been somewhat exaggerated. Darwin perhaps overemphasized the significance of the external factor of environmental stress in the struggle for existence as originating species by long-continued (evontualiy) "natural" selection. Mendel and de Vries have indicated the internal biochemical forces at work in bringing about the mathematical permutations and combinations of the determinants 
in the supposed discontinuous origin of species de now or per sultum. But whether evolution proceeds by slow gradations or by lazps and bounds or, what seems most likely, is capable of both continuous and discontinuous processes, it is probable that the apparenty spontaneous results of saltatory or Mendelian variation had, in each case, "a long foreground," in the sense of being the end product of a complex series of physico-chemical changes. In other words, Mendelian mutations are probably latent factors or coefficients of a given species which crop ont occasionally and breed true to their kind, and, in any case, represent the term and end of some physico-chemical process. Old Sir Thomas Browne, the first to use the term, said that "mutations, however they began, depend upon durable foundations, and such as may continue forever," which secms the conclusion of the whole matter. Natural selection and mutation may "explain" the origin of structural adaptations, so that their transmutations can be verified, if need be, in the laboratory, but of the origin of organic and functional adaptations, such as the regeneration of tissues, automatic regulation of form, development of embryos from fractions of the ovum or by chemical activation (parthenogenesis), these theories tell us nothing, because the "power of adaptation" which is assigned as a reason is the very thing we are called upon to account for and explain. At most, we can only explain adaptation by harking back to the old Hallerian doctrine of the specialized "irritability" of individual protoplasmic tissues, which Ehrlich has declared to be one of the most obseure provinces of physiology.

In striking contrast with Mendelism stands the new statistical science of biometrics, which is the special croution of Francis Galton and his brilliant pupil, Karl Pearson (1857- ), The theory of probabilities was first applied to sociological phenomena by the Belgian astronomer and statistician, Adolphe Quetelet (1796-187 $\left.4^{2}\right)$, but Cialton's Natural Imheritance (1889) introduced the statistical study of biological variation and inheritance. Pearson, an English barrister, now director of the Laboratory for Nattional Eugenies, founded by Gialton, has applied the higher mathematies in the most ingenious way to the solution of these problems and has created a rational school of iatromathematics. His fascinating volumes on "The (hances of Death" (1897) opened out many new views as to the moaning of statisties as interproted by algebraic curves, the significance of correlations, and the use

"Pseudodoxia Epidemiea, Book vi, ch. x, "Of the Blacknesis of Vegroes" (Bohn's ed., v. ii, p. 18s), cited by Pumnett.

${ }^{2}$ Quetelet: Sur l'hommo, Brussels, 1sisti; Lettre Sur lat theorie des probabilités appliquée aux scienees morales et sociales, Brusicels, 18t6; Loi de périodicité, Brusseds, 1870 , ote. 
of the same in obtaining accurate data as to the hidden causes of biological and social phenomena which eamnot themselves be measured quantitatively. (ialton used the term "regression" to indicate the extent to which an average biological unit is more like the mean or medioce level of the general stock than like its parent. By correlation, Pearson means the logical opposite, viz., the extent to which the offspring is more like its parents than like the average unit of the species. If parent and offspring are exactly alike, in respect of the quality under investigation, the correlation curve will be a line making an angle of $45^{\circ}$ with the abseissae or the ordinates. If the filial quality exists to a lesser degree thin the parental, the eurve will have a more insignificant slope, the degree of slope ("corrclation-coefficient") being the tangent of the angle made with the horizontal. If there is no correlation, the curve will be a horizontal line. By this means, Pearson has brought out many new facts and bionomie theorems, particularly in the journal Biometrika.' For example, he has shown that, in the case of tubereulosis, it is not the disease but the diathesis which is inherited, not the seed but the soil; that there is no neurotic inheritance from alcoholie parentage unless the stock itself be neurotic; that the death-rate from disease is selective in a large pereentage of cuses, and that a higher infantile death-rate implies the survival of a stronger and more enduring stock. There is a definite tendency in nature to handicap the first-born, who are weaker than subsequent offspring. Pearson maintains that "to make the first-born 50 per cent. instead of something less than 22 per cent. of the whole number of births," spells degeneracy. ${ }^{2}$ Pearson believes that the improvements of medical seience and the tendency of nature to insure the survival of the fittest are diametrically opposing forces, and he contends, $e . g$. , from the surprising fertility of successive generations of achondroplasic dwarfs, that the humane tendency of modern medicine to preserve the diseased and deformed is not only detrimental to the human species, but ean only be set off or obviated by preventing these defectives from breeding their kind. He has indieated how Galton's law of ancestral inheritance can be improved upon by selective breeding, so that regression, the tendency to revert to a mediocre average, will in a few generations be hardly sensible. He claims that tall women procreate faster than small women, that dark-eyed people are more fertile than the light-eyed, and has established the law of "assortative mating," in virtue of which human beings, in most cases, mate, not as usually believed, with their opposites in stature,

${ }^{1}$ Founded, in 1901, by W. F. R. Weldon, Francis Galton and himself.

${ }^{2}$ Pearson: On the Handicapping of the First-born, London, 1914, p. 66. 
complexion, etc., but with their own kind. In this respect, he finds that husband and wife are more nearly alike than uncle and niece or first cousins, in accordanee with the French proverb, Les époux se ressemblent. The inference is that, according to Galton's law, the strong tend to perpetuate and strengthen their kind by mating, biologically speaking, in their own elass. Similarly, it is held that a greater amount of high-grade ability could be produced by seleetive breeding, since "the average genius we meet is more likely to be an exceptional variation of a mediocre stock than a common variation of an exceptional stock. This accounts for the fact that the sons of geniuses are often so disappointing." These theories of Galton and Pearson have met with no little opposition, not because they are incorreet, but beeause, as already stated, Darwinism has often a brutalizing effect upon shallow minds, who take theories too literally. Aceording to Weismann's theory, acquired characters are not inherited, and the finest moral or mental traits in the parents will not benefit the offspring unless they have the right start in life. Oliver Twist may go to the bad in a den of thieves, and Bill Sykes may have it in him to steal and murder, even with the most careful upbringing. That conduet is reaction to stimuli, that morality is always an inhibition, showing, at least, the importance of "early training" (euthenics), was sensed by the broad-minded Goethe, who declared himself capable of committing any crime. "The environment of today is the heredity of tomorrow" (Tredgold). The studies of the Jukes family by R. L. Dugdale (1877), the Hill Folk, and the Nams show one side of the shield, Galton's investigations of talented families the other, the record of the Kallikak family by H. H. Goddard (1915) and A. H. Estabrook's summary of The, Jukes in $1915^{1}$ both sides. In 130 year's the five Jukes sisters produced 2094 descendants, 1258 living in 1915, of whom half were feeble-minded, shiftless and inmoral, the other half, mentally and emotionally normal, rising or sinking in the social scale aceording to the reaction of environment. Estabrook's findings show that consanguineous marriages of defectives produce defectives, that licentiousness is hereditary, pauperism and crime resultants of feeble-mindedness, ehange of environment benefieial to degenerate stock and that sterilization of defeetives would interfere less with personal liberty than custodial care. Thus nature eares nothing for the ways of man, but takes care of her own, be they lewd, thievish, murderous, or even feeble-minded, provided they are sufficiently well-sexed to propagate their kind. As passive agents of social degeneracy, the feeble-minded are as potent as the aggressively

1 A. H. Estabrook: The Jukes in 1915, Washington, 1916. 
criminal. "A flea is as untameable as a hyena." The work of Bateson, Pumnett, of ('halles 13. Davenpolt and the experts at the Cold Spring Harbor station (oreanized 1910), bears out the Mendelian axiom that, as the individuality of a living organism is astablished by the presence or absence of certain biological determinants, so qualities may be inherited, but not their absence. As brown eyes are due to the presence, blue eyes to the absenee, of a ecrtain pigment in the iris, as dancing mice differ from normal mice in lacking part of the internal ear, so brachydactyly (short fingers), presenile cataract, keratosis, xanthoma, hypotrichosis congenita, diabetes insipidus, night-blindness, and Huntington's chorca indicate the presence of certain factors in the germ-plasm which may interdict the union of two such abnormals; but albinism, deaf-mutism, retinitis pignentosa, congenital imbecility, and the tendeney to respiratory and neurotic disorders are due to an inherent lack of something which may be supplemented by judicious cross-breeding with sound stock, ${ }^{2}$ although Pearson contends that it is a waste of good material to employ sound stock for this purpose. Hence consanguineous marriages are not necessarily bad if both units be sound. Nature's tendency to revert to the mediocre level of the common stock, to Walt Whitman's "divine average," will make the average a very low level indeed if it proceeds downward from poor or faulty material to start with. It is a well-ascertained fact that the thoroughbred animal, with generations of biologically desirable ancestors behind him, is prepotent over the normal animal. But actual selection is often influeneed by the bizarre caprices of "the unstable heart of man," and while individual propagandism could be made extremely effective, social control would be difficult of accomplishment without tyramnous espionage and surveilance. In the lower strata of society, marriage laws may not prevent illegitimacy or incest, vasectomy is dubious, ${ }^{3}$ and selective pure-line breeding, without some striking quality to start with, might only result in a race of negative prigs. "A far more effective means of restricting bad gem-plasm than placing elaborate marriage laws upon our statute-books is to educate the publie sentiment and to foster a

${ }^{1}$ R. W. Emerson: The point is well brought out in Mrs. Finlayson's study of the Dack Family, as an example of nature's power of perpetuating hereditary lack of emotional control (Eugenics Record Office, J3ull. No. 15, Cold spring Harbor, 1916).

${ }^{2}$ C. B. Darenport: Eugenics, New York, 1910; Heredity (etc.), New York, 1911, passim.

${ }^{3}$ The undesiralile tendencies of mutilated or runuchoid individuals, let loose upon soriety, are well known in the Orient and are frequently emphasized in the foot-notes of Sir Richard Burton's Arabian Nights. 
public eugenic conseience in the absence of which the safeguards of the law must forever be largely without avail" (Walter).

Much time and energy have been expended in the long-standing controversy between materialists and vitalists. The trend of all recent biojogical, and especiatly physiological thinking has bern away from vitalism, because, like other forms of intellectual complacener, it only drives the subject into a blind alley and sidetracks the chances of further investigation. The materialist, who regards the living coll as a physicochenical unit, furnished with at center of oxidation (nucleus) and bounded by a semipermeable membrane, its physiological processes being looked 11 oon as resultants of mechanical, physical and chemical laws, at least offers something which can be tried ont experimentally to its last eonsequences. The vitalist has nothing to offer except sterile phrases like the "entelechies" of Driesch," which only beg the question. Ontside the laboratory, and in our secret hearts, all of $1 \mathrm{~s}$ are vitalists, in so far as we recognize the limitations and fallibility of the human mind in the face of seemingly insoluble problems. But digestion, metabolism, growth and immmity have born imitated in test-tubes and Loeb has produced fatherless irogs from the unfertilized orum. Even the trillion or more isomerix compounds which (Abderhalden calculates) may be formed in intracellular metabolism from the linkage of fifteen amino-acids will not daunt some master mind of the future, for Nature's ways are usually found to be simpler than man's interpretation of hem. In the laboratory, vitalism would seem to be on its last egs, for the aim of science is not to "explain" biological phenomna, in the last amalysis, hut, as Karl Pearson says, to interpret iological investigations in the "conceptual shorthand of physics and chemistry." Even the regeneration of substance and regulation of form in autogenous bone-grafts probably depend, in the ast analysis, upon some subtle ebemical likeness. Carrel's ('Xeriment of making the excised viscera functionate extravitally or a definite time goes to show that, even in the higher animals. he separate organs have a mechanical autonomy of their own. There appear to be configurated phases of protoplasm which lic etween plants, with a limited number of mechanical degrees of reedon, and animals, with an unlimited number, and also phases hich, as King puts it, "are neither alive nor dead but between the

${ }^{1}$ Drieseb defines an enteleeby as a nen-spatial, non-pereeptual agent which un suspend or modify physiologieat professes at will, so that two al solutely lentical systems may, if alive, behave differently under absolutely identionl onditions (biologieal indeterninism). But he adinits that he can produce no atamples to prove his ease and that his doetrine does not atply to act dul "xeriment. As. Jennings says, "he maintains in general what he denies in par" cular," which, of course. pulverizes hes theory. 
two." The only true critcrion of death is the themodymanic, in which the substance is reduced, as Willarel (iibhs said, to a "phase of dissipated chelegy," $e$. $/$. has hecome an inert mass, incapable of spontaneous change, because its froc oncrgy or ehemical potentiality is practically nil. Aceording to physicochenical theory, an unfortilized ovum, a senile paranceim, an encysted ameba or an inactivated pathogenic bacillus are all in a temporarily insulated or "adiabatic" state, in which encrgy an neither go in nor out of them; and such "storehouses of energy" begin to functionate only when subjected to the catalytic influence of external physicochenical agencics, which stimulate their surface energies. Eximples of these phenomena are fomnd in the experiments of Mampas and Calkins on the ehemical rejuvenation of protozoa and of Loeb on the chemical activation of the ovmun.

Jacques Loeb (1859- ), a medieal graduate of Strasshurg (188t), who has heen professor of biology and physiology at Bryn Mawr (1892-1900), University of Chicago (1900-1902), University of California (1902-1910), and is now lead of the department of experimental biology in the Rockefeller Institute, has been a brilliant investigator in many branches of physiology, but his most characteristic work is that upon the dynamie or chemodynamic theory of living processes. In his work on the physiology of the brain, he made original researehes on the chain reflexes, and overthrew Munk's position that the Polandic area is made up of cellular "sensory spheres," by showing that the particular paralysis occasioned by each cortical excision will be abolished as soon as the wound is healed. He was one of the first to settle the question: of what order of magniturle is the smallest particle that ean show all the phenomena of life? (18931) and the experiments made by himself and pupils upon temperature coefficients have established other important eriteria of physiological processes. He has made extensive investigations of the effects of electrolytic, thermal, and radiant energy upon living matter, and he founded the theory of "tropisms" (18892) as the basis of the psychology of the lower forms of life, purely mechanical and ehemical data displacing the old theory of purposeful instinctive reactions. Even for the higher forms, his main position is that all actions of fundamental importance are instinctive, and have nothing to lo with states of consciousness, and even these may have a chemical basis. In 1899 he causer the unfertilized eggs of the sea-urchin to develop into the swimming larva by treating them with hypertonic sea water (i.e., in which the concentration has been raised by the addition of

${ }^{1}$ Loeb: Arch. f. d. ges. Physiol., Bonn, 1894-95, lix, 379-394.

${ }^{2}$ Der Heliotropismus der Thiere, Würzburg, 1890, and later publieations. 
salt or sugar). Similar results had been published by Tichomiroff (1886), who claimed to have developed mnfertilized silkworm egess by rubbing then gently with a brush or by temporary immersion in concentrated sulphuric acid. Bataillon got similat offects by needle-punctures (1911). Loeb carried his imitation of normal fertilization further by a preliminary treatment with butyric acid, producing an artificial fertilization membrane with complete development, following immersion of the eggs in a hypertonic solution before returning them to normal sea water. The formation of the membrane is supposed to accelerate oxidation, which Loeb regards as the criterion of a living process. He has further shown that the ovum has a selective, specific activating influence on the spermatozoön. In 1916, Loeb stated that he had seven male parthenogenetic (fatherless) frogs (Rana pipiens), over a year old, produced by the Bataillon method of pricking the unfertilized egg. ${ }^{1}$ Thus the ovum can be activated just as a protozoön can be rejuvenated or an asphyxiated hody resuscitated, by purely physicochemical means, although the result is an organism whose somatic cells lack one-half the normal number of chromosomes.

In 1902, Clarence Erwin McClung stated that the accessory chromosome, which Henking and Montgomery had located in cortain spermatozoa, is the determinant of sex.2 In McClung's view, each animal produces two kinds of spermatozoa in equal proportions, one set of which possesses the accessory chromosome. This has been found to be true of many animals by Edmund B. Wilson, who holds that all unfertilized eggs contain a sex chromosome, and that, after fertilization, those which acquire two by the process produce females, those which remain with onc only, males. This has been confirmed by T. H. Morgan, who has shown that in organisms like plant-lice, in which fertilized eggs produce fonales only, the egg is always fertilized by spermatozoa containing an accessory chromosome, becalse the other kind camnot live to maturity. Twins developed from cells with the same number of accessory chromosomes always have the same sex. Hence, as [oob says, "it is impossible to influence the sex of a developing mbryo by external influences." Morgan's experiments on seximited inheritance in Drosophila indicate that the accessory hromosomes are also the transmitters of the hereditary qualities vhich predominate in ach sex. All these experiments tend to do way with the untenable theories of sex determination which have reen advanced in the past.

'Two features of recent physiology may be especially signalized,

${ }^{1}$ Loeb: Proc. Nat. Arad. Sce, Wash., 1916, ii, 314.

2.IcClung: Biol. Bull., Bost., 1902, iii, 43-84. 
the doctrine of the hormones and the application of advaneed instrumental methods in the study of discases of the heart. In 1902, William M. Bayliss and Frnest II. Statling amnounced to the Royal socedy that the serection of pancreatic juice which is 'alued by introduction of acid into the duodemum is not a local reflex, but is produced by a substance (secpetin) thrown out from the intestinal mucous mentrane under the influence of the acid and earried thence by the blood-stream to the glands, as shown by experiment. Parloff's subsequent discovery of enterokinase confirmed the views of Bayliss and starling and the latter have developed the theory of the chemical eont rol of the body by means of "hormones" or chemical messengers, which pass from the organs and glands by the blood-channels to other parts of the body. This theory had already been advanced, qua theory, by Bordeu in the eighteenth century; the idea was inherent in Darwin's "pangenesis," and it has been admirably adapted to explain the many clinical phenomena produced by disturbances of the duetless glands, and the general theory of treatment by animal extracts. In 1903, Charles E. de M. Sajous (1852- ), of Philadelphia, published a system of medicine based upon the internal secretions in which the suprarenal, pituitary, and thyroid bodies are held to control the immunizing mechanism of the body. The old notion of "diathetic discases" is now giving place to the more definite concept of disorders of metabolism, many (perhaps all) of which are bound up with some bouleversement of hormonic equilibrium or some disturbance of function in the ductless glands. Operative surgery has played the most important part in working out the phrsiology and pathology of these glands, a branch of internal medicine which has, indeed, been almost entirely developed by scientific experimentation.

The starting-point of the doctrine of internal secretions was Claude Bernard's work on the glyeogenie function $(1 S+\$-57)$ and Arldison's aceount of disease of the suprarenal capsules $(1849-5.5)$. The former was thrown into striking relief through von Mering and Minkowsi's experimental production of diabetes by excision of the pancreas (1859) and the later studies of E. L. Opic (1901), Ssobolsff (1902), and W. G. MacCallum (1909), showing that the presumable souree of this pancreatie glyeosuria is in the islands of Langerhans. Arldison's deseription of the suprarenal sundrome led Brown-Séquard to excise the adrents in 18.56 , reprodueing fatal symptoms resembling Addison's disease, and his result was repeatedly confirmed by Tizzoni (1856-89). Abclous and Langlois (1s91-93). Sehäfer, and others. In 1s94-95, Oliver and schäfor found that injection of the watery extract of the suprarenal gland into the blood produced marked slowing of the heart and rise of blood-pressure. The active prineiple was obtained in errstalline form by Jokichi Takamine in 1901. The description of hyperthyroidism or exophthalmie goiter by Parry

${ }^{1}$ This phenomenon had been ascribed by Payloff and his pupils to an "acid reflex," proceedling by a reflex are of which the vagus was regarded as the efferent nerve. 
(1786), Graves (1835), and Basedow (1S40), and of hypothyroidism or myxedema by Curling (1850), Gull (1875) and Ord (1577), emphasizerl the mysterious importance of the thyroid gland, which was exeised with fatal results (in the dog) by the Cieneval physinlogint, Moritz Sodhiff, in 1856. In 1582, Reverdin of Geneva produed experimental myxedema by total or partial thyroileetomy and, in 18s:3, Theodor Kocher of Berm reported that 30) out of 100 thyroidectomies were followed by a "cachexia strmipriva." In 18s4, Stehiff produeed 60 eases of fatal exeision in dogs, and pointed out that the inimals could be saved by a previous graft of part of the glands, which led Murray and Howitz to the treatment of myxedema with thyoid extract, with wonderfully successful results. Horstey's observations on monkeys and the collective investigations of Sir Felix Semon showed that cretinism, myxedema, and cachexia thyreo-strumipriva are one and the same. The part playerl by the internal seeretion was first pointed out by Sehiff, and the isolation of jorlothyrin by Baumann, in 1896 , indieated its relation to iodine metabolism. In 1906, Erwin Payr transplanted a bit of thyroid from a woman to the spleen of her myxedematous daughter, with successful result. The parathyroid glands were deseribed by Ivar Sundström in 1850 and, in 1891, Eugène Gley showed that negative thyroidectomies in certain animals would be rendered speedily fatal if the four parathyroids were also removed. This was eonfirmed by Vassale and (ienerali (1896). Transplantation of the parathyroids was then essayed by von Eiselsberg (1892), Leisehner (1907), and WT. S. Halsted (1909), and it was shown that tetany will be produed if at transplanted gland is removed and per contra that the tetanic spasms will disappear after injecting the saline extract of the gland or after parathyroid feeding or transplantation. Halsted, in 1906, treated tetany sucecsufully by administration of the paratthyroids of beeves. In 1908, W. G. MacCallum and C. Voegtlin showed that exhibition of caleium salts will remove tetany, cven in man, which seems to connect the parathyroids with ealeium metabolism. The function of the thymus gland was first invest gated by lriedleben (1s5s), but the effects of its excision or of the injection of its extracts are still obseure. Fedix Platter (1614) and Kopp (1830) deseribed early cases of thymus death in infants. 'The status lymphatieus was first sketched out by Rirhard Bright (1838) and more fully described by Paltauf (1SS9). Henderson got retardert atrophy of the gland on castration (1904), and Paton found that thymertomy increases the growth of the testes. The first experiment in physiologieal surgery upon human beings was made by the gynecologist, Robert Battey, who exeised the normal healthy ovaries for the relief of neurotie and non-menstruating women in $187^{2}$. The rationale of this operation, in relation to a supposed internal secetion from a specialized set of ovarian eells, has sinee been justified in many remarkable ways, particularly in osteomalacia and by the experiments of "Starling and Lane-Claypon, which show that seetion of the mammary nerves or of the spinal cord in rabbits does not produer the inhilitory effeet of Battey's operation upon pregnaney or lactation. The relation of the Leydig eells in the testis to internal secretion is sub judice, the most signifieant (xperiments so far being those of Brown-siépuard (1859-91) and Poehl (1896-7) upon the injection of testieular extracts. In the last twenty vears, mueh attention has been paid the pituitary body. Fatal excisions of the gland in animals had been made by Marinesen (1892), Vassale and Seechi (1S94), and others, but Nicholas Paulesco of Buchatrest was the first to point out that removal of the anterior lobe is fatal and removal of the posterior lobe negation (1908). Neanwhile Mohr had described obesity with pituitary tumor (Ist0), P'icre Marie hard shown the relation of the pituitary to alcromegaly and gigantiom (1SSt), Fröhlich described pituitary tumor with obesity and sexual infantilism (1901), and Harvey Cushing and his assoeiates at the Johns l Iopkins llospital actually produced an experimental pathologie reversion to the frohlich syndrome by martial excision of the anterior lobe in adult dogs (190(S). Cusing has shewn that the anterior lobe secretion influene's normal growth and sexual deretopment, while the posterior lobe has to do with motabolism of carbohylrates and fats, the high toleranee of sugars in posterior lobe insufficieney viekling to treatment with pituitary extract. Cushing and his pupils have ako shown the reation of the hypophysis to diabetes insipidus (1912) and hibernation (1913). 
That the internal secrotions control the configuration of the boly and are the activators of emotjon is cmphasizel in the writings of W. I3. Cannon (19)1.1-16), (i. IV. Crilo (1915), I. I. Barker, and of hers.

The doctrine of the correlation of the different internal seeretions has been especially emphasized by the Viennese elinicians, Hans Eppinger, W. Falta, and C. Rüdlinger (1908-9). Eppinger and Leo Hess' have also applied the ideas of Gaskell, Langley and sherrington as to the opposing functions of the two "autonomies" of the sympathetic system in the elucidation of the complex mechanism of physiological equilibrium and of visceral nemrology (1910). They postulate two opposing diathetic conditions, vagotonus and sympathicotonus, described in 1892 by S. Solis Cohen as "vaso-motor ataxia," the semeiology of which ean be thrown into relief by certain phamacodynamic tests. These have been likened to "tuning keys by means of which we ean operate upon the complicated stringed instrument of the body, and voluntarily make one string tighter to inerease its vibrations, or another looser to dampen its function."2 Eppinger and Hess also assume that the pancreas secretes a hormone, "autonomin," which antagonizes adrenaline, the hormone governing the sympathetic antonomic. While much of this is in dispute, it seems probable that the chemical hormones act via the blood upon the central nervous system, while the two opposing autonomics of the sympathetic system control the ductless glands and the viseeral organs made up of smooth (involuntary) muscle.

The trend of recent thinking in regard to the heart's action is overwhelmingly in favor of the myogenic theory of Gaskell and Engelmann, which received its strongest support from embryology.

By 1ss3, Gaskell and Engelmann had proved that heart impulses are conducted by muscular pathways. In 1893, Wilhelm His, Jr. (1863- ), and, a little earlier, Stanley Kent (1892), discovered a narrow band of muscle, an embryonic rest between the auricles and ventricles, now callerl the auriculoventricular bundle of His, which acts as a bridge for contractile impulses, in accordance with Gaskell's theory that this cardiac phenomenon is clue to the inherent contractility of its muscles alone. Later, Arthur Keith and M. Flack (1907) discovered a tissue-rest of fine, pale, faintly striated fibers in the heart wall, supplied with arterioles and connected with the Purkinje fibers and nerve terminals, the so-called Keith-Flack or sino-auricular node, now dubbed "the pacemaker of the heart." S. Tawara traced out the muscular ramifications from the His bundle (the ventrieular basket-work of cells noted by Purkinje), and discovered another muscular (atrioventricular) node in close relation to it $\left(190 \mathrm{~S}^{3}\right)$. If the His bundle is destroyed in the rlog, the contractile impulse will no longer pass from the auricle to the ventrieles, and the latter will immeliately assume their own autonomy, beating at a much slower rate, while

${ }^{1}$ Eppinger and Hess: Die Vagotonie, Berlin, 1910.

2 Januschke: Cited by L. F. Barker.

${ }^{3}$ For the significance of these structures in relation to Gaskell's contraction wave and the mechanism of the heart-beat, sce Thomas Lewis: Proc. Roy. Soc., Lond., 1917, Ser. B, lxxxix, 560-572. 
the auricles, controlled by the vagus, will go on as before. 'This is the condition known in pathology as complete heart block or Stokes-Adams disease, which His produced experimentally in 1895. At the Johns Hopkins Hospital, Erlanger, by means of a clamp compressing the His bundle, in the dog, thus blocking the auricular impulse, has, like Gaskell, produced two-time, threetime and four-time rhythms, finally passing into complete heart block. Further light upon the intimate pathology of cardiac disturbance wiss thrown by the string galvanometer inventer by Willen Einthoven of Leyden in 1902.1 In 1878, ${ }^{2}$ Burdon Sanderson and Page made the first records of the heart-beat with the capillary electrometer; Gaskell's galvanometer studies of the electrical condition of the heart followed in 1S81. In 1855, Kölliker and H. Mïller showed that the action currents of a contracting heart will eontratet the muscle of a muscle-nerve preparation, if the nerve of the latter be laid across the heart. In $1859,{ }^{3}$ Augustus D. Waller conceived the idea of measuring and figuring the variation of the action currents in the living heart by leading them off throngh electrodes placed upon the moist skin, connected with a zalvanometer, the curves being obtained by photographing the movements jroducel by the mercury of a Lippmann electrometer, which was first done by Marey in 1876. Owing to the lag or inertia of the mercury meniseus, the curves n Waller's method were not true eurves and harl to be corrected by mathenatical computations. The process was rentered accurate by the sensitive nstrument of Einthoven, which consists essentially of an extremely delicate hread of platinum or of quartz coated with silver, which is strung, like a iolin-string, millway between the poles of a stationary eleetromagnet. This everses the ordinary conditions in galvanometers, in which the magnet is novable and the measurable current passes through stationary coils. When he feeble heart currents pass through the delicate string, they cause deflecions which are smaller and shorter, or greater and longer, in proportion to its tate of tension. The pictures of carliac excitation which are thrown off in his way Einthoven calls "electrocarliograms," or telegrams from the heart, that they give an accurate bulletin of its electromotive condition. Although is instrument is expensive, it has been of material aasistance in analyzing and ven diagnosing such conditions as valvular disease, heart block, auricular brillation, paroxysmal tachycardia, pulsus alternans, pulsus bigeminus, threend four-time gallops and other rhythmic changes. The pioneer in the graphic udy of cardiae rlisease was the Scoteh practitioner, Sir James Mackenzie 353- ), of Scoone, Perthshire, who first made simultaneous records of ze arterial and venous pulses to eluciclate the clinical condition of the heart; nd by raising the question, "How much work can the heart do?" coneentraterl it ure investigation upon the energetics of heart-muscle (1893-94). Mackenzie rst investigated the multiform arhythmias, and differentiated the "norlal iythm," which Thomas Lewis afterward defined as "auricular fibrillation" id identifiel with the "pulsus irregutaris perpetuus" of Hering, producing the ondition experimentally by sewing electrodes into the auricle of an animal. Iackenzie also demonstrated the wonderful efficiency of digitalis in auricular brillation (1910), and the use of this drug is now interdieted in the sinus hythmias, heart-block, paroxysmal tachyeardia anel pukus alternans. ushny showed the value of the electrocardiogram in checking up the effect: digitalis, which apparently depresses the conductivity of the bundle of is. Thus the view of Schmiedeberg, that digitalis not only slows the heart ivagal stimulation, but stimulates the earliac muscle (187.4), hats given place the older, classical view of Bouillaud, that, elinically, digitalis is a true pium of the heart" (1835). Many other investigations have been made, ad the new English periodical, Heart (London, 1909), has been founded for ch sturlies. In 1906 , Einthoven lidid wires between the Leyden Hospital and

${ }^{1}$ Einthoven: K. Akad. v. Wotenseh. te Amst. Proc. Sect. Sc., 1903-1, $107-115,2 \mathrm{pl}$.

${ }^{2}$ Sanderson and P'age: Jour. Ihysiol., Lond., 1879-80, ii, 34. 1853-4, 347.

${ }^{3}$ A. D. Waller: Phil. Tr., 1859, Lond., 1890, clxxx, B, 169-194. 
his latoratury and was able to take eardiat tracings from ward pat ients at a distance of more that at mile. Further, it has been foumd possible to obtain graphic figurations of the rhethm of the heart-soumd (phouocardiograms) by meatus of a stethosecope sud a Marey tambour, the receiver being a microphone or such devices as manometric flames, or the Weiss phonoseope, the receiver of wheh is a sosp-bubble. These records can be placed in juxtaposition with

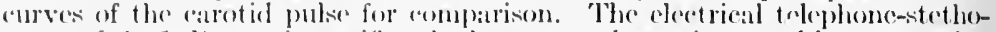
scope of $s$. (i. Brown intensifies the heart sounds 60 times and by connecting this with the kong-distanceservioe, heart sommes in Jondon have been heard distinctly by physicians in the lske of 11 ight, a distance of about 100 miles.

The ploblem of the synthesis of proteins from their amino-acid constituents will always be associated with the great name of Emil Fischer (1852-1919), of Euskirchen, Rhenish P'russia, who, as

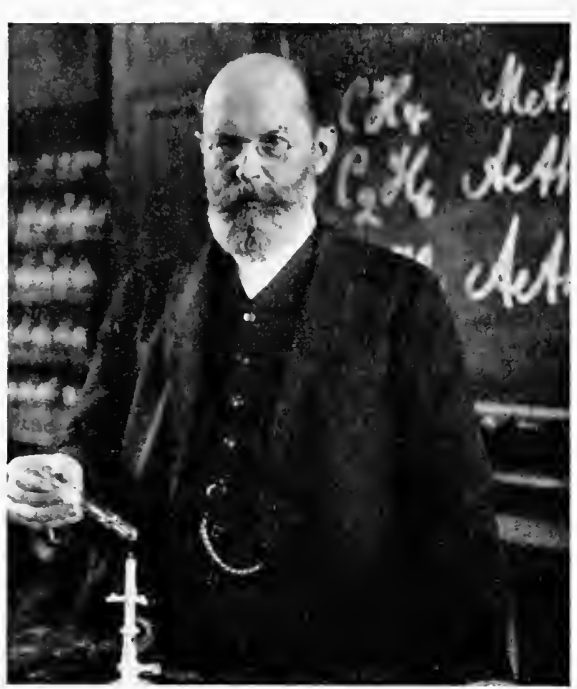

Emil Fischer (1852-1919). (From a photograph in the Surgeon-General's Library.) professor of chemistry at Munich (1879), Erlangen (1882), Wïrzburg (1885), and Berlin (1892), devoted his whole career to this work.

Fi:cher discovered, isolated and formulated a host of new substances, such its phenylliydrazin (1875), which Abderhalden ealls "the pathfinder of carbohydrate ehemistry," the aliphatie hydrazins (1875-77). mannose, fsomaltose, and the drugs veronal (1902), proponal (1905), saiodin (1905) and elarson (1913). He made vast researehes in the synthesis of the purin compounds, including caffein, xanthin, theobromine $(1879-95)$; and developed a "family tree" of gout, demonstrating the purin nucleus as a sort of germ-plasm common to all the metabolic produets of the disease. He synthetized and supplied structural formula for most of the sugar groups (1883-94), incluting the six hexoses derived from mannitol, a hexose from formaldehyde, and fourteen out of the sixteen possible isomeric aldohexoses predieted by van't Hoff and LeBel; and, in his studies of the polypeptides $\left(1899-1906^{2}\right)$, he linked together great ehains of amino-acid substances (eventually $1 \mathrm{~S}$ in all), to form these compounds, which are essential parts of the different protein molecules. Liebig believed that there is only one aboriginal protein. Paul Rehiut zenberger and other recent ehenists have shown that individual proteins differ from each other in respeet of the various aminoacids produeed by hydrolysis.

${ }^{1}$ For a full account of these instruments, with illustrations, see the admirable résumé by Professor L. F. Barker, Johns Hopkins Hosp. Bull., Balt., 1910, xxi, 35s-389.

${ }^{2}$ Fiseher: Untersuchungen über Aminosïuren, Polypeptide und Proteine, Berlin, 1906. 
Fischer devised quantitative methods for isolating these, and he has shown that there is an amido group or nucleus common to all the proteins. His investigations of the enzymes (1894) show that they are specific in action, affecting only certain chemical sub)stances, to which, as he puts it, they are related as a key to a lock or a glove to a hand, an analogy which Ehrlich has cleverly applied in his side-chain theory. A brilliant stroke of genius was Fischer's deliberate attempt to produce a reliable hypnotic, ending in the synthesis of veronal $\left(1904^{1}\right)$. His last researehes covered the depsides and tamnin substanees. During the war, he displayed phenomenal energy in furthering the manufacture of synthetic substitutes for nitrogenous products, animal fats and food-stuffs. No chemist of morlern times better deserved the honor of the Nobel prize, which he reecived in 1902.

Emil Abderhalden (1877- ), of St. Gall, Switzerland, a pupil of Emil Fischer, professor of physiology at Halle, is the author of a bibliography of alcoholism (1897) and a text-book of physiological chemistry (1908), and is the editor of a hand-book of biochemic technic (1909 $-10)$, to which he hats added many new procedures. He has made a vast

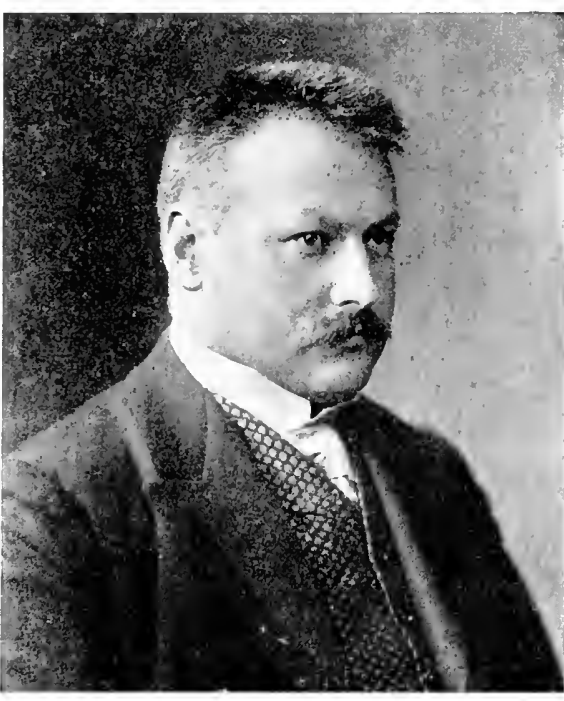

Emil Abderhaliten (1S7- ). number of investigations of metabolism and food-stuffs, adopting ('arl Ludwig's method of publishing his researches in collaboration with his many pupils. His special field is the integration and disintegration of albuminoids and nucleic acids in the animal body, the metabolism of the cell (1911), the synthesis of its Bausteine (1912), and the synthesis of artificial food-stuffs, as tried out experimentally upon animals. He holds that the individual cells of animal and vegetable foods are made up of a number of chemical or phasic units which, in digestion and metabolism, are split up and transformed into other substances, to be assimilated by the body cells, according to their needs. In

1'Therap. d. Gegenwart, Berl., 190.4, xlv, 14.). 
his attempt to synthetize an artificial food, he has shown that dogs can be successfully fed upon the anino-acid constituents of albumen, that tryptophan is essential to nutrition, but glycocoll is not, that grape-sugar can be substituted for complex carbohydrates, that glycerin and fatty acids can take the place of fats, and that mucleic acids an be replaced by their split products (nucleosides, ctc.). Abderhalden has also taken up the study of the protective forments of the animal body and has evolved a biochemical test for pregnancy and other conditions by a ferment reaction (1912 $2^{1}$.

In America Thomas B. Osborne and Lalfayette B. Mendel have also done important experimental work on artificial or synthetic foods (1911), the mutritive values of various substances (1913-15), the rôle of the vitamins as accessory diet factors and of protein-free milk and fats as determinants of growth (1915).

Of late years there has been an amazing inerease in the literature of psychology, normal, morbid and comparative, including such related subjects as pedagogies, psychoanalysis, psychotherapy, epistemology, the scientific aspects of evidence and the relation of everyday thinking to border-line insanity. Comparative psychology turns mainly upon Loeb's theory of tropisms in the lower forms (or the views of those who, like H. S. Jennings, oppose it) and the study of "behavior" in the higher animals. The mental development of the newborn infant has been specially studied by Kussmaul and Preyer. Pedagogies and juvenile psychology have been treated by Binet, Claparède, Stanley Hall, Séguin, Maria Montessori, and others. Among the leaders in morbid psychology is Pierre Janet (1859-99), professor at the Collège de France, who developed the theory of psychologic automatism (1889), the relations between neuroses and fixed ideas $\left(1899^{2}\right)$ described psychasthenia (1903), and made extensive investigations of the mental status of hysteric patients (1903-8). In 1905-8, Alfred Binet (1857-1911) and Th. Simon introduced a remarkable series of graded tests for mental retardation by which it is possible to localize the developmental status of a patient's mind in relation to his age and the growth of his body, thus enabling sehool-teachers or school inspectors to segregate defective or "unusual" children. Another characteristie development is the exhaustive or intensive study of sexual psychology, with which modern writers, from seientific students like Krafft-Ebing and Havelock Fillis, down to insane men of letters like Nietzsche and Weininger, have been vastly preoceupied. The atmosphere of

${ }^{1}$ Abderhalden: Ztschr. f. physiol. ('hem., Strassb., 1912, lxxvii, 249; lxxi, 90.

${ }^{2}$ Année psychol., Paris, 1905-08, passim. 
the present time, its art, poetry, fiction, and drama, is saturated with sexualism. Poets like Goethe, Swinburne, and Walt Whitman did much to dispel the ancient theological nightmare of the sinfulness of normal sexuality in men and women, and were forerunners of the scientific view that the instinct, guided by proper ethical restrictions, is an all-important part in normal human development which has to be either recognized or reckoned with. Schopenhauer wrote on the subject with bitter and unsparing realism, and latterly women of such high repute as Rahel Varmhagen, Ellen Key, and Helen Putnam have considered the matter from a higher viewpoint, on account of its importance in comnection with such problems as the proper hygiene and well-being of growing children, the growth of prostitution and commercialized vice, the social enslavement of women in crowded communitics, and other degradations of a purely industrial age. In Cermany, several periodicals are devoted to the sexual instinct alone, and the problem of biological teaching of school-children in these matters is under consideration. On the pathologieal side, there is the question of sexual perversion and the erimes resulting from it, for which, in young, healthy frontier communities like the United States no special provisions had been necessary in criminal procedure until the crowded conditions of modern cities brought the unsavory

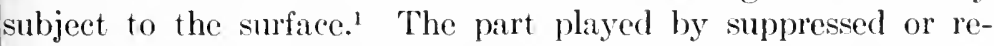
pressed sexuality in the development of neurotic conditions has been especially studied by Sigmund Freud (1856-1017), of Freiberg in Moravia, a pupil of Charcot, and professor of neurology at Vienna. Charcot, as we have scen, threw the sexual theory of hysteria into disrepute, Janet, from 1889 on, emphasized its emotional causation, Breuer and Frend introduced the cathartic treatnent (questioning under hypnosis) and Freud interprets the nechanism of hysteria as the resultant of a psychic traumatism or rervous shock, of sexual nature in the first instance, leading to norbid brooding and a kind of mental involution. Freudians now lold the sexual factor to be existent in normal people, but the way $\mathrm{n}$ which the individual reacts to the experience localizes the newotic. The basic idea of Freud's theory is that a large number of ven ordinary mental processes come from hidden sources, unnown or unsuspected by the individual. He has also developed he theory of the significance of dreams (Traumdeutung), witti-

1 J. I. Caspar, in his Practueal Handbook of Legal Modicine (1850), rearded these erimes as among the "strange bublbes which sometimes rise from he low life of towns." Their modern study is due to Krafft-Ehing (18S6) and beopold von Mcerseheidt-Hiillesem, ehief of police at Berlin, who showed he necessity of the segregation and survellance, under humbne restrietions, of erverted individuals in larese eities, if only on aceome of blackmat and the omicidal tendeneies which these charueters are known to develop. 
risms, infantile ammesia, anto-cotism (Ellis), unconscioms,memories, absent-minded actions, anxiety-nemoses, also various aspects of the "psychopathology of everyday life." He believes that there is a rigid deteminism of psichical effects and that many complex memtal processes nevel attain to consciomsness and cau he elicited only by a long process of "psychoamalysis," in developing which he was assisted by his pupil, ('. C. Jung. Freud's famous suceessful casc, that of the patient "t)orat," wats of this kind. The correctness of his reasoning socms borne out by the

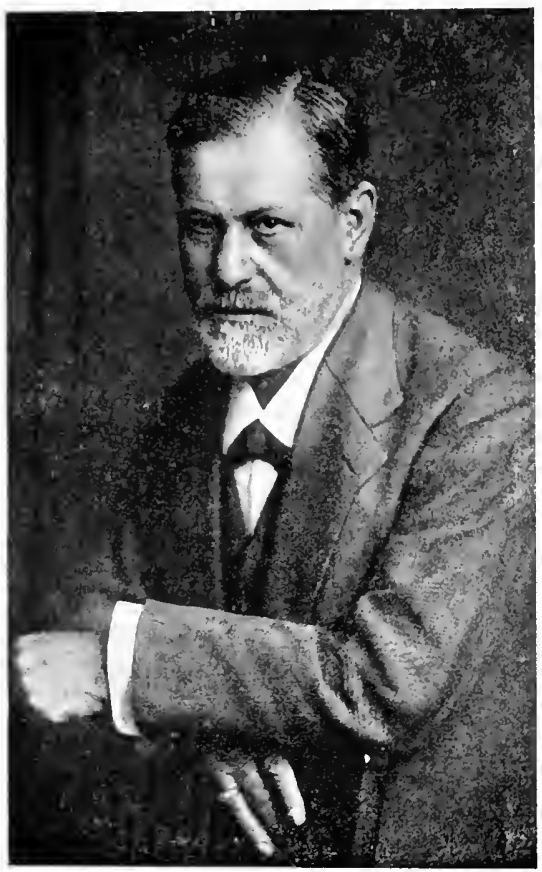

sigmund Freud (1856-" - 1$)$. suceessful treatment of hysteria through the dishurdening of the mind of other appropriate psychotherapy. In his view, the hasis of all sexnal nemoses is the child's unconscious attachment to its parents, sometimes with hostility to the parent of the same sex. The dedipus myth, what is styled the "family romance," symbolizes, in plain telms, the struggle of the individual to attain to self-confidence and self-reliance by breaking away from dependence upon his parents. It is thus regarled as a measure of the degree of infantilisin in the neurotic.' The interest of Freud is his profound insight into primitive mentality, or what Jelliffe calls "paleopsychology," the historic past of the individual psyche. He has given neurologists a new instrument for exploring unconscious states which, in competent and temperate hands, may be effective. In America, his ideas have been followed by J. J. Putnam, A. A. Brill, William A. White, and others, and such variants as Bleuler's theory of normal "autistic thinking" go to show the very thin partitions which sometimes divide sanity from insanity.

${ }^{1} \mathrm{IV}$. A. White: Mechanisms of Character Formation, New York, 1916, $145-176$. 
Parasitology and Chemotherapy.-In the last decale of the nineteenth century, as a result of the many improvements in microscopic and bacteriological technic, plysicians began to study the animal and vegetable, and particularly the protozoan parasites as causes of discase, but the greatest trimmphs in this field belong to the twentieth century.

Before this time, Agostino Bassi had found the pathogenic organisu (Botrytis Bassiana) of silkworm disease, or museardine (1837), Sehondein, the achorion of favus (18:39), Donne, the Triehomonas vaginalis (1837), Johannes Mïller, the psorosperuts (1s+1), Davirl Grüby, the Trypanosoma sanguinis in frogs (1843), Davaine, the Cereomonas hominis (1557), Malmsten, the Balantidium eoli (1557), Lambl, the Lamblia intestinalis (1559). Kïchenmeister. diseovered that parasites change their hosts (metaxenia) (in 1851-53). Leuckart extenderl the general law of intermediary hosts to the Arthropoda and under his direction Fedschenko determined the life-history of rilaria medinensis in Cyelops in 1869 . This led to the sturlies of Patrick Manson on the development of Filaria banerofti in mosquitoes (1879), Smith and Kilborne on ticks and Texas fever (1SS8), Bruce on the tsetse fly and nagana (1894), Ronald Ross on malaria and mosquitoes (18S9-9s), Finlay (1Ss1), Walter Reed and his associates on yellow fever and stegomyia (1900). The first group of parasitie diseases to be investigated was that of the protozoan dysenterics, the amebe of which had beren seen by Lambl in 1860 , by Lewis in 1870, and by Loesch $(1875)$, who male flawings of both the innocious and pathogenic forms, with the latter of which ho was able to infeet rogs. Koeh and Kartulis, in Egypt, found amebe to be invariably present in dysenterie postmortems, even of liver abscess, and differentiated between endemic dysentery due to amelae, and epidemic lysentery lue to bacteria. Osler confirmed this at the Johns Hopkins Hospital (1S90). The term amebic drsentery was introduced by IV. T. Councilman and 11. A. Liffeur at the Johns Hopkins Hospital in 1891, two types of parasites being recognized, the harmless Amoba coli, and the pathogenie Amoba dysenterise. These views were eonfirmed by Casagrandi and Barbagallo $(1897)$, and particularly by Fritz Schaudinn, who styled the harmless form Entamoba coli and the pathogenic form Entamobat histolytica (1903). These species were first confirmed by Craig, who aftrrwarl found Viereek's pathogenie: Entamoeba tetragena in the Philippines and rliseovered a new species of fliartheal parasite, Craigia (Paramoba) hominis (1906), which Calkins regards as a new genus. Other pathogenic species of amoba have been reseribed by various observers, and rliarrhal and lysenterie infeetions have also been foimel to be associated with Laverania, Lrishmania, Balantidium coli, and the above-mentioned flagellate forms, Cereomonas, Trichomonas, and Lamblia. Meanwhile the question of baeillary dysentery had been settled by the rliscovery of bacilli by shiga in Japan (1s9s), Kruse in Germany (1900), and Flexner at Manila (1900). Much of tropioal dyentery is now known to brs amebic, while that of temperate zones is usually bacillary. The Fndamoba buecalis, described by Prowazek, in 1901, has bern iolentifiol as an rroanism associated with pyorrhou alveolaris.

The symptoms of hook-worm infection were vaguely outlined in the Egrptian papyri, and for eenturies the disease was variously known as Eevptian or ropical chlorosis, miner's or bricklayer's anemia, and st. Gothard tumnel lisease. The parasite was described as Aneluylostoma luodenale by Angelo Dubini (1843), and its causal relation to the discase was pointed ont by Wilhelm Griesinger (186(i). In 1900, Captain Bailey K. Astoford, U. S. Army, liscovered the great prevalenee of the discase in Porte Rieo, and it was soon ound to be very common among the rural population of the Southern states U. S.) by Charles Wardell Stiles (1867-) ), of Stpring Valley, Now York, vho discovered that the parasite of the Ameriean infections is a new suecies vhich he called "Uneinaria amerieana (1902) and liter Neeator americanus. stiles, who had already male his reputation in parasitology by his work on 
revision of speries and nomenclature and his contributions to descriptive zoology, hats sincer devoted himself, as professor of zoölogy in the U. S. Public Ilealth and Marine-Hospital serviere, to the task of exterminating the discase in the south, in connection with the Rockefeeller Commission (now the Intornatienal Health lowatl) established for this purpose in October, 1909. Under the administration of Wiekliffe Rose, this Bontre soon suecerded in engiging the newspalpers, boards of health, sehools and medical organizations of the south to cooperate in starting outhoor chinies, so that the local anthorities are now able to take eare of themselves by "intensive eommunity health-work," and the Rockefoller Board has extended its activities to other fields. In three vears (1910-12), no less than 393,566 persons have been treated for hookworm at these open-air elinies in the Southern States. In 1898, Arthur Looss made the important diseovery that the hook-worm larval can penetrate the skin, reaching the intestines by a devious route, and this fact has enabled Stiles and Ashford to devise effective means of prophylaxis among rural populations. In Ashford's empaign arainst the disease in Porto Rieo (1903-1)4), some 300,000 out of a population of a million have been treated. with a reduction of 90 per eent. in the mortality from anemia. lellagra, which has latterly been identified in America, has been elosely studied by Lombroso, Théophile Roussel, Simbon and others in Europe, and by James W. Babenek, Claude H. Lavinder, Joseph Goldberger and other Ameriean physicians. Variously attribufed to a parasite transmitted by the Simulium fly, or to food poisoning from photodynamic substances, it is now classed, with ergotism, beri-beri, seurvy and riekets, among the defieieney diseases (avitaminoses), the to lack of the liypothetieal activators of digestion and nutrition (vitamins) of Casimir Funk (1913ㄹ). Joseph Goldberger and his assoeiates have demonstrated its experimental proluction in patients subsisting upon a faulty diet, carried over a sufficient length of time, and its alleviation and prevention by proper dict (1915-20).

In 1911, Laveran's malarial parasite was obtained in pure cultures in ritro by Charles C. Bass, of New Orleans. Howard Taylor Ricketts (1870 1910), of Findlay, Ohio, a pupil of Hektoen, discovered that the Rocky Mountain spotted fever is transmitted by the wood-tick (Dermacentor occidentalis) in 1907, and (with R. M. Wilder) that Mexiean typhus (tabardillo) is transmitted by the body-louse (Pediculus vestimenti) in 1910. This had already been demonstrated for European typhus by Charles Nicolle (1909), and in the same year, John F. Anderson and Joseph Goldberger, of the U. S. Public Health Serviee had produced suecessful inoculations of typhus from man to monkey. The disease diseovered by Nathan E. Brill in New York in 1910 was shown by Goldberger and Anderson to be a mild form of typhus. The presumable baeillus of typhus fever was discovered by Harry Plotz, of Mount Sinai Hospital, New York, in 1915, and was given the name "Bacillus typhi exanthematici" by William H. Weleh.

The trypanosomes diseovered by David Grüby (1809-98) in the frog (1843) and by Lewis in the rat (1878) were non-pathogenie, but a new interest in these organisms was awakened when Ciriffith Evans. in 1880, diseovered in India that surra, a disease of horses, mules, eamels and eattle, is eaused by a variety which was afterward named by Steel and Crookshank, Trypanosoma evansi (1885-86). It is of historie reeord that the African traveler, David Livingstone, gave an aceurate aecount of the tsetse fly disease in his Missionary Travels $\left(1858,94-97^{2}\right)$. In 1894, Sir David Bruce (1855-) found that the tsetse fly disease or nagana of Zululand is due to the Trypanosoma brucei (Plimmer and Bradford, 1899), whieh he proved experimentally to be conveyed from the blood of hig game animals to eattle and horses by this fly (Gilossina morsitans). In the same year (1894), Rouget discovered T. equiperdum (Doflein, 1901) as the cause of dourine or mal du coit in horses; in 1901 Elmassian found T. equinum (Vosges, 1902) as the eause of mal de caderas in South American dogs and horses; Theiler, in 1902, found T. theileri (Bruce,

${ }^{1}$ C. Funk: Die Vitamine, Wiesbaden, 1914.

'See E. W. Guiger: Boston Med. \& Surg. Jour., 1919, elxxx, 523-527. 
1902) in the bovine gall-sickness or galzickte of siouth Afriea and $\mathrm{T}$. dintoryhon (Laveran and Mesnil, 1904) was found to be the (allse of another animal disrase in equatorial Africa by Dutton and Todel in 1904. The most important find, however, wis that of ' $\mathrm{T}$. gambiense in the blood of min by $\mathrm{J}$. Everett Dutton in 1901, which was afterward seen by Aldo Ciastellani in the cerobrospinal fluid and blood of five cases of African slecping sickness (1903). It was then shown by Bruce and Nabarro, of the Royal society Commission, that the tsetse fly is the vector of the discase, and that Gambia fever, the disease first seen by Dutton and Todd in 1902 , and slecping sickness are two stages of the same infection. A Brazilian variety of human trypanosomiatsis, due to $T$. cruzi and transmitted by a bug (Conorhinus sanguisuga), was deseribed by Carlo Chagis in 1909. Another remarkable organism was found in $1900 \mathrm{by}$ Sir William Boog Leishman (1S65- ), in a postmortem film lrom a case of fever at Dum Dum, near Caleutta, and afterward deseribed by him, in May, 1903 , as possibly a trypanosome. In July, 1903, Najor C. Donovan found the same bodies in blood taken in life from splenic punctures. In July, 1904, Leonard Rogers announced the development of these parasites into flagellates and, in 1906-07, Walter Scott Patton deseribed their development into flagellates in the bedbug. All these discoveries have associated the LeishmanDonovan bodies with the tropical splenomegaly, flumdum fever or kala-azar. In 1903, James Homer Wright found similar parasites (Leishmania tropica) in Oriental endemic ulcers, and in 1908 Charles Nicolle found Leishmania infantum in infantile kala-izar. In 1SSS, Vietor Babes (1S51- ), a Roumanian physician, liscovered a small protozoön in the blood of sheep suffering from an epizoötic disease called "carceag," and the genus was called in his honor Babesia by Stareovici (1893), the term Piroplasma having been proposed by Patton in 1S95. A similar parasite was claimed by Babes as the cause of hemoglobinuric fever of European cattle, and in the same year Theobald Smith (1859- ) found the organism "Pyrosoma bigeminum" in Texas fever, which, with F. I. Kilborne, he demonstrated to be transmitted by the tick. 'This was the first demonstration, after Manson's, of the transmission of infection by a blood-sucking insect, and after this time knowledge of the different piroplasmoses or babesioses grew apace, the best known being the canine form (Piroplasma or Babesia canis. Piana and Galli Valerio, 1895), the life eycle of which has been carefully traced by G. H. F. Nuttall and Graham Smith. The so-called Piroplasma hominis, assumed to be the cause of spotted fever of the Rocky Mountains, was shown by Craig to be an artefact in the rythrocytes (1904). In 1903, cell-inclusions, staining deeply with methyleneoluc-eosin were found in the eentral nervous system in luydrophobia by Adclehi Negri (1876-1912) and a culture of these was made by Hideyo Noguchi n 1913. Cytoryctes variola, a protozoön found in the skin lesions of smallpox, was described by Giuseppe Cuarnieri (189.4) and its life history was raced by Gary N. Calkins (1904), while similar bodies were found in variola sy W. T. Councilman and others in 1903 and by Mallory in scarlatina in 1904 . Fistoplasma capsulatum found in a tropical splenomegaly on the Isthmus of anama by S. T. Darling in 1906 is said to be an veast. The spirochete or pirillum of relapsing fever, discovered by one of Virchow's assistants, Otto bermeier (1843-73) in 1873, was to open out the most important phase of arasitic discases yet known, viz., the eonquest of syphilis by Schaudinn, Vassermann and Ehrlieh. In 1904, the spirochete of African rolapsing fever tick fever) was discovered independently by Nabarro, Ross and Milne in Janda and by Dutton and Todel in the Congo and was called Spirochate uttoni, in honor of Dutton, who died from the clisease after he had proved its ransmission by a tick (Ornithodorus moubata). The spirochete of the Amerian variety of relapsing fever was diseovered by Frederick G. Novy in 1907.

\section{Alphonse Laveran (1845- ）, of Paris, a Strassburg graduate} f 1867 and Nobel prizeman of 1907, diseovered the parasites of ralarial fever (November 6, 1880), while an army surgeon in lgeria, and described them in all their various aspects (1881). 
He has published no fewer than four separate treatises on pahdism (1854, 1891, 1892, 1898). Ho is also the author of Tryponosomes et trypanosmiases (190), and of treatises on military medicine (1875) and military hyerione (1896).

Sir Ronald Ross (1557- ), of the Indian Medical Service (18S1-99), located the anopheles mosquito as the vector of malarial fever, discovered the Laveran plasmodia in the stomach wall of amopheles which had fed upon the blood of malarial patients (1857), proved that the spores of the parasites are concentrated in the salivary eland of the insect (1S98), and devised the culicidal methods (1902) which he employed with suceess in moseputo reduction in sierra Leone, Lagos, the Gold Coast and Ismailia

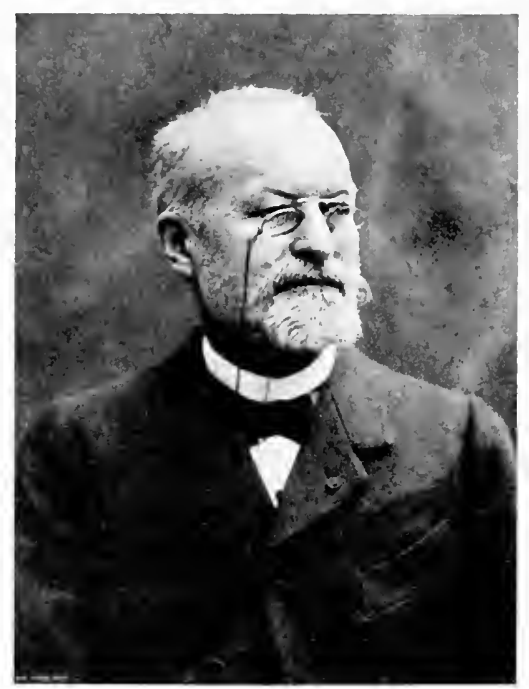

Aphonse Laveran (1845- ).

(1899-1902). For this work, which led to effective prevention of malarial fever all over the world, Ross received the Nobel prize in 1902. In mathematics, he has applied the theory of probabilities to the statistical prognosis of epidemics ("a priori pathometry," 1916). His plays and poems are the productions of a highly original mind.

The most telling advances in protozoölogy and the most striking applications of this science to medicine were made by Fritz Schaudinn (1S71-1906), the son of an East Prussian innkeeper, who took his doctor's degree in zoölogy in Berlin in 1894, and, after some studies of the Foraminifera, devoted the rest of his life to the Protozoa. 
As a deseriptive zoologist, he isolated many new speeies, such as Ambobat

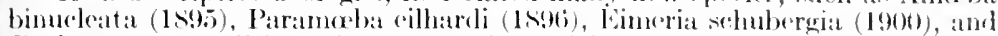
Cychospora caryolitica, the cause of pernieious enteritis in the locelgehog (1902), but his imost imprortant work was in the development of the life-eveles of different protozon as distinctive or differential criteria of specese and the bearings of the same upen diseatie.

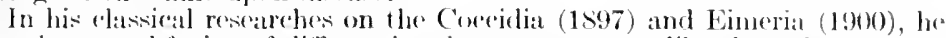
showed at sexual fusion of differentiated ganetes, mot unlike the union of spermatozoën and ovum, and his work gradually overthrew the notion that the protozea are "inmortal" thromgh any simple process of asexual cenl-elivision.

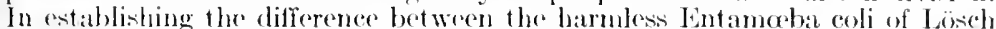
and the pathogenie Entamodat histolytiea (1903), he showed that, in the foruer, over amel above asexual multipliation, the meleus sometimes divides into two daughter nuelei, which umbergo ehromatin redutions and corentually fuse and fertilize areh other; in the latter, he thought that reproduction is aceomplishert by fission, gemmation or formation of speress with nuclei ferived from the patrental chromidia, but this has reerenty beconshown to he arroneous, in that $\mathrm{E}$. histolytira is now known to reproduee itself by the formation of cysts containing four daughter nuclei. In his work on two new species of haseteria, B. biitschlii and B. sporonema, Sichaudimm demonstrated that there is a similar autogamy of speres in the former and spore formation in the latter, when the posibibilities of transverse fission have beeone exhatusted. Thus it becamb clare that, even in plant organisus like the bateteria, a speedes may wear itself out and beceme exinet monless rejurematted and romvigurated by sexual conjugation, a view which has bern strikingly enfirmed for protezon by sinde observers as Gary ‥ (alkins (1S69- ),

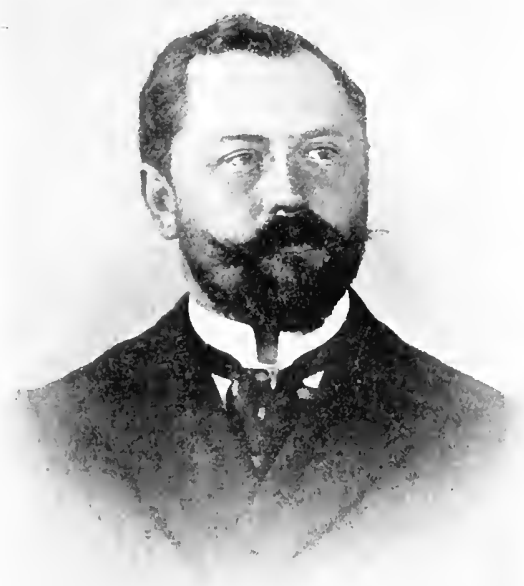

Fritz Sichaudinn (1871-1906).

who has carried Paramenum through sereral hundred generations by this means (19)2). In investigating the alteruation of generations and of hosts in

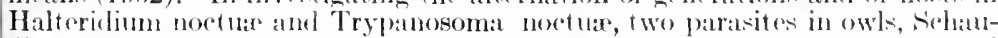

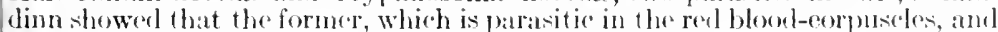
the latter, a parasite of the plasma, are really phases of a single life-yede, the sexual period of which oecours in the mesquito. This has led many obsorers to believe that the Ilamesporidia and the 'I'rypanosomata are monbers of a single oreler of flagellates. In addition to his work on amehie dycentery, whieh he carred out experimentally upon animals, sehaudinn confirmed the work of

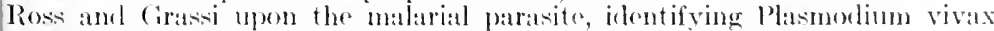

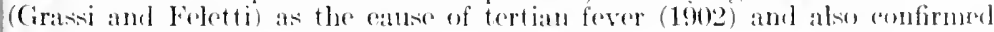
Loos's demonstration of hook-worm infortion through the skin (1901).

In May, 1905, working with Erich Ioffmann, Schaudinn crowned his life-work by the discovery of the Spirochat an pallida of syphilis, and in a valuable paper of his own (october,

1 Arb. a. 1. k. Gesundheitsamte, Berl., 1905, xxii, 5i27-53)1. 
$\left.1905^{-1}\right)$, he described the morphology of the spirochetes, that of syphilis justifying the establishment of a new genus, Spironema or 'Treponema. Schaudinn's discovery of this almost invisible parasite was due to his incomparable skill in technic and staining methods and the causal relation was rapidly established by thousands of confirmatory observations made by enthusiastic microseopists all over the world. Schaudinn was Privatdocent at Berlin (1898) and director of protozoölogy in the Kaiserliches Gesundheitsamt (1904) and the Institut für Schiffs- und Trophenhygiene at Hamburg (1906). In 1903 he founded the Archiv für Protistentizude, the literary organ of protozoology, which he had found in the descriptive stage and loft an ex-

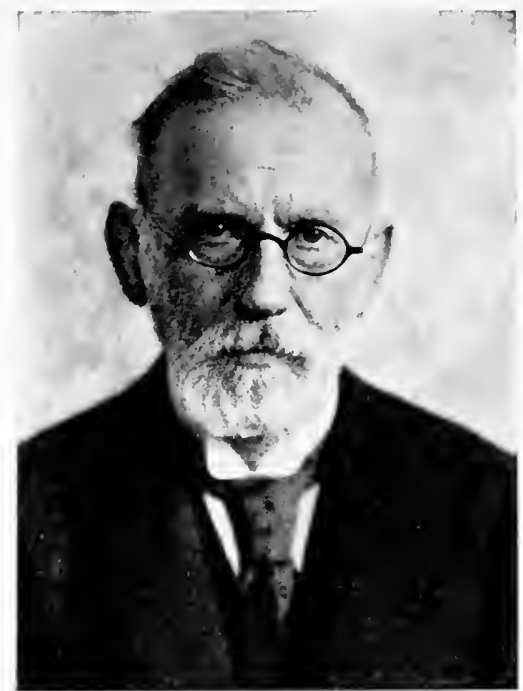

Paul Ehrlich (1854-1915). perimental science.

The first steps in the con(quest of syphilis had thus been marle by professional zoölogists, Metehnikoff and Schandimn. The next advances were marle by an investigator who, although educated as a physician, has practically worked out his results as at chemist and pharmacologist.

Paul Ehrlich (1854-1915), of Strehlen, Silesia, was a clinical assistant of Frerichs (1878 -85) and Gerhardt (1885-89), Privat-docent (1889) and professor (1890) at Berlin, where he became an assistant in Koch's Institute. In 1896 he was entrusted with the directorship of the newly founded Institut für Serumforschung at Steglitz, which was transferred, under his direction, to the Institut für experimentelle Therapie at Frankfort on the Main (1899).

At Breslau, Ehrlich was but an indifferent student, occupying his time mainly with experiments on dye-stuffs and tissue staining, but the results of his labors soon appeared in his improved methods of drying and fixing blood smears by heat, his triaeid stain, his discovery of the mast cells and his detection of their granulations by basic aniline staining (1877), his division of the white blood-corpuscles into neutrophilic, basophilic and oxyphilic, his fuchsin stain for tubercle bacilli, based upon the discovery that they are acid-fast (1882), his diazo-reaction of the urine, used in the diagnosis of typhoid fever

${ }^{1}$ Deutsche med. Wochenschr., Leipz. \& Berl., 1905, xxxi, 166.5-1667. 
(18521), his sulpho-diazo-benzol test for bilirubin $\left(1883^{2}\right)$, his method of intravital staining $\left(1886^{3}\right)$, in all of which he has been a great pioneer in merging descriptive cellular pathology into experimental intracellular chemistry. He was the pione'r of Farbenamalyse or the mierochemical relation of the tissues to dye-stuffs. This is partieularly the ease in his study of the oxygen recpuirements of the organism (1855), in which he applics the itloa of a selective affinity between chemical substances and borly tissues to protoplasmic chemistry and first outlines his "side-chain theory." This theory was suggested by Mugust Kiekule's hypothesis of the closed benzene ring (1865), in which the six carbon atoms of this compound $\left(\mathrm{C}_{6} \mathrm{H}_{6}\right)$ are assumed to form at stable hexagonal nucleus anong themselves, while their fourth affinities are linked with unstable "side-chains" of easily replaceable hydrogen. Hoppeseyler had assimed that the emission and absorption of light in chlorophyll are accomplished not by the entire molecule itself but by cortain specialized zrouls of peripheral atoms. In like manner, Ehrlich assimed that the living rotoplasmic molecule consists of a stable nucleus and unstable peripheral ide-chains or chemo-receptors, which enible it to combine chemically with ood substances and neutralize toxins or other poisons by throwing out deached side-chains into the blood. In spite of the enormous amount of critiism which bas been heaped upon this theory and its author, it may safely be ffirmed that, as based upon a fundamental postulate in organic chemistry, t has proved to be a valuable "heuristic principle" in developing the seicnce of immunity and serum reactions. Thus, August von Wassermann (1866-

) did not hesitate to affirm that without it he could never have hit upon he special and extremely reliable hemolytic diagnosis of syphilis with which is name is associated and which was discovered one year after Schaudinn ad found the parasite of the disease $\left(1906^{4}\right)$. Although the original Wasserrann reaction has been much simplified by such ingenious modifications as lose of Hideyo Noguchi $\left(1909^{5}\right)$, particularly his "luetin" reaction, based pon pure cultures of the Treponema (19116), yet it is plain that no such dvances could have been made upon a purely physical or mechanical hyothesis. From the discoveries of Schaurlinn and Wassermann, it becane nown that such immunes as come under Colles' and Profeta's law have the philitic spirochetes in their blood, whenee Ehrlich reasoned that protozoan iseases cannot be treated by special antitoxins, but must be handled by drugs hich can at once sterilize the patient's body of the parasites without injuring ie body tissues. In attempting to treat trypanosomiasis in mice with certain ecific dyes, he found that if the doses were too small to completely sterilize ie animal of the parasite, a race of trypanosomes could be bred which proved srmanently "fast" or resistant to the effects of the drug. This power of trasites to immunize themselves and their descendants against the action drugs was the Leitmotif of the long series of "trial and error" experiments to al a therapia sterilisans against syphilis, and it proved to be the weak point their final result, "606," or salvarsan. Salvarsan, which was first tried out r Ehrlich's Japanese assistant, S. Hata (1910), and has since been tested in ousands of cases, is, in itself, as reliable a specific as quinine in malarial fection, and is, moreover, a valuable prophylactic, in that it ripidly cleans , the ugly luetic sores and eruptions and sterilizes the blood, thus minimizing c possibility of infecting others. But the fact that it does not appear to ich some of the spirochetes, which, like the gonococeus, hide in otler tissues, responsible for disconcerting relapses, while " 606 " itself sometimes causes vere collateral effects upon the eye or the nervous system. The merits of

'Ehrlich: Ztsehr. f. klin. Med., Borl., 1822, v, 285-2ss. Charité Ann., 31, Berl., 18s:3, viii, 140-166.

2 Centralbl. f. d. med. Wissensch., Berl., 1883, iv, 721.

${ }^{3}$ Deutsche med. Wehnschr., Icipz. 11. Berl., 1886, xil, 49-52.

4 Deutselse med. Wehnschr., Leipz. u. Berl., 1906, xxxii, 7.5.

${ }^{5}$ Noguehi: Jour. Exper. Med., N. Y., 1909, xi, 392-401.

${ }^{6}$ Jour. Exper. Med., N. Y., 1911, xiv, 557-568, 3 pl. 
"noo-salvarsan" ("9)19" in Ehrlinh"s experimental series) are now on trial, but it is hardly likedy that any drug will prove al complofe sterilizer under the

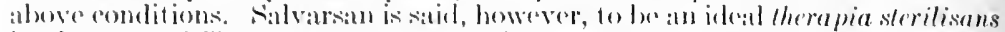

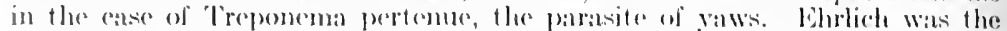

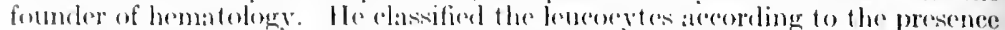
or absenee of gramules, differentiated the leukemisis, deseribed polychromat-

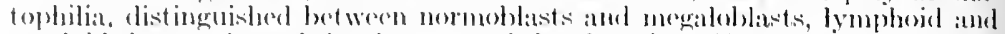
myelerid tisstues, showed that fencocretosis is a function of bone-matrow, stunlied apilastie anemiat and late the foundition for the study of the specifie reatetions of eclls to varions infeetions and stimuli. of the oflere features of Ehrdieh's scientifie work, his introduction of such remedies as mothylene-blue for cluartin ferer, trylan red for bovine pireplasmosis, arenephenylglyein for the try-

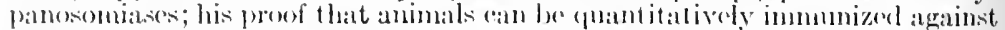
veretable proisons like abrin and ricin; his improvement of Behring's diphtheriat antitexin and his establishment of an international standard of purity for the same; his demonstration that eaneer ean be (hanged into sareomil in animals by sucessive inosudations, and that the growth of cancer depends "lpon the presence of certain food substances in the body and that immunity from eancer depends upon their absenee (atrepsy); his vist researches in the whole fiekd of serology and inmunity ean only bi mentioned.

In his skill in improvising hypotheses to meet the opponents of his theories, Ehrlich resembled Galen. In his predilection for quaint and archaic Latin phrases, he was like Paracolsus. But he has done the most effective work since Pastenr and Koch in the science of infertious diseases, and he has added new territory to the domain of experimental pharmacology and therapenties by his genius for research and his wonderful industry.

The trend of recent medicine from the bacterial theory of disease toward the biochemical is strongly marked in Ehrlich's work. The fallibility of the many tests for differentiating the psendo-typhoid, psendo-tubercle, and psendo-diphtheritic bacilli, the fact that only a fixed laboratory strain of a given bacillus is definitely pathogenic, the uncertainty of the behavior of many barilli in fermenting sugar-media, the puzzling mutations and polymorphisms, such as Penfold's Bacillus coli mutabile, which generates incontinently typhoid or coli germs, the apparent changes of one bacillus into another, the effect of meteorological conditions on inulin fermentation, the strange vagaries of agghtination and of Wassermann tests, all show the inadequacy of our present knowledge, and how little we really know of intracellular chemistry. As in applied sanitary science, opinion is divided between those who maintain that the prevention of disease and mortality rests mainly with the individual, and those who believe that eausation and prevention are multiplex and largely external to the individual: so, in the infantile science of epidemiology, just emerging from the descriptive stage, there are already two schools, one relying upon the bacterial theory of infection for its data, and one, headed by Crookshank, harking back to the Sydenham doctrine of epidemic constitutions, family relationships between diseases and 
extermal (cosmic and telhuric) phenomena as contributory causes of epidemies. ${ }^{1}$

In Crookshank's view, the bad practice, introduced by Sydenham, of ranging discases in species, like plants, is illogical, since a true disease can be only differentiated from a symptomgroup when the intra-corporeal cause is ascertained; but he rightly upholds Sydenhan's view of epidemic constitutions as somd, since an epidemic, while intra-communal, is protean in symptomatology and of remote external causation, as borne out by Pasteur's doctrine of the effect of enviromment on the relative virulene of microörganisms.

Jules Bordet, Director of the Institut Pastem de Brabant (Brussels), who won the Nobel prize for 1919 , has been a great pioneer in the theory of serology and immonity reactions, for the plienomena of which he gives a simple and purely physical explanation. He discovereal batcterial hemolysis $\left(1898^{3}\right)$, and, with Octave Gengon, fixation of the complement $\left(1900-01^{4}\right)$, and, with the latter, he also discovered the specific bacillus of whooping-cough (19065), the causal relation of

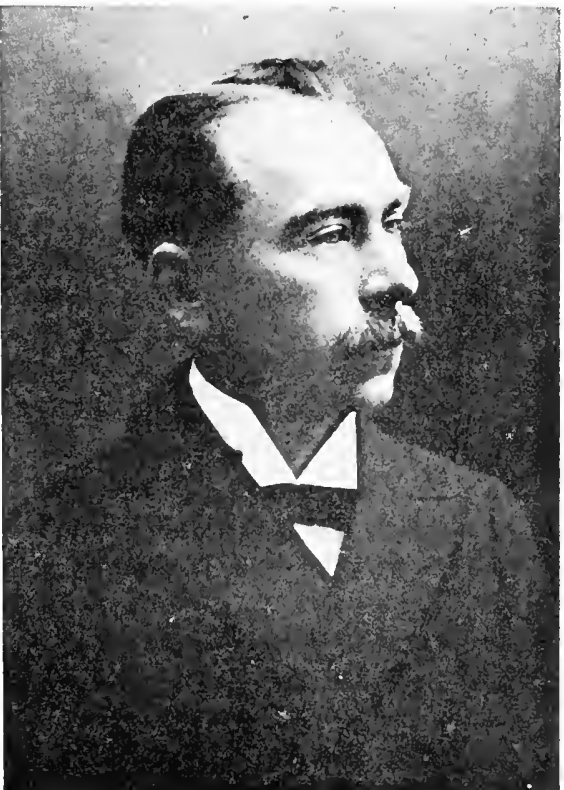

Jules Bordet. which has recently been demonstrated, aceording to Koch's postulates, by F. B. Mallory and others $\left(1913^{6}\right)$. As compared with Ehrlich's complex terminology, Bordet's theory of serum reactions is simplicity itself.

See Howack: Indian Med. Gaz., Calcutta, 1916, li, 161-165.

${ }^{2}$ F. G. Crookshank: Proc. Roy. Soe. Med., Lond., 1920, xiii, Seet. Epidemiol., 159-1st.

${ }^{3}$ Ann. de l'Inst. Pasteur, Paris, 189S, xii, 6SS: 1899, xiii, 273.

${ }^{4}$ Ibid., 1900, xiv, 257: 1901, xv, 289: 1902, xvi, 734. Deviation of the romplement was discovered by A. Neisser and F. Werhsberg (München. med. Woehenschr., 1901, xlviii, 697-700).

${ }^{5}$ Ann. de l'Inst. Pasteur, Paris, 1906, xx, 731, 1 pl.: 1907, xxi, 720.

${ }^{6}$ Mallory, Horner and Henderson: Jour. Med. Researeh, Bost., 1913, xxvii, 391-397, 2 pl. 
He assumes that the toxin is nentralized by an antitoxin through absorption, comparable with that shown by a fabric in taking up) dyes. Complete neutralization would be like complete saturation of the fabrie with the dye-stuff, but if the toxin be added in divided doses, the dast portion of the toxin could not be absorbed, because its first portions have become supersaturated with antitoxins and ean take up no more of them. Similary, he assmmes a substance sensibilisatrice in antitoxic sera which sensitizes the red blood-corpuscles or bacteria to the action of the alexins, as a mordant does for al dye-stuff. The disputes between Bordet and lehrlich turn upon the simple fact that the former explains what he has seen in terms of physies, the latter in terms of structural chemistry.

Apart from the work of Metchnikoff, Bordet and Ehrlieh, there have been many advances in serology of great practical value, notably the applications of Quincke's lumbar puneture (1909) in eytodiagnosis, the discovery of agglutination and its application to the diagnosis of typhoid fever (1896) by Ferdinand Widal (1S62- ) and A. Sieard; the diagnostic use of tuberculin by the conjunctival reactions of Albert Calmette (1907) and Alfred Wolff-Eisner (1907), and the eutaneous reactions of Clemens von Pirquet (1907) and Ernst Moro (1908); Nir Almroth E. Wright's preventive inoculation against typhoid fever by dead cultures of the bacillus, with the opsonic index as a guide (1900); eobril venom reaction in insanity (Much-Holtzmann, 1909); the discovery that water can be sterilized by ultra-violet rays by Vietor Henri, André Heilbronner and Max Recklinghausen (1910); B. Sehick's reaction for finding how much diphtheria antitoxin in the blood will render preventive inoculation unnecessary (1910-11); Emil Abderhalden's enzyme reaction in the diagnosis of pregnancy (1912); and the theory of filterable viruses. Many new modes of treatment with baeteria or bacterial products abound, such as Besredka's sensitized vaceines, Cirl Spengler's employment of the bovine type of tubercle bacillus, and the use of bacilli attenuated in the cold-blooded animals against tubereulosis (Klebs, Friedmann), all of which have been on trial.

The theory of filterable viruses as a cause of disease was first put upon a definite basis through the discovery of Friedrich Löffler and Paul Frosch that the inoculable virus from foot and mouth disease will pass through the finest filters (1898). Shortly afterward, Beijerink diseovered the same phenomenon in the mosaic disease of the tobacco plant, and down to the present time, a large number of filterable viruses have been found, notably in the pleuropneumonia of cattle by Edmond Nocard (1899), in African horse sickness (1900) by Allen Macfarlyen (1861-1907), in yellow fever by Reed, Carroll and Agramonte (1901), in eattle plague by Nicolle and Adel Bey (1902), in fowl diphtheria or epithelioma contagiosim by Marx and Stocker (1902), in hog cholera by Dorset, Bolton and MeBryde (1905), in molluscum contagiosum by Julius Berg (1905), in dengue by Ashburn and Craig (1907): in trachoma by Bertarelli and Cecchetto (1908), in three-day or Pappataci fever by Doerr and Russ (1908), in typhus fever by Nicolle (1910), in tabardillo by Howard Taylor Ricketts (1911), in measles by Goldberger and Anderson (1911), and in chicken sarcoma by Peyton Rous (1911-121). Some of these viruses, such as those of rabies, molluseum contagiosum, verruca vulgaris, chicken sarcoma and probably trachoma, require an abrasion of the surface for infection, others simply contact with the mucous membrane; and some, such as variola, measles, scarlatina, rabies, trachoma, etc., exhibit specific cell inclusions (Prowazek's chlamydozoa). Reports of experimental inoculation of measles has been made by Anderson and Goldberger, Nicolle, Sellards,

1 For a full account of present knowledge of the filterable viruses, see $\mathrm{S}$. B. Wolbach in Jour. Med. Research, Bost., 1912-13, xxvii, 1-25, 1 tab. 
Hektoen and others. As in the case of such minute organisms as Bordet's whooping-eough bacillus, or the organism recently isolated by Flexner in infantile poliomyclitis, it is probable that all filterable viruses will oventually turn out to contain filtered mieroscopic organisms not yet visible by present modes of investigation.

Great practical advances in the science of infectious diseases have been made in recent times through the coöperation of army surgeons. The work of Alphonse Laveran on malarial fever, of Ferdinand Widal on typhoid fever, of Friedrich Löffler and Fimil Behring on diphtheria, of Colonel Sir Ronald Ross on malarial fever, of Surgeon-General Sir David Bruce on Malta fever and sleeping sickness, of Colonel Nir William B. Leishman, Major Donovan and Colonel Sir Leonard Rogers on kala-azar, will compare favorably with what John Hunter or Helmholtz accomplished during their period of military service. In the United States Army the labors of such men as William Beatmont, Jonathan Letterman (1824-72), who revived Larrey's methods of rapid vacuation of the wounded and reorganized the whole administraion of medieal service in the field, William A. Hammond, creator of the Army Medical Museum, Joseph Janvier Woodward (183334), pioneer in photo-micrography, Alfred A. Woodhull (1837- ), who introduced the Indian method of giving massive doses of pecac in dysentery, ${ }^{\prime}$ Billings, Otis, Smart and Huntington have et an example which has been followed by a number of able rorkers in recent times. The first American army surgeon to ake up the study of bacteriology was Surgeon-General George M. iternberg (1838-1915), who isolated the diplococcus of pneumonia imultaneously with Pasteur $\left(1880^{\circ}\right)$, and published valuable reatises on bacteriology (1896) and disinfection (1900), and hrough the localization of "Bacillus $\mathrm{X}$ " in yellow fever as a egative find, eleared the ground for later investigators. During is administration, Major Walter Reed (1851-1902), of Virginia, tho had studied under Welch at Johns Hopkins and had done ood work on the pathology of typhoid fever in his laboratory 1895), was detailed as the head of a Board consisting of James arroll, Aristide Agramonte and Jesse W. Lazear, to study yellow ever in Cuba, then occupied by the American Amy (1900). Carlos inlay (1833-1915) had already atvanced the theory that the disase is transmitted by the mosquito (1881), but when the Army bard went to Cuba, the Bacillus ieteroïdes of Sanarelli held the eld. In 1900, Henry R. Carter (I. S. Public Health Service) had hown that a lapse of twelve to fifteen days is necessary before

1 Woodhull: Studies, ehiefly elinical, in the non-emetic use of ipeeacuanha, hilatelphia, $18-6$.

2 Sternberg: Rep. Nat. Bd. Health, 1\$81, Washington, 18\$2, iii, \$7-92. 


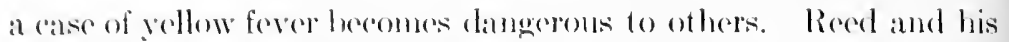
associates soom disposed of somancelli's bacillus (identionl with the

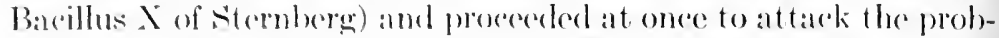
lem of transmission he mosepuitos. During the course of their experiments, twenty-two ases of rellow fover were produced experimentally, fomrteon by infocted mosanito-bites, six by the injection of blood, and two by the injection of filtered blood-serum, thus proving the existence of a filterable virus (19012), (onfirmed hy liosenan at Vera ('ruz, in 19)3, while seven onlisted men disproxed the fomites theory of transmission by slecping in inforted hedding. Carroll was the first to submit to mosenuto inoculation ancl ame through an at tack - of yollow fever suceossfully.

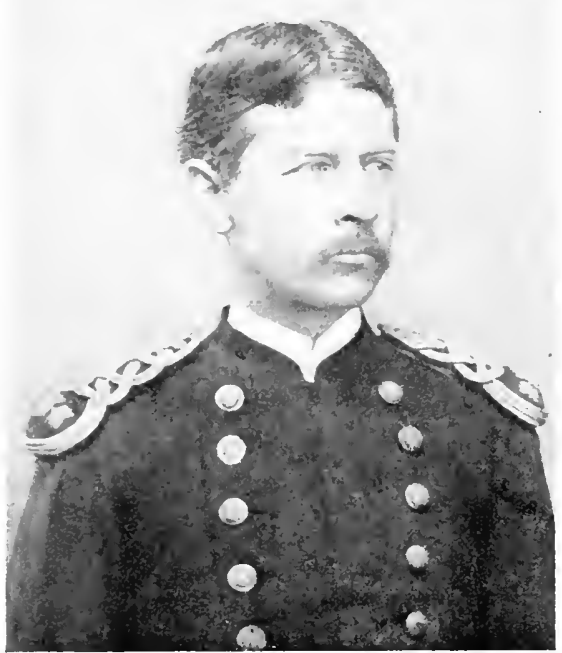

Wialter Reed (1851-1902). Latzear died from the effects of an aceidental moscunito hite. 'Thus it was proven, according to the most rigorous ronventions of formal logic, that the (atuse of yellow fever is cither an ultramicroscopice organism or a filterable virus which is transmitted to man by a particular species of mos(juito, the Stegomyia fasciatr or calopus. With reference to the conditions under which the experiment was performed, particularly the period of development in the hody of the mosquito, the demonstration of the Army Board is one of the most brilliant and conclusive in the history of science. It s economic importance is indicated by the immense saving of life and money through the eladication of yellow fever in the United States and the West Indies, if not throughout the entire world. In February, 1901, shortly after Reed hall proved his case, Major William C. Gorgas (1854-1920), of Mobile, Alabama, as chief sanitary officer of Havana, Cuba, began to sereen yellow fever patients and destroy mosquitos, and, in three months, Havana was freed from the clisease for the first time in 150 years. In connection with the

1 Reed (ct al.), Philardelphia Med. Jour., 1900, vi, 790-79;.

2 Tr. Ass. Am. Phys., Phila., 1901, xvi, 45-72. 
work on the Panama Canal, Colonel Corgas has freed that part of the Isthmus not only from yellow fever, but from all dingerous infections, and through this great triumph in sanitation, Panama, formerly a notorious plague spot of disease, the "White Man's Grave," as it was called, is now one of the healthiest communities in existence. In 1913-14, General Corgas, at the invitation of the Chamber of Mines of Johamnesburg, South Africa, investigated the causes of the high death-rate from pneumonia among the native miners of the Rand, devoted the summer and autumn of 1916 to a survey of the endemic foci of yellow fever in South America for the Rockefeller Foundation, upon which work he was engaged at the time of his death. The investigations of typhoid fever incidence in camp during the Spanish-American War (1898), by Major Walter Reed, Victor C. Vaughan and Edward O. Shakespeare demonstrated the transmission of the disease by flies. During the American oceupation of Porto Rieo, the island population was vaccinated and freed from small-pox under Colonel John Van R. Hoff, and shortly afterward Captain Bailey K. Ashford discovered the presence of hook-worm infeetion in the Istand $\left(1900^{1}\right)$ and has since devoted himself to the task of stamping it out. In 1915 he began the study of sprue as a moniliasis. Captain Charles F. Craig (1872- ) demonstrated that intracorpuscular conjugation in the malarial plasmodia is the cause of latency and relapse, and that there are malaria carriers $\left(1902-05^{2}\right)$; showed that the so-ealled Piroplasma hominis of Rocky Mountain spotted fever is really an artefact in the erythrocytes (1904); and, in the Philippines, showed with Major Perey M. Ashburn that the caluse of dengue is a filterable virus transmitted by the mosquito Culex fatigans $\left(1907^{3}\right)$. (raig also discovered two new parasites, Paramoba hominis (19064) and (with Ashburn) Microfilaria philippinensis $\left(19066^{5}\right)$, and is the author of extensive monographs on the malarial fevers (1901. 1909) and the parasitic amobae in man (1911). Captain Henry J. Nichols collaborated with Ehrlich in his initial work on salvarsan (1910) and has since investigated the experimental production of vaws (1910-11). Under the arlministration of Surgeon-Gieneral ficorge H. Torney, Miljor Frederick F. Russell, in 1909, began the huge experiment of vacrinating the Cnited states Army against typhoid fever, after the methods alvocated by André ('hantemesse (1851-1919) and F. Widil in

${ }^{1}$ Ashford: New York Med. Jour., 1900, Ixxi, 5.52-556.

${ }^{2}$ Craig: Ann. Med., Phila., 1905, 982; 1029.

${ }^{3}$ Craig and Ashburn: Philippine Jour. Se., Manila, 1907, B. ii, 93-146

${ }^{4}$ Am. Jour. Med. Sc., Phila., 1906, cxxxii, 21t-220.

${ }^{5}$ Ibill., 435-443. 
France (1SSS), Pfeffer and Kolle in Cermany (1896), and Wright and Semple in England (1896). Fyom a morbidity of 1733 (16 fatal) (ases of trphoid in 1909, Russell was able to bring his statisties down to 9 ases of the disease with one fatality in 1912, while at present the army is ahsolut dy free from typhoid. The mobilization of Lnited states troops on the Mexican border in $1912^{1}$ gave Major Russell an opportunity such as never came even to Jemnel or Pasteur, viz., that of testing his varedine at a huge out door clinic consisting of some 20,000 men. The absolute suecess of his experiment is now a matter of history. Captain Edward B. Vedder (1878- ), of New York (ity, has made important studies in beri-beri as a "deficiency disease," summed up in his treatise of 1913 , and was the first to determine the specific anchicidal action of emetine in the treatment of amobie dysentery (1910-112). In 1911, Captains Emest R. Gentry and Thomas I. Ferenbaugh discovered that Malta fever is endemic in southwestern Texas, and transmitted by the goats of the goat-ranches. In 1916, Major George B. Foster made an important investigation of the causation of common colds by a filterable virus. Lient.-Col. Charles E. Woodruff (1860-1915) investigated the deleterious effects of tropical light upon the blonde Northern races (1905) and wrote interesting volumes on Expansion of Races (1909) and Medical Ethnology (1915). In his Mütter lecture (1902) Colonel Louis A. La Crarde (1849-1920) demonstrated that sterile gunshot wounds are non-cxistent, because the microörganisms in powder or projectiles are not destroyed by the heat of firing, but convered dircetly into the wound. He wrote a standard treatise on gunshot injuries (1914). The manuals of military hygiene by Colonel Valery Havard (1909) and $x$-ray technic by Captain Arthmr C. Christie (1913) are in the same class. Col. Edward L. Munson, editor of the Military Surgeon, is the author of important works on military hygiene (1901), sanitary tactics, the military shoe (1912) and the Management of Men (1921). All these works, with the various manuals of military medicine by Charles S. Tripler (1858), Alfred A. Woodhull (1898), Paul F. Straub (1910), Charles F. Mason (1912), and others, have added much to the lustre of the U. S. Army Merlical Corps at home and abroad.

Intimately connected with the history of infectious diseases is the illustrious bead-roll of its medical martyrs. With Servetus. and Semmelweis, who died for their opinions, should be elassed such names as Daniel A. Carrion (verrugas), Jesse W. Lazear (yel-

1 Russell: Harvey Lecture, 1913.

${ }^{2}$ Vedder: Bull. Nanila Med. Soc., 1911, iii, 48-53. Jour. Trop. Med., Lond., 1911, xiv, 149-152. 
low fever), A. Yersin and Hermann Franz Müller (bubonic plague), Tito Carbone (Malta fever), Allen Macfadyen (typhoid and Malta fever), J. Everett Dutton (African relapsing fever), Howard Taylor Ricketts (tabardillo), and Thomas B. MeClintic (Rocky Moun-. tain ferer), all of whom lost their lives in investigating the diseases with which their names are associated.

The surgery of the twentieth century has been devoted mainly to refinements, inventions, and improvements in procedure, such as the operations for the excision of the prostate by P. Johnston Freyer, of the Indian Medical Service (1901), and Hugh Hampton Young (1903), of Baltimore, the use of hismuth paste in the treatment of chronic tuberculous sinuses and cavities by E. Beck (1906), the injection affording at the same time a complete radiogram of the ramifications of the cavity; the treatment of eancer by a bombardment with high-frequency sparks of wide dimensions (fulguration), introduced by de Keating-Hart (1910), the elastic pressureforceps, and other instruments invented by Eugène Doyen, the use of the "Cargile membrane" in preventing postoperative intestinal adhesions (1912), etc.

August Bier (1861- ), von Bergmann's suceessor at Berlin (1907), introduced intraspinal anesthesia with cocaine (1899), a new method of treating amputation stumps (1900), and active and passive hyperemia as an adjuvant in surgieal therapy (1903'), in which he was preceded by Hugh Owen Thomas (1876-86). In cocain anesthesia by the spinal route, Bier was preceded by James Leonard Corning ${ }^{2}$ (1855- ), of New York City, in 1885, and by Rudolph Matas (1899). It has been well saiel that "Corning first blocked the spinal cord, Cushing first blocked the larger nerve-trunks, and Crile applied the principle to the sunaller and more active nociceptor nerves of the skin and superficial tissues." Infiltration anesthesia was introduced by C. I. Schleich (1894).

Ernst Ferdinand Sauerbruch (1875- ), of Barmen, Rhenish Prussia, professor at Marburg (1907), while working in Mikulicz's elinic at Breshau, greatly alvaneed the possibilities of intrathoracic surgery by his invention of the pnemmatic (hamber at reduced atmospheric (negative) pressure for the prevention of pneumothorax (1903-04). The idlea of using differential pressure was first concoved by Quénu and Tuffice in 1896. Saucrbruch also devised the positive pressure cabinet in which a patient breathes compressed air, while the plemal cavity is opened at ordinary at mospheric pressure. The earlier cabinets were clumsy and had many inconveniences, but, with the modern improve-

Hier: Hyperämie als Heilmittel, Lejpzig, 1903.

${ }^{2}$ Corning: New York Med. Jour., 1855, xlii, 317-319. 
ments of Sinterhench and Willy Meyer (calbined for differential positive and negative pressure), groat advaluese in the surgery of the esophateras and the chest have been made. Forecel respilattion in poisonimg was first used by ( ieorge ledward Fedl, of Buffilo, $\mathrm{X}$. Y., on July 23, ls8, ${ }^{1}$ and this led to positive pressure hy moans of intubation the (Fell-( $)^{\circ}$ Dywer method), which was also recommomded by Rudolph Matas in 1899. In 1909," Sammel James Moltzer and John Auce, of the Rockofolley lnstitute, ereatly simplified matters by the method of intratracheal insullation of air through at tube passed into the trachea, producing "continuous respiration without respiratory movements." Matintenance of respiration in a strapped animal by means of a bellows hatd been demonstrated by lesalius and Robert Hooke, but the ingenious Melizer-Auer experiment made the procedure viable and was a true advance in physiological surgery.

Much effective work in visecral surgery has been dome by Eugene Doyen (Paris), César Roux (Latusanne), Emil Wermer Kö̈rte (Berlin), A. IV. Mayo Robson (London), Fir berkeley Moynihan (Lerels), John Bs. Murphy (Chicago), Charles Il. Mayo and William J. Mayo (Rorbester, Minnesota), and John M. 'T'. Finney (Baltimore); in the surgery of the head by von bergmann, Mackwen, $W^{*}$. W' Keen, H. Schloffer, Iarvey Cushing; in the surgery of the vaseular system by brwin Payr (Leipzig), W. 'T. Halsted, J. B. Murphy, Alexis Carrel; in osteoplastic and orthopedie surgery by Albert Hoffa, Erich Lexer, E. Lorenz, J. 13. Murphy, John B. Roherts, ind the remarkable group of New England orthopedists, viz., Edward H. Bradford, Robert W. Lovett, and James IV. Sever, who introdueed the treatment of scoliosis by plaster jitckets applied in suspension, Elville G. Abbott (Portland, Maine), who introduced the treatment of lateral curvature by abplication of jackets in flexion (1911), Howird Osgoos, who, simultaneonsy with C. Schlatter, described adoleseent apophysitis of the tibia (1903) and studied poliomyelit is earriers (1913), Charles F. Painter, who excived the innominate bone (1908), Joel Emest Goldthwait, of Marblehearl, Massalehusetts, who has done mueh to simplify the eomplieated subject of "rhemmatic disorders" by his elassification of arthritis into the villows, infectious, at rophie and hypertrophie varieties (1904), and Emest A. Codman, who describol subarromial bursitis its a common catuse of shoulder disability (1906-11), the pathology and treatment of which were further clucidated by Walter M. Brickner, of New York (1915). In the treatment of Pott's disease, fraetures and deformities by bonegrifts, Fred H. Alloer (1876- ), of New York, has achieved a well-deserved reputation $\left(1915^{3}\right)$. The Italian method of eineplastic treatment of amputation stumps was introduced by G. Vanghetti (1906).

Of English surgeons who have rendered distinguished service during the European War, Sir Berkeley Moynihan (1865- ), a native of Malta, has made valuable contributions on retro-peritoneal hernia (1899), gall-stones (1904), ablominal operations (190.5), surgery of the spleen and pancreas (1908), duorlenal ulcer

${ }^{1}$ Fell: Tr. Internat. Mad. Cong., Wash., 18s7, i, 237. Buffalo Med. \& Surg. Jour., 1887-8S, xxvii, 145-1.57.

2 Meltzer and Auer: Jour. Exper. Med., N. Y., 1909, xi, 622-625.

${ }^{3}$ F. H. Albee: Bone-graft surgery, Philatelphia, 1915. 
(1910) and gunshot wounds (1917). He is author of an interesting volume of essiys (Pathology of the Living, 1910), and collaborated with A. IV. M. Robson in his treatises on diseases of the stomach (1901) and pancreas (1902), and with Makins, in his book on surgery of the stomach and intestines (1912).

Sir George Henry Makins (1853- ), in addition to the work just mentioned is author of Surgical Experiences in South Africa (1901), being a clinical study of the effects of small calibre bullets, the Bradshaw lecture on gunshot wounds of arteries (1914) and a treatise on gunshot injuries of the blood-vessels (1919).

Sir Anthony Alfred Bowlby (1855- ), who also served in South Africa, is author of treatises on Surgical Pathology and Horbid Anatomy (1887) and Injuries and Discases of Nerves (1889).

Sir Robert Jones (18.55), of Rhyl, Wales, the guiding spirit of the British and Anerican orthopedic services during the war, has made many individual contributions to his subject, smmmarized in his book on injuries of the joints (1915), his Notes on Military Orthopedic Surgery (1917) and a later text-book.

Alfred Herbert Tubby (1862 - ) was consulting surgeon of the British Mediterranean Expeditionary Force (1915) and of the Exyptian Expeditionary Force (1916-19). He

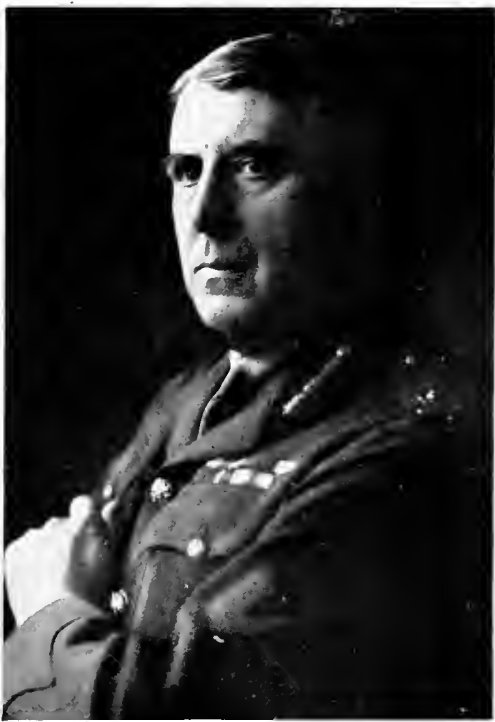

Sir Berkeley Moynihan (1865- ). has written treatises on Deformities (1896), and (with Jones) on the modern surgery of paralyses (190:3).

Sir William Arbuthnot Lane (1856- ), of Fort Cieorge, Scotland, noted for his work on the treatment of fractures by plates and serews (1892-1905) and on treatment of chronic intestinal stasis (Tane's kink) by short-circuiting the intestine, is allthor of a manual of operative surgery (1886) and played an important part in the administration of surgical service during the war.

Hans Kehr (1862-1916), author of authoritative treatises on gall-stone surgery (1896-1901); Werner Körte (1853- ), of Berlin, who has written well on panereatic (1898-1903) and visceral surgery; Edwin Payr (1871), of Inmsbruck, director of the 
Iniversity Clinic at Leiprig, who has worked in intestinal suturing and thyroid transplantation (1906), and Erich Lexer (1867), of Würzburg, professor and director of the Surgical Clinic at Jena, are prominent Cerman surgeons of today. Lexer is the anthor of a surgical treatise (1901-05), investigated the microörganisms of acute osteomyclitis (1897), and has made a gleat reputation in the recent European War by his effective work on the surgery of the bones and joints. ${ }^{1}$

As in eighteenth century Paris, modern cities abound with able operators whose innovations have been prineipally along the lines of technical procedure.

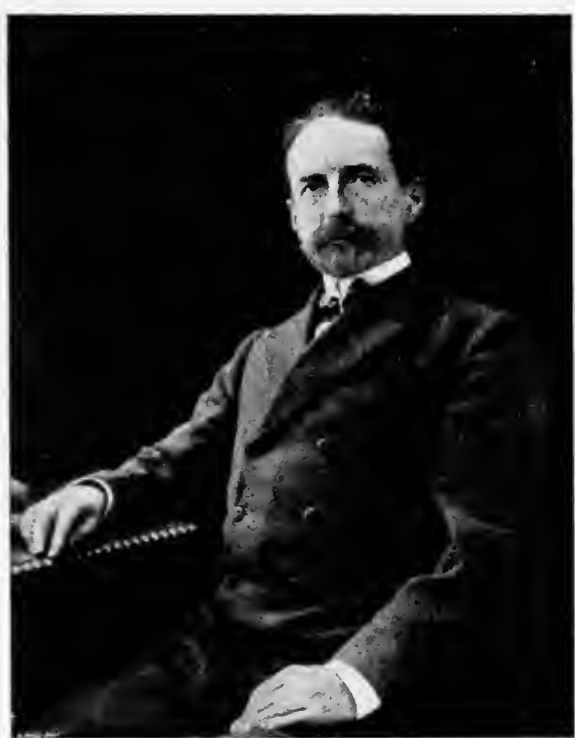

Théodore Tuffier (1857- ). This is particularly the case with the ParisiansTuffier, Terrillon, Chassaignac, Faure, Jaboulay, Hartmann, Pozzi, Delbet, Quénu, Doyen, Kimisson, Morestin, Albarranmany of whom have included gynecological work as part of their specialty. During the recent war the attention of all surgeons in the combatant comntries has been concentrated upon gunshot wounds and their. sequelæ.

Marin-Théodore Tuffier $(1857-)$ ), of Bellême (Orne), a Paris medical graduate of 1885, who taught surgery at the Paris Faculty and experimental surgery at the Sorbonne, is the author of experimental studies on the surgery of the kidney (1889), and of monographs on the surgical treatment of phthisis (1897-1909), subarachnoid cocaine anesthesia (1901), the semeiology of the blood in surgery (1905), and the surgery of the stomach (1907). He popularized spinal anesthesia in France, and during the war he collaborated with Simonin in standardizing wound treatment and other administrative phases of military surgery, and, although in Mufti, his status was that of a medical officer along the whole French line.

${ }^{1}$ For which see, H. G. Beyer: Johns Hopkins Hosp. Bull., Balt., 1916, xxvi, $267-270$. 
Hippolyte Morestin (1869-1919), a Paris graduate of 1894, was a dexterous operator in all branches of general surgery, particularly in such difficult feats as his methods in sliding hernia (1900), spino-facial anastomosis (1901), resection of the wrist (1902) and the inter-ilio-abdominal amputation (1903). He made many contributions to anatomy, wrote a treatise on diseases of the joints, and, after 1904, devoted himself almost exclusively to plastic and maxillo-facial surgery, of which he was one of the most brilliant exponents during the war.

The last few years are remarkable for a revival of Hunterian or physiological surgery. Even as Marion Sims and Bilhoth in their specialties greatly advanced the elinical patholegy of clisease: of the abdominal and pelvic viscera, so we find Kocher, Horsley, von Eiselsberg, $\mathrm{Hal}_{\mathrm{a}}$ sted, Crile, Cushing, Carrel, Murphy, not only thinking physiologically in their work, but making many new departures by means of experimentation on animals. Hunter, Merrenr and Sir Astley Cooper did this, as also Jameson and Cirossin America, but since their day the method had been almost non-existent.

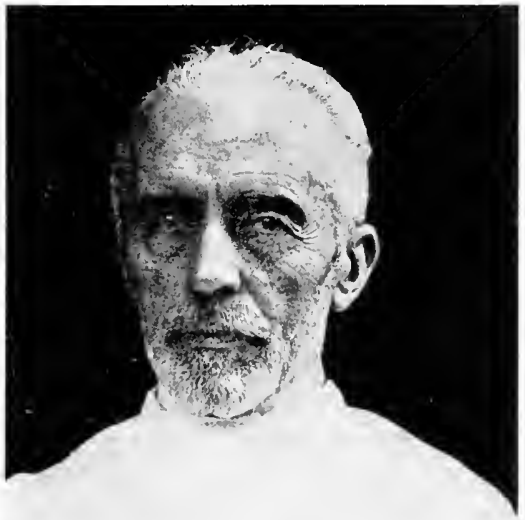

F

Theodor Kocher (1841-1917). By Courtesy of Profossor Iarvey Cushing. Harvard University.)

At the head of the surgical profession today stands by common eomsent the honored name of Theodor Kocher (18+1-1917), of Bern, Switzerland, who was at pupil of Langenbeck and Billroth, and held the chair of surgery in his native town since 1872 .

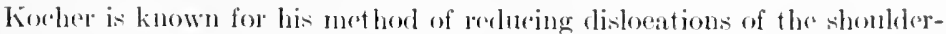
joint $\left(1870^{1}\right)$, for his cont ributions on hernia, osteonyeditis, his operations for artifieial anus, ofe., his hydrodynamic theory of the effeet of emnshot wounds, and especially for his work on the thyroid gland. He wats the first to excises the thyorol for goiter $\left(187 S^{2}\right)$, and he has performerl this diflieult operation over 2000 times with only four and a half per cent. mortality. In $185: 3^{3}$ he published his deseription of the "achexia strumipriva," which he hat found as a sequel in 30 out of his first 100 thyroidectomies, and which, in connection

${ }^{1}$ Berl. klin. Wochenschr., 1870, vii, 101-105.

${ }^{2}$ Cor.-B]. f. Sechweiz. Aerzte, Basel, 1s78, viij, 702-705.

${ }^{3}$ Arch. f. klin. Chir., Borl., 1883, xxix, 254-337. 
with the pioneer experiments of Moritz sehifT on dogs (1859) and the work of the lieverdins and Horsley inamgurmed the physiolong and physiologiend

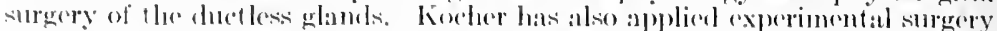
wo the physolegy of the bran and spinal aerel. In 1912 he conerived the ideat of injecting sterilized angulene (drived by fonio from the blood-platelets)

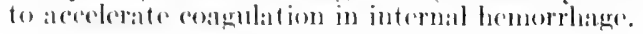

Kocher is described as a slow, atreful, precise and absolutely skilful opserator, a typical scientific surgeon, who obtains the completest dinical history of his patients before begimning, and with whom sucerse is an alnost foregone conchusion. He maintains an absolutely aseptic field of operation and is a master of minute dissecting. His text-book of operative surgery (1894) is an index of his great learning. In appendicitis a chanx and $i$ froid he is said to be excelled ly his pupil C'esar Ronx, of the Canton de Vautl, whose post-haste, slight-of-hand methods, sometimes to the exclusion of anesthesia and antisepsis, can scarcely be recommended for imitation. The same thing is true of the sensational, cinematographic methods of Doyen in Paris, and, in general. the less showy the operating, the better the patient's chances. ${ }^{1}$

Anton von Eiselsberg (1860- ), of Steinhaus, Austria, professor of surgery at Ltrecht (1893), Königsberg (1896) and Vienna (1901), is a pupil of Billroth. He was one of the first to notice the appearance of tetany after goiter operations (1890), and, in 1892, he produced tetany experimentally by excising a cat's thyroid which he had successfully transplinted into the abdominal parietes." He has also studlied the metastases of thyroid cancer, has been a proninent worker in the surgery of the pituitary body, and dirl effective work during the recent war.

William Stewart Halsted (1852- ), of New York, is professor of surgery in the Johns Hopkins Lniversity (1889). In 1884, he first performed refusion or centripetal transfusion of a patient's own blood, after defibrination, in ( $O$-poisoning. He was a pioneer in cocaine anesthesia (1885); was the first to ligate the sublavian artery in the first portion with success $\left(1891^{3}\right)$; devised the well-

${ }^{1}$ As Professor Harvey Cushing says, in his recent aldress before the Intornational Merlieal Congress (London, 1913): "The accurate and detailed methods, in the use of which Kocher and Halsted were for so long the notable examples, have spread into all clinies-at least into those clinies where you or I would wish to entrust ourselves for operation. Observers no longer expeet to be thrilled in an operating room; the spectacular public performances of the past, no longer condoned, are replaced by the quiet, rather tedious procedures which few beyond the operator, his assistants, and the immediate bystander can profitably see. The patient on the table, like the passenger in a car, runs greater risks if he have a loquacious driver, or one who takes close corners, exceeds the speed limit. or rides to admiration." Brit. Med. Jour., London, 1913, ii, 294.

${ }^{2}$ von Eiselsberg: Wien. klin. Wochensehr., 1892, v, S1-85.

${ }^{3}$ Halsted: Johns Hopkins Hosp. Bull., Balt., 1892, iii, 93. 
known supraclavicular operation for cancer of the breast $\left(1889^{1}\right)$, and, simultaneonsly with Bassini, the modern operation for hernia $\left(1889^{2}\right)$, which, in its later phase (1893), diverges widcly from Bassinis in technic. In 1916 he first excised Vater's ampulla for cancer. He has done much work in experimental surerery, particularly in circular (1885) and bulkhead suturing of the intestines (1910), occlusion of the aorta and larger arteries by means of a metal band as a substitute for ligation (19093), and in auto-and iso-transplantations of the parathyroid glands $\left(1909^{4}\right)$, which, in connection with H. Leischner's classical paper of 1907, have had much to do with establishing the functional status of these organs. In aid of a strictly aseptic technic he introduced gutta-perchat tissue in drainage (1880-81), rubber gloves (1890), silver foil dressing (1896), transfixion of bleeding tissues and vessels by fine needles and finest silk. Quietly and unobtrusively, Halsted has taught the delicate art of the perfect healing of wounds, which has been nowhere more beautifully demonstrated than at his clinic.

George IV. Crile (1864- ) of (hile, Ohio, professor of ("linical surgery in the Western Reserve University since 1890, is the author of highly original experimental researches on surgical shock (1899), blood-pressure in surgery (1903), hemorrhage and transfusion (1909), which procedure he has carried almost to perfection by his skill and technic. He has introduced various new operations for cancer of the lip, uterine prolapse, ete, and he was the irst to perform a major operation with intraneural injections of socaine as an anesthetic (1887). He has worked with particular bility in minute "block dissections" of the lymphatics in cancer. Fis operations on the head and neck for this condition (1908) are omparable with the Halsted hreast excision or the WortheinClark operation for nterine cancer. His theory of "anoci-asisociation," the blocking of shock in operations by the combination if general and local anesthesia (morphia and scopolamine followed y nitrous oxide and novocaine), with less than 1 per cent. mortalty, is his most important contribution to surgery.

Harvey Cushing (1869- ), of ('leveland, ()hio, professor of urgery at the Johns Hopkins (1902-11) and Harvard Lniverities (1912), has devoted himself latterly to nemological strrery, and particularly to the surgery of the head and the pituitary ody.

1 Johns Hopkins Hosp. Rep., Bitt, 1\$90-91, ii, 277-280); Tr. Am. Surg. ss., Phila., 1S9s, xvi, 144-1\$1, 5 pl.

${ }^{2}$ Johns Hopkins Hosp. Bull., Balt., 1\$\$9-90, i, 12; 1\$93, iv, 17, 3 pl.

${ }^{3}$ J. Exper. Med., N. Y., 1909, xı, 373-391, 3 pl.

${ }^{4}$ Ibid., 175-199, 2 pl.: 1912, xv, 20.5-215, 2 pl. 
Ho has dome much original work in exporinnental physiology, pathology and surgery, such as experimental production of gatl-stones (Is)99), experi-

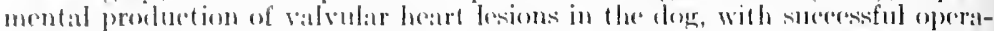

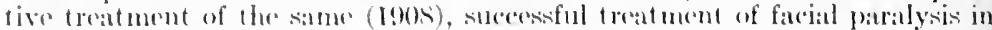
man by atnastomosis of the spiual aceessory and fardal merves (1903); he has

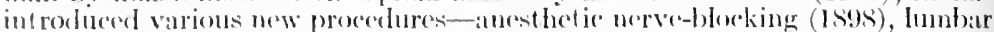

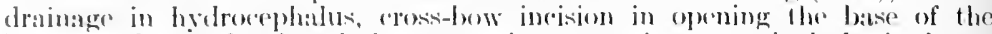
brain, and has dereloped decompressive operations, patedealarly in intracranial hemorthages in the newborn (190i) and inacersible tumors (190i).

In his work on the pituitary body, Cushing has thrown much light on its physiological funetions by the experimental production of sexual infantilism in animals, by the study of pituitary metabolism in discase, pregnancy, hibernation and other conditions, and by the general consideration of its disorders as "dyspituitarism." His monograph on this subject (1912) contains his mode of operating and is an exhaustive study of the condition as approached from the physiological, pathological, elinieal, and surgical sides.

Great advances in vascular surgery have been made by the experimental method, with the aid of the aseptic absorbable ligature.

Indeed, the first case of a sllceessful venous suture was the eelebrated "Eck fistulia" (1S77), which has since been applied by Pavloff and others in experiments requiring the physiologieal exelusion of the liver. In 18\$1, Vincenz Czerny tried to suture an eroded jugular vein, with fatal results, but schede sueceeded in suturing the femoral vein, and, by 1892 , had 30 successful eases. In 1890, Jassinowski made 26 experimental arterial sutures upon animals, all lateral, and was followed by Dörfler (1890), who, like Murphy and Silberberg before him, employed a suture pissing through all three arterial coats. By procedding aseptieally, he avoided thrombosis, and, in 1891, Durant appliel the mothol with sucess in two cases of arterial suture in man. These were all lateral sutures. The first end-tomend suture of veins was attempted with sueeess upon a dog by Hirseh in 1s81, and, in 1898, Jaboulay and Briau suceessfully applied their U-suture to the severed earotid artery of a donkey, to be followed with equal success upon animals by Salomoni and Tomaselli. The first successful circular suturing of blood-vessels in man was done by

John Benjamin Murphy (1857-1916), of Appleton, Wisconsin, was professor of surgery in the Northwestern University, Chicago (1895-1916). After many experimental end-to-end resections of wounded arteries and veins, he successfully united a femoral artery, severed by a gunshot wound, in $1896 .^{2}$

Murphy had already done epoeh-making work in the prorluction of "cholecysto-intestinal, gastro-intestinal, entero-intestinal anastomosis and approximation without sutures" by means of a special button (18923), which was preceded by the decaleified bone-plates of Nicholas Senn, potato and turnip plates, ete. Neanwhile, Robert Abbe (18.51- ), of New York, harl intro-

1 The Pituitary Body and its Disorders, Philadelphia, 1912.

2 Murphy: Med. Record, N. Y., 1897, li, 73-88.

${ }^{3}$ Murphy": Ibid.. 1892, xlii, 665-676. 
duced eatgut rings for intestinal suturing (18921), and had attempted prothetic union of blood-vessels by means of a fine glass tube (1894), which was improved upon by Erwin Payr's device of absorbable magnesium eylinders (1900). In $1897^{2}$ Murphy introduced end-to-end suture of blood-vessels by meins of invagination, the intima being brought into apposition with the arlventitia, but, although there was no hemorrhage, the eirenlation was restored in only four eases out of thirteen, on aeeount of the narrowing of the lumen of the vessels, with consequent thrombosis. This was finally obviated by the triangular suture of Carrel (1900). Before this innovition, Höpfner and others had transplanted piees of artery or vein by means of Payr's magnesium rings, and Ulmann had tried to tramsplant a kidney in the dog in 1902 . All these experiments fell through, however, on aceount of septie complieations, and even Carrel suceceled only by dint of the most refined asepsis.

Murphy developed anastomosis of the intestines by invagination and had renuakable results with bone-grafts, which, curiously, do not suceed, as a rule, unless the sliver of tissue used is autogenous-from the patient himself. The graft will, in time, reproduce the exact contour of the lefective bone, in accordance with Driesch's morphologieal law of the "totipotency of protoplasm."

Rudolph Matas (1860- ), of New Orleans, has greatly imoroved the operation for the radical eure of ancurysm by his orocedure of aneurysnorrhaphy $\left(1902^{3}\right), i$.e., intrasaceular suturng or closing the mouths of the ressels entering int o the aneurysm, und was one of the earliest to work in nerve-blocking (1898-9), ;pinal anesthesia (1899), and laryngeal intubation (1902).

Alexis Carrel (1873- ), of Sainte-Foy-les-Lyon, France, a praduate of the University of Lyons $(1900)$, who eame to America n 1905 and is now an associate nember of the Rockefeller Instiute, has revolutionized the surgery of the vaseular system and nade great advances in physiology and physiological surgery, for which he was made a Nobel prizeman in 1912. In 1902, he pubishod his first paper on vascular anastomoses and visceral translantation, ${ }^{4}$ in which he showed that perfect end-to-end anastomois of blood-ressels ean be secured by inserting in the opposing nols a triple-threaded suture, which, when drawn tightly, eonverts he round humen of the vessel into an equilateral triangle, thus ecuring rlosest apposition, without leakage, preserving the coninuity of the lumen, and so avoiding thrombosis. Before Carel's time, a wounded artery was treated only by ligation in coninuity. From end-to-end anastomosis of arteries he advanced, $y$ means of sperially invented needles and rigid asepsis, to the ubstitution of a lost piece of an artery by pieces of artery or vein, nd thence to the transplantation of organs from animal to animal.

1 Abbe: Med. Record, N. Y., 1s92, xli, 365-370.

2 Murphy: Ibid., 1897, li, 73-88.

${ }^{3}$ Matas: Tr. An. Surg. Astoe., Phili., 1902, xx, 396-434, $16 \mathrm{pl}$.

${ }^{4}$ Carrel: Lyon méd., 1902, xeviii, 859-\$64. 
'Thus, he has transplanted a kidney, with its vascoular supply, from

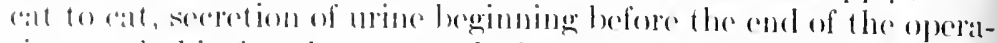
tion, and this fout has not only bern proved sucoessful in man, but retended to other viseredalso. Transplantations in mass of

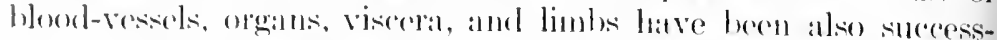
ful. carrel's investigations of the latent life of arterios (19)102) led to the preservation of portions of blood-ressols in colel storage for days of weeks hofore using them in transplantation. Latterly, ho has applied the principle of R. G. Harrison's experinent on extravital aultivation of nervereells (1910) to the extravital cultivation and

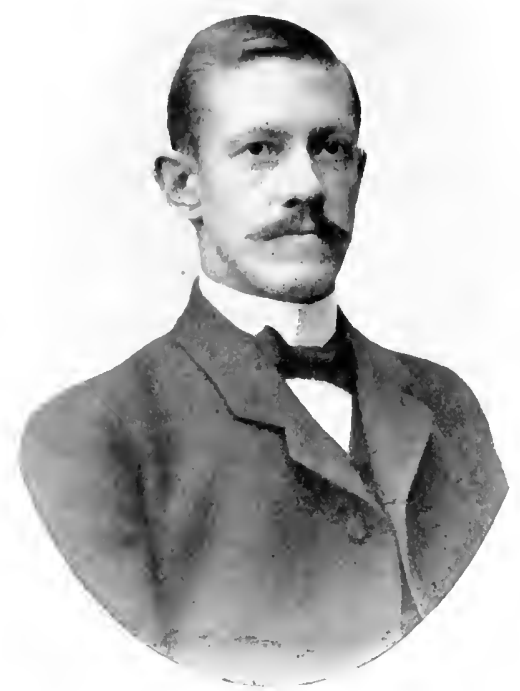

Ally:ir Ciullstritnd (1562- ). rejurenation of tissues $\left(1911^{3}\right)$, culninating in his remarkable experincent of kerping the excised viscera of an animal alive and funetionating physiologically in vitro $\left(1912^{4}\right)$. He has also suceceded in activating and accelerating the growth of comnective tissue by dressings of thyroidal, splenic, embryonic, and ofler animal extratets (1913). During the World War, Carrel dicl work of lasting value in the treatment of wound infection with the Dakin solution and on the rate of healing of wounds.

The Nobel prize in medicine for 1911 was awarded to Allvar Gullstrand (1862- ), of Lamdskrona, Sweden, professol of ophthalmology in the Eniversity of Upsala (1894), for his mathematical investigations of dioptrics or the science of the refraction of light through the transparent media of the living eve. As Willard Gibls founded the chemical theory of heterogenous substances, so Cullstrand has founded the dioptries of heterogeneous merlia.

${ }^{1}$ Jour. Am. Med. Aswoe., Chirago, 190s, li, 1662-1667.

${ }^{2}$ Jour. Exper. Med., N. Y., 1910, xii, 460-486.

${ }^{3}$ Jour. Am. Med. Assoc., Chicago, 1911, lvii, 1611.

${ }^{4}$ Jour. Exper. Med., N. Y., 1913, xviii, 155-161. 
Formerly, the inage in the eve was regarted as a schematice "colinear," or point-for-point arrangement, like that studied on the lenses of optical initruments. The course of the rays in astigmatism, for instance, was repreiented by the diagrammatic Sturm's conoid. Gullstrand took up the study of he oeular image from the viewpoint of reality, elcarly differentiating its atual ormation from its optical projection. He showed that the assemblage of ays in sturm's eonoid has not the slightest resemblance to the actual conlition in astignatism. By applying the methods of mathematical physies, specially those of sir William Rowan Hamilton (1S2S), he treated the problem is one concerning a set of wirlely diffused bundles of rays, refracted thremgh it ystem of continually eurving planes, and showed that, during accommodat ion, the index of refraction of the lens is angmented by an actual change in its trueture. His principal works on this theme are his study of astigmatism 1891), his General Theory of Monochromatic Aberrations $\left(1900^{1}\right)$, and his ssiays on dioptries of the crystalline lens (1908) and the real optie image (1906). n 1859, he introduced a practical method of estimating corneal astigmatiom y a single observation, an arlvantage possessed by a single instrument, the utcliffe ophthalmometer. In $1 \$ 92$, he introduced a photographie method of beating a paralyzed ocular muscle. He also introduced a micrometric method f estimating the photographed corneal reftex, as giving the most exact knowldge of the form of the normal and diseaserl cornea. His work in this fiekl iot unlike Burdon-Sanderson's photographic determinations of reaction time 1 muscle. In 1907, he showed that the yellow color of the macula in the retina ; a cardaveric phenomenon, not existing in life; and, as above stated, he disovered the intracapsular mechanism of atcommodation.2 He also devised the eflexless stationary ophthalmoscope (1912), which exeludes all light not benging to the ophthalmoscopic image, and is thus free from all reflcetions from xe mirror or the eye itself, giving a better image, better stereoscopie effert, nd a witler field of vision. He has invented eorrective glasses with aspherieal nses for those operated on for eataract, which give cleaner eut and more minous images, with wider range of vision, than spherieal lenses with the tune focal rlistance.

Two prominent innovations in eye surgery of recent times have een made by officers of the Indian Medical Service. The operaon of extraction of cataract within the capsule was introduced y Lient. Colonel Henry Smith in $1900,{ }^{3}$ and his success with it as been remarkable. As a benefactor of humankind, he is known l over northern India, where the reflection of the pitiless sunlight om the dusty plains tells with terrific force upon the eyes of the atives. His clinies at Jullundur and Amritsar, in the Punjab, are equented not only by streams of blind people, coming by every ode of travel, but by ophthamic surgeons, even from the wost'n United States, who travel across the world to learn his mothods. e teaches by making the pupil perform the operation before him. e averages about 3000 extractions a vear, and, by 1910 , he had t,000 to his credit, of which 20,000 were done by the intracapsular ethod. Another new operation, that of selerocorneal trephining $r$ glaucoma, was introduced by Major Robert Henry Elliot,

1 Gullstrand: Allgemeine Theorie der monochromatisehen Aberrationen, osala, 1900.

2 Arch. f. Ophth., Berl., 1912, lxxii, I69-190.

${ }^{3}$ H. Smith: Indian Morl. Gaz., Calcutta, 1900, xxxv, 240; 1901, xxxvi, $0 ; 1905, \mathrm{xl}, 327$. 
I. M. S., in August, 1909.' 'The operation of von Gratefe had held the ficld for hall a century, latgrange and Horlort bad emphasized the value of selelectomy, and erent eorneal trephining had been essiged by Argyll Robertson, Bancos, Fröhlich, and Freoland Fergus, but Elliot has mate the operation bis own by many improvements and hats made it viable.

Great advances in the diagnesis and treatment of discase of the internal ear have been made by Robert Bárány (1876- ), of Vienna, Privatelocent at the Iniversity, who has done much to (rear up the hazy subject of atural vertigo, or Menière's disease, especially in dilferentiating it from allied or adjacent lesions in the repelollum, froms epi-

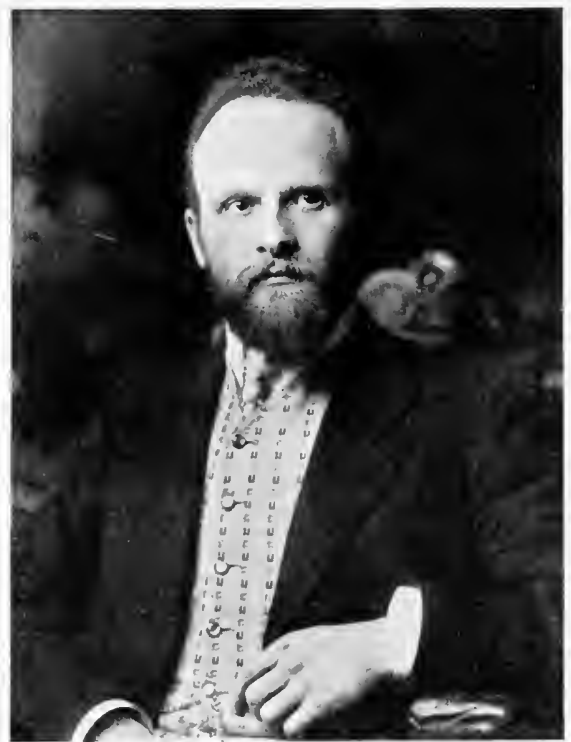

Robert Bárány (1876- ). (From a photograph in the Surgeon-General's Librury.)

lepsy, (11 from ordinary nystagumus $\left(1906^{2}\right)$.

Labyrinthine vertigo or "vestibulat nystagmus" is intorpreterl by Báríny ats a disturbanere of function of the vestibular nerre or the orgatus to which it is distributed, and he hass traced its origin to a large number of clifferent eillses with which it might be enfured. Ile has introrlueed a mumber of ingemions difforential tests, such as proluetion of nystagmus by irrigat ion of the external meatus with rold or warm water (ealorie test) or by having a patient try to point it in object with his reves shut after having previously touched it (static test), and be has been able to prove his (aise by suceessful operations on the cerebellum or the internal ear. He has also devised a "noise machine" for testing paraensis Willisii, and other diagnostic novelties.

Here may be signalized two recent phases of twentieth century medicine, namely. the rise of medicine in Latin America and Japan.

Although up to recent vears, the Latin-Ameriean countries have been intellectually provinces of Spain, with some impetus from Freneh and German influences here and there, the medicine of Spanish America bids fair to surpass that of Spain. With all reverenee to the name of Ramón y Cajal, one of the greatest histologists of all time, in spite of his strenuous efforts for

${ }^{1}$ Elliot: Ophthalmoscope, Lond., 1909, vii, S04-808.

${ }^{2}$ Bárány: Arch. f. Ohrenh., Leipz., 1906, lxviii, 1-30, and later publications. 
university autonomy in medical teaching, and of the work of such men as Juan Ferran of Bareelona on vaccination against cholera and tuberculosis (1S55-1919), the pediatrist Tolosi Latour, the physiologist. Gomez Ociña, and the journalist reformer, Rodriguez Nendez, Spanish medicine has beren dominated by what the Spanish themselves call "caciquism" (nepotism). Medieal practice is poorly paid and the doetors are driven to the bread-basket view of life. In the western hemisphere, Mexico had the first hospital (1524), the first chair of medicine (1578-80), the first medical books to be printed $(1570,1578)$ and the first medical periodical $(1772)$. Some 315 medical books were published between 1570 and 1833 (León). Eminent in Mexiean medicine are the names of Eduardo Lieéaga (1\$36-1920), the surgeons Rafacl Lavista, Luis Muñoz, the obstetricians Juan Maria Rodriguez, and Juan Duque de Estrada, the statistician Antonio Peñafiel and the eminent medical historian and anthropologist, Nicolas León. In Cuba, Carlos Juan Finlay (18331915) first stated the theory of mosquito-borne yellow fever (1881), and excellent work has since been done by Juan Guiteras, Aristides Agramonte (yellow fever) and Juan Santos Fernandez (ophthalmology). In Brazil, parasitology received a great impetus at the hands of Oswaldo Goncalvez Cruz (1872-1917), who beeame director of publie health at Rio in 190\%, and through his energetic and drastic reforms was ultimately aceepted as sanitary dietator of Brazil. In 1900, he founded the Institute, to which the citizens of Rio gave his name in 1908. Here Carlos Chagas discovered the Trypanosoma Cruzi and deseribed the infeetive thyroiditis produced by it (1909), and Cruz liscovered the anopheline sub-speeies Chagasia and a species of psorophora. From this Institute have emanated innmmerable investigations of the novel nseets, parasites and venomous reptiles with which Brazil abounds, usually ublished in the transactions of the Institute or the columns of the Brazil Hedico. Excellent beginnings in seientific medieine have been marle in Buenos Aires. Caracis, Lima and other South American eities.

Modern Japan has now 50,000 doctors, 21 medical schools, ver 100 govermment and prefecture hospitals, about 1000 private ospitals, about 8000 isolation hospitals, 10 leper hospitals, one asane hospital, 8 research institutes and nearly 50 medical jourals, of varying merit. Medieal education and investigation have hriven largely under German influence. Anatomy was established Japan by Kazuyoshi Taguchi, physiology by Kenji Ozawa, iochemistry by Muneo Kumagawa (1839-1902) and Toraburo Araki, pathology by Moriharu Miura, baeteriology by hibasaburo Kitasato and Masaki Ogata. Kitasato is the founder the Covermmental and the Kitasato Institutes for Infections iseases in Tokyo. The bacilhus of dysentery was discovered by iyoshi Shiga (1897). In parasitology, introduced by Isao Ijima, upan has alrady achieved a most brilliant record, particularly the science of the trematode worms. In 1904, Fujiro Katsurada ad Akira Fujinami diseovered Schistosommm .Japonicum and seribed schistosomiasis, the intermediate host having been disvered by Keinosuke Mujairi and Minoru Suzuki. Metagonimus okogawaj and its second intemediats host were, both of em, discovered by Sadamu Yokogawa in 1913, and the first itermediate host by M. Muto (1916). Ryukichi Inada and Itakir Ido discovered the spirochete of infections jaundice (veil's disease) and developed a successful serum-therapy for the 
infection in 1914-15. The patrasile of rat-hite ferer (Spirochata muris) Was discoveled by Konzo Futaki and Kikutano lshiwara (1915). The secomel intermediate host of Clonorehis sinensis was discoremed by Hatrujiro liobayashi (19)1-14); the intomediate host of Paragonimms Westermanii (Ringer, 1879) by Koan Nakagatwa (1914-15). The migratory combe of human ascaris was domonstrated hy sadalo Yoshida, and the exporimental production of cancer flom eontimuous stimmhe hy Katasusaburo Yamagawa and Koidhi l(bikawa (1915). In 1920, Hideyo Noguchi discovered the parasite of yollow forer (Leptospira icteroides) at Guayacpuil.

The last ten or twenty goars have witnesed an unusual growth

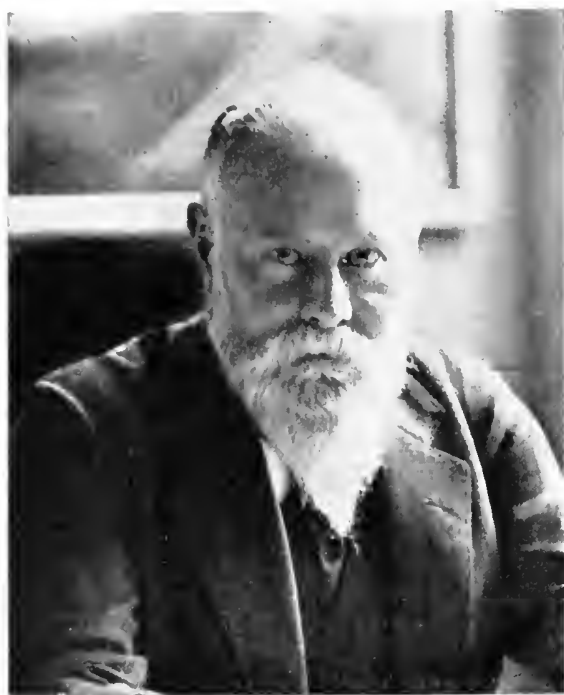

Karl Sulhoff (1853- ). (From a portrait in the Surgeon-General's Library.) of interest in the history of medicine. Miany arlmirable monographs and cisiays have alppeared, socicties have been formed in Germany, France, England, Italy, and the larger American aities, expositions of rare objects, books, and pictures have been botk, and many modern phrsicians have made valuable private collections of the same. The most important advance of recent years was the foundation of the Institut für Geschichle der Medizin at Leipzig, in 1905, under the direction of Professor Sudhoff, for whom a special chair of the subject was created in the University (1905). This Institute and its publications are supported by a special endowment of 500,000 marks left for this purpose by the widow of the late Professor 'Theodor Puschmann, and in accepting the directorship Professor Sudhoff stipulated that a separate home for the new specialty should be erected. Karl Sudhoff (1853- ), of Frankfort on the Main, who had practised medicine for many years before this event, and is entirely self-taught in medical history, began his studies with his important investigations of Paracelsus (including a thorough study of the Paracelsus manuscripts), begun in 1876, and published 1887-99, which are 
still authoritative. He has written exhaustive and seholarly monographs on the iatromathematicians of the fifteenth and sixteenth centuries (1902), manuseript and other fifteenth century medieal illustrations (1907), the early history of anatomical illustration (1908), Germam medical incunabula (1908), the Greek papyri of the Alexandrian Period (1909), ancient balneology (1910), and the early history of syphilis (1912). These are all original researches of the highest order, and, in addition, Sudhoff has published a host of minor investigations of value, particularly in the Archiv für Geschichte der Medizin, which he founded in 1908. He has made many of the rarer medical texts accessible to German readers throngh his Klassiker der Medizin, a series of inexpensive reprints which, in style and format, are like Ostwald's well-known editions of scientifie classies. His method of investigation is a new departure. With the financial resources at his command, he travels ar and wide in search of rare or umprinted medical manuscripts and illustrations in the European libraries, private and public, and, oy photographing these and collating them, he has been able to apbly the induetive method with signal ability in bringing out many new facts, settling disputed points, and exploding much of the raditional Papierwissenschaft which has been slavishly aceepted o date. Thus he has shown, by collation of umprinted manuieripts, that up to the time of Vesalius, anatomical and other llustrations were for centuries based upon servile tradition and Imost devoid of any signs of original observation. No one has vritten more effectively upon anatomical illustration since Chouant. Sudhoff has also developed the whole science of the Lasstaelkunst, against which Paracelsus brayed with such obscene vigor n his Liber Paragramm (1589), and, during this research, he disovered the first medical publication to be set in type, Gutenberg's surgation calendar of 1457 , in the Bibliothèque nationale in Paris. fis philological researches on the Alexandrian papyri (1909) hrow much light on the status of Egyptian medicine in this period, nd his recent investigation of the early history of syphilis (1912), thich we have already described, furnishes a formidable argulent against the theory of the American origin of the disease. Iis path-breaking study of medieval surgery (1914) was completed 1 1918. He has also addled much to our knowledge of the adancement of state medicine during the Mirdlle Ages. His original vestigations and reproductions of the medieval writings on lepssy, plague and syphilis, including the preventive ordinances, go $r$ beyond the labors of Haleser in this field. To look through his onderful catalogue of the Dresclen Historical Exhibit (1911) is - realize how little one knows about medical history. His vast ading gives him an insight into medieval medicine, such as is 
possessed by no other living man, and his conversation alone is said to be an inspiration to his pupils. Fulloff believes that dassical philologists who have exhausted the possibilities of the

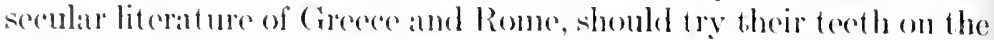
okler medical writings and help to chudelate them. Ilis exhanstive study of the (ierman modieal incumbtula (1908) supplements and completes the work of ('houlant, and is a forermmer of the movement, stated in Borlin (190)t), to got up an international catalogne of all the incomabula in public and private libmaries, in order to decide the many mectled points as to time, place of publicafion and authorship.

With the work of this distinguished scholat this sketch of recent medicine may fitly close. 


\section{CULTURAL AND SOCIAL ASPECTS OF MODERN MEDICINE}

Readers of Lecky's "History of European Morals" will recall the impressive pages in which this eminent philosophical writer discusses the effects of the modern spirit of industrialism upon ethical relations, even upon sexual morality. Two types of character, he says, are apt to be produced-the thrifty and cautious, which has "all that east of virtues which is designated by the term 'respectability" "; and the speculative, enterprising type, which is "restless, fiery, and uneertain, very liable to fall into great and conspicuous vices, impatient of routine, but by no means unfavorable to strong feelings, to great generosity or resolution." The first type is prevalent in poor, isolated eommunities, the second among the busy marts of commerce. These phases of the great industrial movement of modern life have not been without their effect upon medical practice. During the nineteenth century, we see the physician becoming more and more impersonal, more of a business man and not so much influenced by the social and ethical obligations which were certainly a characteristic of the eighteenth century physician. The "family doctor" of the past has wellnigh disappeared, except in small communities, and, in the modern period, we find the eity physicians, under stress of competition, reating everywhere loeal codes of medical ethies. The reasons or this are not far to seek. They have been set forth at sufficient ength in Mr. Bernard Shaw's clever but superficial tirades on the commercialization of the medical profession. Otto Juettner, 11 his interesting life of Daniel Drake, tolls of a certain gruff physcian in the Western Reserve in the early thirties who, when :ummoned to see any patient of whose financial status he was ig1orant, always demanded, on entering the roon: "Who pays this jill?" This is a crude instance, yet compare it with what Abraham Nlexner says about the careers of the two Hunters, Matthew 3aillie, Bright, Addison, and Hodgkin:

"These men all ran substantially the same course. As unknown youths hey beeame assistants in the deat-house or the ont-patient department of the 10spital. This was their opportunity; obscurity was their protection. They pent years in working out, on both pathological and clinicat sides, the imporant problems with which their names are severally associated. When, at the lose of a decade, they hatd achieved seientifie eminence, they were whirled off nto busy practices. The rest of their aetive lives they spent as prosperous onsultants, visiting the hospital and teaching in its medical sehool, of course, ut without the leisure, environment, or stimulus requisite to further scientific ursuit. The hospital as an institution was indifferent; other inducement 
thre was none. Fifteen or twenty unproluetiore geatrs followed. Thus men blossomed early, but they left mo soed; they had no scientific heirs; they estatblished no line."

Flexuer is apparently not familiar with dohn Hunter's pupils, with the actual facts about Addison and Hodgkin as "prosperous consultants." nor with the suceresors of Briglit and Adelison at (iuy's Ilospital; yet it is not unlikely that a good consulting practice, a comfortalle berth in Harley street, has been a prominent ambition of the London practitioner in the modern period. been in (iermany. Flexner is disposed to adnit "a growing suspicion that the idealism of the elinical professors is yielding to the temptation, perhaps the need, of increased income.

The scale of living has been altered by industrial prosperity; new ideals, material in chanacter, are creping in." From the days of John Hunter's unwilling quest after "that damned guinea" to the disputes of our own time about "fer-splitting," contract practice, lodge doctors, Kranlienliassen, paitent medicines, ungualified practitioners and general surplus of doctors, the necessity of struggling for a competence, instead of laving it assured by family practice, as in the eighteenth century, has wrought a change in the modern physician. The ideal is scientific and impersonal, to be as efficient as an engineer and to look and act like one.

In spite of themselves, men are influenced by the social conditions which impinge upon them. It is a noticeable fact that the pietures of Americans of the Civil War generation have a more sincere and ideal look than those of the present time. The modern type everywhere is one of clean-cut business efficiency. In the advaneement of science this has been an immeasurable gain. Modem science has done away with the idea of personal infallibility, has centered itself upon results and has a fine probity of its own. "The scientific gentleman," said Billings, "is the blueribbon of our day." It is to the credit of modern medicine that, in spite of intense competition, thousands of physicians have continued to practise their profession along the old honorable lines, giving largely and nobly of their time to the poor, although, in the crowded streets of finance, a man whose heart is better than his head is a fool by definition. The most enlightened physicians of today are advancing preventive medicine, which tends to do away with a great deal of medical practice. "Certainly men who regularly render a large part of their services gratuitously and are constantly striving to eradieate their own means of livelihood cannot be convieted of being altogether mercenary.".

${ }^{1}$ A. Flexner: Medical Education in Europe, New York, 1912, 13.

2J. B. Nichols: "Nedical Sectarianism," Wash. Ned. Ann., 1913, xii, 12. 
As Harver Cushing quaintly puts it: "Dr. Pound of cure Lane is being superseded by his young disciple, Dr. (Ounce of l'revention Street."'1

The increased cost of living, the automobile, expensive office appointments and instruments, foreign study and travel, make heavy imoads on the modern physician's income, and, honce, have almost tripled the rate of medical fees. In other work, the purchasing power of money is stcadily declining. Accorting to the laws of economics, the greater the supply of gold, the more it becomes a commodity and the fewer the things it will buy. It. is easier to get money nowadays than unadulterated food and raiment or unscamped labor.

At the end of the eighteenth eentury (1798) the professional charges of "practitioners of physic and surgery in the State of New York". were $\$ 1$ for an ordinary visit or $\$ 1.25$, with a single dose of medicine, 12 cents each for pills and powders, $\$ 5$ for a consultation ("verbal advice") or a night visit, $\$ 1$ to $\$ 2$ for bloodletting, $\$ t$ for cupping, $\$ 100$ each for amputating a joint, exeising an eye, operating for aneurvism, while operating for hernia, stone, or cat aract cost \$125; an ordinary labor case was $\$ 15$ to $\$ 25$; a difficult one, $\$ 25$ to $\$ 40$. S. C. Busey, commencing practice in Washington, D. C., in 1849, got $\$ 1$ a visit, and "many times the bill was settled with a fraction, and of ten a small fraction, of that amount." 3 At present, the average bill for a city visit is $\$ 3$ ( $\$ 2$ in some localities), and (eonsultations and obstetrical and surgical eases are paid in proportion. In England, the average consultation fee was a guinea up to $1 \times 70$, after which it became customary to ask two guineas for the first visit atnd one guinea afterward. If required to travel the eharge was an adrlitional guinea a mile, until about 1s45, when railway locomotion reduced this to two guineas per three miles (Power). In the country distriets, or among the poor, visits may be variously ten shillings, five shillings, eightsen pence, or sixpenee. The country doctor usually elarged for the medicines he prepared and supplied rather than the advice rendered. $e . g$. bleceling 1 s. 6ol., bolus $1 \mathrm{~s}$. 6d., dranght and pill 1s. 9d., iter (journey to house) 1s. (bl. The Poor Law appointment in 1845 was usually £20 per annum for each parish, 10s. extra for a midwifery case, with an additional 2s. 6d. if the patient lived three miles away (Power ${ }^{4}$ ). The socialization of medicine by panel practice has impored mich extra work at small compensation upon English physicians, and hats dombled the labors of those not on military duty in the recent war.

In France, during the Napoleonie wars, a cabinet consultation or a city visit was 10 solu (1805-39); by 1 s.50 it was 1 frane. Bloodletting w:Ls 1 livere; an aceouchement, 12 liver. In Prussia (1906), physicians and patients make whatever bargain they choose: 2 to 20 marks for an oflice visit, 1 to 10 marks for a subsequent visit or a consultation, 4 to 10 marks for a confinement, with half as much again for twins, 3 to 15 marks for removing a tonsil, 10 to 30 marks for setting a fracture. In 1892, over half the physicians of Berlin were making less than 3000 marks annually; about one-tenth were making over 10,000 . At Berlin, in 1908, the salary of a professor ordinarius was 1800 matrks, with increases of 400 marks every four years, up to a limit of 7200 mitrks at the end of twenty-four vears' service. Outside Berlin, it begins with 4200 and ends with 6600 marks. A stlarierl extrutordinarius gets 2600 marks to

1 Cushing: Brit. Med. Journal, Lonıl., 1913, ii, 291.

2 J. J. Walsh: "Ihysicians' fees down the ages," Internat. Clin., Phila., $1910,20 \mathrm{~s} .$, jv, 259-275.

${ }^{3}$ Samuel C. Busey: Personal Reminiscenes, Washington, 1895, 63.

${ }^{1}$ D. A. Power: Janus, Amst., 1909, xiv, 292-293. 
start with, with 4800 matrs as the limit. In Austria, the extraordinarius etarts with 3200 kronen and reakehes 1000 kromen in a decarde. Flexner salys that a prominent corman profexser disctoserl the soureses of his income as "s300 as hospital plysician, paid by the city; so00 als professor, paid by the

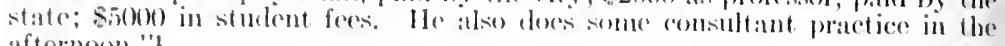
if ternoon."

Modern art, like that of the seventeenth century, has represented medicil subjects in varied and manifold ways. One prominent characteristic of modernity, "the strange disease of modern life," is to seck what is odd and new, and, in art, to find inspiration in ugliness. (iogra's canvilsses in the Prado, for instance, and particularly his etchings, are trimphs of the macabre. His figurations of teratology, illiocy, insanity, death by violence and general bloodshed, show the curious interest in the horrible, the solemn delight in death which the (imeourts thought essentially Spanish: "Le génie de l'horreur, c'est le génie de l'Espagne." The Musée Wiertz in Brussels affords another example of this tendency. Infanticide, suicide, premature burial, and eroticism are the special themes of this artist. Charcot gives an interesting group, of blind men by the Japanese artist Hokusai. The impressionist Degas, working with the precision of a Dutch interior painter, has exeelled in rendering the artificial movement of the ballerina. His nudes are as ugly as those of Rembrandt. A more recent development is the scabreux, which has been exhaustively treated by modern cartoonists and caricaturists, like Gavarni, and in the eanvasses of the German Secessionists, some of whom have represented childbirth, for instance, with appalling frankness. Every recent Salon des réfusés at Paris has had something of this kind. Along more conventional lines there have been plenty of canvases representing doctors at the bedside or surgeons operating in elinic; and of pictures of the old-fashioned literary type, which tell a story, such as Wilhelm von Kaulbach's "Narrenhaus" (1837), E. Hamman's Vesilius; Germain Colot cutting for stone in the presence of Louis XI (1414), by Rivoulon; Paré operating on the outskirts of a besieged town by L. Matout; the "Pestifères de Jaffa" of Antoine-Jean Gros; Géricault's "Femme Paralytique" (1820); Robert Henry's "Pinel à la Salpêtrière"; Feven-Perrin's "Leçon de Velpeau"; or Péan demonstrating hemostasis by foreipressure (L. Gervex). Others, such as Andrea Cefaly's dentist (1875), Laurent Gsell's picture of Pasteur inoculating against hydrophobia, Edelfelt's "Pasteur in his laboratory," Camille Bellanger's art-students dissecting at the Ecole pratique, A. Brouillet's pieture of Charcot demonstrating a hysterical case at the Salpêtrière, or Julian Story's laboratory at St. Lazare, show the

${ }^{1}$ Flexner: Op. cit., pp. 148, 293-299. 
tendency toward realistic or photographic representation, as of something "canght in the act." Carolus Duran, Sargent, Cecilia Beaux, and others have made many excellent oil portraits of recent physicians. Many modern medieal men have illustrated their own works, in particular the Bells, Henle, His, Leidy, and Lister. Auvert, Cruveilhier, Bright, Lebert, Hope and Carswell left great polychrome atlases of disease. Paul Richer made a beautiful drawing of Chareot, and Chareot himself was a talented draughtsman and decorator of porcelain. His pencil followed the lead of the comic and the fantastic, and his caricatures of the Paris Faculty, as friends in council (L'Aréopage) and in Indian file (en queue), are delicious. Sir Seymour Haden, the surgeon, was one of the most accomplished of modern etchers. In seulpture, we have Alfred Boucher's bas relief of Tobias restoring his father to sight (Musce de Troyes), Falguière's full-length statue of Charcot (Salpêtrière, 1898), and the more conventional figures of English and American physicians in various localities. Rodin has made a large number of eurious shorthand notations of human anatomy, as preparatory to his peculiar mode of treating marble. Of the many recent monuments to Servetus, we may mention the figure on the funeral pyre in the Place de Montrouge (Paris) by Jean Baffier, the contemplative Servetus, in doctor's cap and gown, in the vestibule of the Museo Velasquez at Madrid, the statue of the martyr in prison by Roch (Annemasse), the Rodinesque nude by Joseph Bernard at Vienne (Iscre), the gowned seated figure on the portico of the edifice of the Faculty of Medicine at Zaragoza, and the expiatory plinth of rough-hewn granite at Geneva. Servetus has also been commemorated in a play by the Spanish dramatist and physician, José Echegaray (La muerte en los labios ${ }^{1}$ ).

As modern physicians have been abundantly earicatured in the graphic arts, so the business-like tendeneies of the profession in our own time have afforded liberal opportunities for literary satire. Baas has hit off the early nineteenth century doctors of this type as characterized "by the fashionable cut of their clothing, their universal greetings and rapid gait, their imperturbable amiability, and the thermometer, stethoscope, percussion hammer, ete., peeping out of their coat pockets."' All this implies a somewhat sweeping survey of a whole period, but we find similar traits of smartness in such characters as Dickens' Dr. Slammer in Pickwick or Dr. Jobling in Martin Chuzzlewit, and Charles Reade's Dr. Aberford in C'hristie Johnstone. Thackeray's Dr. Firmin and

1 Osler mentions another: "The Reformer of Geneva" (privately printed, 1897), by Professor Shields (Princeton).

${ }^{2}$ Baas: Op. cit., p. 770. 
Wilkie Collins's Dr. Downward represent types of a craftier and more dubious kind. 'The hest imsanative portmat of the highloned physician of intellectual fype is that of lydgate, in Cieorge bliot's "Midnllenareh," a novel whinh, on the whole, affords the most offertive side-light on English medicine in the late Georgian and early Victorian periods. The kernest edge of the author's sattire is reached in the mediat gossip of the gentlewomen in the tenth rhapter. Mrs. Cadwallader likens ('asaubon, the fossil bridegroom of the heatut iful Dorothea, to a close of medicine, "nasty to take and sure to disagree": and latly Chettam, in discussing Ixyluate's superior family connections, observes:

"One does not expecet it in a practitioner of that kind. For my own part, I like a medical man more on a footing with my servints; they are of ten all the eleverer. I assure you I found poor IIick's judgment unfailing; I never knew him wrong. Ile was coarse and buteherlike, but he knew my constitution."

The same note is sounded in Major Pendennis' horror lest a lady matry her uncle's doctor, which would seen a far cry from the present esteem in which physicians are held. Honry James' "Washington Square" (1880) opens with an amusing assurance of their superior status in the United States. Balzac immortalized the French country doctor, ${ }^{1}$ no less than Dupuytren was the original of his Desplein, but his Horace Bianchon is a fancy portrait. Gustave Flaubert, Samuel Warren, Charles Lever, Oliver Wendell Holmes, Weir Mitchell have all approached the subject from different angles. Mitehell has made a clever study of a quack.2 The medical students of Dickens, Albert Smith, and others are sufficiently well known. Turgenieff's Bazaroff, ${ }^{3}$ the agnostic, anarchistic student of Eastern European type, is a genuine creation.

The conditions of medical education in modern times may be briefly stated as follows: The teaching of medicine as a science, as something of larger scope than its practice, began with the foundation of laboratories and with the gradual assemblage of specialties as units in university instruetion. From Boerhaave's time on, great teachers have always had a limited number of brilliant pupils, who had it in themselves to be what they were, but the average medical student did not begin to come into contact with the actual working facts and experiences necessary for his "education," until he was given an opportunity to test and try things for himself, and this was only possible, even in anatomy, when

1 Batzale: Le médecin de campagne (1833).

2 IVeir Mitchell: The Autobiography of a Quack, New York, 1900.

3 Turgenieff: Fathers and Sons (1862). 
practical work was substituted for routine didlactic lecturing, of ten based upon fantastic theories emanating from the teacher's brin. German university teaching was for a long time didactic, but with the foundation of such liboratories as Purkinje's at Breslan (1824), Liebig's at Giessen (1825), or Virchow's at Berlin (1856), there was a new departure; and, although it took a long time for the new movement to get under way, ret, since the advent of Virchow and his contemporaries, the modern world has been going to school to Germany in the sciences upon which medicine is basorl, while England and France have mainly excelled in the organization of hospital and clinical teaching. As late as 1842, Helmholtz, graduating as an army surgeon, discussed, among other theses, a surgieal operation which, like Haller in the past, he had never seen or tried. While German medicine was in the throes of "Nature Philosophy," Laënnec and Louis, Bright and Addison, Ciraves and Stokes, Dupuytren and Astley Cooper, were turning out crowds of competent clinicians and surgeons. At the present time, Geman medical education is based upon the sound assumption that all the specialties, even dentistry or obstetrics, are so many phases of physies and chemistry, and there is hardly one of her eminent teachers who has not done original work in some fundamental branch of medicine at the beginning of his career. In the United States, conditions were entirely different. In colonial times, the medical student, however pooly educated, had, at least, the advantage of being under a preceptor, and thus coming into actual contact with the details of medical practice. But in the stress and competition of a growing democracy, this custom was soon discontinued, and while one or two medical sehoots maintained a certain level of excellence, a vast number of inferior schools were permitted to spring up which had no reason for exstence. In the first half of the century, ambitious and enterprisng American students, who had the means, were going to Paris to ;tudy under Louis, or to Astley Cooper in London; in the later beriod, they were swarming to Virchow in Berlin, to Chareot in Paris, or to Billroth in Vienna. It was only toward the end of he nineteenth century, under the direction of Eliot at Harvard, Billings, Welch, and Osler at the Johns Hopkins, and Pepper in Philadelphia, that medical teaching began to be true university eaching, in the sense of training a stuclent to make use of his own nind as a substitute for blind acceptance of clogma. In the early period, scores of able American physicins, it is true, came out of nferior schools and learned their medicine by practising it, but vhat they accomplished was due to themselves and not to the conlitions from which they sprang.

On the continent, clinical medicine was ably taught by Cor- 
visart, I ä̈mnec, Louis and Tronssantu in Paris, Schönlein and Frerichs in Borlin, Skoda and ()polzer in Vienua. At this time, "snaty diagnoses," like sloight-of-hand surgery, were the fashion. Corvisart once remarked that the subject of an oil painting must have been a vietim of heart disease and it proved to be so. Frerichs was so infatmated with this cult that he never admitted a diagnosis to be wong. Yet the most exact mothods known were employed in the clinies. Corvisart was the reviver of percussion. The stethoscope, in Laënnec's hands, was the means of developing the science of diseases of the ehest. Louis and the Irish clinicians introdueed pulse timing by the watch. Piorry invented the pleximeter. Wunderlich put clinical thermometry upon a scientific basis. The stethoscope was first mentioned in the Harvard Catalogue in 1868-69, the mieroscope in 1869-70. Thermometers began to make their appearance in English hospitals about 1866-67, and came into general use about 1868-70. They were about ten inches long, so large, in fact, that it took at least five minutes for them to register the axillary temperature, and so clumsy that, as Brunton relates, they were carried under the arm, "as one might carry a gun." the pocket thermometer, was due to Sir Clifford Allbutt (1868). Neither Keen nor Tyson saw a clinieal thermometer or a hypodermic syringe during 1862-65. Billings, however, in taking eare of the wounded from the seven days before Richmond (1862), had provided himself with both. ${ }^{2}$

In 1840, Schönlein introduced the novelty of lecturing in German at the Charité, while Geheimrat Wolff, his Berlin rival, conducted in opposition a "lateinische Klinit," where there was neither pereussion nor auscultation, and this pedantry was not suspended until shortly before Schönlein's retirement in 1857. Schönlein's elinics, as deseribed by $\operatorname{Naunyn}^{3}$ were of the highest scientific order. Upon entering the ward, the short, fat Schönlein would sink into a comfortable arm-chair beside the patient's bed, while his assistant read the case-history with the necessary details of auscultation and pereussion and all the chemical and microscopical findings. He would then rise and examine the patient, and, dropping into his chair again, proceed to develop his diagnosis upon pathological grounds, and then discuss the case from the point of view of

${ }^{1}$ Sir Lauder Brunton: Lancet, London, 1916, i, 317. See, also, the interesting history of clinical thermometry by G. Sims Woodhead and P. C. Varrier-Jones in Lancet, Lond., 1916, i, 173; 281; 338; 450; 495.

${ }^{2}$ J. S. Billings: Tr. Coll. Phys., Phila., 1905, 115-116. Clinieal thermometry was popularized in the Inited States by Edouard Séguin's books of 1873 and 1876.

${ }^{3}$ B. Naunyn: Die Berliner Schule vor 50 Jahren (Samml. klin. Vortr., No. 478), Leipz., 1908, 210, 211. 
ptiology and therapy. If a patient died, there was an autopsy with an "epicrisis" in which possible error's in diagnosis were discussed. After Schönlein came Frerichs (1859), who kept up the same traditions. He would examine new cases directly upon cntering, and, if he found that his assistants had thoroughly studied them, the histories would be read, with all the aceessory data of examination of urine, excreta, sputum, larynx, even the fundus of the eye; while microscopic slides would be denonstrated and pietures (often from his private collection) landed abont among the students. He never nagged or bullied his assistants, treating them, Naunyn says, as if they were essential organs of his own body. His recapitulation of the case, with diagnosis, sometimes theatrical, was esteemed a masterpiece. It rested upon a rigorous scientific basis, yet, in closing with his subject, Frerichs favored the minute bedside casuistry of the English; and the patient, if not removed in time, sometimes heard a bad prognosis. Therapy was carefully considered by Frerichs and prescriptions forthcoming, as part of the subject, although, Naunyn thinks, the results did not greatly concern him. Upon the recovery or death of the patient, Frerichs gave a vivid and instructive epicrisis and, at the end of each semester eame the "grencral epicrisis" in which all the cases gone over were carefully reviewed.' Upon such teaching as this was based the German development of internal medicine as a seience. even down to the great clinics of Naunyn or Friedrich Müller. Traube, who became clinical director of the other wing of the Charité in 1853, was also esteemed for his exact diagnoses. ${ }^{2} \mathrm{He}$ was more conseientious and sincere in bedside examination, more interested in his patients than Frerichs, and was consequently better liked in private practice; but, according to Naunyn, he knew little chemistry, was an almost servile follower of Virchow in pathology, and, in his efforts to make clinieal medicine subservient to physiology, sometimes went into wire-drawn subtleties and superfine distinctions. Virchow favored Traube and hated Frerichs, so that the relations of these two were never cordial. Naunyu relates ${ }^{3}$ that it was a common circumstance for the two great clinicians to stalk by at the head of their classes in the Charite without taking the slightest notice of each other, and their pupils were tacitly forbidden to associate in publie. Meanwhile Virchow was the bright particular star of the Berlin school, a political revolu-

1 Naunyn: Op. rit., 212, 215-21s.

${ }^{2}$ For example, that of aortic aneurysm by laryngoscopie detection of paralysis of the left voeal cord (Deutsehe Klinik, Berl., 1860, xii, 395: 1861. xiii, 263). Osler relates that on one occasion, when a postmortem diil not confirm his views, Traube simply said "Wir haben nicht richtig gedacht!"

${ }^{3}$ Naunyn: Op. cit., 219. 
tionary in his youth, an intellectual tylant in old age. His public lectures, at which he was often late for political reasons, were diffusc, todions, and diflicult to follow, on acoomt of his lengthy, often involved, sentenes, but he was a brilliant master at the postmortem table and mereiless in examining students. ' To the north of the old ( harite stands the new ('harité, an ugly, gloomy building with grated windows eontaining the insane, the syplilitic, and a "combinerl station," the patients of which were sick convicts taken from the prisons. Of this "combined station" Virchow was phrsician-in-chief, and here, most assiduous in his duties, he actually posed as a "clinician.". At Vienna, Skoda was all for aluserultation, Rokitansky all for postmortems, and Oppolzer was the best all-round teacher. Of the later Berlin group, it was said: "Cichardt makes a diagnosis nsually, Senator often, Leyden never" (Jacobi). Leylen, when his clinical assistant reported "unreine Herztöne," said: "Very woll, then, wash them" (Klebs). In England, Addison was easily the greatest clinical lecturer of his time, handsome, brilliant, and eloquent, but feared by his students on account of his cold, arbitrary manners and his martial outside. The genial, even-tempered Bright ran him an easy second, and although not so imposing in the lecture room, did more scientific work in the end and had a much larger practice. With these men, and with Hodgkin, pathology and clinical medicinc went hand in hand. After them came Gull, Wilks, and Fagre, all attractive teachers. In France, Trousseau was the most rivid and picturesque lecturer of the period, setting the pace for Diculafoy, Marie, and other teachers of the courteous, quickminded French type. Charcot's public clinics were unique of their kind, and designed to meet the needs of the great throngs who followed them. In order to throw his teaching into stronger relief, he demonstrated his cases in a miniature theater, the stage of which was furnished with footlights and all the scenic accessories of illumination from different angles. The patients stood before the footlights or in the limelight, if necessary, while Charcot, from the sicle of the stage, elucidated their cases in a slow, distinct manner, for the benefit of foreigners. When the patient was disrolith

${ }^{1}$ Hi- occasional bitterness Naunyn attributes to the hardships of his early

2 "Die Assistenzärzte jener Abteilung, erzählten oft, wie regelmässig und ausführlich er dort die Visite marhe, und wie gern er den Arzt spiele," Naunyn, op. cit., 215, 222. This may have been part of Virchow's ironical program in reference to Frerichs. MI. Regensburger relates that he once saw Frerichs harpoon the biceps of a living patient to secure a preparation of trichina. Four days later the patient died of pyemia. The ease was posted by Virchow, who began the necropsy by mimicking the solemn pontifical manner of Frerichs: "Gentlemen, another sarrifice to our science!" (Calif. State Jour. Mert., San Francisco, 1914, xii, 179). 
missed, the pathologieal lesion would immediately be thrown upor: a sereen at the back of the stage, and this theatrical effect never failed of impressing his large audience. Chareot's wonderful lectures were always carefully written out in his own hand and handed to his assistant, as he passed out, to be published in due course. His sereen effects have now given place to the epidiascope and the cinematograph, which has been utilized by some modern surgeons as the only way of making a large concourse of students see the details of an operation. In the carlier American schools, clinical teaching was largely didactic, most of the schools lacking true clinical facilities, and hospital work being usually accessible only to those who obtained positions as internes or externes. These deficiencies were set off, in the later period, by the postgraduate school, in which the teaching was entirely practical, and which Flexner has satirically described as "an undergraduate repair shop."' Private preceptors and quiz-masters were employed by those who could afford it during their medical courses. A good example is to be had in Busey's account of the private teaching of George B. Wood, of Philadelphia, about the middle of the nineteenth century. Wood, a grave, dignified Quaker who had a private botanic garden, spent $\$ 20,000$ on cliagrans and models, and gave over $\$ 60,000$ in endowments to the University of Pennsylvania and the College of Physicians of Philadelphia, would meet his students nightly at his private house, around a table lighted by silver candelabra, and here he would cxamine them, line by line, precept by precept, through the two volumes of his book on practice of medicine. ${ }^{3}$ This method was fairly typical of American teaching in the period. Its defects were that it was a mere peckagogic rubbing in of what had already been heard in routine lectures, with hardly any practical clinical experiences whatever. W. W. Keen says that the Philadelphia clinies, "until Da Costa, in the session of 1866-67, took hold of them, were about as inane and useless as one could imagine." 4 Bedside teaching in pediatries, and indeed, in internal medicine also, was introduced by Jacobi in New York in 1862-4. What clinical teaching should be is seen in Flexner's spirited account of Friedrich Müller's clinic at Munich:

1 Naunyn, for instance, has likened Langenbeck's clinic in Berlin to an arena in which one saw Langenbeck himself, a number of backs, and great streams of blood, a common enough experience in the larger surgical amphitheaters. 174.

${ }^{2}$ Flexner: Medical Edneation in the United States, New York, 1910,

${ }^{3}$ Busey: Op. cil., 31-37, 45-46.

${ }^{4} \mathrm{~W}$. W. Keen: Jeffersonian, Phila., 1912, xiv, 3. 
"A path is opened in order to whed the pationt in. The professor reads the history, displays on the blackloard the temperature chart, then, in quick, clate fathon, explores the paticnt, pointing out what be finds, discoursing on its signifieanee, slgggesting alternative explanations, mutil he settles down on the most probable diagnesis. This furnishes the topie for development and furthere illustration. The etiology, the pathology, the therapentics, of the condition are set forth with wonderful viger and lucidity. . A master mind at work is exhibiterl daily to two humdred students or more."

Teaching of this type depends upon the man, and, other things being equal, has existed in the past here and there. The means of its more general extension in the present were afforded by the liberality of monarchical governments in Europe and of millionaires in America.

So far ats original research is concerned, brilliant investigators have seldom failed of obtaining laboratories or institutes in the end, as witness the cases of Purkinje at Breslau (1824), Licbig at (iessen (1825), Buchheim at Dorpat (1S49), Virchow at Berlin (1\$56), Bowlitch at IAarvard (1871), Pettenkofer at Munich (1872), Schmiedeberg at Strassburg (1872), Liebreh at Berlin (1853), Welch at Baltimore (1884), Pasteur at Paris (18s8), Pavloff at Protrograd (1890), Koch at Berlin (1891), Kitasato at Tokyo (1892), Mosso at Turin (1594), and Ehrlich at Frankfort (1896), the Imperial Institute for Experimental Medicine at Petrograd (1S90), the Lister Institute for Preventive Medicine at London (1891), the Institute Oswaldo Cruz at Rio de Janeiro (1901), or suel American institutions as the laboratories established in Philadelphia by William Pepper (1895), the Wistar Institute of Anatomy and Biology at Philadelphia (1892), the Rockofeller Institute in New York (1901), the Memorial Institute for Infections Diseases in Chicago (1902), the Henry Phipps Institute for Tuberculosis in Philadelphia (1903), The Carnegie Institution of Washington (1903), the Rudolf Spreckels Laboratory (1910) or the Henry Phipps Psychiatric Clinic of Baltimore (1913).

The nuclei of medical education in the United States and Canadia have invariably been associated with some eminent name or names.

With the foundation of the medical faculty of the University of Pennsylvania (1765) are associated Morgan, Shippen and Rush; with that of King's College, New York (1768), John Jones and Samuel Bard; with that of Iarvard (1783), John Warren and Benjamin Waterhouse; with that of Dartmouth (1797), Nathan Smith; with the College of Physians and Surgeons, New York (1810), Samuel Bard, Davir Howaek, Valentine Mott, Iright Post, Samuel Latham Mitehill and John W. Francis; with the Medical Department of Yale (1810), Nathan Smith, Jonathan Knight and Benjamin Silliman; with that of Transylvania University, Lexington, Ky. (1817), Benjamin W' Dudley and Daniel Drake; with that of the Medieal College of Ohio, Cincinnati (1S19), Daniel Drake; with that of Bowdoin College, Brunswick, Me. (1820), Nathan Smith; with the Medical College of South Carolina, Charleston (1824), Samuel Henry Dickson; with the Jefferson Nedical College, Philadelphia (1825), George McClellan, John Eberle and Nathan R. Smith; with the Rush Medical College, Chicago (1837), Daniel Brainerd. A remarkable center of medical education in its day was the College of Physicians and surgeons of the Western District of the State of New York, founded June 12, 1812 , and located at Fairficld, $\mathrm{N}$. Y. In its palny days, this was the second largest medical school in the country, with a roster of 217 students in 1834 , and a total record of 3123 students and 589 graduates. Its faculty included such men as Lyman Spalding, T. Romeyn Beck, Reuben D. Mussey, and Frank H. Hamilton. ${ }^{2}$ Cpon its extinction in 1840 , its effects were divided between

1 Flexner: Medical Edueation in Europe, p. 170.

2 N. S. Davis: Contributions to the History of Merlical Education (ete.), Washington, 1877 . 
the medieal schools of Albany and Ceneva, N. Y., the latter of which (opened February 10,1835) became, in 1872 , the present Medieal Department of Syracuse University, associated with the names of II. D. Didama, Willard Parker and Alonzo Clark.

The Melical Faculty of MeGill University, Montreal (1829), sprang from a course of teaching at the Mont real General Hospital (1820), which originated as a small house in Craig street (1819), aequired for the sick by the Female Benevolent society, organized to relieve the suffering poor of Montreil during the severe Canalian winter of 1817 . The Faculty acquired its splendid new buildings in $1901 .^{1}$

In 1869, according to the Bureau of Education, there were 72 medical colleges in the United States, of which 59 were regular, 7 homeopathic, 5 eeleetic and one botanie (Tyson). In 1859 the Chicago Medical College introduced the novelty of a three years' graded course of study, but the requirements were not rigidly adhered to. The first real reform in American medical education was made, in 1871, by President Charles $W$. Eliot, of Harvard, who raised the entrance requirements of the Harvard Medieal School, lengthened its curriculum to three years, and graded it, providing at the same time better facilities for elinieal and laboratory instructions. In 1880, the three years' course, of nine months each, was extended to four years; in 1892-93 it was made obligatory; and an academie degree was required for admission in 1901. The three years' graded course was introduced in the medical departments of the Universities of Pennsylvania and Syracuse in 1877, to be followed by Ann Arbor (1880) and others. In 1893, the Johns Hopkins Medical School, organized by President Daniel C. Gilman, John s. Billings, Henry Newell Martin, and William H. Welch, was opened, and with it came the opportmnity for teaching scientific medicine by modern methods. Billings's original recommendations for the Johns Hopkins Hospital, made in $1875,{ }^{2}$ included not only the care of the sick poor, but the graded accommodation of pay and private patients in rooms or suites of rooms, proper education of physicians and nurses, and, above all, the promotion of "discoveries in the science and art of medicine, and to make these known for the general good." He insisted that the out-patient department should be connected with the builkling set apart for the instruction of students, and separated from the administration buildings; that elinical instruction should be mostly given in the wards and out-patient department, and not in an amphitheater, except in the surgieal unit; that medical cases should not be brought from beds to an amphitheater; that there should be two pharmacies and a training-school for nurses; and

1 Maude E. Abbott: An Historical Sketch of the Merlical liaculty of MeGill University, Montroal, 1902.

${ }^{2}$ Hospital Plans, five essays, New York, 1875, 3-11, passim. 
that a perfeet system of reorels, financial, historieal, and elinical, should bo kept. With ()slew as physician-in-ehief, Weleh, Halsted, and lielly in the chairs of pathology, surecery, and gyneology, a brilliant and oflicient modical faleulty was soon developed, with antual work in wards, dinic's, dispensarjes, laboratories, and deadhense as the basis of teaching. A bachelor's degree is required for admission, the students serve as clinical alorks and surgical dressers, after the seoteh and English fashion; the laboratories and clinies coöperate as hospital units, as in Ciermany. Billings lectured on medical history before the hospital was opened, the subject being furthered by Osler's evenings with his students at his home and by the meetings of the Hospital Historical (lub). Oster required his students to read and report on the foreign medical journals, and otherwise develop the art of self-direction. The example of Johms Hopkins soon set the pace for Boston, Philadelphia, New Haven, Ann Arhor, Chicago, and elsewhere. The New York Polyclinic, our first institution for postgraduate instruction, was founded by John A. Wyeth (1881) and opened in 1882. At the University of Pennsyliania, a fourth-year course of entircly practical work was introduced in 1892-93, laboratories of hygiene (1892) and elinieal medicine (1895) were added through William Pepper's efforts, and, in 1903, the Phipps Institute for Tuberculosis was added as a clinical plant. On September 25, 1906, the Harvard Medical school acquired a magnificent set of new buildings. Such American schools as the Jefferson (Philadelphia), the University of Michigan (Ann Arbor), the Rush and Northwestern (Chicago), the Eniversity of Minnesota (St. Paul), have now very good laboratory and clinical facilities, and there is much prospect of improvement in the South. The Medical Department at Washingtom Lniversity (St. Louis) has recently acquired a handsome endowment and buildings. Minneapolis is equally well off in this respect. The two leading Canadian schools, McGill (Montreal) and the Cniversity of Toronto, are organized on the English plan and are of a high grade of excellence.

In 1909-11, Abraham Flexner, at the instance of the Carnegie Foundation for the Advancement of Teaching, made two close and comprehensive studies of the status of medical education at home and abroad, ${ }^{1}$ and his strictures on American conditions excited a storm of comment and eriticism. In a work of this small compass, it is not proposed to go into details. Flexner's descriptions of what he saw are truthful and sincere, and therefore authoritative. Many inferior medical schools, brought face to face

1 Hexner: Medical Education in the United States and Canada, New York, 1910. Medical Education in Europe, New York, 1912. 
with the fact that "An unpleasant truth is better than a pleasant falsehood," doubtless resented an invitation to go out of business if they could not improve themselves. That there have been too many American medical schools-39 in Illinois, 14 in Chicago, 42 in Missouri, with 12 survivors, 43 in New York, with 11 survivors, 27 in Indiana, with 2 survivors, 20 in Pennsylvania, with 8 sulvivors, 18 in Tennessec, with 9 survivors, 20 in Cincinnati, 11 in Louisville-was an inevitable resultant of conditions of growth in a demoeracy, as also the amazing overplus in the number of physicians-one doetor on the average for every 691 persons in the entire United States, $1: 460$ in New York, 1 : 580 in Chicago, $1: 365$ in Washington, D. C., as against $1: 1940$ in the whole German Empire, 1 : 2120 in Austria, and 1 : 2834 in France. Tho surface explanation is simple. There are more people in the world, consequently more physicians, American conditions indicating a definite lack of restrictive requirements. Billings, in his survey of American medicine in 1876, accepted these conditions philosophically for two important reasons, viz., that a young man who has spent so many years "in the study of medieine as it ought to be studied, that is to say, in preparing himself to study and investigate for the rest of his life, will not set tle in certain districts," and that to set a definite standard for medical matriculation, graduation, and registration would be hazardous in a country of such wide extent, since, to be uniform, it must necessarily be made a low one. ${ }^{1}$ Moreover, the financial and other resourees for inmproving medical education on a grand scale were not at that time fortheoning in this country. The present ideal is summed $u_{\rho}$ in Weir Mitchell's aphorism that "the rate of advance in medicine is to be tested by what the country doctor is," in other words, the people of the United States should see to it that they have the same highly trained physicians that every peasant can have in Germany. Of his early student days in the Western Reserve (1857-60), Billings wrote: "They taught us medicine as you teach boys to swim, by throwing them into the water"; and, in 1878, he believed that it would be long before the annual number of medical graduates at the Johns Hopkins exceded 25. Yet, in the third vear, there were 32 , and today many are set ling in the smaller localities of the South and elsewhere, showing that advantages for income and investigation have materially improved since the Centennial vear. The future of Anerican medical oducation is, like all other higher developments, simply in the hands of the only aristocracy we strive for-the aristocracy of an enlightened public opinion. One ideal of our country, what Emerson called

1 J. S. Billings, Am. Jour. Med. Sc., Phila., 1876, n. s., Ixxii, p. 480. 


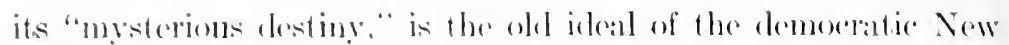
England commmmity the "onsersion of latw material into offirieney," and its lesults amel fabhes ean be properly judged only

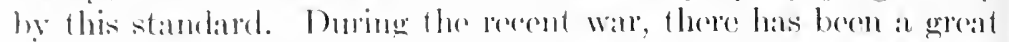

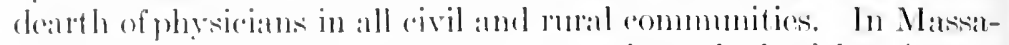

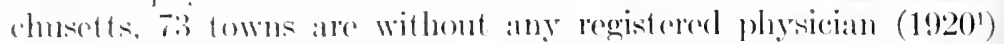
amd worse anditions ohtatin in other parts of the anutry, where the defiedoney has to be supplied by Public Hatth Nurses. The

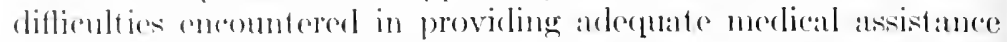
for vast tracts of territory are well illustrated in the case of Russiat, where all aceredited physicians have to be miversity medical eraduates. The defiedoney was supplied by the institution of "civil Felelseherism," which ame into being with the emancipation of the serfs (Fobruary 19, 1Stil), and has been a subject of heated dispute. The military Feldschers were originally those pupils of Peter the Great's medical school at Moseow, who had suffered a cropitis dimimutio for insubor(ination or inefficiency and were abased to the level of playing regimental barber or nurse to the barrack hospital. The civil Feldsebel has been defined ats the "leib-medik of the moujik," in other words, he is a half-flecleed, half-educated medical assistant, who is deputized by the government to take "are of the vast numbers of peasants, of whom the mirs or village communities of Russia are lingely made up." The village doctor receives the peasant at stated intervals, the Feldscher looks after him the rest of the time, while "flying corps" of oculists and other specialists are occasionally sent across the Cau(asus into viberia or wherever needed. 'The Feldscher is thus a sort of pis aller, and the roason for his existence is a tacit agreement that it is better to have a half-doctor than no doctor at all.

The tendencies of German, French, and English medical teaching have been determined by the racial and national characteristics of these peoples, which are as definite as the physical configuration or the chemical composition of their bodies. For centuries, Cerman university teaching has followed the ideal of academic freclom. Fducation being, as Flexner says, a game in which the student must make the first move, he is left to think and act for himself, and if he hecomes a poll-parrot, it is his own fault. Cierman professors and students alike migrate from town to town, as in the Middle Ages, and miversity appointments are not local, but based solely upon fitness and ability. The medical Faculty of Berlin is made up of outsiders. When the student has passed his university and state cxaminations, he may practise

${ }^{1}$ Boston Med. \& Surg. Jour., 1920, clxxxii, 327.

${ }^{2}$ Lancet, Lond., 1\$97, ii, 359-361. 
or, if he has distinguished himself by original researeh, become a Privatdocent, with the venia legendi or right to teach on his own account, from which status he may, if he bujls up his reputation, rise through the various grades of professorship. Conditions like these make for original research and it seens natural that the very idea of public seientific laboratories or institutes for hywiene or psychiatry should have originated in Germany. Add to this the sharply drawn distinctions between Wehrstand, Lehrstand, and Nährstand, and the singular fitness of the race for classifying and coördiuating knowledge. The faults of the German system are mainly along practical lines and are summed up in the phrase "survival of the fittest." The nurses, as in France, are of poor quality, but there is no dearth of clinical material, only the difficulty of making it available for large bodies of students, who are usually taught, not in the wards, but in the amphitheater. "The dullest rustic," says Flexner, "has long since grasped the idea that the professor is chosen for his skill and learning." The hospitals are full of patients, but to get in elose touch with them, one must be either a Hospitant (Famulus) or a Praktikant, and the former has the advantage. The Hospitant can follow his chiefs through the wards and examine patients, but otherwise, as a professor's fag, engaged in recording cases, examining urine, preparing slides, and other things which Sir Clifford Allbutt designates as "merely clerks' work," his opportunities are not overwhelmingly sought for by German students. The Praktiliant is "a non-resident interne of vague status,"' abruptly chosen from his class and pitchforked into the elinical arena, where, as a raw student, his ignorance is thrown into the limelight, and his chief has little time to correct his fumbling. He must sink or swim on his own merits. The German professor, a high priest of his science and its teaching, his brain stored with elassified knowledge, sometimes acquires, it is said, a heaviness of mind which may degenerate into topheaviness, and his autocratic position may sometimes be manifested as a "stiff Vormehmheit," an umpleasantly impersonal manner toward pupils or patients, ${ }^{2}$ which is in odd contrast with the easy informality of the best modern English, French and American traditions. The advantages of modern French and Enghish clinical teaching are precisely in the latter direction. The relations between teacher and pupil, professor and patient, are less official and formal, and the ideal is, in Huxley's phrase, to make the greatest possible number fit to survive. Parisian patients are cven

' Flexner: Op. cit., 163.

2 This may be regarded as of little moment, sinee the general testimony is in accordance with Flexner's view that, all things considered, patients and pupils are very fairly treated in Germany. 
salid to contribute much to the suceses of clinical instruction by their quick, intolligent replies.' In Paris, the hospitals, being mublic charities, ane thrown open fo students everywhere, and the whole aim of French teaching is hodside instruetion. Ward teaching is cleverly exploited by means of steggiaires or student assistants, of whom each professor has to instruct a lange number, and to whom two or three beds aach are allotfer for instruction. Slatgiaires, externes and internes, are quizzed, in suceession, by a jumning fire of questions from the chicf, as he considers cach catse, and, so informal is procedure that it is no discontesy for even an out sider to ask pertinent questions." Clinical study is optional in the first year and obligatory from the second on. Upon graduation, the student must write and publish a thesis and it is open to him to compete for the position of agrégé or assistant professor by means of the concours or public examination. The French graduating theses differ from the German or Russian in that, as a rule, they are exceedingly clever and well-written résumés of what is known rather than records of original work. They are invaluable for reference. As with the French, the strong point of English medical teaching is clinical instruction. Emerson said of the English that "theirs is a logie that brings salt to soup, hammer to nail, oar to boat," and, necessarily, the physician to the bedside. The English hospitals are not, as with the Germans and French, governmental institutions or public charities, but are supported by voluntary contributions, and, with the exception of Oxford, where medical teaching is academic, and Cambridge, where it is eonfined to the fundamental seiences, the English type of instruetion is that of the hospital medical school. Here, the student is given the same clinical advantages that obtain in Paris, the nursing system is the finest in the world, but the institutions not being connected with universities, little opportunity for postgraduate or other instruction for outsiders has been afforded until recently. Of the English clinical teacher, Flexner says, "No matter who or how many attend his lectures, his pupils are specifically those with whon he talks at the bedside." These make their rounds daily with the house physician, rendering complete ease histories with microseopic findings. All are put through their paces twice weekly, in a rigorous but urbane, informal spirit, by the senior physician. The same thing obtains at the final examination, which is a severely practical grilling, although the bearing of the examiners is said to be "informal, sympathetic, and easy, even to the point of joining in tea with the onlookers who happen to be present when that national function becomes due." 3

${ }^{1}$ Flexner: $O p$. cit, 229-230.

"Flexner: Op. cit., 229-230.

${ }^{3}$ Flexner: Op. cit., 18s-205, 282. 
In modern teaching of the fundamental seienees, the prineipal drawback has been the descriptive or expository lecture. In anatomy, this vonge was started by the eighteenth eentury men, the so-called "surgeon-anatomists," and particularly by the Monros at Eddinburgh, of whom the "fvergreen tertius," tup to 1846, "unconcernedly at noon ate cranberly tats in the midst of grinning students at a small pastry cook's, and with digestion mimpared the next hour read his grandfather's essays on hydrophobiat as part of an atnattomical course.'1 Honest John Bell tilted vainly against these ineptitudes of "the windy and wordy school," pointing out that "in Dr. Monro's class, unless there be a fortunate succession of bloody murders, not three subjects are dissected in the year," while "norves and arteries which the surgeon has to dissect at the peril of his patient's life" were demonstrated on a subjeet fished up from the bottom of a tub of spirits and exhibited at a distance of a hundred foet.2 Robert Linox deseribes the anatomical teaching in London during 1S10-25 as the crudest conceivable: "There were in the metropolis but two great sehools. In one of these the course began with hernia and the faseia and ended with hernia and the faseie. 'The lecturer read the descriptions of the museles from Fyfe's wretched work. At the other a man of high genius (Abernethy), affecting to despise deseriptive anatomy, which his natural indolenee and the spirit of his age and country prevented him mastering, talked of the abolominal museles as so many steaks, which he buffoon-like tossed over each other, when dissected, counting them as steak first, steak second, steak thim, muscles and tendons which the first of deseriptive anatomists have failed clearly to doscribe." 3 But even after Bichat, Bell and Knox, and the Warburton act of 1832, anatomy was still treated as the handmaid of surgery (or of the fine arts) until the modern Germans-Henle, Gegenbaur, Waldeyer-correlated it with histology, morphology, and embryology. The dingy, ill-lighted, malodorous disseeting room, where, as Flexner says, "eight or ten inexpert boys hack away at a cadaver until it is reduced to shreds," still survives in some loealities in the United States. The anatomical laboratory or institute, such as the CloverLeaf Hall at Munich, with 500 students dissecting at once umler the eyc of the professor, or Mall's series of separate rooms at the Johns Hopkins, or Harvard, with its extensive cold-storage plants, is an innovation of reeent date. Dearth of material and too many students are the great handicaps, and, even in Grermany, Flexner argues, the most scientific lecturing will never compensite for insuffieient experience in disseeting. In England, where the utilitarian view has provailed, it is signifieant that there have been no great anatomists sines the time of Sir Charles Bell. Horner, Holmes, Harrison Allen, Leidy and Dwight were able teachers in America, but the modern seientifie nethods were: introdueed by Minot at Harvard and by Mall at the Johns Hopkins. Mall isolated his students in separate rooms and done away contirely with dirlactic, descriptive leetures. Edmond Souchon, who did much for anatomicul teaching at New Orleans, has a unique nussum for didactic purposes at 'Tulane Tniversity. Fratuee has had no physiologists of the first rank sinee Claude 13'rnard, unless we regard Pasteur as an example. In England, Foster at Cinnbridge and Burdon Sanderson at Oxford, both pupils of Sharyey, set the pate in physiologieal teaching. In Ameriea, alvaneod instruetion began when Bowditch opened the first physiologieal laboratory at Harvard in 1871 and lluxley brought Newell Martin to the Johns Hopkins (1S76), the traditions heing ably kept up by Porter in Boston, Howell in Baltimore, and others. Corman physiological teaching, the highest development of the century, grew out of the great, laboratories of Johannes Müller at Berlin, Eudwig at Laipzig and Voit at

I Lonsdale: Cited by Stirling (Some Apostles of Physiology, London, $1902,119)$.

2 John Bell: Letters on Professional Chatracter and Manners, Edinburgh, 1810, eitcel by I lexner.

${ }^{3}$ R. Knox: Laneet, Lond., 18.54, ii, 393.

${ }^{4}$ For a full aecount of the stafus of anatomy and its teaching in Americat, see C. R. Bardeen, Bull. Finiv. Wisconsin, Madison, 1905 (No.115), scient. ser. iii, No. 4, 85-208. 
Mumich, hut, even in Cormany, it is urged that there is too much claborated

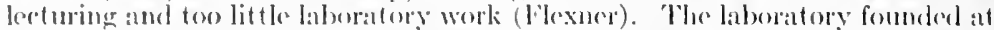

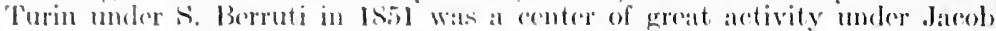

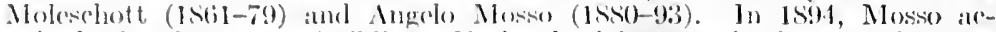

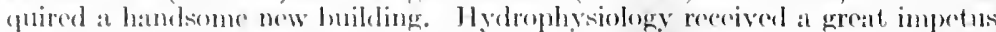

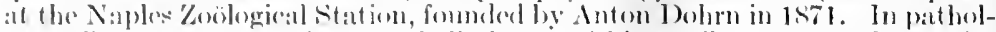
ogy, all Jurepe sat at the feret of Virchow and his pupils, of whom Cohnheim wis the teacher of Weleh, who, with P'rudelen, brought experimental pathology and bateteriology to Anerieit. Welch estalblished at researeh laboratory at the

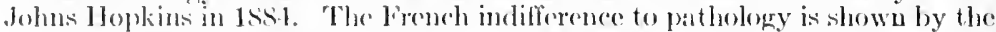
fatet that twe nemologists, Chareot and Mirre, held the whair for vears, the former sucereding Vulpian in 1\$72. Natrie wats apponted to Vietur Cornil's (hair, "very much," as Osler puts it, "as if Allan starr or Dama were selected as sureesorer to l'rudden." Bacteriology has bern best taught in France at the Pasteur Institute and its branches; in Germany, at the institutes of lioeh, Ehrlich, von Behring and others; in Brogium, by Bordet; in Ameriea, by Woldh, Simon flexuer, Vaunham, Novy, Abbott, Wust and others. "Bacteriology," says Flexuer, "tramsformed hygiene from an empirical art into an experimental seiener," and the traching of the two hats gone hand in hand since the foundation of Koch's Institute. Experimental pharmacology was first tatught by Matgendie in Framee and by Buchhoim, Traube, and Schmiedeberg in Cirmany. Bronton, Ringer, Langley and Cushny in London, Fraser in Edinlurgh, represent the height of English tearhing. IJ. C. Wood founded clinieal pharmacology in Ameriea and taught therapenties by means of rharades. Cushny at Amn Arbor, and Abel at the Johns Iopkins introduced the modern German methods. The medicinal plant-garden of the College of Pharmacy of the University of Mimmesota (Mlinneapolis) was started in 1910-11, and was followed by similar gardens at the Universities of Wisconsin (Madison), Miohigan (Am Arbor), Nebraska (Lincoln) and Washington (scattle). In 1751, John Hunter found himself unable to answer a simple, important guestion put to him by a judge in a poisoning case. Impressed by this and other shortcomings of medical evidenee in criminal trials, Andrew Duncan, sr., memorialized the patrons of the University of Edinburgh and rven approached the Crown authorities in aid of founding a chair of forensic medicine. Through his repeated efforts, the Edinburgh chair. the first in Great Britain, was instituted by the Crown in 1806. Germany had precerled this record by some fifty years. Louin gave voluntary leetures in Paris before the Revolution, and a chinir was subsequently founded at the Ecole de santé (1794). Stringham began to give voluntary leetures at the College of Physjeians and Surgeons of $\mathrm{New}$ York and was appointed professor in 1813. Romeyn Beek acquired a chair in the Western Medical College in 1815, and the example was followed by other schools. By 1832-33 every medical school in Great Britain harl lectures on forensic medicine. Attendance was irregular. Christison's class in $1 \$ 22$ consisted mainly of law students. Edinburgh made it a compulsory subjeet in 183:3, and separate examinations were required by London University in 1863. None are required in Germany and Austria. ${ }^{1}$ Legal medicine is now best taught at Vienna, where all judicial autopsies, reroner's cases, and anything medical connected with court-room procedure, are under control of the university professor; in Paris and Lyons, in connection with the admirable service of the Prefectures of Poliee; and at Edinburgh, where the prefesser is also poliee surgeon. It is ably argued by Abraham Flexner that the most scientifie lecturing in all the subjects mentioned will be imperfeetly assimilated if the student has not received proper preliminary instruction in physies, chemistry, and general biology. In clinical medicine, not even the splendid lectures of a Chareot or a Fredich Müller can take the place of bedside teaching, which it is one of the chicf merits of English medicine to have consistently followed.

Schools of tropical medicine were established at London (1899), Liverpool (1899), Hamburg (1900), and Brussels (1906), an Imperial Bacteriological Laboratory at Muktesar (1895), a Plague Research Laboratory at Bombay

' H. Litt\}ejohn: Tr. Med.-Leg. Soc., Lond., 1911-15, xii, 3-6. 
(1896), Pasteur Institute daboratories at Kasauli (1900) and (inindy, Maulas

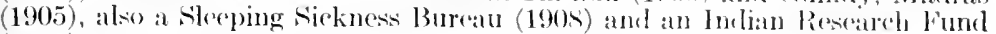
(1911).

In 1916, a siohool of Ilygiene and Publio Iloulth was astablished (by endownent of the Rockefeller Foundation) at the Johns IIopkins Lniversity, under the directorship of William II. Weleh, and will cooperate with the schools of medicine and rugineering.

America, begimning with Flizabeth Blackwell's graduation in 1849, was the pioneer in medical education for women. In the United states and Canada, women can now study medicine anywhere on the same terms as men.

The Woman's Mredieal College of Pennsylvania (Philadelphia) was organized in 1850, and the Woman's Mcolical College of Baltimore in 1852 . The earliest lady graduates after Elizabeth Blackwell were Sarah Adamon Dolly (1S19), Emma Blackwell (1850), Ann Preston (1S50), Marie Zakrzowska (1850) and Mary Putnam Jacobi (1S70). The English Medieal Register of 1858 eontains the name of a single lady graduate of Geneval, and at seeond was examined and qualified in 1865. In 1874, the Londen Fehool of Merlieine for Women was opened with fourteen students; and, in 1896 , they acquired the privilege of resident posts at the Royal Free Hospital. In the same year, the Royal College of Physieians in Ireland and the London University arlmitterd them to the privilege of examination. No other Londom hospital schools are open to women, but the unversities of Durham, Manchester, Liverpool. Birmingham, Leeds, and Bristol are eo-edueational. At Glasgow, Aberdeen. Dundee, and St. Andrew's they are given every facility, but there has been much opposition in Erlinburgh.

On the continent, the Swiss universities tonk the lead in 1876 . the German states followed, one by one, Prussia being the last to throw open the right of miversity instruction and erraduation to women in 1908. Paris, Vienna, Rome, Brussels, Tpsala, and Copenhagen are all co-educational. The faculties of Paris and Bern are the most frequented. Crowds of enthusiastic young Rusian Jewesses flock to the latter, and turn out huge anmul batches of inaugural dissertations. The number of women gracluates who get into practice is said to be relatively small, probably by reatson of marriage.

Of the many admirable hospitals constructed in the modern period, the pavilion system attained a high plane of development in the Johns Hopkins Hospital, plamed by J. S. Billings and opened in 1889, and the Hamburg-Eppendorf pavilion, opened in the same year. In hrgienic advantages and economy of administration, these structures marked a great advance mpon the luge, manystoried buildings (block hospitals) of the past. The Peter Bent Brigham Hospital at Boston (1913), also originally planned by Billings, follows the same idea. With the opening of the Rudolf Virchow Hospital at Berlin (1906) a new idea was introduced, that of a community of separate pavillions as detached hospital units, and upon this plan are based such hospitals as the new 


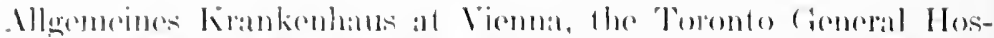

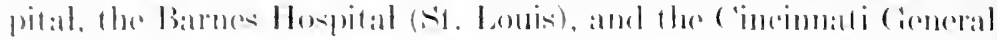
Hospital.

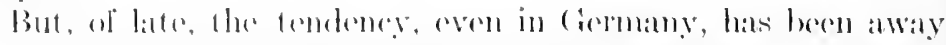

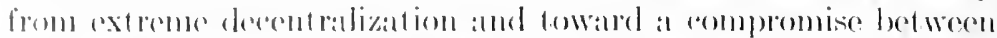

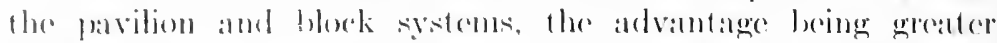

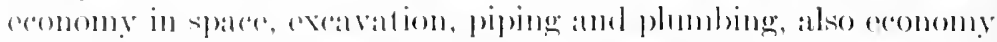
amb rentratization of alministration. Examples of this tondency

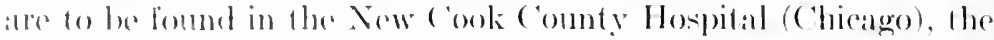

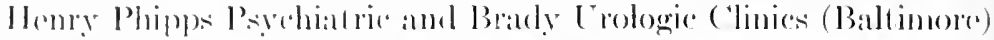
and the new fulklings of Ballevere ( Now York).

The first children's hospitals to be established in this aomtry were the ('hild se Howpital and Nursery in Now York (18ist) and the Childiren's llospital of Philadelphia (15is).

some 37 institutions for the blind were estalslisher in Great Britain beween 1791 and 1s!7. The Berners steret workshop, started by Miss (iilbert, the blind datughter of the Bishop of Chichester, set at motel which has been widely eopied. loollowing the example of leaner and lingland, atslums for the

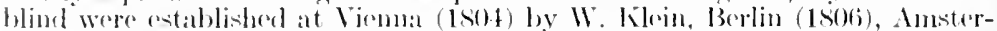
dam. Prague and Dreselen in 1 sos and there are now more than 150 on the rontinent, mostly gerernmental. The first Amerient school for the blind was the Perkins Institution, fommied at Boston by John 1). Fishrer in 1829, under state aid. Here sammel (i. Howe, who also founded the first American sehool

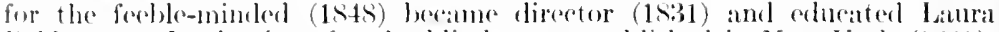
Brilgman. Institutions for the blind were establisherl in Now York (Is'sI). Plibatedphia (1533). Columbus, Ohio (Is:37), Staunton, Virginia (1839), and now exery state in the Union makes provision for this purpose. Schools for the deaf were establisherl at Edinburgh (1S10), Glisgow (1s19), and elsewhere. There are now over 99 in Germany, 95 in Great Britain, 71 in France, 47 in 1 aly, 38 in Aust ro-J Inugary, 34 in Russia, and 126 in the United States. The Ameriean movement began witl the investigations of Thomas llopkins (iallaudet in Europe (1815), and the foundation of the Connectieut Astrom (1sib). The Columbia Institution (Wishington, D. C.) was foumded by CousEress in 18.57. under the direction of Edward M. Callaumlet. The American

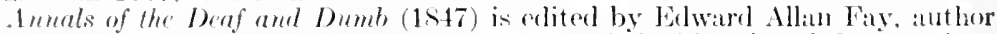
of Marriages of the Denf in Amerian (1S9s), and the bistories of the Ameriman caldeols. The Voltal Bureau (Washington, D. C.) was founded in $1890 \mathrm{by}$ Alexander (iralain Bell.

The introduction of outdloor life and open-air sanitaria for phthisical patients is a foature of modern medicine. Open-air treatment existed in Fotland about 1747 and a seaside hospital for scrofula was opened at Margate in 1791. Cieorge Bodington (1799-1882), of Sutton Colfichl, England, in his Essay on the Treatment of Pulmonary 'onsumption (1840) anticipated many modem views as to the at rantages of cold dry air for "healing and closing of cavities and ulcers of the lumgs," as also of exercise in the open and abundant nutrition: but his theory was so roughly handled by the medical critics of his day that he was discouraged from carrying it into practice to any extent.

The first sanitarium for phthisical patients was established at 
Görberstorf, in the Waldemburg Mountains, by Hermann Brehmer in 1859. It still exists, and its suceses has led to the foundation of many similar institutions in momtain and winter lesorts, notably those of (arl Spengler at Davos and Edward Livingstone Trudeau (1848-1915) at Sarama Lake in the Adirondacks. In 1876, Peter Dettweiler founded the sanitarimm at Falkenstein in the Taumus, introducing the reclining chair for rest-cure in the open air, portalbe receptacles for sputa, and otber novelties. By 1886, England had 19 hospitals for consmptives. The sanitarim movement in Germany was especially fostered hy Ernst von Leyden and there are now thousands of these institutions all over the world. Besides the mountain and winter resolts. like Aneville or Sankt Moritz, the climatie treatment ineludes the arid and semi-tropical, like Arizona or Yalta in the ('rimea, and the maritine, like the Riviera and Algiers. The seashore sanitaria also include those for serofula, with which the coast-lines of commtries like Italy and Norway are dotted. The first international congress for tuberculosis was held July 25-31, 1888, at Parlis, and, after the sixth (1901), an International Association wats formed, which holds annual "conferences" in different cities and prepaures for the now triennial international congresses, of which three have already been held at Paris (1905), Washington (1908), and Rome (1911). A French society of similar title exists in Paris, and pul, lishes a Reme. Since the gift of the Phipps Institute in 190:3, the subjert has awakened keen interest in Anerica, especially through the labors of Trudean, Vincent Y. Bowditeh, L. F. Flick, Arnold Kilebs, S. Adolphus Knopf, Henry Barton Jacols, George E. Bushnell, Frank Billings, Edward R. Baldwin, Lalwason Brown, Theodore Bernard Sachs (1868-1916), and others.

The nursing of the sick at the hands of trained, well-bred women is an institution of modern times. The period from the latter part of the seventeenth century up to the midule of the nineteenth has been called the "dark age" of sick nursing, in which the status and competence of female attendints had sunk as low as the bospitals in which they served. Outside the Romian Catholic orders, in which discipline and decency still prevailest, this was almost universally the case. The puldgy, slatternly, dowdy looking female, of drunken and dubions habits, wats the type from the old colored prints to the time of Sairey Ciamp. In 1857, the servant murses in the larger london hospitals were eferred to in the Times as follows:

"Lectured by Committees, preached at by chaplains, seowled on by treasrers and stewards, seodded by matrons, sworn at by surgeons, bullied by Iressers, grumbled at and abused by patients, insulted if old and ill-favored. alked flippantly to if middle-aged and good-hmmoured, tempted and seduced 
if young and well-koking they :tre what any woman might be under the sime

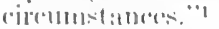

The idea of training muses to attend the sick in a special sehool for the purpose originated with Theolon Fliedner (1800-64),

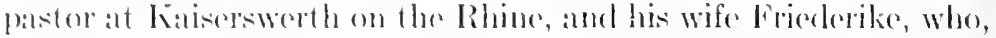
in 1s:3. turned the endreln-house of their pastorate into an asylum for dischatred fomalo prisoners, and in Oetober, 1836 , founded the first school for deateomesces (Diacomissemanstall), whieh berame the motel for similar institutions in comany and olsewhere. 'To the

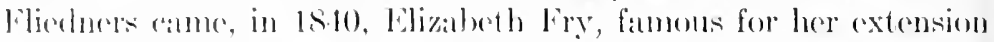
of John Howard's work in roforming prisons, and later Florence Nightingale (182:3-1910), an English lady, boln at Florenoe, Italy, who devoted her whole life to sick nursing and, indeod, makr it the model institution which it is in English-speaking comutries today. When the Crimon War broke out in March, 1854, Miss Nightingale, at the instance of Lord Sidney Herlocet, then serectary of $1 \mathrm{Har}$, went ont with a body of murses to take charge of the barrack hospital at seutari, where her ministrations and reforms soon became a matter of history. In the fares of the indifference of public officials and the opposition of narrow bureanrats, she received the loyal support of Lord Raghan and the hardworking army surgeons, and. within ten days, was foeding nearly 1000 men from her diet kitehen, and, in three months, was providing 10,000 men with clothes and other necessities from her own supplies. The effect of her unexampled sucess was such that

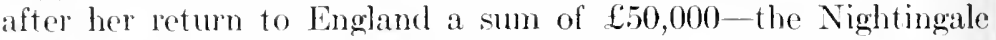
fund - was raised to establish a school for nurses at st. Thomas' Hospital, which was opened on June 15,1860 , with fifteen probationers, who were scientifically trained as "new style nurses." These soon filled up vacancies in the larger hospitals, which brought about a wholesale regeneration of English nursing. Nightingale nurses were sought for everywhere. The adoption of the Cieneva Convention, in 1864, reated the necessity for better nursing on the continent; and, in America, the movement was especially furthered by Marie Zakrzewska and Elizabeth Blackwell, the first training-school for nurses in the United States having been founded by the former in 1873. Elizabeth Blackwell (1821-1910), of Bristol, England, the first lady medieal graduate in England² (1849), Clara Barton (1821-1912), of Oxford, Massachusetts, and Louise Lee Schuyler were instrumental in organizing sick nursing and medical aid during the Civil War.

${ }^{1}$ London Times, April 15, 1857. Cited by Nutting and Doek, History of Nursing, New York, $1907, \mathrm{i}, 505$.

${ }^{2}$ Dorothea Christiana Erxleben was the first woman to receive a medical degree in Germany (at Halle in 1754). 
During the Spanish-Ameriean $\mathrm{W}$ ar, army musing was organized by Anita Newcomb MeCiee; and during the European War by Dora E. Thompson, Jane B. Delano (1862-1919) and Julia Stimpson. In 1873, three traming-sehools were established at the Bellevue, New Haven, and Massachusetts Cienelal Hospitals, and the Johns Hopkins Training-Sehool for Nurses was superintended by Miss M. Adelaide Nutting, who, with Miss Lavinia I. Dock, wrote a "History of Nursing" (1907). Miss Nightingale's "Notes on Hospitals" (1859) and "Notes on Nursing" (1860) are true medieal elassies, distinguished by the rarest rommon sense and simplicity of statement. She defined nursing as "helping the pattient to live," introduced the modern standards of training and esprit de corps, and early grasped the idea that diseases are not "separate entities, which must exist, like cats and dogs," but altered conditions, qualitative disturbanees of normal physiological processes, through which the patient is passing. While she did not know the bacterial theory of infectious diseases, she realized that absolute cleanliness, fresh air, pure water, light and efficient drainage are the surest means of preventing them.

Since the time of Pinel and Reil, Tuke and ('onolly, the proper study and care of the insane has been an object of ambition, often dimly realized. When Esquirol succeded Pincl at the Salpêtrière, in 1810, he made great reforms in housing and regimen, traveled all over France to carry out Pinel's ideas, founded ten new asylums and was the first to lecture on psychiatry (1S17). Cardner Hill introduced the idea of "no restraint" at Lincoln Asylum, Fngland, in 1836, and in 1839), in the fare of bitter opposition, John Conolly discarded all mechanical restraints at the Hanwell Swym. The abuses attending the commitment and care of the insane in private asyhums were vigorously attacked by Charles Reade in "Hard Cash" (1863).

Early Ameriean institutions were the State Hospital at Willimsture, Va. (1773), the Bloominglale Asylum, New York (1809), now at White Plains (1821), the Friends Asylum, at Frankford, outside Philadelphia (1si7), the MeLean Hospital, Boston (1S18), the Hospritals at Columbia, South (arolina (182S), and Woreester, Mass. (1S33), the Hartford and Brattleloro Retreats (1836-38), and the Now Jorsey state Asylum at Tronton (1Sts). The last was established through the propagandism of Miss Dorothea Lynde Dix, of Maine, whose work in amelierating the condition of the insune in Americat, and even in Great Britain, is similar to John Howard's prisen and hospital reforms. She is stid to have been instrmental in foundling no less than thirtytwo asylums. With the opening of the Utiea state Hospital in 1848, begain what Hurd calls "the era of awakening,"' and by 18.0 ) the movement for State provision for the insane was well on its wity. The state asylums at Willard (1869) and Bingloment Now York (1851), were founded to sot off the barbarities in the treatment of the eluronic insane in county asylums.

${ }^{1}$ H. M. Hurd: The Institutional Care of the Insane, Baltimore, 1916. 


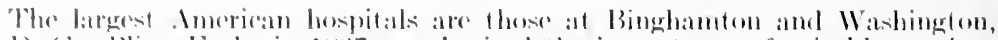

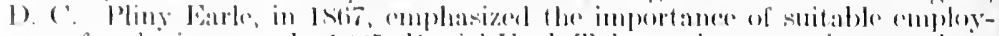

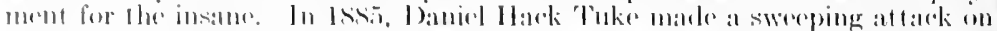

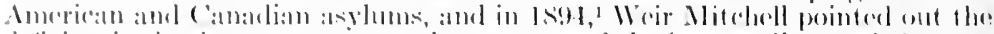

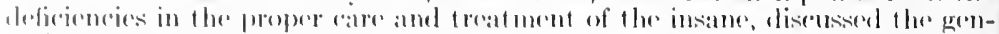

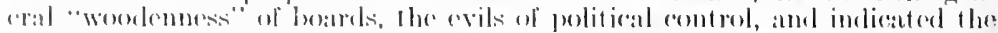

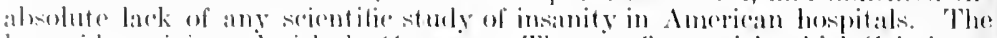

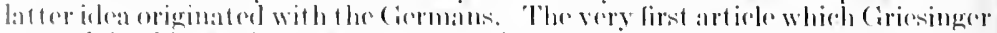

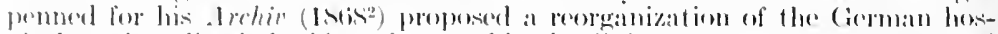

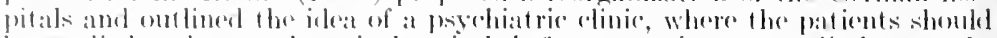
fer soldied and treated, as in hospital, belore eommitment or discharge. In

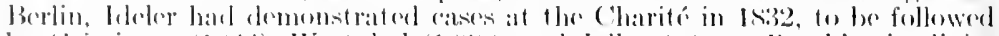

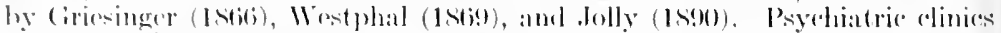

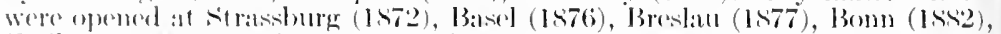

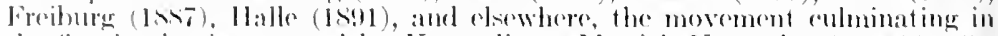
the fino institution opened by Krapertin at Monich November 7, 1904. ()n April 16, 191:3, the Psychatrie Clinic, domated to the Johns Hopkins I ni-

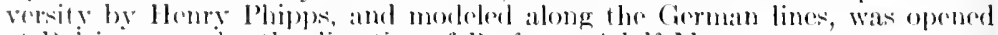

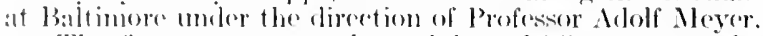

The first attempt at the training of idiots was made by the ecolobated

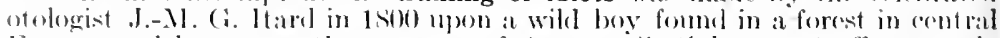

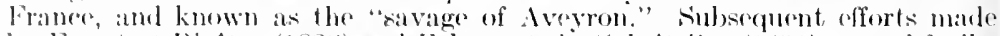
by Ferret at Bicetro (IS2s) ancl Fabret at the salpêtrière (1831) proved futile.

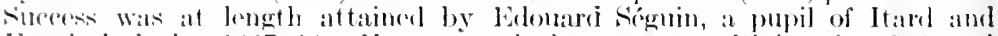
Escpurel, during 1s:37-4s. 1le was made instructor at bicêtro in $18+2$, and in 1s.t, the feademy of seieness reported favorably upen his mothods. Rofurming to Imerioi, he establishorl schools in several states, after which his mothods, smmmarized in his treatiso on idfocy (1846), were taken mp all over the comtry. Subsequent work by Couggenbühl on erotims (Isi2), by

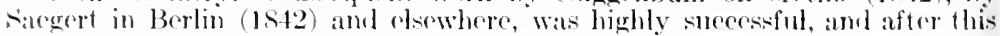
time the subject became a matter of legislation.

In the development of national and international regulation of public hygiene, necessity has been the nother of invention. There was nothing spontancons about the movenent. It was simply foreed npon the attention of legislators by the modern outbreaks of epidenic disease and by the evils resulting from crowled cities and slums, factories, ateliess, and the like. Its developments bave been slow. The first big sare came from the invasion of Asiatic cholera (1826-37), which had been endemic in India for centuries, was pandemice in Asia dming 1816-30, had spreal over Russia hy 1830, skirted Noptheastern Gemany in 18:31, reaching England in .June of the same year, and Calais, Mareh, 18:32, and invaded Ameriea tia Quebee and New York. Heinrich Heinc has left a graphic and memorable account of its outhreak in Paris. On the twenty-ninth of Mareh, the night of mi-careme, a masked hall was in progress, the chahut in full swing. suddenly, the gayest of the barlequins collapsed, eold in the limbs, and, molerneath bis mask, "violet-blue" in the face. Jaughter diecl ont, dancing reased, and in a short while carriage-loads of

1.. Weir Mitchell: Proc. Am. Med.-Psychel. Ass, 1s94, Utica, N. Y., 1595, i, 1t)1-121

2II. Griesinger: Arch. f. Psychiat., Berl., 1stis-69, i, 8-43. 
people were hurried from the redoute to the IIoted Dien fo die, and. to prevent a panic among the patients, were thrust indo rude graves in their dominoes. Soon the public halls were filled with dead bodies, sewed in saleks for want of roffins. Iong lines of hourses stood en quene outside Père Iarhaise. Everybody were flannel bandiges. The rich gathered up their belongings and fled the town. Over 120,000 passports were issued at the Hotel de Ville. A guillotine ambulante was stakling abroad, and its offect mpon the excitable Parisians reduplicated the seenes of the Revolution or the plague at Milan. With signal intelligener, Heine puts his: finger upon the chief obstacle which pullic health movements lat ve ever encomtered, viz., the dread of disturbing private business. In this case, an émente, with barricales, was stirred up anomg the rag-pickers, who resented the removal from the streets of the piles of offal from which they derived their livelihood. The suspicion of secelet poisoning was raised, as a counter-theory to that of infection, the ery "i la lenterme" was hearel, and six persons were murdered and naked corpses dragged through the streots, umber this belief. Finally the public press quieted the panie, and the Commission samitaire was able to alecomplish something. ${ }^{1}$ Finilar panies, such as the shot-gun quarantines at the fouth during yellow fever, with the lugubrious "Bring out your dead!" have led to the necessity of enfightened organized control of public health.

Cholera was again pandemic in 1840-50, 1852-60, 1863-73, and at later intervals in Europe. It is still wide-spread in the Far East. Cerebro-spinal fever appeared periodically at the intervals $1805-30,1837-50,1854-74$ and 1875 to the present time; influenza, in 1830-33, 1836-87, 1847-4s, and 188990; vellow fever in the southern states in 1853, 1867, 1873, 1878 , and 1897-99. Typhus fever was rife during the Napoleonie wars and smote Ireland severely in 1517,1819 , and 1846 . Typhoid, searlatina, measles, and ot her infections appeared at intervals. Bubonic plague was spread from Hong liong all over the work from 1894 on, and without modern santation, the pandenie would probably have attained to medieval proportions. Polities came near wreeking the situation in San Franciseo in 1907-8, and it was only through the Marine Hospital serviere experts, who diagnosed the disease and destroyed the rodent earriers, that the eity, perhaps the eount ry, was saved. This was the first time that a city was macle rat-proof. The epidemir chandeter of poliomyelit is wats first neted by Medlin in Sweden (1SST), and its incidenee in the seandlinavian countries, Aistria, and the United States (1907-10) has been severe. Its pathology was ably investigated by Simon Flexner, who jolated a germ in 1913. In 1762, a santary eomeil was established in "very Prusiam provinee. but it was not unt il the second pandemie of eholerat (1840-50) that france and England began to wake up to the task of organizing puble health. In SII), it national organization of conseils d'hygien for for the cities with special commit tees for the provinees was formed in leranee, the essenee of which still nurvives.

The English cole of sanitary legislation, in some respects, the best and most progressive in the modern world, had its origins on

${ }^{1}$ Heine: Französische Zustïnde, letter of April 9, 15:32 (sämmotliche Werke, Cotta ed., Leipzig, xi, $88-102$ ). 


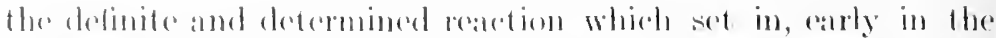

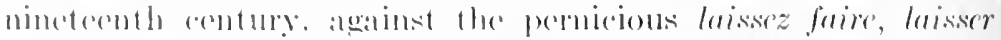
aller lootrines of Mlam Smith, Malthus, James Mill, amel other professors of the "dismat serenere." The Fremeh Revolution and

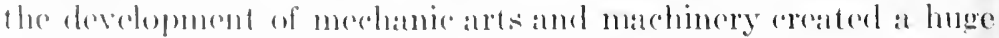

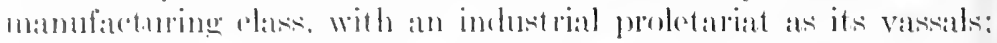

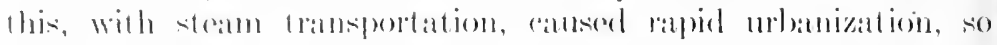

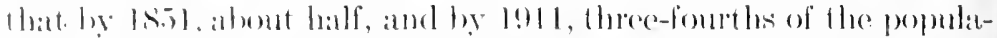
lion of bugland and Wales were hudelled in towns, and thas exposed to the arils of orereroweling, poverty and had sanitation.

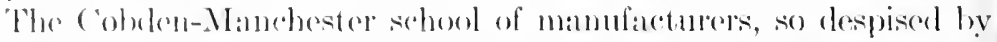
(anter maintained that the puthe and the govermment have no right to interlore with husiness onterprises, and were even supported

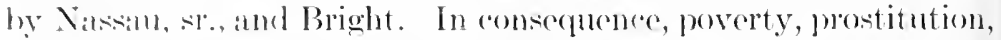
discaso and mortality rates inerrased apare. Children, indentumed as a plomenters, were practically solel into slavery and subjected to shorking andty by the hard-fistod taskmasters who axploited 1 h(111.

The fommlation of Methodism at ()xford by John and (harles IV esley (1729), John Howard's prison reforms, the efforts of 'Tuke, Pincland lieil for humane treatment of the insane, the Abolition Act of 1807 , and Romilly's efforts to humanize the penal code (1808), all tended to the development of altuistie sentiment (Morris). Through the offorts of surh great writers as Chasles Dickens, (tharles Reade, Thomas (arryle, Goethe (Mignon) and Victor Hugo (cosette), it began presently to be pereoived that the real wealth of a nation is its population, as Joham Peter Frank had originally maintained; and that the food-fallacy in Malthus lay in the faret that production of food itself depends upon the mumher, ability and industry of the people producing it, upon material froduction (including mardhinery and labor-saving devices), and upon adequate means of transportation, without which, as in the recent war, whole rommunities maty starve with superabundant food neal at hamd. As Newsholue says, philanthropy was the motor power in initiating sanitary roform, but the driving power (ame from the great expense of sanitary Poor-Law ardministration and actual fear of the ever-recurring epidemics of communicable discases. ${ }^{1}$

Early English legislation, such as the Perel Aet of 1802 , to preserve the "health and morals" of cotton-spinners and factory hands, was directed mainly toward the hygiene of ocenpations, particularly child labor. The Factory Art of 1.333 restricted hours of labor in children and introduced professional in-pretors of factories; the Poor-Law Amendment Aet, of 1834, placed local

1 ,ir A. Newsholme: Public Health and Insuranee, Baltimore, 1920, i, 70. Sir M. MFrris: The Story of English Public Health, London, 1919. 
relief of poverty umber eentralized government antrol, grouped parishes into "unions" for tbis purpose, and interdieted outdore rediof to ablo-bodicet men. In 1848, Parliancmt pasioel the Public: Heath Aet hased upon the startling returns of the IIealth of 'Towns Commission (1St4) and eonstituting a (iencial Board of Health, with sanitary inspeetors to report mon the health of rities. This was followed hy a long line of progressive legislation, induding the Com-

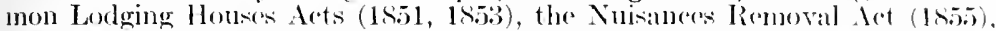

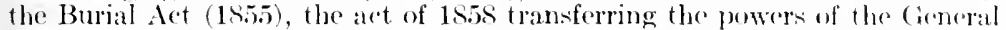
Board of Health to the Privy Comnejl, the organization of the Loeal (iovernment Boarrl (1870), the Public llealth Act of 1875, the Infoctious Discases (Notifieation) Aets of 1889 and 1899, the Infectious Diseases (Provention) Act (1S90), the Contagious Diseases (Animals) Act (1s91), the Puthe Howlth (London) Art (1591), the Isolation Hospitals Act (1893). tho Loeal (invernment Aet of 1894, the Public Health (Ports) Art (1S96), the Varecination Arts of 1898 and 1907, the Rivers Pollution Prevention Art (1898), tho Provision of Meals Aet for sehool ehildren's lunehes (1902), the Notifieation of liinths Aets (1907), the Howsing and Town-Planning det (1909), the National lnsuranee Aet (1911) and the Notifieation of Births (Extension) Aet (1915). The investigations and reforms instituted by Lord Ashley (1833) in regard to chikd labor, culminating in his famous reports on mines and collieries (1st243), led to a succession of acts $(1844-1912)$ which have raised the age lunit of employment to twelve years. Children were forbilden to work in white learl in 1878 , the factory aets of $1864,1867,1870$ and 1878 were extended to workshops in 1891, a Coal Mlines Rregulation Aet was passed in 1896, Workmen's Compensation Acts in 1897 and 1906 , and, in 1901, medieal officers of health were required to keep registers of workshops and report upon them annually. Medieal inspection and treatment of sehool children was dolegated to the Board of Education in 1907. The delegation of the treatment of discase in paupers to the Poor Law authorities, of disease prevention to the Local Government Board (1S71) and of medieal inspection of school children to the Board of Edueation (1907) was eontrary to the fundamental principles of sound administration, sinee it deeentralized authority, assigning duties of irdentieal order to different organizations, on the ad hoc prineiple, with eonsequent overlapping of functions, group competition and obliteration of the true objects of eommunity serviee and team-work. This was further intensified in the National Insuranee Aet of 1911, whieh through a tax levied upon working people, employers and the state, guarantees weckly sickness and maternity benofits, sanatorium treatment in tuberculosis and at tendaner by a contract phrsician (panel practice) to about one-thind the total populationi, with no provision for nursing, surgery, hospitalization, sperial treatment or medieal aid other than of orfinary eharaeter; although eomplete medical and sanitary servies would have been avaibable to the total population if placed

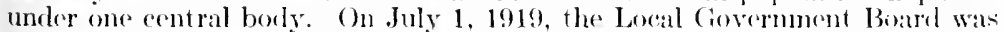
abolished and sanitary administration was ecntralized in the Ministry of Health, with sir Christopher Addion (1869-) as the first minister. Child labor laws were enacted in Massachusetts (18:36, 1s42), Comnoetiout (1842), Maine (1847), Pennsylvania (1845), but there was no indastrial dast legislation mntil the Massachusetts act of 1877 and no provisions for factory inspection prior to those of Massachusetts in 1ssi. The best pionere work was done by the $U$. S. Department of Iabor and much was alcomplisherl through the labors of George M. Kober, W. (iiman Thompson, John 13. Andrews, Alice Hamilton, J. W. Achereschewsky. S. S. ( ioldwater. and others. Industrial museums of safety have bern establisherl at Berlin (19)4), Vicnma (1909), New York (1911), and twolve other cities. A traveling rexhibit of this kind was set $" 1$ in Washingtom in 1915-16. The first relinje for oceupational diseases was opened at Milan on Mareh 20, 19)]0. Another was mitablished at New York by s. S. Coldwater in 1915. Researeh lnstitutes for industrial hygiene have heen opened at Frankfort on the Main (19f0), Pittsburgh, Par.

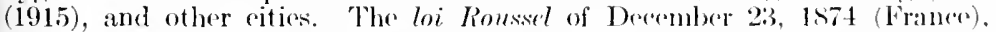
for the proteetion of friendless children, was a great advanee iu humbnitarian legislation. In the roforms of prisons, insane asylums and dangerous trates, the effeet of the writings of Charles Diekens and Charles Rearle should not be 
forgotten. The sprech eledivered hy forkens at the anmiversary festival of

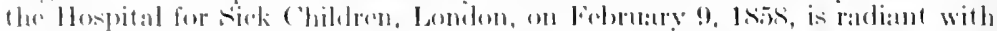

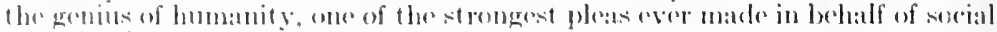

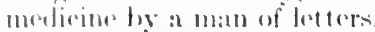

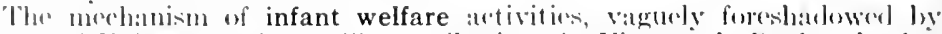

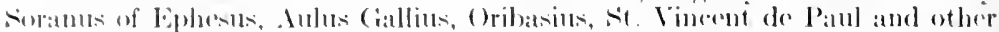

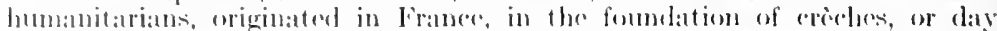
murseries for the infants of working mothers, by fimin Marbean (November 11. 14.1.1), in the two laws for the pootection of infants and childeren (1874, Ist!), through the influne of Therphile Roussel (1S16-19():3), and in the

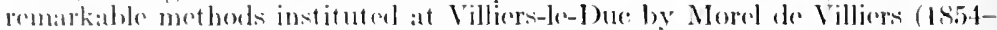

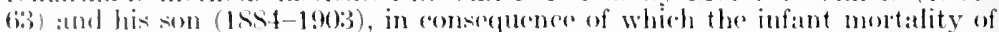

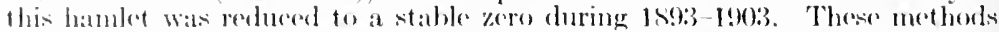
were laken up by Bonjamin Broadbent, major of Hulelersfeld (lengland)

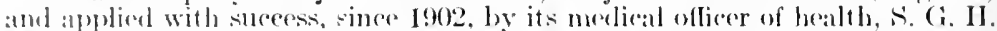
Mlenre. Thenesh the pioneer work of the borough of Hudelersfiedd, the Notification of Births Act was pasied (1907). Infant motality work wats then taken up he English publie health oflicials, motably A. K. Chalmers at Gilasgow (1900) and J. F. J. Sykes at St. Pancras, culuninating in the four epochal reportio of sij Irthur Newsholme to the local (iovermment Boaril (1910-16), which are the basic texts of infant welfare work. Newholme mantains that infant nuortality is of multiple causation, to be met by multiple infant welfare artivities. "To these, the leading pediatrists of England and other eountries have devoted their best efforts. In 1912, the Children's bureau was established at Washington by the government, under the direction of Miss Julia C. Lathrop. Infant welfare activities in Ameriea have bees laregely furthered by women, notably Dr. S. Jesephine Baker (New York), Mrs. Mary Lowell Putnam (Boston), Miss Ellen C. Babbitt (Washington) and Dr. Holon Mardurchy (Toronto). In England, Dr. Janet Lane-Claypen has done splemeliel and eflicient work for this eallse.

The ghastly details of intra-mural burial, the overeroweling of ehurehvards with sucersive Iayers of dead bodies, were referred to in Hamlet, Tom Jemes, Diekens's Bleak House and Swinburne's Bothwell. The development of extra-mural eemeteries was due to the propagandism of Sir Eclward Chadwick, whose reports (1843-55) led to the Burial Aet (1855), abolishing inhmmation within the limits of rities. Pietro Ciuparoni deseribes a simular Napoleonic ordinance of 1809.1 England has now a very effieient corps of medical ufficers of health, a body which is almost extinet in France. Every Cicrman university bas now a hygenic institute, and the Cerman physikus is at onee a public healt boffieial and an expert in legal medieine. In the Inited States, there were no advanes in public hygiene beyond a few stray smallpox regulations, until after the seeond cholera pandemice, when a sanitary survey of Massachusetts was made in 1849. A State Board of Health for Lonisiana was established at New Orleans in 1S55, to be followed by Massachusetts (Is69), California (1570). Mirhigan (18732), and the other states of the Union. In 1001 , only ton states had a satisfactory sytem of vital statistics (Kober). The Ameriean Public Health Asociation was organized in 1872. (Quarantine regulations against yellow fever were stablished in Philadelphia in 18.56 and later, but owing to the jealous insistence of the seaboard cities upon the right to operate their own stationc and enforee their own laws, there was no uniform system of regulation until Frbruary 15, 189.3, when Congress passed an act establishing a national quarantine sytem and vesting its powers in the Marine Hospital (Public Health) Serviee. The ebolera epidemie of $1572-73$ lext to the appointment of a Cholera Commision, and the yellow fever epidemic of $187 \mathrm{~S}$ to the creation by Congress of a National Board of Health (Mareb, 1S7S), which died out from lack of appropriations. Its place has been taken, sinee

1 Capparoni: Riv di storia erit. 1. se. meel., Rome, 1915, vi. 586.

2 For an interesting account of the constructive work of Henry 13. Baker in the Michigan state Board, see Jour. Mich. State Med. Soe., Girand Rapids, $1916, x v, 424-427$. 
1S83, by the United States Marine llompital sirviee, now the Publie Ilealth service (1912). 'The lattor has a good Ilygienie Labotatory and its rxperts have done much admirable work. In sueb matters as the slipervision of milk supply, child hygiene, and the close and aceurate registration of disease-the sanitary surveys for diagnosing the condition of a sick commonity whin l'aul II. Kellogg has likened to "blue-prints"-the best reeent work has hren done: by the state Boards of Massachusetts, Miehigan (H. B. Baker), P'onnsylvania (Famuel Gibson Dixon, 1852-1918), Maryland (John s. Fultom), in eonnection with the municipal government of Washington, D. C. (C. M. Kober, W. ('. Woodwar(d), by the Department of Health of New York City, the excellent status of which is due to the altrustic labors of Stephen smith, Hermann N. Biggs, s. S. Goldwates, and others. The latter is now of sperial importance in relation to the great overplus of foreign population in the Borough of Manhattan. Hygienic improvements in nearly all countries and eities have produced a very striking liminution in the death-rate and a corresponding increase in the mean duration of life. The celebrated Paris sewers were installed in 15.51-56, those of Hamburg in 1542, to be followed by lrankfort (1867), Danzig (1869), Berlin (1873), and Munich (1SS0). In England, where sewagis is commonly discharged into the soa, filtration beds were first employed at Wimbledon in 1576 . Before 1947 the sewers of Lenden were merely drains for storm-water, and the discharge of sewage into them was not permitted before that time. The labors of Edward Frankland (1525-99) and the experts of the Rivers Pollution Commis:ion establisbed the principle of sewage purifieation by means of intermitent filtration through difforent soils (1564-74). This was vastly improved by H. F. Mills, T. M. Drown, and W. T. Sedgwiek at the Lawrenee Experiment Station of the Massachusetts State Board of Health (1887). Fermentation of stored sewage in a elosed tank was eleveloped from the fosses fixées of Mourus (1s60), ly seott-Mloncrieff (1891). Talbot at Erbana, Illinois (1894), and Donalel (ameron of Exeter, England (is95), who named the proecsis. Pasiage through eoke and stone in elosed iron cylinders (eontact sytem) was devised by $W^{2}$. J. Dibrin, ehemist of the Lomblon Count Council. Trickling filtration was introduced by Loweock at Malvern, England (1892), and by Colonel (i. E. Waring at Newport (189.1'). The improvements in sewage dispesal, such as those of Pettenkofer in Munich and Virchow in Berlin, or the bacterial system of purifieation, introduced in England by William J. Dibdin (1s9ti), have had great offeet upon the mortality of typhoid fever and other water-borme diseases, as alse the purification of the waterstupply by sand filtration. This was introheed he the Chelsea Company in London in 1829 , but diel not reach perfection until recent times. In 1837 , it was satid that, in eontradistinction to forcign eities, London swallowed its filth but soldom smolt it. The investigation of learl-poisoning at Claremont, the'

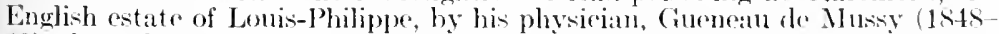
49), showed some of the dangers of piping, but that water is a velhicle of infortion wits not recognized until well after the London eholera epidemic of 1854 , in wheh John snow traced the infeetion to a pump in Broal street. Althomgh Snow's views were opposed by Farr and fir J simon (18.5), removal of the pump-handle stopperl the epidemie. In the cholera ropdemie of 1stitit was shown that the infortion eame from unfiltered water furnished by one of the Metropolitan Witer ('ompanies, wheh had been orelered filtered by the act of 1852 (15. and 16. Vietoria, ("ap. \$4). The writinge of William Budlil (1571-73)

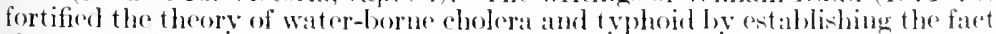
that infertion eomes from the dejecta of the patients. The typlusid epilemie. at Latusen, Fwitzerland (1S72), which rame from water pasing through a hill. upset belief in the water theory, and real progress eame only with bactoriology.

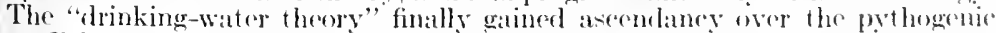
or filth theory (Murehison), and the "wromel-water" theory (Pettenkefor)

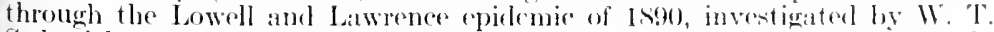
Sedgwiek, and the fact that Hamburg, with unfiltered water, suffered severely

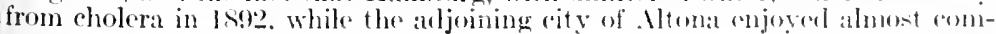

1 C. -E. A. Winslow: Trehnol. (2uart., Boton, 190.7, xrii, 31s-3332. 


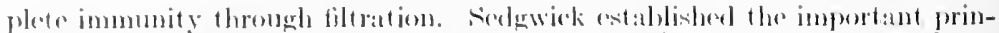

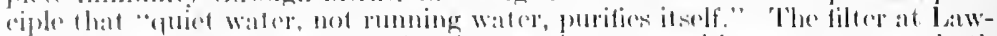

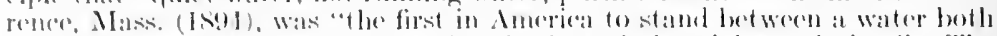
highly polluted and highly infoetod and al large imslustrial population." The Bulnont filtalion plant of Philadelphia (1593) and the Itashington plant

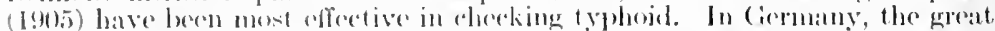

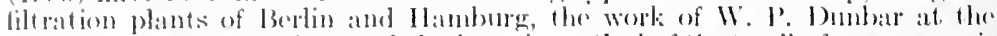
Hamburg Tosting station, and the ingenious "Jumbef System" of scwage puri-

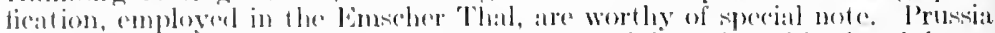

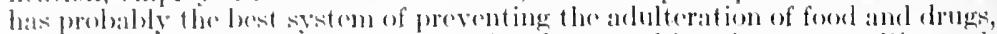
punishing such offenses, not by fincs, but ly anctual interisomment. Bismatrek leclared the alulteress of fored to be, next to the anarchists, the greatest

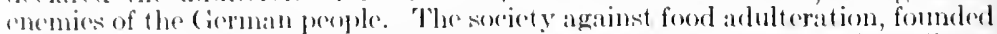
in Hamburg in 14.

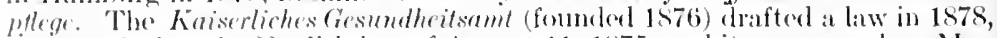
patterned afier thw English law of August 11, 1575, and it was pasioed on May 14. 1579 , and followel hy a long line of similar enaroments, the most important being the ordinane of Fetoruary 22,1694 , for aret if ying food-chemists and profocting mannfactures's against the false indictuments of the incomperent llinkeletemiker. There was no pure food legislation in the lnited states until jsib, when laws were passod simultancomsly by New York, New Jersey, and Melhigan, and no adefuate natjonal legislation until the passage of the Ford and Drugs Act of Jume 30, 1966, and the Mrat Inspection Aet of the same year, which still secmos upon a somewhat unsatisfactory fasis. For a fong time progressive legislation in public hygieno in the United states has becu blocked by individuals or corporatjons who do not want their business interfored with, if they can help it, and who regard Anerican ritizenship as conferring a mystrrous "right" to do as they please, irrespective of thejr noighbols. The injudent claims of white-slave traders along these lines were quashed by the ruling of the Siupreme Court of February 24, 1913, which explieitly denies the existence of any private riglit in itself, partieularly the right of crooks to do wrong. The broall distinetion, male by Tacitus, Milton and Goethe, betwen "license" and "liberty" as upheld by a tribunal of this minenec, has an important bearing upon our future develepments in state medicine. ${ }^{2}$

The movement for "Birth Control," a commonplace right of continental European women, although interdieted by our fedcral and state laws, has beren advocated, mainly by William J. Robinson (New York). As stated by 1)r. A. Jarobi, before the New York Acarlemy of Medicine (May 26, 1915), the object of this jlea is primarily engenic, to improve the quality of the human stock by the limitation of reekless focretting, by the deliberate regulation of the number and time of arrival of children, and by enlarging the responsibility of paternity.

In the distant past a few severe and even cruel laws were enacted and enforeed to protect society from the criminal. The tendency of recent times has been the proliferation of complex codes of petty statutes, many of them vastly curtailing the private rights of the individual, with the superadded paradox of leaving society at the mercy of the criminal, since almost any law has been evaded by sharp practice and chicanery. The great danger of the hour is legal and medical Bolshevism, which springs from the basest of human passions, namely, a mean envy of the private

1. Soe IV. T. Fedgwick: Jour. New Engl. Water Works Asis., Bost., 19001901. xv, 315: 1916, xxx, 183.

"For a discussion of the legal aspects of this matter, see the paper by Dr. William C. Woolward, Health Officer, D. C., in the Georgetown Law Journal, Washington, 1913, i, No. 3. 
personal rights, possessions and privileges of others. As was shown in the Freneb Revolution, rowel psychologre the spirit of the mols is fatal to merlieine. The object of sorentific teaching is to level the people up to its standarels. It cannot be levelled down to popular standards. While much has been learned, especially from army experienee in the reent war, as to the value of centralization and organization in group medicine, such schomes as compelling the people to "sell themselves" health insurance (admittedly a faihure in England) are subversive of the true aims of merlical science.

Sectarianism and quackery flourish apace in modern life, often under strange guises. According to Flexner, "the homeopath is the only sectarian found at all in Great Britain or on the Continent," because a qualified physician, no matter what he may eall himself, must pass the necessary examinations in order to practice. The proportion of homeopaths was $211: 30,558$ in Germany in 1909, and 193:31,154 in Great Britain in 1907. In Americat, under existing legislation, every species of medical sect-ostoopathy, chiropraxis, Christian Seience, eclecticism, botanic medicine, etc.- has been permitted to flourish. In 1909, there were 15 homeopathic, 8 relectic, 1 physiomedical, and 8 osteopathic schools in the United states. There are no sectarian institutions in canada. In respect of fiduciary allegiance to Hahnemanu's original doetrines, the modern homeopath is often like a skeptical or backsholing clergyman. Seientific medicine is neither homeopathic nor allopathic. Upon the subject of treatment, which is often very much in the air, hinges the whole matter of toleranoe of sectarianism and quackery. In the past, as we have seen, many important features of medical treatment were actually introduced by laymen. Therapentics, in fact, began with herhdoctoring. It is the purcly experimental status of actual therapeutics which opens a loophole for the modern quack. "The very canclor of scientific medicine gives him his chance, for, just. where the scientific physician admits his inade(unacy, the charlatan is most positive" (Flexner). The tendeney to consult quateks is analogous to the phrsician's liability to le deduded by wild-cat investments. "Some of the most respomsible doctors," says Robert Morris, "will always be in the hands of financial faliers, and some of the most responsible besiness men will always be in the hands of medieal falkers." In the early part of the nineteenth century, John St. John long, a handsome imposter, who traded upon his influence over women withont morting their advanes, had enormons suceses in England, and even Napoleon consulted the pythomess Ienommand. In 1815, by the law of 5is cieorge III cap. 194, an English apotherary was still entitled to diagnose 
and prescribe, and the society of Apothecaries was anthorized to lienser him for registration in the Medienl Register; but, in 1886, the old-tine strifo was setted hy repuiring that the governing bodies in medicine, surgery, and pharmatey should grant no certificate or license unless the canclidate should qualify hy eximmination in all three bramehes. On June 21, 1869, Comany made the serious mistake of passing a statute abolishing the obligations of physidians to attend monent alls and to treat the poor gratis, which incielentally let down the bars to all unlicensed practitioners who might profoss merely to treat disease. 'The result of this "Kurierfreiheit" was a tremendous outpouring of nature-healers, faith healers, Bamnscheidtists, exoreists, masseurs and masseuses, and devotees of vegetarianism, Kneippism, Nachtlultur, bhe and green electricity, and ocenltism of all kinds. Police retums show as many as 1013 registered quacks in Berlin (1903), as against 28 in 1879 , and 1:349 quacks ont of 3584 physicians in 1909. There were 4104 registered quacks in Prussia in 1902, 5148 in 1903, and, in 1905, there were 61:37, and 2112 in Saxony. In Great Britain, qualified physicians have been listed in the Nedical Register since the Medical Act of 1858 , but there is no police registration of quacks. As in Germany and the United States, they may use the mails and advertise ad libitum. "The newspapers, the billboards, and the 'bus give the charlatan easy and continuous access" (Flexner). There were 31,592 licenses for the sale and manufacture of proprietary remedies in 1894-95 at five shillings each, and 40,734 in 1904-05. The blue book report issued by the Privy Council Office in 1910 shows that herbalists, bone-setters, naturehealers, abortionists, venereal and consumption speeialists, hernia and cancer quacks abound. As in Gemany, they are punished when caught in heinous malpractice or murder, but they are usually too shrewd to be caught.2 The British Medical Journal devoted a whole number to the exposure of quackery in 1911. In France, there are better laws, but they are not rigidly enforeed. America has been a paradise for quacks, from the time of Perkins down. Nowhere have patent medicine vendors made so much money.

1 see, in addition to Flexner's observations, H. Magnus: Die Kurierfreiheit, Breslau, 1905.

"The ease against the "healers" of the novelist Harold Frederie, whose death at the hands of these "Christian Scientists," in 1898, was, as Bernard Shaw puts it, "a sort of sealing with his blood of the eontemptuous disbelief in and dislike of doctors he harl bitterly expressed in his books," was reluetantly dismisied by Justiee Hawkins at the Central Police Court, London, on the ground of insufficient evidence as to Frederic's own part in the transaction. The supposed private "right" of a person to do imbecile things, even to his own detriment or destruction, is a delicate pcint in legal and political casuistry, but it was rleciderl adversely, as we have seen, by the U. S. Supreme Court, in the case of those who are in a way to becone a public nuisance. 
"What need of Aladdin's lamp when we can build a palace with at patent pill" was one of Lowell's witticisms, and it illustrates the easy-going, humorous, Amelican tolerance of humbuggery and fraud. The complex scheme of medical laws in our several states is inferior to the English system, which has a fow liberal laws, seldom changed through the centuries, but susceptible of an elatstic interpretation where the merits of the ease require it. As nuder our divorce laws, a divorced or separated couple may change their marital status as they cross successive state lines, so a borier physician in Indiana was non-suited for his fee for the after-treatment of an amputation over the state line, although the operation itself was excused as within the legal exception of an emergency; and a confidential communieation made in New Jersey by a Colorado patient was held not to be privileged when the Jersey physician gave testimony in a Colorado court.' People tend to become lawless through a multiplicity of uscless laws, an odd contrast to the simple common law book of switzerland, which any peasant can understand and use. The difficulties with a multiplex system of laws are sensed in Lord Beaconsfield's aphorism that where the soeial order is very strong (in rural communities) it ean put up with weak govermment; where the social order is weak (in large cities) it requires strong government. The whole theory of interpretation of existing law is contained in Bismarck's view that there are times (e. $g .$, in peace) when government must be liberal, and times ( $e \cdot g$. , in war) when it must be despotic. "Everything changes, nothing is constant here below." As it is, quacks have eommonly thriven best in our liberal and thickly settled states and cities and not at all in the agricultural districts of the South, where doctors are few and socicty is very strong. So long as therapenties is what it is, quackery is almost beyond the reach of legislation, and, as in France, rigid legislation might tum out to be a farce. The newspapers, reaping the harvests they do from advertising quackery, are indifferent, although the location, citation, and exposure of quacks and quack medicines have latterly afforded rare sport for keen-sighted journalists who are something more than pressmen. The only serious attempts to take up the cudgels on behalf of the public are those made by the British Medical Association and the American Medical Association.

The British Medical Association was organized on July 19, 15:32, in the board room of the Worcester Infirmary, at the instance of the late sir

'See, on this head, the able legal study of C. A. Boston in Med. Times, N. Y., 1916, xliv, i, $113 ; 15: 3$.

2 The advertising and sale of secret and unoffieial remedies was interdieted in France by the laws of 1803 and 180.5, which have wallaly been ignored. (G. Bourgeatu: Paris diss. No. si3, 1916, p. 37.) 


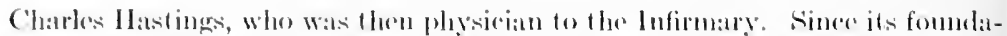

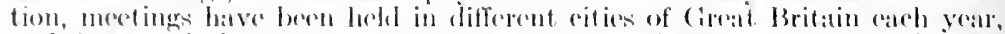
and the Association now has many home and colonial branches. Its publishod

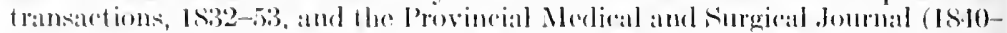

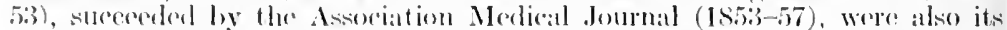
olyans unt il the British Modical Jommal was fomderl in 1s.5. As representing the muited profesion of timat Britain, the Asocelation has played an imbertant part in the development of lenglish modicine in the morlern poriod, particularly in medioal reform, looking after parlianentary bilk relating to public health locrislation and poor laws, and in the exposion and rensure of guackory, patent nostrums, and other fratuls. In 1909, it publisherl "ficeret. Remudices," il eonvenicut directory of enrent nostrums.

li 1817 , the American Medical Association was organized, owing its inerption to a national convention of delegates from medical soceretios and colleges alled by the Mediral society of Now York siate, largedy through the offorts of Nathan Smith Davis, to improwe the then disgracoful status of modical rolucation in the United States. Buring the first fifty years of its rxistruce it atetivitios mere confined to discussion rather than aceomplishment, and its nombership was limitod to specially aleeted delegates. Since its reorganization at sit. I'aul, in 19()1, memhership in the $\Lambda$ ssociation has been hased upon memborship in the state modical soevetios, which are again hased upon membership in the eounty societics. Both state and national olganizations have a specially clected Howise of Delegates to transact husiness, whieh welds the whole profesion of the country into an efficient organized borly, capalsle of accomplishing things. Under the earlior dispensation, tho aims of the $A$ ssociation wore restrieted mainly to the narrower problems of modical othies; its present purpose is largely the direction of public opinion in regard to pullic liygienc and medical reducation. In spite of much opposition, the Association, in the last twolve yoars of its existroce, has aceomplished many important things, first and foremost, in checking, through its Couneil on Phamacy and Chemistry, the exploitation of the medical profession by patent modicine makers and the swindling of the people by quacks and quackery, special records of "Now and Non-Offeial Remedies," proprictary medieines, diplomatmills and other frauds being kept and pulblished for publie use. It has vastly improved the status of the state medical societies as to increase in membership and efficiency, so that where formerly the state socioties published moager volumes of "transactions" at rare intervals, there were, by 1910 , some twenty-t wo state socicty jomrnals, a groat improvement in the contralization of periodical literature. The Council on Medical Education (1904), has, through its propaganda in the last eight years, fone much to decrease tho mumber of low grade medioul schools and eonseguently of incompetent or unkerupulous physicians. It has also dene much to secure four-yoar courses and "full time" professors for the more scientific disciptines. According to data recently supplied by the Assoeiation, ${ }^{1}$ there have been some 335 medical colleges, with 118 other institutions of dubious character, in the Inited States during the periol 1765-1913, of which there were 6 in existence in $1810,160 \mathrm{in} 1904.95$ in $1816-17$, and 88 in 1920 , of which 75 ale non-sectarian, 5 lomeopatbic, 1 eclectic, and 3 nondeseript. Since 1904, 94 medieal sehools have ceased to ('xist, 53 by merger, 41 by extinetion. During 1912-13, some 14 medical colleges were closed, and 2 in 1916-17. In 1919-20, there were 14,08s medical students, as against 28,142 in 1904 and 18,412 in 1911 ; and 3047 medical graduates for the vear $1919-20$ as against 2673 in 1850,5747 in 1904 and 2656 in 1919 . These decreases indicate, of course, the prospect of a corresponding average improvement in quality. There are "fewor but better colleges," 57 of which have met the improved requirements for admission of the Assoriation of Ameriean Medical Colleges (January 1, 1912). The present proportion of physicians to the total population of the Enited States is $145,608: 105,708,771$, or one physician to every 69] persons. In proportion to the actual population, South Dakota has the smallest supply of physicians (1:1160) and the District of Columbia

1 Jour. Amer. Med. Assoc., Chicago, 1920, lxxv, 379-415, passim. 
the largest ( 1 : 365), exelusive of some 500 government pliysieians who do not practice (otherwise $1: 259)$. Thirtern State lieveing boateds have recently insisted on higher preliminary repuirements. Finally, through its Coumeil on Health and Public Instruction, tho Asisociation las now puldie speakers in pratieally every stats of the I nion, who instruet the people directly in regard

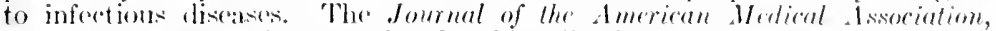

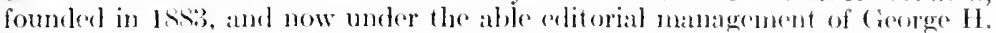
Simmons, las stearlily advanced to a position corresponding with that of the British Medical Jomrial in Enghand or the Detseche medicinische Horhensehrift in Cirmany?

There is no modern science or group of seiences which has so many eurrent periodicals as medieine. In striking contrast with the eighteenth century, which had hardly any medieal journals, our own time, particularty our own cometry, has literally swarmed with medieal journals, many of which are, ats the Germans say, Eintagsflegen-of ephemeral duration. Each of the latter has, or has had, its use in some particular locality or as subserving the interests of some theory or sect, some "ism" or "pathy." There are too many medieal periodicals in the modern world. Mr. Charles Perry Fisher estimated some 1654 caurent up to January, 1913.' Of these, 630 are American, 461 (ierman, 268 French, 152 British, 75 Itatian, 29 Spanish. Mr. H. (). Hall, of the Surgeon General's Library, estimates some 1895 on hand in $1916-17$, and 1240 in 1920-21. In the first series (1880-95) of the Index Catalogue, 4920 medical periodicals were indexed: at the end of the fiseal year, June 30, 1916, the total mumber ind lexed (1880-1916) was 8289. The great number of medical periodicals, ats of medical societies, in the Inited States is due, not to social or scientific conditions, but, as in Russial, to the extent of national territory and to the expansion of eities. ${ }^{2}$ All eomntries have periodicals which atre obviously "home-grown" and intemed for home consumption. As a rule, the journals of the latgere citiesBoston, New York, Philadelphia, Chicago, New Orleans, and others-are of botter cunality and of more metropolitan chatracter than those of the sereral states, but some of the latter have attained a much higher standard by the centralization of states medical sorieties, through which the state medieal journat is also the organ of the state medieal society.

Following the Nerlical Repocitory (1797-1524) eame, in order of time, the

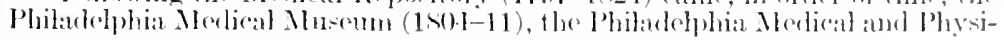

1 Bull. Merl. Library Asooe, Balt., 1913, n, s., ii, 22,

${ }^{2}$ In 1sit, Dr. James R. Chatwiek, late librarian of the Boston Medieal Library, saill: "In England, it is possiblo for those who are spercially interested in gynerology and obstetries to attend the meetings of the (Obstatrical soeder of Lonelom, at actually bappens, whereas in Aenerica the distanees to be traversed are so great ats to render this impersible." (Bostom Mled. and surg. Journal, 1881, ev, 245.) At the present time there are national Americad societies of all the specialties, which meet annuatly. 


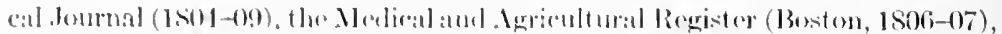

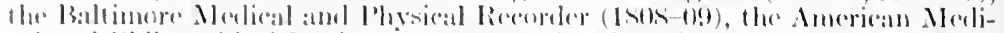

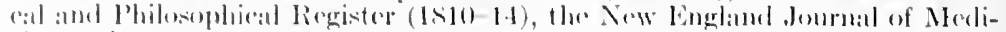

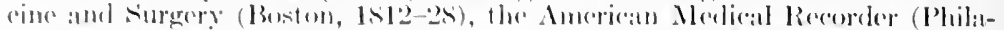

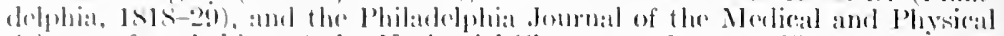

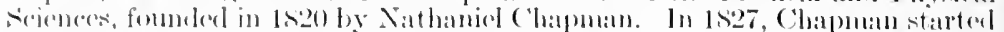

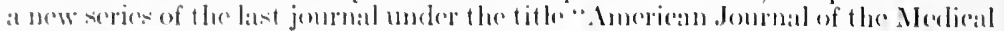

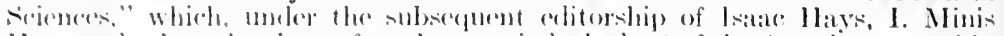
llays and ot hers, hate been, for al long periond, the best of the Ameriean monthly merlieal perionliats. Among the best of the medical werklies have been the

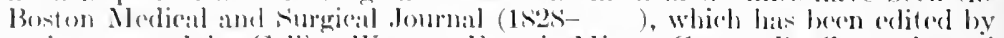

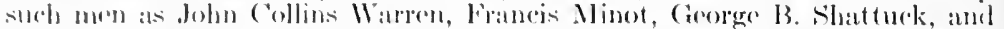
others: The Merlical Nows (Philadelphia, 18:3-1905), foumled by 1. Minis

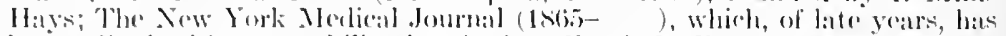
beren colded with oreat ability hy the late framk P. Foster (1s11-1911) and

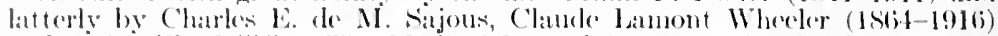

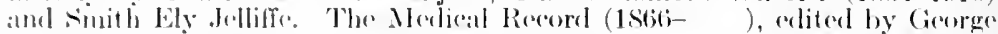

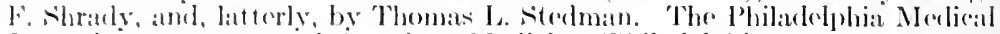
Journal (1s95-19013) and Imeriean Medicine (Philadelphia, 1901- ) wore originally edited by (ieorge M. (ionld. Among the best periodieals devoted to -precial subjects are The Ameriean Journal of Obstetries (New York, 1 stis-

). founded by Emil Noeggerath and Abralam Jacobi; The Amals of surgery (18si)- ); The Ameriean Journal of Physiology (Boston, 189S). The Arehives of (Ophthalmolegy and Otology" (Now York, 1869- ), founded by IJerman linapp; The Journal of Experimental Medieine (New York, 1896- ), founded by William H. Weleh; The Journal of Infeetious Diseases (Chieago, 1904-_ ), founded by Ludvig Hektoen; The Journal of Biological Chemistry (New York, 190:- ), founded by Christian $A$. Herter; The Journal of Medical Researeh (Boston, 1896- ); The Journal of Morphology (Bo-ton, 1857- ), founded by the late Charles O. Whitman, the Journal of Experimental Zoölogy (Baltimore, 1904- ), edited by Ross (iranville Harrison, and the Journal of Laboratory and Clinieal Medievie (St. Louis, 1916), founded by Vietor C: Vaughan.

The better sort of medical periodicals may be roughly divided into three classes: those devoted exclusively to purely scientific and experimental-researehes: those devoted to the specialties; and those which include, along with clinical and surgical cases, papers, original or sophomorical, upon set subjects, reports of progress, abstracts, reviews, translations, historical tidbits, facetia, and medical gossip. In periodicals of the first class, Germany takes the lead in number. In respect of quality, the transactions of such learned bodies as the Royal Society of London, the scientific arademies of France, Prussia, Saxony, Bavaria, Austria, Italy, or the Socicte de biologie of Paris, stand first, as regards occasional rontributions to physiological science. Then come the publications of university laboratories and clinics, of medical sorieties, institutes, and other foundations, in relation to which the titles Annalen, Arbeiten, Archir, Beitrïge, Berichte, Centralblott, Jahrbuch, Mitteilungen, Monatsschrift, Sammlung, Verhandlungen, Teröffentlichungen, Tierteljahresschrift, or Zeitschrift usually connote something of positive value, just as Blätter, Correspondenzblatt, Calender, Organ, Repertorium, Wochenschrift, or Zeitung have a more dubious implication. Of annual pub- 
lieations, Ergobmise contain valuable résmnés of current sceientific work; Iahresberichte, the equivalents of our your-books, are wsoful for bibliographical reference or statistical ampilation. Is a rule, the periodicals dovoted to anatomy, physiologer, barteriologr, psychology, anthropology, surgery, or the different medial spercialties are good of their lind in any combry. The veterinatry joumals are sometimes of better quality than the dental. Homeopathic jommals are almost uniformly poor, and jommals devotor to osteopathy, antivivisection, and other fads have no seientific value whatever. Of the general medieal periodicals of the third class, the Wochenschriften of the larger Germanic rities-Berlin, Munich, Viema-the British Medical Jomrnal, The Lancet, and the jourmals of the larger cities of (meat Britain-Edinburgh, Cilasgow, Dublin, Bristol-are all of the best quality. The corresponding publications in the Latin, Scandinavian, and Slavic comntries are of monequal value. Aside from decarlent literature, almost anything printed in France is well written, and the witty fenilletons in the Parisian medical journals are no exception to the rule. Some, like the chronique módical, are capubles de tome in this respect. Many of the French and Italian wecklies are printed on large, inconvenient sheets like newspapers, which suggests the advantages of Ostwald's idlea of a definite Heltformat, a miform size and shape for all scientific books and periodicals. An undesirable feature of the smaller-sized Latin periodieals is the actual advertisement of nostrums within the text, or the hinding of such advertisements between the leaves of the jommal. Italy is practically the only eountry which glorifies the names of its great and small reputations eponymically by bestowing them upon medical periodicals, as in the asse of Cesalpimo, Cirillo, Ercolani, Fracastoro, Cialiani, Cingliplmo da saliceto, Imyrassia, Malpighi, Horgagni, Orosi, Pisani, Ramazzini, Selmi, Spallanzani, Tommasi. Most of the spanish medial jommals are inferion even to those of South Americal in quality. The beantiful language of Spain is a social rather than a sceientific meclime, and much of her medical literatume is takes up with rhotoric and problemes pora solucionar. Printed with aniline inks upon inferior priper, most of om valued merlieal produrtions will have armubled or their contents faded away in a century or more, and criticism of medical periodicals seems idle or mengrabioms. The slightest of them may subserve a usoful purpose in sotting some anxions inculuer upon the path of study or of original investigation. Walsh, in his studies of medieval medieine, has emplasized the falet that the

"The Dutch journals "Pieter Camper," and "Boerhave" are other examples. 
human mind soon tires of diffieult or insoluble problems, and may drop a subject for conturies. To insure continuity of interest there must be constant rejuvenation and restimulation, and in no phase of modern activity is it so imperative that the secientific spirit shomld burn and shime like a sarered fire, as in the field of medicine. The highest function of the medieal jommalist today is to introduce new eurrents of seientific ideas and to keep them in circulation. The public would be much better protected from quacks if onr nowspapers drew their information from reliable replesentations of the morical press, instead of from reporters, mutrancel in sorence and with a mania for advertising the sensiltionil.

One of the most striking features of modern medicine was the tendeney toward internationalism, even on the field of battle. In 1862, Incmi Dumant (1828-1910), a Swiss philanthropist, publisher his "somvenir de solferino," and this accomet of the barbarities of warfare led to the Intermational Conference of the Red Cross Societies at Geneva in 1863, and to the signing, on August 22, 1864, of the Geneva Convention, in which fourteen different States pledered themselves to regard the sick and womnded, as also the army medical and nursing staffs, as nentrals on the battlefield. This movement was warmly supported by Queen Augusta of Prussia and the Grand Duchoss Maria Pavlovna of Russia, and today its intention is carried out over all the civilized world.

In $1 \times 67$, the first international medical congress was opened at Paris, at the instance of IJenri Guitrac, to be followed by those at Florence (1869), Vienna (1s73), Brussels (1575), (ieneva (1877), Amsterdam (1879), London (1)s1). Copenhagen (1854), Washington (1857), Brrlin (1890), Rome (1894), Moscow (1597), Paris (1900), Madrid (1908), lisbon (1906), Budapest (1909), and London (1913). It had already been preceded by international eongresses on statistics (Brussels, 18,j1), hygiene and demography (Brussels, 1852), ophthalmology (Brusiels, 1857), veterinary medicine (Hamburg, 1S63), anthropology (Spezia, 186.5), and pharmaey (Brunswick, 1S6.5), and was followed by a series on otology (New York, 1s76), laryngology (Milan, 18s(0), criminal anthropology (Rome, 1555), tubereulosis (Paris, 1858), dermatology (Paris, 1589), physiology (Basel, 1889), psychology (Paris, 1890), grnecology and obstetries (Brusels, 1892), aleoholism (Brussels, 1S94), tubereulosis (Paris, 1895), leprosy (Berlin, 1s97), dentistry (1900), surgery (Brussels, 1902), care of the insane (Antwerp, 1902 ), unificition of heroie reinedies (Brussels, 1902), milk (Brusiels, 1903), habitations (Paris, 1904), school hygiene (Nuremberg, 1904), physiotherapy (Liège, 190.), eancer (Heidelberg, 1906), pellagra (Turin, 1906 ), occupational diseases (Milan, 1906), epilepsy (Budapest, 1909), tropical medicine (Manila, 1910), comparative pathology (Paris, 1912), eugenics (Lonlon, 1912), and history of medieine (Antwerp, 1920). These are only a few of such international gatherings, which include almost every speeialty.

1 This is now the ease with the leading New York newspapers. For the harm done by the press in misleading statements and flamboyant advertising of proprietary remedies and quack procedures, see the Paris thesis of Dr. Georges Bourgeau: Les erreurs et les dangers de la grande presse en matière médicale, 1916 , No. 83. 
Another sign of the international spirit was the award of the Nobel prizes for medicine to von Behring (1901), Ronald Ross (1902), Finsen (190)3), Pavloff (1904), Foch (1905), Golgi and Ramón y Cajal (1906), Laveran (1907), Metchnikoff and Ehrlich (1908), Kocher (1909), Kossed (19)10), (inltstramil (1911), Carred (1912), Richet (1913), Bárány (1914), Bordet (1919), August Krogh $\left(19^{2} 0^{1}\right)$, as also to Roentgen for physies (1901), Emil Hischer for chemistry $(1902)$, and INenri Dunant for promotion of peace (1901).

In America, men of ereat financial resources have outpaced foreign govermments in liberal endowments for scientific and medical rescarch.

The recent war, a betrayal of European humanity by some of its overlords, turned the world's elock back, upset all previous calculations, overthrew the results of a hundred years' patient, devoted work for social betterment. In the twinkling of an eye, nations accredited with the highest civilization, lapsed into the barbarism and, by Newton's third law of motion, the neeessity of fighting for their existence was literally rammed down the throats of the Western nations, including the United States. Though we have scientifie eriteria of evil, dimly apprehended by theologians, but known to all scientific men, no great European statesmen existed to save Europe from destruction; no stern Tacitus or Dante or Hugo lived to denounce the crimes of kings or the monstrous designs and pretensions of their vassals.

The close of the war disclosed the peoples of Eastern Europe starving and nationless, "eddying at large in blind uncertainty," the vagrant terre filii of the Dark Ages, willing to make any man leader who might give them bread.

The opening of the war revealed Ciermany in a state of perfect military preparedness, England and France in a state of partial preparedness, and our own country in the gerundive state of being about to be prepared. Yet, twenty months after our entry into the war (April 6, 1917), the armistice was signed (November 11, 1918).

To raise medical personnel, England had to draw some 11,000 eivilian practitioners; in France, the whole medical profession was mobilized; and in our army, expanded twenty-fold over the aruny of 1919 , no less than 29,602 physicians were in uniform as reserve officers. Welch, Vaughan, Flexner, Billings, Thayer, the Mayos, Finney, Cushing, Crile, Camnon, in fact, the élite of our Aneriean profescion, flocked to the enlors. Under the arhinistration of the late General William C. Gorgats, the Surgeon General's office wats expanded to gigantic proportions, commensurate with our far-flung array of 32 training camps, each a community of 30,000 to 40,000 soleliers. On the Western front, modical administration was an affair of providing for the supplies, sanitation, hospitalization, medieal and surgical serviees of immense training areas, hospital areas, hines of communication and miles of trenches, while the open fighting at the end of the war brought up a new problem, the complex sanitation of great moving armies. The chicof surgeons of the American Expeditionary Forees during the fighting period were Cenerals

1 No awards of the Nobel prize in medicine were made during 1915-1s. 
Merritte W. Iroland and Walter 1). MICaw. The medieal estahlishment of the British Army wats alministered by Gencal Sir Alford limogh and later (iencral sir foln Goodwin, that of the lirened Army by M. Simonin (1stit1920), Thullier and Justiu (iodart. The Surgeon (ieneral of the Gorman Arury

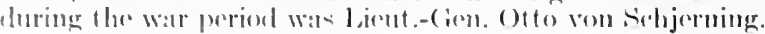

For medieine, the greatest trimmph of the war was in the direct application of the science of infections discases to military sanitation, in this ease the group sanitation of armies of millions. This is the first war in history in which the mortality from battle casualtics has exceded that from communicable diseases. In the Europen War, the official German losses were 1,531,048 killed, 4,211,569 wounded, and 155,013 died from disease. In our ('ivit War, there wore 44,238 killed in action, 246,712 wounded, 31,978 (10.18 per 1000) died from wounds, 186,216 (61.0.t per 1000) died from disease. In the World War, 34,249 of our forces were killer in action, 224,089 wounded were admitted to hospital, of whom 13,691 (4.5 per 1000) died, and 50,714 (16.67 per 1000) died from disease. Thus there were four times as many deaths from discase in the Civil War as in the World War, while our recent death-rate from wounds in hospital was reduced one-half. In other words, the next greatest medical achievement in the World War was the conquest of wound infection. Trench warfare in soil contaminated by decades of cultivation made every soldier a potential bacillus carrier, and on the Western front the revival of Listerism (antisepsis) was a foregone conclusion. Passing through the experimental phases of dressing with colored antiseptic pastes, salt pack and hypertonic solution (Wright), there was at length evolved the physico-chemical principal of wound irrigation by a solution of a gas in a liquid (Carrel-Dakin), and later, the mechanical principle of débridement or wound excision with primary suture (Cray-Lemaitre). H. D. Dakin's device of setting free chlorine gas from sodium hypochlorite or dichloramine-T constitutes the most refined antisepsis. The excision of all devitalized wound tissues prior to suture is an aseptic principle of the first order, destined to be of capital importance in industrial or future war surgery. These were the only advances made in Western front surgery, the rest of which has been well described as a general harking back to first principles. ${ }^{1}$

In internal medicine new and strange pathologic concepts came into play, such as the longitudinal sinus disease, Volhynian (five-day) fever, trench-foot, trench-nephritis, spirochætal jaundice, the toxic jaundices from picric acid, trinitrotolnene and tetrachlorethane poisoning, the terrible effects of gassing, the disorders

${ }^{1}$ M. W. Ireland: Jour. Am. Med. Ass., 1921, lxxvi, 763-769. 
of peripheral nerves and the nemotic effects of emohot womme of the nervous systen, partioularly from shell shock and wind contusion, gas gangrene from the batcillus Woldhii, and other complications of wound infection.

The mental tests of Binet and others were introdued into om recruiting system for the first time by Robert $M$. Verkes (1917), and revealed the large pereentage of twolve-year-old minds in modern populations. Psychology and neuro-psychiatry did much for mobilization by weeding out mental defectives, always bat risks for armies. The notley complex of nemrotic phenomena going under the name of "shell-shoek" was earefully studied by F. IV. Mott, T. W. Salmon and others; and great impetus wain given to the study of wound shock by the investigations of W. T. Porter, Camnon and Crile. The effects of gunshot wounds on peripheral nerves were intensively studied by Maric, Mne. Athanassio-Benisty, and many others, including the Peripheral Nerve Committee of our Medical Corps. Camptocormy was described by Achille Souques in 1916.

Of communicable diseases, measles, mumps and moningitis smote our camps heavily during 1917-18, due to the fact that comtry boys, being seldom exposed, are non-immune; and the great epidemic of spanish influenza (1918-19), with its complicating pnemmonias and empyemas, was more fatal everywhere than the war itself. That measles is a respiratory affertion, transmitter via the air-passages, was emphasized ly E. L. Munson in the Texan epidemic of 1917, and from that time on interest lecame concentrated on the sputum-borne infections (inchuding meastex, meningitis) as the outstanding problem of preventive medicine. Contact infection by hand and hreath beeane of eardinal importance, since the first principles of public hygiene were obliterited in the slave-ship overerowding of puhlie vehicles and places, eonsefuent upon war conditions everywhere. The pmommomias, including the typing of pneumonia bacilli, were investigated, at the Rockefeller Institute and elsewhere, hy Wr. (i. MacCallum, Rufus Cole, A. R. Dochez, O. T. Avery, ('. (i. Bull, Joseph Miller, It. E. Inons and J. A. Capps; influenza by ('ole, Arely, and s. H. Jacols: Streptococeus hemolyticus infection by (). T. Avery, R. A. Kinsolla and H. F. Swift; the surgical aspects of the empyomas by s. K. Dunham, Bell, Graham, Finsella and Stevens of the Enpyema Commission of the Enited States Army; exporimental parotitis by Martha Wollatein; meningitis by Simon Flexner; 1 uberentosis by G. E. Bushnell; typhus fever by II. Plotz; anthrax by Richand Pearce: erysipelas by A. B. Kanavel and paratitio infertions by C. A. Kofoid. The net result of watr expeliener was the nowel hygienic principle that the infected or exposed individual is more 
dangerous to society than the disease itself. Commmnity welfare now demamels, not only isolation of anders, contacts and suspects, hut also education of the individual to realize that, as long as he is a disease carrier, he must voluntarily protect the community from himself.

That trench ferere (l'. T. ().) is a lonse-borne infection was realized by the British Commission under (ien. Sir Datvid Bruer and finslly demonstrated by the Aneriean Commision under R. P'. Strong. The relation of pediculosis fo typhus (noted by 'Tohias Cober in 16060 ), berame of noment on the lastern frent, partieularly in Siervia, where many Americats physicians suceumbed 16 the discise. In the trenches every soldier became lousy and "Fighting the Coolie," by the various methods of delousing, taxed the ingemuity of atl military sanitarians at the front. Spirochetal jaundier (Wril's disease) was investigated by R. lnada and Y. Ito (1914-15), E. B. Krumbhatar, Adrian stokes and others: effort srndrome (D. A. I1.) by 'Thomats Lewis. 'Trench

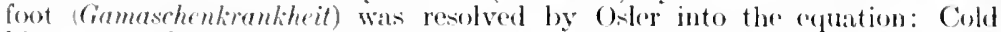
bite + nussele inertial = trench foot. Volhynian fever was first deseribed by 11. Werner (1916). Ender the leadership of Coneral sir Robert Iones, 11 . Moresin and others, orthopedic or reconstructional surgery of mangled bones and limbs was materially advaneed in England. "In the treatment of gunshot fractures, the use of continuous extension by the Hodgen splint and Batkan frame greatly accelerated the evaemation of the wounded and their prompt return to duty. In Belgimm, C. Willems substituted the principle of arly active mobilization of joint lesions for the old arthopedic teaching. lininakable was the work of Alexis Carrel at Campiegne on wound treatinent, of Crile, (iwathmey and Marshall on gas-oxygen anesthesia, of H. D. (iillies (Nideup), Delagenjè̀re (Le Mans), H. Morestin (Val de Grace), A. C. Valadier (Boulogne), Derwent Wood (London) and of Hayes, Hutchinson, Blair and other Americans at Neuilly on maxillo-facial surgery, of J. A. Blake (Neuilly), M. Sinclair (Wimereux), H. D. Souttar (Netley), R. Leriche (Lyons) and of Gosset, J. P. Goldthwaite, I1. Osgood, N. Allison and W. L. Fieller on fractures and splints, of Pedro Chutro (Paris) on fractures and bone-sinuses. of H. Cushing (Boulogne) on brain surgery, of Nlorestin, (Chutro and Gosset on "ranioplasty by cartilaginous grafts, of Stassen (Port Villez) on amputation, of Tuffier (Paris) on reamputation, of Vanghetti on cincplastic amputation, :Ind of Arbuthnot Lane, Calot, Tuffier, Morestin, P. Bistianclli and E. Lexer (Hamburg) on general plastic and orthopelic surgery. Reconstruction and reedueation of the disabled, planned in Germany ten years before the war, has been carried forward evervwhere on a grand seale, and vocational rehabilitation, adumbrated by Juan Luis Vives (1531), is now a matter of national administration.

The physiological requirements of aviators and the pathology, prevention and treatment of war-gassing were entirely new subjects, in the development of which American medieal officers played an important part. Notable contributions to the pathology of war-gas poisoning are the studies of Sir Leonard Hill, A. S. Warthin, M. V. Winternitz, and F. P. Underhill.

Through infant welfare activitjes, in the very mirlst of the war, the infant death-rate was, in 1916, brought down to 91 per 1000 in England, and 97 in scotland, in both cases, the lowest on record. In Germany, although 40 per cent. fewer babies were born in 1916 than in 1913, the infant death-rate of 164 in 1914 was well kept down thereafter. In France, due to the increased emplorment of women in munition factories, there was a steady rise in infant mortality after $191 \overline{5}$, reaching 126 in 1917 . As the war-time birth-rate was 50 por cent. less than normal and 40 per cent. less than the annual death-rate, France was facing national extinetion. Uniformed infant welfare units were therefore sent overseas by the Red Cross, under direction of William Palmer Lueas, numbering many of the leading pediatrists of this country. Through their activities much beneficent work was done for the children of France. 
Remarkable suecess was attained in the prevention of trphoidal infections by trivalent vaceines, in the tetraviecines employed against typhoid, the two paratyphoids, and cholera, in the treatment of burns by the paraffin-resin solution (ambrine) of Barthe de Sandifort (keritherapy ${ }^{1}$ ), in the purification of anmy watersupplies, in the localization of projectiles in the body by the Hirt compass, the electrovibrator of Bergonie, and by radiologic methods, in the wonderful prosthetic devices speedily improvised to serve as artificial hands and limbs, and in the training of the badly mangled defectives, of the blind and deaf and of "ircliac, pulmonary, and neurotic defectives for future efficiency in life.

Nuch as the friends of our common humanity may atspire toward Kant's noble ideal of a Eniversal Peace, the constant shiftings and migrations of peoples about the surface of the globe, the impermanenee of national alliances and their effects upon history, the fact that democracy is not (like monarehy) an absolute form of government, but an education of the people for citizenship, the actual existence in nature of peaceful and warlike (or predatory) races side by side, the conmereial rivalries of nations and the hatred of the "have-not's" for the "have's," make the inmediate future of humanity extremely dubious. Wars are "wished" upon peaceful and friendly (and therefore defenseless) nations through the concatenation of political intrigues and events. The example of the sturdy little republic of Switzerland goes to show that the only way in which wars may be avorded or invasion repelled by these nations in the immediate future is through the rational manful course of physical and military preparedness, the apotropaic signifieance of which was strongly signalized by the late Sir Lauder Brunton during the last seventeen years of his life." It is strange that most of the blame and odium for the evils wrought by wars should be visited upon the heads of the soldiers and army surgeons who risk their lives to fight the battes imposed upon their respective countries. Modern wars are usually made by the commercial rivalries of nations with the consequent appeals made to race-hatred and moh-sentiment by "mad monarehs," "racial biologists," irresponsible historians and sensational journalists. In this regard the dictum of the French psychologist that "the collective intelligence of a crowd is usually less than that of some one of its individual members" is well worthy of consideration. Yet the mass of mankind eamnot be held entirely responsible for the errors made by the moulders and directors of

- 1 Barthe: Jour. de méd. int., Par., 1913, xvii, 211-214. 1915.

${ }^{2}$ Brunton: Collected Papers on Physical and Military Training, London, 
public opinion. Concerning the "quam parta sapientia mundus regitur," Jaregues loob has recently voiced an aspiration which is a distant, perhaps an matlainable, ideal:

"If we sueced in substituting for the present a new type of statesmen whe : re familiar with and follow the development of the exact-i. e., the experimental and quantitative-scienees, and who are willing and eapable of applyine the results of exact seienee to the intellectual, noral, physieal, and cemomiend uplift of the matseses, we shall at least diminish the danger of war."

\section{In the same key Ostwald says that-}

"sidene may therefore be comsidered as the surest and most lasting part of the spiritual treatsure which man posisesses. Such predictions as are endersed by seienee are iecepted as the most reliable ones by the intelligent matjority of men."

\section{President Eliot remarks that}

"the devotees of matural and physiend scienee during the last hundred and fifty rears have not shown themselves inferior to any other class of inen in thitr power to reason and to will, and have shown thenselves superior to any other "lass of men in respeet to the value of worth to seciety of the product of these powers. The men who, sinee the nineteenth century began, bave done most for the human race through the right use of their reasons, imaginations and wills are the men of science, the artists and the skilled eraftsmen, not the metaphysievans, the orators, the historians, or the rulers."

In regard to the actual cliseases of society, very few statesmen and statists see that, as the wise Pagel said, all nations have to go through the diseases of infancy, ehildhood, and old age-to get rid of graft, alcoholization, and syphilization of the people, the production of degeneracy by the oppression of the poor (the roots of the tree), the corruption of the people by pornography, commercial exploitation of prostitution, and the deliberate inbreeding of thieves and harlots, the external fraus innexa clienti with a whole nation as client, ret even adult nations may be at the mercy of Casarism and psychic diseases of the masses.

\section{"Quiequid dehrant reges, pleetuntur Achivi."'2}

Whether war will become a vanishing fraction in human affairs is, therefore, dubious under present conditions of the world's economy. But the whole duty of the medical profession is plain. In wartime its device has been "inter arma caritas," and when wars and rumors of wars have again passed away, our profession may do what it ean to promote, "with charity toward all, with malice

1 J. Loeb: Science, N. Y., 1917, n, s., xly, 7t.

2 "Kinder- und Entwicklungskrankheiten muss ja jedes Volk durchmachen, of sehen wir aber auch sehon entwickelte Kurlturnationen von traturigen Kämpfen hemgesicht." J. Pagel: Cirundriss cines Systems der medizinischen Culturgeciehichte, Berlin, 1905, p. 77. 
toward none," the sentiment of peace and good will among mankind, who are its true dients. In 1915 Dr. Sammel J. Meltzor founded a Medical Brotherhood for the Furtherance of International Morality, based upon the concept that while individual nations are civilized, with decent comity and humanity within their own boundaries, humanity at large is not; that there is an abyss between intranational and international morality, and that no matter how highly cultivated or enlightened nations may be, they still tend to settle their difficulties by brute force-ly killing and maiming their adversaries. This brief for intranationalism as well as internationalism deserves the future consideration of merlical men in all countries.

Concerning the effect of scientific research upon medicine, the physicist Rowland has spoken with a force that is apocalyptic:-

"The ordinary erude mind has only two eompartments, one for truth and one for error; indeed, the contents of the two eompartments are sidly mixel in most cases; the jeleal seicntifie mind, however, has an infinite number. Each theory or law is in its proper compartment indicating the probability of its truth. As a new fact arrives, the seientist ehanges it from one eompartment to another so as, if possible, to always keep it in its proper relation to truth and error. . . Natural laws there probably are, rigid and unchanging onc's at that. Understand them and they are beneficent: we ean une them for our purposes and make them the saves of our desires. Misunelerstand thrm and they are monsters who may grind us to powder or erush us in the dust. Nothing is asked of us as to our boliof; they act unswervingly and we must understand them or suffer the conseguences. Our only course, then, is to act aceorling to the ehances of our knowing the right laws. If we alet eorrecetly, right; if we act incorrently, we suffer. If wo are ignorant, wo die. Whit greater fool, then, than he who states that beliof is of no eonserpuenee providerl it is sincere. An only child, a beloved wife, lies on a bed of illness. The physician says that the disease is mortal; a minute plant called a microbe hats obtained entranee inte the borly and is growing at the expense of the tissues. forming deadly poisons in the blood or destroying some vital organ. The physician looks on without being able to do anything. Daily he eomes and notes the failing strength of his pationt and daily the patient goes downwarl until he rests in his graws. But why has the physician allowed this? Can wo doubt that there is a remerly which shall kill the microbo or neutralize its poison? Why, then, has he not neel it? Ho is employed to eure, but hils failex. His bill wo eloerfully pay beeane he has done his best and given a

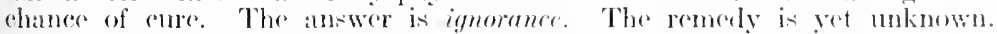
The plosicedan is wating for others to eliseover it, or porhaps is experimenting

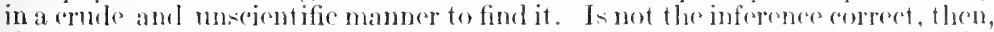
that the worlel has heen paving the wrong alass of mon? Ifonlel not this ig-

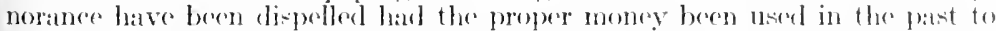

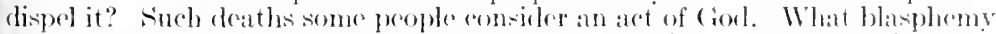

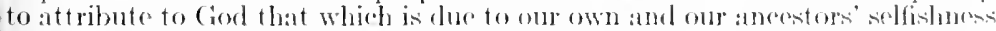
in not founding institutions for molical rovearoh in sufficient number and with

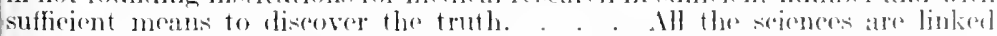

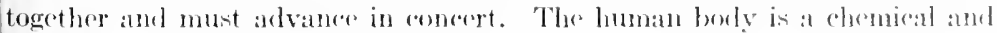

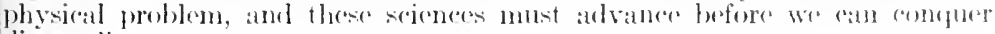
discave."

1 Meltzer: Serenee, N. Y., 1915, 11. ×., xli, 515-523.

${ }^{2}$ H. A. Rowland: An. Jour. Sc., New Haven, 1s99, 4. ¿., viii, 109-H1. 
This pronomement, of rightern yous ago, is now "ancient history" and may sem to mamy omotional and ommonoled. But it sombi not be forgotten that the man who mate it believed with intense convietion that sorentific rescalleh implies "that love of truth, that are in its pursult, and that humility of mind which makes the possibility of error always present." In the attempt to bridgo over the vast gap betwern the microcosm which is aceessible to onr semses and the unknown miverse which lies beyond om ken, the hmman mind reveals itself at revery tum as a very foeble instrument of precision. Top-heaviness is not for secience. For centuries solence, as Huxley said, "hats played the gart of ("inderella." If she is to retain her eharm and fascination, she must not berente too vain nor make unduly extravagant elaims. As Bais has (puaintly observed: "When the smmmit of anything is reached, all paths laal inevitably to the bottom."

The high function of the physician is still the relief of human sulfering, not merely to drug his patients, but to are for them; and, as the surgeon must know how to think dinically, the elinician to think surgically, at need, so it is possible that, some day, the word "cure" will, as part of the same Hipporratic ideal, be restored to its ancient meaning (curare). Meanwhile, it is recognized that the whole of medical science includes its parts, is greater than its pratetice, applies to the ills of society as well as to human aiments.

The aim of modern medicine, coindinate with the advancement of all the seiences, is the prediction and control of phenomena, the prevention, as inclusive of the cure, of disease. Preventive medirine has no fairer ideal than that contained in the beautiful sontence of Minot: "Te have enthroned science in the imagination, but we have crowned her with moklesty, for she is at once the reality of human power and the personification of hmman fallibility." 


\section{APPENDDICES}

\section{MEDICAL CHRONOLOGY}

B. C.

7000-2000. Neotithic Age in Europe (Osborn).

5000-4500. Dawn of Sumerian, Egyptian and Mino:m Civilizations.

2900-2630. Age of the Pyranid buiklers.

2697. Huang-ti.

2500. Surgieal operations drpieted upon tomb of Pharaohs at Siqquarah.

2250. Corte Hammurabi.

2000-1000. Bronze Age in Europe (Osborn).

1500. Ebers Papyrus.

1300. Berlin Papyrus.

1000-500. Earlier Iron Age (Halstatt culture) in Europe.

$950 . \quad$ Homer.

800. Periot of Brahminic medicine.

776. First Olympiarl.

753. Founding of Rome.

639-544. Thates of Miletus.

600. Massage and atrupuneture practiond by the Japanese.

Lex regia (post-morten Cassarean seetion).

580-4\$9. Pythagoras.

522. Democedes founds: a mertical sehool at Athens.

504-443. Empredoctes.

500. Later Iron Age (Lat Tène (culture).

501-428. Anaxagoras.

490. Battle of Marathon.

480. Thermopyla and Satamis.

461-430. Agr of Porictes.

460. Ilipporates born.

431-404. Preponnesian War

430-425. Plague of Athens.

429-347. Plato.

400. Thucydides deseribes Athenian epidemic in his history.

$384 . \quad$ Aristotle.

370-286. Theophrastus of Eresos.

338-323. Alexander the Cirrat.

300. Alexandrian School. Euclicl.

$280 . \quad$ Herophitus.

212. Archimedes killed at capture of syracuse.

146. Siege of Corinth.

124. Asclepiates of Prusa (Bithymia) born.

80. Mitbridates, liing of Pontus, experiments with poisons.

55-63. Lueretius deseribes epidemic in "De rermu natura."

50.5 Themison.

31 B. C. -14 A. D. Augustus Casar.

A. D.

23-79. Pliny the Edder.

4i. Sieribonius Largus.

it-6s'. Naro. Dioscorides.

79. Plague following oruption of Vesurius.

98-117. Trajan. Rufus of Eptrostrs.

117-138. Jialrian. Aretalus. Soranus of Ephesus.

125. Plague of Orosius.

131-201. Gialen.

16it-180. Plague of Antonimus.

251-266. Plague of Cyprian. 
302. Euscluits, Bishop of ('asalres, describes sivrian "pidemice of smillpox.

303. Martyrifom of sints Cosmas amd Dimian.

325-403. (Oribasius.

335. Constantine eloses the Asclepiedia and oflere patgin temples.

369. Howpital of sit. IBasil crected at Cacsiarcal by Justiniatn.

375

Plaguc Ilospital at Edessil.

395-1453. Byzantine Empire.

400. Fabiolat founds first nosocominm in Wiestern Europe.

476. Jall of Western Roman Empire.

525-605. Alexander of 'Tralles.

527-565. Aetills of Amida (rign of Justinian I).

529. Nonte Cassino formded by Bonediet of Nursia.

542. Nosoeomia fommled at Lyons by Childebert I and at Arles by Cessarius.

543. Plague of Justini:m.

570 Marius, Bishop of Avenches, employs the term "viriola."

571. Mohammed born.

580. Hospital at Merida founded by Bishop Masona.

581. Gregory of Tours describes smallpox epidemic at Tours.

590. Epilemic of st. Anthony's fire (orgotiom) in Franee.

600. Aaron, a Christian priest, describes smallpox in his "Pandecte."

610. Hospital of st. Joln the Almegiver at Ephesus.

622. Nohammed's IJegira. (i25)-1990. P:tul of Kiginat.

(ii) H. Hotrl-1)ien founded hy Saint Landry, Bishop of P'iris.

675. Monastir records of smallpos in lrelamel.

732. Battlo of Poiticers.

73 S. Sirhool of Montpellier foumderl.

750-12.5. Batern Caliphate.

$766-802$. Reign of Harm alRashicl.

794. Sit. Albans Hospital (Jinglind).

799. Coronation of Charlemagne.

so9-873. Johamnitius.

525. Xinoclochinm at Mont sit. Cenis.

r29. IJôtê-Dienu (Pariss) first mentionerl.

\$30-920. Isatac Judieus.

84S-85ti. Sehool of Salerno first heard of.

860-932. Rhazes.

$962 . \quad H o s p i e r$ St. Bernarel.

980-1036. Avicenna.

1020-10s7. Constantinus Africinus.

1021. Daneing mania.

1025. University of Parma founded.

10,50. Albucasis.

106ifo. Battle of Hastings.

1073-1080. (iregory VII.

1096-1272. Crusades.

1099. Grder of St. .Iohn of Jerusilem founded.

1110-1113. Iniversity of Paris founded.

1126-119s. Averroes. Avenzoar.

1131. Council of Rhoims forbids eleries to pritetice medieine.

1132. Holy Crose Hospital foumled at Winchester.

1135-1204. Moses Maimonilles.

1137. St. Bartholomew's Hozpital (Loniton) founded by liahere. 
1139-1254. Holenstaufon Emperors. 1139. Lateran Comneil interdiets surgery ameng the higher clergy.

1140. Nicolaus Salernitanus ("Antilotarium").

King Roger II of sicily. restricts medical pratctice te liecontiates.

1145. Hospital of the Holy Gihost foumder at Montpellier by William VIII of Aontpellier.

1158. University of Bologna foumelerl.

1161. Jewish physicians burned at Prague on charge of "poisoning wells."

1163. Council of Tours ("Eeclecia abhorret a sanguine").

1167-6s. Migration of sturlents from Paris to Oxford to form a "studium generale."

1180. Roger of Parma complotes his "Practical chirurgie."

1181. Montpellier declared a free school of medicine.

1187. Mohammedans confuer Jerusalem.

1191. Tentonic Order applorover by Clement III.

1193-1280. Albertus Magnus.

1197 .

St. Mary's sprital in Jendon.

1198. Hospital movement inaugurated by Innoeent III.

1199-1214. University of Paleneia forunded by Alplonso VIII.

1201.

Oxlord first ealled a [niversity.

1201-1277. Sialiceto.

1204. Innocent III opens sianto Spirito Hospital in Sassia.
120.4. University of Viecenza founder (b) inigration of sturlents).

1209. Migration of stuclents from oxford to cimbridge.

1210. Collige de st. Côme founded at P'aris by Je:in P'it:ard.

1211. Innorent 1 II rexognizes Iniversity of Patris.

1214. Ugo Borgognoni marle rity physician of Bologna at a fixed salary.

1214-94. Roger Bacon.

1215 Nagna Charta.

St. Thomas's Ilowpital founded by proter, Bishop of Winchester.

1222. University of Piulua started (migration of students from liolognat).

1223. Cambrilge first called a University.

1223-1226. Louis VIlI. 2000 lazar lomses in France.

122.1. Frederick II issues law regulating the sturly of mediciue and foumels Iniversity of Mrsinial. Frecleriek î́ founds l'niversity of Naples.

1227-1274. Thomals Aritinals.

122s. Iniveresty of Vereelli founderl abolished, $1: 372)$.

1231. Salerno anstituted a merlieal sechool by Frederiek 11.

Gregory $1 \mathrm{X}$ iswars bull larens scientiarum anthorizing fareulties to gevern minersities.

Frerlerick II istues law antlorizing al quinguennial disseetion at salerno. 


\begin{tabular}{|c|c|c|c|}
\hline 233. & 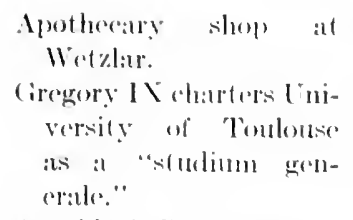 & 125. & 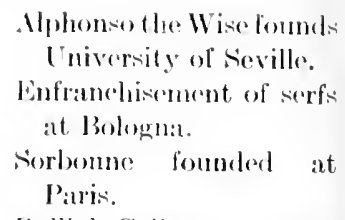 \\
\hline $\begin{array}{l}334-1312.2 \\
23 i 5-131.5\end{array}$ & $\begin{array}{l}\text { Arnold of Villanovia. } \\
\text { Ratymomel Lally. }\end{array}$ & $1263 ;$ & $\begin{array}{l}\text { Balliol College (Oxford) } \\
\text { fommled. }\end{array}$ \\
\hline $2+1$ & 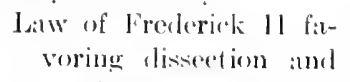 & $1: 21 \% 4$ & $\begin{array}{l}\text { Merton College (Oxford) } \\
\text { fommled. }\end{array}$ \\
\hline & $\begin{array}{l}\text { reculating surgery :mel } \\
\text { pharmuar. }\end{array}$ & $126 ; 5$ & $\begin{array}{l}\text { English llowse of Com- } \\
\text { monsis organized. }\end{array}$ \\
\hline 42. & $\begin{array}{l}\text { Roger bacon refors to } \\
\text { gumpowder. }\end{array}$ & $\begin{array}{l}126.5-130 \mathrm{~s} . \\
12(6.5-1321 .\end{array}$ & $\begin{array}{l}\text { Duns Sirolus. } \\
\text { D):nte. }\end{array}$ \\
\hline 43. & $\begin{array}{l}\text { University of Salamanea } \\
\text { founded by Ferdinand } \\
\text { III of Castile. }\end{array}$ & 1266 & $\begin{array}{l}\text { Funl of Westem Cali- } \\
\text { phate. } \\
\text { Eniversity of Perugia }\end{array}$ \\
\hline $44-\overline{5}$ & $\begin{array}{l}\text { University of ()xford } \\
\text { chatrtered by Henry } \\
\text { IIl. }\end{array}$ & & $\begin{array}{l}\text { founded. } \\
\text { Teorlorico Borgognoni } \\
\text { traches axeptie trout- }\end{array}$ \\
\hline & $\begin{array}{l}\text { University of Siena } \\
\text { founderl. }\end{array}$ & 1267. & $\begin{array}{l}\text { ment. of wounds. } \\
\text { Comeil of Venice forbids }\end{array}$ \\
\hline & $\begin{array}{l}\text { Hospital of st. Nary of } \\
\text { Bethlehem founded as }\end{array}$ & & $\begin{array}{l}\text { Jews to practice medi- } \\
\text { cine among Christians. }\end{array}$ \\
\hline & $\begin{array}{l}\text { a priory ly simon } \\
\text { Fitmmary. }\end{array}$ & 1275 & $\begin{array}{c}\text { Saliceto eompletes lis } \\
\text { treative on surgery. }\end{array}$ \\
\hline & $\begin{array}{l}\text { Comneil of LeMans pro- } \\
\text { hibits surgery to } \\
\text { monks. }\end{array}$ & 1252. & $\begin{array}{l}\text { Peterhouse College (Ciun- } \\
\text { bridge) founded. } \\
\text { sirilian Veepers. }\end{array}$ \\
\hline & $\begin{array}{l}\text { University of P'iacenzal } \\
\text { founded by Papal }\end{array}$ & 1255. & $\begin{array}{l}\text { Salvino degli Mrmati in- } \\
\text { vents spectacles. }\end{array}$ \\
\hline & $\begin{array}{l}\text { charter (reeonstituted, } \\
\text { lisgs). } \\
\text { University College } 10 \mathrm{x}-\end{array}$ & 1257 & $\begin{array}{l}\text { Plica Polmica in Po- } \\
\text { land after Mongol in- } \\
\text { vasion. }\end{array}$ \\
\hline & $\begin{array}{l}\text { ford) founded by Wil- } \\
\text { liam of Durham. } \\
\text { Roland of Parmil, sur- } \\
\text { n:uned Capellati, edits }\end{array}$ & 1289 & $\begin{array}{l}\text { University of Montpel- } \\
\text { lier (11s1) chartered } \\
\text { by Nicholas IV as a } \\
\text { "stuminm generale." }\end{array}$ \\
\hline
\end{tabular}
the surgery of Roger of Palermo.

Joinville describes seurvy in troops of Ioun IX at siege of Cairo.

1250-1320. Peter of Abano.

1252. Bruno of Longobura publishes "Chirurgia magna."

1295-96. Lanfrane empletes his treatise on surgery.

1300. Lniversity of Lerida founded by dames II of spain.

Boniface VIll istues bull De sepulturis.

1302. Creation of the States General in France.

1253. University College, Oxford, founded.

First judicial post-mortem (Bologna). 
1303.

1304.

1305.

1308.

1309.

1312.

publir disceetion of a
buman subject.

1316.

1317.

1315.

1319.

$13: 20$.

1321.

1326.
1325. universities of Rome and Avignon.

Henri de Mondeville teaches anatomy at Nontpollier.

Clement V charters Univorities of Orleans and Angers.

City Hospital of Siena established.

Clement V charters University of Perugia.

Papal see removed to Avignon.

Unisersity of Coimbra chatrtered by King Diniz of Portugal (reconstituted, 1772).

University of Palermo founderl.

Henri de Iondeville's surgery completed. buman subject.

City surgeon at Lüberk at 16 marks ( $\$ 1$ ) per annum.

Monlino's "Anathomia" written.

John XXIl issues bull spondent pariter against abuses of alchemy.

University of Treviso chartered by Frederiek the Fair.

First criminal prosecution for borly-snatching.

University of Florenoe founded.

John XXII issues bull establishing medieal school at Perugia.

John XXII issues bull Super illius speculo against practice of magic.
City Physician at Strassbure.

1330. Invention of gunpuwder.

1331. Fïrst mention of firearms by Muritori.

1332. John XXIl charters Iniversity of Calors ats a "studium generale."

1333. Publie merlien-botinical garden at Venice.

1336-1453. Humlred Yoars' War.

133s. Exorlus of students to Pisal.

1339. Benelict XII charters Lniversity of Gremolole as a "studium generale."

1340. 14,000 students at Oxford.

1343. Clement VI charters Inivorsity of Pisa as "studium generale."

1345. First apotlecary shop in Lomdon.

1346. Clement VI charters I niversity of Vallaslolid ("studium generale"," $1+1$ s').

Cannon used at battlo of Crép.

1347. Pembroke Hall (Cambrilge) founderl.

1348. Boart of Heilth and quarantine (quaranta giomi) estallisher at Venione.

Clement VI charter: Iniversity of Protgue ats a "sturlium generale."

1348-1350. Blarek Death.

Giuy de ('hamliale surecors plague-stricken at Arignon.

1349. Clement Vilhaters Iniversity of Florenee ats "studium generale."

1350. Trinity Hall (Cambrilgr) founted. 
13.5. Podro IV foumels Iniversity of Huescis.

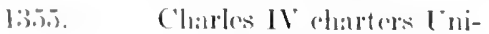
versity of Arezos (1215) is "stutlium generale."

13.5. Chatrles 10 aharters lniversity of sicha (124ti) as a "sturlium generillo."

1360. Innocent Vi recognizes lniversity of Bologena as a "studium gener. ille."

1361. Coniversity of Javial chatrtored by Chartes $1 \mathrm{~V}$.

1363. Ciny de Chanliac eompletes his "Chirurgia magna."

1364. Casimir the Great chatters Iniversity of Cralcow.

136.5. Duke Rudolph IV foumds Iniversity of Vienna.

University of Ortuge founded by Charles IV.

1367. University of Fünfkirchen founded by king Louis of Hungary.

1370. John of Arderne write surgical treatises.

1374. City ordinance of Reggio against the plague.

1376. Board of merlical extmi ners in Lomilen.

1376-7. Return of Popes to Rome. 1379. Clement Vil charters Lniversities of Erfurt and Perpignan.

1396. Urban VI charters University of Heidelberg as a "studium generale."

13ss. Crban Vl charters Lniversity of Cologne as a "studium generale."

Salaried city veterinarian at $\mathrm{T} / \mathrm{m}$.

13\$9. Urban Vi recharters University of Erfurt.
$13: 11$.

1399.

$1+112$

1404.

1406.

1409.

1410.

University of St. Andrews founded by Bishop Henry Wardlaw.

1412. University of Turin founded by Counts of Saroy (refounded, 1431).

1419. Martin $V$ charters University of Rostock.

1422. University of Parma founded.

1425. Insane asylum at Saragosia.

1426. University of Louvain founded.

1431. Charles VII founds University of Poitiers (chartered by Eugenins IV).

1437.
Eugenius IV charters University of Caën. 
1441. University of Bordeaux founded.

1445. Alphonso of Aragon charters University of C:ataniit.

1448. Invention of printing.

1450. Cardinal Cusanus suggests timing the pulse and weighing blood and urine.

Nielolas V found: Iniversity of Bareelona.

University of Treves founded (academic sessions, 1473).

1452.

Barber surgeons of Hamburg (Meister Bartscheerer) ineorporated.

Ratisbon ordinance for millwives Regensherger Hebammenbueh.

1452-1519. Leonarto da Vinci.

1453.

Fall of Constantinople (end of Byzantine Linpire).

University of Glaterow founded as a "stlidium generale."

1456. University of Cireifswall] founcled by Bull of Calixtus HI.

Osperlale maggiore at Ml $\mathrm{i}-$ lan.

1457. Purgation-Calendar printed be Giutenberg (first medical publication).

University of Ireiburg founcled by Albrecht VI (first sesion, 1ftio)).

1459. Pins II founds University of Ingolstault (acardemic instruction, 1472 .

1460. University of liasel founderl by eitizens of Bil*el.

Heinrich von Pfolspeundt writes treatise on surgery.
1462.

1463.

146.5 .

1

1469-71. Ferrarida (irarlu's "Practien" printerl.

1470. Merlieal troation by Valeseres de Tarantia, Jaeopo de Dondis and Mattharus sylyatious printed.

1471. Treatises by Mesue and Nieolaus Sitlernitanms (Antidotarium) printed.

1472. Unjersity of Ingolstadt opened.

Hoehenburg Regimen sanitatis (German text) printed.

Bagetlardo's treatice on peeliatries printed.

1473. Simone de Cordo"s "sinonyma" printed (first. medical dictionary).

1474. University of Sariagosia founded.

1475. Sixtus IV charters I'niversity of Copenhatgen (opened, 1479).

1475-1564. Michael Angelo.

1476. Saliecters "Cyrurgia" printed.

Salierete describes renal (lropsy.

Sixtlas IV charters lniversity of M:Linz.

1477. Universities of Tïbingen and Lpsala fommled.

1478. First adition of (ists: printed at Florenere.

First edition of Ketham's "Fasecienlus medieinar" printerl.

Momlino's "Anuthonia" printerl at lecipzir.

Spanish Inquicition. 
1479.

$1+4(1)$.

1454.

1156.

1459. 16s bath houses at Tlm. "Malleus malleficatrum" (Witches' ('orlex) of Jacedsisprenger printed.

1490. University of Ileidelberg moves to spryer on aceount of plagure.

1491. Jortus sanitat is printed.

1492. Discovery of Americis.

John of Ciaddroilen's "Rosa angliea" printed.

Nicholas Leonicents eorreets botanieal errors in Pliny.

1493. Paracelsis born.

Smallpox in Germany.

1494. University of Aberdeen foumled.

First Alline elition printed.

1495. Maximilian I issues Ediet against Blasphemers (first mention of syphilis).

1496. Albert Dürer's drawing of a syphilitic printed.

1496-1500. European pandemic of syphilis.

1497. Aldine edition of Theophrastus printerl.

1498. Florentine "Ricettario" (first official pharmacopocia).

1499. University of Alcala founded.

Johann Peyligk publishes anatomical drawings.
1500

.

1501.

1502.

1504.

1505.

1507. Benivieni's collection of

Jaeob Nufer performs first Cosiarean section on living subject.

Berengario da Carpi troats syphilis with norenrial inunctions.

Alexancler VI charters Eniversity of Valeneia.

Maguns Ilundt's "Anthropologium" pub. lisherl.

Morbus Itungarieus palldemic in burope.

Maximilian I constitutes University of Wittenberg as a "studium generale" (July (i).

University of santirgo (spain) founded.

Royal College of Surgeons of Edinburgh ehartered.

Julius II charters University of Serille.

1506. University of Frankfort on the Oder founded by bull of Julius II. post-mortem sections printer.

1508. University of Madrid founded.

Guaiae wood brought from America.

Jerome of Brunswick's Book of Ilound-Siurgery published!

1509-1547. Reign of IIenry VIII.

1510. Ambroïe Parć born.

Petrir Ilele (Henlein) of Nuremberg makes pocket watches.

Pandemic influenza.

1513. Röslin's Rosegarten printed.

1514. Vesalius born.

Gunshot wounds first deseribed in Vigo's "Practica." 
1514. Brisot opposes derivative bloorl-letting.

1517. Fugitive anatomiral plates published by .Johamn Sehott of Mainz.

Ciersclorff"s licld-Book of Wound-surgery published.

Linaceres first transtation of Cialen publisherl.

1517-1521. Reformation.

151s. Royal college of Physicians founded.

Nuremberg ordinanee regulating sale of foorl.

1518-1545. (ollege dr france (Paris). 1519-1556. Charles V. King of spain ancl limperor of (iermany.

1519-1522. Magollan eircumnavigates the globe.

1519. Friesen's "ipiegl der Artzny" and "synonima" published.

1521-1523. Berengario da Carpi publistres anatomieal troatises.

1524. Linaere foumdation of merlical leet ures at ( )xford and Cambridge.

Cortes ereets first liomital in eity of Mexieo.

Lueas van Leyden's portrait of Ferdinand $I$ of Spain (admoid face).

1525. First Latin translation of Hippocrates publiwhed at Rome.

1526. Clement VII charters Iniversity of Sinntiagse.

"Gymnasium Egirlianum" founded at Nuremberg.

First (Aldine) (ireek text of Hippocrates published at Venice.

Paracelsus founds chenotherapy.
1526-94. Palatrina.

1527. Eniversity of Mitarburg foumber (Maty 30) be Philip, Lamlgrave of Hesse (first Protestant univarsity).

Sack of Rome by (harles $\mathrm{r}$ (deceline of It:alian humani:mi).

152n. First Mlline oxlition of Paul of Hgina.

1529. Sweating sickness spread over Europe.

1.530. Fracastorius joom on syphilis publisherl.

Otto Brunfols publishes his atlas of plints.

Sarsaparilla introclueed.

1531. Clement VH fouml- Iniversity of Ciranadit.

1532. Albert Dürer'stratior on human symmetry gut lislierl.

Rabolais publishes firnt Latin rersion of the aphorims of Hippoerates,

1533. Charles I issues Constitutio Criminalis Carolinat.

Buomaferde hohls first chair of material needica al Padua.

Montaigne boln.

1534. Aleline edition of Aetius publistred.

Jesuit order foumded.

1535. Mariane sianto di Barletta gives first account of median lithotomy.

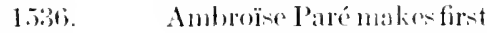
axcision of rllwow-joint.

1.537. Vesillits graduates at Batsol.

1)rrander's "Anatomia" publisted.

1538. Vesalius publishes hiv "Tabular anatomina sex." 
1 isto.

1542.

1543.

1544.

1545.

1545-1563. Council of Trent. 1546 . siurgeons." tions annulally. sury. Mankynde." treatise. menclature. anatomy. liament. (August 17). Thomas Vieary.
English barbers and sulgeons unitul as " "Comparty of the barlore

Statute of llomry Vll1 permitting four dissere-

Villerius Cordus discovers sulphurie other.

Mattioli treats syphilis by internal use of mer.

Raynarle translates Röslin as "The Burth of

Solatianus Austrius publishes his pediatrie

Lconharel Fuehs attempts a rational botanieal no-

Copernieus deseribes revolution of planets around the sum.

Vesalius publishes the "Fabriea" (June 1) and founds modern

English apotheearies legalized by atet of Par-

Lniversity of Königsberg founded by Albert III

st. Bartholomew's Hospital refounded under superintendence

Paré improves amputation and treatment of gunshot wounds.

Vilerius Cordus publishes first pharmacopariat,

Ingrassias describes stapes.

Jerome Bock's "Kräuterbuch" published. 15ti. Regius Professorship of l'hysir formeled at C:mmlorilge.

1547. Insanc axylum extablisherl at st. Mary of Bethlehem ("Bedlam"). Landon.

1548. Charles V declares surgery homoralule.

1549 Anatomical theater at Pirluar.

1550. darés resty on poclalic version published.

Bartolommeo Naggi proves that gunshot wollnds are not poisonons.

Hollerius preseribes spectacles for myopia.

551. Anatomieal theaters at Paris and Montpellier.

1552. Cains publishes treatise on sweating sickness.

M. Friedrich publishes first tract on aleoholism.

1553. Servetus burned.

The eolleetion "De Balneis" publisherl.

University of Lima founcled.

1554. Johann Lange describes chlorosis (morlous virginets).

Jacob Rueff's midwifery (De conceptu) published.

Editio princeps of Areteus printerl at Paris.

1555 Diet of Augsburg.

Pierre Franco performs

1556-159s. Philip II. suprapubic lithotomy.

15.55. Ferdinand I charters and opens University of Jena (February 2).

Cornaropullishestreatise on personal hygiene. 
155S-1603. Reign of Elizabeth.

1559 .

1561.

1562 .

562-15̆b. Pandemie platgue.

1562-1529. Iluguenot warsin Franee. 1.563 .

Witeheraft al eapital erime in sieotlanel.

1.564. Medieal dietionaries of stephamus and (intreus publishou.

Eustachius discovers abducens norve and supraronal glands.

1564-1616. Nhakespeare.

1565. Statute of Elizabeth permitting alissection of exeruterl reriminals.

Jean Nimet brings tobatero plant to France.

Johann sturm's "Akardemic" operned at sitrassburg.

1567. Ulisse Mletrovandi tablishos botanical garilon in Bulogna.

Paracelsus' account of miners phthisis pullisliced.

1568. Constantino Varolio deseribes the pons Varolii.
1570. Folix Plattor urges piycluie treatment of the insine.

1571. Battle of Lepanto.

linancesce bravo deseribes "tabarlillo" (Fipanish typhus).

Caroline Medien-(lireurgieal lnstitute of sitockloolm founderl.

1572. Geronimo Mereuriali publishes his troutise on skin diseases.

Lead poisoning (rolica I'irtonlum in Poiton.

1573. Arlan Lonitzor's orelinance for milwives Frankfort on the Main).

1574. Gregory XIIl marters University of ovielo.

1574-1577. Pandemie plagne.

1575. Eniversities of Lerden a na $H: l$ ms t a d fommlerl

Parce introderexe matriage and artificial eyos.

1576. Paracelsus publislos tract on minclal waters.

1578. Guillamme do Baillom describes whomping eolugh as "quinta."

Millian Ilarver lonn.

Roulolple 11 ahioters Eniversity of Altelorf (opmenal, 1;iso).

15̃so. Pathdemie influchzat.

Prospero Mlpino introfluers moxil from thes ()rient.

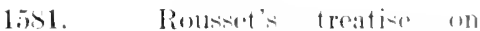
( a publisherl.

15\$2. Eniversity of Eilinbureh ebartereal by Jamos Ií.

Augsourge "Collogium medicume" foundarl. 


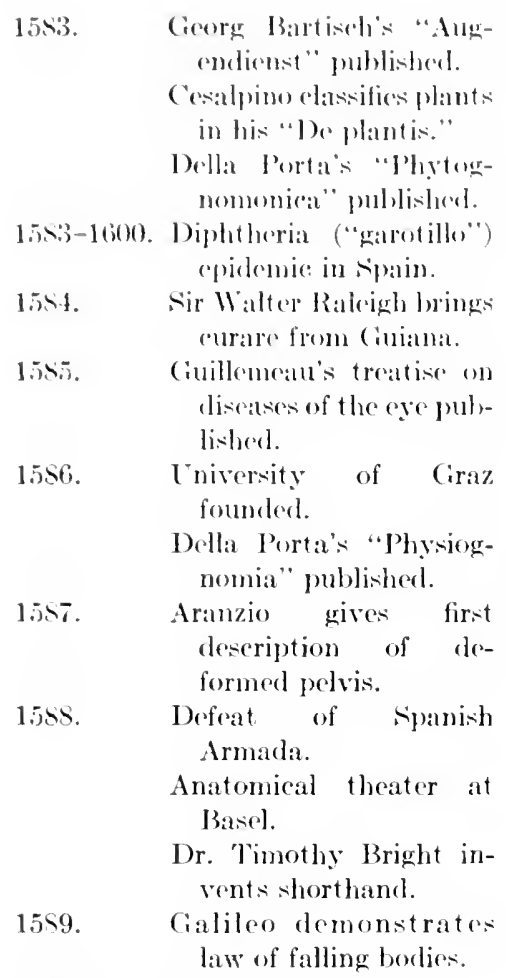

15\$9-1611. Henri IV.

1590. Invention of compound microscope by Hans and Zacharias Janssen.

José d'Acosta deseribes mountain sickness.

1591. Pandenie plague.

1593. Narischat College (Abordeen) founded by George Keith, Earl Marischal.

Tniversity of Dublin (Trinity College) founcled.

1595. Libarius publishes first treatise on ehemistry ("Alchymia").

Querectanus uses calomel. City of Passau issues ordinance for midwives. 159t. Iniversity of Cagliari (śardinia) founderl.

Harington's "Netanorphosis of Ajax" publisherl.

1597. Tagliacozzi publishes treative on plastic surgery.

Codronchin's troatise on medical jurisprudenee jublished.

Isract Spach's "Cyna("ia" publisted.

James VI of Seotland publishes "Demonol"ogy."

1598. Edict of Nantes.

Mercurio gives pieture of the "Wilcher position" in "lal Comare."

Carlo Ruini jublishes treatise on diseases of the horse.

1599. Ulisse Aldrovandi's "Historia animalium" published.

Royal Faculty of Physjeians and surgeons of Glasgow established.

1599-1660. Velaspuez.

1600. Queen Elizabeth charters East India Company (December 31 ).

Gilbert's "De magnete" published.

University of Harderwijk founded.

"Foglietti" published in Venier.

1602. "Hamlet" produced.

Harvey graduates (M. D.) at Padua.

Felix Platter publishes the first classification of diseases.

Fedeli publishes treatise on medical jurisprudence. 
1603.

1604. Johann Kingler demonstrates inversion of optic inlage on the retinat.

1605. Verhorvan publishos newspaper at Antwerp).

1606-69. Rambrandt.

1607. Settlement of Jamestown, Virginia (May 1:3).

Rudolph I I eharters University of Giessen (May 19).

1609.

1610.

1611.

1614.

615.

Henry Hudson anchors "Half Moon" in Now York Bay.

Kepler's "Astronomia Nova" published.

Jalap brought from Mexico.

Louise Bourgeois publishes obstetrie treatise.

Gialileo devises microseope.

Cristoforo Guarinoni describes gummata of the brain.

Minderer introduees ammonimm acetate (spiritus Mindoreri). founded.

Union of Brandemburg and l'russia.

Villa Real publishes aecount of garotills (diphtheria).

University of Cironingen fomnded.

Rocleriens at Castro publishes treatise on medieal jurisurudenee.

Franlifurter Postamts-
1616.

Harvey begins to lore ture on the circulattion of the blocel.

University of l'aderborn folmeled.

Cesitre Mileati treats wounds with blain watitis.

1617. Briges and Xitpire introcluer logarithms.

Cinild of Apotheraries of the City of Lomelon formelore

1618 First edition of London pharmacoporiat.

Comntess of Cluinehon cured of matarial fever by ainchomat.

Rosierneian Order zuilung (newspalper) published.

\section{S-1645. Thirty Years' War.}

1619. Christoph sobeiner's "Oculus" publisherl.

1620. Landing of the Pilgrims at Plymouth. Nassachurett: (Deember 21).

Bacon's "Novum Organum" published.

Botanie (iarlen at Strakblure.

Raymund Minderer's "Medieina militaris" published.

Van Ilolument teatehes that a chemical smbstanee survires in it: compounds (Conservation of Matter).

1621. Universitios of Strissburer and Rinteln founded by Emproror Ferrinand It.

Zarechias publishes troatise on modieal jurisprutenere.

Cornclins Inobled inproves the microseoper.

Botanie Garden at $0 x-$ ford. 
162.2. Asetli diseovers the lateteal resisels.

Lomelon Heckly Veress puthished.

1622-1763. Molicre.

162:3. Now Nothertants rolunized by the Duteh.

Eniversity of Aleala moved to Mantrid.

Merlieal fraculty added to University of $\mathrm{Alt}$ dorf.

1625. Botanic Garken at Mltdorf.

1626. Jardin les Plantes at Paris

162s. Ilarvey publishes "De Motu Cordis."

1629. Botanic Garden at Jena.

Severino makes first. resection of the wrist.

Petrolem described by the liancisean friar De la Roche d'Altion.

1630. Thuillier père shows that ignis suleer (orgotism) is due to eorn smut.

1631. Théophraste Renambot edits Gazette de France.

1632.

1633 .

1634.

1635.

16336.

Gustavus Molphus tomels University of Dorpat.

Botanie Garlen at Hampton Court.

\section{Spinoza.}

stephen Bradwell publishes first book on first-ainl.

Universities of Etrecht and sussiri founderl.

Richelien founds the Acatlémio francaise.

Harvard College founded
$1636-76$

16337.

1638.

1639.

$16+0$. by act of Cieneral Court of Massachusetts: Oetolor $2 s$ ).

Assembly of Virginiat passes aet regulating physicians' fees. (itisom Regius Professor it Cambrictge.

Deseartes shows that accommodation depends upon change in form of lens.

Royal Coltege of Physiciluns issues report upon public health.

Cornelius Drebluel inproves the thermometer.

Padre Acugna, a Portuguese nonk, introluees oil of copaliva.

Assembly of Maryland passes act regulating surgeons' fors.

First printing press in North Ameriea (Cambrielge, Massolduset ts).

First hospital in Canarla.

Virginia Assembly palsses law regulating medieal practice (October 2 ).

Queen Christina charters University of $\AA$ ibo.

Bay State Pralm Book published.

Juan del Vige introduces cinchona into Spain.

Severino produces local anesthesia by means of snow and jice.

Werner Rolfink revives dissecting("rolfinken") in Germany,

1640-1658. The Great Elector.

1642. Jacol, Bontius tescribes beriberi.

1612-1649. Civil War in England.

1642-1727. Newton.

Torricelli constructs barometer.

164t. Descartes describes reflex action.

Deseartes' treatise on dioptries published.

Hôtel Diru in Montreal. 
1644. Matthew Hopkins, the 1652 . witch finder.

1645. Battle of Nischy.

"Invisible Socioty" founderl in Lomdon.

1646. Sanetorius dexeribes new instruments in his commentary on Aricenna.

Diemerbroek publishes monograph on pligur.

Syphilis appears in Boston, Miss.

1647. Pecquet discovers thoracie duct.

Wirsung discovers pancreatie duet.

Giles Firmin leetures on anatomy in Missatchusetts.

1645. Peace of Westphalia.

University of Bamberg founded.

Van Ilelmont"s "Ortus medicina" published.

Athanasius lircher describes the ear trumpet.

Glauber prepares fuming hyalrochloric acid.

Francesco Redi disproves theory of spontaneous. generation.

1649. Aet regulating the pritetice of merlicine in Massachusetts.

1649-1660. Commonwealth in England.

1630. Glisson describes rickets.

1651. Harvey's treatice on thir generation of animat publisherl.

Highmore diservers the maxillary sinus.

Rudbeek discovers the lymplatties of the intestines.
Thonas Bartholin droseribes the intestinal lymphaties.

Johann Hoppe describe: miliary feyer.

Lorenz I3ausch of Erlut founds the Gesellschut uaturforsehend, Freunde.

1653-1659. Proctertorate in England. 1654. Otto ven Guericke of Mageleburg introduces: the air-pump (16+1).

Glisson describes the capsule of the liver.

University of Horborn founded.

16.54-1715. Reign of I touis XIV.

16.5.). University of Duisburer tounderl.

Secultetus publishes Iiis "Armamentarium,"

1656. Wharton's "Arlenogr:1phia" published.

Rolfink shows that citaract is clouling of the lens.

Lazar houses abolisherd in France.

1657. Aceademia del Cimento founterl at Florence.

Wolfasing Hoefor describes arotinism in his "Horeules mediens."

Jan ì Gohema urges that field chests of aruge be furnished armies by the state.

Comenius publishes "Orbis pictus."

1657-1669. Pandemic malariai feres. 165s. Swammerlam decribes red blood-corpuseles.

Wrepfor demonstrites lasion of the britin in apeplexy.

Athanasius lireher attributes plague to :2 contagium animatum. 
16.59

1660.

1662.

1663.
1661. Stensen discovers duet of

Malpienti ontlines lymph- 1663. alenoma or Hodgkin's discise.

Diphtheria at Roxhury, Missachusetts.

Selnneider shows that natial secretion does not come from pituitary borly (Gialen).

Willis describes purerperal fever.

Hormann Conring publishes statistical treattise (Examen rerum publicarum).

Malpighi discovers anastomosis between eapillaries.

1660-85. Chatrles II. parotid gland.

Malpighi publishes first account of eapillarysystem (De pulmomibus).

Robert Boyle dofines chemical elements and isolates aectone.

scarlatina appears in England.

Charles II charters the Royal Society.

Newton and Leibnitz originate the lifferential calculus.

John Graunt founds medical statisties.

Descartes publishes first treatise on physiology (De homine).

Lorenzo Bellini disrovers exeretory ducts of kidneys.

- De Craaf show that ova arise in the ovary.

Meibom discovers Mejbomian glands.

First hospital in American colonies (Long Island, N. Y.).
Hendrik van Roonhuyze describes operation for vesion-ratginal fistulat

sylviue treats of cligestion als at formentattion.

I664. Willis's "crebri amatome" publisherl (clatssification of erretral nervers).

Swammerdam discovers valyes of lymphaties.

De Graaf examines panereatie juice.

Solleysel transmits glanders from horse to horse.

De la Martinière deseribes gonorrheal rheumatism.

166is. Newton announes law of gravitation.

Great Plague of London.

Richard Lower tranfuses blood from $1 \log$ to dog.

- First volume of Philosophical Transactions (Royal Society) published.

Colbert founds Académie des sciences (Paris).

University of Kiel founded by Duke Christian Albrecht of Holstein.

First number of Journal des sçacans published (January 5).

1666. Great Fire of London.

University of Lund fornded.

Malpighi's treatise on the viscera published.

Coroners appointed for ach county of Maryland.

1666-1675. Smallpox in Europe. 
1667.

1668.

Robert Ilooke describes
plant cells in his
"Mlicrographia."
Denys of Paris first
transfuses blood in
man.

Swammordam desibribs: docinasia of fotal lings.

Hooke shows true function of lungs by artificial respiration.

Walter Needham shows that fetus is nourished by the placenta.

Mayow finds "igneoaërial spirit" (oxygen) essential for combustion and respiration.

Mauriceau's obstetric treatise published.

Yellow fever appears in New York.

1668-1672. Epidemic dysentery in England (deseribed by Sydenham and Morton).

1669.

Riehard Lower's "Tractatus de corde" published.

Stensen founds statigraphie geology (De solido intra solidum).

Lower shows that venons blood takes un air in the lungs.

1670. Malpighi discovers Malpighian bodies in spleen and kidneys.

Swammerdam diseovers muscle-tonus.

Willis diseovers sweet taste of diabetic urine ("De nedicamentorum operationibus").

Kerekring describes valvula conniventes of small intestine.
1670.

1671

1672.

1673.

1674

1675.

1676.
Physic Garden at Edinburgh.

Arsenic poisoning at Paris (Ste. Croix and Brinvilliers).

Redi's treatise on the generation of insects published.

University of Urioino opened as a "studium generale."

University of Inusbruck founded by Emperor Leopold I (Academia Leopoldinis).

Le Gras introduces ipecac in Europe (mentioned by Piso, 1648).

De Graaf describes the Graafian follieles in the ovary.

Malpighi deseribes development of the ehick.

Leeuwenhoek makes microseopes.

Printing press at Boston, Massachusetts.

Velsch publishes monograph on Filaria medinensis.

Morel invents tourniquet for checking hemorrhage.

Hamen, a pupil of Leenwenhock, discovers spermatozoa.

Leeuwenhoek discovers protozoa.

Malpighi's "Anatome plintarum" published.

Sydenham describes searlatin:t as it appeared in 1661-75.

Richard Wiseman describes tubereulosis of joints (tumor albus).

Isaar Barlow invents repeating wateh. 
11 iii.

Katiserliche lapoledinische Mlademic der Niturforseher fommled.

Gilision's doetrine of irritahility of tissues (I66iz) published.

Perer describes Iyimphoid follicles in sinall intestine.

smallpox in beston (Thateher's "Brief Rule" pulplishedl).

167-1681. Pandenie malarial forer in Europe.

167s. De Marchetti shows anastomosis of arterioles and veins by injertion.

1679. Rivinus discovers sublingual gland.

Leeuwenboek discover: striped musele.

Nieolas de Blegny publishes the first medical perierlieal ("Nouvelles (léconvortes").

Bonet"s "sejulchrotum" published.

James Yonge deseribes flap amputation.

16s0. Denis Papin enstruets a miniature steam engine.

Leeuwenhoek "liseovers veast plant.

Caspar Bartbolin di-covers exeretory duet of sublingual gland.

De Marehetti perform nephrotomy for renal ealeulus.

Plague hospital at Magaleburg.

16ৎ0-1681. Borelli's "De motu animalium" published.

1681.

Poval College of Phyicians of Edinburgh founded.
1685. Printing press at II'illiamsburg, Vinginiat.

165.3. Brumer deseribes dooxlenal glands (dis-) eovered in 1672).

Nehemial Grew's "Anatony of Plants" publisherl.

1682-1725. Poter the Great.

l6s:3. University of Modena ehatrtered by Dike lirancis II of Este.

Sydenham's treatise on gout publisherl.

Lecuwernhoek dercriber bacteria (witls figurations).

Duverney publishes first treatise on of ology.

1684. Bernior elatsifies races of mankind by color of the skin.

1685. Revocation of the Ediet of Nintes.

Medieal Faculty at the University of Edinburgh.

Printing press at Plilitdelphia.

Bidloo"s "Anatomia" published.

Viensiens" "Nevrographia" published.

Paul Portal publishes obstetric treatise.

Prussian ordinance reguliting medieal fees.

165.5-1750. Johann Silastian Bach.

1686. Sirdenham describes ehorea minor.

1687. Newton's "Principia" published.

Sir William Petty publishes "Essays in Politieal Arithmetic."

168s. Revolution in England.

1689. IR iehard Morton's "Phthisiologia" published. 
1689.

1690.

1691.

1692.

1693.

1694.

1694-17\%. Voltaire.

Valter Ilarris publishes
treatise on diseases of
rhildren.

Jeeuwenhook diseovers rods in retina, and fincr anatomy of cornea.

Locke's "Essay on the Hunatn Understandingr" published.

"Publick ()ecurrences" (newspaper) published at Boston, Massiachusetts.

Justine Sirgemundin publishes treatise on midwifery.

Floyer counts the pulse by the watch.

Clopton Havers publishes "Osteologia nova" (Haversian canals).

Autopsy of Governor slatughter in New York.

Yollow ferer in Boston.

Sialem Witeheraft.

Ammann traches deafmures.

University of Halle founderl.

College of William and Mary founded at Williamblurg, Virginia.

Printing press in New York.

Arobuthus of Breslatu resects the lower jaw.

169.). Nehemiah Grew diseovers magnosium sulphate in Eposom waters (Epson salts).

1697. Anatomical theater receted in surgeons' Hall at Erlinburgh.
1697.

Pacehioni liscovers glands in the dura mater.

1698. Stahl's treation on disrasese of the portal system publisherl.

1699. Mistory and Memoirs of the Fronch Acarlemy.

of Scienees published.

Tyson's "Orang (Bttang" published.

Infectious diseases act in Massachusetts.

1700. Königliche Akademie der Wissenschaften founded at Berlin.

Ramazini publishes treatioce on trade diseases.

1701. Frederiek, Elector of Brandenburg, crowned King of Prussia.

Yale College founderl (New Haven).

Deventer's "Novum lumen" published.

Robert Houstoun titps ovarion eyst.

17)1-13. War of the spanish suecesiston.

1702. University of Brestan founded by Leopold 1 .

Stalla stater phlogiston theory.

1702-14. Rreign of Queren Anure.

1703. Founclation of St. Peatersburg.

IIouse of Lords anthorizes apothesearies to prescribe ats well ats diepense druges.

Lecuworhboek discovers parthengenesis of plant liee.

1704. Valsalval publiwhes "De" aure humatual" and describes "Valsalval's method." 
170.4

1705

1707.

1708.

1710.

1711.

1712-78.

1713.
Dr. Fysenbarth pratetises as a mountebank in Giormatuy.

Robert lilliot first professor of anatomy at Edinburerh.

Brisiseall and Malitre Jiln show that rataract is the elouded lens.

First 1:aboritory of matrine zoülogy at Marseilles,

Senckenburg Found:tion for aldvaneement of science.

Dionis" "Cours d'opérations do chirurgice" published.

Haller born.

Influenzar pandemic in Europe.

Charité Hosjuital opened at Berlin.

Morand and Le Dran perform first exartieulation of shoulderjoint.

Anel operates for aneurysm by ligating above the sac.

Thomas Newcomen invents fire engine.

Santorini's muscle in larynx discovered.

School of Physic at Trinity College, Dublin.

John Shore invents tuning fork.

Rousseau.

Torti of Modena uses einchona bark in pernicious malarial fever.

St. Côme merged into Acarlémie de chirurgie (Paris).

Theatrum anatomicum founded in Berlin.

Anel catheterizes lachrymal ducts.
1714.

Aecession of llouse of It:monover (Linglami).

rahrenheit construets 212 degree thermometer.

(i. IV. von leibnitz founds pavilion system of hospitals.

1715. J.-L. Petit differentiates botween eompression and concusion of the brain.

J. 'T. Hensing aliseovery phosphorus in the bloorl.

1716. Surgeon (iencral appointed in fierman Army at 900 markis per allnum.

New York City issutes ordinance for millwives.

1717. Timoni has daughter inoculated against smallpox.

Howpital for infortious diseases in Boston.

1718. Theatrum anatomicum in Viennat.

Lindy Mary Wortley Montagu has son inoculated for smallyox.

Hoffmann's anodyne.

Edward strother describes puerperal fever.

1719. Westminster IIospital founded.

Kaspar Neumann jsolates thymol.

Morgagni describes syphilis of cerebral arteries.

Heister's surgery published.

172t). Kew Gardens opened.

1721. General Holtzendorff creates "Collegium nedico - chirurgicum" at Berlin. 
1721.

1723.

1724.

1724-1s04. Kant.

Philadelphia Hospital founded.

Universidad central de Venezuela foundod at Caracas.

Palfyn exhibits obstetric foreeps to French Acadeny of surgery.

Zabdiel boylston inoeulates for smallpox in Boston (June 26).

Eniversity of Dijon foundeil.

Apothecaries Company of London organized.

Floyer's "Psychrolusia" published.

Chesclden's treatioce on lithotomy published.

Yellow-fever reaches Lonton.

Guyot of Versialles attempts catheterization of the Eustarhian tubes.

John Maubray gives private instruction in obstetrics in Englant.

A. de Moiver publisher meneir on "Annuities upon live.."

1725.

1726.

Prussian eflict regulating practioes of medieine.

Ciny's 11ospital opened (Jamuary (i).

Freind's History of Physiek published.

stephen llales makes first measurement of blood-presisure.

1727. Pourfour du Petit investigates functions of eervical sympathetic.

Cheseden performs lateral operation for stone.
1725.

John Ifunter born.

Fauchard publishes "Is chirurgien dentiste."

Cheselden introducese operation for artificial pupil.

1729. Influenzal pandemir in Europe.

1730. Daviel improves cataract operation.

James Douglas deseribes the peritonemm.

Gaspar Catal deseribes pelligra as "mal de lia rosil."

Réaumur introluees: so degree thermometer.

Frobenius deseribes preparation of sulphurie ether.

1730-31. Thomas Carlwalader teaches anatomy in Philardelphia.

1731. Friedrich Hoffmann ilescribes chloresis.

Le Dran improves lithotony.

Académie royale de ehirurgie fommled (Derember 18).

1732. Borhataves "Elementa chemise" publisherl.

Winslow's anatomy pubIisherl.

Influenz: pandenie in Europe.

1733. St. George's Hospital foumderl at Lomelon.

Cheselden's "Osteogratphia" publisherl.

(ienrge Cheyne deseribes "Cheyne-stokes respiration."

Stephen Hales produees: dropsy by injecting water into the veins.

John Machin deseribes iehthyosis histrix in the Lambert family. 
$173 \%$

1735.

1736.

1737.

1739.

1739.

1740.

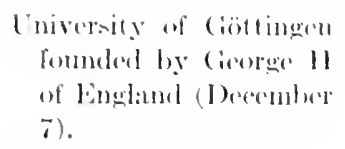

Friodrich Withohn I of Pruswi: issurse first regulation of liclil hospitals.

Linnaris" "syotomat natmace" publislied.

Wrothof describes purpura harmorrhagieat.

Merlical somerety in Boston formdert.

Setarlitinat atppears in the Inited stittes.

English laws agrinot witeheraft repeated.

Edinburgh Hosplital fommerl.

J.-L. Pertit operems mastoill for abseress in midllle. car.

Ilatter pointe out fimction of bile in cligestion of fats.

Eniversity of ciöttingen ("ieorgia Augusta") formally opened (nep)tomber 17).

Roval Medical society of Edinburgh founded.

Hatler ealled to coottingen.

Lieberkühn invents reflector microsecone.

Damios Bernouilli states the kinetic theory of gitses.

special chair of mislwifery in the University of Edinburgh.

F.-. Merand makes first excision of hip-joint.

Royal swedish Aearlemy. of Melicine formderl.

University of Pemmsylvania founded as "Co]lege of Philadedphis."
1740.

London Hospitalfoumded.

Findrich Holfmam doscribes rubclla.

Thomits Dover invents "bover's Powaler."

1710-4s. II:ar of Austrian sueassions.

17.10-sti. Roign of frecleriek the (irciat.

1711. Chair of chinienal medi(ine at Edinburgh.

sitismileh's treatise on vital statisties jublisherl.

Arehibalal ('laland eatlesteriges linstachian tube.

1742. (celsius invents 100 degree tlyermomoter.

Jimners describes aphatsial.

Pandemie inflien\%: in Europe.

1743. Iniversity of Erlangen ehartered (Fobruary 21) and opened ( $\mathrm{No}$ (1) vember - t) by karl VII.

Ameriean Philosonthical Soeiety founderl.

Iniversity of sintiago (Chile) foundert.

stephen Inales publishes treative on ventilation.

Freflerick tlee Great separates main hespitaks from flying ambulanees.

1744. Trembley dexcribes regeneration of tistues in hyirtozoa.

Alexinder Monro publishes bandlbook of comparative anatomy.

1745. Barbers separated from higher surgeons in England.

Midrlesex Hospital founded. 
1745.

1746.

1747.

1745.

1749.

1749-1s32. Gioethe.

Ambulatory elinie opened at l'rague.

Heberden's "Antitheriakil" published (innprovement of London Phamareoporia).

C. (i. Liratzenstoin ('nuploys eleetrotherapy.

William Cooke introduees steam heating.

Antoine Deparremx intronlueres idleat of "moan expectation of life."

Princeton College founded.

London Lowk Hospital foumderl.

Fauclard describes pyorrhex:e alveolaris and malocelusion.

Hallor's Prima linea physologie published.

Collecium medien-ehirurgieum at Dreiden.

Mreckel describes splenopialatine ganglion.

Medical soriety in Vew York.

British Lying-in Hopptal founded.

Sinates treatise on the heart published.

Mleyer orters phthisical patients to mountains it Appenzell.

Buffon's Nitural History publislert.

1750.

Erole pratique estab-
1751.

1752.

17.53.

1754. lishorl at Paris.

City of Lomrlon Lyingin Inospital fomuled.

Antonio Nuñe\% libero sinnelarz introduces corrovive sublimate in syphilis.

Russel describes Aleppo button.

Zittmann's deroetion.
Königliche Gesellschaft der Wissenselaften at Göttingen founderl hy Haller.

Penusylyania Hempital foundor at Plibiadelphili.

Haller publishes memoir on specifice irritalsility of tissues.

Smollie's Midwifory publisheel.

Pringle's treatise on s'anty) discases published.

Réaumur experiments on digestion in lirds.

Queen Charlotte's Lying-in Howpital at London founded.

Merlical Society foumderl in tomelon.

Daviel publishes menosir on extraction of cataract.

Levret's "Art des Aceouchemens" pultlished.

Van Swioten organizes dlinical instruetion in Vimmis.

Watson deseribes scleredermal at curzio's rlinic.

Kinge College (columbia Iniversity) founded at New York.

1755. Earthquake of Lishon.

Eniversity of Moseow founded by ('zitrin:l Elizabeth.

Cinn's atlas of the rese publisherl.

1756. Mleath Hoppital, Dublin, formbled.

Plalfes treation on dentistry publisherl.

Nimbles André describes infraorhital neuralgiat.

1756-63. Seven Jears' llar. 
1757

1759.

1760. 1760-76. Berk City.

1761.

1762. proves mieroscopes.

\author{
William Hunter de- \\ seribes arterier-bonous \\ ameurysum. \\ Lind's treatione on natral \\ hygiene published.
}

Return of Halley"s conted (end of comet theors of diseatso .

Do IIän employs thre mometer in elinic:al work.

Riehard Brocklesby introduces ventilated barrack hospitals (deeentralization).

Königliche Balyerixche Akademie der Wisonschaften founded at Numich.

Wolff's "Theoria gremeraltionis" published.

Mestivier describes and operates for loealizod appendicitis.

John Bard operates for extra-uterine pregnaney.

Physic (iarden at liew (England).

William Shiplen, Jr. lectures on inatomit in Philadelphia.

def to regulate prisetice of medieine in Now

Morgagni's "De serlibus" published.

Auenbrigger's "Inventum novim" published.

Pope Clement XI gives: MS. of Eustachius to Lancisi.

Plenciz announces theory of contagium animatum.

Roederer and Wagler deseribe typhoid fever at Göttingen.
$17 t i 2$

John Clayton's "lloras Virginie"a" published.

shipenen's private maternity hosprital costahlishord at Philadelphia.

first modical library in Initad States (P'ronsylvanial Hospital).

Bilguer resects wrist.

Stonerk introduces atennite and other nareotios.

Surgical elinic opened at lisbon.

1762-96. Reign of cittherine II of Russi:t.

1763. Joseph [3]ack differentiates between speeific and latent heat.

1764. Cotugno describes sciatin'il.

Louis introrluess digital compression for heusorrhage.

First pavilion hospital at Plymouth.

1765. Medical Faeulty of University of Pennsylvania founded.

Fontana publishes memoir on viper poison.

National veterinary school at Alfort (sinesine).

Royal veterinary school at Dresden.

Witt invents steam engine.

1766. Cavendish diseovers hydrogen.

Desalult's bandage for fractures introduced.

New Jersey State Mediical Society founded.

1767. Heberden deseribes varieclli.

Charles White reseets shoulder-joint.

Influenza pandemic in Europe. 
1768.

Wolff's memoir on entbryology of the intestines published.

Robert Whytt deseribes tubereulous meningit is.

Heberden deseribes augina peetoris.

Charles White resects head of humerus.

Theatrum anatomieum (Senekenberg) at Frankfurt a. M.

Medieal School, Kings College, New York, founcled.

Lind's treatise on tropieal medicine published.

1769. Citlen's Synopwis nowologia published.

Constitutio criminalis Theresiana (Law of torture).

Pott's treatise on fractures and dislocations published.

Watt's steam-engine (176ij) patented.

Merlical Soeiety of New York City, founderl.

Dartmouth College founded.

1770. Willian Hunter founds school of anatomy in Great Windmill sitreet.

Rutty deseribes relapsing fever.

Cotugne demonstrates albumen in the urime.

Willian Hunter deseribes retroversion of the uterus.

Abbé de l'epée invernts sign language for deafmutes.

First medical degree in Unitedstates eonferred by Kings College.

Pennsylvania quarantine aet.
1770-71. Simallpox destroys three million people in taxit Indies.

1770-1827. Beethoven.

1721. Priestley and sicheele isolate oxygen.

Arkwright perfects spinning jentuy.

John llunter's treatise on the teeth publisherl.

1772. Rutherford discovers nitrogen.

"Eneyclopédie" (1)irlerot and l'Alembert) eompleted.

Priestley aliscovers nitrons oxicle.

New Jersey ant to regulate the practice of merdicine.

1773. Medical Society of London founded.

First insane asylum in U. S. at Willismsburg, Virginiat.

Fothergill describes f:1eial neuralgiia.

Charles White urges asepsis to provent puerperal fover.

Jesint order suppressed by clement XIY.

1773-74. Revolution in Russi:

1774. William Huntr's "An:1tomia uterg" publishod.

Benjamin desty vaceinates against smallpox (Dorsetshire).

Priestley discovers ammonia.

Sicheelediseoversednorine.

Abraham Choveet teaches anatomy in Philandphis.

17\%5. Lavoisier discovers and defines oxygen.

- Pole and Dobson find gratpe-sugar in the urine. 
1765. $177 t$

1778.

1779
John Morgan appointed Direcelor (ieneral of Amerienur Army.

Ameriean Rivolution.

Cullen's "loist lines" publisherl.

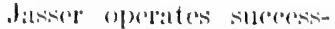
fully on the mastoid.

Selherdo and Borgmamn disoreser urie aleid in veris:al rillenli.

Plenck's alasification of skin discases publishert.

Cruikshank discovers that severed nerves will grow together.

1756-180.). Seartatina pandemic in both hemispheres.

1777. Lavolsier describes exchamge of gises in respiration.

Sigiult performs symphysiotomy.

John Howard's investigations of prisons and hospitals published.

School for army veterinarians at Viennal.

William Shippen ehosen Director General of American Amy Medical Department.

Count Rumforr! investigat exmehaniend erpuivalents of heat.

C. C. von Niebold performs symphysiotomy in Germany.

William Brown pulylishes first Amerientu pharmacoporia in lhilarlelphia.

University of Palemo founderl.

J. P. Frank issues first system of public laygiene (vol. i, April 24).

Bylon of Java deseribes dengue.
1779.

1780.

1781 .

1782

1783.

$1783-8.5$.
Irilliam Wright of littinburgh introdues "seoteh dourehe."

Ingen Housz discovers that plants give off $\mathrm{CO}_{2}$.

Pott describes deformity and paralysis from spinal raries.

Mesmer's memoir on animal magnetism publishod.

University of Oxford establishes aherir of clinicul medieine.

University of Münster inamgurated.

Chabert's menoir on animal anthrax published.

Benjamin Franklin invents bifocal lenses.

American Acadeny of Arts and Sciences founded at Boston.

Cavendish effeets synthesis of water.

Kant's "Critifue of Pure Reation" published.

Massachuset ts Medieal Soeiety founded.

Georgetown Iniversity (D. C.) founded.

Mediend Department of Harvard Iniversity founded.

University of innsbruck redueed to is lyceum by Joseph II.

Austria separates surgeons from barbers.

Royal Focioty of Edinburgh publishes transactions.

Marschat (Ntrasburg) excises a prolapsed cancorons uterus.

Lavoisier analyzes water and overthrows phlogiston theory. 
1784.

1755.

17ati.
Allgemeines Krankenhatus opened at Vienna (August 16).

Goethe diweovers intermaxillary bome.

Cotugno discovers arebro-spinat fluid.

Cavenelish diseovers hydrogen.

Royal College of Surgeons in Ireland foumder.

Josephinum extablished at Viennil.

Fowler introduces potassium arsenate (Fowler's solution).

Jolun Hunter discovers collateral circulation and introduces proximal ligation in anerlrysm.

Withoring's treatise on the fox-glove publisherl.

Charles White describes phegmasia alba dolens.

Sir Gilbert Blane publishes treatise on naval medicine.

Chair of anatomy astahlisherl in the Iniversity of Dublin.

Iniversity of Creorgial ([…. A.) founderl.

John Honter publishos Trration on the Vererreal Discase.

Parry describes exophthalmie groiter.

Lettiom describes drug habit and alcoholiom.

P.-F. Mloreatu rexcisest rlbow-joint .

Fourcroy and Thouret diseover adiporerere

Royal Colloge of Physieians (Lonilon) publishes transactions.
$175 \%$

College of Physiciams of Philadelphia formded.

Maseagni publishes atlats of the lymphaties.

Guild of Bathkeresers abolished in Wür\% burg.

1788. Unirersity of Lomvain removed to Bruscels.

Influenza pandemic in Europe.

1789. John Hunter describes intussuseption.

Matthew Baillic deseribes dermoid ovidjian ersts.

Medical Society of Delaware founderl.

Medical siserety of south Carolina foumderl.

1789-99. French Revolution.

1790. Royal Veterinary sehool establisherl at Berlin and Munich.

Medical journal pulslisherl in New York.

1791. Socmmerring publishes first volume of his anatomy.

University of Innsbruek restorerl to rank by Leopold II.

New Hampshire Modiat society foumblerl.

Rosal Veterinary (inloge establisherl at $\mathrm{l}$,ondon.

Dr. Cinillotin invents the guillotine.

Royal Seat-Bithing Infirmary for serofulat at Norrgate.

1791-99. Willi:m Baynham of Yirginia operates for extrat-17trine pregnamer.

1792. mat electricity publisherl.

Voltaie pile. 
1792. , Foleré mblisles troitise on goiter and cretinism.

sprengel's history of medicine published.

Comerticut Merlieal socicty founderl.

Cottongin (Eli Whitney).

Establishment of fremeh lipublie (September 21).

1793. Matthew Baillie's "Norbicl Anatomy" publishert.

Bonj:umin Boll differentiates between gonorrhea and syphilis.

Matthew Carey describes yellow fever epidemie in Philidelphia.

1793-94. Reign of Terror in France.

1794. Lavoisier beheaded (May s).

John Hunter publishes treatise on blood, inflammation, and gunshot wounds.

John Hunter deseribes transplantation of animal tissues.

Dilton deseribes colorblindness (October 31).

scarpa's Tabute nevrologice published.

Era-mus Darwin's "Zoönomia" published.

École de santé ereated at Paris.

Gumpert publishes Greek text of Aselepiades.

1795. Surgeon General Görcke founds Pepinière (Kaiser-WilhelmsAkademie) at Berlin.

Institut de France founded.

Abernethian Society founded at London.
1796.

Jenner vaccinates William Phipps (May 14).

Abormothy first ligates externat iliac artery.

Wright Post successfully ligates femoral artery in America.

Société de médreine de Paris founded.

Yollow fover in Boston.

1796-1815. Napoteonic Wars.

1797. Wollaston discovers uric acid in gouty joints.

Currie pulbishes reports on hydrotherapy in typhoid fever.

John Rollo arlvoeates meat diet in diabetes.

Medical Repository (New York) published.

1797-99. Yellow fever in Philadelphiir.

1798. Jenner's "Inquiry" published.

Malthus' Essay on Population published.

Medieal and Chirurgical Faculty of Maryland founded.

ImperialMedieo-Military Academy founded at St. Petersburg.

John Haslam describes general paralysis.

Medical School of Dartmouth College organized.

Gas lighting introduced.

1798-1805. Willan's treatise on skin diseases published.

1799. De Carro introduces Jennerian vaceination on the continent and in Asia.

Matthew Baillie deseribes endocarditis.

Anderson's College Medical School established at Glasgow. 
1799.

Cinitod states Congress passes gllarantime ant.

1799-1s04. Napoleon First Consul.

1800.

1801.

\section{loyal College of surgeons} (Lomedon) chartered.

Bichat's "Traté des membranes"published.

Sir Ilumplary Davy discovers anesthetic offeet of laughing gas.

Benjamin Waterhouse in troduees.Jennerian vacfination into Americat.

Cuvier's Comparative Anatomy publisbed.

Pincel publishes psychiattie treatine.

Thomas lonng deseribes astignatism and states indulatory theory of light.

Bichat's "Anatomie descriptive" published.

Oxy-hydrogen blowpipe (Itare).

$140: 2$

Heberden's "Commentaries" published.

Conseil général de Santé founded in Franee.

Bichat's "Anatomie générale" publistued.

London Fever Hospital establisherl.

1s03. Anatomical and pharmaceritional societios founder in Paris.

Otto describes hemophilia.

1804.

Eniversitios of Kasan and Clarkor founded by Mlexatnolur 1.

Diltonstates atonie theory.

Scarpa deseribes arterioselorosis.

Roval London Ophthalmic Hospital formert.

Philadelphia Medical Musenum published.
1404-15. Napoleon Enyperor of the French.

1405. Battle of Trafalgar.

siertürner isolates morphinc.

Viemserux describes eeren bro-spinat meningitis.

Merlico-Chirurgical Soa i t y (London) formelere.

140ti. Fnd of Holy Romatn Empire.

Fulton invents steamboat.

1S0\%. Compulsory vaccination introlueed into Bavaria and Hesse.

Procival publishes code of medical ethies.

Iniversity of Altdorf united to Erlangen.

College of Medicine of Maryland founded at Baltimore.

Davy isolates $\mathrm{Na}, \mathrm{K}, \mathrm{Ca}$, $M g, S$ and $B$.

1S0S. Universities of Lyons and Clermont-Ferrand founded.

Physikaliseh-medizinische sozietiit founderl at Erlangen.

Sweelish Medieat Society fountled.

Medical Faculty at Rio de Janeiro founded.

Barbam publishes tratise on bronchitis.

1809. University of Berlin founded by Friedrich Wilhelm III of l'rusisia.

MeDowell performs ovidriotonsy.

Allan Burns deseribes endocarditis.

socmunerring invents alectric tolegratph.

Freneh Ilospital tounded at $\mathrm{N}$ 'work. 
$1 \leqslant 10$.

$1 S 12$.

1513.

$1 \times 14$.

$1,15$. (iall and sipurzhoim pullish treitise on the nervous system.

Hildenbrand publishes aceoment of typhus and typhoinl forer.

Wells describes rluetumattivm of the hestrt.

Mar\%ari attributes pellat[x: to eorn.

Dary analyzes corrosive sublinate.

Yale Medical sichool founderl.

University of Christiania founderl.

Napoleon abolishes [niversity of Salerno (November 29).

Sir Charles Bell describes functions of spinal nerve-roots.

Massachusetts General Hospital (Boston) established.

Univrsity of Genoa founded.

Parkinson deseribes perforative appendieiti:.

Legallois deseribes action of vagus on respiration.

Aearlemy of Natural seienees founded at Philarlelphia.

Bellevue Hospital (New York) establishorl.

Sutton differentiates delirium tremens from phrenitis.

Ling introduces swerlish movements.

Royal Hospital for Diseases of the Chest (London) founded.

Stephenson's first locomotive.

German Confederation. Battle of Waterloo.
ISI.T.

Datry invents safety lamp for coal-miners.

Cuirersity of Witteubere remeverl to Hatle.

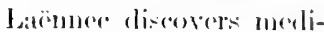
atr atuseultation (Maty $1)$.

listrane performs exarticulation of tatronmetatarial joint.

Surecial chair of midwifory in Cilasgow I’niversity.

1816. University of Ghent founterl.

Delpeeh performs subeutancous tenotomy.

Royal Ear Hospital (Lon(lon) founcled.

1s16-30. Pindemie of eholera.

1817. University of Liegr founded.

Pelletier isolates emotine.

Friedrich Wilhelm: Institut estiblished it Borlin.

Parkinson deseribes patralysis agitans.

John King publishes book on extra-uterine pregnaney.

Sir Astley Cooper ligates abdominal arorta.

1s1s. Eniversity of Bom founded by Friedrieh Wilhelm III of I'rusia.

De Riener introdues: frozen seetions.

Vilentine Mlott sueersfully ligates the innominate artery.

Thénard discovers hỵtrogen peroxide.

Pelletier and Carentou isolate stryehnine.

1\$19. Eniversity of st. Petersburg founded by Alexandler 1. 
I\$19.

1520.

1521.

1522.

1823.

1824.
Steamship erowes Atlantic: ()eeall.

John Bostock aleserilues 1:iy-ferer.

Pelletier and Cinventons isolate quinine.

Medienal College of Ohio formeded.

Hunterian Society (Lomdon) founded.

Merlical Society of District of Columbia founderl.

Acalémie de mélectine fomicled at Partis.

Coindet were iosline in goiter.

First U.s. Pharmatreporia publisherd.

Philatelphia College of Apotheraries of enerl.

Itard's treation on otology publisherl.

McGill College and Lni. versity fommlerl at Montreal.

Philatelphia Colloge of Phamarey founded.

Magemelie demonstrates Bell's law of the spinal nerve roots.

British Assoetiation for llye Alvinerment of sievenos foumelesl.

Gescollschaft dentiogere Niturforselerer ant Aerzte founderl.

James Jatekson describer alcolwelie neuritis.

Purkinje investigates tinger-prints.

Cherreul investigatesanimal fats.

Chevallior lnotluers introducr athromatio mieroseope.

Flourens publishes work on ererebral physioling.
1521.

Prout investigater areility of gastrit juire.

Sirdi carmot states the seromel law of thermodyominies.

1525. Eniversity of Virgini: founderl.

Jeffersen Mredical ('ollege establisherl at Phil:ulelphia:

Bonillatud deseribes and focalizes apluasia.

short introlueses olemen tiglii from Intliz.

Fever lospital in Now York City.

1826. University of Munich fommled (by removial of University of [ngolstarlt from Landslutur.

University of $11 \%$ (1tifo) mover to llelingfors.

Laënnee gives elassical deseription of bronchitis and other thorateine diveasers.

Dupuytrendexcribersmgentatal diskexattom of the hip-juint.

Calmeil describus 2 entcral palralyoir.

1.527. Lerd listw born (April j).

Von Biare discovers mammaliam ovimn.

Richald Bright deseribuexsential mephritis.

Adoums rexeribes le:mlblowk.

Anira and Cutlubert invent peflecting microsicope.

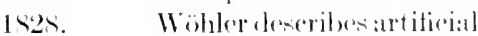
synthesis of ureat from ammominum erantete.

Piong introllates pleximeter.

Ilorlgkin dereribes atorlic regurgitation. 


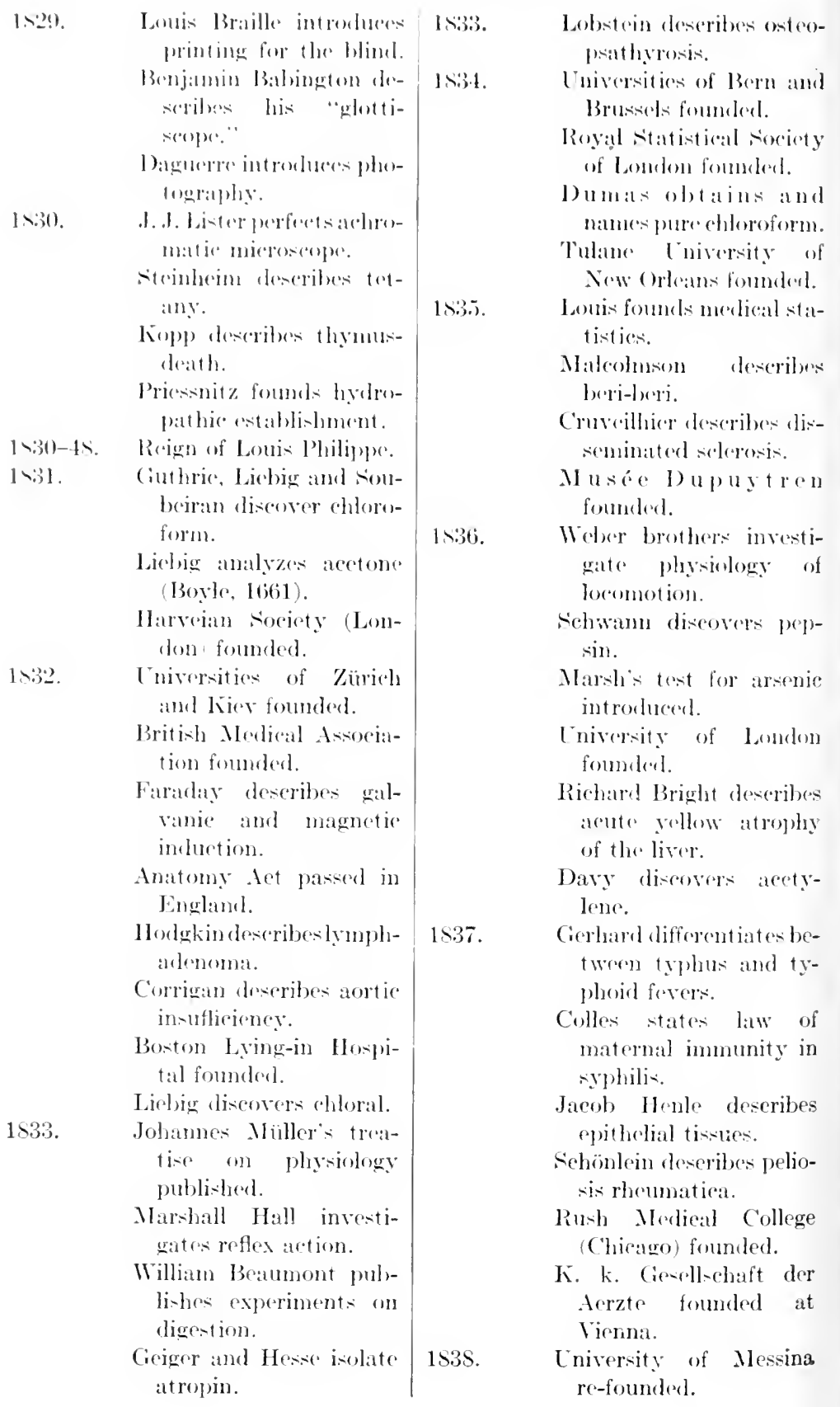


18.38.

18.39 .

1840.

$15+1$.

1.842.

1843.
Scblejelen describes plant (*ills.

Ehrenberg publishestreattise on infusoria.

Johbannes Mijtlers treat tise on tomeors yublishreal.

Mettauer suecestully operates for vericovaginal fistula.

Joyval orthopardie Jlospital foumded.

sebwamn publishes treatise on the erell theory.

skoulas treatise on pror(nission and ansondtation publiwhere.

First volume of Littrós Jipperater published.

First elental journal (Now Iork).

Rowlanel llill intromincest postages stamps.

Jareob Hoine describles infantik poliomyelitis.

Basedow describes ex(9) hathahnice goitar.

Jirst dental erelooul and

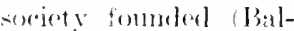
timores)

JIente: "Allgemeine Inatomie" mblisherl.

J. Ji. Mayer states law of (imcervation of Enerery.

Long operates with of her anestheria.

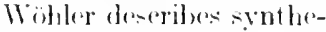
sis of hipporit from b) लuszoje alciel.

Dieffentarels publishes treatise on strablism]11:

O. IV. Ilolmes points out (e)ntagionsmest of jucrperal fever.

Carl Lulwig invertigates mochanism of urinary secretion.
1843.

1844.

1845

$15+6$.

Whare hrothers disenerer inhibitery offect of valgus norve.

Mertom intromtures rether amesthesiat.

Kintliker deseribes snosth musele.

Marion firns invents vaginal sperulum.

C'amele bernaled disosers digestive functions of Jatrereats.

stokes deseribes lowartlifork.

Elias Howe patents sowing mashine.

smithonian Imstution ni 14 a $\leqslant$ b i ngton formelex).

Pathological society (Lomelon) fommeder. 
1547.

1848.

$1545-52$. 1849.
Ilelmholt \% publishes lreattise on Comservation of bucrey

Sir J. Y. Nimpson introduces chloroform anesthesia in olostertric's.

semmelweis diseovers eatuse of pherperal fover.

Carl Ladwig invents kymograph.

Gerlach injects anpill:tries with carmine stain.

American Medieal Association founded.

Royial Acinlemy of Sciences founcled it Viennil.

New York Acatemy of Medicine founderl.

O. W. Holmes alppointed Parkman professor of anatomy at Harvard.

Ifromholtz locates souree of animal heat in the muscles.

Claule Bernard discover: glycogenic function of the liver.

Du Bois-Reymond pulslishes treatise on animal eloetricity.

Société de biologice founded at Paris.

American Association for the Advancement of science founderl.

English Act creating general amel local boards of health passed.

Second French Republic.

Addison describes pernicious anemia and suprarenal divease.

Claude Bernarl produres diabetes by puncture of the fourth ventriele.

Marion sims operates for vesico-vaginal fistula.
ISt.

J. K. Mitchell publishes treatise on eryplogatmous origin of malatial fovers.

Nillon introduess raagent for proteins.

Intrhinson invents spirometer.

University of Wisconsin forminerl.

15.00. IIelmbolty measures the velority of the nerve eurrent.

Waller states law of degeneration of spinal norves.

Daniel Dralke publishes treatise on diseases of the Mississippi Valtey.

William Dotmold (New York) opens abseess of the brain.

Epiclemiological Society (London) founded.

1851. Helmholtz invents ophthalunoseope.

Clatule Bernard explains vasomotor function of sympathetic nerves.

Ludwix and Rahn investigate nerves of salivary secretion.

Falret describes circular insanity.

Nélaton describes pelvic hematocele.

1852. Pravaz introduces hypodermic: syringe.

International Congress of Hrgione at Brussels.

Kölliker's treatise on histology published.

Pirogoff employs frozen sertions in his "Anatone topographica."

()bstetrical Society (Lonlon) founded.

1852-70. Second Empire in France. 
1853.

Marion Sims publishes treative on vesiecovalginal fistula.

Cohn demonstrates vegetable nature of bateterial.

Gilman Kinnball excises uf (rus for fibromyomit.

1853-56. Crimean War: Florence Nightingale.

1554. Graefe founds Archiv für Ophthalmologic.

University of Marseilles founded.

Virchow deseribes neurogliia.

Claude Bernard discovers function of vaso-dilator nerves.

Hermann Brehmer opens hospital for phthisis at Görbersdorl'.

1855. Nanucl Garcia introduces laryngeseope.

- Addison publishes memoir on diseases of the suprarenal capsules.

Marion sims founds Howpital for Women's Diseases New York City).

Graefe introduess irideretomy.

Buesemer steel proesess and Bumsen burner invented.

Paris exposition.

1856. Sir W. II. Porkin (1S3s1907) obtains aniline dyes (coal-tar produets).

Panmm investigates cheuniral profuets of putrefaction.

Caspars: tratise on medieal jurisprutenee publisherl.

1857.
$1 \times 57$.

1858.

1559.

$1 \$ 60$. tion for strabismus. 
1860.

1561.

1861-65. Civil War in the Lnited Sitates.

1862. Raynaud describes symmetrical gangrene.

Donders publishesstudies on astigmatiom and presbyopia.

V. von Bruns performs first laryngeal operation with laryngoseope.

Winternitz and Oppolzer found first hydropathic establishment at Vienna.

1863. Helmboltz's "Tonempfusdungen" published.

Voit and Pettenkofer publish investigations of metabolism in respiration.

William Banting publishes "Ietter on Corpulence."

Pasteur investigates silkworm rlisease.

1864. Donders publishes treatise on anomalies of aecommodation and refraction.

Traube investigates pathology of fever.
1 stis.

Parkes' Mamual of Practi(all llygione publishorl.

(ienevil Convention.

Lo Verrier founds Association framsaise pour l'avanement des seiences.

1565. University of Odessia foumded.

Cornoll Iniversity fommled at Ithaca.

Vee and Leven ixolate escrin.

Gregor Mendel publislues nemoir on plaut hybridity.

Villemin demonstrates infeetionsness of tuberculosis.

Chicago Hospital for Women founded.

1S66. Seven Werks' (AustroPrusian) War.

Voit establishess first hygienic lathoratory in Nunieh.

Ludwig and Cyon investigate the vasomotor nerves.

Marion Sims publishes Clinical Notes on Eterine Surgery.

Graefe describes sympathetic ophthatmia.

1867. Lister introcluess antiseptic surgery.

Helmholtz publishes treative on physiologieal opties.

Kussmaul introduces intubation of the stomach.

Moritz Traube devises semi-permeable membranes.

First International Medieal Congress at Paris.

Siemen: brotbers introduce dynamo. 
1567.

1869.

1570-71. Franco-P'russian Wir (tert of valecination).

1571. Establishment of (iorman Empire and lirench Repullic.

Darwin's "l)seent of Man" publisherl.

Woigert stains baeteria with carmine.

English Local (iovernment board creited.
1571.

1572.

New York Orthepedie Ilospital fombled.

Eniversity of stratsolurg reopenerl.

Iniversity of derlatrle (Australia) fommloxl.

Abbe introluares oil intmersion loneses.

Battey performs normal oviariotomy.

Noeggerath describes of feets of batent gonorrhea in women.

Infant life proteretion aset patsised in linglamel.

1873. Eniversity of Geneva formded.

(1) bermejere eliscovers spirillum of rolitping fever.

Femarch introduces hemestatie bamdage.

- Cinll dereribes myxalminit.

Billrothexeisesthe Garymx.

Sehwartzo and bysell drvise matstored operation.

Coiguet introlueres rotincserengy.

Canalization of Berlin brom.

Larynghogical socioty of Nim York organizol.

Revarination rompulsory in (iermany.

1574. Choleria conferenore in Vimmat.

Intornational postal itrevion.

Loi Rousserl conacted for the protection of infants (Jinee).

Ehrlich introrluces driml blome smeatrs aml intproves stain mothods.

Killbaum describes kit itconia.

Willỳ Kühne discovers trypsin. 
1575.

Iniversitios of 1 ambere

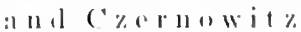
founderl.

1 andois discosers hemolysis from transmusion of alien bloos.

sir Thomas Barlow dre scribes infantile menry

lösch observes parasitic amebse in dyoutery.

Woir Miteholl introluess rest ellre.

Jeat inspertion (ompulsory in (icrmany.

Public Ilealth Act in Englanel.

linglish Food diulderition Aet (August 11).

Boston Medieal Lilnrary formelerd.

1s 6 . Imperial board of llealth formeded at Berlin (April :30)

Royal Simitary Institute fomided (London).

Johus Hopkins Eniversity founded.

Roval Acarlemy of Medirine foumded at Rome.

Plysiologieal society of London founded.

International Hygienic Congress at Brisisels.

filvre introduees gypsum eorset for spinal deformitios.

Kolloe isolates sulieglic alcirl.

Lombroso publishes treatixe on eriminal man.

Paquelin cautery introduced.

Porro introduces Cawarran section with exrision of adnexa.

Koch grows anthrax bacilli on artificial melia.
STH.

Peter Deltwoiler treats consumptives at l'alkenstein by rest rure in open atr.

Ball tolephone introdiserd.

University of Amstordim foumdert.

157. Pastourdiscoversbatitus of malignant colemat.

Gimst von Borgmamn introduers eorresive sul)limate ant jecpris.

Bozold deseriber mastoirlit is.

1S7-7S. Ruso-Turkinh War.

1sis. Koch discovers allises of trammatic infections.

II. A. lireund excises canecrous uterus.

International Congresis of IIygieno at P'aris.

1879. Neisser discover's gonococcus.

Nitze introduenes artonropy.

German food law pasised.

1880. Pasteur isolates streptococens and staphyolococeus.

Eberth isolates typhoid bacillus.

Sandström describes parathyroid gland.

Balfour's Embryolegy published.

Mosetig Moorlof introduess iorline in surgery.

Billings publishes Index Catalogue (Vol. I).

American surgicial Assoriation founded.

London Association of Merlical Women.

1SS1. Laveran discovers parait e of malarial fever.

Billroth resects the pylorus. 
1ss1. Czerny deseribes vaginal excision of uterine tumors.

Hathe performe nephrorpexy.

Wölfler introulueses gatstro-enterostomy.

Merlin diserserseputenie nature of poliomyelitis.

lioch introduces plate cultures.

New York Polyedinis: foumbel.

1852. Koch discovors tuberele bacilluss.

Leiffler disenvers bacillus of gramilars.

Walther Flemming investigates cell division.

Max Sänger improves Casareath sections.

Lamgenbuch exeises the gall-blackder.

1ns. Edwin klels diseovers diphtheria bacillus.

Pastenr vacoinatos agatinst :nthrax.

Coma introthers iallthyol.

Lawson Tait operates for extra-uterine pregniney.

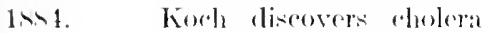
barillus (Fehruary 2).

Nicolajer discovere totatmus bacillus.

Crelle introduces silver nitrate instillations for infantile "onjunntivitis.

Lulwig knorr preparew antipyrine.

Baumann discovers sulphonal.

Carl Koller employs anatione in eyesurgery.

1s55. O'Dwyer improves intubation of the larynx.
1 1ST:

Woismatm publishers momoir on continuity of the germ plasm.

Ewald and boats intoduere test-breaklasts.

IVeigert introduces bematoxylin statinge of nerve-fibers.

1ssti. Escherieh discosers Bit(illus enli.

Von Bergmann introducess ste:tut sterilizattion in surgery.

Fit? deseribes pathology of appendicitis.

Marie describes aceromegaly ats comneretoel with the pituitary berly.

Marcel von Nencki introducess salol.

Soxhlet introlueres sterilizod nuilk for nutrition of infants.

Cahn and Hopl introduee aceotamilide ( iorharelt, 1s4:3).

R. II. Falkin lectures on tropical medieine at Etlinburgh.

1s57. Clark Iniversity fommled (Woreester, Matso.).

Bruee diseovers arene of Malta forer.

Wrejalsollanum discosers meningereneroms.

1) Arsonval introcheres ligh frergueney corrents.

Howard Killy pertorms hysterorthaphy.

Gowers and Ilorster operate on the ypinal (")

Slonane Malernity IJuspital (Now York) openent.

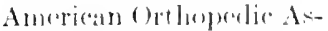
sociation founderl. 
Iริง.

1589.

1590.

$1 \$ 91$.
Enirersty of Tomsk ls'31. foumdiol.

Institut Pastene formuled. lowa :mel Versin investigats the toxins of diphtheria.

Nuttall diseovers the balctericiclial powrers of beod-sermm.

lohns Hopkins lloppital and llamburw-lippendorff llospitalsopened.

Buchner discovers alexins (protective berlies).

von Mering and Minkowski produre experimental pancreatic diabetes.

Infectious distatses notifreation act in lingland.

Behring discovers antitoxins.

University of Lausanne founder.

Imperial Institute of Experimental Medicine founderl at st. Petersburg.

Bohring treats diphtheria with antitoxin.

Koch introduess tuberculin.

Infectious Discatses Prevention Ict in Englinnd.

Bowditch demonstrates non-fatigability of nerve.

Weigert stains neuroglia with methyl violet.

Institute for Infections Discases opened at Berlin under Koch.

Lister Institute for Preventive Medicine (London) founded.

Waldeyer founds neuron theory.

1592.
Quincke introdueres lut11bar puncture.

Hyeirmine Institute at llamburar openerl.

Wi-tar Institute of Anatomy amel Biolocy (1sos) incorporated.

Halsted sureosisfolly ligates subclavian alltery in lirst portion.

lowsel and Notullamn discover pentesse.

Cholerar epirtrmio in II:mbutro.

1s93. Sunith and Killoum demonstrate transmission of parasitio discases by arthropodal.

Gilhert discovers parat colon and paraty. phoid baeilli.

Fins'n light introslued.

International Cholera Conferenes in Dresten.

Society of Anathetists (London).

1594. Kitasato and Yersin diesver plague bacillus.

Irirstein devises direct larynguscopy.

Selleich introrlues infiltration anesthesia.

Local Government Act in England.

1ऽ95. Pfeiffer diseovers bacteriolysis.

Röntgen discovers $x$ rilys.

Nobel prizes int roduced.

Wilhelm II is reforms anatomical nomenclature.

Marconi introduces wireless telegraphy.

1596. Max Gruber discovers bateterial agglutination.

Murphy produces snc('istul rireular anastomosis of blood-vessels. 
1896.

1897.

$189 \mathrm{~S}$.

1899.
Dibdin and schweder introduce biological purifieation of sewage.

Wilal and Ficard introdues agglatination tost for typhosid feres.

Shiga discovers dyenentery bateillus.

Emil Fischer syuthetizes caffeine, theobromine, xanthin, guanin, and adenin.

Bordet diseovers bacterial hemolysis.

killian introluess dircet bronchoseopy.

Löfler and Irosch investigate filterable viruses.

Radium diseovered by the Curies.

Dreser introduces heroine.

Emil Fischer isolates the purin nucleus of urie acid compounds.

Loosidemonst ratestransmission of hook-worm inforction.

Theobald simith differentiates between bovine and humand tuberele bacills.

Mrelieal Library Association tomemed.

Reed and Carroll (wtablish transmission of yellow forer by mosruitom.

Jacepues lach promluess rhemiend activation of sea mehin ego.

Ehrlich's Institute for Experimental Therapy fommded at Frankfort.

Liverpool, London and Ediuburgh sedrools of tropiral melicine founcled.
190()$.

Robert (iersuny introdueces paraflin injeretions.

Gärtner introlaces tonomenter.

Widal and Ravalut introduere rytodiagnosis.

llertleim interenlues: raclical oporation for utrine cancer.

1901. De Vuiesstates mutation theory.

Chlombuth introduces precipitin test for blowl stains (Bordot, 1s9s).

Dutfon and Ford discover parasite of slepeing sickmess.

O. Colmbrim discovers (crepsin.

Takamine isolates atrenalin.

Roekefellor Institute for Medical Research opened in New York.

Instituto (bwalle Cruz opened at Rio do Janeiro.

"Biometrika" fommded by (ialton, Pearson and Wralon.

1902. Carrol introluces mothofls of vaseulale andistomoris and transplantation of tisisurs.

(i. Kelling introthers exploration of peritanowl ravity by inflittion.

Ilerzoge discovers site of Asclopoion at Cos.

Carmogie Institution of Washingten fommlert.

lomperial cincer linserisch linnel (lingbind) fommlorl.

1903. Mrotrinikoff inoculates highere apes with syphilis. 
1903.

1901.4

$190 \%$.

1906.

1907.
Emil findher and rom Mrring introdues veronal.

Bier intreslueses artilicial hryperminis.

Einthoven invents string mat vithemerter.

Broler showe that stere ing sicknessis is transmitted by tsotse fly.

Homry lhipps Institule for Tuberenlosis opened.

Atwater invents respiration caloringeter.

satuerbruch introluces pneumatic cabinet for surgery of the chest.

schaudinndiseoversparasite of syphilis.

Alfred Einhorn diseovers novocaine.

Robert Koch investigates African fever.

Institut für Gesehichte der Medizin (Loipzig) founded under Karl sudhofe.

Burdet and Gengou di:cover Lateillus of whooping-cough.

Rudolf Virchow Ilospital opened at Berlin (October 1).

Bíriny develops theory of vestibular nystagmus.

Sehool of Tropieal Merlieine established at Bruscels.

Nutrition Laboratory (Carnegie Institution) restablished at Buston.

Food and Drugs Adt (U. S.) pasised.

Wasermann introduces sero-diagnosis of syplitlis.
19107.

1908.

1909

1910.

1911. von Pirgtet introduces cutameouss reaction in tubereulosis.

Calmette amd Wollif-Fisner introduce eonjumetival reactions.

Royal Society of Modirine (Iondoni) founded.

Society of 'Tropical Medicine ( I on lan) founderl.

Sileeping Sickness Bureau (Lonton) founded.

Royal Army Morlical College opemed at Millbank.

Eniversity foumeled at Manila.

Föster introduecs operation for locomotor ataxia.

Much introduees cobra venom reaction in inlsanity.

Ehrlich introduces salvarsan.

Noguehi improves the Wassermann reaction.

Harrison demonstrates nerve-fiber outgrowth extravitally.

Hemi and others introduee ultraviolet sterilization of water.

Flexner produces poliomyelitis experimentally.

Verder demonstrates amebicidal action of emetine.

Law against White Slave traffie (U. S.) passed.

Carrel investigates extravital culture and rejuvenation of tissues.

Noguchi introduces luetin reaction.

Cushing deseribes dyspitujtarism. 
1911.

1912.

1913.

914-15. Inada and lto invertigato

1914-1s. Pan-Furepe:an IVar.

1915. spiroeluetal jatumlioe.

Ciullstrand receives Nobel prize for option rescarches. sitrooma by moams of a filtrable virus.

Bass enltivates malarial plasmorlium in vitro.

Sudhoff opposes theory of Anorican origin of syphilis.

F. Wober ambl Iarey (1mploy $x$-rays to visualizas abolomimal viscera.

Childron's Bureatl astablished (IVishingtorr, D. C.).

Abrlerlableder introlures ferment radetion for diamnosis of pregrnancy and demontia priecos.

Barthe devises ambring troatment.

Supreme Court (I. S.) denies "rights" of individuals where inmial to public wolfare.

Phipes Pserehiatrio C'linir. (Battimere) openost.

International Mertical Congress in lemelons.

Gassing of tmopen in warfarer.

Futaki and Ishiwara diseover patalsite of rallbite fores.
Peyton Rour transmit
1915

Defresing of troops:

Carrol-1)akin treatument of inloeterl woumbl:

Potanus incoulation in gumshot woumds.

1915-16. Mlott et al. investigate shell-sherek.

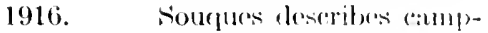
tocoming.

Wremer deseribes Vollownitin f(rer.

Vanghetti introluessin(r)latity.

Dakin introduces thchlorinnince-T.

bull introduess antitoxin for gat githeren!?

1917. l'rincipte of wommel exoisioll astablisherl ( iallelemanîtron).

von Exomomo describu

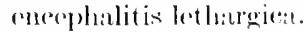

Mental testsemployerl in recruiting soldiers.

IVilleme itandirelizes raty mobilization in joint wommls.

1917-18. American (ommixion invertigater trench forer.

1915-19. Fpanish influmbal (p)idemie.

1919. British Ministry of Health ritalinglind (July 1).

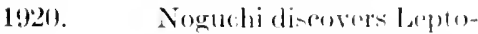
spira in rollow fover.

First Congreses of Mlerlical llivtory Antwerp). 


\section{HINTS ON THE STUDY OF MEDICAL HISTORY}

"Creater even than the greatent discosery is to kere open the way to

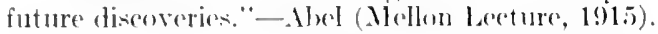

In the oxamination-papers of the I. S. Xaval Acarlemy, ats they were publicty printert in the carly eighties, one enoomtered a large number of questions like these:

Draw a map of liurope after the peace of [trecht.

show that the later Roman Republic was nominally a denoeraey but with aristorlat ie tendencies,

thip lving head to wind, get underway under sail, and stand out on the port tark.

Make all preparations for a gake. Main tack and clew-garnet gone, what is to be dome?

- How by a genealogieal table, how ('harles $\mathrm{V}$ obtained the different parts of his domioions, and draw a map of the same.

Dexign boilers to supply steam for an engine of 2000 I. II. P., ete.

In pedagogies of this kind, in whieh the Naval Academy wat a pioneer, what a breozy, ]efreshing eontrast to the kind of thing other students endured in the same jerionl!

This method of teaching, the Socratic, which recpuires the student to use his own mind and do his own thinking, is now eoming to be accepted everywhere as the best substitute for what (Mborn describes as "the prevailing system of werfeceling. Whieh stuffs. "rimus, pours in, spoon-feeds, and, as a sort of death-bed repentance, institutes creative work after graduation." The same althority" instanees "the famols method of teaching law re-disroveref hr the educational genius of Langdell," in which "the students do all the lecturing and theoursing, the profesor lolls quietly in his chair and makes lik romments." At Weimar. as Imy Fay tells us, Liszt formed eapable pianists by making his pupils do all the plaving. "Je ne suis pas un profesieut du piamo." he would sav, although he sometimes condescended to help them out with some diffienlt passage or some subtle nuance of expression. That is how Giler taught his students to think elinieally, and the methods of teaching medicine by "ease histories" introrlueed by Riehard Cabot and otbers, are in the same trend. The extreme of spon-feeding is Vivian Poore's "idiot satant." an asylum inmate, who could repeat most recondite passages learned hy auditory memory, much as Blind Tom played the piano or as a type of Chinese sorvant, in preparing a purlding, is said to imitate every slightest gesture made breforehand by his mistress?

One of the pioncers in teaching usedical history by the newer methods was the late Dr. Jamos Finlasen of Gitagow, who early saw that for retails and minutie, tle printed volume is better than systematio lectures, and that medieal libraries are really the laboratories in which the professor and his students must work. He sometimes amtsed himself by asking his hospital assistants "whether Cialen wrote in Latin or Cireck, and whether before or after the Christian era." Their wrong answers eonvineed him that the mere handling and inspertion of some of Galen"s works would have embedled the faets in their minds better than any spoken or writen statement, and he accordingly gave ifmonstrations in the Library of the Faeulty of Physicians and Surgeons, to which a small audienee was invited. The same idea was utilized by Billings,

${ }^{1}$ H. F. Osborn: Huvley and Edueation, New York, 1910, 25, 35.

2 Ponre: Treatise on Medical Jurisprudenee, London, 1901, 403. Cited by Georgo Pernet. 
Oster, Welch and others at the Johns IIopkins Hospital Historieal Chub, and its suecess is suflieiently reveleneed in the work of some of the pupils. Finlasson's printed demonstrations of Hiplowates (1892), Cialen (1592), Celsus (1892), Egrptian Nelicino (1893), Jferophilus and Erasistritus (1893) are perfeet modrls of what such things shoukl be-genial, simple and immensely interesting. The demonstrations by John s. Billings (Johns IIopkins Itos). Bull., Balt., 1890, i, 29-31) and George Dock (Physieian and Furgeon, Dertroit, 1906, xxviii, 1s0-1s(i) deserve study. The syllabus ame specimen-extraets printed by Dr. John D. Comrie, lecturer on the history of medicine in the Eniversity of Edinburgh, utilize an idea of Wunderlich's in a very helpful and practical way.

Dr. C. ‘ X. B. Camae's "Epoeh-making Contributions" (Philadrlphia, 1909), from Lister, Harvey, Auenbrugger, Laënnec, Jenner, $t$ al., is the best book of this kind for American students.

In the ortinary medieal eurrieutum, the subjeet of medieal history commonly goes a-begging, because set leetures have bern found to be so inevitably try and disappointing that students avoirl them, even as pupils at nusieal conservatories are said to a void the elasses in harmony and counterprint. It is a mistake to overburden the student with extra eonrses of lectures, given, say, in his graduating year, when such a eourse might defeat its own object by interfering with his work at the most important period of his student life: for his personal interest in medieal history witl naturally depend upom what he does with himsedf after gractuation. Osler set off this cliffieulty by bringing historieal topies directly into the clinies and by his "ronings at home with his "boys." In any merlical faculty of size, there will always be some member who takes a jorsonal interest in eneouraging and stimulating young men, after the example of Pasteur, Jublwie. Hente, IIytl, and of Weleh, who, in his later period, has hern content to live forward in the work of his pupils. Here, the field of mediral history holds out perhaps the most attrastive opportunity, and the following simple plan is sug-

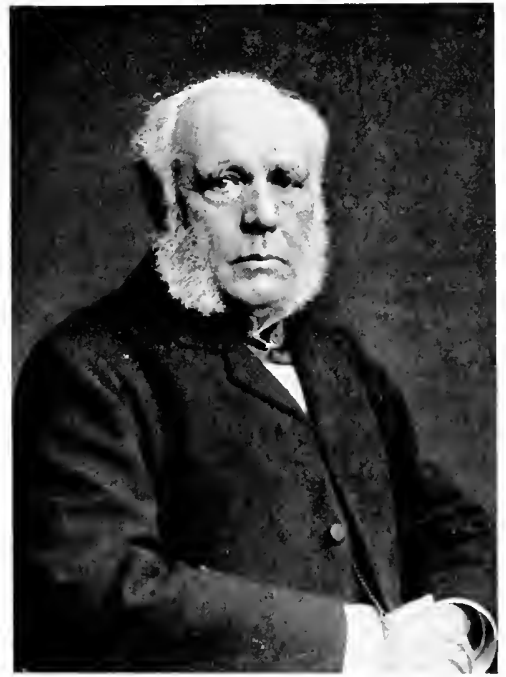

James Findayeon (1840-190(i). (('oultesy of Fir William (siler.) gested. Asimming that rom have,

like ()sker, a personal interest in the welfare of studrents, ask any of your elass who have the time or inclination, to look uj a particular subject, such as Sydenham, or Laënnes, or Virchow, or the history of our knowledge of the heart sounds, and report to you about it some evening, either at your home or dsewhere. At the meeting give each an opportanity for a five- or ten-munutes extempore talk on the given theme, and, as they speak, notiee if they have really got at the inwardness of Sydenham, the signifieance of Laënnec or the real facts about the heart sounds. Then amplify and eorreet by whatever you choose to say yourself, at the same time demonstrating looks eonneeted with the author or subject. In these davs of laree modical dasses, compulsory attendanee upon mortico-historieal demonst rations would reguire a good-sized room, preforably in a medieal library, but a laissez faire poliey will soon sift out vour available material, and the smaller the gatherings, the bet ter. Joseph Svlvester onee lectured on the higher mathematies to in aurlienee of one, Trousseau arlvised his students to get their bedside medicine in the lit te 


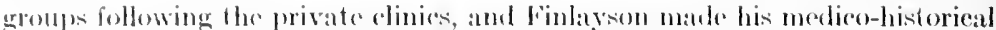

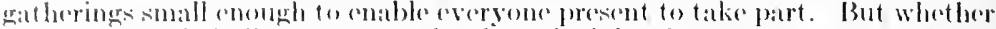

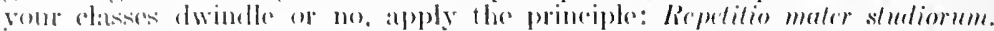
sere to it that the points you have attempted to bring out in your private

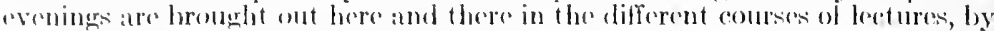
moans of lantern slieles and demonstrations of books, piotures, instruments or what not. As you procered, different themes might be assigned to different students, sometimes their findings might bo eommitted to writing, or a compre tition for an anmual prize exsiy eould be mate possible by a sumall fund. 'The main object is to draw ont the student's lacultios and possibilitios by making him do his own work entirely, and, in view of the gigantic proliforation of useless medieal literature in orie dav, a ereat boon might be conferred upon the sulfering medieal humanity of the future by insisting that he be as brief as

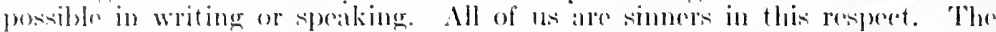
ieteal of rach extempore talk or essay should be a multum in porro, and to aroid l'mumi de tout dien. A humane habit of brevity will males the student a very arecotalbe contributor to medieal gatherings and medical jomrnals of the future. Try to make these (erenings dolightful ones for rour stulents and they

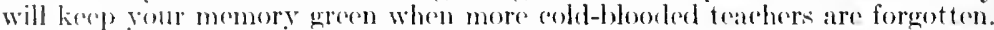
More than anything else will the student apprediate the faret that you are not there to hear youlself talk, but to help him to develop himself in writing and speaking. Jouteach buys to swim, as Billings sald, by "throwing them into the water." "The books, fatets, and dates ale as nothing in eomparison with the rebanee of giving the student an enlarged view of the humaniore, the namelest, unremembered things whieh holp to make him a gentleman in his profescion. Youth is, or onght to be, the perion of generous self-surrender to ideals. Many fine traits, katent in young men, wan be brought out by contact with a superior tracher. Thr general tendeney of ()sler's teaching, rven in the elinic, has beon achmirably conveyed by Dr. Arnold Klebs:

"Never can one forget the seenes in the out-patient department, where he stood, surromded by his boys, helping thrm as a friend in their struggles with some diffientt rase. He would go to one, put his arm a round his shoulder, and then bogin a friondly infuiry, interspersed with humoroms remarks, and allusions to the work fone by special students on a given subject. Urging, rucouraging, inspiring, so we saw him, exalet always, fogmatic never, and when the humorons and friendly fire kindled in his eve wo rould not help but love him and with him the task we had chosen as olur lifework. Thus wo inagine those mâtres of the old French sehool, a sehool no longer limited by national boundaries, one of those nen who have troblen the paths through the warks of the salpetrière, the Charite and Lariboisière, the Necker, the llotel Diell, making alpostles and mi-sionaries in the great rause of seientifie medieine."

'The tracher who stands out best in the present writer's memory was a stalwart Viking from the state of Maine, who has his pupils assemble at his hous: of evenings to work over algebraic problems. In the enter of the table, by the latup, there was always a large pyranid of good-cized apples, which we boys were froe to muneh as we fiddled over our quadratic equations, while our teacher real his nowipater and his good wife pursucd her knitting. Now and then, he would say, with a New England twinkle, "Be spry! be prompt! be brief!" as our fingers flew to get the solution. In his clasiroom, all the work was lone by the students at the blackboatel. There were no recitations. but, like Arthur Sherburne Hardy or Mentworth. our preceptor rould always ascertaiu, by a few leading questions, whether his students understood algorithmies or not. In his rugged Northern way, he was like Liszt at Weimar.

As you proced with rour evenings, your own mind will suggest to you any number of topies for diseusion: Why did English and continental physjeians, for a long time, stuly the diseases of their cities in connection with the weither?" "Epidemie constitutions," "Cenius epidemicus." What are they? Why is meteorology important in medicine? How and why did physicins come to elasify diseases like families of plants? What is a disease". "Why is it not a "rhiniml entity"? What diseases wore individualized by llipeoerates? Sydenham? Laënnec? Contrast the first exlition of Laëuner's treatise on 
mediate auseultation with the second. When did Gaten's influenee disappear in internal merlicine? Are we not still uneonseions (ialenists.?

Why was epilepsy regareled as a entagions disease in the Middle Ages? Why was it alled "morbus comitialis"? Why did the andents rall it the "sacred disease". What famous men wore epilepties? Why is the biteterial theors of infection giving place to the hio-chenieal".

lith were medieval surgeons so cantankerous alout their fees, and why did they shun major surgery?

Was syphilis really epiflemice at Naples and ( lsewhere in 1494-95? What was Pasteur's explanation for the sudelen appearanee or disappraranee of erertain infections diseases?. What were Pettenkofer's initial eonditions for the phenomenon of infection? How did sloven tramblating olstruet medieal progress in the Middle Ages? Itow has the original meaning of the elaswies been obseured by overlaid material? Give the humorons side of ecrtain medical controversies in the past. Why should we flit "when doetors lisagree"?

What is the savare's coneept of "making molicine"'? Explain Huxley's statement that "medieme is the foster-mother of all the serenees." Migr did medieine always lag behind the other seiences up to 1850 ? What diel wir Michael foster mean when he said that "her childen are always coming back to her"?

Melical history ean be taught in this way either by the seminary plan of Finlarson, which his been so suceessfully emploved by Prolessor W. S. Miller at the Eniversity of Wiseonsin, or by the symposiun or home plan of ()sler, with inweaving of the subject in the elinies, laboratories and lecture rooms of the different medieal disciplines and specialties. These methods have been used with suceess by (ieorge Dock (St. Loubis), Harvey Cushing (Harvard), David Riesman (Philarlelphia), and others.

Another pleasant way of studying the history of melieine is by means of the medical history rob, which rlifers from the formal merlico-historieal soefety in that the papers reat serve as an introduetion to a rongenial conversazione. with rofreshmonts or otherwise. As the private musical elub dopends for its suecess upon thr disinterested spirit of the refined amateur; so the law of the history elub is that eaeh member must sherl all assumption or any trace of the profesionat jealousy whieh is eommon to physeians, musieians, politicians, and those posiesserl of histrionic or operatic talents. Ftrenson sitid of the Barbizon commmity of painters that "formal mamors being laif aside, exsential eourtesy was the more rigilly exacted; . . to a tomel of presumption or a word of heetoring these free barbizonians were as sensitive as a tea party of maiden ladies." The medieal history elul will never thrive unless eath infividual member preserves the modest, comsistent attiturle of a learner. Miehad Angelo's arteon of Father Time in a go-eat, with the legend "Aneora impare," might be its levice, if sueh a club is to be a "gomg eomerern."

At the Johns Hopkins Hospital Historieal ('lub), the usual plan is the rearling of one or more formal papers followerl by a general disension. In these disensions, the luminous talks of Profesisor liveleh have gone far to matke the delicate appreatat jon of values in medieal history a fine art. The grogram maty

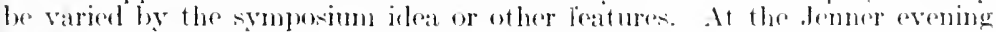

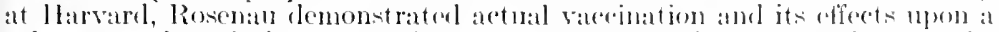

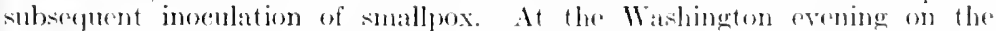
Irish elonicians, Stokes, Giraves, Corrigan and others were asigned to ditferent

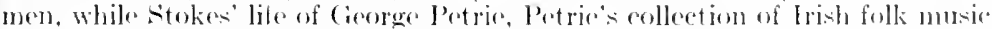

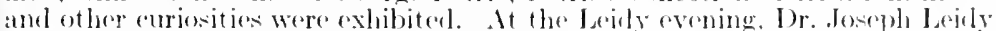
of Philadelphia rehibited many juteresting polies of his illustrions uncle. Incidental musie illustrating a period or a nation, sueh as bverals's termeto in

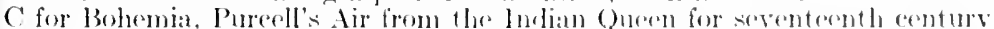

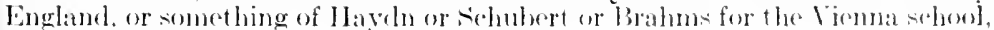

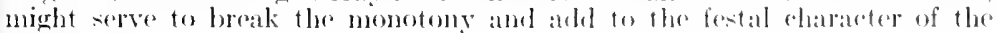
evering.

Advaneed instruction in medieal history, that is, fouphing the student

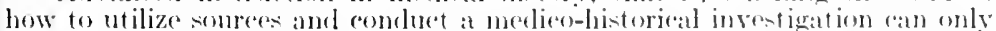
be given at an institute with the aid of a good molioal library. It an institute. the sturlent would be taught how to use the best reference books and 
hibliographieal tools: how to doteet and correct possible sourees of prror in

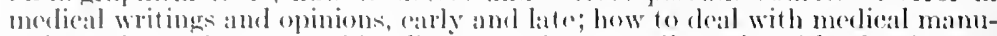
seripts, the pathway to which lise through the rarlier printed books; how to evolve new farts from the findings of ermblitum; and how to trach others to robeh and to think historieally. A medieo-listorical institute should therefore be not only a plant for researeh work but also a seerl-plant of medieal culture. This onil would best be attained by the study of the general history of

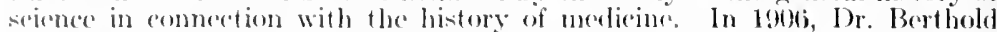
Latufer fild an impresive plea for the study of the history of medicine and the natural seienees in this eombly. 'The best aceount of institute teathing incluling the best reforenee books, mothods of researeh, exhibitions and muscums, and the endownent of medieo-historical researeh, is to be foumd in the valuable and exhaustive paper of Dr. Amold Klels (19142) which all who are interested in the subject should lead. Dr. Cororge siaton, of Hanvard, a seholar leamed in the mathematies and the history of eulture, bas endeavored to stimulate an interest in the establishment of an institute devoted to the history of the serences and medieine, and it is to be hoped that his efforts may move sueeessful. Dr. Sarton is the founder and editor of "Isis," the first periodieal to eo-ordinate the results of historical researeh in all the sejenees.

In pursuing medical history, whether as a private recreation or as at seientifie discipline for the mind, the student may well eonsider the arlvice of the gifted mathematieian N. H. Abel: Situdy the texts (Si l'on w'ut faire des progres dans lo mathématiques, il faut ótudier les matres et non pas les eeoliers). In other words, it is better to begin anywhere with some definite sulheet, sueh as Harvor or the history of fever, and study it exhatustively and well in the original texts, than to attempt to compass everything at once by superficial skimming. The subject of medical history is coextensive with the eultural history of the human race and no single mind can hoge to absorb all of it. Here as dkewhere, "general knowledge means general ignoranee" (Froude). Dr. John .J. Aloel is quite right when he says that "there should be in researeh work a eultural character, an artistic quality, elements that give to painting, music, and poetry their high place in the life of man." The real student of modical history will see his Hippocrates as lie loes his Homer, his Harvey as he does his shakespestre, his Sydenham as he does his Milton. This is a large eontraet perhaps, but it is the roval roal to learning anything well. Dr. Johnson said that if any man will read intelligently on any subject so many hours a day he will soon be learned. It is only in this way that the things we read becone part and pareed of ou mental being and "make ineision in the memory." 'The best models in writing for the student are the clarming essays of Osler, of which Sudhoff observed that they eontain more of the true historieal spirit than many a learned work of the professional historian. The reason is that Osler loved hisold authors as he does his profession. If the student reads (ireek or latin, be will find mueh help in sueh admirable bilingual texts as Ioch's Classieal Library for the ancient poets and authors, who abound in medico-historieal details, Monro's Lueretius (1S6i). Alexander Lee's Celsus (1831), Littrós Hipporates (1839-i1), Daromberg's Oribasius (1851-76), Francis Adams' Aretaeus (1856), Leon Memior's Fraeastorius (1893) and sir Arthur Hort's 'Theophrastus (Loob Classical Library, N. Y., 1916). For beginners, sudhoff warmly recommends 'Theodor Beck's charming introduction to the Hijusoratic anon by means of remarkably well-chosen excerpts $(1907)$, a Cierman bilingual which might well be translated for English and American stuflents. Dr. C. N. B. Camae's "Counsels and Ideals" from the writings of William Osler (Boston, 190) ), and the "Aphorisms and Reflections" of Huxley, selectel by his wife (I, melon, 1907), should be on every student's table. The historical booklets jublished by Burroughs, Welleome \& Company (London) are useful and aceurate. But, as Carlyle says, "not many books are nerelful; an open, patient, valiant soul-that is the one thing needful." To this may be added a monition from a later writer: "Better keep yourself elean and bright; you are the window through which you must see the world."

${ }^{1}$ Latufer: Fieience, N. Y., 1907, n. s., xxv, S89-895.

2 Kilebs: Bull. Johns Hopkins Hosp., Baltimore, 1914, xxv, 1-10. 


\section{BIBLIOGRAPHIC NOTES FOR COLLATERAL READING}

\section{A. Histories of Medicine}

Of the larger works, the "Crundriss" of Johamn Ifermann Baas (1Sisi1909), of Worms on the Rhine, translated into English by H. E. Handerson (New York, 18S9), is still in many respects the most readable. The rariier works of Le Clere (1696), Friend (1725-27), Schulze (1728), Haller (1751), Blumenbach $(1786)$, and Surt Siprengel (1792-1803), are mainly of antiguarian interest, while the histories of Ilecker (1822-29), Bostock (1834), Puecinot $i$ (1S50-66), Meryon (1861), Daremberg (1870), and Bouchut (1873) are now of a vintage that could appeal only to the special "taster." Sprengel's work is unrivalled for its close rendering of the facts of ancient medicine and the unimpeachable accuracy of its footnotes. Heinrich Haeser's great work (3d ed., $1875-82)$ is based upon original research and is remarkable for erudition but not always for aceuraey. The third volume, on epidemic chiseases, is invaluable. The merits of Bans's history are that he covers the whole ground in a thick, but not too long-winded, volume; that his statements of fact are all of them accurate as far as they go; that he gives a very thoroughgoing account of the different medical "theories," the condition of medicine and surgery in the different periods; and that he frequently carries his readers over many dull patches by his keen and froliesome sense of humor. His faults are a certain diffuseness, the poor arrangement of his subject-matter, his long lists of relatively unimportant names, his failure to diseriminate many things of scient ifie moment from things that are trivial, his whimsical tendency to wander away from his subject or to enlarge upon comic or erotic details and, finally, a curious lack of balance and proportion which, with all his glaneing wit and humor, indieates, at times, an absolute contempt for the exigeneies of literary style. He gives us many dates, but not always those we want, and like most medical historians Bais is at his wakest when he gets into the modern period. He cannot see the woole for the trees, dilates more upon theories than facts, is behind the times in his attitude toward the germ-theory, and has more to say about Bromsiats and Raxori than about Laënnec or Louis, Chareot or Pasteur. Fet no nodern historian has given a finer appreciation of the great English physicians, with whose practical aims he was evidently in cordial sympithy. Nthough a Rhinclinder by birth, Baas represents the extreme North Gernian or Protestant view of inedical history. IIe is, everywere, an essentially maseuline-minded writer, hating all shams, humbugaery, frands and superstitjons. His footnotes and marginalia, like Gibbon's, suggest a certain sympathy with tabooed subjects. Nothing dolights him more than to isolate some inferorous or ineonsistent trait of character and brandish it aloft in what swinburne ealls "the hroad light of German laughter."

Julius Pagel ${ }^{1}$ pulblished, in $1 \mathrm{~S} 9 \mathrm{~S}$, a one-volume history of medicine in the form of lectures. This is a very readable book, the work of a broad, groodnatured, tolerant spilit, but sometimes inacemate, and the bibliography is a hasty pudeling. The new alition (1915), revised and partly re-written by Karl surlhoff, has been purged of much inaceuracy, particularly in the earlier periods. In 190:3-5, l'agel amd $\mathrm{I}_{\mathrm{ax}}$ Nouburger collaborated in bringing to editorial completion the Handbuch der Geselichte der Wedizin, which was begun by Theodor Pusehmann. This work, in three volumes, is the most geliable source of referenee for facts, dates and bibliograpny after Ilacser. It is written upon the eooperative plan, and, in dealing with the modern perjod,

1 A charming aecount of Paged and his work hy Drs. Ceorge Dock and M. G. Seelig of St. Louis is to be found in the Jour. Missouri state Med. Ass., St. Louis, 1910 , ix, 3t6-369. 
the editors have resorted to the ustal plan of having meh specialty treated separatcly by a particular anthority. As with many books written by different authors, these special monographs have, at times, a somewhat dry, perfunctory, and routine character. But the substantial merits of the Puschmann liandbueh ats a referenee work cannot be overestimated.

$A$ best modern work is uncuestionably the reent "Ilistory of Medicine" by Pangel's collaborator, Professor Max Neuburger (Istis- ), of Vienna, which is still coning out in parts and also in process of translation by lanest Playfair under the clirestion of Sir Willian Oser (London, 1910). Prior to this publication, Neuburger had established a well-deserved reputation for aceuracy and seholarship through his valuable historical monographs on the physiology of the nervous system before the time of Flourens (1897), the mechanism of speeifie nutrition (1900), the prehistory of antitoxie therapy (1901), old medieal Vienna (1920) and medieine in dosephus (1920). As a writer Neuburerer is cloquent, profound, absolutely sincrere, and a good stylist. As a scholar, he is richer, deeper and more serious than Batas, and his accounts

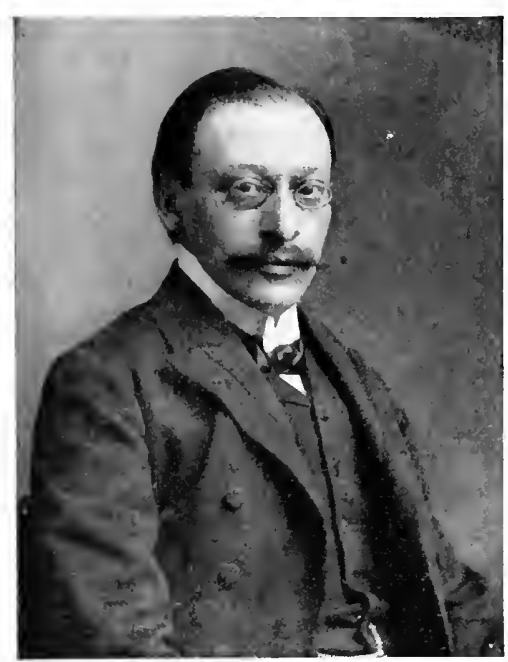

Max Neuburger (1868- ) of folk medicine and of Greek and Arabian medicine are by far the fretter of the two. Yet he has no saving salt of humor and often exhibits the Germanic tendeney to rhapsodizs and to wander off into philosophie reverie. The intention of his great work is, in fact, to present a philosuphic synthesis of medical history. He throws many new facts into the field, but does not always present them in a simple, direct manner. The second volume of Nellburger's treatise, covering medieval medicine, is a masterly synthesis, opening out many new viewpoints. The author's firm grasp of the complex details is everywhere manifest, but the reader is apt to lose himself at the first reading. The large first volume of the English translation is printed on light-weight eloth paper, a great comfort in large-sized books. The substratum of erudition (footnotes and marginalia) has been largely omitted from the English version.

Of the smaller handbooks, Wunderlich's "Geschichte der Medizin" (1859) has never been translated and does not go beyond Schönlein's time. It was written by the hand of a master elinician, and is interesting for its anthology of illustrative excerpts, including the different elassifications of clisease down to the time of Schönlein. The brief and little known sketehes of William Farr (1839) and Edwin Klebs (186S) are highly original and suggestive. The British Medical Almanack of 1839 (pp. 113-178) eontains the neat history up to sydenham's time by the eminent English statist, William Farr. The preeding volumes of the journal (1836-38) contain his valuable and seholarly medical ehronologies. The "Mrdical History" of Edward 'T. Withington (London, 1S94) is the work of a genuine scholar, written in an unusually engaging manner, with many valuable terminal notes and appendices. Unfortunately, it stops at the beginning of the nineteenth century, but it is based upon original research and there are few of the smaller sized books which eonvey so much accurate information. The "Epitome" of Roswell Park (1897) was preeeded by the excellent history of Robley Dunglison (1872). Léon Meunier's "Histoire de la médecine" (Paris, 1911) has the merit of being very full on the morlern period and is very readable, but not entirely accurate. The recent studies of Charles and 
Dorothea Singer and the essays by Capt. J. S. Taylor, U.S. N. in U. S. Naval Bull., Wash., 1919-20, passim, are interesting and valuable.

\section{B. Medical Biography}

The earliest exhanstive eollection is the "Diretionnaire historique de la méderine (1755) of N.-F.-J. Eloy, which, in its later four-volume form (1778), is invaluable. Bavle and Thillaye's "Biographie médieale" (Paris, 18.55) is a sort of medieal "Who's Who" ip) to the middle of the nineteenth eentury, eminently useful as far as it gow. The seven volumes by A.-J.-l. Jourtain prefixed to the "Eneyclopedie des scirnces médieales" (Paris, Panckoucke, 192()-25) are indispensable, eontaining unany valuable bibliographies. August Hirseh's "Biographisehes Lexikon" (6 vols., Wien u. Leipzio, 1ss4-8), and Pagel's "Biographisches Lexikon" of nineteenth century physicians (Berlin u. Wien., 1901), are standard modern works, which may be supplemented by the many admirable biographies of English physicians in Leslie stephen's Dictionary of National Biography (6s vols., London, 1855-1912), by the Biographie française (46 vols, Paris, 1852-75), the Neuer Nekrolog der Deutsehen (1523-52), the Biographisehes Jibrbuch (1596-1911), and other referenee works listed in the extensive biblingraphy given by Hirsch. The standard cources of American medieal biography are those of James Thacher (1S2S) and Samuel D. Gross (1S61), which are marde up of extensive lives of a few men; $\lambda$ thinson (1878), Stone (1894) and Watson (1S96), which are good directories of eontemporary names. Howard A. Kelly's Cyelopedia of American Medieal Biography (Philadelphia, 1912) is the most recent work. For recent names, the various Who's Who's of different countries may be consulted. Many entertaining volumes of biographieal essays have been written by (i. T. Bettany (185.5), sir B. W. Rieharkon (1900), Vietor Rohineon (1912), and others.

For biographies of individuals, the following are either readable or otherwise valuable for reference or for a eertain perspieuity.

Acland (Sir Henry W.): Memoir by J. B. Atlay, London, 1903.

Addison: Wilks \& Bettany, History of Guy's Hospital, Lond., 1892, 221234.-Guy's Hosp. Gaz., Lond., 1874, iii, 193; 201: 1901, xxii, 520, port., 1 pl.

Albertus Magnus: Janus, Brest., 1s46, i, 127-16,0 ( $\mathrm{I}$. Choulant).

Alibert (.J. L.): Achille Alfarie, Paris dliss. No. 5s, 1917.-Ciaze méd. de Paris, 1839, 2 s., vii, 193-198. Paris méd., suppl., 1914, 575-591 (L. Brodier).

Arbuthnot: Life by G. A. Ailken, Oxford, 1892 .

Arderne (John): Introduction to his. "Treatises of fistula in ano" by l)'Arey Power (Early English Text Soc., No. 139, Lond., 1910).

Aretæus: Francis Arlams, Preface to "The extant works [otc.]," Lomd., 18.56, pp. v-xx.-München. met. Welmschr., 1902, xlix, 1265-1267 (R. Kossmann).-Johns Hopkins Hosp). Bull., Balt., 1909, xx, 371-377 (1) J. Cordell).—Am. J. Clin. Merl., ('hieago, 1911, xvii, 1055-105s, or P'ath-s finders of Medieine, N. Y., 1912, 33-43 (V. Robinson).

von Arlt (C. F.): Meine Erlebnisse, Wiesbarden, 1SS7.

Arnold of Villanova: Areh. f. Geseh. d. Mred., Laipz., 1909-J6, pressim (P). Diepgen).

Auenbrugger: Jahresb. d. Ver. d. Aerzte in Steiermark, Ciraz, 1S6if, ii, 19-52 (Clar).-Jahresb. 1. Gescllsch. f. Nat.- 11. Ileilk. in Dresk., 1stis, 5972.-CTr. ('ong. Am. Phise \& surg., 1S!)1. Now IJaven, 1s92, ii, 180 ) (Weir Mitchell). - Walsti: Makers of Mlerdern Medleine, X. Y., 1907, i.i. $-8 . \bar{i}$.

Averroès: E. Renan, Averroès of l'Averroisme, Parik, 1852, 1565, 14tig.

Avicenna: Paris thexis (No. 182) by J. Eddé, 1859-CEtude by Baron ('arra do Vaux, in series "Les gramds philesophes" (Paris, J. Alean, 1900)Johns Hopkins Hosp. Bull., Balt., 190s, xix, 157-160 (.J. A. Chatard).Arch. f. klin. Chir., Berl., 1sst, xxx, 745-752 (H. Frölieh). 


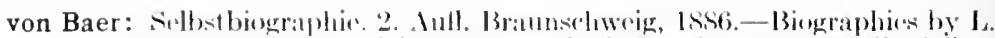

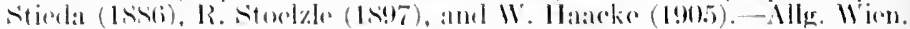
mol. \%tg., 1sit, xxii, 357: :369) (11. 11:1leleyer).

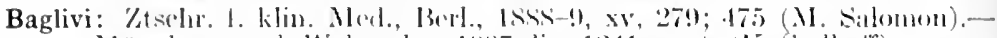

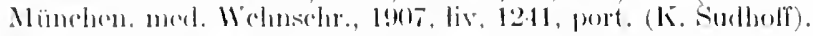

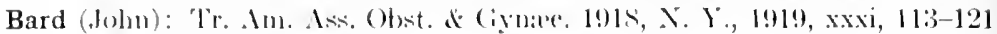
((i. K. Dickinson).

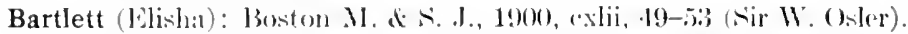

Beaumont (William): life and Letfers by Jesse s. Myer (st. Lomis, 1912).

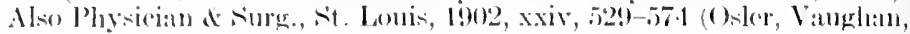
it al.).

von Behring (Enil): Nünchen. mod. Wochenswhr., 1917, Kviv, 1235-1239)

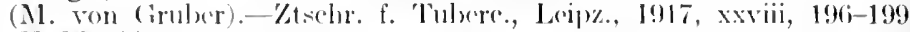
(II. Muchli).

Bell (John): Johns flopkins llowp. Bull., Balt., 1912, xxiii, 241-250 (E. R. (orson).

Bell (Nir Charles): Life by A. Jichot, Par., 1sis, English transl., London,

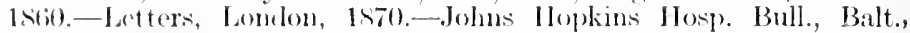
$1910, x x i, 171-1$ š2 (E. R. Corson).

von Bergmann: Iifo by A. Buchlolz. 2. Aufl., Leripz., 1911.

Bernard (Clamde): Claude Bernard by Sir Miehael Foster ("Masters of Irdicine"), london, 1s99. Clatude Bernatud par (ieorges Barral

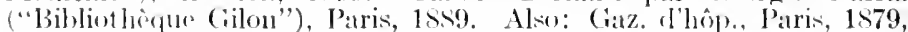
lii, $326 ; 3333$ (E. Roman).

Bichat: laneet, lond., 1851, ii, 393-396 (R. Knox).-Bull. soe. franç. d'hist. dr mél., Par., 1902, i, 214; 261; 269; 277; 280; 285; 293; 309.-Interstate M. J., st. Louis, 1908, xr, 297 ; 667 (1. C. Eycleshymer).

Billings (John shaw): Menoir by F. H. (atrrikon, New York, 1915-Bull. X. Y. Public Library, 1913, xvii, 511-535 (s. Woir Mitchell, at al.).Brit. M. J., Lond., 1913, i, 641-613 (sir W. Osler, of al.).-Hospital, Lond., 1913, liii, 671-673 (Sir II. Burdett).

Billroth: Autobiograply (Wien. mol. Bl., 1s94, xvii, 92-94) and his "Briefe" (7. Aufl., Hannover, 1906).-Berl. klin. W(hnsehr., 1S94, xxxi, 199-205 (J. Nikuliez); 205-207 (E. von Borgmann).-Deutsche Rundschau, Borl.. 1893-4, xx, 274-277 (E. Jansliek).

Blanchard (Raphael): Ácience, N. Y., 1919, n. s., xlix, 391 (F. H. Carricon).

Boerhaave: Life by W. Burton, London, 1746.-Ci. Neiret: Piris diss. No. 11.), 1488.-A-Aepiad, Lond., 185.), ii. 230-248, port. (Nir 13. W. Richardson).—Janus, Leyden, 191s, xxiii, 19.j-369 (E. C. Van Lecrsm, ( $t a l$.$) .$

du Bois Reymond (Emil): Deutsehe med. Wehnschr., Leipz. u. Berl., 1897, xxiii, 17-19 (I. Munk).-Merl. Chron., Manehester, 1s96-7, n. s., vi, 2+1-250) (II. Stirling).-Nature, Lond., $1 \$ 97, \mathrm{lv}, 230$ (J. Burdon sanderson).

Bowditch (Henry Ingersoll): Life and Letters by V. Y. Bowditch, 2 vols, Bost., 1902.

Bretonneau: Life and Letters by P. Triaire, 2 v. (Paris, 1\$92).

Bright: Wilks \& Bettuny; IIstory of Cuy's Hospital, Lond., 1892, 212-221.Johns Hopkins Ifosp. Bull., Balt.. 1912, xxiii, 173-186 (F. I. Garrison).

Broadbent (Sir William): Life by Miss E. B. Broadbent, Lond., 1909.

Broca: Rev. d'inthrop., Par., 1Sst), 2. s., iii, 577-608, 1 phot. \& bibliog. (S. Pozzi).-Bull. Soe d'anthrop. de Par., 1S84, 3. s., vii, 921-956 (E. Dally).-J. Anthrop. Inst., Lond., 18s0-81, x, 242-261, 1 phot. (E. W. Brabrook). - Saturfay Leetures, Wash., 18\$2, 113-1.42 (R. Fleteher).

Brodie: Lives by H. W. Aeland (Lond., 1864) and by Timothy Holmes ("Masters of Medieine"). Lond., 1897.-G. T. Bettany, Eminent Doetors, Lond., 18s.5, i, 2s(i-30)3. 
Browne (Sir Thomas): Biography by Edmomd Cosie, Lomdon amel Vin York,

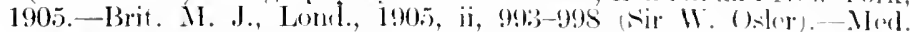
Library \& Hist. J., Brooklyn, 1905, iij, 24i-27:) (c . Milliams):- Malter Pater: Macmillan's Mag., Loml., 1S\&6, liv, 5-1S.

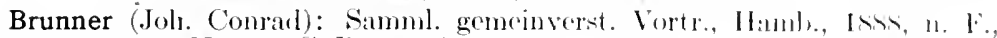
3. ser., No. 62 (C. Brtunner).

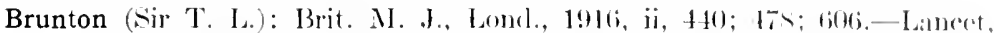
Lonel., 1916, ii, 572-575.-Mil. Surgeon, Wath., 1917, .xl, 369-377, port. (F. H. (iarrison).

Budd (William): 13ull. Johns Hopkins Hosp., Balt., 1916, xxrii, 201-21.; (IV. C. Ruckir).

Caius (John): Menuir by John Venn, in eolloctive works, ol. l:. s. Robrert. Cimbridge, 191:2, 1-i)t.

Cardan (Jerome): Lifo hy Henry Morley (2 vols., Lomd., Lsit) and by M. ( ; Wiaters, lond., 1897.

Celsus: Monograph by (anl Kixsel (Ciessen, 1s4t)._Fare de méd. do I'ar. Confér. listor., 1stjt, t45-497 (P. Brocal)-E. Littré, Médrejer ot

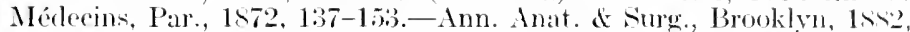

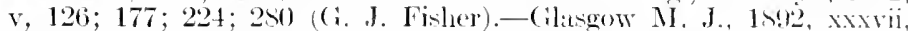

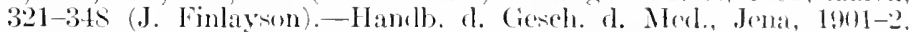
i. $415-443$ (I. Bloch).-Nene Jahrb. f. d. klass. Nlertum, 1907, xix,

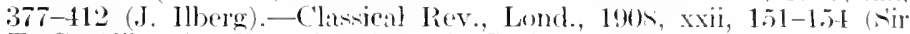
T. C. Allbutt).-Fortsehr. 1. merl., Borl., 1909, xxvii, 120\%; 1216.

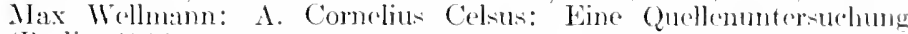
(Berlin, 1913).

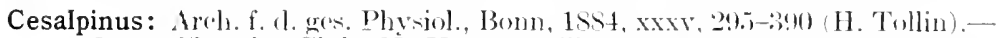
I'roc. Charaka Club, N. Y., 1916, iii, 150-1,if (J. (collins)-Tiv, di storia erit. d. se med. e nat., Fandenz, 1912, iii, 73-1)2 (C'. ('icones).Cesalpino, Arezzo, 1916, xii, 237; 357; 413; 473: 1917 , xiii, 73 ; >!): 153, 17()$; 222 ; 248 ; 263 ;, 22 \mathrm{pl}$. (['. Viviani).

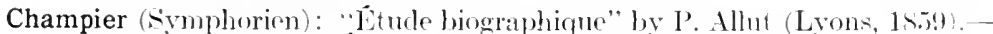
E.-F-A. Potton's "Ftudes historiques," Lyons, 1si3.

Charcot: N. ieonog. do la Salpêtriore, Par., 1893, vi, 241-250) (Cillos do lis Tourette). Jnauguration du monmment: Ibid., 1s!s, xi, 401-41s, put.

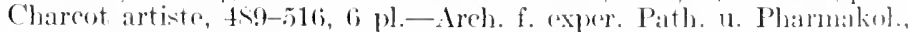
Lxipzig., 1493-1, xxxiii, pp. i-x (13. Naunyn).-Doutsche Ztsoir. f.

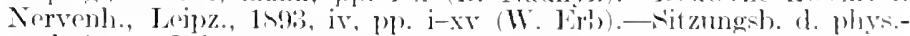

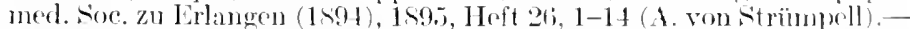

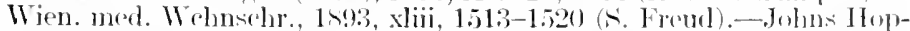

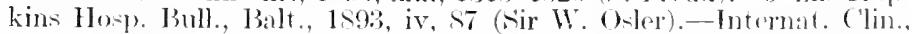
l'hila., 1s94, 4. s., i, pl. xr-xxi, port. (M. A. Starr).—Cilasgow M. J. 1893, xi, 292-29s (Jane 13. Jendrorson).

Chauveau (Auguste): liev. gén. (l. se., Par., 1917, xwviii, 298-29); (.). P.

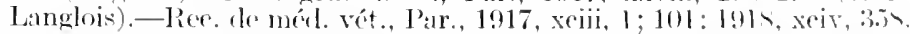

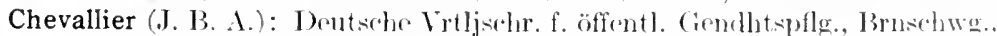

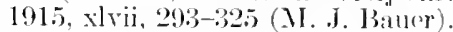

Chovet (Abraham): Anat. Ree., Philit, 1911, v, 14t-172, 2) port. (II. $\rightarrow$. Miller).

Christison (sir Robert): Autobiography, 2 v. Edinb., 1Sti.

Cohnheim: Ges. Abhandl., Ber]., 18s5, py. vii-li, port. (M. Kïhne).-Ireh. f. exper. Path. "1. Pharmakol., Leipz., 1s84, xriii, 3.-4. Ilft., pl. i-x (F. Klebs).

Colles: Workis (Fydenham Soe., Lond., 1Ss1), i-xvi, port. (H. Mel)onnell.

Cooper (Sir Astley): Lifo hy B. 13. Coopor, 2 v., Londen, 1 - 13.-I3radshaw

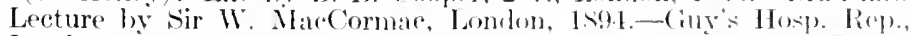

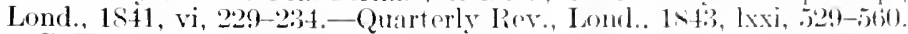

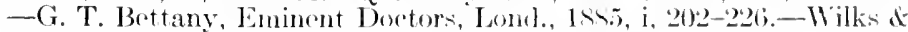
Bettany: History of Guy's Hospital, Loml., 1s92, 317-329. 
Cordus (Valerius): L. L. Cireene: Jandmarks of Botanical History, liash.,

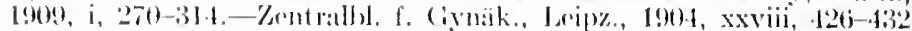
(k. $\operatorname{lin} z)$.

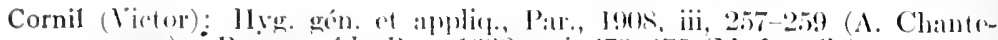

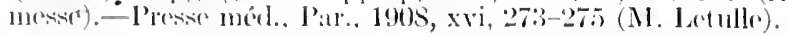

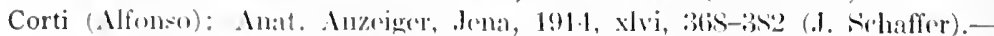

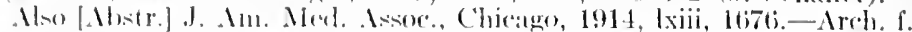

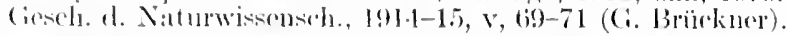

Cruz (Oswallo): Brazil-med., Rio do Janciro, 1s97, xxxi, 51; 2751.-L. L. Nav. M. Bull., Wash., 1917, xi, 521-525 (IV. C. Wolls).

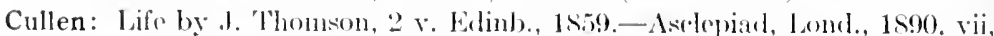

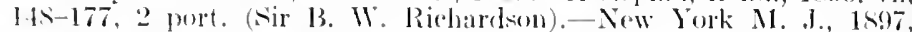
lxvi, 6sig-691 (F. staples).

Currie (Jumes): Memoir by W. W. Curre, Lend., 1s:31.-Ann. Mod. Mistory, ‥ Y., 1919-20, ii, s1 (Nir W. Oster).

Czermak: Prag. med. Wochensehr., 1906, xxxi, 571-573 (R. von .Jakich).Areh. f. Ophth., Leipz, 1906, lxv, pl). i-iv (E. Fuchs).

Darwin: Life and Letters by F. Darwin, 2 v., N. Y., 1898-More Letters, 2 v. London, 1903.- - Life ly E. B. Ponlton, London, 1s96. Gerdenkschrift, stuttgart. 1909._- Abernothian address by Sir T. L. Brunton, London, 1S83. Pamphlets by Grant Allen (New York, 1886) and A. E. Shipley (Cambridge, 1909).—British Musem (Natural Ilistory), special guide No. 4. Memolials. London, 1910.-Proe. Roy. Acor., Lond.. 1ss', xliv, pp. i-xxxy (T. H. Huxley).-Dentsche Rundschan, Berl., 1sis, Ivii, 231-2.t4 (T. W. Preyer).-Proc. Am. Phil. Soro, Phili., 1909, xlviii, pe. iii-lvii (sir J. IBryce, et al.).-Pop. Sic. Monthly, N. Y., 1909, lxxiv, 315-343, 6 pl., 1 port. (H. F. Osborn).

Déjerine (Jules): Bull. Aearl. de méd., Pall., 1917, 3. s., Jxxriii, 30\$-312. Compt. pend. Soc de biol., Par., 1917, lxxx, 416-420 (André-Thomas).J. Nerv. \& Ment. Dis., N. Y., 1917, xlyi, 239 (S. E. Jelliffe).

Delano (Jane): Paeific Coast J. Nurs., San Fran., 1919, xv, 266-26.

Deventer: Janus, Amst., 1912, xvii, 425; 506 (B. J. Kouwer).

Dieffenbach: 11. Rohlf:: Gesch. d. deutsch. Med., Leipz., 1855, iv, 1-13ৎ.

Dieulafoy: Bull. et mém. soce méd. des bôp., Par., 1911, 3. s., xxxii, 755-769 (sirerley).

Dioscorides: E. L. Greene: Landmarks of Botanical History, Wash., 1909, i, 151-155.-Paris méd., 1919, xxviii, suppl., 336; 374 (i. Moulé).

Dodoens: DAvorne: Eloge (Malines, 1850).-Janus, Loyden, 1917, xxii, 141-204 (E. C van Leersum, ef al.).-Nederl. Tijdichr. v. Geneesk., Amst., 1917, 2. R., liii, pt. 1, 210s-2139 (E. C. van Lerersum, et al.).-Ber. d. deutsch., pharm. Gesellsch., Berl., 1918, xxviii, 51-53 (11. Schelenz).

Donders: Life by J. Moleschott. Giessen, 18ss._- Citzungsb. d. math.-phys. Cl. d. k. bayer. Akarl. d. Wissenceb., Mïnchen, 1859, xix, 11S-124 (C. von Voit).-Inn. d'ocul., Bruz., 1589, rii, 5-107, port. (J.-P. Nuel).Areh. d'opht., Par., 1859, ix, 193-204 (E. Landolt)-_Proe. Roy. Soe. Lond., 1890-91, xlix, pp, vii-xxiv, port. (II. 13.).- Theview of his work by Ernest Clark (London, 1914).

Drake (Daniel): Memoirs by E. D. Mansfield, Cincinnati, 1851. Daniel Drake and his Followers, by Otto Juettner, Cineinnati, 1909. S. D. Gross, Lives (etc.), Phila., 1S61, 614-662. Also: Jour. Am. Med. Ass., Chicago, 1895, xxv, 129-436 (W. Pepper). Also: Am. Jour. Med. Sc., Phila., 1N76, n. s., 1xxii, 451-452 (J. s.. Billings).

Duchenne: C. Lasègue: Eturles méd., Par., 1s\$4, i, 17s-206-Rer. internat. d'électrothér., Par., 1895-6, vi, 257-270 (Motrt): 305-3333, 1 pl., 2 port. (Inauguration du monument): 1599-1900, x, 69-90 (Brissaud). - Med. Rec., N. Y., 1908, lxxiii, 50-54 (J. Collins).

Dupuytren: Vidal de Cascis: Essai historique (Paris, 1835).-Larrey (H.): Discours (Paris, 1\$69)._-Mém. Aead. de múl., Par., 1836, v, 51-82 
(E. Pariset).-Monit. d. hôp., Par., 1S56, iv, 145; 153; 161; 169

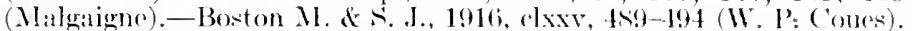
-Biog. Lexikon (Hirsh), Wien \& Joipz., 1sis, ii, 2lo-2.13 (curlt).

Ehrlich (Paul): Festsehrift, Jona, 1914-Arch. f. Domat. u. Trph., Wion \& Leipz., 1915-16, exxxi, 559-578, port. (A. Nejs:er).-I3erl. kilin. Wochenselur., 1914, li. 529-531 (Joux of Netrhnikolf).-Dentsehe morl. Woehenschr., Leipz. U. Bert., 1915, xli, 1103; 1135 (A. von Wasisermann).-Naturwissenschaften, Berl., 1914, ii, 243; 2(is: 1916, iv, 137; 149): 1919, vii, 165 (C. Oppenlseimer, et al).

Emmett (Tlomas Adelis): Reminisenees, N. Y., 1905).-Tr. Am. (iynee. Sioe., I'hilat., 1919, xliv, 365-371, port. (J. R. Goffe).

Erasistratus: J. F. Ilieronymus: Jena dliss., 1790-R. Fuehs, Erasistratea, Lripzig, 1s92.-Glasgow, M. J., 1\$93, 4. s., xxxix, 340-352 (J. Finlay-on).

Esmarch: H. Rohlfs: Gereh. dl deutseh. Mrol., Loipz., 18S5, iv, 353-411.Jïmehen. med. Wrhuschr., 1s93, xl, s (A. Hoffa).-Berl. klin. Wrehns.hr., 1908, xh, 57s (1. Brer).ZZtselur. f. Kranlienpflg., Berl., 190:3, хxу, 91; 1908, хxх, 65.-Med. Mag., Lond., 1893-4, ii, 9-21 (Kobeltitz).

Fabry of Hilden: Janus, Bresl., 1s4s, iii, 22.5-252 (Bénediet).-Deutseles Areh. f. Cresch. (l. Med., Leipz., 1883, vi, 1-25 (P. Mïller).-Mbhandl. z. Gesch. (l. Med., Bresl., 1904, Heft xiii (R. J. Schaefer).-Janm, Imst., 1910, xv, (55-72, 1 port. (R. J. Schaefer).-Miunehen. med. Wehnseler. 1910, lvii, 1401-1403, port. (K. Nulhoff).-Johns Hopkins Hope. Bull., Balt., 19(1), xvi, 7-10 (IV. B. Platt).

Favill (Henry Baird): Memorial volune, ed. J. Favill, Chicago, 1917.

Fayrer (Gir Joseph): Rocolloretions of My Life, Eilinb., 1900.

Finlay (Carlos): Finnidad y Bencficoncia, Habana, 1916, xv, 257: 191s, xx, 3-197 (E. Nunez, et al.).-New Orl. M. \& S. J., 1916, lxix, j,j-to (A. Agramonte).

Fischer (Emil): Die Naturwisiensehaften, Berl., 1919, vii, \$41-\$\$2 (('. Harries, et al.).- Seience, X. Y., 1919, n.s., 1, 1.50-154.

Fitz (Preginald Heber): Boston M. \& .. J., 1913, elxix, s93-908 (W. W. Kén, et al.).

Fletcher (Robert): Bristol M.-Chir. J., 1912, xxx, 2s9-294, port. (Nir II. Osler).-Index Mod., Wasl., 1912, x, No. 12 (W. H. (iarrison).

Flint (. Iustiu): Johns Hopkins Hosp., Balt., 1912, xxiii, 182-186 (H. R. .I. Lamdis).

Foster (sir Miclacl): J. Physiol., Lomul., 1906-7, xxxy, 233-246 (J. N. Langloy - Proe. Roy. Soe. Loml., 1908, s. B., lxxi, obit., pp. lxxi-lxxxi, port. (IV. H. Ciaskell).-Baston M. \& s. .J., 1907, alvi, 309-311 (W. T' Porter).-Publ. Med. Far. Queen's Lniv. Kingston, No. 7. 191\%, 1-17 (J. G. Adami).-Nharyland NI. J., 1915, Lviii, 105-118 (F. H. Garricon).

Fothergill: Memoirs by J. C. Iottsom, 4. al., Lomd., 17s6.-Lifo ly R. Hingston lox (Lonclon, 1919).

Fournier (Alfred): Amm, de dermat. et syph., Par., 1914-15, 5. s., v, 51:3-52心, port. (J. Darier).-Bull. Acad. de méd., Par., 1917, 3. s., lxxviii, 6stj6i:7 ( ( :. M. Debove).

Fracastorius: Life by F. O. Mrneken, Ieipz., 1731-1. Rittmann. Culturgroch. Abhanill., Brïnn, 1s69-70, 3. Jaft.-Cior. ital. di mal. ven.,

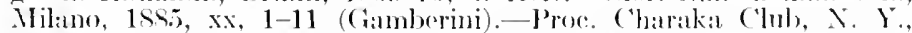

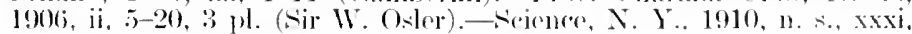
500) Sis (F. II. (iarrison).-Ann. Mor. Mlistory, N. Y., I917-18, i, $1-34$ (C. d D. Finger).

Frank (J. P.): Autohiography, Vienna, 1802.-Biography by K. I oll, Kirlsruhe, 1910, and the stivly of Frank's influener on social luygene by $\mathrm{K}$.

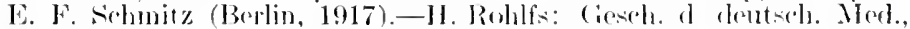
stuttg., 1siso, ii, 127-211.-Morl. Jahrl,. Wien., 1sst;, n. F., i, 97-116; (H. von Bamberger).-Wion. klin. Wehnschr., 1909, xxii, 1341: 1913, xxvi, 627 (M. Neuburgrr). 


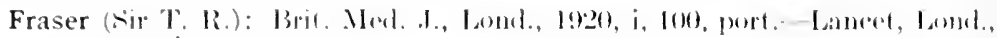
$1920, \mathrm{i}, 122 \mathrm{2}$.

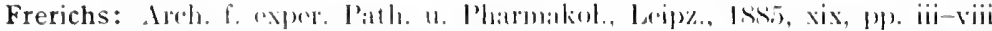

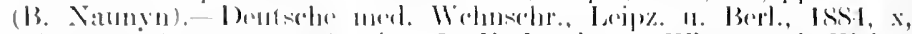

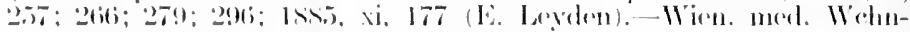

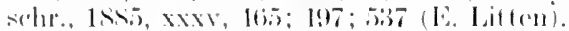

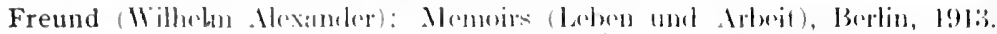

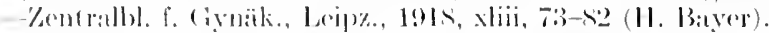

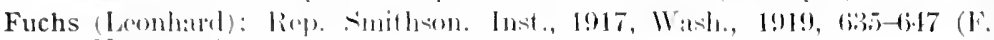
Xinum:ann).

Gaddesden (John): Momograph by II. P. Cholmety. Oxford (c'larendon l'ress), 191?

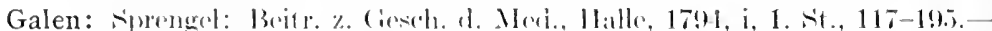

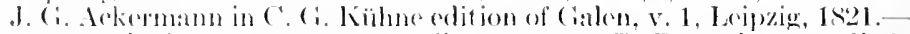

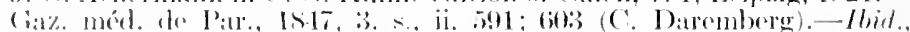

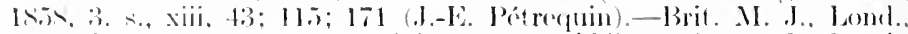

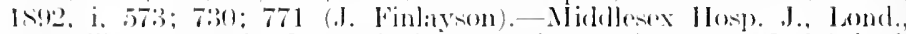

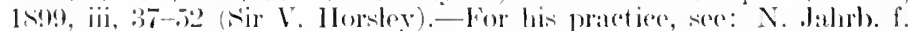

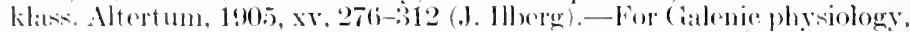

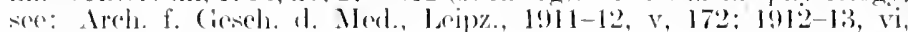

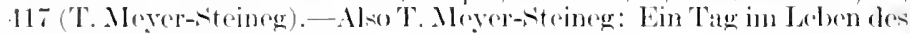
(iillen, Leipzig. 1!13).

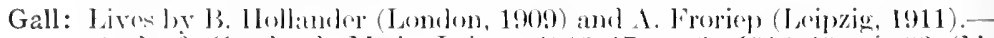

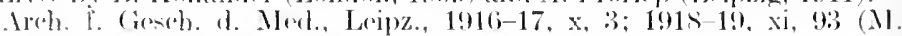

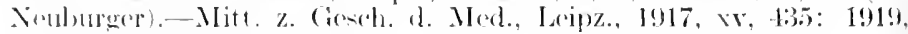
xviii, 25s (11. Neuburger).

Galton (sir Franeis): Memories of my life, X. Y., 1909.-Life by Karl Pearson, v. 1. Cambrilge, 1914.-Eugenies Rev.. Lond. 1911-12, iii, 1-9) (XI. (C)-Nature, Lomi., 1910-11, Kxxy, 410-145-Jog. Sic. Monthly, 1911, lxxis, 171-190 (.J. 1. Harris).

Galvani: J.-L. Alibert: Eloges historiques, Par, 1866, 187-398.

Garth Sir Sumucl : Johns IJopkins [losp. Bubll., Bait., 1906, xvii, 1-17, port. (11. Cukhing).

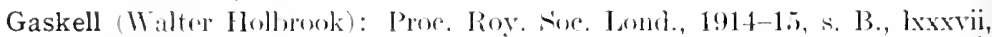

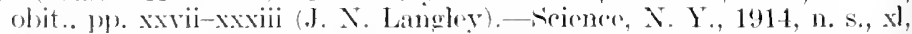
s)-sot (F. 11. (iarrison and F. H. Pike).

Gegenbaur (Carl): Erlebtes und Erstrebtes, Laipzig, 1901.

Gerster (Arpall (i.): Recollections, N. Y., 1917.

Gesner (Comad): Papor Bibling. Soe. America, Chicago, 1916, x, 53-86 (.J. E. B:is:).

Gilbert (William): Jour. Roy. Nav. Mod. Serv, 1916, ii, 495, 510 (C. Sin$\underline{a(}(\mathrm{r})$.

Gilles de Corbeil: Study by C. Vieillard, Paris, 1909.

Goltz: Arch. f. d. @ges. Phyciol., Bonn, 190:3, xcir, 1-64, port. (I. R. Ewald). Gorgas: Neienee, N. Y., 1920, n. s., lii, 53, (MI. W. Iroland).

von Graefe (Albrecht): Lifo by E. Michaclis, Borl., 1s77.-Bor. ii. (1. Versimml. 1. ophth. (icsell.ch.. Stuttg., 1sitt, xive, i-52 (Donders \& Flelmboltz).-Ann. d'oeul., Brux., 1s72, Ixvii, 5-56 (Warlomont).

von Graefe (Carl lepdinand): 11. Rohlfs: Gesch. d. deutseh. Med., Leipz, 1 ș. 3 , iii, $247-324$.

Graves: Biography by W. Stokes in hi "Studies in Physiology" (ete.), Lond, 1863, pp. i-lxxiii. Also: Med. Times \& Gaz., Londi., 1S53, vi, 1-i) (IV. Stokes).-Hed. Hist. Meath Hosp., Dublin, 1888, 122-129, port.

Gray (Henry): Am. J. M. Se., Phila., 1908, n. s., exxxvi, 429-435, port. (F. K. Boland).

Greenhill (William Alexander): Lancet, Lont., 1894, ii, 948. 
Gross (A. D.): Autobiograplyy, Plita., 1sta-Tr. Am. Surg. Ast., Phila.,

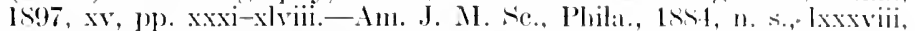
29:3-30s, port. (I. M. Ilays).-. Johus Ilopkins Ilosp. Bull., Balt., 1912, xxiii, s:3-9) (C. IV. (i. Rohrer).

Grüby (David): Arch. de parasitol., Par., 1s99, ii, 43-7t, port. (R. Blanchard).

Guérin (Alphonse): Anclré Conrbe, Paris diss. 1913, No. 45.

Gull (Nir William): (Gyy's Hosp. Rep., Lond., 1s!n, 3. s., xxxii, pl. xxv-xliii,

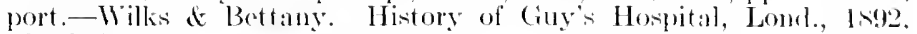
$261-274$.

Gurlt: Areh. f. Klin. Chir., Berl., 1899, lviii, pp. i-vi (E. Bergmann).

Guy de Chauliac: E. Nieaise: Introduetion to his edition of "Isat Cirando

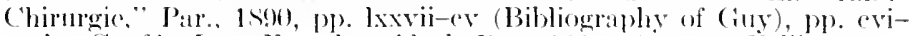
cxci.-Confér. Inst. Fare de méd. do lar., 1s60, 17:-20s (Follin).

Haeckel: Jifo by W. Bölsche (English transl. by J. Mac'alor, Philat., 1966.München med. Nochensehr., 1920, lxvii, 135 (R. Hertwig).-Monist, ('hicago, 1920, xxx, 1-18 (R. C. Sichionlt).

Hales (sitephen): Contleman's Mag., Iond., 17tit, xxxiv, 273-27s (P. (ollinson).-Diet. Nat. Bjog., Lond., 1s!on, xxiv, 32-3(i (Nir F. Darwin).-

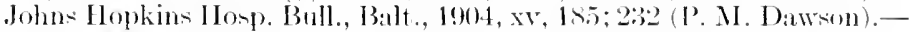

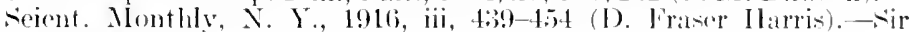
F. Darwin: Rustie sounds, Lond., 1917, 115-139.

Hall (Mlarshall): Memoirs by Chartotte I Iall, Lond., 1 tiil,-Isancet, Lomd., 15.50, ii, 120-12s, port.; 1557, ii, 172-175.-Diet. Nat. Biog., Lomd., I\$90, xxiv, so-83 (C. T. Bettany).

Haller: Lives and Eulogies by J. Ci. Zimmermann (Zürich, 175i), F. (i. Bablinger and C. (i. Hevne ( iöt ingen, 176s).-T. Ironry (Warring-

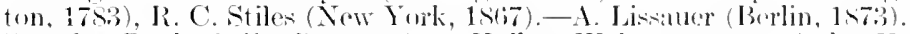

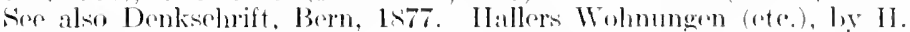
Kronecker, Bern, 190s, has many interesting illustrations.- Dir Bilelnisise (ete.), by Artur Weese, Borm, 1909, gives all extant portraitsEsperially interesting are "IIallor Redivivas" hy ll. Kinonecker (Mittl.

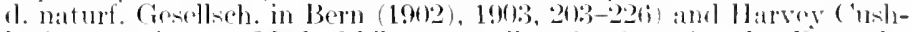

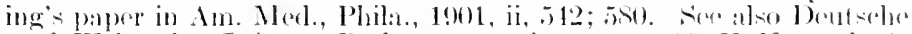

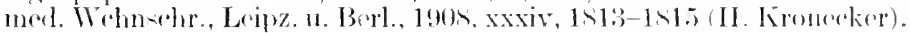

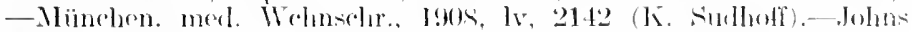

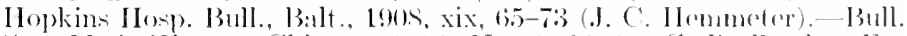

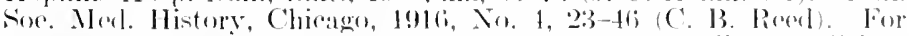

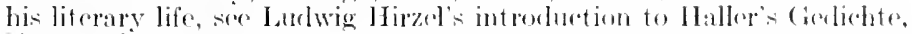
Firatenfolid, Isxiz.

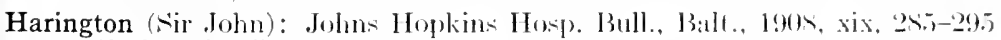
(.l. (i. Arlimi).

Harris (Walter): Ann. Med. History, N. Y., 1919-20, ii, 229- (J. Riihrah).

Harvey (William): Millian Harvey by D'Arev Power ("Mastres of Modi-

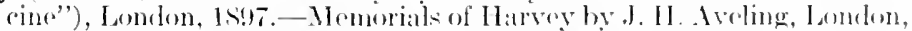

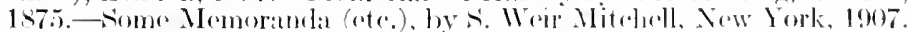

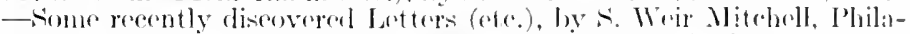

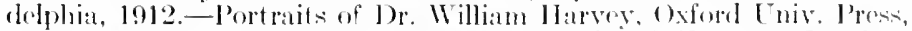

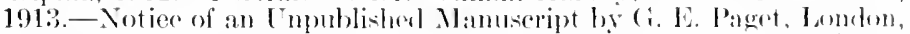
1S01.- John Call Dalton's "Doetrines of the "irembition," Philamblphia, 1sst, is the best history of the subject in English, and "Ilarvery"

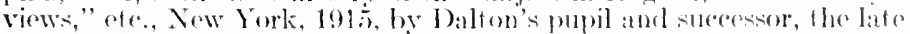
John G. Cuntis. is another important eontribution to . Imeriean scbolar-

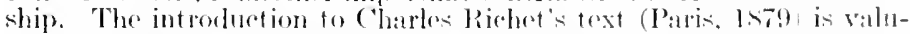

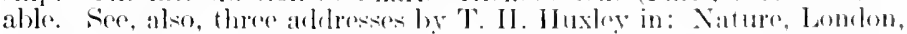
1S7s, svii, 417; xviii, 146, and P'op. Si. Nonthly (smpl.). New York, 1s7s, No. xi, 3si-3s9. Also: Aolum Ilopkins Ilosp. Bull., Baltimore,

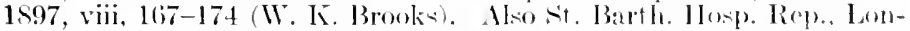
don, 1SS7, xxiii, 1-12 (WV. Munk). Also: Jancer, London, 1STs, ii, 776-778, i pl. (Sir B. W. Richatrison). Also: Aselepiad, London, 


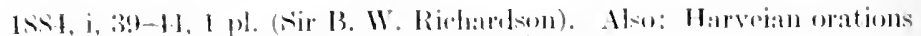
(listal in Index (attilogur, l!)(0), 2. s., vi, 7s(0).

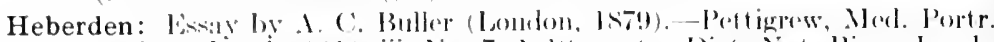

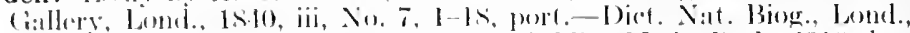

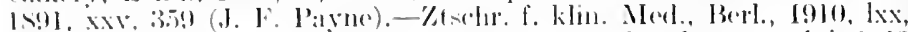

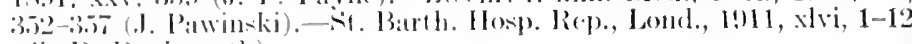
(iir I). I) (110kworth).

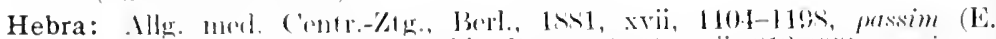

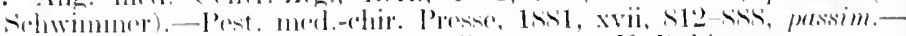
Mend. Rer. of lime, X. Y., 1!)16, xxii, 719-724 (V. Robinson).

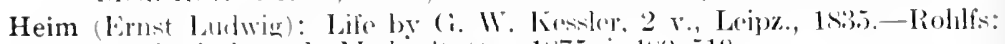

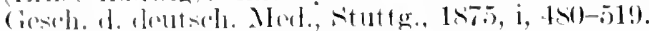

von Heine (Jilknlı): B. Bïrger, Bumn diss., I!)11.

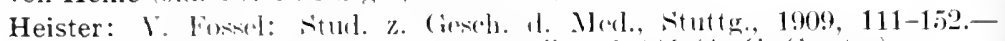

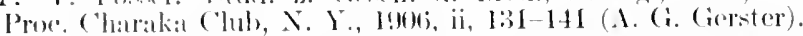

Helmholtz: Lives by L. Loenigsberer, 3 v., Brunswick, 1902 (English transt. by li. A. Wriby, oxford, 190(i); and J. (i. M Kéndrick, London, Is!st).

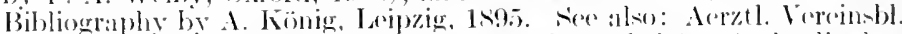

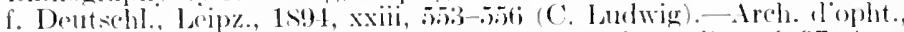

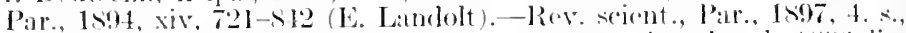

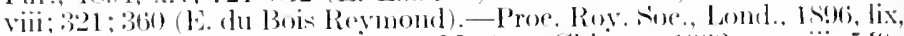

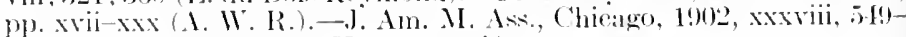
56!) (II. Friculonwali: H. Knapp, at al.).

van Helmont (.J. B.): Studies by J. J. Loos (I Ieidelbele, 1s/7), D. H. Fraenkel

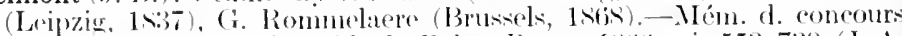

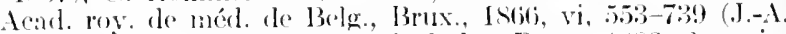
Iindion).-Bull. Joarl. rove de mód. de Bolg., Brux, 1ss6, 2., s., is,

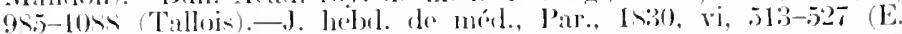

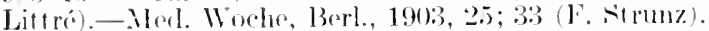

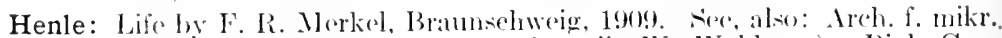
Alat., Bonn, 1sis-6, xxvi, pp. i-xxii (IV. Walderer).-Biol. Cen-

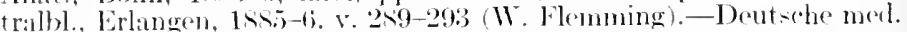

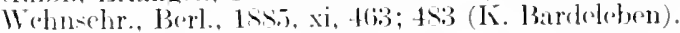

Herophilus: K. I. H. Marx: IIerophilus, Carlsuhe d Baden, Is38, Göttingen,

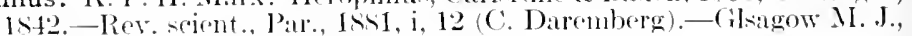

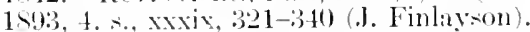

Hewson (William): Tr. Mlet. Nue. Lond., 1s10, i. j1-6i3 (J. C. Lettiom).Acelepial, Lond. 1s91, viii, 148-17- (sir B. II. Richarlson).-Diet. Nat. Biog., lond. 1\$91, xxvii, 312 (J. F. Payne).

Heysham (John): Lifo ly H. Lonsidale, London. 1s70.

Hicks (Braxton): Solect Essuys (sydenhan Soc. l'ubl., rol. 173), Lond., 1901, 93-11 . with bibliography (C. .l. Cullingworth).

Hinton (James): Life by Mrs. Havelock Ellis (London, 191s).

Hippocrates: Introduction to Emilo Littrés translation, v. 1, pls. 1-5ist, Par.,

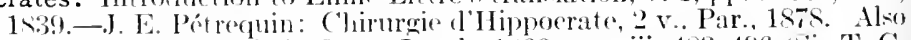
Brit. \& For. Meel.-Chir. Rev., Lond., 1866, xxxviii, 4s3-496 (sir T. C. Allbutt.-ilasgow M. J., 1492 , xxvii, 253-271 (J. Finlayson).-Brit. I. J., Lond., 1906, i, $571-577$ (R. Caton).

His (Witheln): Lehenterinnerungen, 1903. Am. J. Anat., Balt.. 1904-i, iv, 139-161 (F. P. Mall).-Isaneet, Lonrl. 1904, i, 14t6-1449 (IV. Stirling). -Dentshe med. Wehnichr., Leipz. 11. Berl., 1904, xxx, 1438; 1469; 150) (IV. Waldeyer).-Terhandl. 1. naturf. Gesellseh. in Basel, 1904, $434-464$, port. (J. Kollmann).

Hodgkin (Thomas): Wilks \& Bettany": Hist. Guy's Hosp., Lond., 1s92, 380346.-Cruy" Horp. Rep., Lonil., 1sts, 3. s., xxiii, 5i-127 (sir s. Wilks.-Ciny's Ho-p. Cinz, Loind., 1909, xxiii. 52s: 1910, xxiv, 13 (IVilks).

Höfler (Max): Miunchen, mel. Wochen-rehr., 1915, lxii, 79 (K. Sudhoff). 
Holmes (O. W.): Lives by W. S. Lennedy (Bost., 1\$\$3), H. Lee (Bost., 1s94) and J. T. Morse, Jr. (2 v., Boston, 1896).-Boston M. \& S. J., 1s!?4, (xxxi, 375-380, port.-Lancet, Lond., 1886, ii, 6-9 (sir s. Wilks).Brit. M. J., Lonnl., 1894, ii, \$39-841 (Sir W. T. Gardner).-Jolum Hopkins Hosp. Bull., Balt., 1894, v, s.5-8s (Nir W. Osler).

Hooke (Robert): Dict. Nat. Biog., Lond., 1891, xxvi, 2\$3-287 (Miss A. M. Clerke).-Am. Naturalist, Lancaster, Pil., 1919, liii, 247-264 (L. L. Woolruff).

Hoppe-Seyler: Arch. f. path. Anat. (ete.), Berl., 1895, exlii, 386-33s (R Virchow).-Ztschr. f. physiol. Chem., Strassb., 1s95, ple. i-lxii, port. (E. Batumann \& A. Kossel).

Horsley (Nir Victor): Life by Stephen Paget (Lomlon, 1919)._Brit. M. J.. Lonrl., 1916, ii, 162-167, port.-Laneet, Lond., 1916, ii, 200-203. port.

Howard (John): Lives by Aikin (1792), J. B. Brown (2. exl., 1823), T. Taylor (2. ed., 1836), Hepworth Dixon (2. ed., 1850).-Correspondenee, rilited by J. Fielrl, Lonton, 1855.-Also: Asclepiad, Lond., 1s9\%, xi, 5.5-\$) (Sir B. W. Riehardson).

Huchard (Henri): Bull. Soe. méd. de l'Yonne, 1911, Auxerre, 1912, lii, 9-17 (1. Roché).

Hufeland: Life by 3. 1. J. Sachs, Berl., 1832. Also Ned. Alm., Berl., 1s;3. 39-54, port.-Berl. klin. Wochenschr., 1910, xlvii, 243-24s (D). von llanscmann).-München. med. Wochens(hr., 1910, Ivii, 250-2.52, port. (K. sudhoff).

Hughlings-Jackson: Brit. M. J., Lond., 1911, ii, 950-9.51, wort. 15.51-15.54 (Sir J. Hutehinson); 1912, i, S. (C. A. Mereier).-Brain, Lond., 190:3, xxvi, 305-3610 (Nir W. Broadbent): 1915, xxviii, 1-190 (H. Head); 391-117 (J. 'Taylor).

Hunter (John): Stephen Paget, John Hunter ("Masters of Modicine"), Lon(lon, 1s97.- Iremoirs (ete.) by .J. Adams, London, 1817. -John Hunter and his Pupils by simnel D. (iross, Philardelphia, 1sist.-Jolin Hunter and Odontology, by J. F. Colyer, Lomen, 1913.-Aleo Brit. Merl. Jour., London, 1\$90, i, 738-740 (J. Finlayson); Ibit., 1899, i, 389-89.5

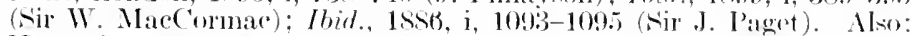
Hunterian orations (listed in Index (atalogue, 1902, 2. s., vii, 45:3).

Hunter (Willian): William llunter by R. Hingston Fox, Lomelon, 1901.

Hutchinson (Jomathan): Brit. M. J., Lomd., 1913, i, 139s; ii, 1632.Lancot, Lond., 1913, i, 18;2; ii, 430-Ophth. Rev., Loml., 1913, xxxii, $22.5-230$, purt. (E. Nottleship).

Huxham: Diet. Niat. Biog., Lond., 1s91, xxviii, 393 (N. More).-Johns Hopkins llosp. Bull., 1906, xvii, 305-311 (T). G. Vogdcr).

Huxley: Lifo and Lettors by L. Huxley, 2 v. Lomul., 1900).- Imoliographionl skoteh (Hosp. (iaz., Lond., 1891, xix, 312-3141.-Proc. Roy. Am., Loml., 1896, lix, ple slyi-lxvi, pont. (Nir. M. Foster\%-Din. Nat. Biog., suppl., Lond., 1901, iii, 22-31 (W. F. R. W(don).-Acience, X. Y..

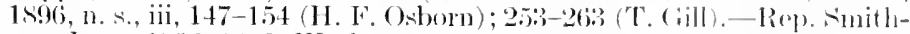
son. Inst., 1s9s-1900, Wash., 1900, 701-72s (W. Ki, Brooks, et al.).

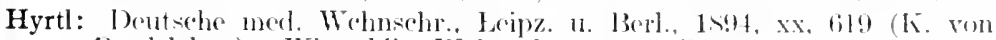

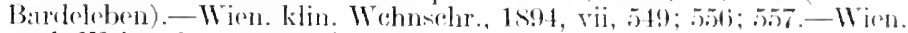

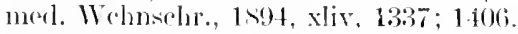

Jackson (James): Memoir by J. J. Putnam, Bowt. \& X. Y., 1907.-Buston

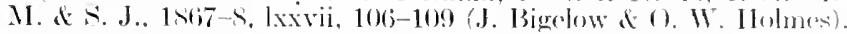

Jacobi: Science, X. Y., 1919), n. s., 1, 102-10.1 (F. II. Garrism).-1nn. Ilorl. Hist., N. Y., 1919-20, ii, 194-20;) (F. H. (iarrison).

Janeway (E. G.): J. B. Clark: Prersonal recollections, X. Y., 1917., X. Y.

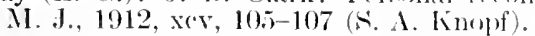

Janeway (T. C.): Bull. Johns IIopkins 1locp, Balt., 1918, xxix, 142-11 \.Science, N. Y., 191s, n. s., xlvii, 273-279 (L. F. Barker). 


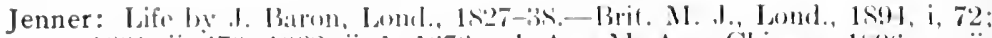

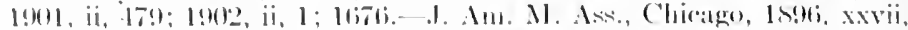

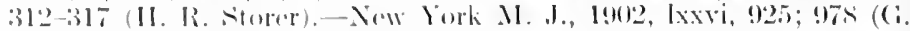

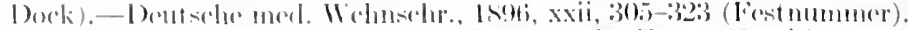

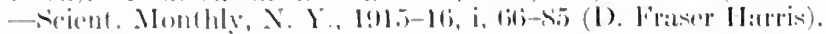

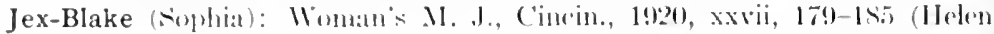
II:Mur(hy).

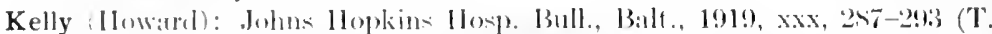

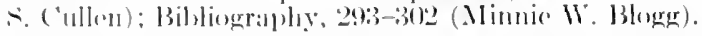

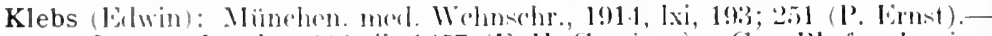

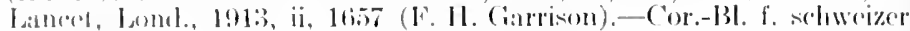

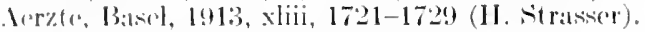

Knox (loblert): Lilo by ll. Lomstale, Lomdon, 1 s7o.

Koch: Bibliegraphies ly W. Boeker (Borl., 1s91) and K. Wezel (Borl., 1912). Winn. klin. Wohinechr., 1903, xvi, 1377-13541 (R. Paltanf).-Delutsche mod. Wehnechr., Leipz. 11. Berl., 1910, xxxy, 2312-2324 (G. (ialfiky).Johns Ilopkin How. Bull., Balt., 1911, xxxiii, 415-125 (W. WT. Lord). - Jbid., $125-128$ (s. A. knopf).

Kocher (Theodor): Cor.-Bl. f. Sehweiz. Aerzte, Bascl, 1917, xlvii, 1217-1219.Mänchen. med. Woehenschr, 1918, lxv, 7s-80 (F'. Sanerbruch).

Koeberlé (Lugèn('): Rey, de gynée., Par., 1915, xxiii, 311-392 (Ciross).

Kölliker: Erinnerungen. Leipz, 1s!9.-Ztsehr. f. Wisenwed. Zö̈l., Leipz., 1906 , lxxir, pp. i-xxyi (Ehlers).

Kronecker (Hugro): Sejence, N. Y., 1914, n. s., xl, 441-444 (s. J. Meltzer).

Küchenmeister: Janus, Anst., 1900, v, 629-6i34 (J. C. IJuber).

Kühne (Willy): Ztschr. f. Biol., München u. Leipz., 1900, n. F., xxii, pp, iviii (C. von Voit).-Merl. Chron., Manchester, 1901, 4. s., i, 401-415, port. (W. Sitirling).

Kussmaul: Jugenterinnerungen, 4. Aufl., Stuttg., 1900.-Münehen. med. Wrhnsehr., 1902, xlix, 2\$1-2s6, port. (L. Edlinger).-Therap. d. (isgenw., Berl., 1902, n. F., iv, 2s9-291 (B. Naungn).-Deutsches Arch. f. Klin. Med., Lipz., 1902, lxxiii, 1-89 (II. Fleiner).

Laénnec: Life by A.-L.-J. Bayle, Par., 1s26, and II. Saintigon, Par., 1904.Rouxean, Laënnee avant 1806, Paris, 1912.-N. Orl. M. News \& Hosp. Gaz. 18.79-60, vi, 736-756 (A. Flint).-Conf. hist. Fae. de méd., Par., 1>6fe, (j1-107 (Chauffard).-Wash. M. Ann., 1910-11, ix, 250-260, 1 pl. (.J. D. Morgan \& D. S. Lamb).-Bull. Johns Hopkins Hosp., Balt., 1920, xxxi, 425-435 (IV. s. Thay(er).-Canakl. J. Al. \& s., Toronto, 1919, xlvi, 2.53-261 (W. S. Thayer).

Lamarck: Lifo by A. s. Packart, Lond., 1901.

Lancisi: Lancisi Memorial number of Ciior di mel. mil., Rome, 1920, lxviii, it1-642 (Marehiafava, ft al.).-Internat. Clin., Phila., 1917, 27. s., ii, 292-308, 2 ‥ (J. Foote).

Lanfranc: J. Missouri M. Ass., St. Leniis, 1910-11, vii, 402-408 (F. J. Lutz).

Larrey: Lifo hy Paul Triaire, Tour- 1902.-Johns Hopkins Hosp. Bull., Balt., 1906, xvii, $19 \bar{j}-215$ (J. C. Da Costa).

Lavoisier: John: Hopkins Hosp. Bull., Balt., 1918, xxix, 254-264 (J. C. Hemmeter).

Leeuwenhoek: Asclepiarl. Lond., 18si, ii, 319-346, port. (Sir B. W. Richartson).-J. Roy. Mierose. Soc., Lond., 1913, 121-135, port. (H. G. Plimmer).

Leidy (Joseph): Proc. Acad. Nat. Ac., Phila.. 1s91, 342-3ss (H. C. Chapman). - Pop. Be. Nonthly, N. Y. 1907, lxx, 311-314, port. (W. K. Brooks).Science, $\mathrm{N}$. Y.. 1913 , n. .., xxxvii, s(09-814 (C. S. Minot).-Alumni Reg. Eniv. Penn., Phila., 1919, xxi, 553-570 (F. H. Garrison).

Leonardo da Vinci: Sne Index Catalogue, S. (i. O., 1915, 2. s., xx, 256, also: Bull. Ned. Hist. Soc., Chicago, 1916, 66-83 (A. C. Klebs); Boston M. 
E. J., 1916, elxxv, 1; 45 (A. C. Klebs).-Gior di med. mil., lioma, 1919, Ixvii, $1179-1281$ (A. Angeducei, el al.).

Lettsom: Life by T. J. Pettigrew, 3 vols., Lond., 1517.-Momoirs, lond., 1\$17.-Dict. Nat. Biog., Lond., 189)3, xxxiii, 134-136 (.J. I. Payno).-Tr. M. Soc. lonel., 1917-1s, xli, 1-6il (sir st. ( . Thompson).

Leyden: Lebonserinnerungen, stuttg. 11. Leipz., 1910.-Internat. Beitr. z. imn. Mel., Berl., 1902, i, 1-12, port. (11. Nothmiged).-Nitl. a. d.

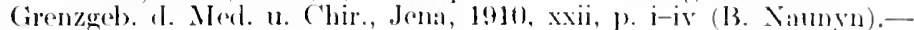

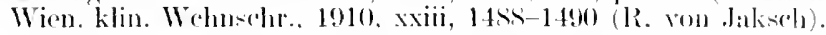

Liebig: Essay hy T. I. IV. von Biseholf, Münehen, 1s74.-I,ifo by .J. Volhard,

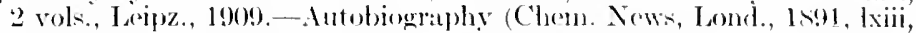

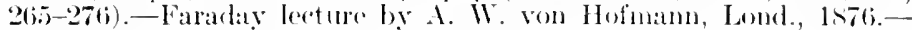
Allg. Wien. med. Z̈tg., 1s99, xliv, 4s]; 494; $505 ; 514$ (C. Klenperer).

Linacre: Nir W. Oser, Thomas Linacere, Canbridge, 190א.

Linnæus: Life by Brightwell, Lomd., 1s.5.-Album of Portrats by T. Tullberg. stuckh., 1907.-J. Am. M. Ass., Clicago, 1902, xxxix, 598-595

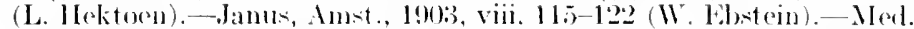

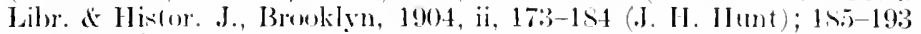
(A. Egalithl).

Lister (Lord): Life by fir J. R. Gorles (Lomdon, 1!)17).-Collected l'apers. Oxford, 1909, i, pp. i-xliv.-Brit. M. J., Imml., 1912, i, 397-402.Lancet, Jond., 1912, i, 465-472.-Cilasgow M. J., 1912, Ixxvii, 190-

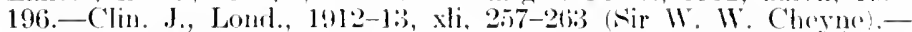

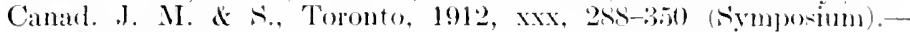

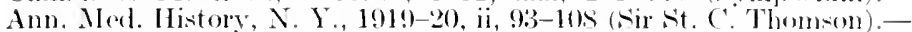
Doutsche Ztschr. f. Chir., Laipz., 1912, cxx, 1-6 (li. Payr).

Littré: Notice by C.-A. Sainte-Benve. Par., 1863. (Repr. from: Nouveanx lundis. v. 5, p. 200.) Rev. d. deux mondes, Par., 15:2, lii, (6:34-67\% (C.-V. Daremberg).-Chron. méd, Par., 1895, i, 11-16, port. (Cabanós).

Lobstein (Joh. Friedrich): Biography by E. Lobstein, Stratsburg, 1sti.

Locke (John): Janus, Amst., 1899, iv, 393; 457; 527: 579 ( $\mathrm{E}$. T. Withington). -Lancet, Lond., 1900), ii, 111;-1123 (sir W. ().ler).

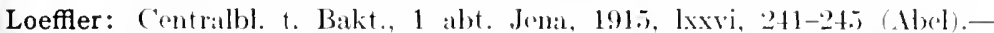
Dortsche med. Wochensehr., Laipz. \& Borl., 1915, xli, 59:-595 ( (iatfky).

Long (crawford W.): Johns Hopkins Hosp. Bull., Balt., 1s97, viii, 174-1s4 (II. H. Young)

Louis: Life by E.-J. Woille, Par., 1s73. Johns Mopkins IIosp. 13ull., Balt., 1S97, viii, 161-166 (sir 11 . Oslor).

Lower (Richard): "Two Oxford Physiologists," by F. Cinteh. Oxforl, 190s

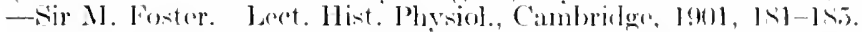

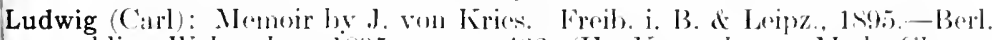

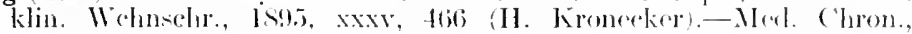

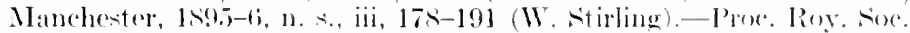

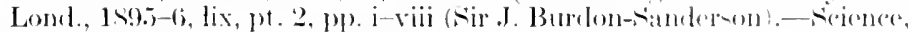

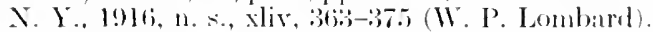

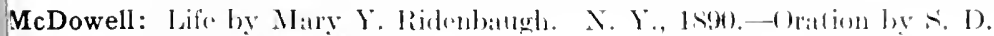
Gross, Ismisville, js79.

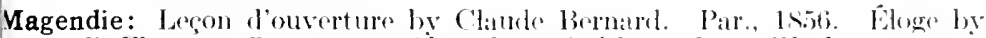

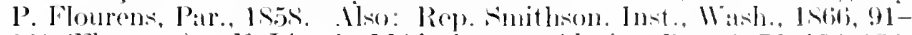

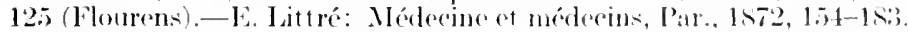
-Med. Libr. \& Hlixt. J., Brooklyn, 1906, iv, 4.; 194; 293; 34il; 1907. y, 24, 2 port. (I'. MI. Dawion).

Aall (Franklin Paine): Johns llopkins Almmni Mag., Balt., 1917-18, vi, 261263, port. (IV. H. llowell).-I3ull. Johns ] fopkins I Iosp.. Balt., 191s.

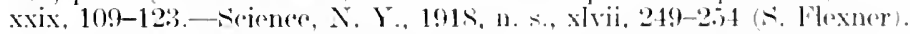

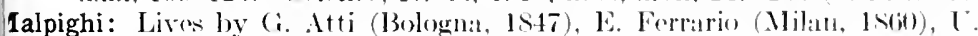

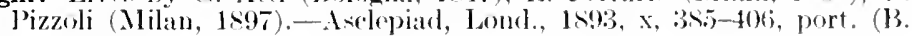




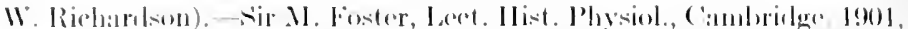

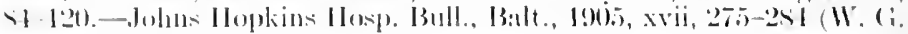
Mare(:allum).

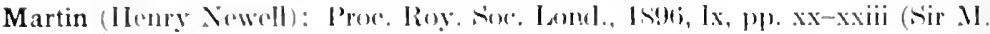
lioster).

Martin (s̈ir James Ramald): Lifo l,y Sir J. Foyrer, Lomel., 1s!97.

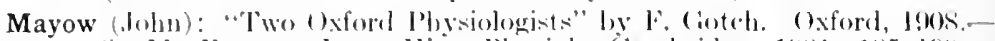

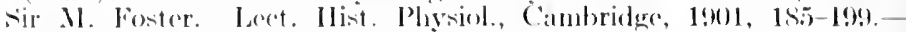

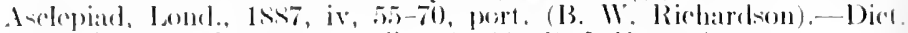
Nill. Bing., lomel., 1s94, xxxvii, 175-176 (1'. J. Hartog).

Mead: Memoirs by T. lemon. lond., 175.5.Cientlements Mag., lomel.,

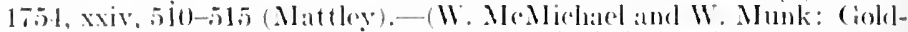

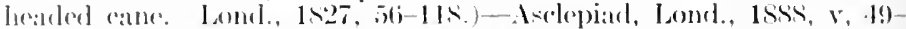

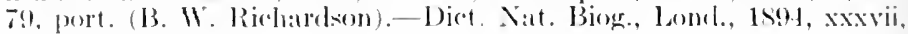
1S1-1Sti (N. Moore).

Meltzer: sojoner, X. Y., 19!21 11. s., liii, 99-106 (II. H. Howe!l).

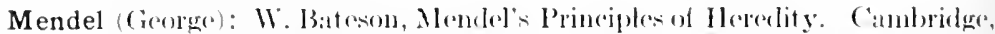
1918, 327-33.1, 3 port.-J. J. Walsh, Catholic Churchuen in serence, P'lili:., 1906, 195-221, port.

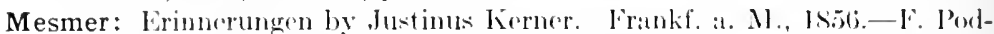
more, Mesmerism and Christian Siciener, Phila., 1909.-Brit. M. J., Lom(l., 1!)11, ii, 1555: 19221, i, 79; 133; 1999;249.

Metchnikoff (Elie): Ann, de l'hnst. Pasteur, P'ar., 1915, xxix, 357: 1916, .xx, 297. -P'roc. Roy soe. Lond., 1917, Ixxxix, pl) li-lix (Nir E. R. Lankester).

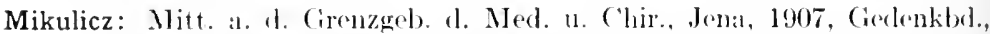
1-it, port. (IV. Kamoh).-München. med. W'lnswhr., 1905, lii. 1297-

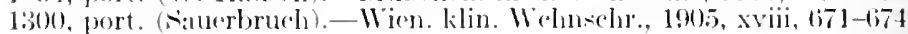
(ron Eisclsberg).

Minot (Charles Sedgwick): Anat. Roe., Phila., 1911, x, 133-155 [13ibliography],

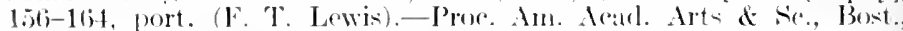
191s, liii, S41-it7 (IT. T. Councilman).

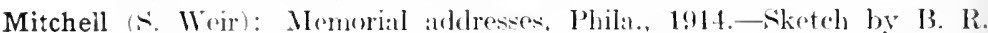
Truker) Boston, 1914.-Brit. II. J.. Lomel, 1914, i, 11! (Sir 1\%. Osler). - Tature. Lond., 1913-14, xcii, 534 (Sir L. Brunton!-Boston 11. \& $\therefore$ J. 1914. rlxx, $21-825$ (J. J. Putnam).-J. Nerv. \& Mont. Dis., X. Y., 1914, xli. (6.5)-74 (C. K. Mills).

Mondeville: J. L. Pagrel, Leben, Lohre, und Leistungen (ote.), Berl., 1so2.E. Nicalises: introduetion to his translation of Mlondeville, P'aris. 1893, ph. v-lxxii, with biblingraphy, pp. li-lxii.-Proc. Charaka Club, N. Y., 1910, iii, 70-9s, port. (A. (i. Gierster).

Morestin (Hippolyte): Prese méd., Pal', 1919, xxvii, annexes, 109 (J.-L. Faure).

Morgagni: Atti al. X1. Cong. mol. internaz, 1s94, Roma, 1s95, i, 18s-197 R. Virchow).-A-ckpiarl, Lond., 1stss, v, 147-173, port. (Nir B. W. Richardeon).-J. J. Walsh, Makers of Modern Medieine, X. Y., 1907, $2 !+51$.

Morgan (John): Joumal of 1764, Phila, 1907.--Life Wy M. 1. Willort, Phila.,

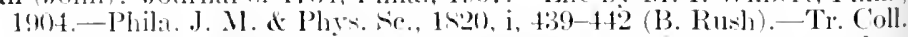
Phys, Phila., 145, centennial vol., 26-42 (W. \&. W. Ruschenberger).

Morton (Richard): Ienl. Libr. \& Hist. J., Brooklyn, 1904, ii, 1-7, port. (sir W. ().ler).

Mosso (Angelo): Arch. di fisiol.. Firenze, 1910-11, ix, 121-130 (C. Funo \& A. Herlitzkis); [Bigliography], 131-136, port.-Lancet, Lond., 1910, ii, 1650.

Mott (Valentine): Memoir by s. D. Gross, Phila., 1 Stis. 


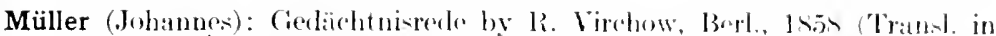

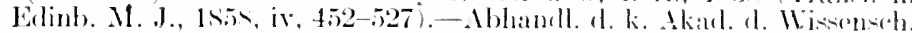

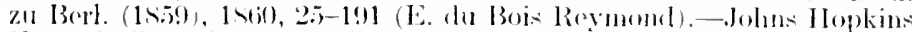

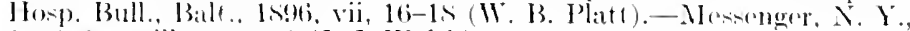
$19(9)$, i. $s$. iii, (ibi-69)3 (J. J. Walsh).

Mumford (James (ircoury): Boston M. \& s. J., 1915, (•lxxil, 470-17:) (R. C. ('al)ot).

Mundinus: Notizie by V. Joppi, Ldine, Is73.-Ann. Anat. \& Surer. Brouk-

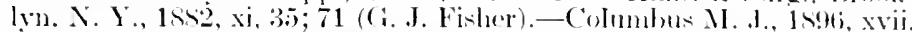

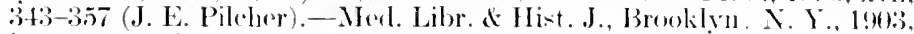
i, 1-s; 1906, iv, 311-3:31, 4 pl. (L. S. Pileher).

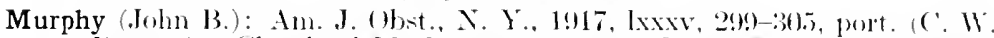

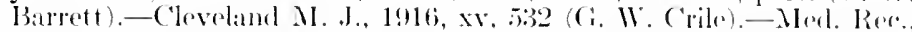
N. Y., 1916, xl, s.3:3 ( i. E. Brewer).-Furg. Ginece d (lbst., X. Y.. 19I6, xxiii, 234 (II. J. Mayo).

Neisser (Albrrt): Mitt. d. deutsch. (iescllsch. z. Bckämpf. d. Cirschlechtskl.

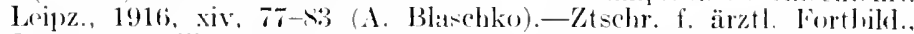
J(na, 1916, xiii, 519; 545).

Nightingale (Florence): life by Sir Erlward Cook. 2 vols. Lomd., 1913.Nuttiug and Dock: History of Nursing, N. Y., 1912, 62-311.

North (Elisha): Johns Hopkins Hosp. Bull., Balt., 1908, xix, 301-307 (W. R. steiner).

Nothnagel: Obiluary by B. Naunyn, 19().5.

O'Dwyer (Joseph): Pediatries, N. Y. \& Lond., 1s9s, v, 95-97, port. (A. Jacobi). —J. J. Wilsb. Makers of Modorn Medicine, N. Y., 1907, 325-3.56.

Oken (Lorenz): Alexander Erker, Lorenz Oken, Transl. by A. Fulk, London, 1S.

Osler: Biography by Harve Cushing [in preparation]. Brit. M. ... Hond..

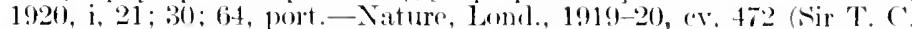

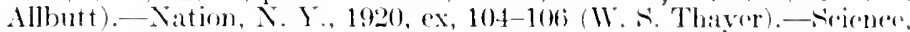

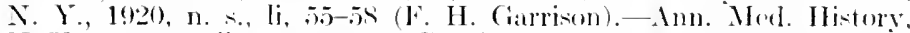
N. Y., 1919-20, ii, 1.57-157 (H. Cushing, al.).Therab. (iaz., Plilil. 1920, 3. s.. xxxvi, 160-164 (IH. A. IIare).-Johns Hopkins llosp. Bull., Balt., 1919, xx, 195-21s, 9 port. [Bibliography by Mimnic l3loge, 219-238].-J. Canad. M. Ast., 1920.-Mïnchen. morl. Wrehenschr. 1920, Jxvii, $26 \%$ (F) Mïller).

Owen: Lifo by R. Owen. 2 v., Lond., 1s95.-Proc. Rong. Sor. Land., 1s!9!.

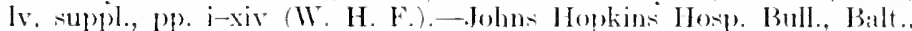
1911, xxii, 1:33-137 (C. IV. (i. Rohrer).

Pagel (Julius): Münehon. merl. Wehmschr., 1912, lix, 42., port. (K. Sulloli)

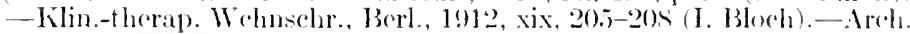

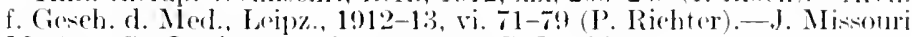
M. Ass., St. Louls, 1913, ix, 366;-36!) (Ci. Dorke).

Paget (Sir James): Memoirs and lotters Dy Stophen Paget, Lomrlon, 19()1.-

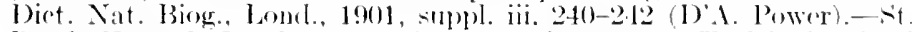

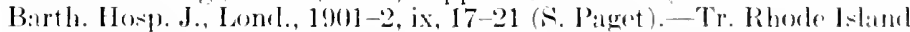

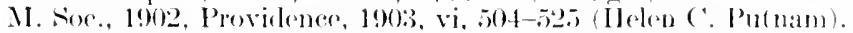

Paracelsus: Afudies and hiographies by: ls. F. Il. Marx (fiottingen, 1sl2),

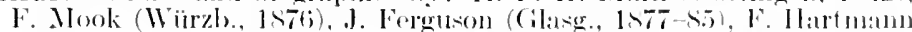

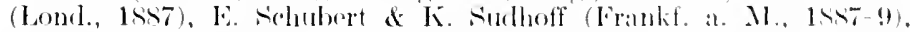

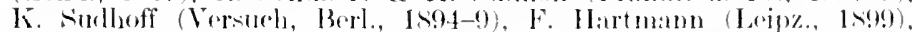

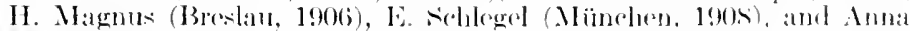

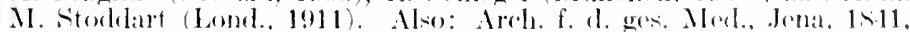

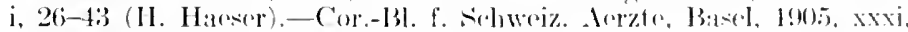

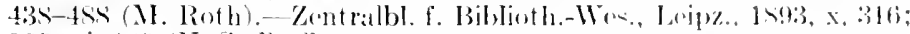
3.5: xi, 169 (K. Sulluoff).

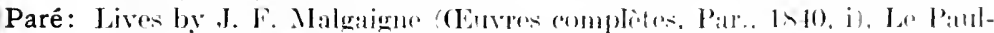

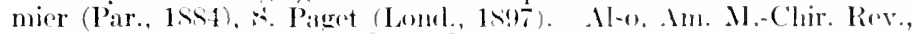

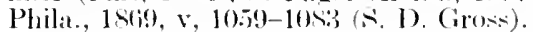


Parkinson: Johns Hopkins Howp. I3ull., Balt., 1!9f2, xxiii, 33-45 (I. G. lown$1 \mathrm{loc})$.

Pasteur: R. Vallery-Radnt Ja vio do l'asteme, l'aris, 1900 (English transl,

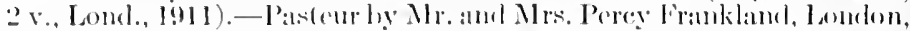

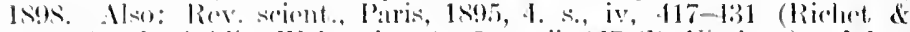

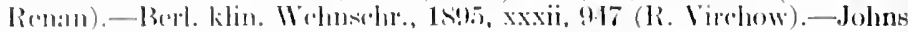

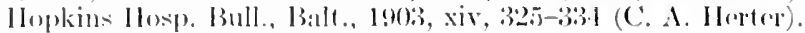

Patin ((iug): life hy l'. l'ir, l'ar., 1!11.

Pavloff: Buston M. \& S. J., 1911;, dxxiv, 799 (F. G. Bencdict).-Brit. M. J.,

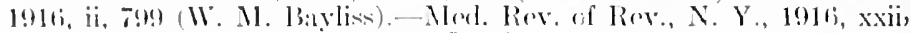
252-259 (V. Rohinson).-Nature, Lond., 1916, xcrit, 9-11 (W. II. T.).

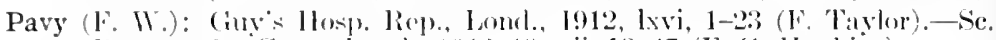
Progress 20. ('ont., Luml., 1912-13, vii, 13-47 (F. (i. Ilopkins).

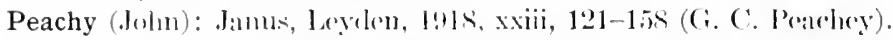

Pepper (William): Lives by l. N. Thorpe (Phila., 1904) and J. Tyson (l'hila.,

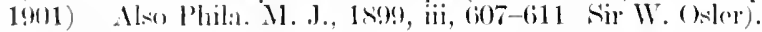

Peters (Iormann): Ber d. deutseb. pharm. Gesellsch., 1920, xxx, 333-3399 (II. s.hulenz).

Pettenkofer: Memoir by C. von Voit (Münchon, 1902)._-Berl. klin. Wchnschr., 1901, xxviti, 268; 301;321 (1I. Rubner).

Peyer (Joh. Conrad): Jamus, Leydon, 1914, xix, 61-83 (R. Lang).

Pflüger: Memoir by N. Nusbamm. Bonn, 1909.

von Pfolspeundt (II.): Janus, Leyelen, 1913, 109-119 (F. J. Lutz).

Pinel: Mrm. Arad. de mód., Par., 1s2s, i, 1s9-223 (E. Pariset); 224-231 (kisquirol).-Ann. méd.-pureh., Par., 1885, 7. s., ii, 185-193 (A. Ritti). - F. Tiffany: Philippe l'incl. [n. p., 1898.]

Pirogoff: Med. \& surg., St. Louis, 1917, i, 5-13 (W. P. Coues).

Platter: Sirlsstbiographie, ed. by H. Boos, Leipz., 1878.

della Porta (G. 13.): Am. Naturalist, Lancester, Pa., 1918, lii, 455-461 (T. IIolm).

Post (Wright): Memoir by Valentine Mott, N. Y., 1829.

Pott: Life by sir J. Earle, prefacing Pott's "Chirurgieal Works," London, 1790, i, pp. i-xly. Diet. Nat. Biog., Lond., 1896, xlvi, 207 (D'A. Power)._.t. Barth. Hosp. Rep., Lond., 1S94, xxx, 163-167 (Horder). -Boston M. \& S. J., 1915, clxxii, S07-812 (R. W. Lovett).

Power (Henry): Autobiography. (Stratford-ipon-Avon, 1912.)

Priessnitz: Biogriphy by Philo vom Walde (Berlin, 1899).

Priestley (Joseph): Memoirs, Northumbrrland, 1806. Also: Pop. Sc. Ifonthly, N. Y., 1875, vi, 90-107 (T. II. Huxley).

Pringle: Pettigrew: Med. Port. Callery, Loml., 1840, ii, No. 14.-Dict. Nat. Biog., Lond., 1896, xlvi, 386 (J. F. Payne).

Purkinje: J. Am. M. Ass., Chicigo, 1\$99, xxxii, \$12-\$14 (R. Burton Opitz).Areh. f. Krim.-Anthrop. 11. Kriminalist., Leipz, 1906, xxii, 326-335 (G. Roseher).- Valuable analysis of bis works by Th. Eiselt in: Vrtljschr. f. d. prakt. Heilk., Pritg., 1859, lxiii, Beil, 1-20.

Radcliffe: Life by J. B. Nias. Oxford, 1918.

Ramazzini: Franz Kinelseh, Bernardino Ramazzini, Stuttgart, 1912.

Rasori: Osp. maggriore, Milan, 1918, vi, 60-69 (C. Pasetti).

Récamier: P. Triaire: Récamier et ses contemporains. (Paris, 1899.)

Reed (Walter): Biography by H. A. Kelly, Balt., 2. ed., 1913.—J. Hyg., Cambrilge, 1903, iii, 292-296, port. (C. H. F. Nuttall).-Pop. Sc. Month., N. Y., 1904, 1xv, 262-268 (W. D. MeCaw).

Reil (Joh. Christian): Memoir by Heinrich Steffens, Halle, 1s15.-Gedenkrede by Max Neuburger, Stuttgart, 1913.-J. Nerv. \& Ment. Dis., N. Y., 1916, xliii, 1-22 (W. A. White). 
Remak (Robert): Berl. klin. Wehnselhr., 1stis, ii, 372.-Wion. med. Preste, 1865, xxxvii, 915 (11. Benedikt).

Renaudot (Theophraste): Life by (a. Gilles de la Tourette. Par., list.Albany M. Ann., 1907, xxviii, 599-623 (C. (i. Cumston).

Retzius (Gustay Magnms): Nature, Lond., 1919-20, (iii, 4 Is (Nir A. Koith).Seient. Month., 1920, x, 559-569 (O. Lairsoll).

Richter (August (rottlieb): II. Rohlfs, Geseh. d. deutsol. Med., Leipz., Iss.3, iii, $33-172$.

Ringer (Nidney): Proe. Roy. Soe. Lond., 1912, s. B., lxxxiv, pp. i-iii, port. (E. A. S.).-Biochem. J., Liverp., 1910-11, v, pl). i-xix (B. M(or(2).

Rokitansky: Festreden, Wien. klin. Wehnsehr., 1s9s, xi, 559-564.-Wien. med. Presse, 18it, xv, Fest-Nummer, 1-S (J. Sebnitzler); 1s7s, xix, S(i.j-97t (Arneth); 1549-1554 (T. Meynert).-Prag. mod. Wehnechr., 1878, iii, 309 (E. Klebs).-Allg. Wien. med. Ztg., 1879, xxiv, 111-143 (s. Strieker).

Rose (Valentin): Zentralbl. f. Bibliotheksweren, Leipz., 1917, xxxiv, 16\$-182 (E. Jacobs).

Ruffer (Sir M. A.): Ann. Med. History, N. Y., 1917-18, i, 218-220 (F. II. (turrion).

Rush (Benjamin): Recollections by J. C. Lettsom, Lond., 1915. Reminiseenees by T. D. Mitchell, Transylvania J. Med., Lexington, Ky., 1839, xii, 92-116.-S. D. Gross. Lives, ete, Phila., 1861, 17-\$5. mot. (S. Jaekson).-Aselepiad, Lond., 18s5, ii, 3\$-57, port. (Sir B. W. Richardson).-J. Am. M. Ass., Chicago, 18s9, xiii, 330-335 (H. R. Storer).Med.-Leg. J., N. Y., 1S86-7, iv, 238-273, port. (C. K. Mills).

Sanctorius: Resoc. r. Acead. med-ehir. di Napoli (18s9), 1890, xliii, is-113 (M. del Gaizo). - Tr. Cong. Am. Plys. \& Surg., 1s91, N. Haven, 1S92, ii, 1ss-19s (Weir Mitehell).

Sanderson (Sir John Burdon): Memoir by Larly Sanderson, Oxford, 1911.

Scarpa: Diseourse by s. Liberali, Treviso, 1\$3.- Mem. Aead. de mód, Parr,

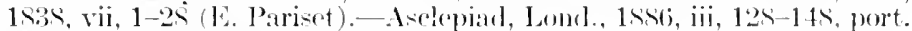
(Sir B. W. Richardion).

Schelenz (Hormann): Janus, Leyden, 191S, xxiii, 1-4, port. (J. Wr. S. Johnsson).

Schönlein: Gedäehtnisrede by R. Virehow. Berl., 1s6,5.-Berl. klin. Wehnsehr., 1864, i, 276-279 (C. Griesinger).-Wien. med. Wohncehr., 1stit, xir, 107 (Frerichs).-Zt.sehr. f. klim. Mel., Bert., 1910, lxxi, 471-477 (E. Ebstein).-Areh. f. Gesch. d. Met., Leipz., 1911-12, v, 419; 1915-16, ix, 209, 1 pl. (E. Ebstain).

ichultze (Max): Ar(h. f. mikr. Anat., Bonn, 1874, x, pp. i-xxiii, port. (G. Sichwalbe).

ichulze (Joh. IJeinrieh): Lifo by J. M. Eder (Vienna, 1917).

ichwann: Liber memorialis. Dïsseldorf, 1\$79.-Areh. f. mikr. Anat.. Bonn, 18\$2-3, xxi, py) i-xlix (J. Ilenle); 1909, lxxiv, 469-473, port. (0). Ilertwig \& W. Waldeyer).-Arch. f. path. Anat. (ate.), Borl., 1s\&2, lxxxrii,

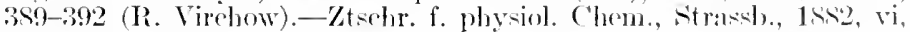
280-285 (A. Fossel).-Nature, Lond., 1ss1-2, xxv, 321-32:3 (E. R. Lankester).

emmelweis: Life by Sir J. W. Sinclair. Manchester, 1909. Sommetwers Denkmal, Burlapest, 1909.—Studies by A. Hegtr (1S52), I. Bruck (Wien, 1S57). J. Grose (Leipz. \& Wien, 189s) and F. Sehürer von Waldheim (Wien \& Le(ipz, 190:5).-Med. Rev. of Rev., N. Y., 1912, xviii, 232-246 (V. Rohinson).

znator: Gedäehtnisrede by A. Cioldseheider, Berl. klin. Wohnschre, 1911, xlviii, 1961-1968. Alio: Niünchen. med. Wehnschr., 1911, Iviii. 173391735 (A. Wolff-Einner). 
Sertürner: Bor. d. dentich. pharm. (iesellsch., 19)1, xxvii, 500-507 (C. Stich):

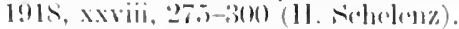

Servetus: Sirvetus and ('alvin by Rolert Willis, Lomd., 157.-John llop-

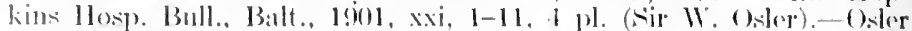
Auniversiry Volumes, N. Y., 1!19, i, 111-121 (1. 1. Markall).

Simpson (sir James Y.): Lives by .l. Jums (Wolinh., 1873), Eva 13. Simpson

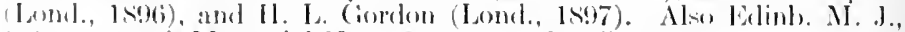
1!)1 1, H. s., vi, Memorial No., 4\$1-5(t), 9 1).; vii, 12-17.

Sims (Jame Mlarion): "The story of my Life" (N. Y., 18s.1).- "U(wer Matrion sims" ly. R. Olshamsen (13irl., 1S97).—Am. J. Obst., N. Y., Issi, xvii,

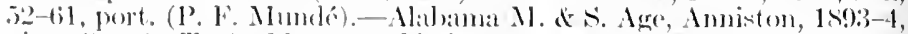
vi, 607-6il6 (T. A. Mans).Mled. Ree., N. Y., 1s91, xtvi, 705-70s

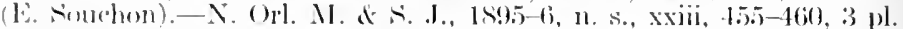
(E. souchon).ZZtwehr. f. Cimburtsh. 11. Ginäk., Stuttg., 1913, lxxiii, !) Iti-!) (A. Martin).

Smellie: Willian, Surllie and his Contenporarios by John (ilaister, Glasgow, 1s94. Nemoir in: "Work" (Now Sydenham Soc., 1s;ti, vi) by A. 11. Mf" Clintock.

Smith (Nathan): Life and letters by Enily A. Smith, New Haven, 1914.

Soemmerring: Lifo by W. Strieker (Frankf. a. M., 1862).

Soranus of Ephesus: Samml. klin. Vortr., Leipz., 1902. n. F., No. 335 (Gynäk. No. 121), 703-744 (J. Lachs).-Abhandl. d. K. sächs. Gesellsch. d. Wissensch., phil.-hist. Kl., Dresd., 1910, xxvii, No. 2 (J. Hberg).

Spalding (Lyman: Lifo by J. A. spalding, Boston, 1917.

Spallanzani: J.-L. Alibert: Eloges historiques, Patris, 1s06, 1-1S6.-Sc. l'rogress, London, 1916, xl, 236-245 (B. Cummings).

Stensen: Opera v. I (Copenhagen, 1909)., Sir M. Foster. Ieet. Hist. Physiol., Cambridge, 1901, 106-110.-Med. Libr. \& Hist. J., Brooklyn, 1904, ii, 166-182, port. (F. .J. Lutz).-J. J. Walsh, Catholie churehmen in science. Phila., 1906, 137-160, port.-Johns IIopkins Hosp. Bull., Balt., 1914, xxv, 44-51 (W. S. Miller).

Steinschneider (Noritz): Biog. Jahrb., 1907, Berl., 1909, xii, 171-175 (J. Pollak).

Sternberg (George M.): Bingraphy by his widow (Chicago. 1921).-Tr. Am. Soe. Trop. Ned., N. Orl., 1916, x, 19-26 (E. I. Munson).

Stokes: Life by Sir W. Stokes (Lond., 1897).-Dublin J. M. Sc., 1Sis, lxv, 186-200) (J. W. Moore).-Med. Hist. Meath Hosp., Yubl., 1888, 129$13(i, 1$ pl.

Stoll: V. Fossel: Stud. z. Gesch. d. Med., Stuttg., 1909, 153-191.

Stromeyer: H. Rohlfs. Gesch. d. deutsch. Med., Leipz., 188.5, iv, 139-260.Wien. med. Wehnsehr., 1576, xxxvi, 1064 (T. Billroth).

Süssmilch (J. P.): Publ. Am. Statist. Ass., Boston, 1900-1901. vii, 67-46 (F. S. Crum).

Swammerdam: Werk. v. h. Genootseh. t. Bevord. d. Nat.-Gienees- en Heelk. te Amst., 1sso, v, 1-64 (B. J. Stokvis). "Some Apostles of Physiology" by W. Stirling (Lond 1902, p. 34). See, also: novel "Swammerdiun" by $H$. Klencke, $3 \mathrm{v}$. (Leipz., 1860 ).

Sydenham: Life by J. F. Payne (Lond., 1900)._J. Brown "Ifora subseciva,' Lond., 1858, 1-98.-Dent-che med. Wehnsehr., Leipz., 1Ss!), xv, 10681070 (Pagel).-Aselepiad, Lend., 1892, ix, 35.5-401, port.. pl. (Sir B. IV. Richardion).-Med. News, Phila., 1894. lxv, 234-236 (Sir H. Acland).-Janus, Amst., 1s99, iii, 4-11 (J. F. Payne), and M. Greenwood on Sydenham as epidemiologist (Proe. Roy. Soe. Med., Lond., 1918-19, xii, Sect. Epidemiol., 55-76.

Sylvius (Franciseus): Sir M. Foster. Leet. Hist. Physiol., Cambridge, 1901, 145 -173.-Johns Hopkins Hosp. Bull., Balt., 1909, xx, 329-339 (F. Baker). -Proe. Charaka Club, N. Y., 1910, iii, 14-2s, 2 pl. (S. E. Jelliffe). 
Syme: Memorials by R. Patcrson, lidinb., 1>74.

Tait (lawson): Brit. M. I. lomel., 18!99, i, 1561-1564.-J. An. M. Issoc., Chicago, 1s99, xxiii, s75-sso (C. A. L. Reed).

Thackrah: J. Intustrial Hyg., Boston, 1920, i, 57s-5s1 (T. M. Msegro).

Theophrastus of liresos: F. L. Cireene. Landmarks of lbotanical llistory, $1 V_{i 1}=\mathrm{h} ., 1909, \mathrm{i}, 5^{2}-14^{2}$.

Traube (Ludwig): Berl. klin. Wohnkehr., 1s76, xii, 20) (R. Mirchow).- ('harite Ann., 1575, Berl., 1877, ii, 767-800) port. (1). Leyelen).

Tronchin: Lifo by 11. 'Tronohin, Par., 1906.-Areh. f. Ciesch. 1. Mrd., Idipz., $1907-8, \mathrm{i}, 81 ; 2 \mathrm{~s} 9$ (A. (ivy).

Trotter (Thomas): J. Roy. Nav. MI. S'erv., Lond., 1919, v, 412-119 (Nir 11. D. Rollaston).

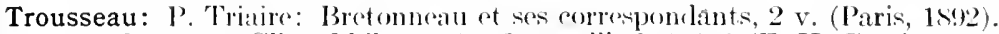
-Internat. Clin., Phila., 1916, 26. s., iii, 2st-303 (F. H. Garrison).

Trudeau: Bjography by \$. Chalners, Boston, 1916. Bull. Johns Hopkins Hosp., Balt., 1916, xxvii, S6-107 (W. B. James [et al.].-J. Am. M. Ass., Chicago, 1916, lxvi, 24t-216 (s. A. Knopf).

Turner (Sir William): Life by A. Logan Turnes (Elinburgh. 1919).

Venel: Zentralbl. f. chir. 11. mech. Orthop., Berl., 1912, vi, 432-435 (М. Klemm).ZZtschr. f. Krïppelfürsorge, Hamb. \& Lojpz., 1914, vii, 216224 ( MI. Kirmsise).

Vesalius: Eturles by A. Burggraeve, Cihont, 1St1.-Lives by Ml. Roth (Berlin, 1\$92), J. Ml. Ball (St. Louis, 1910), and J. Olmedilla y P'uig (Madrid, 1913).- - ir M. Foster: Lectures on the IJistory of Physiology, Ciambridge, 1901, 1-24.-Elinb. Ml. J., 1914, n. s., xiii, 324; 3ss, 1 pl.

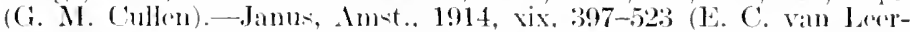
sum, at al.).-Ibid., 1915, xix, 435-507, s pl., 1 tab. (F. M. Ci. de Fryfer).-Nederl. 'Tijolsehr. v. (imerek., Imst., 1915, 2. R., li, pt. 1, 4-130 (E. C. van Leersum, et al.).-Neel. Pee.. N. Y., 1915, lxxvii, 245247 (W. H. Weleh, et al.).-Johns Hopkins IIosp. Bull., Balt., 1915,

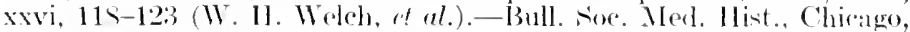

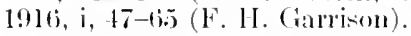

Virchow: Biography by 11 . Becher (Brel., 1s91).-Briefo (Leipz, 1907).-

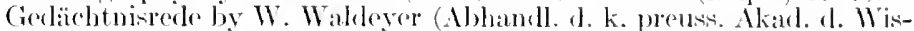
sensch., Berl., 1903, 1-52). Cierläehtnis-lejer. Verbandl. d. Berr. Gesellseh. f. Anthrop., 1902, 311-330), port.-Areh. f. path. Anat. (otc:), Berl., 1903, exxi. 2-7 (F. yon Rerklinghansen).-Johns Ihopkins lniv.

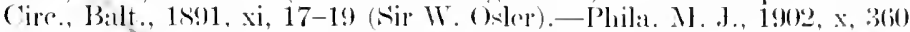
(IV. H. Wreh).-Acience, N. Y. \& Lancaster, Pa., 1902, n. s., xv, 141445 (1). Bois). - Virchow-Bibliographie (Berl., 1!)(1).

Vulpián: l'aris méd., 1912-13, xii (stuppl.), 733-747 (J. Camus).

Warren (John Collins): Life by E. Warren, 2 vols., Bost., 1S60.

Weigert (Carl): Biography by R. Rierler, Berlin, 190(i.

Weismann (August): ścience, N. Y., 1915, n. s., xli, $917-92:$ (l. ( . Conklin).

Welch: Seienee. N. Y., 1920, n. s., lii, 417-4:33 (s'. Flexner)

Wells (William Charles): Skoteh hy Elisha Bartloft (lomisville, is 19), -

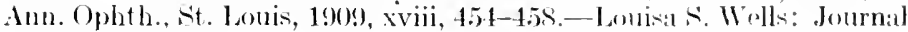
(New Fork IIstorical Socioty), 1906, st-106.

Werlhof: ()pera medica Hannov., 1775, pars i, plo. i-xvii (J. W. Wichmann).II. Rohlfs: (ieseh. d. deutseh. Med., stuttg., 1575) i, 32-sl.

Weyer (Johann): Biography by Carl Binz, 2. Aufl., B(rrlin, 1s96._. Ied. Mag., Lond., 1897, vi, 520;(609; 651; 769) (W. T. Withington).

White (Charles): Med. Libr. \& Ilist. J., Brooklyn. 1907, v, 1-1s (.J. C. Arlımi).

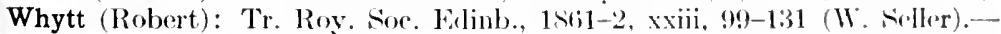
Med. Libr. \& Hist. J., Brooklyn, 1904, ii, 153-16i), 1 pl. (J. Ruhräh). 
Wilks (sir S:muel): Biographical leminisences (Lond., 1!11).-Guy's Ilosp. (i:1\%, I coml., 19)11, xxr, 5018-510, purt.-Bibliography of his writings by

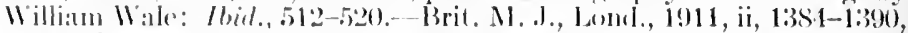
port.-Lanere, Lond., 1911, ii, 1.11-1415, port.-Ciuy's Hosp. Rep., lond., I!) is, 1xvii, 1-39) (W. II. White).

Winternitz (Wilhelm): Nünchen med. Wochensehr., 1917, lxiv, 38.) (J. Marcuse).—Wien. klin. Worhenschr., 1!917, xxx, 347 (A. Strasser).

Wiseman (Richarrl): Life by Sir 'T'. Longmore (Iond., 1891). - Sir B. IV. Richatrdion, Disciples of Aesculapius, Lond., 1900, i, 15s-175, port.IV (st. Lend. M. J., 1912, xvii, 20:3-205, (\$. D. Clippingdile).

Withering: Lifo profucing his "Misecllancous 'Traets," Lond., I\$22, i, 1-206 [Biblingraphy], 207-209.-Droc. Roy. Soe. Med., Jond., 1915, viii,

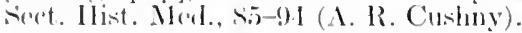

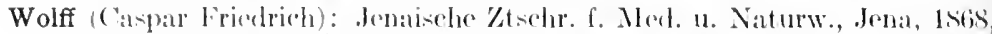
ir, 198-2:20 (A. Kirchholf). - W. M. Wheeler: Woods Iloll Biol. Lect.,

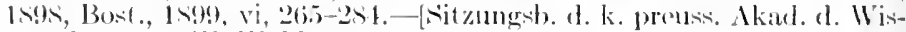
sensch., 190). (II, Waldeyer).]

Wood (Horatio ('.): Alumni Rog. I'niv. Penn., Phila., 1906-7, xi, 1966-200

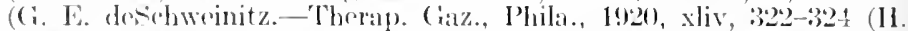
A. Hare).-Med. Ree., X. Y., 1920, xeviii, 393-396; (11. Breates, jr.).

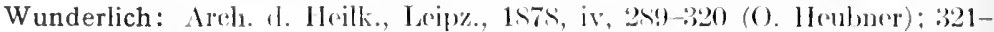
329 (W. Roser).—Merl. Klin., Berl., 1915, xi, 901-903) (A. Strümpell).

Young (Johm R.): Bull. Johns Hopkins lkosp., Balt., 1918, xxix, 186-191, 2 pl., (11. A. Kinly).

Young ("Thom:s): Lives by Gurney (Lomd., 1.331) and Peacock (Lond., 1855). -Diet. Nat. Biog., Lond., 1900, lxiii, 393-399 (C. 11. Lees).

Yperman: Janus, Amst., 1913, xviii, 1; 197 (E. C. van Leersum).

Zacchias: I. Fossel: Studl. z. Gesch. d. Med., Stuttg., 1969, 46-110.

Zimmermann: Lives by Tisot (1797) and R. Ischer (1\$93).

\section{Histories of Special Subjects}

Alchemy: K. C. Schmieder: "Gesehichte der Alehemie" (Halle, 1832).E. Berthelot: Les origimes de lalchimie (P'aris, 1S5.5).

Alexandrian Medicine: K. Sulholf. "Anztliches aus griechisehen Papyrusl'rkunden" (Leipzig, 190)

American Medicine: James Thacher's sketch in his Ameriean Medical Biography, Bost., 1S2S, i, 9-85, which contains separate histories of medieine in the enlonial states. ('ontury (A) of Ameriean medicine (Phila, 1876), in particular the critieal survey by J. S. Billings (pp. 290-366).-S. D. Cross: "History of Ameriean medical literature" (Phila., 1876).J. M. Toner: "Contributions" (ete.) (Washington, 1871). - F. R. Packard: "History of Medieine in the Inited States" (Phila., 1901).J. (i. Mumford: "A Narrative of Nerlieine in Ameriea" (Phila., 1903). -University .I. Matg., Phila., 1s97-S, x, 136-140 (Sir W. Osler).J. Am. 1l. Ass., Chicago, 1911, lviii, 437-441 (11. A. Kelly).-Med. Pec., N. Y., 1904, lxv, 361-3677 (S. Smith); 1913, lxxxiv, 277-283 (T. Abbe).-Mled. \& Surg. St. Louis, 1917, i, 1068-1073 (C. Vabre).)Tr. Am. Surg. Ass., Phila., 1917, xxxy, 65-171 (E. Souchon).

Anatomy: Ludwig Choulant's "Gesehichte und Biblingraphie der anatomisehen Abbildung" (Leipzig, 1852), recently translatel, with additional matter by Mortiner Frank (Cniv. Chicago Press, 1920); Hyrtl's studies of Arabie and Hebrew terms (1879), anatomical terminology (1850) and old German termini technici (18S4); Robert von Töply's sturlies in merliaval anatomy (Jcijuzig, 1898), the Histoire de l'anatomie plastique of Mathias Duval and Edouard Cuyer (Paris, 1898), Ludwig Hopf on the carly cultural phases (Ablatndl. 3. Gesch. d. Med., Breslau, 1904, Heft 9), and Karl Sudhoff on traditional (1907) and graphic 
phases of anatomy (1908) are the most remarkable works in this field. The anatomical illustration of the uterus alone is most exhaustively treated in "Jutero attraverso i secoli" (Castollo, 1917) by l. Fa Torre. The late Sir William Turner's history in the Eneveloparlia Britannica (sub ioce "Inatomy") and Frank 13aker's article in stedman's Reforenes" Ilandbook (N. Y., 1913, i, 323-345) are the best monographs on the general subject in English. Töply's monograph in the l'uschmann Fandbuch (1903, ii, 155-325) is a good routine and biloliographic account of the whole subject. Thomas Latuth's unfinisherl "IIistoire de lanatomie" (1S15) is an earlier work. Antrror (ren to this is the "Ilistoria anatomiae" of Caspar Bauhinus (1597), which gives marerinal bibliographieal references to all the diseoveries listed. A similat service is rendered by surengel (passim). I. H. Chievitz's Auntomiens II istorie, in the Danish language (Copenhagen, 1904) has many interesting illustrations. Wr. W. Keen's "sketeh of the Early History of Pratical Anatomy" (Jhilarlelphia, 1s $\mathbf{4}$ ) is a valuable history of discosting and injecting. Charles R. Bardern's "Anitomy in Amcriea" (Bul]. Eniv. Wisconsin, Matison, 1905), No. 115, si-20s) is the best aceount of this phase of the subject. For cross-sectional anatomy, see, the introduction to the atlas of A. C. Ercleshymer d D. M. Firhormaker, N. Y., 1911, pp. ix-xvi. For terminologr, see J. Briscalul: Ilistoire des expressions populaires (Paris, 1S5s); A. Bort \& C Prollandal: I, nomenclature anatomique of ses origines (Paris, 1904); H. Triefol: Dir anatomischen Namen (Wiesbaden, 1910), and the aloovenentionsel looks of Ilyrtl.

Anesthesia: Dublin J. M. Se., 1875, lix, 32-3s (T. M. MArluln)._/birl., 1sts.

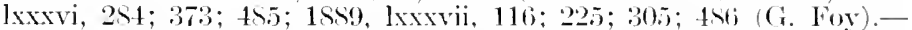
Deutsehe Zt:ehr. f. Chir., Loipz., 1s95-1;, xlii, 517-59t (Th. Itusemann).

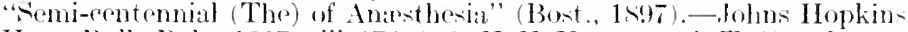
Hosp. Bull., Balt., 1s97, viii, 17t-1st (H. 11. Yumg).—. T. ( iwathmer:

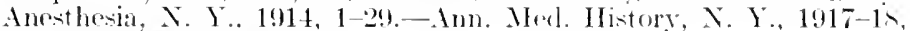
i, 329-332 (-ir W. Osler).

Anglo-Saxon Medicine: O. Cockayns: "Lerehdoms. wortemming" (otr.). (3) v., Lend., 1864-6).-J. F. Payne: "lnglish Mroticine" in thes Anglosixom Times" (Oxford, 1904).

Anthropology: "History of Anthropology" by A. C. Hlarklun, Loml. and T. Y.. 1910.

Arabian Medicine: F. Wüstenfehl: "Geschichte der arabischen doptro" (otr.

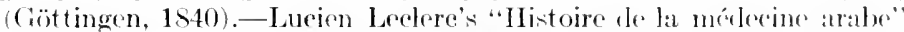

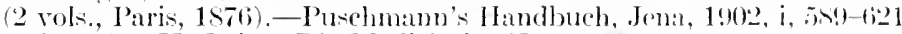
(Aclurutz).-K. Opitz: Die Medizin in Koran (Ftuttgart, 1906i)

Art (Medicine in): The suldject was opener up by Virehow in Areh. f. path. Anat. (ete), Berl, 1861, xxii, 190; 1562, xiii, 194; and the mat rial exhaustively listed by Marx (Abhandl. d. k. Ciesellseh. d. Mixingeh. zu Gïttingen, 1S61-2, x, 3-74; but was really the creation of charcot and his pupils in the files of the Nomvello leonomraphio de las salpetriere, Par., 18ss-1!)1:, passim. The two monogruphs of Chareot is P'. Richer on the demoniac, the leformed and the flerased in art (Par. 1 P. Richer's L'art ot la méderino (1'ar., 1902); Eugen Holläinder's monegraphs on medieme in elassiend painting, "aricatume and plastire art

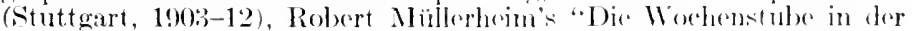
Kunst" (Stutte., 1904), and F. Parkes Wrber"s "Aspects of 1)oath in Art" (2. ed., Lomd., 1914) are the best books on this subject. Finh essays as those of J. W. Chureliman on dan Siteen and Velasifury (Johns Hopkins Hosp. Bull., Balt., 1907, xvii, 4s(); 1911, xxii, 32:3) ant Mlortimer Frank on Caricature in Modieine (Bull. Noe. Mred. 1list., Chicago, 1911-15, i, 46-57), are: well worth roading.

Assyro-Babylonian Medicine: F. von Oefele: "Keilsehriftenceliein" (Abhandl. 3. Gesch. d. med.. Breslau, 1902, Ileft 3.).-1. Kïehler: Beiträge zur Kenntnis der assyrisch-babylonischen Mediein (Leipzier, 1904).- 


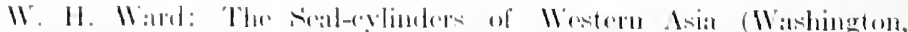

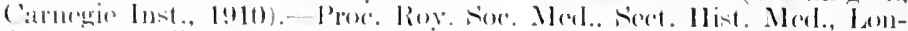
don, lol1, vii, 109-17t (.M. Jastrow).-Anu. Mad. Mistory, N. Y.,

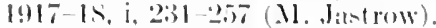

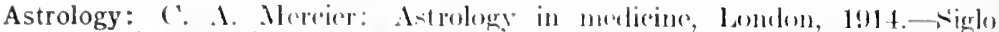

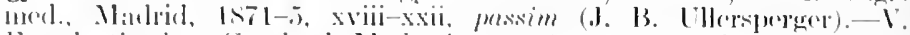

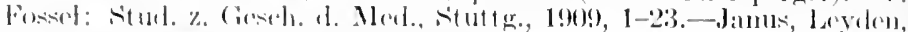

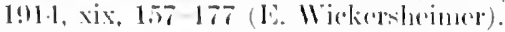

Austrian Medicine: M. Nouburger: Dio butwieklung der Molizin in Ooter-

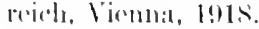

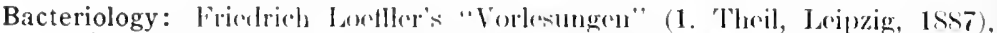
incomplote, which may los supplomented by Mïller and Pratsinity

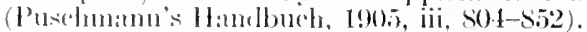

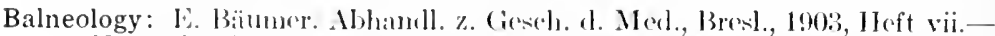

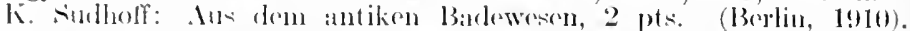

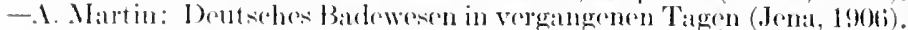

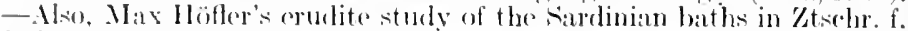
Balneol., Berl., 19) 1 , vi, 51 ; 65, 76; 91, see, also, the bibliography in Indrex Cat.. 1920,3. s., ii, 3331.

Bibliography (Medical): Inaller"s re-issue of the Bocrtatave "Methodus Studii Merlici" (2 vols., Amsterdim, 1751), and his bibliographies of botany $(1771-2)$, anatomy $(17 \overline{7}+\overline{7})$, surgery $(17 \overline{7}-\overline{5})$ and practice of modicine $(1776-5)$, make up the best of the cighteentle century contributions-

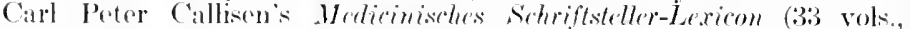
Copenhagen, $1530-45)$ is a sort of anthor Index-Catalogue of the latter hall of the eighternth and the first guarter of the nincteenth centurjes. The eallier bibliographies of G. G. do Ploucepuet (1St)s-9), Robert Watt (1524), James Itkinvon (15.34), and Juln Forbes (Is35) are valuable. Ludwie Choulant's Mandbuch der Brörherlinude (2. od., Leipzig. 1840), and his Bibliothere medico-historica (Lajozig, 1812), with . Wulius Rosenbitum's Additanchte (Hallo, 1S42-7), Haeser's Bibliotheca cpidemiographica (Jena, IS43), with J. G. Thierfelder's" Ardlitamenta" (Meisien, 1843; (ireifswald, 1862), Rupurecht's Bibliothere medico-chirurgica (1s17 at seq.), W. Engelmann's Bibliotheed medien-chirurgiea (Ieipzig, 1Sts), Aplanse Sanly's Biblingraphic des scimeses módicales (Paris, 1574), and Lucion Hahn's Essati de bihliographer medieale (Paris, 1897) are invaluable works of their kind. Quérarl's la Frane litteraire (12 vols. 1527-51) and Brmat's . Memuel du libraime (s vols., Paris. 1860-6.5, suppl., Paris, $1878-50)$ are expecially good for French medieine. Spanish medieine has been rxhatstively treated in the II istoria bibliográfica of Antonio Hernández Morejón (T vols., Madrid, 1s4252 ) and the "Colecrión" of Migurel de la Plata y Mareos" (Madrid, 1882). The most exhanstive modern bibliography of morlicine is the IndexCatalogue of the Library of the Furgeon-Ceneral's Olfice (37 vols., 1ST9-1916), supplemented by the monthly Index Medims (1879-99; 19(2)-1917). The hiatus eaucel by the suspension of publication of the latter journat was filled in part by the French Index Medicus (Paris, $1900-1902)$. For historie study of the fundamental texts, see the Colalogue des secienres métienles of the Bibliotheque impériale (3 vols., Patris, $1857-69 /$, and the special bibliographies of the Index Catalogue, partieularly its lists of historical texts (2. ser., xvii, pp. s9-178).

A valuable select bibliography of important scientifie papers for the years 1800-1 593 is the Royal Society"s "Catalogue" (14 vols., Jondon, is $67-$ 1915), and for anatomy, physiology, bacterjology, chemistry, biology and antluropology, the "International Catalogue of Scientific Literature," printerl hy the Royal Society (London, 1907-12). For parasitology, C. IV. Fitiles and A. Ilassall's "Index Catalogue of Medical Zoölogy" (36 parts, Washington, 1902-12) is nnigue and invaluable. I. Pfeiffer"s bibliography of smallpox and vacoination (Woimar, iS66), E. .J. Waring's Bibliotheca Therapentien (1578), H. C. Bolton's bibliog- 
raphy of chemictry (Washingtom, 1s85-93), 1. Sehnid's bibliography

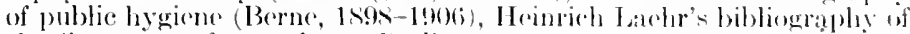

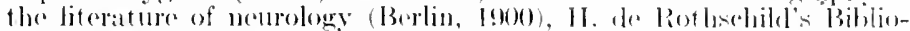
thera lactaria (l'aris, 1901), Le Rothe bibliograply of mursing (Borlin, 190:3). (Gottlieb Port's imdex of dental literature (licidelberg, 1901-11),

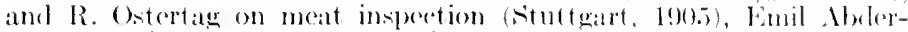

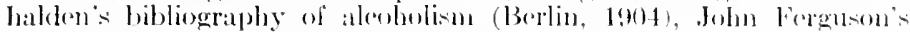
Bibliothera ('benieal (Glasgow, 1906i), and the bibliographlies of E. F. Cyriax on meslieal gymnatices (Worishöfen, 19099), H. (iocht on Rexutgen

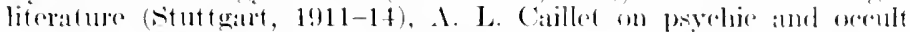
seiences (Paris, 1912-13), Domald MeNurtrie on erippled children Now York, 191:3), the New York State lboard of ("harition on engentes (Albany, 1913), A. C. Klebs on variolation (Baltimore, 1!)13), and $\mathrm{F}$. salveraggio on pelligra (Pavia, 1911) deserve mention.

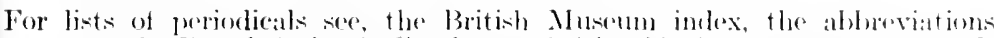

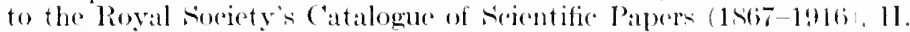

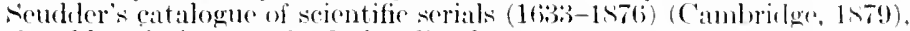
the abbreviations to the Index (atalegue (1St), 1916), II. ('Bellon's ratalogue of seientifie and technieal periodieals $(1665-189)-2), 2$. ed.

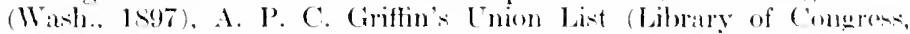
Washington, 1901), Hl. O. Soverance's Guide (Aun Arbor, (i. Wahr, 1914), the French Anmuaire tes journame périodicfues (Paris, 18s1-1916) and the Gesamt-Zeitsehrit(en-Verzeichnis of (iorman lihraries (kionigl. Bibliothek, Berlin, 1914). For seientifie sorieties, the seetion "Ararlemies" of the British Museum Catalogue, the International Exchange

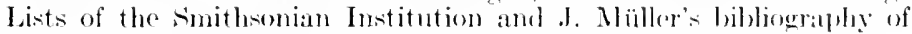
German sejentifie soeieties (Berlin, 1883-7) atre valuable.

Indiepensable works for general referenee in a library of large wze are the ('atalogues of the British Musem and of the Pealerdy Library of Balci-

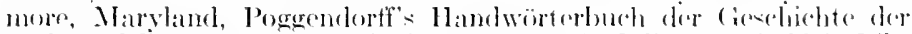

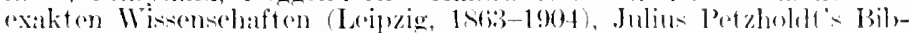

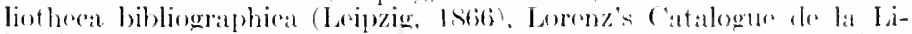

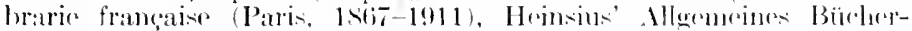
lexieon for the vears $1700-1912$ (36 vols. Leipziq, 1412-1913), Lion

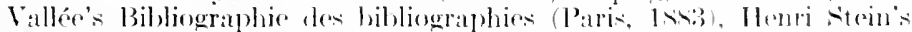

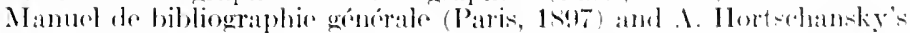

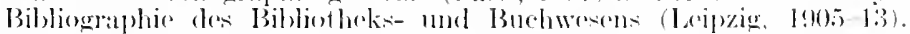

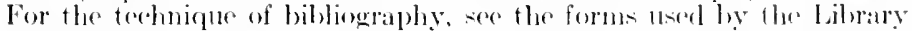

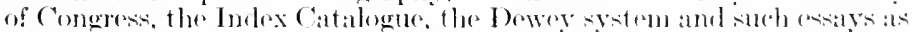

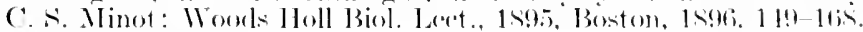

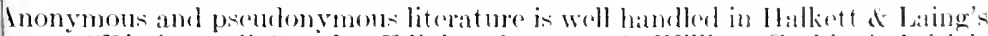
"Dietionary" (4 vols., Edinhurgh. 1s's-s'), Willian ("ushing's huitials

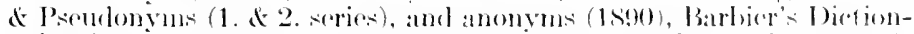

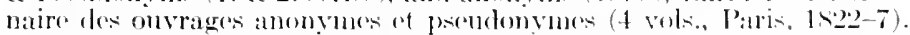
lot these may be added John Martin's Bibliography of privatedy printed books (2. ed., Lond., 1sit), and the Bibliography of unfinisied books in English by A. R. ('orme and A. Sparke (1,ond.. 1!15).

biology (History of): J. A. Thomson: The serenere of life (Chicago d Xew

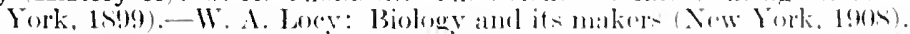

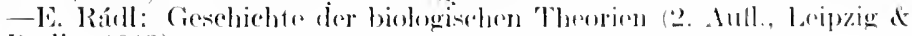
Borlin, 1913).

irth-control: V. Robiuson: Pioneers of birth-eontrol. N. Y.. 1920).

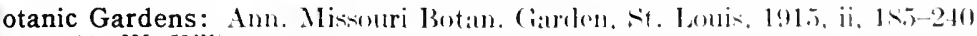
(A. W. Hlill).

otany: E. H. F. Meyer: "Geschichte der Botanik" (4 v., Känigsbre, 1451).

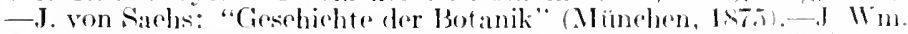
Harshberger: "The Botanists of Philatelphia" (Phila., 1s!99)-..1. llamen: "Die Entwieklung der Botanik" (Cirsen, 1902), - E. l.

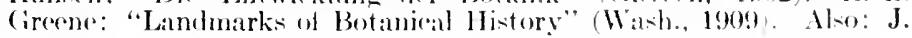


Am. M. Ass, Chicago, 1!)11, Iviii, 137-141 (H. A. Kelly)-Sicienee,

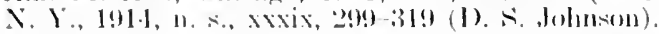

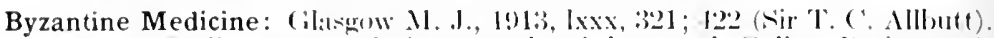

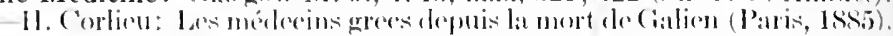

Caduceus: Am. J. Aroharol., ('oncord, N. I1., 1916, xx, 175-211 (A. L. Froth-

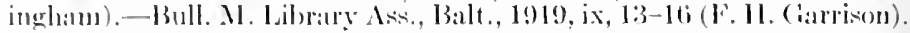

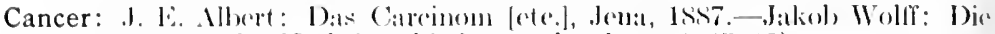

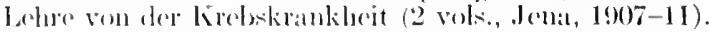

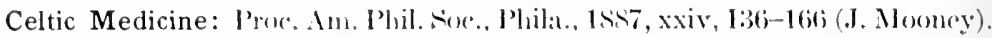

Chemistry (History of): Histories ly H. Kopp) (B/ns(hwg., 18.13-7, 1-71-3),

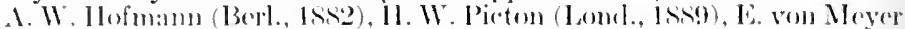

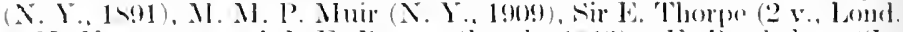

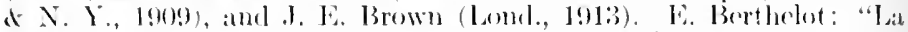

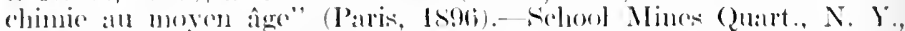

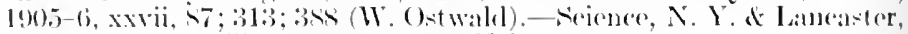

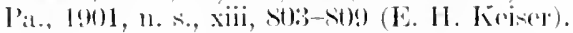

Chinese Medicine: M. Boym: ('lavis merliea (Frankfurt a. Ml., 16s(i).-A.

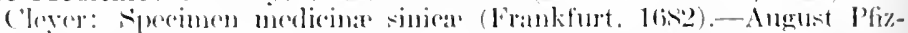

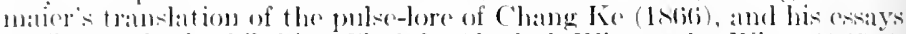

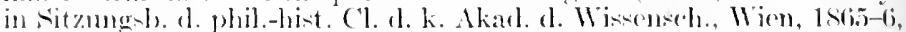
on ('hinese pathologr, semejology and toxicology-P'. Dabry: Iat

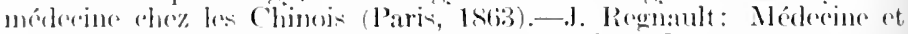

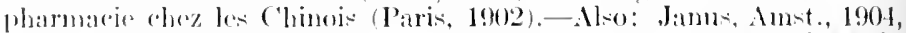

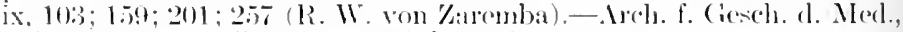
leip\%., 1913-14, vii, 11:-12s (Hubötter).

Cholera: (i. Sticker: Dic ('holerat (Gieson, 1912, 104-2k1).

Chronology (Medical): The talbles prepared hy Ludwig ('homlant (1822),

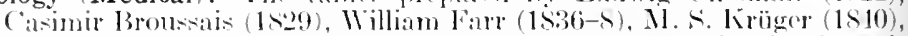
L. Aschoff (1898), and Jutius Pagel (1908), are useful, as also the ehronologies eontained in the hiwtories of sprengel, E. Isenwe, and L. Sichwalbe.

Clinical Medicine: J. Peerson: IIamptmoumente in der älteren Geschichte der merlicinj-chen Klinik (Kopruhagen, 1s90).

Contagion and Infection: (A. Ntirker: Mblandlungen ans der Souchengeschirlite, 2 r., (iimen, 1900-12. - Ann. Merl. History, X. Y., 1917-18, i. $150-173($. C. C. Kl(b)

Deaf-mutism: Thomat Aroold: Edueation for Deaf-Mutes. Lond., 1Sss, $1-110$.

Dentistry: Vineenzo Cuerini- !li-tory of Dentistry (Philadelphia, 1909), and

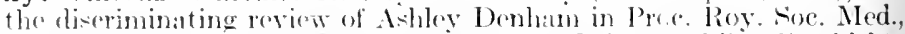

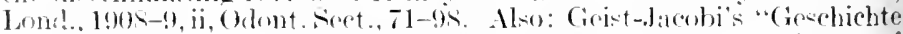
der Zahnheilkunde" (Tübingen, 1s!m), (. R. E. Foch: History of Dental surgers, 3 $\%$.. Fort Wivne, 1910, Dental Cosmos, Phila.. 1920, lxii, 1-73, and the exhaustive history of ortherlontia by 13. W. Weinbereer in Internat. J. Orthodont., st. Lenui-, 191:3-20, jassim.

Dermatology: Handh. d. Ciesch. d. Med., Jena, 1905. iii, 393-4tiis (1. Bloch). -Lincet, Lond., 1911, i, 15.5-1.860) (J. 11. Sequariri).-J. Am. 1l. Ass., ('hicago, 1915, lxy, 469-47t (H. Fox).

Dietetics: II. Lichtenfelt: Dic Ceschichte dor Ernährung (Borlin, 1913)Festochr. z. 3. Siecularfeier - d. medl. Fac. Würzb., Leipz., 1\$s2, ii. $17-41$ (A. Stöhr). - Ztschr. f. diätot. 11. phys. Therap., Leipz.,

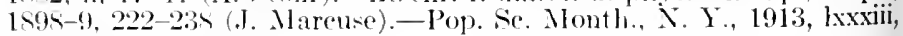
417-423 (.J. B. Nichols).

Diseases (Early History): C. G. Ciruner: Morborum antiquitates, Breslaul, 1774.-C. F. H. Narx: Origines contagii, Carlsulue \& Baden, 1827.C. Pruys van der Hoeven: De historia morborum, Jeyden, 1846.

Drugs: C. Pruys vam der Hoeven: De historia medieamentorum, Leyden, 1847.-F. A. Flückiger \& D. Hanbury: Pharmacographia. (2. ed., London, 1S79.)-A. Tsehireh: Pharmakognosie (Leipzig, 1908-12).- 
Troussean \& Pidonx: 'Traité do thérapentique (7. onl., Paris, 186s).-

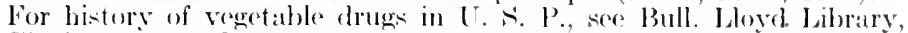
Cincinn., 1911, No. 1s, 1-1333 (J. U. Lloyil).

Education (Medical): T. Puschmann, "Gesehiehte des medizinischen lnter-

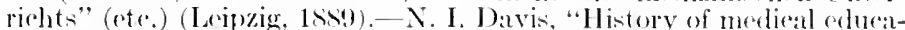
tion" (ete.) (Chicago, 1851).-A. Flexuer, "Reports to the Carnegie" Foundation for the Advaneement of 'Teatehing" (Bull. No. 4, 6, N. Y., $1910-12$ ).

Egyptian Medicine: Papyros Ebers (od. by (i. Ebers). 2 v. Ioripzig, 1875, later ed. Wr. Wrezinski, Leipzig, 1913, and transl. by Ił. Joathim (Ber-

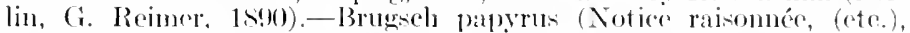
Leipzig, Hinrichs, 1863), also facsimile Brugseh major (Ree. de monum. egyet ., Leipz. 1863, pt. 2, p. Kxv-(evii).-Brugreth-minor (Abham ll. d. Berl. Akad. d. Wissenseh., 1901). - The llearst medieal Papyrus, ed. by (i. A. Reisner (Univ, Calif. Publ, v. 1).-The Potrie Papyri, ol. by '?. L. Grillith (London, 1s9s).-K. Sulhoff. Arztliches aus griechiselon Papvrus-trkmulen, Leipzig, J. A. Banth, 1907.-P'rosper Alpints. Do medieina Egyptorum, Fenier, 1591.-Richard Millatr, Disequisitions in the history of medieine, Edinburgh, 1s11 (ete.).-.ll. L. E. Lüring's Strassburg dissertation (Leibzige, 1SSS) is experially valuablo as showing, by textual comparion, the indebtedness of the Cirese and Roman writer's to papyrie medieine. - Medieine in Ancient Egypt by Bayard Holues and P'. G. Kitterman (Cincinnati, 1914) is very helpfuil. For an excellent réstmé of Egyptian medieme, see Brit. M. I., Lond., 1893. i, 7As; 1014; 106i1 (J. Finlay'son).

Electrotherapy: Ann. d'électrobiol. (ete.), Par., 1901, vii, 12!)-1 t6 (A. Tripier). -ll. Chaufour: Les origines th galvanisme. Paris dist. No. 6, 1913.Tr. XVII. Internat. Ned. Cong., 1913, Lomd, 1914, sect. XXill,

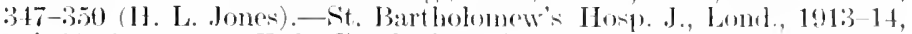
xxi, 39; 61; 70;90 (E. P. ('umberbateh).

Embryology: O. Ilertwig: "Lehrhuch, ate." (9. Aufl, Jena, 1!10, 5-, is). Basel diss. by B. Bloch (1904).-W. A. Loer: "Piology and its makers" (N. Y., 1908, 195-236i).-St. J anis M. Per., 1904, xlix, 273-2\$1 (A. (' Eyclestymer).-Pop. Se. Month., N. Y., 1906, lxix, 1-20 (C. S. Minot). Also Introduction to: "Manual" (ete.) by F. Kosbel and F. P. Mall (Phila., 1910, v. 1).

Endoscopy (History of): Areh. f. Latryngol. 11. Rhinol., Berl., 1915, xxix, 346398 ( ( 1 . Killian).

Epidemic Diseases: (i. Sticker: "Abhandlungen" (ete.) (Ciirsen, 1904-12).

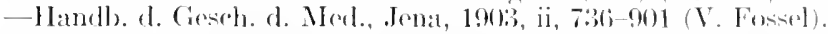

Epigraphy (Medical): J. Arata: Laartemetlen melle inserizioni latine (conoa, 1902).- R. Blanchard: Epigraphie médieale, $2 \mathrm{v}$ (Paris, 190!)-15).Janus, Anst., 1909, xiv, 4; 111 (J. Oehler, with index of names). Soee, also, the landbooks of latin epigraphy by R. Cagnat (1. od., Paris, 1914), J. ('. Erbert (New York, lsogi) and Sir .1. E. Simely (Cambridge, 1919)

Ethics (Medical): J. L. Pagel: Modieinische Dontelogio (Borlin, 1 1S97).-

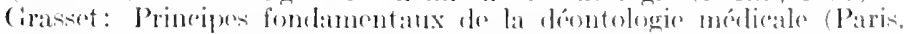

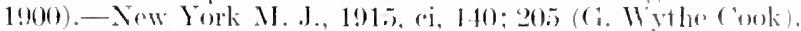

Fees (Medical): Internat. (lin., Plilia., 1910, 20. s., iv, 259-275 (J. .l. W:alsh).

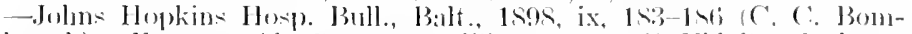

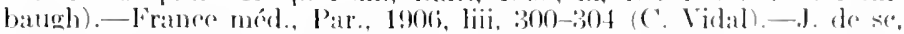

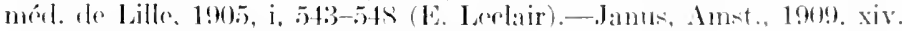
247-293 (D'.1. Power).-New York .I. .I. (ete.), 19l2, xeri, 370-373

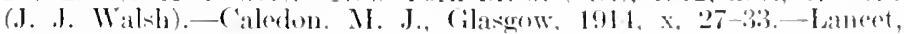
Lomil., 1915, i, 121:3.

Folk-fore (Medical): W. C. Black: "Folk-medieine" (oto.) (Lond., 1Ss:3).— A. Bouchinet: Des états primitifs do la médecine (Paris thesis No. 194, 1891).-D. Bartels, "Die Mediein der Naturvölker" (Leipzig, 1s93)._- 


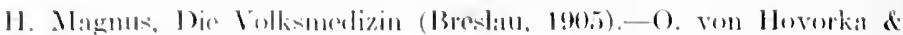

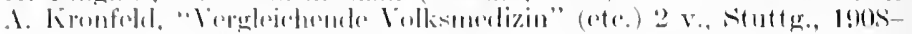

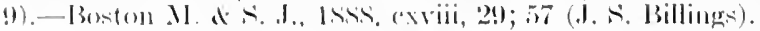

Graduation Ceremonies: Mal. I.il) d Ilist. I., Bromklyn, I!nci, iv, 1-1.1 (II. II. livil).

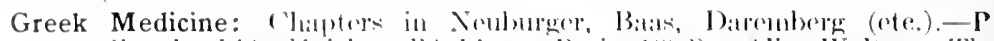

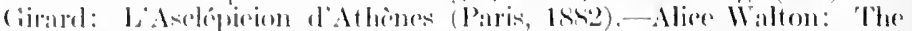

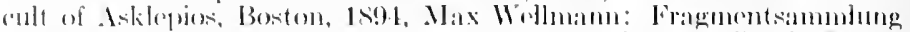

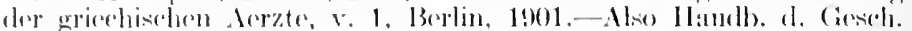

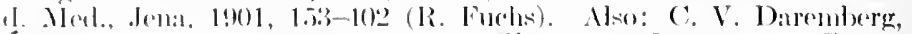

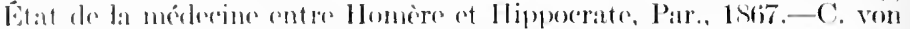

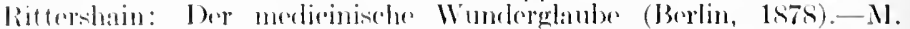

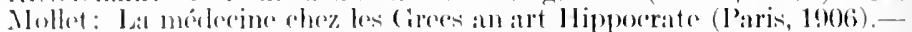

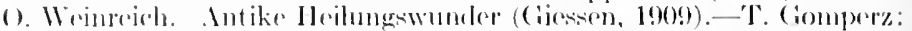

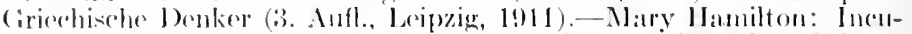

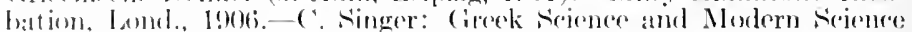
(1)xfore, 1!20).-13rit. \& lint. M.-Chir. Rov., lomel, 1ssti, xxxvii,

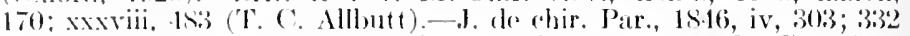

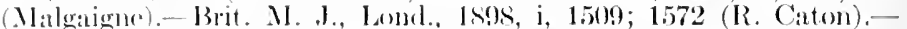

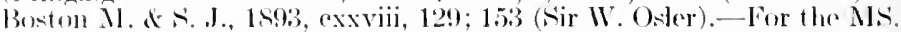
of the andent Geok molieal writers, see: 1I. Diels, Dir llandschriften der antiken Aerztr, i-ji (Abhandl. d. k. preuss. Akad. d. Wissensch., [3erl., 1905). Fere atso: Itomerio molicine.

Gynecology: Franz ron Wincket's "loberbliek" in his IIandb. 1. Goburtsh.

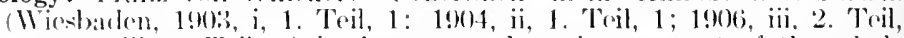
1: 1907, iii, 3. Toil, 1) is the most exhaustive areount of the whole subject. Kossulann (in the Puschmann Hamdbued, 1905, iii, 95:3-9s(3) grises a good short account. The essay by lIandfichl fomes at the begiuning of Allbutt's Fystem of Gymeeology (1906) is an exeellent flere-hatud

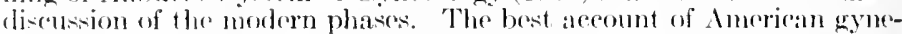
anloge is the essily hy IJoward $A$. Kelly in the introdnction to his "Cejopedia of Ameriean Meolieal Biography" (Philatelphia, W. B.

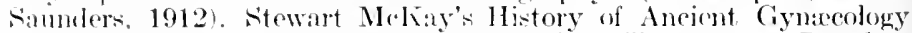
(1901), Weindley"s history of gynecologieal illustration (Dresden, 19(0), F. Seluata's Gynackologische Behandlung einst mol jot at Salzbure, 1910), and the sylabus of 1. S. Stone (Internat. Clin.. Phila., 191S, 25 . S.. ii. $266-2 \times 1)$ mav also be consulted.

Heraldry (Medical): Antiquary, Lond., 1915, n. s., xi, 415; 45.) (S. D. Clippingdillo).

Hindu Medicine: F. Trendedenburg: De votermm lndorum chirurgia (IBerdin,

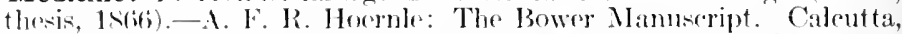
1\$93-S.-J. Jolly, Cirundrisi al. indo-arisehen Philologie 11. Alterthumskunde, strasslurg. 1901, iii, IIft. 10.-P. Cordier, Etudes sur la méderine hindome (Paris, 1s94).-Jee, A short history of Arvan medical :ronee. London, 1896.-A. F. R. Hoemle: Studies in the medicine of Incient India, I. (Oxford. 1907).-Puselimann's Handbueh, Jena, 1901, i, 119-152 (l. Bloch).-Guy's Hosp. Gaz.. Lond., 18s9. n. s., iii, $117 ; 145 ; 157$ (13. D. Basu).-Proc. Charaka Club, N. Y., 1902, j, $1-2$ (13. Sichs).

Histology: Eniv. M. Mag. Phila., 14\$\$-9. i, 82-87 (C. A. Piersol).

Homeric Medicine: C. V. Daremberg: "La módecine diass IIomèro" (Paris, 1S(i.j).-W. Froclieh: "Die Militärnedizin Homer's" (Stuttg., 1897). - (). Körner: Teber Wesen und Wert der homerjechen Heilkunde (IViesaden, 19(1)).-Paris thesis by $\mathrm{A}$. Floquet (1912)

Hospitals: Virchow: Virehow's Arch., Berl., 1S60, xviii, 135; 273; xix, 43; 1sfil, xx, 166.- Is. Sulhoff: Aus der Gesehichte des Krankenhauswesens, Jena, 1913--T. Meyey-Steineg: Jenaer med.-hist. Beitr., 1913, Hft. 9.-C. A. Mereier: Leper Houses and Medierval Hospitals, LonIron. 1915.-J. - :. Tavior on the Hotel Dien (U. S. Naval Med. Bull., Wash., 1918, xii, 653-691, 2 p.). 
Hydrotherapy: M. J. Oertel, "Gesehiehto der Wissorlecilkundo" (ote.) (Leipz.,

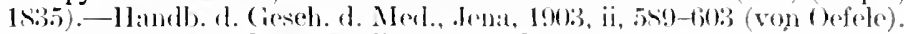
-Boston M. \&. S. J., 1906, cliv, si-!)1 (J. II. Pritll).

Hygiene (Public): 'The subject has never heren exhatustively treated. A glanee at Profesior Sindhoff's remarkible 59:3-page "atalogur of the "Ilistoriselye Abtheihuse" of the Dreselen Ilyeienic Exhibit (1911) will show

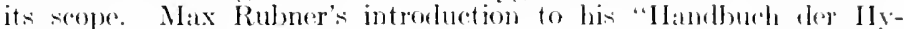

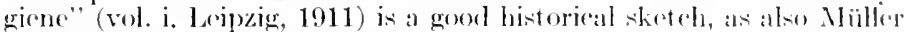
and Pramsnitz in the Puschmam Ilandbuel (1905, iii, $75.3-852)$.

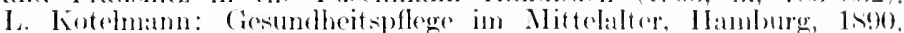

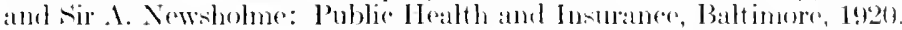

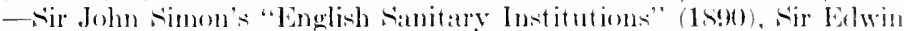

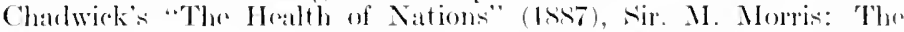
Story of British Publir Health (London, 1919), "A I History of latetory Legislation" by B. L. Hutehins and A. Itarrison (1903), and "A C'ritury of Publie llygiene in Amoricat" (1sig) are good histories of the legislative phases. For history of industrial hygiene morler modieval trade-guilds, sere Jom. Industr. Ilyg., 130ston, 1920, i, 175; 550; 57

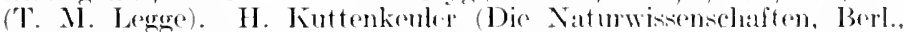
1915, iii, 50!):521) gives a good history of Gorman fool chemistry and

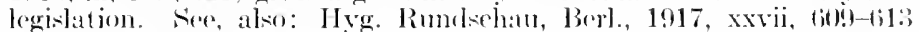
(1). Nipiegrellberg).

Hypnotism: W. Preyer: Dir Entdeckung des IJypotismus (Brorlin, 1sis ).

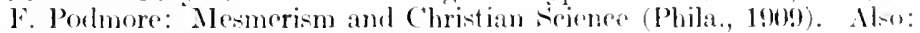
Maryland IJ. J., 1910, liii, 81-97 (II. A. Kidly).

Iatromathematics: Karl Sudhoff: Ahhandl. z. Coceh. d. Med., Broslan, 1902 , IJoft 2.-Ann. Ned. History, N. Y., 1917-1s, i, 125-140 (1\%. (". simith).

Incunabula (Study of the): R. A. Peddie's chaming manmal on "Fifterenth-

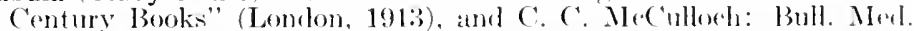
Library Ass., Jalt., 1915, v, 1-15. The arlicet work was Michael Mattaire's Armales typographici (5 vols., Ilague, Amstordam \& lonton, 1719-41). with supplement by Miehael 1)(nis (Vimna, 17s9). (: II. Panzer's Annales typographici (11 vols., Nuremberg, 1793-180:3) is the oldest chronological list by towns. Ludwig 11 ain's Reperomium (4 vols., Stuttgart, 1s:2ti-2s). with W. A. Copinger's "supploment" te the samo (3 rols. London, 1s95-1902) is the standard ratalogue, which is further supplemented by Panzer's ehromolugical Anmelen of German incounts-

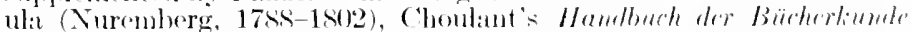

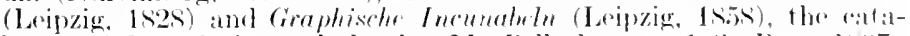

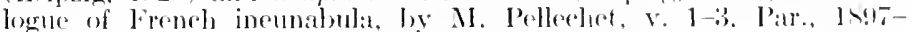

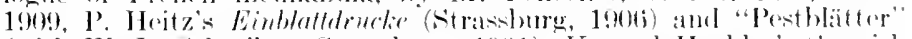

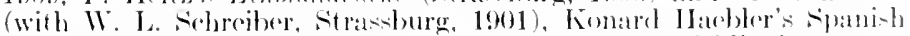

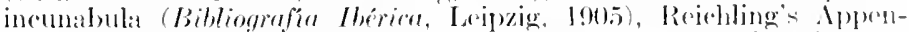

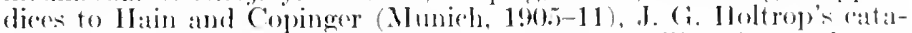

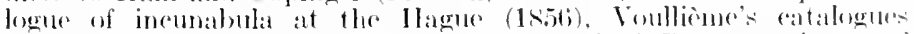
of the Borlin Inemabula (Ixipzig. 1906i) and of Corman printers of the fifternth century (1916), I. Colliju's lists of Epsala (1939) and

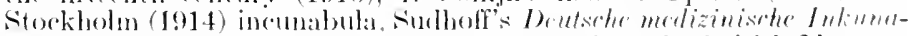

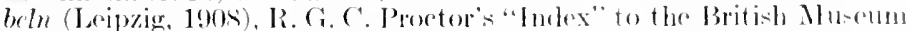

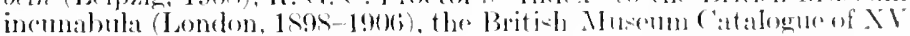

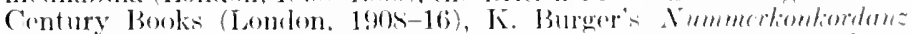

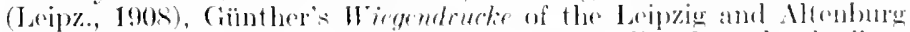

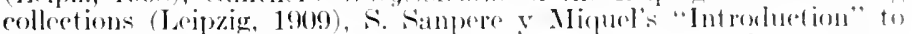

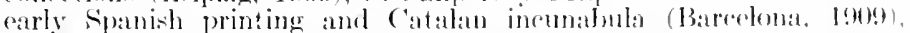

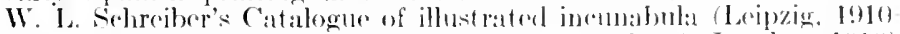

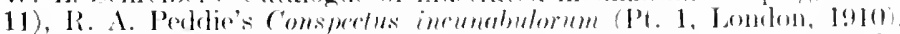

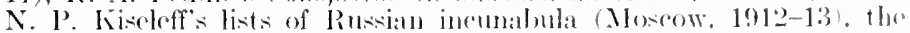
Nuchträge to Hain (1eip). 1910), publisber by the Jpuscian Kommission für den Gesamtkatalog der Wiegendrucke, which propmes to catalegue all the incumabula in existenee. Vory important is its cata- 


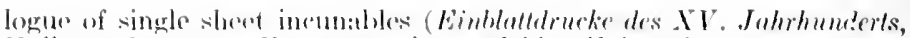
Halle a. S., 191.1. For comparing and identifying the typography of the different imprints, Komsal Il:ablar's Typenrepertorium (.1 vols., Halle, 19t)i-10) is indispensable and invaluable. 'The abovementioned mantal of Peolder (1913) contains valualshe bibliographies of initials, printers" marks, colophoms, titlo-pages, signatures and watermarks,

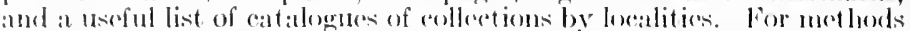

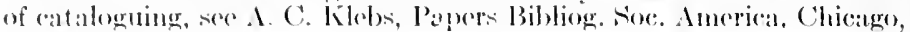
$1916, x, 143-163$.

Japanese Medicine: Y. Fujikawa's ( Beshichte der Mrulizin in Japan, Tokyo,

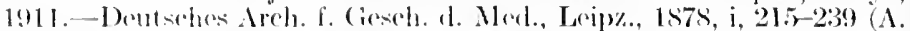
Wermich).-K. ()gaw:a: Ilistory of Japanese (Ophtbalnology (Tokyo, $1904)$

Jewish Medicine: T. Bartholinus: De morbis biblieis, Copmhagen, 1672.J. I3. Friedreich: Zur [Bibe] (Nuremberg, 1s.s')...Julius Prouss, Bibliseh-talmulisehe Medizin. Berlin, 1911.-A. Friedenwald: Jewish Physicians [ote.], Gratz. Coll. Pub., No, 1.-L. Voncoianer: Asaf Judisus, l'. 2. v. (Strassburg, 1916-17),-N. Neuburger: Die Medizin im Flavius Josephus, Roichenhall, 1919.-Joscph Jaeobs: Jewish Contributions to Civilization, Phila., 1919.-Also: C. D. Spivak and F. 'T. I Ineman in Jewish lineyel., N. Y.. 1904, viii, 409-422.-R. Meat: Medicina sacra (Lond., 1749).

Journalism (Medical): Ref. ILamb. Mel. Se. (Stedman), 3. ell, N. Y., 1915, ․ 706-712 (F. H. Garrison). -Union mél., Par., I\$67, 3. s., ii, 151; 179; 193; 229; 47t (A. Chéro:ulu).-München. meel. Wehnsehr., 1903, I, $45-163$ (K. Sulluofi).

Jurisprudence (Medical): Handlb. d. geriehtl. Med. (Maschka), Tü̈bingen, 1ssi, i, 1-:32 (V. Janowky), with bibliegraphy.

King's Evil: Monograph by Raymond Crawfurd, Oxford, 1911. Nlso: Proc. Charaka Club, N. Y., 1906, ii, 58-71 (J. S. Billings).

Laboratories (Scientific): Johns Hopkins Hosp. Bull., Balt., 1896, vit, 19-24 (W. H. Weleh).

Laryngology and Rhinology (History of): Jonathan Wright's "History of Laryngology ant Rhinology" (2. el., Phila., 1914) is the best account in English, a very valuable and aecurate work. The history by (iordon Holmes (Med. Pross \& Cire., London, 18s,i) was translated into French and German (1SS7). Paul Hevmann's monographs in Handbuch d. Laryngol. und Rhinol., Vienna, 1896, and in the Puschmann IIandbueh (1905. .iii, 573-600) are worthy of note. For history of laryngoseopy, sere Verneuil (Caz. hebl. de méd., Paris, 1863, x, 201-20i) and Louis Elsberg (Phila. Mecl. Times., 157:3-1, iv, 129-134), who hats also left the best aceount of laryngology in America (Tr. Am. Larrngol. Ass, 1879, st. Louis, 18\$2, i, 33-90. Chanveau's "Histoire des malarlies du pharynx" (1901-6) is an exhaustive work in five volumes. The history of rhinology by Karl Kassel (Würzb., 1914- ) is a recent and reliable work.

Libraries (Medical) : Ref. Handb. Med. Sc. (Stedman), 3. ed., N. Y., 1915, v, 9)1-910 (F. II. Garrison).-E. Edwards: Memoirs of Libraries, 2 v., Lonton, 1S59.-.J. W. Clark: The Care of Books, Cambridge, 1909, -J. W. Farlow: History of the Boston Merlieal Library, Norwood, Jass., 191s.-Bull. M. Lilorary Ass., Balt., 1918, viii, 41-50 (J. Ruhräh).

Magnetism: Deutiches Arch. f. Gesch. 1. Med., Leipz., 1878, i, 320; 381 (W. Waldmann).

Manuscripts (Medical): Daremberg: Notices et extraets (Paris, 1853).Areh. f. Gesch. d. Med., Leipz. 1908-9, ii, 1; 38.5 (P. Pansier)._Ibid., 1909-10, iii, 273-303 (Surlhoff).-II. Diels: Alhandl. d. k. preuss. Akart. d. Wissensch., Berl., 1905.

Massage: Hanılb. d. Geseh. 1. Med., Jena, 19103-5, iii, 327-340 (L. Ewer). 
Mechanotherapy: Jamus, Amst., 1914, xix, 178-240 (R. J. Cyriax).

Medieval Medicine: G. F. Fort: Medical Eeomomy During the Middle Ages,

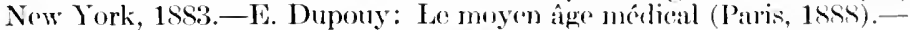
sij. T. C. Allbutt: "Seience and Medieval "Thought" (Jomd., 190)1); his "Historical Relations of Medicine and fiurgery" (ete) (lombl., 190)i); H. M. Ferrari da Grado: Une chaire de médecine au XVe siende (l'aris thesis No. 3:33, 1899) and Allbutt's aecount of the same in Med. Chron., Manchester, 19(0)3, 4. s., v, 1-15.--J. J. Walsh: "The Popes in sirienee"

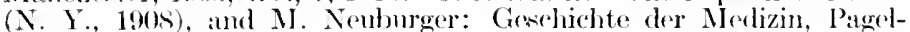
Sindhoff, Berlin, 1915, 152-195, also: Proe. Roy. Sioe. Med., Lomil., 1916-17, x, soct. Hist. Med., 107-160, and numbers eontributions of sudluoff in his Archive für Geschichte dor Medizin, Laipzig, 1907-20, pasizim.

Mexacan Medicine: F. A. Flojes: Historia de la medicina en Mexieo (:; vols., Iexieo, 18s(i-8).-Wien, med. Presse, 1905, xlvi, 1s97-1905 (11. Neuburger).-Crac. med. de Mexico (1915), 1916, x, 3; 46ti (1916), $191 \mathrm{~s}, \mathrm{xi}, 210(\mathrm{X}$. Leon).

Microscopy (Medical): Jroe. Roy. Soe. Med., Lond., 1914-15, vii, Sind. Hist. Med., 247-279 (C. Ninger).-J. Roy. Mier. Soc., Lonil., 1915, 317-340 (C. Singer).

Military Medicine: The prolegomena to Hermann Frölich's "Militärmedicin" (Brunswick, 18\$7) constitnte the authoritative souree for bibliographical refereness up to 1s\$7, and his many essays on the subject should be collected, bound and read. Gurlt's history of international and voluntary muring in wastime (1873-9), his history of military surerery in Prussia (1575), and the military portions of his history of surecry (189s) are very important, as also J. S. Billings' reports on the Amprican Army hospitals and posts (Cireulars No. 4 and $8,1870-75)$, the Medieal and surgical History of the llar of the Rebellion (1870-8S), Virchow's review of the progress of military medieine (1874), A. A. Woodlull's report upon the medical department of the British Army (1s:4), A. von Coler's history of military surerery (1901) and the modieal histories of the Revolutionary, Mexiean and Civil Wars by Lours (C. Duncan. The transportation and surgieal treatment of the womblert has been exhaustively handled by Cabanes in "Chirurgiens of blescés à travers l'histoire" (Paris, 191\$), with many historje illustrations. For medieo-military arministration during the sixtenth to rightrenth centuries, see: Ann. Med. IJistory, N. Y.. 1917-18, i, 281-300 (C. J. Heizmann). For bibliographies of eampaigns by title, sop lndex Catalogue, viii, $1055-1072$ and 2. s., x, 500-517; also the biblionraphies of surery (Military).

Numismatics (Medical): J. C. IV. Moehsen: Beschrejbung riner Berlinischen

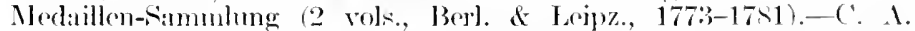
Roudolphi: Index nmmismatmo (Borl., 1823, with the ememditions of C. I. von Duisbere, 1Sfi2-S).-H. Khtryskens: Des hommes rólibres fete.] (2 vols., (iand, 15.5!).-E. Rüppell in Numismat. Katsetur., Mirn.,

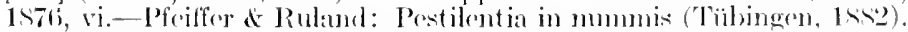
-H. R. Storej in Am. J. Numismaties, Boston, 1sit-1912. pasim.-

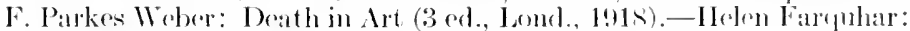
Royal Chatrities, lond., 1919.

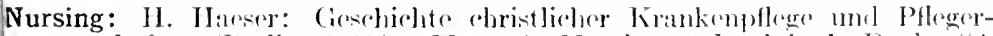
schaften (Brrlin, 1Siz).-Mary A. Nutting \& Lavinja l. Doek: "A llistery of Numing" (4 v., N. Y., 1907-12).-Arell. f. Ciscol. 11. Medl., Lrip\%., 1914-15, viii, 147-16.1 (K. Bass).

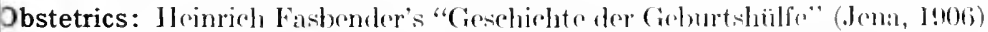
is one of those extraordinarily exhaustive and acourate monowraphs suld as only a German scholar cotild turn out, of('apying $102 \mathrm{~s}$ pages of closely woven narrative, with full bibliographir data. It is the most valuable reference work. Siebold's Geschirchte (2. Aufl., 'Tïbingen, 19)()1-2), wjth the supplements on the moderu period by Rudolf Dohrn (1903) and on 
American obstetries hy ,I. Whitridge Willians, is the most readable Nlax Wegsederider's monograph in the Puschmann llandbuch (1905,

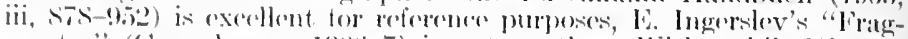

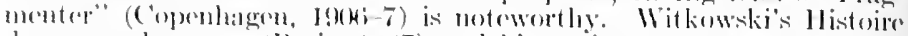

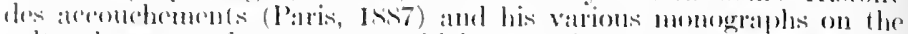

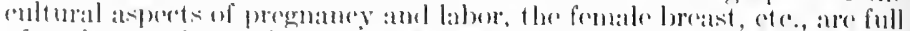
of corious and anmsing facts. A notable contribution on the graphic side is Folier La Torres "lintero attraverso i secoli (Citstello, 1917), which is replete with port raits, reproductions of title-pages and plates from the eartior works and Mlst., including all known pietures of re-

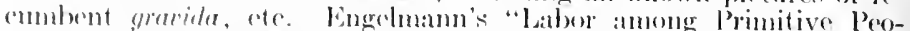
Hes" (st. Lomis, Istre) is an antloropological classice, and his historical

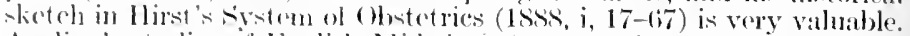
Areling's stutien of English Mirlwives (1872) and of the Chambertens (1s.2). lngersloy on Röslin's Rosegarten (1902), sinelair's life of

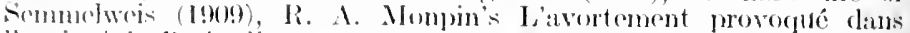
l'antiguite (I'alis dis's. 111, I91S), and WV. II. Allport's sturly of the

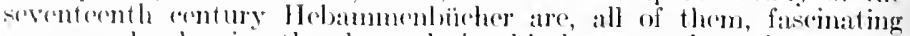
monographs showing the (dose redationship between obstetries and the cultural history of mankind. The history of ebstetries in Mexico has beren ably and exhaustively treaterl in the volume of Nicolas Leon (Anexico, 1910), with mamy unicgue illustrations.

Ophthalmology: Julius Ilirschberg's (icschichte der Augenheilkunde in the new celition of the Cirarfe-tacuisch Handburch, passim, will, when completed. be the anthoritative work for rearling and reference. It is a wonderful monument of Coman thoroughness. The shorter histories of Angust IIirsch (Cracfo-sacmisch Handbuch, 1st ed., 1877, vii, 235jist), Pansier (in the Lagrange \& Valude Encyclopedie, 1903, i, 1-86), Horstmann (Puschmann's Haudbuch d. Geseh. d. Med., 1905, iii, $489-5,2)$ and (in English) that of $T$. H. Shastid in Am. Encyel. \& Dict. Ophth. (Wood), Chicago, 1917, xi, S524-8904, with supplement by Elward Jackson in the literature, Ibid., \$905-\$925, are also valuable. special studies of worth are H. Magnus on the history of cataract (Lejpzig, 1s76) and aneient ophthalmology (Breslan, 1901), Victor Deneffe on the (allo-Roman oculists (Antwerp, 1896), Pansier (1901), Emil Bock (1903), and K. K. Lund gaard (Copenhagen, 1913) on the history of spectacles, Mortimer Frank on representative ophthalmic surgeons (Wood's system of Ophth. (Operat., Chicago, 1911, i, 17-4I), 13. Laufer on optical lenses (Leiden, 1915), and Alvin A. Hubbell on "The Development of (Ophthahmology in America" (Chicago, 1908). Sure also: Japanose Medieine; Spectacles.

Opotherapy: Arch. f. Cesch. d. Med., Leipz., 1910-11, iv, 138-156 (H. schelenz).

Orthopedics: J. K. Young: Manual and Atlas of Orthopedie Surgery, Phila., 190.5, 1-14. Nir A. Keith: Menders of the Mamed, London, 1919.

Otology: Adam Politzer's Geschichte der Ohrenheilkunde (v. i, Stuttgart, F. Enke, 1907-13), now completed, is the authoritative and standard work. Xichael sachs in Puschmann's Handbuch (1905, iii, 464-488) grives a good shorter account.

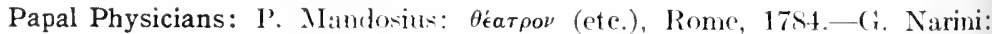
Degli arehiatri pontifici, $2 \mathrm{v}$. Rome, 178t. For history of the Papal physicians at Avignon (1305-1403), see Janus, Amst., 1909, xiv, 405434 (P. Pansier).

Parasitology: Arch. de parasitol., Par.. 1908, xiii, 251; 1913, xv, 543 (L. Moulé).-Handb. d. Gesch. d. Med.. Jena, 1903, ii, 64\$-665' (H. Vierorlt ). - Paris thesis by H. Rémignard (1902).

Pathology: The best modern history is that of Hans Chiari in Puschmann's Handbueh (1903, ii, 473-559). Earlier sketches, as cited by Chiari, were given by Morgagni (1761), Rayer (Paris thesis, 1815), Cruveillier (Ann. de l'anat. et physiol. path., Paris, 1S46, i), Eugene Boeckel (N. 
diet. de méd. ot de chir. prat. Paris, 1S6ij, ii), and Rudelf Virchow ("Hundert .Jahre Pathologie," Berlin, 1s9.5).

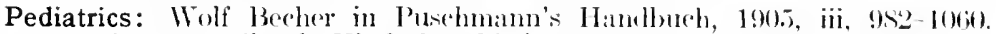
Also: Handl). d. Kinderkrankheiten (Cerhardt), 'Yïbing('n, 1s77, i, 1-50 (C. Homnig). - Syst. Proliat. (Abt.), Philil. 1921 (F. 11. (

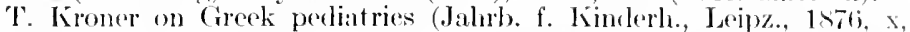
$340 ; 1877$, xi, 83; 2:36).-J. W. Troitzky: Ihippoerates als Kimlorar (Areh. f. Kinderh., Stuttg., 1900, xxix, 25-247). Cister Mary Rosallia: The Nurse in Greek Life, Boston, 1917.-The adelesss of Abraham Jaeobi (Am. Med., Phila., 1904, viii, 795-805) and his history of American pediatrics in Areh. f. Kinderh., Stuttg., 1913 (BagrinklFestschrift), $413-426$.

Percussion and Auscultation: IIandb. 1. Geseh. d. Med., Jena, 1903. ii, (i0)1 611 (H. Vierorelt).-Areh. [. Gesch. dl. Med., Leipz., 1907-s, i, 32!): 403 (B. Noltenius).-Ibid., 1910-11, iv, 43-78 (E. Ebstein).

Persian Medicine: A. M. Fonahn: "Zar Quellenkunde der persisehen Merlizin" (Leiptig, 1910).-Ann. Med. History, N. Y., 1919-20, ii, S-l:' (II. A. Jayne).

Pest: (i. Nticker: Dic Pest (Giessen, 1908, 1. Thr, 1-478).-I. A. Gaspun: The. Black Death, 1893.

Pharmacy: Hermann Sehelenz's Gesebichte der Pharmacie (Berlin, 1904) and A. C. Wootton's "Chronicles of Pharmacy" (Lomlon, 1910) are the best works for reading and referenes. Adrien Philipge's "Histoire de. apothicairs" (Paris, 185:3), enlarged and translatel into Cieman by Hermann Lubwig (2. Aufl., Jena, 1859) is an earlier work, of soliil claracter, on the history of druggists. Herman Poters" "Aus pharmazentischer Vorzeit in Bild und Wort" (2 vols., Berlin, 1ss9-91) take. up the eulturil side of the subject, with many interesting pietures. The fragment of J. Berencles (1s9S), his translation of Diosererides and thr Histoire te la pharmacio of L. André-Pointier (Paris, 1900) may bo consulted. An exeellent bistory of Ameriean phamaey by Edward Kremers has recently appeared in Am. Druggist, N. Y.. 1920, hriii. No. 3, 9; No. 4, 9; No. 5, 13. The sturties by David I. Maleht in Bull. Johns Hopkins Hosp.. Balt. See, also, Drugs.

Physiology: The most readable work on this subjoct in English is Fir Micharl Foster's "Lectures on the Mistory of Physiology" sixterenth to eighternth centuries, Cambridge, 1901), whieh is based ipon original researeb amel full of atmosplere and eohor. .Tohn Call Dalton's "Doctrinesof the ("irculation" (Philadelphia, 1SS4), Milliam Mareet's "History of Respirattion in Man" (Lomelon, 1s!97), Max Neuburger on the development of experimental physiology of the brain and spinal cord before the time of Flourens (Stuttgart, 1\$97), and William Stirling's "Somo Apostles of Physiology" (London, 19t2) are works of a similar chinaleter. Fitirling's work is a beautiful folio, fillerl with fine pietures of the great masters. and, like Foster's book, insingerl with enthusiasm. Moinrieh Boruttal's "Cieschichte" (Pusehmamn's Handbuch, 1903, ii, 327-156) and Joln C. Cardwell's "Development of Animal Physology" (Meal. Library d Histor. Jomr., New York, 1904-6, ii-iv, pressim) may be consulted for the whole subject in its bibliogralphical relations, fore, also, Nature, Lond., 1S96, liv, 580; 600: 1897, lvi, 43;) (Fir M. Fostor).

Poets (Medical): T'. Bartholinus: Do melieis poetis. ('openhagen, 16ti9.Janus, Bresl., 1\&17, ii, 772-812 (O. Scidensehmur). Diet. enevel. d. se. méd. (1)echimbre), Par., 1577, 2. s., v, 715-727 (1. Chóprail).C. L. Dana: Poctry and the Doetors, Woolstock, Vt., 191s.-Ann. Med. I Tistory, N. Y., 1919-20, ii, 213-227 (.J. Foot( ).

Prognosis: Wien. med. Presse. 1907, xlvizi, 1-7 (M1. Neuburger).-Areh. f. Geseh. 1. Naturw., vi, 163-17S (T. Meyer-stcineg).

Psychiatry: The subject has been almost entirely in the hamls of Girman writers. Heinrich Lachr, fo begin with, has madr a conplete history of psychiatry in the form of a calenclar, now in its fourth reition (13erlin, 
1593), ame is the anthor of an unsurpassable bibliography of the literature of psychiat ry, nourology and peychology from 1459 to 1799 (Berlin, 1900). i. B. Friedreich published : h history in 1830 which is being

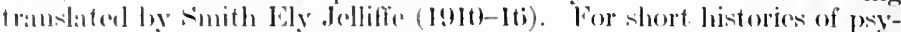

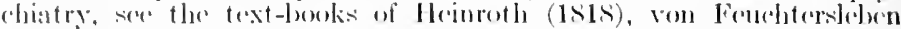

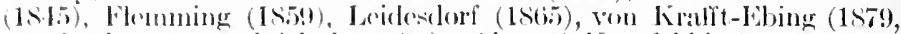

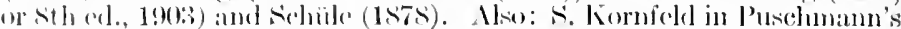
Ifandbuch (19)5, iii, bet-72s) and Th. Kirehhoff on the history of (icman perchistry (Borlin, 1s!90). - Otto Nönkemöller's history of

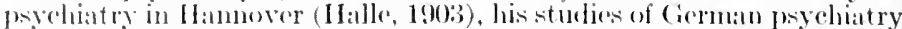
in the righterenth (1902) and early nincterenth centuries (1905), and his book on the sitirieal and humorous aspects of the subject (1906) are of great rulturat value. Sien, also, li. Kratepelin: Ilumert Jahre Psychistrir Ztsehr. f. d. ges. Neurol., Berl., 1917-1s, xxxviii, 161-275.

Psychoanalysis: ‥ Freull: History (Norv. \& Ment. Dis, Monogr. Ser., No. 2.). $\mathrm{N}$ (w) York, 1916.

Quackery: H. Magnus: "Dis Kurpfuscherthum" (ete.) (Breslan, 1903).Brit. M. J., Loml., 1911, i, 12.50-12(i3.).

Quarantine: Johns llopkins Hosp. Bull., Balt., 1914, xxv, s0-st; (W. W. Fordi.

Roman Medicine: A. M. Birkholz: Ciecro molieus (Leipzig, 1806).—- R. Ritter von Rittershain: Die Heilkünst]er des alten Ronss (Berlin, 1875).Th. Meyer: (ieschichte des römischen Arrztestandes (Kiel, 1907).llanib. d. (ieseh. d. Mod. (Pusehmamo, dena, 1901-2, i, 403-414 (1. Bloch).-Brit. Ned. Jour.. Lond., 1909, ii, 1149; 1515; 1595 (Nir T. C. Allbut t).-Prosper Menière (185s) and Erlmond Dupouy (1885) on medieine in the Latin poets.-N. Meyer: Theodorus Priseimus, Jena, 1909._-W. Schönack: Seribonius Largus, Jena, 1912._A. sölner: Vitruvius (Jena med.-hist. Beitr., 1913, Heft 4).

Russian Medicine: W. M. ron Riehter: Geschichte der Mediein in Russland, 3 v., Moccow, 1813-17.-Jamus, Amst., 1901, vi, 130; 175: 1906, xi, 314: 1912, xvii, 4S. (F. Hermann).-Ibid., 1902, vii, 352; 404; 568 ; 63.) (1. Lachtin).-Lancet, Lond., 1897, ii, 343-374.

Saints (Medical): L. Deubner: Losmas und Damian (Leipzig \& Berlin, 1907). -Bristol M.-Chir. J., 1912, xxx, 289-294 (R. Fletcher).

Salerno (School of): Collectio Salernitana (S. De Renzi), 5 v., Naples, $1852-$ 9.-P. Giacosil. Magistri Salernitani (ete.), Turin, 1901.-H. E. Handerson: The sehool of Silernum, N. Y., 1S\$3.-Med. Chron., Man(hester. 19(4-4), 4. s. viii, 67-93, 1 pl. (IV. Stirling). Arch. f. Geseh. 1. Mel.. Lripz., 1913-14, vii, 360; 1914-15, viii, 292; 352: 1915-16, ix, 221: 1916-17, x, 91: 1919-20, xii, 149 (K. Suchoff).

Scandinavian Medicine: Janus, Amst., 1907, xii, 665: 1909, 72 passim (F. (irön)._- Latache: Norsk Medicin $\mathrm{i}$ hundrede Aar (Kri-tiania, 1911).

Schematic Eye: Janu<. Amst. 1909, xiv, 135-456 (E. Pergens).

Science: Riulolf Eislor: "Gesehichte der Wiscenschatten" (Leipz., 1906).F. Dimnemann: Die Naturwissenschaften, 2 v., Leipzig, 1910.Stulies in the History and Methor of Seience, ed. C. Singer, Oxford, 1917 . - Nko, the briefor histories of $\mathrm{W}$. T. Seedgwiek \& $\mathrm{H}$. W. Tyler (Boston, 1917).-Biblingraphy by Aksel Josephson (John Crerar Library. ('hicatgo, 1911).

Shakespeare (Medicine in): J. C. Bucknill: The Medical Knowledge of Shakepeare (Lombon, 1860).-T. E. Thiselton-Dyer: Folk-lore of Shakespeare (London, 1853).-.J. Moyes: "Merlieine \& Kindred Arts" (etc.) (Cilasgow, 1896).—Cinada Laneet, Toronto, 1919, lii, 546-574 (Nir it. Clair Thomson).

Spectacles: D. M. Manni: Degli ocehiali da naso [etc.], Florence, 1738.P. Pansier: "Histoire des lunettes" (Paris, 1901).-E. Bock: "Die Brille und ihre Geschichte" (Wien, 1903).-Ber. ï. d. Versamml. d. ophth. Gescllsch., 1912, Wiesb., 1913, xxxix, 419-451 (R. Greeff).- 
Ztschr. f. ophtal. Optik, Berl., 191:3-14, i, 16: 1916, iv, 142: 1917, v, 42;6.5: 191s, vi, 1; 36; 97 (R. Cireoff). Ibid., 1917, v, 1; 33; 7s (ii. von liohr).

Surgery: For prehistoric surgery the essays of H. Tilmanns (1883), R. Lehmann-Nitsche (1896-S), (․ Buschan (1902), and K. Jüger (1907). Rohert Fletcher on prehistorie trephining (Washington, 18s2) and Lueas-Champiomnière: Les origines fo la trépanation (l'aris, 1912).Up to the end of the sisteenth century Gurlt's Geschichte der ('hirmege (189S) and Malgaigne's Histoire de chirurgie (1S10) are the atuthoritative somrees, the former mrivalled for aecuracy, and containing many interesting plates of surgical instruments. Sce also, lriedrieh Helfreich in Puschmann's Handt)uch (v. iii, 1-306), a valuable souree of reference. Karl Sudhoff's splendid volumes on medieval surgery (Stud. z. Ciesels. d. Med. (Puschmann Stiftung), Leipz., 1914-18, IJelt 10-12) open up a vast anount of new material on horoseopic surgery, unprinterl texts of the older writers, history of instrumentation, ete., with many wonderful pictures from the MSs. Kurt Sprenged's "Cieschichte" (Halle, 1805-19) gives histories of the different operations. (ieorge J. Fisher's essay (Internat. Encyel. Surg. (Ashburst), N. Y., 18sti, vi, 1146-1202) gives a very aceurite and full account of the earlier writers up to the eighteenth century. The best history of the whole subject of surgery in English is that of John S. Billings, forming the introductory chapter to Dennis's System of Surgery (New York, 1895, i, 1-144). It is not only wonderfully aceurate in respect of facts and dates, but imbued with a genumely critical spirit. In the same class are Sir William Fergusson "s "Lectures" of 1s67, and the important monograph of Sir Clifford Allbutt on "The Historical Relations of Medicine and surgery to the End of the Sixteenth Century," the best history of medieval surgery in English. See also Zeis's history of plastie surgery (Leipzig, 1S63), (ieorge Fischer on the eultural aspects of righteenth century surgery (Chirurgie vor 100 .Jahren, is76, and transated into English by Carl 11. von Klein in J. Am. M. Ass., Chicago, 1s97, xxvii, 30S-1S9s, xxx, 211, passim. J. S. Milne (Oxforl, 1897) and Th. Meyersteineg (Jena, 1912) on surgical instrments, and the excellent article by Charles Creighton in Eneycl. Britan., 11 ed., Cambridere, 1911, xixi, 125-129. English surgery is ably specialized in Jolm lint south's Memorials of the Craft of surgery in England (1siti), sidney Young's Annals of the Barber-surgeons of London (1s,o(o), and the interesting monographs of D'Arey Power. Ge'man surgery may b" studied in Rolılfs" "Die chirurgisehen Klassiker Dentsehlanels" (Leipzig, 18s:3-5), in Cieorg Fischer (1876), H. Tilmamn's "Ilunetert Jahre Chirmeie" (1S9s) and Ermst Breker's rssay on old-time llildesheimer surgeons (1902). American surgery up to 1876 is rxhaustivaly treated by samual D. Gross in Am. Jomr. Mled. Sie., Phili., 1九7 6 , n. s., lxxi, 431-484. The essays of James Evelyn Pilcher (Jour. An. Med. Asioc. 1890, siv, stupul. No. 1s, 629-636i) and Frederick s. Demnis (Mod. Ree., N. Y., 1902, xlii, 6.37-64s) arre also valuable for leferenes.

Symbolism (Medical): 'T. s.. Sozinskey: Modical Symbolism (I'lil:t., 1S91).H. Bayley: The Lost Language of Symbolism, 22 vols. (1ond., 1912).

Technics: 1'. M. leldhaus: Die Technik der Vorzeit (Leipz. \& Borl., 1914).L. Darmitadeder: Handbuch zur Geschiehte der Naturwisenseluaften (130r., 19008).

Test-types: Janus, Amst., 1905, x, 419; 1906, xi, 360 (li. Pergens).

Therapeutics: R. Ifipine: La thérapenticue sols les preniers ('óstrs (Paris,

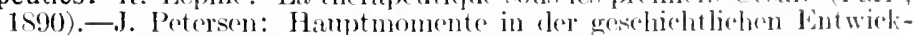
hung der modicinisehen Therapio (Kopenhagen, 1577).-1\%. J. IVaring: Bibliotheca therapentica (Londom, 1s7s).-Ch. Fiessinger: Ial therapeutique des viens mâ̂tres (laris, 1s!97)

Theriac: Janus, Amst., 1911, xvi, 371;457 (C. E. Daniöls).-John- Ilopkins Hosp. Bull., Balt., 1915), xxvi, 222-226 (C. W. Corner).-Bull. Soc. d'hist. de pharm., Par., mars, 1920 (E. Wickersheinen), 
Thermometry: 11. C. Bolton: "Lvolution of the thermometer" (Waston, Pa.,

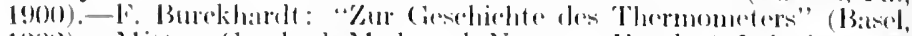

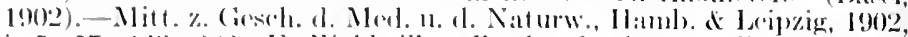

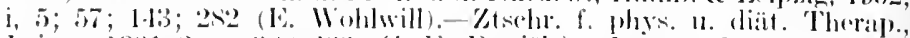

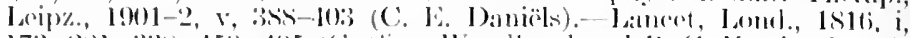

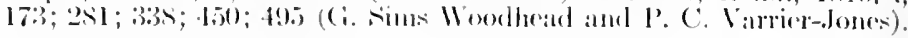

Theurgic Therapy: Acl. Irmm: Dir kirehlichen Benodiktionm in Mittolalter, 2 v. (Frilourir i. B., 1909)

Thibetan Medicine: 11. Laufer: "Bowträgu zui Kenntnis der tiletichen Medirin" (Loip\%, 1900).

Transfusion: (i. W. Crile, Heruserhage and Tramsfusion, N. Y., 1909, 151-158. Tuberculosis: A. l'redöhl: Zur (ieschichte der Tuborkulowe (IIamburg, 1siss). Urology (History of): The monograph by E. Desnos in Enevel. franc. d'urol., Parr., 1911, i, 1-291, distances every other publication on this theme. It is very exhatustive and its many interesting illustrations include rare illuminated pictures from old MS. never betore reprodueed. Sere, also:

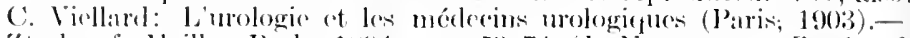

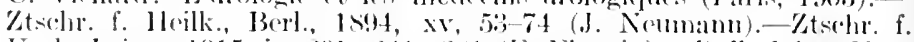

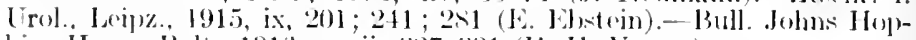

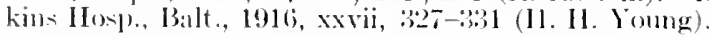

Variolation: Jolms llopkins Jlosp. Bull, Balt., 19)13, xxiv, (j9-83 (A. C.

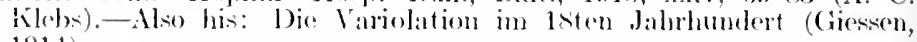
191.1).

Veterinary Medicine: L. Moulé: Histoiro de la médecine vétérinaire, Paris, 1591-1911.-11. Neffgen: Das Veterinär-l'atyrus von Kahun, Berl., 1901.-C. 1" lyman: "A history of veterinary medicine" (ete.) (Cambridge, Mass., 1s9s).-Bull, Soe eentt. do méd. vét., Par., 1s9o, 7. s., vii, 519, passim. Sir F. Smith: The early history of veterinary literiture, v. 1. [to 1700], Lonil., 1919.

Witchcraft: J. Weyer: Histoires, disputes ot discours, 2 v., Paris, 1885.Fare de mérl. de Par., Confér. histor., $1866,383-443$ (Axonfelil).-Areh. Nomrol. \& Psychiat., Chicago, 1920. iii, 40.5-404 (C. A. Potts).

Women in Medicine: H. Sehelenz: "Frauen im Resehe Aeskulaps, Lripz,, 1900.-MI. Lipinski: Hixteire des femmes médecins, Paris diss., 1900.

Zoölogy: Bibliography of Zoölogy by J. V. Carus and W. Engelmann (Leipzig, 1s61). $-V$. Carus: Cieselichte der Zoologie, lsis. 


\section{INDEX OF PERSONAL NAMES}

[Entries in heave type refer to hiograplical data.]

1.1ROS, 119

Abbé, Ernst, 425

lbbe, Robert, 6.17, 697, 762

Sbbott, Edville G., T5ti

Nbott, Maude E., 45.5, 658, $78: 3$

Holerhalden, Emil, 611, 729, 737-738, เง!

Abdollat if, 121

- Ibel, Tohn Jacol, 25, 707, 790,

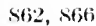

Mbel, Niels I1., stof

Abelous, I.-Emile, 732

Abernethy, .John, 356-357

Abt, Isaar Arthur, fist

Abu Mansur, 123

A(hillini, Alessandro, 209

Aekermann, J. C. G., 385

Arland, Sir Henry W., s69

Arolutlus, 276

l'Acosta, Jose, 201

Arosta, Iricl, $2 \mathrm{so}$

Mrlanictz, Frü, 514

Arlani, John George, 603-604

di Alamo, Teofania, 298

Arlans, Franeis, 92, 102, 113 , 715, stit;

Alans, Jaum: Mexander, 650)

Arams, Robert, Jiso

Arlams, sianuel shuecrt, bsfi, tiss

Arlinson, Micharel, 316

Addison, fir ('hristopher, 7!t9

Adlison, Tluomits, 137,442

$443,446,617,706,732,780$

Fochlus, 91

Sinlapius, 76-77, 92

Actius of Amida, 98, 112

Afanissyeff, M., 670;

Agassiz, Alexander, jog

Agasiz, Iouis, 473474

Arathinus, clauclius, 9s

Aplietti, $\mathrm{H}, \ldots, 3 \mathrm{si}$

Annews, cormalius Ro:a, f; $;$ il

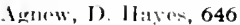

Annivira, $6 ; 3$

Agramont:, Aristides, 751,767

Agricola, Gorger, 23s

Airy, sir George, tiss

Aitur, William, 115
Alamson, Fidward, 518

Alharran, Joaquin, 641, (is!)

Albee, Fred II., Tist

Alberti, Miehael, 3st

Albertotti, Giuseppe, 717

Abrrtus Magnus, 156

Albinus, Bernhard Sirefried, $327,335,339,342-343,415$

Albrecht, H., 711

Alburasis, 1 I3, 121-122

Alcmieon, 83

Alderotti, Taddeo, 153, 158

Aldrovandi, Llisse, 223

Alexander Trallianus, 113, 122

Alexander, William, 650

Alibert, Jcan-Jouis, 290, 437

Alllutt, Sir Thomas Clifford, $4 ., 87,96,98,103,111$, $132,133,142,160,163$, $223,227,267,319,320,363$, $385,512,650,681-682,699$, $715,723,778,757,895,899$

Allen, Frederiok $\mathrm{Ml}, 595$

Allon, llarrison, 789

Allicon, Nathaniel, s14

Alpino, Prospero, 201

Alzheimer, Alois, 702

Ambard, I..-1., 689

Amnann, Joliann Conrad, 279,376

von Ammon, Friestrich duglist, tisf

Inaxigoras, 80

Inaximandrer, 80

Anavinuenes, 80

Andorloni, fantino, $34: 3$

Anders, Jame's .11., 6sis

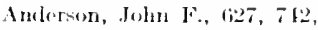
7.50

Anclison, Patrick, 2!1

Anclerson, Thomati MaCall, 131

Andral, Giabriel, 434-435

Ancles, Nicholas, 349, 35:3

Androu del sarto, 240, $31: 3$

Andreas, Johann Valentin, 2,

Inelrews, John B., 71 1, 7!!

Invl, Iominiqua, 112, 349

Angle, libin Hartley, 663

Anguillara, Juigi, 226
Anrep, V. K., 70s

Anson, Lord, 375

Anthimus, 135

Antommareli, Franceses, 338

Antonius, Musa, 107

Antony, Milton, 5.3S

Antyllus, 100, 105, I I I

Apáthy, si, $50 ;$

Apollo, 75

Apollolorus of Alexandria, 9.5

Apollonius of Kitium, 114

Apostoli, Georges, 6.51, 705

Araki, T., 767

Aran, Francois-Amilcar, ti9l

Arbuthnot, John, 396, 405

A reeo, Francisco, 222

Arehagathus, 97

Arehigenes, 98, 100, 101, 112

Archimathan1s, 139, 1fit

Areolani, Giovanni, 149

Irderne, John, 148-149, 174, 231

Arotapls, 26;, 98, 101-102, 112

d'Argelata, Jicro, 148

Aristophanes, 76, si3, st, 52

Aristotle, 51, ti5, 93, 10.5, 132, 244

voa Arlt, Carl ferdinamd, 6ist, 714

d'Armatu, Salvino, 177-178

Armstrong, (itorge, 3451, 117

Arnold, Mattlu(w, s), 90, 130 , 395

Arnold of Villamo: $1,120,139$, 154, Iti

Arrhenius, svante, 37

('Arsenval, Jiropues-Armine, Tos

Arthur, Thomals, 245

Irtmann, I., 711

Axrhoff, Jatulig, fils

Asclepiitles, 97-98, 100,103 , Iis

Iarlli, (itsibatro, 246

Ashburn, Ierey . W., $75: 3$

1-hford, 13:ail'y K., 741, 74:

A.hling, Lord, Ty!n

Istrut, Jean, 314

At hanassio-lseninty, . H me, $\$ 13$ 
Allumans of Mttalia, as

Athinson, Jimas, sis

Atkinsm, Willian Biddle, 717

. Mtere, John 1..,513

Atlew, Washingt on 1 .., .713, 514

Atreyn, ti3

Atwater, Willur Olin, 545

Aubrey, boln, 215

Anenbrugger, lapolel, 362363,1333

Atur, John, 707, 75t)

Auerlatel, lapolel, 5ist)

Aulus Cellius, 107

Austrius, Sebatstianus, 201

Auvert, Al'xamker, tils

Avemzoar, 122

Averill, Charles, 521

Averrois, 122-123

Avery, Oswald Theodore, 813

Avicenna, $88,120-121,149,731$

Axenfeld, Theodor, 660-661

Ayres, Manisl, 539, 511

BaAs, domann IJerman, $91,163,199,233,241,24 \mathrm{~s}$, $274,2 \times 3,2 \times 5,295,296,303$, $320,357,400,407,408,410$,

$454,725,818,867$

Babbitt, Ellen C., 800

Babcork, James W., 742

Babes, Virtor, 743

Babington, Benjamin, 459, 661

Babinski, Iules, 43

Baceelli, Guido, 67\%, 70s

Bach, Johann Sebastiun, 566

Bache, Franklin, 46ti

Bachofen, Johann Jacol), 555

Backer, Alriaen, 2s4

Bacon, Francis, 281

Bacon, Roger, 156, 161

Baelz, Erwin, 627

Baer, Benjamin Franklin, 650

ron Baer, Carl Ernst, 340 ,

$478-479,568,569$

Bagellardo, Paolo, 190

Barrinsky, Adolf, 673

Batglivi, Ciiorgio, 257-258, 420 , 121

Bailey, Walter, 195

Baillis, Natthew, 332, 34s, 364-365

Baillou, Guillaume, 200, 201, 239,279

Baker, Frank, 216, 300, 887

Baker, Nir George, 373

Baker, Ilenry, 330, 384

Baker, Ilenry Brooks, 800, 801

Baker, Sara losephine, 800

Baldinger, Ernst Gottíried, Bastian, Adolf, 1,, 554, 555 38.5
Baldwin, Lalwarl R, 79:3

Baldwin, J. Mark, Bst

13:1fome, lerameis Matitane, 508 Ballantyme, John Willim, bis9

13:Lllonius. Sin Batillms. (1. [3atzac, 1]onore, 756 von B:mberger, 1leinrich, 6ss lancroft, Edward, 3st

Banister, dohn, 2:31

Banister, Richard, 195

Banks, Nir Joseph, 415

Banting, William, 70!

Bárány, laobert, 2193, 195, 766

Barbere, 'Thomas, 16.5

Barbeirae, Charles, 283, 307

Barbier, Charles, 656

Bareroft, .Joseph, 604

Barl, John, 357, 390

Barl, Louis, 667

Bard, samuel, 390, 391

Bardeen, Charles R., 789

von Bardeleben, Kiarl, 556557

Bardsley, 708

Barduzzi, Domenico, 717

von Bärensprung, Friedrich, 699

Barker, Lewellys Franklin, $564,566,683-684,734$

Barlow, sir Thomas, 681

Barnum, S. C., 663

Baron, Hyarinthe-Théodore, 397

Baronio, Giuseppe, 529

Baronius, 114

Barry, Edward, 258

Bartel:, Max, 5.55

Barth, Michel, 412

Barthe de Sandifort, Edmond, 815

Barthez, A.-C.-E., 667

Barthez, Paul-1oseph, 377

Bartholin, Thomas, 246

Bartiseh, Georg, 195, $24 \mathrm{~S}$

Bartlett, Elisha, 466

Bartolochi, Josef Ignacio, 423

Barton, Clara, 794

Barton, John Rhea, 538

Bartram, John, 423

Barry, Martin, 567

Baruch, Simon, 709

de Bary, Heinrich Anton, 483 ron Baseh, samuel S. K., Ritter, 577, 688

Bass, Charles C., 742

Basmett, John Y., 4 tit

Bassi, Agostino, 619, 741

Bassini, Edoardo, 761

Bastian, Adolf, 18, 554, 555 699
B:onti, Guide, bis, biz7
13:L-ti:unelli, I'., SIt

Ba:1:aillon, li., 7:31

Bite, Willi:un, 271

Bateman, l'kmats, 436-437

Batessm, J. C., 32

Bat iselhua, (iabricl, 125

Batter, Rebert, 548, 615, 73:3

Batudedocefue, dean-1 douin, 317, (i.i.i.

Banhin, ('taper, 101, 22:3, 224, 292,856

Bammann, kugen, 733

Bazmer, fohann Wilholm, 345;

Batumgarten, fulius, 623

Bauscli, Johann lorenz, 28z

Baverius di Baveriis, $15 \mathrm{~s}$

Bayle, Gaspard-1,aurent, 431

l3ayliss, William Maddork, 590, 612,732

Baynham, William, 357, 542

Baxter, Jedediah 11., 55.5

Beaconsfielı, Lard, s05

Beale, Nary, 270

Bearl, George Niller, b!g

Beardsley, llezckiah, 3\$3, 390

Beaulieu, Jaeques, 275

Beaumont, William, 506-507, 590

Beauperthuy, Louis-Daniel, 628

Beaux, Cerilia, 774

Bechtereff, V. M., 580, 701

Beck, Emil J., 755, 705

Berk, Theodor, 92, 866

Berk, Theodrie Romeyn, 467, 714,782

Becker, E., 5999

Beeker, Traey C., 714

Béclard, Pierre-Augustin, 526

Bedlloes, Thomas, 336

Bede, Tenerable, 137

Bednar, Alois, 673

Beer, Georg Joseph, 359, 656

Beham, Hans Sebald, 237

von Behring, Enil, 629

Bell, Alexander Graham, 792

Bell, Benjamin, 384, $50 \overrightarrow{7}$

Bell, Sir Charles, 469-471, 493,508

Bell, John, 411, 508-509, 543, 789

Bellanger, Camille, 771

Bellingham, O'Bryen, $51 \mathrm{~s}$

Bellini, Lorenzo, 247

Belloc, Hippolyte, 661

Belon, Pierre, 224, 226

Bence Jones, IJenry, 504, 611. $68 \mathrm{~s}$

Bundz, Jaeob Christian, 655

Benedetti, Alessandro, 209

Benedict, Franeis Gano, 595 , 68s, 700 
Benediet, Moriz, 70s

Benivieni, Antonio, 89, 227

Bennet, Parker, 40;

Bennet f, James Henry, 544

Bennett, John Hughes, 16s, 614, 627,651

Benzi, l go, 15s

Berendes, J, 101, 716, S97

Berengario dia Carpi, Giaeon16, 201, 208, 217, 220, 245

Berg, Julius, 7.50

von Bergmann, Ernst, 635, 639

Bernard, Claude, $58,493,506$, 585-588, 593, 597, 60:3, 621, 650,732

Bernard de Gordon, 155, 178

Bernhardt, Nax, 699

Bernheim, Hippolyte-Narie, 709

Bernonilli, John, 32:3

Bernstein, Julius, 576, 578, 612

Bernutz, Gustav, 650

Berruti. S., 790

Bert, P'aul, 336, 589, 60s, 623

Bertharius, 136

Bertillon, Alphonse, 554

Bertillon, Jacques, 714

Bertuecio, Niecolò, 146, 15]

Berzelius, dohann laeob, 591

Besredka, Alexander, 750

Bessau, Georg, 674

Bettany, George Thomas, 510 715,869

Bettinger, Julius, 630

Beyer, llenry G., 629

Beyer, Johann II artmann, 292

von Bezold, Albert, 576,602

Bezolel, Friedrich, 1562, 663

Bial, Manfred, 658

Bianchi, 1., 701

Bichat, Franceris-Xavier, 468$469,516,56,5$

Bidder, Friedrich Wilhelm, $552,590,592,602$

Bidlon, Govert, 247, 248

Biederminn, Wilhelm, 579

Biedert, 1'hilipp, 674

Bier, August, 643, 755

Biett, Laurent-Theodore, 437

Bigelow, Henry Jacob, 538, $511,6+1,644-645$

Bigelow, Jacol, 463

Biggs, Hermann M., s01

Bignami, Amiro, 6i2s, 677

Bilguer, Johann Clrie, 350

Billard, Charles-Michel, 667

Billings, Frank, 685, 793

Billings, John Nhaw, 12, 43.

$89,125,171,390,409,415$,

409, 415, Bonet, Juan Pablo, 279

$524,536,706,714,719-721$, Bonet, Theoplite, 272, 282, $772,778,753,784,785,791$,

$863,864,895,899$

Bleuler, Paul Eugen, 700, 740
Billroth, Theotlor, 636-637, Bonnet, Charles, 3360 $63 \mathrm{~s}$

Binet, Altred, 738

Binz, Karl, 705

Birch-Hirschfeld, Felix Vietor, bis

Bird, Golding, 446, 680, 70s

Bisthoff, Theodor L. W., 479, 593

von Bismarck, Otto, 805

Bizzozero, Giulio, 5ti3

Black, Joseph, 334

Black, William George, 31, 32, $34,35,38$

Blackader, Alexander D., 618

Blackall, John, 441

Blackmore, Nir Richard, 405

Blackwell, Elizabeth, 791, 794

Blair, Vilray P., 663

Blake, James A., $\$ 14$

Rlancaard, Stephen, 261, 2so, 375

Blanehard, Raphite], 627,717

Blane, Sir Gilbert, 375

de Blegny, Nieolas, 272, 275, 282 Blix, Magnus, 576, 577

Blizard, sir William, 416

Bloch, lwan, 59, 183, 716

Bloce, Paul, 699

Blogg, Minnie W., 65]

| Blumenbarh, Johann Friedrich, 208, 209, 318, 326

Blumer, George, fis3

Blyth, Alexander Wynter, 71

Boas, Ismar, 676

Bobbs, John Stough, 539

Boccaecio, Giovanni, 181

Bock, llicronymus, 223

Bodington, Grorge, 792

de le Boë, Franeiscus, 260

Boeck, Cæasa, 70:3

Bö̈r, Lueas Johann, 3ls

Boerhave, Jermann, 251 , $320-322,355$

Boithius, 135

Bohn, .Johann, 264, 272, 199

Bohun, Laurence, 306

du Bois Reymond, Emil, 4i9, $574-575,596$

Boissier de la Croix de Sauvages, Francois, 318

Boivin, 1fmr, 652

Bollinger, Otto, 627

Bolton, Henry" Carrington, 202, 889

Bonafede, Frineesco, 231

Bonet,

Bonifacio, Giovanni, 279
Bonoms, Comino, 70:2

Bontius, Jarol, 272

Bordet, dules, tiะs, 715, 740750

de Borim, Theophile, 376-377

Berelli, Giovani Alfonso,

256-257, $2(f+i, 310$

Borgegnoni, Todorieo, 142

Borgogneni, [go, 142

Born, (iustav, 570

Borsieri đe Kianilfeld, Ciambattista, 4lt;

Boruttau, lleinrich, 897

Bossi, Luigi Maria, 655

Bosworth, liancke lluntington, 661

Bouchard, C'harles-Jacques, 667

Bouchard, Henri, 69:3

Bouchardat, Apollinaire, 504

Boucher, Alfred, 775

Boucher, Jrançois, 395

Boucher de Perthes, Jacques, 555

Boucher, Le Sieur, 343

Bouchut, Eugène, 655, 662, 696,717

Boughton, Gabricl, 446

Bouillaucl, dean-Baptiste, 427 , 432-433, 699, 735

Bourgeois, Louike, 277

Joussingault, J.-13.-J.-D., 594

Bovell, James, 6ss

Boveri, Theodor, 567

Bowditch, Ilenry Pickering, $576,577,575,600$

Bowditeh, lineent Y., 793

Bower, Litut., 64

Bewlly, sir Anthony Alfred, 757

Bowman, fir William, 500$501,599,656$

Boyer, Alexis, 522

Boyle, Robert, 267, 25í, 2!91, 292,499

Boylston, 7abuliel, 387, 389

Boym, Mirlatel, 67

Bozeman, Nathan, 547

Bozzini, Philipp, 459, 66i1

Bradford, Ealward II., 750

Bradwell, Steplaen, 277

Brahnu, Johannes, 637

Braill, James, 65, 448

Bratler, Lonis, 656

Brainerd, Danicl, 535, 782

Brambilla, Johann Alexander, H:3

Bramwell, Juln Milme, 701

Brand, Ernat, 3tit;

Brant, sbatistian, 231

Brantôme, 218, 220 
Brialer, Pierre, 349

Brashenr, Waltur, ,3s

Mrass:uvola, Intonio 224

Bratur, Judoli, bitz

Brame von lirmwali, Carl, $4.55,6.52$

Bramm, Chrixtian Wilhelm, $5.5(3,879,6.5 .5$

Bravo, lotanciseo, 20(), 22s

Brohmur, llermann, 793

Brejky, lugust, (bis

13re-gen, Maximilian, fitio

Profomnealu, Picre, 431-432

I3reurer, Jusceph, 7:39

Breughel, l'idter, :30:3, 312

Brewster, Nir David, 6iso

Brizu, Renc, I]:3

Brivkner, Walter M., T56

Brideman, latura, 5S/

Bricger, Lutwig, 627

Brigham, lilwin $\mathrm{H}, 721$

Bright, Richard, 196, 368, 418 ,

$440-442,116,7 \leq 0$

Bright, 'Inmothy, 196

Brill, Abrabam Alton, 740

Brill, Nathan E., 742

Brinton, William, 6sil

le Brinvilliers, Marquise, 293

Brissot, l'ierre, 226-227

Broalbent, Benjamin, 800

Broca, Paul, 100, 525-526, $554,555,694$

Broeklesby, Riehard, 375, 407

Broeq, Louis, 703

Brodie, wir Benjamin Collins.

516-517

Brooks, William Weith, 24.5, 569

Brophy, Truman W., 663

Brouardel, Paul, 715

Brougham, Lord, $\$ 71$

Brouillet, A., 774

Broussais, Casimir, 890

Broussais, F.-I.-T., 426-427, 429,511

Brouwer, Adrizen, 303

Brown, Alexander Crum, 703

Brown, Charles Brockden, 392,390

Brown, John [173.5-88], 97, $319-320$

Brown, John [1s10-82], 715

Brown, Lawrason, 793

Brown, Robert, 480

Brown, s.. G., 736

Brown, Thomas R., 68.3

Brown, William, 390

Browne, Isaae lenox, f62

Browne. Sir Thomas, 290, 725

Browning, Robert, 1Ss, 19.9. fiol

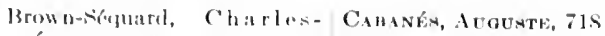

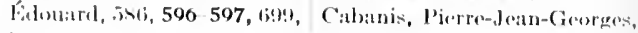
$7: 32$ 116,717

Bruce, sir 1)aviul, ti27, 7t2- Cubot, Richard Clarke, 686, $7.13, \mathbf{1} 1$ iti:

von Brücke, limst Wilhelm, Carlogan, William, 3-1

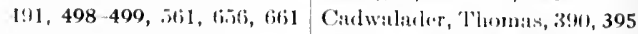

Brunct, (1:utul, 25:2

Brunfols, thes, 223

Brumner, Iothann Conrad, 247, 264

von Rruns, l'aul, i3:1, (3i3.i, tion von Brums, Vietor, 6082

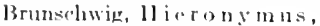
194

Brunton, sir Thomas Lauder, Callion, Carl Peter, 719, sts $598,600,703,705-706,77 x$, Callis(n, Meinrich, 3s? 815

Buchanan, Andrew, :3:31, 602 Buchlieim, Ruclolf, 704

Buchner, Ihans, 627, (32!)

Burk, Gurdon, 537, 53s, 539

Buckle, Ilenry Thomas, 15, 296

Burknill, John Charles, 699, $89 \mathrm{~s}$

Budd, George, 713

Budd, William, 712-713, s01

Budge, F. A. Wallis, 95, 587

de Buffon, Georges-L.-C., 311 Bull, Charles G., S1:3

Buller, F., tisl

Bulwer, ,John, 27!

von Bumm, Ernst, 6.51

Bünger, Christian Hoinrich, $52 \mathrm{~s}$

Burbank, luther, 724

Burdett, Sir Henry, 711

Burdon sanderson, Sir John, $576,584,601,735,765$

Bürger, 596

Burne, Charlotte S., I7

Burnham, Walter, 541

Burns, Allan, 445, 518

Burroughs, John, 19

Burton, IIenry, 46s

Burton, Sir Riehard, 29, 64, 124, 12S, 728

Burton-Opitz, Russell, 606

Burv, Judson s.., T03

Busehoff, Hermann, 293

Buser, Samuel Clagett, 688 , 773,781

Bush, Francis, 709

Bushnell, George E., 793, Carnot, Sarli, 4.53 SI 3

Butler, samuel [1612-80], 221. $287,265,29 !$

Conlius Aurolianus, Ios

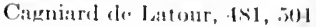

Cahn, Aruole, Tox

Cains, Jolun, 189, 193, 2:30

Caldani, Mareo Antonio, 3:3s

Caldwall, Chatries, difi

Calkins, Citry N., 730, 7.1, $713,71.5$

Callot, discofuse, 16i3, 312

Calmoil, Lomis-lolorentin, 131 , 701

Calmette, Albert, (\$21, 750

Calot, François, 90, 1:ュ1

Citvert, W. I. tiss

Camae, C. N. 13., N63, S6f;

Camerer, Willelm, $67: 3$

Cameron, Donial, s()]

Camper, Pieter, 326-327, 34:3

Cammidge, Perey John, (is?

Campbell, A. W., toos, 699!

Camplell, llenry Fraser, $5 \pi T$

Campbell, William, ist

Camus, Jean, 70!)

Cinappe, Jean, 146

de Candolle, Ilphonse-P., $316-317$

Cinniff, William, 717

Cannon, Waltor Brarlford, 42, $43,590,73.1,813$

Canstatt, Carl Friedrich, 45I, 6.s.

Capelluti, Rolando, 141

Capparoni, Piet ro, 717, 800

Capps, J. A., s13

Carbone, Tito, 7.5.5

Cardamatis, J. P., Ts, S , 110

Cirtano, Geronimo, 203

Carden, Richard, sis

Careño de Miranda, .Iuan, 3I2

Carey, Matthew, 390, 394, 467

Cargile, Charles 11., 7.5.)

Carlyde, Thomas, 41, 5I9, 7os, s66

Carnochan, John Murray, 537 538,539

Carotto, Frantemeo, 2:3s

Butler, Samuel [18:5-1902], Carrel, Nlexis, 590, 729, 763533

Bufied, Timothy, 402

Bylon, 3si3, 394
$764,812,811$

Carrion, Daniel .1., 754

de. Carro, Iean, 3S! 
Carroil, dames, 751, 752

Carron du Villatrils, C.-.t.-F., $6.21 \%$

Carswell, sir Robert, 444

Carter, Henry R., T.)

Carter, Ifonry Vindyke, 447, .3.5.

Carticr, dacques, 25)

Canal, (isispar, 3-30)

Castnova, 400)

C'anh, lolin Theodore, 703

('aspar, Johann I,udwir, 714, 739

Casserio, (itulio, 2215

Cassiodorus, 135, 136

Cassius Felix, 100, 10s

Castellani, Ndo, 677, $7+3$

Castelli, Bartolommeo, 280

Castle, William E., 567

ì Castro, Rodericus, 272

Catlin, Creorge, 41, 66:2

Cato the Censor, 41, 96

Cattani, I., 628

Cattel], 11, W., 719

Cavontou, Joseph-Bienaimé, 501

Cavidias, 77

Caxton, William, 195

Cayol, Jean-Bruno, 430

Cazcaux, Pierre, 652

Cecirenus, 114

Cefaly, Indrea, 774

Celli, Angeto, 62s, 677

Calls, 31, 98-100, 10s, 459, Si]

C'ermisone, Andrea, $15 \mathrm{~s}$

Cesalpino, Andrea, 225

Chabert, Philibert, 3.54

Chadwick, sir ldwin, ill, $712,8(0)$

Chadwick, James R., s07

Chagets, Catrlos, 743, 767

Chatin de Vinario, 181

Chalmers, A. I., 677

Chalmers, . 1. K, 800

Chamberland, Charles, 621

Chamberkn, Hush, 277, 279, 344

Chamberlen, Peter, 277, 313

Chamfort, Nicbolas, 15)

Champier, Symphorien, 146 , 154,188

Champollion, .1. F., 360

Chantemesse, indre, 753

Chapin, Ilenry Dwight, 687

Chapman, Nathaniel, $467, \mathrm{~s} 0 \mathrm{~s}$

Charcot, Jean-Martin, 43, 53, $175,238,398,615,46 f_{i 3}, 692$ -

693, 739, 774, 775, 780-781, 871,887

Charles II, 2\$1, 292

Charles V, 226, 232
Chauveatu, Aluguste, 576

Chaturam, Claude, 662

Chelius, Max Joseph, 51s, 527

Chepovalnikoff, Nikolai Petrovieh, 592

Chéreau, Achilie, $41+, 717$, s!)

Cheselden, Willitm, 338, 350$351,401,411$

Chesher, Robert, 518

Chevallier, Jemn-Baptistr-Alphonse, 711

Chevreul, Michel-Engène, 505

Cheyne, George, 3st, 6s:

Cheyne, John, 437-438, 661

Chiari, Hans, 896;

von Chiari, 1)ttokar, 662

Chievitz, I. 11., s\$i

Chinchon, Countess of, 292

Chiron, is

Chisthin, sergiei E., 592

Chittenden, Russell Ienry, 589

Chodonieeki, Daniel, 395

Chomel, A.-F., 127, 42s, 618

Chopart, François, 349

Choulant, Ludwig, 193, 217, $245,323,339,341,343,556$, 716, 718, 719, 770

Chovet, Abraham, s71

Christie, Arthur C., 754

Christison, sir Robert, 402, 706,714

Chureh, Renjamin, 391

Churehill, Fleetwood, 652

Chutro, Pedro, sit

Cicero, 107

Citois, François, 272

Civiale, Jean, 526

Clirendon, Earl of, 272, 370

Clark, Alonzo, 466, 783

Clark, Sir Jatmes, 446

Clarke, John, 556, 689

Clansius, R. 1. F., 452, 572

Clay, Charles, 543

Clatyton, John, 390

Cleghorn, Grorge, 386

Cleland, Arohibald, 361

('lement, Julien, 298, 343

Cloment Vil, Pope, 92

Clement Xi, Pope, 215

Clemow, Frank G., 619, 717

Clermont, Charles, 273

Cleyer, Andreas, bi

Clift, William, 361, 473

Clocttil, Arnold, 600

Clopuet, Hippolyte, 662

Clorpuet. Jules-Germatin, 169

Clouton, sir Thomas Strith,

\section{1}

C'lowe, William, 221, 232

Clusius, Carolus, 212

Cobbold, Thomas Speneer, fi2
Cober, Tobias, 271, 811

Codman, Ermest A., 7.56

Codronchi, Battista, 310

Coga, Arthur, 267

Cogswedl Mason Fitch, iziz

Cohn, Ferelinand, is:?, 619 , 623

Cotm, llermann ludwig, b60, 711

Cohntreim, Julius, 591, 614, 615-617, 123,631

Coinder, Charles, 30.5

Coit, Ilenry Leber, riss

Colbert, iean-Baptist (', 282 , 309

Colden, (adwallater, 390)

Cole, Rufus, 813

Cole, T., 519

von Coler, Alwin, \$95

Coleridge, samuel Taylor, 43 , 240,324

Coley, Willian B., 647

de Coligny, Gaspard, 235

Colles, Arraham, 512

Collijn, Is:aae, 893

Collins, Joseph, 630, 692

Collins, Wijkie, 776

Colombier, Jean, 375

Colombo, Nalteo Realdo, 212, 216-217, 243, 244

Colonna, Falio, 226

Colot, Germain, it4

Combe, 1., 6it

Comby, In]es, 667

Comenils, Amos, 314

Comparetti, Andres, :36il

Comrie, lohu 1)ixon, 52, 717, 86.3 .

de. Condoreet, J.-A.- - ., 714

Congreve, William, 288

Coningsby, sir Thomas, 296

Conklin, Edward G., J65

Conolly, dohn, 434, 699, 795

Conrid von Megenburg, 193

Conring, Ilermann, 2xis

Constantinus Ifricinus, 119. 138-139

Cook, George wythe, s:

Cooper, fir Astley Paston, 509-511, 537, 66:3, 711

Copper, samuel, sls

Copernims, Nimolats, 1s5, 229

Copho, 140, 150

Copinger, Walter Irtiur, 719, S:13

Copland, James, If6, 71s

Coplend, Robrert, 233

Corlun, Froderick, 4.4

Corrlall, bugene $F$, bos, fiss, 717

Corclus, Euririss, 225, 238

Cordus, Valerius, 223, 224 
Corlim, Augunte, 717

Cormarius, , 1anus, !2

Cormaro, 1.uipi, 228

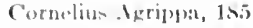

Cornil, Victor, tils, 691, 790

Corniug, dames leonard, 755

Corrule. lugustin, 279

Corrali, .llowso, Tlti

Coerem, Carl, T:1

Corrikan, sir Dominie John, 440

Corsini, Indreat, 717

Cortrz, Ilurmatudo, 30s

Corti, Alfonmo, 4s!?, 56:2

Corvisart, Je'an-Nicolas, 363, $433,7 \pi$

Corvisurt, lucien, is 1

Conchwitz, (ieork ) aniel, 322

Conte, Jean-Francois, 3:30

Cottle, Wyndham, 703

Cotugno, Domenico, 333, 338

Couneilman, William T., 683, 741,743

Cowdry, Exlmund $4 ., 67,68$, 69

Cowper, William, 247, 248, $33 \mathrm{~s}$

Coxe, John Redman, 389, 422

Crabhe, George, $\$ 00$

Craig, Charles F., 628, 741, 753

Cranach, Lucas, 212, 237

Crashaw, Richard, 267

Crato ron Kraftheim, Johann, 202

Crawfurd, Raymonel, 289-290

Credó. Benno, 345, 70s

Credé, Carl siegmund Franz, 654

Creighton, Charles, 715

Crespi, Benedetto, 136

Creve, Carl Caspar, 653

Crile, George Washington, 42, $575,734,75.5,761,813,814$

Crisaphis, 699

Croll, Oswald, 202

Cromwell, oliver, 286

Crookshank, Francis Graham, 180, 201, 239, 270, 311, 421, 748,749

Crosby, Dixi, 538

Crowe, samuel James, 707

Cruikshank, William Cumberland, 331-332

Crusell, Gustav, 708

Cruveilhier, Jean, 469

Cruz, Oswaldo Gonçalvez, 767

Cryer, Matthew 11., 663

Cuignet, Ferdinand, 660

Cullen, Thomas S., 651

Cullen, William, 318-319, 368-369
Culpeper, Nicheslas, 271, 20!1

Cuming, Ratph, 51s, ins

Cumning, Willa:mo, titet

Cunnimglatm, 1)anicl John, sisti

Curling, Thontas Blizard, 468 , (isil

Currie, Jamen, 3titi

Currie, Willium, 390

Curtis, John (i., s9, 93, 243$2 \cdot 14,715$

Curzio, Carlo, 38s

Cusanus, Cartinnl, $25 \mathrm{~s}$

Cushing, llarvey, 578, 591, $643,733,760,761-762,755$, $773,811, \mathrm{sij} .5$

Cushny, Arthur liobertson, $704,706,735,790$

Cutter, Ephraim, 651, 661

Cuvier, Georeses, 472-473

Cuyer, Edouard, 5ist

ron Cyon, Elie, 600

Czermak, Jolaann Nepomuk, $459,-190,661$

Czerny, Adalbert, 673, 671

Czerny, Vincenz, 635, 650, 762

Daça Churox, Dioxisıo, 222

Daça de Valdes, Benito, 178

Da Costa, Jarob MI., 652, 684685,781

Diskin, llenry D., 812

Dalby, sir William B., 662

Dalgarno, George, 279

Dalton, John, 358, 425

Dalton, John Call, 555, 582, van Deventer, Hendrik, 278, 612,715

Dana, Charles Loomis, 697, 790,897

Dance, I. B. H., 689

Daremberg, Charles-Victor, Deyman, Johan, 284 7s, 79, 85, 92, 102, 195, 106, Diaz de 14la, 1s2 112,717

Darling, samuel T., 743

Datrier, Jean, 703

Darwin, Charles Robert, 37, Dickinson, Richard, 398 199, 341, 549-550, 569, 691, Dickinson, Willian Howship, $724,723,872$

Darwin, Erasmus, 341

Davaine, Casinir, 619, 627, Dickson, Sanuel Henry, 466, 741

Davenport, Charles B., 5.5.5, 714,729

David, Jean-Pierre, 349, 351

Davidge, John B., 537

767 Davidson, Anclrew, 619, 717

Daviel, Jaeques, 100,358

Davis, Nathan Smith, 685, 782,806

Davy, Sir Humphry, 326, 540,
Deaclrick, William Henry, 538

Jolun 202

Degats, H.-4i,-Lis, 764

Giovanni, Achille, 67

Déjerinc, Jomeph-Jules, 699

)

Delamate, V., 71!

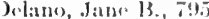

Delorme lidlunoult iote

Denocedes, is

Denuefold, latulwig, 55

Dennett, W. S., 661

De Quines, Thomas, 351 sigs

De Rosklès, Arthur Washington, thes

Pierre-lomeph, 349, Destarter, Rene, 255, 256, 259

Desmarres, Louis-Auguste, 656

Desnos, Ernest, 900 279

Dibdin, William J., 801

Dickens, Charles, 37, 39, 775, soo 579

Dickinson, W. I., 606 782

Didama, llenry D., 783

Diday, Paul, 666

Diderot, Denis, 360

Dirffenbaeh, Johann Friedrich, 528-529, 545, 656

Diels, Hermann, 94, 716, 892, 891

Diemerbroek, Isbrand, 271

Dietl, Josef, 450, 455-456

Dietz, Friedrich Reinhold, 102
Delamarte, (inorges, 6933

Deteum, Francis Xavier, 696

Deschanps, Jacques-Louis, 


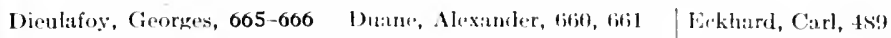

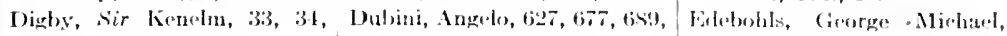
$279,288-289,307$

Digges, sir Dudley, 306

Dimsilate, Thomas, 107

Diodorus simulus, 50, 51, 84

Dionis, Pierre, 338, 348

Dubois, Paul \{1755-1s71\}, 652

Ducrey, Auguste, 627

Dwight, Thom:s, 789

Dover, Thomas, $10 x$

Doron, Eugène, 75, 760

Dragendorff, Grorg, 71 t

Drake, Dini $21,464-466,475$

Drebbel, Cornelius, 202, 25s, $2 \mathrm{ST}$

Drechsel, Edmund, 611

Dreser, IJermann, 708

Oriesch, 1I:ms, 13, 106, 569, $570,571,729$

Drown, Thomas Messenger, 801

Oryanter. See lichmann.

Pryken, John, 241, 216, 2ss, 295
T+1

Du Bois, Dolatielal, 595

Dubois, Eugrne, 46 , 5.5

Du Bois, Eugene l', 593, 595

Dubois, dacques. See Sylvius. Dubois, Pant, 709

Duchenne, G.-B.-A., of Bouloume. 550, 690-692

Durkworth, sir Dyce, 370

Ducley, Benjamin Winslow, 539

Dugdale, R. I., 727

Duhring, Louis A., 703

Dïhrssen, Alfred, 650

Dujardin, Félix, 452

Dumas, Jean-Baptiste, $5 \$ 6$

Dumoutier, .loseph, 667

Dun, sir Patriek, 411

Dunant, Ilenri, 374, s10

Dunbar, William P.. 802

Duncan, Andrew, sr., 790

Dunean, Louis C., $\$ 95$

Dunglison, Robley, 466-467, $715,718,868$

Dunham, E. K., 813

Dunstan, Wyndham R., 703

Dujouy, Filmond, 107, 717

Dupuytren, Guillaume, 290, 520-522, 525, 540, 554

Duran, Carolus, 775

Düre, Albrecht, 210, 237

Dususe, 347

Dutrocket, Henri, 50.4

Dutton, Joseph Everett, 713 , 75is

Duval, Mathias, 5is6

Duverney, Joseph-Guichard, 21., 33s

Dyer, Ezra, 6i56, 6i61

Dyer, Isidore, 6ss

Dristzke, Karl, 157

bzondi, is 28

\section{7,650}

Lder, doham 11 einrich, 3\$5

Ealison, Thomas, fos

Eelward 11, 234

Edwaril V1l, dil

Egar, David, 196

Ehtres, Fdward, 17!

Ehrlich, F., (ill

Ehrlich, l'atul, 1st, 5ti2, fi3:2, 72.5, 736, 746-748, 750)

Ehrmann, Chitrles-1lenri, tifiz

Eichmann, Johann, 204, 20s

Einhorn, Alfred, 70x

Einhorn, Max, 686, tisx

Winthoven, Willem, 73:

von Eiselsberg, Anton, 733, 760

505, Eisenberg, P., 625

Eisemolrath, 1)aniel N., 5.tef

Eisenmann, Georg Ileinrirh, $33 \times$

Eisenmann, Gustav, 6.52

Eliot, Charles William, Gs, 783, s1ti

Eliot, George, 7 it

Elizabeth, Que'n, 230, 231

EH:i, samuel, 27

Elliot, Robert IIenry, 765-766

Elliotson, lohn, 448-449

Elli-, llavelock, (693, 73心

Ehassian, Ml., 7.4.

Eloy, N.-F.-J., S6!

Elsberg, Loulis, 6itiz

Elsholtz, Johann Sigismund, 249,273

Elsner, Henry Leopold, 685086

Emeron, Charles P., tis?

Emerwon, Ralph Walte, 31.i, $632,729,7 \times 5$

Emmetf, Thomas dddis, 547

Empertoeles, 80-81

Engetmann, Goror Julius, 30, sit;

Eneclmann, Theoker Withelm, $576,(90)$

de l'fore, Charles-llichel, abse, 3 hil

Fiarle, Pliny, 796

Fastman, Joseph Rilus, 650

Eberle, Johann, 586, 7s2

Whers, Georg, 4!

Bberth, Carl Joseph, 627

Fbotein, Erich, 121, 272, 332. $361,451,501,506,572,6999$, !)

Ehstein, Wilhelm, 6:3, 689

Echegatray, Jose, 7t5

Eck, Nikolai Vladimirovich, 596, 762
Eppinger, 11:1n\%, 6776, 731

Erasist rat 1ts, 91, 95

Erb, Wilholm Ilrinrich, to9, 691, 694-695, 704

Erskine, loblert, 11:3

Erxlaben, Destothes Chrisfi:m:t, 891

Escheriwh, Theostor, 627,073

Eorlaile, Jaines, 449

d'lision, Chartes, 342

von Limareh, Frielrich, 639

Esupuirol, 1.-1..-D., 431, 79.3 
Fintibrouk, A. X, T27

Fistemer, ("listlos, 218

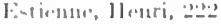

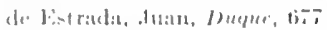

Fulenburg, Ilermann, TI

linsthins, 111

Fustuli, R:ırtulummun, 215 $210,2 \cdot 2 ! 3$

Fints, sir Irthur, 7! 73

livalu, Cirillith, 712

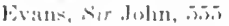

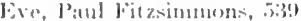

lwald, Cirl Intur, 076

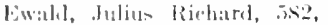
(itii)

Paner, sigmunt, 5x:

vin livek, Jasn, 17.5, 17x

Fyeleshymer, Albert C., 5.56

Eysell, Malph, ritiz

Eiscnharth, I)r., 111

Famples, lfis

liahius Calvius, on

labricius ah defuapendente.

Hieronymus, 217

Fabricius Ilidanus. Sie Fabry von bilden.

Fabry von llilden, Wilhelm,

$275-276,2 \times s, 30: 2$

Faget, dean-Charles, (ix)

Fager, Cluarles llilton,679-6iso

Fitgon, (illy-Crescent, 29s

Fahrombei, Crabriel Daniel, $3: 30$

Fatrucei, Nicollo, 1.ss

Falguiere, Ilexanclre, 7.5

Fallopple, Gabriel(, 212, 217

Falrot, Juan-l'ierre, 134, 702

Falta, Wilhelm, 595, 679, 734

Farina, Guido, 64 :

Farlow, John W., 721, S94

Farfuhar, Gorgen, fol

Farquhar, IJ lon, equ, sas

Farr, stmuel, 385;

Farr, Willian, 713-714, 601 . atis

Fithender, IJrinrich, sis

Fitio, Johann, if.

Fanchard, Jierra, 356

Faute, dean-I, tuis, (i.j)

Favill, Henry Baird, fix

Faty, Folwarl dllan, 7!

Fayrer, xir Joweph, 447

Fazir, Futernio, T11

Fechucr, Ginstav Theodor $4 ! 4,584$

Forleli, Fortunato, 272

Feluehenko, 711

Frhleisen, Frifdrich, 627

von Fehling, IJermann, 504, fis.
Foletio, Rainumalo, lizs

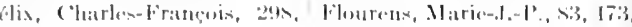
$10 ?$

Jialkin, Rolwert II illiam, "2!

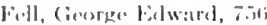

jonger, ("hristian, 040

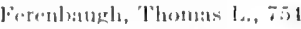

Ferguson, gohn, sis!

Fremsisol, sir Williat:1, 514 515

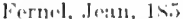

firrtan, duan, 7tia

lierrari da Cirato, Ciammaton, $1.7,1.5,1.56$

Firrier, sir 1):avid, 580

Ferro, Jaseal, 3is!

Fiek, ldulf, 570

Fielitz, J. (i. 11., 3til

Fiessinger, Charles, :01

Filohne, Itilhelm, 7 (x)

Fillebrown, Thomas, tixi:

Finger, lernst, bio

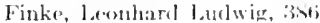

Finkelstoin, Heinrich, 674, tits

Finkler, l)ittmar, 62:

Finlay, Carlos Juan, fizs, ril, 767

Finlayson, James, : 1, sit: stil

Finney, dohn M. T., T.,t;

Finsen, Niels Rubera, 35, 70s

Firntin, Giles, 300

Jiseher, Bornharel, 70x

Fischer, Enil, $8(4), 60 \mathrm{~s}, 1 ; 11$,

\section{0s, $736-737$}

Fiseher, Ceorg, sity

Ficeher, Martin H., bis

Fiseher, Otto. $57 \%$

Fisluer, Charles Perry, siot

Fisher, George dackom, 71.j, so?

Fisher, doln D., 792

Fiteh, Jabrz, 390

Fitz, Reginald II., 387

Flack, Martin, 5.5x, 73-

Flaxman, John, t.2

Flechsig. Paul Fnil, iso, fol

Fleck, II, TI

Fleming, Duvirl, jl?

Flemming, Walther, 562

Fleteher, Robert, 4t), 17!1, 150, $304,55,75.5,719-720,409$

Flexner, Ibraham, 771,772,

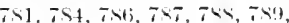
790,433

Flexner, sinon, $92-7631,711$. Franklin, Christine Ladd, 660 $7.51,797$

Flirk, 1,amenen $\mathrm{J} ., 79.3$

Fliedner, Theodor, 794

Flint, Iustin, jr., inl, 675, 644 Frazer, sir Janus G., 23, 33

Flint, Austin, r., 684

Flint, James .1., 40

Flores, Francisco $\mathrm{A}, \mathrm{i}, \mathrm{t}$
$191,495,51$

Flower, sir Honry, 17:3

loger, sir John, 272, 27. 300,341, lisi

linekiger, frienlrieh Imgast, 70

linelel, Robert, 2x!1, Itio

Fligere, (arl, 711

Foleró, firancoim-bintuanum, $341,34.5,711,71$

low-ins, Inutius, !2, 189, 222

Fulin, (nto, till

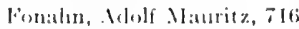

Fomin, 1., Fot

Font:un, Filice, 334, 115, 70s

Foxit, hesser, H1j

Forbes, John, tis

Formu, Finile, 2o7

Forlanini, Carla, Fu

Forster, John Coupur, is!?

lijroter, licharal bito

loster, Frank Pierea, - 19, s08

linter, Cimorge 13., 7,il

Finter, sir Michael, 106, 260,

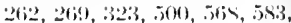
SN(j, 602-603,

Foster, William, 22⿺

Fothergill, John, 371

Fothergill, John Milnes, tivs

Fouillfe, Mfred, sisi 666

lowler, George Riverson, 647

Fowler, Thomas, $10 \mathrm{~s}$

Fox, Joseph, is

Fox, Tilbury, 70?

Fracastoro, Cirolamo, 227 228, 873

Franee, Inatole, lis

Francis, John Wakefield, 467

Franco, Pierre, 221

Francois-Frank, CharlesEmile, $5 \mathrm{~s} 0$

Frauk, Johann Peter, 327-328, $405,10 x, 440,506,723,795$

Frant, Mortimer, 1.51, 5.56, sti, scio sito

Frinkel, Nlbert, 625

Frankland, Edward, sol

Franklin, Benjamin, 371, 390 395

Frapolli, Franeecoo, 34

Fraser, sir Thomas Richard, $703,706,704$

$34,35,74,5.5$.

Frederic, Harold, 804

Frederick 1I, 16 ; forehlemer, Froderiek, (is) 
Frederick the Great, 412

Freer, (1)to T., t562

Freind, loher, 385

Freke, dohn, 3x:3

French, Thomisis Rushmore, 661

von Freriels, Friedrich Theoflor, 6i1 I, 667-669, 670, 1999!, 7.7!

Freud, simmund, 43, 31s, 739$740, \mathrm{~s} ! \mathrm{s}$

Freund, William Alexander, $312,(6.5)$

von Frey, 11:2, 582, 602, 612 Freyer, l'. Johnston, 755

Frick, George, tist

Frielliander, Carl, 627

Friedleben, Alexander, 733

Friednanu, Friedrich Franz, 7.)

Frielreich, dohimn Baptist, s! $4.4,89$

Friedreish, Nikelan-, 34:3, 6s:9, 69) 1,695

Frisdrich, Mattheus, 1933

Fritach, Ahaswer, 2-3

Fritsch, Ciustay Theoflor, 5.59, isto

Froben, Johimn, 22.4

Frohlich, Alf red, 23, 73:3

Frölich, Hermann, 235, 716, 892, 69.5

Fromeperger, Loonhard, 235. rati

Frowch, Pitul, 750

Froude, James Anthony, 233

lingarali, Ruggiero, 141

Fry, Elizabeth, 7!)4

Fuchs, Conrad lleinrich, 716;

Fuchs, Ernst, 660

Fuehs, locontart! 223

Furhs, simulel, 273

Fujinami, A., J67

Fuller, Roburt M., 708

Fuller, simuel, :306

Fuller, Thomis, 187

Fulton, Johns., 714, s01

Funk. Casinir, it2

lutaki, K., Tiv

Eutcher, Thomas B., Gsis

iabpreser, domx, 35, 155

raertner, Girstar, 6ss

Jaffky, Georg, 623, 626-627

lel Gaizo, Modestino, 717

rale, Thomas, 220

yalen, $42, k 3, x 4,49,94,103$

$107,111,113,116,11 \varsigma, 121$.

$132,13:, 134,175,144,200$.

$210,211,213,242,243,244$.

206, $\times 1: 2,-7$
Gialilece, 25, 2.5

Gall, Franz loseph, 579

Gallaudet, belwart M., 792

Galtier-Boiswière, E., 719

Galton, Sir Douglas, 711

Galton, Sir Franeis, 4ss, 553

j.) $4,663,724,725,726,727$

Galrani, Luigi, 333

Gamaleiz, Nicolaus, 627

Garcia, Mlannel, 459, 661

Garibaldi, Guiseppe, 525

Gariopentus, 13s

Garnior, A.-L., 7 I9

Garretson, James Eilmund, $60 ; 3$

Garrod, Sir Alfred Baring, 681

Garth, Sir Sammel, 294, 405, 406

Gaskell, Walter Holbrook, 604-605, 734

Gaspard, 4!4

Gassner, Joseph, 382

Gatti, Angelo, 422

Gaub, llieronymus David, 366

Gatucher, Ernest, 66t

Gates, Carl J., 6.j5

Gautier al'Agoty, Fabian, 34l342

Gavarni, Paul-Chevallier, 7t

Gavarret, lules, 429

Ciayterd, llarvey R., $61 \mathrm{~s}$

Geluer, 127

Gegenbaur, Carl, 560, 567

Geger, Philipp Lorenz, 504

à Golurma, danns Abraham, 276

Generali, Franesseo, 73:3

Genga, Bernardino, 247

Gengem, ().tive, 627, 749

Gensonl, Joseph, 526

Gentile da foligno, 152, 15s

Gentry, Ernest R., 75t

Geoffroy, Ettienne-Louis, 361

George 11,510

Geraghty, John Timothy, 6s9, 707

Gerard, dohn, 225, 226, 307

Gerhatrl of Crumona, 153

Gerhard, Willian Wood, 463 464

Gerhardt, Carl, 662, 673, $7 \times 0$

Gericault, J.-1.-T.-.1., 774

ron Gerlich, loseph, sr., 560, Ditit

Gortier, Fólix, bitis

Gerrish, Freeleriek II., sist

von Cierstorff, IIans, 194-195

Gerson, Johirn, 157

Gerster, Arpad (i., 647

(iersuny, Rolwerl, 638

Gervex, 1.. 771 (it:n'r, Conrath, 16)6, 223, 224 , 7I!

Ghirlandajo, Domenico, 175, $17 s$

Giarosa, Piero, 1339, 172-174, 717

Gibbon, lidward, lib?

Gibbs, losial Willard, 425, $572,573,730,764$

Gibson, Benjatmin, (i5.5)

Gibson, William, 537, 544

Gigli, leonardo, 6.,0)

Gilbert, William, 241-242

Gilhertus Anglicus, 15s

Gilehrist, Thomas ciapar, 627,703

Gilinni, Alessindra, 211

Gilles de Corbeil, 140-141, 17.)

Gilles de lat Tourrette, Georges. 693,699

Gillies, Harold Dilf, 663, SI

Gillray, James, 395

Gilman, Danid C., 7s:3

Gilmer, Thomas 1., 66i3

Giotto, 175, 20心

Girtanner, Christoph, 320, $3 \times 4,355$

Giunti, $92,111,120$

Glauber, Johann Ruclolph, 286, 291

Glénard, frantz, 667

Glénard, Roger, 590

Giley, Engine, 607, 733

Glison, Francis, 246, 266, 32:3

Gmolin, lropold, 506, 591

Godenius, Rudolf, 2sis, 24!

Godart, Justin, s12

Godelard, 11. 1), 727

Golman, John D), 475

von Goethe, dohann Wolferang. $94,230,314,317,321,310$ $341,411,486,539,699,727$. 739

Goforth, William, 4tis

Goldberger, Joseph, 712, 750

Goldflam, ㄴ. T'., 695

Goldmark, Josphine, 71]

Goldsedender, Nlfred, $\quad \therefore$. 58:3, 703

Goldsmith, (bliver, 40:

Goldthwait, doet Emet, Riti. in

Goldwater, sigrimund schuly. $79(1, \infty) 1$

Golgi, camilln, 562, 563, (42), titi

Gidis, lowpuld Anton, 417

Golfz, Fricelriet l,cosuld, sis, $580-581$, titiz

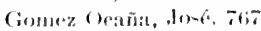

Comperta, Conracl, bol

Gomperz, Theodor, as 
Goncourt, frits, 77.

cinoleve, Henry Hurry, 117

(iesclliut, William, 51!)

(iomlir, Jolun, 557-558, (i1!)

(iondwin, sir doln, sle

(ieculyestr, Churles, jr., tifis

(iorilum, Mareatef, 5l!)

(iorkals, William Crawford,

752-753, \$11

de. (iorric, Jean, 22:2

Gosset, Intonin, silt

(iolch, sir lirancis, 26s, 579. (6.11

Gouhl, (inorge Milbry, 660, 71!), sos

Goulin, Jean, 416, 717

(ioupil, Jean-Emest, (i.)

(iowers, Nir William Richard, $643,696,699$

Goya y Lucientes, Francisco, 7.1

de (irataf, Regner, 247, 24s, 263-264, 506

von Gracefe, Albreclit, 6.55, 656-658, 766

Graefe, Alfred Karl, 659

von Graefo, Carl Ferdinanul, 527-528

Grafe, lirich, 595

(iraham, James, 352, 402-403

(iralam, Thomas, 505, 603

Grainger, Richard Dugard, 499

Granchar, Jacrues-Joseph, 667

Grant, sir lames, 6st

Grasi, Battista, 628, 677

(irasi, Benvenuto, 195

Graunt, John, 273, 325

Graves, Robert James, 438439

Graves, William W., 55.5

Grawitz, Paul, 61s

Gray, Henry, 557, fifo

Gray, llenty M. W. S12

Greatrakes, Valentine, 289

Green, Irancis, 361

Green, llorace, 661, 662

Cirene, bilwarel Lee, 94, 101, 203

Grernhill, William Alexander, 71:

Gregory, dames, $50 \mathrm{~s}$

Gregury 1X, Pope, 132

Grezory of Tours, 114, 136, 159,171

Gregory XI\}1, Pope, 129

Grew, Nehmiah, 250-251,274 Griesinger, Wilhelm, 699-700, 741, 7!36

Grimm, Jakob, 37

Grimmelshausen, llans J. C., 310,616
Ciroeen, Pinetro, 677, bist

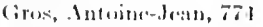

(irans, samuet David, Hot, ii3s, 045 646, titil

(irote, Cieorge, 71

Grotius, Hugo, 2>0)

(iruluer, Nis, 6:2

Girulere, Wonzdiau, 532

(irïls, Daviki, ti27, 702, 7.11, 712

Gruner, Christi:tn Gottfried, $376,385, .990$

Grümwald, Matthias, 238

Grünwale, ludwig, b62

Grützner, l'aul, 57

Guarnicri, Giuscppe, 1677, 743

Cindelen, Bernbated Aloys, 5so

Gurleer, E. W., 272, 381, 742

Guenean de XIussy, llenri, 801

Guerini, Vincenzo, 109, 717 , $\$ 90$

Guggenbühl, .., 796

Guicciarlini, Franceseo, 183

Cuirli, Guido, 115, 217

Guillain, Georges, 69!9

Guillemeau, Jacoues, 112, 195, 296

Guiteras, Juan, 767

Guitrae, Henri, sıo

Gull, sir William Withey, 437 , 413, 677-678, 6it1, 70s

Gullstrand, Allvar, 764-765

Gully, James Manby, 709

Günther, Siegmuml, 71s

Gurlt, Ernst Julius, 122, 640, 895,899

Gusarem, Adsolf, 65.5

Gustaves Adolphus, 296

Gutenberg, Johann, 185, 192

Ciuthrie, George James, 656

Guthrie, James, 519

Guthrie, Simuel, 502

Giutitrez de Angulo, Nicolas, 239

Guttmann, W., 719

Guy do Chauliae, 131, 146 148, 1 \&1

Guy, William Augustus, 714

Guyon, Félix, 641

Guyot, 360

Gwathmey, James Taylor, S14

Haddon, Alfred C., 5.55

Hacbler, lionrad, \$93, $\$ 94$

1 I aeckel, Ernst, 552-553, , 669

de llaen, Anton, 320, 378, 416

Ilaeser, Heinrich, 105, 1tit; $193,235,308,310,311,716$, $\mathrm{S} 6 \mathrm{i}$

Ilahn, Eugen, 640

Ilahn, Johann Sigmund, 367
Hahuemann, Samucl C. I., 460

Itain, Latwig, 719, s93

11:allortsma, Tjalliug, tiso

11:ales, strphets, 328, 373, 196, 199

Ilalford, (i. 13., 70s

1lall, Granville stanley, 581

lt:tl, Marshall, 499

ltalle, John, 141

von llaller, Alhrecht, 119, 120 , $267,266,322-324,333,310$, $345,100,111,115,494,598$, S75

Halley, Edmund, 273, 309, 420 lislliburton, William D., 579

llallome:tu, Ilonri, tis

11:als, lirans, 303

Halsterl, Willian Stewart, 537, 6i3s, 760-761, 7s1

llaly ben Abbas, 119-120

Haly ben 1sa, 119

Ilamberger, G. 1.., 608

11 imburger, II. J., 612

llamen, fohann, 252

llamilton, Alice, 632, 711

llamilton, Frank llastings, 647, 714, 7s

IIamilt on, Litdy, 382

Hamilton, Mary, 892

II amilton, Robert, 383

Ilamilton, William, 446

llamilton, Sir William, 369

llamilton, Sir William Rowan, 76.5

Hamman, E., 774

llammarsten, Olof, 602

llammond, William Alexinder, 696, 751

11 anbury, Daniel, 705

llaneock, Henry, 539

llanderson, II. E., 280, 296 , $307,390,715$

IIanenan, Frederick T., 129, 715

llanes, Frederick MI., 684

Hanot, Victor-Charles, 667

llansen, Armaver, 627

llanson, William C., 711

llardy, Art hur shesburne, 864

llare, Edward, 447

Hare, Hobart Amory, 683, 707

Hare, William, 471

Ilarington, Sir John, 228

1 larpestreng, Henrik, 139

llarrington, Charles, 711

IIarris, Benjamin, 282

llarris, D. Fraser, 253, 502, 6.5S

llarris, Walter, 271, 311

11 arrison, Resw Granville, 564, $764,80 \mathrm{~s}$ 
Hartland, Edwin Sydney, 555 Helain, Richard, 204, 20s Hartley, Frank, 647

Hartmann, Kuno, 703 Hartwell, Elward $11 ., 60 \mathrm{~s}$ Harvey, Gideon, 221, 272

Harves, William, 106, 217 . $225,242-246,295,698,875$

Harvie, dohn, 345

Haslam, John, 3it, 701

Halsenfratz, Jean-1lenri, 33i, (ii)

Hasting, sir Charles, 4tfi, sot

Hat:a, s., 7 t.

Haught on, Samuel, 307

Hauptuann, Gerhart, 613

Hauy, Valentin, 360

Havarl, Valery, Tis

Havers, Clopton, 246

Hawkins, sir llenry, sot

Hawkins, Nir Richarel, 375

Hay, Mattlew, lis?

Hayden, Sir seymour, ös

Haydn, dosef, fit)

Hayem, Georeses, 6ti

Havgarth, John, 370 402

Hays, lsarar, 467, sos

Ilays, lsac N]inis, sos

Hayware, Georere, j45

Head, Henry, 567, 684, 609, biti?

Ifoth, 514

tebenstreit, J. G, 3is

frberden, William, 274, 35s, $369-370,395,40 \mathrm{~s}, 420$

foperden, William, jr., 370371

on Hetra, Ferdinand, 456

on Ifebra, llans, 702

Iecker, lugust lieidrich, 345, is

lesker, A. F. K., 716, 717

Ingar, Alfred, ists, 6193

legel, (i. W. F, 133, 425

leik 4 , William 1., 716;

Ieidenhain, liudolf, $5 \pi 7,52$, $590,592,596$, , ins

eilbrouner, André, 750

fin, Ermet Ludwig, 380, $40 \%$

eine, Heinrich, 170, 796-797

on 11 (ind, Jalob, 640, 6is

einroth, Johann Christian

Aupust, 131, 5nt

eint $z, W . .591$

eister, lorenz, 347, 349, 111

ijt $z$, P., Ai?

eitzmann, Carl, 556, 562

Gomann, Charles L., 236; $296,111.895$

ktoen, ludwig, 316, 3ss, 632 , sos

llediodorus, 100

$260,318,334$

Helvetius, 292 $485,622,624$ 436,673

Henti, Vietor, 750

Henrotin, Fernand, 650

Ienry, Robert, 774

Hense], Fanny, 451

Hepp, P., 70s

Herarlitus, 80 $7 ! 4$

Herbst. Sef Oporinus.

Hericourt, Jules, 627 735

Hernandes, Franciseo, 292 SSS

llerophilus, 94-95 $697, \mathrm{~s} 0 \mathrm{~s}$

Hart wige, ()andar, 5fi

Hertz, Heinrieh, 573

Hersheimer, J., 703

$110 \times 1061,3 i 5$

Hese, Alfted F., fiss

Hess, Ifen, 73]

11 sese, 1., 5014

Heufner, leomlarel, 674

van 1]eurne, Jan, 20:3

Hey, William, 518

II ysham, John, 375

Highmore, Nathaniol, 216

lfildburgh, W. L., 40 Valentin, $37 \mathrm{~s}$
Hena Pavlovna, Grand Blill, sir leonard, toss, tiss, Duchess, $532 \quad$ (io9, 711, \$14

Her, lohann Florian, 504 llilion, Joh, ,

Himly, Karl, bis;

con Helmboltz, Hermann, Hinton, Janues, fiti3

265, 359, 360, 475, 571-573, Hippoerates, 36, 50, 71, 77. $575,655,659,664,775,876 \quad 92,8693,94,99,1013,115$, $133,131,319,440,16.5,172$, SIS, 876

Henmeter, John Conrad, 686

Jenle, Jacob, 462, 47\%, 483-

Henoch, Eduard Heinrich,

llenry Vill, 232, 234, 235

IJensehel, A. W. E. T., 718

Hensler, Philipp Gałriel, 385

Heraelides of Tarentum, 100

Herbert, Sidney, Lord, 712, IIorlgson, Joseph, 445

llering, Ewalll, 553, 608, b60,

Jermann, Ludimar, 575, 576

Hernández Morejon, Antenio,

Herodotus, 50, 51, 5t; 81,59

IIerter, Christian Archibide],

de Hery, Thierry, 2:31, 236

Henrteloup, Chatrles-1..-., 526;

Hewitt, W. M. Graily, 6..0)

If(w⿻on, Willi:2m, 330-331

IIeyool, Thomas, 2s\&, 401

Jicks, John Braxton, 654-655

von llildenfrand, foluann
Hirsels, August, 111, fil!, titil, $716,717,869,896$

Ifirshberg, Julies, 111, 116 , $115,125,660,719,5 ! 36$

llirt, Ludwig, 711

Hirt $z$, F.,.J., s15

11is, Wilhelm, 496, 560, 562, $563,564-566$

IIis, Wilheln, jr, 5is9, 734

1Hitzin, Eluarl, 580

1]ohlyn, Richard D., 7lis

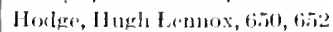

Hodgen, John Thompson, 646

Hodges, Nathanich, 310

Isclgkin, Thonas, 254, 443444

Hoefnagl, Ciecorg. 22t;

Hoernigk, Julwig, 272

Iformla, August J. R., TIT, 502

van't Hoff, dakobus Henricus, (i:2)

Ifoff, J)hn V'in R., 753

Hoffin, Ahert, 640

Iloffulann, Erich, 6.30, 71.5

Hoffmann, Froderick L., 711 , 714

Hotfmann, Friodrich, 97, 310 , $319,393,355,409,115$

110ff mann, Juhann, (i!n?

Ifoffer, Max, 3h, 7.5, 16il, 1רo, 716, sise

Ingetrth, William, 34t

Ifohman, fionren, 123

lfokusai, $7 \pi$ l

Ilollein, 175, 176, 1s1, 234, 235

Holden, Luther, .556

Holder, William, 27?

Hollindler, Eugan, 23, 235. 291, 30.7, 313, 717,

Holmes, Batyart, s!1

Holmer. Christian Ratume. rists

Helmes, Gorton, 6 fid

Jlolmes, Oliver Windel], :30. $33,40,45,218,301 \%, 391$, $427,436,453,457,463$, 52:3, 535, 511, 559-560, $715,721,776$ 


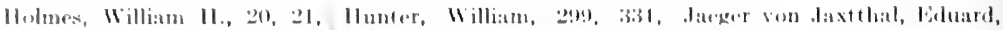
inil

Holmgren, Marik Jrithiof, 600

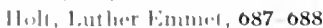

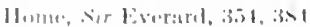

Hume, Froncio, is.3, 1:31

11 mur, $3:, 7,7,1$

$31: 3,345,340-347,34 i t, 34 i s, \quad$ ti.it

(1) 5,5$), 5,13.5 \%$

Jalfe, Mix, 5!tl, f11, fist

1huntington, 1): witl 1.., 5ists

Jumtingtum, (incorge, lit4i

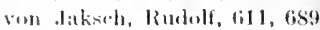
.14marilss, 1.12

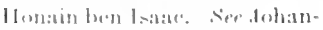
witim-

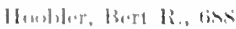

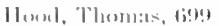

llowke, Rolucrt, 250, 256, 267

Ilomer, John, 10)

Houpur, Buhert, 3\6

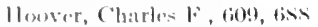

Ifopo, James, 445, 116

Ifopkins, Frouleriok Cowlanel, 604, (i11, fist), fis!

11н中lusister, Filix, 609-610

Itoriter, 107

Iforbaczewski, Johann, 59t4

Horn, Ernst, gs!

vom Herm, Wilhelm, fos?

Hermer, William Mdnonds, $474-\mathbf{4 7 5}$

llor-l@y, sir Victor, 5s0, 643$644,696,733$

llor-tmanm, Carl, 661

Hort, sir Irthur, s66

Hosack, 1)avid, 3s!), 467, 711

lloustom, Robert, 348

von llovorka, O., 31

Howard, Henry, 6ing Hure, Hemry Mills, 701, 7.)1, $\overline{7+1, i}$

Husemann, Therelor, 113

Hutohinson, Jolnu, dous

$M(1011 \%$

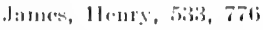

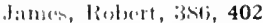

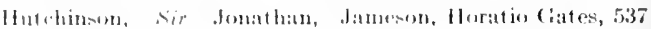
I.:3, 042 643, 70:3

Jouet, P'ierre, 702, 738

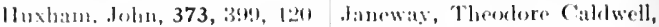
Huxley, Thomats llonry, 221, 685

79, 110, 215, 173, 551-552, Itumw-ky, 1., 70.3

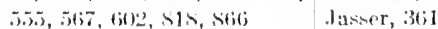

Ilyiuia, 7

II) I I, Josef, 2si5, 490-492

Iassinovesi, Ml'xander, $7 t 2$

Jast row, Mlorris, 5.5, 56, 226

Javil, Eusile, 660

.layle, Felix, 71!

dayne, Walter A., tisis

IBN IBAITAR, 123

Irhikawa, K., Ttis

bleler, lizrl Wilholn, 796

Ido, $\mathrm{I} ., 767$

I-ent-latep, $1 \mathrm{~s}$

Ijina, Isao, 767

Ilberg, Johinnes, 7 it

Inarla, R., 767,814

Ingals, Ephraim Fleteluer, 66:

Innocent VIII, Pope, 267

Ireland, Nerritte, W., S12

Irons, Frnest Edward, 6:32 $\$ 13$

Isace Judrus, 121

Нохиге, John, 375-376, 417, $+20,7 ? 4$

Howarl, Fetand O., 62s

Howard, Roleet Palmer, bsis

Howe, Lucion, lifil

I1owe, samauel $\mathrm{C}, 792$

Howell, Willian Henry, 604, (i) 2

Howland, John, 595, 6ss

Hrahanus Maurus, 137

Irdlickis, Nlos, 26, 163

11 sioh, E. T., 66

lluang-ti, 65, bfi, 67

ltucharr?, Ifenri, si, 666-667, 70.4

Ineple, Ferdinanel, 711

Hufulanl, Christian Wilhelm, 380,40 ;

Hirgh of Jucea, 142

Hughes, Giriffith, 421

Hugo serensis, 158

Hugo, Virtor, 711

Huguier, Pierre-Charles, 544

Hulliken, simon P.. 663

Hundt, Magnus, 204, $20 \mathrm{~s}$

Hunt, Reid, 707

Isabella, Quetn, 235

Ishiwara, K., 76is

Isidore of Sevill(", Bishop, 136

Israd, James, 62-

Israrls, Abraham IIartog, 716

Itard, J.-NI.-G., 662, 796

Iwte, 48

Jouffreson, Jotin Cordy, 404, 106,715

Jeanselme, Fdouarel, 114

. Tee, sir Bhatgvat Sin, 717

Jalliffe, smith Ely, 107, 701, 740, s04, 8984

Jemner, Edward, 370, 386-389, 494,878

Jenner, sir William, 164, 680

Jennings, Herlert spencer, $567,584,729,738$

Jenson, Nicolas, 186

Jenty, Charles Nicholas, 341

Jerome of Brunswick, 194

Jesty, Benjamin, 345, 422

Joachim, Heinrich, 4:, 8:1

Jobert de Lamballe, AntoineJosegh, 545

Joffry, Alexis, ti93

Johannes Aetuarius, 114

Johannes Afflacius, 139

Johannitius, 118, 119

JABOULAY, MATHIEU, 637,641, John of Burgundy, 181 762

Jacroud, Sigismond, 666

Jackion, Charles T., 541

John XXI, Pope, 155

John XXII, Jope, 2\$6

Joln of salisbury, 132, 146

John of Toledo, 134

Johnson, Samuel, 298, 290, $261,332,401,406,407,860$

Jackson, James, 46

Jackson, James, jr., 461

Jackson, John thughlings, 5s., Johnston, William it., 6ss

\section{5-696}

Jackion, Robert, 375

Jacobi, Abraham, 311, 405, . Jolyff, 246

$416,450,451,469,686-687$, Jones, F. Wood, 52 6Ss, 780,802, sos, s97

Jarobi, Johannes, $19 ;$

Jacobi, Mary Putman, 791

Jacobs, Ihenry Barton, bse. 7.93

Hunter, John, 43, 100, 112, Jarobs, S. H., S13

352-356, 346, 347, 39s, 403, Jacobson, Julius, 659

$407,535,702,772,790,877$.Jadassohn, fomef, 702 bis

Jones, John, 390

Jones, Joseph, 6si

Jones, Sir Robert, 757, s14

Jones. Thomas Wharton, 656

. Fonson, Ben, 2AS

Joseph II, 344 
Joubert, Joseph, 2sI

Jonle, James Frescett, 572

Jourlatin de Comte, 375

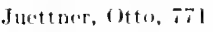

Jukes, Welward, 70!

Juliux If, Pope. 2I9

Jung, ('. J., 70)

Junse, Victor-Theselore, 709

de lusicu, Antoine-Eaurent, 316 i

Justinian, 240

Juvenal, 96, 100, 107

\section{KiALBACM, KarL, 702}

Kilkar, ,an, 21:3

Kïmpf, Johann, 320

Kienavel, Allan B., \$13

Kint, fmmanuel, 125, 815

Kitnutus, Bishop, 195

Kiposi, Moriz, tift, 702

Ki: $=t$, , ifferl, 61s, 70s

Katsurata, F., 767

von kiaul, Johan, 19:3

won Kanlbark Wilhelm, 7it

Kaye, .tohn, 189, 193

Kay-Shuttleworth, sir J. P., 712

Ke:ting, John M., 68:

1e linating Ifart, 75i

Keats, John, 61t;

Kern, William Williams, 510, 646, 19:

Jethe, Hans, 757

Selurer, Ferdinand Adolph, (6.5) Seibel, Franz, stif;

Eeith, Sir Irthur, 558, 734

Eekule, Angu-t, 612

Eeller, Arthur, 673

ieller, Fordinaml, 5.5

Eeller, William L., 814

ielley, Whard, 202

inlloge, Panl .11., s01

Eelly, lloward Atwool, 220,

$278,352,475,411$, b.5 651-652, 715, 7. 151,892

avin, Lord, $151,503,572,712$ ent, stanley, 7:34

epler, lohann, 202, 25is, 254, 2.54, 2स⿺

errkring, Theollor, 257

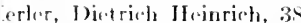

erley, Chatres Gilmore, dist

on kirn, lincent, 527

erner, Justinus, 382

ernie, Vladimir Miehailovinh, fist

lioth:tm, Johannes, 203$201,20 \mathrm{~s}$

ey, Charles Aston, 511

ey, Ellon, 739

Kesser, Thomas, $2 \mathrm{sl}$

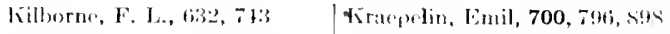

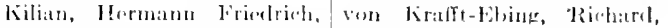
(i.i.)

701, 711, 71.7

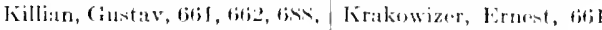
s!1

Kimball, Gilntun, itl

King, Abert F. A., 62s, 72!)

ling, John, 542

Kinsilla, Ralph Aloy-ins, s13

lipling, Rudyard, :26

Fïrcher, Athanasius, 250, 311

Kirchhoff, Gottlebsigismund, .01, 611

Kirkpatrick, James, 4:21

Kirstein, Alfred, titil

Kirntein, Gustav, biss

Kitas:ito, s., 3\$8, 627,767

Kiwiseh, Franz, 544, 0.52

Kicllahl, Johann, 594, till

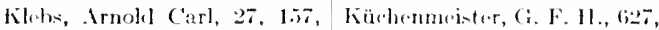
$2(19), 293,357,421-422,780$, $79: 364,859,890, \times 94$

Klebs, Wlwin, b21, 625-626, itis

von kilein, Carl tl., 4s, s99

Kllin, W., 7!!2

Kloncke, Hermann, 251, 619

Kinapp, F. C., 711

Linapp, Hermann Jakob, 660

Jindip, l'istor, 709

Kinirht, ionathan, 53!

Kinepr, ‥ Ailolphus, 7933

kinos, Robert, fos, 471-472, TS!

Kintuson, Bengt, 19.5

Kobayashe, 11. 76 sis

Lober, Greotere MI, fizs, tist, $711,799, \mathrm{~s} 00, \mathrm{~s}(0)$

hraske, Paul, till

liration, Ferlor, fill

lirels, Nikulans, 2.25

liremers, Walw:arl, s:97

lírice, liobert, bitiz

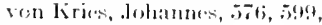
(io) 1 , bit: , bito

lirogh, August, s11

liromeker, Hugn, 32:3, 576577, $589,(60),+601$

lirinter, Bernatrl, ti-i.

liruge, filorian, diso

lirukenberar, Poter, 24

lirumbha:tr, Elwarl B,, \$1

liruse, W., 7.11

$7+1$

Kürhler, If cinrich, t.s6

Kühn, Carl (iottlob, 92, 102, 10it;

Kühme, Will, 329, 5ł2, 588589, .i(9), tili

Komatawa, X]., T67

Junkel, dohann, 2xf;

Liurellet, Ernst Gestfriet, 109 kissmaul, Adolf, fist, 670671, 6999, 70!?

Kiistor, Ernst, 6633

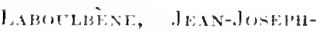
ATEX INBRE, 717

L.a ('bajuelle, .11 mit, firiz

I.adusiral, d:an, 34]

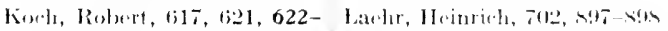
$625,626,13 ; 2,7+1$

Korher, Thoolor, 642, 732, $759-760$

Korberle, Eugène, tal3, 544$545,13.35,650$

Kisfoil, Charles . I., istir, s13

lisle, Willuelm, i.jt

kiollar, carl, oos

lämen, limis-T.-11., 420$431,15.5,725,5.2$

Jat Jot rat, I innorum lidforel, bis

Jafteur, Ilenry 1., ti>3, 7t

La Carde, Louis inatole, 754

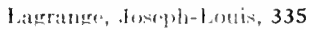

latlomint, Améder-flenti, 5i2t;

ron kiblliker, llbert, 488-490, Iamarek, hein-Baptinte, 172

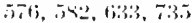

Kolluann, Julius, 2219, iif

Kislpin, Alexander, $34 t$

lioplik, Henry, tist, tist

Kopp, Johann Ieinrirh, 7:31

koringi, sintlor, fil1, fis!?

von lïrimi, Josef, 71t

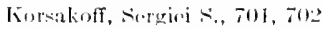

Lürte. Emil Werner. 757

Konsel, Albreht, .896, 610

komwer, B. ., ti.t)

Lovalevki, l', 1., 701

Kovalevky, Alexander Onufrievieh, itis-, 569 l.ambl, ("harles, 2!0

lambl, | Maniel smith, for

Latmbl, W., T]1

Lat Montarne, dohannes, sori

1.antis, (iovanni Maria, 215, $310,381,121$

Landerer, dllurt rigmund, 708

l.andois, fomblated, til:2, 627

Landolt, Edenomel, biti]

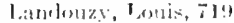

1.andry, oct:ate, to99

Ismleteiner, K., $62-7$ l.andiserer, Henry, 172 


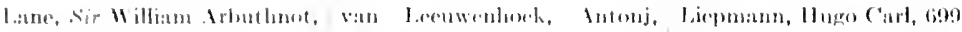
757 251252,$25 ;, 159$

l.tentsucl, demonds, 3isis

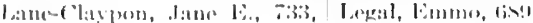
$\rightarrow(N)$

I แnfrimlli, 144-145

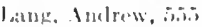

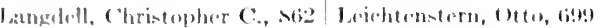

lanke , bohann, :2(1)

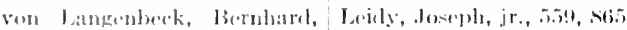
$530,13=7$

lamgenberk, comral .1. M., Leischner, Ilugo, 7(il $527,511,7 \mathrm{x}$

Langenbuch, ('irl, (illo

langhes, John Jiwnort, 333, Lembert, Jrancois-Jules, 526 005606

J.angluis, 1'., 73:2

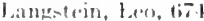

lankester, sir lichand liay. 1.:

le. Jas Jeyronie" Franceris(iierot, 110

de laplater, l'ierresinun, 335, $3(i), 1: 34,5 ! 9: 3$

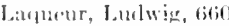

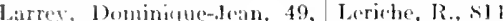

\section{$519-520$}

Jaskaris, danos, 114

Iassiar, ()scitr, 709

Latham, l'eter Nere, 446

Iathreqs, dulia C., 700

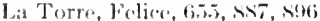

Janfer, Burtholel, 27, stif, sito

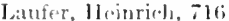

du laurens, Andrá, 27

Linth, Thomats, >T

Lavat(r, Johann Caspar, 22.), Levacher de lat Jeutrie, A.-F,$312,3 \times 2$

Laviran, Alphonke, 627, 743- Lever, John C. W., 652 744

Lavinder, Claude H., 7.42

Lavista, Rafael, 767

lavei-ier, Antoine-Iaurent, 335, 593,609

Ja Voisin, 2933

Lawrence, sir Thomas, 510

Lawrence, sir William, 5is, 6.56

Layarl, Sir Austen Henry, 54, von I,eyden, Ernst, 669, 671$5,5,1] 6$

Jazarus, Afulf, (i]s

Jazarus-[3arlow, W. S., 614 Libavins, Andreas, 202, 274

Lazear, Jesse W., 751, 752,751 Licéaga, Eduard,, 767

Leber, Theodor, 660 Iichtheim, Ludwir, 6969

Le Blon, Jaerues-Christophe, Licbault, Ambroine-Auguste. 341

Lecky, William Edward Hartpole, 771

Leclere, Daniel, 279

Le Clere, Gabriel, 275

Iee, Alexander, 866

van Leersum, E. C., 149, 175, $3: 21$

larillois, Julien-J.-('., 494 495

Jegramel, Nixi, :3477

Inidy, dostoh, 171, 559, 62s

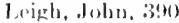

Lenuire, frotucois-, hules, (i,3)

Lemutre, Rene, >l:

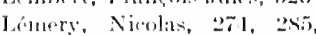
:!) 3 , 3 if

Lemos, .I., 716, 7Is

1.e( Africanus, 127

Jenn, Niolats, 235, 767, sofi

leonarelo dis Vinci, 209-210, $226,228,31: 2$

Leonicenus, Nicolsus, 186187,$130 ;, 197$

leopardi, Giacoume, 2ts

Leroy d'Etiolles, J . - J .-.J., 5:26

Le Sagr, Ilain-12oné, 3(k), 39!3

Lesplingey, Thibault, '2:';

Lessing, Ephraim Gottloll, 177,390

Lettorman, Junathan, 75]

Lettsom, John Coikley, 364, $371-372,34.5,394,404,107$

Leulse, Wilholm, (ion)

Leuckart, Rudwlph, ti27

$$
\mathrm{T}, 386
$$

Levret, Andre, $317,345,456$

Levy, Miehel, 711

Lewandowsky, Max, 695

Jewis, Morris , J, 5. S

Jewis, Thonas, 6s'2, 734, 735, Sit

Iewis. Tinothy Richards, 742

J.ewtas, J., 53.

Lexer, Erich, 758

$672,790,793$

Jestlig, Franz, 561, 733 709

lillie, lrank lanttray, 5id

Limare, "luonas", 187188 , 194

lind, damus, 375, 117

ling, Pre llonrik, Tl1

Jining, Jolın, 3:30

von l,inne, Curl, 91, 2.25, 315 $316,: 326 ;$

ran Jinsehot(-n, , J:1n, 29).

I.inton, W. . ., 29.7

Iippmann, Gabrict, 7:35

1,isfrine, dacefurs, 522

Jist(r, Joseph Jackson, 125, 6.33

lister, Lord, 633-636, 711, s7?

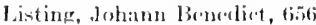

Iiston, Robert, 1.ig, 512-513, ill, fitil

Jittl., William Jolın, 5330, 699

littró, limile, sx, $90,91,92$, $206,121,717,71 \mathrm{~s}$

von Jittrow, Joseph Johann, 309

Iitzmann, C:arl C. T., $4.52,653$

liveing, Edwarl, (i!)!

Livi, Rodolfo, 5is

Livingstone, David, 7 t2

Iivs, 107

Iizars, .lohn, 517, 513

lobstein, J. C. (․ I. MI., 61s

lorke, John, 15s, 3!3!

I.ors, William d., 201, 243. 56s, Sis?

von Louler, Just Christian, $33 \mathrm{~s}$

Iofh, J:teifues, 42, 5\% 1,583 , $593,724,730-731, \times 16$

Locerch, Friedrich, $7+1$

Löffler, A. F., 3ł

Ioffler, Friedrich, 250, 623, 626,750

Iombroso, Cosare, 5st, 742

I ong. Crawford Williamson, 540

I wong, John St. John, 80:3

Iongfullow, Ilenry Wadsworth, 32, 13:

Jonghi, Pietro, 398

van de Ixm, J. II, P., 526

Joomis, Alfreel I., 684

Jooss, Arthur, 742

Jopez de II inojoso, Alphonso, 228

Jorain, Patul, 667

Jorenz, Adolf, 640

Jorenz, F., 756

von Liebr. waster, Carl, 61s Intze, Rudolf IJernann, 584

von Liebig, Justıs, 501-503, I,ouis, Antoine, 384, 386,790 593,604

Louls, P.-C.-1., 428-429, 778

Jouis XIV', 292, 296, 298, 310 
Love, Albert G, 555

Lovet, Robert W., 756

Lowe, Poter, 221

Lowell, James Russell, s05

Löwenberg, Benjamin, lifi2

Lower, Rieharil, 246, 2602, 2fit

Lucae, Johann C. A., 66:3

Lucan, 107

Lueas van Leyden, 238

Lueas, William Palmer. s]t

Lueas-Championnicere, Iust11.-11., 25, 6.35, 641

lucian, $\$ 3$

uciuni, Juigi, 5s1, 612

ucretiss, 34, 107

udemann, Johann Christoph, 40.1

sudwig, Carl, 496, 56.5, 576, $582,598-602,606$

ully, Raymond, 154

üring lleinrich 1. Inil, s!!1

on Luschan, Friedrich, is

on luschka, Hubert, fitil

usk, (iraham, 595

usk, Willi:um Thompsen, 652

utleer, .Martin, 37

ycurgus, is

1aar, Villhelu, 718

lacallum, Archibald B., 57!1, 612

facCallım, William George, $683,732,733, \$ 1: 3$

[arCormac, Sir William, (i4: acliwen, Sir William, 5.5.5, 643

acfadyen, Allan, 750, 755

aegill, James, 5337

achaon, 77, 78

achen, John, 34.

acht, 1)avill I., 25, 707, s97

arkenrodt, Alwin Kark, (a.5e

ackenzic, Sir James, 735

ackenzie, Sir Morell, 661, $66 i^{2}$

arkenzie, William, 656

aelemnan, Joln Ferguson, 5isis

ackirhad, William, 715

weMurelyy, IJelen, soo

te. Namara, E. C., 117

lePherson, John, 117

Burney, Cluarles, 647

Caw, Walter Drew, $\$ 12$

. Clellan, Georme, 537, 782

Clintie, Thomas B., 75.5

-Clung, Clarenee Erwin, 731

Crae, John, fise

Creary, Charles, jiss

Dowell, Ephraim, 507. :42-543
MeGee, Anifa NewcomL, 795 | Marie, Picrre, 693-694, 699, MrGuire, Hunter, 537 7!og, st3

McMlurrich, James Playfair, Marineseo, (imorges, 733 tis8

MeMurtrie, Donald, sa! Marius, Bishop, 114, 120

Mardelung, Otto Wilhelm, izl Mark, Leonitul, 175, 39

Maes, Nicholaes, 284 Marlowe, Clarintopher, 143

Nagati, Cesare, 274, 527 Marshall, (hirf fustire, 539

Magendie, François, 171, 47ti, Marshall, John s., tifi3 492-494, 507,585, isti, 587, Martin, August, 516, (550) $589,590,593$

Maggi, I3artolommon, 2:20

Magnus, Gustav, 335, (6)

Magnus, Hugo, s9s

Magnus-Levy, Adolf, 595, 676

Naine, Sir Ifeury, 116, nsi

Maisonneure, Jacepues-G.--T., 526,545

Major, Johann Danicl, 27:3

Makins, Sir George Ilenry, 757

Nalacarne, Vincenzo, 381

Nalfi, Tiberio, 302

Malgaigne, Joseph-François, $70,522,524$

Martin, Benjamin, 384

Martin, Ilenry Nincll, 604, $60 \times, 7 \times 3$

Martin, Sir James Lianall, 880

Martine, Cieorge, 366

Marx, K. F, I1., 94, 615, 7II

Maryatt, Frederick, (ij)

Matsacedio, 209

Mastiani, Piolo, 338

Maschek, J, 578

Mason, ('harles field, 754

Mastalier, Joseph Johitnn, 417

Natas: Jiulolph, 755, 756, 763

Nather, Cotton, 37, :38!

Mall, Franklin Paine, if66, Mathijsen, Anthonius, 526 569,590

Matout, J., 784

Mallory, Jrank Burr, 619, 749 Mattaire, Mirhel, \$9:3

Malmsten, Petr llenrik, 741

M:21pighi, Mareollo, 247, 252$254,257,264$

Malthus, Tlemas Robort, 519, 714

Mandeville, Sir John, 1S1

Mangrin, Louk, 7I 1

Mann, James, 53s

Manemvricr, Léonce, 27

Manion, Sir Patrick, 62s

Mantrona, Andre:i, 2at

Manzini, Carlo Antonio, tos

Manzoni, Mlessandro, 309

Mapw, Mrs., foz

Mapp, Mare, 40 .

Mamaclli, Francesco, 506

Maragliamo, Feleardo, 627, 677

Marbou, Bishon, 13:9

Mareellus Empirients, 11

Mareet, Nexander, 501, 596

de Marelest i, l'ietro, 27-1

Marchiafara, Etforr, 624, 67

Mareo Polo, (6.)

Matteuci, Carlo, 489, 57.

Matthaeus Silvaticus, I53154, I57

Matthis, Florian, 276;

Mattioli, Pietro Andrai, IOI, 225

Manclsley, II Inry, , 01

Maumuert de la Mofte, Guillatume, :34t

Mauricean, Francois, 277

Maturolyeo, francesen, 226

Maximilian 1, 2355

Maxwell, Sir William Sterling, 213

Xay, Johann, 231

Mardl, liarl, tito

Mayer, lobsert, f24, 572

Iayo, Clarles Jlorace, 647

Mayo, William , fames, 647

Mayow, lohn, 268-269, 318, 17is

Mand, Riehaml, 295, tofi, tor, 120

Marey, IIenry Grlande, 647, Merkel, Muguh . Mbrecht, 340 (6ist)

Nareschal, (icoreres, 29, 409

Marey, Étienne-lules, 575, Mrekel, Johann Ileinrich, fif $576,602,696$

Marfan, A.-I3., titit Durhes, , s]0

Maria There:3, 3633, 342, 412

Marianini, Stefano, 57.t

Grand Meslin, Osear, 7\$7

von Mrererturidt-Hiillesem, Le(j) (3) $7: 3 ! !$

Nogess, 100

Meihom, Ireinrirh, 247, 285

Meige, Jlenri, tis:3 
Mrigs, ("hartles 1), 511, 652

Mrigs, linums litken, 2q!)

M.inlulel, Willulm, $2 \times 7$

Mrisi-ner, (ienre, 5909

Mrister, losephe ti2t

Mnllin, (hristoph , lahob, 3it

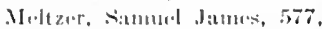

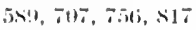

Mrenlel, Gremor Jultann, Ls!? 5..1), .7.33, 723-725

Mendel, Lafityette 13, 738

Meneltier, Pierre-Eugene, Tiz

Mrenite, Prosper, 107, 495, bitis, 717

Mrumn, 94

Metrulin, fohann, 157, 185

Meterer, Hugh, 391

Mardier, Charles Alfred, 70) 711

Merenriali, Geronimo, 92, 189, 201,222

von Mering, Joseph, 676, 70s

Merkel, Carl Ludwig, 661

Werkel, Friedrith, 210

Morkel, Friedrirh Sigmund, $5.3 t, 5)^{2}=$

Merling, Tos

Merrit, E., 6it;3

Meryon, liflward, 715

Mesner, lranz Inton, 382

Mustivier, 352

Yesue, lohtantme, 118

Misiz̈, junior [Pseudo-Mesü̈], 123

Metchnikoft, Elie, 625, 629630

Irttlinger, Bartholomeus, 190

II+1-11, Gabrill, 304, 305, 312

Jettauer, John Peter, 545

Neunier, leon, 717, s66i, sist

Ityer, Arlolf, 700-701, 79f

Heyer, E. II. F., Sit!

Mreyer, Hans, 705

Neyer, Lethar, 599, 60s

Neyer, Lurlwig F., 674

Neyer, willy, 75f

Meyer-kteinog, Theodor, 71s, 492

Meynert, Theodser, 700

de Mexiser, 375

deNezeray, François-Eudes, $17 !$

Mialhe, lomic, 591

Iibelli, Vittorio, 703

Michard AngeIo, 86.5

Micharlis, Guntav Adolf, 278 , 541,653

Michelet, 298

Miehelspacher, Stephan, $24 \mathrm{~s}$

von Middeldorpt, Albrecht

Theotlor, 531

Mirldleton, Petr.r, 391, 715
Midhleton, Thumbits, 1 s

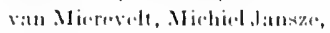
2is

van .llieris, Frans, 303, 301, 312,313

Minsther, lohann friedrich, $5 ! 96,6009$

von Nikulic\%-Radecki, .loh:1nn, 637-638, 65:s

Millar, , lohut, 3Ni

Miller, Jeseph, s1:3

Vidler, William s., sio., s7

Nillar, Willoughby 1):yton, 6(i):

Nillon, A.-1.- Eugene, 501

Nills, Chartes liarsner, 394, 697

Nills, M. P., soI

Nilne, loshua, 375

Milroy, William $F_{., 697}$

Milton, John Laws, 695, 703

Minderer, Raimund, 27.1, 276, $25,296,291$

Minkowski, (1)sar, 591, 676

Ninnins, Isate, 27ti

Iinot, Charles Sedewick, 489, 569-570, 7\$!, \&1ऽ, 8\$9

Minot, Franeis, sos

Witchell, John Kearsley, 462

Nitchell, Silas Weir, 2.j, 343. $363,366,540,542,551,+112$, 660, 697-698, 715, 776. 7\$4, 796

Mitchill, Samuel Latham, 422, 762

Withridates, 95, 103

Niura, M. itis

Möbius, Paul Jılius, 695

Mlork, Harry E., T11

von Mohl, Ihugo, 482

Mohnike, 70

Mohr, Bernard, 733

Nohsen, J. K. W., 385, so.

Nolrsehott, Jareb, 711, 790

Molière, Jean-Porquelin, 11 , 298-300, 320

Molins, Euwarl, 277

Moll, Albert, 701

Nöller, J. O. 1.., $6 \$ 1$

Molyneux, Thomas, 416

Nomburg. Fritz, 65s

Monardes, Nicolas, 239, 292

de Nonteville, Henri, 145 $146,150,174,205$

Nondino dri Luzzi. See Mun dinus.

Nönkemöller, Eduard Otto, $418,702, \mathrm{sin}$

Ionro, Alexander, primus, 336-337

Monro, Alexander, serundus, $331,337,507,534$
Monre, Alexabder, tertius, $337,557,7 \times 9$

Mout:ennana, Bartolommen, I.s. $17: 3$

Montagu, Lady Mary Wort$1, y, 27,37$

Ionteliote, sir Mloses, 111

Mosn, William, fisti

Moore, Norman, 221, 2tif, 390,116

Moore, S. G. HI., Soo

Morax, Vietor, t660

Moreau, P'- Prancis, 33f

Moreatu fele la siathel, Jaceques-lonis, 116, 717

Morehouse, (icerge Rearl, 5.10, fists

Wrow de Villiers, 800

Morestin, Jlipulyte, 759, SI4

Morgagni, Giovanni Battinta, 363-364, (i) t

Vorgan, C. Iloyel, 5st

Morean, dohn, 349, 390-391

Morgan, John, I1, 11:3

Jorgan, Thomas Jjunt, 554, 570,731

Norison, Robert, 255

Mörner, K. A. II., \$11

Worris, Sir Maleolm, 7!s

Morris, Robert T., 44, 646, $\$ 03$

Murase, dohn lovett, tisti, 6s7

Worselli, Enrico, 67\%

de Nortillet, (itlbriel, 47, 555

Morton, Richard, 27:2, 310, 311

Morton, Samuel Gorsere, 475

Morton, Thomas G., 696

Jorton, William T. G., 540541

Worvan, Augustin-\$arie, 699

Moschion, 204

Moses Maimonides, 123

Mosic, Bartholomew, 416

Nosso, Angrolo, 576, 577, ist, is $89,600,608$

Motley, John Lothrop, 295

Motherby, Gorge, 422

Mott, Frederick Walter, 701, $\$ 13$

Nott, Valentine, 509, 523524, 535-537

Mouffet, Thomas, 226

Noultrie, John, 422

Woxon, Walter, 679

Moynihan, Sir Berkley, 756757

Wueh, Hans C. R., 7I5, 750

Mujairi, K., 767

Müller, Friedrich, 595, 676, $781-782$

Müller, Fritz, 552, 568

Nü̈ller, G. F., $\$ 60$ 
Müller Il., 73:;

Mï̈ler, Hermann Franz, 75,

Mislle.r, foh:mue, 471, 476478, \, 49八, 622 6,661

Müller, W. Max, 40, Is

Müllerheim, Robert, ZI:

Mumford, hames Gregory, 39) $1,636,715$

Munde, Carl, 700

Annlinus, 150-151, 211

von Mumly, Jaromir, 712

Munk, Hermamn, 5>o, 730

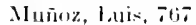

Munson, Edward L., 754, s]3

IIins-terberg, Ilugo, in 1

Murclison, Charles, 448, sol

Murillo, 310

Murlin, John R., ins, bis

Murphs, John Benjamin, 704, 762-763

Murphy, Shirloy F., 711

Nurechhauser, 11. bit

Murinna, Christian Ludwig, 517

Musier, John Ilerr, 6at

Ilusery, Reruben Dimond, 537, 535, - - 2

Nuto, , N., itio

Maybride, Eadweard, 5.56, 576

Myer, lisise W. Wo

Mynirht, Nrian, 292

Myrdarz, Paul, 3ss

Nafiele, Franz Cirt, 652

Nigeli, Carl, 453,612

Nagelseluminlt, F., 706

Nakagawa, K, T6

Napoleon I, 335, 404, 503

Napoleon III, isis

Naseher, Ignatz leog, gse

Natule, Gabriel, 279

Naunyn, Batruarel, ti37, b6s, (6t) 69, 674-676: 789, 7>1

van Noxk, Johtion, 2st

Xollam, Marehamont, 2az 291

Needham, Iohn Turberville, 329

Negri, Adelehi, 677, 743

Neister, Allert, 622, 719

Nalaton, Auguste, 5i2i, 544

Nelnes, Sitrah, 38T

von Neneki, Nareed, 70s

Noro, 10:3

Nenburerer, Max, 11, isi, bi, $106,132,135-137,114,151$, $152,154,166,173,18,5,1 \backslash 4$, $257,26-1,247,270,274,292$, $336,361,376,375,400,412$, $427,429,451,490,689,467$. $868,89.5,897$
Nomuam, Felix, 1!n

Nesmonn, Isidor, 702

Newman, Cartenal, tize

Newhohn", sir Irthur, ros, 800

Nenton, fir Inatu, 255, 2.56, :321, 72:3

Nientise, Eflouard, 145, 221, 641

Nicholats, (i. E E, bi3s

Nichols, Henry .1, 753

Nichols, John Bonj:min, 6s.s, $7 \% 2$

Ninolitior, Arthur, tiz-

Nicolatus lorentinus, 15

Nicelitus Physicus, 140

Nicelaus silernitanus, 140 , 142

Nicolle, Charles, 712, 743, 750

Nintzselse, Friedrieh, 5.50, $73 \mathrm{~s}$

Nightingule, Florence, $\mathrm{J} 1$, $712,794,795$

Nikander,

Niketas, 114

Nisul, Franz, 564

Nitze, Max, b11, tiss

Nobili, lespoldo, ist

Noble, George IJenry, bin

Norarrl, Edruonel, (62\%, 750

Noegrerath, Entil, 651, 쇼

Noguchi, HI., 7.13, 747, 76.

Noll, Friedrifh Wilhelm, bis

von Noorden, Carl, 504, 593, $59.5,676,7(0)$

Norini, 14.5

North, Elisha, 462

Nothnagel. IIermann, 672

Sott, .owiah Clark, 5iss, 547 548 , ti2s

Novy, Frederick George, 631, $7+3$

Sores, Henry Drury, 6ti1

Noge, Marriar C., 72l

Ninck Anton, 247

Nufer, Jaeoh, 22:2:

Nurbatum, Maritz, 5is

Nuttall, Georer I1. F., 501, 6:- 6332,713

Nuttall, Zeliat, Z?

Nuttine, Natry Mdelaide, Jls, 795

Nister, Pierre-llubert, is

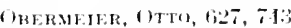

Odo of Mlenten, 1:39

O'I wyer, Iosep $]_{1}, 662$

ren Oefole. Felix, 716

orertel, Max .lo-eyh, 70!)

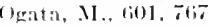

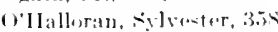

oken, lorenz, 341,449
(1) liver, ciesorge, 70s

Oliver, sir Thomas, fII

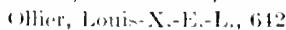

(1) Shatusen, Rolert, illi, tiso)

Omont, llenri, 11 is

Omderelonk, Ilenry . II, sist

opie, bugene linday, tis,3, 732

1),itz, litrl, 7116

(1)orinus, 213

(1)krthein, llormann, 695, (ib)?

von (Jppedzer, lohaneses, 455456 , $7>01$

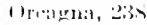

Grelponalus, bohn, 711

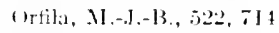

1) ribitius. 111-112

1)merod, Jomeph Arderne, 2ss

Grialls, Guntitv, lot

()rtolle of Bavaria, 190

Gibern, Henry Fatirfiłl, 16, $\rightarrow$ tiz

(1.) Horn", Thomas 13., 738

(1). ibist, 121

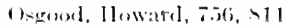

O-iander. itt

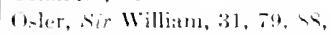
$93,95,102,10 \%, 112,123$,

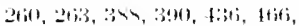
50, .t5, fi2, 682-683, ti93, 715, 7ts, ist, sti3, stif, stiti, stim, sis

van 0-talle, Mrlian. 312

Ostrieher, seblation. Sie lustrink.

O-twakl, Wilhelm, 769, sos, sil;

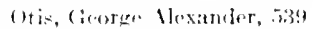

(1)tes, Juhn Conrale, 461

(1uld, ser firdeling, :317, 116

(1)erton, F... 70.

Orid, 33, $10 \%$

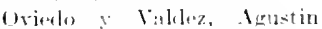
Naria, 2011, 2"2ti, 23:4

Owen, tir Richard, 473, 51!, i.il . is.

Oz:1n:1, . 1.-1.-F, 716

():แ⿰氵, К., 7t

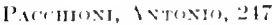

Parchom, V.-.II., bisa

Parkiarel, A, T., ti2

Packatrel, Frameris Ramlelph, 22.2, 310, 11\%,71\%, 71

Patel. Itlius, 142, 14:3, 145, $717,816,467,461$

Paten-eecher, Aluenduler, 659 Pagemeterher, Hermann, 6.54

Pagrt, Sir landes, 642

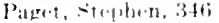


Pagnis\%, Phihipme, tom

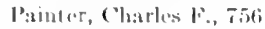
Pals n, Jann, 3.17

Paltanf, druokt, 73:3

[':m:a, P'ontinos, tite

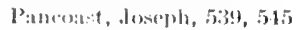

P:anizza, Bartolomeo, 5x:

l'ansier, l'., titil

Panum, Peter latuig, 151s

Panzer, (ieorge Wolferang, s:13

Paracelsus, Aureolus, $\$ 3,196$

200, 201, 768, 764,

Paré, Imbroise, $70,91,99$, $102,113,218-220,231,235$,

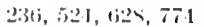

larent-1)urhitele, A.-J.-B., 7II

Parinamu, Ilenri, 660

Park, Roswell, 646, 715, s6s

Parker, Gerge lloward, 569, 570

Parkier, Peter, 6s

Parker, Willard, 46.5, 537, 539, 7.t.

Parkes, Alexander, 712

Parkinson, James, 444-445

Parrot, J.- M.-1., 717

Parry, Caleb IInllier, 370, 372

Parry, John S., (it9, 650

Pascal, Blaise, 255

Paschutin, Victor, 619

Pasteur, Louis, 503, 616, 619-

622, ti23, ti27, 634, 635, 719, 771,452

Pater, Walter, 72, 73, 76, 5\%

Patin, Guy, 2(31, 298, 302

Paton, Diarmid Noël, 733

Paton, Strwart, 701

Patton, Walter sott, 743

$P^{2}$ aul of Aigina, 112, 122, 195

Paul IV, Yopt, 12!

Paulesno, Nicholas, 733

Paulini, Christian Franciscus, 274

Pansanias, 77

Pavloff, Iran Petrovich, 42, 505, 507, 583, 591-593, 762

Pary, lirederick William, 5s9, 680

Payne, Joseph Erank, 150, $187,193,218,715$

Payr, Erwin, 753, 757-758. $76 ; 3$

Prace, Edward, 537

Peacork, Thomas Bevill, 45.;

Péan, Jules, 544, 545, 774

Pearee, Richard, 813

Pearl, Raymond, 714

Pesirson, Kár!, 5i53, 714, 725 727,729

Peclex, dohn, 272, 292, 295, 311

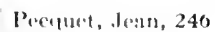

Perlider, Roburt Alexameler, (2):3, > $>19$

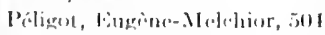

Prollewher, M., Sis

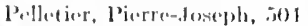

Prñaliel, Intonis, 7tit

Penfold, William dames, 7ts

l'epper, William, 084, 7s:, 751

l'ppss, simucl, 267, 270, 273, 31.1

Peres, Pierre-Francuis, hitron, 522

Pericles, st, si

Perkins, Elisha 10:

P'ernet, Goorge, s6:

Perrin, M., $46 \mathrm{~s}$

Perry, Thomas sergeant, 101

Persius, 39

Pestalozzi, Johann Iloinrill, 376

Peter of Abano, 153, 201, 208

Peter the Gre:1t, 41:3

Peters, Hermann, 10s, 237. $293,717,8 ! 77$

, lakob Julius, 716, Placido, A.,660 890, 899

Peterson, Frederick, 701

Petit, Jean-Louis, 348-349, Plato, 75, 93, 132 361 Platter, Felix, 272, 73:

du Petit, Stephan-l'ourfoir, Plattner, 59l 333

Petrarea, 175, 231

Pétreruin, Joseph-P.-F., 90, 92, 521

Petroncellus, 13s

Petrus Ilispanus, 155

von Pettenkofer, Max, 270 , $504,591,710,801$

Petters, Wilhelm, $\$ \$ 11,053$

Petty, Sir William, 273, 2si

Peyer, Johann Conrat, 277 , 264

Peyligk, Johannes, 204, 20s

Pfaff, Philipp, 350

Pfaundler, Meinhard, 674

Pfeiffer, Richard, 627, 630, 751

Pfeufer, Karl, 484

Pfizmaier, August, 890

Pflïger, Eduard F. W., 570, $590,607-608$

von Pfolspeundt, Heinrich, 193

Phayre, Thomas, 201, 23?

Philagrins, 112

Philuminus, 11:

Phipps, Henry, 791, 796

Phipps, James, 347, 3\$s

Phryesen, Jorenz, 201, 20s, 222

Physick, Philipp Syng, 533$534,539,662$
Pir, Alrien, bitiz

Pirk, lilipe fosef, tisis

inotrale belantre, lerunçois

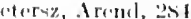

arini, 3⿻7, 424

70

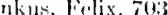

Piorry, Pierre-Arlolplie, 435, 239?

irogoff, Nikolai Ivanovich, $514,531-533,511$

von Jirqutet, Clemens, $6: 37$.

Pitcairn, Archibald, 258,365

Pitres, Albert, 5s0, (592, 70x

Platner, Johann Zatharias, 352,383

Plautus, 107

von Plenciz, Marcus Anton, 378

von Plenck, Joseph Jacob, 37x

P!ett, 3ss

Pliny, the elder, 33, 96, 97, 98, $102-103,17 \%, 186,187$

Pliny, the younger, 107

P'loos ran Amstel, Cornelis, 312

Plotz, Harry, 627, 742, 81:

de Plouerinet, G.-G., s88

Podalirius, 77

loehl, Alexander V., $7: 33$

Pogrrio, 232

Poiseuille, Jean-1.-M., 494, 495-496

Politzer, Ad:am, 662, 663, 896 Polk, William M., 650

Pollajuolo, Antonio, 209

Pollitzer, sigmund, 703

Poncede Leun, Pedro, 203,279

Poncet, Antonin, 642

Ponfick, Emil, 627

Poore, Vivian, S6?

Pope, Alexander, 294, 396, 401

Popham, Alexander, 420

Porro, Edoardo, 6.50

Port, Gottlieb, ss?

della Porta, Giovanni Battista, 225-226 
Portal, Antoine, 385

Portal, P'atul, 278

Porter, Willitm Townsend, 51s, 607, 6iti, S13

Post, Wright, :35, 535

Postnikoft, Prter V., 30.5

Pot, John, 30ti

Potain, P.-C.--1., 65s

Pott, Pereival, 351-352, 411

Poussin, Nirolas, 310

Power, sir 1)'Arey, 149, 165, $231,231,107$, i1s, 715

Power, llenrs, 719

Power, Jolu Hatrh, 556

Pozzi, simucl-Je:in, 651

Pretorius, Joh:mn, 232

Prausnitz, Wilhetn, 711

Pravaz, Charles-Giblicl, 526, 708

Praxagoriks, 9:3

Praxiteles, !12

Preciani, 1ti

Preston, . Inn, 791

Preuss, Julius, 62, 716

Prevost, Fratucois, 514

Prevost, Nicole, 140, 143

Price, Gerser M., 711

Price, Jos(ph, 6.50)

Prichard, lugustin, 451

Prichard, James Cowles, 434, 702

Priessnitz, Vincenz, 709

Priestley, Joseph, 334-335

Prieur, A., 71s

Primaticrio, Franceseo, 115

Pringle, Sir .Joln, 373-374, 420

Prior, J., 1527

Prosper Alpinus, 6\$t)

Prout, Willi:ım, 505-506

Prowazek, Stanislaus, 750

Prudulen, Theophil Mitchell, $618,79)$

Ptolemy, 13:2

Puceinotti, Franceseo, 717

von Pufendorf, Samul, 280

Purchits, Siamuel, 29:2

Purkinje, Whannes Evangelista, 486-488, 19.5, 591

Purmann, Mattheus Gottfrick, 276

Puschmann, Theodor, 716, 867

Putnam, llolen, 739

Putnam, Jamest farkoon, 740

Putnam, Mary Putnim, 800

Pye-sumith, Philip IIenry, foso

Pyl, Theodor, 3til

Pythagorats, 36, 81-83

Quan, Jones, Jiso

Quain, Sir Richard, 719 de Quatrefages, Armand, 249, | Reirlyling, Dich rich, 719 $554,1 \mathrm{ilt}$

Quénu, li., 7iss

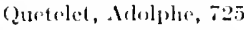

(2uillet, Clatule, 279

(2uincke, IIrinrich, 695, 750

(2uiney, John, 356

Quintilian, 9s

Rabelais, François, 44, 92, 189

Rachford, Benjamin Knox, 687

Radcliffe, ,John, 405-406, 407, 411

Rademather, Johann Gottfriect, 460

Racburn, Samuel, 398

Riahere, 171

Rahn, Conrad, 599

Raimbert, louis-Adolphe, 628

Ramizzini, Bernardino, 292, $310,324-325$

liambounek, Josel, 711

Ramón y Cajal, santiago, 563, 766

Ramsbotham, Francis Henry, $31 \mathrm{~S}, 6.52$

Ranby, Jolin, 411

Ranvier, Louis-Antoine, 562

Riphael, 23s

Ritsori, Giovanni, 97, 427

Rattray, Sylvester, 289

Ratzol, Frielrich, 1s, 554

Ravaton, Hugues, 375

Ray, Isaae, $341,467,714$

Ray, John, 255

Raver, Pierre-F.-O., 435

Rayleigh, Lord, 572

Raynalde, Willian, 102, 190

Raynaud, Naurice, 299, 300, 6999

Read, sir William, 400

Reacle, Charles, 775, 795

le Rénumur, lento-A.-l', 328329,505

Réamier, Joseph-C.-A., 544

von Rreklinghanem, Friodrich Danicl, (its, 703

Rerklinghausen, Max, 750

Redi, Franoese'o, 24.5, 254255, 25.5

lieel, Walter, 6i29, 751-752, 7.33

Regensburger, Mistin, Txo

Rolnn, Ionis, 612

IRoich, $F$.., 711

yon Rrichenbach, karl, 38:

Reichert, Edwared Tison, tily (i)

Reichert, Karl Bogrislates, 179
Reiul, Willian W., 53!)

Raicle, Thomats i)irkson, 375

Rerilf, Waliher, 1 m)

liril, hohann Chrintian, 379

$380,118,131,151$

lamblarcl, lolix, 50

Rcisch, Girengr, 201, 20s

Reisinger, Franz, 65t;

Remak, IRobrit, 179, 495-486, $49.5,70 \mathrm{~s}$

Rembrandt van Rijn, llar-

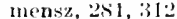

Remmelin, Johann, 248

Renaudot, Theophraste, 2s'2

Respighi, Emilio, 70:3

IRctzius, Magnus Christian, 662

Retzius, Magnus Gistav, 5.54, 563

Reverdin, Jacpues-1 suis, 642, 733

Reynolds, fir Joshua, 398

Rh:izes, 119, 121, 125, 17x, 446j

Ribera, Jusepe, 312

Ricarcus Anglicus, 150

Rirarclus sialernitanus, 140

Ricluardson, vir Benjamin

Ward, 29, 252, 715, 71s

Richelieu, ('ardinal, 296

Richer, P'uul, 5ist, 693, 775

kicherand, Anthelmo-Balthasar, 520

Richet, Charles, 606-607, 622, 719

Richmond, C. M., 66i:3

Richmond, John limbert, 544

Richter, Auguat cottlieb, 350 , 411

Richter, Paul, 19, sis, 311

Richter, Wilhelm Michatel, 716

Ricketts, lloward Taylor, 712. 75.5

IRiord, Philinpex, 435-436, ti.30 rlo. Riemer, Pieter, s.3.3

vin Riomsliik, Joinnes, 341 , 317

Riesman, Darid, (i1s, s6.5

Rigers. John M., 3.96, (36;

Rillict, Freleric, for

Rindthei:ch, litharel, fis

Rinerer, sirlnar, (606, 703. - (1)

Rintre, . 1., 60:3

Rielan, Jeat1, 211

Rippstrin, H., bots

Ritaren, Forelinanel 1. М. F. $\therefore 11,514$

Rifter von Riffershain. Costfrimel, $703, \mathrm{~s} 9 \mathrm{~s}$

Riva-Roerei, seripones, tist

Rivers, W. IH. R., 23, 27, 17 
lininus, hugustus Ghirinus, 255. 3411

listurert, tiatis

lisluertom, dolın,

linluerts. Jobn 13.. Titi

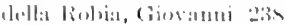

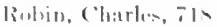

liobinson, Andrum liand, 70:3

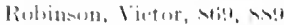

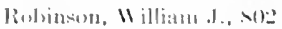

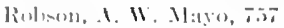

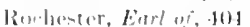

lioulgers, Juhn kivarny, sise, sis

limbin, Inemste, -75

lislriguez, Juan Maria, 767

limelriguex Mende\%, Rafacel, 7†

Roulerer, lohamn Gieorg, 116, $1: 1$

Romlants, ('ormelius, 190

liomer, oluf, 2uss

Reentern, Wilhelus liontad, (i)ti, Tos

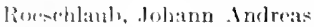
$1: 27$

Ruger of l'al:armo, 141-142

Rogers, 1)avid 1.., 537, 533

Rogers, sir Leonard, 147, 708, 713

Rohule, Erwin, 74, 75

liohé, George II., 711

Rohlfs, Heinrich, 716, 7ls

Rokitankky, Carl, 454-455, fi $1.5,6.53$, , is $)$

Roland of Parma, 141

Relametr, Daniel, 408

Rolanto. Luigi, 5s1

Rolfink, Werner, 2s3

Rolleston, Humphry Davy, $3 . \overline{1.5}$

Rollo, John, 3st

Romanes, Georg- John, 5st, (i) ().

Promanovks, Dinitri L., 628

Romlore, Moritz Hesnrich, $689-690$

Romilly, Sir Simuel, 79s

van Roonhuyse, Ifondrik, 278-279, 54:;

Romea, I). Is. st. John, fif:

Roosevelt, Theodore, 131 I

Rorie, David. 34

Posa, Elward Bennett, 595

Pose, F., 504

Rose, Valortin, 102, 107, 716

Rosit, Wirkliffe, 7.12

Porén von Roumetein, Nils. 344.416

Romenau, Milton Inseph, 627. 711,752

Rosenbach, Ottomar, 591, 662

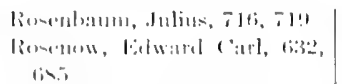

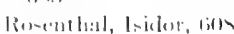

Ruslin, Fucharius, 10:2, 113 , 100

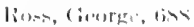

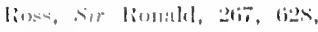
744

Roman, 1,oon, tiv?

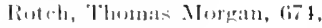
687

Rath, ()tto, i Is

lietlı, Vlatimir hitrlovicl, (i)

Rethmann, $1: 21$

de Rothathilil, llenri, st?

Romalle, iss.3

Rominat, . ., 712

Pons, leyton, (ils, 750

Rousoneatu, dean-Jacegues, 360 , 419

Rotustel, Theophile, 7.12, 800

Rouxet, lrangois, 222

lonx, C'enar, 7for

Roux, Finile, (i2) 6i2, (i2). 6.30

Roux, Plilibert-loseph, 522

Roux, Willelu, 570, 571, 719

Rowlanel, Henry Augu-tu- 31 . 575,917

Rowlandson, Thomas, 398

Rowntree, Leonard R., 441, 6s:! 707

Roy, Charles Soott, 603

Rubens, Jet:r Paul, 247-248, $303,310,312$

Rubner, Max, 594, 674, 711 , S 93

Rurlluesk, Olof, 246

Riulinger, Nikolaus, 676, 734

Ruclolih. I1, 201

Rueff, .Jaeob, 190

de la Ruelle, Jean, 101, 224

Ruffer, Sir Nare Armanrl, 52, 53, 5.55

Rufus of Fphesus, 102

Ruge, Carl Arnold, 6,51

Ruhräh, .Iohn, 68т, 721

Ruini, Carlo, 228, 274

Rumforel, Contut, 407, 711

Rumno, Gactano, fit

Rumpel. Theotor, fis

Rumsey, Henry Wylabure, 712,711

Pusch, Adolf, 157

Rush, Benjamin, 3s9, 390, 393-395

Ruskin, John, 209, 3.54

Rus, V. K., 750

Ru-sell, Frederick F., 753-754 liusinell, P'atritk, 447

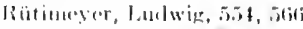

Ratty, lobte, :38:3

Raypel, lindirik, 297, 248, 219, :24,

Rinul, francis, $438, \vec{\imath} 0 \mathrm{~S}$

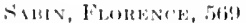

siabusamul, Raymonul, 1:37, 702

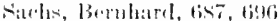

von siachs, Julius, s.t?

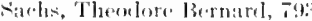

Silrepert, Karl Willulu, F!H,

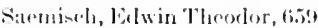

satTurd, William li, 2, 29, 292

Salıli, Ilermanu, 70

16. Sime Anmuel, Jean, 153

firint lbaril, lit

Sitint Renecliet, 136

suint Chryostom, 11

saint Franeis Xavier, 70

Siant llilderarele, 141

sinint lerome, ltit)

sit. Martin, Mloxis, 506

saint Teresa, 267

siant Vincent de Paul, 311

sainte Beuve, Charles-Augustin, 395

Sajons, Charles E. de M , 732, sos

Salicetti, Guplielmo, 143-144, 110

Sialignae, 235, 236

Salkowski, Ernit, 610-611, (issi, 6 sis?

Salmon, Daniel Elmer, 6.32

Salmon, Thomas William, sl3

Salvage, Jean-Galbert, 312

Salvenmoser, 59!

sambon, lonis Westerna, 712

Sanarelli, Giuseppe, tit., 7.jl

Sianderson, Sir John Burdon. Sie Pardon Sanderon.

Samelifort, Eluard, 326, 33S, 6.53

Sandström, Ivar, 5is6, 73:3

Sänger, Max, 6.50, 6.51

Santorini, Giovanni Domeniuro, 338

Santorinos, Jan, 11.

Santorio, Santorio, 258-259

Siantos Fernandez, Juan, Tfi

Sappey, M.-P.-C., 5.j6

Sarrent, Jolun Sinerer, 775

Sarton, Cienrges, S66;

- Gauerbruch, Ernst Ferdinand. 755-756

Sauter, J. N., 547

Savage, $\mathrm{C}, \mathrm{C}, \mathrm{,}, 6 \mathrm{6}]$

Saxtorph, Mathias, 347 
Sayre, Louis Albert, 539, 647 scanzoni, Friedrieh Wiheln, $613,6.52$

Scarborough, sir Charles, 216, 2,1

Scarpa, Intonio, 33ss, 343

sibufer, sir lodwarl A., bl2. (it1, 704, 7i32

Sethafer, Aifred, stist

Sehambere, Jay F., 70:3

fihatulinn, fritz, 741, 744746

seherle, dlax, Fi:

sehelel, Hartmann, Ja?

sicheete, ('ant Wilhelm, 59.5

scheiner, Christoph, 259

sichelent, Hermann, 70.5, s97, 900

sirhelling, kontrat, 152, 42.5

Shenenek, Benj:unin R., 627, 70:3

Schereshewsy, Joseph W., 799

Schick, B, 750

Schiff, Xloritz, 597-598, 732

von 'chiller, J', 324, 327, 341, 400

von Shlijerning, Otto, s12

Schlatter, Cart, bill

Schlegel, Friedrich, 451

Schleich, Carl ludwig, 75:

Sehteiclen, Natthias Jarob, $480-481,482$

Schliemann, Joinrich, 71

Schloesser, Karl, T0s

shblotfer, II., T.t;

Schlusimann, Arthur, 674

Schmaus, Leonhard, 1s:3

Sehmict, Alexander, 5i2, 602

Schmidt-Mülhrim, Molf, roo

Schmidt-Rimbler, Hermann, 660

Schmiedtherg, (0)walfl, 596, (600, 704-705

Schneider, Conrad Victor, 247 , $26 \pi$

Sehoepf, Johann David, 25, 390

Schönlein, Johann Lacas, 450451, 702, 7TS-77!)

Sehounlein, Karl, 5og

Sehott, Johann, 201, $20 \mathrm{~S}$

Sehot, 'Theodor, 709

Sehratur, Max, 676

Schreyer, Johann, 27:3

Sehröler, Kiırl, (i.j)

sehroefor van der kolk, Jacol, 65:?

Sehultex, Johann, 276

Seluultze, Max, 15:3, 560-561, $563,564,660,661,662$

Schüt zenberger, Paul, 611, 736

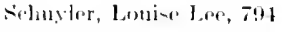

sichwabe, ly:micl, 270

s.thwann, Theorlor, 481-482, 14. 507,575

Shwartze, llermann, fitis

Shweigger-koidel, Franz, sh. (6)1

de sichweinitz, Goorge E., (icil scott, sir Wilter, $116,39 s$

sitribonius, (i. A., 272

Scribmins Latrous, 107

solutedus, dohann, 276

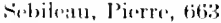

sibiz, Mrelehior, 272

simerla, legidion, T:3:3

Suflewiek, Julins Parker, Gss

sedeniek, lerenarel W., 71 !

serburek, Willian Thompson, (jo) $, 711, \mathrm{~s}(0)$

Séclillot, Charles, 526, 641

sectig, Major (iabriei, sia

Séquin, Érlousard, Tis, 7!n

Seiler, Carl, bifiz

Noligmann, Franz Romeo, 717

Soligmann, sionfried, 3\&, 3!)

sellarels, Andriw Wation, 750

somaslweis, lgnaz lhilipm, 457-459, (335)

somon, sir Jinlix, 662, 732

te senae, Jean-Baptiste, 3St

Senator, Hermann, 618, 672 673, $7 \mathrm{~s}(1)$

Senckenbere, Johann Christian, $37 !$

Senn, Nichol:1s, 646, 762

Sonnert, Danicl, $261,271,236$, 311

Sirenus Samnonirus, Quintus, 105

Sergi, Ginkepper, 554

sertumer, Friedrich Wilhelm 1.t:111, 5) (1)

Servefus, Mictiol, 214, 216, 212,76

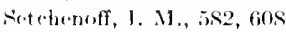

siver. James W., 756

Surerino, Mareo Auralio, 249

sererinus, Peter, 199)

Ar. Sevigne, Madame, 285, 293, 292

Sewall, llesry, 606

Shakespeare, Etward O., fi2! 753

Shakespeare, William, 26, 3! $90,200,231,290$

Sharp, d:ine, 27\%

Sharpey, William, 4S9, 800 fio: 2,633

Shastiu, Thomas Ilall, soge

Shattuek, (ivorge Brmue, sols

Shaw, Bernard, 5\&1, 771,
Sherrington, Charles fieoft, $194,5,2,583$

Shew, dor!, 709

Shigi, lsigriogi, 627, 741,767

shipum, Willism, 392-393

Shrarly, (iongr. F, sos

Sibson, limaneis, 4t6

Siearel, Arthur, 7.0

Sieari, C'ururron, . J the, $36 \mathrm{ti}$

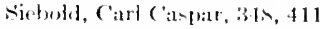

von siedold, cart pheotor Eimst, 1s?, tiz

von sielold, Estuard Caspar Jacob, (65), s195

Siegrmumlin, Justine, 278

Nigitult, J'tun-Rent, 317

Silvation, (irambitt ista, 201

Simms, Jamos Marion, 539, 545-547

Simen, (int:1v, 531, 539

Simon, sir .John, 712, s(0)

Simuln, N:1x, 107

Simon, Throdore, 738

Simonin, M., 75s, \$12

Sinumon, fir damess Young. $5+1,213,653$

Sincitir, M., M14

singer, Charles, $41,111,178$, $1 \times 1,201,205,226,2191,715$, $\rightarrow 69$

singer, Dorothea Wale!, IsI, S(6)

Sinklar, Whartom, tiss, bet

Skene, Alexamler J. C., fiis

Skorlit, Josed, 1.60, 453-454

siarlen, J. J., tos

sloane, vir llans, 3\$7, 405, $466,104,411,119$

Hye, Mand, TIS

Smart, Charlos, 53:9

Sucllir, Willi:um, 345, fis.3

Snith, Girston Elliot, 17, 18, $47,52,74,352,510$

Sunth, Grah:tu, 713

Snith, Ilenry, 765

Smith, lamrs, 3s!

smith, Jub l.awis, (ist

Stuith, Nith:1n, 534-535, 53s, .3:9, 543

Suith, Nithan Ryno, 539

Snith, liohertson, 33

smith, stephen, sol

smith, Therobsld, 6i21, 6:27, 632,713

smith, Thomas southwood. 712

Sinollatt, Tobits, 146, 399, 100 smyth, Indrew Woods, 5isi, 537-538

snilu, Indrew, 271

Surllen, llemann, fisf

snow, John, 713, s01 
Sobotta, Joh:tunes, 5.5i, 569 Socin, Auguale, ti]: von sismmering, simmel

I'homts, 2962, 327, 330, 33:3

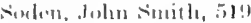
sulis-Cohen, Jatol), titil, titi2 silis-Cohen, Sulonnon, 3336, 731

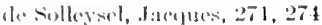
sollmann, Tor:als, 707

sommer, Robert, 701

Soramus of Ephesus, sti, 102, 107,111

Sirtis, Jules, 6999 sumberan, fugene, 502

souchon, bilmond, dist, ts?

souques, Achilla, s1:3

South, John Flint, 518, - 1 is

Southes, Robert, 10:3

Souttar, II. 1)., sil

soxhlet, frumz, (i)2

Apach, Isracl, 222

Spadara, Miceo, 310

Sparna, G., $23 \mathrm{~s}$

Spalding, Lyman, 752

Spallanzani, Lazaro, 329-330, $356,50.5$

Spalteholtz, Werner, 555, 6s3

Spencer, IIerbert, 550

sipengler, Ciarl, 7.50, 793

Spiegelberg, Otto, 652

van Spicghel, Ailrian, 248, 249 , 271

Spinoza, Baruch, 2so

Spitza, Edward Anthony, 5is

Spitzka, Edward Charles, 701

Spivak, Charles D., ti2, 6as, 715, 721

spreckels, Rurlolf, 782

sprengel, Christian lionrad, 311

siprengel, Kurt Polyearp, 112, $160,162,385,899$

Apurzheim, Johann Caspar, 579 .

Ssoboleff, Leonid Vasilievich, 732

Stacke, Ludwig, 66:3

Staflemann, Ernot, 675, 676, 703

Stahl, Georg Ernst, 272, 310,

$317-318,334,348,358,453$

Stair, Earl of, 374

stanley, Elward, 691

Stannius, IIermann, 602

Sitarling, Ernest IIenry, 590, 732,733

Starr, Louis, 687

Starr, M. Allen, 688, 790

Nitasen, S11

Stearns, John, 6.52

Steflman, Thomas L., 719, sos

Stcen, Jan, 30 ?
Stenger, le. d., stiti

sitcin, ficotg Wilhedul, 6.53

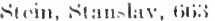

strinlurim, sillemum Jevi, bs?

stoinseluncicler, Meritz, 123, 125,710

Strinthal, Martin, tis?

stedlwar von Carion, Carl, tisti stronger, dlforel, tists

Stenn. Sire stanarn.

Ntunsen, Nids, 217, 264-266

Stephanus. Sir Botienne.

Stepholuson, 'Thentas, 711

starnbers, (icorge Miller, ti27, (i2?), 751

Sterne, laturence, 11

Stevens, Georga T., fitil

Stevens, doanna, 10:2

Stevens, Willian, 519

Stevenson, Robert Louis, 4t, S6.5

Stewart, Alexancler Patriek, 461

Stewart, Charles, 383

Stewart, George Neil, 606

Stieker, Geork, 1s1, 310, 716, sio

Stiles, Charles Wardell, 741, sss

Still, George Frederick, 681

Stilli, Alfred, 46it, 685

Stilli, Moreton, 714

Stilling, Benedikt, 543, 557

Stimpson, Julia, 795

Stimson, Lewis Atterbury, Symons, Arthur, 39 647,650

Stirling, William, 245, 25I, $496,601,602,789,897$

Stoerek, Anton, 378

Stokes. Adrian, 814

Stokes, Sir Groorge Gabriel, $60 \mathrm{~s}$

Stokes, Whitley, 437

stokes, William, 439-440

stoll, Maximilian, $378,395$. 421

Stone, Riehard French, 717

stoter, Horat io R., 895

Story, Julian, 7at

Strabo, Walafred, 137

Stratz, Carl Jleinrich, .5.5t

Straub, Paul F., Tist

Nitrecker, Adolf, 504, 591, 596, 611

Streeter, Edward C., 146, 1.18, 200,208

Stricker, Salomon, fis!

Stromeyer, Georr F. L., 27s, $523,529-530$

Strong, Richard P.. ilt

strümpell, Adoli, 695

sturm, J. C. F., T6.5
Sulhof, Karl, :36, 19, 52, 53, $5(6,57,60,95,103,109,114$, $12.2,136,133,139,111,1.13$, 150, 15s, 14i5, 167, 171, 175, $179,1 \times 1,1 \times 2-151,159,191$, $192,19 \%, 195,200,201-201$, 210, 2311, 210, 717, 715, 768 770, stiti, sti7, s93, s9\%, s98, s.99

Sinetonitus, 107

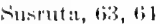

Sissmileh, Johann Peter, 325326,120

Sutton, 1):minel, 421

Sutton, lioslsert, 421

Sutton, 'Thomis, t6i3, 689

Suzuki, Ml., 767

Swammerl:an, Jan, 2.18, 251, $\div 73$

Swan, Jeseph, 5s:

vin Siwieten, Gerlarel, 321, $314,377-378,416,813$

Swinburne, Algernon Charles, $131,170,293,313,739,800$, $\$ 67$

Sydenham, Thomas, 269-271, $293,295,310,311,749,884$

sykes, J. J'. J., sou

Sylvester, Joseph, sti:3

Sylvius, Franciscus, 260-261, 310

Sylvius, Jacolus, 211, 212, 216

Syme, Jannes, 513-514, 633, 635

Tarites, $107,161,551$

Tagliacozzi, raspare, 221

Taguchi, K., 767

Tait, Rolert Jawson, 548, 635, 648-650

Takamine, Johiki, 708, 732

Talbot, Fritz B., 545, 6Ss

Tamburini, Augusto, 677

Tanquered des Planches, L.T., 711

Tanzi, Eugenio, 701

Tarlieu, Auguste-Ambroise, 714

Tarnier, Etienne, 652

Tavernier, Jean-Baptiste, 295

Tawara, s., 734

Tay, Warren, 697

Taylor, Cheralier, 401

Taylor, E. W., 6\$6

Taylor, James Madion, 710

Taylor, James spottiswoode, sim?

Taytor, Rolyert William, 703

Teale, Thomas Pristgin, 427, 518 
Teichmann, Ludwig, 504

Toidhuever, llermann Friedrich, 3 st

Telesphorus, 77

Toniers, 30:3-304, 312, 313

Tennent, John, 390

du Tennetar, Nichel, 3st

Tennyson, Alfred, 39

Tenon, Jakobus Renf, 417

Terboreh, Gerard, 312

Terence, 107

Terrior, Louis-Félix, lit2

Testut, Jatn-16́o, 5.j6

Thacher, James, 280, 306, 389, 391,715

Thackeras, W. M., 775, 776

Thackrah, Charles Turner, 446,711

Thaddeus lilorentinus, 153

Thales, 80

Thaon, Louis-Albert, 667, 699

Thayer, William sydncy, 683, 684

Theden, J. C. A., 411

Themison, 97

Thénard, Jaerjues-łouis, $59 \mathrm{I}$

Theocritus, $\mathrm{S3}$

Theodorie, Bishop of Cerria,

$142,147,167$

Theodorus Priscianus, 108

Theophilus Protospatharius, 114,141

Theophrastus of Eresos, 9394,100

Thévenin, Frangois, 280

Thevet, André, 201

Thewlis, Malford W., $68 \mathrm{~s}$

Thierfelder, IIans, 591

Thierfolder, Johamn Gottlieb, 716

Thiers(b), Karl, 618, 638

Thiery, François, 381

Thiry, Lawlwig, 600

Thölde, Johann, 197

Thomits, Henry M., 68S

Thomis, Jlugh Owen, 643, 755

Thomas, Theodore (iaillare, 548, 650)

Thomas, William 1., 21, 5.5.5

Thompson, J)ora E., 7.5

Thompeon, W. Gilman, 711, 709

Thomsen, duliu, 699

Thomson, Benjamin, 497

Thomson, sir II (nry, fitl

Thomson, William, 660, 695

'Thoreat, Ilenry Daxid, 251, t(in)

Thoringt on, Jimes, 6 (6)

'Thorpe, wir Edward, 2St;

Thoth, 49,51

Thurydirles, 72, 90
Thuillier, Charlen, 271

Tsebermitk, E., 721 203

Tichomiroff, $A ., 731$

Tichy, Joseph Wenceslaus, 383 Tullicr, Marin-Thécolore, 753,

Tiedemann, friedrich, 506

Tiepolo, 39s

Tigerstedt, Rolnert, 577, 6\$1

Tilesius von Tilenau, W. G., $3 \mathrm{St}$

Tilt, Edw:ard Jolın, 544

Tilton, tames, 391

Timoni, Emmanucl, 387, t21

Tissot, Simen-André-1)., 380, 404,407

Titian, 213

Tizzoni, Guislo, (i2s, 732

Tobler, Ludwig, tizt

Todd, John Lancelot, T+3

Toldt, Carl, isi;

de Tolosa latour, Manuel, 767

Tomes, sir Juhn, 664

Tommasi, Nilvatore, 677

Tommasi-crucleli, Corrado, 626,677

Toner, Joseph Meredith, 307, 715

Tooth, Henry lloward, 69:

Topinard, Patul, 554

Torney, George H., 75:3

von Török, Aurel, isst

della Torre, Nare Antonio, 209

Torti, Francesco, 381

de Tournefort, doncph-Pitton, 255

Toynbee, ,Joseph, 662

Triadeseant, John, 306

Trugus. S'st Bock.

Trall, Ruswoll Thacher, 709

Traube, Isidor, (j12

Traube, I.udwig, 602, 615, 668, 669-670, 77!

Truube, Morit $\%, 612$

Travers, Benjantuin, 427, 511, 656

'Frélat, Ulyisere, (ite

'Frembley, Abraham, 330

Trenholme, E. H., its

Treverus, Peter, I9:5

Treves, Sir Freclerick, 644

Tripler, Clatrles - ., 751

ron Trïltsth, A. F, 662

Trommar, iot

Trommedorff, Jolan Bartholomii, 416

Tronchin, Théculore, 380-381

Trotter, Thom:t: 375

Trotula, 140

Trousseau, Armamd, tifi1, 665, Van Gehuchten, Albert, 556, $6660,691,6999,780,8633$

Trudeat, Edward livingstone, Van der Gucht, (ierard, 351 793 ichirch, Alexander, 172, 223, 2.39, 29.5, 705

Cubby, Alfred Henry, 75

758, s1:

Tuke, Dani,l Hack, 699, 796

Tuke, Willi:ın, 4ls

Tulp, Nicholis, 272, 284

Türrk, Lutwig, 459, 552, 6f

Turgenielf, Ivian, 5333, 776

Tumbull, Lawrence, 662

Turner, Daniel, 122

Turner, sir William, 558

Turquet de Mayerne, Theodore, 263,295

Tylor, sir Edward Burnett, $40,318,555$

Tyndall, John, 712

Tyson, Edward, 249

Tyson, James, 685

Tyzzer, E. E., 618

VON СExKÜLL, .J., 577

Iffelmann, Julius, 711

[ffenbach, Peter, 274

Clsenius, Theodoricus, 182 , 237

Enderwool, Mirhael, 381, 418

[nna, laul Cirrson, 702-703, 708

1 rbantschitsch, Victor, 662

Ire, Alexander, 503

Estinovitch, C., 600

Valentin, Gabriel Gustav, 450 . $487,586,612$

1 Valentinc, Basil, 197-i 98

Valentini, Michacl Bernhard, 351

Valescus de Tirant:a, 35, 36, 159

Valsalva, Antonio Maria, 338, 361

Valverde de IIamur(o), Juan, $21 \times$

Vian Buneten, Fidlousurd, 567, sti?

Van den liongaterdt, Ilerman, 306

Vinnlorugh, sir .John, 398

Vian Buren, bohn, 123

Vin Drek, Anton, 312

Vingleetti, $(5 ., 756,811$

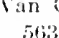

Vitunez, Henri, 667
Twitchell, Amos, 537

Valader, A.-C., t6t33, 814 


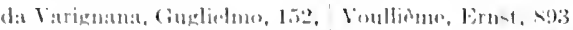
$2: 31$

Vitubigen vin linne, Raliel. $7: 3 ! 1$

V:aroliu, ('ostitnzu, 217

Vassale, cimber, $7: 3: 3$

Vitter, Alraham, :3:3s

V:tulinus, 2!ni

Vaughan, Vietor clarenes, i(t), (i2!), 631, 7.83, s

Voduler, litwaril 13., 70s, 754

Vegentius, 114

Veit, Johamm, tisil

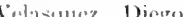
$31:$

Velpeatu, 1.-1-1.-11, \$2:2, $523-524,771$

Vimel, Jean-Inelre. 349

Vernevil Iristide-inguste. 641

Vironese, Pablo, 2:34

Verworn, Max, fil:

Vesalius, Indreas, $61,89,105$. 106, 11!, 211-214, 21s, 2:31, $242-213,245,771,855$

Vesling, folnann, 210

Vitch, John, (i.5), 6ist)

Vicurs, Thomas, 194, 214, 231

Vicel at'Azy, Palix, 341, 34t;

Vidius. Sof Ciuidi

Vierordt, liarl, 60102, fists

Vieusiens, Raymond, 247, 261, $25: 3$

(1. Vigevano, (aublo, 150

di Vigo, Giovinni, 219, 220

do Vigo, Juan, 292

Villemin, Jean-Antoine, fil9. 664-665

Vindicianus Afer, 10s

Virchow, Rudolf, 16, 47, 170 , $143,266,317,356,363,425$, $451,454,455,474,141,5.23$, $554,555,558,560,562,567$. 611, 612-616, 8f99, 710, 711 $715,779-780,855$

Virgil, 107

Vit ruvius, 97

de Vitry, Jafques, 17?

Vires, Juan J uis, s1.

Voentlin, Carl, 733

Vogtherr, (i., 195

Vogtherr, lleinrioh, 204

von Voit, Carl, 590, 594, 607. $\rightarrow 10$

Volkmann, Alfred Willrelm, $5 \times 2,602$

von Volkmann, Richard, 638

Volfa, Alessundro, 333

Voltaire, Francois-MarieArouët, $3 \mathrm{sin}$

Vöter, Christoph, 276

Voltolini, Rudolph, 662

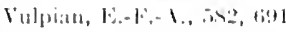

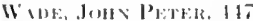

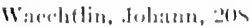
Wilgner, ('lintom, titiz

Wugner, Erust, 70:3

Wigner, liwbard, 21, 11]

II:tener, limlole, 179, $1 ; 12$

Walcher, Ciustav Wholi, 12z, (i.5.)

Waldendaurg, Janis, 3:30 andarer, Willetm, 556, stil Exis

Waldavein, Nir Charles, >.

do $1 V_{\text {iale, foum, } 244}$

Wallare, Alfred liused, 5t!t, 5.) (1)

Wallare, William, 43N

Waller, Iugustuk 1) eisiro, 73.5

Waller, Augnstus lolney, 563, 579, 5x

Wallix, Jolin, 27?

Wakh, James J., 109, 14.5, $117,152,163,164,170,231$, $246,295,715,773,891$

W:kls, John, 33:3

Walter, Friedrich, 70:

von Walther, l'hilipp Franz, $(i, \bar{i} 6 \mathrm{j}$

Walton, Hice, si:

IValton, John, $3: 40$

Wandelaer, Jin, 313

Warburton, Lord, 172

IV:ard, Joshna, 401

Wardrop, James, 517-518, 6.56

Ware, John, 462-463, 6s?

Waring, Edward John, 447

Warren, John, 357, 391, 534

Varren, John Collins, 534, $535,541,80 \mathrm{~s}$

Warren, John Mason, 53S

Warren, Joseph, 3!)1

Warren, siamuel, 7.76

Warthin, Allred Scott, \$14

Washington, George, 341, 394, 123

von Wasermann, Ausust, 747

Waterhouse, Bunjamin, 3si

Wateson, Georee, 201

Wathen, Jonathan, 3til

Wation, Almiral, 375

Watson, Irving Allison, 717 , sio?

Watson, Robert, 3st

Watson, Sir Thomas, 445

Wation, William, 3St

Watt, James, 336;

Watt, Robert, shs

Weber, Eduard Friedrich, 497-498
W'Mrr, Ernst Jleinrich, 496498, istis, int

Weber, l', Jarkes, TIT, S\$.

Wraler, Harman, (it)!?

Wiser, Wilhulu lidluard, 498

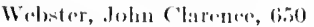

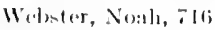

Werlasberg, F., TI!

de Wieker, louis, ditil

Wedensky, N. 1., 57s

Wiacks, John E., 1;21, bijo

Wricluscllyum, Inton, 618, di27

Weigert, C:srl, inti3, 617-618, 6i:3

Wail, Adolph, Fir

Weininger, otto, 7iss

Weir, Rolurt Fulton, 647

Weismonn, Aurust, 553-554

Whah, Willism llenry, 67, 396,741, ti1s, 6i27, 630-631, 751, 7:10, 791, s0s, 865

Wollmann, Max, $97,98,100$, $101,112,716, \mathrm{~s} 92$

Wells, 11. (i., 63:2

Wells, Iloruce, 5.10

Wells, Sir Thomas Siencer, 513,648

Wells, William Charles, 125, 411,445

Welsoh, Cottfried, 272, 27!

Wenzel, Carl, 652

Wepfer, Johann Jacob, 271

Worrluier, Guido, (i9)?

Werllof, I'aul Cottlicb, 378, 397,406

Werner, H., \$11

Wernicke, Carl, 535, 699, 700

Worth, Richard, 6.50

Wertheim, linst, 6ijo, 651

Wesley, John, 40!t, 798

West, Charles, 681

Westplal, Carl F. O., 695

Wesprómi, Ntephan, 3s's

Weyer, Johann, 222, 288

Weyl, Theodor, 711

Wharton, Edith, 212

Wharton, Francis, 711

Wharton, Thomas, 216

Whotstone, sir Charles, 656

Wheder, Claude Lamont, sos

Whistler, Danicl, 260 ,

White, Anthony, 518

White, Charles, 347, 351

White, Gilbert, 34

White, S. Pomeroy, 537

White, William Alanson, 36 , 701,710

Whitman, Charles Otis, 567 $569, \mathrm{sOS}$

Whitman, Walt, 72S, 739 


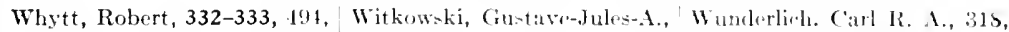
499 s!lt;

Wichmann, Johann lirnst, Witthats, Jiulolf 1., 711 $379,3 \backslash 4,702$

Wickersle.imer, Ernest, 139, $150,294,40 \times, 410,7 \mathrm{I}$

Wittwor, P. I.., 1:36, 35.5

Wöfler, Inton, 638

Woller, Fricelrich, 503-504

Widal, Fordinand, 1927,6330 , $676,750,753$

Wieler-hin, Robert, 560

Wiertz, Anton, 7T1

Wiran, John, 102

Wilcle, sir Milliam, 518, 663

Wilder, Rusisell Morsi, 742

Wilks, sir simutel, 434,411, $412,414,679,699,715$

Willan, Robert, 3s1, 436

Willems, Charles, s14

Williums, Charles J. B., 681

Williams, II. B., in

Willians, Henry Willarel, (j6)

Williams, Jolın, 40is

Milliams, John Whitriclge, $6.50,0.52,896 j$

Williamson, Wallace, 636

Willis, Thomas, 246, 261-263, $340,311,695$

Wilner, William Ilolland, fitil

Wilion, Edmund Beecher, .3t5, 731

Wilson, s. A. Kinnear, 699

Wilnon, Sir William James Erasmus, 702, 703

von Winckel, Fronz, 892

Wintow, Jakol, Benignus. 338

Winter von Aller-füge], Geory simon, 27t

Winter, Geore, 6.51

Winternitz, Jilton Charles, $>11$

Winternitz, Willelm, 3ti. . T09

Winthrop, folne, 306;

Wint ringlam, ("lifford, 25)

Wirdig, siobetstian, 2y

Wirsung, Ciererg, 246

Wiseman, Rirhard, 276-277, 290,296

Wistar, Caspar, 474

Wister, (wwen, diss

Withering, Willian, 367-368

Withington, Edwart T., >3, $133,715, \Delta 6$

Wulcott, Eratus Bradles, 5is9

Wolf, Catsar, 2:2*2

452-453. 7T, , sis

Wumlt, Wißulu, jis. 584

Wizt $z$, Folix, 221

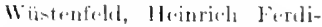
namel, Tt6

II y+r, Inoluert, 14

Winth, duhn $1 .,-\rightarrow 1$

Wolff, Cispar Jrieclrich, 340, Wyman, Juffries, 17 $47 !$

Wolff, Julius, 61\$, 640

Wislf-Einner, Alfred, 7,00

Wollaston, William llyde, Xexuphux, st $38: 3,425,504,6 \mathrm{i} 11,6.55-6.56$

Wollstein, Marth:t, >1:3

Wood. Mexamder, 7ox

Woud, C'aser A., firl

Wood, Drewent, 14

Wool, George I3:100r, 466, Thl

Niond, Iloratio C.. 703, 706707, 790

Wors, Willinm, fix!!

Hoodall, Jolun, :375

Woothull, Alfred Alexander. .51, $7.54,8,5$

Woorleuff, Charle E., 7is.

Woodward, ionell Janvier, 539

Woodward, William C., sot, $\mathrm{SO}_{2} \mathrm{z}$

Wooklrielere, Iandari Clatem, $601,6+4$

Wyokn de Wurde, 1ito, I95

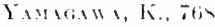

Ferken, Robert M., jos, sot. $\rightarrow 13$

Yersin, Alexamlre, 621, ti27. 7..5.5

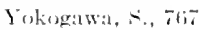

Jonge, Jamles, 237

Joshila, sulato, Tho

Sotung, Jlugh Hawupton, -ifo, -...)

Joung, John R., :324, hint S.

Young, sidney, 71.

Yomme, Thopuas, 4!", 358-360,

$3 \times 5,42.5,6.56,715$

Yjerman, Jeatn, 149

Woollogu-o, Thomas, 400

Wootton, 1. ('., :-1)

Wurcester, Elmwand, 7(1)

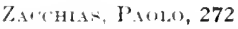

Zatoutum Justumar, 272

Zathm, fuhn furmatime, 27, 30)

Zakrzownka, Marie, T.91, 7.t

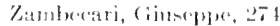

le Zaturaiis, Nlberto, 16\%

Zatutal, Jinnamurel, fitis

von Zaiml, llormann, tjiti

sun Zui-el, Mtaximiliun, h-7

Zulfi, (ialurivle, Jli., 209

Zir.gler, lintant, tils

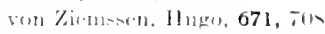

Wresinki, Waltur, 19

Zimmermanu, Juhinn (imer.

$378,1 \geq 1$ (i:-7, 630, 7.;

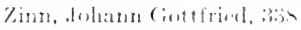

Zinsurer, 11 ithe, 632

Wright, Jonithin, 41, tiriz, s!!t

Wrielet, Mitrmarluke Inorr. $\left.(i .)^{2}, 6,5.5\right)$

Wrisbere, Mlointicls Augtent, $3: 34$

II H Lien Tin, bis

$$
101+1,434
$$

\%uckrtinuml, Inuil, too, titit

Zuntz, Nathan, E!t,

Zwaturdemaker, Ilendrik, il:? 



\title{
INDEX OF SUBJECTS
}

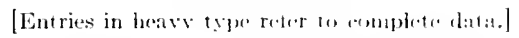

$\overline{\mathrm{A} A \overline{\mathrm{A}} \text { DJKE ISE, 40 }}$

Abloasiles, 117

Abortion, 107, 10s

Absorption, 3331, 3333, t7s, Aloholism, is, 149, 15s, 19:3, 494

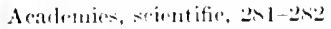
Acanthosis nigricanc, 7(1);

Ae:umia, bis

Accommothation, 259, 359, 76is

Aretanilide, Tos

Aretone, 59.5, 6iz:;

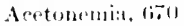

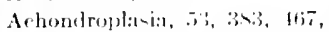
726

Achorion schrinteinii, 1.5], 1s;

Arid, $\beta$-oxybutyrie, (izt;

benzoir, in:?

earbolic, (ii3)

carbonic, 25:3, :334-3355

hippurie, 70.5

mucleic, sofi, (ilo, 70.5

thymic, (i)t

Acidosis, 2.5. 67-5

Acrodormatitio, 703

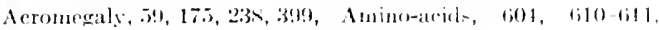
$679,+694$

Aetinomycosis, ti2

Acupuncture, 27, titi, 15

Adaptation, 72:

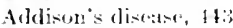

Arlenin, 6ion

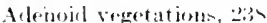

Arliposis doloresat, bitti

Alministration, metien-mititary, 23;, 29) $11,3-411$, \$11-\$12

Fyophony, 4:31, 15:3

Aerotheraps, 3336

Affinity, rhemieal, 321-32:2

Agrlutioation, 627,750

Ageregators, $15 \%$

Agmatin, 6ilo

Agorapholui:t, (ig:)

Agraphia, $7(0)$

Air-hunger, $6 i_{0}$

Alanin, (610)

Albuminuria, 332, 411, 445, 672,676

Albumosuria, 501

Aleaptonuria, 271

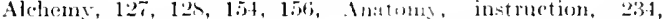
$19 \mathrm{~s}-199,201-20 ;, 2 \times 6-287 \quad 336,337,316,411-115$,

Aleobol, 120

$371,706,735$

1]exandrian sithond, (9.)

Al'xia, 700

Mlexiphamaty, !n

itkahust, 2si;

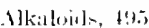

". 111 or nome, "36, 601

Alopecia, ito, 106, (i2s, 70)

Amblyopin, tis

Ambrine, slis

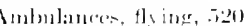

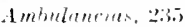

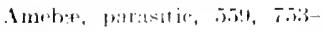
7it

Amelinasis, T11, Th

Amenorrhea, (ixol

Amentia, 7on

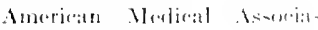
tion, volfi-sot

fmetropiar, thes

$15 ! 3-491,532,789$

sacriticial, l(i)

surerical, 33:3, 523, 5.5.

Inatomy $1 \cdot t^{2}+72$

Anemith, 6is

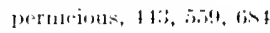

Ancsthesia, 29-36, 62, 101 ,

$142,14,510-542$

intrapinal, 7.4, 7.59

Aneurysin, 100, 101, 112, 214,

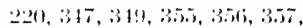

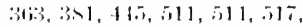

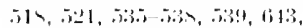
(6)

Am-ury-morthiphy, 763

Inginat pertorits, 272, 3064, 370 . $1672,711$.

Ineisharatomat, 70)

fugle, farial, 324;

Inmaima, :317 3is

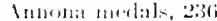

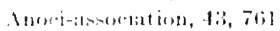

Amolrow berklaces, 402

Antrrier splint, siso

frthrax, $4,120,121,311$,

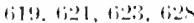

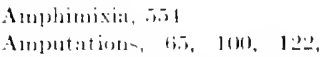

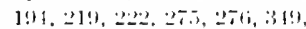
$35,513,511,514,511, \pi 2$.

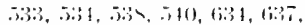
. $.5 ! 1$

Simulets $39-10$

Amyl nitrite. 706

Amyotonis congentat, 699

Anaplylaxis, 3is, dy4, forti, 6i2 7,632

. Jeatomin fortuita, 217

Anatomy, fil, 6i3, fiti, fir. 79 . -.7, 94, 102, 104, 1.20-1.22. 196, 203-215, 224, 211i

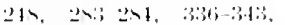
$34,464-47.5,504,5.5$, lis:

artistic, don, sis

compratative, 93, 190, 224, $219,251,340,341,472$

$474,475,175,472,569$ "nlinary, li1

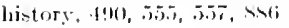

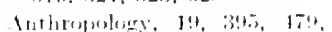

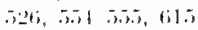

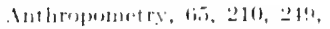
int

Antitum!, $497,2929,294,301$,

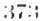

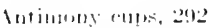

Intiprén, 707

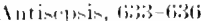

Intimplitu, 15]

Intitoxins, (i2!)-6i31, 7.50

Aptus:ia, 1is, 432, 526, to94. (i) $14 i$, fi!n,, 700

Iplumis, tis?

Inturismo, medic:81, 43, 3:21

Afincis, 6 it)

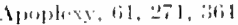

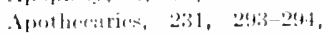

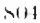

1ppondicitis, 352, 4.1.6.644, (itti, 6it, it;o

Apraxi:1, 6ian 
Nefuti regia, Io

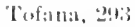

Arabints, 1:is, 151-1.is

Iramen, $1 ! n$

Arelinus, I!ts, : 161

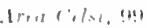

Areinm, tiol, tillt

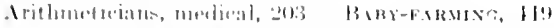

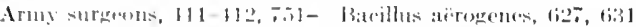
7.5

Irria and Giale fonmblations, 11:

trrow poisons, 70 ti (w)li, 1927, $67-3$

Autenemuic sistem, :336, is is $2,801-60.5,6 \mathrm{isl}, 734$

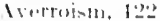

Ariation, titis, sll

laimerslinter, MI, Ha, itis

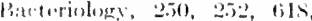
$619-633,745,760$

Bis teriolysis, ti2 7,630

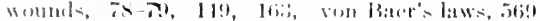
$19 ;$

A $r s$ sphysm $r a, 10.5$

Arstice, $292-2933,394$

Art, melleine in, 6993, 75.-75. in

Irteries, thiseases, fis, for ] ligation, 100, 112, 119, 2222, $344,3.5,350,4,4.5,304,509$, 510, 511, 511, 517, 519, 521, .324, $83.5-5399,760,762$

Arterionleronis, 3 tis, fititi

Arthrsti=, 7.5.)

eleformans, $47,54,72,870$, i3), 615

Arthmpathy, spimal, 16:2

Ascarik, 76

Aselepicia, 76-77

Ashmean Xuseum, 306

lophetele 26

1*ortative mating, 726

Asthempia, tists

A=thma, 22-2, 6 -

thymicum, thit

Astirnatism, 354, 6.56, 76.5

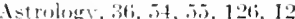
$1 \times 1,1 \times 9,190,191,192,194$, $232,296,204$

Ataxia, eereledlar, 694

hereslitary, 69.5

locomotor, 6iz2, tize, finl, 659?, $6990,6991,6993,6913$

visumentor, 734

throtosis. bitm

Ithleties, st

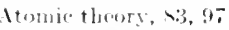

Atreps. 7 a

Atrofhy, muscular, 169,691 , Bismuth paste, 705, 75. (3) 93, , 101$)$

Aulition, 3651, 6562, 66ti?

lugury, 5.5

Auricubs-ventrieular buncile, 731

1erum potubile, $127,154,202$ Ausultation, $129,453,6>4$

Autism, 700, 7isy

futo-crotism, 739

Autointoxieation, 666

Autornatism, 73s

Bencolictines, 136, 137
Bamlatring, is, 526, 6i3!t

Barlere surgeons, 16i3-161, Blexl-pressure, 32s, 191, 196, $231,297-295,111,112$

Barlow's diseande, tisl

Bath keepers, 10s, 16it, 302

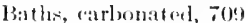
mublic, 10s, 233

Battey's operation, 518

Bu, zente, 30:2

Berll:m, 234, 240

Breluar's aphthare, 673

Brednores, 6:13

Bellevue llompital, 422

Becll's palsy, 471

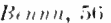

Benzene ring, 612

Beriberi, 272, 4t7, 75t

Bertillonage, 554

Bistiaries, 137, 220, 222

Bezoars, 40

Bhathg, 127-128

Bibliegrapliy, mediat, 224, $323,324,719-721$, sh- $\$ 99$

Bile, 32:3, 452, 504, 506, 591

Billarziosis, 49

Bilirubin, , sol

Biliverdin, is!

Billo, apotheraries', 295

Biochemistry, 736-73o

Bingraphy, medieal, 717 , stoini;

Biolugy, 549-554, 72:3-731

Biometries, 5.33, 725-727

Birth control, 802

Birth omens, 5is-5i

Blark Death, 180-181

Bladkler, surgery of, 640, fitl, Brill's diecase, 742 (it:3, 644, 64.5

Blis, 25!

Blistomycosis, 627, 703

Blefuling glasses, 302

Bligharoplasty, 52s

Blizil spot, $25 \mathrm{~s}$

Blindness, 39, 20:3, 6.56, 79:2

Bibek disesetions, 761

Bloek hospitals, 791

l3otanical garfens, 137,167,

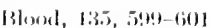

virculation at, 10.5, 104i, 21.4,

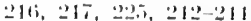

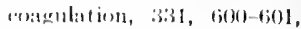
(i) I, 1015, ti:3t

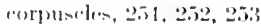

ixamination of, 135, 136

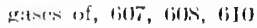

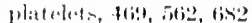
viseosity of , 196, tiot; luesl-lotting, 24, 36, $(33,137$, $1 \rightarrow 1,226,271,301,302$, $303,391,423-12 \mathrm{~s}, 433$. $1 ! 1$

("ileneulars, $15 x$

5.4, 602, 601, 646, 761

liloxl-stains, 715,

Bloul-ressels, 210;, 603 surgery of, $76 i^{2}-764$

lioxly-sutching, $415,471-472$, 510

liologna, Sehool of, $15 \mathrm{~S}$

Julshevisn!, 802

Bone, this

Bone-rlrill, 535

Bone-grafting, 756,763

Bonesetters, 402 $230-231,252,371,415,790$

Botany, 93-94, 100, 101, 102, $1,7,156-157,193,2 \div 2-226$, $230-231,250,25.), 31(j-317$, 3+6-34I, 367-365, 415, 447, $41 i 3$, siti?

bowe' manuscript, 61

ratiolism, 44

Britin, s.3, 41, 101-10.5, 205, $204,210,213,217,265$, $44,5.51,5.5,730$

diseases of, $45 ! 1,657,672$ localization of function in, 580

sirgery of, $640,613,762$

brass-fonders' ague, 71]

Brrast, 211, 524, 5s!t, 761

Brephotrophia, 1ti?

Breslau Corlex, 13!

Brixlowell, 240

Briclere-work, 10!)

Bright's disease, 410-14I, 617 , titis:

British Medical Assoriation, 806

Bronchitis, 430

Bronchopneumonia, 271, 494

Bronchotyphus, 454

Brurine, 50t

Brunner's glands, 264

Brumonian theory, 319,320

Buek's extension, 539 
Budd's disease, 713

Bufagin, 25, 706

Bullet-probe, 525

Burial, 72

intramural, 800

Burking, til

Burning spatres, (6)

Bursitis, subacromial, 755

Carhesia strumipriva, 759

Caciquism, 767

Caisson disease, 711

Caleulus, urinary, 104, 198, 615

Calorimetry, 95, 59.4

Camptocormy, 813

Caneer, 96, 101, 147, 395, 556, $595,604,618,638,714,745$, 755

Cannabis indica, 29, 127-128

Copsula eburnea, 136 ;

Carbohydrates, tirs

Carbon dioxide, 260, 334

Carceag, 743

Cargile nembrane, 75.

Caricatures, $39 \%$

Carnot's principle, 425

Cartilage, 610

Castration, 65

$147,103,195,221,354,364, \quad(11010: 1,179,271,442$

$6.57,655,659,6031,765$

Catharmata, 33, 34

Catharsis, ritual, 26, 56, 75

Cathetrers, 395, 525)

Caul, 3s

Cauterization, 121-122, 143, $145,17 \overline{7}, 191$

Cave gout, 17, 192

Colestial Berls, 102-103

Cell-rivision, $5 x^{2}, 251$

Cell-linetge, stis

Call-theory, 479-483, 157, 1sh, $561,5+2,610$

Cellulitis, petvie, (j.51

Celts. Sie Flints, ehipped.

Cemeteries, extramural, soo

Consus, 59, 109

Centroseme, ifis

Cerebellum, 491, 581, 69s

Cerebral breathing, 440

Cerebroseps, lis.

Cerebrominal fluid, 333

Cestatent sertion, 29, 62, 99, $222,2-2,52 \lambda, 511,650$

Chatin reflexes, is 3

Chair, obstetrie, 30, \$, 102

Chumbre ardente, ents

Clancre, Hunterian, 3\%3

Charities, medieal, 16s-171, $233,406-107$

Chemiatrists, 197

biological, 699 $697,736-735$ 440,453 91, 438

Chilil labor, 799

China smilax, 213, 237

Chlamydozoa, 750

Chloral, 502, 704 708, 713

Chlorophyll, 610, 747 $312,319,372$

Cholungitis, 640,649 $796,797,701$

infantum, 394

Cholesterin, 591, 675 elecetric, b7 hereditary, 696 postparalytie, foss

Chromophanes, 5s?

Chronology: medieal. $861,5 ! 90$ $7.5,75$

Cineplasty, 7iti

C"irea instenes, 140, 1s:3 ind - 60 ior

('ircuneision, is

Clinatoleser, 124

C'limatotheraty, 10

('luberout, 5i2:

('lsoters, 14!1, 24t4, 320)

Costeulition-time, (i30)

(roaturulene. Ttio

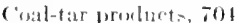

(') (1):a, 30

Coeryerimia, 547

Coction, 106
Clarms, 41, 42, 112, 288

Chemistry, 53, 127-125, 15t, $199,201-203,320$

intracellular, 610, 71s

1 physical, 425, 571, 610, 611 hysiologicat, 260, 5011-506,

Cheyne-stokes' respiration, Color, folklore of, 35

Chloroform, 542, 605, 653,

Chloresis, 158, 200, 271, 304, Complement, fixittion and de-

omy, 539, 547, ("omerours, 110, Tws

Cholera, 440, 447, 460, 461,

('laronosomes, ist5, 731

Chethonian deities, 72, 73, 74

Ciliary motion, $4 \times 5$, son ('inchuna, 292, 373, 3at

('irmulation, phrisoleger.

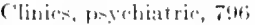

('lemerehis sinensis, ofis

Cobra-venom reatetion, 71:

(')ratime, 6.51, 704, 755,760
Code Hammurabi, 56

(2)

Collhirnm, 113, 402

Cokls, i5t

Colict Pictorum, 238, 272

Colloids, 505

pereeption of, 476,477 ,

dostoms, 640

Colunns of infamy, 30 ?

viation of, 7 :

Congresses, international, $793,-10$

Congruenee, litws of 31

Conjunctivitis, 49, 520, fi21, Gijl

infantile, $6.52,6.5)$

Conservation of energy", 121, 572

C'onsilia, 158

'ountilutes criminalss forroline, 193, 23:3

Therestum, 112

Constitutions, epidenjic, 3t. 270,715

Contagion, 5ti, 57, 60, 155, $178-179,224,210,250,378$, $462,+19 t$

Contrattures, ,izI inclapmine, ti3s

controversies, modieal, 405 , 45), $300-509$

of, convention theory, 1s

(i)nveresenes theorsy, Is

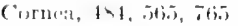

(e)

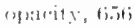

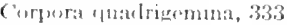

Corfultiuns, statistical, 725$7: 21$

Corrigan:- pmlstat $\$ 10$

Coracte. 333!

Cosmation, 1int

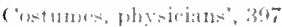

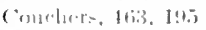

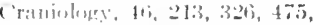

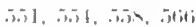

('ranionictry, 219, 526, 554, itt, $64 t 6,7 t 2$ 
('ronsts, 155)

(reale's methesl, tist

Cremention, 7:2

('rete, , 72

('rotinistm, 1!!!, 17\%

criok-stone', 3.1

C'rimets wat, 7!)

('rints, Bti, liit)

('ritical days, ; 36

('rimll, 11:2, 1i::3

('rutent:tion, tii.

('ruvejllier's pals! , li!)

('ryoseculy, tiat

("upping, "2)

Cystin, ilo

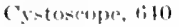

Cyotutomy, 22:1, 53:1

Cyoblatet, 4>0

Cyemtiagnosis, 7.50

Cytogemesis, 5titi-5tiz

Cytomorphosis, jo

1) AFFY's FilXIR, 2(4)

1)aft Jamie, 17:2

1)akin's solution, 12

Dance of Death, 150

Dark Ages, 1:36

Darwinism, 7:24

Dead, disposal of, $\pi$, , on

Deaf-mutism, 29 !, bii3

1) minness, $203,263,361,510$ $7: 32$

1) wath-prognoses, $1.5 \mathrm{x}$

Death-rate, 2-:2

Débridemtnt, s12

Decerebrat ion, . \1-542. 543

Deciduorta maligntm, 6.j1

De ompresion. (․rebral, $27,7 i \mathrm{il}-7 \mathrm{iz}$

Decrese. 1'ajual, 129, 152, 154t$160,2 \times i$

Deglutition, 193, 5u!4

Dorgrees, menlical, 16iti-167

Diril's Needle, 34

Deliriun tremens, 463

Dementia paralytion, 243.3 pracos, 700

Demonology, 35, 55, 56, 6i2, Dourine, 74: $6 ; 4,16 ; 1$

Jengue, 363, 394, 753

Jenti-try, 114, 122, 147, 14s, $14 ! 4,220,235,303,356,51$, i1 11

Depopulation, 714

Dermatitis exfoliativa, 702 herpetiformis, 703

Dermatologe, 3zis, 34t, 436439, 456, 702-703

Devonshire eslic, 373

Dew, 14.5 $7: 32$

$$
\text { bis, 7Tx Tat }
$$
714

Diss mefusti. 3t; 73.5

Diplonnas, 111

Discise, 30, ti.3 (ifi)

1) inrectios, forti

Divination, 5.5

1) crematisun, !y

Droille, is

Dropus, Bir (4)

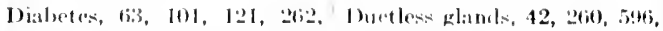

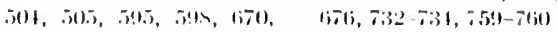

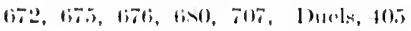

ins-ifrilus, 7:2:3

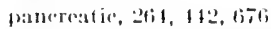

Dingnosis, tik, 91, 121, 36t3

1)iaferlemis, 611, 6i1

1)iathorme, 707

1)ichleramino, 7, sis

1)upustren's fractur", 521

D) 11st, T11

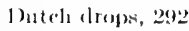

1)warf gorls, 5.3

1)warfs, 17.5, 233, 312, 393

1):senf(ery, 113, 270), 271,310, $371,+21,117,627,633,705$, $711,751,751,767$

1) sisulrosis, $70: 3$

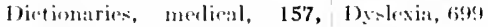

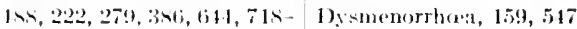

Dirs . Etuptiori, 36, 160

Dieteties, $63.3,91,135,507,709$

Dietl's (erises, tis.)

Differential prosilre, 751-755

Digestion, 24i1, 261, 323-32!9, $355,505-507,540 ;-513$

Digitalis, 367-36x, 705, 704,

\section{Dioptries, $7(; 1-76$.}

Jyspituitarism, 7(i2

Dysionmetey, molerular, 620

Ear, 112, 2019, 216, 335, 360301,129

intrutal, 3 $3: 3,501,76 t ;$

sltrerery of, ,is, tili;

Fast lublia Cimpany, 116

Eistern ('aliphate, 117-121

Ebers papurus, 49-50

Diphtheria, $122,101,112,114$, Eck fistula, $357,596,762$ $179,234,311,370,371,373$, Ecoles te sente, 110

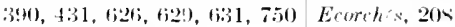

Diplococenis, 751

Jiplomar mills, sof;

transference of, $3: 3-34,57$

Disenstes, ralusification of, 270 , :316-31s, $3639,4.30$ ducriptions of, 20), 270 $272, \quad 342-3 \times 5, \quad 11 ;-14 i \mathrm{i}$

Dislor:tions, 90, 114, 12:2, 3.51, $521,534,1510,644,759$

Dispensitorits, 2:3, 46iti

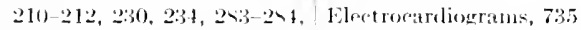

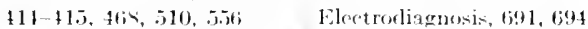

Disipation of enerery, 425, 57: Dilectrolysis, 333

1) orimasia, 271,272

Doveres powoler, 40s

Drarenculis, 121

Drains, B:1 bylonian, 57

Drue habit, 372

Drue trarle, 172-172, 239

Eluct rophysiology, 3333, 575579

Electrotheraps, 104, 333, 395, 44i, 5ls, fit4, 70x statir, 143,67, , (imo

Eleretrotonus, 57, 567

Electrovibrater, 75

Elementargelonke, $1 \mathrm{x}$

Element-s, chemical, 127

Elophantiasis, 147

Elf-bolts, 40

Emlalning, 51, 5\%

Drugs, 24, 24, 32-33, 56, 67, Embotement, 340

94, 127, 124, 223-225, 241, Embolism, 614, 615, 631,

Dublin method, 345

Duct, pancreatic, 246 (iti)

mesonteric, 670

retinal, 6.5 
Embryograph, .76.)

Embryology, 93, 253, 340, $355,474,175-479), 151$, 4ss, 5.t2, 560, .761, itit, $52 \mathrm{I}$

experimental, .50-.532, tiot, $730-731$

Emesis, 91

Emetin, 70s, 7it

Emotions, 731

Empirics, 9:3

Empyema, 145

Enecphalitis lethargiea, 2:39. 311,421

Encyclopedias, medical, 22:2, $44 t i$

Findocarditis, 365, 433, 454, Examinations, medical, 410 467, ti14, $6 ; 26$

Endothelium, stis

Engincering, sanitary, $5 \pi, 97$, IOS

Enormon, 92

Eintamela, 745

Entelerhies, (3), 72!)

"Wnterie fever," 67 ;

linterokinase, , 59:3

Enteroptosis, 66 it

Enterorhaphy, 524;

Enterotome, 52l

linzyme reaction, 750

Enzymes, 5is, 737

Eoanthropus Dawoni, to

Epicystotomy, ist4

Epidaurus, it;

Epidemies, 90, 17- - NA, 236239, 30\$-311, 341, 420-422, $713,744,748-7+9$

Epirle rmolysis bullost, 703

Epizenexi-, 215, 340

Epigraphy, medica!, sit

Epilepsy, :32, 56, 74, ה4, $101,112,179,290,380$, 597, 1607,627, 6966 lacksonian, 442, (i9tj

Fpincphrin, 707

Fpithelium, 1s:3

Eponyms, sog

Ergot, 6.i.

lergotism, 179, 19.5, 22.5, 239, 271, :11

Virrsiplas, :37, 4, 102, t26t, 1,27

Erythema, 4:ti, 70

bisythromelallatil, fitz, 69

Esmareh banclater, (i;3)

Esophagoserop, 670

Esophagus, 4s I rupture of, $: 321$ surgery of, $6 \mathrm{izi}$

Whar, 2:23 ancethesia, it4, $-332,540$ 542 7\%, M11;

Ethmoirl lome, 17t

Eitiquette, nuedieal, 167

Etruseams, 96, 10s

buenine, $70 \mathrm{~s}$

Eumeneis, 526

liugenies, 5.5is, 7.2 tion of, 3 til

Euthenics, 727

Evil ere, 38-39 6.17

Exerutioners, 411

Exoreism, 56

Extrats, anim $1,75,597$

Extravital aulures, 764

Exurlation diatlimo in, tizas .01, T6.5-76t6 6.ifi

schematie, 11\%, 11s, 20); $764-76.5$

bye-ntrain, (i.s)-6itil, bis

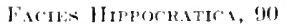

Faxtory inspection, 799

Fatith-4ure, 2.2, 13, s03

Falkenstein, 7a:?

Faneotherape, 403

Fares, 13.5

Farricry, 15is, 2as

Fitigue, sat;

Favus, 15], 4ר, 702

Fear, 42

Fechmers law, t9s

Ferblemindednes, 727, 724 7.4. 3.45

miliurs, :311

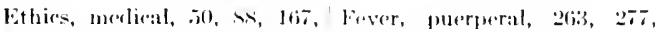
$23.5,272,325,40.5,40-1$,

surricial, 144, 145, 115, 14

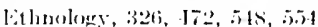

liustachiatn tulee, eatheteriz:1-

lixcisions, $349,331,513,51 \mathrm{~s}$

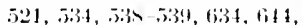

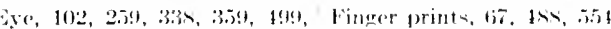

$457,455,652$

relatysing, 33:3, 6i31, 74:3

tophoil, 141, 2(iis, 2(i1, 310, $36.7,37 x, 840,420,12 x$, $1: 31$ 1:3, 131, 142, 14, 4.il, 461, 4ti3 164, 545,

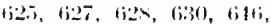

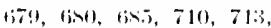
7.51, 7.3.3, 7.51, 801, 813, sis

typlus, $32,201,22 \times, 234$, $239,271,310,374,375$, $380,120,139,140,1+33$, 464, 235, fi27, 742, 797

अ⿺10w, 2:34, $311,390,391$, $121,514,477,751754$ $767,765,797$

Prore, 366, 367, 373, 120 . (3.), $4.17,700$

Fihrill:ation, :auricular, 605, 73.

Fil,rinugen, 331,602

Fielli-cliensts, atrmy, 276

Fichl-hosprit:1ls. 23:3

Filtarable virusets, 750751

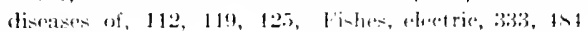

sureery of, 113. 276. 319,

Fintine mallats. 2:36, 30n-30!

intula, : anat, 14!4, 351

setstrie, 506, 5:31

Literinal, 15s, :317, :34!

vesicovaginat, 279, 529, .331, $545 \quad 547$

Flueleric, (iz)

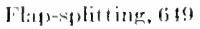

Flies, $52,54,220,5.54,62-, 62$

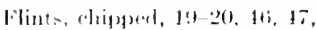
is

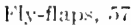

Fing ambul:unces, in!

fixal infortion, (ix.)

Folklore, merlicill, $17-45$, 12:3, is.

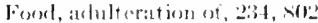

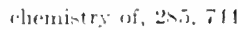

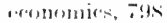

inspertion of, 16.5, sol

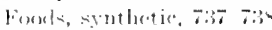

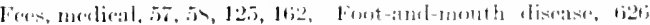

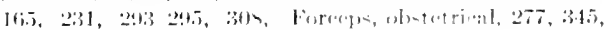

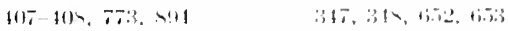

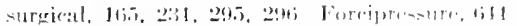

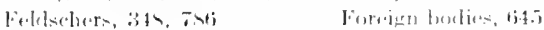

Jernontation, 241. 502, 561, formularies, 140 ti20 dresile, to

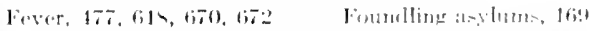

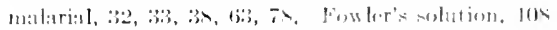

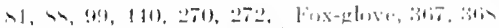

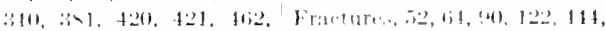

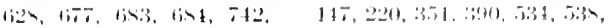

Framlunis, 201 
Franklinism, 3:0,

frozen sertions, 5ibs, 5.5.

Funfliderserice 200

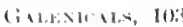

(iatconism, 195-198

(iall-mtones, 15x, 7ti2

Gallamocautery, 5i3I

Galvanumuter, 57 -

Gamereme, 275)

symmetrieal, 378

Garlin, tit

Gurrotillo, 2330

Giss syliestre, 2you

Gatsmetry, 336, 607

Gats-poisoning, $\$ 11$

Gats-p)ump)s, 607-60s

(rassing, s12

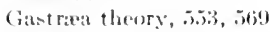

Gistrectomy, 611

Gatstrir juice, 329, 505-507, Dig), bitis

Gastrodiaphany, bist

Gast ro-dytrotomy, 54t, 54s

Gastromentoritis, 127

Giastro-enterostomy, bi3s

Gitstroptosis, bitis

Gastrosene, 6iat)

Gatrontomy, 276, 526, titl

Generation, 93, 245, 4ha spontanowls, 251-2.5., 329, $4 \rightarrow 1,620$

Geneva bands, 254, 397

Geneva Convention. $\$ 10$

(ienito-urinary organs, surgar $+5,6+1$

Genius, int

Gt niks epidemirus, 3t, 270

Geomraphy, modical, 124, 3৯t;, 717

Grologists, medical, 120, 22s, $24 t i, 445,417$

Germ-layers, 179, 4ho;

Gorm-plis:m, 5.51

Gorninal - - wot, 179 vericte, thi

Gerontuchiat, $16 \mathrm{~S}$

Gipantism, 73:3

Gil Blas, 300-301

Glanders, 114, 272, 435, (i2)

Glatuber's salt, 24i;

Gilaroma, 35s, 76.5

Glimon's eapsule, 24t), 260

Gilettincoper, 45!

Gloves, surgical, t33s, atjl

Glyeoroll, (i11

Gondard"- drops, 292

Gorls, merlinal, 3i-3is

Goitre, 112, 112, 190, 505, 635, 732-733, 759, 760

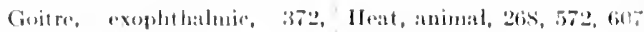

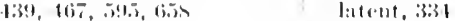

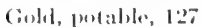

(iomdisuber, 14T

IIntinu, ;11

Ileitstroke, 707

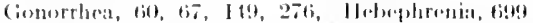

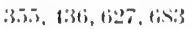

(iïrlerertorf, 7!!3

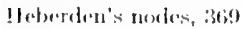

Heithribls, 35

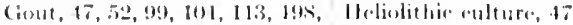
$271,369,395,402,116,596$, Helleloret, 91,101 (is) 736

Giratian vestedes, $26 t$

Itematocele, pelvir, 525

Honatotherame, bor

Graduation eremonies, 167, Ilematuria, codemie, 1335 $2091-300,302$

(irstefo's sign, bis

(iramulusis, 70):3

Grathir mothonl, 5ner

IImianomsia, to:7

Homiat rophy, facial, :372

Hemirataia. 300

Hemiplegia, sot

Great Windmill street, 33I, thenlusek, 142 $316,470,516$

Cireen corn feist, 26

Grocero's triatugle, bit

Grot to del Canc, 260

(irowth, tiot;

Guaiae, 2337

Guilds, medicat, 162

Gunshot wounds, 6945, 7.51, 413

Guy's Hospital, 116, 440-114, $6 \pi-\sin ()$

Homochromegen, 610

blomodrnamirs, 325, 196

Ilenoglobin, 5s's, 60\%, (i10

Hemoglebinuria, so

Hemolysis, 627, 7.19

Hemophilit, 151, 141

Hemorrhage, 141, 115, 146, 191

Ilemospisiat, 709

Gymnatios, 201, 710 Ilemostisis, 102, 639

Givmnaxts, 79 Henle's tubules, ts

Gynecology, 102, 222, 27s, H4noch's purpura, 67:3 $315,542-545,64-6.52,75 s$ I Iepatitis, 667

IHepatoseops, is

Hepitotomy, ist!

HAARLEM OIL, 292

Ilabitations, 711

If:ralelry, molieal, so2

Ilorbals, 15t;, 19:3, 195, 226

Fintish, 220ti

Heredity, $472,553-551,569-$ 570, $604,726-720,731$

II.

Hanl, artificial, 10 ?

Ilanging, judirial, 3is

Harelip, 14!, 515

llartmann's diapasons, 6033

Harvard Medieal sichool, ts3

Hashish, 127-12h

Ilay fever, $46 \pi, 573$

Jlead injuries, 91, 100, 143$14 ., 200$

IIe:ul's zones, for,

Jearlardie, 10s, tios

Health insuranec, so:3

Iternia, $34,113,147,158,159$, 1ti3, 21!?, 221, 275, 327, $339,350,351,510,518$, (i) 43,617

femoral, 5ls

infantile, jis

retroperitoneal, 5.56

Hernistomy, $! 9$

Haroin, $70 \mathrm{~s}$

H('rpes zoster, 609, 699)

IJ examethylenamin, 70s

11ex-doctoring, 42:3

Heart, 93, 95, 10.5-10t, 210, Hibernation, 329. 355 213, 244, 25, 265, 323, Hioroglyphies, 45, 45, 360 $343,430,45.5,45.5,456$, Ilittz compass, $\$ 1.5$

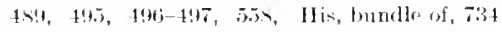
$597-602,603-605,607$, Ifistanin, 70.5 6̧4, $734-736$

Histidin, 604, $611 \mathrm{I}$

diseases of, 217, 3ti3, 351, Himtology, 52, 468-469, 477, $430,433,440,445,654,461-45,454-159,560-$ 709

surgety of, 612

$56.5,549,54 \%, 616,633$

vegetabla, 250, $4 \times 0$

Heart-block, 363, 436, 440, Histozymes, 611, 705

Hodgkin': disease, 444 
IIohlengirht, 46

Hollandt/ther+i, 419

IIomeopat thy, 460, 903

Homeric poems, is 7 !)

Hookworm disease, 19, 3is9, latromathematies, 725

627, 677, 700, 7+1-7t2, 745, lehthyol, 70: 753

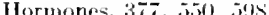

IIorn., cutaneous, 3nt

Hortus sunitutis, 193, 2:22

Hospitalization, 157:-2

Hospitals, 169, 2210, 304, 411, $416,711,791-792$

eigliteenth renturs, $416-$ 117

Indian, 6.3

medimal, 168-172

military, $104,235,2906,414$

Mohrmmelan, 126;

obstentriv, 410

Hôtel I Dieu (Paris), 117

Humanist =, medical, 185-189

Jumoral pathology, 82-83, 90

Ifumorilism, 94, 103

Ifunterian Museum, 3.5t

I]uxham's tincture, 373

Hybridity, 475, 72:3-725

Hyclatid $<, 36,5,+12$

Hydrarthrosia, tivi

Hydrazins, 736

Hivlroia, T0:3

Hydrocele, 3.51

Hydrocephlatus, 333:3, 434

Hydroesstoma, 703

Hydrodynamies, t97

Hyelropholiat, 112, 321, 37s, 621, 611, 67 $7,74: 3$

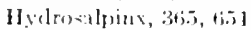

Hydrotheraps, $366-367,434$, $70 ?$

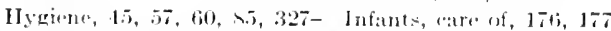

$32 \mathrm{~S}, 710713,722,701$,

$7940-802,80.3$

inclu-trial, 711, 797-799

military, $37,711-712,75$.

naval, 375

Hyosein, $70 \%$

Hyoseymus, 26, 29, 101

Hyperemia, pasise, 75.5

Hyperkeratois, 3-1, 703

Hipermet ropia, ti.js

Hyperthresilisn, 732

Hypnot i-m, 27, 250, +1S-119, t69) $701,70 ! 9$

Ilypothyroilim, 73:3

I1ystop, 5x

Hystoril, 43, 2ti3, 2-71, 20s, $442,693,739-740$

Ilystere-emuleper, 6983

I]ysterorrhaphy, (5i)

JATREM, Sit $256-250$

Inthyosis, 430

hystrix, 3\t

Icliocy, amaurotic, fom

Idlots, 79t; 5) 559 $2 \cdot 23$

Imhof :istem, 402

mpetige, f:36 horpetiformic, 4.th

Inanition, .59;

Incantations, medical, j.; $162-163,193$

Incubation, it $203-201,770,-693$ craphic, 203-208

Index C:atalogne, 719

Index Inedienes, 720 $27,73,395$

Industrialinm, 121, 731

Infant, newlorm, in

Infintiliam, ti!s, isto

arexual, fitit, $7: 33$

hyerene, 190

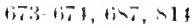

welfiares, s(x), ble

Infarctus, :3:20

Infertion, ij르 $\rightarrow 12 \rightarrow 13$ $-97$ ti2

smanish, 413

Inhalation tharilye, 3:3tj

Inhibition, 1!+1i-4!9 249 latrechemical school, 259-262

lat romathematical sehool,

Jlews, List romesenterie, tisot

Illustration, anatomical, 77, Insanity, f(6, 611, 99, 102. 113, 1.7), 191-1!2, 2(1):-211, $212,214-216,217,24$, $326-327,339, \quad 311-313$,

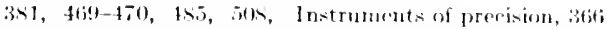

medieal, 111-115, 191-195,

Immunity, ti29)-(j;30, (6331, ti3:

Incisors, sureient, $14+11 \%$

lncumabula, 15i, Nis-1>ti,

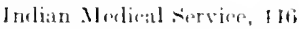

Inclinns, North Amerisan, 2:-

Infantirille, 23:3, 347, 341

mortillity, $2: 33,311,419,800$ nutrition, 2233, 311, 119,

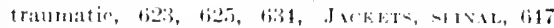

Inflammation, 101, 311, 35, danndire, 121 :373, 394, 615, 617, 625, 6330, :4cholurie, t67

Influenz:1, 179, 311, 374, 121,

lnjortion, anatomical, 215- Joint-, for

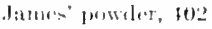

Injection, hypodermin, 13s, $52 t ;, 70 s$

intravenons, 273,704

lnks, purmative, 12:

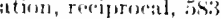

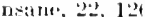

(are of, 210, 119-119, 79);-

231, 272, 276, 379, 433-1:34, ti! $19-7() 2,71$.

Instruments, surgical, 2a-29), .i2, $111,99,119$

Insulliation, intratracheal, 7.51;

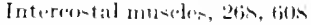

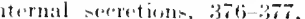

nt rnationalism, sio-h1]

atestines, 24ti, 217,590

(10) $189,64+4,6)$

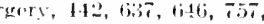
7ite-7tis

Intravital staining, i.t.

ntubation, deodenal, tose

loclothyriu, 7:3:

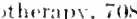

Irirlentomis, 3ist, 6.5

Iridowloisis, , j27

iricloclatyois, $34: 3$

Iridotomy, 3is

I rish sehool, 83 a -410

Irritalility, 26ti, :323, 725

Irrit:tion, f27

Islanul of Reil, 37!

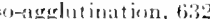

Isag)athy, the

lsotonic ansen, sol

arrhotice, tetio

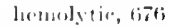

toxic, 412

spirowhetal, atio

Icomites - 70

John- Ilopkin IJompital, 783

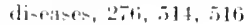

anylumis, ils th! 


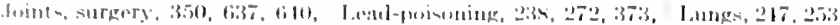

tis:3, 7.5,

loseplinmm, 113

fournalisms, molical, s!n

Jirelioin astrorum, :34;

lukes family, 7:25

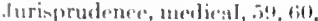

14i1, 1!93, 2:20, 2:3:3, 27:2 273,

$341,15.50,711-715,7-1)-7 ! 01$

Iswleberpes, agt

lint-17, AR, F1:

liallikak family, 7.24

liarrokinesis, 5042

Korith-Plark mole, 7:3

livelinl, 1:3\%

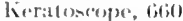

lieritherups, $\rightarrow 15$

Jivlney, 247, 60:3

discasts of, $141,435,410$, $+56,672-67 ; 3$

-14 recry of, $531,5339,647$

lincstherapy, 710

ling"s lvil, 24?

Klopfrersuch, 5x

liner-jerk, 695, dith

Knights of saint .lohn, $16 !$

Knives, obsidian, $2 T$

linossos, rseavations at, 7172

Koch's jostulates, 623

loul-Oba vase, 161-162

Kiraurosis, 6.51

Kriebelkrankheit, 23!

Ii ubisagari, fi67

Kurierfreiheit, 801

Kymogriph, 496, 599

l.ABOK, 220, 277, 345

1.aboratories, 202, 457, 604, $77,752,783$

Jarteals, 216

Laisse faire, Tas

lake dwellings, $2 \mathrm{~S}$

lambert family, 381

l.aminectomy, 614

l.anca-hire witches, 246,287

lane's kink, 757

Lapasotrony, 276

I aryngology, 661-662, 67?

ditryg s ope, 450, 6s.

1.aryngos(⿻)

L.arynx, 147, 66]

dismases of, 159,673

intubation of, 681, 6fis

surgery of, 637

Lasstifulkunt, 159-192

1.a Tine, as

l.audanum, 19!

Lazar-houses, 171
$3 \times(0,390,3395,401$

leneclulomas, 15is

laneling, lint

loetes berberornm, 16 ie

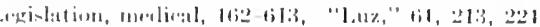

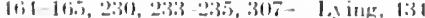

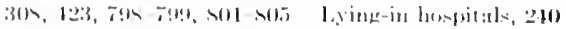

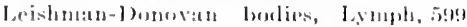
7.33

Lat murn!lestall, 150

Ienk, 252, $354 !, 834 !$

1.enses, 226 i, $391 \mathrm{i}$

Jeontiasis, 611

Lepraschau, 15s, 16i.i, 170

1.teprosoria, 171

1.prosy, 57, 56, 59, 14!1, 155,

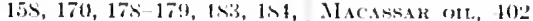

$195,235,310,345,177,627, \mathrm{Magic}, 21,23,110-111,226$ 6.53

s.rmpathetice, $23,31,34$

Mignesium, 70)

Mannetism, 211, 2511, 4! physical, 22:

"Xlaking medivine," $21,22,5 x$

Mal al'umour, 301-30:-

Leukemia, 6ta, bist, (is.j

Leukorytosis, 611

Lexicograplay, medical, 279, Mul de la.rosa, 3si $3 \mathrm{sti}, 7 \mathrm{is}$

libido, 30

Mal franzoso, 1 s.:3

Mal occhio, 3s-3!

Libraries, medical, 159, 166. $414,423,721,891$

Lichen exsudativus, 450 niticlus, 703

urifeatus, $4: 36$

l.ichig's extract, 502

Life, $469,724,730$

Ligature, 9y

light. $359-360$ tropical, 754

Lignum nephriticum, 292

limbs, artificial, 16:3, 219

lines atrophice, 67?

lingam, 34

Linitis, 6sl

Lipoids, $70 \%$

Litholapaxy, 645

J.ithotony, $99,113,122,150$, Marritere, 5.5; $221,275,345,350-351,115$, $504,511,515,518,522,526$. j.3!

Lithotrity, 122, 520

Liver, 55, 266, 559, 591, 600 atrophy, 363, 442,454, 667 disesses, 365, 1830, 145, 667 glycogenic function, iab, 680

Local Governuiment Roard, $795,79 !$

Loconotion, 14t, 574

Loi Rimssifl, Toin

Luetin rouetion, itf

lumar excles, 30

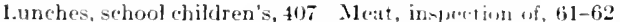

300 larial.

Malingering, 312

Maloreclusion, 2:3, 515,663

Malfa fever, 62t, 754

Malthusianisun, 711

Mnlum malannum, 36, 180)

Man, descent uf, 5.50-5.52 prehisteric, $19-21,16-47$, 5 is-5is

Mandragora, 2!! 101, 112

Hano ficer, 3)

Manometer, 323

Manmeripts, medical, 716 , sit

consanguineols, $72 \mathrm{~s}$

Martyrs, merliual, 754

Massage, 26; $27,47,219$

Mastoifl prowess, surgers, 349 , 30i1, difi3

Mastorlitis, titis $101,102,123,199), 291-293$, $3(1), 1(x-109)$

1aterialisni, 729 7:36)

Matrrmal imeremions, is

Mathematics, 12?

Ilatter, sti-n

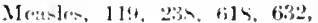
(is), $21: 3$
Malarial fever. Sie liner, ma-

Nateria merdiea, $64,65,100$ 
Nechanotheraps, 710

Meckel's diverticulum, 340 ganglion, 310

Medals, modieat. Sief Numismatic's.

Medical Brotherbood, sit

Medicine, Acralian, 5457 Mexamlrian, 94-96, Nר;

American, 240, 306 30<, 359-39k, 42:-423, 161467, 7S2-7sti, siti

Anglo-Indian, 446-449

apotropaic, 75

Austrian, 377-37s, 453-159

Babylonian, 54-57

Biblical, 57-60, 61

British, 155-15t, 195, 22s, $241-246, \quad 261-2633,26 \mathrm{ifi}-$ $272,273,319,330-3333$, $364-374,345-3849,405$ $407, \quad 437-449, \quad 67 \tau-653$, $78 \mathrm{~s}$

Byzantine, 110-115

Canatian, 683-6st, 685

Chinese, 65-69, 890

domestic, 96-9s, 115

Druidieal, 160

Egyptian, 46-53, 891

French, 297-300, 376-377, $426-436,664-667,690-$ 694, 7s0-7s1, 787-7s8

German, 161, 189-201, 44!)460, $786-788$

Græeo-Roman, 96-109

Greek, 71-107, 892

herbal, 96, 101, 136, 139, $156,160,223,231$

hilastic, 75

Il indu, 62-65, 892

history of, $91,99,121,188$, $27 !), 372,385-386,416$, 651, 641-682, 698, 711. $715-719,764,862$

Homeric, 77-79, $\$ 92$

horoseopic, 36, 247-2ss

internal, 54-57, si, 119, 124-125, 139, 231-233, 269-273, 24:3, 3ti1-3ti3, 366-34t, 39\%, 415-416, $426-124,445-446, \quad 664-$ $6 \times 9,77-7 \times 1$

I rish, 1fio-16i1, $437-440$

Japanese, 69-70, $767-768$

Jewish, $57-62,12--129,159$, $172,8 ! 19$

melicval, $130-184,769,895$ Mexican, $x+35$

military, 107, 104, 235, 276, $296,373,375,390-393$, $400, \quad 112-113, \quad 519-520$, $532-5333,751-755,895$ modern, 424-818
Medicine, Mohammelan, 116- Mirwifery, male, 343-344, 423 129

mon:1stic, 135-137

naval, $221,375,400$

()riental, 54-69

paptric, $48-50$

prehistoric and primitive, Nilk, tis 17-45

preventive, $h 18$

Rimaistance, 185-240

loman, 96-109, $\mathrm{k} 9 \mathrm{~s}$

Russi:un, 161, 30.5-306, 113, Ninistry of 11ealth, 799 786,898

scholastic, 157-159

social, 816

South American, 767

sp:inish, $766-767$

sumerian, 54-57

Syrian, 95

systems of, $311-320,376-$ $377,44 t ;$

Talmudie, 61-62

theurgie, $62,136,173$

tropical, 201, 446-147, 624, 1877, $7 ! 90$

veterinitry, 111, 22s, 27t

Mcdicine-man, 22-20

Medicines, proprietary, 291, 402, $\rightarrow 06$

Megrims, 699

Melaremia, 112

Memory, facultative, 553

Ieulds law, 723-724, 728

Meningitis, aercbrospinal, $462,627,631,797$ tuberculous, $3333,463,632$

Menstruation, 2x, 61

Meralgia parast hetica, 699

Mereury, 142, 18:3, 236, 456

Nerseburg triad, 167

Mesmerism, 382, 462

Netabolism, 250, 502, 50350), 593-596, 6i59, 674, 676, 690, 703, 710, 732

intracelhular, 610, 737-73s

Metagnnimus, 767

Metal, planetary, 127

Metatars:llui:t, tisti

Metaxenia, 711

Metempsichosis, s.3

Metooraloger, medieal, 373 , 37

Methemoglobin, 610

Methodiom, gy

Mezzotints, 311

Mica operition, 29

Mierochemistry, 715, 7.17

Microphestography, 5tis

I icroscopy, 226, 249 254, 12.5, $457,491,630$

Microsporon furfur, 702

Microtone, 457,560
Iir!wive, 5s, 10s, 125, 190 , $2: 33,2-4,416,123$

Mikuliez's - cliscasce, 633

Miliary forer, sin lower, mili:15:

laburatorian, bis 7 nickness, 46i.j

Milroy's disease, 609

Miners, discitsess of, 200

Ninoan culture, 7172

Niracles, is

Missions, medieal, 6s

Mistletoe, 100

Mithridate, 95, 291, 370

Iolluseum cout;igiosum, 436;

Monro dynasty, 3336-3:37

Monsters, $5 t^{i}$

Nonte Cassino, 134;

Iontpellier, sehool of, 15t, $15 s-159$

Moon-lore, 36;

Morality, international, 817

Morbus Mungaricus, 239

Morphine, 504

Morphogenesis, 571

Morphology, $329-330, \quad 473$ $477, \quad 179, \quad 551, \quad 552-553$ 560

Mosquito nets, 63, 107 theory, 5.4, 62.4, 751-752

Mosquitoes, $57,6 \% 3$

Mountain sickness, 201

Nouth, diveases of, 6i3s

Noxa, $27,67,699,293$

II umit, 195

Nummies, 51

Mumps, :3:3

Nurphy button, 762

Musearin, 705

Iuscle, 257, 265, 3223, 459, $575-576,606$

Muscle-sonse, 3s.5

Muscles, 111, 209, 210, 216

Musenus, :ubitomieal, 230. $241,346,3.54,415$

Mutation, 4s9, 5ist), 724-725

Mrathenial gravis, 263, 695

Myectomst, 44

Myeris fungoides, 437

Irdriaties, 70.1

Myomectomy, .214,545

Iresitis osificans, $3 \times 3$

Iyotonia, 6989

Iythology, mediand, 33, 69, $7-75,90,97,107$

Iryedema, $168,595,644,677$, 641,733
Muscardine, 711

Mrooses, fil1, 702 
YMis. 7.4.2

Xancy, seluesul of, 693

Naples, singe of, 1s:3

Nareasis, Toj

Viarentis:s, 30

Vitrenturm. 418

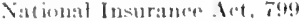

Situral llisturs sohum, Il! ti1

Nature l'hilosishy siboul, 114

Siulueim, 7ts!

Seamlerthal-kull, li;

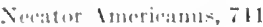

Secromis, 5i3.s, tils, tiks

Negro, 3is!?, 17

Nimallvarsin, 747

Nepenther, 29!

Sipleritis, $111,440,615,6 \pi$, (i) 1

Sephropsesta (ile)

Fierve. 37.578

deptenerution of sig

physiology of. 77

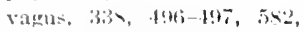
$600,605,600-605$

Nerve-bluking, 7.5.5, -661-762, atis

Norveredls, 4t. $54 ; 2-561$

Nirverendinges, $561, \quad 562$ sis

Xerve-filers, 1h!)

Dirve-impmlse, 17:

Xorvesuture, 113

Xerves, gla

cercitrat, 105, 217, 262, 334, 333,471

optic, 5\%

periptzeral, $575,542,815$

regeneration of, $3: 32$

spinal, $470-471,477,4 ! 33$, 694

vasoconstrictor, 594

vasoditator, $5 \times 7,594$

vasomotor, 5xi, 594

Nerrous sytem, 94, 105, 516. $57(1,5), 545$

stmpathetic, 10,; 333 $5 \times 1-5 \times 2,601-605$ vasomutor, is 5,594

Sestorians, 117

Neuraleria, 6990,704 facial, 371

Neurasthenia, 6968, 710

Senrectormy, 647

Neuritis, 461, 4\6, 540, 659, 6an, biss

Neurofibrilla, 56;3

Veurofibroma, 614, 699

Neurogenic theory, 243, 25., 49.5

Neuroglia, 562,615

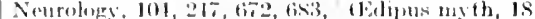
tis!) bis!

Sinuromat bix!

Venten theors: 563-564

Nemroses, fitit, Tiss

s.v11:1, $73 ! 1710$

tratumation, 510, fi!s

visereral, fis

Nenrotomin, 115

riw-hirth, 31

Nimepaners, :2x,

Sin Vin'nna sichoul, $453-459$

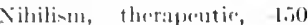
$4.5 .5,1.76$

Yitro-är, 2tis

Nitrogen, 33.5, 5!31

Nitrous axidt. 516

"So restraint," (i9)9, 795

Nobel prizemen, 811

Nodial rhethus, 7is.

Sient atal, 49.5

Voise mathine, Ttiti

Yomenclaturo, anafomionl, $216,335,491$

binomial, 316

Vominalism, 132-133

Nortencin, till

Norm, anatumie, 213, 339

Nose, 112, 247, 561

disetisis of 662

surfery, 537, tifi2

Nosocomia, les

Nosologes, 316, 317, 31s, 369

Tostrums, 402

Tutochord, $4 x !$

Sovels, medieal, $775-776$

Nosocain, 70

Nuclein, 59t, 610,611

Nucleo-proteins, 6:31

Nuelens, 4 -

Nimber-lore, 35, 36, S1-52

Numisnutifs, merdical, T-. 92, $236,304-309,34.5,695$

Nursing, 164-172, 792-796

bottle 419

Sutrition, 595

Nyetatopia, 35\%, 370

Nystagnus, vestibular, 766

OBEsITY, 709

pitnitary, 467

Obstefrics, 30, 99, 102, 176. $190-191,233,277-279,343-$ $345,392,416,42: 3,457-455$, $6.52-1.5 .5,6.57,8.4 .5$

oeeupations, 324

hyiene of, 711, 79s-799

Orhronosin, bl

weulists, Roman, 108

(x) foree, 382

Odisenti, 73

()ruithin, 611 oblimm, lici

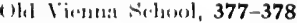

(Hofens, is iti

tmuialo dymasty, 121

biphorectomy, 518, 7:3:3

Oown-air treatmant, 7022

"(1pen-4loor," $700-702$

Ophthalmia, Fepptian, 520

(O)hthalmologr, $99,105,119$, $195,256,321,355-360,600$ $101,113,655-661,761-766$, s!lti

Ophthalmumeter, 572 , ti.s

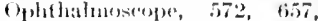
(i.).9, 15:15, 765.5

Opium, $-19,101,113,199,390$, 707

Opsonic index, 7.50

()

(1)tics, $22.5,3.54-360,765-766$ physiolugrio:at, 6.58 - 65.59

O)fograns, in!

t)reanotheraps, 75

()тphanotroplia, $16 \mathrm{~s}$

Orthopedies, 120, 278, 349 , $515-519,522-523,529-530$, iito, 7.36, 7.5

Orritaln, 2994, 398

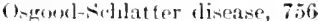

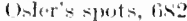

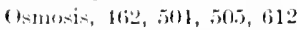

Ostritis deformatus, 612,60

Osteoarthropathe, 694

Osteology, 66, 101, 213, 215, $33 \mathrm{~s}$

Osteomaticia, 39.5

Osteomyelitis, 312, 75s

Osteopsathyrosis, 467

Otologry, 360-361, 6fi2-663

Ovaries, 217

Orariotomy, 29, 276, 34s, 517, 525, 535, 543-544, 548, 635, (i) 6 , (j4)

ovary, 24;

diseases of $347,365,545$

Ovurn, 332, 479, 556, 560, 566, $730-731$

()xahria, 610

Oxiclation, 7.31

Oxyenen, 26is, 33is

Oxyhemogtubin, 610

Oxyprolin, 611

Ozeni, 662

PACCIIGNAA BODIES, 247

Parlua, school of, 158

Puintingr, melieal, 172-175, $234,237-23 x, 254-255,303-$ $305,312-313,615,774-775$ 
Palate, eleft, 52s

Paleontology, 173, 551

Paleopathology, 52

Paleopsychology, 740

Palmistry, 190, 232

Panaeeas, 24

Panama Canal, 753

Panereas, 2633, 591, 592, 606 surgery of, 757

Pancreatitis, hemorrhagie, bis

Panel practice, 77:3

Pangenesis, 550, 5i:3

Pantheism, 122, 131-132

Pantopon, 70s 196, S96

Pappataei fever, 750

Papyri, nedireal, 4a-50

Parabolani, 162, Iti!

Paracentesis, 91, 113, 150, 331

Paracusis Willisii, 26i3, Thto

Paraffin injections, ti3s

Paragenomiasis, 1427

Paralysis, 105, 200, 312, 442, 6) $2,691,694,696,699$ agit ans, 444

buthar, 670

facial, 159,471

psemelowpertroyhic, 47?

Paralytic secretions, 5ht

Paranecenutu, 71.

Paramyelenus, 695

Paraplesia, alcoholie, 659

Parapeoriasis, 703

Paraschistes, 51

I'aratoitology, 121-12:2, 6:276i2s, 741-742, 7.33, 76-76s

P'aratsyphilis, tititi

Parathyrelel glands, 556 sirgery, 761

T'aregoric, 40 .

I'aris Faculter, 297-3010

Partheresenesic, experimenttal, $730-731$

Pasteur Institute, fi2:2

Pasteurization, fish

P'inst-pinting, 7 (tif

Patella, fracture of, its

I'alholugia animeter, 25:5

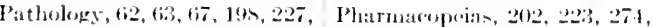

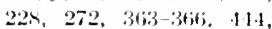
$454-455,492,606,613-$ 6119, 625, 63.31-6i3:2, ti.5, 790

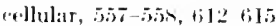

experimental, 32:3, 4!12, 5s

humoral, 82,270

primitive, $23,55-54$

surgite:al, $637-6,40,612$

Pathometrs, 7.1.1

Pavilion hospitale, 791
Pary's joint, tiso

Pébrine, 6:0

Pectineus musede, s5

Pectoriloguy, 131, 675

Pedagogie's, 73s

Pediatries, 56, 190, 201, 673, Jhlogiston, 31s, 33., 335

674, 681, (ist)-tist, 897

Pedieulosis, 61, 742, 81.1

Pedieurists, 303

Peliosis, rheumatic, 45]

Pellagra, 381, 742

Pelvimeter, 345

Pelvis, deformitie's of, $27 \mathrm{~s}$ morphology of, ti.i2- (i.5)

I'epinière, Aledico-Chirurgiensl, 412

Pepsin, 452, 507

Peptonuria, 610

Pereentage feeding, tis-

Pereussion, 362-363, 133, 435, $453,6 \times 5$

Perfusion, 214, 600), 600i

Periapts, 41

Periarteriitis nudosin, tion

Perineum, rupture of, iz:2 surgery of, ith

Periodicals, medical, 242, 3.20. $379,340,346,414,422,417$. $451-452,14 \pi, 475,5311,6 \pi 1$, $701,721,807-810$

Periolicity, 35-37, 270

Poripnemonia, bovine, tiez

Peritonemun, 327, 335

Peritonitis, 384, it 1

Prlsurht, $6: 20$

Perspiration, insensible, 259, 3332,593

Peruvian bark, 290

Pessaries, 327, 6.20

Pent-doctors, 310

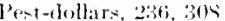

Pestetracts, 1s

Jererer's patches, 26 il

Phageretosis, tiz?

Phakereope, 5i:

Pharmacestynamirs, 70:

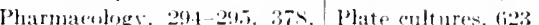
for 109, ins, 703-704, 790 Plays, modient, 164, 295-300

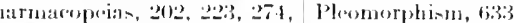
$30.5,390,409,417$ P'lethora, 317

Pharmacy, 54, 94, 12:3, 127, Plethymengaphy, tion $17 \cdot 2,23: 4$

Pharmakes, 24, 33

Pharyngotomy, tiat

Pharynx, diseanes of, bitio

Phenolsulphonephthalein, 707

Pliknylatanin, (i)

Philologists, meelieal, lsti-1s9) Pnemnenia, lo1. 104, 112, 363,

I'hilosopher's stonc, 2066

Philosiophy, Greek, 79-82
Philosephy, meqlie:al, 93, 717

Phlebitis, 35is, 350, 169, 614

Phlegmasia alba dolens, 351

hlegmon, peri-pharyngeal,

Phomecartiograms, i3ti

Photography, 125, nzt

Photomierography, 75

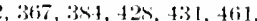

Phylogeny, jfit

Physicians, 57, $7 \mathrm{~s}-79,81, \mathrm{~s}$, s9, $97,3 ! 4 i-397,405-106$, Txi, sok, sls

Physies, 156, 23.5-256, 360, $24-425,20$

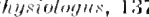

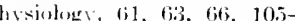
$106,256 \cdot 2619,32 \times-336,476-$ 47. $480-149,492-501,571$ 612, 646, 731-736, 759-790 $\$ 97$

Plysostimina, 660, 706

Pill- 12:3

analeptir, fos

Pinhoke pupil, 430)

Pin-hole tant, 250

pon, 2s

Piroplasmosis, 627, 743

(lis $-60,-60^{2}$

y.riasic, lizit

15, , $33,19 \%, 236,237,238$ 2it $304-310,120,625,797$ Plint-lore, $2.7-36$

Plasmanharresio, 707

Planter-of-l'aris, itzti

P']eniri-y, 101, 101, 112,321

Pleximeter, 13:5

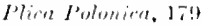

Preveme, 94, 10:3, 106;

Pnemmatic chamber, 755

Prennatio selyeml, !

$365,-130,453,151,627,753$

Pnevumothersus, 3336
Ihosphenes, 17t;

eostume of, 92,171 
P'reumuthor:4s, 331, 653 artificial, 70, 75, 75

l'ne-13notsphus, 15is

I'on'ules imetica, :3!?'

Pon-1s, medices], 3:21

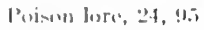

Poisoning, 2:48

Pristom, fis, 9.5, 10s, 123, 16i.j, $11: 3$

P'oitem solic, 27:

Polien, herginne, 5i-is, 3is, 711

Poliesencephlatitis, 7(o)

Jeliomyelitis, 5i3, fhit Mis, ti31, tilo, tifi, till, 7.j. $7 ! n !$

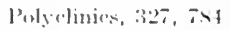

Polycythemia, titio, tis?

Polygentism, 526, 5is

Polyperticles, 736;

Pohpharmacy, 116, 11!

Polyonatio, tiot

l'olypragmatism, 10:3

lolytheism, medical, 37

Pomem ambre, 181

Pons Varolii, 217

poor law, Ta!s

Porokeratosis, 703

Porrigo, 703 Portal system, diseases of,
:317

Postat service, 242

Post-irraduate schools, Tal$7 \times 3$

Postmortems, 151, 234, 491

Postures, olstetric, 30, 12:

Pott's discase, 351

Powder, sympathetie, 2s9

Preeipitin test, 16, 1332, 715

Praformation, 340

Pregnaney, 205, 205, 23s, 311 , $342,34 h, 652,734$

duration of, 384

extrauterine, $35 \%, 542,649$, 650

tubal, 277, 6it!

Preparedness, \$11, \$15

Presbyophrenia, 700

Preseriptions, 409

Priests, 57, 79

P'rioters, medical, 1s.5- Istj

Prisons, 375

Probalilities, 725

Prognosis, 5.5, ,4, s4, 15s, 64t. $714,8: 9$

statistical, 714, 744

Prolin, till

Prophylaxis, 150

Proponal, 705

Prostatorrhea, (4)

Prostitution, 711, 802 l'roteretive ferment:- 733

Proteisls, (60)

P'rotcins, 611, 6i3 1

l'rotoins, sinthesin of, 7:36;

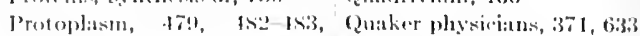
(x), itis, 562

I'rot tomo:i, 25:-2

P'rofozerislogy, 711 715

l'rurigo, tisti

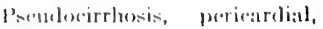
bist

Perodohypert rophie's, 6991

Perplelolenkemia, 251

Psemdescelerosis, 6e95

Ponsis, 160

Poriatsis, 5id, 1360

Pherospermosis, 177, 703

l'merhathenta, 736

Poychiatry, 415 119, 134, tis? $702,795,897$

Proverical foceding, 5:92

Psichounalysis, 43, 31s, 701, 7.10

Psycholugy, 213, 500, 55.5. Ropiprocal innervation, 583 $5 \times 1-5 \times 5,735-70$

sexuml, 735-7.40

Psychopathology, 739-710

P'sycluphysirs, ist

Psyllotheraps, $4: 3-1.4$
$156,31 \mathrm{~s}, 351,709$

Ptuchia, 165

P'tomiains, 612, (631

Ptosis, ti61

P'tyalin, 591

Pubiotomy, 650

Public liealth serviee ( $\mathrm{l} . \mathrm{S}$.), sol

Puerperal convulsions, 652

fever, Sif Fever, puerperal. Regimen sanitatis, 139

Puke, 67, 9.1, 104, 141, 234, Reginina, hygienie, 139, 155 $255,366,429,438,410$, Regression, 726

$197,602,655$

water-hammer, 440

Pulsus alternans, 735

bigeminus, 735

irregularis perpetuns, 735

paractoxus, $6 \overline{7} 0$

Pupil, artificial, 519, 527

Purgation, 36, 51, 91

Purgation ralendiars, $15 \mathrm{~s}$, 190

Purpatives, 102, 12?, 125, 15t, 205

Purin nueleus, 736;

P'urkinje cells, 487

Purples, the, 311

Purpura hemorrhagiea, 378

Pus, laudable, 11:2

Putrefaction, 502-503

Pyemia, 355, 35ti, fi14

Pygmies, 24!

Pyorrlicea alveolaris, 356
QUaCkEM, 23, H, 125, 158, 17., 2:32, 303, 394, . $100-104$. s(l):- $(0)$, soti

(Qualdrivium, 16t

Quaramtine, Ist, soo

Qu:1sisi:1, fos

('u1)

(2uinine, 50.1

"K" РแNTEK, 157

Rademacherism, 460

Rauliograply, 755

Ratium, 425, 708

Raclius curvus, 521

Rales, 4:31

Rat-lite fever, 768

liat-proofiog, 68

Reaction time, bist)

Roilism, 132-13:3

Reeapitulation '1'heory, 474. 569

Reconstruction, $\mathrm{S14}$

Rectum, 591 surgery of, 522, 638, 641

Rod Cross, 373-374, 114

Red, folk-lore of, 35

Red-light treatmont, 35, 70

lefflex action, 256, 264, 329, $332,499,552,598$

Reflexes, 58:3, 688, 697 conclitional, 593

Refraction, 25!), 658, 659

Rofusion, 760

Regeneration, 329-330, 356 . 528

filial, 5.5.3

Regurgitation, aortie, 440, 444

lieil, island of, 379

Rejuvenation, 715

Relapsing fever. Sife Fever, relipsing.

Religion, 21, 23, 44, 72

Remak, fibres of, 485

Remedies, animal, 49-50, 56

Resorcine, 708

Respiration, 105, 266-269, $329,334-336,494,495$, 607-609

fetal, $47 x$

Responsibility, 701

Rest cure, 698

Resurrectionists, 471-472

Retina, 259, 476, 561, 589, 765

Fetinoseops, 660

Revolution, War of the, 389393 
Rheoscopic frog, 489, 374

Rheumatism, $40,432,756$

elaronic, 369

Rhinology, titil

Rhinophymat, 175

Rhinoplasty, til, 221, 518, 528

Rhinosederomat, 702

Rhinoscopy, +15!

Rhizopods, 5isg, itjl

Rhizotomists, $81,10 \mathrm{~s}$

Rhodopsin, $5 s 9$

Ribs, $26 \mathrm{~s}$

Rickets, 260

Riggs' disease, $3 \overline{5} 6$

Rigidity, decerebrate, is..3

Rigor mortis, 598

Rinderpest, 624, 713

Ringer's solution, 60 ;

Rinne's test, 663

Rochelle salts, 292

Rodents, 59, 310

Roentgen rays, 708. 7.j

Romberg's sign, 69)

Rosicrucians, $25 i-2,5$

Royal society, 281

Royal Touch, 34, 119, 29!9

Rubella, 31!

Rumination, $26 !$

SABAATh, 60

Sucrifice, ritual, $33,73,10.5$

Safety-lamp, 711

Saint Côme, 14t, 161

saints, medical, 35, 17!

saiodin, 736

salerno, school of, 137-140, 172,898

Salipyrin, 70s

Salivit, 329

Sislivary glands, 591

Salivation, mercurial, 670

Salol, 705

Salpetrière, 692,693

Salvarsin, 747, 75:3

Samme de shinta, 29

Sindalani, 127

Singrarlo, 301

Sanitaria, 702

Sanitary surveys, s01

Saranac Jake, 79)

sarcine, 55s, 619

Sarcode, 4 4.2

sircoid, 703

Sarsaparilla, 2:37

Sissafras, 237

Sitires, meelirat, 399-100

Scabies, 122, $379,351,702$

Scapegoat , 3:3

Scarlitina, $270,311,367,378$, 421,743

Scarlet red, 708
Searpa's triangle, :34:3

Sicheinfütrong, 592

Sehistosomum, itir

schizophrenia, 7(0)

schol-children, lyyeine of, Sino-auricular node, s.j (560, 711

school-hunches, 71

sehoolmen, 152

siciatica, 33:3

Seience, $816-817$

Siclerectoms, 7tit;

Seleriasis, (iso)

sicleroderma, 3\$4, 439, 41 :

selerosis, disseminat: $\mathrm{d}, 46$ ?

scopelism, 40

Scot's Pill, 291

sicrofula, 34, 38, 149, 27 1, 249, 793

Sicurvy, 103, 238, 373, 375

'teals, oeulists', 10s

seaside hospitals, 793

secretin, 592

Secretions, 606

internal, 42, 596, 607, 732-

\section{4}

Sirctariunism, medical, 803

sintions, serial, 565,566 ;

Seidlitz powders, 109

figuetetes salts, 292

silection, natural, 549-550

Sel ive breeding, 726-727

Semicircular eanals, 495

$\therefore$ mip rmeable membranes, 505,612

Sienega, 390

Siensition, 260, 477, 498

Sifnsitizing substanees, 750

Septicemia, 626

traunatic, 623, 626, 634

Scrine, 611

\section{Serology, 746-750}

serpents, $72,73,77,97$

poisonous, $4.17,706$

Servi midici, 107

Seton, 142, 194, 301, 303, 534

Sicwage, $5 \pi, 4(0)-\$(0) 2$

purification of, $\$ 01-\$ 02$

Sex, determination of, 731

Sexual instinct, $735-7+10$

perversions of, $13,701,739$

Sham meals, 592

Shamanism, 22'

Sharpey, fibres of, 500

shell shook, 813

shoek, 42, 5*1, 761

Shoes, military, 751

Shorthand, 1!96

Sittu, 56, 179

Side-chain theory, 747-748

signatures, doctrine of, 3.5, 198,232

Silkworm, diseases of, 619,620
Simples, 223-226, 231

Himpson's pains, ti.5:3

Sims' position, 5.15

Sinistrin, 705

skeletal rematins, tit

skeleton, 339

skin, atrophy of, 70:3

disentses of, 1\$3-184, 201, $435,436-137,702-703$

Skoda's resontne' 453

Sleeping siekness, 167, 6it, 677,743

Simall-pox, 69, 70, 114, 11! $120,155,238,2 \times 0,311,35 t$ $347-358,617,711,743,75:$ smell, 662

snap-diagnoses, 454

snuffs, narcotir, 25

Societies, medieal, 422, 807 seientific, 2\$1, 414

Solidism, 9s

Soporifies, 29

Soul, sensitive, 317

Sound, 572

Sounds, uterine, 54.

Sipecies, fixity of, 316,473

origin of, 549-550

speeticles, 27, 103, 155, 177, $195,655,765$

Spectrum analysis, 425

Speculum, 544, 5.5

Speerh, 659

Spermatozoa, 252, 258, 489, 567

Siphygmograph, 602

sphygmomanometry, 577, (58)

Sivjces, 172, 239, 29.1-295

ipigelian lobe, $2 \mathrm{ts}$

spinal animal, 5\$1

spinal eord, 105

disenses of, 32s, 691,694

puncture of, 69:5

surgery of, $643,690 \mathrm{j}$

spine, caries of, 52, 349,351, $52: 3,617$

deformities of, 90, 120, 27s. $319,3 \rightarrow 1,756$;

surerery of, 6335,613

spirillosis, 117

spirochartal pallide, 7.15

spironeter, bos

Sptren, dise:ses of, 66 t excision of, 531, 5.5, 1303

splenomegaly, tropical, 713

splints, 52, 631, 5331

siondylit is deformans, i2, 716

spondylolisthesis, 15i5, 65i3

Sipondylosis, rhizomedic, 694

Sponge, soporifire, 30, 142 skin-grafting, 529?

sprochetosis, 7.13 
Enorolrichosis, $02.27,703$

Spritag oatarrh, tido

Eurue, 753

staffordshire host, fi.t)

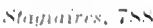

staining, intravital, sti:

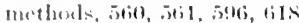

Stammering, 5z?

Stannius ligatures, tion, tions

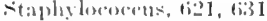

staphy lophsty. 21!

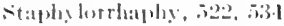

state melieine. T!) $-\mathrm{s}^{*}$

statisties, 711, 72.5 7.27 moliwal, 124-129, 7 1:3-71/

vital, 273, 32:3, 7 $13-711$

status lymphaticus, 412,556, 73.3

Steram sterilization, ti:35

stegonulis faseiata, 752

stenos: 1110.t, 205

sitereorin, s!?]

stereorhenuistry, ti20

Sterility, 3.1, 517

stotlos(ot)e, 129, 139

still's discased, tis

stokes-dolans dinease. Sif

II (uitt-blirek

Stom:teh, 2043, $50.5-507,530$, (i) 1

discusps of, 390, tito, tizt, fivti

intulsation of, $355,534,676$, 709

surgery of, 6.3.

stomacli-pump, 709

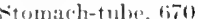

Siones, folk-lore of, $40-11$, $30: 3$

citrahimous, $39,195,529,6.56$ tio, 6.jo

seteptomenests, 6.21

string galvanom(ter, 73:5

stroking, 2-9

sitromuler, 5:19, 600

Strophanthus, 700

struchnine, 504

stuffinss, 711

Stumps, anputation, 69s, 75f

sturm?: conold, Tlis

sueches pertius, 257

suceussion serund, 91

Sugars, 730

Sulphonal, 70s

Superfotation, 103, 35f

Superstitions, medieal, 31-42, 291

Suppuration, I06;, 134

Suprarenal extract. 70 s

glands, 216, 596-597, 732$73: 3$

diseares of 143

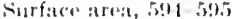

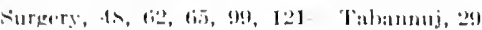

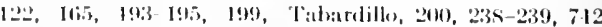

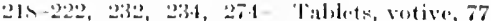

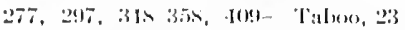

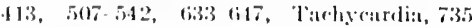

75,7011

Talismatu, 41

antiseptic, 112, 115, 633- Talmurl, til

036, (ii3), 6.11

ascetic, (1) 41, (if!)

experinurental, $521,75 \mathrm{~s}$

llimlu, di2- $(i, 1)$

Tarantism, 250

T'aricheutes, 51

Tartar (ametic, 29$) 2$

l'artaric diseases, 198

history of, 350, 515, 521, Taxonomy, 316-317

(i) 1, (i.16,, ! I!)

Tolins, 413

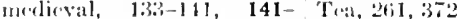

150, 160, I6il, I6i2-16i- Te(etli, 104, 112, 216, 356, 395, 174

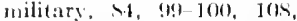

194, 51t 520, 2139,736

759,811

nourologic:al, 761762

orthoperlit. Sies orthopedit's.

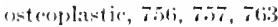

physulosical, $750-762$ I7:

artificial, (ii)

divectises, 52

Telanguedasis, fise

Toletriphe, dectric, 339, 198

Teloolegry, 105

Temperature cerellicients, 730

Temperatiuresense, 19s

lomplestrep, th

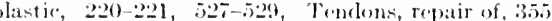
517

primitive, 27-29

Salernitan, 141,174

viscerat, 756, 757

Tenotomy, subcutaneous, $52 ! 9-530$

Tonsor tarsi, $4 \overline{7}$

Terminal infecetuns, ti.3 1

Terres sigillater, 101

Sumpension-larvnguseopy, fitil Test breakfast, dif6

sutures, silvor, ils

Situring, 761

T'est-types, tisto

Testicle, 26.

Tests, diagnostic, Gs nent:1], s13

Sweating sieknosit, 1.4!, 19:3, 200

Tetanomotor, 506

Tetanns, 161, 627, 677, 707

Tetuny, 467, 605, 689, 733, 760

Tetravaceines, 815

Tetronal, 70s

Texas ferer, 6332

Thalamus, optie, 494

Theaters, anatomical, 152 , $230,244,415$

Theism, 1:31-1:32

Theoloromine, 736

Theoplange, 33

Sincrotion, is

Syndromes, pluriglandular, 443

Synthesis, chemjeal, 503

synthetic foods, 7:37-73s

Siphilis, 67, 17!, 151-154, $1 ! 3,200,224,228,231,236$ $237,855,363.3,361,37 \diamond, 355$, $39,436,434,413,456,6330$, $643,6 f i f, 670,677,679,745-$ 746,747

syinge, Jypedermic, 438,520 , $70 \mathrm{~s}$

syringomyelia, 21s, 699
Theorists, medieal, $317-320$, $426-12 x, 460$

Thurapeutics, 43-44, 49-50, sti, 63-tit, 75, 76, 97, 9s, $113,427-424,671,672$, $704,747,403,899$ primitive, $30-42$

Therapia sterilisans, 747

Thermodsnamies, 425,452 , 576

Thermometer, 176

Thermometry, 25s, 778, 900
Theriac, 96, s99 
hermometry. elinieal, 321, Tripod of life, 376

$366,375,452,775,900$

hirty Years' W:ar, 211, 283, $310,3+5$

homsen's disease, 171

horacentesis, 6065,670

horacir duct, 216;

hor:ueoplasty, 6.17

hor:acotomy, 6.10

hroat, discases of, 662

hrombin, 60.4

hromboplastin, $6(0) 4$

hroml,oxis, 3566, 614

hymin, 610

hymis death, 272

gland, 510, 556, 565, 685

hy roid gland, $607,707,767$

surgery of, 642, 759

cks, +3.32

u's, 6999

de, turning of, 37

neaz siveosis, 702

versicolor, 436

sone respiration, 607

ssues, extravital eultivation of, istit, 761

transplantation of, 356,529

mombrer, 324, fixs

insillotome, 534, fifiz

pography, itil-1titi

Tripurates, $70 \mathrm{~s}$

Trivium, 166

Truear, 66i.j

Tropisus, 730, 738

Truss, 15.5, 21!, 27.

Trypanosoniasis, 631, 742- Vaceinotherapy, 630, 750

$743,744,747,767$

Trypsin, $58 x, 591$

Tryptophan, 604, 611

Tsetse fly, 742

Tuberculin, 624,750

Tuberculosis, 431, ti17, tils, Valin, 611

624, 626, 628, 6tit, 667, Variation, 550, 724-72; 750,793

bovine, 632,750

Varicella, 201, 360

gangrenosa, 643

Tumors, $50,477,604,647,747$ Variolation, 27, 633, 65s, 327,

orture, judicial, 2n, 164, 412 ["leers, 147

it +mism, 23

iuch, lis

urnienct, 275, 315

xierology, 37,711

xins, $(127,631,750)$

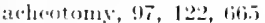

achoma, liguptian, f!

actors, mignctice, 40:3

ansformism, izli

ansfuxion, 267., 273, 627,

3.32, itil

enslations, $152-153,1 \mathrm{~h}$

instators, $11 \mathrm{~s}, 119$

unbe-1laring (nrves, 602

Lumble utun!, 73!

whels, medieal, 504-509

matola, 75. 7.50

'mlse, 4tis

mor, intentional, 15:t3

meli forer, all

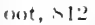

sarfare, $\rightarrow 12$

(it)

cherocorneal, 7ti. , 7iti

ponema, 632, 715-716

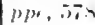

hina, 473

hinosis, 559,643

bophyton, 702

unal, ios transplantation of, 5is?

Twilight slecep, 6ij5

Typhoirl fever. Site Fever, typhoisl.

Typhus fever. Sef lever, Vasodilator remedies, fof typlete.

Tyrosin, (111, fit;

Tyrotoxicon, 6i:31

Tyson's glands, 249

I HEDI DIAFLE, 19

Ilecen syrigen, 101

condenice, far

letraviolet rays, 7.00

Íncinaria Imerieana, 71

Enimern, 22:03, 305"

Iniversities, $41,1660-1697,2204$ 니, 112

( $\mathrm{res}: \mathrm{i}, \mathrm{z}): 3$

entination of, .702, (611, 6s? syothenis of 50 : 3

Iremie (")nstint, tis?

[resumeter, 501

Creothria, 33is

[rethrotomy, 100, 112, 275

['ric areic], 502, $50 \%, 535,896$ 60) 1

I rine, 111, 121, 134, 2400, 22, $3333,323,115,1914,501$, 503, 501 -505, .343, 5945.

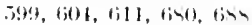
diazerereaction, Titi

['robilin, istr]

I'rology, ! $(0)$

$340,3,7-3 \times x, 354,395,421$

Viscular -yitem, surgery of, 75ti, 762-764

Vasectomy, $72 x$

Vater's ampulla, 333

Verlantism, 6.5

Vegetative nervous sintem, 731

Veins, 246, 217, 21s

Venercal dismases, 59, 144, 355, $356,37 \pi, 435-436,512,675$

Venoms, 334, 631, 6i!n, 70t;

Ventilation, 109, 32x, 373, 710

lierat rine, $; 04$

Viratrinized museld, 5,6

Vironsil, 70), 737

Vermuca nererogenica, 67!

Version, 9.4, 27t, 6is,

perlalie, 102, 113, 190, 220, (i.).

Vertigo, gastrice, 1.35 labrinthine, 45, 495, 766 paralytir, titiz

Veterinarians, st, 161

Vinegatr, 1M1, 32:

Virginity, signs of, 272

Virmase, attenuated, 621, 6;2! filteralule, $750-51,7.51$

Vimera, 192, 201, 206i, 20\%. $20 \mathrm{~s}, 211,251$

tranculantation of, 763

Visionimeter, 19ti

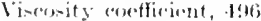

Vision, 119, 3359-3(t), 14.; 14, bisti

roserps, [2., 110, 173-171, lisual purple, 32!t, is! $232,301,312,101$

[rotropin, $70 \overline{7}$

l'rticaria, fis $199.5,703$ traberosa, lisi

Lterus, 3.31, 2(0.5, 333, 5.5ti discases of , $6.50-6.51,6.53$ displifement of, 1.s.) excision of , 220 , 311
Vitalism, 106i, 31 $19,37,3 \times 0$,

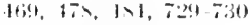

Vitamins, fol) 730

Vitiliguideit, 113

Vivilimuson, 70

Yivionetion, 21:3, 216, 1:13

fincal corrle, patralyois of, 63.3

Voien, 17. 
Vilhyginn fever, sil

lolkhom, 1til

Vimbiting, 4!9, 5iso werisklie, tio:-2

butive offerings, 7T, 1 til

WA1. Fits, aym riment of, 244

Wallher's position, 122, 1 i.5

Whaleleyer's ring, 5iti

W:ar, Pan-European, 811-810

Wir-gatses, s11

Warel's pills, fol

Wars, Napoleonic, 519-520

Wasaermann resation, 747

Watch glass theory, 4רo

Water, filtration of, sol sterilization of, 750

Water-easting. Ser l'roseopy

Water-clusets, 72, $116,2.25$

Waters, mineral, 10s, 200, 203, 274,319

Wave-motion, 497

Weapon salve, 34, 2s,

Webrés law, 19s syndrome, 699

Wedensky effert, o-

Wrigert's latw, tils

Wrells, holy, 35

Western Citliphatu, 121-123

Wet mursing, 233, 311, 119
White slawe trallie, st, ste

Whitworth dowtors, 10:3

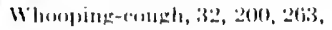
112, 629, 719

will-fire, 37

Willis, cirele wf, 2thi

Wint, disctase of, (i2)

Wise women, 24, 101, 16i]

Wistar Lustitute, 17, Tㄹ

Witcheraft, 222, 22.5, 2-sis

Witele-tectoring. 42:3

Woltlian luelies, 310

Women, melieal eluestion of, 791-792

Wool-skein test, tibo

Woorara, slli

Word-blindness, be99

Worms, intestinal, 50

Wound-4rinks, 146, 119, 191

Wound-excision, s12

Wound-surgery, 112, 115-146, 14, 164, 193, 221, 6ith

Wounded, disposition of, $\pi$, 235, 296, 411

Wounds, 5s, 122, 144, 50s funkhot, 163, 193, 19+1, 219, 2ํ, 221, 274, 27t, 351, $356,519,75 ., 512$

infertion of, 5332, 623, 626, ti34, 812
Wounds, treatment of, $Z$, 90. $27.1,527,6334,701$

Writur's rraump, 159

Wry-neck, 274, 27s, 521, 615

Xantuelahim, 678

Xanthin, 5ats

Xanthom: 437, 413

Xenodochis, lis

Xeroderma pigmentosum, 703

YANS, 201, 677, 753

Yeast, 1:2

Yellow fever. sin Fever, yellow.

Y-liganent, 6.15

Yoni, 31

York retreat, 419

ZaNier INstitute, 710

Zaraith, 59

Zebethum oecidentale, 291

Zenechton, 236

Zorliar manikins, 191-192

Zomotherapy, dot

Zö̈logy, 93, 223, 224, 25. $417,455,484,485-4 \$ 9$, 5.51, 3694,59

mediral, 627-625, 741-7.5 






Garrison, Nielding Hudson
131 An introduction to the hi
63 of medicine $3 d$ ed., rev. an
1921
Bioidicil
\& Medical

\section{PLEASE DO NOT REMOVE} CARDS OR SLIPS FROM THIS POCKET UNIVERSITY OF TORONTO LIBRARY 


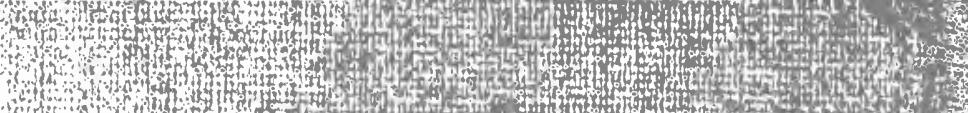

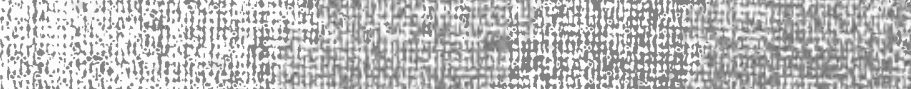

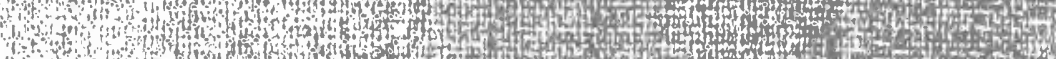
1. 1. \begin{tabular}{l}
30 \\
\hline
\end{tabular}

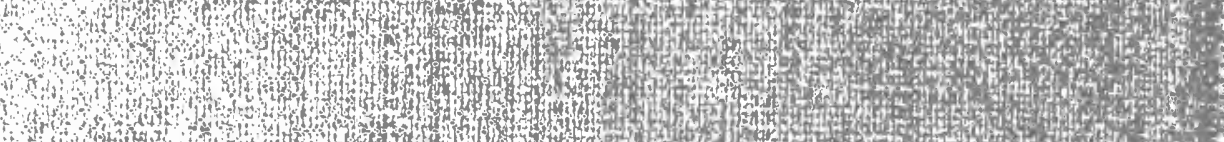

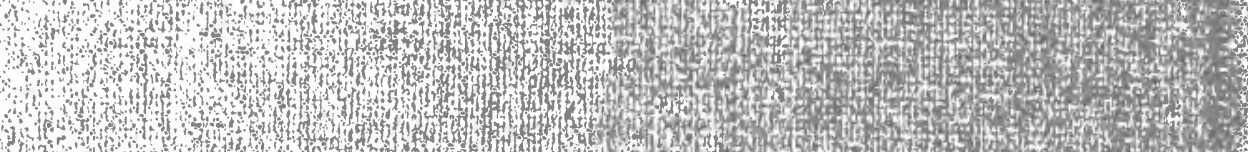

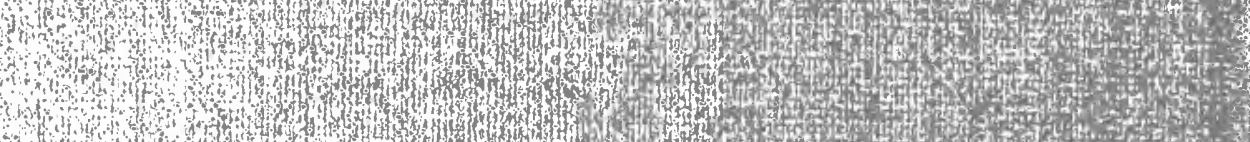

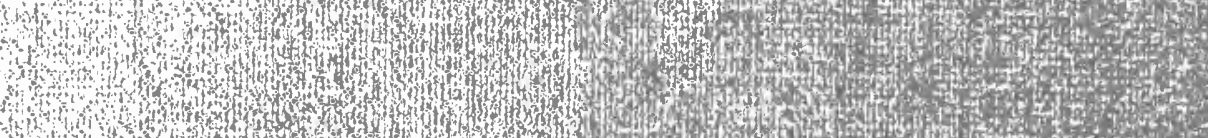
Whoth

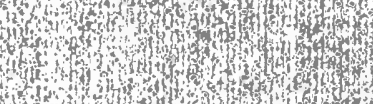
W 4
7 